Movimientos en masa en las sierras de Bravard y Curamalal, Sierras Australes de la Provincia de Buenos Aires

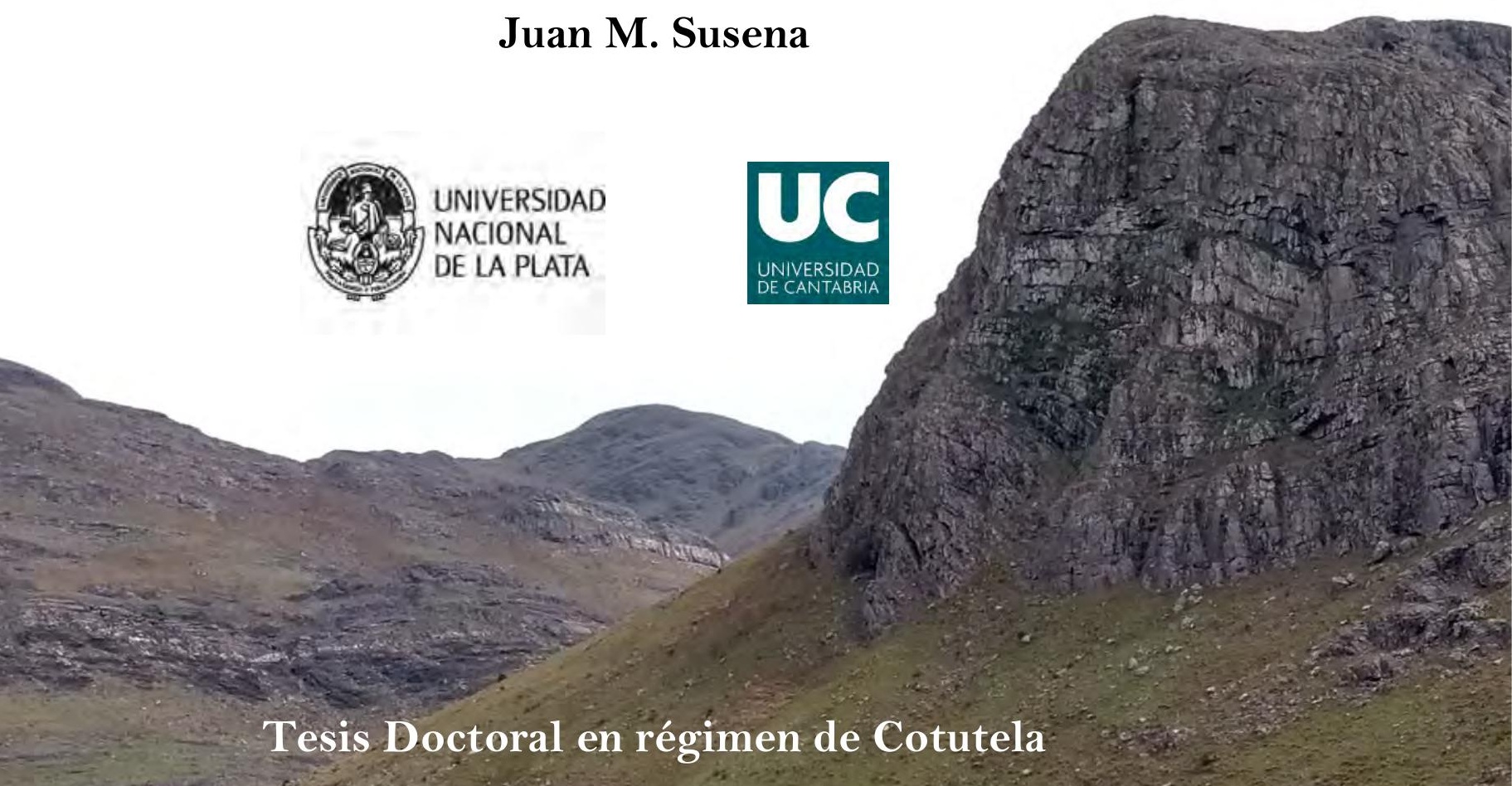

Universidad Nacional de La Plata - Universidad de Cantabria

Directores: Rodolfo 0. Gentile y Juan Remondo Tejerina

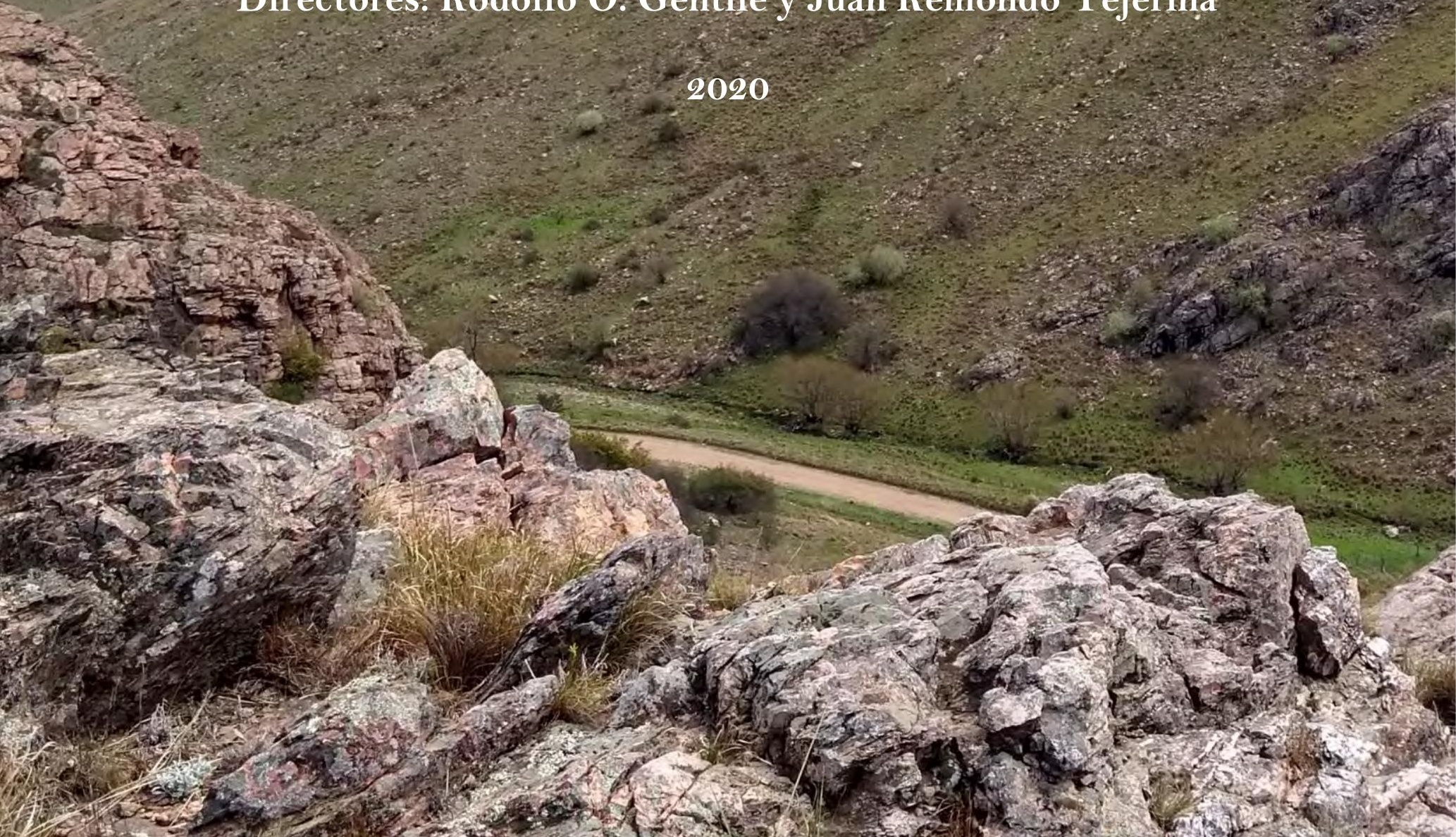



Movimientos en masa en las sierras de Bravard y Curamalal,

\author{
Sierras Australes de la Provincia de Buenos Aires
}

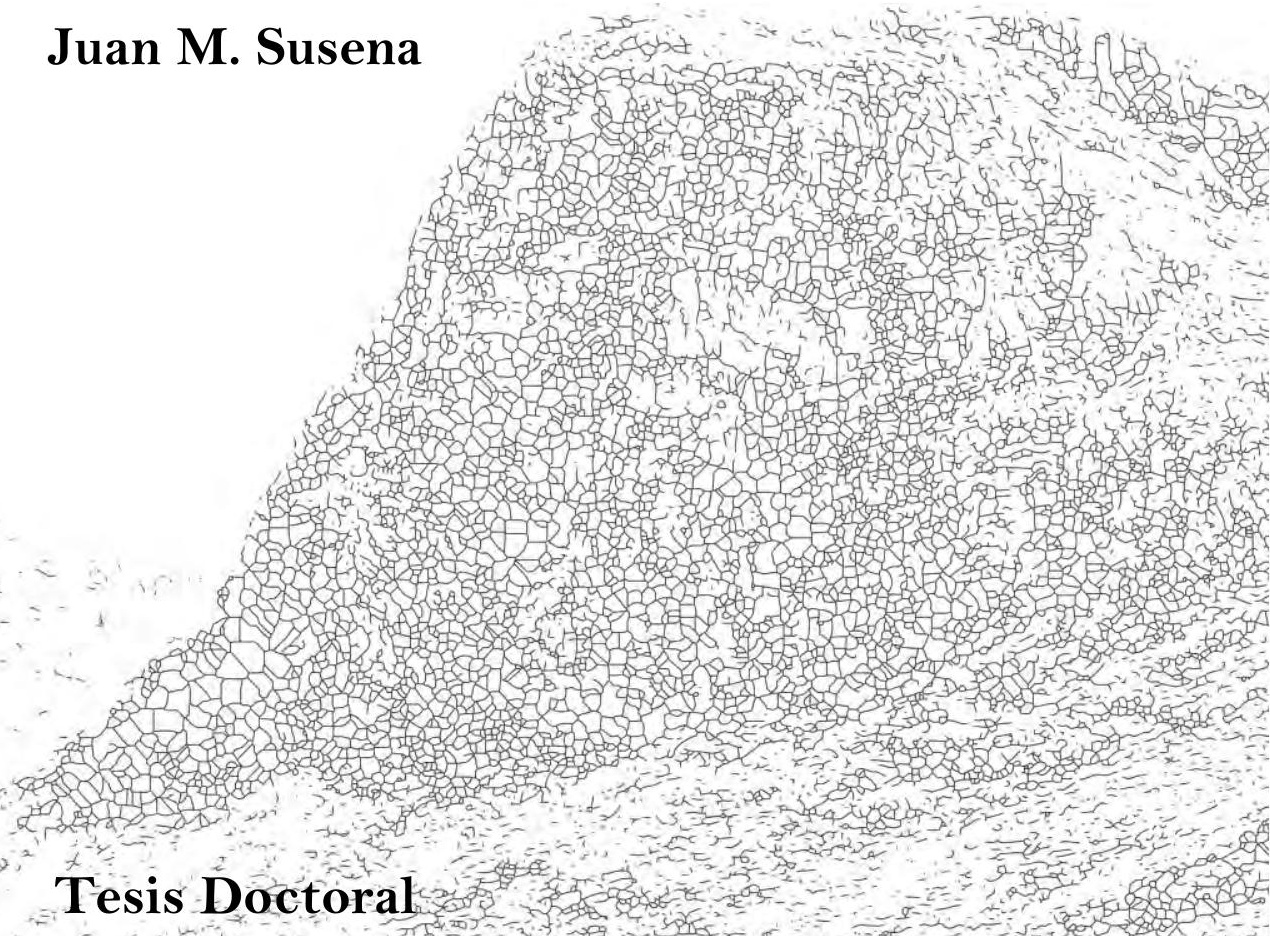

Universidad Nacional de La Plata Universidad de Cantabria

Directores por la Universidad Nacional de La Plata.

Rodolfo O Gentile y Nauris V. Dangavs

Directores por la Universidad de Cantabria: Juan Remondo Tejerina yodolfo O. Gentile

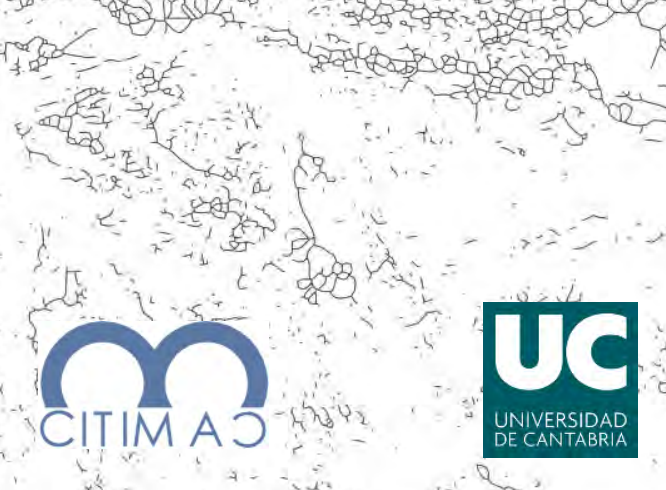



A mi esposa 



\title{
Movimientos en masa en las sierras de Bravard y Curamalal, Sierras Australes de la Provincia de Buenos Aires
}

\begin{abstract}
RESUMEN
Los movimientos en masa son procesos geomorfológicos que consisten en el desplazamiento de materiales de la superficie terrestre por acción de la gravedad. Estos materiales pueden ser masas de roca, detritos o tierra, con cantidades variables de agua o hielo. En las sierras de Bravard y Curamalal, ubicadas en el suroeste de la Provincia de Buenos Aires, Argentina, estos movimientos se desarrollan en diferentes contextos geomorfológicos del ambiente serrano y pedemontano, bajo condiciones de clima húmedo. Aunque en otras regiones del mundo e incluso en otras partes de Argentina se conoce bastante sobre el papel que juegan los movimientos en masa desde el punto de vista geomorfológico, dicho conocimiento en las sierras mencionadas es muy escaso, especialmente si se lo compara con otros aspectos geomorfológicos y geológicos de la región. ¿Qué características tienen los depósitos producidos por movimientos en masa en esta zona? ¿Cuándo ocurrieron los movimientos? ¿Pueden volver a ocurrir?, ¿dónde? Al momento, no se había publicado un inventario de movimientos en masa en el ámbito serrano del suroeste bonaerense, que permitiese analizar y cartografiar la susceptibilidad, amenaza o riesgo de estos procesos. Disponer de un inventario es una base imprescindible para afrontar la problemática de los movimientos en masa de manera cuantitativa. ¿Qué características deben tener los materiales para ser susceptibles de movilizarse? ¿Cuáles son los mecanismos preparadores y desencadenantes? Se necesita profundizar en el conocimiento de los factores que propician la ocurrencia de movimientos en masa para conocer mejor las particularidades de estos procesos en el área, y así afrontar más adecuadamente la prevención de posibles consecuencias no deseadas debidas a su actividad. Escasea también la información geoespacial existente sobre variables ambientales (geomorfología, litología, vegetación, etc.), que son de gran interés para el estudio de los movimientos en masa, y que además servirian para otros tipos de estudios. Estas preguntas y problemas identificados en el conocimiento de los movimientos en la zona motivaron la realización del presente trabajo de tesis.

El objetivo general es conocer los movimientos en masa del área de estudio y sus mecanismos de formación, así como su contribución al modelado del relieve. Para ello se busca establecer criterios morfológicos que permitan la identificación de los movimientos y su actividad, reconocer, caracterizar y clasificar los movimientos en masa,
\end{abstract}


inventariarlos, analizar cómo se relacionan con los factores preparadores y desencadenantes, y analizar y cartografiar la susceptibilidad de movimientos en masa.

Para alcanzar tal objetivo se caracterizó la geomorfología del área en el terreno y por fotointerpretación, se identificaron y cartografiaron unidades con diferentes características geomorfológicas y se reconocieron, caracterizaron e inventariaron a escala 1:5.000 distintos tipos de movimientos en masa en tres subzonas representativas. Se identificaron y analizaron los principales factores preparadores y desencadenantes, por medio de análisis de muestras del terreno en el laboratorio y datos de precipitaciones de estaciones meteorológicas locales y regionales. Mediante la elaboración de un inventario de movimientos en masa y de cartografía temática de distintas variables del terreno que participan en su desarrollo, se hizo un análisis de susceptibilidad de estos procesos.

Se reconocieron 22 unidades geomorfológicas, diferenciadas por sus características morfológicas y los procesos predominantes en ellas. Se las agrupó en 6 grandes categorías, de acuerdo a los materiales y procesos involucrados: unidades influenciadas por la estructura geológica, cimas planas y divisorias principales, piedemonte inactivo, unidades aluviales activas, unidades coluviales activas, y cubierta eólica periserrana. En las dos primeras dominan los afloramientos rocosos, mientras que en las demás unidades lo hace el regolito, sea su génesis coluvial, aluvial o eólica. Los afloramientos rocosos corresponden predominantemente a secuencias sedimentarias paleozoicas, principalmente de areniscas cuarzosas, con intercalaciones menores de wackes feldespáticas y pelitas, y diferentes niveles de conglomerados. Estas rocas se encuentran intensamente plegadas y tienen diversos juegos de discontinuidades. También afloran en menor medida el basamento ígneo-metamórfico neoproterozoico-cámbrico, y brechas sedimentarias cretácicas-paleógenas. En el piedemonte y parte del ambiente serrano afloran además calcretas del lapso Plio-Pleistoceno con un grado de cementación variable. Los depósitos no cementados corresponden al lapso Pleistoceno tardíoHoloceno tardío.

Se reconocieron 14 tipos de movimientos en masa: caídas y vuelcos de rocas/detritos, caídas y vuelcos de tierra/suelo, flujos de tierra, de barro y de detritos, deslizamientos rotacionales y traslacionales de detritos y de tierra/suelo, deslizamientos planares y en cuña en roca, y reptación de suelo/detritos. Se estableció una serie de criterios y rasgos morfológicos útiles para reconocer los movimientos y su actividad en el terreno o mediante técnicas de teledetección, según sus dimensiones, y se indicó el potencial interpretativo de cada uno de ellos. Se diferenciaron así movimientos jóvenes y movimientos antiguos. Los movimientos más conspicuos son los deslizamientos rotacionales y traslacionales de detritos, los vuelcos de suelo, las caídas y vuelcos de 
rocas/detritos y la reptación. La representatividad de cada tipo varía de acuerdo al contexto geomorfológico. En las unidades influenciadas por la estructura geológica abundan las caídas y vuelcos de rocas, mientras que en las unidades coluviales activas predominan los deslizamientos y flujos de detritos, flujos de tierra, caídas de rocas y reptación, y las caídas, vuelcos y deslizamientos de suelo y deslizamientos de detritos son comunes en unidades aluviales activas. Los demás grupos de unidades geomorfológicas tienen escasos movimientos en masa.

En cuanto a la interacción con otros procesos geomorfológicos, se estudiaron especialmente las relaciones entre los movimientos en masa y el escurrimiento superficial y sub-superficial, y la actividad antropo y zoogeomorfológica. El desarrollo de movimientos en masa en las laderas modifica la distribución del agua en superficie y subsuperficie, favoreciendo la infiltración, la surgencia o el estancamiento. A su vez, la acción del agua modifica la fábrica de los depósitos por lavaje e incisión en los límites de las acumulaciones. El agua actúa como mecanismo preparador y desencadenante de movimientos, produciendo la saturación de poros en las laderas, el lavaje de la matriz del regolito en el contacto roca-detritos y el socavamiento basal en laderas y cursos de agua. La actividad antrópica influye en el desarrollo de los movimientos mediante la creación de componentes geomorfológicos susceptibles como taludes en caminos y canales, y mediante el aumento de susceptibilidad de componentes preexistentes, por la modificación de la fábrica y las propiedades geomecánicas y geohidrológicas de los depósitos. La actividad zoogeomorfológica influye también en el desarrollo de los movimientos mediante la generación de sobrecargas, puesta en movimiento de detritos rocosos y excavaciones.

Mediante el análisis cartográfico del inventario de movimientos en masa a escala 1:5.000 y variables del terreno que representan los distintos factores condicionantes y desencadenantes, se estudió la distribución de los movimientos respecto a distintas características del paisaje. Se elaboraron y validaron modelos de susceptibilidad de movimientos en masa y se identificó la combinación de variables más adecuada para establecer de manera confiable los sectores más susceptibles: geomorfología-pendienteorientación-altitud-distancia a cursos de agua.

Los movimientos en masa tienen gran influencia en el modelado de ciertos rasgos geomorfológicos de las sierras de Bravard y Curamalal, particularmente en las laderas de detritos, generando una topografía de montículos y depresiones. Las caídas de roca tienen especial importancia en sectores concretos de los frentes escarpados rocosos, contribuyendo activamente al modelado de gargantas y pequeñas cuencas rocosas, taludes y conos de detritos. En los cursos de agua participan en el retroceso y 
ensanchamiento en cabeceras y la destrucción de las barrancas. Junto a la erosión hídrica, los movimientos en masa contribuyen a la erosión del piedemonte y la consecuente pérdida de suelos con potencial agropecuario, especialmente en cursos de agua y taludes en caminos.

Los avances logrados en esta tesis sobre el conocimiento geomorfológico de los movimientos en masa en las Sierras Australes de la Provincia de Buenos Aires y el establecimiento y validación de técnicas cartográficas y análisis de susceptibilidad constituyen una base para la gestión de uso del territorio y la apertura de nuevas líneas de investigación. 


\title{
Mass movements in the Bravard and Curamalal ranges, Southern Ranges of the Buenos Aires Province
}

\begin{abstract}
Mass movements are geomorphic processes consisting of the displacement of Earth's surface materials under the influence of gravity. These materials include masses of rock, debris or earth with variable amounts of water or ice. In the Bravard and Curamalal ranges, located in the southwest of the Buenos Aires Province, Argentina, mass movements develop in different geomorphologic contexts of the mountain and piedmont environment under humid climate conditions. Although the geomorphologic role of this processes is well known worldwide and even in other regions of Argentina, their research in the aforementioned ranges is very scarce, especially in comparison with other local geomorphologic and geologic subjects. Which are the characteristics of the geomorphic features generated by mass movements in the area? When did the movements occur? Could they develop again? Where? Nowadays, an inventory of mass movements at the mountain environment of the southwest of Buenos Aires Province, that could allow the analysis and mapping of susceptibility, hazard and risk by these processes, is unavailable. An inventory is an essential basis for quantitative research of mass movements. Which are the properties of the most susceptible materials? Which are the conditioning and triggering mechanisms? A more detailed knowledge of the factors that favor the occurrence of mass movements is needed to improve the understanding of these processes in the area and prevent suitably possible threats due to their activity. Geospatial data about environmental variables such as geomorphology, lithology and vegetation (among others), which is very valuable for the study of mass movements and other kind of topics, is also scarce. All of these identified issues in the knowledge of mass movements at local scale motivated the work of this thesis.

The general aim is to know mass movements of the area, their genetic mechanisms, and their contribution to landscape evolution. To achieve this objective, morphological criteria for the recognition of mass movements and their activity must be established, as well as the characterization of these processes, their classification, the elaboration of an inventory, analysis of relationships with conditioning and triggering factors and susceptibility assessment and mapping.
\end{abstract}

A characterization of the geomorphological setting of the area was carried out on the basis of field work and remote sensing, resulting in the identification and mapping of 
different geomorphological units. Different types of mass movements were also recognized, characterized and inventoried at 1:5.000 scale in three representative subareas. The main conditioning and triggering factors were identified and analyzed applying laboratory techniques on ground samples and studying local and regional precipitation data. Mass movement susceptibility assessment was carried out on the basis of the mass movements inventory and thematic mapping of different terrain variables that contributes to their development.

Twenty-two geomorphological units were differentiated through morphological characteristics and the dominant operating geomorphic processes. These units were grouped into 6 greater categories according to the processes and materials involved: units influenced by geological structures, high sub-horizontal ridges, inactive piedmont, active alluvial units, active colluvial units, and mountain-surrounding aeolian mantle. In the two former units, rock outcrops are dominant, whereas in the other ones, the most common material is regolith of either colluvial, alluvial or aeolian genesis. Rock outcrops are mostly Paleozoic sedimentites consisting of quartz sands with minor intercalations of feldspathic wackes and pelites, and some conglomerate levels. These rocks are intensely folded and have various sets of discontinuities. Also there are, to a lesser extent, outcrops of the Neoproterozoic-Cambrian igneous-metamorphic basement and Cretaceous-Paleogene sedimentary breccias. In piedmonts and part of the mountain environment, exist outcrops of Plio-Pleistocene calcretes with variable cementation. Finally, late Pleistocene-late Holocene non-consolidated deposits are widespread in the studied area.

Fourteen types of mass movements were recognized: rock/debris falls and topples, earth/soil falls and topples, earth-flows, mud-flows, debris flows, rotational and translational slides of debris and earth/soils, planar and wedge rock slides, and soil/debris creep. A set of field and remote sensing morphological features and criteria for the recognizing of the movements and their activity was established according to the dimensions of the analyzed movements, and the interpretative capability of such features and criteria were indicated. Thus, young movements were differentiated from old movements. The most conspicuous types of movements are rotational and translational debris slides, earth/soil topples, rock/debris falls and topples, and creep. The representativity of each type vary according to the geomorphological context.

Rock falling and toppling are profuse in geomorphological units influenced by geological structures, whereas debris slides and flows, earth-flows, rock falls and creep develops predominantly in the active colluvial units, and earth/soil fall, topples and slides and debris slides are common in active alluvial units. The development of mass movements in the other groups of geomorphological units is scarce. 
Regarding the interactions with other geomorphic processes, the relationships between mass movements and overland/underground water flow and anthropic and zoogeomorphologic activity were studied. The development of mass movements in slopes modifies surface and subsurface water distribution, contributing to infiltration, upwelling or stagnation. Furthermore, water action modifies the fabric of the mass movement features by washing of the matrix and incision in the limits of the accumulations. Water operates as a conditioning and triggering mechanism of mass movements development, through pore saturation in slopes, washing of the regolith matrix in the rock-debris contact zone, and undercutting in both slopes and streams.

Anthropic activity contributes to mass movements due to the creation of susceptible geomorphic features like talus in roads and artificial channels, and the increasing of the susceptibility of previous geomorphic features by modifications of the sediments fabric and geomechanic or hydrogeologic characteristics. Zoogeomorphologic activity favors mass movements through terrain overloading, rocky debris mobilization and excavation.

Spatial distribution of movements according to different landscape characteristics was studied on the basis of cartographic analysis of the inventory at 1:5.000 scale in combination with different terrain variables which represent conditioning and triggering factors. Thus, susceptibility models were made and validated, and the most suitable combination of variables for a reliable susceptibility assessment was: geomorphologyslope-slope aspect-elevation-distance to streams.

Mass movements have a great influence on the modelling of certain geomorphic features of the Bravard and Curamalal ranges, like debris hillslopes, where this processes generate a hummocky topography. Rock falls have special significance in specific sectors of rock cliffs, contributing actively to the modelling of rock gorges and little rock watersheds or hollows, straight talus and debris cones. In streams, mass movements contribute to headward and lateral erosion of the heads and the destruction of the barrancas. Together with hydric erosion, mass movements contribute to piedmont erosion and resulting loss of soils with agricultural potential, especially in streams and road talus.

The progress made in this thesis in terms of geomorphologic knowledge of the mass movements of the Southern Ranges of the Buenos Aires Province, as well as the establishment and validation of cartographic techniques and susceptibility assessment, comprises a basis for land use management and planning and the opening of new topics for future investigations. 


\section{Ordenamiento de la tesis}

\section{Justificación del ordenamiento en unidades}

El cuerpo principal de este documento se distribuye en unidades que tratan interrogantes básicos de la tesis: el qué, el para qué y el cómo de la tesis, el dónde y el cómo del objeto de estudio, el cuándo y el por qué. Finalmente se reflexiona sobre el trabajo realizado.

Unidad I: el qué, el para qué y el cómo de la tesis: esta unidad es una introducción al objeto de estudio, los movimientos en masa. Se presenta una delimitación semántica (definición) de los movimientos en masa y sus clasificaciones y una introducción y reflexión sobre el estado general del conocimiento de los mismos (el qué). Esto conduce al planteamiento y justificación de los objetivos (el para qué) y al establecimiento de una metodología para su estudio (el cómo de la tesis).

Unidad II: el dónde: el dónde contempla la delimitación espacial del objeto de estudio, mediante una introducción general a las sierras de Bravard y Curamalal, desde el las perspectivas geográfica, geológica y geomorfológica. Esta caracterización se enfoca necesariamente en aspectos determinantes en el desarrollo de movimientos en masa.

Unidad III: el cómo del objeto de estudio: este cómo corresponde a morfología: ¿cómo son los movimientos en masa? Contempla el aspecto descriptivo (con algunas interpretaciones preliminares) con un ordenamiento basado en el contexto geomorfológico. En este sentido, el cómo implica también un dónde del objeto de estudio, más detallado que el dónde de la unidad anterior. Dos capítulos muy particulares se incluyen en esta unidad, titulados "Relaciones entre movimientos en masa y escurrimiento superficial/sub-superficial" y "Movimientos en masa y actividad antropo y zoogeomorfológica", debido a que tratan las interacciones entre los movimientos y otros procesos en contextos geomorfológicos particulares y tienen una influencia decisiva en el cómo de los movimientos en masa.

Unidad IV: el por qué: aquí se presenta un análisis de las causas de los movimientos en masa del área a partir de datos de distinta índole y origen. Se utiliza también el inventario de movimientos en masa, relacionándolo con datos cualitativos y cuantitativos del terreno que expresan las causas de los movimientos. En el último caso, se presentan análisis geoestadísticos. La evaluación de la participación de estos procesos en el modelado del paisaje y el establecimiento de modelos predictivos son el objetivo de esta unidad. Constituye la etapa final, y en cierta manera aplicada de esta tesis.

Conclusiones y consideraciones finales: en este apartado se resumen los principales resultados del trabajo y se evalúan críticamente los aspectos metodológicos abordados. Se hace una valoración/reflexión sobre las terminologías empleadas en cuanto a practicidad, la metodología empleada tanto en el mapeo como en el desarrollo del inventario de movimientos en masa y la generación de los modelos de susceptibilidad. Finalmente se enumeran posibles líneas de trabajo relacionadas con esta tesis. 


\section{ÍNDICE}

Resumen

Abstract

Ordenamiento de la tesis

ix

UNIDAD l: el qué, el para qué y el cómo de la tesis...

Capítulo 1: Introducción al objeto de estudio.

1.1. Definición de movimientos en masa 5

1.2. Algunas consideraciones generales sobre los movimientos en masa ............ 6

1.3. Clasificaciones y características ...................................................................... 7

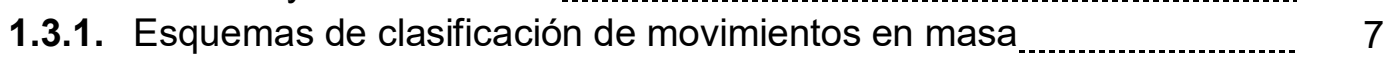

1.3.2. Tipos cinemáticos .............................................................................. 10

1.3.3. Material ...................................................................................... 17

1.3.4. Profundidad de los materiales afectados _................................. 18

1.3.5. Actividad 18

1.3.6. Magnitud de los movimientos en masa $\ldots 22$

1.4. Causas

1.4.1. Factores que contribuyen a una baja resistencia o a reducirla _......... 24

1.4.2. Procesos que favorecen la inestabilidad _..................................... 25

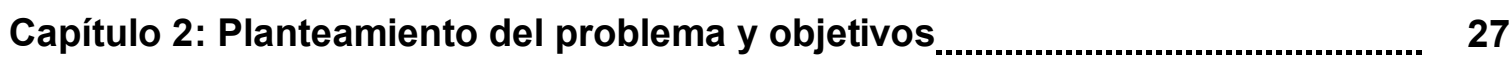

2.1. Breve reseña sobre la evolución del conocimiento de los movimientos en masa

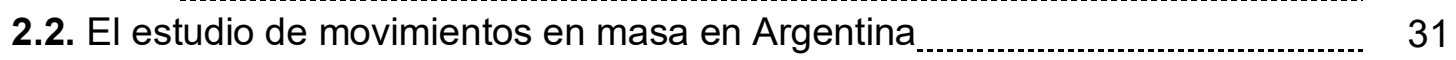

2.3. Estudios de movimientos en masa en la Provincia de Buenos Aires _............ $\quad 32$

2.4. Interrogantes planteados a priori ........................................................ 34

2.5. Síntesis del planteamiento del problema $\ldots$

2.6. Objetivos

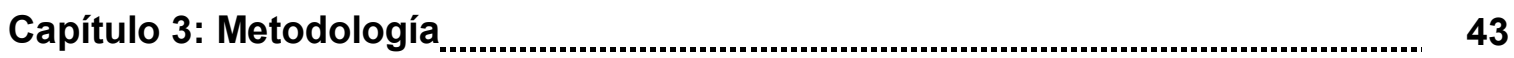

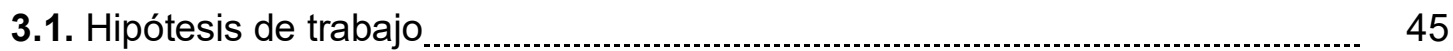

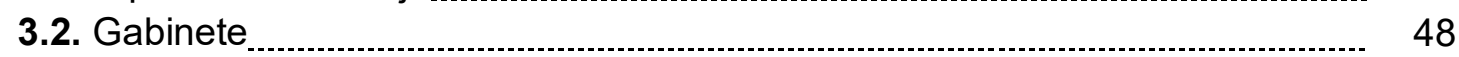

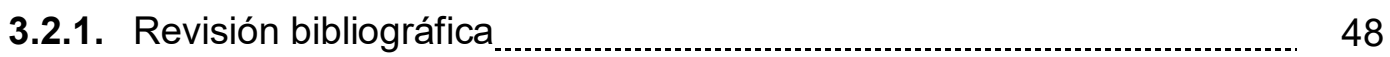

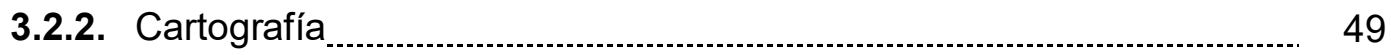

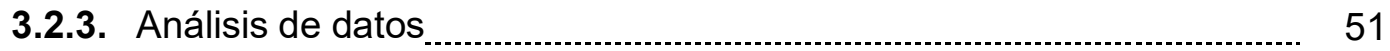

3.3. Laboratorio $\ldots$

3.4. Campo 
UNIDAD II: el dónde...

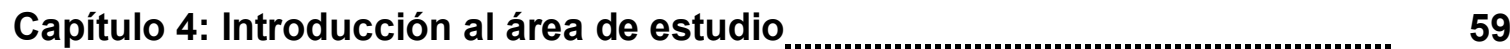

4.1. Objetivos y ordenamiento del capítulo $\ldots$

4.2. Ubicación del área $\ldots$

4.3. Orografía

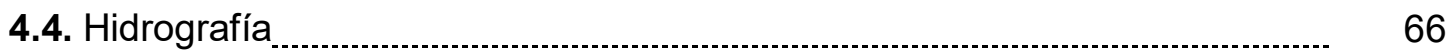

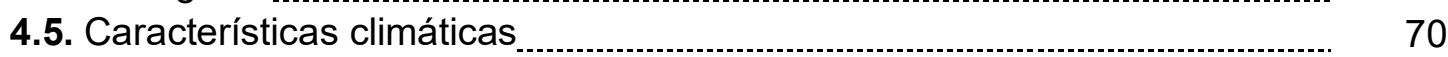

4.6. Suelos

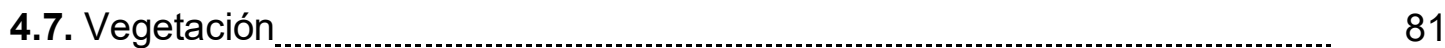

4.8. Fauna

4.9. Demografía y actividades económicas principales _............................... 85

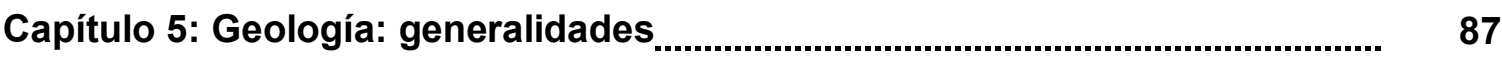

5.1. Objetivos y ordenamiento del presente capítulo $\ldots$

5.2. Litología general de las Sierras Australes $\ldots$

5.3. Litología del área de estudio $\ldots$

5.3.1. Unidades pre-paleocenas .................................................................. 94

5.3.2. Fm. La Norma

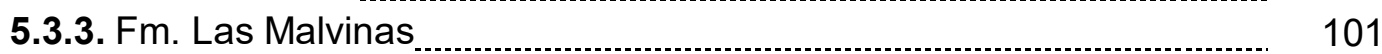

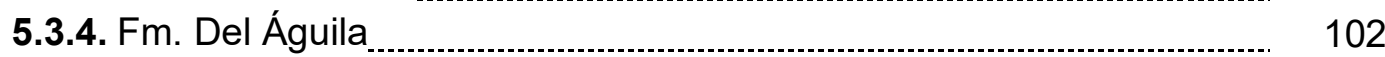

5.3.5. Fm. Agua Blanca ............................................................................ 103

5.3.6. Fm. Saavedra $\ldots \ldots$

5.3.7. Aluvio

5.3.8. Detritos de ladera $\quad 106$

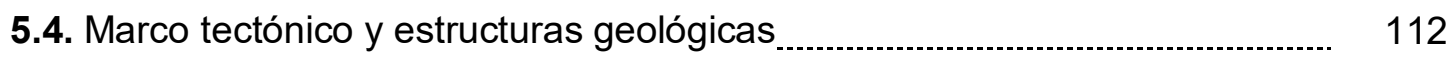

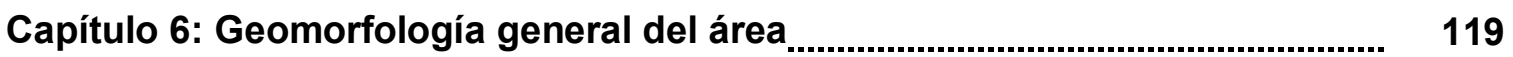

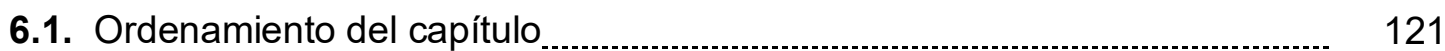

6.2. Aspectos geomorfológicos generales ....................................................... 121

6.3. Unidades geomorfológicas $\ldots$

6.3.1. Unidades influenciadas por la estructura geológica ........................... 131

6.3.2. Cimas Planas y Divisorias Principales $\ldots 137$

6.3.3. Piedemonte inactivo $\ldots . . . . . . . . . .139$

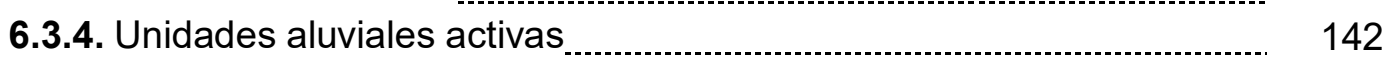

6.3.5. Unidades coluviales activas $\ldots 147$

6.3.6. Cubierta eólica periserrana $\ldots 154$

UNIDAD III: el cómo del objeto de estudio...

Capítulo 7: Criterios de reconocimiento de los movimientos en masa y su actividad

7.1. Objetivos y ordenamiento del capítulo 
7.2. Evidencias de movimientos en masa

7.2.1. Rasgos vinculados a caídas, vuelcos y deslizamientos de rocas ........ 162

7.2.2. Rasgos vinculados a deslizamientos y flujos $\ldots$

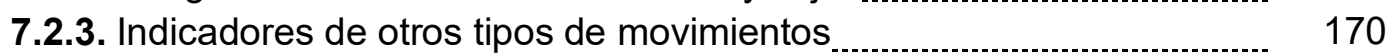

7.3. Actividad de los movimientos: criterios utilizados como indicadores de edad relativa

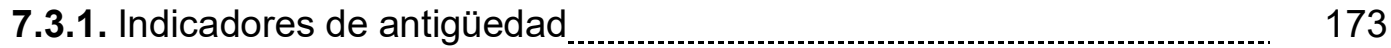

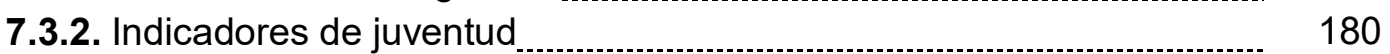

Capítulo 8: Movimientos en masa desde frentes escarpados rocosos ............ $\quad 185$

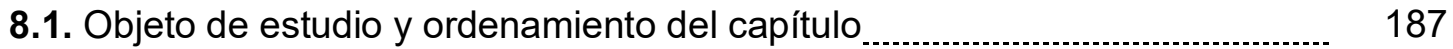

8.2. Frentes escarpados rocosos

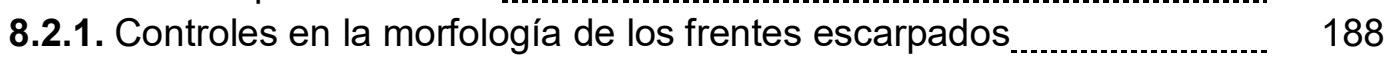

8.2.2. Generalidades sobre morfología y distribución ............................... 190

8.2.3. Frentes escarpados en las Sierras de Bravard $\quad 191$

8.2.4. Frentes escarpados en las Sierras de Curamalal $\ldots 196$

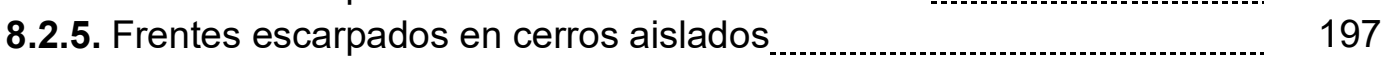

8.3. Movimientos en masa

8.3.1. Caídas

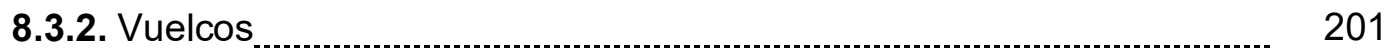

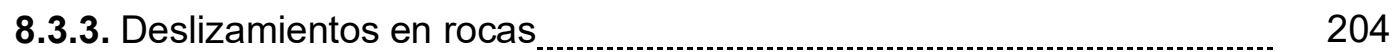

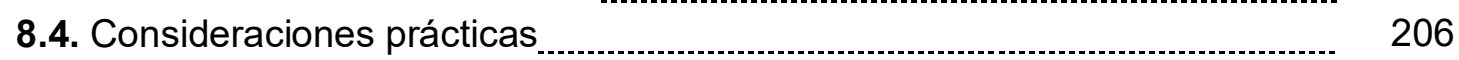

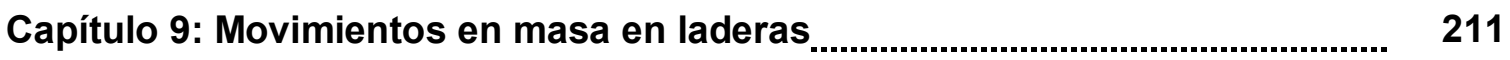

9.1. Objetivos y ordenamiento del capítulo

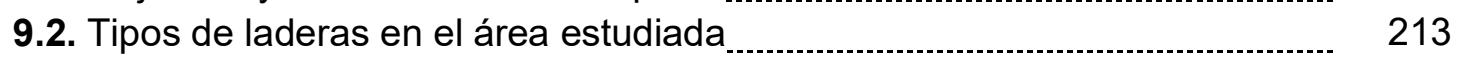

9.3. Movimientos en masa en las unidades Laderas de Detritos y Laderas Compuestas

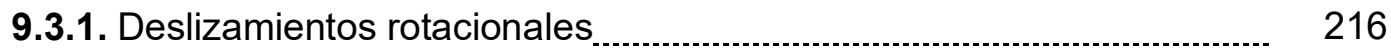

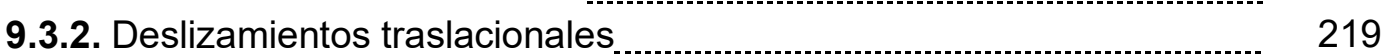

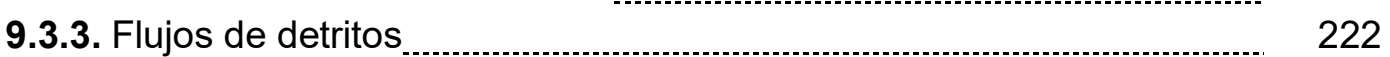

9.3.4. Flujos de tierra $\ldots$

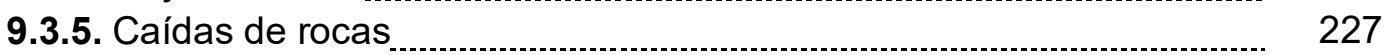

9.3.6. Reptación

9.4. Movimientos en masa en la unidad Bajada Coluvial Fina _....................... 230

9.4.1. Deslizamientos _...................................................................... 231

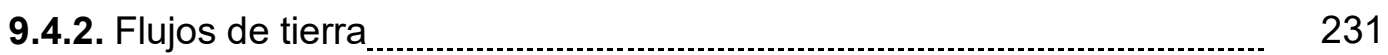

9.4.3. Reptación $\ldots$

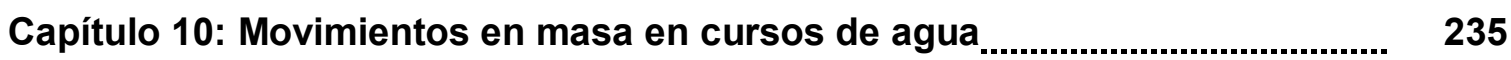

10.1. Justificación y ordenamiento del capítulo ............................................... 237

10.2. Cursos de agua en Fajas Aluviales ........................................................ 238

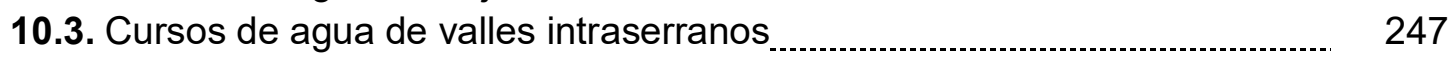


11.1. Objeto de estudio y organización del capítulo _..................................... 255

11.2. Interacciones con el escurrimiento superficial encauzado ...................... 256

11.2.1. Interacciones en cauces de Fajas Aluviales e Incisiones Fluviales ... 256

11.2.2. Interacciones en otros componentes geomorfológicos vinculados a acción fluvial

11.2.3. Interacciones en canalizaciones incipientes en laderas de detritos... $\quad 265$

11.3. Interacciones con el escurrimiento superficial no encauzado..................... $\quad 267$

11.3.1. Interacciones en laderas de detritos ................................................ 267

Capítulo 12: Movimientos en masa y actividad antropo y zoogeomorfológica. $\quad 275$

12.1. Objetivos y ordenamiento del capítulo _................................................ 277

12.2. Antropogeomorfología $\ldots \ldots \ldots$

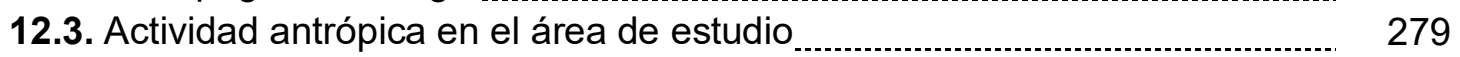

12.4. La Zoogeomorfología y su relación con la actividad antrópica en el área de estudio

12.5. Actividad zoogeomorfológica en el área de estudio ................................... 285

12.6. Relaciones entre movimientos en masa y componentes antropogénicos... 293

12.6.1. Movimientos asociados a caminos y canales antrópicos .................. 293

12.6.2. Movimientos asociados a forestaciones .............................................. 295

12.7. Relaciones entre movimientos en masa y actividad zoogeomorfológica.... 297

12.7.1. Caídas, vuelcos, deslizamientos y reptación de suelo en torno a $\begin{array}{ll}\text { cursos de agua y caminos } & 297\end{array}$

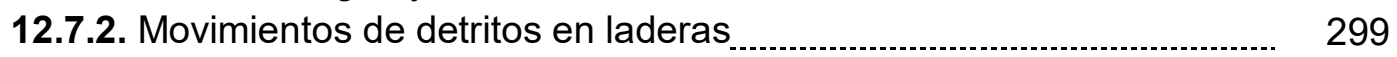

12.7.3. Flujos de tierra en tramos distales de las laderas ......................... 300

12.8. Conclusiones preliminares sobre los movimientos en relación con la actividad antropo y zoogeomorfológica

UNIDAD IV: el por qué...

Capítulo 13: Causas de los movimientos en masa

13.1. Objetivos y ordenamiento del capítulo.

13.2. Factores que contribuyen a una baja resistencia o a reducirla $\ldots \ldots \ldots \ldots . . . . . . . . . . . .307$

13.2.1. Fábrica de los Detritos de Ladera $\ldots 310$

13.2.2. Textura

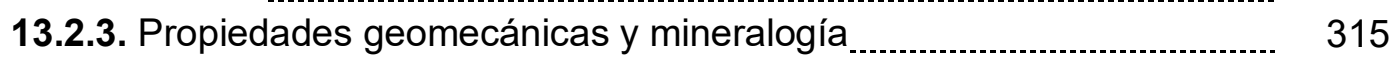

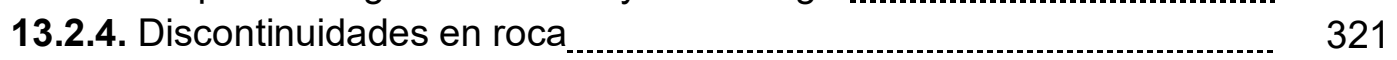

13.2.5. Morfología del terreno .................................................................... 324

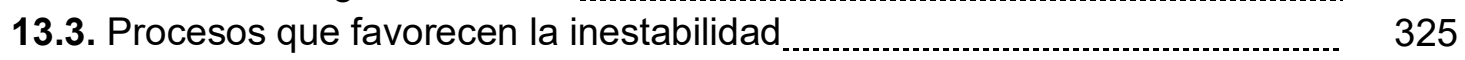

13.3.1. Acción del agua ........................................................................... 325

13.3.2. Sismos $\quad 329$ 
14.1. Justificación y ordenamiento del capítulo

14.2. Algunas metodologías comunes de análisis de susceptibilidad.

14.3. Variables analizadas

14.4. Consideraciones geomorfológicas sobre las variables

14.5. Análisis para la selección de variables

14.5.1. Matriz de correlación.

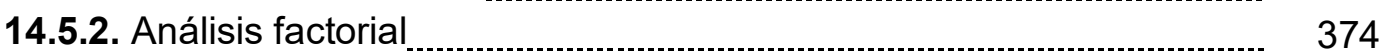

14.5.3. Variables seleccionadas .............................................................. 375

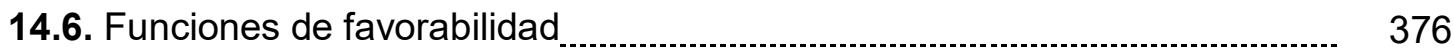

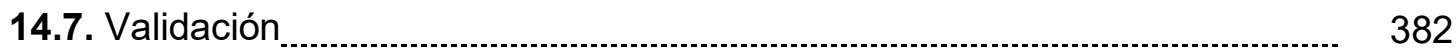

14.7.1. Análisis de sensibilidad $\ldots$

14.8. Conclusiones sobre el potencial de las variables utilizadas para analizar la susceptibilidad

Conclusiones y consideraciones finales

Bibliografía citada

Anexo

Picos principales del área estudiada

Muestras tomadas y análisis de laboratorio efectuados

Resultados de los análisis de laboratorio efectuados

Difractogramas de la fracción arcilla

Datos de precipitación mensual

Eventos de precipitaciones extremas.

Referencias del inventario de movimientos en masa 



\section{UNIDAD I}

El qué, el para qué y el cómo de la tesis... 



\section{Capítulo 1}

\section{Introducción al objeto de estudio}

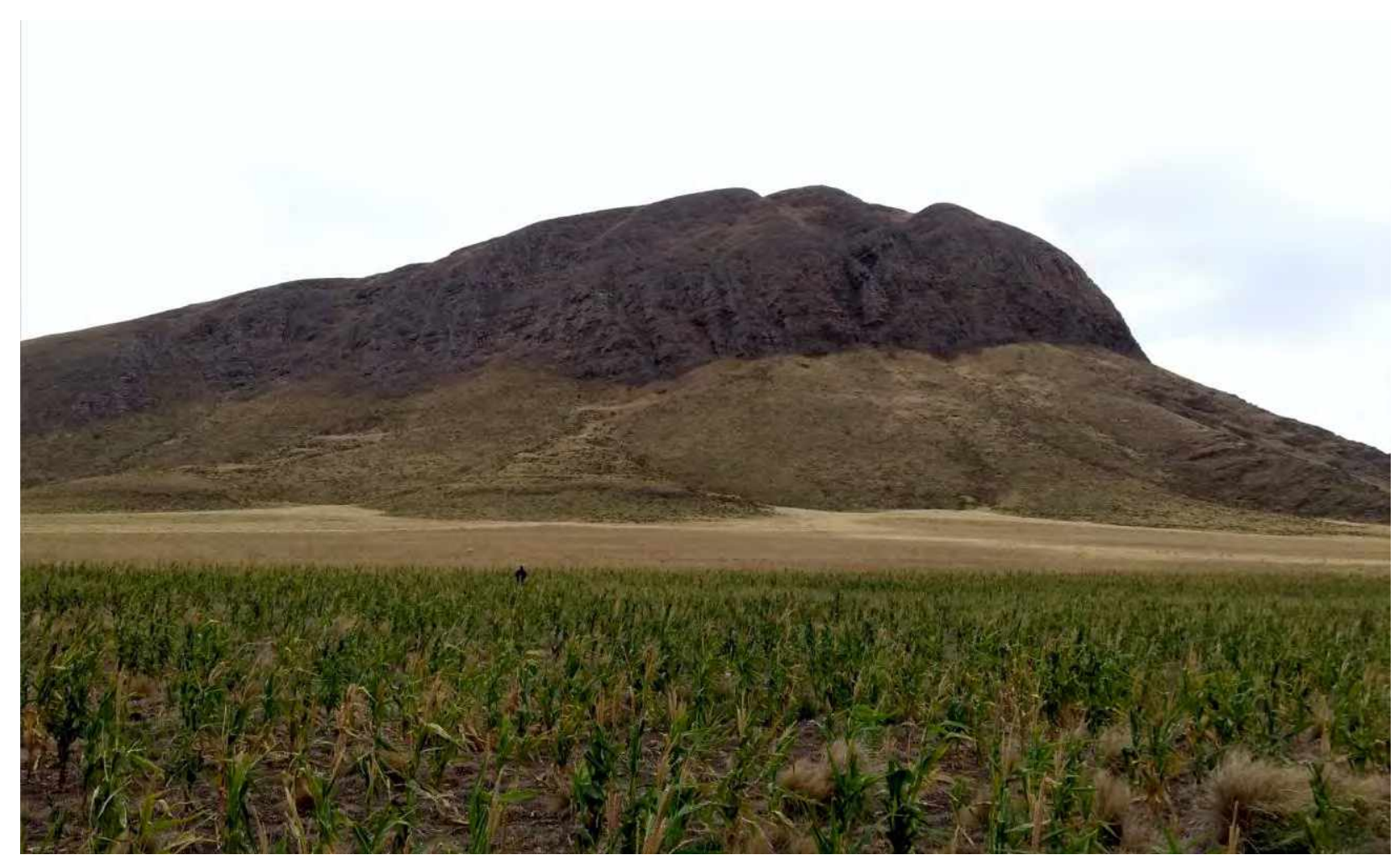

"Primera impresión"

Geomorfólogo observando

rasgos de movimientos en masa del cerro Pan de Azúcar, antes de adentrarse en las laderas.

Fotografía tomada durante la quinta campaña. 
Movimientos en masa en las sierras de Bravard y Curamalal, Sierras Australes de la Provincia de Buenos Aires.

Juan Manuel Susena 
Como lo mencionara el título, esta tesis trata el estudio de los movimientos en masa en un sector serrano particular de la Provincia de Buenos Aires. Su enfoque es principalmente geomorfológico, es decir, se busca conocer sus características morfológicas, distribución espacial (y en algunos casos temporal), y los procesos y condiciones del paisaje que determinan o condicionan su ocurrencia y/o recurrencia. En este aspecto, se intenta comprender a las sierras de Bravard y de Curamalal como sistemas geomorfológicos, con especial énfasis en la producción de movimientos en masa. A continuación, y en los capítulos subsiguientes, se delimita el ámbito espacial y temporal en que se desarrolla el trabajo, y se fija la terminología referente al objeto de estudio, el problema de investigación y la hipótesis de trabajo.

\subsection{Definición de movimientos en masa}

Existen en la literatura científica y la cultura general, diversas denominaciones para los movimientos en masa, debido en parte a la gran variedad de materiales involucrados, morfologías, mecanismos y velocidades. Los movimientos en masa (en inglés mass movements, landslides sensu lato 0 antiguamente landslips) se refieren al desplazamiento de materiales en la superficie terrestre por acción de la gravedad. Cruden (1991) recapituló y analizó distintas definiciones del término inglés británico landslip y su análogo estadounidense, actualmente más difundido, landslide. Concluyó que, desde el primer uso técnico con cierta popularidad del término landslip (Lyell, 1830-1833) en adelante, muchos términos han sido calificativos -por lo tanto, restrictivos-, y propuso una definición "informal", adoptada por el Working Party on World Landslide Inventory: "movimientos ladera abajo de una masa de rocas, de detritos o de tierras por efectos de la gravedad" (Cruden, 1991 en PMA-GCA, 2007). En este punto, es importante distinguir entre el mecanismo de movimiento en masse de estos procesos, y el transporte de sedimentos partícula a partícula por la acción de un agente, como el agua o el viento. En los movimientos en masa, el peso de la masa es un factor determinante para el movimiento, mientras que el transporte por acción de un agente está condicionado por la competencia del último (Huggett, 2007).

A esta definición se agregará, de acuerdo a Brunsden (1979), que los movimientos en masa (= procesos de remoción en masa) no requieren el transporte de un agente, como el agua, el aire o el hielo, aunque de acuerdo a Sharpe (1938) puedan contener cantidades variables de los mismos.

En la literatura hispana, es común relacionar la generalización landslides con el término "deslizamientos", convirtiendo al último en sinónimo de movimientos en masa. Aunque 
Movimientos en masa en las sierras de Bravard y Curamalal,

Sierras Australes de la Provincia de Buenos Aires.

Juan Manuel Susena

pudiera pensarse que este término no debería usarse como tal, puesto que los deslizamientos constituyen un tipo particular de movimientos en masa, en la práctica no suele ocasionar mayores dificultades en la comunicación técnica-profesional. Según Cruden (1991) la palabra landslide no significa literalmente "deslizamiento del terreno" (pensando al deslizamiento como un tipo de movimiento), sino que es una palabra compuesta, cuyo significado difiere del de sus componentes land (= terreno) y slide (= deslizamiento); es decir, landslide implica algo más que estrictamente un "deslizamiento del terreno". Esta problemática es analizada con detalle por Alcántara Ayala (2000) para el idioma español y por Shanmugam (2015) para el idioma inglés. Para evitar confusiones terminológicas, en esta tesis se optó por utilizar el término "movimientos en masa" para generalizar, como asimismo en inglés se utilizan "mass movements" o "landslides".

Debe agregarse que cuando se utiliza en esta tesis la generalización "procesos de ladera", son incluidos los movimientos en masa, el lavaje superficial no encauzado de las pendientes o arroyada difusa, y parte de los procesos asociados a la actividad faunística. Esta generalización se emplea como análoga del término en inglés mass wasting (Savage, 1968; Bloom, 1991; Summerfield, 1991). En definitiva, "procesos de ladera" se emplea aquí como un término más abarcativo o amplio que "movimientos en masa".

\subsection{Algunas consideraciones generales sobre los movimientos en masa}

Como proceso geomorfológico, los movimientos en masa intervienen en el modelado de la superficie terrestre, mediante su contribución en la erosión, transporte y acumulación de materiales desde áreas de denudación hasta zonas de acumulación, tanto en ambientes subaéreos como subácueos.

Los movimientos en masa pueden desplazar volúmenes muy variables (órdenes ${\mathrm{de} \mathrm{dm}^{3}}^{3}$ hasta $\mathrm{km}^{3}$ ), implicando la destrucción de laderas enteras (Hacker et al., 2014). Estos pueden ser transcendentales para el desarrollo del paisaje, operando como procesos formativos, es decir, "dictando" la morfología del paisaje y controlando la erosión (Crozier, 2009). Participan en el modelado componentes geomorfológicos de las cuencas fluviales, por ejemplo, abanicos (de Haas et al., 2014; Tomczyk y Ewertowski, 2017) y laderas de detritos (Luckman, 2013) que suelen constituir laderas de valles, y pueden incluso afectar directa o indirectamente la morfología de los canales (Benda et al., 2003). Los rasgos producidos por movimientos en masa pueden persistir en el paisaje desde días hasta cientos de miles e incluso millones de años (Crozier, 2009; Hacker et al., 2014). Su persistencia puede utilizarse como indicador temporal para analizar la contribución de estos procesos a la evolución del paisaje (Cendrero y Dramis, 1996; Korup et al., 2010). 
Los movimientos en masa pueden ocurrir tanto en zonas de relieve pronunciado, como lo son cadenas montañosas con pendientes elevadas y prolongadas y determinados sectores de taludes continentales submarinos (Shanmugam, 2015), así como en sectores de menor contraste topográfico, como por ejemplo serranías bajas (Gentile, 2011), donde su ocurrencia y expresión morfológica pueden ser más o menos exiguas. Más aún, en una misma región puede existir variabilidad temporal en la representatividad de estos procesos, debido a modificaciones en las condiciones geomorfológicas por cambios climáticos o tectónicos (Cardinali et al., 2002), o antropogénicos (Remondo et al., 2005), entre otros.

Además de modelar el paisaje en mayor o menor medida, los movimientos en masa son, directa o indirectamente, responsables de desastres naturales en todo el mundo (WPMLI, 1991; Sassa, 1999; PMA-GCA, 2007; Latrubesse, 2010), ocasionando cuantiosas pérdidas económicas y humanas.

\subsection{Clasificaciones y características}

Debido al enorme campo de aplicación que tiene el estudio de los movimientos en masa, existe de igual manera un inmenso número de clasificaciones y terminologías. Como señalara Gentile (2011), aun refiriéndose a clasificaciones geomorfológicas o geotécnicas, "todas estas clasificaciones, pueden mostrar diferencias y similitudes en los procesos o tipos de movimientos de similar grado jerárquico, términos nuevos utilizados en algunas clasificaciones y no en otras, cambios en las jerarquías de algunos procesos y en algunas ocasiones significados distintos para el mismo proceso". Los objetivos de este apartado son: brindar una aproximación a la terminología comúnmente utilizada, haciendo énfasis en los esquemas de clasificación vigentes; describir las características principales de cada tipo de movimiento en masa; y establecer el esquema de clasificación a seguir en el desarrollo de esta tesis. La descripción de los distintos tipos se hará solamente al tratar el esquema de clasificación adoptado.

\subsubsection{Esquemas de clasificación de movimientos en masa}

Las clasificaciones de movimientos en masa más citadas y utilizadas, al menos en el ámbito geomorfológico, son las de Sharpe (1938), Varnes (1978), Hutchinson (1968; 1988), y Cruden y Varnes (1993).

Sharpe (1938) ha basado su clasificación en las proporciones de agua o hielo en la masa movilizada, en la distribución de la deformación que afecta a la misma -esto es, si la 
Movimientos en masa en las sierras de Bravard y Curamalal,

Sierras Australes de la Provincia de Buenos Aires.

Juan Manuel Susena

deformación se concentra en una superficie de ruptura o si se distribuye indistintamente dentro de la masa movilizada- y en la velocidad del movimiento. Separa además los movimientos confinados lateralmente, donde predomina el movimiento vertical, de los que presentan un lado libre, hacia donde se produce una componente horizontal del movimiento (Tabla 1.1).

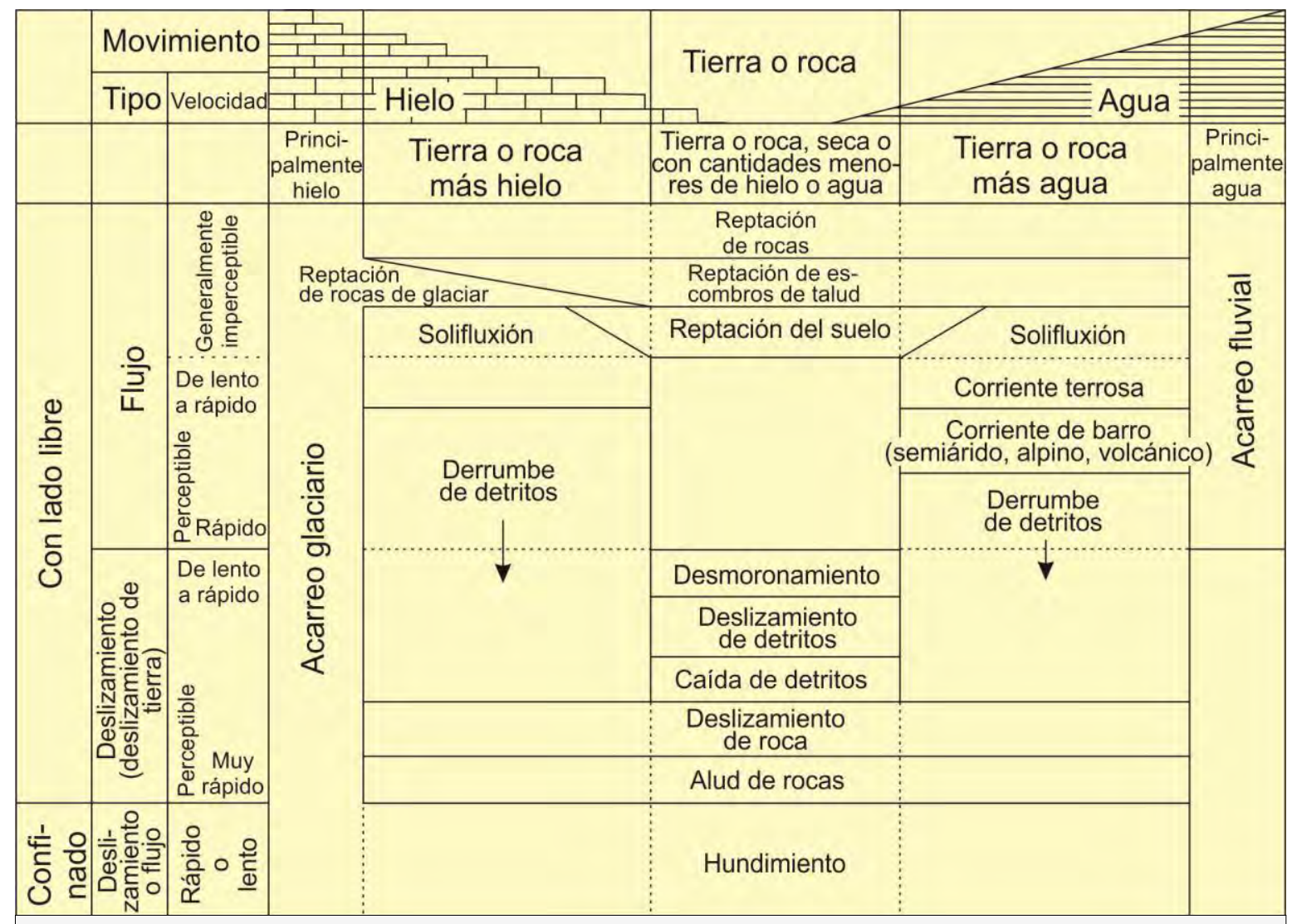

Tabla 1.1. Clasificación de movimientos en masa de Sharpe (1938). Tomado de Thornbury

Varnes (1978), clasifica a los movimientos en masa según el tipo cinemático y el material involucrado (Tabla 1.2). Clasifica los movimientos en cinco tipos principales: caídas/desplomes, vuelcos/desmoronamientos, deslizamientos, expansiones laterales, y flujos; añade un sexto tipo, los movimientos "complejos", que son la combinación de dos o más tipos de movimientos principales. Respecto al tipo de material, diferencia roca de suelo ingenieril, separando al último en tierra y detritos/derrubios. Asimismo, describe términos relacionados a la edad y estados de actividad del movimiento, este tipo de clasificación se retomará más adelante.

La propuesta de Hutchinson (1988), más compleja que las anteriores, se basa principalmente en el tipo de movimiento, diferenciando rebote, reptación, hundimientos de ladera, deslizamientos, movimientos de detritos similares a flujos, vuelcos, caídas, y movimientos de ladera complejos. Secundariamente la clasificación utiliza criterios morfológicos, del estado del movimiento, de la velocidad, del tipo de material y del 


\begin{tabular}{|c|c|c|c|c|}
\hline \multirow{3}{*}{\multicolumn{2}{|c|}{ TIPO DE MOVIMIENTO }} & \multicolumn{3}{|c|}{ TIPO DE MATERIAL } \\
\hline & & \multirow[b]{2}{*}{ ROCA } & \multicolumn{2}{|c|}{ SUELOS INGENIERILES } \\
\hline & & & $\begin{array}{c}\text { PREDOMINANTEMENTE } \\
\text { GRUESO }\end{array}$ & $\begin{array}{l}\text { PREDOMINANTEMENTE } \\
\text { FINO }\end{array}$ \\
\hline \multicolumn{2}{|c|}{ CAÍDAS } & Caída de roca & Caída de detritos & Caída de tierra \\
\hline \multicolumn{2}{|c|}{ VUELCOS } & Vuelco de roca & Vuelco de detritos* & Vuelco de tierra \\
\hline DESLIZAMIENTOS & \begin{tabular}{|l|} 
ROTACIONALES \\
TRASLACIONALES
\end{tabular} & $\begin{array}{c}\text { Deslizamiento } \\
\text { de roca }\end{array}$ & $\begin{array}{l}\text { Deslizamiento de } \\
\text { detritos* }\end{array}$ & Deslizamiento de tierra \\
\hline \multicolumn{2}{|c|}{ EXPANSIONES LATERALES } & $\begin{array}{c}\text { Expansión } \\
\text { lateral de roca }\end{array}$ & $\begin{array}{c}\text { Expansión } \\
\text { lateral de detritos }\end{array}$ & $\begin{array}{c}\text { Expansión } \\
\text { lateral de tierra }\end{array}$ \\
\hline \multicolumn{2}{|c|}{ FLUJOS } & $\begin{array}{c}\text { Flujo de roca } \\
\text { (reptación } \\
\text { profunda)* }^{*}\end{array}$ & \multicolumn{2}{|c|}{ (reptación de suelo) } \\
\hline \multicolumn{2}{|c|}{ COMPLEJOS } & \multicolumn{3}{|c|}{ Combinación de dos o más tipos principales de movimiento } \\
\hline
\end{tabular}

entorno geomorfológico.

Cruden y Varnes (1993) desarrollaron una clasificación basada en los tipos de movimiento y de material, y otra complementaria, según el estado, distribución y estilo de la actividad, como se muestra en la Tabla 1.3 (los aspectos de actividad se explican más adelante en este capítulo). Son diferenciados los mismos tipos que los de Varnes (1958, 1978), con la excepción de los complejos. Este término, es diferenciado en esta tesis como un estilo de actividad (junto a compuestos, múltiples, sucesivos y simples) y no

\begin{tabular}{|l|c|c|}
\hline \multicolumn{1}{|c|}{ Estado de actividad } & Distribución de la actividad & Estilo de la actividad \\
\hline Activo & Retrogresivo & Complejo \\
Reactivado & Avanzando & Compuesto \\
Suspendido & Ensanchando & Múltiple \\
Inactivo & Confinado & Sucesivo \\
Latente & & Único \\
Abandonado & Creciente \\
Estabilizado & Decreciente & \\
Relicto & Móvil & \\
\hline
\end{tabular}

Tabla 1.3. Aspectos de la actividad de movimientos en masa según WP/WLI (1993a). Tomado de PMA-GCA (2007). 
Movimientos en masa en las sierras de Bravard y Curamalal,

Sierras Australes de la Provincia de Buenos Aires.

Juan Manuel Susena

como un tipo de movimiento en sí. Esto concuerda con lo planteado por Hungr et al. (2014), quienes revisan y actualizan la clasificación de Varnes de 1978 y descartan los movimientos complejos como tipo cinemático.

En los últimos 25 años, se han desarrollado trabajos de colaboración a nivel internacional, en el intento de establecer esquemas de clasificación y metodologías de estudio comunes para el análisis de amenaza y riesgo por movimientos en masa. Tales son los ejemplos del Working Party on World Landslide Inventory de la UNESCO (WPMLI, 1991), el proyecto The Temporal Stability and Activity of Landslides in Europe with Respect to Climatic Change-TESLEC (Dikau et al., 1996) de la Comisión Europea, o el Grupo de Estándares para Movimientos en Masa (PMA-GCA, 2007) en los países andinos. No se pretende decir aquí que los esquemas clásicos hayan perdido vigencia, de hecho, muchos profesionales continúan utilizándolos. Más aún, la mayoría de estas clasificaciones se elaboraron a partir de los esquemas clásicos mencionados, entre otros. El rótulo "vigente" se utiliza aquí en referencia a esquemas consensuados a nivel mundial, como una puesta en valor de los esfuerzos realizados para lograrlos.

De los esquemas mencionados, se utilizan en esta tesis los del WPMLI y del PMA-GCA, basados principalmente en los de Varnes (1978) y Hutchinson (1988). No se incluyeron los colapsos, la subsidencia, las avalanchas de nieve, ni las caídas de hielo glacial. Proponen allí una nomenclatura de varios términos para los movimientos en masa, respetando la siguiente secuencia: actividad, velocidad del movimiento, contenido de humedad, material y tipo de movimiento. En el idioma español, primero se menciona el tipo de movimiento, ya que las demás características pueden entenderse como adjetivos. Cada uno de estos términos, presenta un sistema de clasificación, como se desarrollará a continuación.

\subsubsection{Tipos cinemáticos}

La cinemática de los movimientos en masa hace referencia al mecanismo de movimiento y el grado de deformación de la masa desplazada, y es el componente principal de la clasificación adoptada. Se distinguen cinco tipos principales: caídas, vuelcos, deslizamientos, expansiones laterales y flujos.

Caídas: también llamadas desprendimientos. Bloques de suelo o roca son separados de un talud. La individualización de bloques se materializa a través de discontinuidades, y descienden a través del aire por caída libre, rebotes y/o rodaduras (Figura 1.1). Se desencadenan frecuentemente por socavamiento basal. El socavamiento puede 
vincularse a acción del oleaje, común en costas con acantilados, o a erosión fluvial en barrancas de cursos de agua. En pendientes extraplomadas y aleros, y cuando las pendientes que subyacen a los bloques superan los $76^{\circ}$ el mecanismo de movimiento más común es la caída libre (Cruden y Varnes, 1993). Las rodaduras son dominantes en pendientes menores a $45^{\circ}$. Los rebotes dependen de las propiedades del material, y el ángulo entre la pendiente y la trayectoria balística (Hungr y Evans, 1988). Muchas veces, el material puede fragmentarse al impactar la superficie.

Los sturzstroms (Hsü, 1975)

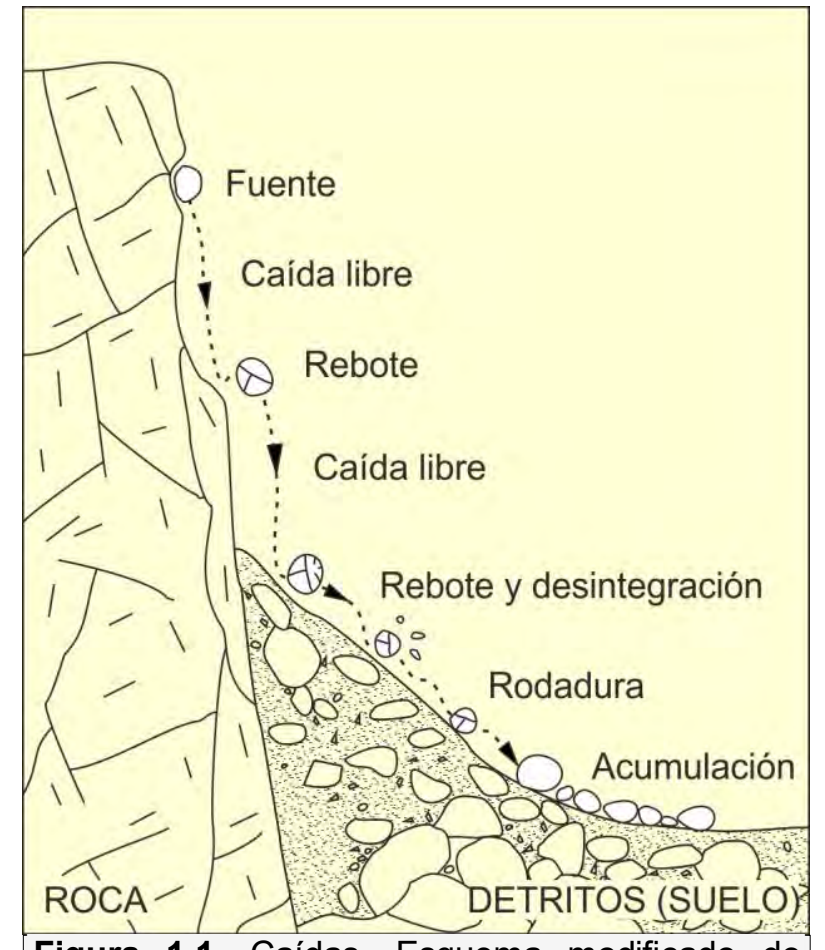

Figura 1.1. Caídas. Esquema modificado de PMA-GCA (2007).

constituyen un movimiento de distribución compleja, del tipo caída de rocas-flujo de detritos, también llamados caídas-avalanchas de rocas y avalanchas de rocas (Cruden y Varnes, 1993 y trabajos allí citados). Se trata de flujos de detritos secos y rápidos, (pueden superar los $50 \mathrm{~m} / \mathrm{s}$ ) iniciados a partir de grandes caídas o deslizamientos, en los cuales el aire atrapado entre las partículas y la energía acústica generada por el impacto entre ellas funcionan como mecanismos fluidizantes (Shreve, 1966; Melosh, 1987).

Vuelcos: consisten en una rotación generalmente hacia adelante de una masa de suelo o roca, alrededor de un punto o pivote de giro ubicado por debajo de su centro gravitacional. Los vuelcos pueden ser inducidos por empuje de materiales adyacentes, o de agua, hielo, detritos o raíces en las grietas, así como por actividad antrópica. Estos movimientos pueden transformarse en caídas o deslizamientos, según la geometría de la masa desplazada y de la superficie de separación, y pueden ser desde extremadamente lentos hasta extremadamente rápidos, muchas veces acelerándose durante el movimiento (Cruden y Varnes, 1993). Se distinguen dos tipos principales, los vuelcos en bloque (Figura 1.2.A) y los vuelcos flexurales (Figura 1.2.B). Los primeros se desarrollan a partir de bloques consistentes de suelo o roca, demarcados por sistemas de fracturas o diaclasas, con un espaciamiento relativamente grande. Los segundos, también llamados vuelcos flexurales del macizo rocoso, ocurren a escala de laderas, son profundos, e involucran la deformación flexural de estratos, con buzamientos altos, 
usualmente de esquistos y filitas (Nichol et al., 2002 en PMA-GCA, 2007).

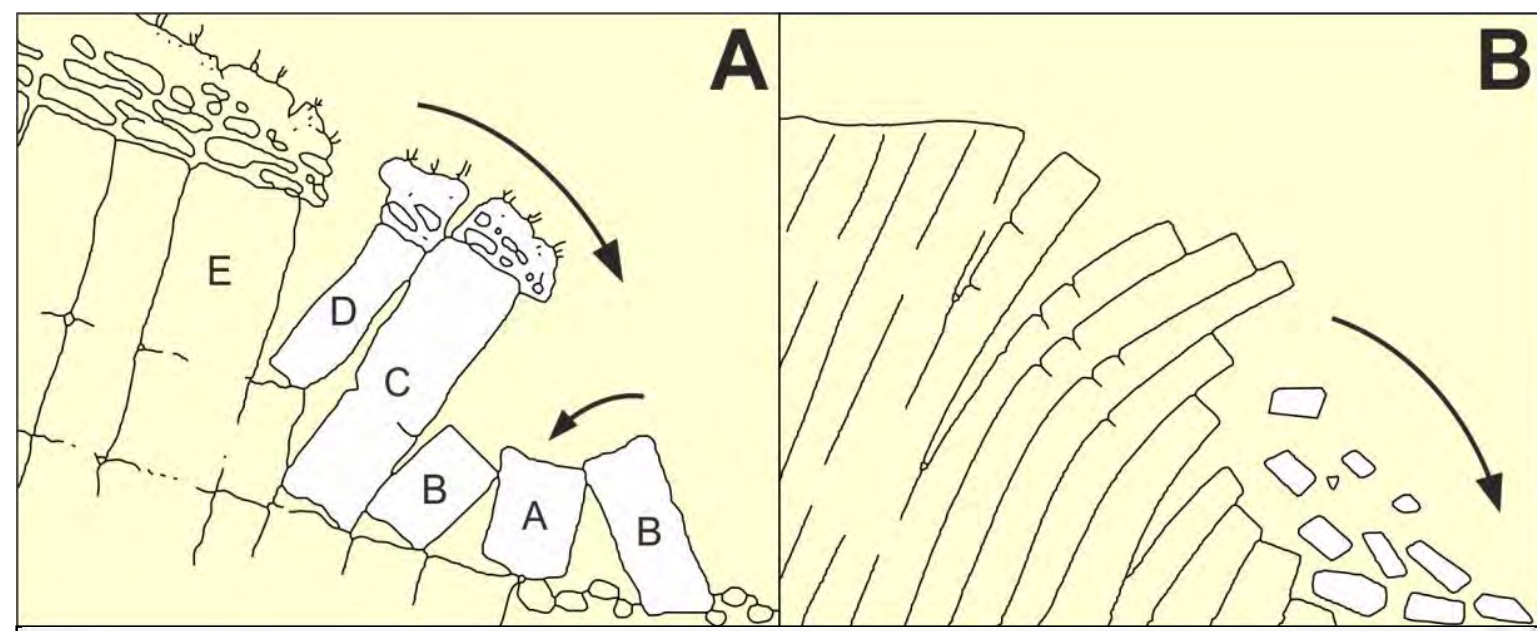

Figura 1.2. A. Vuelcos en bloque. El bloque $A$ inhibe el movimiento de $B$, C y D; E no se desplazaría por estar cohesionado (en continuidad) al macizo rocoso. Las flechas indican el sentido esperable de los movimientos. Adaptada de de Freitas y Waters (1973). B. Vuelcos flexurales. La flecha indica el sentido de los movimientos. Tomada de Corominas y García-Yagüé (1997).

En estos últimos, extremadamente lentos, la deformación suele ser dúctil. En vuelcos flexurales múltiples, puede desarrollarse una superficie de bisagra de vuelco, potencial superficie de ruptura de posibles deslizamientos; este tipo de vuelco flexural es denominado volcamiento chevrón (Cruden et al., 1993) o cabeceo (Corominas, 1989). Por otra parte, los volcamientos flexurales pueden originar fracturas tensionales en las partes superiores de los estratos flexurados, posibilitando caídas. Existe una variedad de vuelco denominada vuelco flexural en bloque (Goodman y Bray, 1976), que afecta macizos rocosos con densos sistemas de diaclasas entrecruzadas, donde la conjunción de pequeños deslizamientos múltiples en torno a las mismas, resulta en una deformación pseudo-continua a escala de ladera.

Deslizamientos: son movimientos de suelo o roca en los cuales la deformación se desarrolla dominantemente en una superficie de ruptura, o en una capa relativamente delgada del material (Cruden y Varnes, 1993). Según la morfología de la superficie de ruptura, los deslizamientos pueden ser rotacionales cuando la superficie es curva y cóncava hacia arriba, o traslacionales cuando es plana u ondulada. Los deslizamientos rotacionales (en inglés slump, Figura 1.3), más frecuentes en materiales homogéneos, se caracterizan por una rotación de la masa desplazada en torno a un eje transversal a la pendiente. La masa desplazada presenta poca deformación y una fuerte inclinación de las cabeceras en el sentido de la pendiente, mientras la superficie del material desplazado se inclina en sentido opuesto a la pendiente (contrapendiente). Estos movimientos no superan velocidades de $1 \mathrm{~m} / \mathrm{s}$ y suelen presentar una actividad de 


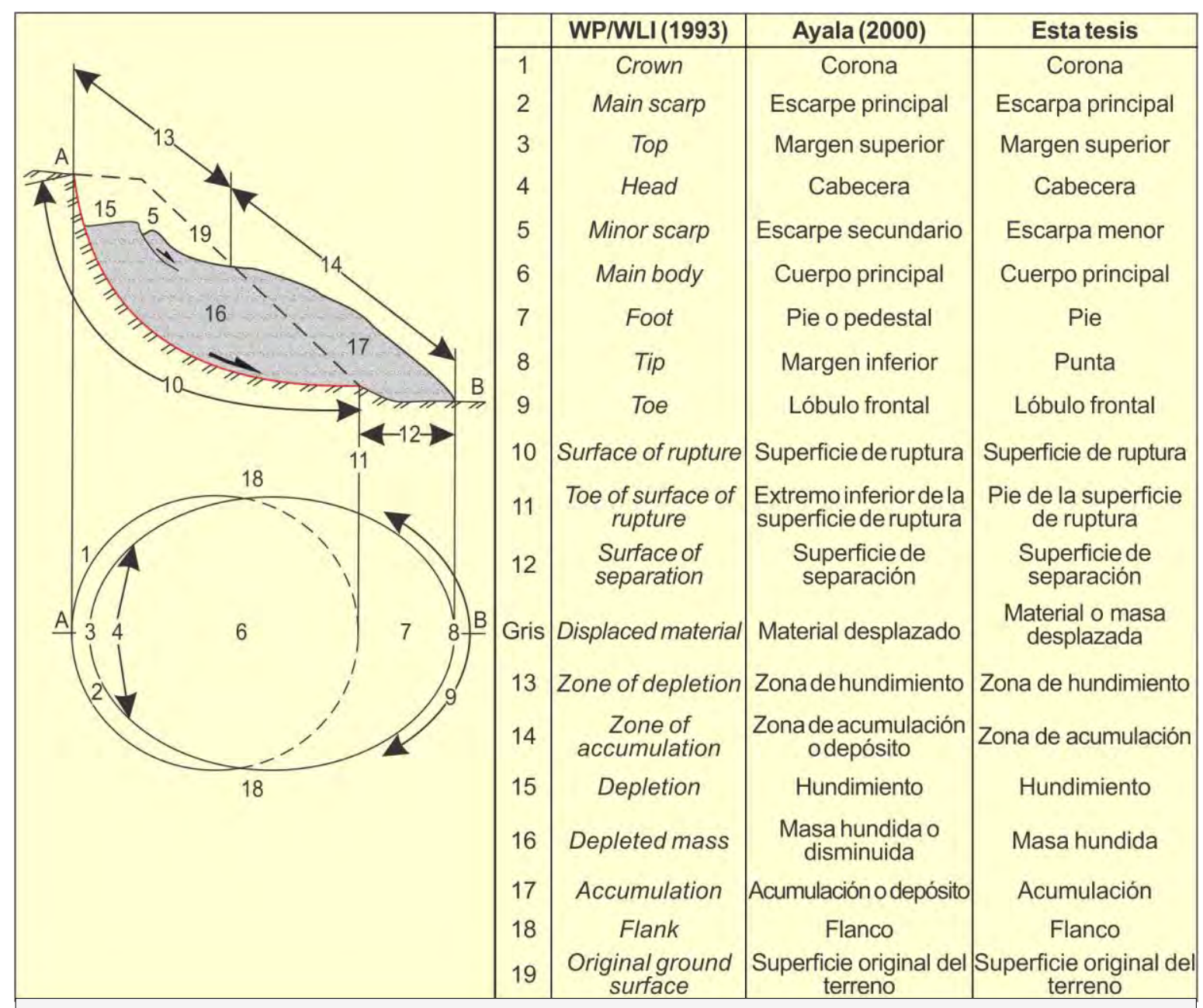

Figura 1.3. Esquema en perfil (arriba) y en planta (abajo) con las partes de un deslizamiento y terminología utilizada. El ejemplo utilizado es un deslizamiento rotacional (modificado de WPMLI, 1993b).

distribución retrogresiva, debido a la fuerte inclinación de la escarpa. Este tipo de movimiento ha sido utilizado frecuentemente como modelo para ilustrar la terminología de las partes de los movimientos en masa. La terminología propuesta por Dikau et al. (op. cit.) y WPMLI (op. cit.), fue traducida al español por Alcántara Ayala (2000) y es mayormente la utilizada en esta tesis, con modificaciones menores, como se muestra en la Figura 1.3.

Los deslizamientos traslacionales (Figura 1.4.A), suelen producirse a lo largo de discontinuidades preexistentes, como contactos entre suelo y roca y planos de estratificación. Particularmente en deslizamientos producidos en roca, cuando la traslación se desarrolla sobre un plano único, el movimiento se denomina deslizamiento planar (Hoek y Bray, 1981), (Figura 1.4.B). Un tipo particular es el deslizamiento en cuña (Londe, 1965; Hoek y Bray, 1981), (Figura 1.4.C), que se desarrolla donde se intersecan dos planos de discontinuidad, y el material se desplaza en la dirección de la línea de contacto entre dichos planos (Cruden y Varnes, 1993), o siguiendo el buzamiento de uno de ellos (PMA-GCA, 2007). 


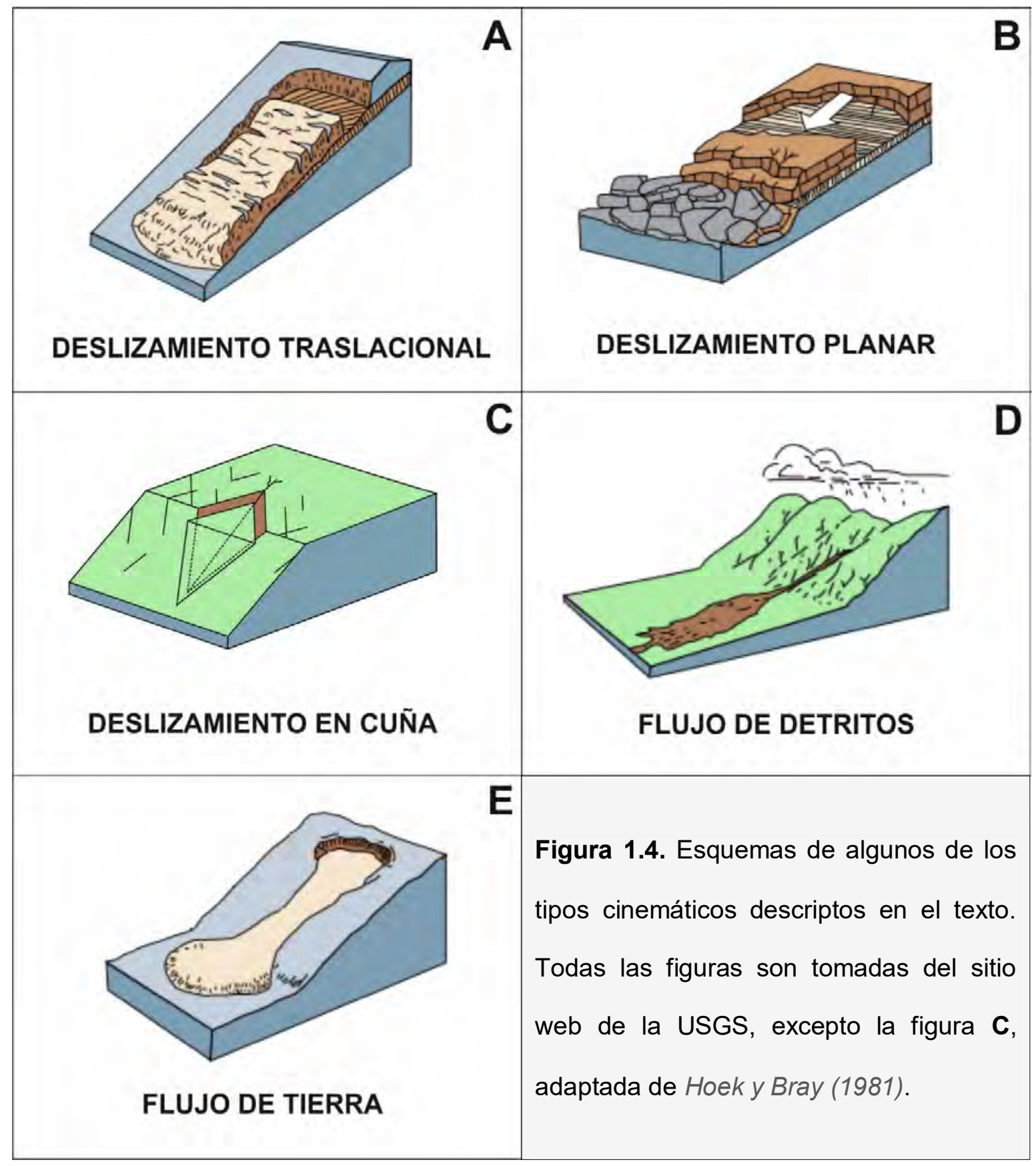

Existen deslizamientos compuestos (compound slides sensu Hutchinson, 1988), en los cuales la superficie de ruptura está controlada por la estructura geológica, y pueden tener características de deslizamientos traslacionales y rotacionales en diferentes sectores de la masa desplazada. Hungr y Evans (2004) los denominan "colapso de rocas". En esta tesis, los deslizamientos compuestos son entendidos como un estilo de actividad del movimiento (ver más adelante) y no como un tipo cinemático en sí.

Expansiones laterales: son movimientos extensivos de grandes masas cohesivas generalmente de roca, que se mueven sobre niveles que sufren alta deformación interna, a veces manifestada como licuefacción. Cruden y Varnes (1993) definen estos 
movimientos como "una extensión de una masa cohesiva de suelo o roca combinada con una subsidencia general de la masa fracturada de material cohesivo, sobre un material infrayacente más débil". Estos movimientos ocurren donde hay un plano de expansión más o menos profundo y muy bajas pendientes, y en varios casos se reconocen en superficie por una sucesión de escarpas en la superficie de separación (parte proximal del movimiento), e inclinación en contrapendiente de la parte distal del terreno desplazado. Las expansiones laterales en bloque son generalmente lentas, donde los bloques de roca competente se fracturan y separan, y el material infrayacente suele intruirse en las fracturas generadas. Secundariamente, los bloques pueden rotar y deslizarse. Las expansiones laterales por licuefacción, más peligrosas, rápidas, se desarrollan a partir de perturbaciones en arcillas tixotrópicas o limos con estructuras débiles y son comunes en zonas sísmicas. Este último tipo de expansiones laterales, suelen confundirse con los "deslizamientos por flujo" o "flujos deslizantes".

Flujos: un flujo es un movimiento espacialmente continuo en el cual las superficies de ruptura son de corta vida, están muy próximas entre sí y no suelen conservarse (Cruden y Varnes, 1993). Los flujos pueden ser secos o saturados, canalizados o no canalizados, rápidos o lentos, y afectar detritos o tierra. Los flujos secos se desarrollan generalmente en detritos y en tierra (arena o limo), y son importantes en la formación de conos de talud (Hungr y Evans, 2004). Los flujos de detritos (Figura 1.4.D), extremadamente rápidos, son movimientos encauzados de materiales cohesivos no plásticos, saturados. Suelen generar abanicos de detritos, y son característicos los depósitos con albardones longitudinales, cauces en forma de "u", trenes de bloques rocosos y grandes bloques individuales en la parte frontal, denominada cabeza (PMA-GCA, 2007). Los lahares son una variedad de flujos de detritos de gran magnitud, desarrollados en materiales piroclásticos. Los flujos de barro (flujos de lodo o torrentes de barro) son movimientos encauzados muy rápidos a extremadamente rápidos, de detritos saturados plásticos, cuya plasticidad está influenciada por el contenido de la fracción arcillosa, mayor que en los flujos de detritos. Los flujos de barro incorporan agua durante el movimiento. Los flujos de tierra (Figura 1.4.E), son movimientos no encauzados intermitentes, rápidos o lentos, de suelos arcillosos plásticos (Hungr et al., 2001). Sus velocidades pueden variar entre centímetros/año y metros/minuto (Hutchinson, 1988). Estos movimientos pueden desarrollar formas de lengua o lobadas alargadas, y presentar superficies de ruptura basales y laterales que experimentan deslizamiento (slickensides, Keefer y Johnson, 1983). El mecanismo de movimiento se vincula a la deformación plástica intermitente combinada con deformación interna de tipo reptación, asistido por variaciones en la 
Movimientos en masa en las sierras de Bravard y Curamalal,

Sierras Australes de la Provincia de Buenos Aires.

Juan Manuel Susena

presión de poros (Hungr et al., 2001). El aporte (reposición) de material desde la superficie de ruptura (degradación de la superficie de ruptura por deslizamientos u otros procesos), puede contribuir a que las formas del paisaje desarrolladas alcancen cierta estabilidad o permanencia en el paisaje. Las avalanchas de roca y también las de detritos y son un tipo de flujo no encauzado, ambas son morfológicamente similares. Son movimientos rápidos a extremadamente rápidos, sus materiales están un poco menos saturados que en los flujos de detritos, y entre los mecanismos responsables de sus altas velocidades, pueden mencionarse la incorporación de aire durante el movimiento, la fluidización acústica, y la licuefacción del sustrato al impactar la masa movilizada.

Reptación: este tipo de movimiento, extremadamente lento (milímetros/año), imperceptible, puede desarrollarse en suelo o roca, y no se distingue una superficie de ruptura. Este movimiento puede ser continuo en el tiempo, o intermitente, y generado por sobrecarga o por expansión/contracción. En la reptación de suelo (Figura 1.5.A), el material se expande en dirección normal a la pendiente, y se contrae en la misma dirección, pero con una componente gravitacional añadida; así el material se desplaza ladera abajo. Este tipo de movimiento es superficial, normalmente no supera un metro de profundidad (Hungr et al., 2014). Según Bloom (1991) el material sometido a reptación se denomina coluvio. La reptación de roca afecta la parte superficial de estratos subverticales, mediante una deformación continua. Se diferencia de los vuelcos flexurales del macizo rocoso en que la primera afecta sólo la zona próxima a la superficie. La solifluxión (Figura 1.5.B), puede ser considerada una variedad particular de reptación, muy lenta (no extremadamente lenta), ocasionada por una expansión estacional, por humedecimiento del material, combinada con el movimiento ladera abajo por acción de la gravedad (PMA-GCA, 2007). Se diferencia de la reptación en que el proceso es más

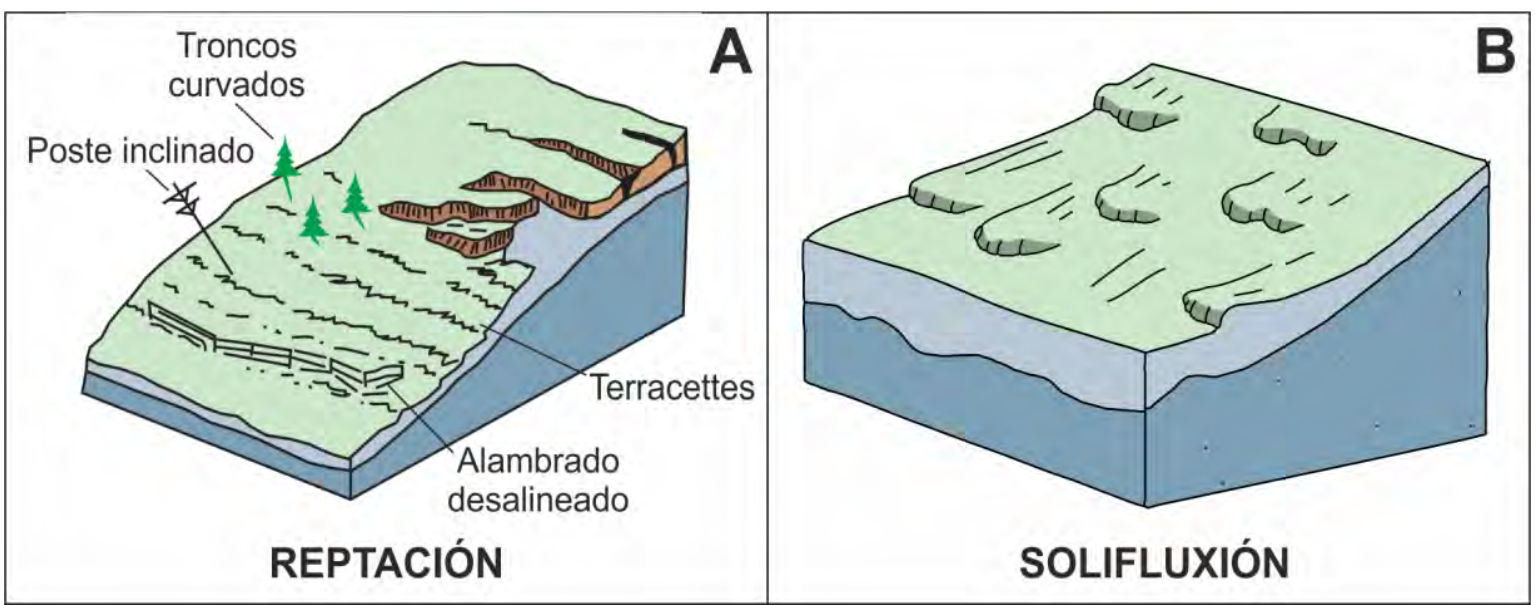

Figura 1.5. A. Reptación de suelo. Figura adaptada del sitio web de la USGS. B. Solifluxión. Figura tomada de Corominas y García Yagüé (1997). 
intenso y se desarrollan formas lobadas. Se diferencia a su vez de los flujos de tierra en que no presentan superficies tipo slickensides laterales ni basales. La variedad de solifluxión ligada a ambientes con permafrost, donde el mecanismo de expansión estacional se relaciona con el congelamiento del agua, se denomina gelifluxión (Washburn, 1979).

Las terracettes (= terracetas o terrazuelas), son geoformas características de laderas sometidas a reptación, y en particular los lóbulos de solifluxión son típicos de dicho proceso. Postes inclinados, árboles curvados y suelos disturbados son otras características asociadas.

\subsubsection{Material}

Como ya se ha mencionado, se hace una distinción entre roca y suelo ingenieril. Siguiendo a Schroder (1971) y Varnes (1978), WP/WLI clasifica como roca a una masa dura o firme que estaba intacta -individualizada por discontinuidades- y en su sitio natural antes del movimiento, y suelo a todo agregado de partículas sólidas de rocas o minerales que pueden haber sido transportados o haberse originado in situ por meteorización, y los gases y agua contenidos en los poros. El suelo se divide en detritos, cuyo contenido de materiales mayores a $2 \mathrm{~mm}$ se ubica entre el 20 y el $80 \%$ (siendo el resto menores a 2 $\mathrm{mm}$ ), y tierra, con un porcentaje de partículas menores a $2 \mathrm{~mm}$ igual o mayor al $80 \%$. Esta clasificación hace referencia al tipo de material antes del movimiento (Figura 1.6). Puesto que el agua juega un papel importante en la estabilidad, el contenido de humedad en materiales del tipo suelo ingenieril, es un parámetro de interés. El contenido de humedad de la superficie es un parámetro muy variable, pero se puede estimar a escala de cuenca, por ejemplo, mediante el procesamiento de imágenes satelitales.

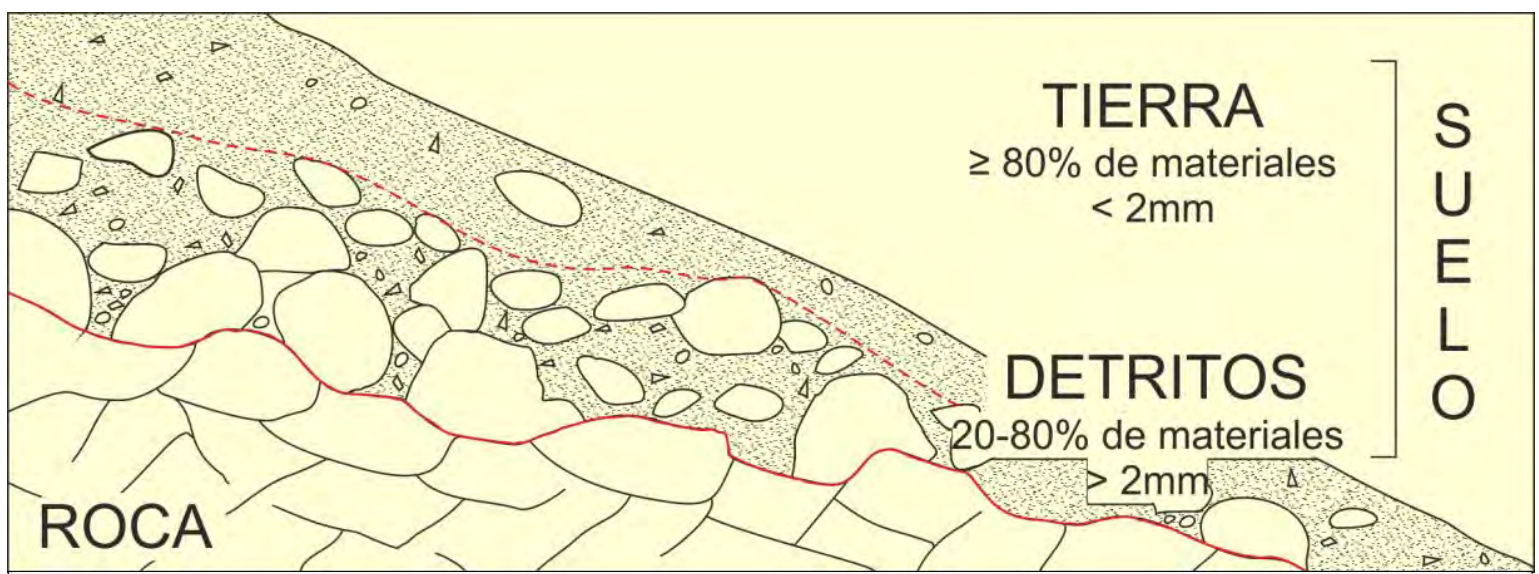

Figura 1.6. Clasificación de materiales afectados por movimientos en masa. Elaboración propia. 
Movimientos en masa en las sierras de Bravard y Curamalal,

Sierras Australes de la Provincia de Buenos Aires.

Juan Manuel Susena

\subsubsection{Profundidad de los materiales afectados}

Existe en la literatura una diferenciación informal, pero muy difundida y aceptada, entre movimientos superficiales (shallow landslides) y movimientos profundos (deep landslides) (Zêzere et al., 2005; Fell et al., 2008; Felicísimo et al., 2013), entendiendo a estas dos clases como dos extremos. En principio, los superficiales suelen involucrar regolito o las partes superficiales de rocas meteorizadas, mientras que los profundos afectan también mayores espesores del sustrato rocoso. De alguna manera, se entiende a los movimientos profundos como procesos de mayor magnitud que los superficiales, y mayor potencial destructivo (en líneas generales). Como señalaran Dou et al. (2015a) y trabajos allí citados, la diferenciación de entre estas dos grandes clases de movimientos es útil para evaluar la amenaza de estos procesos para la protección de infraestructuras y asentamientos humanos. Asimismo, los movimientos profundos tienen mecanismos más complejos que los superficiales. Según los movimientos sean profundos o superficiales, se requieren distintas aproximaciones metodológicas para su estudio.

\subsubsection{Actividad}

El término actividad contempla tres aspectos, mencionados más arriba en la Tabla 1.3: estado, distribución y estilo.

Estado de la actividad: hace referencia a la regularidad o irregularidad temporal del movimiento. Se diferencian:

- Activos: los materiales están en movimiento, incluyen los movimientos que ocurren por primera vez y los reactivados.

- Reactivados: son nuevamente activos después de haber sido inactivos.

- Suspendidos: los movimientos se produjeron durante el último ciclo estacional, pero no se están desarrollando al momento de la observación.

- Inactivos: se han movido por última vez hace más de un ciclo estacional. Se dividen en latentes, cuando las causas del movimiento parecen permanecer; abandonados (estables) en caso de que las causas del movimiento ya no existan; estabilizados, si el movimiento cesó por intervenciones geotécnicas; y relictos, que han sido desarrollados en entornos geomorfológicos o climáticos diferentes a los actuales, y que se han preservado durante miles de años.

Debe destacarse aquí, que a veces puede resultar imposible reconocer el estado de actividad de los movimientos. En tales casos, WPMLI recomienda clasificar los 
movimientos como activos. En esta tesis, puesto que se considera tal práctica como un criterio orientado a la zonificación de amenaza (y no es el objetivo principal aquí planteado), se opta por consignar la ausencia de información en los inventarios.

Distribución de la actividad: describe si el movimiento crece o decrece. Se clasifica como sigue:

- Creciente: la superficie de ruptura del movimiento se está extendiendo en una o más direcciones (Figura 1.7.A), incorporando material al movimiento. Según la dirección, puede decirse que está avanzando (= progresivo) cuando la superficie de ruptura se extiende en la dirección del movimiento (Figura 1.7.B); que se encuentra retrocediendo (= retrogresivo) cuando lo hace en dirección opuesta a la del movimiento (Figura 1.7.C); o que se está ensanchando, cuando la superficie de ruptura se extiende hacia los flancos (Figura 1.7.D).

- Decreciente: el movimiento decrece con el tiempo. Este tipo de movimientos pueden ser progresivos, afectando parte de las acumulaciones (Figura 1.7.E).

- Móvil: en este tipo de distribución, no se aprecian cambios en la superficie de ruptura, aunque la masa se siga desplazando (Figura 1.7.F). 


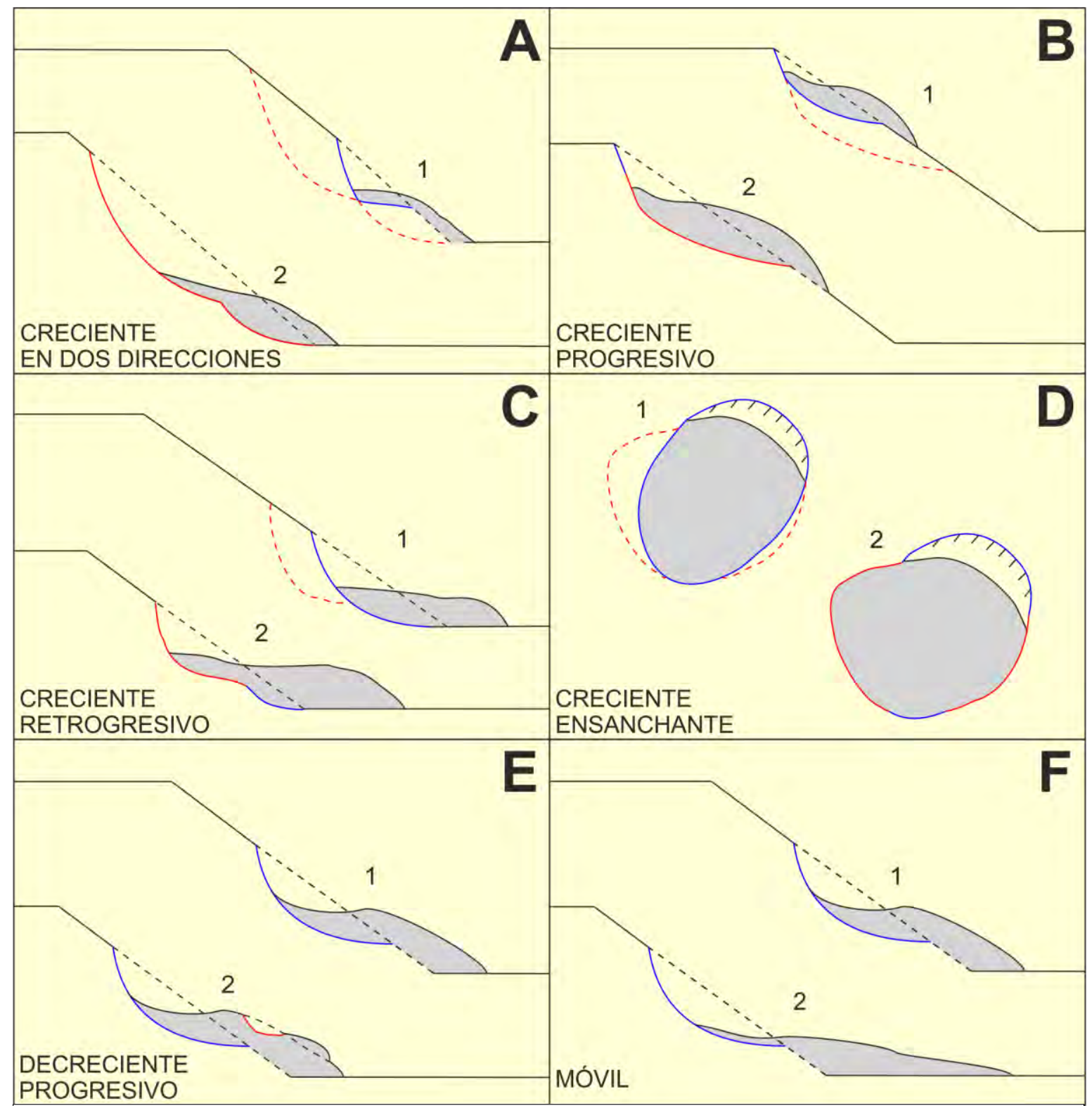

Figura 1.7. Distribución de la actividad de movimientos en masa. Todas las figuras son esquemas vistos en perfil, excepto D (vista en planta). Formas grises: materiales desplazados. Líneas azules: superficie de ruptura del movimiento 1. Líneas rojas: superficie de ruptura aún no producida (líneas de trazos) y ya producida (líneas continuas) del movimiento 2 . Líneas de trazos negras: superficie previa a los movimientos. Modificado de WPMLI (1993a).

Estilo de actividad: indica el patrón espacial de los movimientos en una ladera (aplicable también a otros componentes geomorfológicos). Se clasifica en:

- Simple: un movimiento único.

- Múltiple: movimientos repetidos del mismo tipo, con una distribución de actividad creciente o decreciente, es decir, el nuevo movimiento comparte parte o la totalidad de la zona de ruptura, y/o parte o la totalidad de la masa desplazada con el movimiento previo. El esquema gráfico ideal clásico de los deslizamientos rotacionales, donde existen diversos bloques de masa desplazada que tienen en 
común una superficie de falla mayor, representa un estilo de actividad múltiple.

- Sucesivo: el movimiento es del mismo tipo que otro desarrollado previamente en otra parte de la ladera, pero está separado de aquel.

- En enjambre (en inglés cluster): este estilo de actividad corresponde a conjuntos de movimientos individuales en varias laderas en una misma zona; se diferencian de los sucesivos, en que los movimientos en enjambre ocurren simultáneamente, mientras los sucesivos ocurren secuencialmente. Se desencadenan a partir de un único evento detonante (lluvias intensas, sismos). Los materiales suelen movilizarse a una red de drenaje en común, generando flujos o crecidas de detritos de dimensiones catastróficas, como hubiera ocurrido en Tartagal, Provincia de Salta, en los años 2006 y 2009 (Fauqué, com. ver.), (Figura 1.8).

- Complejo: durante el movimiento, el tipo cinemático evoluciona de uno a otro tipo.

- Compuesto: existen distintos tipos cinemáticos en diferentes partes de la masa desplazada, simultáneamente. En estos casos, se menciona primero el tipo de movimiento desarrollado en el sector topográficamente superior de la masa desplazada.

Los movimientos complejos de Varnes (1978) (como tipo cinemático según el autor) pueden atribuirse a estos estilos de actividad complejos o compuestos.

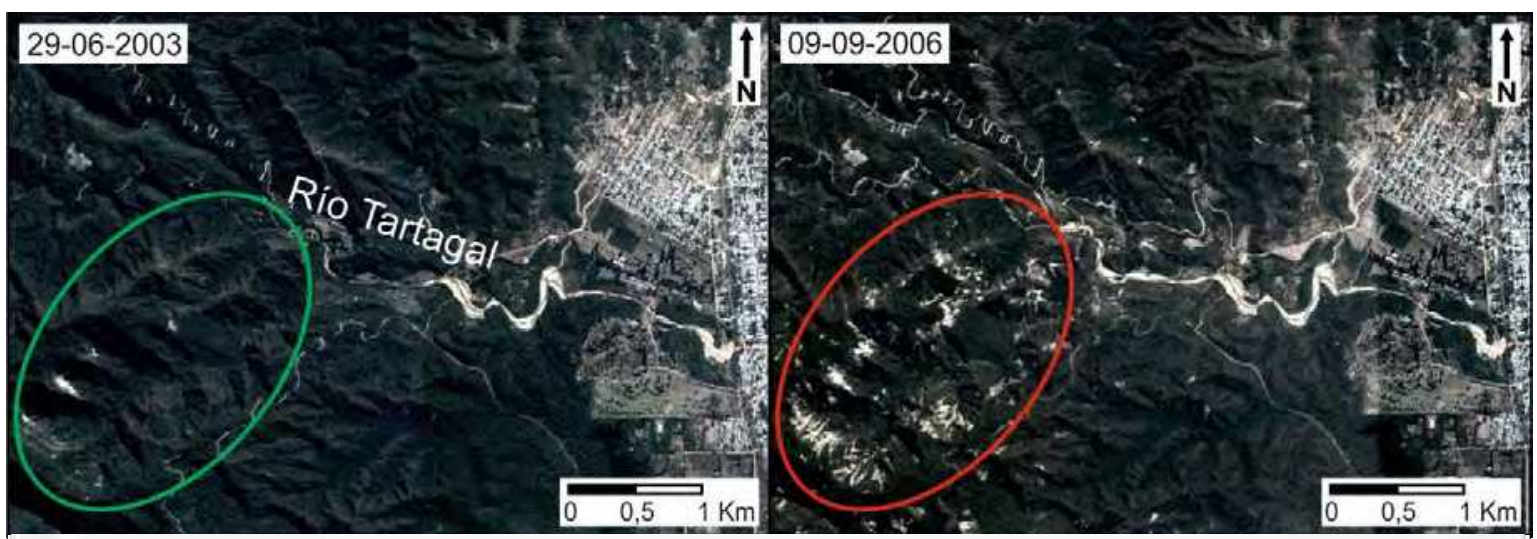

Figura 1.8. Deslizamientos en enjambre en la cuenca media del río Tartagal (coordenadas centrales: $22^{\circ} 31^{\prime} 09^{\prime \prime}$; $63^{\circ} 49^{\prime} 30^{\prime \prime}$ ). El evento se produjo en febrero de 2006 y afectó seriamente a la ciudad de Tartagal (parte derecha de las imágenes). Las elipses muestran el cambio en la cobertura vegetal antes (verde) y después (rojo) de los deslizamientos en enjambre. La ausencia de vegetación (elipse roja) corresponde a superficies de ruptura de deslizamientos. Elaboración propia a partir de composiciones de imágenes satelitales de World View-2 (Google Earth).

Cabe resaltar que, a pesar del esquema presentado de caracterización de la actividad, en la práctica es difícil establecer los tres aspectos. Debe reconocerse también que toda clasificación o esquema descriptivo responde a un propósito. Al respecto, en esta tesis se 
Movimientos en masa en las sierras de Bravard y Curamalal,

Sierras Australes de la Provincia de Buenos Aires.

Juan Manuel Susena

utilizan sólo algunos de estos conceptos, principalmente los referidos a la distribución de la actividad, en los casos en que encontraron reactivaciones.

Los movimientos en masa con frecuencia tienen un desarrollo complejo. Varían los mecanismos de deformación y velocidades durante su desarrollo. De hecho, es más común un movimiento con fases diversas con distintos mecanismos de movimiento, que un movimiento que comience y finalice con el mismo mecanismo. Así, un bloque rocoso puede volcarse y golpear la superficie del terreno y fragmentarse, e incluso incorporar material de la superficie afectada, originando así un flujo (avalancha) de detritos; o un deslizamiento puede incorporar agua durante su recorrido, transformándose en un flujo. La fábrica de los depósitos generados por movimientos en masa usualmente evidencia la etapa final o la más importante del movimiento; por tanto, no puede por sí sola, brindar información sobre todos los mecanismos que han actuado durante el movimiento (Middleton y Hampton, 1973, en Shanmugam, 2015). De esta manera, cuando reconocemos flujos, deslizamientos, caídas, reptación, etc., solemos referirnos a la fase más evidente del movimiento. Resulta sumamente importante para una efectiva gestión de amenaza o riesgo por movimientos en masa, entender que en estos procesos las fases iniciales presentan rasgos morfológicos que permiten reconocerlas, y así tomar las medidas preventivas o remediadoras correspondientes. De esta manera, se puede dar aviso, o en el mejor de los casos evitar que el movimiento alcance su "clímax", minimizando los perjuicios posibles.

\subsubsection{Magnitud de los movimientos en masa}

Este parámetro, utilizado para análisis de riesgo por movimientos en masa, es una medida del poder destructivo de un movimiento dado (Hungr, 1997). Cardinali et al. (2002) lo definen como una función del volumen desplazado y la velocidad esperada. La

Tabla 1.4 muestra las intensidades esperadas de distintos tipos de movimiento.

De acuerdo a WPMLI (1991), los movimientos pueden producirse a diferentes velocidades, de extremadamente lentas a extremadamente rápidas. En el trabajo citado se proponen clases de velocidad, vinculando los diferentes rangos de velocidad con la intensidad de los movimientos y su posible peligrosidad. Cabe aclarar que la peligrosidad del movimiento no depende sólo de su velocidad, sino también del volumen, entre otros aspectos. No obstante, en términos generales, para cada clase de velocidad pueden esperarse determinados tipos de daños (Tabla 1.5). 


\begin{tabular}{|c|c|c|c|}
\hline \multirow[b]{2}{*}{$\begin{array}{l}\text { Volumen } \\
\text { estimado } \\
\qquad\left(\mathrm{m}^{3}\right)\end{array}$} & \multicolumn{3}{|c|}{ Velocidad esperada del movimiento } \\
\hline & $\begin{array}{l}\text { Movimientos con } \\
\text { desplazamiento } \\
\text { extremadamente rápido }\end{array}$ & $\begin{array}{l}\text { Movimientos con } \\
\text { desplazamiento rápido } \\
\text { (rapid) }\end{array}$ & $\begin{array}{l}\text { Movimientos con } \\
\text { desplazamiento lento } \\
\text { (slow) }\end{array}$ \\
\hline$<0,001$ & Leve (1) & & \\
\hline$<0,5$ & Media (2) & & \\
\hline$>0,5$ & Alta (3) & & \\
\hline$<500$ & Alta (3) & Leve (1) & \\
\hline $500-10.000$ & Alta (3) & Media (2) & Leve (1) \\
\hline $10.000-$ & Muy alta (4) & Alta (3) & Media (2) \\
\hline$>500.000$ & & Muy alta (4) & Alta (3) \\
\hline$>>500.000$ & & & Muy alta (4) \\
\hline \multicolumn{4}{|c|}{$\begin{array}{l}\text { Tabla 1.4. Magnitud esperada para distintos tipos de movimientos en masa. Entre paréntesis se } \\
\text { enumeran las cuatro clases de intensidad. Todos los tipos cinemáticos se han agrupado por } \\
\text { Cardinali et al. (2002) en tres grandes grupos (columnas). Traducido y adaptado de Cardinali et } \\
\text { al. (2002). }\end{array}$} \\
\hline
\end{tabular}

\begin{tabular}{|c|c|c|c|c|}
\hline Velocidad & $\begin{array}{l}\text { Clasificación } \\
\text { de la } \\
\text { velocidad }\end{array}$ & $\begin{array}{l}\text { Limite } \\
\text { inferior de } \\
\text { velocidad }\end{array}$ & $\begin{array}{l}\text { Descripción } \\
\text { de la } \\
\text { velocidad }\end{array}$ & Naturaleza del impacto \\
\hline $3 \mathrm{~m} / \mathrm{s}$ & 7 & $5 \mathrm{~m} / \mathrm{s}$ & $\begin{array}{l}\text { Extremadamente } \\
\text { rápido }\end{array}$ & $\begin{array}{c}\text { Catástrofe de gran violencia, edificios expuestos } \\
\text { totalmente destrozados y deceso de la población } \\
\text { por el impacto del material desplazado, o por la } \\
\text { disgregación del material desplazado. }\end{array}$ \\
\hline $0,3 \mathrm{~m} / \mathrm{min}$ & 6 & $3 \mathrm{~m} / \mathrm{min}$ & Muy rápido & $\begin{array}{l}\text { Pérdida de algunas vidas debido a que la } \\
\text { velocidad del movimiento es muy rápida para } \\
\text { permitir que todas las personas escapen, gran } \\
\text { destrucción. }\end{array}$ \\
\hline $1,5 \mathrm{~m} / \mathrm{dia}$ & 5 & $1,8 \mathrm{~m} / \mathrm{hora}$ & Rápido & $\begin{array}{l}\text { Posible escape y evacuación, estructura, } \\
\text { posesiones y equipo destruido por la masa } \\
\text { desplazada. }\end{array}$ \\
\hline $1,5 \mathrm{~m} / \mathrm{mes}$ & 4 & $13 \mathrm{~m} / \mathrm{mes}$ & Moderado & $\begin{array}{l}\text { Estructuras poco sensibles pueden ser } \\
\text { mantenidas si están localizadas a una distancia } \\
\text { considerable en relación con el pie de la masa } \\
\text { desplazada. } \\
\begin{array}{c}\text { Estructuras localizadas en la masa desplazada } \\
\text { son dañadas en gran medida. }\end{array}\end{array}$ \\
\hline 1,5 m/año & 3 & 1,6 m/año & Lento & $\begin{array}{l}\text { Carreteras y estructuras poco sensibles pueden } \\
\text { ser mantenidas a través de frecuente trabajo de } \\
\text { mantenimiento, si el movimiento no es de mucha } \\
\text { duración y los movimientos diferenciales a lo largo } \\
\text { de las márgenes del movimiento están } \\
\text { distribuidos a lo largo de una zona ancha. }\end{array}$ \\
\hline $0,06 \mathrm{~m} / \mathrm{año}$ & 2 & 0,016 m/año & Muy lento & $\begin{array}{l}\text { Algunas estructuras permanentes no son dañadas } \\
\text { y, si son agrietadas por el movimiento, pueden ser } \\
\text { reparadas. }\end{array}$ \\
\hline & 1 & & $\begin{array}{l}\text { Extremadamente } \\
\text { lento }\end{array}$ & $\begin{array}{c}\text { No hay daño a las estructuras construidas con } \\
\text { precaución. }\end{array}$ \\
\hline
\end{tabular}


Movimientos en masa en las sierras de Bravard y Curamalal,

Sierras Australes de la Provincia de Buenos Aires.

Juan Manuel Susena

\subsection{Causas}

La estabilidad de una ladera o de una masa de material, puede traducirse sencillamente como la relación entre el conjunto de fuerzas que se resisten al movimiento, y el conjunto de fuerzas que favorecen el movimiento. A esta relación se la denomina factor de seguridad, y es un reflejo de las diferentes causas de los movimientos en masa. Entre estas causas pueden diferenciarse características propias del material, o procesos externos que pueden tender a aumentar el esfuerzo de corte o a disminuir la resistencia del material, según Varnes (1978).

\subsubsection{Factores que contribuyen a una baja resistencia o a reducirla}

Hay materiales que por naturaleza presentan baja resistencia, como los materiales orgánicos y los limos, y su proporción en el regolito determina la resistencia de la masa. Asimismo, los macizos rocosos pueden presentar una baja resistencia debido a la presencia de discontinuidades, como diaclasas, grietas, zonas de falla, y contactos sueloroca (en sentido ingenieril).

En el regolito, la proporción y estructura cristalina de los argilominerales son cruciales en la capacidad de expansión-contracción ante humedecimiento-secado o la tendencia a la deformación plástica y pérdida de cohesión por adición de agua. La fábrica del material ocasionalmente contribuye también a una baja resistencia. La distribución granulométrica de los materiales influye en la permeabilidad y el comportamiento geomecánico, aspectos fundamentales en la inestabilidad. La existencia de superficies dentro de la masa delimitando contrastes de estas propiedades puede determinar la distribución del agua superficial y sub-superficial, afectando la estabilidad. Dichos contrastes pueden ser también laterales dentro de una misma capa de sedimento u horizonte de suelo, sean singenéticos (distribución original de los materiales) o epigenéticos (redistribución de los materiales por procesos post-depositacionales).

La meteorización química de las arcillas puede modificar su estructura, tornándolas más débiles; asimismo, pueden resquebrajarse por secado, creándose posibles superficies de ruptura. Los efectos de los cambios de temperatura o de condiciones de humedad también pueden afectar rocas cohesivas y las fracturas pueden desarrollarse a partir de discontinuidades en la estructura geomorfológica de las rocas (planos de estatificación, foliaciones, concentraciones de minerales más solubles, etc.). En este sentido, la meteorización es un mecanismo preparador de movimientos en masa, ya que tiende a reducir la resistencia de los materiales, inicialmente más alta.

La morfología del terreno influye en la concentración y acción del agua, la distribución de 
la humedad e incluso de los componentes vectoriales de la fuerza de la gravedad que actúan en el material. Distintos aspectos de la morfología del terreno y su relación con el desarrollo de movimientos en masa se tratan en detalle en el Capítulo 14 Análisis de susceptibilidad. De la misma manera, la vegetación puede afectar la estabilidad del terreno, influyendo en la concentración de humedad, la infiltración del agua, la acción hídrica, la retención de material y la adición de carga.

La acción zoogeomorfológica puede reducir la resistencia de los materiales, considerándose un mecanismo preparador de movimientos. Algunos animales modifican localmente las propiedades hidrológicas y geomecánicas de los materiales mediante la compactación e incrementan la exposición a los contrastes de humedad al reducir la cobertura vegetal. La acción antrópica también modifica rasgos geomorfológicos, la fábrica del material, y crea estructuras de debilidad como líneas de arado y huellas de maquinaria, e incluso nuevos rasgos susceptibles, como taludes de caminos. Estas relaciones se abordan con detalle en el Capítulo 12 Movimientos en masa y actividad antropo y zoogeomorfológica.

\subsubsection{Procesos que favorecen la inestabilidad}

El agua es el principal factor desencadenante de movimientos. Por un lado, la presión de agua actúa en los poros que ocupa, tendiendo a separar el material que los delimita y reduciendo así la resistencia de la masa. Este mecanismo es especialmente relevante en el caso de deslizamientos superficiales y flujos. Por otra parte, en los macizos rocosos el agua que circula por las discontinuidades favorece la inestabilidad. El incremento de volumen del agua al congelarse en grietas de bloques rocosos que integran frentes escarpados puede ejercer una acción de cuña, provocando caídas o vuelcos.

La actividad sísmica actúa como un factor desencadenante, en tanto que la aceleración que produce el terremoto puede acoplarse a la componente de la gravedad en la dirección de la pendiente; favorece también la licuefacción. Explosiones (naturales o artificiales), y pasaje de vehículos pesados y de animales pueden producir efectos similares.

La erosión basal (fluvial, glacial, oleaje, etc.), el pipping (= sufusión), la acción faunística (excavación de cuevas y galerías) y antrópica (excavaciones para cortes de caminos, canales, canteras y galerías, y dragado), son procesos que favorecen la inestabilidad.

Otro proceso que favorece la ocurrencia de movimientos en masa es la sobrecarga por aporte natural de materiales, por acumulación de agua, nieve o hielo, desarrollo de bosques, actividad volcánica y por la acción antrópica (relleno, instalación de estructuras, 
Movimientos en masa en las sierras de Bravard y Curamalal,

Sierras Australes de la Provincia de Buenos Aires.

Juan Manuel Susena

creación de embalses, riego, vertido de fluidos, canalizaciones, etc.).

La acción de los animales también puede generar inestabilidades directamente mediante sobrecarga, e incluso puesta en movimiento de materiales por pateaduras.

Algunos movimientos geodinámicos a escala regional debidos a procesos tectónicos, eustáticos, climáticos, etc., pueden producir modificaciones del paisaje a largo término, que resultan en una descompresión del material, favoreciendo el desarrollo de fracturas, las cuales pueden evolucionar en profundidad hasta constituir superficies de ruptura (deslizamientos y flujos). 


\section{Capítulo 2}

\section{Planteamiento del problema y objetivos}

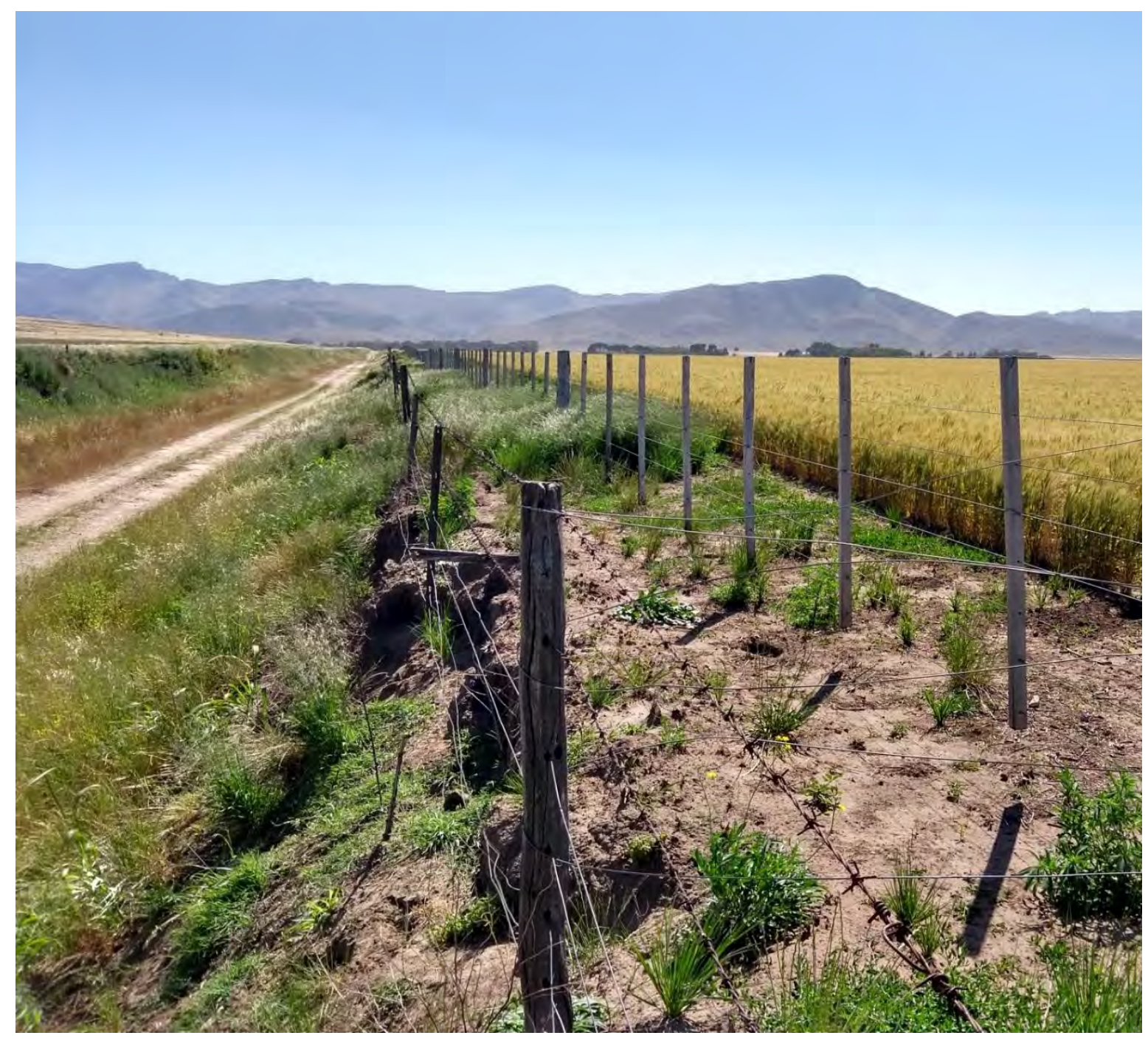

"El camino y los límites".

Fotografía tomada en un camino vecinal en el piedemonte occidental de las Sierras de Curamalal, durante una de las últimas campañas. 
Movimientos en masa en las sierras de Bravard y Curamalal, Sierras Australes de la Provincia de Buenos Aires.

Juan Manuel Susena 


\subsection{Breve reseña sobre la evolución del conocimiento de los movimientos en masa}

Los movimientos en masa son conocidos históricamente debido a los daños que generan. Existen documentos históricos sobre estos procesos en los Alpes, al menos desde el siglo IX, como el caso de Lavini di Marco (Italia) en el año 833 (Bressan, 2010). Unas de las primeras consideraciones científicas mencionan su relación con los eventos sísmicos (Bertrand, 1757). Beaumont (1806) en su descripción sobre la región de Saboya (Francia), incluye los movimientos y sus depósitos, mientras la catástrofe de Goldau (Suiza) fue descripta detalladamente por Zay (1807). Uno de los primeros "inventarios de movimientos en masa" fue desarrollado por Escher (1807) en territorio suizo, y fue extendido por Hoff (1834) a todos los Alpes. Lyell (1830-1833) en el glosario de su obra "Principles of Geology" define landslips, relacionando los movimientos en masa con causas sísmicas o pérdida de sustento por acción del agua. Heim $(1882 ; 1932)$ fue uno de los primeros autores en considerar los perjuicios que representan los movimientos, en relación a las actividades humanas; estudió los posibles mecanismos de movimiento de la avalancha de rocas ocurrida en Elm (Suiza) en 1881, a partir del análisis geológico y geomorfológico de los depósitos, siendo el primer estudio científico de este tipo de eventos (Ward y Day, 2006). En la Cordillera de los Andes, Lemos (1883, en Moreiras, 2005) menciona el colapso de un monte vinculado a la extracción de minerales por parte de la población nativa, sepultando a más de mil trabajadores. Josef Stini, en la primera mitad del siglo $\mathrm{XX}$, fundó la revista actualmente llamada Rock Mechanics, fue uno de los pioneros de la mecánica de rocas, y enfatizó la importancia del estado de las discontinuidades en los macizos rocosos, para prevenir movimientos en masa (Müller, 1979). Terzaghi (1950; 1956) extendió la definición de movimientos en masa a los movimientos subácueos y submarinos, abriendo un nuevo campo de investigación. Como se mencionó en el capítulo anterior, una de las primeras clasificaciones exhaustivas fue la de Sharpe (1938), muy utilizada en libros de geomorfología -o al menos en la escuela norteamericana de la primera mitad del siglo XX(Bloom, 1978), pero no fue hasta la aparición de las clasificaciones de Varnes (1958; 1978) y de Hutchinson (1968; 1988), que se empezaron a utilizar de manera generalizada, a la vez que el estudio de estos procesos cobraba interés mundial y se hacía interdisciplinar. En la década de 1970 comenzaron a desarrollarse mapas de zonificación de amenaza y riesgo por movimientos en masa (Brabb, et al., 1972; Kienholz, 1978; Nilsen et al., 1979, en Fell et al., 2008). La utilización de Sistemas de Información Geográfica (SIG) y las técnicas de teledetección, propiciada por el uso generalizado de los ordenadores personales, ha constituido un importante avance, siendo hoy herramientas imprescindibles 
Movimientos en masa en las sierras de Bravard y Curamalal,

Sierras Australes de la Provincia de Buenos Aires.

Juan Manuel Susena

para este tipo de estudios (Verstappen, 2011; Guzzetti et al., 2012). Gracias a las técnicas anteriores, en las últimas décadas se han mejorado significativamente los modelos predictivos cuantitativos de amenaza (entre otros, Fell et al., 2008; Wieckzorek y Snyder, 2009; Costanzo et al., 2012; Stumpf et al., 2014; Alkhasawneh et al., 2013; Dou et al., 2015b; Galve et al., 2015).

A nivel mundial, las investigaciones sobre movimientos en masa son tendientes al conocimiento, entre otros aspectos, de los mecanismos desencadenantes, la zonificación de amenaza y el desarrollo de sistemas de detección temprana y alarma, así como a la reducción de la vulnerabilidad. La escala de estudio de los movimientos en masa no implica sólo el aspecto espacial, sino también el temporal. Esto requiere análisis multi-temporales detallados, con instrumentación de alta precisión y recursos humanos altamente capacitados. También existen numerosos ejemplos de movimientos específicos monitoreados en diversas partes del mundo (entre otros, Baldo et al., 2009; Wang et al., 2016; González Díez et al., 2014; Leung y Ng, 2015). La mayor parte de las investigaciones se aplican a la reducción de los daños potenciales mediante distintas medidas, como la planificación del uso del territorio o el diseño de acciones específicas de mitigación. En este sentido, existe un consenso en aunar esfuerzos internacionales hacia la creación de un inventario global, promovido por la UNESCO desde la década de 1990, declarada Decenio Internacional para la Reducción de Desastres Naturales. Hay precedentes de otras iniciativas de reunir profesionales de diferentes ámbitos y regiones geográficas para estudiar movimientos en masa con fines de prevención y mitigación. Así, en el año 1988 se creó el Centro Europeo sobre Riesgos Geomorfológicos (Centre Européen sur les Risques Géomorfologiques), integrado por geólogos, geomorfólogos, geólogos ingenieriles, hidrogeólogos y geotécnicos de varios centros de investigación de distintos países europeos, en el que se desarrollan aún en la actualidad actividades de investigación en parte subsidiadas por la Comunidad Europea y el Consejo de Europa. A principios del siglo XXI, las Naciones Unidas crearon la Estrategia Internacional para la Reducción de Desastres; se creó además el "Internacional Consortium on Landslides" (ICL), una organización científica no-gubernamental y sin fines de lucro, apoyada por la UNESCO, la FAO y muchas otras organizaciones internacionales. Al mismo tiempo, la UNESCO creó el "UNITWIN Programme on Landslide Risk Mitigation for Society and the Environment", un programa que busca promover un sistema integrado de actividades de investigación, entrenamiento, información y documentación, mediante la colaboración académica a escala global (Sassa, 2004). Este autor resalta la importancia de la multidisciplinariedad, constituyéndose una nueva ciencia -o al menos una disciplina científica- con una metodología de trabajo distintiva: "Landslides science" (Sassa, 2007). Al respecto, la revista 
Landslides, creada en el año 2004, la cual reúne aspectos técnicos, sociales, sociopolíticos e incluso reportes sobre nuevos movimientos, ha escalado rápidamente en el ranking de literatura científica, siendo actualmente una de las principales en Ingeniería Geológica, Geotecnia y Geociencias Multidisciplinarias (Mikoš, 2017). Asimismo, se crearon bases de datos internacionales que incluyen datos producidos por movimientos en todo el mundo (EM-DATA; Munich RE; Swiss RE).

\subsection{El estudio de movimientos en masa en Argentina}

En nuestro país el estudio de estos procesos data de comienzos del siglo pasado (Burckhardt,1900), con numerosos casos a citar, pero recién a partir de la década del ochenta se produjo un incremento notorio en su estudio, así como también en el número de colegas dedicados a esta temática (González Díaz, 2009).

Una parte importante de los trabajos consideró aspectos vinculados con el riesgo potencial de estos procesos (Burckhardt, 1900; Kantor, 1916; Groeber, 1916; Harrington, 1946; González Díaz, 1973; González Díaz y Malagnino, 1990; Fauqué y Tchilinguirian, 2002; Zappettini, 2008; Mergili et al., 2015). En otros casos, los estudios demostraron la incidencia en la generación de lagos y lagunas por represamiento de valles (Groeber, 1916; Fauqué et al., 2000; González Díaz et al., 2000; Banchig et al., 2008; D’Odorico et al., 2008; Viera y Cencetti, 2008). Otras veces, la caracterización de geoformas producto de movimientos en masa, ha permitido reinterpretar en ocasiones la geomorfología de una zona (Pereyra y González Díaz, 1993) y en otras además, la cronología de los depósitos involucrados (Polanski, 1960; González Díaz y Mon, 1996). Gran parte de los estudios más recientes en Argentina, fueron orientados a la zonificación (cartografía) de susceptibilidad y amenaza (Moreiras, 2005; Lothari et al., 2017).

En general, el grado de desarrollo del conocimiento sobre los movimientos en masa contrasta entre unos países y otros, dependiendo en cierta medida de los daños que estos procesos representan. En algunos países de Latinoamérica como Colombia, Perú, Venezuela, México y Brasil, se ha abordado con cierta intensidad esta problemática. Brasil constituye un ejemplo de esfuerzos en tareas de transferencia a la sociedad sobre amenaza, situaciones de alerta y contingencias ante el desencadenamiento de estos procesos. Actualmente en Argentina, este tema parece cobrar interés principalmente desde el ámbito académico, y existen esfuerzos de muchos profesionales por lograr un interés público. Podría pensarse que este contraste depende de la intensidad, frecuencia y/o perjuicios ocasionados respecto a otros países, y que justificarían o no su estudio. Sin embargo, en la región andina de Argentina, existieron y existen año tras año, numerosas 
Movimientos en masa en las sierras de Bravard y Curamalal,

Sierras Australes de la Provincia de Buenos Aires.

Juan Manuel Susena

repercusiones económicas e incluso desastres vinculados a estos procesos, que alcanzan y sobrepasan las fronteras geopolíticas (Sepúlveda et al., 2014; Mergili et al., 2015). Algunas de las causas de dicho contraste podrían ser, entre otras, la falta de interés general y de comunicación en nuestro país sobre los eventos relacionados, y la ausencia de políticas de gestión que impulsen estudios interdisciplinarios orientados al conocimiento, prevención y mitigación de estos procesos y sus riesgos potenciales asociados. Como contrapartida, el estudio de procesos geomorfológicos en Argentina tuvo mucho énfasis en la dinámica glacial, volcánica, fluvial, litoral y eólica, y el caso particular de los movimientos en masa, se desarrolló principalmente en el territorio andino.

Por otra parte, es notoria la diferencia, respecto a países más desarrollados, de recursos que permitan un análisis multi-temporal extendido de los movimientos en masa. La discontinuidad de los registros de datos climatológicos y la escasez de fotografías aéreas e imágenes satelitales son, entre otros, importantes ejemplos de lo antedicho. No obstante, en los últimos años, se han desarrollado tecnologías de bajo costo, posibilitando la adquisición de datos fiables y sustentables, como el caso de los drones (Ruiz-Carulla et al., 2017), así como también se han explorado metodologías aplicables a estas circunstancias de escasez de datos (Monsieurs et al., 2018). En este sentido podría, quizá, recuperarse en las próximas décadas el "terreno perdido" en materia de calidad e innovación en el estudio de movimientos en masa en Argentina.

\subsection{Estudios de movimientos en masa en la Provincia de Buenos Aires}

El estudio de movimientos en masa en la Provincia de Buenos Aires es relativamente reciente, y aún quedan aspectos y regiones de los cuales se conoce poco, entre ellos, el área seleccionada para esta tesis.

En el cordón serrano de Tandilia, específicamente en el área de las Sierras de Balcarce se diferenciaron distintos procesos de remoción en masa, tales como caídas, solifluxión, deslizamientos, flujos y reptación (Martínez, 2001). Más recientemente, fueron reconocidos distintos tipos de movimientos en sectores localizados de los partidos de Tandil, como los correspondientes al extremo S (Gentile y Villalba, 2003a; 2003b; Gentile, 2006; 2009a) y NE del partido de Benito Juárez (Gentile, 2008a; 2009b). Estas contribuciones se vinculan con movimientos reconocidos principalmente en laderas de detritos y en frentes escarpados, ambos en cerros modelados en sedimentitas de edad pre - Paleozoico superior. Otras referencias han tratado parcialmente movimientos en masa producidos en laderas de cerros labrados en basamento cristalino en los alrededores de la ciudad de Tandil (Gentile, 2008b; 2009c). A éstos, deben agregarse algunas contribuciones que 
puntualizaron la intervención antrópica como mecanismo impulsor de asentamientos y colapsos por cavidades en el subsuelo, debido a antiguas prácticas mineras en la ciudad de Tandil (Gentile y Villalba, 2008), como asimismo, principalmente caídas en frentes escarpados producto de actividades relacionadas con la construcción de caminos (Gentile, 2008b; Gentile y Susena, 2018). Los primeros afectaron materiales de unidades litoestratigráficas del Cenozoico superior (y también producto de actividades humanas) y los restantes, provocaron además el desplazamiento de rocas del basamento cristalino. Específicamente, en el cordón serrano de Ventania, dentro del cual se ubica el área de estudio, las contribuciones respecto a la temática son menores; entre otras: Keidel (1916) diferencia depósitos originados por estos procesos. Harrington (1936) reconoció distintos tipos de movimientos en masa. Figueroa (1968) estudió para las vertientes del Cordón de Ventana acumulaciones de materiales, a las cuales caracterizó y clasificó como flujos de materiales (clasificación de Sharpe, 1938), y los vinculó a condiciones paleoclimáticas diferentes a las actuales, con movimientos recientes sobreimpuestos de tipo reptación. En este mismo trabajo se mencionan deslizamientos rotacionales vinculados a obras viales en el Abra de la Ventana. Los depósitos reconocidos por Keidel (1916), fueron interpretados por Corte y Rodríguez (1971) como correspondientes a lóbulos de solifluxión. De Francesco (1992a; 1992b) para el mismo ámbito caracteriza depósitos antiguos originados por movimientos gravitacionales no encauzados, de corto recorrido, similares a flujos de tierra. Pereyra y Ferrer (1995) diferencian en el flanco nororiental de este cordón serrano distintos tipos de movimientos. Rabassa y Ollier (2014) han destacado la importancia de movimientos en masa antiguos en la caracterización del paisaje de Gondwana. En los últimos años, se estudiaron los movimientos en masa en las sierras de Bravard y Curamalal, caracterizando los tipos de movimientos y las unidades geomorfológicas afectadas, así como criterios de edad relativa de los movimientos e identificación de reactivaciones (Susena y Gentile, 2017). Estos autores consideraron también el carácter multi-temporal de las caídas y vuelcos, criterios para su reconocimiento y sus implicancias en el riesgo turístico (Susena y Gentile, 2018). Otros aspectos de los movimientos en masa, como su influencia en la degradación del paisaje y las geoformas del Cuaternario, y su relación con la actividad humana fueron analizados por Susena y Gentile (2019) y Susena et al. (2019a; 2019b).

A pesar de los trabajos mencionados, el conocimiento de estos procesos en el área serrana de la Provincia de Buenos Aires, y particularmente en las Sierras Australes, es todavía escaso en comparación con otros aspectos de la geomorfología y la geología. 
Movimientos en masa en las sierras de Bravard y Curamalal,

Sierras Australes de la Provincia de Buenos Aires.

Juan Manuel Susena

\subsection{Interrogantes planteados a priori}

El marco teórico planteado hasta ahora es principalmente bibliográfico e incluye conocimientos generales sobre estos procesos, aspectos que se tuvieron en cuenta durante la investigación, como los mecanismos disparadores, distribución espacial y temporal, características de los materiales involucrados, clasificación, etc. En cuanto al apoyo empírico al momento de plantear los objetivos, se realizaron observaciones de los movimientos en masa con imágenes satelitales, referidas a distribución espacial y temporal, densidad espacial relativa, diferentes tipos de movimientos, dimensiones y asociaciones litoestructurales.

A partir de lo antedicho surgieron los siguientes interrogantes:

- ¿Qué características tienen los depósitos producto de movimientos en masa del área de estudio?

- ¿Dónde se produjeron los movimientos?

- ¿Cuándo ocurrieron?

- ¿Cuál es su frecuencia, si pudiera establecerse?

- ¿Qué características deben tener los materiales para ser susceptibles a movimientos?

- ¿Cuáles son los mecanismos preparadores de las condiciones críticas para que se produzcan los movimientos?

- ¿Cuáles son los desencadenantes?

- ¿Pueden volver a ocurrir estos eventos?, ¿dónde?, ¿con qué magnitud?, ¿cuándo?, ¿qué condiciones desencadenan su desarrollo?

- ¿Qué similitudes y diferencias existen con los movimientos en masa reconocidos por otros autores en otras sierras de la Provincia de Buenos Aires?

En el plan de tesis presentado inicialmente en la UNLP se habían planteado un objetivo general y varios objetivos específicos (Figura 2.1):

General: conocimiento de los procesos de movimientos en masa que operan en las laderas y sus mecanismos de formación, como asimismo la importancia relativa de los mismos en el modelado de las pendientes del área. Las interpretaciones y conclusiones alcanzadas permitirían confrontar los resultados con los movimientos en masa identificados por otros autores en el cordón serrano de Tandilia.

Específicos:

1. Reconocer los distintos tipos de movimientos en masa.

2. Caracterizar los movimientos en masa. 


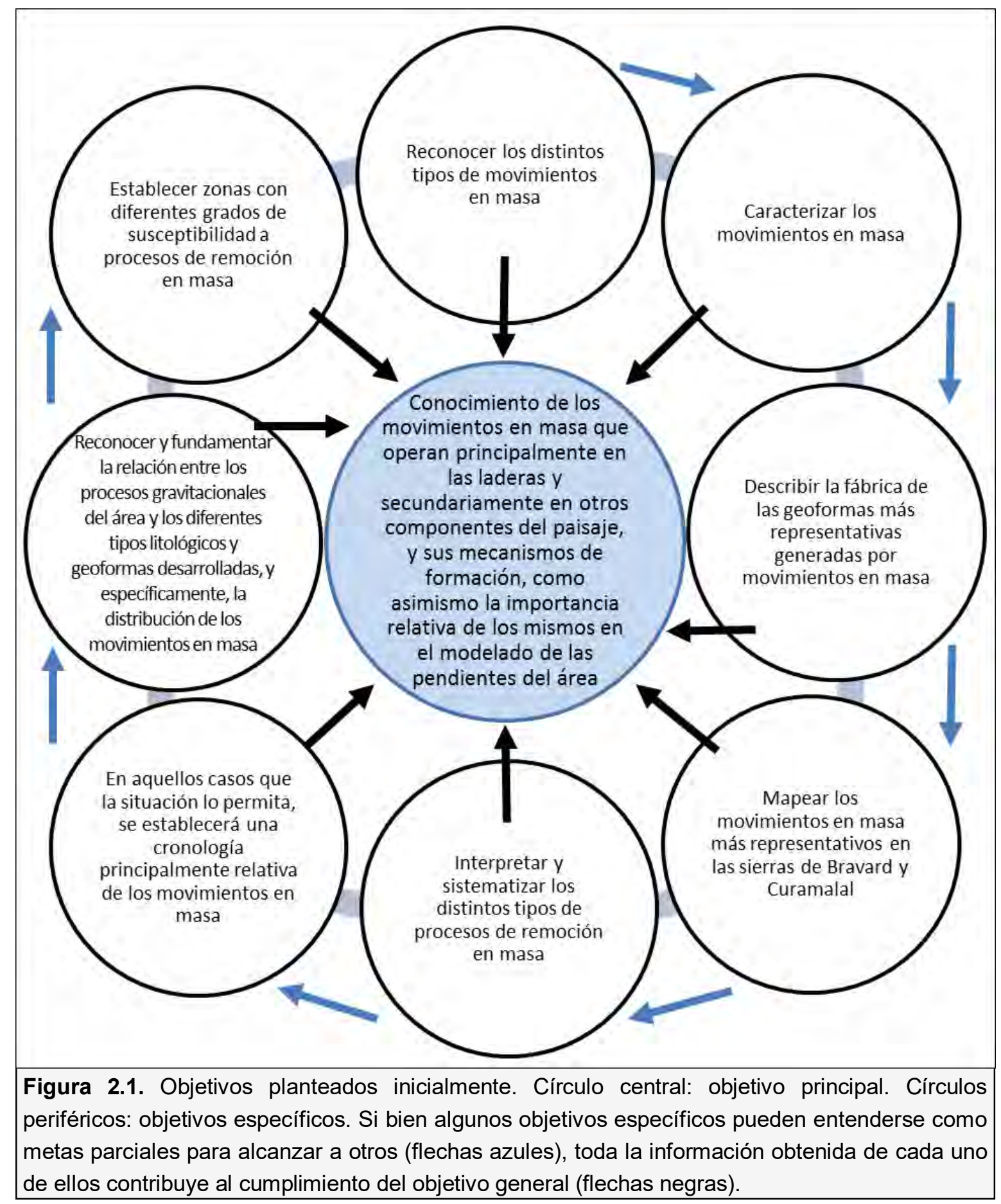

3. Describir la fábrica de las geoformas más representativas generadas por movimientos en masa.

4. Mapear los movimientos en masa más representativos en las sierras de Bravard y Curamalal en el cordón serrano de Ventania.

5. Interpretar y sistematizar los distintos tipos de procesos de remoción en masa.

6. Adicionalmente, en aquellos casos que la situación lo permita, se establecería una cronología principalmente relativa de los movimientos en masa. 
Movimientos en masa en las sierras de Bravard y Curamalal,

Sierras Australes de la Provincia de Buenos Aires.

Juan Manuel Susena

7. Reconocer y fundamentar la relación entre los procesos gravitacionales existentes en el área y los diferentes tipos litológicos y geoformas desarrolladas, y específicamente, la distribución de los movimientos en masa.

8. Establecer probables mecanismos generadores.

9. Establecer zonas con diferentes grados de susceptibilidad a procesos de remoción en masa.

Las hipótesis planteadas en el plan de tesis mencionado fueron las siguientes:

1. Los distintos tipos de movimientos en masa se relacionan a determinados componentes geológicos y geomorfológicos.

2. Los movimientos en masa se han producido en distintos momentos de la evolución de las laderas del área.

3. La fábrica de los depósitos producto de procesos gravitacionales tendría vinculación directa con el tipo o tipos de movimientos en cuestión.

4. La acción del agua actuaría como mecanismo disparador de determinados tipos de movimientos en masa.

Un examen detallado de estas hipótesis durante el desarrollo del trabajo de tesis permitió reconocer que la hipótesis 3 deriva de la 1, y a su vez, puede entenderse a ambas, e incluso a la hipótesis 4, como parte del conocimiento general de los movimientos en masa, contrastadas en investigaciones de terceros, tratándose entonces de hipótesis auxiliares con potencial de subyacer a planteos más avanzados. Esto condujo a un replanteo hacia hipótesis más específicas, gracias al enriquecimiento del apoyo teórico y empírico durante la primera etapa de la investigación, así como el conocimiento de características intrínsecas del objeto y la zona de estudio, que imposibilitan o desmerecen la realización de algunas tareas, y ameritan el desarrollo de otras nuevas. Así, se consideró oportuno y viable replantear las hipótesis originales e identificar las hipótesis auxiliares que las soportan, siendo las principales susceptibles de ser contrastadas (Figura 2.2). El trabajo de tesis se orienta a recabar observaciones y datos más detallados que permitan confirmar, modificar o descartar dichas hipótesis.

A continuación, se explican algunos aspectos estrictamente relacionados con el desarrollo de esta tesis, los cuales son importantes para entender cómo el contexto académicoinstitucional condiciona parcialmente el enfoque, los objetivos y las tareas desarrolladas. 


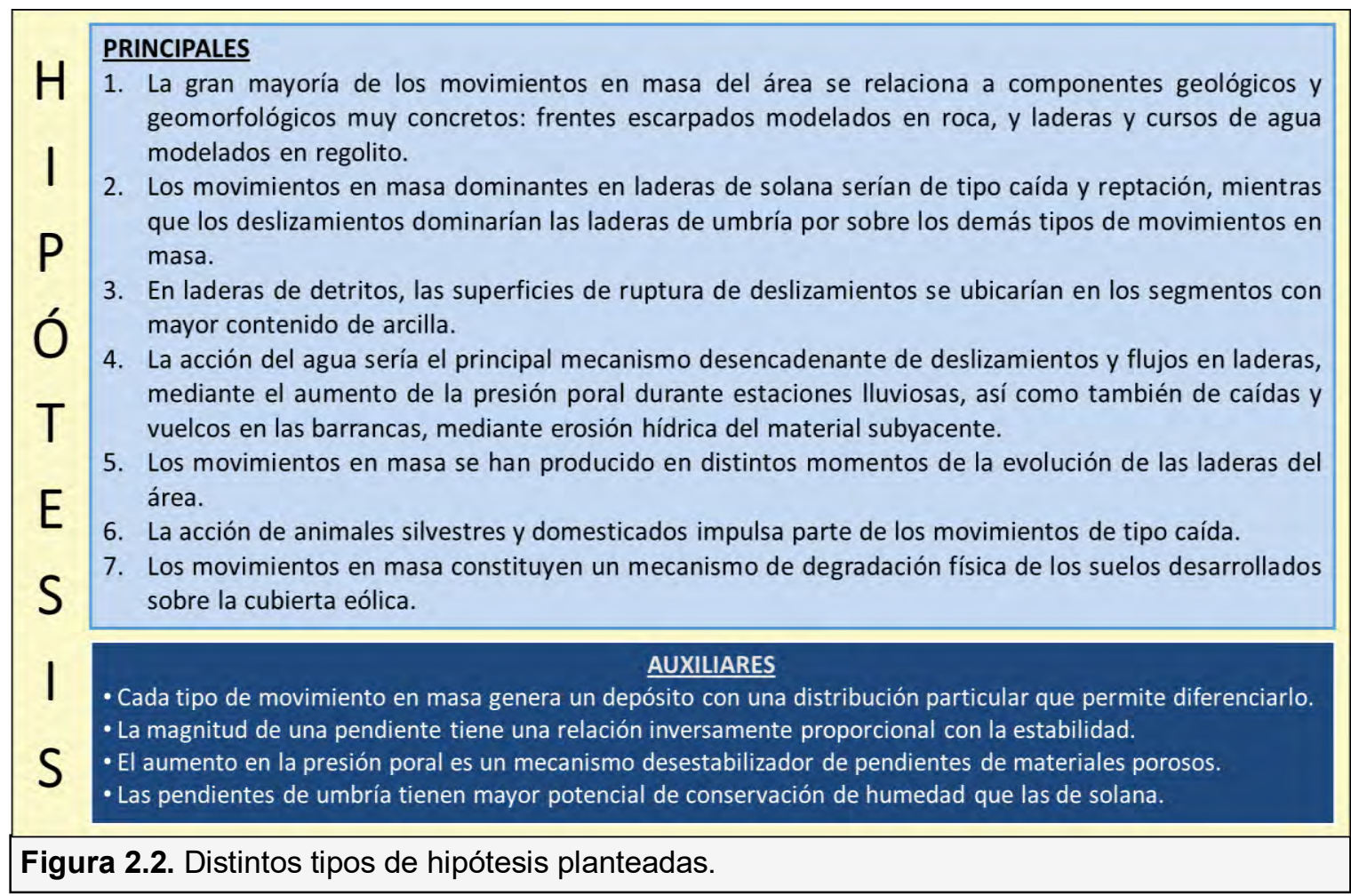

Esta tesis corresponde a una Carrera de Doctorado en Régimen de Co-tutela entre la Universidad Nacional de La Plata (UNLP, Argentina) y la Universidad de Cantabria (UC, España). Mediante un convenio específico, se opta al título de Doctor en Ciencias Naturales (UNLP) y Doctor en Ciencia y Tecnología (UC). El desarrollo del Convenio de Co-tutela entre ambas Instituciones fue posterior a la inscripción a la Carrera del Doctorado en Ciencias Naturales de la UNLP.

El plan de tesis inicialmente presentado en el año 2015 tenía un enfoque principal en el conocimiento del área seleccionada y los procesos geomorfológicos (en particular los movimientos en masa) que allí operan. Dado que, desde este punto de vista, Argentina posee poca información en la zona (y en muchas otras), y se busca a grandes rasgos, un conocimiento del territorio, el tema seleccionado se considera de especial interés en dicho contexto. Por lo tanto, al principio la tesis se enfocaba básicamente en conocer la dinámica de estos procesos geomorfológicos y las variables que influyen en su desarrollo en la zona seleccionada. Asimismo, la inscripción a la Carrera del Doctorado en Ciencias Naturales (UNLP) requiere la presentación y aprobación de un plan de tesis que se debe desarrollar hasta la culminación del trabajo.

Durante el transcurso de la investigación, ya en el marco de colaboración con una universidad europea, se pensó en ampliar el enfoque hacia una perspectiva más amplia, respondiendo a la premisa de que el aporte al conocimiento de una zona en particular no se consideraría un fin en sí mismo, sino un medio para el desarrollo de un conocimiento extrapolable a otras áreas del mundo. Por otra parte, la inscripción a la Carrera del 
Movimientos en masa en las sierras de Bravard y Curamalal,

Sierras Australes de la Provincia de Buenos Aires.

Juan Manuel Susena

Doctorado en Ciencia y Tecnología (UC) no exige la presentación de un plan de tesis inicial, sino que éste se desarrolla y revisa a medida que avanza la investigación, y puede actualizarse debido a cambios circunstanciales debidamente justificados (problemas metodológicos, de infraestructura o acceso a datos, descubrimientos afines propios o de terceros que justifiquen un cambio de enfoque, etc.).

Intentando conciliar estos aspectos propios de cada Institución, a continuación, se plantea el problema de manera concreta y los objetivos del trabajo.

\subsection{Síntesis del planteamiento del problema}

De lo antedicho se reconoce que en la zona de estudio hay lagunas en el conocimiento susceptibles de ser resueltas, de las cuales algunas son de carácter local, pero los resultados de su investigación podrían extrapolarse a otras regiones con características geoambientales similares. Si bien a nivel mundial se conoce a grandes rasgos cómo funcionan los movimientos en masa, cada territorio tiene particularidades geológicas, geomorfológicas, climáticas, socio-económicas, etc., que inciden directa o indirectamente en la susceptibilidad a estos procesos. Por esta razón, para lograr un conocimiento que sea aplicable a la reducción de los riesgos potenciales, no basta describir y conocer los movimientos del área seleccionada, sino también mejorar el conocimiento sobre los mecanismos preparadores y disparadores. Los problemas identificados, que justifican la realización del presente trabajo de tesis se enumeran a continuación:

- El escaso conocimiento sobre el papel que juegan los movimientos en masa desde el punto de vista geomorfológico, en regiones sub-húmedas serranas de Argentina en general, especialmente en el suroeste bonaerense. Esto incluiría aspectos como los principales tipos de movimiento, su morfología, su grado de actividad, etc.

- La inexistencia de un inventario de movimientos en masa en el ámbito serrano del suroeste bonaerense, que permita analizar y cartografiar la amenaza debida a estos procesos. Disponer de un inventario es una base imprescindible para afrontar la problemática de los movimientos en masa de manera cuantitativa en el futuro.

- En relación con lo anterior, se necesita profundizar en el conocimiento de los factores que propician la ocurrencia de movimientos en masa, para conocer mejor el proceso geomorfológico, y para afrontar más adecuadamente la prevención de posibles consecuencias no deseadas debido a la actividad de estos procesos.

- La escasa información geoespacial existente sobre variables ambientales (geomorfología, litología, vegetación, etc.), que son de alto interés para el estudio de los movimientos en masa, y que además servirían para otro tipo de estudios. 
Aunque el riesgo actual en el área seleccionada es relativamente pequeño (debido a la escasa exposición), el conocimiento de los mecanismos actuantes en los movimientos en masa allí presentes puede ser extrapolable, como ya se dijo, a otras áreas del país y del mundo con características geoambientales similares. Asimismo, los resultados obtenidos podrían aplicarse como base para una gestión sustentable del territorio estudiado ante eventuales cambios de uso en el futuro.

\subsection{Objetivos}

De acuerdo con el planteamiento del problema, se formulan a continuación los objetivos de esta tesis.

\section{Objetivo general:}

Conocer los movimientos en masa del área de estudio y sus mecanismos de formación, así como su contribución al modelado del relieve.

\section{Objetivos específicos:}

- Establecer criterios morfológicos que permitan la identificación de los movimientos en masa y su actividad.

- Conocer en detalle las características morfológicas y la distribución principalmente espacial de los distintos tipos de movimientos en masa que se desarrollan en el área de estudio.

- Identificar las relaciones existentes entre los movimientos en masa y los factores condicionantes y desencadenantes.

- Mejorar el conocimiento de las interacciones entre los movimientos en masa y otros procesos geomorfológicos.

Estos objetivos específicos se relacionan con las distintas hipótesis principales (Figura 2.3). Tienen relevancia en el conocimiento general (a nivel global) de los movimientos en masa y sus resultados son aplicables a otras regiones geomorfológicamente similares a la estudiada. De la misma manera, cualquier conclusión metodológica que pudiera obtenerse al trabajar en estos objetivos es extrapolable a investigaciones que se desarrollen en otras partes del mundo.

Se presenta a continuación de manera general -y en detalle en el capítulo siguiente- una serie de tareas necesarias para alcanzar los objetivos (ver relaciones entre actividades y 
Movimientos en masa en las sierras de Bravard y Curamalal, Sierras Australes de la Provincia de Buenos Aires.

Juan Manuel Susena

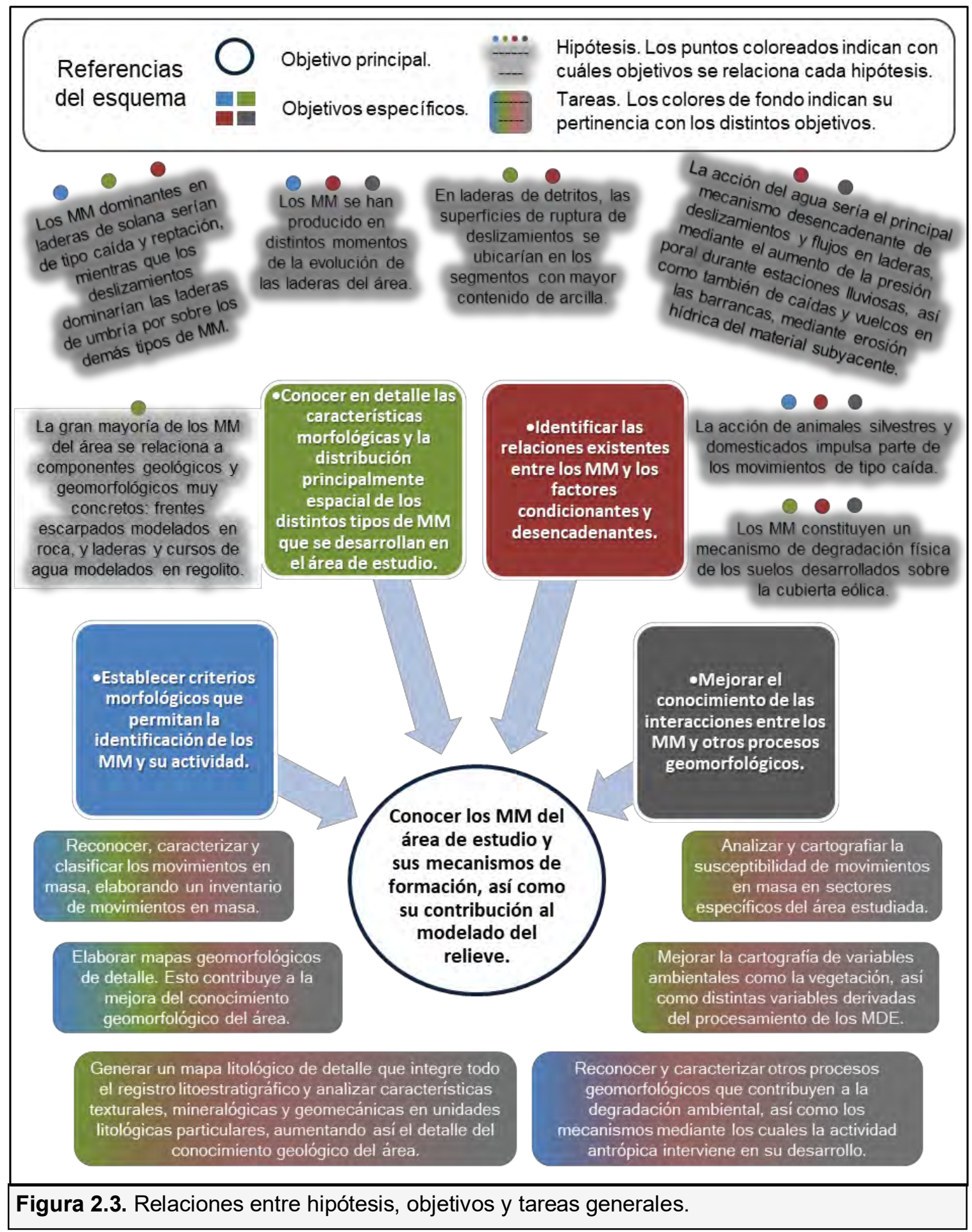

objetivos en la Figura 2.3), a la vez que son de interés para otros ámbitos de las ciencias ambientales:

- Reconocer, caracterizar y clasificar los movimientos en masa, elaborando un inventario de movimientos en masa.

- Elaborar mapas geomorfológicos de detalle. Esto contribuye a la mejora del conocimiento geomorfológico del área. 
- Generar un mapa litológico de detalle que integre todo el registro litoestratigráfico y analizar características texturales, mineralógicas y geomecánicas en unidades litológicas particulares, aumentando así el detalle del conocimiento geológico del área.

- Mejorar la cartografía de variables ambientales como la vegetación, así como distintas variables derivadas del procesamiento de los MDE.

- Analizar y cartografiar la susceptibilidad de movimientos en masa en sectores específicos del área estudiada.

- Reconocer y caracterizar otros procesos geomorfológicos que contribuyen a la degradación ambiental, así como los mecanismos mediante los cuales la actividad antrópica interviene en su desarrollo.

Todos estos objetivos y tareas son factibles de acuerdo con la información de base disponible, y considerando el tiempo y los recursos para la realización de esta tesis. Como se dijo antes, podrían esbozarse muchas preguntas y objetivos sobre los movimientos en masa, pero los aspectos aquí planteados responden a los problemas identificados, que justifican la realización de esta tesis.

Es notorio que "movimientos en masa" aparece en el objetivo general y en todos los objetivos específicos; intenta darse a entender que, aunque existan muchos aspectos y líneas de investigación que podrían contribuir en diferente medida a su estudio (como la dinámica de los cursos de agua, la historia post-rifting de Gondwana, los cambios climáticos, entre otros), no son éstos objeto de discusión ni de análisis detallado. Al irán ocasionalmente tales temas mencionando, si fuera necesario, hipótesis vigentes o contrastantes de posible utilidad para la interpretación de los procesos aquí tratados. 
Movimientos en masa en las sierras de Bravard y Curamalal, Sierras Australes de la Provincia de Buenos Aires.

Juan Manuel Susena 


\section{Capítulo 3}

\section{Metodología}

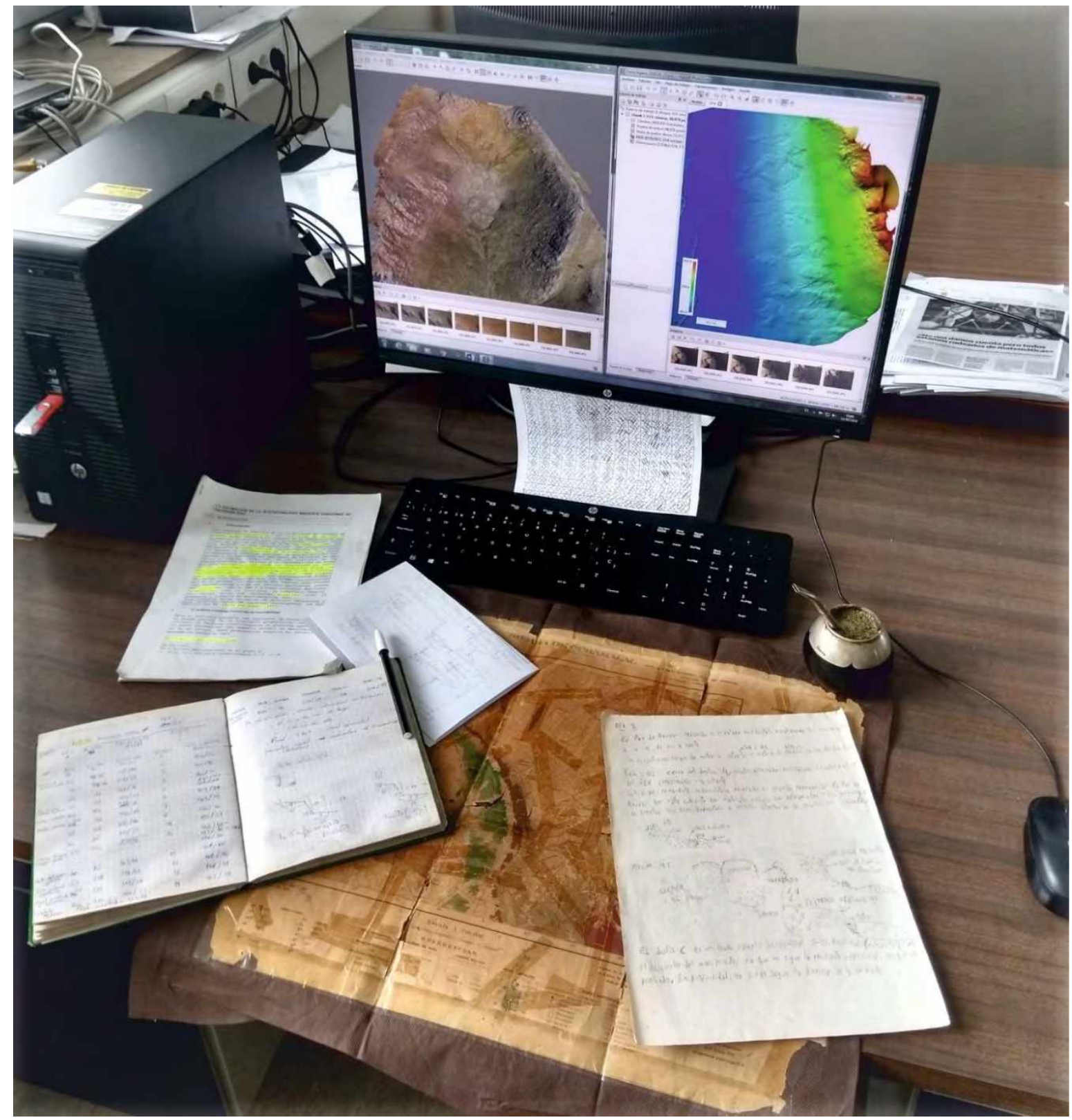

"Las cartas sobre la mesa" Un antiquísimo mapa geológico, la libreta de campo, bibliografía, bosquejos de esquemas, un poco de tecnología... y el compañero infaltable. 
Movimientos en masa en las sierras de Bravard y Curamalal, Sierras Australes de la Provincia de Buenos Aires.

Juan Manuel Susena 


\subsection{Hipótesis de trabajo}

Dados los objetivos y tareas generales planteados en el capítulo anterior (Figura 2.3), se establece la siguiente hipótesis de trabajo: a partir de un análisis geomorfológico (en el sentido amplio del término) pueden reconocerse los procesos de remoción en masa que operan en el área de estudio y sus relaciones con sus condiciones ambientales. Asimismo, mediante la aplicación de técnicas estadísticas se pueden cuantificar algunas de estas relaciones, información que mejorará la comprensión geomorfológica, y a su vez facilitará la elaboración de modelos de susceptibilidad.

El flujo de trabajo desarrollado se muestra en la Figura 3.1. En este flujo de trabajo se pueden reconocer dos tipos de aproximaciones: una geomorfológica clásica y otra estadística, probabilística. El análisis geomorfológico consistió en el reconocimiento y la caracterización de los movimientos en masa, así como otras formas, depósitos y procesos geomorfológicos del área estudiada. Esto significa que hubo un exhaustivo trabajo de campo y de cartografía por fotointerpretación, así como algunos análisis de laboratorio complementarios. Se hicieron descripciones y observaciones mesoscópicas sobre la morfología y los mecanismos asociados a los movimientos en masa (factores o mecanismos condicionantes, preparadores, y desencadenantes de movimientos), así como sobre los procesos de degradación de geoformas producto de movimientos en masa y sus etapas evolutivas, especialmente en laderas. El análisis estadístico se orientó a la comprensión de las relaciones entre los movimientos en masa y distintas variables relacionadas que caracterizan el área. A partir de ello, se elaboraron modelos probabilísticos de susceptibilidad de movimientos en masa. Cada una de estas dos aproximaciones involucra distintas actividades o tareas específicas, que pueden relacionarse entre sí de manera compleja. La Tabla 3.1 muestra la pertinencia de las distintas tareas específicas de este capítulo con las tareas generales mencionadas en el capítulo anterior.

A continuación, se describen las actividades o tareas específicas desarrolladas para alcanzar los objetivos propuestos, con una perspectiva general. La intención es expresar los distintos componentes de la propuesta metodológica antedicha, discriminando tareas de gabinete, campo y laboratorio. Cabe aclarar que, los detalles metodológicos se describen en profundidad en los capítulos correspondientes. 


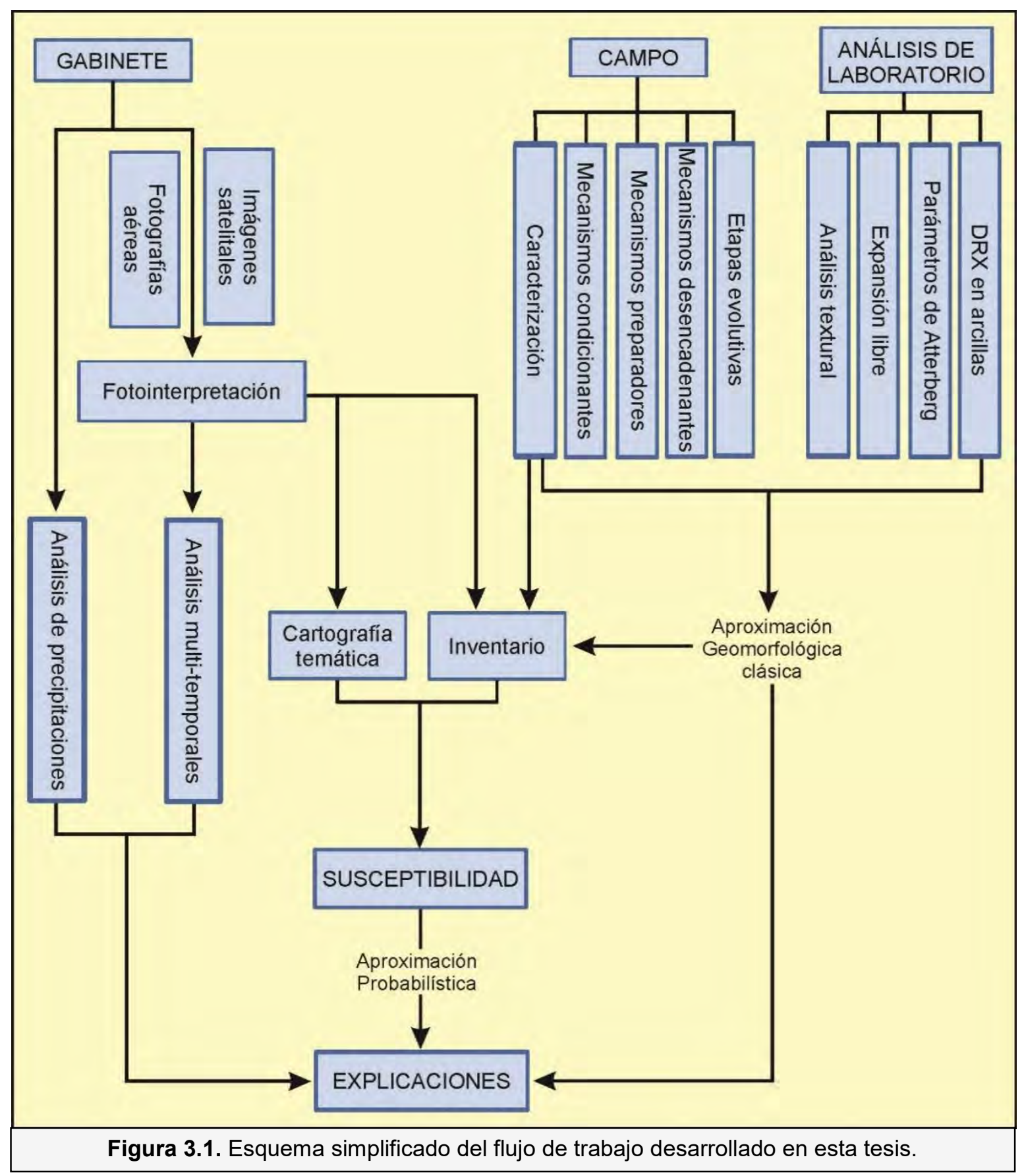




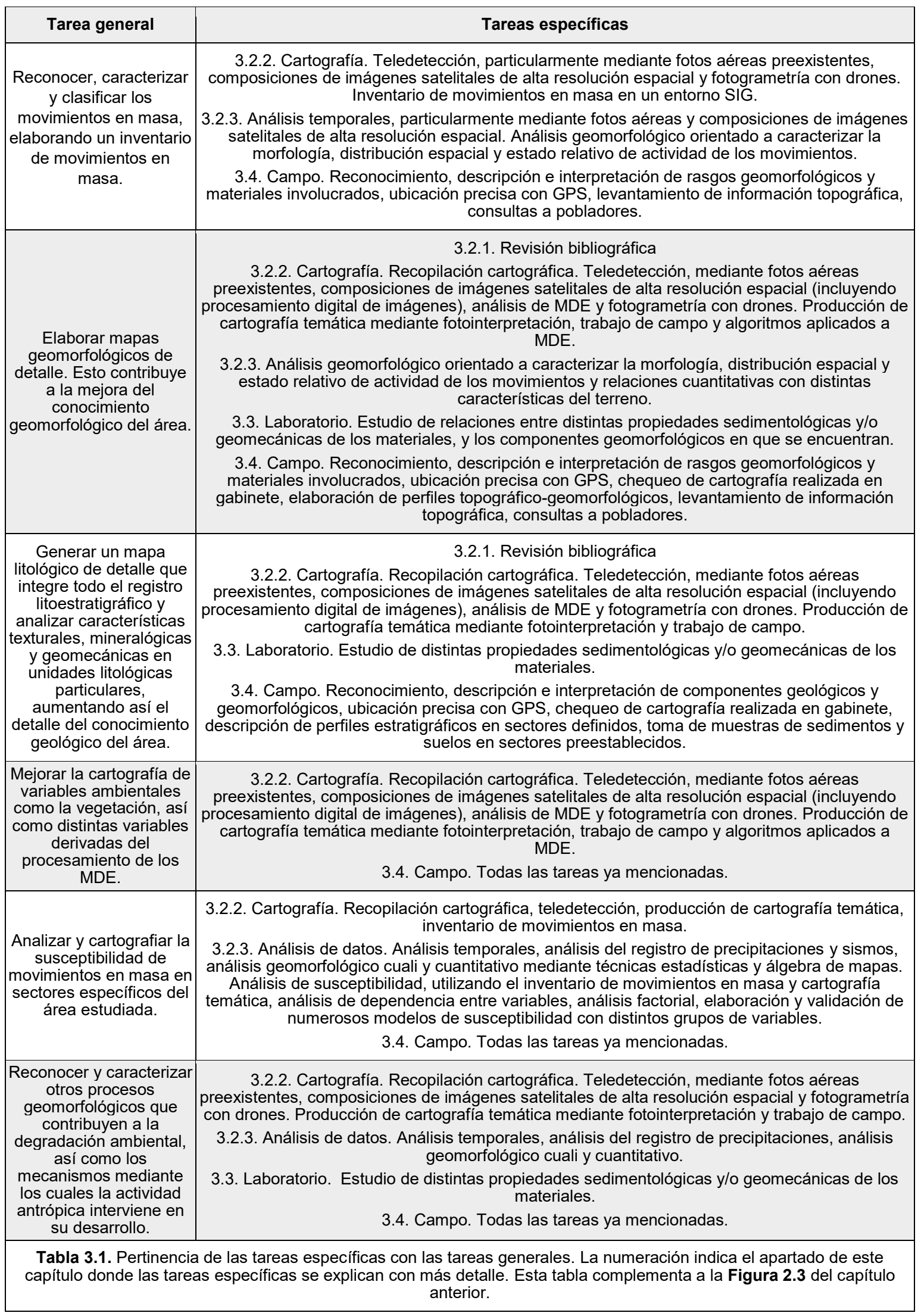


Movimientos en masa en las sierras de Bravard y Curamalal,

Sierras Australes de la Provincia de Buenos Aires.

Juan Manuel Susena

\subsection{Gabinete}

Las tareas realizadas en gabinete abarcan completamente el período de elaboración de esta tesis. Pueden agruparse principalmente en análisis bibliográfico, procesamiento cartográfico, análisis e interpretación de datos, redacción y revisión.

\subsubsection{Revisión bibliográfica}

La búsqueda de antecedentes incluyó consultas habituales a libros, textos, artículos de revistas, comunicaciones a congresos y distintas fuentes de internet, todos ellos de carácter científico y/o técnico. En algunos casos, fueron determinantes las consultas a investigadores con experiencia en el tema de trabajo o conocimiento del área estudiada. Se consideraron tres grandes grupos de antecedentes:

- Antecedentes sobre la geología, geomorfología, biología, clima, pedología, usos del territorio, etc. del área de estudio, información obtenida principalmente de trabajos de mapeo geológico e investigaciones presentadas en congresos y revistas nacionales e internacionales.

- La información general (no necesariamente del área de estudio) sobre movimientos en masa se obtuvo de publicaciones en revistas y congresos nacionales e internacionales, tesis doctorales y reportes de ingeniería geológica. Si bien se recurrió inicialmente a trabajos clásicos sobre movimientos en masa (entre otros, Sharpe, 1938; Varnes, 1978; Hutchinson, 1988; Cruden y Varnes, 1996), se prestó más atención a trabajos de los últimos 20 o 30 años, teniendo en cuenta que las técnicas de estudio han evolucionado.

- Los aspectos metodológicos en general (no necesariamente del área de estudio), principalmente relacionados a análisis de datos, técnicas de teledetección y procesamiento cartográfico en Sistemas de Información Geográfica, se buscaron tanto en fuentes internacionales como nacionales, en artículos de revistas, congresos y tesis de maestría.

Los principales criterios de análisis y selección de bibliografía fueron: 1) aspectos del área de tesis afines directa o indirectamente al desarrollo de movimientos en masa; 2) la similitud de las áreas de estudio (bibliografía con estudios de caso vs. área de tesis), desde las perspectivas climática, tectónica, geomorfológica y de la cobertura superficial y usos del territorio; 3) los tipos de movimientos en masa desarrollados, buscando los afines a los del área de tesis; 4) metodologías asequibles según los recursos disponibles para la realización del trabajo de tesis. 


\subsubsection{Cartografía}

Recopilación cartografía: se considera necesario, previo a cualquier campaña de campo, un reconocimiento del área de estudio, desde diversos aspectos (planialtimétrico, geológico, geomorfológico, edafológico, climático, biogeográfico, socioeconómico, etc.). Esto permite establecer y planificar cada campaña, sus objetivos específicos y las actividades a desarrollar para alcanzarlos, con cierto grado de factibilidad. El nivel de detalle de los conocimientos antedichos depende de la información disponible previamente (bibliografía) y del alcance de cualquier tipo de información que pueda obtenerse o generarse remotamente.

Teledetección: se dispone de fotografías aéreas del área de estudio a escala 1:20.000, de finales de la década de 1960 (Instituto Nacional de Tecnología Agropecuaria = INTA) y principios de la década de 1980 (Ministerio de Infraestructura y Servicios Públicos de la Provincia de Buenos Aires $=\mathrm{ex}-\mathrm{MOSP}$ ). Los proveedores de las fotografías fueron el I.N.T.A. Castelar y la Gerencia General de Catastro y Geodesia (Agencia de Recaudación de la Provincia de Buenos Aires). Las fotos se examinaron con estereoscopios de bolsillo y de espejos, y en algunos casos construyendo anaglifos digitales, a partir de fotos digitalizadas con escáner doméstico. Se utilizaron además ortomosaicos generados con Agisoft Photoscan a partir de las fotografías capturadas con un dron y composiciones de imágenes satelitales de alta resolución espacial de World View-2, disponibles mediante los servidores Google Earth, Bing y ESRI.

Las imágenes satelitales multi-espectrales permiten determinar propiedades de la superficie -y sub-superficie- importantes para el estudio de los movimientos en masa. Entre las operaciones de procesamiento digital de las imágenes, las cuales mejoran su visualización, análisis y clasificación, potenciando la fotointerpretación, se pueden mencionar las siguientes, realizadas en su mayoría con los programas ENVI y SNAP:

- corrección atmosférica;

- corrección radiométrica;

- correcciones geométricas;

- realces de histograma (ajustes del contraste);

- composiciones color;

- aplicación de máscaras;

- cambios de resolución (remuestreo);

- transformación HSI o HSV (tono, saturación, intensidad);

- transformación tasseled cap o TCT (brillo, verdor, humedad); 
Movimientos en masa en las sierras de Bravard y Curamalal,

Sierras Australes de la Provincia de Buenos Aires.

Juan Manuel Susena

- filtrado digital;

- análisis de componentes principales y composiciones color derivadas de éstos;

- álgebra entre bandas; $\mathrm{e}$

- índices estandarizados, como el índice de vegetación de diferencia normalizada (NDVI).

Las imágenes utilizadas para ello fueron Sentinel $2 A$ y Landsat 7 y 8.

Otro conjunto de operaciones involucra modelos de elevación del terreno, y permiten análisis de variables que describen aspectos geométricos del terreno, como:

- corrección de depresiones espurias y generación de matrices de dirección de flujo superficial y red de drenaje (Wang y Liu, 2006);

- generación de perfiles longitudinales de cursos de agua;

- delimitación de cuencas de drenaje; y

- elaboración de mapas hipsométricos de detalle y curvas hipsométricas (para analizar la distribución altitudinal de los movimientos en masa), mapas de pendientes y de orientación de las laderas.

Se utilizaron para tales fines modelos SRTM (Shuttle Radar Topography Mission), ASTER GDEM (Global Digital Elevation Model), DEM ALOS PALSAR, procesados mayoritariamente con Global Mapper y SAGA/GRASS.

Se construyeron modelos detallados del terreno en laderas particulares a partir de aerofotogrametría de imágenes capturadas en el campo durante distintas campañas. Para ello se utilizó un dron Phantom 3 Standard, y el procesamiento de las imágenes se realizó con el software Agisoft Photoscan. Estos modelos de mayor detalle permitieron identificar morfologías de los movimientos en masa enmascaradas en el terreno por la presencia de vegetación, importantes para reconocer la cinemática de los movimientos.

A efectos de desarrollar las tareas mencionadas, las diferentes imágenes, sus productos, y los datos de campo georreferenciados se integraron en un Sistema de Información Geográfica (SIG): QGIS-Quantum GIS. Los productos resultantes consisten en mapas de distintas escalas según los objetos a analizar, con énfasis en la observación de las laderas y áreas aledañas.

Producción de cartografía temática: gran parte de la información sobre el medio físico, particularmente la geomorfológica, puede obtenerse mediante fotointerpretación y análisis morfométrico de fotografías aéreas, imágenes satelitales y modelos digitales de elevación (MDE o DEM). El avance constante de los SIG y la disposición de imágenes satelitales de descarga libre, han acrecentado relevantemente la cantidad de información que pudiera recolectarse. No obstante, es fácil caer en un desequilibrio de información que puede 
dificultar o exagerar el trabajo preliminar de gabinete. Al respecto, se consideró propicio limitarse a la fotointerpretación (y excepcionalmente a la creación de subproductos a partir de MDE) a la hora de elaborar la cartografía, reservando los análisis geomorfométricos para etapas posteriores. Así, los componentes geológico-geomorfológicos mayores del área estudiada se cartografiaron a partir de imágenes de satélite de alta resolución (World View-2, LANDSAT, Sentinel-2A, y ASTER), fotografías aéreas a escala 1:20.000 y mapas bibliográficos, estos últimos corroborados en el campo.

Las variables utilizadas para el estudio de movimientos en masa se mapearon a escala 1:20.000, y en sectores específicos, a 1:5.000. Estas variables pueden ser categóricas, como la litología, la geomorfología y la vegetación, o numéricas continuas, especialmente las que se derivan del MDE. Las primeras se elaboraron fundamentalmente por fotointerpretación y trabajo de campo, mientras que las segundas se han obtenido aplicando diferentes algoritmos. Las variables utilizadas y sus características se describen en detalle en el Capítulo 14 Análisis de susceptibilidad.

Inventario de movimientos en masa: se considera fundamental la generación de un inventario de movimientos en masa del área de estudio, consignando ubicación, tipo (cinemático) de movimiento, estado, distribución y estilo de actividad, material afectado, características indicadoras de edad relativa, y cualquier observación relevante. Si bien algunos de estos datos se obtienen en el campo, el trabajo principal de recopilación e interpretación de la información se hace en el gabinete. Una vez georreferenciado en un entorno SIG, el inventario adquiere especial utilidad para hacer estimaciones cuantitativas de interés geomorfológico (distribución espacial de los movimientos, grado de asociación con distintas variables del terreno, etc.), y para la cartografía de susceptibilidad relativa a procesos de remoción en masa (Figura 3.1). En algunos casos, en geoformas incipientes o muy degradadas, la cartografía de movimientos en masa tiene alguna incertidumbre, lo cual es inherente a todo proceso cartográfico.

\subsubsection{Análisis de datos}

Análisis temporales: los estudios de evolución del paisaje pueden realizarse mediante la observación de diferentes estados evolutivos del mismo en zonas aledañas con características similares, en cuanto a estructura geológica, condiciones climáticas y otros factores que contribuyen a su desarrollo. Dicho de otra forma, pueden observarse en un mismo momento, en diversos sectores del paisaje, distintas "ventanas temporales" de una historia geológica en común. No obstante, en un análisis de la actividad de los movimientos 
Movimientos en masa en las sierras de Bravard y Curamalal,

Sierras Australes de la Provincia de Buenos Aires.

Juan Manuel Susena

en masa es necesario el monitoreo del mismo punto de observación en diferentes momentos. Así, sería posible determinar cambios morfológicos, frecuencias e incluso reconocer -junto con datos de precipitaciones, sismos, intervención antrópica, pasaje de animales, etc.- eventos desencadenantes (o mecanismos disparadores) de los movimientos en masa. Estos estudios multi-temporales son de utilidad para la zonificación de amenazas. En esta tesis se utilizaron las fotografías aéreas ya mencionadas (décadas de 1960 y de 1980) y composiciones de imágenes satelitales de World View-2 (disponibles mediante los servidores Google Earth, Bing, ESRI y Yandex), de alta resolución espacial, desde el año 2006 en adelante. Claramente, la discontinuidad en el registro de imágenes representa una limitación para interpretar fiablemente el estado de la actividad de los movimientos en masa en los últimos 40 años. Asimismo, la discontinuidad espacial de las fotografías aéreas de las que se dispone forzó la restricción de su utilización a aspectos meramente descriptivos, utilizándose como "más confiables" los datos disponibles a partir de la década del 2000 , debido a su continuidad espacio-temporal. De todas maneras, se utilizaron las fotografías aéreas para reconocer movimientos iniciados con posterioridad a la fecha de toma y reactivaciones mediante comparación con imágenes satelitales posteriores.

Análisis del registro de precipitaciones: se utilizaron las estaciones Pigüé, Saavedra, Dufaur y Estancia Cerro Áspero (Pdo. de Saavedra), Coronel Suárez (Pdo. De Coronel Suárez) y Tornquist (Pdo. de Tornquist), (Figura 3.2). Dichos datos fundamentalmente pertenecen al Servicio Meteorológico Nacional (SMN) y/o al INTA, y abarcan datos de precipitación diaria de diversos períodos, todos superiores a 10 años. Como excepción a lo antedicho, los datos de la estación Estancia Cerro Áspero fueron generados y proporcionados por los dueños del establecimiento; para corroborar la confiabilidad de estos datos, se hizo un análisis de doble masa entre dicha estación y la estación Pigüé, lo cual arrojó resultados aceptables (Figura 3.3).

Se procesaron estadísticamente los datos meteorológicos, identificándose los períodos con máximas precipitaciones (estacionalidad, día más lluvioso, mes más lluvioso, año más lluvioso), la tendencia y las anomalías pluviométricas. Se realizó un balance hidrológico de los últimos 30 años con el método de Thornthwaite (1948) utilizando datos de precipitaciones y de temperatura, obtenidos del SMN para las estaciones Coronel Suárez y Pigüé. 

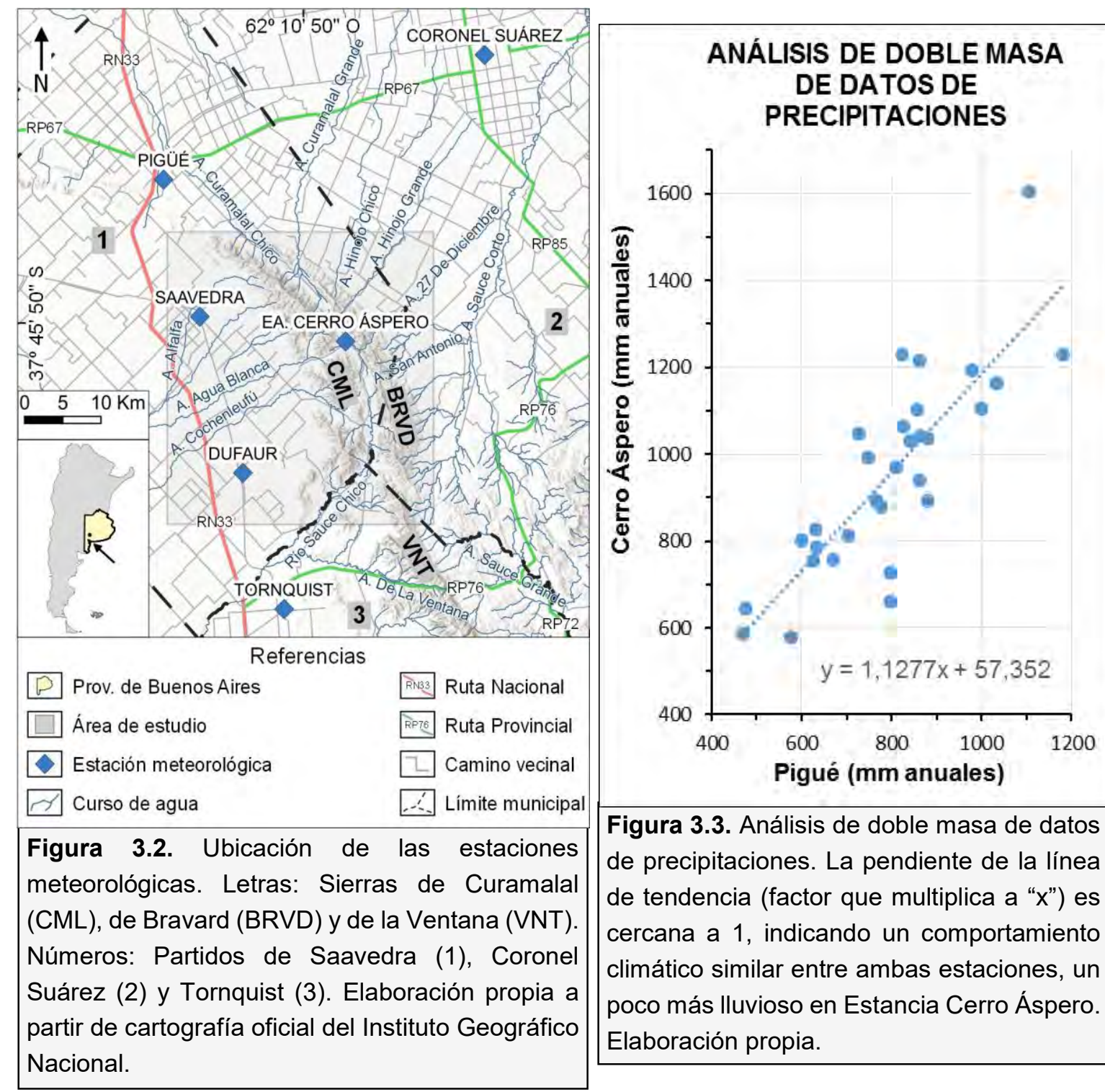

Figura 3.3. Análisis de doble masa de datos de precipitaciones. La pendiente de la línea de tendencia (factor que multiplica a " $x$ ") es cercana a 1 , indicando un comportamiento climático similar entre ambas estaciones, un poco más lluvioso en Estancia Cerro Áspero. Elaboración propia.

Análisis geomorfológico: se realizaron análisis cualitativos consistentes en la identificación de unidades geomorfológicas con mayor desarrollo de movimientos, la distribución de los tipos de movimiento respecto a condiciones ambientales como la orientación de las laderas, el grado de actividad faunística o antrópica, etc. De este análisis se deriva la caracterización, clasificación y estado relativo de actividad de los distintos tipos de movimientos descritos en el cuerpo principal de la tesis (Capítulos 7 al 12). Los análisis cuantitativos de las relaciones entre los movimientos en masa y diferentes características del terreno se realizaron mediante técnicas estadísticas y álgebra de mapas. Para ello se utilizaron el inventario y diferentes variables cartográficas.

Análisis de susceptibilidad: la metodología de análisis susceptibilidad se trata en detalle en el Capítulo 14 Análisis de susceptibilidad, se esboza aquí un resumen del procedimiento seguido. 
Movimientos en masa en las sierras de Bravard y Curamalal,

Sierras Australes de la Provincia de Buenos Aires.

Juan Manuel Susena

Se obtuvieron distintas variables del terreno mediante mapeo o procesamiento de un MDE, y se realizó con ellas un análisis de susceptibilidad. Se utilizaron el inventario de movimientos en masa y cartografía temática como cursos de agua, caminos y huellas rurales, litología, geomorfología y vegetación, pendientes, orientaciones, curvaturas, etc. También se analizó la dependencia entre variables, y se aplicaron técnicas de análisis factorial, para seleccionar las variables más significativas. Por último, las variables seleccionadas se correlacionaron estadísticamente con los movimientos e masa para generar modelos de susceptibilidad. Se desarrollaron varios modelos con diferentes combinaciones de variables y se los evaluó a partir de una muestra de movimientos no empleados en la elaboración de los modelos de susceptibilidad.

Todas estas operaciones se realizaron con los SIG SAGA, QGIS e ILWIS.

\subsection{Laboratorio}

Las actividades desarrolladas en el laboratorio consistieron en la determinación de propiedades útiles para caracterizar el material desde los aspectos sedimentológico y geomecánico, priorizando al último. Los datos obtenidos fueron útiles para explicar aspectos puntuales relacionados con movimientos en masa. Se observó la relación entre las propiedades de las muestras analizadas y su ubicación en los diferentes segmentos de ladera, al mismo tiempo que se compararon con muestras ubicadas en otros componentes geomorfológicos.

La distribución granulométrica se determinó por tamizado de la fracción arena en húmedo y pipeteo (Galenhause, 1971) de las fracciones limo-arcilla, utilizando $\mathrm{H}_{2} \mathrm{O}_{2}$ (peróxido de hidrógeno) y $\mathrm{HCl}$ (ácido clorhídrico) para la respectiva destrucción de materia orgánica y cementos carbonáticos, y $\mathrm{Na}\left(\mathrm{PO}_{3}\right)_{6}$ (hexametafostato de sodio) como dispersante. Los resultados obtenidos se compararon con los de otros autores, para analizar la similitud y contemporaneidad de distintas unidades litológicas.

Mediante Difracción de Rayos X con difractómetro PANalytical X'Pert PRO se determinó cualitativamente la presencia de diferentes tipos de argilominerales en la fracción arcillosa de materiales que conformas las laderas, con el objeto de considerar o descartar la presencia de arcillas expansivas.

Se obtuvieron parámetros físicos de muestras de suelo en distintos tramos de laderas: expansión libre por el método de Expansión Libre (Holtz y Gibbs, 1956; Abete y Sánchez, 1970) y parámetros de Atterberg (1911), particularmente el límite líquido, con el aparato de Casagrande (1932). 


\subsection{Campo}

El trabajo de campo realizado sumó un total de 53 días repartidos en 10 campañas: 45 días en el área de estudio y 8 días en zonas aledañas, también pertenecientes a las Sierras Australes. Debido a la gran extensión del área de estudio (en relación al detalle requerido para el estudio de movimientos en masa), se seleccionaron microzonas representativas de los diferentes contextos geomorfológicos que componen el área de estudio. Allí, las actividades de campo fueron exhaustivas, mientras que en el resto de la región los objetivos fueron constatar la similitud de las condiciones geológicas, geomorfológicas y ambientales, respecto a las microzonas. Cabe destacar que la ubicación de las microzonas se estableció aproximadamente durante la mitad del desarrollo de esta tesis, cuando se obtuvo información suficiente para poder establecer "generalizaciones" de contexto geomorfológico.

Entre las actividades desarrolladas en el campo, pueden enumerarse:

1. Reconocimiento, descripción e interpretación de los distintos componentes geológicos y geomorfológicos, con especial atención en aquellos relacionados con los procesos de inestabilidad.

2. Ubicación precisa de los distintos componentes geológicos y geomorfológicos con GPS Garmin eTrex.

3. Chequeo de la cartografía realizada en gabinete.

4. Elaboración de perfiles topográfico-geomorfológicos en sectores de laderas preestablecidos. Estos perfiles se levantaron con brújula y cinta métrica o con GPS, y a partir de modelos de elevación digitales obtenidos mediante levantamiento con drones.

5. Descripción de la distribución de los materiales (fábrica) en acumulaciones producto de distintos tipos de movimientos en masa.

6. Descripción de perfiles geomorfológicos y estratigráficos en sectores definidos.

7. Obtención de muestras de sedimentos en sectores preestablecidos.

8. Toma de muestras de suelo para determinaciones en laboratorio.

9. Toma de fotografías de componentes geológicos y geomorfológicos.

10. Consultas a pobladores acerca de movimientos en masa ocurridos, eventos climáticos excepcionales y sus consecuencias, historia agropecuaria de la región y en particular de sus estancias, así como sobre actividad faunística local. 
Movimientos en masa en las sierras de Bravard y Curamalal, Sierras Australes de la Provincia de Buenos Aires.

Juan Manuel Susena 


\section{UNIDAD II}

El dónde... 



\section{Capítulo 4}

\section{Introducción al área de estudio}

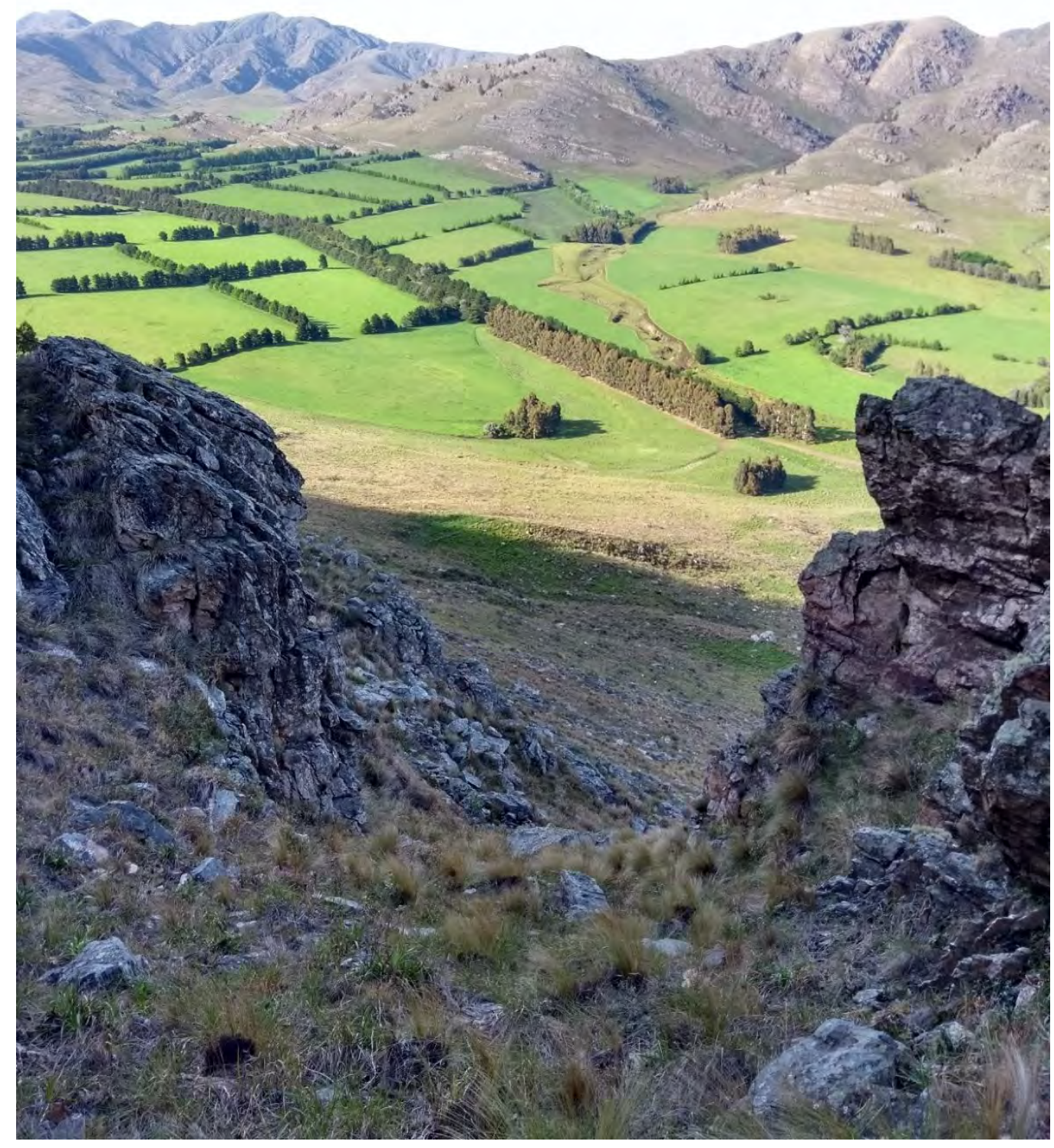

"De Bravard a Curamalal"

Foto en la Estancia Cerro Áspero, durante una de las últimas campañas. 
Movimientos en masa en las sierras de Bravard y Curamalal, Sierras Australes de la Provincia de Buenos Aires.

Lic. Juan Manuel Susena 


\subsection{Objetivos y ordenamiento del capítulo}

El presente capítulo tiene por objeto una descripción general del área de estudio, desde un ángulo principalmente geográfico. Aunque algunos de estos ítems puedan tener un importante significado geomorfológico, como la orografía, la hidrografía, el clima y acción faunística, no se los trata en detalle para no perder de vista el carácter introductorio de este capítulo. Estos y otros aspectos se retoman con mayor detenimiento más adelante en esta tesis para facilitar, por una cuestión de cercanía en el texto, su aplicación al estudio de los movimientos en masa.

\subsection{Ubicación del área}

La zona de estudio se ubica entre los $37^{\circ} 40^{\prime}$ y $38^{\circ} 00^{\prime}$ de latitud sur, y los $62^{\circ} 00^{\prime}$ y $62^{\circ} 24^{\prime}$ de longitud oeste. Corresponde a sectores de los partidos de Saavedra, Coronel Suárez y Tornquist, en el suroeste de la provincia de Buenos Aires, específicamente en las Sierras de Bravard y Curamalal, y sus inmediaciones. Estas sierras conforman una franja de dirección general noroeste-sureste, de unos $35 \mathrm{~km}$ de longitud y un ancho de $15 \mathrm{~km}$, resultando en una superficie aproximada de $525 \mathrm{~km}^{2}$, que se desarrolla desde unos $10 \mathrm{~km}$ al sureste de la localidad de Pigüé (sector septentrional del Partido de Saavedra) hasta las proximidades del río Sauce Chico, que conforma el límite norte del Partido de Tornquist (Figura 4.1). Se delimitaron tres subzonas representativas del área estudiada, a las cuales se pudo acceder y trabajar a escala de detalle, denominadas subzona 1, 2 y 3 , como se aprecia en la Figura 4.2. 
Movimientos en masa en las sierras de Bravard y Curamalal,

Sierras Australes de la Provincia de Buenos Aires.

Lic. Juan Manuel Susena

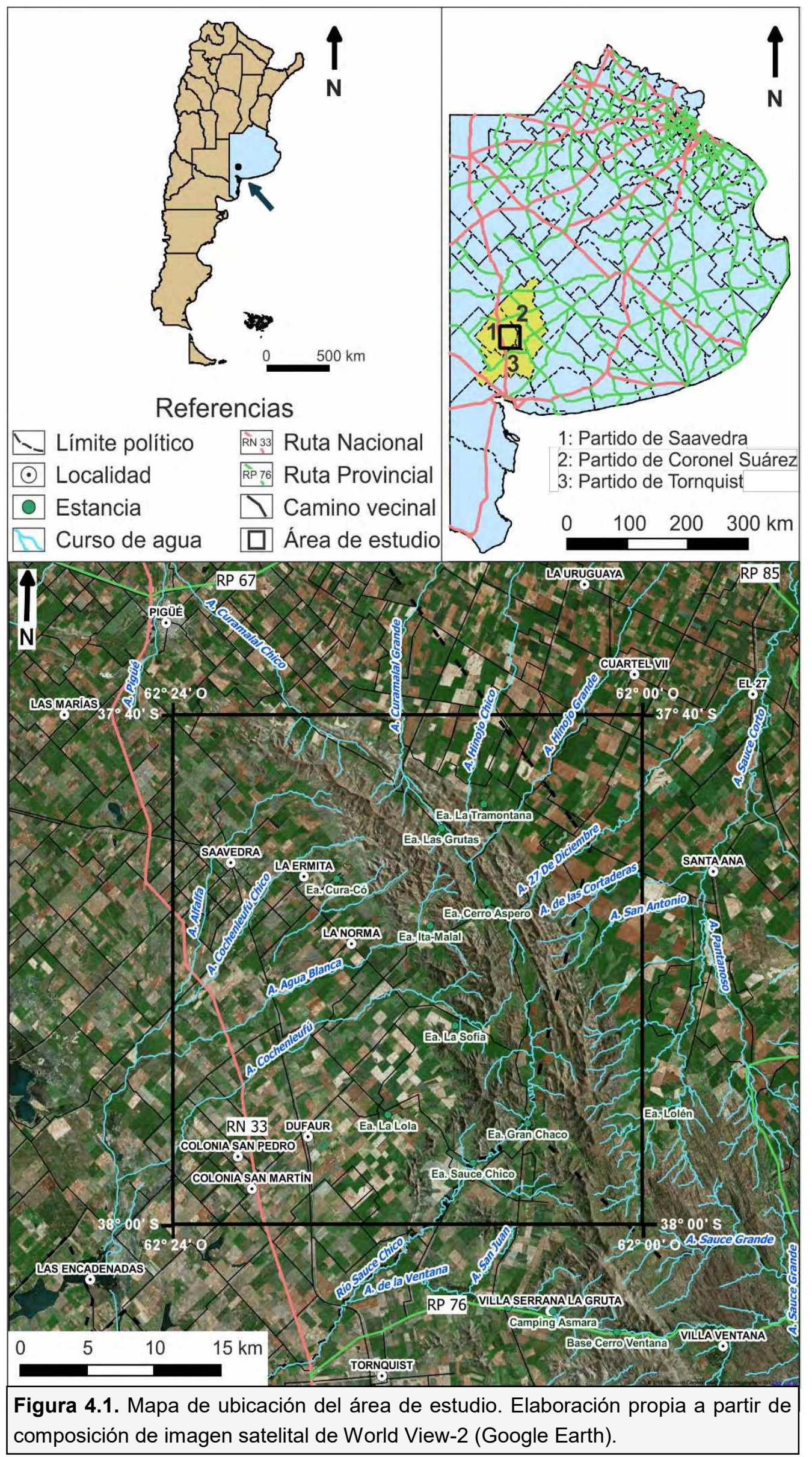




\subsection{Orografía}

Este sector de las Sierras Australes de la Provincia de Buenos Aires consiste en dos cordones serranos paralelos entre sí, orientados en forma de arco cóncavo hacia el suroeste, conformados por las Sierras de Bravard al oriente y Curamalal (o Curá-Malal) al occidente. Dichas sierras se encuentran separadas por un extenso valle intermontano denominado Abra Las Grutas o Abra del 27/27 de Diciembre. A su vez, los cordones se interrumpen transversalmente por profundos valles de relieve abrupto denominados localmente "abras". En las cercanías de Pigüé, la orientación de los cordones serranos es oeste noroeste - este sureste, hasta la proximidad con las nacientes del Arroyo Curamalal Chico en el Abra del Campamento, a partir de las cuales se torna noroeste-sureste, separados entre sí por el Abra las Grutas. En las cercanías del Abra de Hinojo (transversal a las Sierras de Bravard, entre el Cerro Hinojo al noroeste y el Cerro Puntudo al sureste) la orientación adopta un sentido nornoroeste-sursureste, adquiriendo luego un rumbo norte-sur a lo largo del Abra del 27, aproximadamente a partir de la latitud del pico del Cerro Luisa. Finalmente, en las zonas aledañas al Fortín Chaco (o Estancia Gran Chaco), las Sierras de Curamalal culminan en cerros aislados a partir del Arroyo Sauce Chico, y las Sierras de Bravard se continúan con las de Ventana, en dirección noroeste-sureste a partir del Abra del Chaco (Figura 4.2).

Las Sierras de Curamalal tienen una longitud de unos $39 \mathrm{~km}$, y un ancho máximo de 8,5 km en la parte central, disminuyendo hacia el norte y el sur, a un mínimo de 3,5 kilómetros. La cota máxima se ubica en la cumbre del cerro Curamalal Grande, con 1037 metros sobre el nivel del mar, seguida por las de los cerros Chaco/Gran Chaco, Cordón Lehmann/Cumbre de los Alemanes, La Sofía, Agua Blanca, Cordón Hinojo Grande y cerros Curamalal Chico y Pan de Azúcar (Tabla 4.1). 
Movimientos en masa en las sierras de Bravard y Curamalal,

Sierras Australes de la Provincia de Buenos Aires.

Lic. Juan Manuel Susena

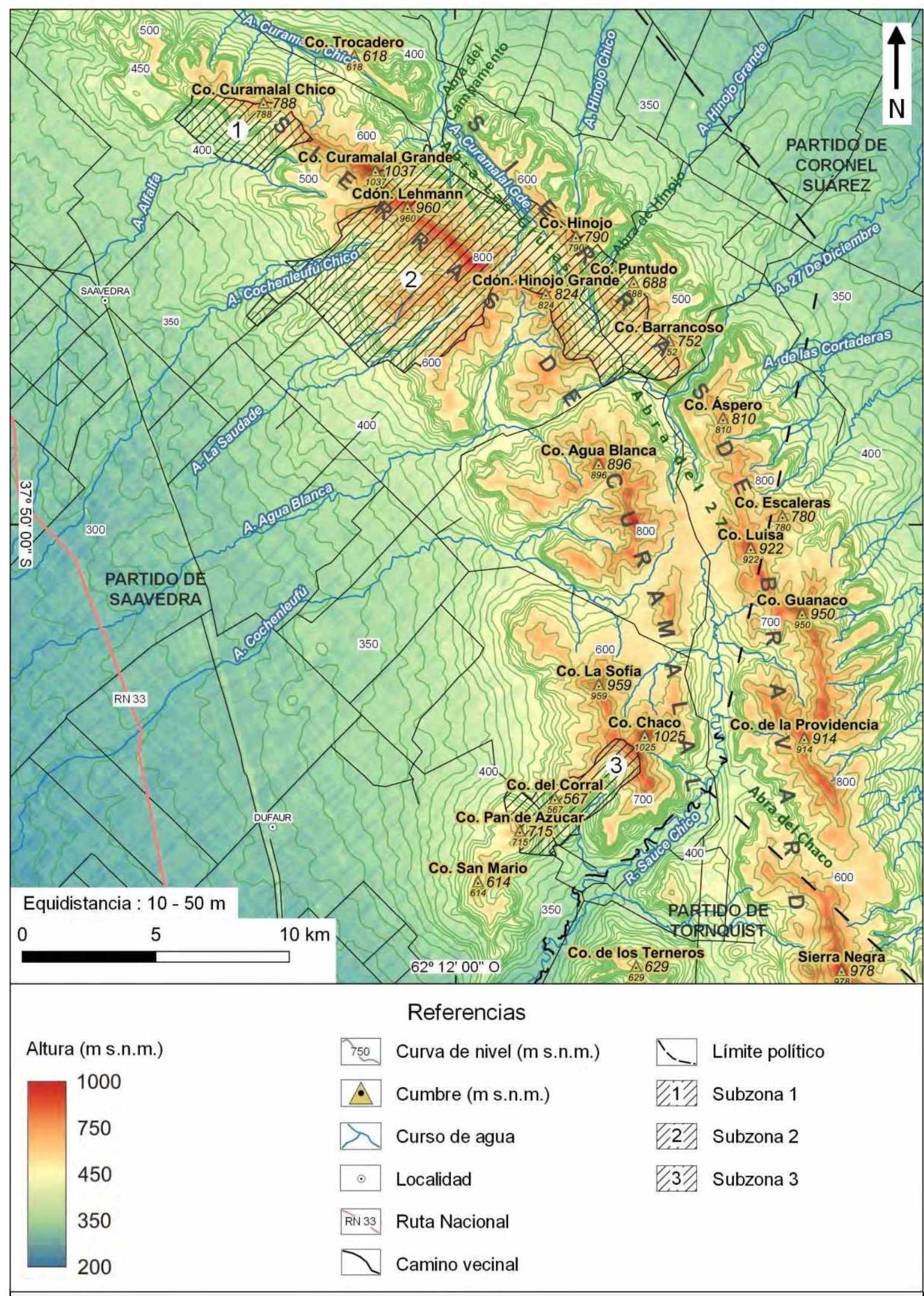

Figura 4.2. Mapa hipsométrico del área de estudio y ubicación de las subzonas 1, 2 y 3. Elaboración propia a partir de la Cartografía Oficial del Instituto Geográfico Nacional (IGN) y de modelo de elevación digital ALOS PALSAR. 
Las Sierras de Bravard se extienden unos $38,5 \mathrm{~km}$ hasta el Abra del Chaco, y su ancho máximo es de aproximadamente 5,5 $\mathrm{km}$, en las inmediaciones del Cerro Guanaco, el cual es también el de mayor cota (950 m). La Sierra Negra (978 m) se incluye en las Sierras de la Ventana, aunque en realidad las últimas y las de Bravard son físicamente un cordón continuo. Se destacan además los cerros Luisa, de la Providencia, Áspero, Hinojo, Escaleras, Barrancoso y Puntudo (Tabla 4.1).

Hacia el noroeste las elevaciones de los cerros son menores para ambas sierras, alcanzando cotas máximas de unos 650 metros.

Las pendientes del área serrana varían según su orientación, entre valores cercanos a $70 \%$ y $20 \%$, siendo en general mayores las pendientes sudoccidentales, a excepción del Cerro Gran Chaco (o Chaco), que presenta altos valores en las laderas orientales (Figura 4.3). Existen además frentes rocosos verticales y subverticales (véase Capítulo 6 Geomorfología general del área), principalmente en los faldeos occidentales de las Sierras de Bravard.

En el área de estudio la llanura periserrana se acota entre los $270 \mathrm{~m}$ en el extremo suroccidental, y aproximadamente $400 \mathrm{~m}$ al pie de las sierras, elevándose las últimas hasta $650 \mathrm{~m}$ por sobre la primera. Las pendientes regionales son hacia el suroeste y el nornoreste y tienen un valor medio de aproximadamente $5^{\circ}(8 \%)$. 


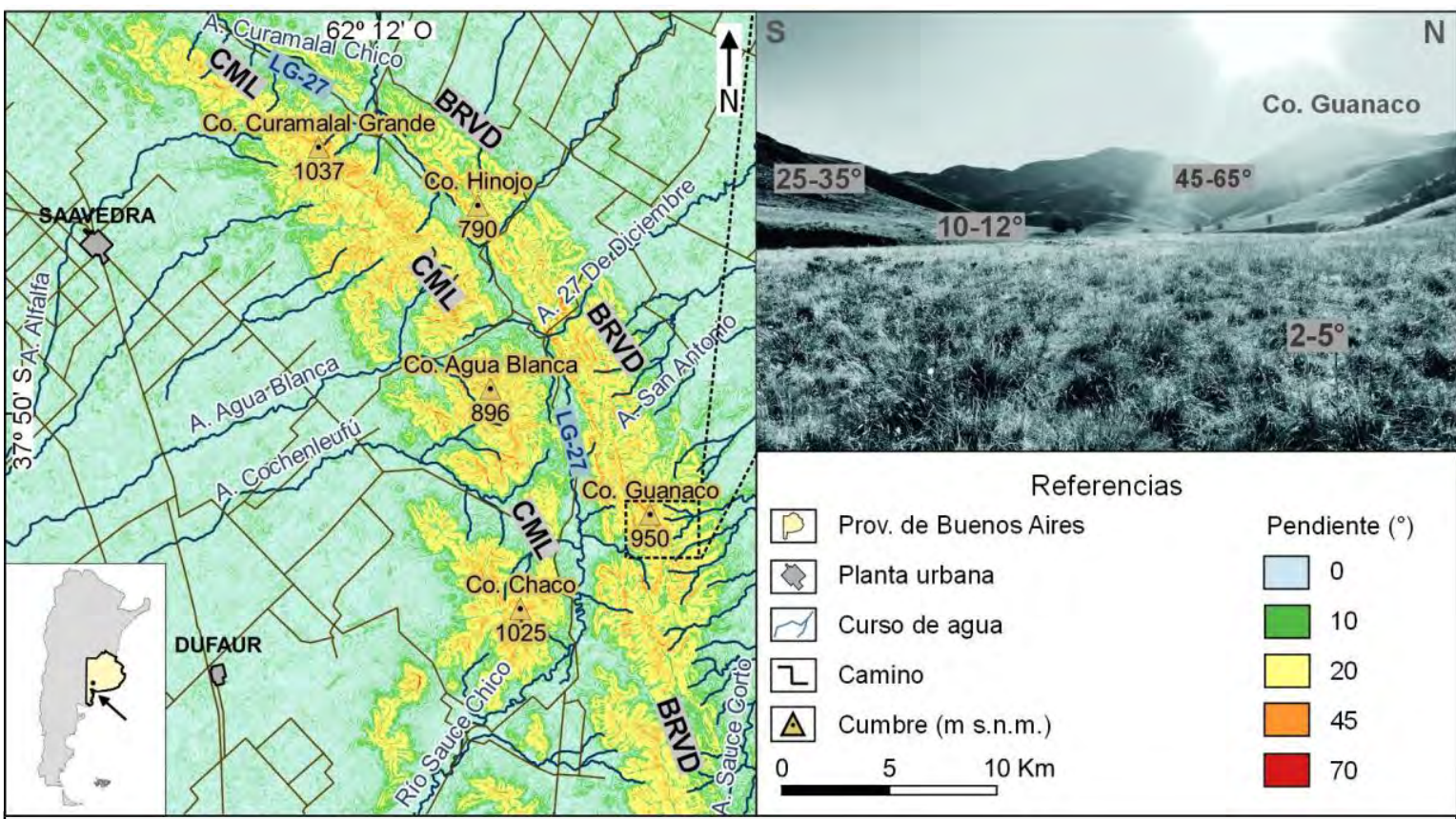

Figura 4.3. Mapa de pendientes del área estudiada. Elaboración propia a partir de la Cartografía Oficial del IGN y de modelo de elevación digital ALOS PALSAR. La etiqueta de $A^{\circ}$ Sauce Corto corresponde sólo a las cabeceras de su cuenca. La foto muestra superficies con diferentes pendientes en un sector el área estudiada. Los árboles próximos al centro de la imagen (levemente a la izquierda) sirven como escala, miden unos 4-5 m de altura. Foto: Juan M. Susena.

\subsection{Hidrografía}

La red hidrográfica se encuentra bien desarrollada, estando representada por arroyos generalmente perennes en sus cabeceras. Éstas se ubican en las zonas altas de las sierras, vinculándose con manantiales, y sus aguas escurren hacia las abras interserranas o hacia las llanuras circundantes. En los tramos medios de los arroyos más pequeños, el escaso caudal recibido suele infiltrarse o evaporarse, adoptando un carácter transitorio, es decir, su ocurrencia está ligada a las precipitaciones. Esta situación se da en casi todos los cursos procedentes de las sierras de Curamalal que drenan hacia el valle interserrano. En la llanura periserrana, los cursos de agua retoman el régimen permanente debido a la confluencia de arroyos perennes de escaso recorrido (como los de las laderas occidentales de las sierras de Bravard), generándose barrancas de hasta varios metros de profundidad. Más adelante en esta tesis se comentarán otras condiciones que propician la presencia de barrancas en la llanura periserrana.

El sector serrano delimitado en la zona de estudio constituye juntamente con el cordón de Ventana la principal divisoria de aguas superficiales del suroeste bonaerense, delimitando dos vertientes bien definidas. Por un lado, la vertiente nororiental y las abras interserranas del sector septentrional (a partir de la latitud del cerro Escaleras) drenan sus aguas hacia 
el norte mediante diferentes arroyos que descargan en lagunas del centro-oeste de la Provincia de Buenos Aires (lagunas Encadenadas del Oeste), como los arroyos Curamalal Grande, Curamalal Chico, Hinojo Grande, 27 de Diciembre, de las Cortaderas y San Antonio; en otros casos los cursos son desviados artificialmente para su aprovechamiento, o desaparecen gradualmente por infiltración y/o evapotranspiración. Por otra parte, la vertiente suroccidental y las abras interserranas del sector sur vierten sus aguas hacia el suroeste mediante arroyos de mayor importancia, como Cochenleufú Grande y Chico, Agua Blanca, entre otros, que desembocan en la laguna Las Encadenadas, o el arroyo Sauce Chico, de vertiente atlántica.

La Figura 4.4 y la Tabla 4.2 muestran la distribución y algunas características de las cuencas de drenaje y cursos de agua del área de estudio.

En cuanto al diseño, la red de drenaje presenta patrones controlados por la estructura geológica y la fisiografía local. A grandes rasgos, el patrón de drenaje es paralelo en el sector nororiental y occidental del ámbito serrano, y dendrítico en el sector suroccidental de la zona de trabajo al pie de las sierras. El valle intermontano (Valle de las Grutas/27 de Diciembre), aparentemente un valle de rumbo, drena las aguas hacia la llanura periserrana, saliendo de las sierras desde los extremos norte y sur de la zona de trabajo, o vertiendo sus aguas en los Arroyos Curamalal Grande, Hinojo Grande y 27 de Diciembre, cuyas abras representan un patrón de drenaje transverso. Los cursos del valle intermontano tienen un patrón de drenaje paralelo en las cabeceras y rectangular en el interior del valle. En sectores localizados, mayormente en las laderas orientales de las sierras de Bravard, la red de drenaje no se encuentra totalmente integrada, siendo éste un diseño de tipo anárquico, con una tendencia dendrítica (no indicado en los mapas previos por razones de escala). 
Movimientos en masa en las sierras de Bravard y Curamalal,

Sierras Australes de la Provincia de Buenos Aires.

Lic. Juan Manuel Susena

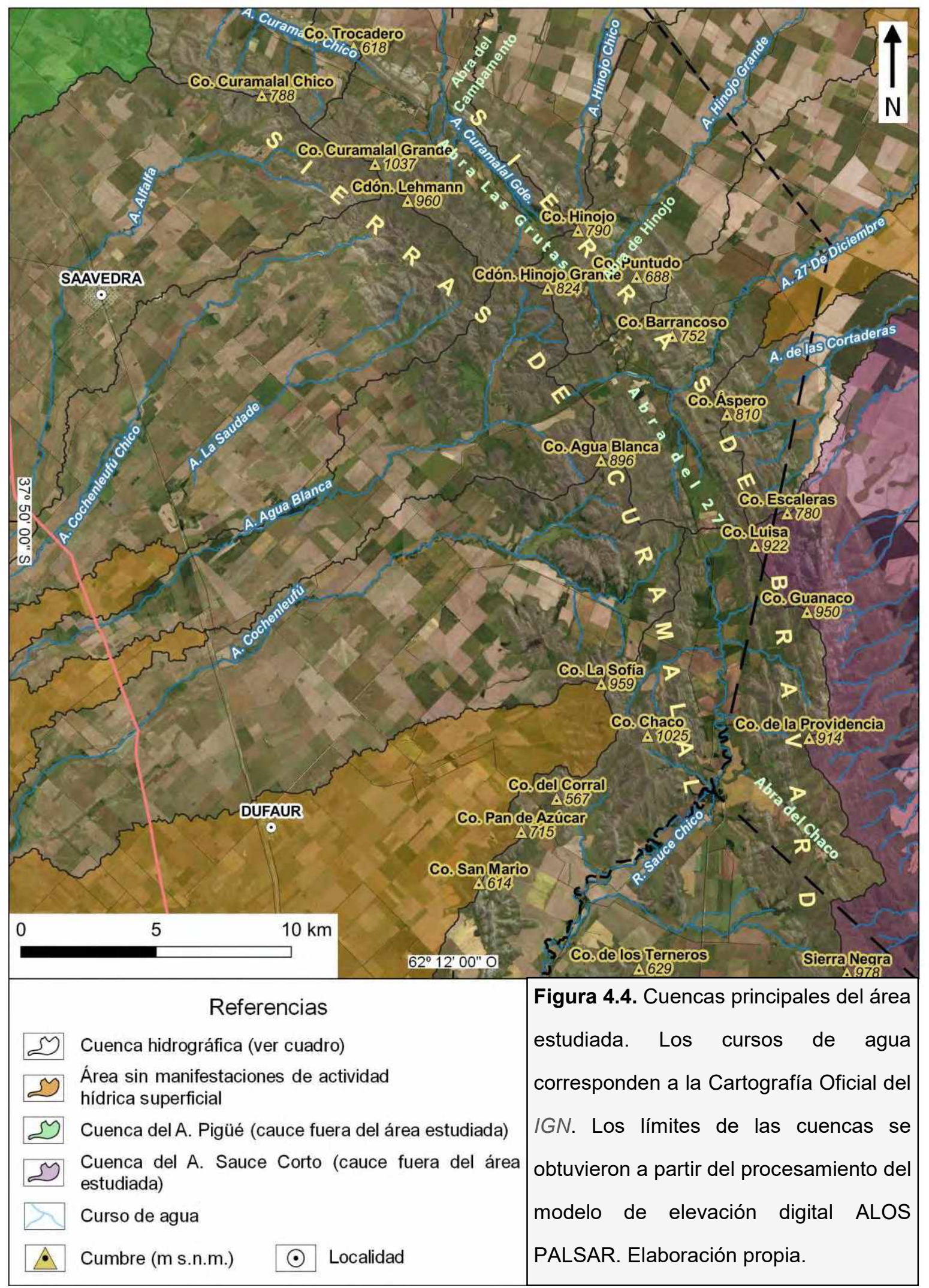




\begin{tabular}{|c|c|c|c|}
\hline $\begin{array}{l}\text { Nombre del } \\
\text { curso } \\
\text { principal }\end{array}$ & Breve descripción del recorrido & $\begin{array}{l}\text { Longitud total } \\
\text { incluyendo } \\
\text { afluentes } \\
(\mathbf{k m})^{*}\end{array}$ & $\begin{array}{l}\text { Área de la } \\
\text { cuenca } \\
\left(\mathbf{k m}^{2}\right)^{\star *}\end{array}$ \\
\hline$A^{\circ}$ Pigüé & $\begin{array}{l}\text { Surge } 7 \mathrm{Km} \text { al sur de la localidad de Pigüé, pasando por dicha } \\
\text { ciudad. Tiene un sentido general SSE-NNO con alternancias de } \\
\text { componentes N-S y E-O, desembocando en la Laguna Epecuén, } \\
\text { sumando un recorrido total de unos } 80 \mathrm{Km} \text {. }\end{array}$ & $\begin{array}{l}\text { No hay cauces } \\
\text { formados en el } \\
\text { área de } \\
\text { estudio. }\end{array}$ & 22,53 \\
\hline $\begin{array}{l}\text { A }^{\circ} \text { Curamalal } \\
\text { Chico }\end{array}$ & $\begin{array}{l}\text { Tiene sus nacientes en las laderas nororientales de las Sas. de } \\
\text { Curamalal (Abra de Saavedra, Co. Curamalal Chico) y } \\
\text { suroccidentales de las Sas. de Bravard (Co. Trocadero), donde } \\
\text { surgen pequeños arroyos que se unen al pie de las Sas. de Bravard } \\
\text { en el valle interserrano. La dirección de escurrimiento es hacia el } \\
\text { noroeste, saliendo de las sierras hasta verter las aguas en el arroyo } \\
\text { Pigüé, que desemboca en la Laguna Epecuén. }\end{array}$ & 16,86 & 24,18 \\
\hline $\mathrm{A}^{\circ}$ Alfalfa & $\begin{array}{l}\text { Surge de la ladera suroccidental de las Sas. de Curamalal y lleva } \\
\text { sus aguas hacia el suroeste, pasando por la localidad de Saavedra, } \\
\text { tributando al Arroyo Cochenleufú Chico en las cercanías de la Ruta } \\
\text { Nacional } 33 .\end{array}$ & 26,53 & 122,45 \\
\hline $\begin{array}{l}\text { A }^{\circ} \text { Curamalal } \\
\text { Grande }\end{array}$ & $\begin{array}{l}\text { Sus aguas descienden desde el Abra las Grutas y el Cordón } \\
\text { Lehmann, conformándose definitivamente el curso donde se } \\
\text { encuentra el monolito General L. M. Campos, al pie del Co. } \\
\text { Trocadero. Con algunos tributarios más provenientes de la ladera } \\
\text { nororiental de las Sas. de Bravard, el cauce vierte sus aguas hacia } \\
\text { el norte hasta culminar en la Laguna Alsina. }\end{array}$ & 25,57 & 51,99 \\
\hline $\begin{array}{l}\mathrm{A}^{\circ} \\
\text { Cochenleufú } \\
\text { Chico }\end{array}$ & $\begin{array}{l}\text { Tiene su origen pocos kilómetros al sur del Arroyo Alfalfa, y se } \\
\text { dirige hacia el suroeste, tributando al Arroyo Cochenleufú. }\end{array}$ & $\begin{array}{l}22,33 \\
\text { No se incluye } \\
\quad \text { al } \mathrm{A}^{\circ} \mathrm{La} \\
\text { Saudade como } \\
\text { tributario. }\end{array}$ & 127,16 \\
\hline $\begin{array}{c}\mathrm{A}^{\circ} \mathrm{La} \\
\text { Saudade }\end{array}$ & $\begin{array}{l}\text { Nace al sur del Cordón Lehmann, y sus aguas drenan hacia el O. } \\
\text { Recorre el piedemonte hasta las cercanías del camino que une } \\
\text { Saavedra y Dufaur, donde es canalizado hasta el } \text { A }^{\circ} \text { Cochenleufú } \\
\text { Chico. El IGN (fuente de los mapas de este capítulo) no expresa la } \\
\text { canalización. }\end{array}$ & $\begin{array}{l}20,03 \\
\text { No se incluye } \\
\text { la canalización } \\
\text { mencionada. }\end{array}$ & $\begin{array}{l}\text { Pertenece } \\
\text { a la cuenca } \\
\text { del } A^{\circ} \\
\text { Cochenleuf } \\
\text { ú Chico. }\end{array}$ \\
\hline $\begin{array}{l}\text { A Hinojo } \\
\text { Chico/Ojo de } \\
\text { Agua }\end{array}$ & $\begin{array}{l}\text { Las cabeceras se encuentran en la ladera nororiental del Co. } \\
\text { Hinojo (Sierras de Bravard) y sus aguas escurren hacia el noreste, } \\
\text { desembocando en una laguna ubicada aproximadamente } 18 \mathrm{Km} \text { al } \\
\text { norte de Coronel Suárez sobre la Ruta } 85 \text {. }\end{array}$ & 9,18 & 38,87 \\
\hline $\begin{array}{l}\text { A }^{\circ} \text { Hinojo } \\
\text { Grande }\end{array}$ & $\begin{array}{l}\text { El escurrimiento superficial proveniente del Cordón de Hinojo } \\
\text { Grande y del Cerro Hinojo se encauza en el Abra de Hinojo, } \\
\text { transversal a las Sierras de Bravard, y discurre hacia el noreste, } \\
\text { hasta su desembocadura en el Arroyo Sauce Corto, } 5 \mathrm{Km} \text { al este } \\
\text { del pueblo San José. }\end{array}$ & 19,61 & 82,42 \\
\hline $\begin{array}{l}\mathrm{A}^{\circ} 27 \mathrm{de} \\
\text { Diciembre }\end{array}$ & $\begin{array}{l}\text { El Abra } 27 \text { de Diciembre se encuentra entre el Cerro Barrancoso y } \\
\text { el Cerro Áspero, en las Sierras de Bravard; en éstos se encuentran } \\
\text { las cabeceras del arroyo, que lleva sus aguas hacia el noreste,... }\end{array}$ & 28,33 & 87,09 \\
\hline
\end{tabular}


Movimientos en masa en las sierras de Bravard y Curamalal,

Sierras Australes de la Provincia de Buenos Aires.

Lic. Juan Manuel Susena

\begin{tabular}{|c|c|c|c|}
\hline & $\begin{array}{l}\text {...tributando al Arroyo Sauce Corto } 10 \mathrm{Km} \text { al sur del pueblo Santa } \\
\text { María, al oeste de la ruta } 85 .\end{array}$ & & \\
\hline $\begin{array}{l}\text { A Agua } \\
\text { Blanca }\end{array}$ & $\begin{array}{l}\text { Drena las aguas de la ladera sur del Cordón de Hinojo Grande y de } \\
\text { la ladera norte del Cerro Agua Blanca, separados entre sí por el } \\
\text { Abra de Agua Blanca, llevando su cauce hacia el occidente, hasta } \\
\text { el Arroyo Cochenleufú Chico a unos } 7 \mathrm{Km} \text { al oeste de la Ruta } 33 \text {. }\end{array}$ & 38,78 & 84,60 \\
\hline $\begin{array}{l}\mathrm{A}^{\circ} \\
\text { Cochenleufú/ } \\
\text { Cochenleufú } \\
\text { Grande }\end{array}$ & $\begin{array}{l}\text { Las cabeceras se ubican en la vertiente sur del Cerro Agua Blanca } \\
\text { y en la vertiente norte del Cerro La Sofía, ubicándose entre éstas } \\
\text { el Abra de la Sofía, dentro de las Sierras de Curamalal. Drena sus } \\
\text { aguas hacia el suroeste, hasta desembocar en la Laguna Las } \\
\text { Encadenadas. }\end{array}$ & 48,36 & 168,64 \\
\hline $\begin{array}{l}\mathrm{A}^{\circ} \text { de las } \\
\text { Cortaderas }\end{array}$ & $\begin{array}{l}\text { Sus cabeceras se ubican en la ladera oriental de los Cerros } \\
\text { Áspero, Escaleras y Mogote San Antonio, y su curso se orienta } \\
\text { hacia el este, tributando al Arroyo Sauce Corto, tras un recorrido } \\
\text { de unos } 10 \mathrm{Km} \text {. }\end{array}$ & 27,09 & 30,27 \\
\hline $\begin{array}{l}\text { A }^{\circ} \text { San } \\
\text { Antonio }\end{array}$ & $\begin{array}{l}\text { Tiene un destino similar al anterior, sus nacientes se ubican en los } \\
\text { Cerros Luisa, Guanaco y Mogote San Antonio. }\end{array}$ & 8,16 & $\begin{array}{c}\text { Pertenece } \\
\text { a la cuenca } \\
\text { del } A^{\circ} \\
\text { Sauce } \\
\text { Corto } \\
\text { (fuera del } \\
\text { área } \\
\text { estudiada). }\end{array}$ \\
\hline $\begin{array}{l}\text { R. Sauce } \\
\text { Chico }\end{array}$ & $\begin{array}{l}\text { Drena las aguas de los Cerros Agua Blanca, Luisa, Guanaco, de la } \\
\text { Providencia y Chaco, a través del valle interserrano desde la zona } \\
\text { del abra del } 27 \text { hacia el sur, tornándose su cauce hacia el suroeste } \\
\text { cerca del Fortín Chaco. Desemboca en el Estuario de Bahía Blanca, } \\
\text { en la localidad de General Daniel Cerri. }\end{array}$ & 73,78 & 165,36 \\
\hline $\begin{array}{l}\text { A o R. Sauce } \\
\text { Corto }\end{array}$ & $\begin{array}{l}\text { Sus cabeceras, en el SE del área estudiada, drenan hacia el ENE, } \\
\text { denominándose Sauce Corto a partir de unos } 8 \mathrm{Km} \text { al O del área. } \\
\text { Este arroyo/río drena sus aguas hacia el } \mathrm{N} \text {, desembocando en la } \\
\text { Laguna Alsina, tras recorrer unos } 150 \mathrm{Km} \text {. }\end{array}$ & $\begin{array}{l}105,98 \\
\text { Incluye } A^{\circ} \text { San } \\
\text { Antonio y de las } \\
\text { Cortaderas, y } \\
\text { sus tributarios. }\end{array}$ & 104,71 \\
\hline $\begin{array}{l}\text { Sin cursos } \\
\text { destacables }\end{array}$ & Cuencas arreicas o de escurrimiento superficial no encauzado. & No aplica & 191,39 \\
\hline \multicolumn{4}{|c|}{$\begin{array}{l}\text { Tabla 4.2. Principales cursos de agua del área estudiada, ordenados en sentido norte-sur. } \\
{ }^{\star} \text { Calculado sólo dentro del área estudiada, en base a la Cartografía Oficial del IGN. }{ }^{*} \text { Calculado } \\
\text { sólo dentro del área estudiada, a partir del procesamiento del DEM ALOS PALSAR. Elaboración } \\
\text { propia. }\end{array}$} \\
\hline
\end{tabular}

\subsection{Características climáticas}

Previo a comenzar la lectura de esta sección se recomienda revisar la Figura 3.2, del capítulo anterior, que muestra la ubicación de las estaciones meteorológicas utilizadas. 
Siguiendo la clasificación de Thornthwaite (1948), en base a datos climáticos del período 1981-2010 de las estaciones Coronel Suárez y Pigüé, se determinó que el clima es B1 B'1 s/w: Húmedo, Mesotérmico, con moderada deficiencia en verano/moderada deficiencia en invierno. Para dicho período, la precipitación anual media en Coronel Suárez y Pigüé es de $807 \mathrm{~mm}$.

Entre las décadas de 1930 y 2010, los valores medios registrados son de $787 \mathrm{~mm}$ en Coronel Suárez (período 1936-2011) y 756 mm en Pigüé (período 1935-2016). Considerando estos períodos, el monto de precipitación anual tiene una tendencia creciente, tendiendo a superar la precipitación anual media aproximadamente en la segunda mitad de la década de 1980 en Coronel Suárez, y entre la primera mitad de la década de 1980 y la primera mitad de la del 2000 en Pigüé (Figura 4.5). Schwerdtfeger y Vasino (1954) mencionan variaciones seculares de precipitación en la Región Pampeana, con un aumento anual de los valores de precipitación de $2,5 \mathrm{~mm}$ en el entorno de las Sierras Australes. Estos autores se basaron en datos de la Estación Tornquist (al sur del área estudiada en esta tesis) del período 1901-1950; de acuerdo con sus predicciones, sería esperable un incremento de unos $150 \mathrm{~mm}$ hacia finales de la década del 2000 . Tomando como base $645 \mathrm{~mm}$, valor medio de precipitación anual del período 1901-1950 en Tornquist (Schwerdtfeger y Vasino, 1954), estas predicciones aproximadamente se cumplen comparando los $645 \mathrm{~mm}$ con los $787 \mathrm{~mm}$ de Coronel Suárez (período 1936-2011) y los 756 mm de Pigüé (período 1935-2016). No obstante, como se indica en la Tabla 4.3, donde se comparan además valores de estaciones del área estudiada en esta tesis, las predicciones antedichas no se cumplen todos los años, lo cual muestra un comportamiento oscilatorio de los montos de precipitación anual en la región.

En cuanto a la estacionalidad de las precipitaciones, la Figura 4.6 muestra las diferencias entre las distribuciones mensuales de precipitación de las series "largas" (décadas de 1930 a 2010) y las "cortas", las últimas, separadas previa y posteriormente a la década de 1980. Los montos mensuales de las series "largas" tienen una distribución bimodal con marzo y octubre como meses más lluviosos, y julio como mes más seco, tanto en Coronel Suárez como en Pigüé. A partir de la década de 1980, esta distribución cambió: en Coronel Suárez el mes de enero se convirtió en el más lluvioso, en alternancia con marzo, enmascarando la distribución bimodal del período 1936-2011, mientras que en Pigüé, un incremento en las precipitaciones de enero y febrero, diluyen la distribución bimodal del mes más lluvioso del período 1935-2016 (Susena y Gentile, 2019). De acuerdo con Rosell y Ángeles (2012), un aumento en la concentración de las precipitaciones podría incrementar la torrencialidad de los cursos de agua en el piedemonte medio y distal, perjudicando potencialmente a las poblaciones establecidas aguas abajo, como Pigüé y Saavedra. Al respecto, Gaspari et al. 
Movimientos en masa en las sierras de Bravard y Curamalal,

Sierras Australes de la Provincia de Buenos Aires.

Lic. Juan Manuel Susena

(2008) determinaron una agresividad (erosividad) de las precipitaciones baja a media a escala regional, indicando por otra parte un aumento en la erosividad debido al incremento en la concentración temporal de las precipitaciones. Particularmente en Coronel Suárez, indican un aumento en la estacionalidad desde 1908 hasta la fecha del trabajo, desde moderada a altamente estacional.

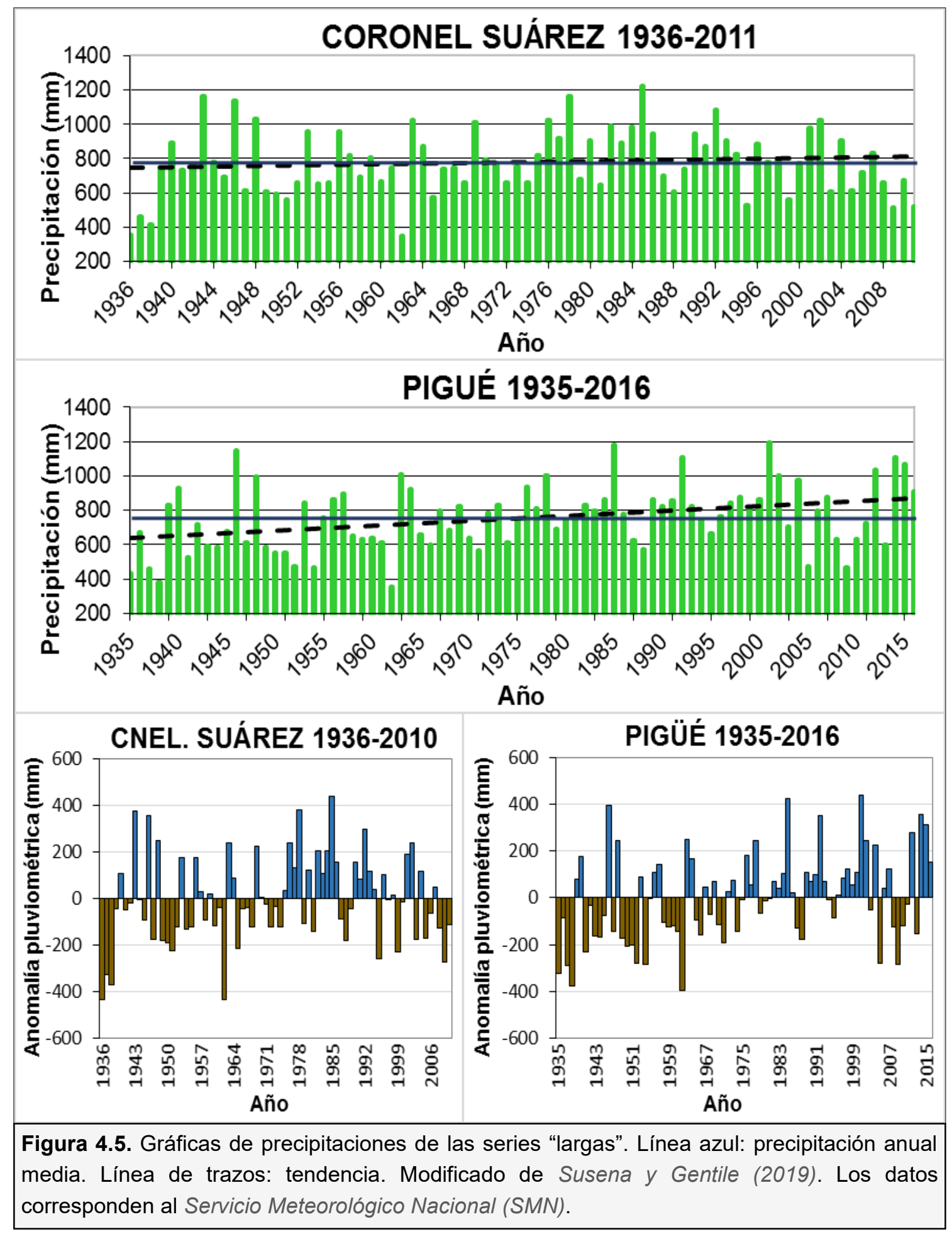




\begin{tabular}{|c|c|c|c|c|c|c|}
\hline Año & $\begin{array}{c}\text { Precipitación } \\
\text { esperada en } \\
\text { Tornquist }\end{array}$ & $\begin{array}{c}\text { Tornquist } \\
\text { (Cuartel II) }\end{array}$ & Pigüée & Saavedra & Dufaur & $\begin{array}{c}\text { Coronel } \\
\text { Suárez }\end{array}$ \\
\hline 2005 & 782,5 & 494 & 503 & 481 & 501 & 462 \\
2006 & 785 & 655 & 772 & 843 & 757 & 615 \\
2007 & 787,5 & 839 & 797 & 719 & 685 & 712 \\
2008 & 790 & 598 & 624 & 620 & 474 & 587 \\
2009 & 792,5 & 652 & 448 & 609 & 540 & 459 \\
2010 & 795 & 754 & 638 & 655 & 649 & 604 \\
2011 & 797,5 & 753 & 615 & 733 & 594 & 591 \\
2012 & 800 & 723 & 1021 & 1012 & 882 & 1090 \\
2013 & 802,5 & 644 & 573 & 609 & 508 & 476 \\
2014 & 805 & 1217 & 1164 & 1224 & 1129 & 1126 \\
2015 & 807,5 & 914 & 1053 & 1108 & 924 & 909 \\
2016 & 810 & 688 & 904 & 737 & 663 & 840 \\
2017 & 812,5 & 710 & 969 & 1008 & 809 & 907 \\
\hline
\end{tabular}




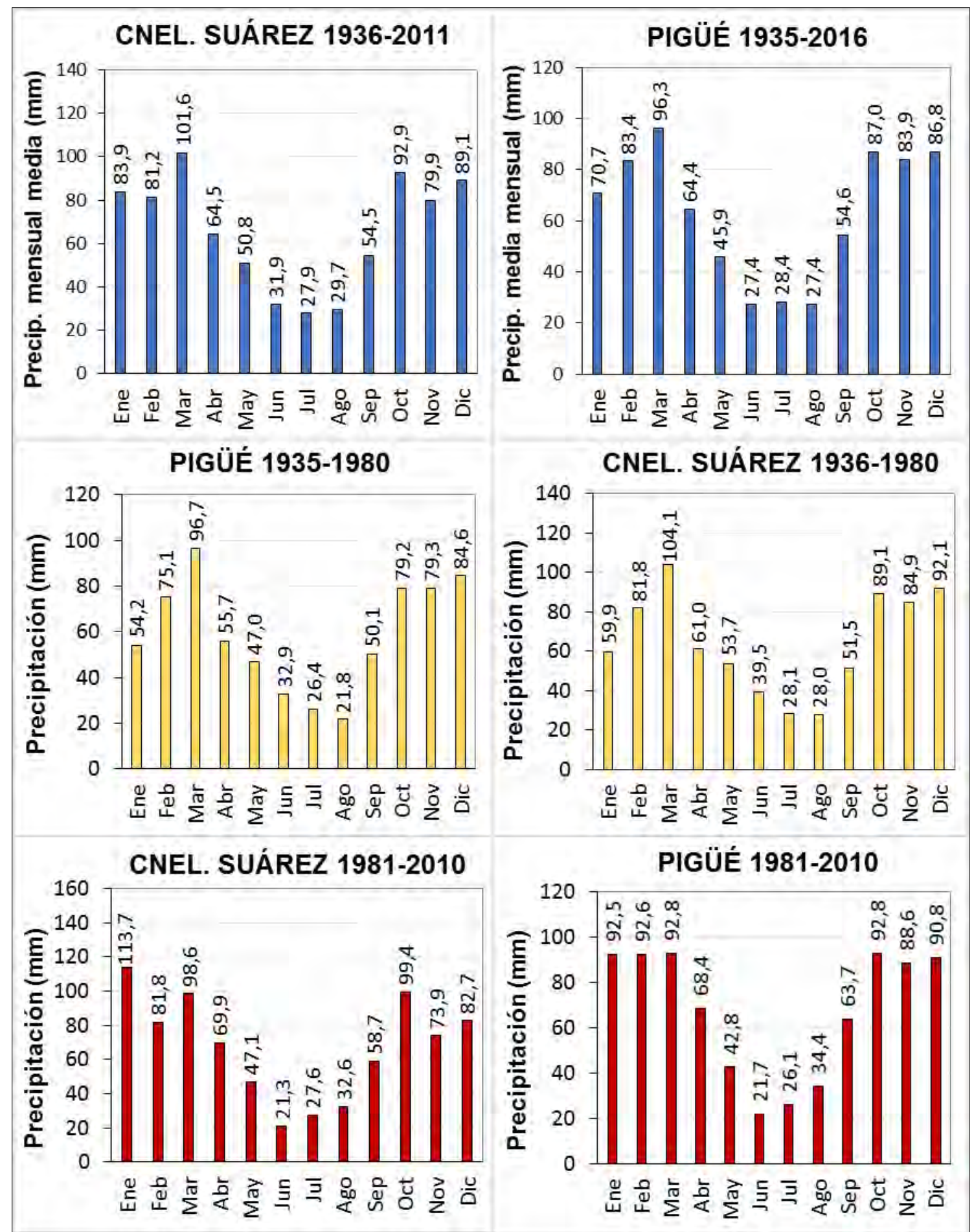

Figura 4.6. Gráficas de precipitaciones mensuales de las series "largas" (azul) y de las series "cortas" previas a la década de 1980 (amarillo) y posteriores a dicha década (rojo). Nótese el cambio en la distribución de las precipitaciones en el período 1981-2010 en ambas estaciones, muy acentuado en el mes de enero. Elaboración propia, excepto gráficos azules, tomados de Susena y Gentile (2019).

Por su parte, en la Estancia Cerro Áspero (período 1983-2013), la única estación ubicada en el ámbito serrano, la precipitación media anual es de $964 \mathrm{~mm}$, más de $100 \mathrm{~mm}$ mayor que en Coronel Suárez y Saavedra, ambas ubicadas fuera de las sierras. Diferencias 
locales en la distribución de las precipitaciones debido a la orografía de las Sierras Australes fueron identificadas por varios autores, entre ellos, Zapperi et al. (2007); Gil (2009; 2011); Gentili et al. (2011); Gentili y Gil (2013). Los meses más lluviosos en la Estancia Cerro Áspero son enero y marzo, y el más seco, junio (Figura 4.7).

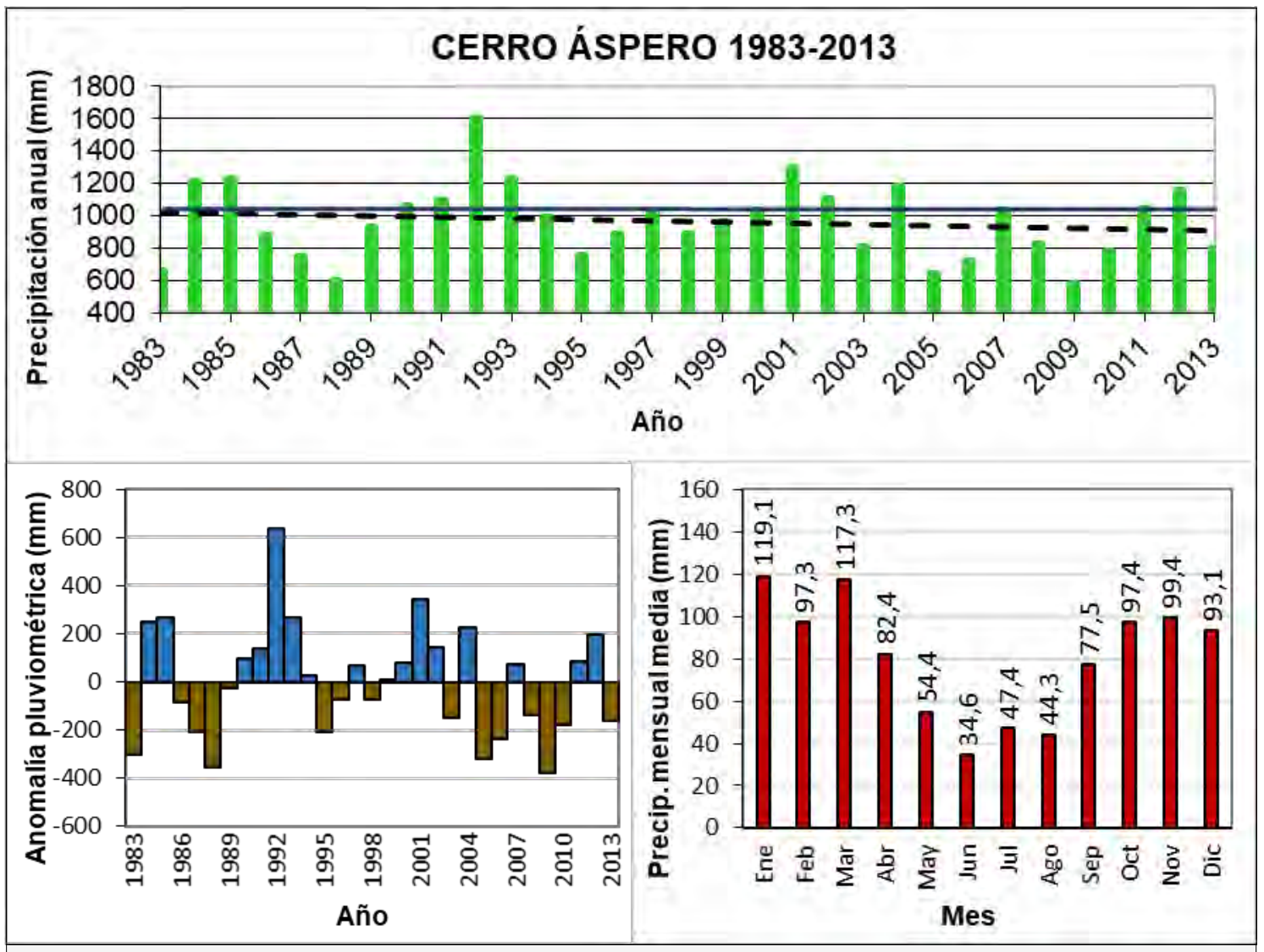

Figura 4.7. Gráficas de precipitaciones en la Estancia Cerro Áspero. Línea azul: precipitación anual media. Línea de trazos: tendencia. Tomado de Susena y Gentile (2019).

En las tres estaciones analizadas, la tendencia de las precipitaciones anuales entre las décadas de 1980 y 2010 (hasta donde se tienen datos), es decreciente (Figuras 4.7 y 4.8). Esto concuerda con estudios de Delgado et al. (2009), quienes detectan la misma tendencia decreciente a partir de la década de 1970 al sur del área estudiada. Al respecto, Campo et al. (2009) remarcan que las variaciones temporales y espaciales del régimen pluvial son una característica distintiva del suroeste bonaerense, y que su conocimiento es importante para tomar decisiones de manejo que mitiguen los efectos adversos.

Scarpati y Capriolo (2013) analizan eventos de inundaciones y sequías en la Provincia de Buenos Aires. Entre sus resultados, indican que el área de esta tesis (a escala regional) es uno de los sectores con menos riesgo de inundación (Tabla 4.4). Allí, los máximos valores medios decádicos de excesos de agua se alcanzaron durante las décadas de 1979-1988 (vertiente nororiental) y de 1989-1998 (vertientes occidental y sudoriental). Durante la década de 1969-1978 la vertiente noroccidental tuvo riesgo de sequía, mientras que la 
Movimientos en masa en las sierras de Bravard y Curamalal,

Sierras Australes de la Provincia de Buenos Aires.

Lic. Juan Manuel Susena

sudoccidental fue afectada por una sequía en la década 1978-1988, y nuevamente afectada junto a las orientales durante la década de 1989-1998. Al sur del área estudiada, Uboldi et al. (2011) indican riesgo de incendios forestales y de pastizales vinculados a la actividad turística y especulativamente a cambios climáticos.

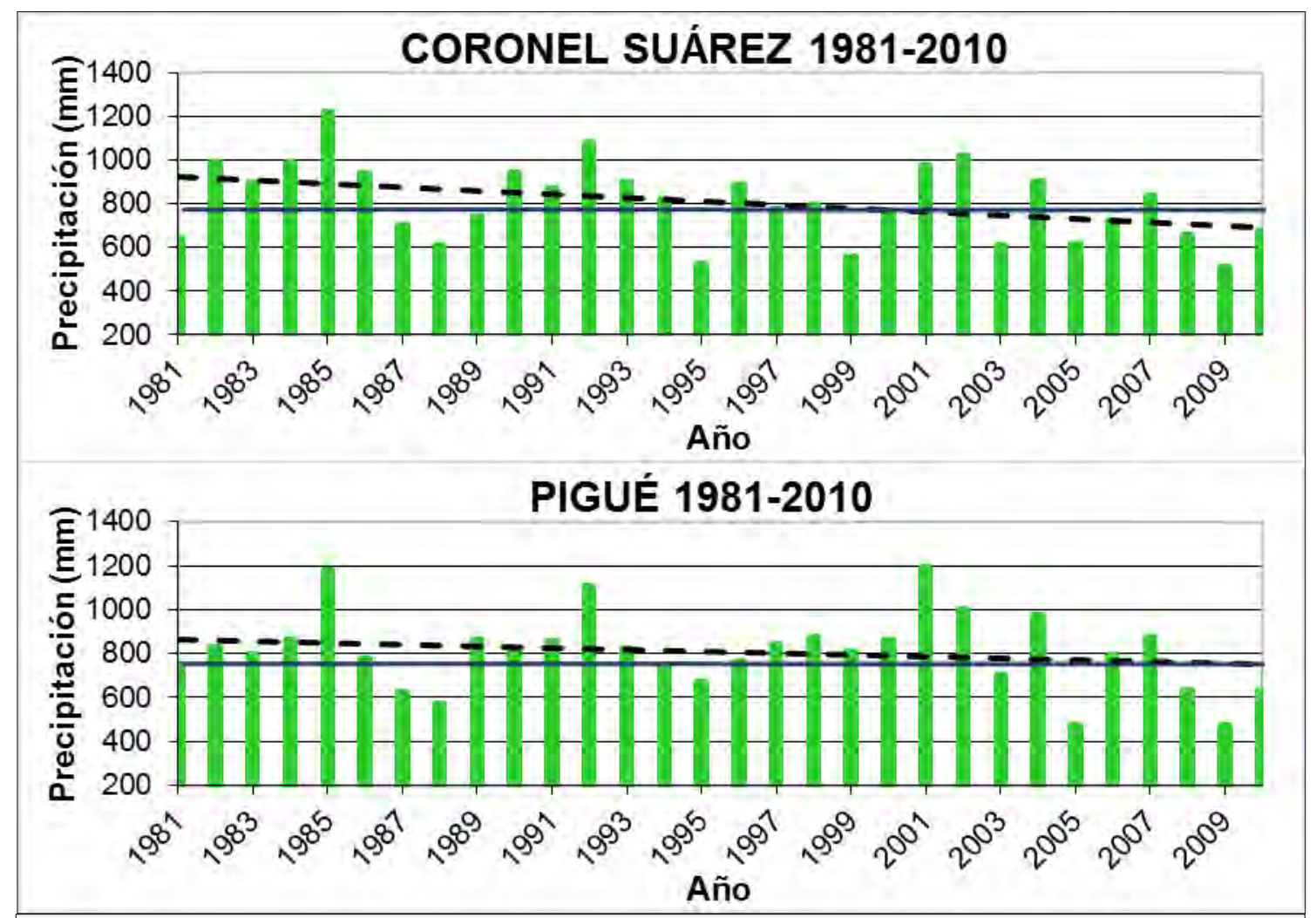

Figura 4.8. Gráficas de precipitaciones de las series "cortas". Línea azul: precipitación anual media. Línea de trazos: tendencia. Elaboración propia a partir de datos del SMN.

\begin{tabular}{|c|c|c|c|c|c|c|c|c|}
\hline \multirow{2}{*}{ Vertiente } & \multicolumn{4}{|c|}{ Nivel de excesos } & \multicolumn{4}{|c|}{ Nivel de sequías } \\
\hline & Bajo & Moderado & Severo & Extremo & Bajo & Moderado & Severo & Extremo \\
\hline Nororiental & 30 & 5 & 5 & 0 & 6 & 20 & 12 & 2 \\
\hline Noroccidental & 33 & 6 & 1 & 0 & 0 & 2 & 19 & 19 \\
\hline Sudoccidental & 40 & 0 & 0 & 0 & 0 & 0 & 0 & 40 \\
\hline Sudoriental & 38 & 2 & 0 & 0 & 7 & 16 & 15 & 2 \\
\hline
\end{tabular}

El área de estudio presenta la mayor duración del período de heladas de la Región Pampeana (185 días promedio entre los años 1964 y 2003), aproximadamente desde la segunda quincena de abril hasta la segunda de octubre (Fernández Long et al., 2005). El promedio de días al año con heladas son 44 en Coronel Suárez y 51 en Pigüé (Pereyra et 
al., 2001). La Figuras 4.9 y 4.10 y sus respectivas Tablas 4.5 y 4.6 muestran eventos fríos extremos, donde puede observarse en algunos casos varios días de duración de heladas (temperaturas bajo cero).

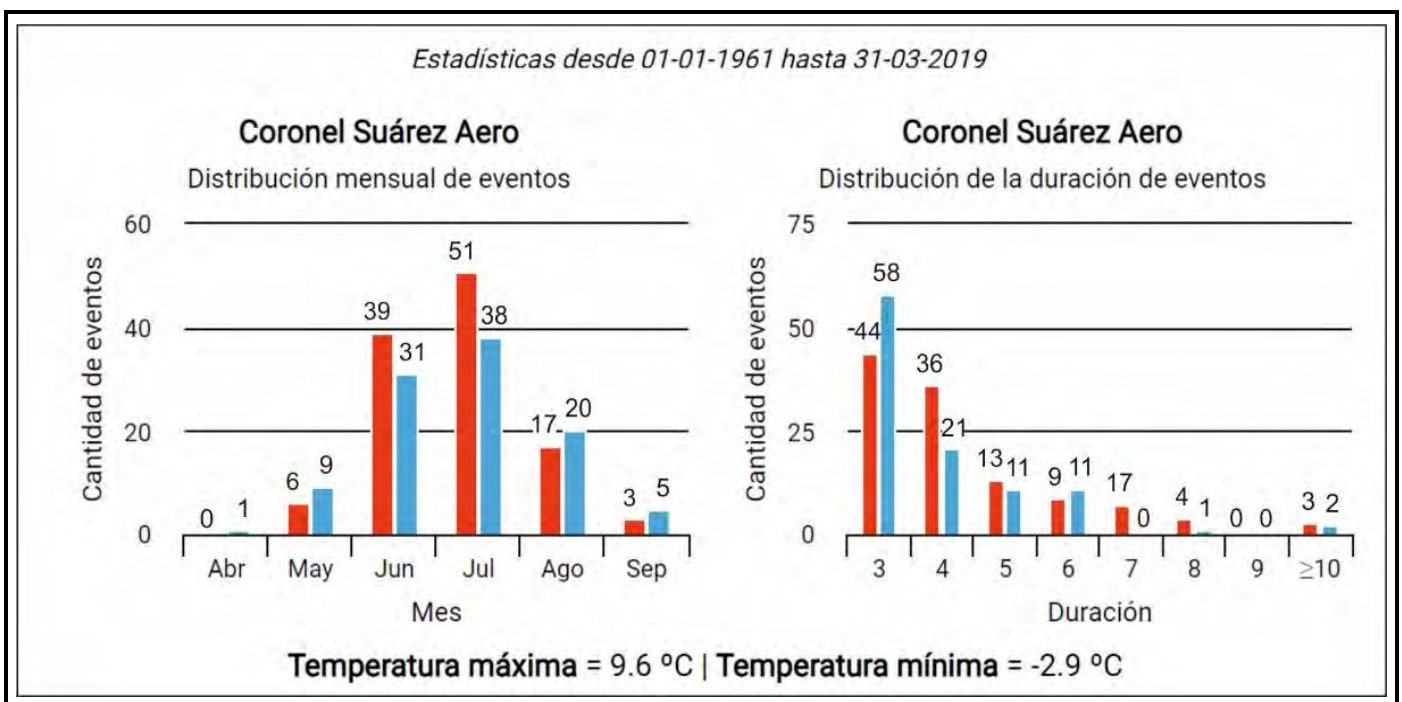

Figura 4.9. Coronel Suárez: eventos excesivamente fríos y distribución de la duración (días). Se considera eventos excesivamente fríos a los que presentan temperaturas máximas (rojo) o mínimas (azul) menores que los umbrales señalados. Total para todo el período: 104 eventos. Fuente: Servicio Meteorológico Nacional.

\begin{tabular}{|ccccc|}
\hline Duración (días) & $\begin{array}{c}\text { Fecha de } \\
\text { inicio }\end{array}$ & Fecha de fin & $\begin{array}{c}\text { Temperatura mínima } \\
\text { absoluta }\end{array}$ & $\begin{array}{c}\text { Temperatura mínima } \\
\text { promedio }\end{array}$ \\
\hline 11 & $2007-07-06$ & $2007-07-16$ & -13.5 & -8 \\
10 & $1988-07-03$ & $1988-07-12$ & -10.5 & -7.8 \\
8 & $2007-06-05$ & $2007-06-12$ & -4.6 & -3.9 \\
6 & $1967-06-12$ & $1967-06-17$ & -10.1 & -6.1 \\
6 & $1983-07-22$ & $1983-07-27$ & -9.1 & -5 \\
\hline
\end{tabular}

Tabla 4.5. Coronel Suárez: períodos excesivamente fríos (con respecto a la temperatura mínima) más largos. Elaboración propia a partir de datos del SMN. 
Movimientos en masa en las sierras de Bravard y Curamalal,

Sierras Australes de la Provincia de Buenos Aires.

Lic. Juan Manuel Susena

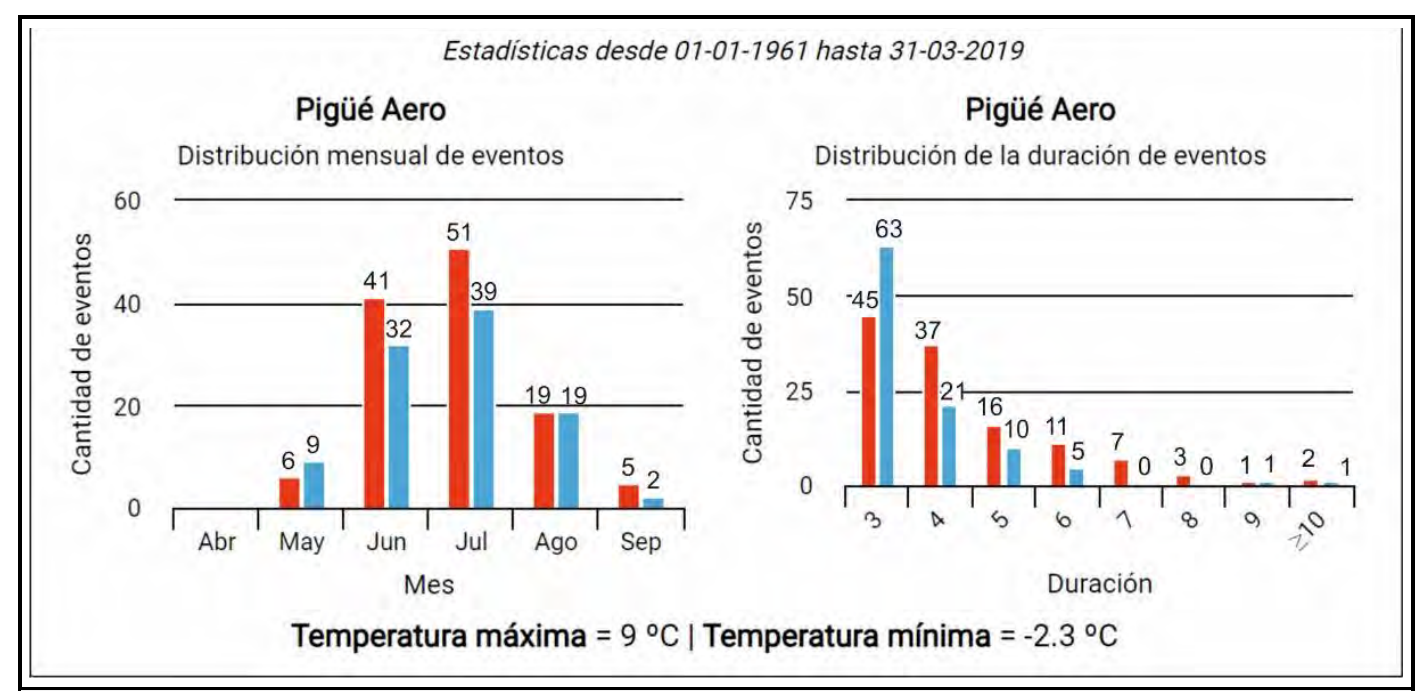

Figura 4.10. Pigüé: eventos excesivamente fríos y distribución de la duración (días). Se considera eventos excesivamente fríos a los que presentan temperaturas máximas o mínimas menores que los umbrales señalados. Total para todo el período: 101 eventos. Fuente: Servicio Meteorológico Nacional (SMN).

\begin{tabular}{|ccccc|}
\hline Duración (días) & $\begin{array}{c}\text { Fecha de } \\
\text { inicio }\end{array}$ & $\begin{array}{c}\text { Fecha de } \\
\text { fin }\end{array}$ & $\begin{array}{c}\text { Temperatura mínima } \\
\text { absoluta }\end{array}$ & $\begin{array}{c}\text { Temperatura mínima } \\
\text { promedio }\end{array}$ \\
\hline 11 & $1961-06-08$ & $1961-06-18$ & -7.3 & -5.1 \\
9 & $2007-07-07$ & $2007-07-15$ & -9 & -5.7 \\
6 & $1967-06-12$ & $1967-06-17$ & -10.5 & -6.2 \\
6 & $1988-07-04$ & $1988-07-09$ & -7 & -6 \\
6 & $1991-07-31$ & $1991-08-05$ & -8 & -5.1 \\
\hline
\end{tabular}

Tabla 4.6. Pigüé: períodos excesivamente fríos (con respecto a la temperatura mínima) más largos. Elaboración propia a partir de datos del SMN.

\subsection{Suelos}

Clásicamente, los suelos y su génesis son estudiados en torno al concepto de factores formadores del suelo (Jenny, 1941). En este sentido, para el ámbito de las Sierras Australes, se considera que los factores formadores de mayor variabilidad son, en orden creciente, el clima, el material parental y el relieve (Cappannini et al., 1974). Respecto al clima, pueden diferenciarse localmente los regímenes údico y ústico, al oriente y occidente de las sierras de Bravard, respectivamente (INTA, 1995). Para el área de estudio, debe considerarse además a la biota como un factor formador de creciente variabilidad e importancia, puesto que la rápida expansión de poblaciones de vegetación forestal introducida en las últimas décadas ha generado fuertes contrastes en varios aspectos. Por un lado, se ha incrementado el aporte de material orgánico al suelo en sectores localizados, originando verdaderos horizontes orgánicos (Figura 4.11). Por otra parte, la presencia de 
árboles en muchos sectores modificó la disposición superficial del material parental (particularmente las fracciones guija, piedra y bloque) afectando la distribución de las condiciones de pedregosidad.

Los suelos con mayor distribución areal en el ámbito de las Sierras Australes corresponden a hapludoles y argiudoles (Cappannini et al., 1974), originados a partir de los sedimentos loéssicos de la Fm. Saavedra y limos loessoides de la Fm. Agua Blanca (Pereyra y Ferrer, 1997). Se encuentran preferentemente en la zona periserrana, tanto en zonas de relieve convexo como en depresiones, y en los valles intraserranos. Su

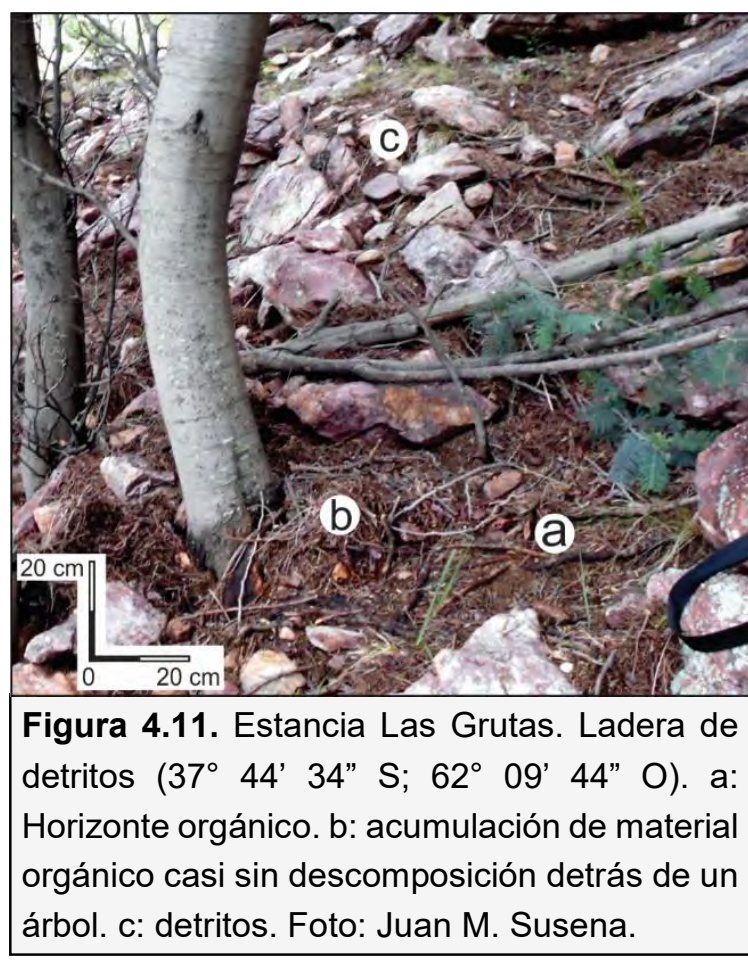
espesor y grado de desarrollo se encuentran fuertemente condicionados por el relieve local y por la profundidad del contacto con la capa de tosca subyacente.

Para el ámbito serrano, los suelos también se desarrollan sobre los depósitos eólicos, mezclados o no con detritos, y sobre materiales de origen aluvial, generando en este último caso, hapludoles cumúlicos (INTA, 1995). En el primer caso, son mencionados hapludoles líticos, bien drenados, que se ubican en lomadas y cuyos contenidos de materia orgánica y texturas los hacen "estables a la erosión" en terrenos con pendientes que pueden ser mayores al 5\% (Cappannini et al., 1974). Los suelos desarrollados sobre material eólico con mezcla de detritos, clasificados por los mismos autores como argiudoles líticos y hapludoles líticos, se encuentran en las laderas de detritos. Estos suelos se consideran resistentes a la erosión hídrica, en pendientes de hasta un $16 \%$ en zonas aledañas. Cabe mencionar que los autores indican, para los faldeos de las sierras, un aumento en profundidad de los detritos rocosos y un desarrollo en profundidad de los procesos pedogenéticos, incluso hasta las grietas de la roca subyacente. Parte de estos hapludoles líticos, fueron reclasificados como udortentes líticos por Hurtado y Giménez (1988), quienes hacen notar que los mayores contenidos de materia orgánica y densidad de vegetación ocurren en laderas de umbría. La Figura 4.12 y la Tabla 4.7 muestran algunos tipos de los suelos mencionados y sus texturas. 


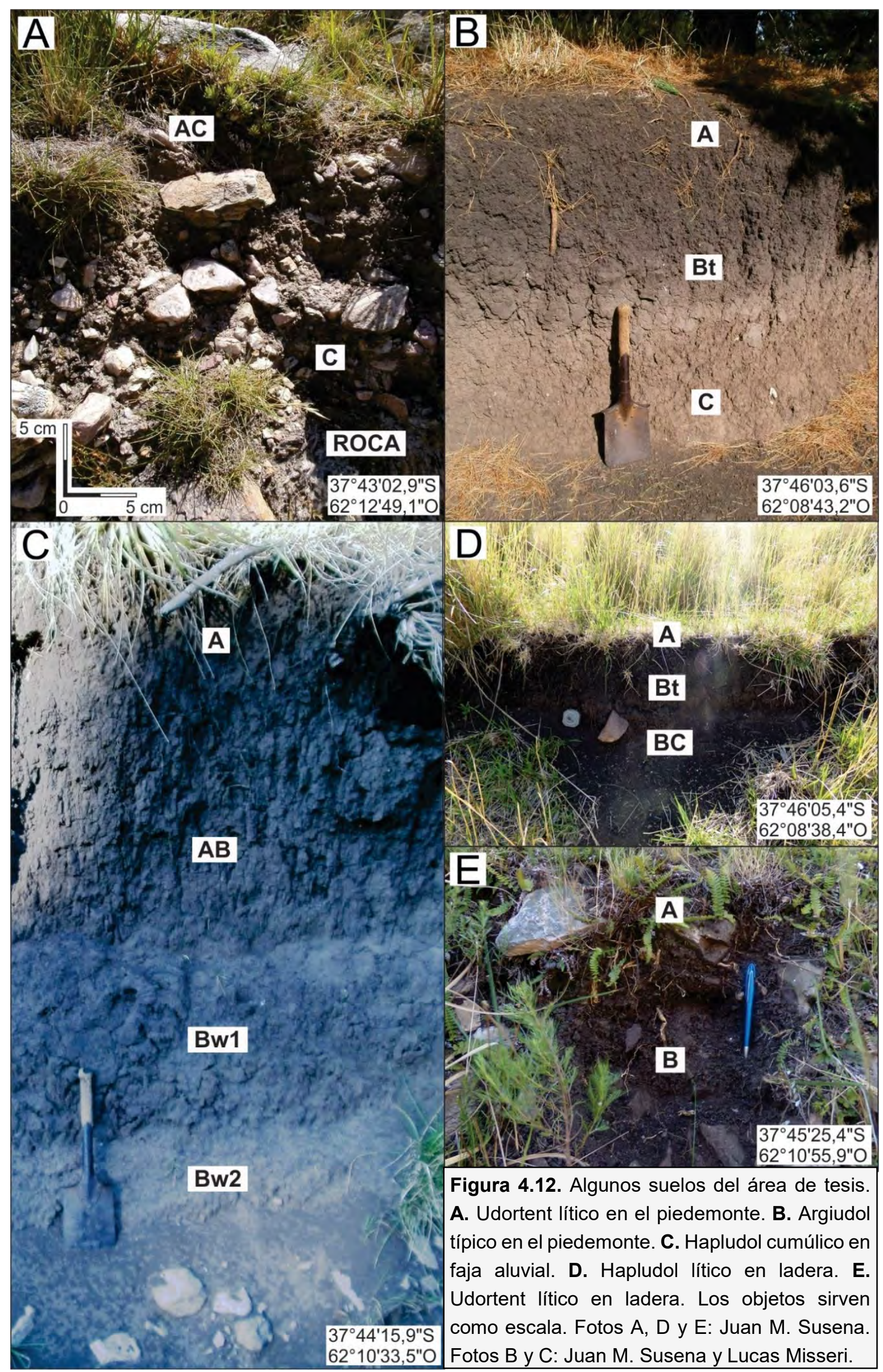




\begin{tabular}{|c|c|c|c|c|c|c|}
\hline Perfil & Horizonte & $\% a$ & $\% L$ & $\% A$ & Clase textural & Ubicación del ejemplo \\
\hline \multirow{2}{*}{$\begin{array}{l}\text { Udortent lítico } \\
\text { (en piedemonte) }\end{array}$} & $A C$ & 5,50 & 32,01 & 62,49 & Franco arenosa & \multirow{2}{*}{$\begin{array}{l}37^{\circ} 43^{\prime} 02,9 " \mathrm{~S} \\
62^{\circ} 12^{\prime} 49,1^{\prime \prime} \mathrm{O}\end{array}$} \\
\hline & $\mathrm{C}$ & 7,50 & 32,00 & 60,50 & Franco arenosa & \\
\hline \multirow{3}{*}{ Argiudol típico } & A & 10,51 & 40,03 & 49,47 & Franca & \multirow{3}{*}{$\begin{array}{l}37^{\circ} 46^{\prime} 03,6 \text { " S } \\
62^{\circ} 08^{\prime} 43,2^{\prime \prime} \mathrm{O}\end{array}$} \\
\hline & $\mathrm{Bt}$ & 22,51 & 36,02 & 41,47 & Franca & \\
\hline & C & 25,52 & 33,02 & 41,46 & Franca & \\
\hline \multirow{4}{*}{$\begin{array}{l}\text { Hapludol } \\
\text { cumúlico }\end{array}$} & $A$ & 11,51 & 44,02 & 44,47 & Franca & \multirow{4}{*}{$\begin{array}{l}37^{\circ} 44^{\prime} 15,9 " \mathrm{~S} \\
62^{\circ} 10^{\prime} 33,5 \text { " O }\end{array}$} \\
\hline & $A B$ & 41,03 & 38,03 & 20,94 & Arcillosa & \\
\hline & Bw1 & 39,04 & 44,04 & 16,92 & Franco arcillo limosa & \\
\hline & Bw2 & 37,03 & 46,03 & 16,94 & Franco arcillo limosa & \\
\hline \multirow{3}{*}{ Hapludol lítico } & A & 21,02 & 58,04 & 20,94 & Franco limosa & \multirow{3}{*}{$\begin{array}{l}37^{\circ} 46^{\prime} 05,4^{\prime \prime} \mathrm{S} \\
62^{\circ} 08^{\prime} 38,4^{\prime \prime} \mathrm{O}\end{array}$} \\
\hline & $\mathrm{Bt}$ & 43,04 & 32,03 & 24,93 & Arcillosa & \\
\hline & $\mathrm{BC}$ & 39,02 & 42,03 & 18,95 & Franco arcillo limosa & \\
\hline \multirow{2}{*}{$\begin{array}{l}\text { Udortent lítico } \\
\text { (en laderas) }\end{array}$} & A & 21,03 & 42,05 & 36,92 & Franca & \multirow{2}{*}{$\begin{array}{l}37^{\circ} 45^{\prime} 25,4^{\prime \prime} \mathrm{S} \\
62^{\circ} 10^{\prime} 55,9^{\prime \prime} \mathrm{O}\end{array}$} \\
\hline & $B$ & 9,01 & 44,06 & 46,93 & Franca & \\
\hline
\end{tabular}

\subsection{Vegetación}

Desde hace casi dos siglos, existen menciones de la vegetación de la zona. En la Colección de Obras y Documentos (Angelis, 1836) se transcriben relatos del jesuita Falkner, quien cuenta que los Puelches, habitantes originarios, utilizaban la denominación Hueyque-leubú (arroyo pequeño de los sauces), en referencia al arroyo Sauce Chico, ya que en ese entonces existían sauces colorados (Salix humboldtiana) en sus orillas (Aguirre, 1891). Aguirre menciona para los alrededores de Tornquist (al sur del área de estudio) árboles de chañar (Gourliae decorticans), piquillín (Candalia lineata), barba de chivito, algarrobilla (Prosopis humilis), sombra de toro (Jodina rombifolia), molle (Duvaua sp.) y algarrobo (Prosopis sp., Figura 4.13), además de arbustos y gramíneas.

La vegetación predominante en la zona de estudio es alóctona o invasora, introducida antrópicamente, con una componente nativa relíctica, limitada al ámbito serrano, a zonas muy bajas y a las vías férreas o postes de alambrados (Cabrera, 1968). En los últimos veinte años se desarrollaron, en torno al valle intermontano, comunidades de pinos, aromos, algarrobos, entre otros, que están modificando la expresión paisajística rápidamente (Figura 4.13). La mayoría de estos bosques fueron plantados para dar refugio y descanso al ganado. Los bosques de aromos más antiguos, situados en torno a 
Movimientos en masa en las sierras de Bravard y Curamalal,

Sierras Australes de la Provincia de Buenos Aires.

Lic. Juan Manuel Susena

manantiales en laderas de detritos, alcanzaron un estado de madurez, con desarrollo de suelos con un contenido de materia orgánica relativamente alto, a pesar de las pendientes moderadas a altas y la erosión hídrica que ello supone.

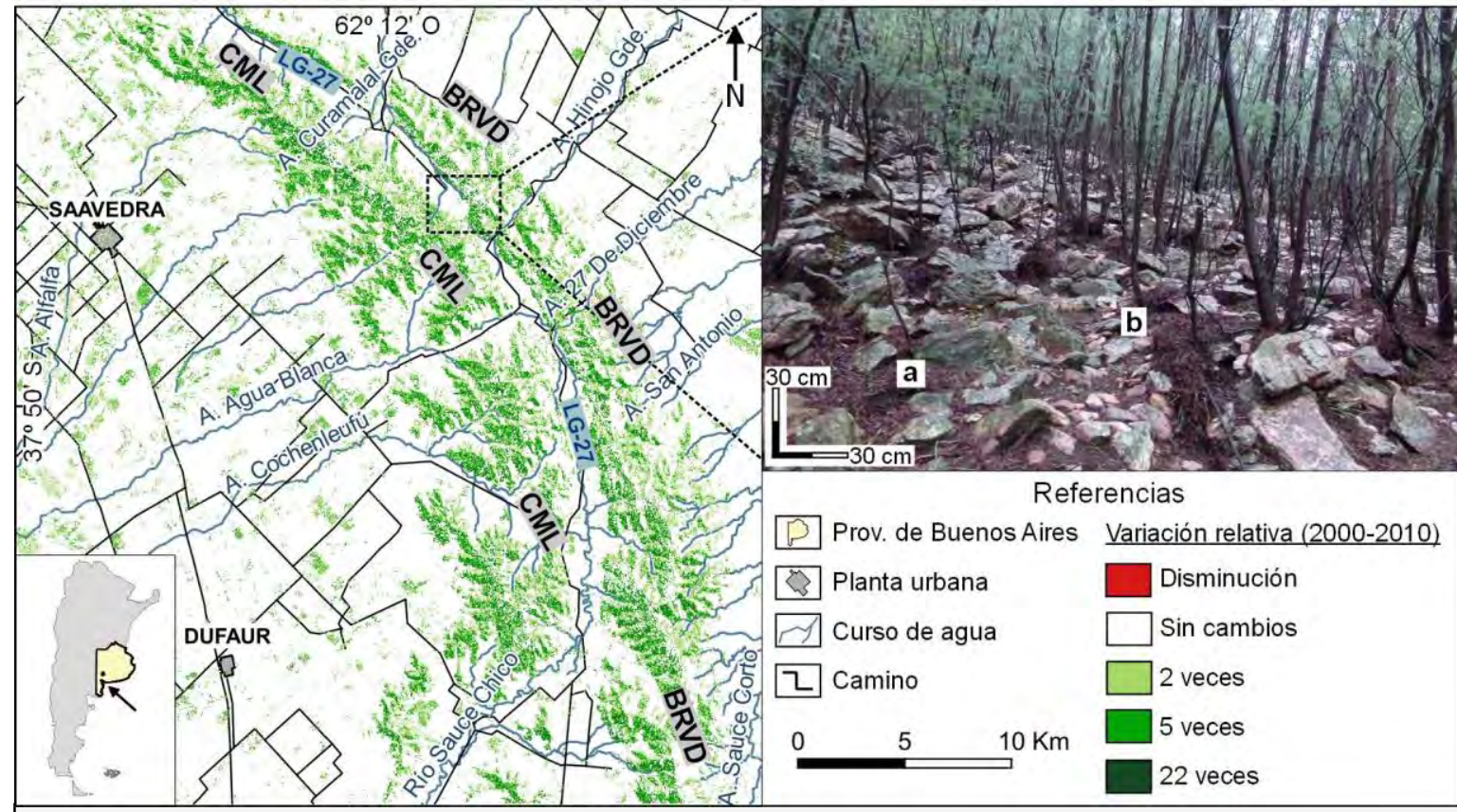

Figura 4.13. Cambios en la superficie cubierta por arboleda entre los años 2000 y 2010. CML: Sierras de Curamalal. BRVD: Sierras de Bravard. LG-27: Valle de las Grutas-27 de Diciembre. La foto muestra un joven bosque de algarrobos. a: horizontes de suelo orgánicos. b: sector con mayor concentración de clastos con partes recientemente expuestas (nótese la ausencia de colonias de líquenes en parte de sus superficies). Tomado de Susena y Gentile (2019).

Siguiendo al autor Cabrera, la reconstrucción fitogeográfica correspondería a la Región Neotropical, Dominio Chaqueño, Provincia Pampeana, Distrito Austral (clasificación de Cabrera, 1953). En la zona de estudio predomina la estepa de gramíneas (poáceas), con comunidades arbustivas subordinadas, formando tres comunidades climácicas (o climáxicas):

1. Asociación de los géneros Stipa neesiana (Figura 4.14.A), Stipa clarazii, Stipa trichotoma, Stipa tenuis, Piptochaetium napostaense, Piptochaetium lejopodium y Poa ligularis (Asociación $1^{a}$ en Cabrera, 1968). Contiene además gramíneas de los géneros Bromus, Melica, Hordeum, Bouteloa, Briza, entre otros. Generalmente esta asociación es denominada estepa de flechillas, aunque también se conforma de diferentes especies de hierbas (Glandularia peruviana, Glandularia pulchella, Pfaffia gnaphalioides, Senecio ceratophilloides, Convolvulus hermanniae, Oxalis cordobensis, etc.), arbustos y sufrútices (Discaria longispina o Discaria americana (Figura 4.14.B), Margyricarpus pinnatus, Baccharis ulicina). Las especies endémicas son Sphaeralcea australis, Micropsis autralis, entre otras. 
2. Consociación de Stipa caudata (Asociación $1^{b}$ en Cabrera, 1968), (Figura 4.14.C). Esta comunidad es descripta como una estepa de matas muy robustas, ubicadas en suelos más húmedos y de relieve ondulado en las cercanías de Tornquist. Las especies Stipa caudata, Stipa neesiana, Paspalum quadrifarium, Bromus unioloides, Poa bonariensis, Oxalis cordobensis, Oxalis articulata, Baccharis coridifolia (Figura 4.14.D) y Solanum gracile integran dicha comunidad.

3. Consociación de Stipa ambigua, integrada por matas robustas de dicha especie, acompañada por otras "flechillas", Glandularia pulchella, Nierembergia aristata, Vicia graminea, Spilanthes decumbens, Facelis retusa, Gamochaeta subfalcata, etc., y la leguminosa Medicago minima (Asociación $1^{c}$ en Cabrera, 1968). Esta asociación se ubica en valles y laderas de la zona de estudio.

Las comunidades serales, es decir, integrantes de una sucesión ecológica primaria o secundaria, y que suelen ser las primeras en crecer luego de algún cambio brusco en las condiciones del ambiente (sequías, inundaciones, incendios, movimientos en masa, cosechas, etc.), constan de matorrales de brusquilla (Discaria longispina o Discaria

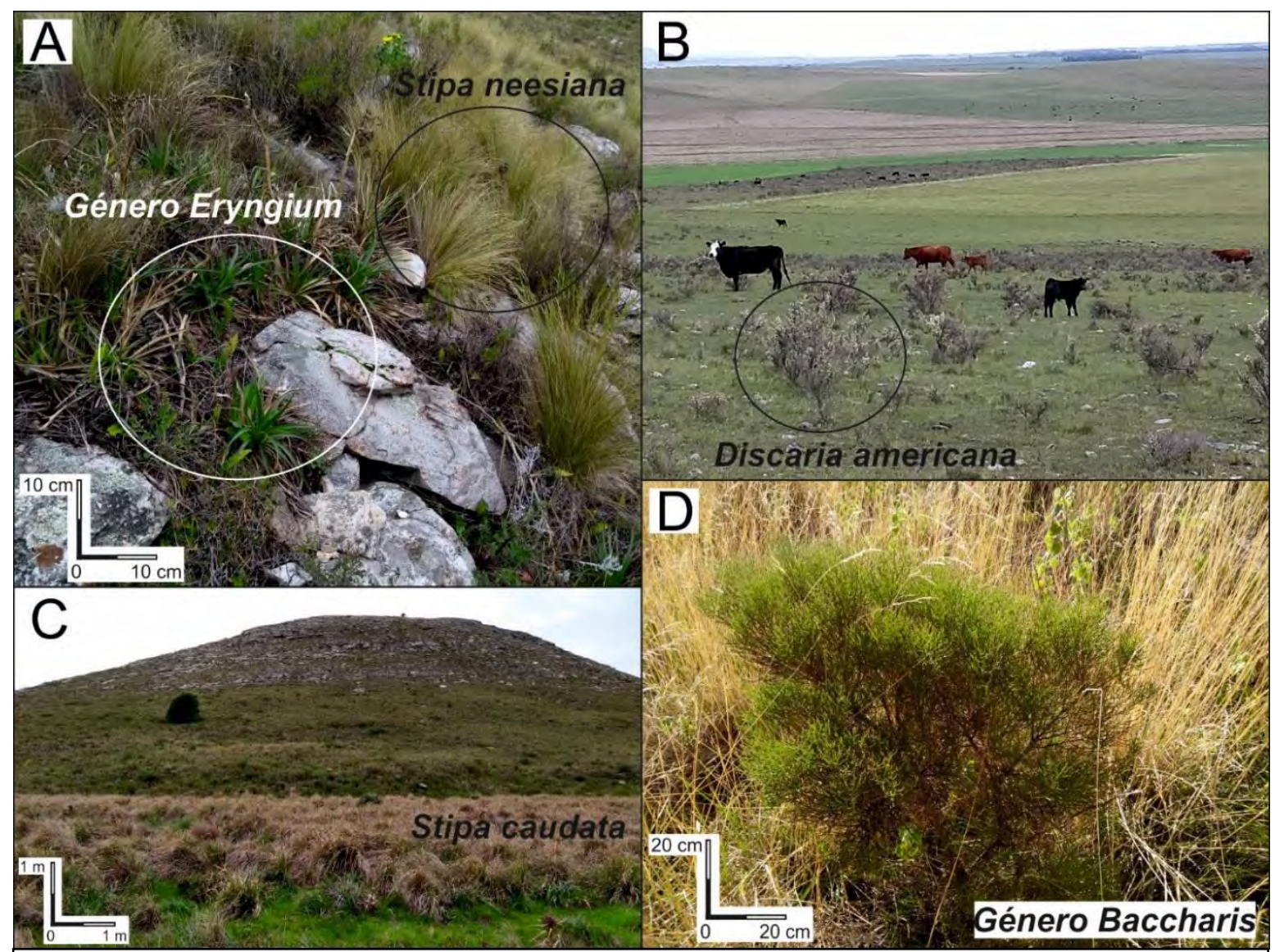

Figura 4.14. Algunas plantas típicas del área de estudio. La ubicación exacta de cada foto se considera irrelevante. A. Foto tomada en una ladera. B. Foto tomada en el piedemonte. Nótese el carácter no palatable de Discaria americana. Los animales sirven como escala. C. Stipa caudata es más habitual en planicies de inundación que en laderas. D. Baccharis es un género común en laderas, así como en niveles de piedemonte. Fotos: Juan M. Susena. 
Movimientos en masa en las sierras de Bravard y Curamalal,

Sierras Australes de la Provincia de Buenos Aires.

Lic. Juan Manuel Susena

americana), asociados con pajonales de carda (Eryngium eburneum) (Figura 4.14.A), Eupatorium buniifolium, Baccharis articulata, Mimosa rocae, Wedelia buphthalmiflora y gramíneas de las comunidades climácicas (Asociación 3 en Cabrera, 1968). Otras especies presentes son Linum selaginoides, Convolvulus hermanniae, Margyricarpus pinnatu, Pavonia cymbalaria, Dichondra argentea, Glandularia platensis, Oenothera stricta, Cereus aethiops, Opuntia pampeana, las cactáceas Gymnocalycium gibbosum, Wigginsia tephracantha y Notocactus ottonis. Existen también especies patagónicas, como Gavilea adoratissima, Mulinum spinosum y matas de Gaultheria phyllireifolia.

En la zona periserrana abundan los matorrales de manca-caballo (Asociación 4 en Cabrera, 1968), característicos de suelos con capas de tosca (calcretas) a poca profundidad. Las especies predominantes son Prosopidastrum globosum, Lycium chilense, Discaria longispina y gramíneas de las comunidades climácicas.

En las laderas orientadas hacia el suroeste, que contienen mayor humedad, predominan los pajonales de carda (Asociación 5 en Cabrera, 1968), con Eeryngium eburneum como especie característica, acompañada por gramíneas como Briza triloba, Schizachyrium intermedium, Festuca ventanicola, Festuca pampeana, a triloba, Schizachyrium intermedium, entre otras de las comunidades climácicas y hierbas de los matorrales de brusquilla. Asimismo, se encuentra la asociación de Paspalum quadrifarium, o pajonales de paja colorada (Asociación 7 en Cabrera, 1968).

Los roquedales ubicados a más de 500 metros de altitud conforman la asociación de las especies endémicas Festuca ventanicola, Stipa pampeana y Stipa Juncoides (Asociación 6 en Cabrera, 1968), denominada estepa oreófila. Conviven además arbustos y sufrútices endémicos como Plantago bismarkii, Mimosa rocae, Senecio ventanensis, y helechos que crecen en grietas. Los líquenes que cubren los afloramientos y detritos rocosos son de la especie Usnea hieronymi, de uso medicinal. Kristensen y Frangi (1996) reconocieron en los roquedales del área de Sierra de la Ventana (aledaña a la zona de estudio, y con características ambientales similares), diferentes mesoclimas, cuyo origen se atribuye a un control geomorfológico determinante en los regímenes de temperatura y humedad. Dicho control se vincula principalmente a la magnitud de las pendientes y su orientación.

\subsection{Fauna}

Existe en el área una gran diversidad faunística, pero sólo se enfatizará en la fauna que pudiera generar algún tipo de expresión morfológica en el paisaje, que de alguna manera se vincule con el estudio de movimientos en masa. Entre los mamíferos pueden citarse animales de mediano a gran porte, como pumas, guanacos, caballos cimarrones, jabalíes 
(Figura 4.15.A) y ciervos colorados (Figura 4.15.B), animales de pequeño porte como antílopes (Figura 4.15.C), gatos monteses y zorros, y animales excavadores o creadores de madrigueras, como liebres, vizcachas, peludos y cuises, entre otros roedores. Entre las aves y reptiles, pueden citarse el avestruz y el loro barranquero (Figura 4.15.D), el lagarto overo y la yarará, un tipo de serpiente venenosa.

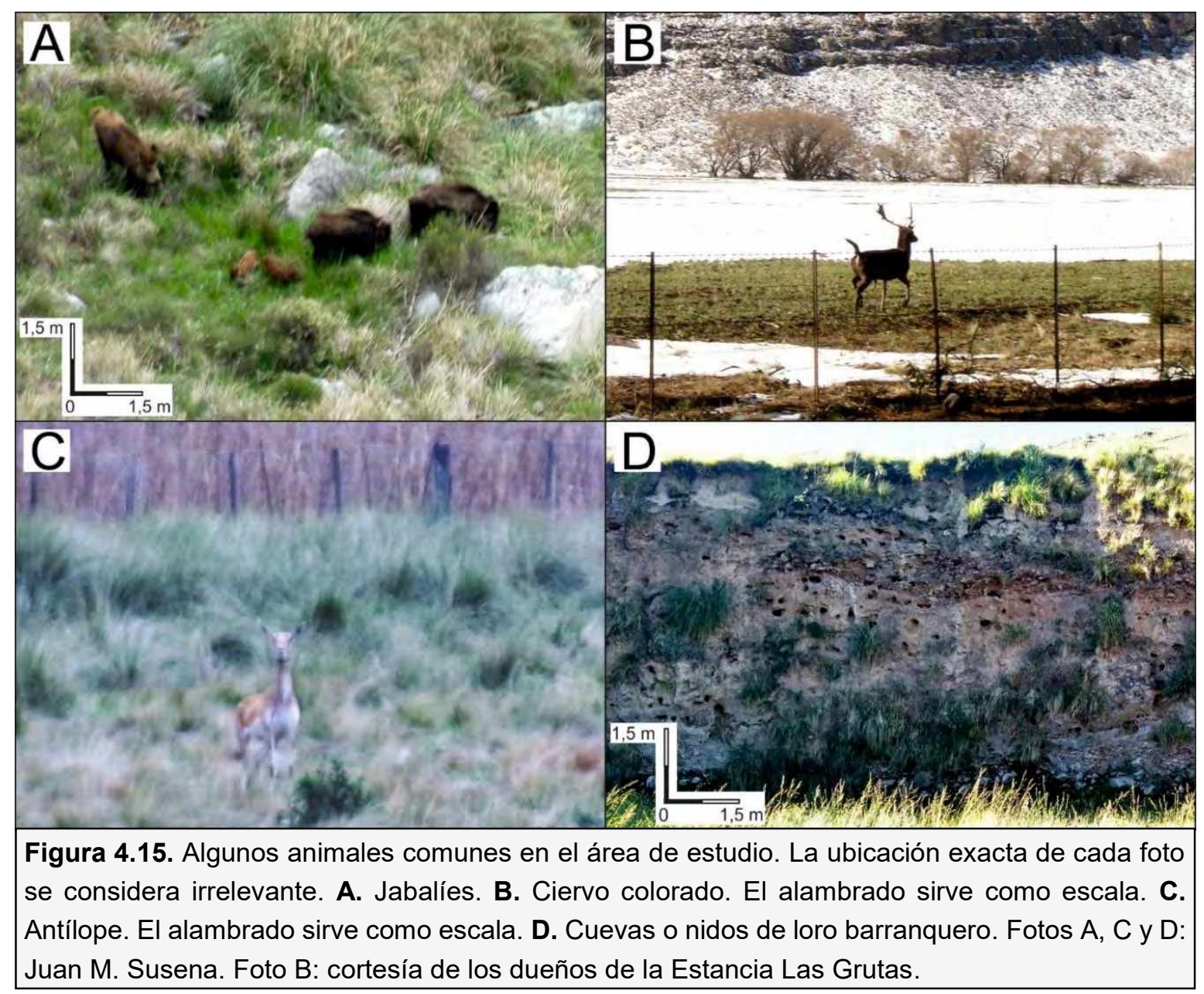

\subsection{Demografía y actividades económicas principales}

Como se mencionara más arriba, el área estudiada se ubica en los partidos de Coronel Suárez, Saavedra y Tornquist, mayormente en Saavedra (Figura 4.2). La densidad poblacional es relativamente baja, y la principal actividad económica es la agropecuaria (Tabla 4.8). El partido de Tornquist es el más conocido a nivel turístico, aunque Saavedra y Coronel Suárez crecieron en dicho aspecto en los últimos años, debido a un impulso del turismo rural a nivel regional. La Figura 4.16 muestra variaciones temporales en la producción agropecuaria. Puede observarse un descenso de la actividad agrícola en Tornquist muy acentuado a fines de la década de 1980, y un fuerte incremento en Coronel Suárez a partir de la segunda mitad de la década del 2000, mientras Saavedra experimenta 
Movimientos en masa en las sierras de Bravard y Curamalal,

Sierras Australes de la Provincia de Buenos Aires.

Lic. Juan Manuel Susena

relativamente pocos cambios. Por su parte, la producción ganadera experimentó un incremento importante en la última década en los tres partidos.

\begin{tabular}{|c|c|cc|cc|cc|}
\hline Partido & $\begin{array}{c}\text { Superficie } \\
\left(\mathrm{Km}^{2}\right)\end{array}$ & Población & $\begin{array}{c}\text { Densidad } \\
\text { poblacional } \\
\left(\mathbf{P} / \mathrm{Km}^{2}\right)\end{array}$ & $\begin{array}{c}\text { Cabezas } \\
\text { de } \\
\text { ganado* }\end{array}$ & $\begin{array}{c}\text { Densidad } \\
\text { de ganado } \\
\left(\mathbf{C G} / \mathrm{Km}^{2}\right)^{*}\end{array}$ & $\begin{array}{c}\text { Sup. } \\
\text { cultivada } \\
\left(\mathbf{k m}^{2}\right)^{* *}\end{array}$ & $\begin{array}{c}\text { Sultivada } \\
\text { (\% de la } \\
\text { sup. del } \\
\text { partido)** }\end{array}$ \\
\hline $\begin{array}{c}\text { CORONEL } \\
\text { SUÁREZ }\end{array}$ & 5.985 & 38.320 & 6,40 & 347.341 & 58,04 & $2.478,51$ & 41,41 \\
SAAVEDRA & 3.500 & 20.749 & 5,93 & 183.550 & 52,44 & $1.645,88$ & 47,03 \\
TORNQUIST & 4.183 & 12.723 & 3,04 & 215.428 & 51,50 & $1.556,95$ & 37,22 \\
\hline
\end{tabular}

Tabla 4.8. Superficie: datos del IGN. Población: datos del INDEC (Instituto Nacional de Estadísticas y Censos), censo 2010. *Datos de producción pecuaria: promedio de existencias de ganado bovino y ovino (no se incluye el porcino por no ser extensivo al ámbito serrano) calculado en base a la serie 2010-2017 del Ministerio de Economía, Dirección Provincial de Estadística. ${ }^{* *}$ Datos de producción agrícola: promedio de la serie 1969/70-2017/18 del Ministerio de Agricultura, Ganadería y Pesca, Dirección Nacional de Análisis Económico Agroindustrial y Dirección de Estimaciones Agrícolas. Elaboración propia.
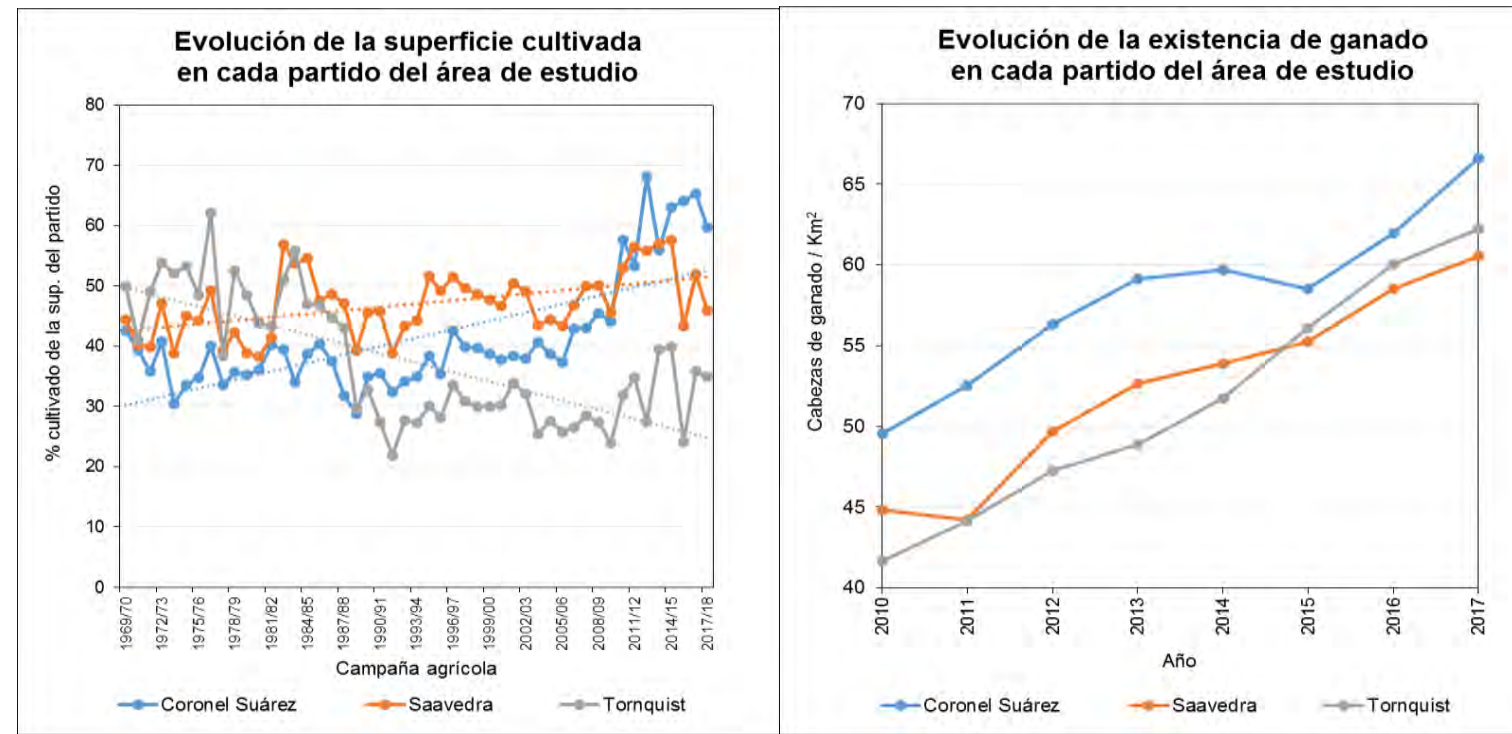

Figura 4.16. Evolución de la actividad agropecuaria. Elaboración propia a partir de datos del Ministerio de Economía, Dirección Provincial de Estadística y del Ministerio de Agricultura, Ganadería y Pesca, Dirección Nacional de Análisis Económico Agroindustrial y Dirección de Estimaciones Agrícolas. 


\section{Capítulo 5}

\section{Geología: generalidades}

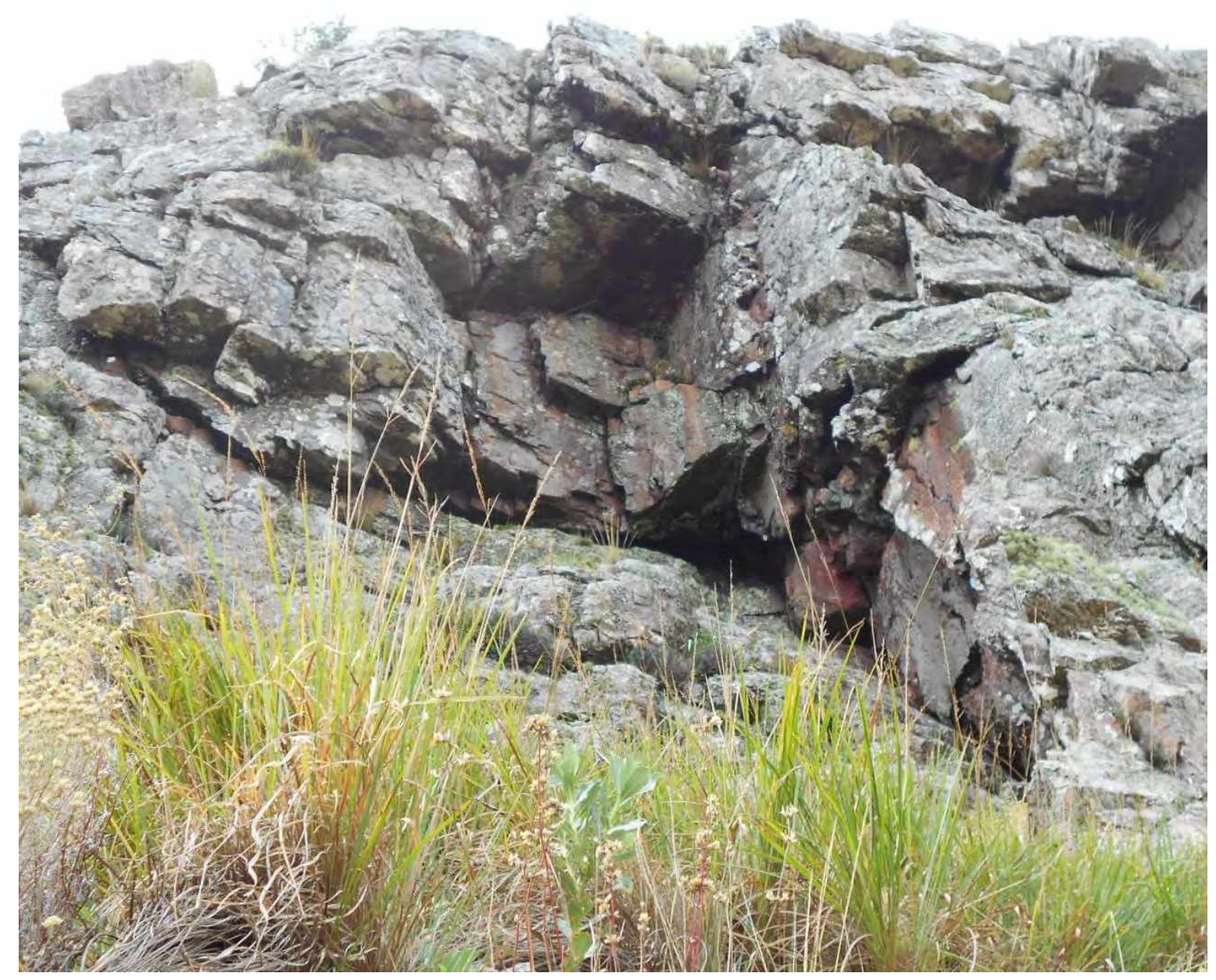

"Planos"

Afloramientos de la Formación Bravard, y sus sistemas de diaclasas, propicios para el desarrollo de caídas de rocas. 
Movimientos en masa en las sierras de Bravard y Curamalal, Sierras Australes de la Provincia de Buenos Aires.

Juan Manuel Susena 


\subsection{Objetivos y ordenamiento del presente capítulo}

Se mencionará primeramente en este capítulo la geología general del sistema serrano; luego se pondrá énfasis en las rocas, estructuras y depósitos de la zona estudiada. Los tipos litológicos presentes en zonas aledañas serán descriptos someramente y con el sólo objeto de brindar un marco geológico general, puesto que no se encuentra entre los objetivos de esta tesis el estudio detallado de la litología de las Sierras Australes. A propósito, existen además muchísimos textos sobre el conocimiento general de la región, que se remontan incluso hasta el siglo XVIII (citados por Schiller, 1930), y numerosas presentaciones de trabajos de campo y recopilaciones bibliográficas, donde se encuentran descripciones litológicas muy detalladas, de las cuales se mencionarán principalmente las de Harrington (1947), De Francesco (1992a) y Sellés-Martínez (2001). Para el área estudiada se considerará todo el registro aflorante, el cual incluye rocas ígneas, metamórficas y sedimentarias, y depósitos inconsolidados, para lo cual se presentará información bibliográfica, enriquecida y mejorada con resultados de tareas inherentes a esta tesis, de cartografía, caracterización cuali y cuantitativa en el terreno y análisis de laboratorio en unidades particulares. Se prestará especial atención a los Detritos de ladera, por ser una unidad intrínsecamente relacionada con los movimientos en masa.

Finalmente se abordará, a modo de síntesis, el marco tectónico vigente -obviando discusiones sobre diferentes modelos tectónicos que no contribuyen al desarrollo de esta tesis- y la configuración estructural a escala regional y mesoscópica. En el último caso, se mencionarán solamente las estructuras que más directamente influyen en el desarrollo de movimientos en masa, con base bibliográfica y resultados de tareas de teledetección, fotointerpretación y observaciones en el terreno.

\subsection{Litología general de las Sierras Australes}

Las unidades litoestratigráficas identificadas en el sistema abarcan el lapso Neoproterozoico-Holoceno, con un hiatus para el intervalo TriásicoJurásico/Cretácico/Paleógeno, siendo discutible el límite superior del mismo (Zárate et al., 1995).

El basamento se constituye principalmente por rocas ígneas graníticas y sus derivados dinamometamórficos (Kilmurray, 1968a), aunque existen también vulcanitas, metavulcanitas asignadas al Grupo Sauce Chico (Cuerda et al., 1975), meta-ignimbritas (González et al., 2004) y el denominado skarn de Loma Marcelo (Kilmurray, 1961; 1968b; de Barrio et al., 2008; Ballivián Justiniano, 2016).

La mayor parte de las rocas de Sierras Australes constituye una secuencia sedimentaria 
de edad paleozoica, integrada principalmente por areniscas cuarzosas, con intercalaciones menores de wackes feldespáticas y pelitas, y diferentes niveles de conglomerados. Dicha secuencia ha sido dividida formalmente, de base a techo, en los Grupos Curamalal, Ventana y Pillahuincó ("series" en Harrington, 1947). Otros autores han propuesto esquemas estratigráficos diferentes (Kilmurray, 1975; Varela, 1978; Buggisch, 1987; Andreis et al., 1989), y se ha llegado a proponer una correlación entre los Grupos Curamalal y Bravard (Kilmurray, 1975; Andreis et al., 1989; Tomezzoli y Cristalini, 2004). No obstante, dicha correlación ha sido recientemente descartada por estudios de procedencia sedimentaria (Ramos et al., 2013), reafirmando la vigencia del esquema estratigráfico planteado por Harrington hace más de setenta años. Debido al metamorfismo sobreimpuesto -evidente en los Grupos Curamalal y Ventana- de tipo dinámico y regional, de bajo grado, en facies de esquistos verdes (Leguizamón y Rodríguez, 1988; Leguizamón y Teruggi, 1991), se ha reclasificado a estas rocas en dicho sentido, como ortocuarcitas cataclásticas (Kilmurray, 1965), milocuarcitas y dinamofilitas (Leguizamón y Teruggi, 1985), o milonitas sensu stricto (Kilmurray et al., 1985; Sellés-Martínez y Quenardelle, 1992). Clásicamente se ha asignado a estas rocas un ambiente de depositación marino somero con tres ciclos sedimentarios (Andreis et al., 1971), con la excepción de los sectores basales del Grupo Curamalal, reinterpretados como sistemas deltaicos (Zavala et al., 2000), y la porción basal del Grupo Pillahuincó, a la que se atribuye un origen glacimarino (Andreis y Torres Ribeiro, 2003, y bibliografía allí citada).

Las unidades post-triásicas de las Sierras Australes fueron identificadas, descriptas y denominadas tanto en la zona de estudio (Harrington, 1936; 1947; Frenguelli, 1950; Andreis et al., 1971; De Francesco, 1970; 1971; 1992a; Fidalgo et al., 1975; De Francesco y Nuccetelli, 1990), como fuera de ésta (Furque, 1967; 1974; Fidalgo et al., 1975; Rabassa, 1989; Quattrocchio et al., 1993, entre otros). Los registros geológicos corresponden a rocas y depósitos continentales con diferentes grados de consolidación, de génesis fluvial, lacustre, de remoción en masa, y eólica, la última con mayor distribución areal; se caracterizan por estar íntimamente relacionados con formas reconocibles en el paisaje actual.

\subsection{Litología del área de estudio}

De las unidades previamente mencionadas, las aflorantes en el área de estudio son el basamento ígneo-metamórfico, los Grupos Curamalal y Ventana, la Brecha Cerro Colorado, las Formaciones La Norma, Las Malvinas, Del Águila, Agua Blanca, Saavedra, el Aluvio, y los Detritos de Ladera, unidad informal empleada en esta tesis (Figuras 5.1, 5.2 y 5.3). De éstas, las rocas consolidadas que pueden constituir frentes escarpados 
rocosos serán oportunamente mencionadas como rocas/unidades pre-paleocenas, agrupando el basamento ígneo-metamórfico y las sedimentitas de los Grupos Curamalal y Ventana y Brecha Cerro Colorado. Para el estudio de la relación de estas unidades con el desarrollo de movimientos en masa, se las agrupó según su participación en el modelado del paisaje y su influencia en el desarrollo de los movimientos, como se muestra en la Tabla 5.1. Cabe destacar que el mapa elaborado a escala 1:20.000 siguiendo este criterio, es el primer mapa de unidades litológicas aplicado al estudio de movimientos en masa en la zona. Al mismo tiempo, se trata de uno de los pocos mapas de la zona a escala 1:20.000 que discrimina unidades litológicas de manera equilibrada, según la distribución espacial de las unidades, de acuerdo a la escala de trabajo.

\begin{tabular}{|ccc|}
\hline Categoría & Código & Litología \\
\hline 1 & BAS AFL & Basamento principalmente aflorante \\
2 & BAS CUB & Basamento principalmente cubierto \\
3 & CML AFL & Gr. Curamalal principalmente aflorante \\
4 & CML CUB & Gr. Curamalal principalmente cubierto \\
5 & VNT AFL & Gr. Ventana principalmente aflorante \\
6 & VNT CUB & Gr. Ventana principalmente cubierto \\
7 & BCC & Brecha Cerro Colorado \\
8 & MALV & Fm. Las Malvinas \\
9 & CALC & Unidades con calcretas notables no diferenciadas (Fms. La Norma, Las \\
10 & ALUV & Malvinas y Del Águila) \\
11 & SAAV & Depósitos aluviales (Fm. Agua Blanca y Aluvio) \\
12 & DETR & Fm. Savedra y similares debido a modificación antrópica \\
\hline
\end{tabular}

Tabla 5.1. Agrupamiento de las unidades litológicas en esta tesis. Elaboración propia. 
Movimientos en masa en las sierras de Bravard y Curamalal,

Sierras Australes de la Provincia de Buenos Aires.

Juan Manuel Susena

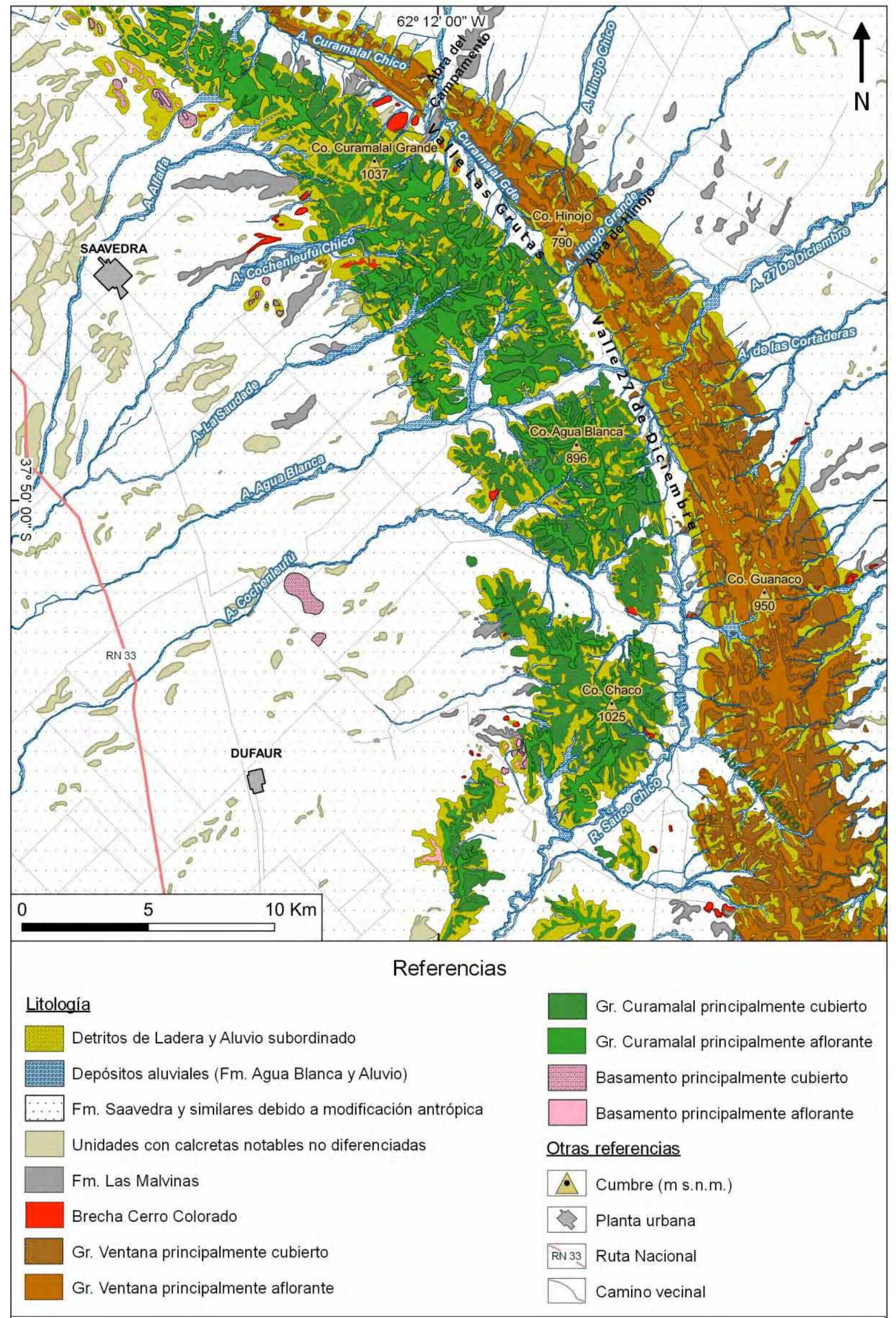

Figura 5.1. Mapa de unidades litológicas del área de estudio. Elaboración propia a partir de cartografía preexistente (Harrington, 1947 y De Francesco, 1992a), fotointerpretación y trabajo de campo. 


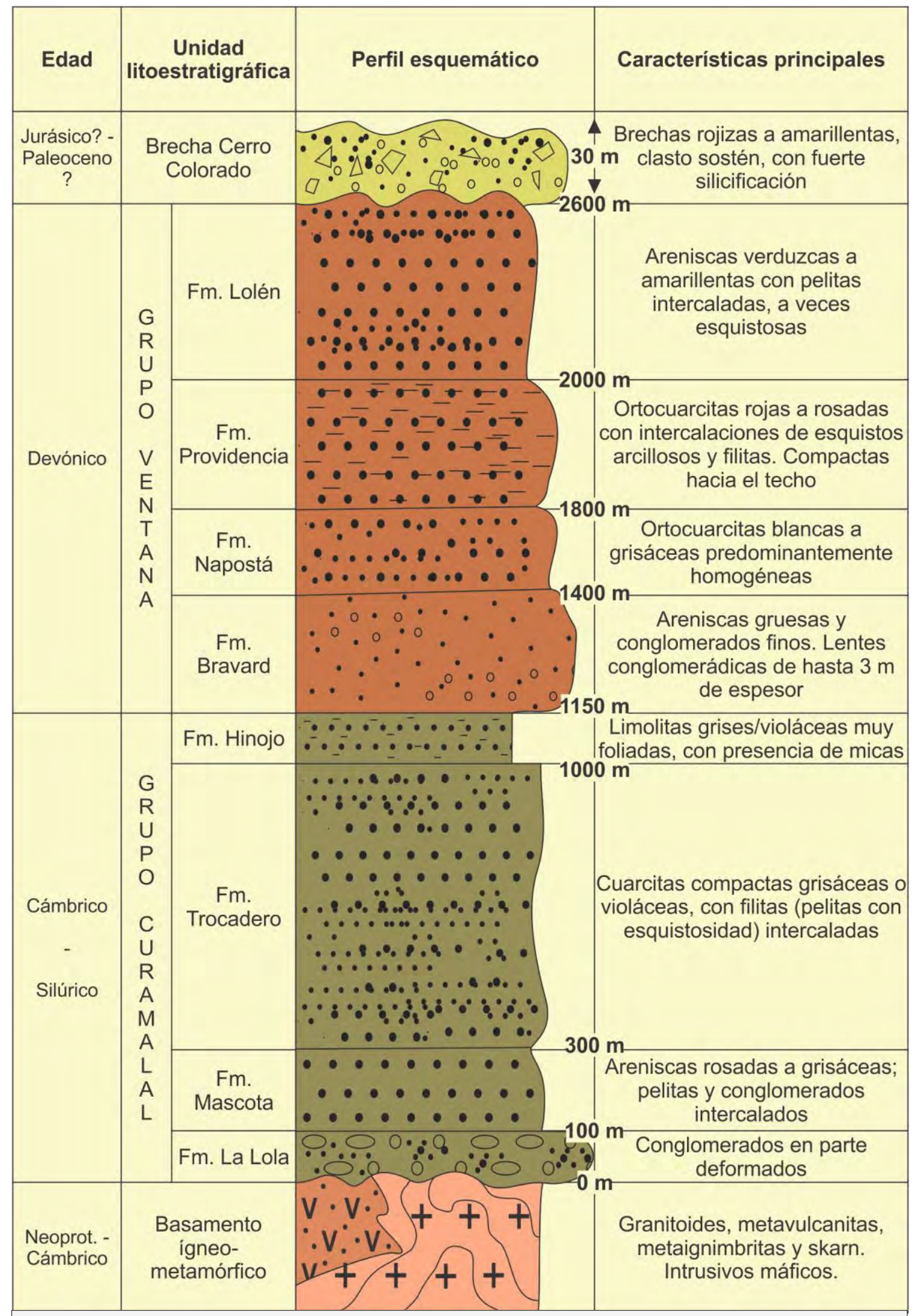

Figura 5.2. Columna estratigráfica esquemática de las unidades pre-paleocenas. Basado en Harrington (1947) y Massabie et al. (2005). 
Movimientos en masa en las sierras de Bravard y Curamalal, Sierras Australes de la Provincia de Buenos Aires.

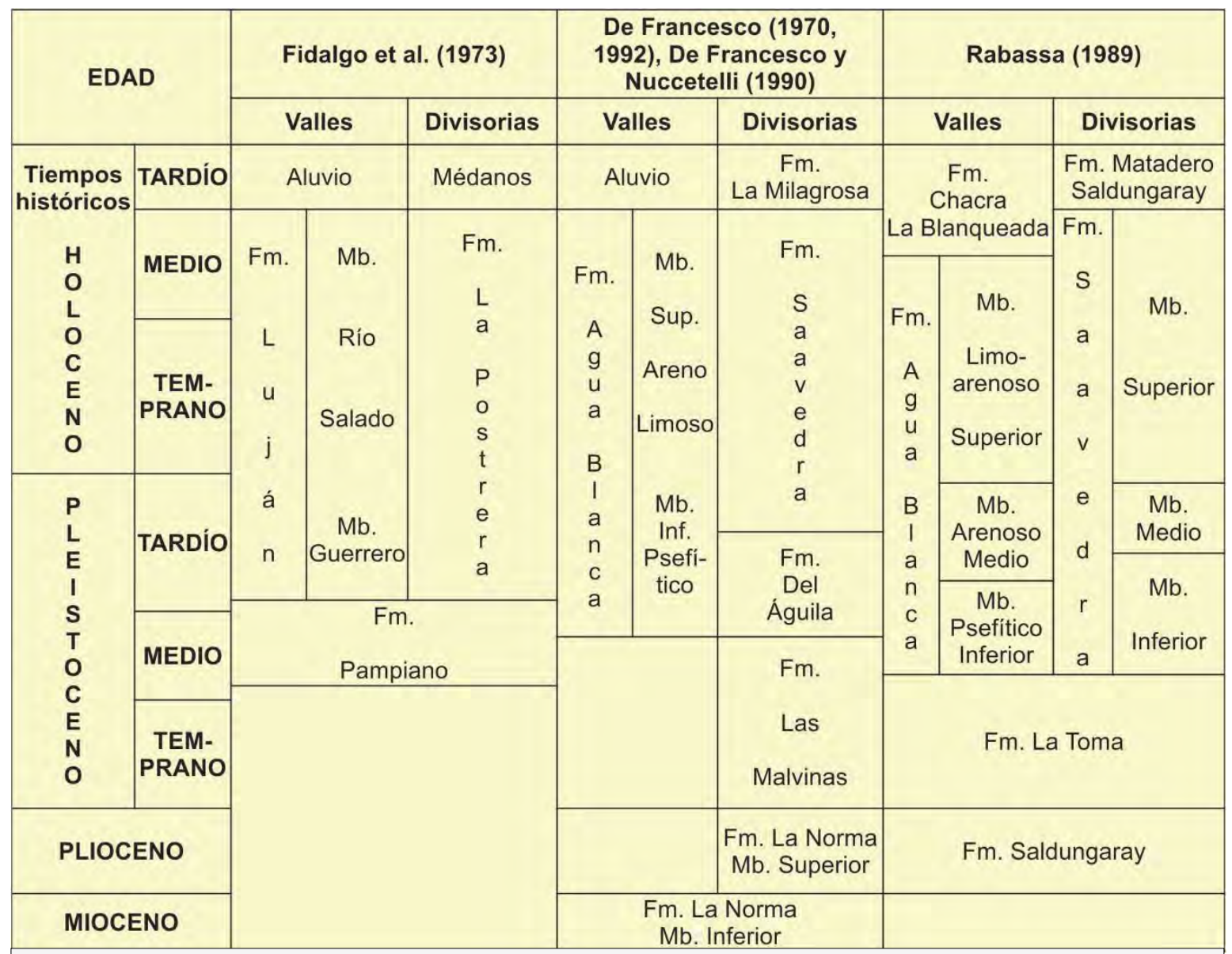

Figura 5.3. Cuadro estratigráfico de las unidades post-paleocenas y correlaciones con otras unidades de la Provincia de Buenos Aires. Basado en Quattrocchio et al. (1994).

\subsubsection{Unidades pre-paleocenas}

Basamento: las rocas del basamento afloran dentro del área estudiada en el flanco occidental de las sierras de Curamalal y en cerros aislados al oeste de éstas, siendo estas exposiciones las más antiguas en todo el sistema serrano. Se ubican en la Estancia La Mascota, al pie del cerro Curamalal Chico; en la Estancia La Ermita, en las cercanías de la localidad de Saavedra; en la cantera de granito perteneciente a la Estancia Agua Blanca; y en el sector austral de la zona de trabajo, en los cerros del Corral, Pan de Azúcar y San Mario, correspondientes a la Estancia Sauce Chico (Fig. 5.1). En la Estancia Sauce Chico, en el área de los Cerros del Corral-Pan de Azúcar afloran granitoides (Figura 5.4.A) y meta-vulcanitas, mayoritariamente de composición ácida, asignadas al Grupo Sauce Chico (Cuerda et al., 1975), meta-ignimbritas (González et al., 2004) y el skarn de Loma Marcelo. Sus edades se encuentran en el intervalo Neoproterozoico-Cámbrico medio (Rapela y Kostadinoff, 2005). Existen además cuerpos sub-volcánicos intermedios a básicos. Estas unidades fueron metamorfizadas por una intensa deformación asociada a la orogenia Gondwánica. En ellas se observa una marcada foliación de dirección aproximada NNO- 
SSE, asociada a fajas miloníticas (Figura 5.4.B).

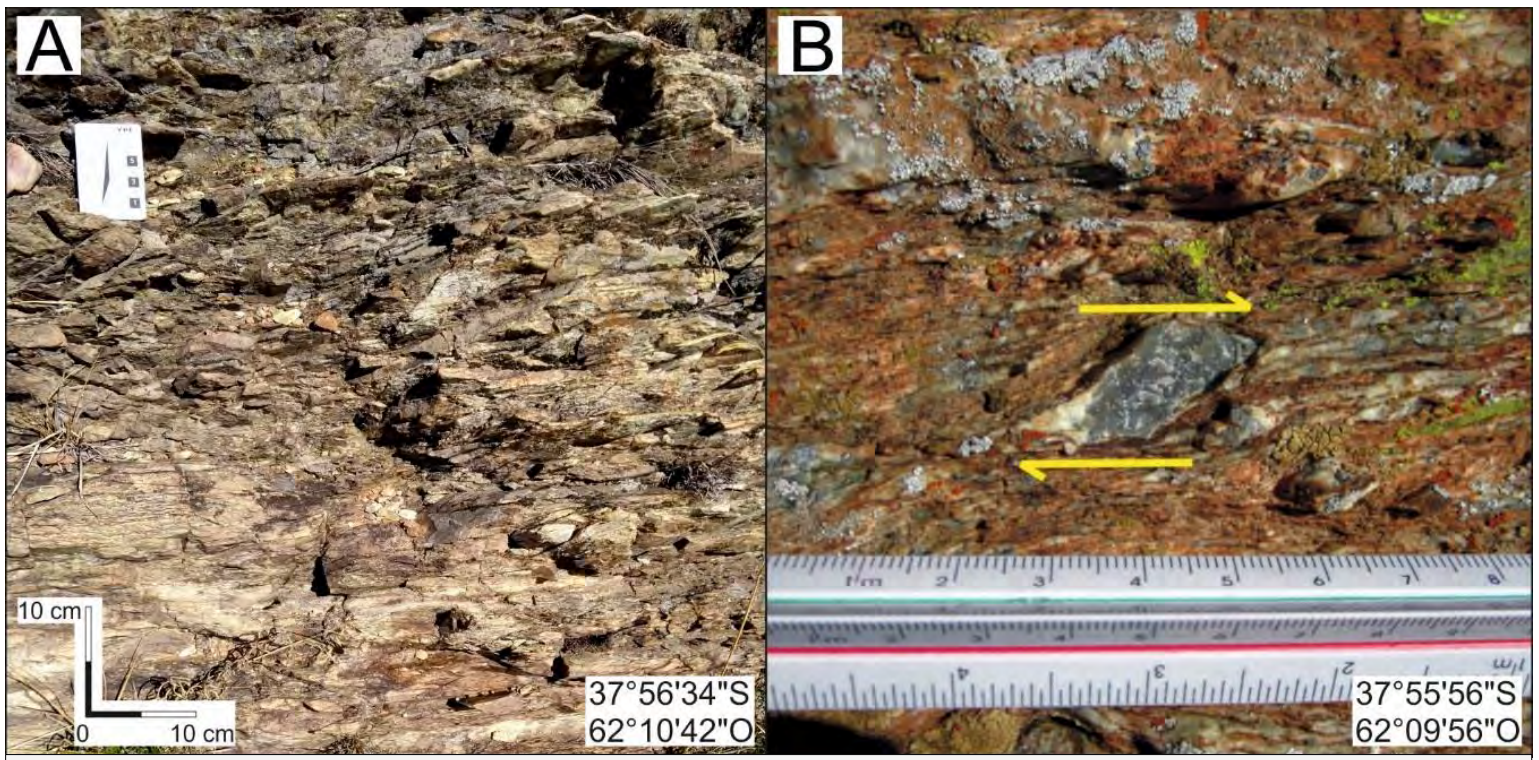

Figura 5.4. Basamento ígneo-metamórfico. A. Granito metamorfizado. B. Milonita con sentido de cizalla dextral. Las coordenadas son aproximadas; las unidades de la parte superior de la regla son centímetros. Foto A: Juan M. Susena. Foto B: Francisco A. Cellone, Pablo Di Cugno, Waldo Maulén García, Agustina Reato y Juan M. Susena.

Grupo Curamalal: esta secuencia sedimentaria aflora en el sector occidental de las Sierras de Curamalal y sobreyace mediante discordancia angular o inconformidad al basamento ígneo-metamórfico. El contacto fue mapeado por Varela y Cingolani (1975) en los cerros Pan de Azúcar y del Corral (estancia Sauce Chico), como de tipos discordante y tectónico, respectivamente. En el último caso, el Gr. Sauce Chico (basamento) se encontraría montado tectónicamente sobre el Gr. Curamalal. En las cercanías del arroyo Cochenleufú Grande (estancia La Mascota), el Gr. Curamalal apoya directamente, mediante discordancia erosiva, sobre el basamento (Harrington, 1947).

El Gr. Curamalal constituye el paquete sedimentario más antiguo de la provincia geológica, con una edad asignada estimativamente al lapso Ordovícico-Silúrico según correlaciones estratigráficas con rocas del Cinturón Plegado del Cabo en Sudáfrica (Buggisch, 1987), o Cámbrico medio-Silúrico, por sus relaciones de contacto con el basamento y el Gr. Ventana. El Gr. Curamalal fue divido en cuatro unidades litoestratigráficas (Figura 5.5): Fms. La Lola, Mascota, Trocadero, e Hinojo, sucediéndose respectivamente en continuidad y presentando, en términos generales, una gradación normal. El ambiente deposicional de esta secuencia se asignó a una plataforma marina estable, con una procedencia de interior cratónico (Alessandretti et al., 2013 y trabajos allí citados).

Formación La Lola: aflorante en los cerros Pan de Azúcar y del Corral, sus espesores máximos rondan los $100 \mathrm{~m}$ (Harrington, 1947). Integra ortoconglomerados oligomícticos gris rojizos, con una matriz arenosa a sabulítica silicificada (Figura 5.5.A). Los fenoclastos 
(clastos del esqueleto), lisos y redondeados, de baja esfericidad, tienen entre 10 y $15 \mathrm{~cm}$

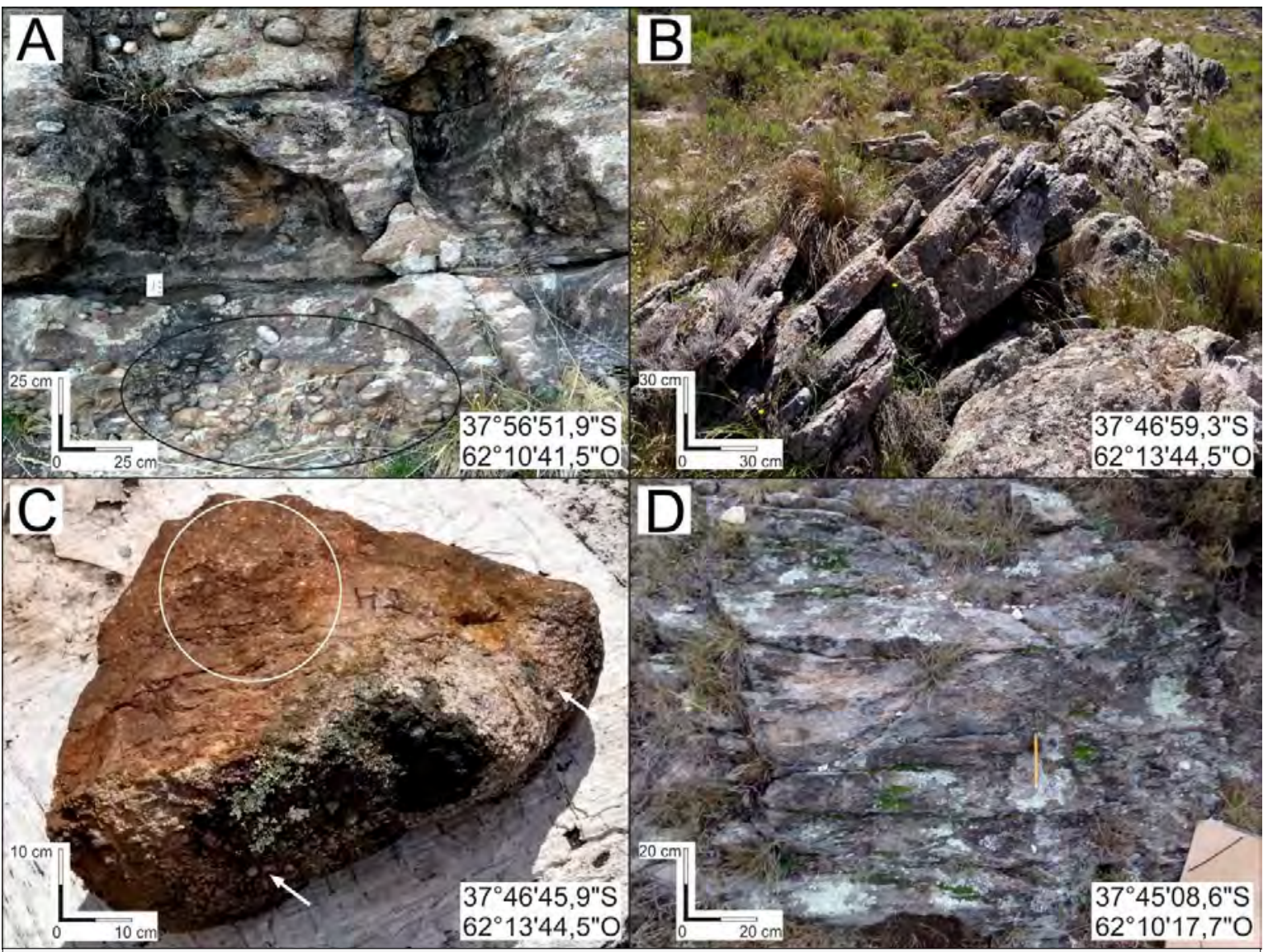

Figura 5.5. Rocas del Grupo Curamalal. A. Fm. La Lola. Elipse: sector con concentración de clastos. B. Fm. Mascota. C. Muestra de mano de la Fm. Mascota (las coordenadas indican el sitio de muestreo). Nótese la similitud con la descripción de Fm. Trocadero. Círculo: sector con sericita. Flechas: granos de cuarzo de tamaño sabulítico. D. Fm. Hinojo. Fotos: Juan M. Susena.

de diámetro promedio, alcanzando hasta $50 \mathrm{~cm}$ (Harrington, 1947; Andreis, 1965). Zavala et al. (2000) reconocieron diferentes miembros, cuyo análisis de facies -en conjunto con Fm. Mascota- les permitió adjudicar su génesis a un ambiente deltaico, con alternancias de episodios de avenidas catastróficas, como contrapartida a lo expresado en el párrafo anterior. En las zonas de los cerros San Mario y del Corral, la matriz presenta foliaciones vinculadas al desarrollo de sericita y magnetita metamórficas de hábitos laminares (Andreis, 1965). Los afloramientos generalmente se encuentran deformados por tectonismo, siendo más intenso en el cerro del Corral, donde los clastos se presentan aplastados y la matriz presenta foliaciones, y en las cercanías del abra de Pigüé, en el extremo norte del área de estudio, donde los términos superiores se encuentran "incoherentes debido a la trituración mecánica que han molido los granos de cuarzo" (Harrington, 1947).

Formación Mascota: sus afloramientos ocupan la porción occidental de las sierras de Curamalal, y parte de los cerros Pan de Azúcar y San Mario, y alcanzan espesores de 
hasta $200 \mathrm{~m}$. En los pocos sectores donde su base está expuesta, se observa una relación concordante sobre Fm. La Lola. Consiste en estratos tabulares generalmente macizos y compactos de cuarcitas (Figura 5.5.B), con alternancia de niveles pelíticos, pudiendo presentar laminación entrecruzada local, y una base psefítica (Harrington, 1947; Suero, 1972). Presenta coloración rosada a grisácea, y corresponde a ambientes de menor energía respecto a los términos basales del Gr. Curamalal. Zavala et al. (2000) han asociado estas sedimentitas a "flujos de alta densidad, sin evidencias significativas de procesos de ola", reinterpretando los orígenes marinos propuestos por otros autores (Harrington, 1947; Andreis y López Gamundí, 1985; Andreis et al., 1989).

Formación Trocadero: constituye el paquete sedimentario más potente de todo el sistema serrano, con espesores máximos de 700-800 m (Harrington, 1947). Dentro del área de estudio ocupa la mayor parte de las sierras de Curamalal (incluyendo los cerros Chaco y de los Terneros), discontinuándose sus afloramientos hacia el norte a partir de las cabeceras del arroyo Curamalal Chico. Se trata de areniscas cuarzosas de grano medio a fino, con tonalidades grisáceas, parduzcas y violáceas, compactas, con estratificación entrecruzada en algunos sectores; se intercalan lentes pelíticas con abundante sericita que le confiere brillo vítreo, y estructura esquistosa (Harrington, 1947). Muchas veces resulta difícil diferenciar las Fms. Mascota y Trocadero (Figura 5.5.C); tal es así, que Suero (1972) denominó Subgrupo Tornquist al conjunto de ambas unidades.

Fm. Hinojo: con sus asomos en la porción centro-oriental de la sierra de Curamalal, alcanza espesores máximos de $150 \mathrm{~m}$ en las inmediaciones del abra de Hinojo (Suero, 1973). Comprende limolitas grises a violáceas, muy foliadas, con minerales cuarzosos y micáceos observables con lupa (Figura 5.5.D). Intercalan bancos de arena media a fina, de coloración castaño rojiza, levemente foliada, perdiendo continuidad lateral, por lo que se los interpreta como lentes de arena interdigitados entre las limolitas, aunque Harrington (1947) destaca las areniscas en detrimento de las limolitas.

Grupo Ventana: bajo esta denominación se agrupó una sucesión continua de sedimentitas mayormente arenosas, con lentes conglomerádicas y algunos niveles arcillosos, con cierto grado de metamorfismo, que conforman la totalidad de las sierras de Bravard, la sierra de la Ventana y otros afloramientos al sur del área estudiada (Harrington, 1947). Según el último autor, presenta un espesor de unos 1250-1400 m, y yace mediante un hiatus erosivo sobre el Gr. Curamalal, disponiéndose transgresivamente. Las unidades que integran el grupo se asignaron a un ambiente de plataforma marina estable (Alessandretti et al., 2013 y trabajos allí citados) y se suceden en continuidad. 
Movimientos en masa en las sierras de Bravard y Curamalal,

Sierras Australes de la Provincia de Buenos Aires.

Juan Manuel Susena

Fm. Bravard: dentro del área estudiada, sus afloramientos se ubican mayoritariamente en las porciones occidentales de las sierras de Bravard, con una mayor representación areal en el sector central, entre los cerros Hinojo y Guanaco, aminorando su distribución hacia el norte y sur, respectivamente. Está integrada por unos 200-250 m (Harrington, 1947) de areniscas gruesas (Figura 5.6) y conglomerados finos, de coloraciones rojizas diversas, pasando a amarillentas hacia el techo. Se intercalan lentes conglomerádicas de hasta $3 \mathrm{~m}$ de espesor, con clastos bien redondeados de $4-5 \mathrm{~cm}$ de diámetro en una matriz de arena gruesa, provenientes de la destrucción de las Fms. La Lola, Mascota y Trocadero, por lo que su composición es principalmente cuarcítica.

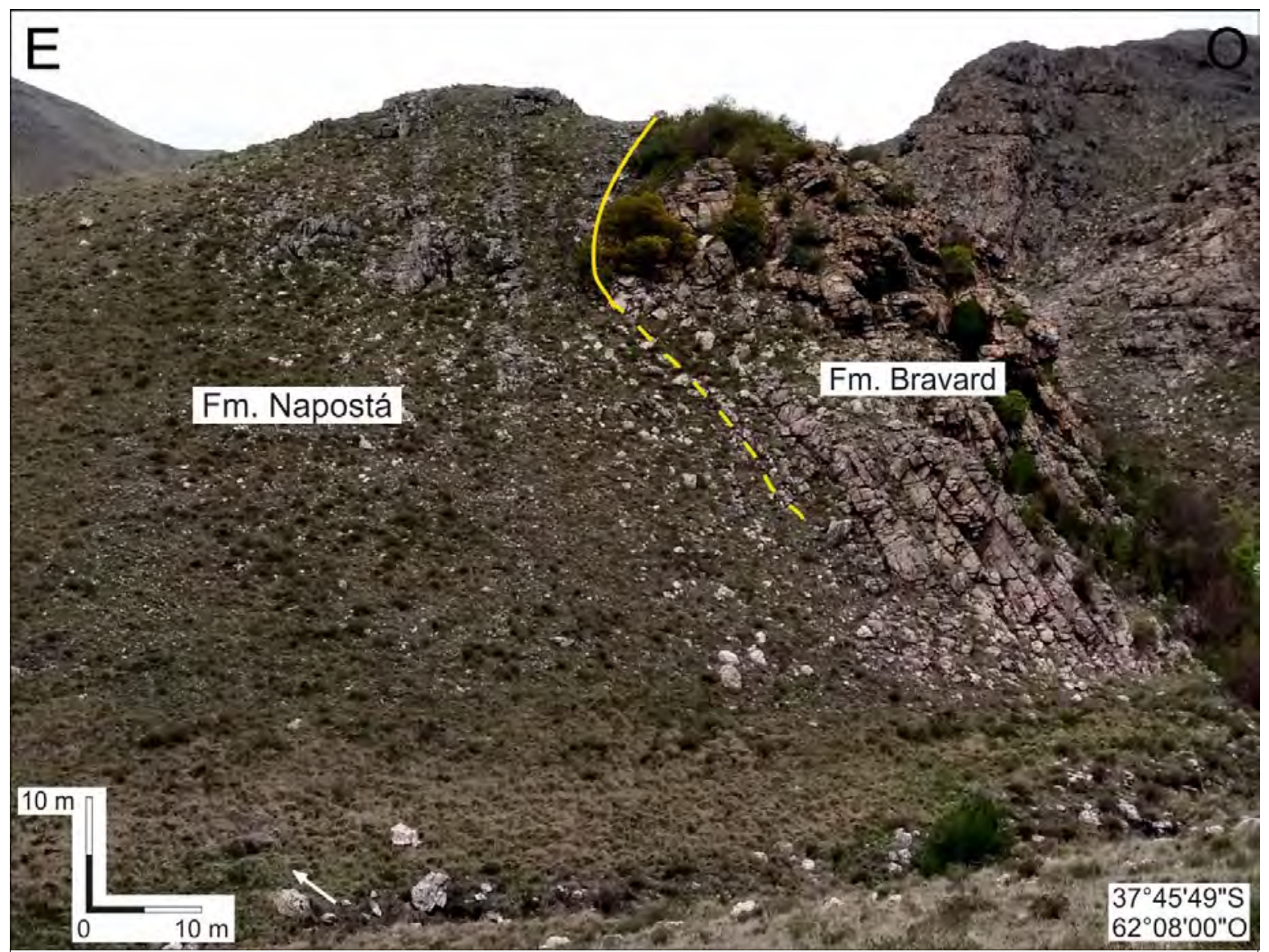

Figura 5.6. Formaciones Bravard y Napostá. Línea amarilla continua (contacto entre unidades); discontinua (contacto inferido, cubierto). La escala corresponde al sector cuspidal del contacto. Las coordenadas corresponden al morro fotografiado. Foto: Juan M. Susena.

Fm. Napostá: con 400 m de potencia (Harrington, 1947), aflora en las partes altas de los faldeos orientales de las sierras de Bravard, adquiriendo mayor importancia en el sector sur, en los cerros aledaños al abra del Chaco. Son ortocuarcitas de color blanco a blanco grisáceo, homogéneas, con laminación entrecruzada (Figura 5.6). Contiene trazas fósiles de Skolithos, Arenicolites y Daedalus (Figura 5.7.A), así como abundantes estructuras sedimentarias vinculadas a acción del oleaje (Ramos et al., 2013). La edad máxima de la 
Fm. Napostá se asigna al Ordovícico temprano, en base al contenido de trazas fósiles (Buggisch, 1987), aunque podría ser devónica (Massabie et al., 2005).

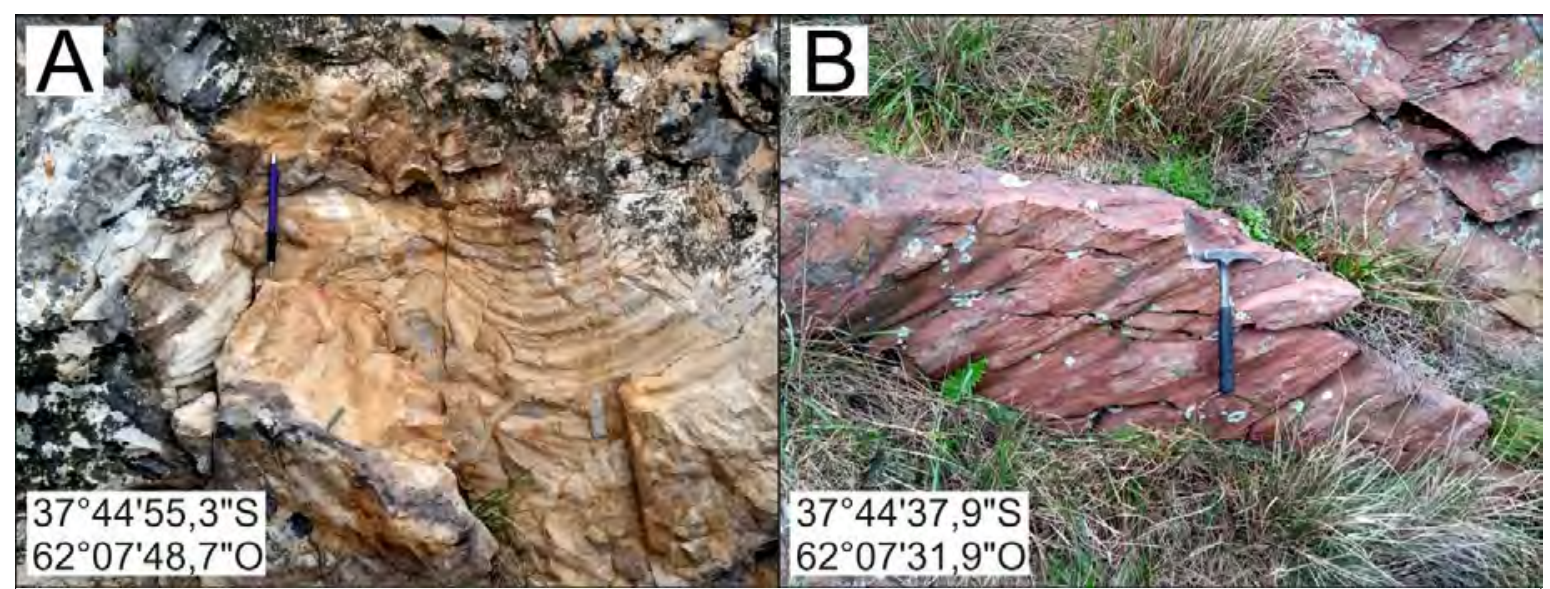

Figura 5.7. Algunas unidades del Gr. Ventana. A. Fm. Napostá con Daedalus. B. Fm. Providencia con calcos de flujo. El bolígrafo (en A) y la piqueta (en B) sirven como escala. Fotos: Juan M. Susena y personal docente de las Cátedras de Geología Histórica y Geología Argentina de la Universidad Nacional de La Plata.

Fm: Providencia: sus exposiciones se ubican en los faldeos orientales de las sierras de Bravard, a menor altitud que la Fm. Napostá. Está formada por unos 200-300 m de ortocuarcitas de tonalidades rojizas a rosadas (Figura 5.7.B), con intercalaciones de esquistos arcillosos y filitas en la base, generando una esquistosidad marcada que decrece hacia las partes superiores, más compactas (Harrington, 1980). En sus términos superiores esta unidad grada hacia la Fm. Lolén.

Fm. Lolén: aflorante en el extremo suroriental del área estudiada, consiste en unos $600 \mathrm{~m}$ de areniscas, a veces esquistosas, grises, verdosas, parduzcas y amarillentas, con diferentes niveles de pelitas (Harrington, 1980). Es la única unidad de la cuenca paleozoica que contiene verdaderos restos fósiles de organismos (en los otros casos se trata de trazas fósiles). Se han citado braquiópodos (Cryptonella sp. cf., C. baini, Schellwienella sp.) constituyentes de la fauna Malvinocáfrica (Keidel, 1916; Harrington, 1947; Andreis et al., 1989), elementos éstos de correlación con el Gr. Bokkeveld, en la faja plegada y corrida del Cabo en Sudáfrica (Newton y Cingolani, 1990), y que han permitido asignar esta unidad al Devónico inferior.

Brecha Cerro Colorado: esta denominación, propuesta por Andreis et al. (1971), reemplaza al clásicamente denominado Conglomerado Rojo (Keidel, 1916; Schiller, 1930; Harrington, 1936; 1947), llamado también Fanglomerado Cerro Colorado (Antonioli, 1969, en Andreis et al., 1971) o Conglomerado Abra (Harrington, 1980). Sus principales afloramientos en la zona de estudio se ubican en el sector oriental de las sierras de Bravard, 
Movimientos en masa en las sierras de Bravard y Curamalal,

Sierras Australes de la Provincia de Buenos Aires.

Juan Manuel Susena

en la porción occidental de las sierras de Curamalal, y en el Valle de Las Grutas, en las cabeceras del río Curamalal Grande; allí, alcanzan un espesor máximo de $30 \mathrm{~m}$ (Harrington, 1936). Se trata de brechas sedimentarias rojizas a castaño-amarillentas, de textura principalmente clasto soportada. Presentan una matriz psamítica gruesa a sabulítica. Los clastos son sub-angulosos, cuyo tamaño medio oscila entre 5 y $7 \mathrm{~cm}$ de eje mayor, con modas menores de $1,5-2 \mathrm{~cm}$ y $130-250 \mathrm{~cm}$. No obstante, existen bloques de hasta $750 \mathrm{~cm}$ de eje mayor, en los faldeos occidentales de las sierras de Curamalal (De Francesco, 1992a). Presenta una fuerte silicificación, con presencia de ópalo, que le confiere una elevada cohesión, interrumpida por discontinuidades sub-horizontales atribuibles a diferencias en la resistencia a la meteorización (Figura 5.8). Así, la Brecha Cerro Colorado constituye cerrillos de morfologías alargadas con cimas planas, o bien similares a buttes, asimilables a remanentes de una paleosuperficie (véase Capítulo 6 Geomorfología general del área), estrechamente vinculada a un pedimento subyacente posiblemente cretácico (Demoulin et al., 2005). Se apoya en discordancia erosiva sobre las sedimentitas paleozoicas, fuente de los materiales que la integran, y es cubierta en superficie, mediante discordancia erosiva, por depósitos pedemontanos de Fm. Las Malvinas, o eólicos de Fm. Saavedra. Andreis et al. (1971) plantean una génesis fluvial para las brechas, en base a variaciones texturales encontradas en el Valle de las Grutas; coinciden con Harrington (1936) en que corresponderían a cursos de agua con características similares a los actuales. Se atribuye su origen a condiciones de clima árido, probablemente durante el Cretácico-Eoceno (Zárate et al., 1995), y su silicificación sería post-deposicional, en condiciones de clima húmedo con marcada estacionalidad, posiblemente durante el Mioceno (Andreis et al., 1971; Zárate et al., 1998).

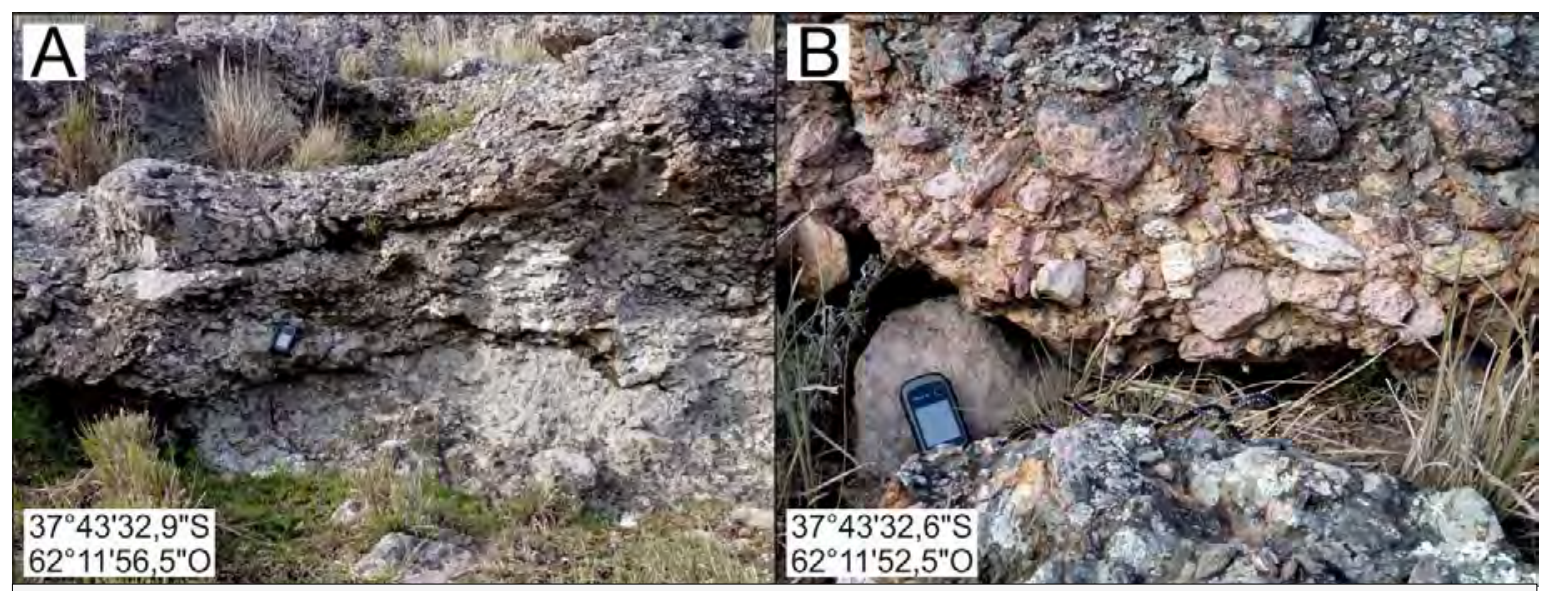

Figura 5.8. Brecha Cerro Colorado. A. Discontinuidades sub-horizontales. B. El mismo afloramiento: nótese la coloración y la angulosidad de los clastos. El GPS sirve como escala. Fotos: Juan M. Susena. 


\subsubsection{Fm. La Norma}

De Francesco (1970) agrupa bajo esta denominación a una secuencia esencialmente limolítica de carácter loéssico, en algunos casos fuertemente calcificada, aunque a los fines del mapeo, incluye depósitos psefíticos en los términos superiores, subdividiendo la unidad en un Miembro Inferior Limolítico y un Miembro Superior Psefítico (Figura 5.9). El primero consta de limolitas castaño rojizas macizas, carentes de estratificación, con una monotonía característica (Harrington 1947;

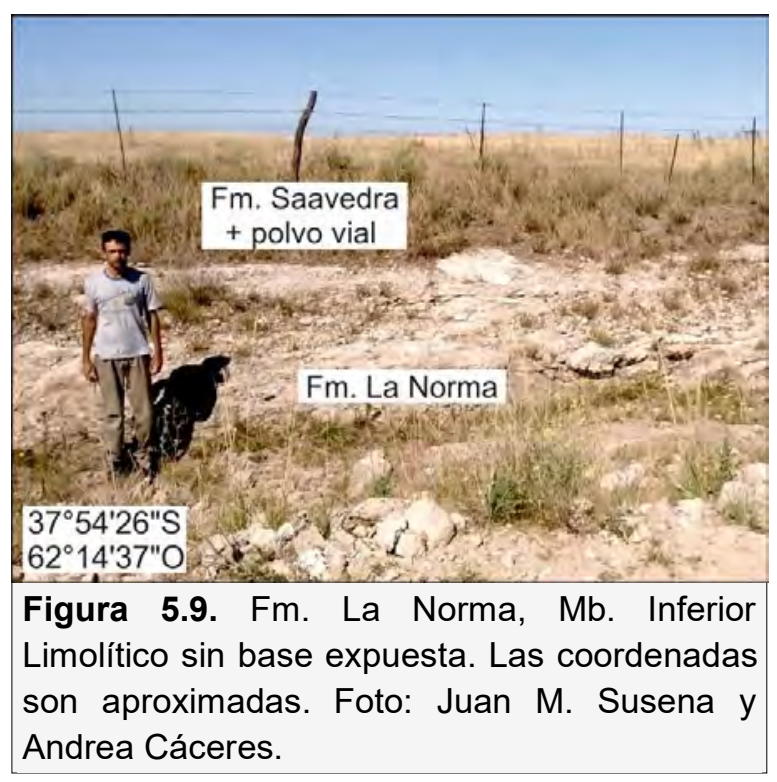
De Francesco, 1992a), ubicadas tanto en el sector pedemontano, donde gradan a depósitos psamíticos y psefíticos, como en la llanura circundante. Constituye el sustrato sobre el que se apoyan las unidades más modernas en relación discordante (De Francesco, 1992a), y se ubica tanto en valles como divisorias, adquiriendo mayor desarrollo en los sectores distales al frente serrano. El último autor citado, menciona espesores observados en pozos para provisión de agua de $45 \mathrm{~m}$, sin base expuesta en el piedemonte occidental de las sierras de Curamalal, y de hasta $130 \mathrm{~m}$, a unos $25 \mathrm{Km}$ al sur del área de estudio. Particularmente el Mb. Superior Psefítico se desarrolla en el sector pedemontano, gradando hacia facies limolíticas en la llanura distal; no sobrepasaría los 8 $\mathrm{m}$ de potencia (Fidalgo et al., 1975). El Mb. Inferior Limolítico ha sido asociado a procesos eólicos, siendo correlacionable con el "loess Pampeano" y unidades afines, mientras el Mb. Superior Psefítico se relacionaría con ambientes ácueos como abanicos aluviales y crecientes encauzadas (De Francesco, 1992a). Folguera y Zárate (2009) correlacionan parte de Fm. La Norma con las Fms. Epecuén (Pascual, 1961), Saldungaray (Furque, 1973), Irene (Reig, 1975) y Cerro Azul (Lambías, 1975); proponen denominar Fm. Cerro Azul a todas estas unidades, a favor de un encuadre regional. En base a restos de Aspidocalypus?, Coscinocercus y Macrachenidia o Promacrauchenia, la edad del Mb. Inferior Limolítico correspondería al Plioceno medio-superior (De Francesco, 1992a).

\subsubsection{Fm. Las Malvinas}

Denominada por De Francesco (1970), esta unidad agrupa depósitos psefíticos constituidos principalmente por bloques cuarcíticos -excepcionalmente ígneos- de variada 
granulometría (25-30 a 120-150 cm), envueltos en una matriz sabulítica a psamítica, gris amarillenta a castaña, con compactación a veces moderada (Figura 5.10). Constituyen remanentes pedemontanos topográficamente por encima del piedemonte actual, con morfologías alargadas de hasta 4-5 Km de longitud y espesores máximos de $15 \mathrm{~m}$ en el flanco suroccidental del Co. Curamalal Grande. Se apoya en discordancia erosiva sobre la Brecha Cerro Colorado, sobre Fm. La Norma, o en discordancia angular sobre rocas paleozoicas. Su edad fue asignada tentativamente al Pleistoceno superior y/o medio. Rabassa et al. (2005) apuntan que habría que reconsiderar la diferenciación de esta unidad (o parte de ésta), puesto que podría corresponder a los términos superiores de la Brecha Cerro Colorado, constituyendo la zona de lixiviación, lo cual explicaría la falta de cementación, que diferencia a ambas unidades. Puesto que Fm. La Norma -sobre la cual yacen algunos depósitos de Fm. Las Malvinas- tiene una edad fundamentada en restos fósiles más joven que la propuesta para la Brecha Cerro Colorado; la reinterpretación de la edad de Fm. Las Malvinas sólo es aplicable con cierta seguridad a los depósitos que sobreyacen a la Brecha Cerro Colorado.

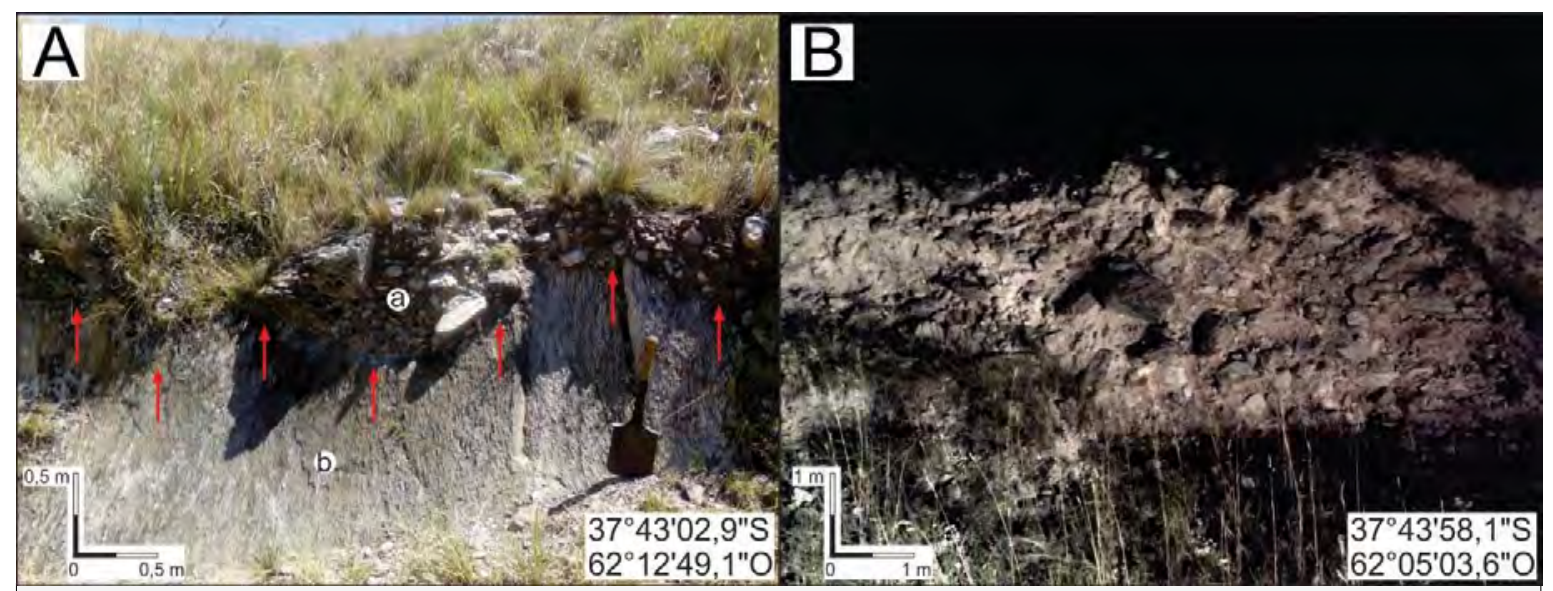

Figura 5.10. Fm. Las Malvinas. A. Fm. Las Malvinas (a) en discordancia sobre Fm. Hinojo (b). Flechas: nótese la irregularidad y nitidez de la discordancia. B. Fm. Las Malvinas en corte de camino, sin base expuesta. Fotos: Juan M. Susena.

\subsubsection{Fm. Del Águila}

Depósitos psefíticos mayormente macizos, ubicados en el piedemonte occidental de las sierras de Curamalal y de Ventana, han sido agrupados en la Fm. Del Águila (De Francesco, 1970) o Diamictón Del Águila (Figura 5.11). Constituyen suaves lomadas acotadas de entre 320 y 350 m s.n.m., con espesores de unos 2,5 m en la zona de estudio; al suroeste de Sierra de la Ventana alcanzan los 4,5-5,5 m. Esta unidad se apoya mediante discordancia angular sobre Fm. La Norma, y es cubierta por Fm. Saavedra. La textura varía de clasto sostén en sectores proximales (clastos de $5-50 \mathrm{~cm}$ ) a matriz sostén en sectores 
distales. Predominan clastos de tosca y limolitas, con muy escasos clastos de cuarcita, en una matriz areno limo arcillosa a arcillosa. Contiene carbonato de calcio diseminado en la matriz y un manto de tosca de unos $0,2-0,3 \mathrm{~m}$ en los términos superiores, con presencia plegamientos y fracturas. Según De Francesco (1992b) esta unidad sería producto de movimientos en masa de tipo flujos de tierra (no encauzados), producidos en el piedemonte, con retrabajamiento de los

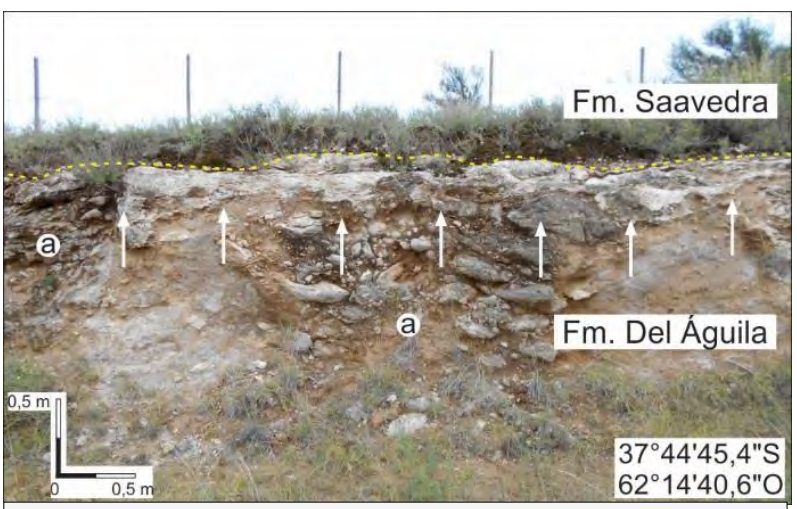

Figura 5.11. Fm. Del Águila en corte de camino. a: lentes con clastos de tosca (calcretas) con fábrica caótica. Flechas blancas: manto de tosca. Línea amarilla: discordancia erosiva. Foto: Juan M. Susena y Rodolfo O. Gentile.

materiales más finos por acción del agua. Su edad se asignó al Pleistoceno superior, en base a restos de Megatherium americanum, Doedicurus cf. Clavicaudatus y Glyptodon.

\subsubsection{Fm. Agua Blanca}

Esta denominación (De Francesco, 1970) agrupa sedimentos fluviales, que constituyen niveles de terrazas, piedemontes proximales, barrancas de las fajas aluviales actuales y suaves depresiones al SO de la zona aquí tratada. Rabassa (1989) la divide en tres miembros en las cabeceras del río Sauce Grande (al sur de la zona aquí estudiada) y De Francesco (1992a) la subdivide en dos miembros (Inferior y Superior) en el piedemonte occidental de las sierras de Curamalal; se adoptará aquí la última subdivisión, por encontrarse en el área objeto de esta tesis. En el Mb. Inferior (Psefítico) predominan bancos, con estratificación grosera e imbricación, de gravas gruesas (tamaño medio $150-200 \mathrm{~mm})$ y bloques $(500-700$ $\mathrm{mm})$, de cuarcitas, con escasa matriz, e intercalaciones arenosas, sabulíticas y limosas, muchas veces teñidas por óxidos de Fe (Figura 5.12). Puede presentar moteados de Fe-Mn y láminas ferruginosas; Rabassa (1989) menciona la existencia de una duricostra de $2-5 \mathrm{~cm}$ de espesor en las cercanías de Saldungaray

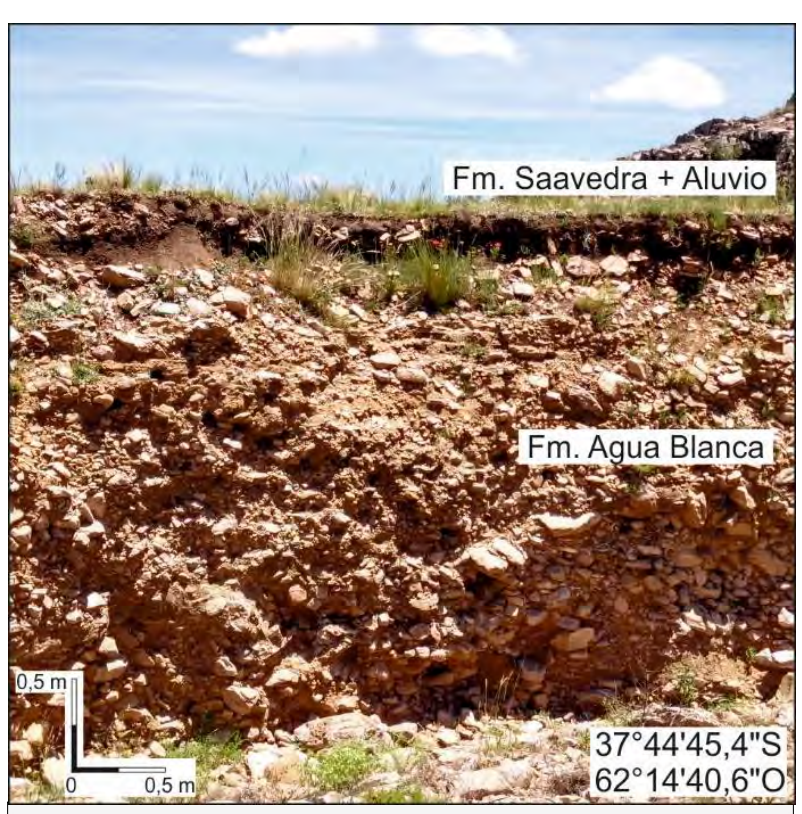

Figura 5.12. Fm. Agua Blanca constituyendo las barrancas de un curso de agua. Foto: Juan M. Susena. 
(Partido de Tornquist). El último autor identifica además deformaciones sinsedimentarias, reinterpretadas como producto de neotectónica en el Pleistoceno superior (Quattrocchio et al., 1994). Yace en discordancia sobre Fm. La Norma (observaciones en pozos), con espesores de 7-8 m, reduciéndose su espesor y granulometría hacia la llanura periserrana. Asimismo, su distribución espacial se encuentra restringida por los niveles pedemontanos antiguos (Brecha Cerro Colorado y Fm. Las Malvinas). Este miembro ha sido datado en $32.300 \pm 1800$ años AP (Pleistoceno medio), mediante $\mathrm{C}^{14}$ en Plagiodontes patagonicus (Figini et al., 1985). El Mb. Superior (Psamopelítico) incluye sedimentos limo arenosos castaño amarillentos y gris verdosos, generalmente macizos, con laminación y estratificación esporádica (Figura 5.13.A). Sus espesores promedian los 1,5-3 m, aunque pueden alcanzar los $6 \mathrm{~m}$. Suelen presentar lentes de gravilla tangenciales (a los cursos actuales), evidenciando migración de canales. A partir del Mb. Superior se ha desarrollado el Suelo Sauce Chico (De Francesco, 1970), parcialmente decapitado y enterrado, con materia orgánica diseminada e impregnaciones de $\mathrm{CaCO}_{3}$, que a veces constituyen capas milimétricas. Datado en $2.240 \pm 55$ años $\mathrm{AP}\left(\mathrm{C}^{14}\right.$ en colágeno de huesos de guanaco, Rabassa, 1989), el Mb. Superior correspondería a tiempos históricos.

\subsubsection{Fm. Saavedra}

Denominada por De Francesco (1970), integra sedimentos limo arenosos, algo arcillosos, castaño claros a castaño rojizos, generalmente sin estratificación, friables, de génesis eólica, interactuando localmente con flujos de tierra (sensu Sharpe, 1938), caídas de bloques desde frentes escarpados rocosos, y algo de acción fluvial (Figura 5.13.B). Bidart (1992a; 1993; 1996) reconoce, en sectores de las Sierras Australes ubicados más al sur que el área estudiada, texturas más gruesas que las mencionadas por De Francesco, proponiendo las denominaciones de "loess arenoso" y "loess areno-arcilloso". Los depósitos de la Fm. Saavedra poseen gran extensión superficial, ya que cubren el paisaje a modo de manto, con espesores no mayores a 1,1 $\mathrm{m}$ en divisorias, y de hasta $3 \mathrm{~m}$ en valles, con máximos excepcionales de $6 \mathrm{~m}$; los espesores aumentan hacia el SE (De Francesco, 1992a). Sus términos superiores constituyen el material original de gran parte de los suelos del área periserrana e intraserrana, los últimos, junto con el Aluvio. En las fracciones arena y limo predominan las trizas volcánicas, incoloras, sin alteración marcada, seguidas de plagioclasas intermedias y básicas, cuarzo, litoclastos de vulcanitas y cuarcitas, feldespatos potásicos con diversos grados de alteración, y minerales pesados. La montmorillonita predomina levemente sobre caolinita e illita, con cristalinidad baja a media. Rabassa (1989), en las cabeceras del Río Sauce Grande (Partido de Tornquist, al sur de la zona aquí considerada) diferenció tres miembros, y realizó observaciones que, 


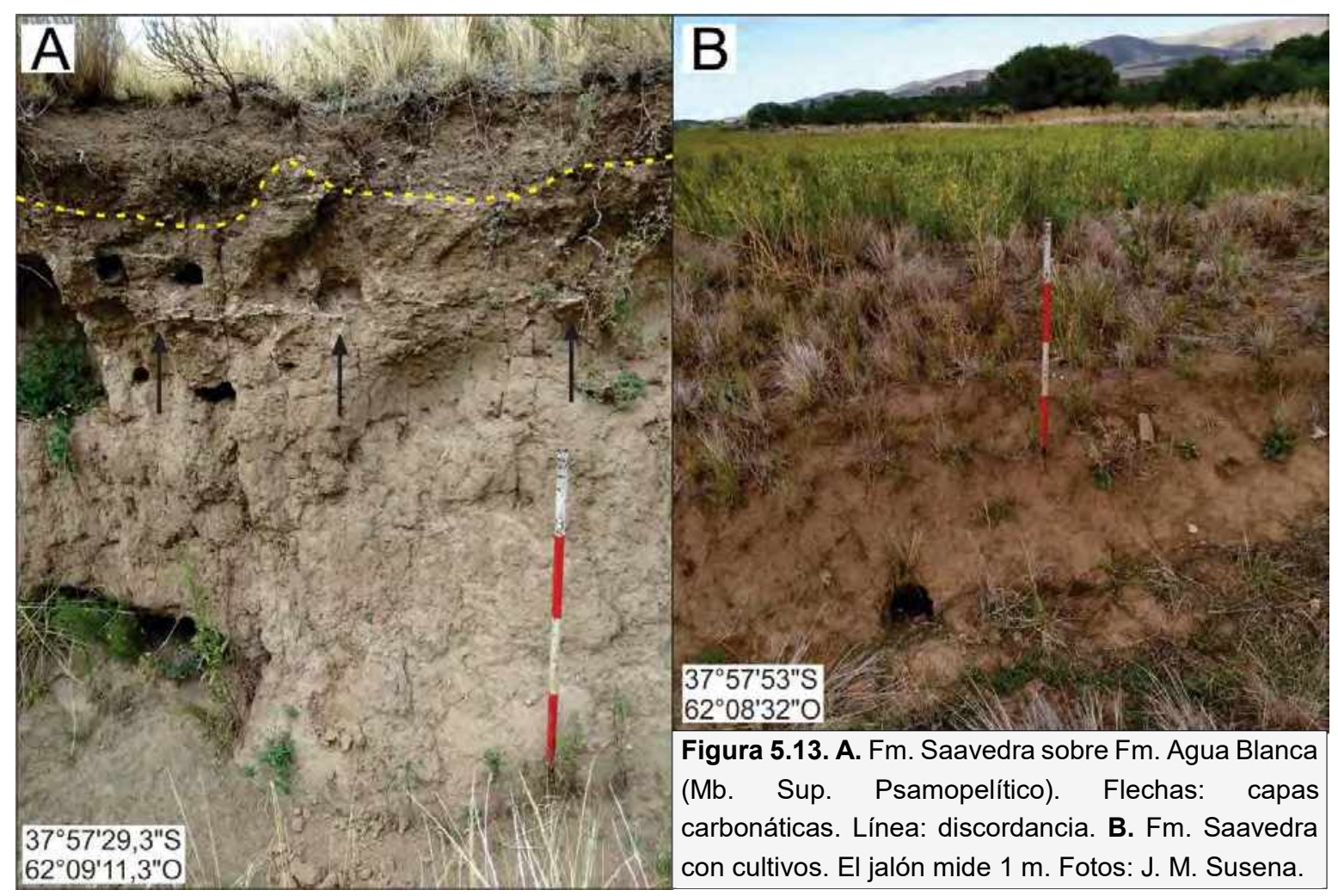

aunque se encuentren fuera de la zona de esta tesis, ameritan apuntarse. En los Miembros Inferior y Medio reconoció facies de movimientos en masa tipo "torrentes de barro", con clastos angulosos tabulares de pelitas, y sub-redondeados y redondeados con morfologías diversas de toscas. Se han encontrado también rizoconcreciones, relleno de crotovinas, y suelos decapitados. Así, podrían correlacionarse totalmente o en parte con Fm. Del Águila (Folguera y Zárate, 2009). Al respecto, se observó en el campo que la Fm. Del Águila presenta una matriz poco cementada y una unidad más limosa superior similar a las descriptas como horizontes petrocálcicos vinculados a Fm. Saavedra en diversos sectores del piedemonte de las Sierras Australes (Blanco et al., 1997). El Mb. Inferior a su vez cubre o es cubierto por parte del Mb. Superior de la Fm. Agua Blanca, indicando migración de los cursos de agua, o alternancias de períodos húmedos y secos. El Mb. Superior, por su parte, correlacionable -en un sentido más estricto- con la Fm. Saavedra de De Francesco (1970), se intercala con lentes pelíticas (depósitos lacustres) y psefíticas (acumulaciones coluviales). Así, la Fm. Saavedra, de carácter eólico, se habría depositado sincrónica y/o póstumamente al desarrollo de movimientos en masa, constituyendo parte de la masa movilizada en el primer caso, o rellenando taludes (sensu stricto) en el segundo caso (ver Capítulo 6 Geomorfología general del área). La Fm. Saavedra puede encontrarse cubierta por el Aluvio (=Fm. Chacra La Blanqueada, Rabassa, 1989). Dataciones radiocarbónicas en Austroburus lutescens y Plagiodontes patagonicus, roedores, guanacos y humanos, arrojaron edades de entre $9780 \pm 140$ y $2075 \pm 70$ años (Figini et al., 1985; Rabassa, 1989), correspondiendo al Holoceno temprano-tiempos históricos. 


\subsubsection{Aluvio}

Incluye unidades con distinta génesis, a los fines del mapeo (De Francesco, 1992a). Corresponde a sedimentos aluviales y coluviales actuales, de escasa distribución areal, ubicados preferentemente en las cercanías de los frentes serranos y en los valles intraserranos. Los depósitos aluviales tienen granulometría variada, desde dominados por bloques de cuarcitas sub-angulosos en una matriz areno-limosa castaña, hasta arenas limosas y limos arcillosos castaños claros a oscuros. En el último caso, la existencia de lentes sabulíticas y arenosas intercaladas en la unidad, pueden ser útiles para diferenciar el Aluvio respecto a Fm. Saavedra (Figura 5.14). Vale aclarar que algunas facies de la Fm. Saavedra que han sido retrabajadas por acción fluvial (denominados comúnmente depósitos loessoides) contienen lentes sabulíticas y arenosas y no se diferencian del Aluvio. Dada la necesidad en esta tesis de analizar diferentes procesos morfodinámicos, se optará por considerar también como Aluvio a tales depósitos de la Fm. Saavedra retrabajados en los cursos de agua actuales; no será así con los ubicados fuera de los cauces vigentes. Por otra parte, las facies coluviales que el autor incluyó en el Aluvio por razones de mapeo, serán aquí tratadas como "Detritos de Ladera", y descriptas en el siguiente apartado. El Aluvio yace en discordancia sobre las Fms. Agua Blanca y La Norma, y se encuentra cubierto al oeste de la zona de estudio, por las arenas grises eólicas de Fm. La Milagrosa (De Francesco, 1971). La Fm. Chacra La Blanqueada (Rabassa, 1989), correlacionable en parte con las facies coluviales del Aluvio, fue datada en 1570-1150 años por $C^{14} e n$ troncos de Sálix Humboldtiana, correspondiendo a tiempos históricos.

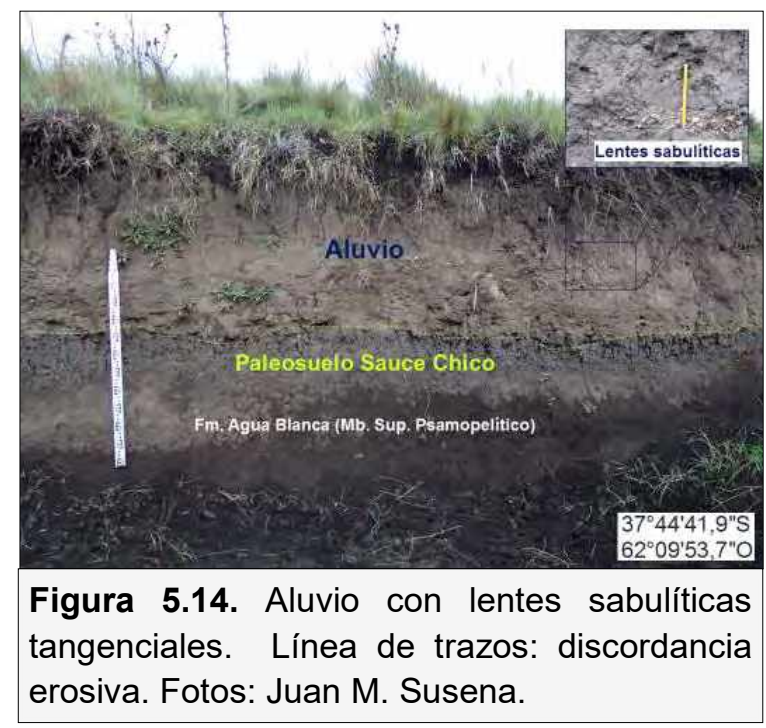

\subsubsection{Detritos de ladera}

Esta unidad es de carácter informal, utilizada en esta tesis. Se trata de depósitos principalmente psefíticos, caracterizados por bloques prolados, tabulares y en mucha menor medida oblados, de aproximadamente $20-30 \mathrm{~cm}$ (Figura 5.15), y hasta $3 \mathrm{~m}$, de eje mayor (Figura 11.15 en el Capítulo 11 Interacciones entre movimientos en masa y escurrimiento superficial/sub-superficial). Éstos, angulosos a sub-angulosos, indican 
escaso transporte, y proceden originalmente de la destrucción de los frentes escarpados y afloramientos de las rocas pre-paleocenas, o localmente del Miembro Cementado (ver más adelante). La textura de la matriz puede variar según la posición en la ladera, pero por lo general dominan las fracciones limo y arcilla (Tabla 5.2 y Figura 5.16), de color castaño claro a oscuro, primariamente eólica, con diferentes grados de pedogenización y retransporte por movimientos en masa y escurrimiento superficial.

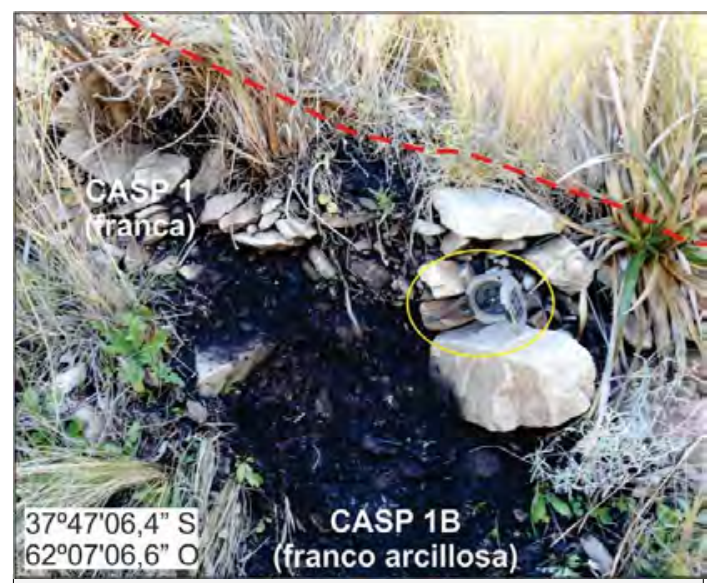

Figura 5.15. Detritos de Ladera (Miembro Suelto). Trazos: superficie de la ladera. La textura corresponde a la matriz de los depósitos. La brújula (circulo) sirve como escala. Foto: Juan M. Susena.

\begin{tabular}{|c|c|c|c|c|c|c|c|}
\hline Muestra & $\begin{array}{l}\text { Distribución } \\
\text { en la ladera }\end{array}$ & $\begin{array}{c}\text { Distribución } \\
\text { vertical }\end{array}$ & $\begin{array}{l}\text { Ubicación } \\
\text { (lat; long) }\end{array}$ & $\begin{array}{c}\% \\
\text { Arcilla }\end{array}$ & $\begin{array}{c}\% \\
\text { Limo }\end{array}$ & $\begin{array}{c}\% \\
\text { Arena }\end{array}$ & $\begin{array}{l}\text { Textura } \\
\text { (USDA) }\end{array}$ \\
\hline CUR 19A & Proximal & Superficial & $\begin{array}{l}37^{\circ} 45^{\prime} 25,4^{\prime \prime} \mathrm{S} ; \\
62^{\circ} 10^{\prime} 56,0^{\prime \prime} \mathrm{O}\end{array}$ & 37,82 & 47,77 & 14,41 & $\begin{array}{l}\text { Franco arcillo } \\
\text { limosa }\end{array}$ \\
\hline CUR 19B & Proximal & $\begin{array}{c}\text { Sub- } \\
\text { superficial }\end{array}$ & $=$ CUR 19A & 18,40 & 70,36 & 11,24 & Franco limosa \\
\hline CASP 1 & $\begin{array}{l}\text { Proximal- } \\
\text { media }\end{array}$ & Superficial & $\begin{array}{l}37^{\circ} 47^{\prime} 06,4^{\prime \prime} \mathrm{S} ; \\
62^{\circ} 07^{\prime} 06,6^{\prime \prime} \mathrm{O}\end{array}$ & 15,35 & 37,01 & 47,64 & Franca \\
\hline CASP 1B & $\begin{array}{l}\text { Proximal- } \\
\text { media }\end{array}$ & $\begin{array}{c}\text { Sub- } \\
\text { superficial }\end{array}$ & $=\mathrm{CASP} 1$ & 30,47 & 48,41 & 21,12 & Franco arcillosa \\
\hline $160 \mathrm{~A}$ & Media & Superficial & $\begin{array}{l}37^{\circ} 47^{\prime} 06,4^{\prime \prime} \mathrm{S} ; \\
62^{\circ} 07^{\prime} 06,6^{\prime \prime} \mathrm{O}\end{array}$ & 25,32 & 60,56 & 14,12 & Franco limosa \\
\hline $160 \mathrm{~B}$ & Media & $\begin{array}{c}\text { Sub- } \\
\text { superficial }\end{array}$ & $=160 \mathrm{~A}$ & 36,57 & 38,23 & 25,20 & Franco arcillosa \\
\hline G 420A & Media & Superficial & $\begin{array}{l}37^{\circ} 44^{\prime} 13,9^{\prime \prime} \mathrm{S} ; \\
62^{\circ} 10^{\prime} 08,7 \text {; }\end{array}$ & 42,78 & 32,09 & 25,13 & Arcillosa \\
\hline G 420B & Media & $\begin{array}{c}\text { Sub- } \\
\text { superficial }\end{array}$ & $=\mathrm{G} 420 \mathrm{~A}$ & 44,92 & 29,37 & 25,71 & Arcillosa \\
\hline $\mathrm{SCH} 4$ & Media & Superficial & $\begin{array}{l}37^{\circ} 56^{\prime} 58,1 \text { " S; } \\
62^{\circ} 10^{\prime} 41,0^{\prime \prime} \mathrm{O}\end{array}$ & 24,68 & 55,79 & 19,53 & Franco limosa \\
\hline $\mathrm{SCH} 3$ & Media & $\begin{array}{c}\text { Sub- } \\
\text { superficial }\end{array}$ & $=\mathrm{SCH} 4$ & 16,88 & 66,51 & 16,61 & Franco limosa \\
\hline CURCO-30 & Distal & Superficial & $\begin{array}{l}37^{\circ} 46^{\prime} 31,6^{\prime \prime} \mathrm{S} ; \\
62^{\circ} 13^{\prime} 02,9 \text { ' O }\end{array}$ & 52,22 & 41,78 & 6,01 & Arcillo limosa \\
\hline CASP-303A & Distal & Superficial & $\begin{array}{l}37^{\circ} 466^{\prime} 05,4 \text { " S; } \\
62^{\circ} 08^{\prime} 38,4 \text { " O }\end{array}$ & 21,02 & 58,04 & 20,94 & Franco limosa \\
\hline CASP-303Bt & Distal & $\begin{array}{c}\text { Sub- } \\
\text { superficial }\end{array}$ & $=\mathrm{CASP}-303 \mathrm{~A}$ & 43,04 & 32,03 & 24,93 & Arcillosa \\
\hline CASP-303BC & Distal & $\begin{array}{c}\text { Sub- } \\
\text { superficial }\end{array}$ & $=\mathrm{CASP}-303 \mathrm{~A}$ & 39,02 & 42,03 & 18,95 & $\begin{array}{l}\text { Franco arcillo } \\
\text { limosa }\end{array}$ \\
\hline
\end{tabular}

Tabla 5.2. Texturas de suelos desarrollados en los Detritos de Ladera. Se utilizó la textura de suelos y no de sedimentos porque representa el estado actual de las laderas, punto de interés en esta tesis. Elaboración propia. 
Movimientos en masa en las sierras de Bravard y Curamalal,

Sierras Australes de la Provincia de Buenos Aires.

Juan Manuel Susena

Cabe aclarar que, dada la amplia distribución del material eólico en el área de estudio y su carácter de matriz, la denominación "Detritos de Ladera" es sólo una herramienta para referirse a estos depósitos, debido a su connotación morfodinámica, ya que están actualmente sometidos (y posiblemente también desde su génesis) a procesos de ladera. En este aspecto, podría ser objeto de trabajos posteriores la formalización de una unidad litoestratigráfica para definir este tipo particular de depósitos en actual desarrollo. En los Detritos de Ladera se reconocen dos litologías diferentes que, a

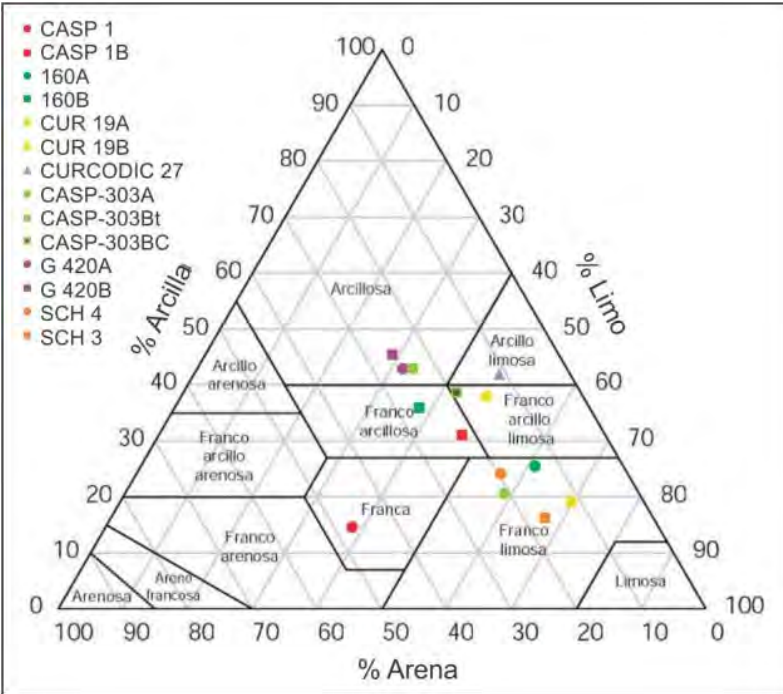

Figura 5.16. Ubicación de las muestras de la Tabla 5.2 en el triángulo textural USDA. Círculos: horizontes superficiales. Cuadrados: horizontes sub-superficiales. Triángulo: muestra superficial sin diferenciación de horizontes (suelo mezclado). Elaboración propia. pesar de presentar fábricas similares, son muy contrastantes en cuanto a su comportamiento geomecánico; se las denominará Miembro Cementado y Miembro Suelto (Figura 5.17.A).

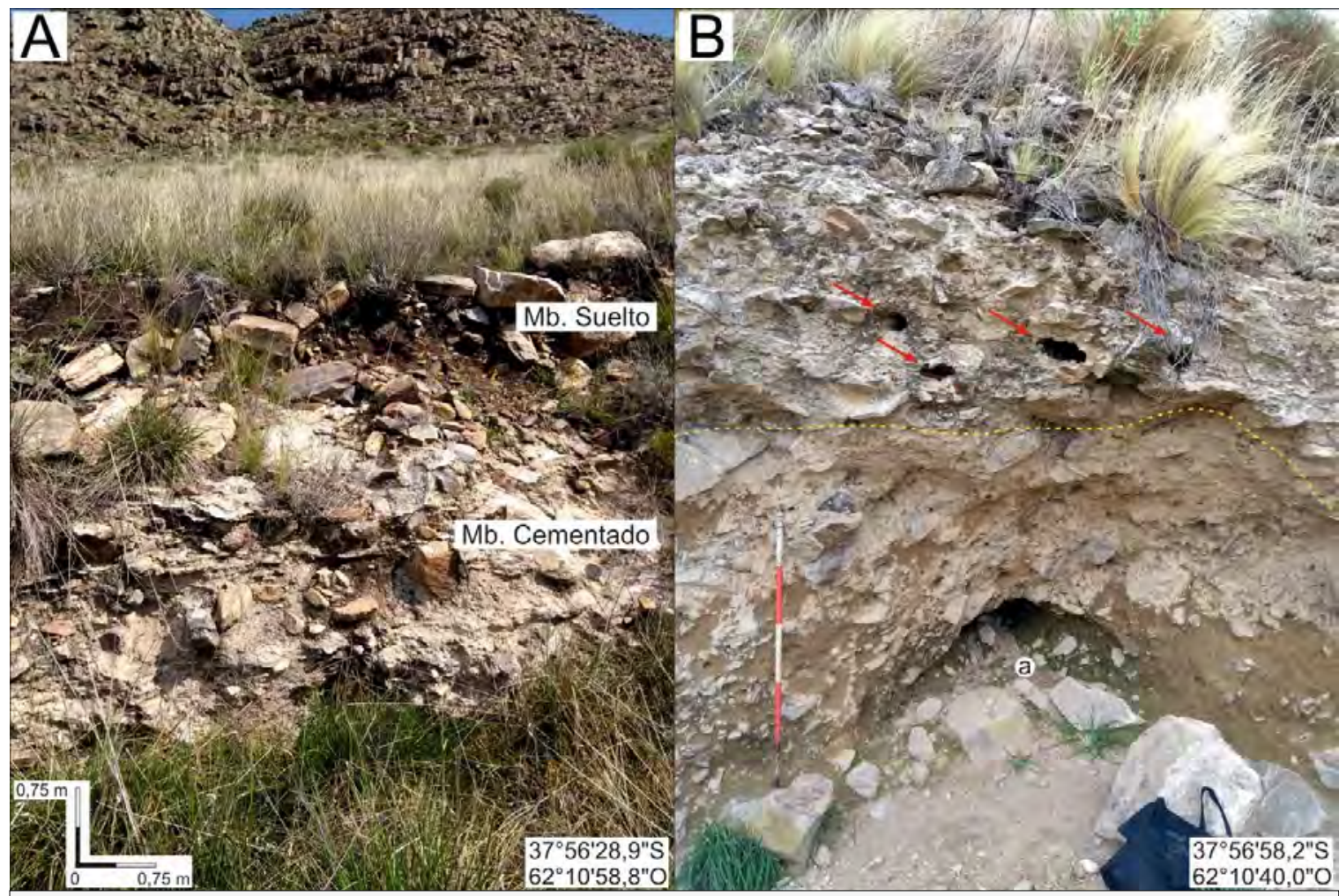

Figura 5.17. A. Corte transversal a la pendiente. Miembros Suelto y Cementado de los Detritos de Ladera. Al fondo: frente rocoso, zona de aporte de los detritos. B. Corte longitudinal a la pendiente. Mb. Cementado. Trazos: límite entre sector más y menos cementado. El sector más cementado presenta oquedades menores (flechas) que el menos cementado (a). El jalón (escala) mide $1 \mathrm{~m}$. Fotos: Juan M. Susena. 
Miembro Cementado: escasamente aflorante, se encuentra generalmente expuesto en escarpas, superficies de ruptura, coronas o flancos de deslizamientos o flujos, entre 0,5 y $3 \mathrm{~m}$ por debajo de la superficie original del terreno. Presenta espesores observados de hasta $3 \mathrm{~m}$ en escarpas originadas por movimientos en masa en las laderas del Cerro Pan de Azúcar, no descartándose que pueda haber mayores, ya que en algunas localidades alcanza dimensiones similares, sin base expuesta. Su distribución espacial es discontinua en las laderas; la gran escasez de clastos o bloques provenientes del Mb. Cementado en las cercanías de sus afloramientos, induce a considerar que la discontinuidad espacial se vincularía al desarrollo localizado de la unidad, y no a la erosión total de la misma. Se caracteriza por presentar carbonato de calcio masivo, impregnando y cementando la matriz, y recubriendo los clastos a modo de costras. En algunas localidades donde no aflora este miembro, la matriz de los Detritos de Ladera presenta $\mathrm{CaCO}_{3}$, diseminado, a veces constituyendo concreciones relativamente continuas, expuestas en superficies de ruptura de deslizamientos, a unos $3 \mathrm{~m}$ por debajo de la superficie original del terreno, a las que suelen asociarse manantiales. Allí, las características mencionadas insinúan la posible presencia del Miembro Cementado en sub-superficie. En cortes estratigráficos paralelos a la pendiente, puede observarse una laminación difusa irregular en la matriz cementada; inclinada a favor de la pendiente actual -aunque con ángulos algo menores-, suele amoldarse a la forma de los clastos del esqueleto. De acuerdo a una hipotética génesis de estas calcretas vinculada a la infiltración (per descensum) del $\mathrm{CaCO}_{3}$ en el perfil (Buschiazzo, 1986), las mencionadas estructuras de la matriz podrían corresponder a fluctuaciones en la profundidad de infiltración alcanzada (estructuras secundarias o postdeposicionales). Esta observación es importante, puesto que en cortes transversales a la pendiente dicha estructura es expuesta parcialmente, y puede ser confundida con una típica laminación vinculada a la acción del agua superficial (estructura primaria o sindeposicional). Asimismo, el cemento carbonático de la matriz es disuelto localmente, desarrollándose huecos de disolución de sección elipsoidal de $2-50 \mathrm{~cm}$ de eje mayor y hasta $1 \mathrm{~m}$ de profundidad, a veces constituyendo pequeñas galerías y cuevas; los mayores se desarrollan en la parte inferior de la unidad, la cual contiene un menor grado de cementación y un mayor lavaje de la matriz detrítica (Figura 5.17.B). Los bloques tienen dimensiones diversas según la ubicación del afloramiento, generalmente no superan los $30 \mathrm{~cm}$ de eje mayor y suelen ser similares en tamaño y abundancia a los bloques integrantes del sobreyacente Miembro Suelto, aunque su disposición es algo más dispersa o desordenada que en los últimos (Figura 5.18).

Las estructuras de la cementación y la disposición de los clastos, pero sobre todo la distribución espacial localizada, podrían indicar una posible génesis relacionada con concentraciones de agua mayores respecto a los sectores aledaños. Esta unidad se 


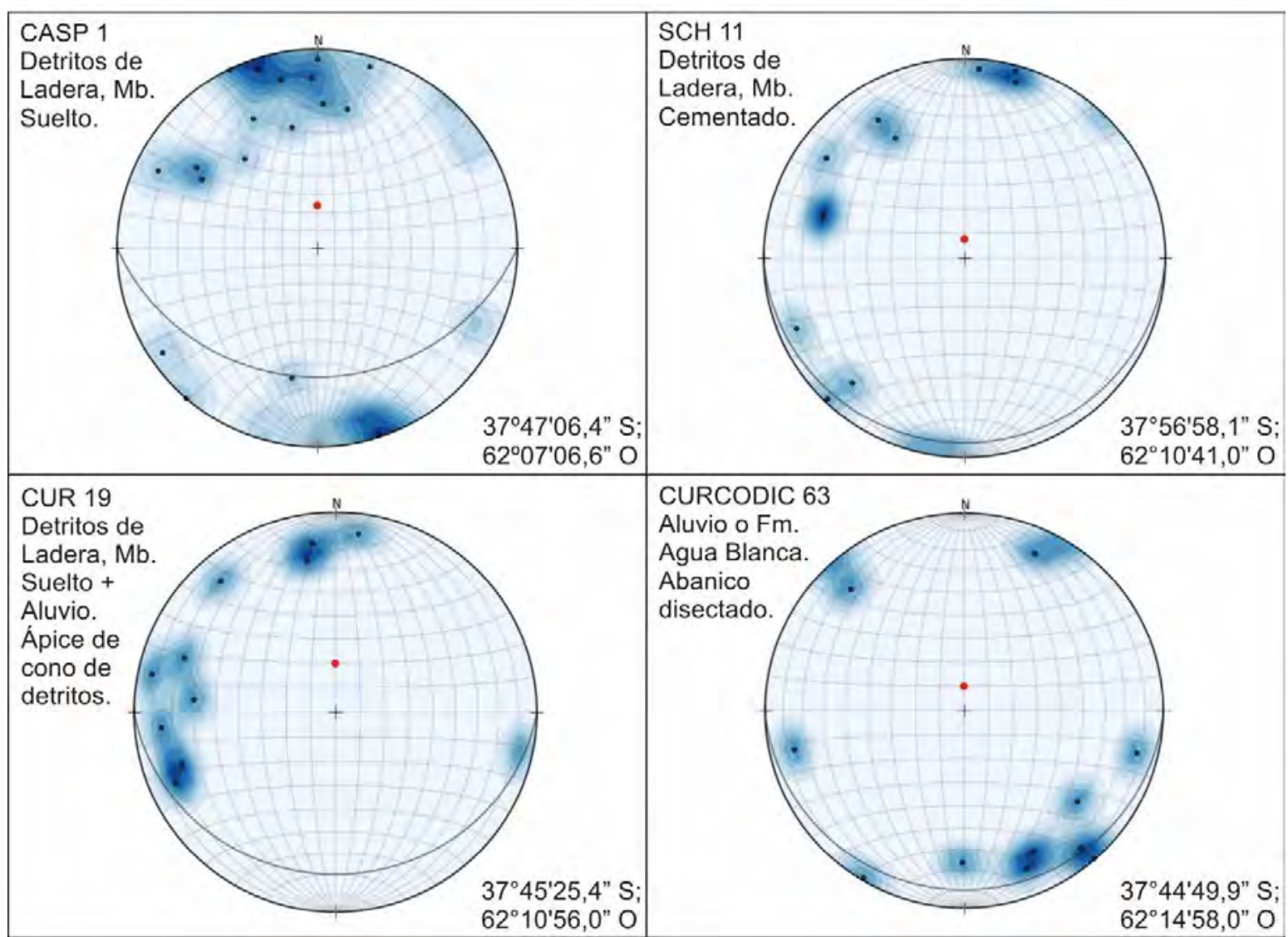

Figura 5.18. Estereogramas en red de Wulf representando orientaciones de clastos mayores a 10 $\mathrm{cm}$ de eje mayor (puntos negros) y su dispersión respecto a la superficie local (arcos y puntos rojos). Para facilitar la comparación, se rotaron los estereogramas hacia el norte. El Mb. Cementado muestra una dispersión algo mayor que el Mb. Suelto (en el primero, las mayores concentraciones de puntos en el diagrama están más separadas entre sí). Nótese cómo en los tramos medios de ladera (gráficos de arriba) los clastos inclinan predominantemente a favor de la pendiente, y con una dispersión del rumbo menor que en sectores con influencia aluvial (gráficos de abajo). En la muestra de Aluvio o Fm. Agua Blanca se aprecia la imbricación de clastos en contra pendiente, poco o nada expresada en laderas. Elaboración propia.

distribuye a escala regional (Gentile, 2011, indica la presencia de carbonatos en laderas de detritos en Tandilia), denotando un condicionamiento principalmente paleoclimático vinculado a un clima semi-árido. Sin embargo, la cementación más intensa de los Detritos de Ladera se ubica en sectores localizados del relieve, donde el mismo acentuaría las condiciones necesarias para su desarrollo. En la actualidad, las depresiones locales vinculadas a movimientos en masa en las laderas (como zonas de hundimiento y partes posteriores de acumulaciones) posibilitan el actual desarrollo de cuerpos de agua con características estratigráficas particulares (ver Capítulo 11 Interacciones entre movimientos en masa y escurrimiento superficial/sub-superficial). De la misma manera, formas similares existentes en el pasado podrían haber favorecido una cementación mayor en ciertos sectores de las antiguas laderas de detritos.

Se observó en el terreno que los niveles cementados se encontraban sobre depósitos 
eólicos no cementados, con lo cual la cementación se habría producido desde abajo hacia arriba, pero luego de un primer evento generalizado de formación de calcretas (Pereyra, 1996a), a partir de las cuales se habrían desarrollado numerosas etapas de endurecimiento (Buschiazzo, 1986). Esto no tiene relación con la presencia de materiales impermeables infrayacentes a las primeras calcretas (Fm. La Norma) puesto que, en primera instancia no los hay; en segundo lugar, si hubiese un material impermeable a escasa profundidad, como podría ser la roca de base, posiblemente existiría un mayor contenido de humedad, inhibiendo el endurecimiento del material suprayacente (Buschiazzo, op. cit.). La clave del desarrollo de estas calcretas está, entre otros factores, en la cantidad de agua que infiltra: debe alcanzar siempre una profundidad determinada (sea por la presencia de un material menos permeable en profundidad o por un monto dado de agua de infiltración), pero no debe permanecer allí mucho tiempo ni ser demasiada (salvo agua con carbonato de calcio concentrado), o el carbonato de calcio se disolvería, que es lo que ocurre en la actualidad, al encontrarse la zona bajo condiciones sub-húmedas.

Miembro Suelto: yace en todas las laderas de detritos, ocupando la mayor parte de su superficie; sus discontinuidades laterales se vinculan a la presencia de afloramientos de rocas pre-paleocenas, y en menor medida a la erosión local por acción fluvial y de movimientos en masa. La matriz es masiva, generalmente friable en seco y firme a levemente plástica en húmedo; presenta elevados contenidos de materia orgánica y se encuentra pedogenizada en mayor o menor medida, con una argiluviación relativamente evidente. La fábrica de los depósitos varía según la posición respecto a las zonas de aporte de los detritos: los frentes escarpados rocosos y las cimas. En las áreas proximales, es común una marcada escasez o ausencia de matriz, encontrándose los bloques trabados entre sí y apoyados sobre afloramientos rocosos, o sobre facies de los depósitos con presencia de matriz (Figura 5.19). En los términos superiores de las áreas

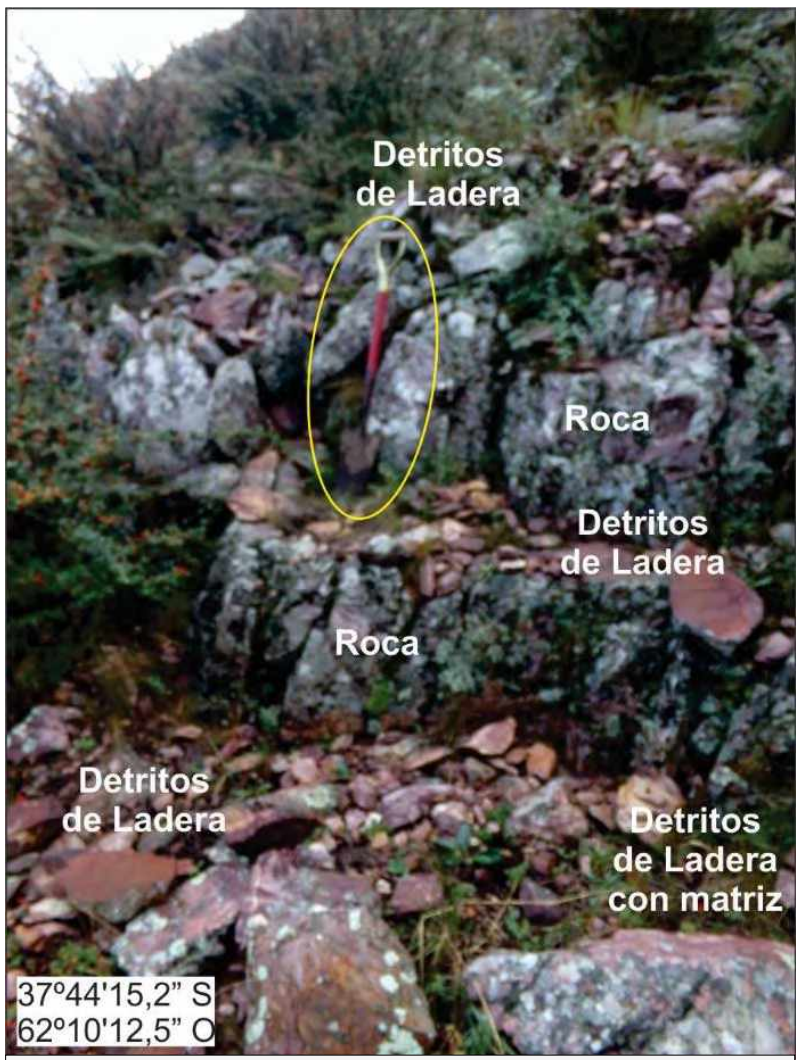

Figura 5.19. Detritos de Ladera carentes de matriz apoyados sobre roca o sobre Detritos de Ladera con presencia de matriz. La pala (elipse) sirve como escala. Foto: Juan M. Susena. 
Movimientos en masa en las sierras de Bravard y Curamalal,

Sierras Australes de la Provincia de Buenos Aires.

Juan Manuel Susena

proximales, la ausencia de matriz generalmente se debe a su no depositación, constituyendo verdaderos scree en el clásico sentido de Bloom (1991). En contextos similares, al sur de la zona de estudio son mencionadas las "gravas abiertas" (Rabassa, 1989), las cuales se originarían por lavado de una matriz preexistente. Dicha situación también se ha reconocido en el área aquí estudiada, preferentemente en los sectores medios y distales de las laderas, muchas veces representando degradación de movimientos en masa. Generalmente, los sectores medios de las laderas -donde los depósitos alcanzan espesores máximos- presentan imbricación pendiente arriba de los clastos menores, mientras que los de grandes tamaños (mayores a $10 \circ 15 \mathrm{~cm}$ ) inclinan generalmente a favor de la pendiente (Figura 5.18). Suelen apoyarse unos sobre otros, con inclinaciones progresivamente mayores; estos rasgos también se observan en superficie (ver núcleos de roca en Capítulo 6 Geomorfología general del área). Como ya se mencionó, las depresiones locales de zonas de hundimiento y partes posteriores de acumulaciones de movimientos en masa producen ciertas particularidades: los materiales finos sepultan parcial o totalmente a los bloques, generando facies estratigráficas locales. Los sectores distales se caracterizan por un mayor contraste granulométrico: son comunes los bloques métricos en una matriz limosa que ocasionalmente los cubre parcialmente, y es llamativa la escasez de bloques decimétricos, tan típicos en los sectores medios y proximales. Esta distribución de la fábrica apoya la idea de una génesis múltiple para estos depósitos. Por un lado, los materiales gruesos se generarían por caídas y vuelcos de roca, y la acción de la gravedad tendría un rol fundamental en su selección, ya que los mayores bloques alcanzan la parte distal debido a su mayor energía potencial, respecto a los bloques menores. Por otra parte, el retransporte de la matriz eólica por el escurrimiento superficial principalmente no encauzado, generaría en una deficiencia del material ladera arriba y una consecuente sobreabundancia ladera abajo y en depresiones locales dentro de las laderas.

\subsection{Marco tectónico y estructuras geológicas}

Se considera a las Sierras Australes (sistema de Ventania) como una faja plegada y corrida durante la orogenia Gondwánica -principalmente durante el Pérmico (Rossello et al. 1997)vinculada a una colisión continente-continente entre el borde occidental de Gondwana y Patagonia (Ramos, 1984). En un marco morfoestructural corresponde, junto a Tandilia y la Llanura Interserrana, al Positivo Bonaerense (Yrigoyen, 1975, véase Figura 6.1 en el siguiente capítulo). Con un diseño sigmoidal en planta, el sistema serrano presenta en el área de estudio una morfología de arco convexo hacia el NNE, cuyo punto de inflexión se ubica en la zona de las abras de los arroyos Agua Blanca y 27 de Diciembre (Figuras 4.1 
y 4.2 en el capítulo anterior). Dicho diseño se debería a un régimen transpresivo dextral (Cobbold et al. 1986; 1991; 1992; Buggish, 1987; Japas, 1987; 1988; Sellés-Martínez, 1989; Rossello et al., 1997; Tomezzoli, 2001; etc.) con vergencia al NE.

Japas (1999) presenta una síntesis de las estructuras deformacionales principales, con sus orientaciones, como se muestra en la Tabla 5.2.

\begin{tabular}{|c|c|c|}
\hline ESTRUCTURA & ZONA CENTRO & ZONA SUR \\
\hline \multicolumn{3}{|c|}{ CUBIERTA PALEOZOICA } \\
\hline Plegamiento & $135^{\circ}-145^{\circ}$ & $150^{\circ}-200^{\circ}$ \\
\hline Clivaje & $135^{\circ}-145^{\circ}$ & $150^{\circ}-200^{\circ}$ \\
\hline $\begin{array}{l}\text { Lineación de } \\
\text { estiramiento }\end{array}$ & $\begin{array}{c}\text { Ninguna }(\mathrm{AAB}) \text { a subvertical } \\
\text { baja/220 }\end{array}$ & $20^{\circ} / 210^{\circ}$ \\
\hline Fábrica deformacional & Aplastamiento $(\mathrm{AAB})$ a plana & Plana \\
\hline Estructuras s/c & Dirección de inclinación sn & $\begin{array}{c}210^{\circ} \text { provergente } \mathrm{dx} \\
150^{\circ} \text { av dx }\end{array}$ \\
\hline Milonitas & No hay información & $185^{\circ}$ \\
\hline Fracturación & $210^{\circ} / 85^{\circ} \mathrm{SO}$ & $25^{\circ} / 80^{\circ} \mathrm{E}$ \\
\hline Diaclasas & $260^{\circ} / 86^{\circ} \mathrm{N}$ & $55^{\circ} / 90^{\circ}$ \\
\hline Fallas & & $220^{\circ} \mathrm{dx}-120^{\circ} \mathrm{sns}$ \\
\hline Bandas kink & No hay información & $\begin{array}{c}\text { Contraccionales: } 80^{\circ} \text { sns y } 120^{\circ} \\
\mathrm{dx}\end{array}$ \\
\hline \multicolumn{3}{|l|}{ BASAMENTO } \\
\hline Clivaje & $135^{\circ}$ & $185^{\circ}-150^{\circ}$ \\
\hline $\begin{array}{l}\text { Lineación de } \\
\text { estiramiento }\end{array}$ & $145^{\circ}\left(235^{\circ}\right)$ & $19^{\circ}$ \\
\hline Fábrica deformacional & Aplastamiento/Plana & Plana \\
\hline Estructuras s/c & $145-150^{\circ} \mathrm{dx}, \mathrm{pv} \mathrm{dx}\left(90^{\circ} \mathrm{sns}\right)$ & $\begin{array}{c}185^{\circ} \mathrm{dx}-220^{\circ} \mathrm{pv} d x \\
196^{\circ}-59^{\circ} \mathrm{NO} d x-150^{\circ} \mathrm{dx}\left(110^{\circ}\right. \\
\text { pv sns })\end{array}$ \\
\hline Milonitas & $\begin{array}{c}145^{\circ}-100^{\circ}-40^{\circ} \\
104^{\circ} / 65^{\circ} \mathrm{S}-217^{\circ} / 81 \mathrm{NO} \\
141^{\circ} / 64^{\circ} \mathrm{SO}-165^{\circ} / 64^{\circ} \mathrm{SO}\end{array}$ & $185^{\circ} 200^{\circ}$ \\
\hline Fracturación & $29^{\circ} / 90^{\circ}-143^{\circ} / 90^{\circ}$ & $145^{\circ} / 30^{\circ} \mathrm{SO}$ \\
\hline Diaclasas & $\begin{array}{c}60^{\circ} / 90^{\circ}-153^{\circ} / 90^{\circ} \\
105^{\circ} / 60^{\circ} \mathrm{S}-35^{\circ} / 90^{\circ} \\
70^{\circ} / 90^{\circ} \\
99^{\circ} / 66^{\circ} \mathrm{S}-216^{\circ} / 79^{\circ} \mathrm{NO} \\
139^{\circ} / 61^{\circ} \mathrm{SO}-63^{\circ} / 78^{\circ} \mathrm{SE} \\
173^{\circ} / 65^{\circ} \mathrm{O}-150^{\circ} / 73^{\circ} \mathrm{NE}\end{array}$ & $\begin{array}{l}150^{\circ} / 24 \mathrm{NE} \\
149^{\circ} / 66^{\circ} \mathrm{SO} \\
176^{\circ} / 29^{\circ} \mathrm{O}\end{array}$ \\
\hline Fallas & $115^{\circ} / 90^{\circ}-215^{\circ} / 90^{\circ}$ & \\
\hline Bandas kink & $\begin{array}{c}\text { Extensionales: } \\
110^{\circ} / 50^{\circ}-70^{\circ} \mathrm{NE} \text { pv sns } \\
76^{\circ} / 38^{\circ} \mathrm{NO} \text { sns y } 80^{\circ} / 70^{\circ} \mathrm{S} \mathrm{dx}\end{array}$ & No hay información \\
\hline
\end{tabular}

Tabla 5.2. Síntesis de estructuras principales, modificado de Japas (1999). Zona centro: Sas. de Bravard y Curamalal; zona sur: $C^{\circ}$ Pan de Azúcar y Del Corral. AAB: Abra de Agua Blanca. pv: provergente. av: antivergente. sns: sinestral. dx: dextral.

La zona de máxima deformación se ubica en el sector de los cerros Pan de Azúcar-del Corral, donde se encuentran fajas miloníticas afectando parte del complejo ígneometamórfico y la base de la secuencia sedimentaria. Asimismo, se desarrollan allí corrimientos que montan al basamento sobre las sedimentitas paleozoicas (Cucchi, 1966; Cuerda et al., 1975; Cobbold et al., 1986; von Gosen et al., 1991, entre otros). Las estructuras mesoscópicas características del basamento son: foliación milonítica y lineaciones de estiramiento de minerales, ambas buzantes hacia el SO, estructuras S/C y 
Movimientos en masa en las sierras de Bravard y Curamalal,

Sierras Australes de la Provincia de Buenos Aires.

Juan Manuel Susena

fracturamiento subsidiario (Dimieri et al., 2005 y trabajos allí citados).

El plegamiento, rasgo más notorio de las secuencias sedimentarias, afecta al basamento y a la secuencia paleozoica y conforma las estructuras sobresalientes de las Sierras Australes (Harrington, 1947), presentándose en forma más conspicua en el área estudiada, perdiendo expresión hacia el naciente. El plegamiento es múltiple, de hasta séptimo u octavo orden, siendo enmascarado el plegamiento mayor, que alcanza unos 4-5 Km de longitud de onda y 0,5-1 Km de amplitud (Harrington, 1947; 1970; Cobbold et al., 1986). Estos pliegues se encuentran volcados hacia el NE, con inclinaciones de unos $20^{\circ}-30^{\circ}$ para los limbos normales, y limbos invertidos inclinando unos $60^{\circ}-80^{\circ}$. Son comunes los pliegues volcados hacia el este (Cingolani, 2005 y bibliografía allí citada), cuyos ejes suelen acompañar la curvatura de las sierras (Llambías y Prozzi, 1975), y se han citado estilos de plegamiento similar y disarmónico (Harrington, 1947), concéntrico y disarmónico (Llambías y Prozzi, op. cit.) y chevrón (Kilmurray, 1975). En las sierras de Bravard, las culminaciones de los pliegues suelen encontrarse en las proximidades de las cotas máximas de sus cerros. Allí, las divisorias principales coinciden con las trazas axiales y el arqueamiento de los ejes. En las sierras de Curamalal las trazas axiales se ubican preferentemente en las laderas orientales, donde los estratos plegados presentan despegamientos (sensu Schiller, 1930) que condicionaron el desarrollo de rasgos muy característicos del paisaje, como "las grutas" (Figura 5.20) y el "valle de los lagos", ubicados en la Ea. Las Grutas. En este sentido, aleros y grutas suelen asociarse a pliegues anticlinales $y$, en contraparte, se desarrollan extensos mantos o conos de talud a partir de los sinclinales (Figura 5.21). Las charnelas de los pliegues suelen estar engrosadas, y los núcleos, aplastados,

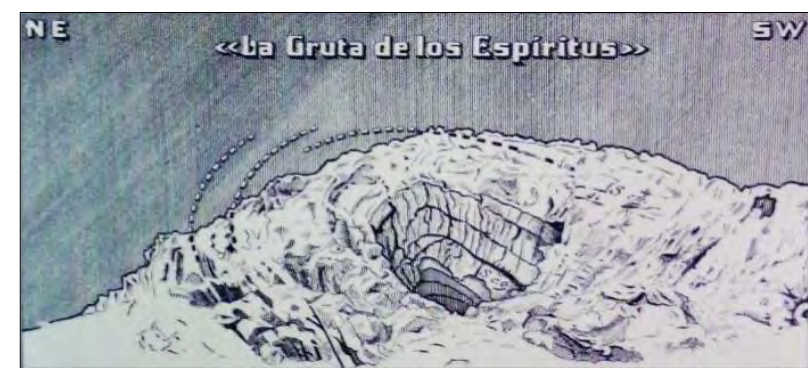

Figura 5.20. Gruta de los Espíritus en el Cerro Curamalal Grande. Tomado de Schiller (1930). Pliegue anticlinal con fracturas transversales. La cueva tiene unos $55 \mathrm{~m}$ de profundidad, y su entrada unos $8 \mathrm{~m}$ de anchura en la base por $4 \mathrm{~m}$ de altura (según Holmberg, 1884). no presentan fracturamiento (Llambías y Prozzi, 1975).

Al plegamiento pueden asociarse corrimientos subordinados (Japas, 1999), como es el caso de los cerros Pan de Azúcar-del Corral, donde se presentan fallas inversas afectando al basamento, con desarrollo de fajas miloníticas (Figura 5.22). Son comunes los espejos de fricción en los planos de estratificación, presentando estrías, esto indicaría mecanismos de deslizamiento durante el desarrollo del plegamiento (Llambías y Prozzi, 1975). Asimismo, la deformación en los planos axiales se evidencia en el desarrollo de foliaciones y lineaciones (Dimieri et al., 2005 y trabajos allí citados). Si bien la deformación es preferentemente dúctil (pliegues y fajas miloníticas), existen indicios de deformación frágil 
a diferentes escalas.

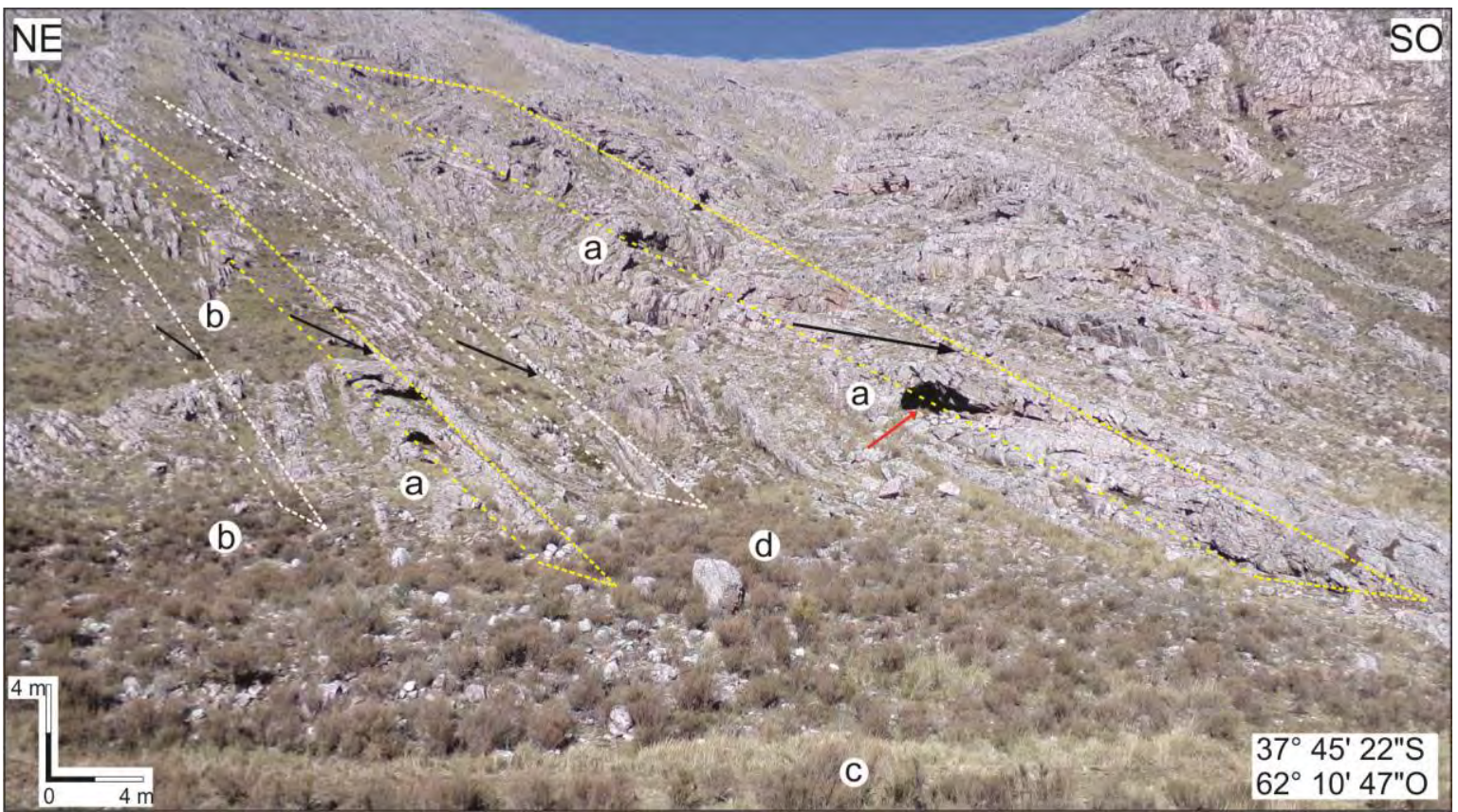

Figura 5.21. Ea. Las Grutas. Vertiente oriental del Cdón. Lehmann, ladera derecha de valle SONE. Pliegues volcados. Líneas discontinuas: planos axiales (amarillas: anticlinales; blancas: sinclinales). Flechas negras: dirección de buzamiento de plano axial. a: Aleros o grutas. b: conos de detritos. c: terraza. d: abanico aluvial. Escala ajustada a la gruta (flecha roja). Foto: Juan M. Susena.

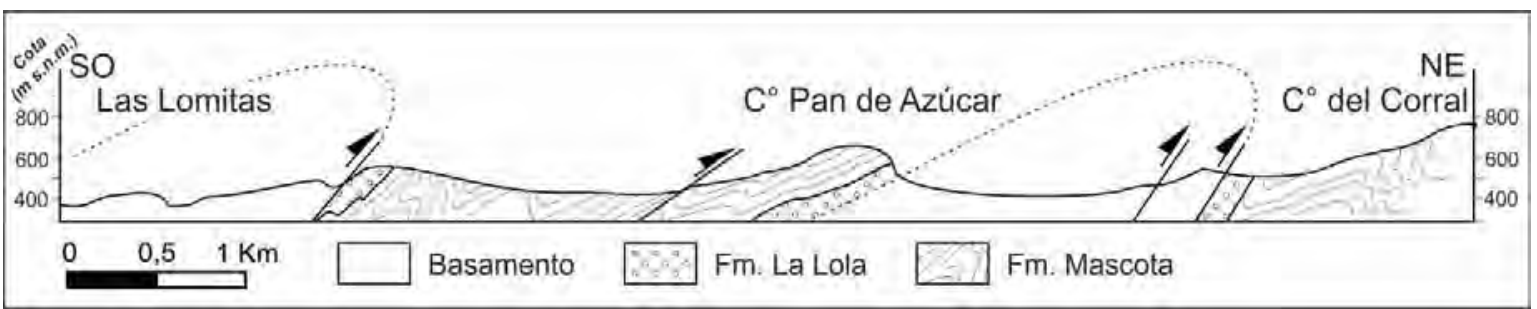

Figura 5.22. Figura 7.27. Perfil geológico esquemático del área de los cerros Pan de Azúcar-del Corral, en el extremo SO del área de estudio. Flechas negras: corrimientos. Líneas discontinuas: proyecciones de plegamientos. Modificado de Dimieri et al. (2005).

El rasgo más conspicuo que actualmente se supone asociado a fallamiento es el valle interserrano o "valle de las Grutas", cuya expresión morfológica dista notablemente de la de un mero valle fluvial (ver Capítulo 6 Geomorfología general del área). En dicho valle se preservaron remanentes de zonas de falla afectando las secuencias paleozoicas, donde se observa una intensa deformación frágil y sericitización (Figura 5.23). Existen fallas que atraviesan las sierras con un rumbo aproximado E-O (Japas 1999 y trabajos allí citados), a las que se asocian valles relativamente estrechos y profundos. Japas (1995) analiza megaestructuras cuyo grado de deformación difiere en mayor o menor medida respecto a su entorno, tales como los lineamientos o megabandas kink Sauce Chico y Pigüé, cuya importancia se relacionaría con el desarrollo de la morfología de arco del cordón serrano. 


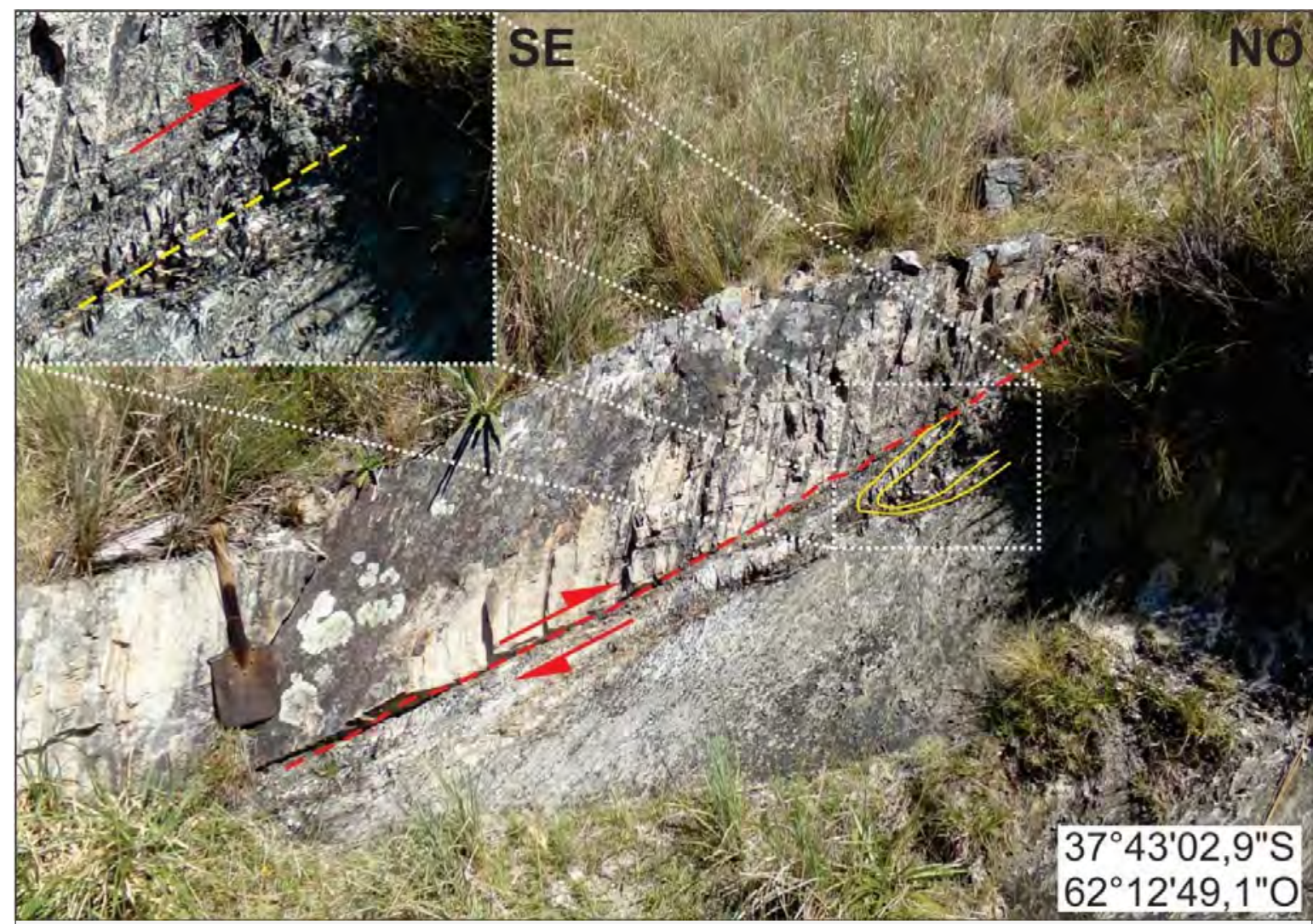

Figura 5.23. Remanente de zona de falla afectando la Fm. Hinojo. Trazas rojas: línea que representa el plano de falla. Flechas: dirección aparente del movimiento relativo. Línea amarilla: pequeño pliegue posiblemente de arrastre (foto aumentada). Trazas amarillas: línea que representa el plano axial. Nótese la intensa sericitización del bloque piso de la falla. NOTA: la sección geológica no está expuesta en otros sectores, por lo cual las direcciones de movimiento relativo podrían representar sólo una componente del movimiento neto. La pala de mano sirve como escala. Fotos: Juan M. Susena.

Quizá las estructuras geológicas mega a mesoscópicas más relevantes en el desarrollo de frentes escarpados y laderas de detritos, y de los diferentes tipos de movimientos en masa asociados, sean las diaclasas. Existen sistemas de diaclasas maestras, de entre 500 y $2000 \mathrm{~m}$, que controlan la red de drenaje y son reconocibles con fotografías aéreas (Llambías y Prozzi, 1975); éstas son fácilmente identificables en el sector sur de las sierras de Bravard (Figura 5.24), y pueden observarse también en las sierras de Curamalal (Figura 5.25). Según Di Nardo y Dimieri (1988) y Dimieri et al. (2005), los sistemas de diaclasas principales son los extensionales normales a los ejes de los pliegues y los juegos conjugados de cizalla, cuyos ángulos obtusos son bisecados por los ejes de los pliegues. Dimieri et al. (2005) destacan además diaclasas paralelas a los ejes axiales y dispuestas en abanico, que delimitan bloques romboidales. Junto con la estratificación, las diaclasas contribuyen a la diferenciación de geoformas similares a flatirons (Figuras 5.24 y 5.26) y condicionan la generación de los bloques de los Detritos de Ladera (Portada de este capítulo). 


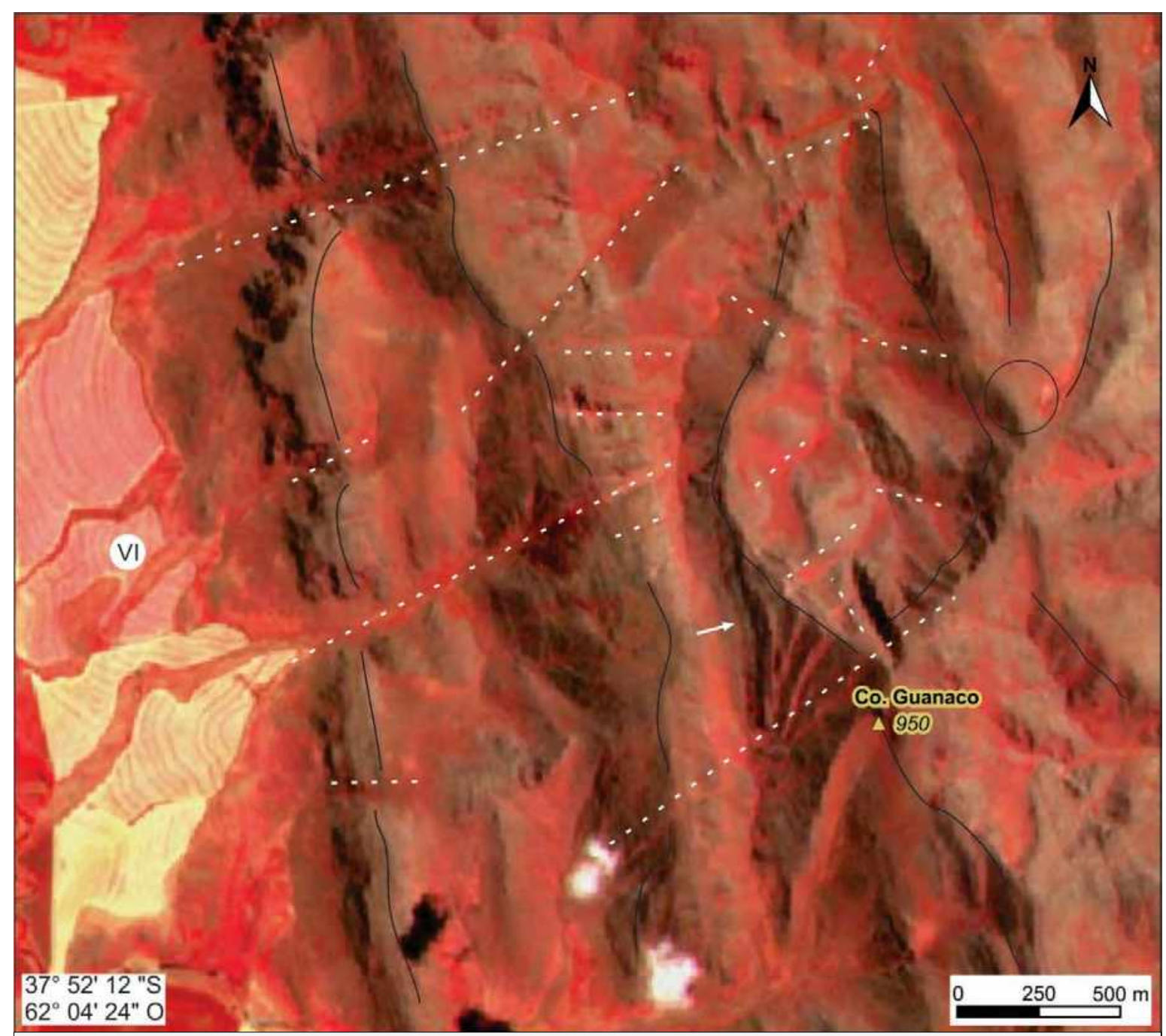

Figura 5.24. Cerro Guanaco. Imagen satelital Sentinel 2 infrarrojo color (17/01/2018). Los estratos buzan hacia el OSO. Líneas blancas: fracturas. Líneas negras: divisorias principales. Círculo negro: movimiento en masa. Flecha blanca: flatirons. VI: Valle interserrano (prolongación al sur del Valle de las Grutas). Elaboración propia. 


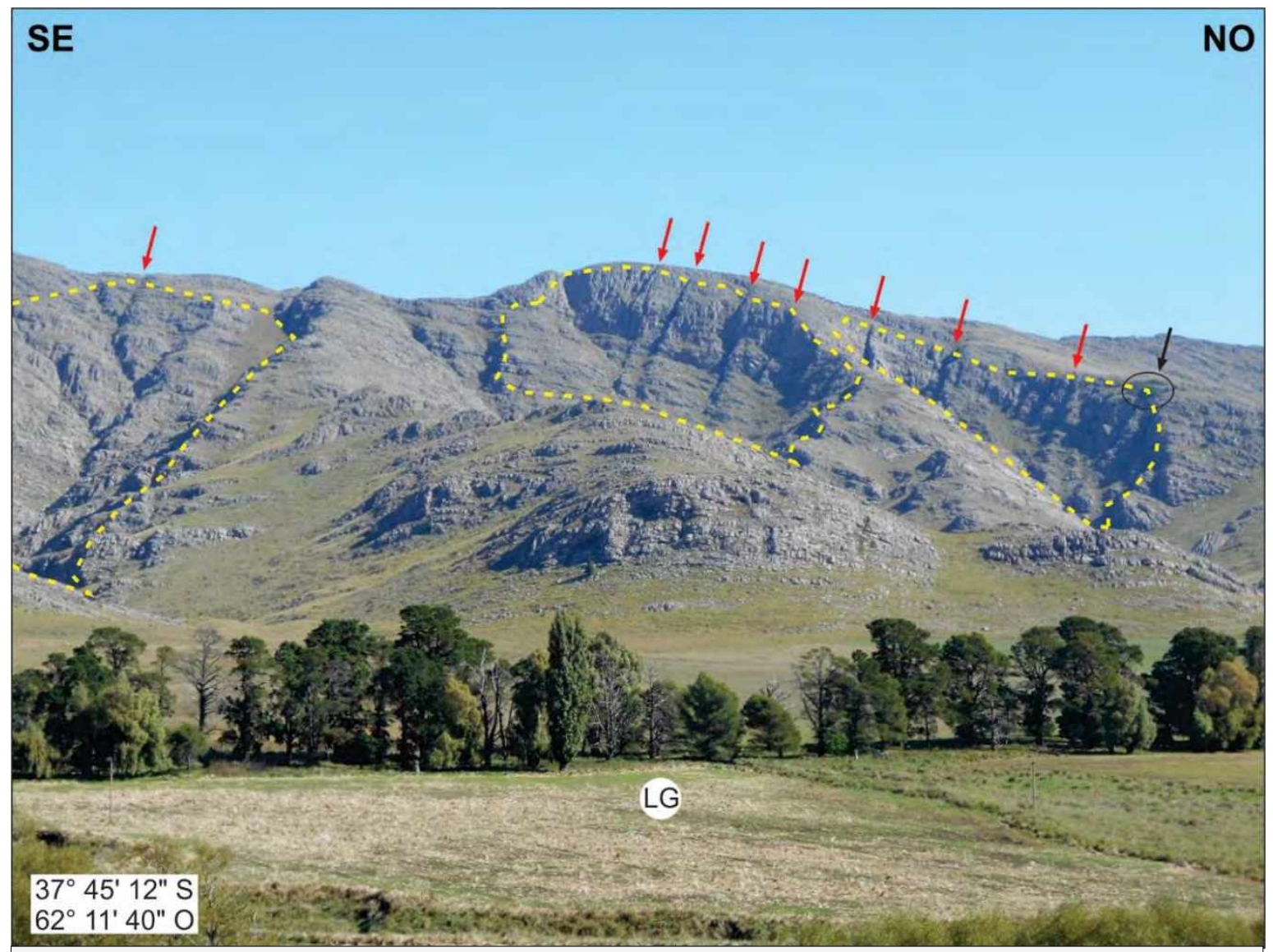

Figura 5.25. Ea. Las Grutas. Cordón Lehmann. Los estratos buzan hacia el SO. Flechas rojas: sistemas de diaclasas; note la concentración localizada en la mitad derecha de la fotografía. Flecha negra: diaclasa con concentración de humedad en superficie, evidenciada por vegetación (círculo negro). Líneas discontinuas amarillas: valles intraserranos. LG: Valle de las Grutas. Los árboles sirven como escala. Foto: Juan M. Susena.

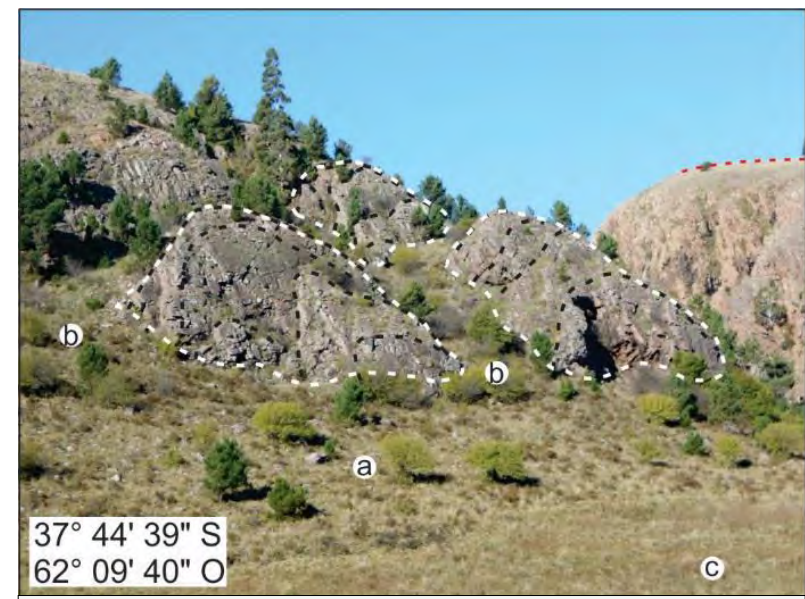

Figura 5.26. Ea. Las Grutas. Vertiente occidental de las sierras de Bravard. Flatirons (líneas blancas discontinuas). Líneas negras discontinuas: estratos. a: ladera de detritos. b: entrantes en laderas de detritos. c: terraza. Atrás en líneas rojas discontinuas: paleosuperficie en el Cerro Hinojo. Los árboles sirven como escala (aprox. 4 $m$ de altura). Foto: Juan M. Susena. 


\section{Capítulo 6}

\section{Geomorfología general del área}

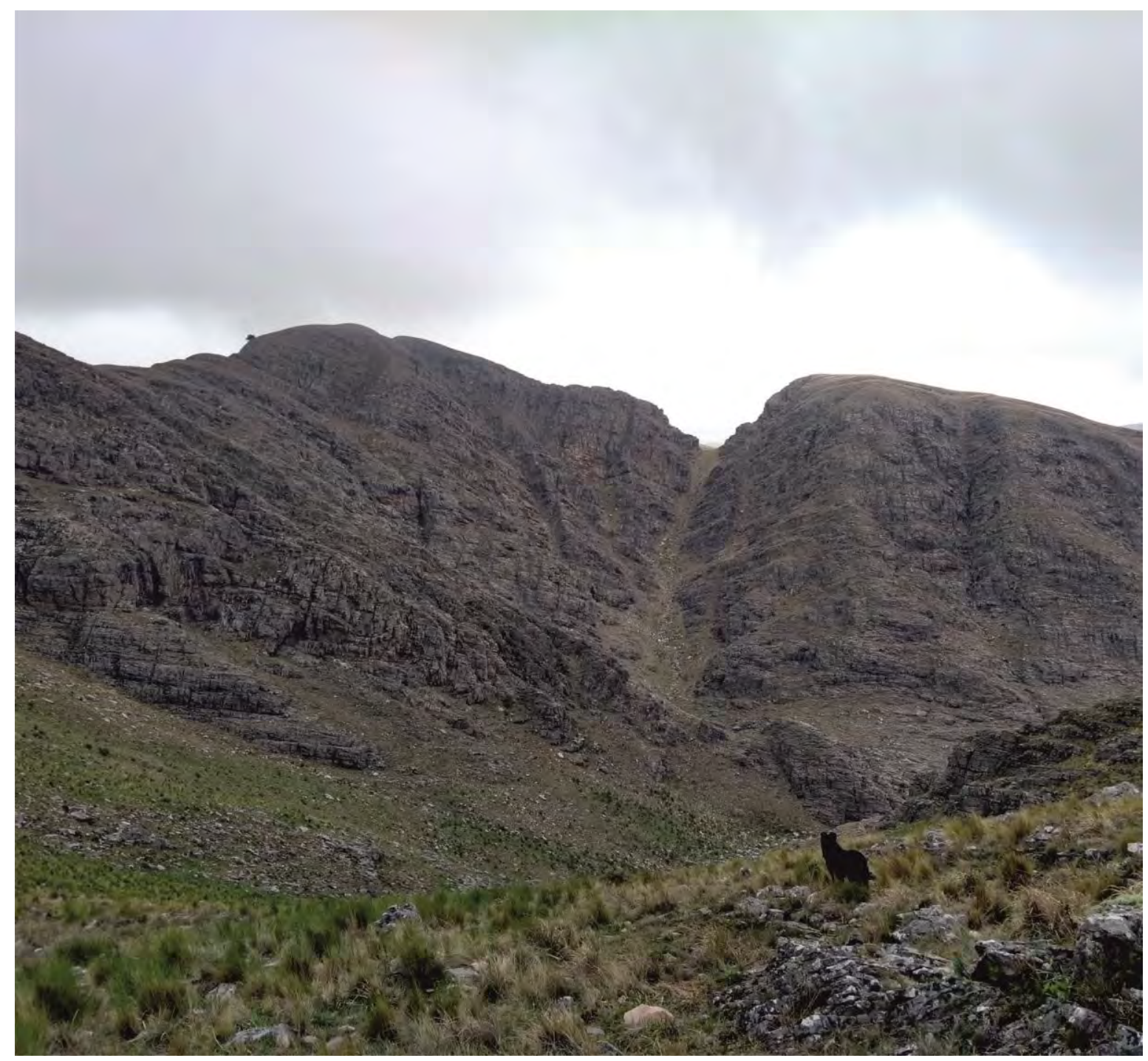

"Acompañante"

Perro de la Estancia Cerro Áspero mirando hacia un valle intraserrano de las Sierras de Curamalal.

Fotografía tomada durante una de las últimas campañas. 
Movimientos en masa en las sierras de Bravard y Curamalal, Sierras Australes de la Provincia de Buenos Aires.

Juan Manuel Susena 


\subsection{Ordenamiento del capítulo}

El objeto de este capítulo es la descripción y sistematización de los aspectos geomorfológicos identificados para el estudio de movimientos en masa. Cabe aclarar que no se trata de una caracterización geomorfológica absoluta del área de tesis: muchos aspectos no se tratan aquí porque no se identificó una clara influencia sobre el objeto de estudio (por ejemplo, acción eólica actual, historia geomorfológica de las superficies de planación regional, presencia/ausencia de procesos geocriogénicos en el pasado o el presente, etc.).

Existen muchos aspectos geomorfológicos de las Sierras Australes que fueron analizados ampliamente por varios autores. Pueden citarse, entre muchos otros, trabajos a escala regional, como los de Keidel (1916), Du Toit (1927), Schiller (1930; 1942), Harrington (1936; 1947), Frenguelli (1950), Furque (1973), Fidalgo et al. (1975), González Uriarte et al. (1988), Rabassa (1989), Rabassa et al. (1995; 1998), Zárate y Rabassa (2005), Demoulin et al. (2005), Trombotto (2008) y trabajos allí citados y Pereyra (2018). Algunos de los trabajos con reseñas y estudios geomorfológicos a escala local son los de Aguirre (1891), Duymovich y Moneda (1965), De Francesco (1992a), Pereyra y Ferrer (1995), Gaspari y Bruno (2003), Ángeles y Gil (2006), Gil y Campo de Ferreras (2006), Torrero y Campo (2008), Gil et al. (2009; 2014), Torrero et al. (2010), Gaspari et al. (2011), Uboldi et al. (2011), Gil y Campo (2012), Rosell y Ángeles (2012), Carrascal et al. (2013), Delgado et al. (2013), García Martínez et al. (2016), Susena y Gentile (2017; 2018; 2019) y Susena et al. (2019a; 2019b).

Por su parte, los antecedentes sobre geomorfología relacionada con movimientos en masa en el área estudiada ya se mencionaron en el Capítulo 2 Planteamiento del problema y objetivos.

Este capítulo comprende una introducción con aspectos regionales muy generales, y luego se procede a la descripción de las unidades y componentes geomorfológicos diferenciados.

\subsection{Aspectos geomorfológicos generales}

A escala regional, las Sierras Australes de la Provincia de Buenos Aires han sido agrupadas dentro del Positivo Bonaerense (Yrigoyen, 1975), junto a las Sierras Septentrionales de la Provincia de Buenos Aires (Sistema de Tandilia) y la Llanura Interserrana Bonaerense (Rolleri, 1975) o Cuenca o Antefosa de Claromecó (Ramos, 1984). Esta unidad morfoestructural está influenciada estrechamente por la morfología del basamento, formando un alto estructural rodeado por cuencas tectónicas (Figura 6.1). La 


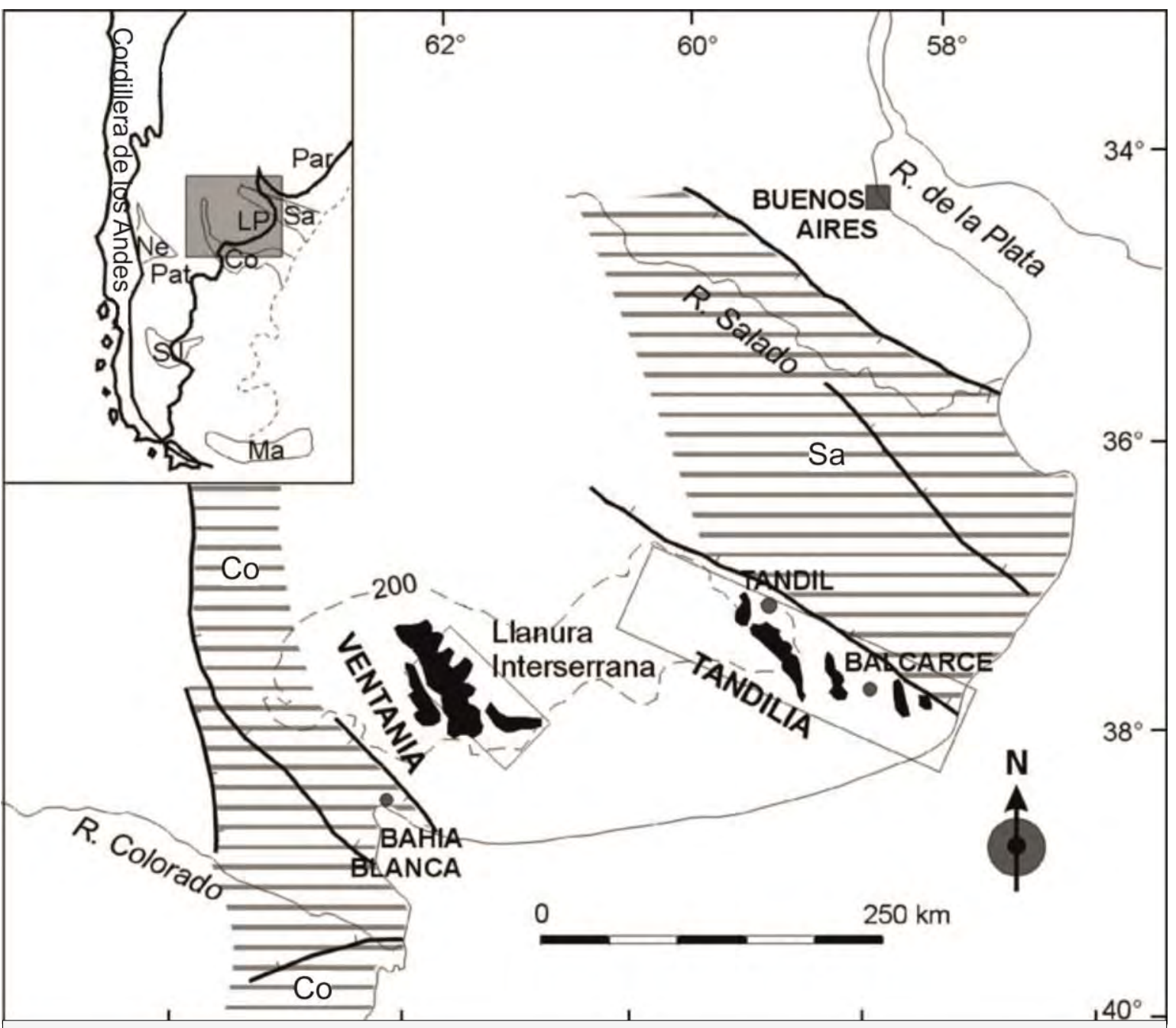

Figura 6.1. Positivo Bonaerense delimitado por la curva de nivel de $200 \mathrm{~m}$ (línea de guiones). El mapa pequeño muestra el Positivo Bonaerense en el contexto de Sudamérica. LP: Cratón del Río de La Plata. Par: Cuenca del Paraná. Sa: Cuenca del Salado. Co: Cuenca de Macachín-Colorado. Ne: Cuenca Neuquina. Pat: Meseta Patagónica. SJ: Cuenca del Golfo San Jorge. Ma: Cuenca de Malvinas. En negro se muestran esquemáticamente las Sierras Australes (Ventania) y Septentrionales (Tandilia) de la Provincia de Buenos Aires. Modificado de Demoulin et al. (2005).

Sierras Australes, o Sistema de Ventania, corresponden a una cadena plegada y corrida producida durante la orogenia Gondwánica, cuyas características tectónicas ya se comentaron en el Capítulo 5 Geología: generalidades. No obstante, el relieve montañoso actual no se relaciona directamente con dicha orogenia, ya que hubo un tiempo prolongado de relativa calma tectónica que permitió el desarrollo de superficies de planación regionales (Rabassa et al., 1995). Demoulin et al. (2005) propusieron un modelo de la evolución del paisaje de Ventania, basados en el estudio de paleosuperficies y de la historia de las Cuencas del Salado y Colorado. De acuerdo a estos autores, el relieve serrano actual iniciaría su historia a partir del rifting de Gondwana, cuando los materiales que formaban parte de la paleosuperficie pre-rifting (representada por cimas planas a $800-900 \mathrm{~m}$ de altitud) fueron denudados para rellenar las Cuencas del Salado y del Colorado durante el 
Cretácico tardío (Urien y Zambrano, 1973). La Brecha Cerro Colorado (véase Capítulo 5 Geología: generalidades), atribuida a este ciclo sedimentario, se habría depositado en condiciones de clima árido durante el Cretácico tardío o Paleógeno temprano, y se habría silicificado durante el Paleoceno en condiciones de clima húmedo (Zárate et al., 1998). Una pedimentación extendida hasta el Oligoceno habría labrado la paleosuperficie principal ubicada unos 450-500 m s.n.m. Un segundo rejuvenecimiento del paisaje (manifestado en pedimentos del Plioceno) habría tenido lugar debido a un levantamiento en la Cordillera de los Andes durante el Mioceno asociado a la fase Quechua de la orogenia Andina (Ramos, 1988), registrado a su vez como un segundo ciclo de rápida sedimentación en las Cuencas del Salado y del Colorado (Urien y Zambrano, 1973). La depositación de un manto eólico durante el Mioceno y su encostramiento calcáreo, habría suavizado el paisaje al menos en el piedemonte medio y distal, hasta que durante en el Plioceno-Pleistoceno, se labró un "pseudopedimento" (González Uriarte, 1984), representado por una discordancia erosiva regional que afecta a calcretas psefíticas y limolíticas antedichas, del Mioceno-Plioceno (Fidalgo et al., 1975; De Francesco, 1992a). A partir de dicha superficie se desarrolla gran parte de las formas del paisaje actual (De Francesco, 1992a). Alternancias de climas húmedos y secos durante el Neógeno-Cuaternario determinaron el desarrollo de una red de drenaje de baja densidad en el piedemonte, con una red de drenaje de los cursos principales mostrando un diseño aproximadamente paralelo, condicionada por la presencia de los niveles pedemontanos previos (Susena y Gentile, 2019). Dicha red está en gran parte obliterada por materiales eólicos del Pleistoceno tardío-Holoceno medio, y es muy característica la transición de cauces entrelazados o trenzados (= braided) en la parte proximal del piedemonte, a sinuosos y encajados en el sector medio-distal, coincidiendo estos cambios con un aumento en los espesores de los materiales eólicos. La presencia de terrazas y un nivel pedemontano (localmente dos) más bajos en el sector proximal a las sierras, podría ser respuesta a rejuvenecimientos del paisaje, producidos por neotectónica o cambios del nivel del mar asociados a las glaciaciones, aspectos poco estudiados en la región (Pereyra, 1996b).

Schiller (1930) caracterizó a las Sierras Australes como "montañas medianas", y menciona a modo de excepción, la existencia de "paredes a pique", que le confieren características de un paisaje netamente alpino. En este sentido, el potencial geomorfológico para la generación de movimientos en masa no depende de la extensión de sus laderas -no superan el orden hectométrico en la dirección de la pendiente, y alcanzan unos pocos kilómetros en dirección transversal a la pendiente- sino más bien se relaciona con sus pendientes elevadas y los espesores de los materiales no consolidados. Schiller menciona que las sierras están "ahogándose en sus propios escombros", refiriéndose a la gran 
Movimientos en masa en las sierras de Bravard y Curamalal,

Sierras Australes de la Provincia de Buenos Aires.

Juan Manuel Susena

extensión de la llanura periserrana, que llegaría hasta los límites de la Provincia de La Pampa al oeste, y hasta Bahía Blanca al sur. Menciona a su vez el gran desarrollo de conos de deyección como un rasgo extraño y "grandioso". A pesar de estas descripciones que aparentan que en la región hubiera una morfogénesis muy intensa, debe recordarse que a escala regional domina la pedogénesis sobre la morfogénesis, restringida esta última principalmente al área serrana y a los cauces fluviales. Pereyra (2018) caracteriza el ambiente serrano, denominándolo "Relieve serrano de Ventania (superficies de planación disectadas)", como una unidad de relieve relativo alto, fuertes pendientes, morfodinámica intensa, baja peligrosidad por inundaciones, alta erosión hídrica (por geomorfología), baja erosión eólica (por geomorfología), zona de recarga de acuíferos, nivel freático profundo y presencia de procesos de remoción en masa.

En cuanto a la red de drenaje, los patrones son controlados por la estructura geológica y la geomorfología del lugar. A grandes rasgos, el patrón de drenaje es de tipo paralelo en el sector nororiental y occidental del ámbito serrano, y dendrítico en el sector suroccidental, de la zona de trabajo, al pie de las sierras (Figuras 4.2 y 4.4 en Capítulo 4 Introducción al área de estudio). En el ámbito serrano de las cuencas que drenan al occidente, las cabeceras tienen una morfología de anfiteatro, como las cuencas de los arroyos Agua Blanca y Cochenleufú Grande (Figuras 4.2 y 4.4). El valle intermontano puede definirse como un valle subsecuente (González Uriarte et al. 1988), cuyos cursos de agua presentan un patrón de drenaje paralelo en las cabeceras, y rectangular en el interior del valle. Desde este valle las aguas drenan hacia la llanura periserrana, saliendo de las sierras desde los extremos norte y sur de la zona de trabajo (arroyo Curamalal Chico y río Sauce Chico), o vertiendo sus aguas en los Arroyos Curamalal Grande, Hinojo Grande y 27 de Diciembre. En sectores localizados, mayormente en las laderas orientales de las sierras de Bravard, la red de drenaje no se encuentra totalmente integrada, siendo éste un diseño de tipo anárquico, con una tendencia dendrítica. En el piedemonte la red de drenaje adopta un patrón aproximadamente paralelo, condicionada por la existencia de niveles pedemontanos antiguos.

El análisis morfológico del perfil longitudinal a la pendiente de las laderas puede dar una idea del estado evolutivo de una región y de los procesos que dominan. Dalrymple et al. (1968) propusieron un modelo de ladera idealizado con 9 tipos de segmentos en los cuales dominan unos procesos geomorfológicos sobre otros (Figura 6.2). En el área de tesis pudieron identificarse estos tipos de segmentos, aunque con leves diferencias en los procesos dominantes, esto se comenta con más detalle en el Capítulo 9 Movimientos en masa en laderas. Desde otro punto de vista, de acuerdo con Selby (1982), generalmente se reconocen dos tipos principales de laderas: las laderas controladas por meteorización y 


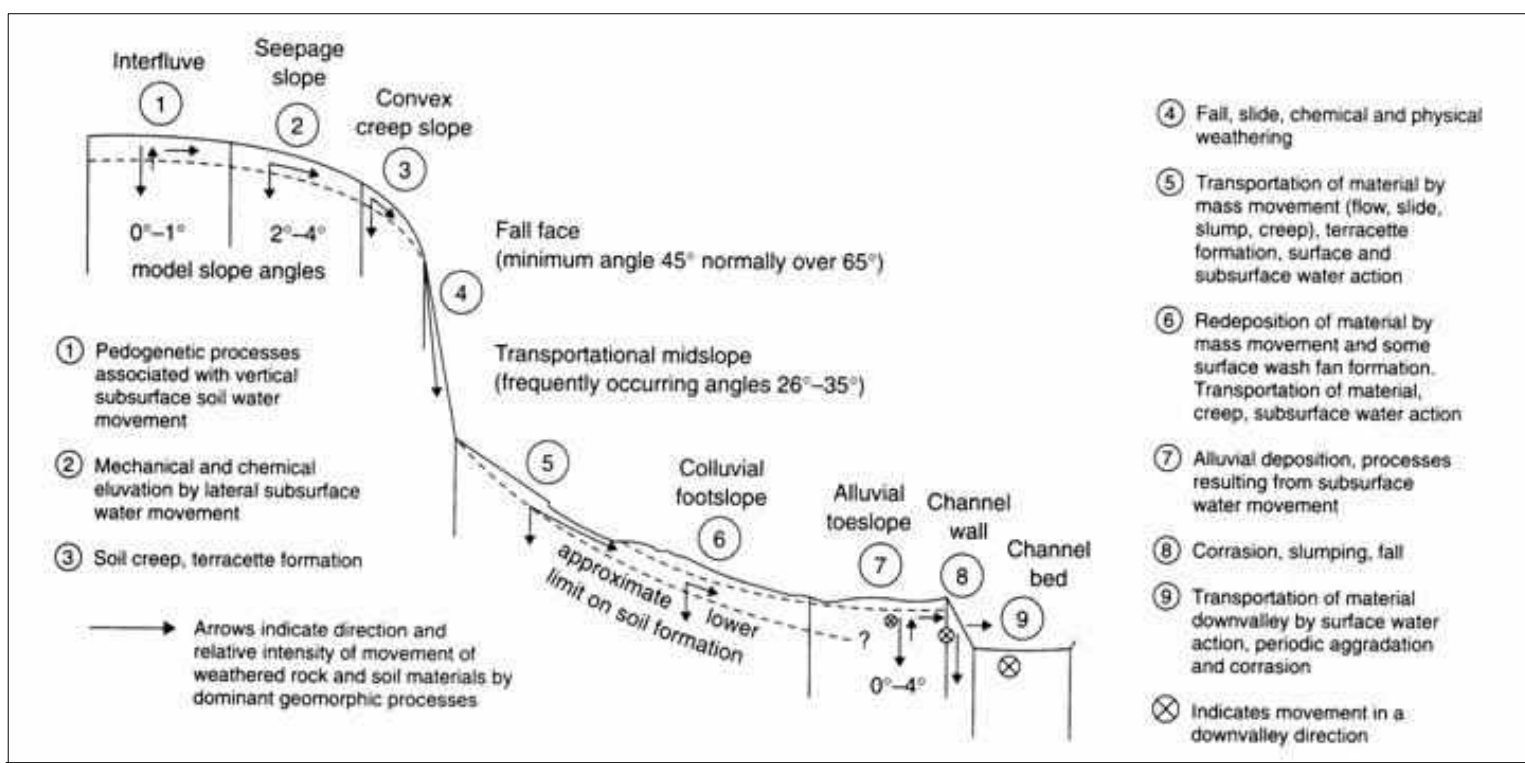

Figura 6.2. Segmentos de ladera en un perfil longitudinal idealizado y procesos geomorfológicos dominantes en cada uno de ellos. Tomado de Dalrymple et al. (1968).

las laderas limitadas por transporte. En las primeras, las tasas de aporte de regolito son menores a las de remoción (a través de los cursos de agua). En estos casos las laderas se encuentran generalmente desnudas y reflejan la estructura de la roca subyacente. En las laderas limitadas por transporte, las tasas de remoción de regolito son menores que las de generación, y la morfología depende de las características del regolito, determinando además el tipo e intensidad de los procesos de ladera. Las laderas de las sierras de Bravard y Curamalal constituyen un grado intermedio entre estos dos extremos, habiendo sectores con dominancia de la morfología de los afloramientos sobre la del regolito en prácticamente toda la extensión longitudinal de la ladera, o de manera saltuaria, mientras que, en otros sitios, las laderas muestran una morfología resultante de la dominancia de procesos coluviales, donde muchos frentes escarpados están ahogados en sus propios detritos.

Si bien a nivel regional el balance morfogénesis-pedogénesis está inclinado a favor de la pedogénesis (Pereyra y Ferrer, 1995), en el área de estudio tienen participación muchos tipos de procesos morfogenéticos (Tabla 6.1) que, aunque sólo influyen localmente en la dinámica del desarrollo de los suelos, sí tienen gran importancia en el modelado del paisaje actual. 
Movimientos en masa en las sierras de Bravard y Curamalal,

Sierras Australes de la Provincia de Buenos Aires.

Juan Manuel Susena

\begin{tabular}{|c|c|}
\hline \multirow{2}{*}{ Meteorización } & $\begin{array}{c}\text { Termoclastía } \\
\text { Crioclastía }\end{array}$ \\
\hline & $\begin{array}{c}\text { Disolución de carbonato de calcio en calcretas } \\
\text { Química } \quad \text { Tafonización en roca }\end{array}$ \\
\hline $\begin{array}{l}\text { Remoción en } \\
\text { masa }\end{array}$ & $\begin{array}{c}\text { Agradación coluvial ladera arriba } \\
\text { Caídas y vuelcos de rocas } \\
\text { Deslizamientos de roca } \\
\text { Deslizamientos de suelo/detritos } \\
\text { Flujos de detritos } \\
\text { Flujos de tierra } \\
\text { Reptación de suelo } \\
\text { Agradación coluvial ladera abajo }\end{array}$ \\
\hline Acción fluvial & $\begin{array}{c}\text { Agradación } \\
\text { Erosión lateral (ensanchamiento) } \\
\text { Erosión retrocedente (alargamiento en cabeceras) } \\
\text { Erosión vertical (incisión) } \\
\text { Socavamiento basal } \\
\text { Concentración del escurrimiento y acarcavamiento incipiente }\end{array}$ \\
\hline Acción eólica & $\begin{array}{l}\text { Deflación localizada } \\
\text { Agradación localizada }\end{array}$ \\
\hline $\begin{array}{l}\text { Acción } \\
\text { biológica }\end{array}$ & $\begin{array}{c}\text { Acción de animales excavadores } \\
\text { Compactación local por pisoteo } \\
\text { Erosión de banco por pisoteo (indentaciones) } \\
\text { Hozaduras (burrowing) } \\
\text { Fracturamiento de roca/suelo por crecimiento de raíces }\end{array}$ \\
\hline $\begin{array}{c}\text { Otros } \\
\text { procesos }\end{array}$ & $\begin{array}{c}\text { Pedogénesis } \\
\text { Sufusión (pipping) } \\
\text { Arroyada difusa } \\
\text { Acumulación coluvial/aluvial de materia orgánica } \\
\text { Mecanización de suelos (prácticas agrotécnicas) }\end{array}$ \\
\hline
\end{tabular}

\subsection{Unidades geomorfológicas}

Para la caracterización geomorfológica se acudió al concepto de unidades del terreno (land units). Este tipo de unidades se definen por condiciones morfológicas, litológicas, de suelos, vegetación, etc. que permiten diferenciarse entre sí con bordes definidos. Pasuto y 
Soldati (1999) y Remondo (2001) analizan los distintos tipos de unidades utilizadas en estudios de movimientos en masa. Las unidades del terreno (llamadas en esta tesis "unidades geomorfológicas"), se distinguen por tener características lito-estructurales y morfológicas relativamente homogéneas (de acuerdo a la escala de mapeo), así como por ser afectadas por procesos geomorfológicos en distinto grado de intensidad, que permiten diferenciarlas entre sí.

Este concepto es aproximadamente afín a los de Hansen (1984) y Cendrero et al. (1992). En el área de estudio Pereyra y Ferrer (1995) diferencian unidades geomorfológicas (U.G.): U.G. Serrana, U.G. Serrana Subunidad Piedemonte Coluvial, U.G. Valles Intermontanos, U.G. Piedemonte Antiguo, U.G. Piedemonte Moderno, U.G. Piedemonte Moderno Subunidad Piedemonte Proximal, U.G. Piedemonte Moderno Subunidad con Calcretes Superficiales, U.G. Piedemonte Moderno Subunidad Vías de Avenamiento Secundarias Proximales y U.G. Fajas Aluviales. En el sector del Valle de Las Grutas/27 de Diciembre, Susena y Gentile (2017; 2018), diferencian unidades y componentes geomorfológicos de distinta jerarquía, de acuerdo a objetivos y escalas

concretos, como asociar espacialmente determinados tipos de movimientos en masa a dichas unidades y componentes, con énfasis en la optimización del uso turístico del territorio desde una perspectiva de la prevención de perjuicios. Pueden mencionarse: Valles Intraserranos, Laderas de Detritos en Valles Intraserranos, Cimas Planas y Divisorias Principales en Secuencias Cuarcíticas, Fajas Aluviales, Valle Intermontano (Valle de Las Grutas), Laderas de Detritos, y Piedemonte Antiguo y Laderas de Detritos Asociadas.

Las unidades geomorfológicas diferenciadas en esta tesis son más o menos similares a la de los trabajos mencionados, con algunas diferencias relativas a la escala de mapeo, 1:5.000. Estas unidades pueden estar integradas por uno o más componentes geomorfológicos (por ejemplo, las laderas de detritos pueden tener deslizamientos, flujos de detritos, etc., mientras los frentes escarpados rocosos pueden ser a veces un componente único). En esta tesis, dichas unidades se agrupan según características geomorfológicas comunes (procesos dominantes y/o estructura geomorfológica), en unidades geomorfológicas más regionales, para dar un marco más general (Tabla 6.2). Existen componentes geomorfológicos o conjuntos de ellos que podrían agruparse como unidades geomorfológicas, pero no se mapearon debido a su escasa extensión. En tales casos, se los incluye dentro de unidades mayores, cartografiables. En algunas fotos de campo se muestran rasgos similares a las unidades que, pese a que son de menor tamaño, ilustran la morfología de las unidades cartografiadas. Otras geoformas menores no mapeables que pueden encontrarse en una o más unidades geomorfológicas se describen 
Movimientos en masa en las sierras de Bravard y Curamalal,

Sierras Australes de la Provincia de Buenos Aires.

Juan Manuel Susena

escuetamente en el contexto de las unidades donde sean más frecuentes y/o relevantes.

Los movimientos en masa no se incluyen en este apartado; su caracterización geomorfológica y clasificación son objeto de los próximos capítulos. De la misma manera, una descripción detallada de geoformas asociadas a la acción faunística y humana se brinda en el Capítulo 12 Movimientos en masa y actividad antropo y zoogeomorfológica.

\begin{tabular}{|c|c|}
\hline $\begin{array}{l}\text { GRUPOS DE UNIDADES } \\
\text { GEOMORFOLÓGICAS }\end{array}$ & UNIDADES GEOMORFOLÓGICAS \\
\hline $\begin{array}{l}\text { Unidades influenciadas por la estructura } \\
\text { geológica }\end{array}$ & $\begin{array}{c}\text { Relieve de Crestas y Depresiones Suaves } \\
\text { Relieve de Crestas y Depresiones Pronunciadas } \\
\text { Frentes Escarpados Rocosos } \\
\text { Laderas Rocosas } \\
\text { Cuerpos Rocosos Prominentes } \\
\text { Gargantas en Discontinuidades Rocosas }\end{array}$ \\
\hline Cimas planas y divisorias principales & Cimas Planas y Divisorias Principales \\
\hline Piedemonte inactivo & $\begin{array}{c}\text { Piedemonte Aluvial Antiguo } \\
\text { Piedemonte Coluvial Antiguo } \\
\text { Piedemonte Aluvial Inactivo Moderno Indiferenciado }\end{array}$ \\
\hline Unidades aluviales activas & $\begin{array}{l}\text { Abanicos Aluviales de Materiales Gruesos } \\
\text { Abanicos Aluviales Finos } \\
\text { Fajas Aluviales } \\
\text { Incisiones Fluviales } \\
\text { Piedemonte Aluvial Activo Indiferenciado }\end{array}$ \\
\hline Unidades coluviales activas & $\begin{array}{c}\text { Afloramientos Parcialmente Ahogados } \\
\text { Collados } \\
\text { Laderas de Detritos } \\
\text { Laderas Compuestas } \\
\text { Bajada Coluvial Fina } \\
\text { Remanentes De Frentes Escarpados Rocosos }\end{array}$ \\
\hline Cubierta Eólica Periserrana & Cubierta Eólica Periserrana \\
\hline
\end{tabular}


Las Figuras 6.3, 6.4 y 6.5 muestran la geomorfología agrupada en unidades mayores en las tres subzonas del área estudiada, para dar una idea de la composición del paisaje. Los mapas geomorfológicos detallados se encuentran en el Anexo.

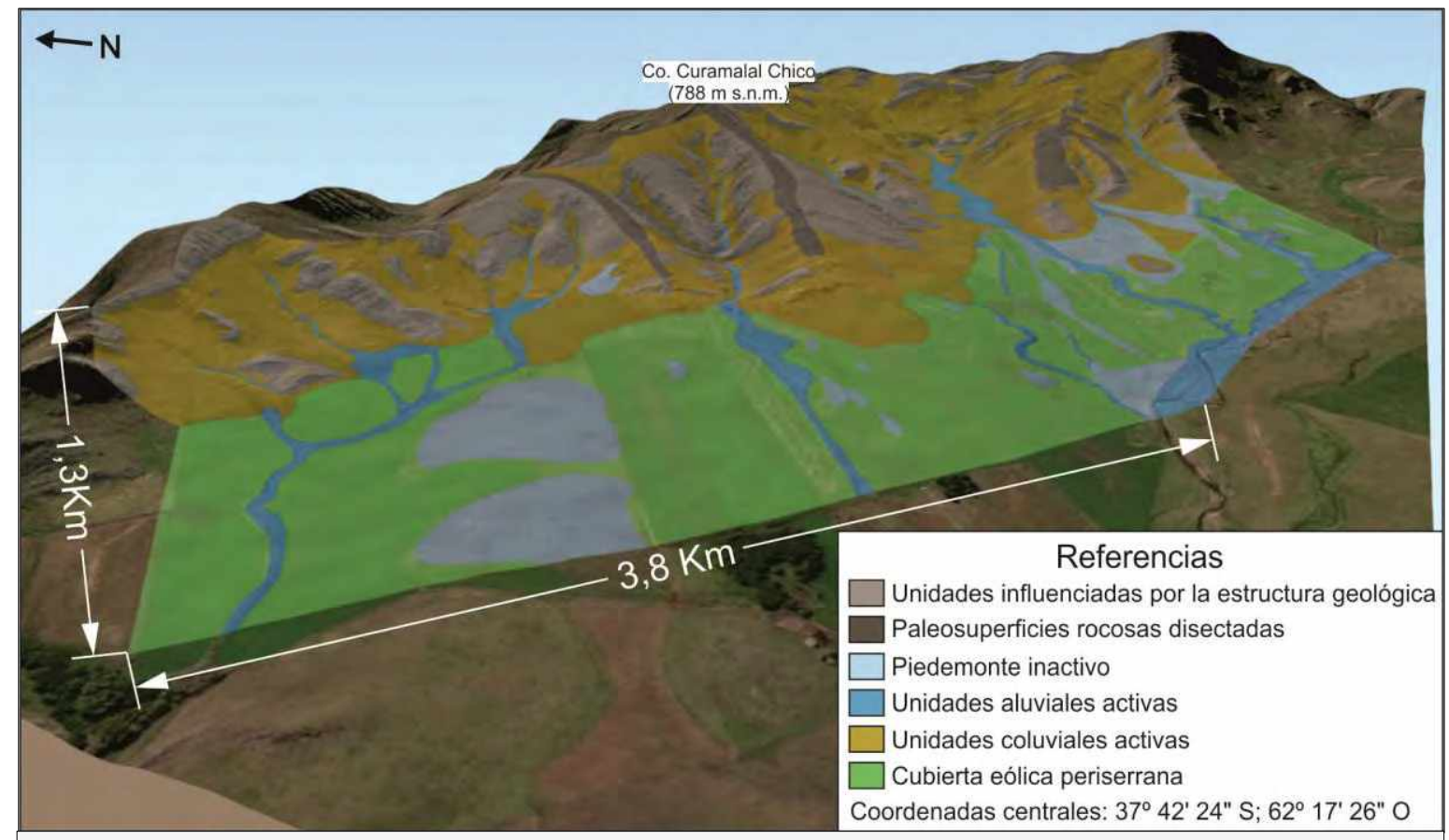

Figura 6.3. Bloque diagrama con unidades geomorfológicas mayores de la subzona 1. En esta subzona se realizó el análisis de susceptibilidad (ver Capítulos 14 y 15). La altura corresponde al MDE ALOS PALSAR, y la imagen de fondo es una imagen de World View-2 (Google Earth). Para mayor detalle, ver mapa geomorfológico del Anexo. Elaboración propia.

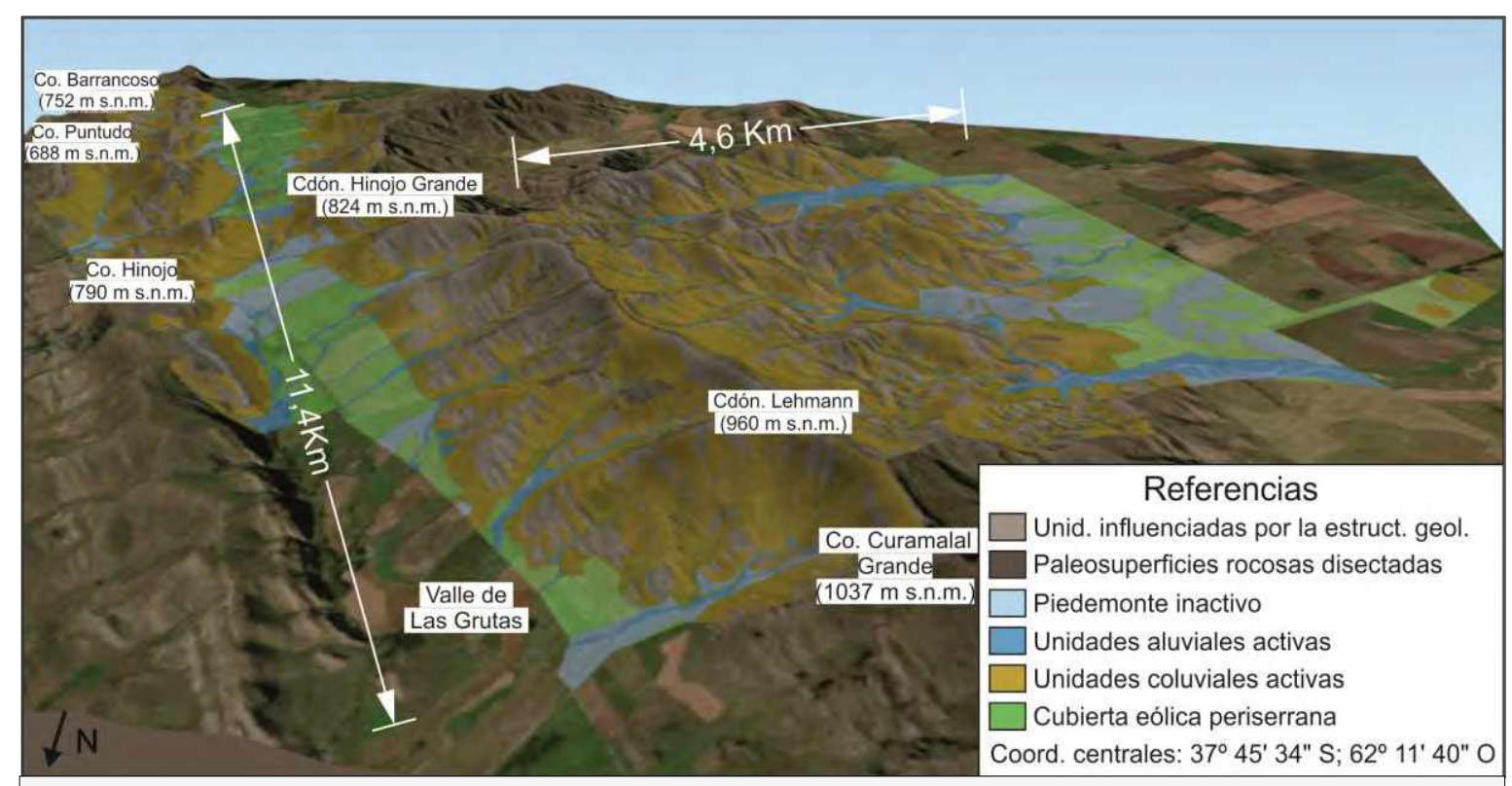

Figura 6.4. Bloque diagrama con unidades geomorfológicas mayores de la subzona 2. La altura corresponde al MDE ALOS PALSAR, y la imagen de fondo es una imagen de World View-2 (Google Earth). Para mayor detalle, ver mapa geomorfológico del Anexo. Elaboración propia. 


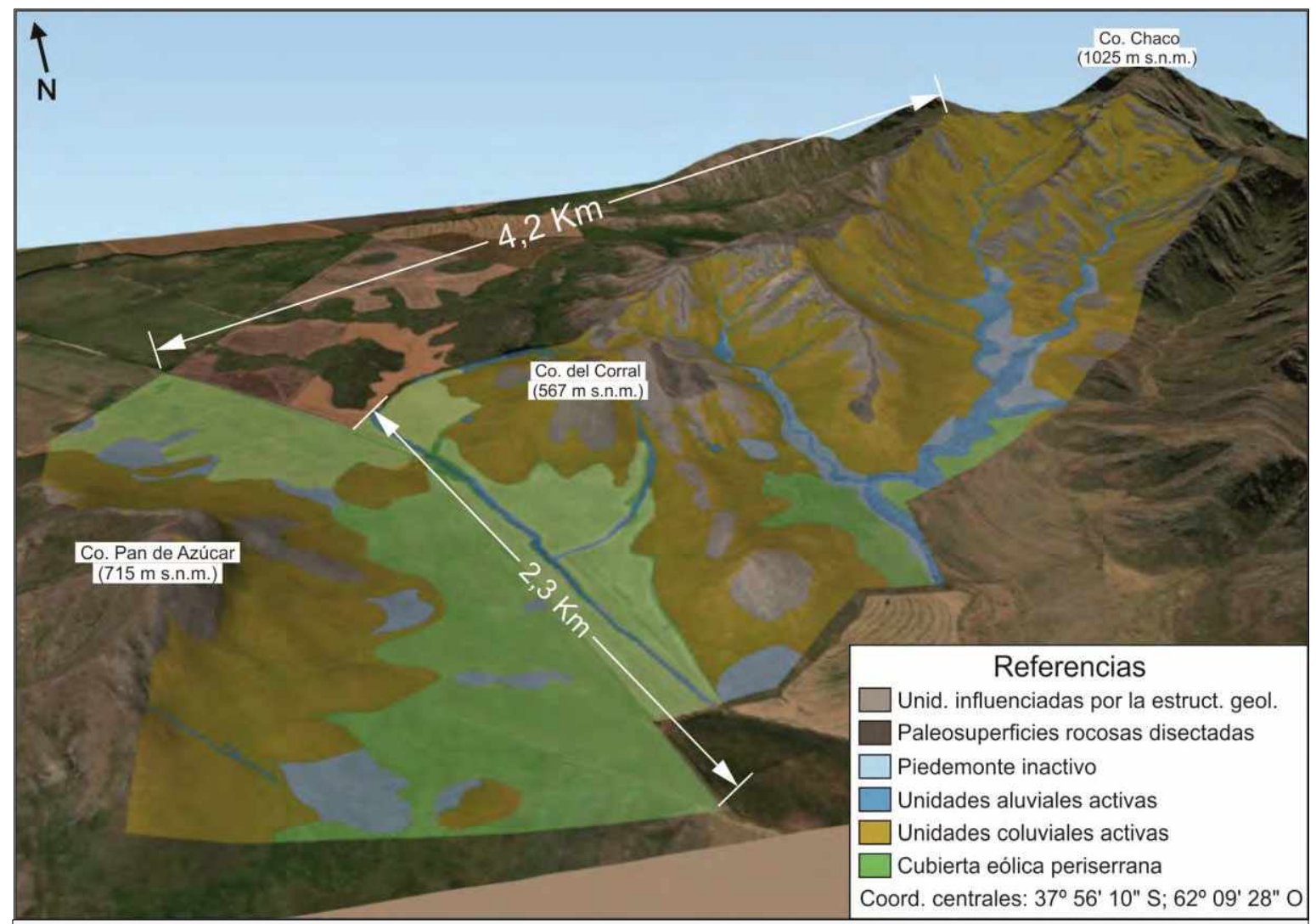

Figura 6.5. Bloque diagrama con unidades geomorfológicas mayores de la subzona 3. La altura corresponde al MDE ALOS PALSAR, y la imagen de fondo es una imagen de World View-2 (Google Earth). Para mayor detalle, ver mapa geomorfológico del Anexo. Elaboración propia.

\subsubsection{Unidades influenciadas por la estructura geológica}

Esta categoría incluye aquellos rasgos o conjuntos de rasgos producidos en rocas paleozoicas cuya estructura tiene una fuerte influencia en la morfología.

Relieve de Crestas y Depresiones Suaves: unidad de escaso relieve, ubicada generalmente al pie de las sierras, en sectores de poca pendiente, constituyendo remanentes de afloramientos aislados. Se caracteriza por una alternancia de afloramientos rocosos muy inclinados, y depresiones entre los mismos con afloramientos o una cubierta de regolito (Figura 6.6). Se producen en rocas con foliación o sistemas de fracturas con una dirección preferencial, como los son las metavulcanitas o metagranitos del basamento, y las sedimentitas paleozoicas de los Grupos Curamalal y Ventana. Los procesos dominantes son la meteorización física y química, y movimientos de tipo vuelco, y en mucha menor medida, caídas. 


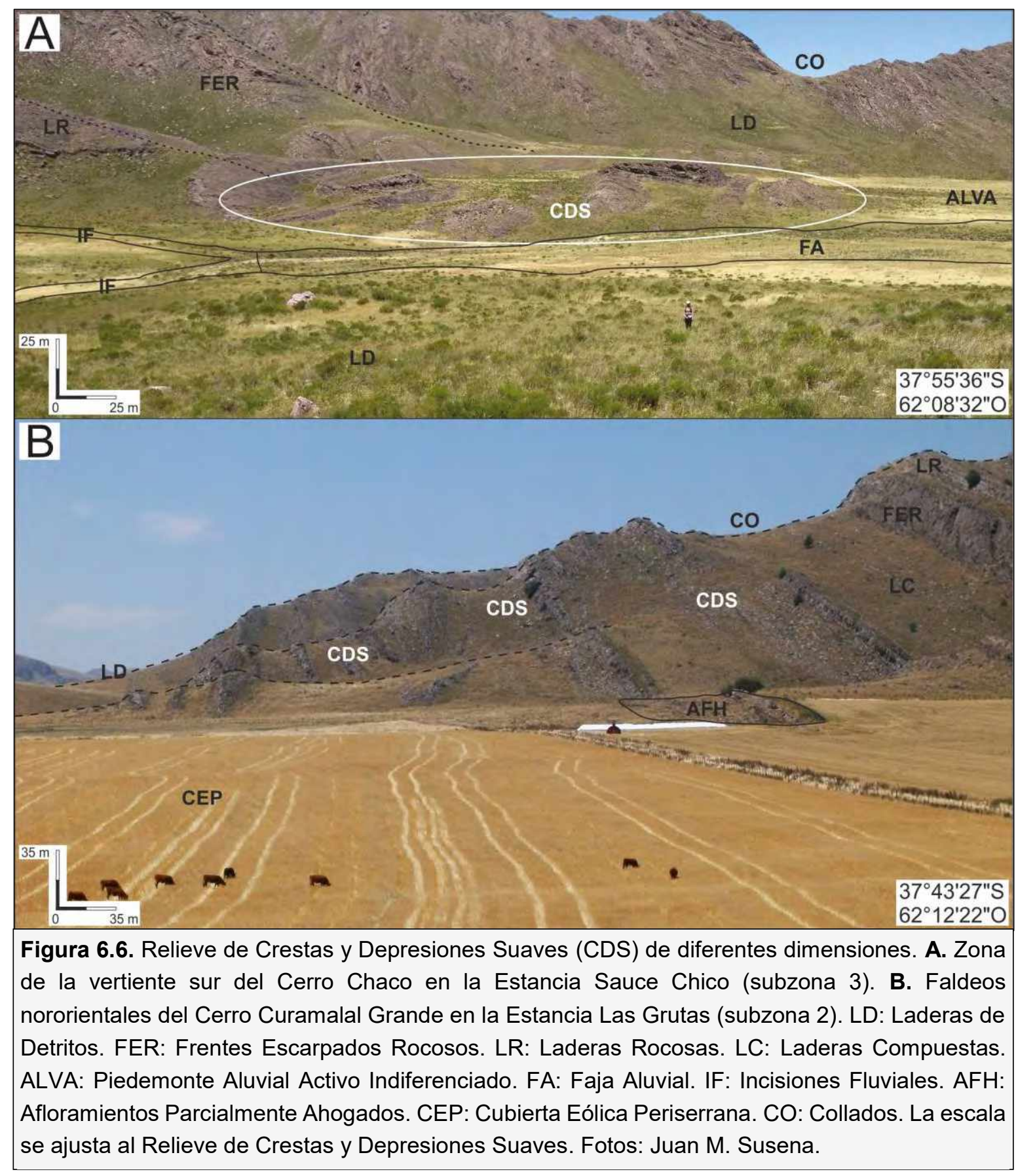

Relieve de Crestas y Depresiones Pronunciadas: esta unidad es morfológicamente similar a la anterior. Difiere de aquella en que los resaltos son más acusados, por encontrarse en sitios (laderas) sometidos a mayor erosión. La estructura es perpendicular u oblicua a la pendiente de las laderas. Los vuelcos o caídas producidos suelen tener algo más de recorrido que en la unidad anterior. Pueden acumularse detritos ladera arriba de los afloramientos, cubriéndolos parcialmente (Figura 6.7). 


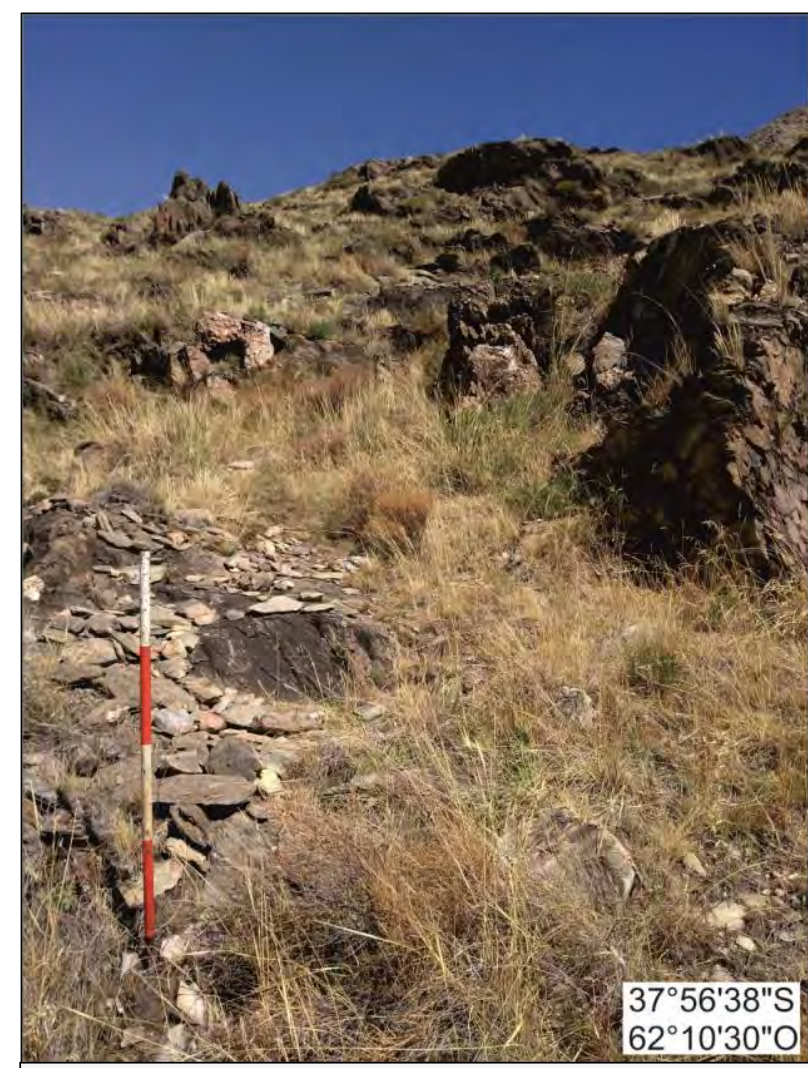

Figura 6.7. Relieve de Crestas y Depresiones Pronunciadas en el cerro Pan de Azúcar (subzona 3). Nótese la distribución discontinua de las crestas, dominando el paisaje la pendiente de la ladera. Al lado del jalón, un afloramiento retiene bloques desplazados por escurrimiento superficial en manto. El jalón sirve como escala, mide $1 \mathrm{~m}$. Foto: Juan M. Susena.

Frentes Escarpados Rocosos: esta unidad involucra superficies dominadas por segmentos de pendiente vertical a sub-vertical con frentes rocosos libres. En las unidades Relieve de Crestas y Depresiones (Suaves y Pronunciadas), Laderas Rocosas, Laderas Compuestas, etc., existen también estos frentes, pero no tienen entidad cartográfica suficiente, como el indicado en la Figura 6.6.B. Los frentes escarpados rocosos son principalmente rectos en planta y pueden ser interrumpidos por valles y gargantas asociados a discontinuidades rocosas o por entrantes suavizadas producidas por una destrucción más acelerada de los frentes. Puede ser notoria la presencia de aleros y cuevas de dimensiones submétricas a decamétricas, generalmente asociadas a pliegues. Los procesos dominantes son los vuelcos y caídas de rocas, en menor medida deslizamientos planares y en cuña, todos ellos condicionados por la estructura geológica. En el mapeo, el agregado de superficies aledañas por encima de esta unidad se debe a que las discontinuidades rocosas se extienden unos cuantos metros hacia el interior del macizo, y en consecuencia se pueden individualizar bloques que pueden caer. Las 
superficies aledañas al pie de los frentes se agregaron para incluir el sector susceptible a recibir (en primera instancia) los materiales resultantes de los procesos que modelan los frentes. La meteorización química se produce principalmente en sectores de umbría, y en zonas con desarrollo de bosques, donde a su vez las raíces pueden influir en la separación de bloques rocosos. Una expresión característica de la meteorización química en algunos sectores es la presencia de tafonis y en

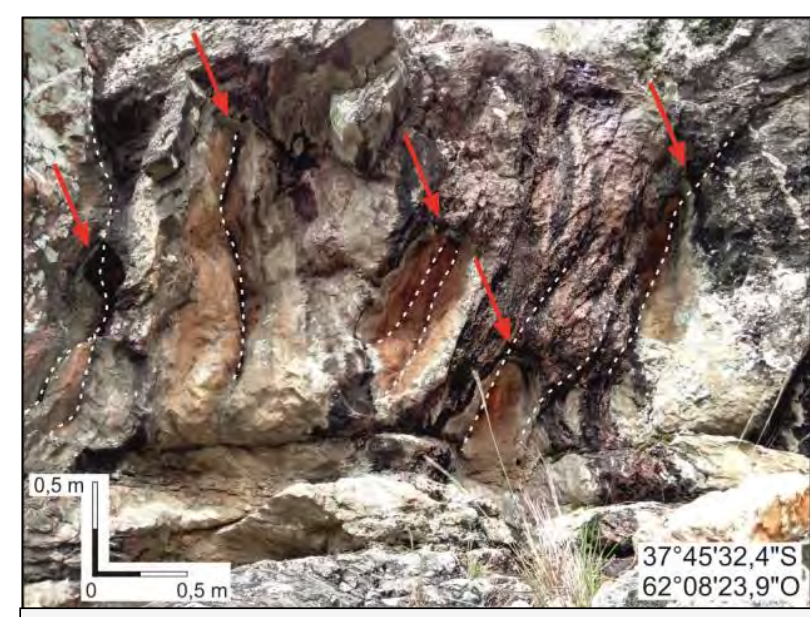

Figura 6.8. Frente Escarpado Rocoso en el abra del arroyo Hinojo Grande (subzona 2). Meteorización química a través de planos de foliación (líneas de trazos) en la Fm. Bravard y desarrollo de tafonis (flechas). menor medida, alvéolos (Figura 6.8). Excepcionalmente se encontraron alvéolos y tafonis métricos, a veces unidos entre sí en laderas de solana (mostrando un estado evolutivo relativamente avanzado), cerca de una paleosuperficie rocosa disectada y afectando filitas de la Fm. Hinojo (ver en el siguiente apartado). Su desarrollo localizado en laderas de solana, orientación típicamente desfavorable para su génesis, podrían indicar, por un lado una génesis acelerada debido al tipo litológico, o bien que estas formas se desarrollaron en sub-superficie y, por lo tanto, serían coetáneas con la paleosuperficie rocosa. En un contexto similar se encontraron tafonis más desarrollados en la Fm. La Lola (conglomerado con matriz arenosa), litología muy favorable para la tafonización (Figura 6.9).

Otros aspectos de esta unidad y su relación con los movimientos en masa se retoman más adelante en el Capítulo 9 Movimientos en masa desde frentes escarpados rocosos. 
Movimientos en masa en las sierras de Bravard y Curamalal,

Sierras Australes de la Provincia de Buenos Aires.

Juan Manuel Susena

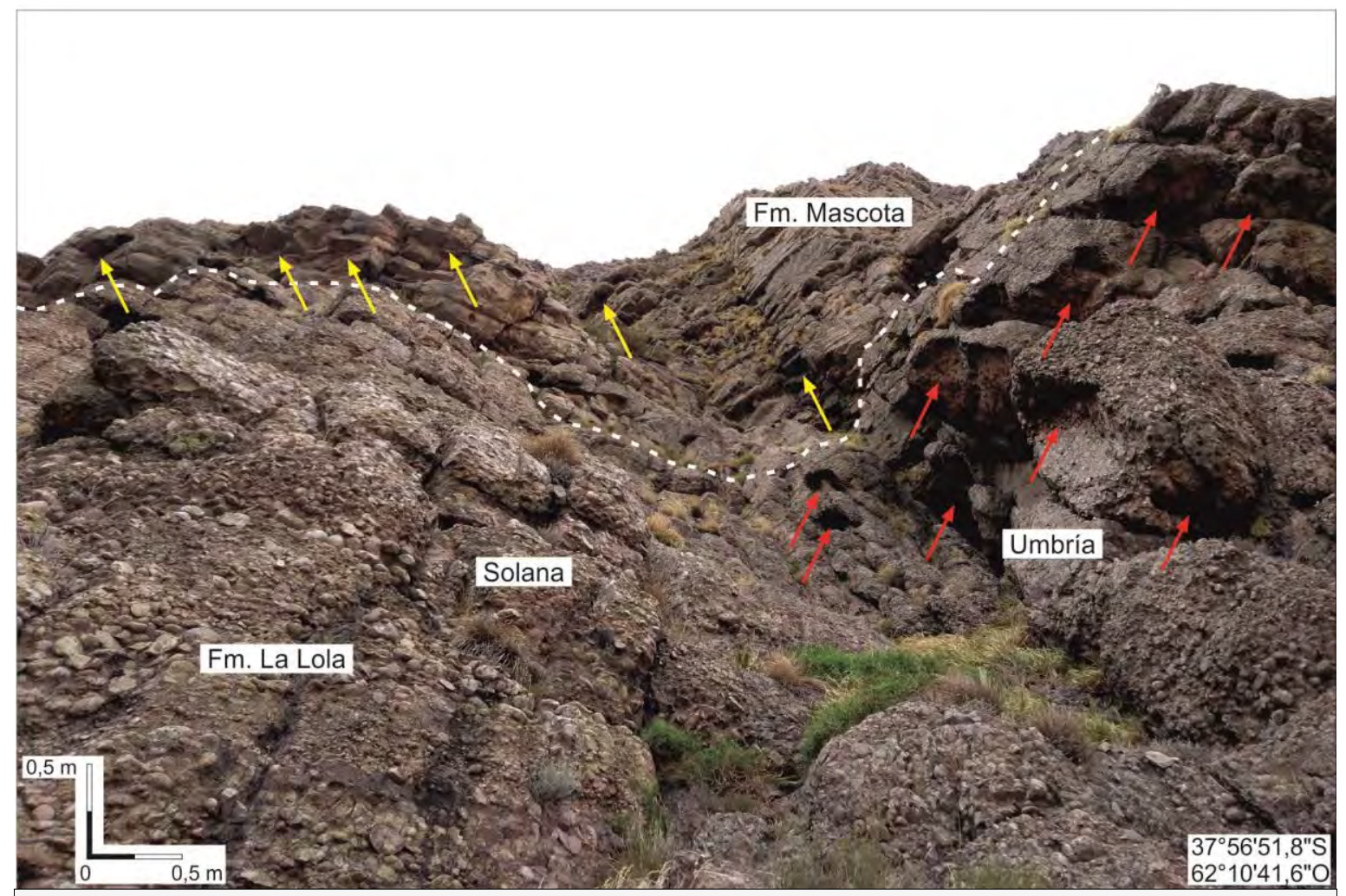

Figura 6.9. Frente Escarpado Rocoso del cerro Pan de Azúcar (subzona 3), modelado en Fm. La Lola y Fm. Mascota. Nótese la preponderancia de los tafonis (flechas rojas) en los conglomerados de la Fm. La Lola, mientras que en las cuarcitas de la Fm. Mascota los planos de discontinuidad delimitan bloques (flechas amarillas). La línea de trazos indica el contacto entre unidades. Nótese el desarrollo de tafonis limitado al frente de umbría. La escala se ajusta a los tafonis. Foto: Juan M. Susena.

Laderas Rocosas: se incluyen en esta unidad las laderas con predominio de afloramientos rocosos. Las pendientes son variables, excluyéndose las subverticales y las sub-horizontales. Son unidades relativamente continuas, ubicadas preferentemente en los valles intraserranos y pueden ser transicionales entre Frentes Escarpados Rocosos o Cimas Planas y Divisorias Principales, y Laderas Compuestas o Laderas de Detritos. Los procesos principales son el transporte lento por acción del agua de una delgada cubierta de detritos (Figura 6.10), y la meteorización química

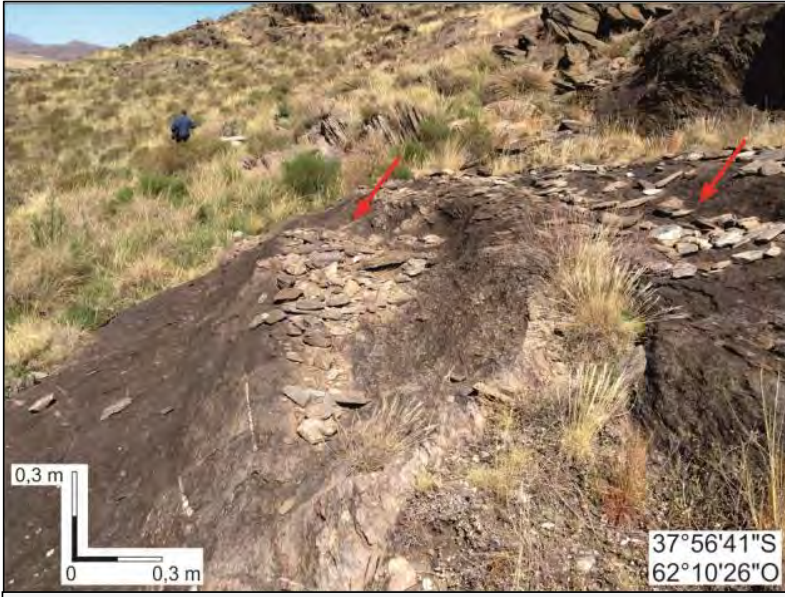
Figura 6.10. Ladera Rocosa menor en el basamento del cerro Pan de Azúcar (subzona 3). Carpetas de detritos transportados por acción del agua (flechas). Atrás: Relieve de Crestas y Depresiones Pronunciadas. La escala se ajusta a los detritos, las coordenadas son aproximadas. Foto: Juan M. Susena.

evidenciada en el desarrollo de pilancones de meteorización (gnammas sensu Twidale y 
Corbin, 1963) y otras formas afines. Los gnammas afectan principalmente sedimentitas paleozoicas, mientras que en el basamento se encontraron otras morfologías, como se observa en la Figura 6.11.

En sectores de las sierras de Curamalal asociados a paleosuperficies rocosas, se encuentran acanaladuras morfológicamente similares al pseudolapiaz (Gutiérrez, 2008). Estas formas se desarrollan en las filitas de la Fm. Hinojo. Tanto en dicho sector, como en la unidad Relieve de Crestas y Depresiones Pronunciadas modeladas en basamento, se encontraron formas similares a flared slopes (Clayton, 1956, Twidale, 1962). Estas formas se encuentran a altitudes de entre 550 y 590 m s.n.m., pudiendo asociarse a la paleosuperficie principal (Rabassa et al., 1995).

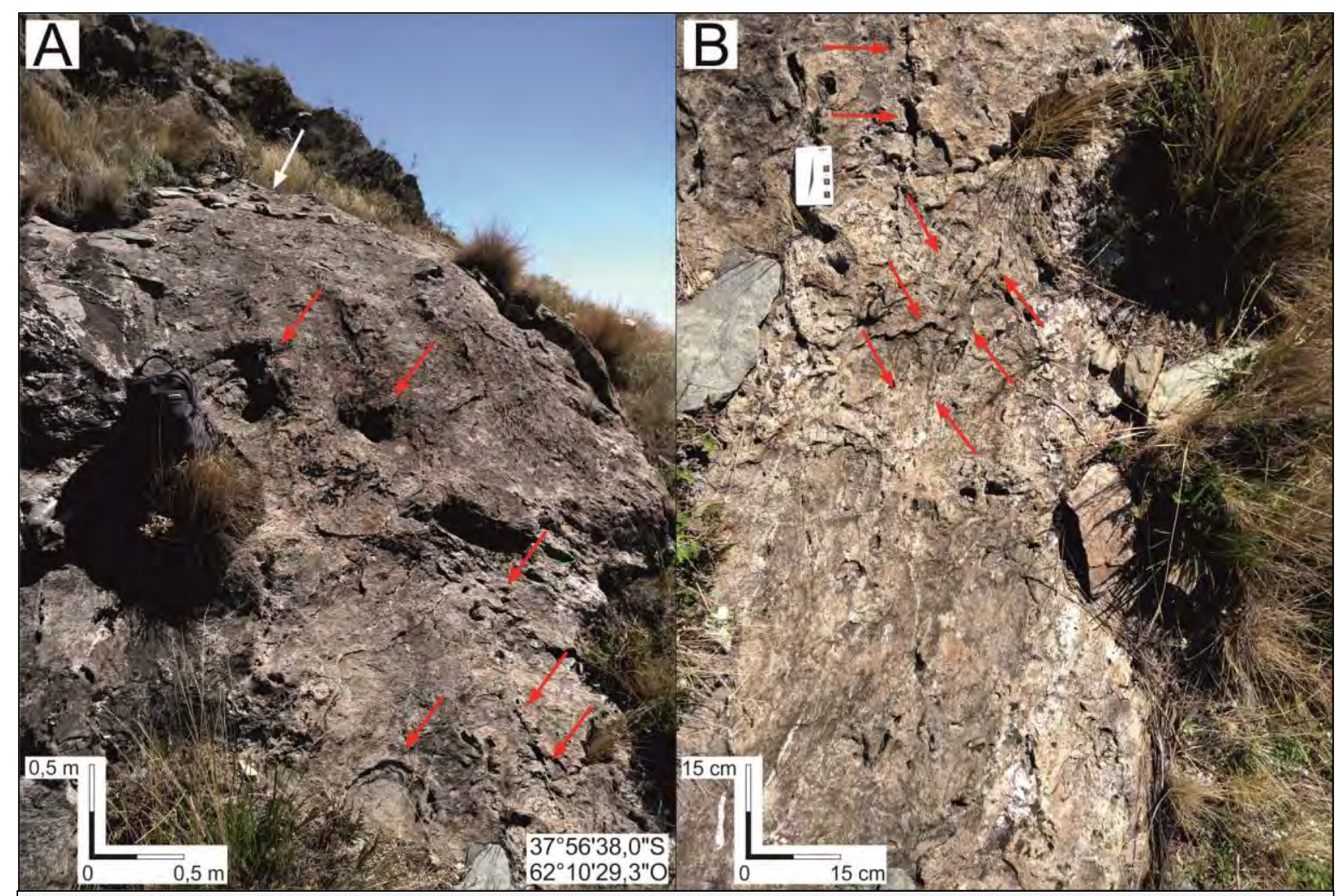

Figura 6.11. Formas de meteorización química en Ladera Rocosa menor en el basamento del cerro Pan de Azúcar (subzona 3). Flecha blanca en A: clastos movilizados por acción del agua sobre la superficie rocosa. Flechas rojas: meteorización asociada a pequeños planos de foliación. La figura B es un detalle de A. Fotos: Juan M. Susena.

Cuerpos Rocosos Prominentes: esta unidad agrupa cuerpos rocosos y sus frentes escarpados rocosos. Son unidades de poca continuidad espacial (Figura 6.12), generalmente de bordes curvados vistos en planta, y se ubican en valles intraserranos, constituyendo divisorias en la confluencia de cursos de agua de primer o segundo orden. Sus cimas pueden ser horizontales o inclinadas, y estar unidos o separados del cuerpo serrano principal. Los procesos geomorfológicos son similares a los desarrollados en frentes escarpados rocosos, y los materiales generados por su destrucción pueden 
Movimientos en masa en las sierras de Bravard y Curamalal,

Sierras Australes de la Provincia de Buenos Aires.

Juan Manuel Susena

acumularse al pie o alcanzar los cursos de agua. Se agrega la erosión hídrica en la base de algunos de sus frentes escarpados, así como la pedogénesis en sus cimas y zonas de transición entre estas y sus frentes escarpados.

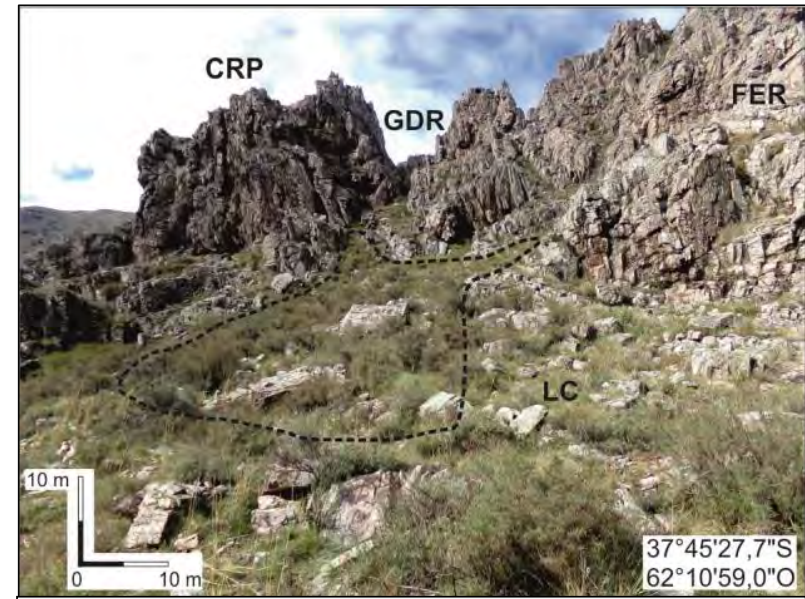

Figura 6.12. Cuerpo Rocoso Prominente (CRP), en un valle intraserrano de la vertiente oriental del Cdón. Lehmann-Hinojo Grande (subzona 2). GDR: Garganta en Discontinuidad Rocosa. FER: Frente Escarpado Rocoso. LC: Ladera Compuesta. Línea de trazos: conos de detritos coalescentes. La escala se ajusta al CRP. Foto: Juan M. Susena.

Gargantas en Discontinuidades Rocosas: esta unidad corresponde a valles estrechos y profundos labrados en roca, rodeados por frentes escarpados rocosos, y de lecho rocoso o de regolito. La altura de los frentes puede superar los $50 \mathrm{~m}$, y su lecho puede tener pendientes superiores a $60^{\circ}$. Los principales procesos son: erosión hídrica del lecho; caídas y vuelcos de roca con rebotes y rodaduras, que pueden quedar en la garganta o salir hacia las laderas ubicadas al pie; desarrollo de suelos cumúlicos orgánicos en gargantas arboladas (Figura 6.13); reptación y deslizamientos de suelos de pocos metros de extensión; meteorización física por acción de raíces y posible crioclastía en grietas rocosas. Los materiales producidos y movilizados pueden acumularse dentro de las mismas gargantas o conformando conos a su pie.

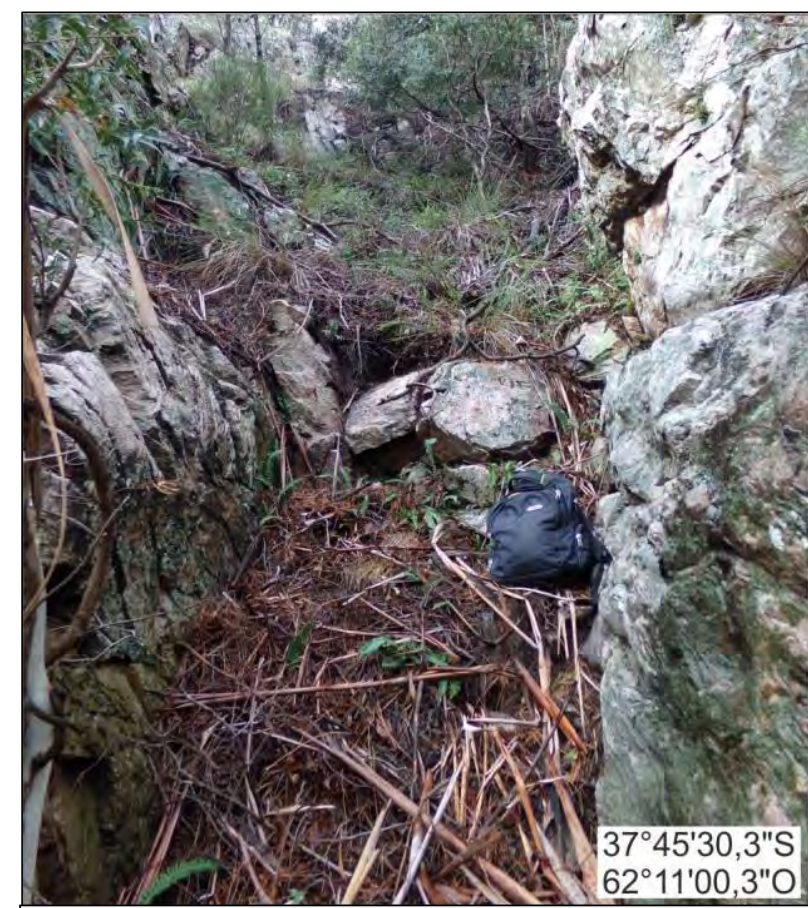

Figura 6.13. Desarrollo de suelos cumúlicos en una Garganta en Discontinuidad Rocosa en un valle intraserrano de la vertiente oriental del Cdón. Lehmann-Hinojo Grande (subzona 2). Foto: Juan M. Susena. 


\subsubsection{Cimas Planas y Divisorias Principales}

Es un rasgo notorio la culminación plana sub-horizontal de las Sierras de Bravard y parte de las de Curamalal. Asimismo, las vertientes occidentales de las Sierras de Curamalal y orientales de las de Bravard, tienen divisorias rocosas prominentes de superficie subhorizontal, transversales al rumbo de las sierras. Tanto las últimas como las primeras corresponderían a diferentes superficies de planación regional (Demoulin et al., 2005), ubicadas en la zona, según estos autores, a 900-700, y a 450 m s.n.m., importantes desde la perspectiva gondwánica (Rabassa y Ollier, 2014 y bibliografía allí citada). En el faldeo oriental del Cordón Lehmann se encontraron rasgos afines entre los 550-600 m s.n.m., que podrían correlacionarse con una paleosuperficie intermedia entre las dos antedichas, identificada por estos autores en la sierra de las Tunas, fuera del área de estudio. Como señalara Pereyra (2018), las superficies de planación regional podrían ser peneplanicies en el sentido de Davis o pediplanicies en el sentido de King, pero el grado de fragmentación y preservación no permiten adoptar una postura definitiva. A los fines de esta tesis, se las agrupa por presentar una morfología bastante similar. Los procesos que en ellas se desarrollan son principalmente la meteorización física por crioclastia y termoclastía, más acentuada la primera en las cimas de mayor altitud (Figura 6.14). Respecto a la crioclastia, cabe recordar que las heladas son frecuentes en la zona, incluso topográficamente por debajo de la zona (véase Figuras 4.9 y 4.10 en el Capítulo 4 Introducción al área de estudio). 


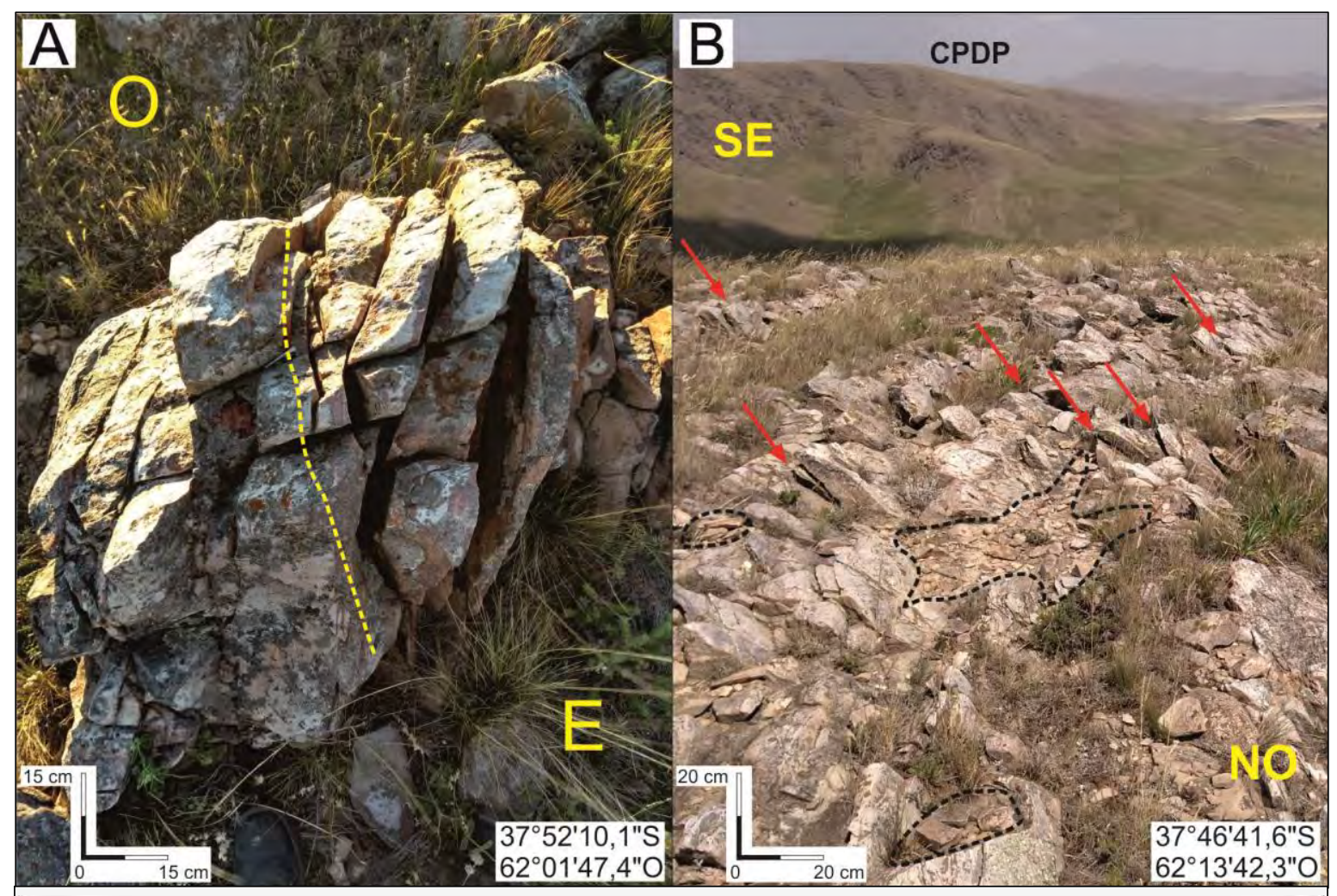

Figura 6.14. Crioclastia en Cimas Planas y Divisorias Principales. A. Vertiente oriental del cerro Guanaco, a 565 m s.n.m. La línea de trazos marca la diferencia en el dominio de la crioclastia, presente sólo en la posición de solana matutina. La foto se tomó al atardecer. B. Vertiente occidental del Cordón Hinojo Grande a 622 m s.n.m. (subzona 2). Flechas rojas: separación incipiente de bloques por crioclastia. Nótese que la separación de todos los bloques es hacia arriba. Líneas de trazos: sectores con remanentes de meteorización química diferencial y pérdida de la matriz (la matriz de los afloramientos es feldespática y los bloques remanentes, cuarcíticos). Fotos: Juan M. Susena.

Se producen localmente vuelcos y en menor medida, caídas. La meteorización química se evidencia en el desarrollo de gnammas decimétricos y otras formas menores, aunque con menor importancia que la meteorización física, en comparación con otras unidades geomorfológicas descritas. En la transición entre esta unidad y las adyacentes topográficamente por debajo, existe lavaje no encauzado de materiales finos, y un leve movimiento de detritos menores hacia los frentes escarpados rocosos o las laderas (Figura 6.15). 


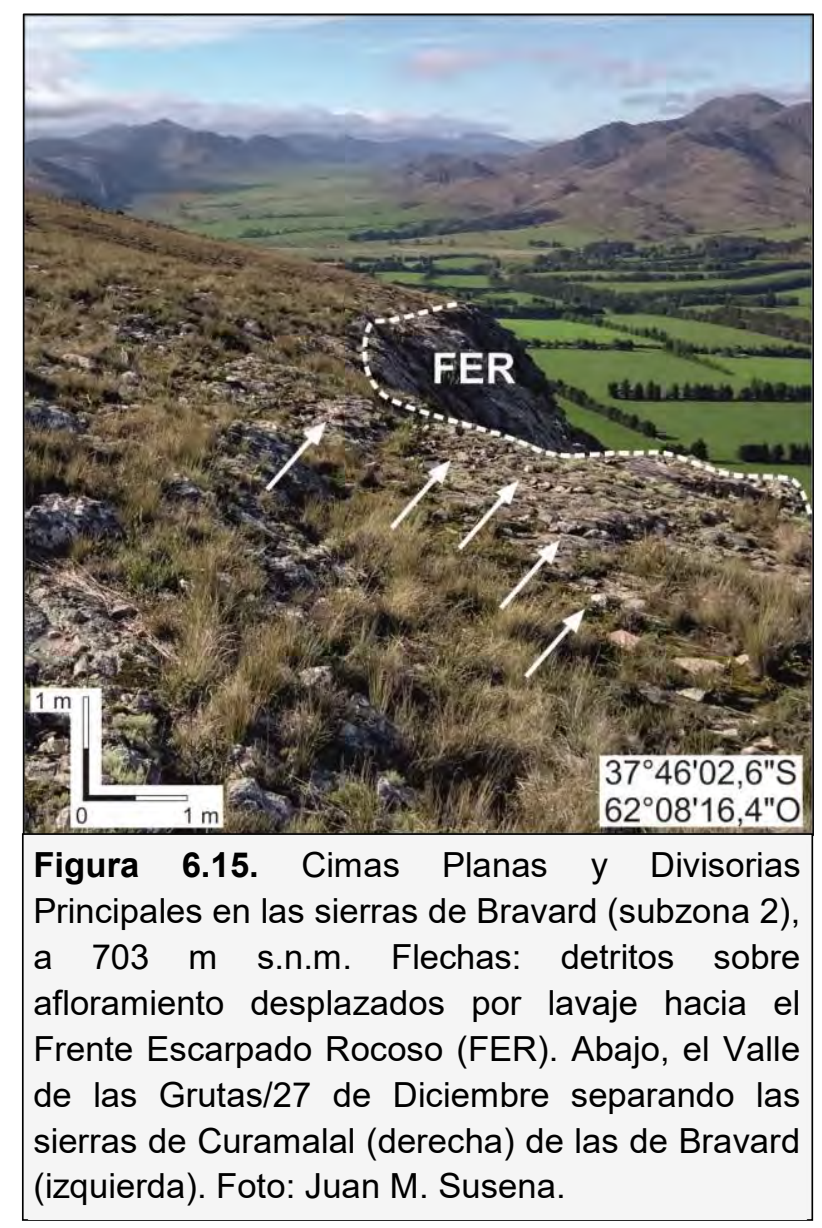

\subsubsection{Piedemonte inactivo}

Bajo esta denominación se agrupan aquellos niveles o remanentes de niveles pedemontanos con cementación moderada a fuerte, que actualmente están siendo erosionados. Estos niveles conforman actualmente divisorias locales o extensiones de Laderas de Detritos con una morfogénesis (erosión, transporte y acumulación de materiales) notablemente menor que en laderas activas. Dada su posición en el piedemonte, condicionan la morfología de la red de drenaje en el piedemonte proximal y distal. Cabe aclarar que la denominación de piedemonte proximal, medio y distal es respecto al pie de los cuerpos serranos, mientras que, en el caso de las laderas, el marco de referencia topográfico (las proximales son las más altas).

Piedemonte Aluvial Antiguo: esta unidad incluye los remanentes de niveles pedemontanos cementados de la Brecha Cerro Colorado y la Fm. Las Malvinas, siendo silcretas y calcretas, respectivamente (véase Capítulo 5 Geología: Generalidades). Se extienden a no más de $6 \mathrm{Km}$ del frente serrano con mayor expresión morfológica en la porción septentrional del área de estudio, elevándose hasta $40 \mathrm{~m}$ sobre las unidades 
Movimientos en masa en las sierras de Bravard y Curamalal,

Sierras Australes de la Provincia de Buenos Aires.

Juan Manuel Susena

adyacentes. La morfología es en general alargada en planta y discontinua, con una orientación parecida a la de los cursos actuales. Presentan una serie de rasgos geomorfológicos que evidencian, en perfil transversal, la antigüedad de estas unidades, como el desarrollo de frentes escarpados rocosos (en Brecha Cerro Colorado), pequeñas laderas y procesos de ladera como caídas de rocas, deslizamientos y reptación (Figuras 6.16 y 9.2 en el Capítulo 9 Movimientos en masa en laderas). Particularmente los remanentes de la Brecha Cerro Colorado ubicados en el Valle de Las Grutas presentan una morfología de butte muy definida (Figura 6.17).

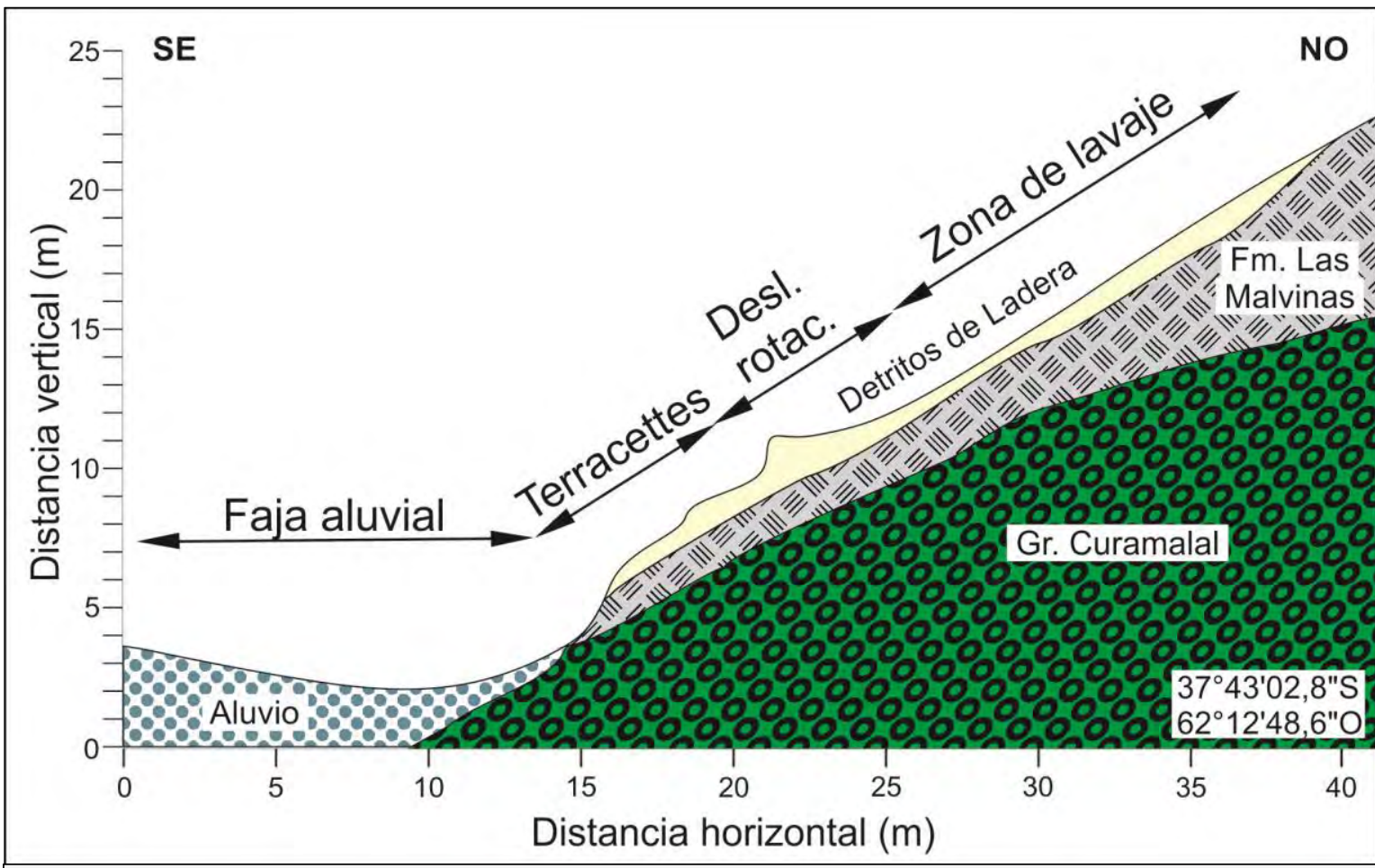

Figura 6.16. Perfil de Piedemonte Aluvial Antiguo en el Valle de Las Grutas (subzona 2), los contactos de la Fm. Las Malvinas son inferidos en base a observaciones en sitios aledaños.

La meteorización física por termoclastía genera fracturas menores $y$ descamaciones de clastos rocosos, mientras que la química se evidencia en disolución de la matriz y consecuente liberación de los clastos, y en desarrollo de gnammas en los clastos de cuarcita expuestos. En el caso de los remanentes de la Brecha Cerro Colorado en valles, el carácter poco penetrativo de las fracturas y su orientación paralela a los bordes de los remanentes permiten suponer que

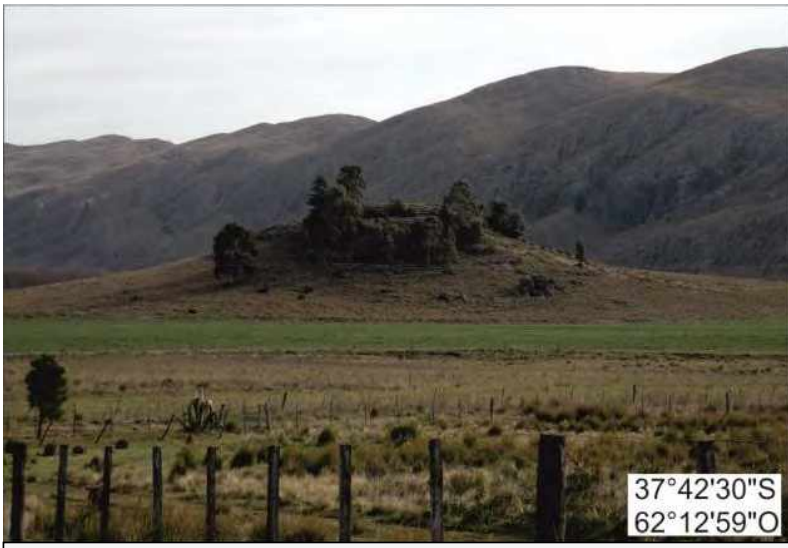

Figura 6.17. Piedemonte Aluvial Antiguo con morfología de butte en el Valle de las Grutas. Los eucaliptos sirven como escala, miden unos $15 \mathrm{~m}$ de altura. Foto: Juan M. Susena. 
podría estar desarrollándose además un proceso de descompresión, posiblemente vinculado a la denudación a largo término.

Piedemonte Coluvial Antiguo: esta unidad agrupa zonas adosadas al pie de las laderas activas, recibiendo en parte materiales de éstas, pero sus pendientes son por lo general menores (Figura 6.18), y con menos procesos de remoción en masa. Hay calcretas y en sectores localizados silcretas aflorantes o subaflorantes con una delgada carpeta de detritos, evidenciando lavaje de la matriz por arroyada difusa como proceso dominante (Figura 6.19). Las calcretas mencionadas corresponden al Miembro Cementado de los Detritos de Ladera. En algunos sectores de las Laderas de Detritos, existen calcretas expuestas por procesos de remoción en masa actuales, indicativas de continuidad temporal
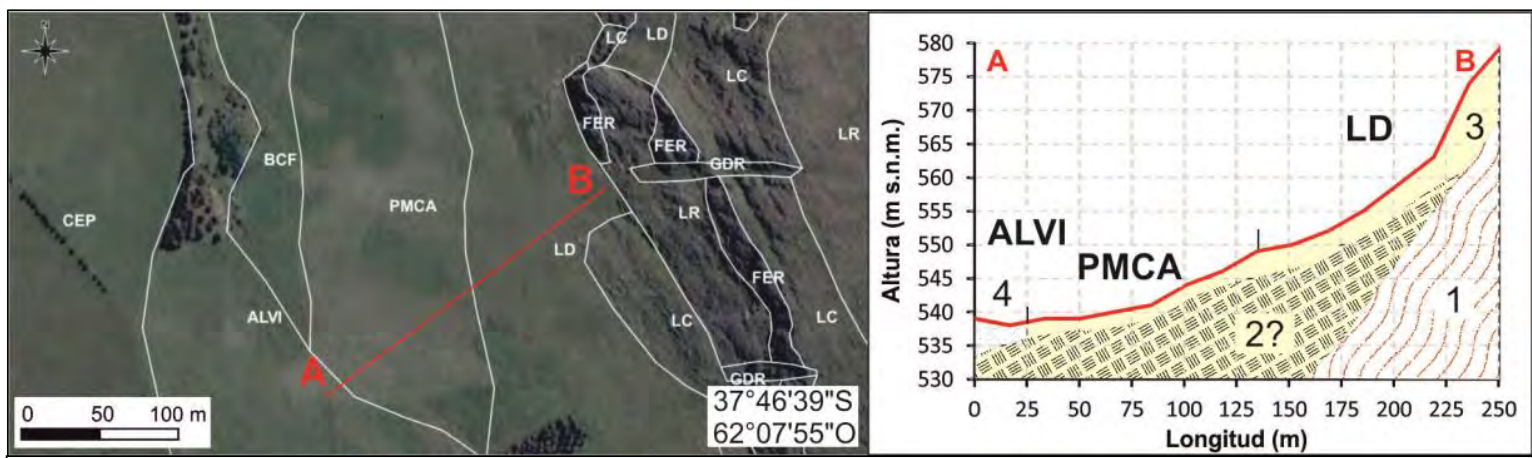

Figura 6.18. Perfil de ladera en el Valle 27 de Diciembre (subzona 2). El perfil del Piedemonte Coluvial Antiguo (PMCA) y el tramo medio/distal de la Ladera de Detritos (LD) son similares. ALVI: Piedemonte Aluvial Inactivo Indiferenciado. BCF: Bajada Coluvial Fina. CEP: Cubierta Eólica Periserrana. FER: Frentes Escarpados Rocosos. LC: Laderas Compuestas. LR: Laderas Rocosas. PMCA: Piedemonte Coluvial Antiguo. 1: Gr. Ventana. 2?: Posible presencia del Mb. Cementado de los Detritos de Ladera. 3: Mb. Suelto de los Detritos de Ladera. 4: Aluvio o Fm. Agua Blanca. El perfil es esquemático, generado a partir del MDE ALOS PALSAR. Elaboración propia.

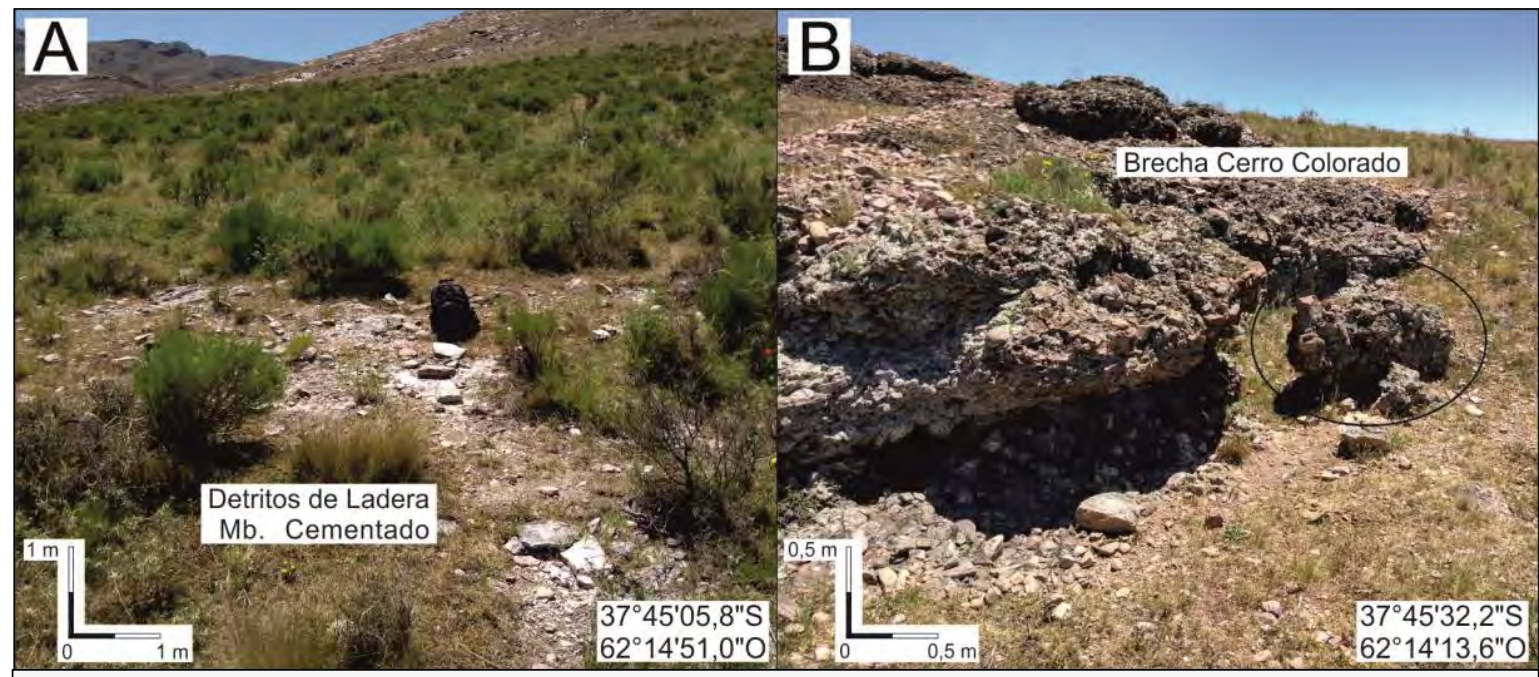

Figura 6.19. Piedemonte Coluvial Antiguo en los faldeos occidentales del Cdón. Lehmann-Hinojo Grande (subzona 2). Nótese la liberación de detritos por el intenso lavaje. Círculo: pequeño bloque caído a partir de alero. Fotos: Juan M. Susena. 
Movimientos en masa en las sierras de Bravard y Curamalal,

Sierras Australes de la Provincia de Buenos Aires.

Juan Manuel Susena

del Piedemonte Coluvial Antiguo y las Laderas de Detritos; dichos remanentes, actualmente sometidos a una intensa disolución en algunos sitios, son espacialmente discontinuos, pudiendo indicar antiguas irregularidades de la superficie en el Piedemonte Coluvial Antiguo (ver Capítulo 5 Geología: generalidades).

Piedemonte Aluvial Inactivo Moderno Indiferenciado: bajo esta denominación se agrupan abanicos aluviales, terrazas, bajadas proximales y distales con grado de cementación bajo a nulo, que constituyen el nivel de piedemonte inmediatamente anterior al actual (Figura 6.20). Se encuentra disectado por los cauces actuales, y se excluye de su superficie la parte modificada antrópicamente para desarrollo agrícola, integrante ésta de la Cubierta Eólica Periserrana. En el ambiente serrano presenta morfologías alargadas paralelas a los valles actuales, mientras en el piedemonte proximal adopta una morfología típica de derrames. Actualmente esta unidad está siendo erosionada en la base por acción de los cursos de agua, pero en los sectores proximales aún recibe materiales desde las laderas. Los cauces antiguos pueden funcionar esporádicamente, pero con escaso caudal. Se observó en valles intraserranos un lavado intenso de la matriz de estos depósitos, con desarrollo de pequeñas cuevas entre los detritos mayores, y pequeños colapsos por cavidad. Los bordes experimentan deslizamientos, así como caídas y vuelcos de materiales más o menos cementados, por socavamiento basal. En dichos contextos, es posible el desarrollo de aleros. La acción de animales excavadores, el desarrollo de galerías y pipping en las mismas, es otro mecanismo que contribuye a la destrucción de esta unidad.

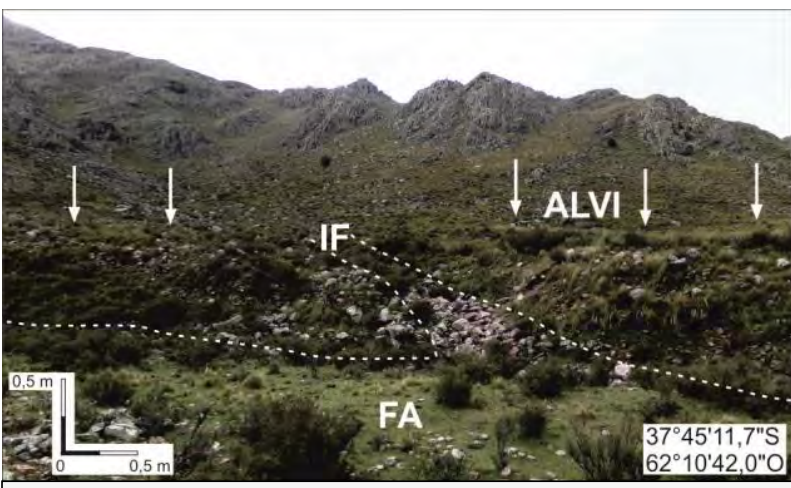

Figura 6.20. Piedemonte Aluvial Moderno Inactivo Indiferenciado (ALVI y flechas) en la vertiente oriental del Cdón. Lehmann (subzona 2). IF: Incisión Fluvial. FA. Faja Aluvial. Líneas de trazos: erosión en la base del ALVI. Foto: Juan M. Susena.

\subsubsection{Unidades aluviales activas}

Bajo esta denominación se incluyen unidades que se encuentran en construcción, vinculadas con la acción del escurrimiento superficial encauzado. Corresponden al nivel pedemontano actual. 
Abanicos Aluviales de Materiales Gruesos: los abanicos modernos se ubican en el piedemonte proximal, constituyendo la transición entre los valles intraserranos y el valle intermontano o el piedemonte externo a las sierras. Su superficie promedia los $3.500 \mathrm{~m}^{2}$, aunque pueden variar entre 400 y $30.000 \mathrm{~m}^{2}$. Su morfología es en parte condicionada por las unidades del piedemonte inactivo que restringe sus laterales, por lo cual no siempre alcanzan la morfología de abanico típica vista en planta. A su vez, esta unidad puede sepultar o estar siendo parcialmente sepultada por alguna Bajada Coluvial Fina. Pueden ser perpendiculares a paralelos a las fajas aluviales actuales (Figura 6.21). Los procesos típicos son: agradación, migración del canal activo, pequeños flujos de detritos, deslizamientos, lavaje de los materiales finos, colapsos por socavamiento basal, pipping en el contacto roca-regolito o en el límite superior de horizontes arcillosos, y con menor expresión acción de organismos excavadores. En algunos abanicos desarrollados sobre lecho rocoso se observó abrasión.

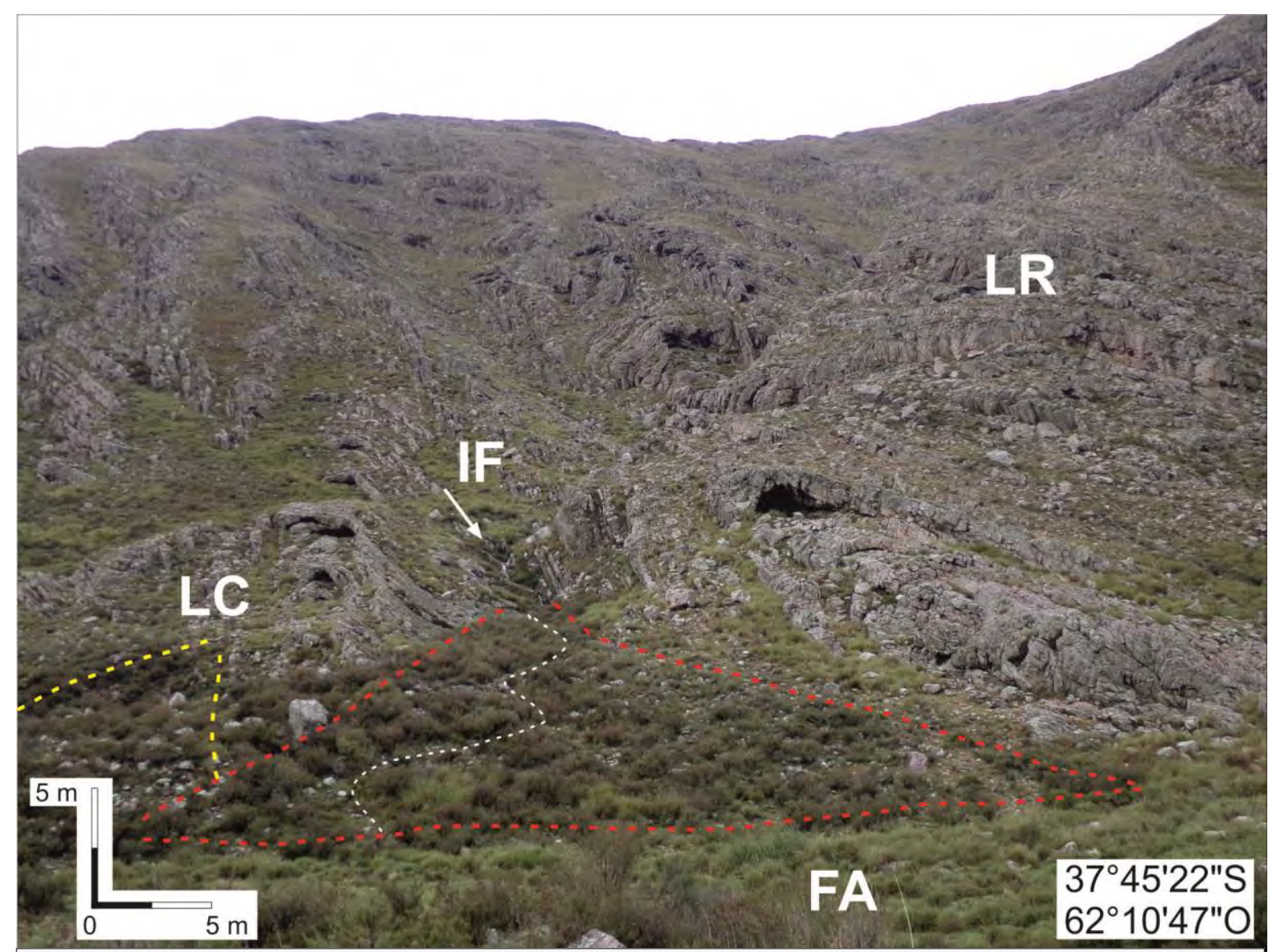

Figura 6.21. Abanico Aluvial de Materiales Gruesos (línea roja) transversal a Faja Aluvial en un valle intraserrano de la vertiente oriental del Cdón. Lehmann (subzona 2). Línea blanca: curso de agua naciente como manantial (flecha blanca). Línea amarilla: cono de detritos. FA: Faja Aluvial. IF: Incisión Fluvial. LC: Ladera Compuesta. LR: Ladera Rocosa. Foto: Juan M. Susena. 
Movimientos en masa en las sierras de Bravard y Curamalal,

Sierras Australes de la Provincia de Buenos Aires.

Juan Manuel Susena

Abanicos Aluviales Finos: en este tipo particular de abanicos domina el material loessoide proveniente del lavaje de la matriz de otras unidades aguas arriba. La morfología de abanico es más conspicua que en la unidad anterior, y pueden no alcanzar las fajas aluviales actuales, dado que muchos de ellos se desarrollan a partir de cuencas pequeñas o de cárcavas menores, cuyo nivel de base es la Cubierta Eólica Periserrana, una Bajada Coluvial Fina o un Piedemonte Aluvial Inactivo Moderno. Sus dimensiones por lo general no superan los $50 \mathrm{~m}$ de longitud, y algunos de ellos incluso no son cartografiables. Están cubiertos por pastizal y excepcionalmente pueden observarse pequeños canales con anchos centimétricos a decimétricos y unos pocos centímetros de profundidad (Figura 6.22). La agradación es el proceso más conspicuo de esta unidad, aunque también se producen deslizamientos de unos pocos metros.

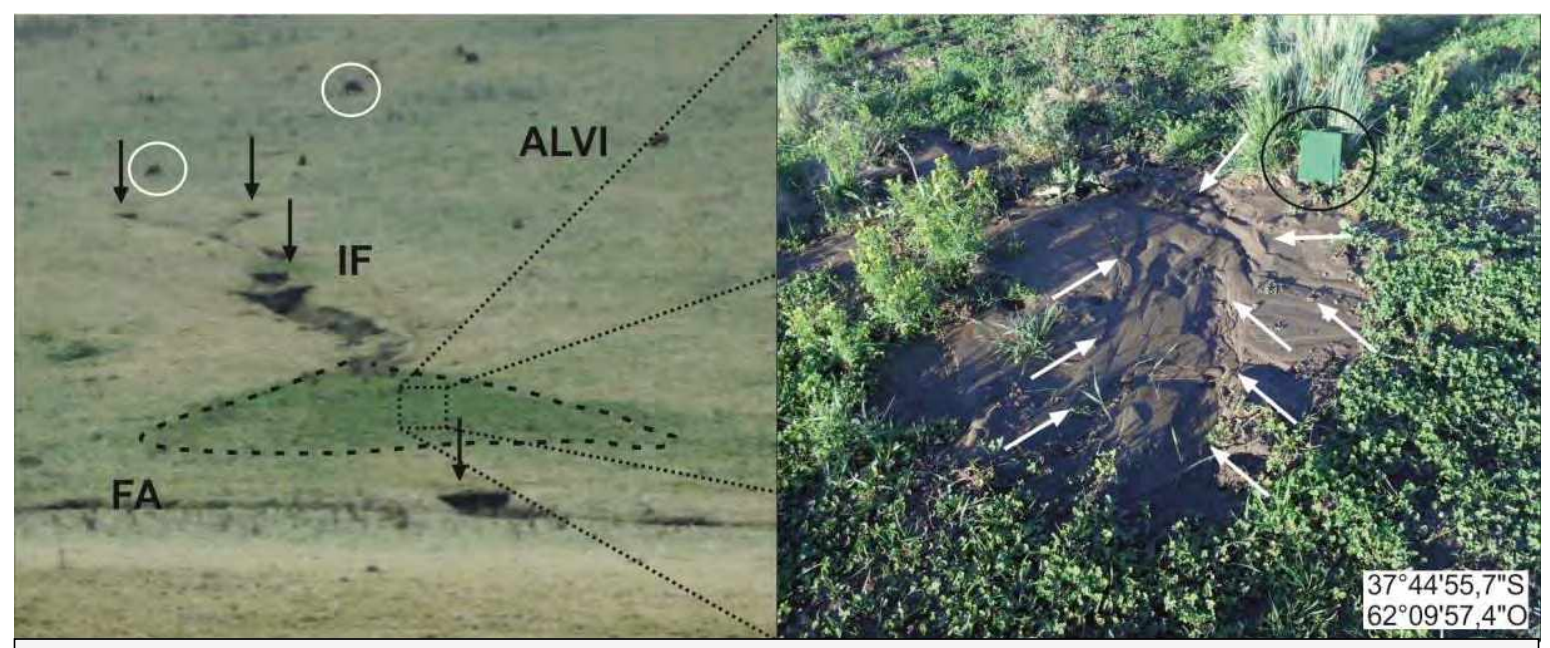

Figura 6.22. Abanico Aluvial Fino (línea de trazos) en el Valle de Las Grutas (subzona 2). Nótese el color verde más intenso debido al mayor contenido de humedad. En la foto de detalle (derecha) se pueden apreciar pequeños canales decimétricos en limo (flechas blancas). ALVI: Piedemonte Aluvial Moderno Inactivo Indiferenciado. FA: Faja Aluvial. IF: Incisión Fluvial. Flechas negras: escarpas generadas por movimientos en masa en cabeceras de cárcavas. Las vacas (círculos blancos) y el cuaderno (círculo negro) sirven como escala. Fotos: Juan M. Susena.

Fajas Aluviales: las Fajas Aluviales incluyen los cauces, planicies de inundación y terrazas bajas, se desarrollan en toda el área de estudio, siendo las unidades de mayor continuidad espacial. Su ancho máximo alcanza los $200 \mathrm{~m}$ aproximadamente al pie de las sierras, para luego reducirse en el piedemonte distal a unos pocos metros. Su morfología y la de los canales están fuertemente influenciadas por los materiales que atraviesa. En el piedemonte proximal y en los valles intraserranos, las litologías cortadas son generalmente conglomerados y brechas con variable grado de cementación, por lo cual la morfología 
típica es la de cauces entrelazados, limitados por barrancas de 1 a $5 \mathrm{~m}$ de altura (Figura 6.23). Por otra parte, en sectores donde los cursos que afectan materiales loessoides, los cursos se vuelven principalmente sinuosos pudiendo desarrollarse planicies de inundación anchas en el piedemonte proximal, o prácticamente ausentarse en el piedemonte medio y distal, donde la incisión vertical es muy acentuada y las barrancas pueden superar los 10 $\mathrm{m}$ de altura. La escasa incisión en los materiales loessoides del piedemonte podría responder a escasas dimensiones de las cuencas, a la presencia de materiales arcillosos más resistentes a la erosión en el lecho, y/o a la intersección con facies coluviales o aluviales antiguas más gruesas y permeables en determinados tramos, que pudieran, por infiltración, reducir el caudal. Al respecto, se observó en algunos sitios que el socavamiento basal por acción del agua de escorrentía no tiene gran participación en el piedemonte proximal, y el ensanchamiento se produce en gran medida por movimientos en masa (Figura 10.1 en Capítulo 10 Movimientos en masa en cursos de agua). Debe destacarse que los cursos de agua del área son generalmente perennes en sus cabeceras y en el piedemonte medio y distal, y secos en el piedemonte proximal, indicando infiltración y escurrimiento subsuperficial en dicho sector. Además de los procesos mencionados, se desarrolla pedogénesis en las planicies de inundación, pipping asociado a contrastes de permeabilidad del material y galerías excavadas por animales, y erosión de las barrancas por acción del ganado.

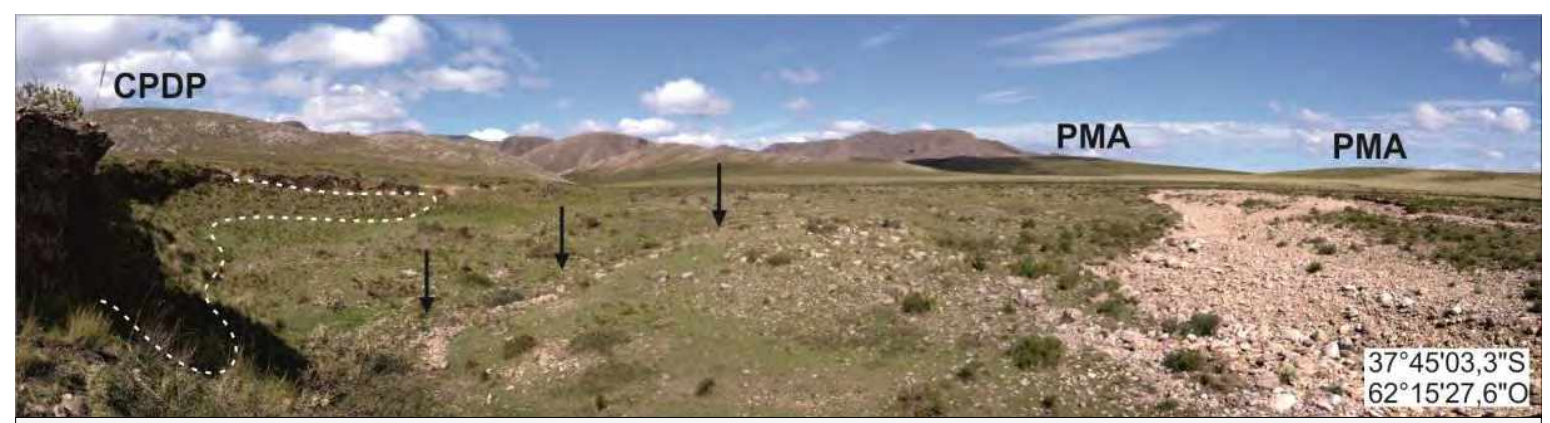

Figura 6.23. Faja Aluvial en el piedemonte occidental de las sierras de Curamalal (subzona 2). Flechas negras: cauce efímero. El cauce actual se sitúa en la porción derecha de la foto. Línea de trazos: talud al pie de la barranca. CPDP: Cimas Planas y Divisorias Principales. PMA: Piedemonte Aluvial Antiguo. La barranca del margen izquierdo de la foto mide unos $3 \mathrm{~m}$ de altura. Foto: Juan M. Susena.

Incisiones Fluviales: se incluyen en esta unidad rasgos erosivos generados por acción hídrica que no desarrollan planicies de inundación ni tienen acumulaciones relativamente perdurables de materiales en el lecho, sino que constantemente transportan material hacia Fajas Aluviales, Abanicos Aluviales de Materiales Gruesos o Abanicos Aluviales Finos. En el ámbito serrano, se ubican en valles intraserranos y excepcionalmente en laderas de detritos, pudiendo tener lecho rocoso o de detritos (Figura 6.20). Los procesos comunes son el lavaje de materiales finos, flujos de detritos y deslizamientos menores, muchas 
Movimientos en masa en las sierras de Bravard y Curamalal,

Sierras Australes de la Provincia de Buenos Aires.

Juan Manuel Susena

veces "encadenados", generando pequeños saltos de agua. La abrasión del lecho rocoso es común, así como el desarrollo de piletones al pie de saltos de agua mayores y gnammas en los afloramientos rocosos. Muchas veces los saltos de agua pueden vincularse a la obstrucción de los cauces debido a caídas, vuelcos, o deslizamientos desde las laderas de valle (ver Capítulo 11 Interacciones entre movimientos en masa y escurrimiento superficial/sub-superficial). En el piedemonte la incisión también tiene lugar, debido a la presencia de materiales muy friables, como lo son los depósitos eólicos (Figura 6.22). El desarrollo de cárcavas es un proceso común, muchas de ellas vinculadas a líneas de arado y huellas de vehículos y animales. El término cárcava (gully en inglés) se adopta aquí en el sentido de la Soil Science Society of America (2008), siendo geoformas profundas y estrechas, con profundidades de 0,5 a $30 \mathrm{~m}$. En el área de estudio, estas cárcavas alcanzan los $2 \mathrm{~m}$ de altura y son modeladas por movimientos en masa en las cabeceras y los laterales, por socavamiento basal por erosión hídrica, y por pipping asociado a contrastes de permeabilidad (Figura 6.24). Muchas de estas cárcavas son muy particulares, ya que no se generan desde un nivel de base típico (por ejemplo, un canal) y avanzan aguas arriba por erosión retrocedente. Su "nivel de base" son las mismas unidades geomorfológicas que están siendo erosionadas, como Cubierta Eólica Periserrana, o Piedemonte Aluvial Inactivo Moderno, y se desarrollan Abanicos Aluviales Finos en sus terminaciones (Figura 6.22). El grado de incisión depende del espesor del material eólico erosionado, ya que generalmente en el lecho son expuestos los clastos de los niveles pedemontanos sepultados por el loess; dichas superficies son más resistentes a la incisión. Como se verá en el Capítulo 12 Movimientos en masa $y$ actividad antropo $y$ zoogeomorfológica, el acarcavamiento se relaciona en gran medida con actividad humana y del ganado. Otra posibilidad del desarrollo de estas cárcavas es la existencia de un nivel de base (terreno deprimido o menor pendiente ladera abajo), y un sector de mayor pendiente a partir del cual se inicia el acarcavamiento hacia arriba.

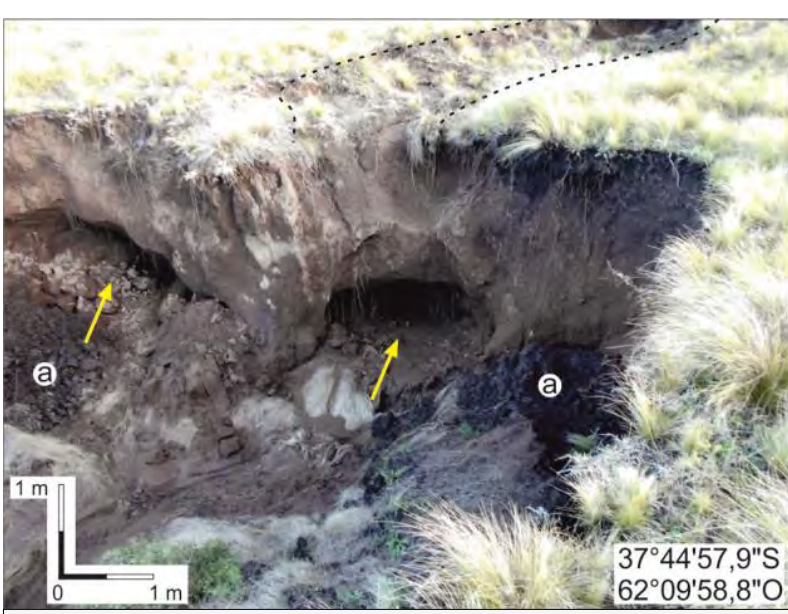

Figura 6.24. Pipping (flechas amarillas) en la Incisión Fluvial correspondiente a la de la Figura 6.22 (Valle de las Grutas, subzona 2). a: material caído. Línea de trazos: nótese el carácter incipiente de la canalización aguas arriba de la cárcava. El lecho del tramo inferior es un material más arcilloso, que dificulta la infiltración y la incisión, y favorece el pipping en el material superior más permeable. Foto: Juan M. Susena. 
Piedemonte Aluvial Activo Indiferenciado: esta denominación agrupa los elementos pedemontanos carentes de una morfología característica que permita clasificarlos en alguna de las unidades anteriores. Representa la bajada proximal del piedemonte actual, donde el proceso principal es la agradación fluvial, en algunos casos con el agregado de una componente coluvial (Figura 6.25). Son comunes remanentes de barras aluviales con una morfología suavizada por la depositación de materiales finos, que pueden ser facies de inundación luego de la migración del canal, o acumulaciones coluviales finas similares a las de la Bajada Coluvial Fina (ver más adelante). Un proceso acentuado es la bioturbación por acción del ganado y de organismos excavadores.

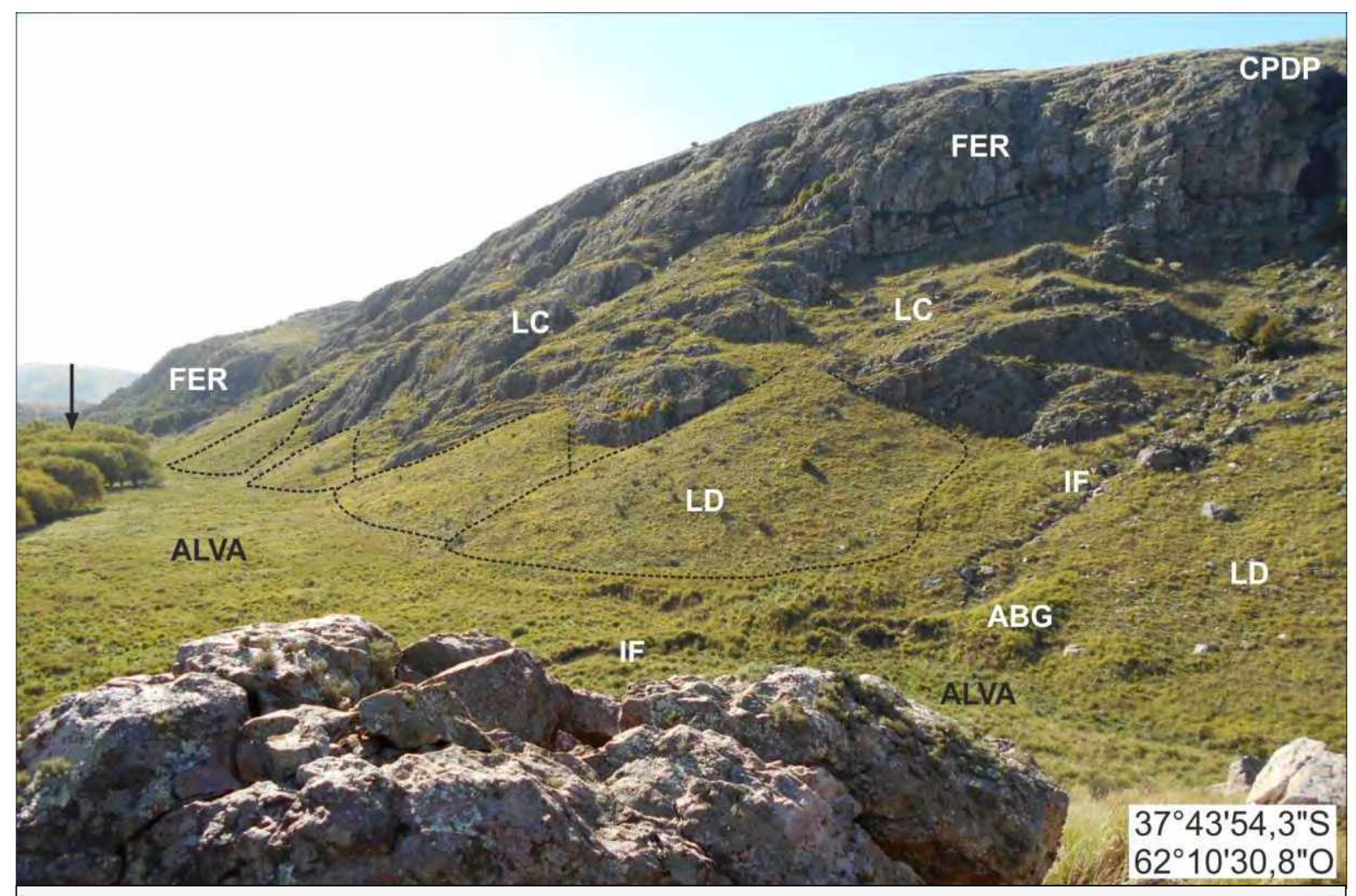

Figura 6.25. Piedemonte Aluvial Activo Indiferenciado (ALVA) al pie de las sierras de Bravard (subzona 2). ABG: Abanico Aluvial de Materiales Gruesos menor disectado. CPDP: Cimas Planas y Divisorias Principales. FER: Frentes Escarpados Rocosos. IF: Incisiones Fluviales. LC: Laderas Compuestas. LD: Laderas de Detritos. Líneas de trazos: conos de detritos. Flecha: los árboles sirven como escala, miden aproximadamente $4 \mathrm{~m}$ de altura. Foto: Juan M. Susena.

\subsubsection{Unidades coluviales activas}

Este grupo contiene tanto unidades dominadas por procesos de remoción en masa (Laderas de Detritos, Laderas Compuestas y Bajada Coluvial Fina), como unidades cuya morfología o grado de desarrollo se debe a una gran participación de dichos procesos (Afloramientos Parcialmente Ahogados, Remanentes de Frentes Escarpados Rocosos y Collados). 
Movimientos en masa en las sierras de Bravard y Curamalal,

Sierras Australes de la Provincia de Buenos Aires.

Juan Manuel Susena

Afloramientos Parcialmente Ahogados: en las laderas existen superficies donde los afloramientos son parcialmente ahogados o sepultados por sus propios detritos o por detritos originados ladera arriba (Figura 6.26). En el primer caso, las tasas de destrucción de los afloramientos y consiguiente generación de detritos superan a las de remoción coluvial y/o evacuación fluvial, por lo cual los detritos se amontonan al pie de los afloramientos, ahogándolos. En el otro caso, los detritos generados ladera arriba se amontonan donde los afloramientos reducen localmente la pendiente, sirviendo éstos como núcleos de acumulación o acreción. Un proceso común en esta unidad es el lavaje de materiales finos, la reacomodación de los detritos y la generación de deslizamientos de detritos de escaso recorrido. En sectores con presencia de materiales finos, puede haber reptación y desarrollo de pequeñas terracettes.

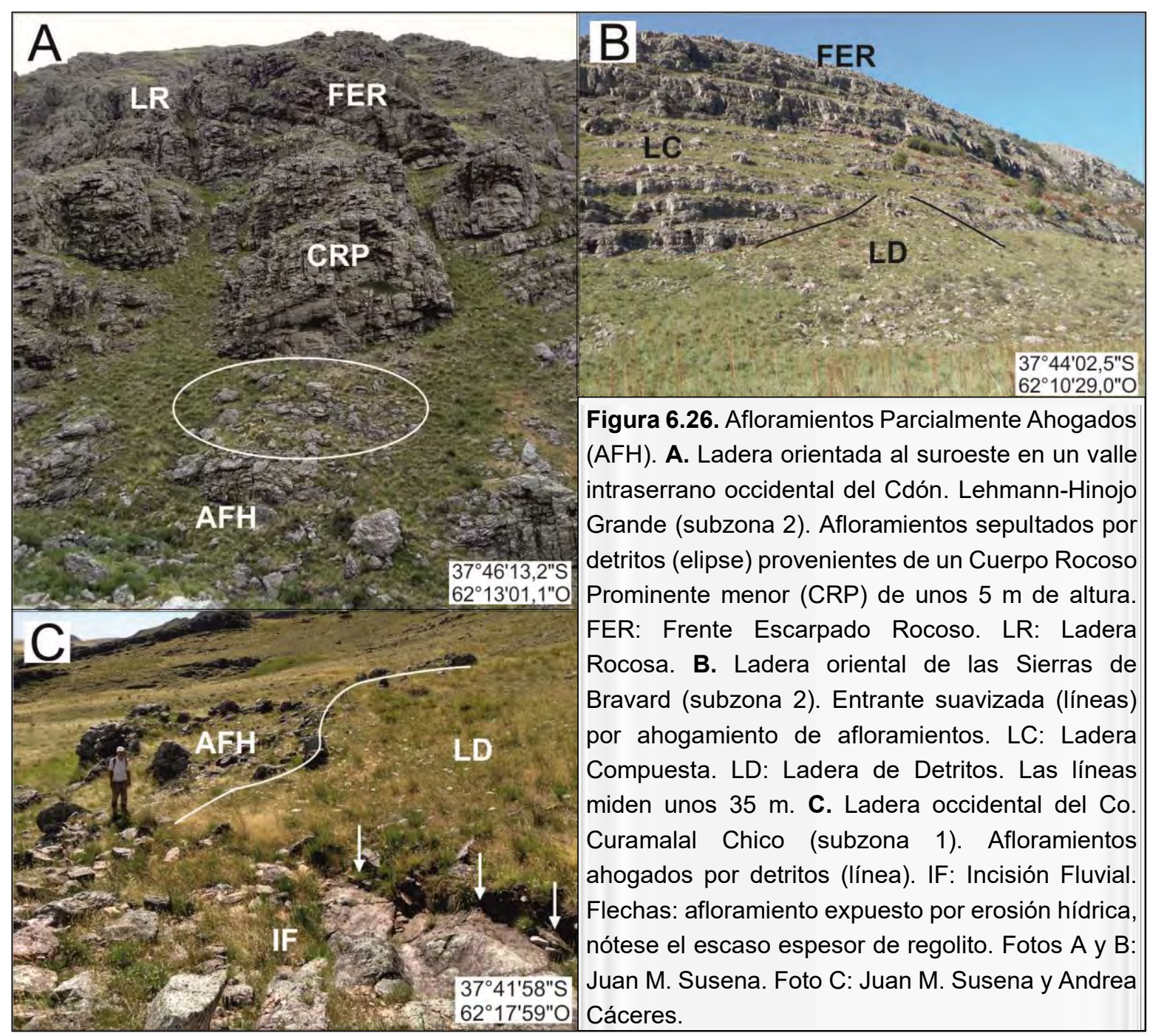

Collados: en las divisorias principales hay sectores que conectan las laderas de detritos de las cuencas aledañas. En dichos sectores, los afloramientos pueden estar total o parcialmente ahogados por detritos y con alguna participación de materiales finos (Figura 
6.27). En los collados los procesos dominantes son la meteorización física asociada a las heladas (crioclastía) el movimiento lento de clastos por acción del escurrimiento no encauzado, reptación en el caso de presencia de materiales finos, y acción del ganado evidenciada en detritos volteados (identificados por presencia de líquenes en las caras de los detritos apoyadas en la superficie).

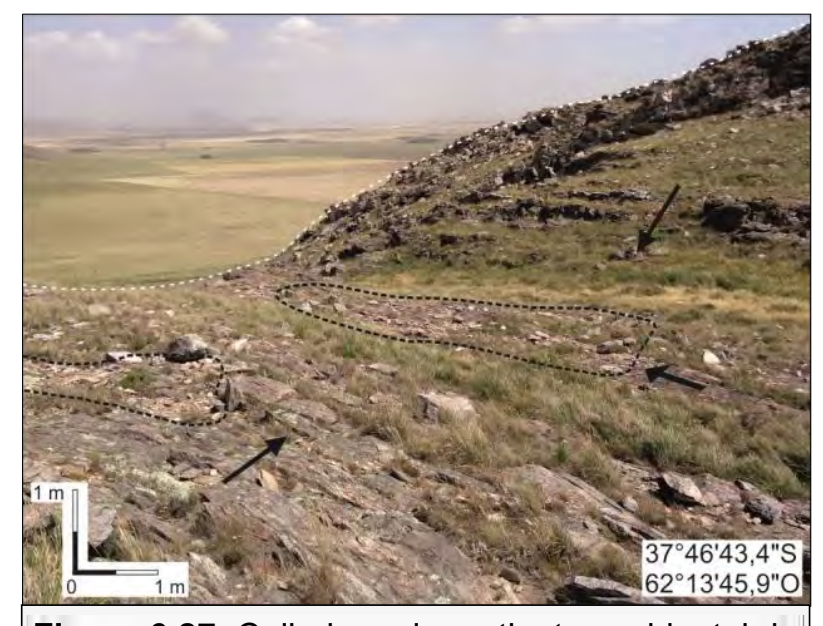

Figura 6.27. Collado en la vertiente occidental de las sierras de Curamalal (subzona 2). Flechas: dirección de la pendiente. Línea blanca: refuerzo visual de la topografía. Línea negra: sectores parcialmente ahogados con detritos. Foto: Juan M. Susena.

Laderas de Detritos: esta unidad es la más extendida en el ámbito serrano; incluye superficies de las laderas con un espesor de detritos tal, que la morfología y los procesos desarrollados dependen primordialmente de las características de los materiales superficiales, con poca o ninguna influencia de la morfología de la roca subyacente. La pendiente media ronda los $20^{\circ}$, aunque localmente puede alcanzar los $70^{\circ}$ e incluso inclinar en contra de la pendiente general de la ladera. Los principales procesos que se desarrollan son la reptación, expresada en el desarrollo de terracettes, los deslizamientos y flujos de detritos, muchas veces desarrollando una topografía hummocky característica (Figura 6.28), el desarrollo de suelos cumúlicos y mezcla de suelos (Figura 6.29) debido a los movimientos en masa y al escurrimiento no encauzado, el lavaje de materiales finos y su acumulación en depresiones locales asociadas a deslizamientos o flujos de detritos, y la canalización incipiente del flujo superficial en sectores localizados. A esto se agregan la bioturbación por acción del ganado y de animales silvestres como los jabalíes, evidenciada en volteo de detritos, compactación local de detritos en terracettes, compactación superficial en abrevaderos y revolcaderos, remoción y mezcla de suelo fino (hozaduras); esto se explica con detalle en el Capítulo 12 Movimientos en masa y actividad antropo y zoogeomorfológica. 
Movimientos en masa en las sierras de Bravard y Curamalal,

Sierras Australes de la Provincia de Buenos Aires.

Juan Manuel Susena

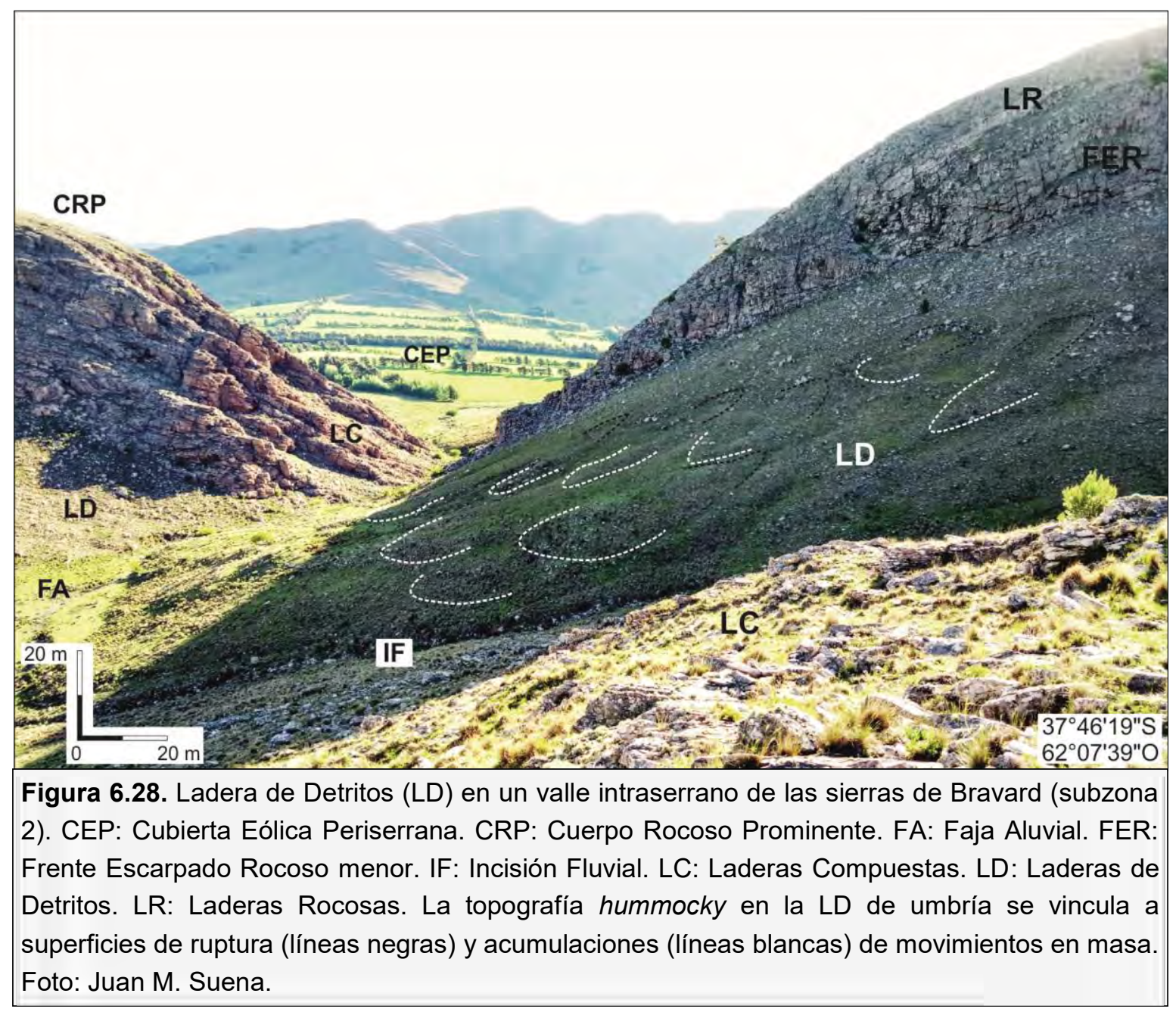




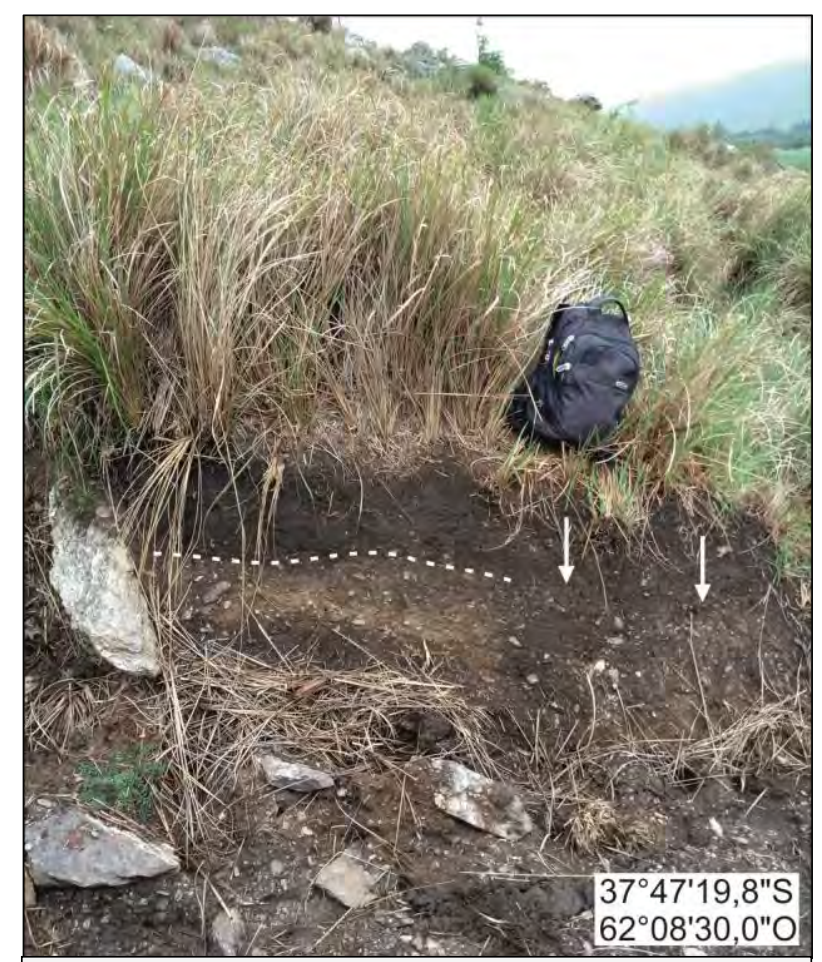

Figura 6.29. Flanco izquierdo de un deslizamiento de tierra en Ladera de Detritos del Cdón. Hinojo Grande (subzona 2). Flechas: mezcla de suelo. Línea de trazos: sector no disturbado, donde se aprecia una discordancia erosiva entre un horizonte B (abajo) de un suelo erosionado, y un horizonte A vinculado a Fm. Saavedra. Foto: Juan M. Susena.

Laderas Compuestas: esta denominación representa una alternancia de frentes escarpados rocosos menores y acumulaciones de detritos a su pie, presentando un relieve típicamente escalonado (Figura 6.30). Se incluyen también superficies con alternancia de afloramientos $y$ detritos sin una morfología característica que, por razones de escala, no pueden segregarse en unidades separadas. La morfología escalonada responde a la estructura de la roca, elemento que permite diferenciar esta unidad de los Afloramientos Parcialmente Ahogados. Si bien la presencia de este tipo de laderas se relaciona con la estructura de la roca, se incluye esta unidad entre las coluviales activas debido a que dominan

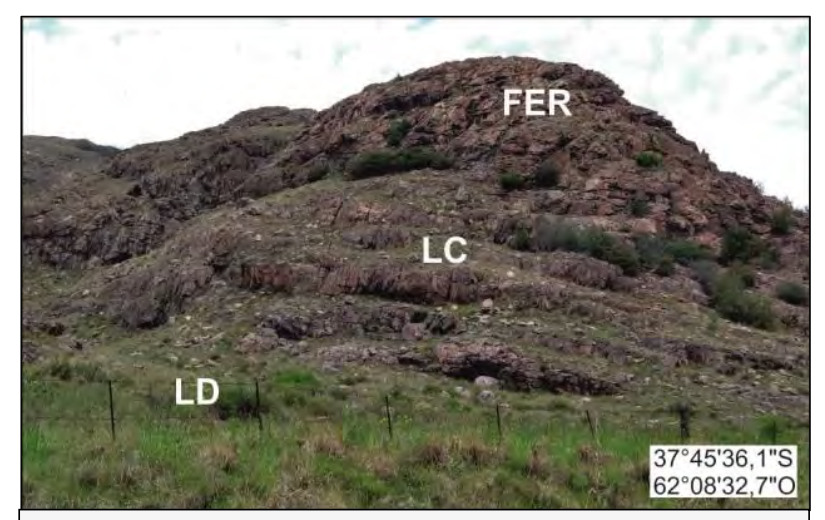

Figura 6.30. Laderas Compuestas (LC) en el abra del arroyo Hinojo Grande (subzona 2). FER: Frentes Escarpados Rocosos. LD: Ladera de Detritos. El alambrado sirve como escala. Foto: Juan M. Susena. 
Movimientos en masa en las sierras de Bravard y Curamalal,

Sierras Australes de la Provincia de Buenos Aires.

Juan Manuel Susena

los procesos y depósitos coluviales. Pueden ubicarse en cualquier sector de las laderas, pero generalmente se encuentran en el sector proximal. Los procesos allí desarrollados son caídas y vuelcos de roca, localmente deslizamientos planares o en cuña de poco recorrido, acumulación local de detritos, movimiento lento de detritos por acción del escurrimiento no encauzado, meteorización química asociada a manantiales en la roca, evidenciada en el desarrollo de gnammas, meteorización física por acción de raíces y localmente concentraciones incipientes del escurrimiento superficial.

Bajada Coluvial Fina: se trata de una unidad ubicada al pie de las laderas, principalmente Laderas de Detritos, semejante vista en planta a la morfología de los bordes de las Laderas de Detritos (Figura 6.31). Pueden presentar ocasionalmente ápices como los de los abanicos aluviales, pero no se encuentran al pie de unidades del tipo Incisiones Fluviales o Fajas Aluviales. Dicha característica podría ser heredada de abanicos subyacentes. Se eligió el término "bajada coluvial" en lugar de

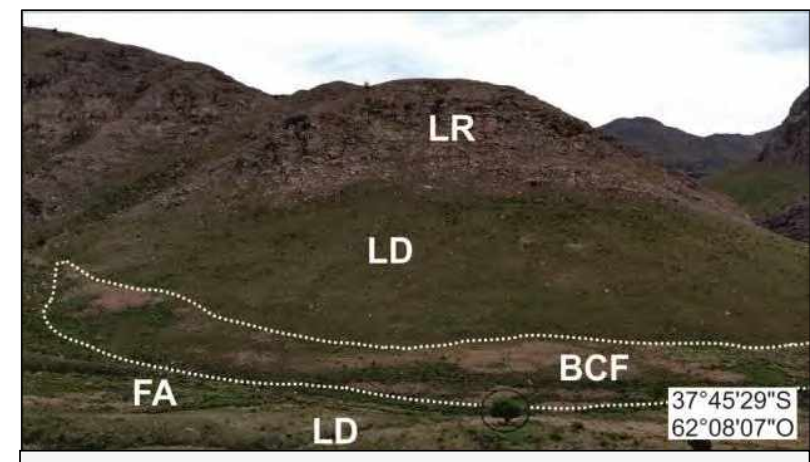

Figura 6.31. Bajada Coluvial Fina (BCF) en ladera oriental de un valle intraserrano en las sierras de Bravard (subzona 2). LD: Laderas de Detritos. LR: Laderas Rocosas. FA: Faja Aluvial. Es notorio el cambio de vegetación (abundancia de cortaderas) en la BCF. El árbol (círculo) sirve como escala, mide unos $3 \mathrm{~m}$ de altura. Foto: Juan M. Susena.

"ladera distal", porque su morfología recuerda a una bajada sensu stricto. En esta unidad domina la acumulación sobre la erosión y los materiales que la componen son preponderantemente limos loessoides provenientes del lavaje de las unidades topográficamente superiores. Es importante remarcar que no hay una influencia importante del escurrimiento encauzado en su desarrollo, y que las formas de ápice podrían responder a una topografía previa, ya que los materiales que los rellenan no provienen de su eje longitudinal, sino más bien de los laterales. Los manantiales son bastante comunes en esta unidad, particularmente en la transición entre ésta y Laderas de Detritos, condicionada por una reducción de permeabilidad de los materiales. Se desarrollan suelos cumúlicos y como procesos principales pueden mencionarse la reptación, el desarrollo de flujos de tierra y la arroyada difusa asociados a manantiales (Figura 6.32). La acción antrópica y del ganado (indirectamente antrópica) son importantes en el desarrollo de estos procesos: la compactación localizada por acción del ganado, el desarrollo de huellas de vehículos y las líneas de arado, son superficies de menor permeabilidad que el resto de la unidad, donde es favorecido el desarrollo de manantiales y procesos asociados (lavaje y flujos de tierra). 
En varios casos se ve un alineamiento de estos procesos y la presencia de alambrados, caminos y líneas de arado (véase Capítulo 12 Movimientos en masa y actividad antropo y zoogeomorfológica).

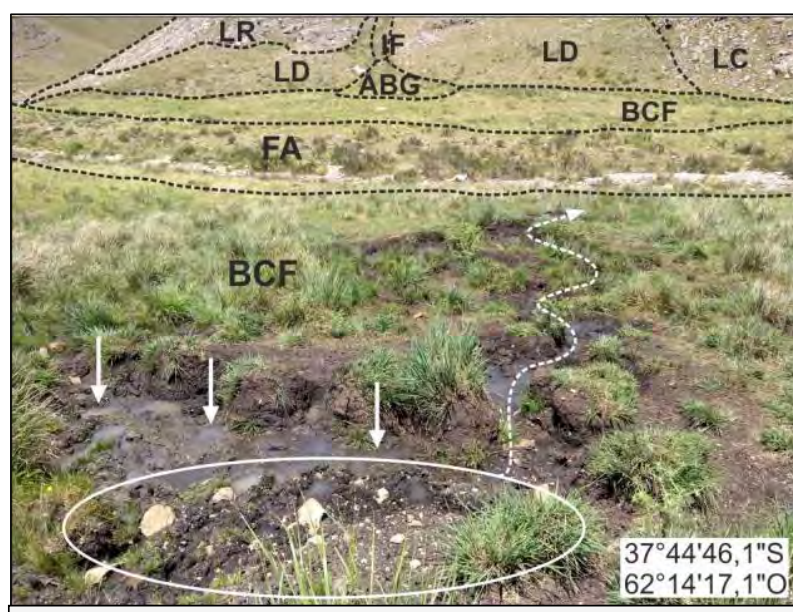

Figura 6.32. Efectos de la arroyada difusa asociada a un manantial en Bajada Coluvial Fina $(B C F)$, en un valle intraserrano de la vertiente occidental de las sierras de Curamalal (subzona 2). Línea de trazos blanca: pequeño cauce de 30 $\mathrm{cm}$ de ancho. Flechas: huellas de animales inundadas. Elipse: exposición de detritos debido al lavaje. ABG: Abanico Aluvial de Materiales Gruesos. FA: Faja Aluvial. IF: Incisión Fluvial. LC: Laderas Compuestas. LD: Laderas de Detritos. LR: Laderas Rocosas. Foto: Juan M. Susena.

Remanentes de Frentes Escarpados Rocosos: esta unidad tiene cierta similitud con los Frentes Escarpados Rocosos, pero la distribución espacial es mucho más discontinua y se encuentran rodeados por materiales coluviales provenientes de su propia destrucción, o de frentes o remanentes de frentes topográficamente superiores. Se diferencia a su vez de los Afloramientos Parcialmente Ahogados en que tienen actividad de caídas y vuelcos, pueden estar alineados y pueden desarrollarse aleros y cuevas, dado que a su pie hay cierto espacio de acomodación o evacuación de los detritos generados. Su desarrollo depende en parte de la presencia de discontinuidades en la roca, orientación de los pliegues (Figura 6.33.A) y diferencias de resistencia a la meteorización (Figura 6.33.B). 


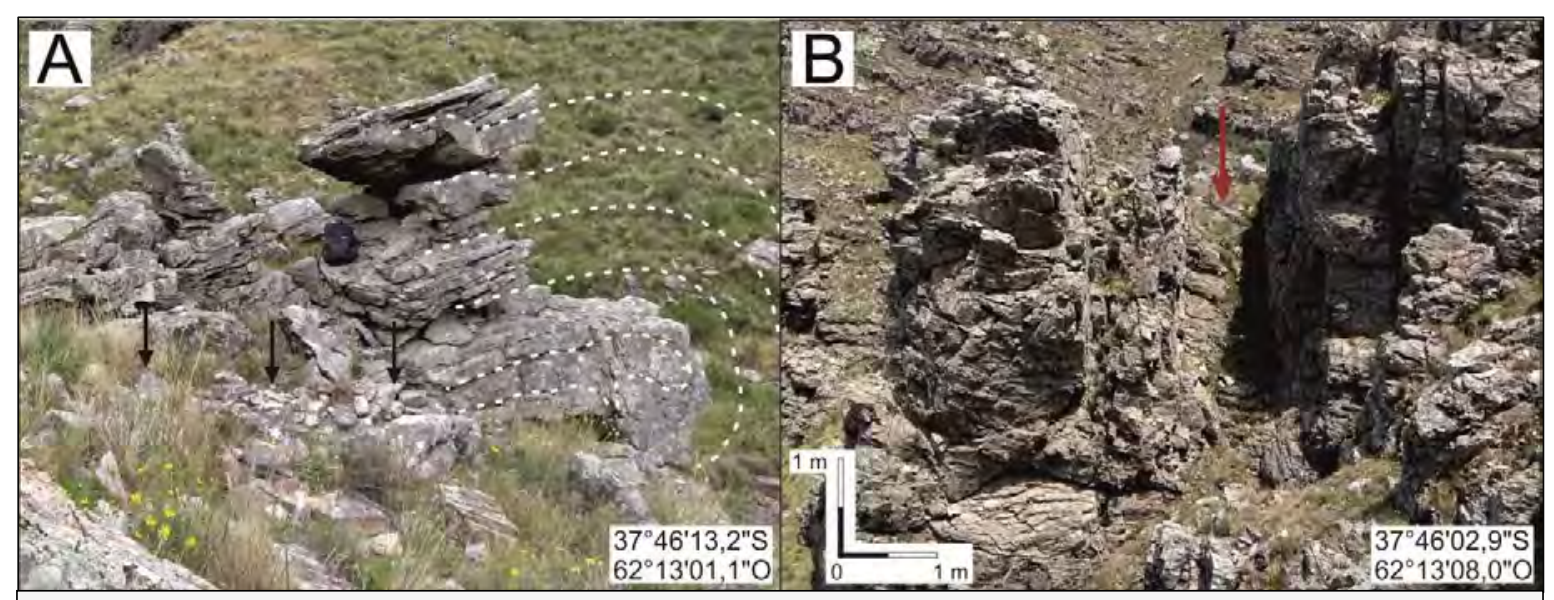

Figura 6.33. Remanentes de Frentes Escarpados Rocosos en valles intraserranos de la vertiente occidental de las sierras de Curamalal (subzona 2). A. Influencia de la estructura en la destrucción de los afloramientos (líneas de trazos). Flechas: detritos sepultando parcialmente los afloramientos. La mochila sirve como escala. B. Individualización de una porción de un Cuerpo Rocoso Prominente por meteorización diferencial en diaclasa ensanchada (flecha). Fotos: Juan M. Susena.

\subsubsection{Cubierta Eólica Periserrana}

En el ámbito serrano y el piedemonte proximal, zona de particular interés en esta tesis, esta unidad es la segunda más extendida, después de las Laderas de Detritos. Se trata de un manto eólico que cubre y suaviza la topografía preexistente. Se relaciona principalmente con la Fm. Saavedra, ya explicada en el Capítulo 5 Geología: generalidades. Como el espesor del manto eólico puede variar, según se ubique en valles o divisorias, puede mantener la morfología de las unidades geomorfológicas sepultadas. De todas formas, como lo que interesa en esta tesis son los procesos geomorfológicos actuales, esta unidad incluye también a los niveles de piedemonte y laderas sepultados completa o parcialmente por material eólico, y la parte distal de ciertas laderas cuya morfología y procesos dominantes son los mismos que en la Cubierta Eólica Periserrana, debido al quitado de los bloques rocosos por acción antrópica. En esta unidad dominan los procesos de pedogénesis y erosión sobre la agradación. Muy sometida a la acción antrópica, la Cubierta Eólica Periserrana presenta varios rasgos geomorfológicos casi característicos. E desarrollo de cárcavas efímeras (ephemeral gullies, sensu Soil Science Society of America, 2008) asociado a líneas de arado y huellas de animales o vehículos es tan evidente que su morfología presenta patrones rectilíneos, paralelos entre sí o radiales a estructuras antrópicas como abrevaderos (Figura 6.34). Estas cárcavas efímeras pueden evolucionar y desarrollarse cárcavas mayores y consecuentemente integrarse a la red de arroyos de la zona. La erosión hídrica también se manifiesta en la arroyada difusa, especialmente notable en cultivos, y en el desarrollo de rills, cárcavas y Fajas Aluviales. Los rills se definen 
aquí en el sentido de Knighton (1998), como microcanales de hasta $3 \mathrm{~cm}$ de profundidad y anchuras de 5-30 cm, siendo formas esporádicas, efímeras, que se destruyen por erosión inter-rill y desmoronamiento de sus laterales (Charlton, 2007). Por otra parte, el trazado de una red de caminos favoreció el desarrollo de acumulaciones lineales a ambos lados de estos, de hasta $1 \mathrm{~m}$ de espesor y $15 \mathrm{~m}$ de anchura, que se acuñan hacia dentro de los campos lindantes (Bidart, 1992b); estas geoformas son producto de la acción eólica asistida por el tránsito vehicular (Susena y Gentile, 2019). La erosión eólica también se asocia en menor medida a construcciones de servicio para el ganado, como lo son los abrevaderos.

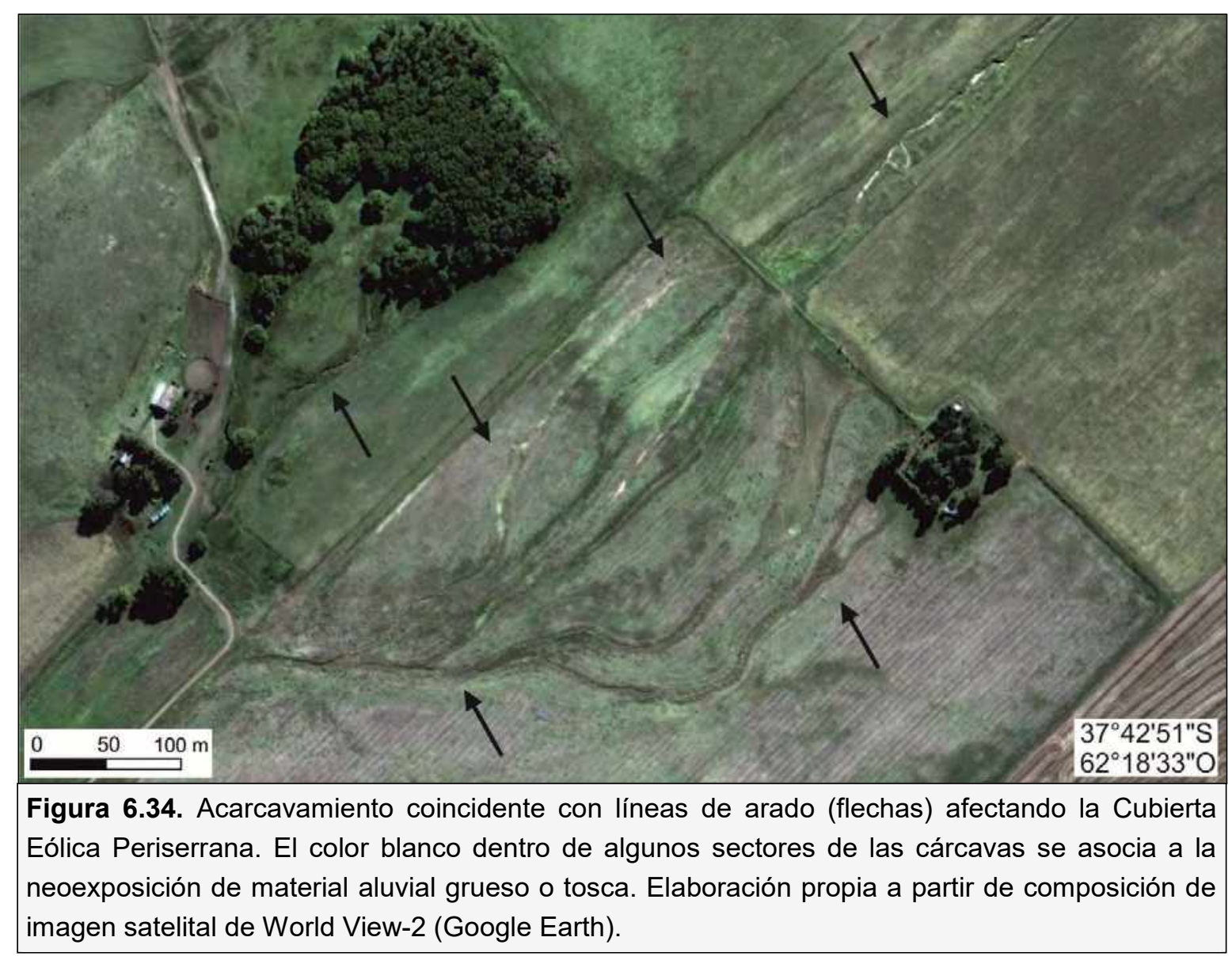


Movimientos en masa en las sierras de Bravard y Curamalal, Sierras Australes de la Provincia de Buenos Aires.

Juan Manuel Susena 


\section{UNIDAD III}

El cómo del objeto de estudio... 



\section{Capítulo 7}

\section{Criterios de reconocimiento de los movimientos en masa y su actividad}

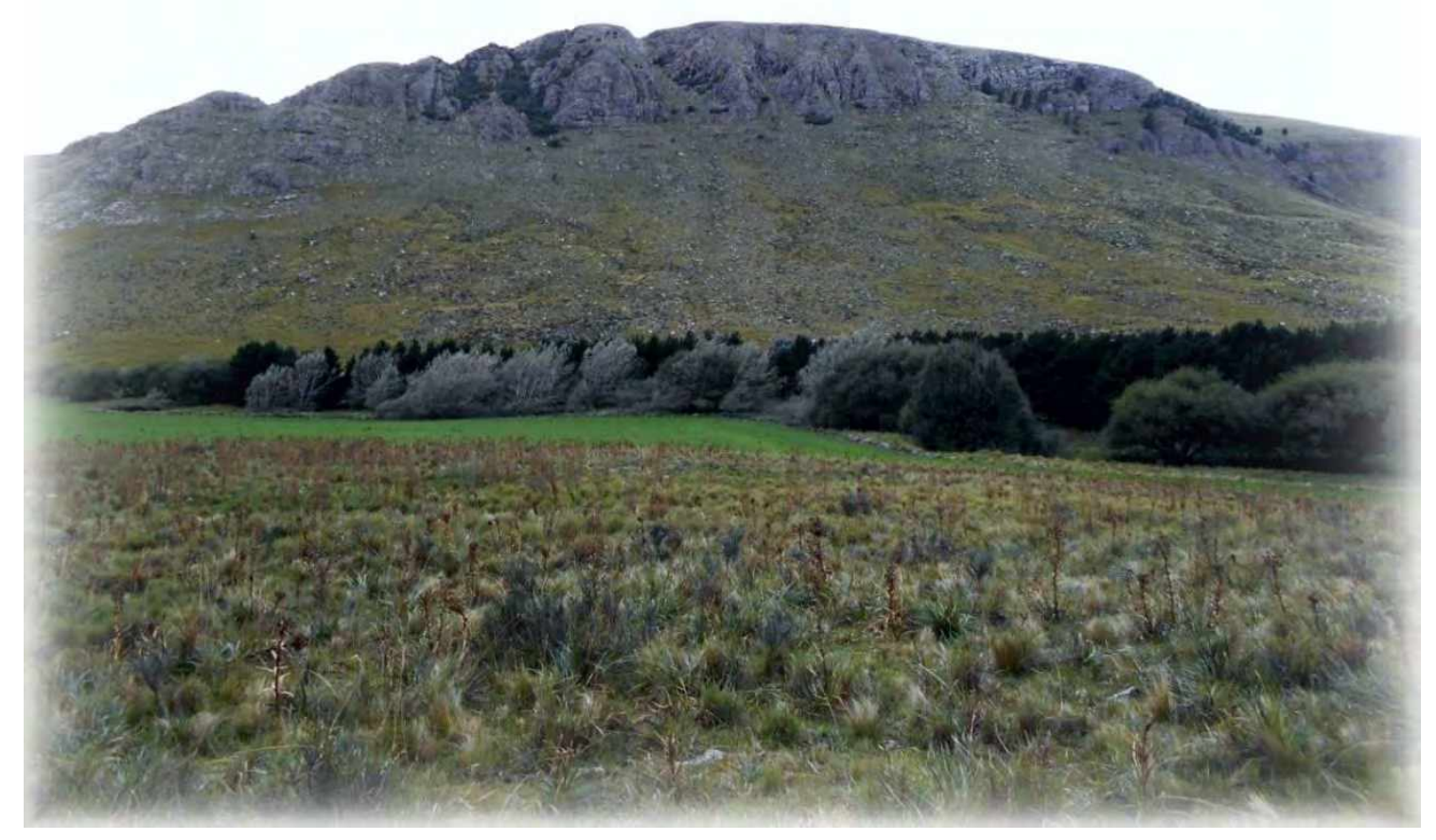

"De punta a punta, con cierta belleza" Ladera occidental de las sierras de Bravard en la Estancia Cerro Áspero.

Los movimientos en masa dominan la expresión visual de la ladera de detritos, con una alternancia verde y gris de pastizal y detritos muy característica. 
Movimientos en masa en las sierras de Bravard y Curamalal, Sierras Australes de la Provincia de Buenos Aires.

Juan Manuel Susena 


\subsection{Objetivos y ordenamiento del capítulo}

La intención de este capítulo es exponer los criterios, fundamentalmente morfológicos, utilizados para identificar los movimientos en masa y su grado de actividad en el área de estudio. Se busca, en concreto, que el lector comprenda "a qué se prestó atención" para identificar los rasgos producto de movimientos en masa. Por tanto, se presenta a continuación una serie de criterios morfológicos que se utilizaron para el reconocimiento e interpretación de dichos procesos. La caracterización sistemática y detallada de cada tipo de movimiento se brindará en los capítulos siguientes, de acuerdo al contexto geomorfológico en que cada uno de ellos se desarrolla, por lo cual aquí sólo se los mencionará.

\subsection{Evidencias de movimientos en masa}

La variedad en los tipos cinemáticos de movimientos en masa en el área implica la existencia de una gran variedad morfológica de los rasgos del paisaje producidos por ellos. Los tipos cinemáticos de movimientos en masa identificados en el área estudiada se enumeran a continuación:

1. Caídas de rocas/detritos

2. Caídas de suelo

3. Vuelcos de rocas

4. Vuelcos de suelo

5. Flujos de tierra

6. Flujos de barro

7. Flujos de detritos

8. Deslizamientos rotacionales de detritos

9. Deslizamientos traslacionales de detritos

10. Deslizamientos rotacionales de suelo

11. Deslizamientos traslacionales de suelo

12. Deslizamientos planares (en roca)

13. Deslizamientos en cuña (en roca)

14. Reptación

La morfología particular de cada tipo de movimiento se describió en un contexto más global en el Capítulo 1 Introducción al objeto de estudio; a continuación, se amplía la información particularizando en rasgos que se vinculan a movimientos en el área estudiada. Cabe 
Movimientos en masa en las sierras de Bravard y Curamalal,

Sierras Australes de la Provincia de Buenos Aires.

Juan Manuel Susena

recordar que en esta tesis los conceptos de movimientos complejos y compuestos se asocian a estilos de actividad de los movimientos, y no a tipos cinemáticos.

Si bien no existe un tipo de material específico que pueda asociarse a los movimientos en masa, ya que todo el rango granulométrico puede movilizarse por acción de la gravedad, sí existe una fábrica o un conjunto de rasgos morfológicos de estos materiales y de las geoformas afectadas, que pueden indicar su origen.

\subsubsection{Rasgos vinculados a caídas, vuelcos y deslizamientos de rocas}

Taludes y laderas: uno de los ejemplos más conspicuos de desarrollo de movimientos en masa se encuentra al pie de los Frentes Escarpados Rocosos. Pueden reconocerse bloques rocosos de tamaños diversos, trabados entre sí en mayor o menor medida, donde su morfología y dimensiones son afines al arreglo de las discontinuidades del macizo rocoso aledaño. Estos depósitos forman parte, al pie del frente escarpado, del talud en el sentido de Bloom (1991), y son producto de caídas y vuelcos de roca (Figura 7.1). La adición de material eólico rellenando el talud favorece el desarrollo de procesos coluviales (es decir, el retransporte por reptación) y otros movimientos en masa, así como también el retrabajamiento por acción del agua y otros procesos. Se usa en esta tesis preferentemente la denominación de "laderas" cuando hay una matriz eólica, que es la generalidad del área de estudio, y "talud", cuando no la hay, siendo casos muy concretos. Aunque morfológicamente se trate del mismo elemento (está todo mapeado como Laderas de Detritos), esta distinción se utiliza para diferenciar aquellas formas integradas prácticamente en su totalidad por materiales producto de caídas -y en menor medida acción

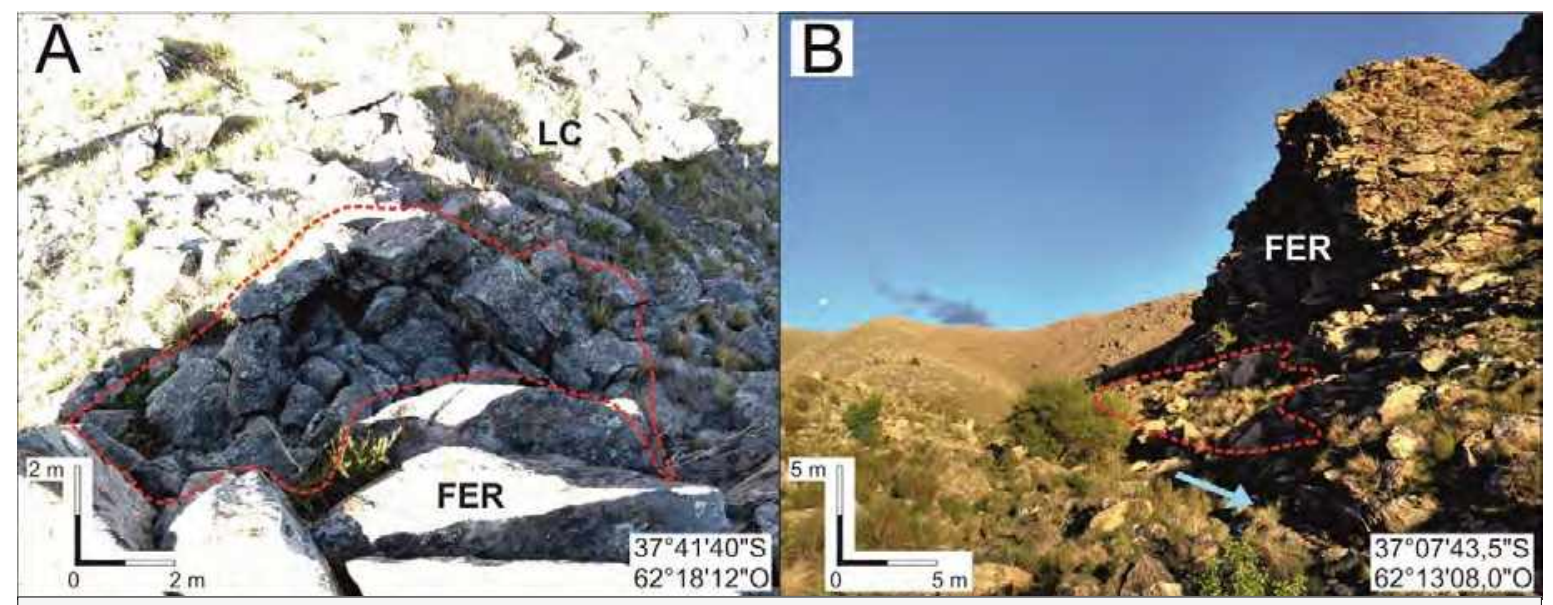

Figura 7.1. Taludes. Los taludes incluyen los depósitos (líneas de trazos) al pie de los Frentes Escarpados Rocosos (FER). LC: Ladera Compuesta. Flecha: curso de agua erosionando el talud o impidiendo su desarrollo. A. Vertiente occidental de las sierras de Curamalal, al norte del cerro Curamalal Chico (subzona 1); las coordenadas son aproximadas. EI FER tiene unos $4 \mathrm{~m}$ de altura. B. Valle intraserrano de las sierras de Bravard, en la Estancia Cerro Áspero (subzona 2). Fotos: Juan M. Susena. 
del agua-, de aquellas que incluyen además depósitos eólicos; estas características inciden en su comportamiento geomecánico e hidrológico, desarrollándose, según sea el caso, diferentes procesos. Los "taludes" tienen un perfil rectilíneo en la dirección de la pendiente, mientras que en las "laderas", el perfil puede ser rectilíneo a cóncavo, o presentar alternancias de segmentos rectilíneos, cóncavos y convexos. Dado que el esqueleto de los materiales de las Laderas de Detritos es originado por movimientos en masa de los cuerpos rocosos, la existencia de estas laderas indica per se la ocurrencia de movimientos.

Conos de talud o conos de detritos: al pie de los frentes escarpados modelados en rocas pre-paleocenas, existen geoformas que componen parte de la zona proximal de las Laderas de Detritos, caracterizadas por su semejanza con conos (o triángulos cuando son vistos en planta), con el ápice ubicado en el contacto entre los frentes escarpados y las Laderas de Detritos, constituyendo sus materiales parte o la totalidad de éstas (Figura 7.2). Generalmente se ubican en zonas donde los frentes escarpados rocosos presentan diaclasas ensanchadas, tanto por meteorización, como por caídas y vuelcos de rocas y acción del escurrimiento superficial. En este sentido, son microcuencas de orden 1 o 2 (sensu Strahler, 1952), con recorridos no mayores a $50 \mathrm{~m}$, y a veces más de $20 \mathrm{~m}$ de profundidad respecto a las cimas de los frentes escarpados, constituyéndose Gargantas

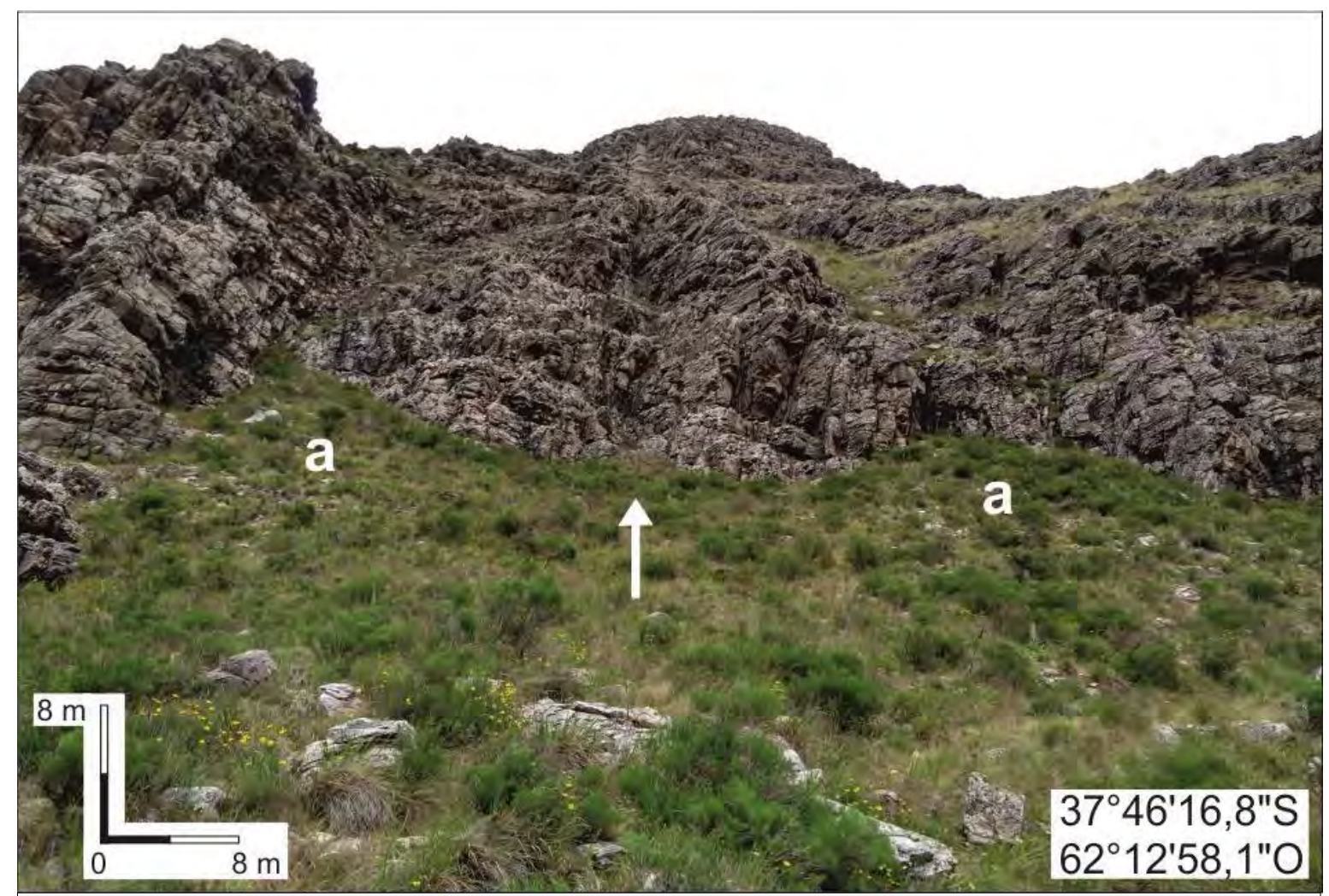

Figura 7.2. Conos de detritos coalescentes (a) en un valle intraserrano de la vertiente occidental de las sierras de Curamalal, cerca del Cdón. Hinojo Grande (subzona 2). Flecha: cono de detritos menor. Foto: Juan M. Susena. 
Movimientos en masa en las sierras de Bravard y Curamalal,

Sierras Australes de la Provincia de Buenos Aires.

Juan Manuel Susena

en Discontinuidades Rocosas. Las dimensiones de los conos son variables, con anchos de 10 a70 m en la parte distal y longitudes entre 5 y 50 m desde el pie hasta el ápice.

La granulometría de sus materiales abarca el rango arcilla-bloques con un tamaño máximo de $4 \mathrm{~m}$ de eje mayor. Los bloques mayores son en general angulosos, con formas tabulares a equidimensionales, y los menores suelen ser tabulares a prolados. El material fino es dominantemente limoso con una componente arcillosa menor, y corresponde a material eólico de la Fm. Saavedra. El término talus cone se refiere a geoformas asociadas a caídas de rocas, con posible retrabajamiento por acción de escurrimiento superficial (incisión en el ápice) y reacomodamiento de los materiales finos por pisoteo o golpes de otros bloques (Luckman, 2013); tal podría ser la génesis de estas geoformas. La distribución granulométrica típica de los materiales es creciente ladera abajo (Figura 7.3), dado que los bloques mayores desarrollan mayor energía cinética y mayor tendencia a rodar y rebotar que los menores, los cuales pueden quedar trabados entre irregularidades de la superficie. En condiciones particulares, los bloques mayores pueden quedar trabados en el ápice o muy cerca de él, cuando existen obstáculos como afloramientos rocosos, árboles o más bloques mayores. Debido a que están constituidas en gran medida por materiales

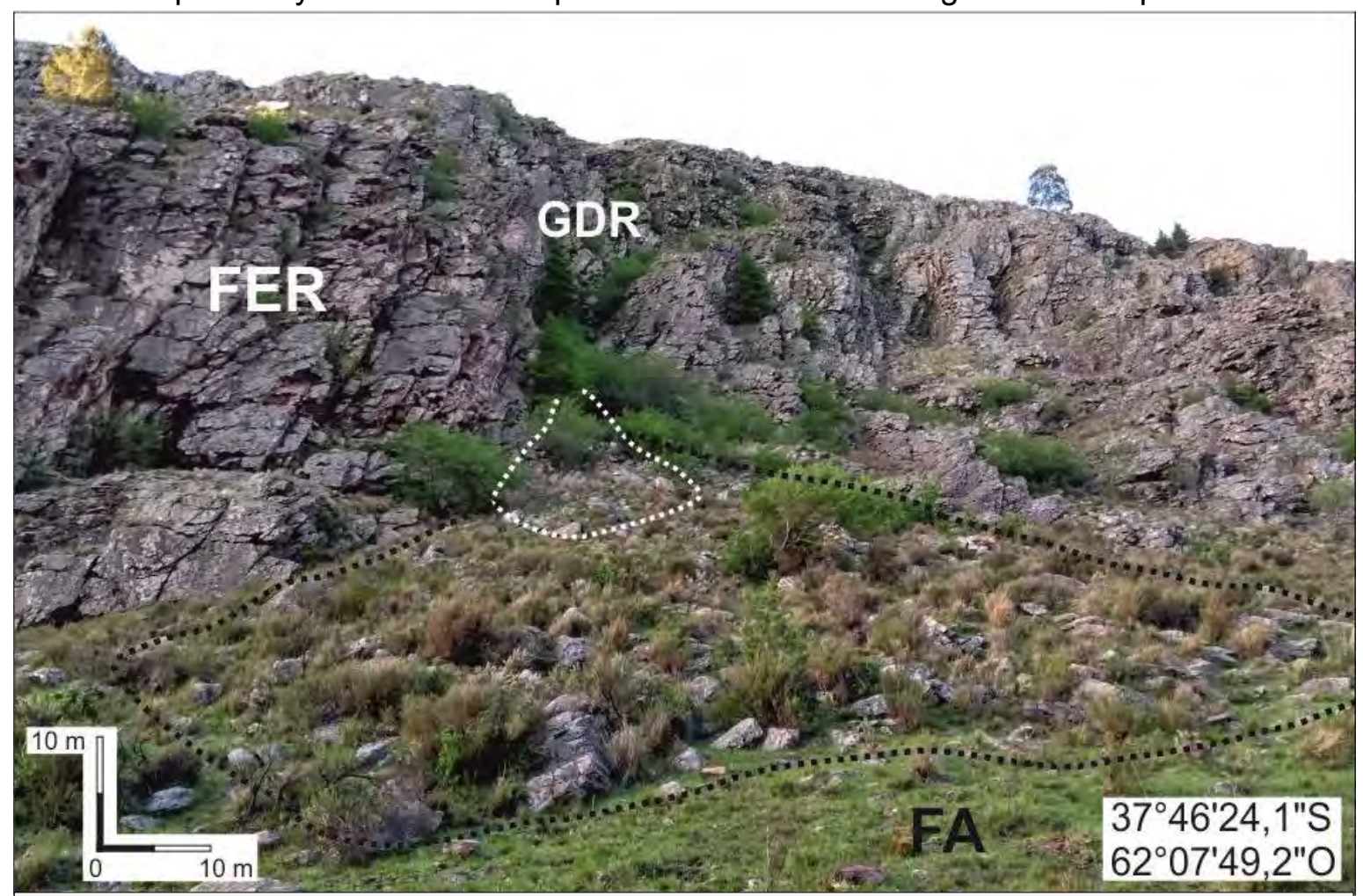

Figura 7.3. Conos de detritos en un valle intraserrano de las sierras de Bravard, en la Estancia Cerro Áspero (subzona 2). Flecha: cono de detritos menor. El cono mayor (línea de trazos negra) tiene los detritos parcialmente sepultados por materiales eólicos, indicando mayor edad. Nótese que los bloques distales son mayores que los proximales, distribución típica de estas geoformas. Línea de trazos blanca: cono de detritos en desarrollo. FA: Faja Aluvial. FER: Frente Escarpado Rocoso. GDR: Garganta en Discontinuidad Rocosa. La escala se ajusta al ápice del cono menor. Foto: Juan M. Susena. 
gruesos, estas geoformas son muy resistentes a la erosión y pueden ser preservadas en el paisaje como formas relícticas o inactivas (Luckman, op. cit.).

Amontonamientos de detritos: en Laderas de Detritos, existen depósitos con morfologías circulares a alargadas vistas en planta, constituidas por detritos rocosos, que en general yacen amontonados sobre algún elemento que genera una irregularidad topográfica local. Estos depósitos se ubican preferentemente en el sector medio de las laderas, y alcanzan dimensiones de hasta 2-3 $\mathrm{m}$ de diámetro y volúmenes de unos pocos metros cúbicos. Los detritos que integran estas formas son principalmente clastos de cuarcita, cuyas dimensiones son variables, en general de orden decimétrico (Figura 7.4). Estos detritos rocosos son en general levemente prolados a equidimensionales, y sub-angulosos a subredondeados.

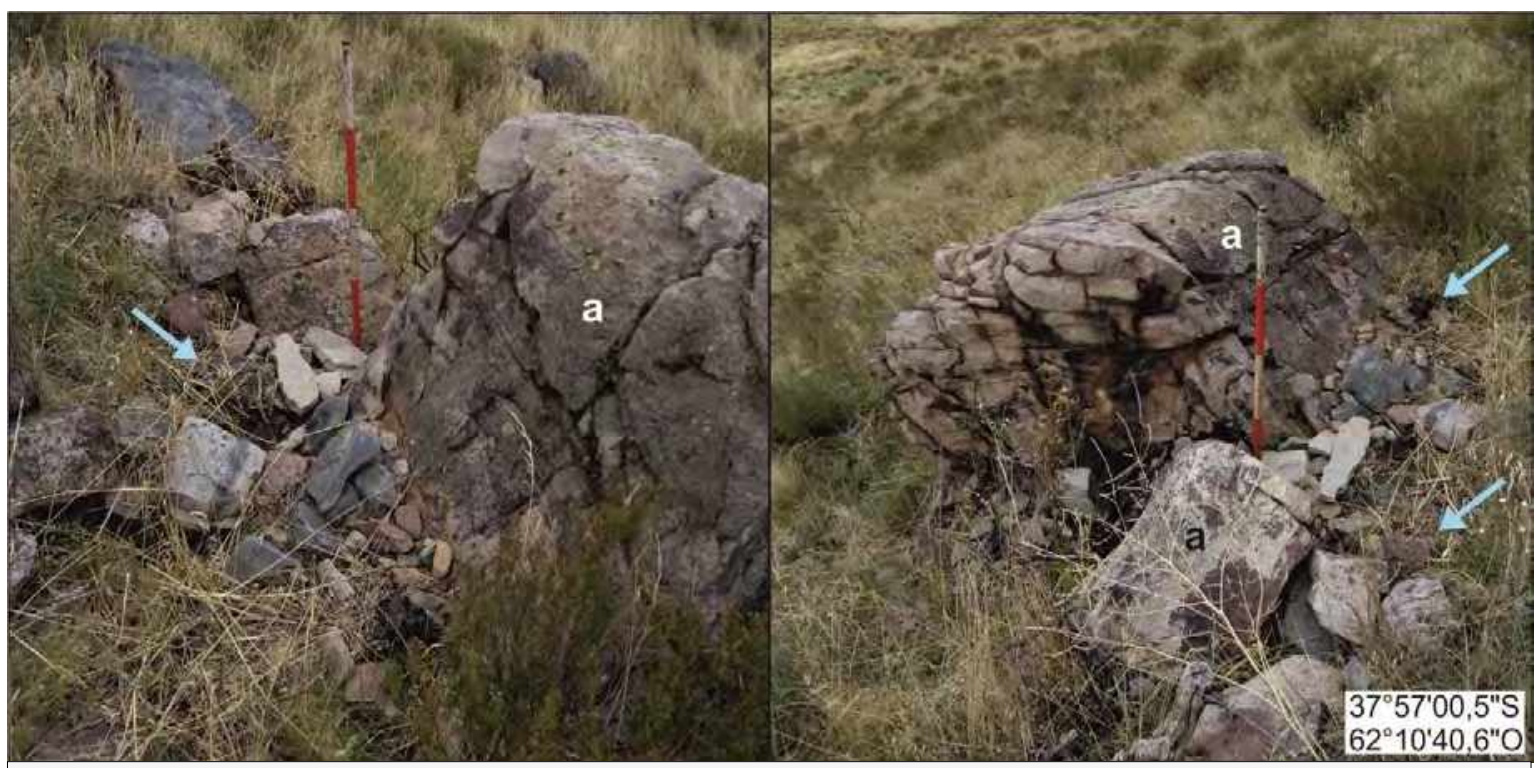

Figura 7.4. Amontonamientos de detritos (flechas) en la ladera oriental del cerro Pan de Azúcar (subzona 3). a: detritos mayores que sirven como irregularidad para propiciar los amontonamientos. Ambas fotos son del mismo amontonamiento, tomadas desde diferente ángulo. El jalón (1 m) sirve como escala. Fotos: Juan M. Susena.

Su génesis se vincula a caídas de rocas, en situaciones en que los materiales encuentran un obstáculo y no pueden continuar desplazándose ladera abajo. La angulosidad de los bloques posibilitaría un ensamble o "trabazón" entre los fragmentos, en torno a algún objeto o irregularidad de mayores dimensiones que, proporcionando espacio suficiente para albergarlos y evitando la continuación del movimiento ladera abajo, actúan como "núcleos de acreción". Grandes bloques parcialmente enterrados o descubiertos, pequeños afloramientos, arbustos, árboles, o incluso disminuciones de pendiente vinculadas a rasgos producto de movimientos en masa, pueden constituir irregularidades locales en el terreno que disminuyen bruscamente la energía cinética de los bloques que se movilizan por 
Movimientos en masa en las sierras de Bravard y Curamalal,

Sierras Australes de la Provincia de Buenos Aires.

Juan Manuel Susena

caídas, desacelerando o deteniendo completamente el movimiento. La Figura 7.5 ilustra ambas situaciones: en el primer caso (desaceleración), el movimiento de los detritos podría cesar muy cerca de dicha irregularidad, pudiendo encontrarse los mismos al pie de ésta (flechas rojas en la figura); por otra parte, si el movimiento fuera detenido sobre la irregularidad, los bloques se acumularían encima, generando progresivamente los amontonamientos (flechas celestes en la figura).

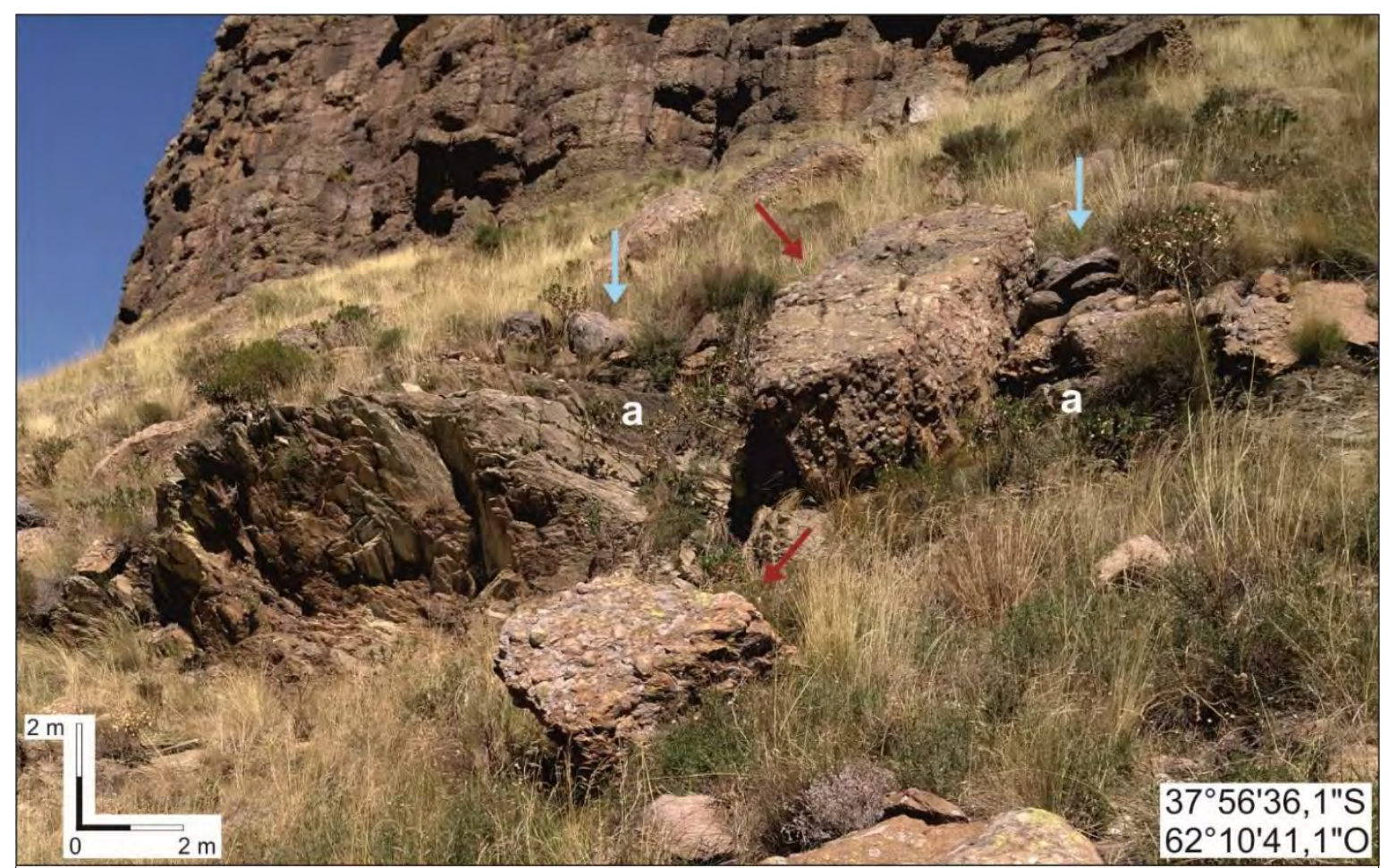

Figura 7.5. Amontonamientos de detritos (flechas celestes) en la ladera oriental del cerro Pan de Azúcar (subzona 3). a: afloramientos del basamento que sirven como irregularidad para propiciar los amontonamientos. Flechas rojas: bloques del Conglomerado La Lola que sobrepasaron la irregularidad y se detuvieron a su pie. Foto: Juan M. Susena.

Hipotéticamente, cuando los núcleos de acumulación son detritos rocosos, la adición de detritos encima generaría una acumulación de energía potencial, siendo un mecanismo preparador de inestabilidad, que podría adoptar dos formas:

1. Si el bloque sobre el cual se apoyan los detritos yaciera apoyado sobre una de sus caras, es posible que el mismo se encontrara en un ángulo cercano a su ángulo de reposo, por tanto, en un equilibrio metaestable. Al añadir carga sobre el bloque, éste podría movilizarse, desestabilizando al mismo tiempo los detritos suprayacentes, constituyéndose nuevas caídas de detritos en la ladera.

2. Si el bloque sobre el cual se apoyan los detritos se encontrara parcialmente enterrado, el material que lo retiene resistiría una carga que aumentaría al acumularse detritos detrás del bloque. El lavaje de materiales finos en épocas lluviosas podría provocar 
una desestabilización de todo el conjunto y consecuentemente, un deslizamiento de detritos con materiales finos asociados.

El acomodamiento de tipo "trabazón" que tienen los detritos, parece indicar que alcanzaron su posición actual en momentos diferentes, y no como consecuencia de un único movimiento, indicando multiplicidad de movimientos en masa (Susena y Gentile, 2018). De cualquier manera, se evidencia que, para zonas con caídas de materiales angulosos, la trabazón de éstos en torno a diferentes obstáculos constituye un retraso temporario para la continuación del movimiento ladera abajo, pero que puede convertirse en un mecanismo preparador y desencadenante de movimientos en masa de mayor volumen, como los deslizamientos de detritos.

\subsubsection{Rasgos vinculados a deslizamientos y flujos}

Irregularidades en la morfología de las laderas: en Laderas de Detritos existen lomadas y depresiones con diferencias de altura relativa de hasta $5 \mathrm{~m}$, que corresponden respectivamente a zonas de acumulación (rasgo topográfico positivo con respecto a la superficie original del terreno) y de hundimiento (depresión con respecto a la superficie original del terreno) de movimientos en masa. En algunos casos, se preserva sólo una de las dos características. Estas características de unmovimiento único pueden solaparse con las de otros movimientos menores o mayores que las afectan, desarrollándose en las laderas una topografía hummocky (= lomadas y depresiones) que puede ubicarse en sectores concretos u ocupar prácticamente la totalidad de la ladera (Figura 7.6). Así, tanto el perfil longitudinal como transversal a la pendiente presentan una sucesión de segmentos cóncavo-convexos que modifican localmente el escurrimiento superficial (Figura 7.7).

Las pendientes pueden presentar quiebres abruptos en perfil longitudinal y transversal, asociados a coronas y flancos de deslizamientos (las coronas y los flancos son el borde del terreno no afectado). Puesto que en un deslizamiento existe una superficie definida sobre la cual se mueven los materiales, al quedar ésta expuesta luego del movimiento, se la observa como una superficie "fresca", carente de vegetación; si estuviera integrada por clastos que no estuvieron expuestos, estos carecerían de cortezas de líquenes. Estas características contrastan con el terreno no afectado en cuanto a tono y textura y en las imágenes satelitales con una resolución mayor a $30 \mathrm{~m}$., así como en fotografías aéreas a escala 1:20.000, estas cicatrices "frescas" son identificables (Figura 7.8). Dichas "cicatrices" se distinguen por la conformación de una escarpa de una altura determinada, cuya pendiente, al menos en el caso de los deslizamientos rotacionales, es considerablemente mayor al ángulo de reposo de los materiales de la ladera. Las escarpas 
Movimientos en masa en las sierras de Bravard y Curamalal,

Sierras Australes de la Provincia de Buenos Aires.

Juan Manuel Susena

pueden superar los $2 \mathrm{~m}$ de altura y ser verticales, o pueden no superar el metro de altura y encontrarse degradadas, parcialmente sepultadas por materiales producto de su propia destrucción o materiales provenientes de arriba (ladera arriba).

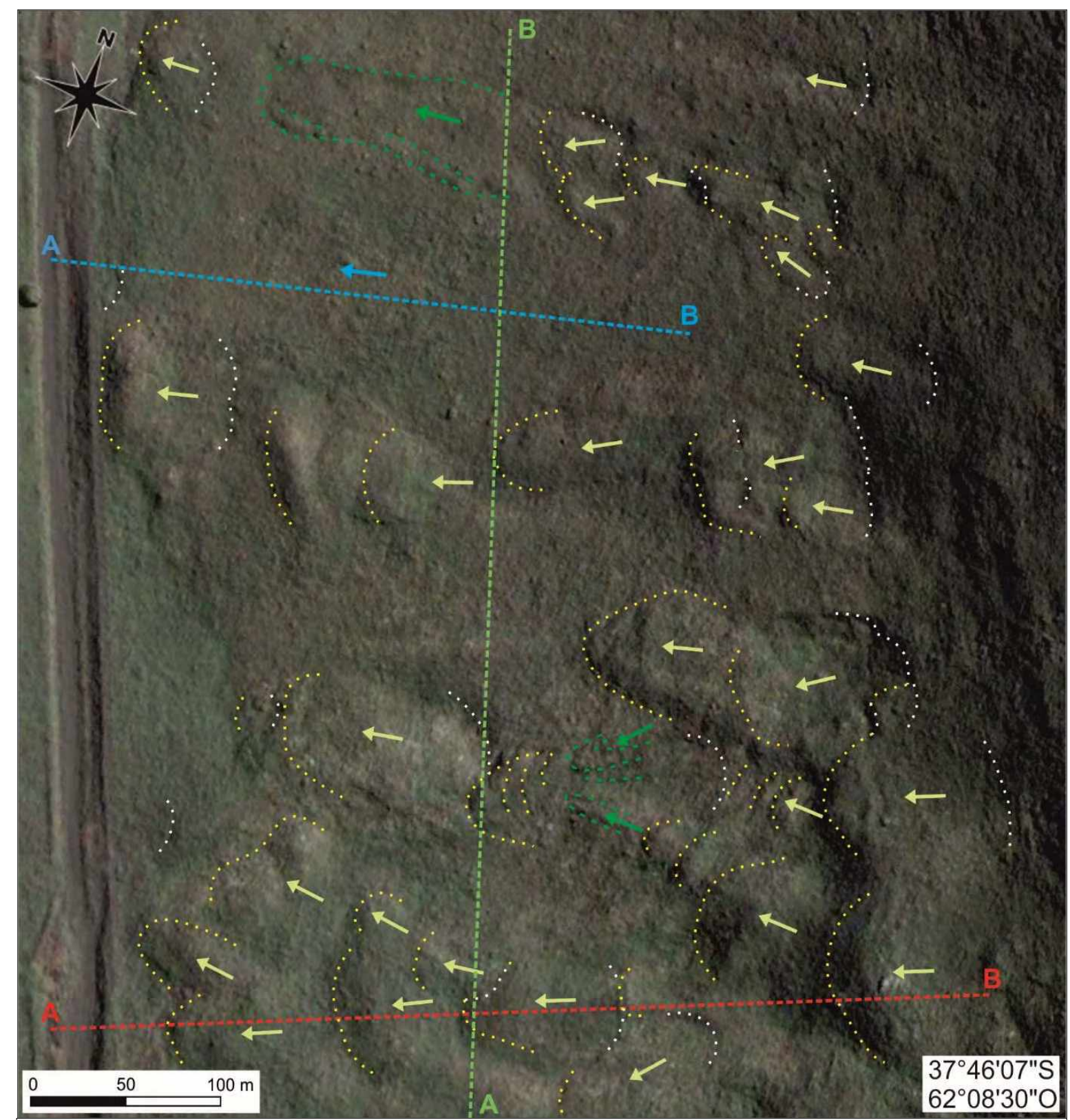

Figura 7.6. Topografía hummocky en Ladera de Detritos occidental de las sierras de Bravard (subzona 2). Las líneas de puntos representan deslizamientos con sus escarpas (blanco) y sus acumulaciones (amarillo); no siempre se conservan ambos elementos, y a veces unos rasgos afectan a otros. Flechas amarillas: dirección del movimiento. Las líneas de puntos y flechas verdes indican movimientos con una componente de flujo. Las trazas A-B corresponden a los perfiles de la Figura 7.7. Flecha celeste: dirección del escurrimiento superficial en terreno no afectado por movimientos en masa. Componentes de la imagen: composición de imagen satelital World View-2 (Google Earth) y mapa de sombras obtenido a partir de un MDE generado mediante procesamiento fotogramétrico de imágenes capturadas con un dron en una de las campañas. Elaboración propia. 


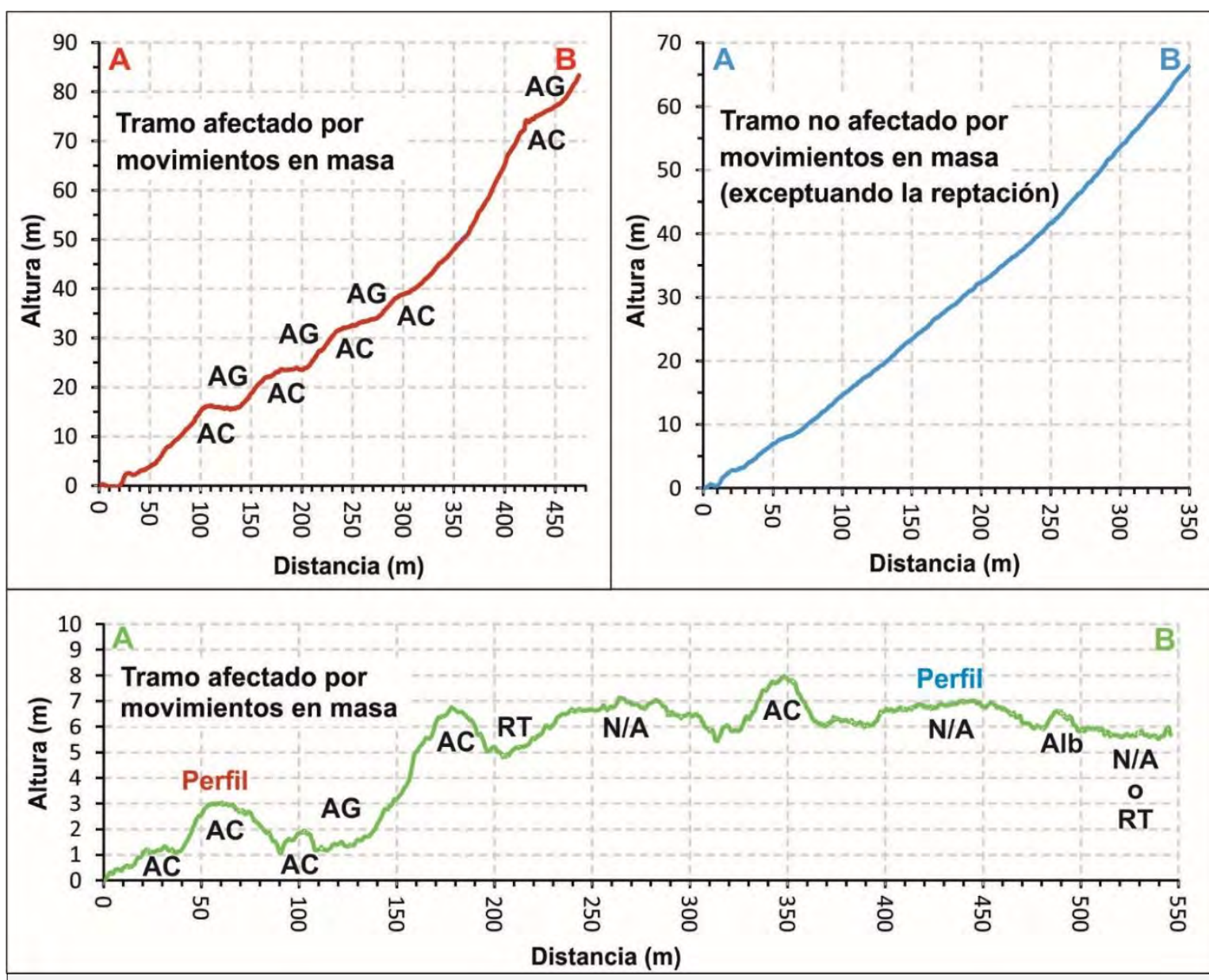

Figura 7.7. Perfiles de la ladera de la Figura 7.6, generados a partir de un MDE por procesamiento fotogramétrico de imágenes capturadas en el campo con un dron. AC: zona de acumulación de movimientos en masa. AG: zona de hundimiento de movimientos. Alb: albardón menor de flujo de detritos. N/A: terreno no afectado por movimientos (exceptuando la reptación). RT: superficie de ruptura de movimientos. Exageración vertical: 5 (perfiles de arriba) y 10 (perfil de abajo). Elaboración propia.

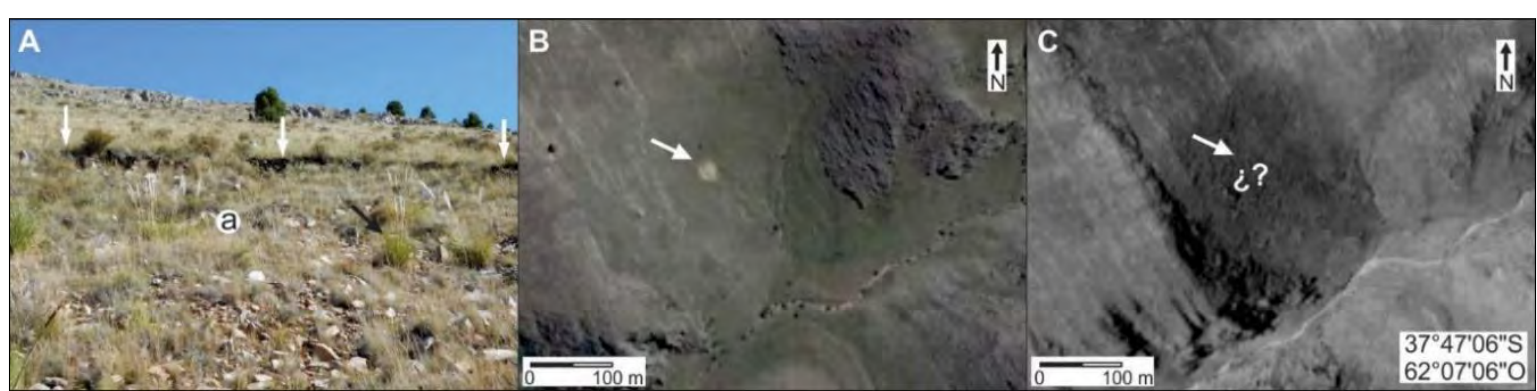

Figura 7.8. "Cicatrices" de un deslizamiento traslacional en un valle intraserrano de las sierras de Bravard (subzona 2). A. Fotografía de campo (19/04/2016). Flechas blancas: escarpa. a: superficie de ruptura. Las colas de zorro (flecha negra) sirven como escala, miden unos $2 \mathrm{~m}$ de altura. B. Imagen de World View-2, servidor Google Earth (26/02/2016). Flecha: superficie de ruptura contrastante con el entorno. Nótese el aspecto "fresco" del rasgo. C. Fotografía aérea (12/01/1981). Flecha: el movimiento aún no se había producido. Modificado de Susena y Gentile (2017). 
Movimientos en masa en las sierras de Bravard y Curamalal,

Sierras Australes de la Provincia de Buenos Aires.

Juan Manuel Susena

La presencia de dos (a veces una) acumulaciones lineales paralelas a la pendiente, que delimitan entre sí una zona de hundimiento son evidencias del desarrollo de flujos de detritos o flujos deslizantes (Figura 7.9).

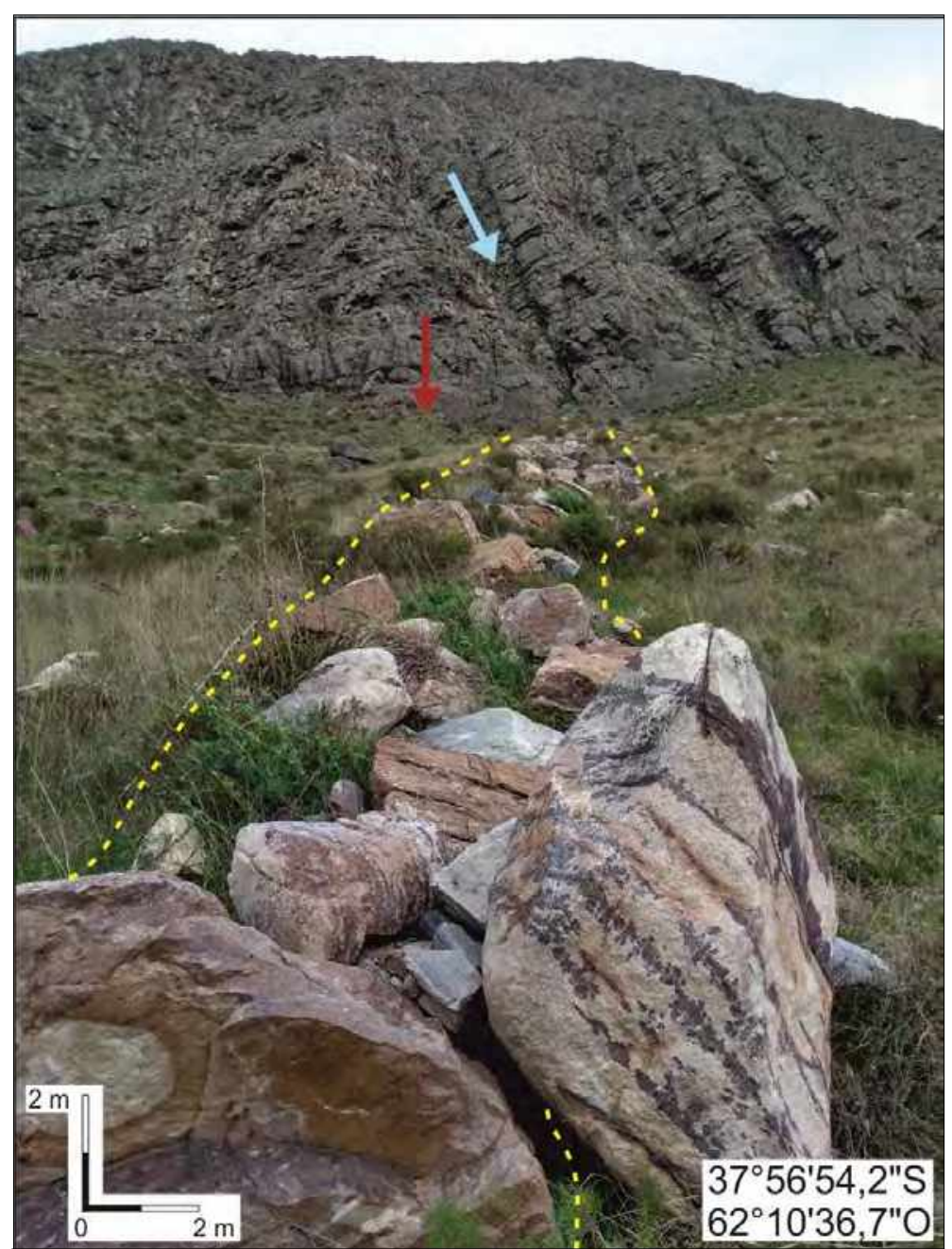

Figura 7.9. Albardón (línea de trazos) de flujo de detritos o flujo deslizante en Ladera de Detritos del cerro Pan de Azúcar. Flecha celeste: Garganta en Discontinuidad Rocosa encauzando el escurrimiento superficial. Flecha roja: zona de hundimiento al pie de la garganta. La escala se ajusta al centro de la imagen. Foto: Juan M. Susena y Lautaro De Luca.

\subsubsection{Indicadores de otros tipos de movimientos}

\section{Discontinuidades producidas en superficies verticales en materiales no} consolidados: tanto en barrancas de cursos de agua como en cortes de caminos, frecuentemente la presencia de concavidades interrumpe la continuidad longitudinal de las paredes. Ocasionalmente la morfología puede ser rectilínea, similar a corchetes vistos en planta. Estas discontinuidades suelen denotar procesos erosivos a su pie, como pipping y socavamiento basal por erosión hídrica. Dicha morfología indica movimientos de suelo, 
donde la resistencia mecánica del material es relativamente homogénea. Tal es el caso de los depósitos de materiales eólicos a los lados de los caminos, originados por acumulación eólica o por obras viales. Estas concavidades pueden superar los $2 \mathrm{~m}$ de altura y sus altas pendientes propician el lavaje y el desarrollo de nuevos movimientos (Figura 7.10). La ausencia de los materiales al pie de las concavidades se debe a fundamentalmente a la erosión hídrica en cunetas o cursos de agua. Como se verá más adelante en esta tesis, estas formas pueden ser importantes en el modelado de los cursos de agua.

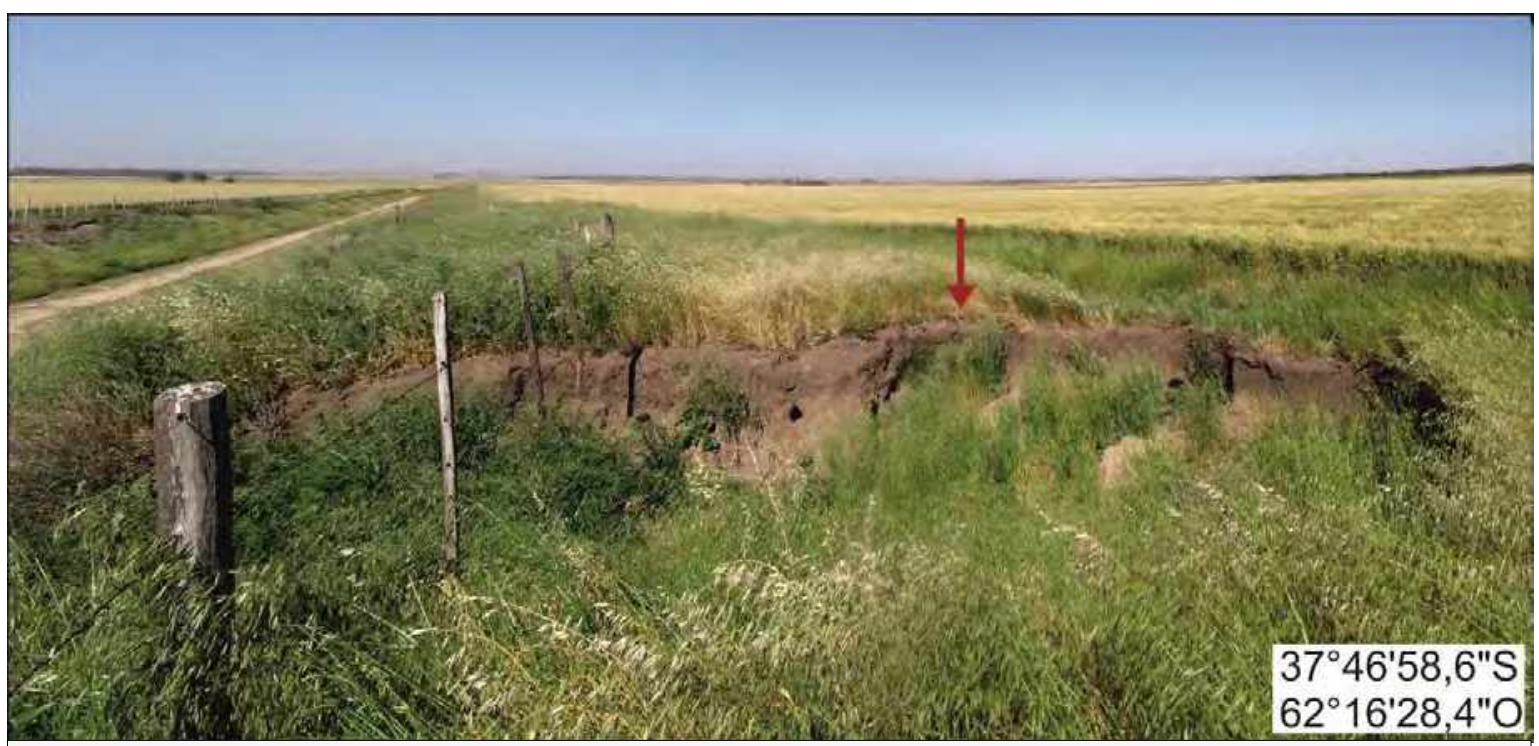

Figura 7.10. Deslizamiento de suelo aledaño a un camino, afectando depósitos eólicos en el piedemonte occidental de las sierras de Curamalal. La superficie de ruptura se ubica aproximadamente $1,5 \mathrm{~m}$ por debajo del alambrado. Flecha roja: nuevo movimiento a partir de la escarpa. El alambrado sirve como escala. Foto: Juan M. Susena.

Modificaciones observadas en la distribución y morfología de la vegetación: en el caso de la vegetación arbórea, la curvatura de troncos puede indicar reptación del suelo. Esto es evidente tanto en árboles aislados como en bosques desarrollados en Laderas de Detritos; no todos los árboles en los bosques muestran este patrón, pudiendo indicar que los efectos de la reptación son más evidentes en ciertas especies, o que se produce especialmente en sitios con mayor contenido de humedad o mayor pendiente. En algunos casos, la curvatura de los árboles puede indicar la recuperación del árbol luego del impacto de alguna roca caída que lo torció. Este criterio es especialmente útil en especies tolerantes a la sombra, ya que los árboles intolerantes a condiciones sombrías desarrollan curvatura por heliotropismo, caso en el cual deben encontrarse evidencias adicionales para asociar la curvatura (o una componente de ella) a la reptación (Harker, 1996). De acuerdo con este autor, la presencia de curvaturas muy marcadas en la base de los árboles indicaría un disturbio cuando el árbol era muy joven, tal como el impacto de una roca (Figura 7.11). Asimismo, la presencia de cicatrices y quebraduras en los troncos podría deberse al impacto de bloques rocosos (Figura 7.12). 


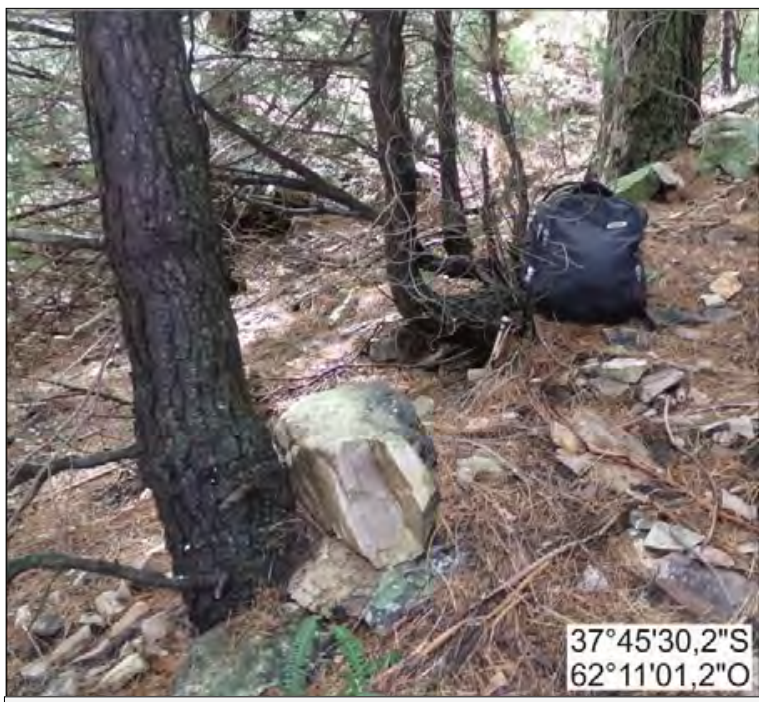

Figura 7.11. Árboles afectados por caídas en un cono de detritos de un valle intraserrano en la vertiente oriental del Cdón. Lehmann. La curvatura en la base del árbol de atrás (donde está la mochila) indica que probablemente sufrió un impacto cuando era muy joven. La mochila sirve como escala. Foto: Juan M. Susena.

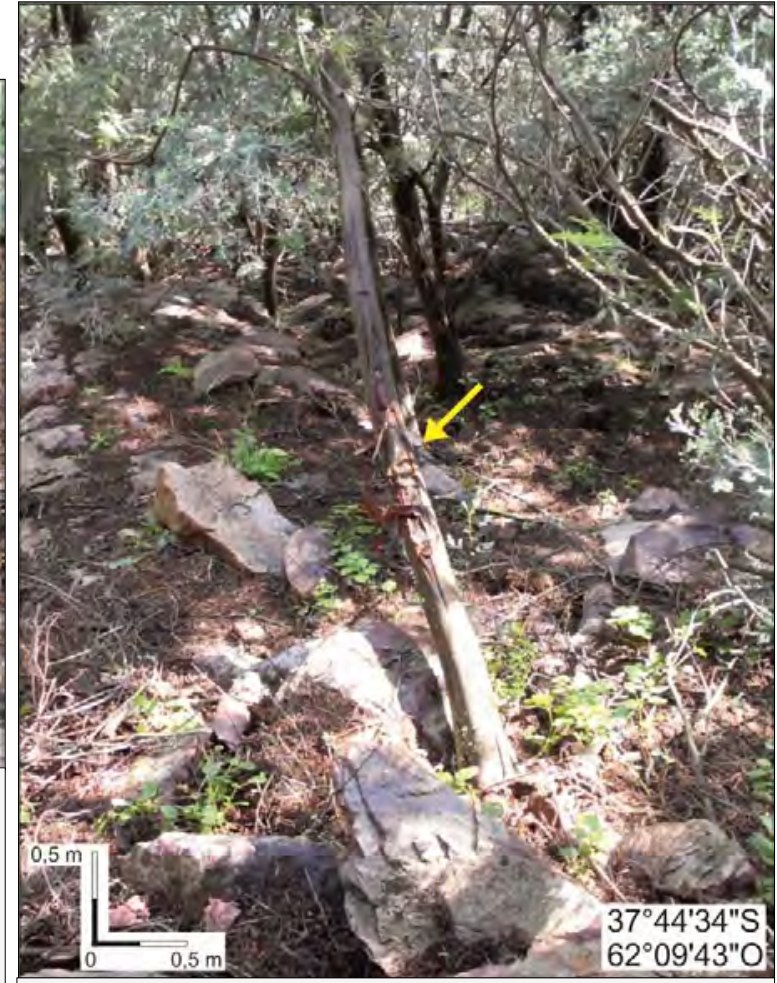

Figura 7.12. Árbol dañado por el impacto de una roca en una Ladera de Detritos occidental de las sierras de Bravard. Flecha: cicatriz del impacto, nótese el carácter reciente. Foto: Juan $M$. Susena.

\subsection{Actividad de los movimientos: criterios utilizados como indicadores de edad relativa}

La escasez de recursos que permitan hacer dataciones absolutas de los movimientos en masa del área de estudio amerita recurrir a indicadores de edad relativa. A continuación, se enumerarán los diferentes elementos que se utilizaron con tal fin. Aunque algunos de estos elementos se volverán a mencionar en otros contextos, una presentación ordenada de los mismos resulta útil desde la perspectiva metodológica, puesto que los criterios a los que se asocian se usaron constantemente, tanto en el trabajo de campo como de gabinete. Los indicadores serán aquí clasificados como indicadores de antigüedad e indicadores de juventud; los conceptos de juventud y antigüedad son relativos, es decir, no todos los indicadores son estrictamente aplicables al estado de la actividad tal y como está explicado en el Capítulo 1 Introducción al objeto de estudio: un movimiento activo es aquel que se ha movido en el último o los últimos años. Reactivaciones posteriores pueden contribuir al mantenimiento de las características juveniles, aunque la etapa principal se haya producido 
hace mucho tiempo (Bell et al., 2012). Se hará mención en cada caso, del potencial interpretativo de cada indicador, y los recaudos necesarios para su correcta interpretación.

\subsubsection{Indicadores de antigüedad}

Vegetación muerta: si bien los árboles no son comunes en el área de estudio, ya que los pocos bosques de las laderas fueron plantados, se encontraron árboles caídos aislados, muertos y parcialmente enterrados, en zonas de hundimiento de movimientos en masa (Figura 7.13). En cursos de agua, algunos bloques de suelo caídos presentan la vegetación muerta (principalmente pastizal), no indica tanta antigüedad como en el caso de los árboles, pero, teniendo en cuenta la dinámica de los arroyos, los cuales crecen y presentan nuevos movimientos tras las lluvias, puede considerarse un criterio de relativa antigüedad. Es importante comparar el estado de la vegetación del bloque caído con el de la vegetación de la superficie no afectada; en verano, en la superficie no afectada la vegetación también está seca, por lo cual la presencia de vegetación seca en un bloque caído en verano no indica necesariamente que haya caído hace mucho tiempo.

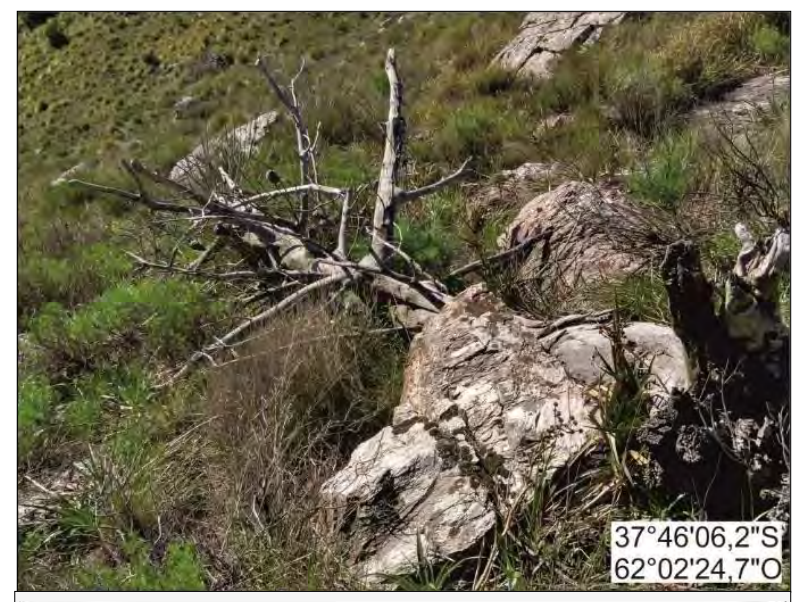

Figura 7.13. Pino destruido por un bloque rocoso en la zona de hundimiento de un deslizamiento, en una Ladera de Detritos de un valle intermontano aledaño al cerro Puntudo. Foto: Juan M. Susena.

Vegetación viva: el crecimiento de vegetación en superficies de ruptura es un criterio indicador de antigüedad de estas. Debe tenerse en cuenta en tal caso, el régimen hídrico local de cada superficie de ruptura, ya que, en los sectores con menor contenido de humedad, la vegetación crecerá más lento, no necesariamente indicando más antigüedad que donde hubiera más humedad (donde la vegetación crece más rápido). Para aplicar este criterio, por tanto, deben tenerse en cuenta los efectos de la humedad en la velocidad de crecimiento de la vegetación, que dependen de: la orientación de la ladera (no comparar laderas de solana con laderas de umbría), y la profundidad de la roca, de calcretas o de horizontes de suelo arcillosos que impidan o dificulten la infiltración, concentrando la humedad en superficie.

El crecimiento de árboles en acumulaciones de movimientos en masa es otro criterio que puede indicar la edad mínima del proceso (Figura 7.14). Como los árboles pueden ser 
Movimientos en masa en las sierras de Bravard y Curamalal,

Sierras Australes de la Provincia de Buenos Aires.

Juan Manuel Susena

desplazados junto con la masa, este criterio sólo se puede emplear en zonas de hundimiento, $\mathrm{o}$ en zonas de acumulación en caso de que el árbol no esté disturbado. A modo de comentario, la dendrocronología es una técnica empleada en la datación de movimientos en masa, donde el estudio de la morfología de los anillos de crecimiento de los árboles puede indicar la edad mínima del movimiento, si el árbol no fue afectado por el movimiento, o la edad exacta del movimiento, si el árbol fue afectado por el movimiento. Lamentablemente, no todas las especies

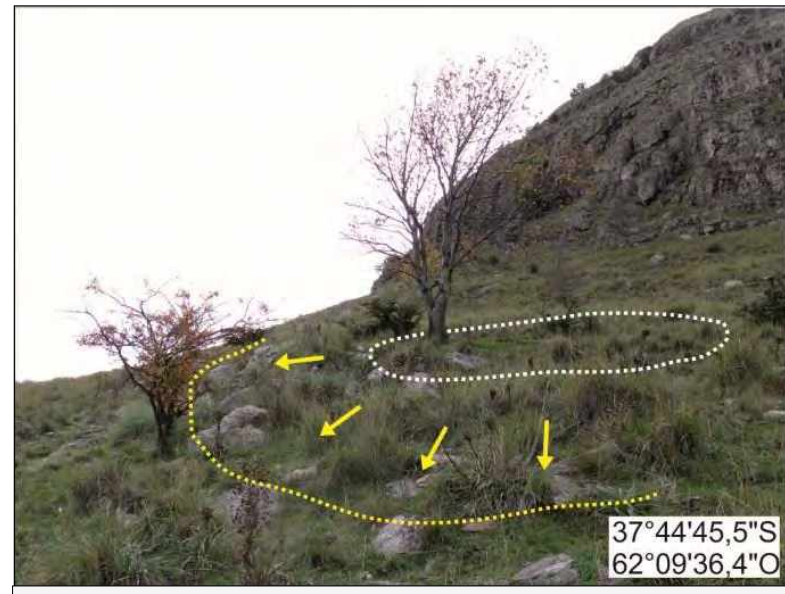

Figura 7.14. Árbol sobre la superficie de una acumulación antigua (línea de puntos blanca), en una Ladera de Detritos occidental de las sierras de Bravard. Línea de trazos amarilla (punta del deslizamiento). Flechas: dirección de la pendiente local. Foto: Juan M. Susena y Rodolfo O. Gentile. arbóreas pueden utilizarse, y es necesario primeramente construir una secuencia patrón de los anillos de crecimiento a partir de muestras de individuos no disturbados (no afectados por movimientos) con un rango de edades variado, para luego poder comparar cada individuo afectado por movimientos, con el patrón construido. En definitiva, hacen falta muchos árboles de la misma especie que desarrollen anillos de crecimiento, que tengan un rango variado de edades, y que se ubiquen tanto "dentro" como fuera de los movimientos, situación poco frecuente en el área de estudio. Por tanto, el criterio relativo subjetivo parece ser, al momento, más factible y expeditivo que la dendrocronología. No obstante, el crecimiento de bosques posibilitaría en el futuro aplicar esta técnica.

Desarrollo de colonias de líquenes: el desarrollo de colonias liquénicas requiere, en general, exposición a la atmósfera y a la luz solar, y tiempo, desde menos de 10 años hasta más de 100 años (Joshi et al., 2012 y trabajos allí citados). El desarrollo de colonias de líquenes crustáceos saxícolas y ocasionalmente terrícolas, pueden indicar una antigua exposición al aire de la superficie de la roca o del suelo, respectivamente. El aspecto antiguo que imprimen las colonias de líquenes debe ser observado como una característica del paisaje local para poder aplicarse como criterio, es decir, la inmensa mayoría de los detritos deben mostrar esta característica. Este criterio es especialmente aplicable a superficies de ruptura, donde se supone que el suelo y los bloques rocosos quedaron expuestos al producirse el movimiento en masa (Figura 7.15.A). Debe tenerse cuidado al observarse las zonas de acumulación, ya que los materiales pudieron estar expuestos con 
anterioridad al movimiento y las colonias podrían ser previas. En dichos casos, la punta del movimiento es el lugar ideal para constatar la antigüedad de la acumulación aplicando este criterio, ya que es el sector de la acumulación donde más disturbios tendrían los materiales, desenterrándose detritos previamente enterrados (Figura 7.15.B). A modo de comentario, la liquenometría, técnica que se ha difundido durante la segunda mitad del siglo XX (Noller y Locke, 2000), es utilizada para la datación relativa de movimientos en masa (Pánek, 2015), ya que provee información sobre la edad mínima de exposición de la superficie colonizada.

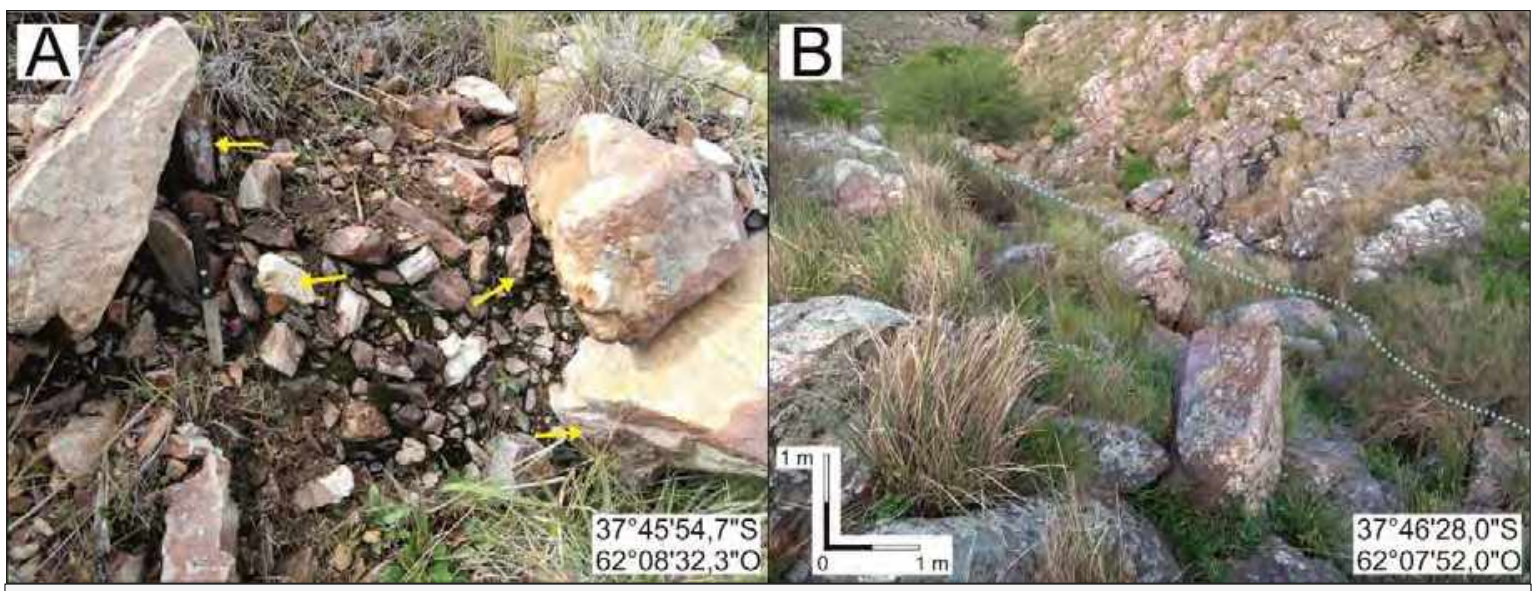

Figura 7.15. Colonias de líquenes en bloques rocosos en movimientos en masa en Laderas de Detritos de las sierras de Bravard. A. Desarrollo incipiente de líquenes en detritos (flechas amarillas) en la escarpa de un deslizamiento rotacional producido antes del 25/02/1967. El cuchillo sirve como escala. B. Líquenes en bloques rocosos de la punta de un deslizamiento traslacional disectado por un curso de agua (línea de puntos). Fotos: Juan M. Susena.

Lavaje de materiales finos: el lavaje de la matriz eólica de las laderas de detritos es un criterio útil para identificar antigüedad de los movimientos. Puede aplicarse en zonas de acumulación y superficies de ruptura de movimientos en Laderas de Detritos, por comparación del estado evolutivo del lavaje respecto a movimientos aledaños. En el caso de depósitos de flujos de detritos en valles, este criterio debe tomarse con cautela, considerando la posibilidad de no preexistencia de materiales finos (Figura 7.16). 


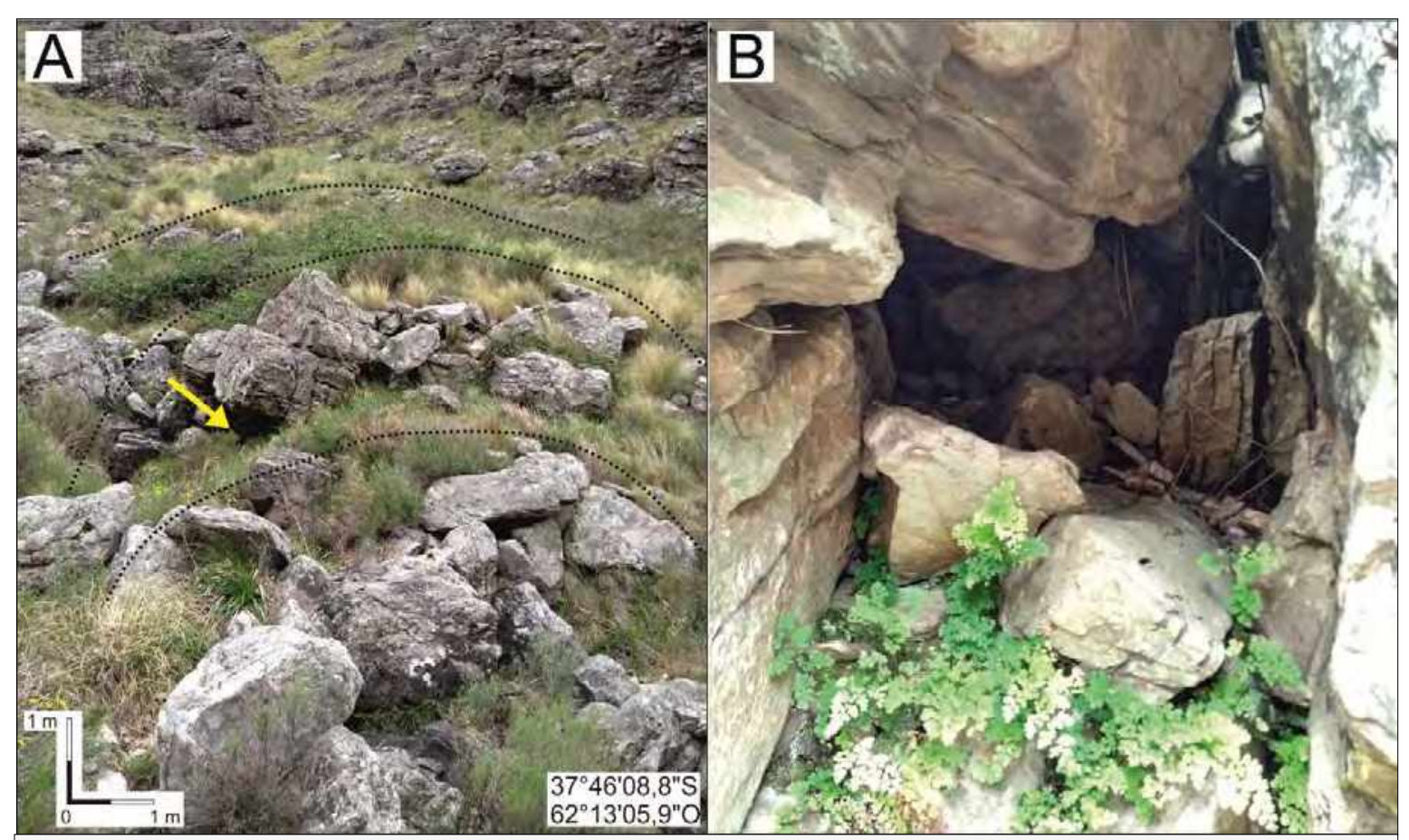

Figura 7.16. Lavaje de la matriz de un flujo de detritos en un valle intraserrano de las sierras de Curamalal. A. Punta de la acumulación. Las líneas de trazos refuerzan la morfología del rasgo. Nótese que algunos bloques aún están inmersos en la matriz. Flecha: sitio indicado en detalle en B, donde se observa ausencia local de la matriz. Fotos: Juan M. Susena.

Acumulación de materiales finos: existen casos en que la zona de hundimiento no tiene vías de escape del agua superficial, siendo una superficie cóncava que funciona como reservorio de los materiales finos procedentes del lavaje ladera arriba. En el campo puede verse en muchos casos que los detritos que integran el movimiento fueron parcial o completamente enterrados por estos materiales finos, denotando la relativa antigüedad del proceso (Figura 7.17). Estas superficies son identificables en imágenes satelitales debido a la presencia de una vegetación más verde (por un mayor contenido de humedad) que en la zona de acumulación o la superficie no afectada por el movimiento (véase Capítulo 11 Interacciones entre movimientos en masa y escurrimiento superficial/sub-superficial). 


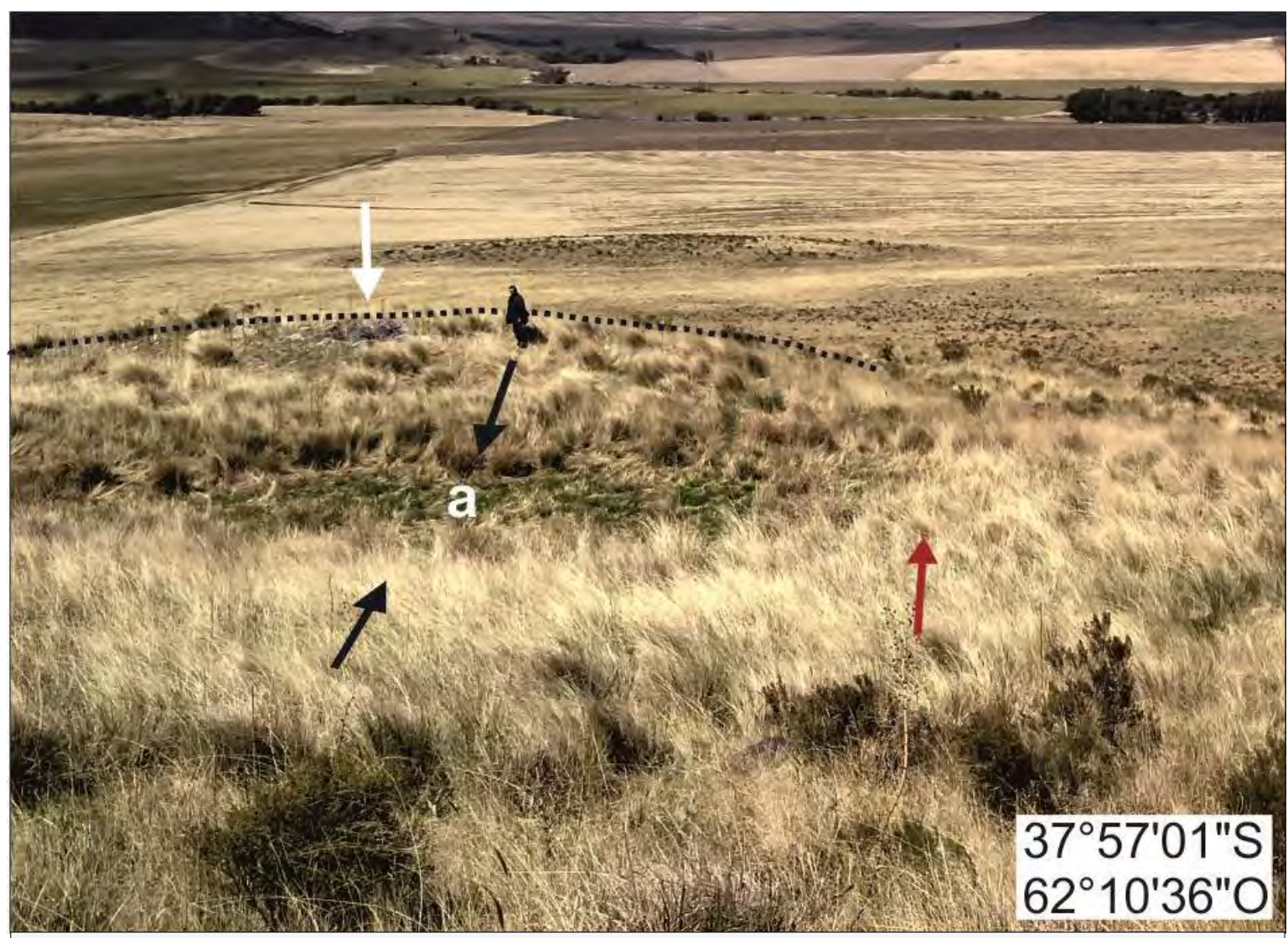

Figura 7.17. Acumulación de materiales finos en zona de hundimiento (sector con vegetación verde), ladera occidental del cerro Pan de Azúcar. Línea de trazos: refuerzo visual de la acumulación. Flecha blanca: detritos de la acumulación. En la zona de hundimiento (a) los detritos no se observan en superficie porque están sepultados bajo los materiales finos. Flechas negras: dirección de la pendiente local. Flecha roja: dirección general de la pendiente de la ladera. La persona sirve como escala. Foto: Juan M. Susena y Rodolfo O. Gentile.

Reactivaciones de movimientos en masa: las reactivaciones implican la multitemporalidad de la actividad de los movimientos en masa (véase Capítulo 1 Introducción al objeto de estudio), y por tanto una diferencia de edad entre un movimiento $\mathrm{A}$ y otro movimiento $B$. Este criterio es aplicable particularmente cuando la actividad tiene un estilo múltiple (parte o la totalidad del movimiento $A$ es afectado por el movimiento B). La presencia de $B$ en la zona de hundimiento, la escarpa o los flancos de $A$, significa que $A$ es más viejo que $B$ (Figura 7.18.A.). El hecho de que el movimiento $B$ sepulte parte o la totalidad de movimiento $A$, indica que $A$ es más antiguo que $B$ (Figura 7.18.A y B). El desarrollo de $B$ afectando la zona de acumulación de $A$ muestra la antigüedad de $A$ respecto a $B$ (Figura 7.18.B). 


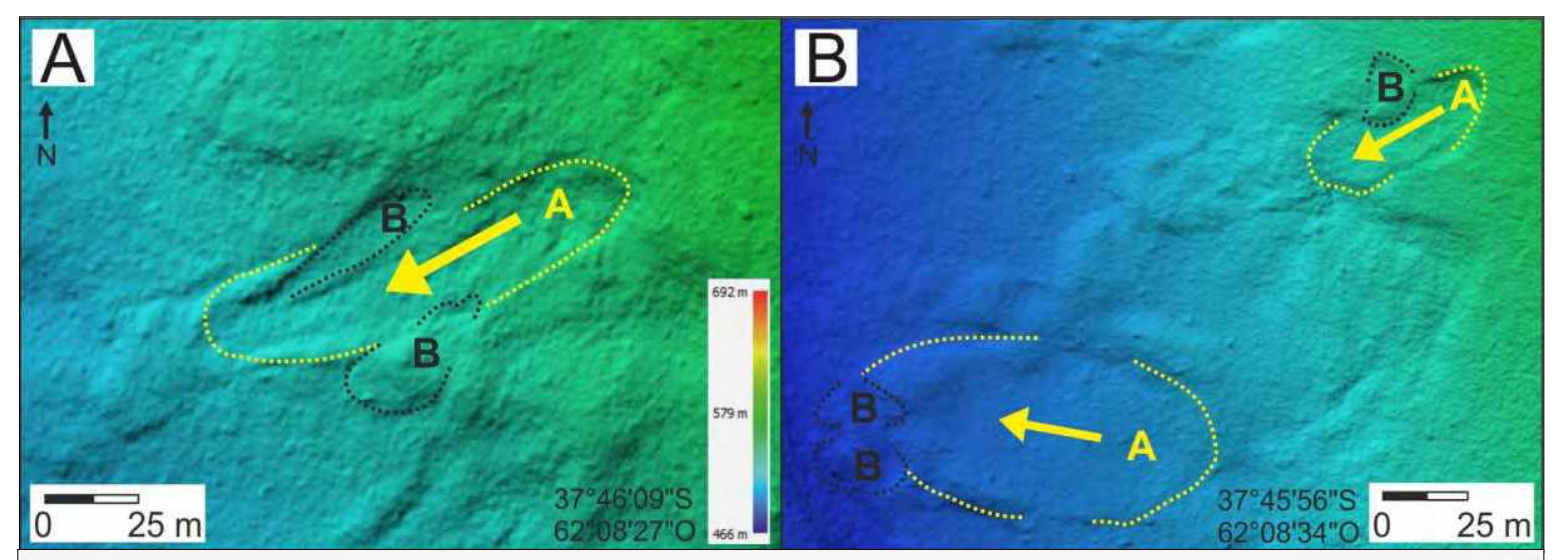

Figura 7.18. Reactivaciones en una ladera occidental de las sierras de Bravard. A: movimiento precedente. Flecha: dirección del movimiento. B: reactivaciones. Las líneas de trazos refuerzan la visualización. En la Figura $A$ el movimiento $B$ afecta los flancos del movimiento A (reactivación lateral o ensanchante). En la Figura B se presentan dos situaciones: al noreste, el movimiento $B$ sepulta parte de la zona de hundimiento del movimiento A (reactivación lateral); al suroeste, los movimientos $B$ afectan la acumulación del movimiento $A$ (reactivación progresiva). Las imágenes son la superposición de un MDE generado por procesamiento fotogramétrico de imágenes capturadas con un dron en una de las campañas de campo. Elaboración propia.

Incisión fluvial: el desarrollo de un sistema de drenaje en torno a un movimiento en masa puede ser un criterio que denota antigüedad. La ocurrencia de un movimiento en masa en una ladera implica modificaciones en el movimiento del agua superficial, debido a la aparición de curvaturas cóncavas y convexas locales, produciendo aceleración y desaceleración, y concentración o dispersión del escurrimiento superficial, además de modificar el sistema de drenaje encauzado previo al movimiento. La incisión fluvial de las laderas, y su conexión con cuerpos de agua en zonas de hundimiento, puede indicar una mayor antigüedad. Varios autores relacionaron el estado evolutivo de este conjunto de rasgos con la edad relativa de los movimientos en masa, estimando que aquellos adquirirían una morfología identificable al cabo de al menos 100 años después de la ocurrencia del movimiento (McCalpin, 1984; Keaton y DeGraff, 1996; Bell et al., 2012), si bien este dato puede ser variable. Este tipo de interacciones entre la acción del agua y los movimientos en masa se trata en el Capítulo 11 Interacciones entre movimientos en masa y escurrimiento superficial/sub-superficial.

Degradación de la forma de las acumulaciones: las acumulaciones producidas por movimientos en masa pierden su expresión morfológica a medida que son afectadas por diferentes procesos. Esto se debe en gran medida a que constituyen un elemento de relieve positivo, y sus bordes tienen pendientes superiores a las de su entorno, aumentando la inestabilidad y la susceptibilidad a la erosión hídrica. La pérdida de expresión morfológica puede utilizarse como un indicador de edad relativa de los movimientos. El concepto de 
persistencia (Crozier, 2010) hace alusión al tiempo durante el cual las características morfológicas de un movimiento en masa son reconocibles en el terreno. Guthrie y Evans (2007) establecieron un tiempo de persistencia de entre 10 y 200 años para deslizamientos y flujos de detritos en la región de la Columbia Británica. Este dato no es aplicable al área de esta tesis, dado que estos autores analizaron movimientos de sectores con más de 2000 $\mathrm{mm}$ de precipitación anual, mientras que en el área de esta tesis caen unos $900 \mathrm{~mm}$, siendo mucho más lenta la erosión de las formas. El grado de degradación como indicador de edad relativa es un concepto que debe extrapolarse con cuidado; debe tenerse en cuenta que los procesos de degradación pueden actuar con distinta intensidad según el contexto morfoclimático, el relieve local, y, como mencionaran Bell et al. (2012), "de movimiento a movimiento (from landslide to landslide)".

Entre los procesos de degradación de acumulaciones, pueden mencionarse el lavaje de los materiales finos de la matriz y la consecuente liberación y caídas de bloques; la incisión fluvial de los bordes de las lomadas en estadios más avanzados; la incisión basal por concentraciones del escurrimiento superficial; el desarrollo de terracettes, deslizamientos y flujos (reactivaciones progresivas). Los procesos de degradación asociados a la actividad del agua se describen en detalle en el Capítulo 11 Interacciones entre movimientos en masa y escurrimiento superficial/sub-superficial.

Meteorización de detritos movilizados: ciertas formas de meteorización en detritos indican estabilidad de la superficie sobre la que se apoyan. Por lo tanto, si se encuentra un conjunto de detritos meteorizados en acumulaciones $u$ otras partes de movimientos en masa, estos rasgos indicarían antigüedad del movimiento. Entre los procesos que alteran los detritos pueden desarrollarse gnammas, meteorización catafilar y lajamiento (Figura 7.19). Cabe destacar que los gnammas deben ser encontrados en posiciones coherentes con su génesis, es decir, deben estar nivelados en el plano horizontal. En caso contrario, los rasgos se habrían generado antes del último movimiento.

Degradación de escarpas de movimientos en masa: las escarpas de deslizamientos, tanto rotacionales como traslacionales, suelen encontrarse enmascaradas y/o degradadas por diferentes procesos. Una característica común en las laderas de detritos del área, sobre todo en las de umbría, es que las escarpas y superficies de ruptura tienen un gran contenido de humedad, al punto que pueden desarrollarse pequeños manantiales. Esta situación favorece en primer lugar el crecimiento de vegetación herbácea, y en segundo término la conformación de pequeños deslizamientos rotacionales o terracettes, que en conjunto enmascaran en las imágenes satelitales el color característico que presentan las 


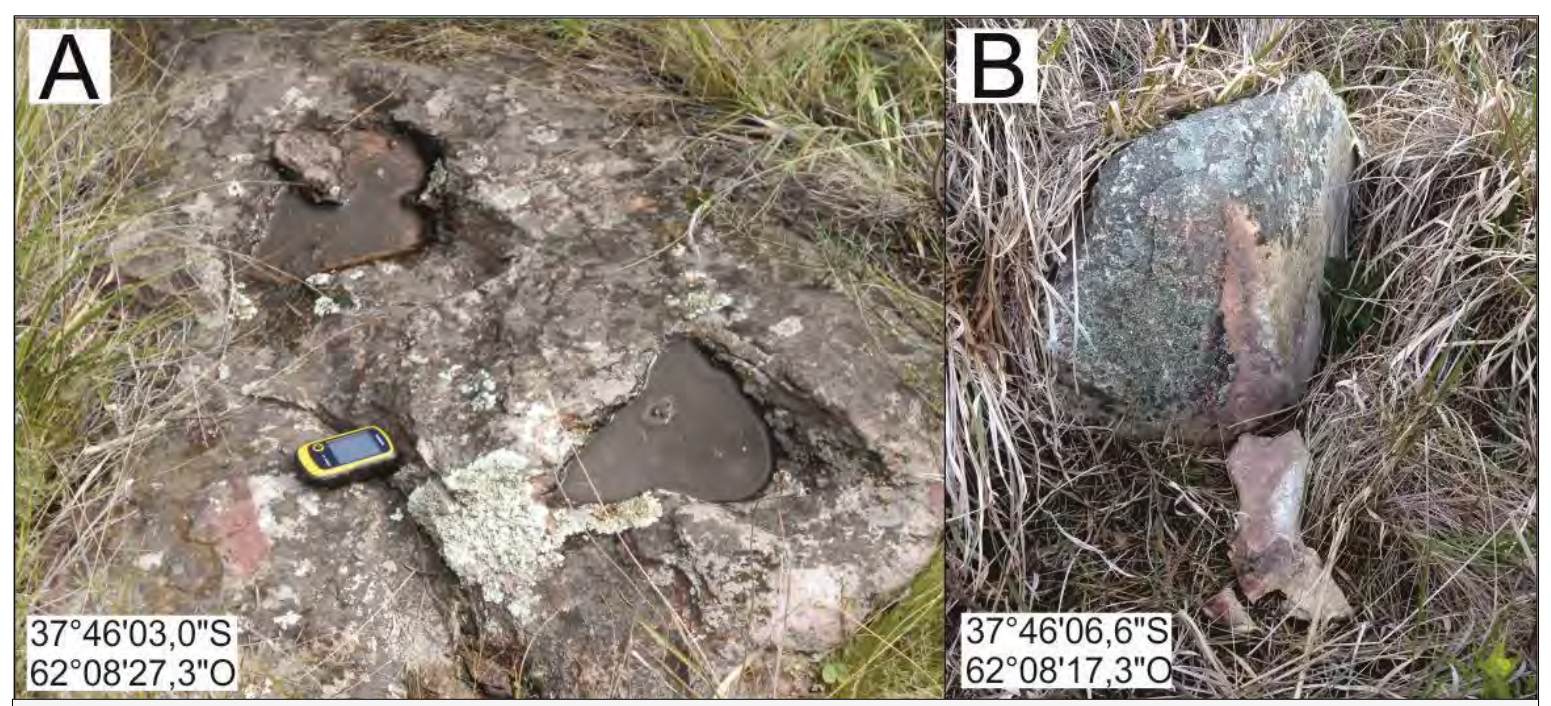

Figura 7.19. Meteorización de detritos asociados a movimientos en masa. A. Gnammas en bloque integrante de la acumulación de un deslizamiento. El GPS sirve como escala. B. Lajamiento de un detrito en un cono de talud. La laja mide unos $10 \mathrm{~cm}$. Fotos: Juan M. Susena.

cicatrices (= escarpas) frescas. Otra de las razones de la pérdida de expresión morfológica de las cicatrices consiste en el aporte de material eólico, que puede cubrir parcialmente la superficie de ruptura. La condición necesaria para que esta situación tenga lugar, consiste en que las tasas de aporte de dicho material deben superar a las tasas de erosión que pudieran experimentar las escarpas. Particularmente el último episodio de depositación eólica intensa corresponde al Holoceno superior, y posiblemente, en menor medida, a la Pequeña Edad del Hielo (800-200 años antes del presente, según Maenza y Compagnucci, 2010), representado por la Fm. Saavedra (véase Capítulo 5 Geología: generalidades). Al respecto, Figueroa (1968) y Pereyra (1996b) mencionan la posibilidad de que muchos movimientos en masa en las Sierras Australes se hayan producido en el pasado con climas diferentes al actual, basándose en la presencia de zonas similares a "nichos de nivación", o a la morfología y fábrica de los depósitos con calcretas. En el caso contrario al mencionado, cuando las tasas de erosión superan a las de acumulación de material eólico (como ocurre en la actualidad), la pérdida de la matriz del depósito conduce a la destrucción de la escarpa por caídas o vuelcos de los bloques o clastos mayores, acumulándose al pie. Así, el material grueso que conforma la escarpa también se va perdiendo, y una parte de la misma queda cubierta, reduciendo sus dimensiones reales y su expresión morfológica.

\subsubsection{Indicadores de juventud}

Vegetación con disposición extraña y signos de daños recientes: en el caso de caídas y vuelcos de suelo, puede encontrarse vegetación viva en superficies con inclinaciones extrañas, correspondientes a la superficie original del terreno (Figura 7.20). Si el 
movimiento se hubiera desarrollado hace mucho tiempo, la vegetación debería haber muerto, o en todo caso desarrollarse nueva vegetación en la superficie estable. Esto es particularmente reconocible en cursos de agua, donde la vegetación de tipo pastizal crece en las superficies cenitales de las planicies de inundación, aunque también puede encontrarse en bloques caídos a partir de escarpas de deslizamientos en Laderas de Detritos y Bajadas Coluviales Finas.

Cuando se producen caídas de rocas, los

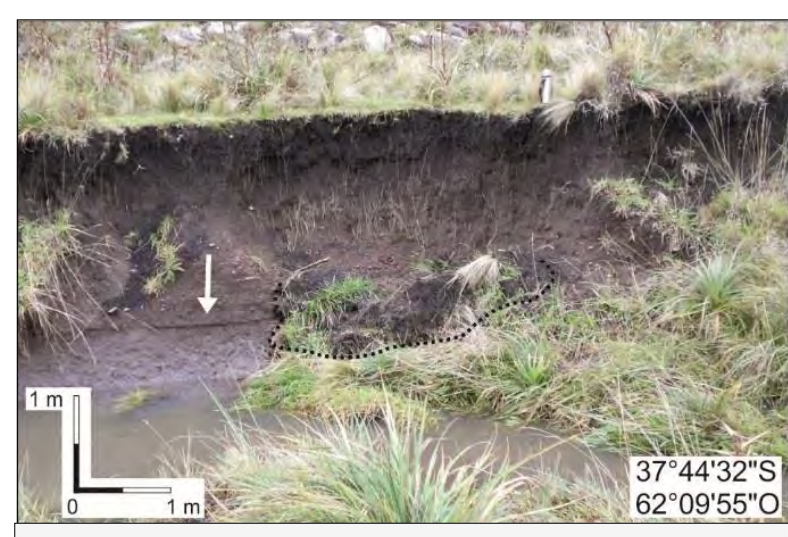

Figura 7.20. Caída de suelo (línea de puntos) y vegetación con disposición extraña en margen derecha de un curso de agua en el Valle de las Grutas. Flecha: marca erosiva de la crecida del día anterior a la toma de la foto; nótese que el suelo caído sepulta la marca. Foto: Juan M. Susena.

bloques pueden impactar árboles, quebrándolos o dejando marcas en los troncos (Figura 7.12). El estado "fresco" de estas heridas indica juventud de las caídas (Susena y Gentile, 2017). En varios casos se encuentra vegetación sepultada por bloques; cuando está viva, o muerta pero aún no degradada, indicaría juventud del movimiento. Debe prestarse atención a que la vegetación esté completamente sepultada, ya que en bloques con oquedades abiertas a la luz las gramíneas pueden sobrevivir y seguir creciendo, o crecer gramíneas nuevas, aunque el bloque haya caído hace mucho tiempo.

Ausencia de vegetación: puesto que en un deslizamiento existe una superficie definida sobre la cual se produce el movimiento de materiales, al desplazarse la masa que yacía sobre dicha superficie, una parte de ésta queda expuesta en el terreno y, por consiguiente, se la observa como una superficie "fresca", esto es, carente de vegetación (Figura 7.21); si además estuviera integrada por clastos, los últimos carecerían de cortezas de líquenes. 


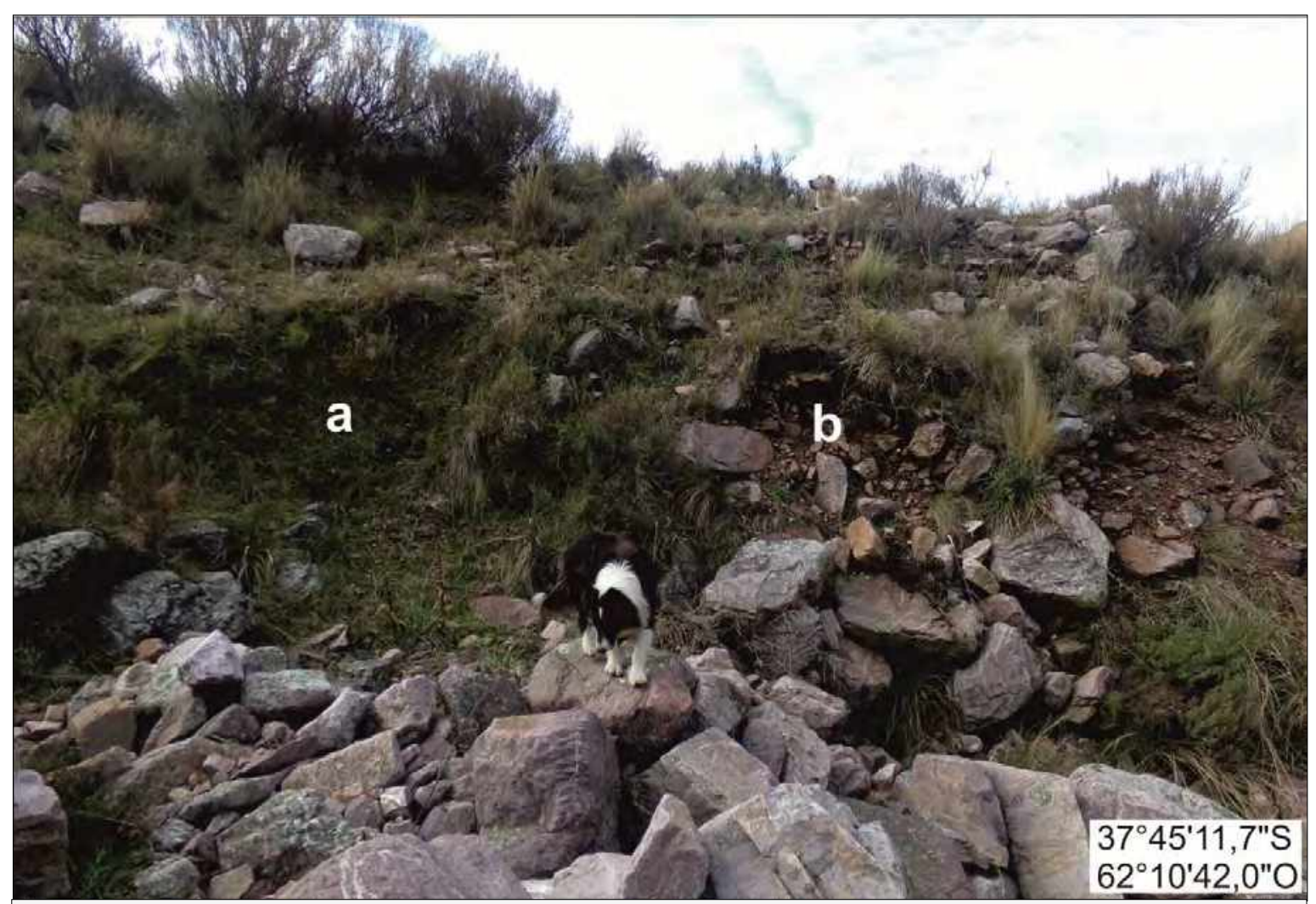

Figura 7.21. Reactivación de deslizamientos afectando Piedemonte Aluvial Moderno Inactivo Indiferenciado en un valle intraserrano de la vertiente oriental del Cdón. Lehmann. Nótese el contraste entre el movimiento antiguo con presencia de vegetación (a), y el nuevo, sin vegetación (b). El perro sirve como escala. Foto: Juan M. Susena.

Ausencia y disposición extraña de colonias liquénicas: en varios casos se encontraron colonias de líquenes en detritos, particularmente en las caras que se apoyan sobre el suelo. Adicionalmente, las caras que miran hacia el sol carecen de colonias. Esto significa que los detritos fueron volteados hace poco tiempo, ya que no se alcanzaron a desarrollar colonias en las caras cenitales (Figura 7.22). En sectores con presencia de volteo por acción de animales, el movimiento puede propagarse por acción de la gravedad mediante rebotes y/o rodaduras, convirtiéndose en verdaderas caídas.

La presencia de detritos carentes de líquenes en un entorno "antiguo", dominado por detritos con líquenes, puede indicar el movimiento de dicho

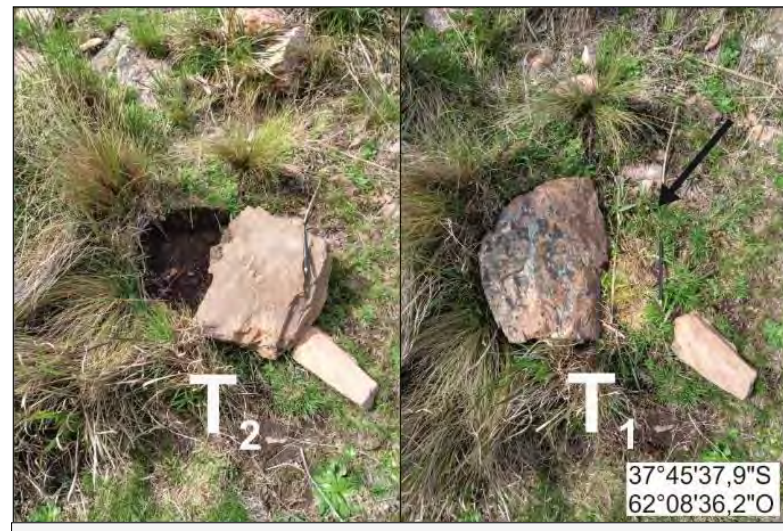

Figura 7.22. Bloque volteado en una ladera en el abra del arroyo Hinojo Grande. $T_{2}$ : posición en que se encontró el bloque. $\mathrm{T}_{1}$ : posición previa inferida. Nótese que las colonias de líquenes estaban hacia abajo. Flecha: vegetación aún viva, indicando que el volteo ocurrió poco tiempo antes de la toma de la foto. Modificado de Susena y Gentile (2019). 
detrito dentro del entorno, o que proviene de otro lugar. En el primer caso, basta con voltear el detrito y observar si tiene líquenes en la disposición explicada en el párrafo anterior. Si el detrito careciera de líquenes, debe observarse la zona topográficamente superior, para comprobar que llegó a su lugar debido a una caída.

Morfologías en desequilibrio con el drenaje superficial: los movimientos de tipo deslizamiento y flujo, especialmente en laderas, afectan la distribución del escurrimiento superficial. El desarrollo de cuerpos de agua locales desconectados del resto de la ladera, y pequeños canalículos no integrados con la red de drenaje de las Fajas Aluviales e Incisiones Fluviales, denotan la juventud de la topografía que concentra el agua, y por consiguiente, de los movimientos que originaron esa topografía. El criterio es el mismo que el de las incisiones fluviales: la ausencia de una morfología que indique cierta integración con el sistema de drenaje superficial de las laderas podría indicar una edad de menos de 100 años para los movimientos (McCalpin, 1984; Keaton y DeGraff, 1996; Bell et al., 2012). Asimismo, los depósitos producto de movimientos en masa que alcanzan cursos de agua pueden permanecer cierto tiempo antes de ser completamente erosionados por acción fluvial. Debe tenerse en cuenta que los tiempos de permanencia son diferentes tratándose de los materiales desplazados, siendo mayores para deslizamientos o flujos de detritos que para movimientos de suelo. Este tema se trata con más detalle en el Capítulo 11 Interacciones entre movimientos en masa y escurrimiento superficial/sub-superficial.

Todos estos criterios de actividad se aplicaron para diferenciar dos grandes grupos de movimientos, respecto a su actividad: movimientos jóvenes y movimientos antiguos. Dicha clasificación se aplicó al inventario de movimientos en masa (ver Anexo). Estos criterios se aplicaron también para reconocer relativamente la antigüedad de otros rasgos del paisaje, en especial de las laderas (ver Capítulo 13 Causas de los movimientos en masa). Los criterios aquí presentados podrían además utilizarse en otras zonas, para establecer clasificaciones similares. En ausencia de dataciones absolutas, éste es el esquema de clasificaciones que pudo obtenerse. Dataciones futuras podrían servir para crear clases de rangos temporales bien delimitados. 
Movimientos en masa en las sierras de Bravard y Curamalal, Sierras Australes de la Provincia de Buenos Aires.

Juan Manuel Susena 


\section{Capítulo 8}

\section{Movimientos en masa desde frentes escarpados rocosos}

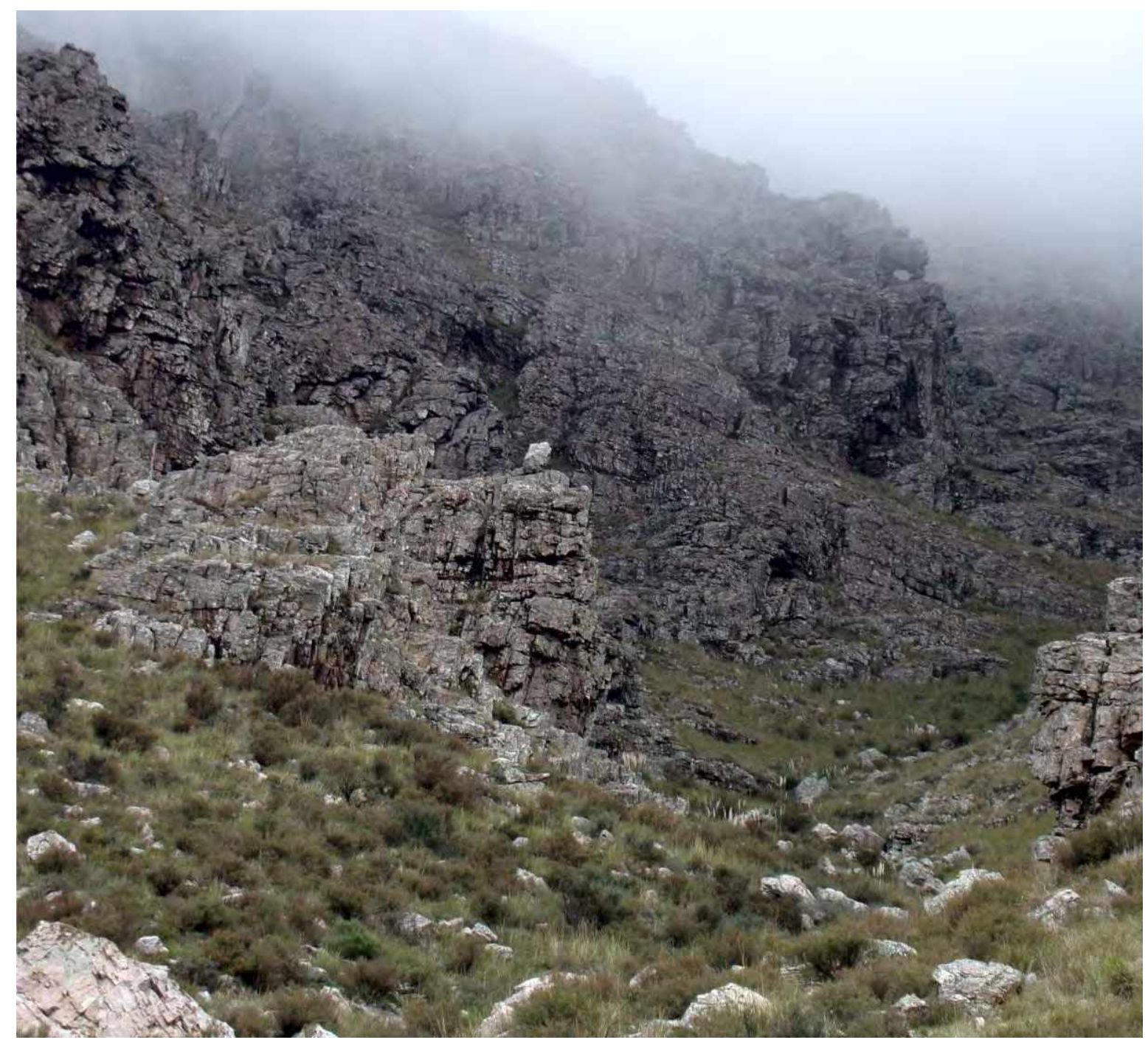

"El vigía de piedra"

El bloque rocoso yace sobre el remanente de un frente escarpado rocoso, firme contra todo pronóstico, como si se le hubiese ordenado vigilar el valle intraserrano.

Foto tomada en la Estancia Las Grutas durante una de las campañas. 
Movimientos en masa en las sierras de Bravard y Curamalal, Sierras Australes de la Provincia de Buenos Aires.

Juan Manuel Susena 


\subsection{Objeto de estudio y ordenamiento del capítulo}

Se tratan en este capítulo los movimientos desarrollados a partir de frentes escarpados rocosos. Los frentes escarpados rocosos merecen un tratamiento particular, puesto que son los componentes geomorfológicos más evidentes de la actividad de movimientos en masa principalmente de tipo caídas/vuelcos de rocas. Además, de su destrucción proviene gran parte de los materiales que integran las laderas, esencialmente el esqueleto de los depósitos (véase Capítulo 5 Geología: generalidades). En este sentido, la existencia presente o pretérita de estos frentes como zonas de aporte de materiales a las laderas es determinante en el desarrollo de unidades geomorfológicas adyacentes topográficamente por debajo, como lo son las Laderas de Detritos y el Piedemonte Coluvial Antiguo, y condiciona en parte los tipos de movimientos que en ellas se desarrollan.

La primera mitad del capítulo versa sobre los frentes escarpados rocosos, contemplando aspectos principalmente geomorfológicos y los factores que controlan su desarrollo y morfología, para comprender la ocurrencia de los movimientos en masa según las características de los frentes. La segunda parte trata en concreto a los movimientos en masa. Se caracterizan los tipos cinemáticos desarrollados, su morfología y estilo de actividad. Se concluye el capítulo con consideraciones prácticas relacionadas con el riesgo por estos tipos de movimientos y su detección.

\subsection{Frentes escarpados rocosos}

Como se explicara en el Capítulo 6 Geomorfología general del área, los frentes escarpados rocosos son superficies verticales o sub-verticales con caras rocosas libres. Forman parte de las unidades geomorfológicas Frentes Escarpados Rocosos, Remanentes de Frentes Escarpados Rocosos, Cuerpos Rocosos Prominentes, Relieve de Crestas y Depresiones Suaves, Relieve de Crestas y Depresiones Pronunciadas, Laderas Rocosas y Laderas Compuestas; en las dos primeras unidades mencionadas, la entidad cartográfica de los frentes es suficiente para mapearse como tales, mientras que en el resto se asocian a otros componentes geomorfológicos, como taludes y gargantas en discontinuidades rocosas.

Los frentes escarpados rocosos constituyen marcados quiebres de pendiente que separan las unidades geomorfológicas de escasa pendiente, como Cimas Planas y Divisorias Principales, y Piedemonte Aluvial Antiguo, de aquellas de pendientes moderadas (en torno a $25^{\circ}$ ) ubicadas al pie, como Laderas de Detritos (Figura 8.1). Estos afloramientos rocosos constituyen paredones imponentes en muchísimos casos, que contrastan tanto con las 
Movimientos en masa en las sierras de Bravard y Curamalal,

Sierras Australes de la Provincia de Buenos Aires.

Juan Manuel Susena

pendientes topográficamente superiores, como con las laderas topográficamente inferiores.

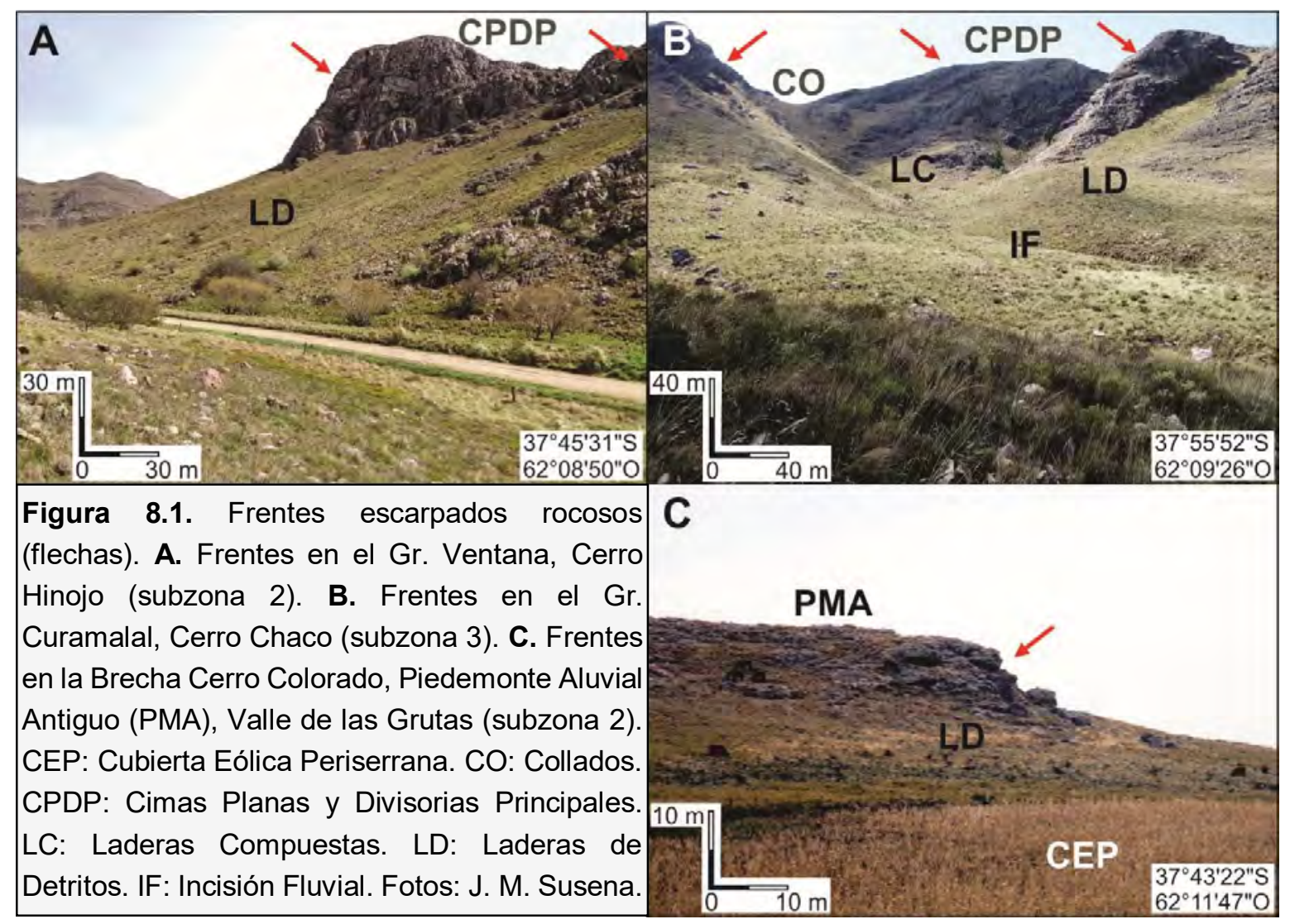

\subsubsection{Controles en la morfología de los frentes escarpados}

La morfología de los frentes escarpados (y los procesos que los modelan) se encuentra fuertemente influenciada por las estructuras geológicas. La influencia de los tipos litológicos sobre el desarrollo de los frentes se observa a escala regional, contrastando la morfología de los frentes del basamento ígneo-metamórfico con los desarrollados en los Grupos Curamalal y Ventana (secuencias principalmente cuarcíticas) y la Brecha Cerro Colorado (silcretas). A escala local la relativa homogeneidad de los tipos litológicos de los Grupos Curamalal y Ventana (ver Capítulo 5 Geología: generalidades) hace poco influyente a esta variable sobre el desarrollo de los frentes, salvo algunas excepciones. Las filitas de la Fm. Hinojo tienen poca tendencia al desarrollo de frentes, de hecho, sus escasos afloramientos por lo general aparecen ahogados por detritos. Particularmente los conglomerados de la Fm. La Lola y las areniscas macizas de la Fm. Bravard, al tener menos estructuras sedimentarias que las demás unidades (son más macizas), tienden al desarrollo de frentes más altos. En todas las demás unidades pueden encontrarse frentes muy parecidos entre sí cuando se las compara bajo condiciones estructurales similares. 
Pueden observarse frentes escarpados que coinciden con la estratificación de las secuencias cuarcíticas o con diferentes superficies de debilidad, como juegos de diaclasas y planos de foliación. La disposición de dichas estructuras en distintas localidades del área muestra una sectorización asociada a estructuras mayores (pliegues y fallas), a lo cual se vinculan las diferentes morfologías de los frentes, como se explica en los siguientes apartados.

La disposición de las estructuras, especialmente la estratificación y los juegos de diaclasas, dependiente del plegamiento, condiciona en gran medida las dimensiones de los frentes, mientras que la presencia de diaclasas maestras (ver Capítulo 5 Geología: generalidades) y grandes fracturas o fallas determinan su continuidad lateral. En un mismo faldeo, los frentes se discontinúan por la presencia de gargantas o entrantes suavizadas que se desarrollan en sectores con la roca fracturada más intensamente, donde el retroceso de los frentes es más rápido que en las inmediaciones. La velocidad con que retroceden los frentes modela también su morfología: donde el retroceso es más rápido que el transporte de los materiales en las laderas y su salida hacia los cursos de agua, los frentes terminan ahogados en sus propios detritos, mientras que, si los materiales son evacuados con una tasa mayor que la de retroceso de los frentes, se forman frentes de mayor desarrollo (ver Capítulo 6 Geomorfología general del área). Este tipo de evolución de los frentes escarpados y las laderas fue identificado y descripto también en otras sierras de la Provincia de Buenos Aires por Gentile (2011).

El espaciado entre discontinuidades determina la morfología y las dimensiones de los bloques rocosos que son individualizados de los frentes y posteriormente desplazados, repercutiendo en la morfología de los frentes. Dicho espaciamiento es muy variado, en general centimétrico (Figura 8.2.A) en las cercanías de valles transversales a la disposición de las sierras y en entrantes suavizadas, donde los frentes son pequeños y muchas veces están ahogados en sus detritos, o pueden alcanzar dimensiones métricas (Figura 8.2.B) en frentes de gran altura, como en los valles intraserranos y en sectores de frentes de gran continuidad lateral.

Los sistemas de diaclasas pueden favorecer la circulación de agua, la cual modifica los frentes menos mediante varios procesos o mecanismos:

1. ensanchamiento por meteorización y lavaje de los productos de meteorización;

2. ensanchamiento por erosión hídrica;

3. transporte y acumulación de materiales hacia las discontinuidades, rellenándolas;

4. ejercicio de presión y desplazamiento de bloques rocosos hacia fuera del macizo, sea por agua en estado líquido o por expansión al congelarse. 


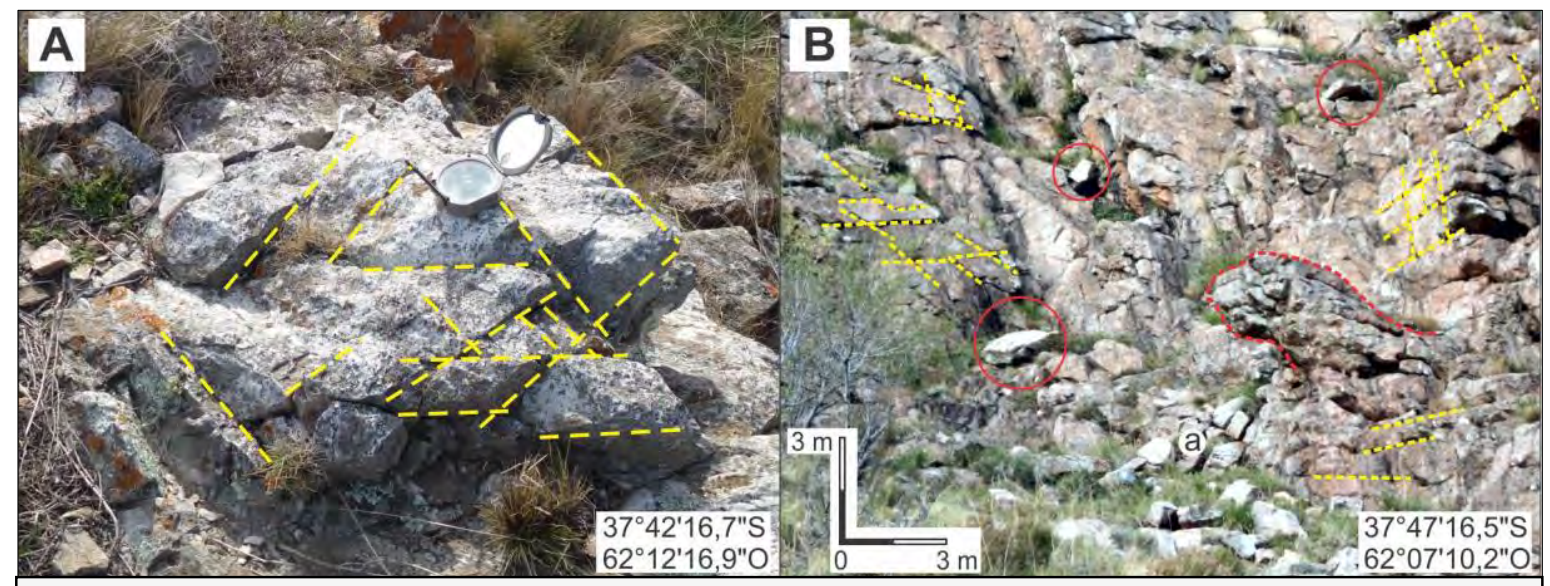

Figura 8.2. Espaciamientos entre discontinuidades (líneas amarillas). A. Espaciados centimétricos en un afloramiento rocoso en las Sierras de Bravard aledaño al abra del Arroyo Curamalal Grande. La brújula sirve como escala. B. Espaciamientos métricos en frentes escarpados rocosos de un valle intraserrano de las sierras de Bravard (subzona 2). Línea roja: bloque originalmente horizontal constituyendo un alero susceptible a caída. Círculos: bloques caídos. a: cono de detritos pequeño. Fotos: Juan M. Susena.

\subsubsection{Generalidades sobre morfología y distribución}

Las rocas a partir de las cuales han sido modelados los frentes escarpados corresponden mayormente a las unidades pre-paleocenas (ver Capítulo 5 Geología: Generalidades). Los frentes modelados en los Grs. Curamalal y Ventana son los de mayor desarrollo y representatividad espacial, ya que dichas secuencias predominan en cuanto a afloramientos rocosos se refiere (ver Figura 5.1 en el Capítulo 5).

Los frentes escarpados de mayor desarrollo y continuidad lateral son generalmente los que miran al oeste o suroeste. A su pie se desarrollan laderas con expresión morfológica variada (ver capítulo siguiente), en general con buen desarrollo (Figura 8.3.A). En contraste, los frentes que miran al este o noreste sólo localmente alcanzan un desarrollo tan conspicuo, siendo más bien discontinuos lateralmente. Habitualmente se intercalan frentes pequeños con tramos sub-horizontales de roca o detritos, de manera escalonada con cierta regularidad topográfica (Figura 8.3.B). 


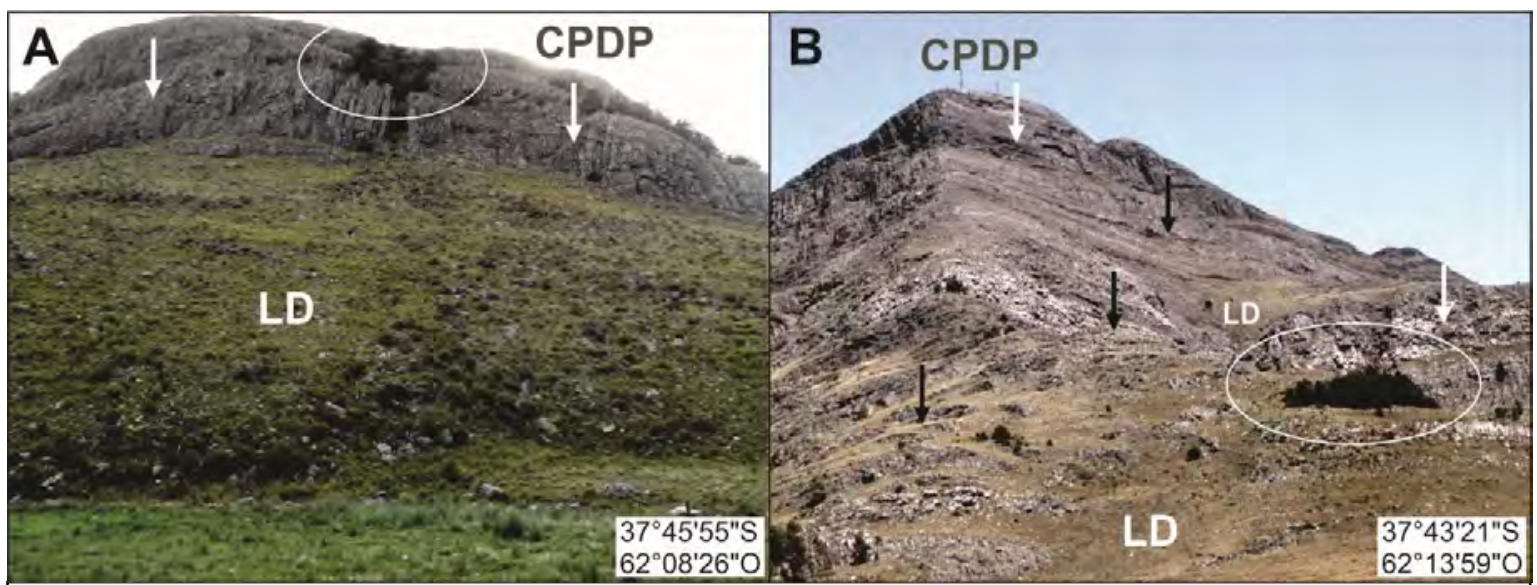

Figura 8.3. Frentes escarpados rocosos en la subzona 2 con diferente desarrollo según la orientación. A. Frentes mirando al occidente en las sierras de Bravard. B. Frentes mirando al oriente en las sierras de Curamalal. Flechas blancas: frentes mayores. Flechas negras: frentes menores. CPDP: Cimas Planas y Divisorias Principales. LD: Laderas de Detritos. Los árboles (círculos) sirven como escala, miden unos $8 \mathrm{~m}$ de altura. Fotos: Juan M. Susena.

\subsubsection{Frentes escarpados en las Sierras de Bravard}

Los frentes escarpados modelados en rocas cuarcíticas de las Fms. Bravard y Napostá (Gr. Ventana), presentan un notable desarrollo, particularmente en el sector del Valle de Las Grutas (faldeos occidentales). Se ubican a distancias de entre 130 y $650 \mathrm{~m}$ de las cimas; los más cercanos forman parte de los valles intraserranos paralelos al valle antedicho y tienen un rumbo general NO-SE a NNO-SSE (Figura 8.4), curvado visto en planta y convexo al NE, acompañando el rumbo general de las sierras. Sus dimensiones son variables, la relación largo/alto puede ser mayor a 10 en el caso de las unidades geomorfológicas Frentes Escarpados Rocosos y Gargantas en Discontinuidades Rocosas, o menor a 1 en las Laderas Compuestas y Remanentes de Frentes Escarpados Rocosos. Existen frentes mayores con alturas de unos 30-60 m y menores, de pocos metros de altura (Figura 8.5 en la página siguiente). Los frentes mayores pueden ser únicos o existir más de uno, separados por superficies sub-horizontales o de escasa pendiente con anchos no mayores a $10 \mathrm{~m}$, a veces con pequeños taludes. Los frentes mayores son continuos, superando el kilómetro de longitud, aunque también los hay discontinuos. Pueden ser interrumpidos por entrantes erosivas que conforman canales rocosos, generadas principalmente por acción fluvial. Otras entrantes se desarrollan por movimientos en masa, predominantemente caídas o vuelcos de rocas, y escurrimiento superficial no encauzado, conformándose conos de talud (= conos de detritos, ver capítulo anterior). Los frentes escarpados menores en general son aledaños a los mayores, tanto por debajo como por encima; en el último caso disminuyen progresivamente su altura hasta ser ahogados por 


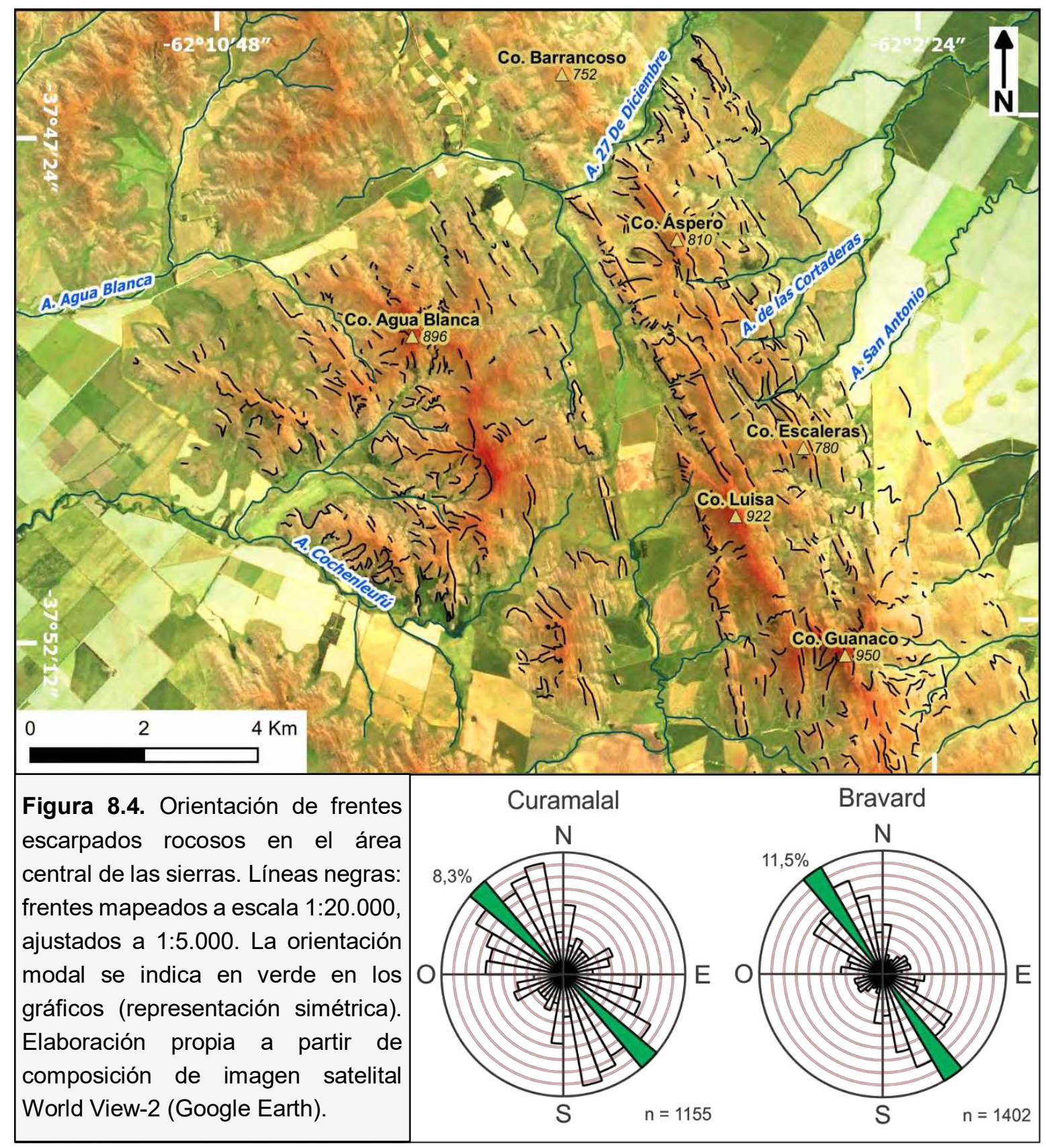

sus propios detritos en las cimas. La alternancia de frentes mayores y menores resulta en un relieve escalonado rocoso.

Los frentes escarpados rocosos de las laderas occidentales son morfológicamente más homogéneos que en las orientales, debido a que el plegamiento controla la relación de dominancia entre distintos tipos de estructuras geológicas. En los faldeos occidentales la estratificación se dispone de manera sub-vertical, ejerciendo un control relativamente homogéneo sobre el desarrollo de los frentes, desarrollándose en general un frente mayor de gran altura y escasos frentes menores arriba y debajo de aquel. En la vertiente oriental, en cambio, la estratificación tiene inclinaciones variadas, perdiendo localmente importancia 
en el control estructural de los frentes en favor de los juegos de diaclasas, generándose una morfología más bien escalonada, con frentes de dimensiones mucho más diversas.

Particularmente en la vertiente oriental, la variabilidad morfológica se produce especialmente en dirección transversal a las sierras. El sector aledaño a la divisoria principal (Fms. Bravard y Napostá) presenta un relieve escalonado (Figura 8.6.A) a irregular (Figura 8.6.B) de escasa anchura, constituido por frentes de dimensiones homogéneas, no mayores a $4 \mathrm{~m}$ de altura. Es notable su continuidad lateral, alcanzando los $4 \mathrm{~km}$ al norte del Arroyo Curamalal Grande; dicha continuidad contrasta con la de los frentes occidentales de ese sector, que

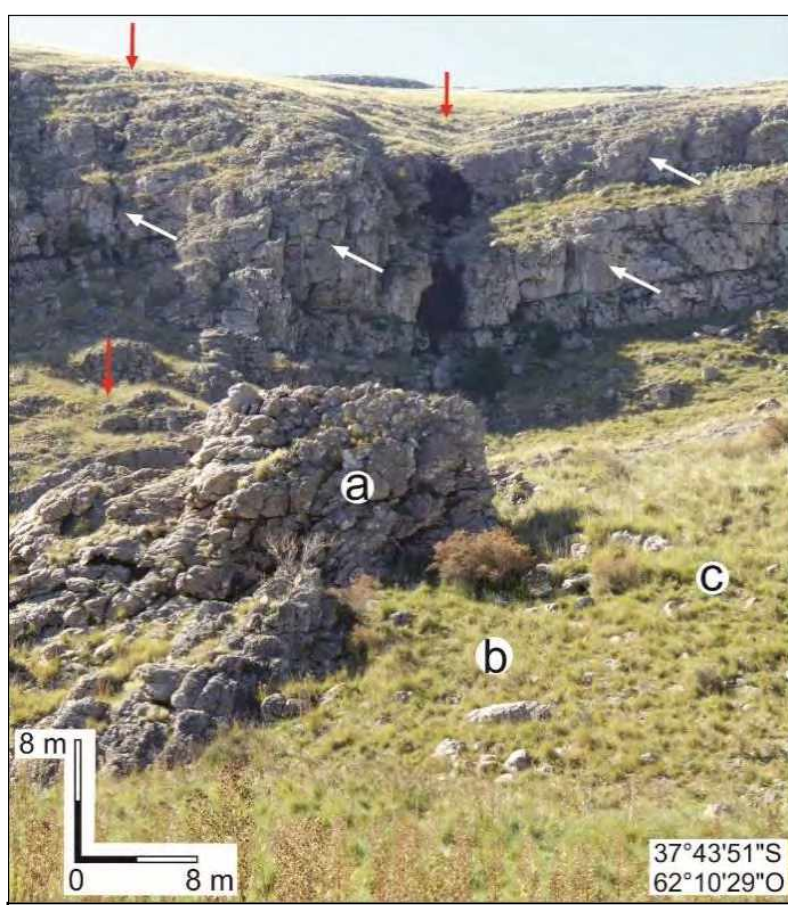

Figura 8.5. Frentes escarpados rocosos mayores (flechas blancas) y menores (flechas rojas) en las sierras de Bravard (subzona 2). a: remanente de frente escarpado rocoso. b: pequeño cono de detritos generado por la destrucción del remanente a. c: afloramientos rocosos ahogados. Foto: Juan M. Susena

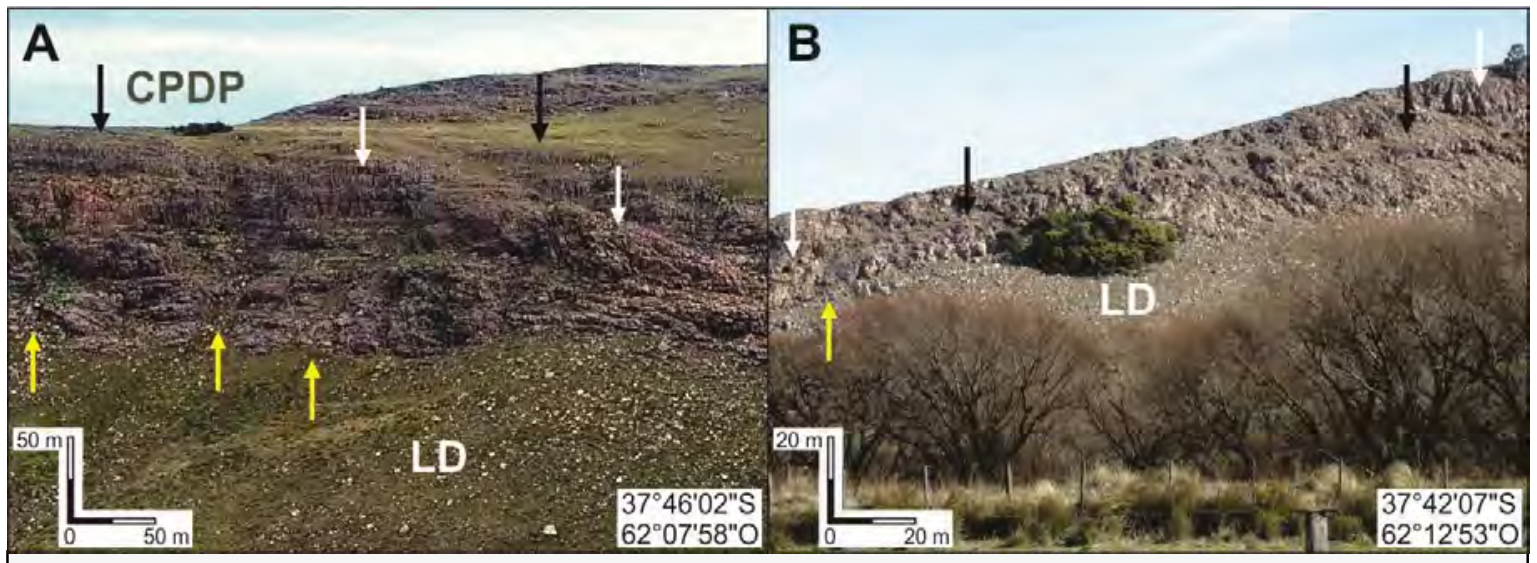

Figura 8.6. Frentes escarpados rocosos en faldeos orientales de las sierras de Bravard (subzona 2). A. Faldeo nororiental de cerro aledaño al Puntudo, visto desde el NE. B. Faldeo nororiental de la porción más austral del cerro Trocadero. Flechas negras: frentes escalonados. Flechas blancas: frentes de mayor desarrollo. Flechas amarillas: entrantes. CPDP: Cimas Planas y Divisorias Principales. LD: Laderas de Detritos. La escala se ajusta a los frentes indicados con flechas. Fotos: Juan M. Susena

son interrumpidos por entrantes suavizadas y gargantas (Figura 8.7). En los sectores central y sur de las sierras, estos frentes pierden continuidad lateral, pero tienen mayor altura, pudiendo alcanzar en conjunto los $100 \mathrm{~m}$. En los tramos topográficamente 


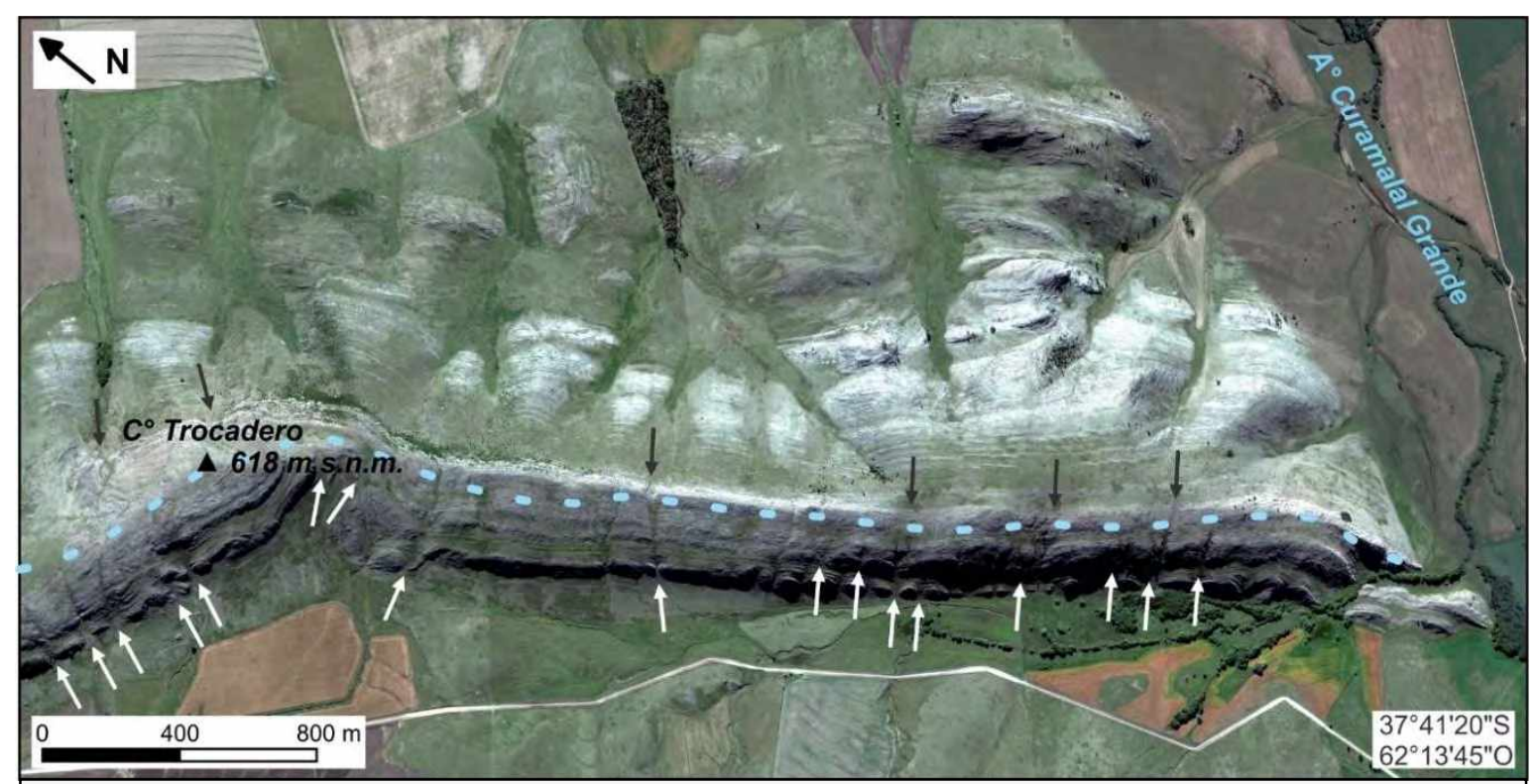

Figura 8.7. Frentes escarpados rocosos proximales en el cerro Trocadero. Flechas blancas: discontinuidades principales (entrantes y canaletas) en frentes occidentales. Flechas negras: discontinuidades principales (entrantes) en frentes orientales. Línea de puntos: divisoria de aguas principal. Elaboración propia a partir de composición de imagen satelital de World View-2 (Google Earth).

intermedios (Fms. Bravard, Napostá y Providencia) los frentes se desarrollan principalmente en el área central del conjunto serrano. Están caracterizados por morfologías rectas a curvadas en planta, pudiendo en el último caso dispersar o concentrar el agua, como puede apreciarse en la vertiente oriental del Cerro Guanaco, donde se intercalan divisorias rocosas y valles con forma de anfiteatros por la interacción entre la charnela de un pliegue antiforme y un relieve transversal de divisorias y valles (Figura 8.8). Tanto hacia el sur como hacia el norte, los frentes pierden expresión, limitándose a afloramientos rocosos no mayores a $2 \mathrm{~m}$ de altura. Por último, en los tramos topográficamente distales (Fms. Providencia y Lolén) los frentes se circunscriben al sector central entre las inmediaciones de los arroyos Hinojo Chico y las cabeceras meridionales del Sauce Corto. Allí, el desarrollo de frentes escarpados prácticamente se limita a afloramientos homoclinales buzantes al oeste o a pliegues volcados vergentes hacia el este o noreste, donde se forman, respectivamente, cerrillos aislados con morfología de cuestas, y lomas alargadas en dirección norte-sur con morfología de crestas y depresiones. Los frentes asociados a cerrillos aislados son por lo general mayores, con formas de arco vistos en planta, convexos hacia el naciente, como los ubicados al pie de los cerros Áspero y Escaleras (Figura 8.9), o cóncavos hacia el poniente, como en las cercanías del Arroyo 27 de Diciembre. 


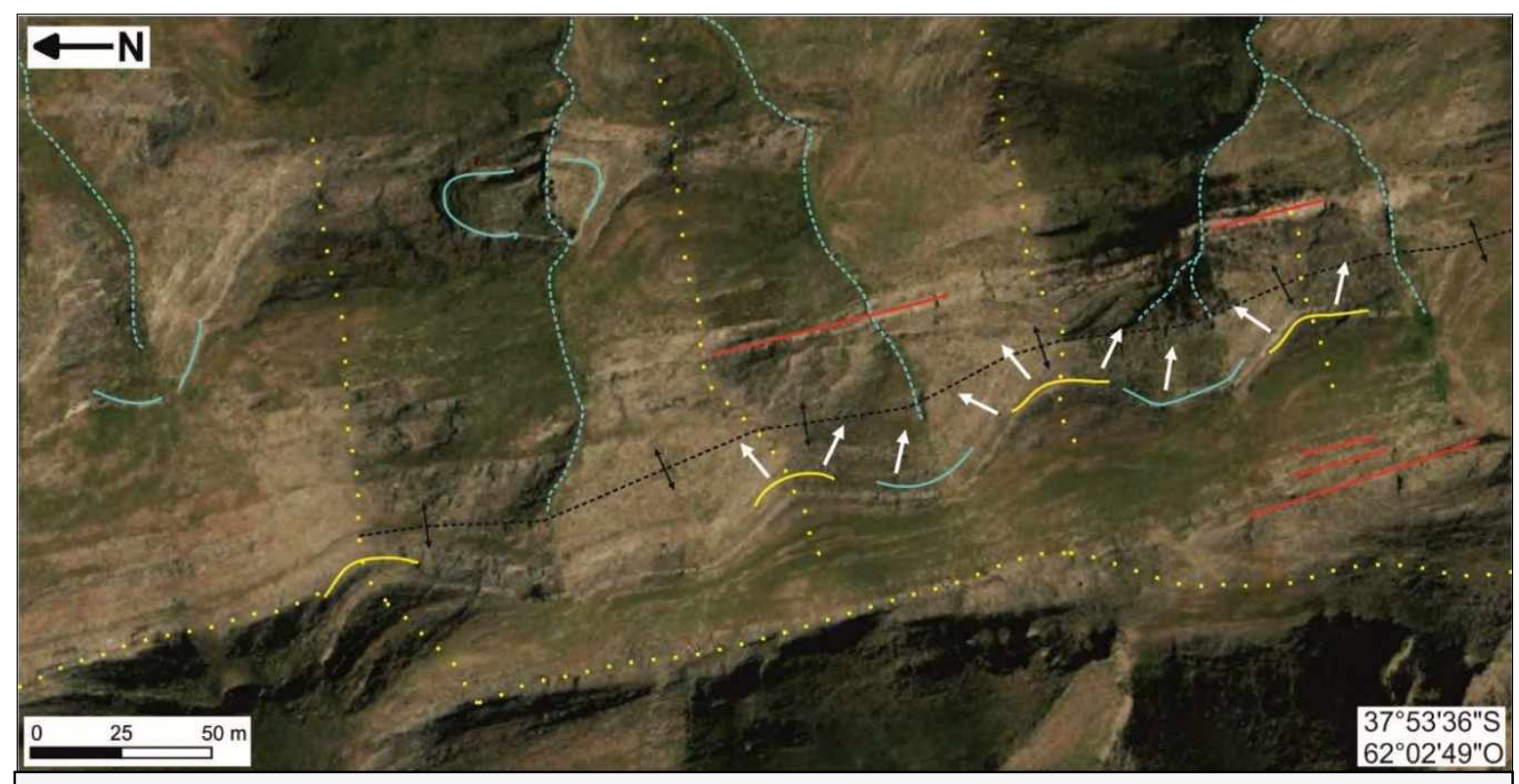

Figura 8.8. Frentes escarpados rocosos en tramos intermedios de los faldeos orientales del cerro Guanaco, sierras de Bravard. Líneas rojas: frentes rectos. Líneas continuas amarillas frentes convexos actuando como pendientes dispersadoras de agua. Líneas continuas celestes: frentes cóncavos funcionando como pendientes concentradoras de agua. Flechas blancas: dirección del escurrimiento superficial. Líneas de puntos amarillas: divisorias de aguas. Líneas de puntos celestes: valles y cursos de agua. Línea de puntos y flechas negras: charnela de pliegue antiforme. Elaboración propia a partir de composición de imagen satelital de World View-2 (servidor ESRI).

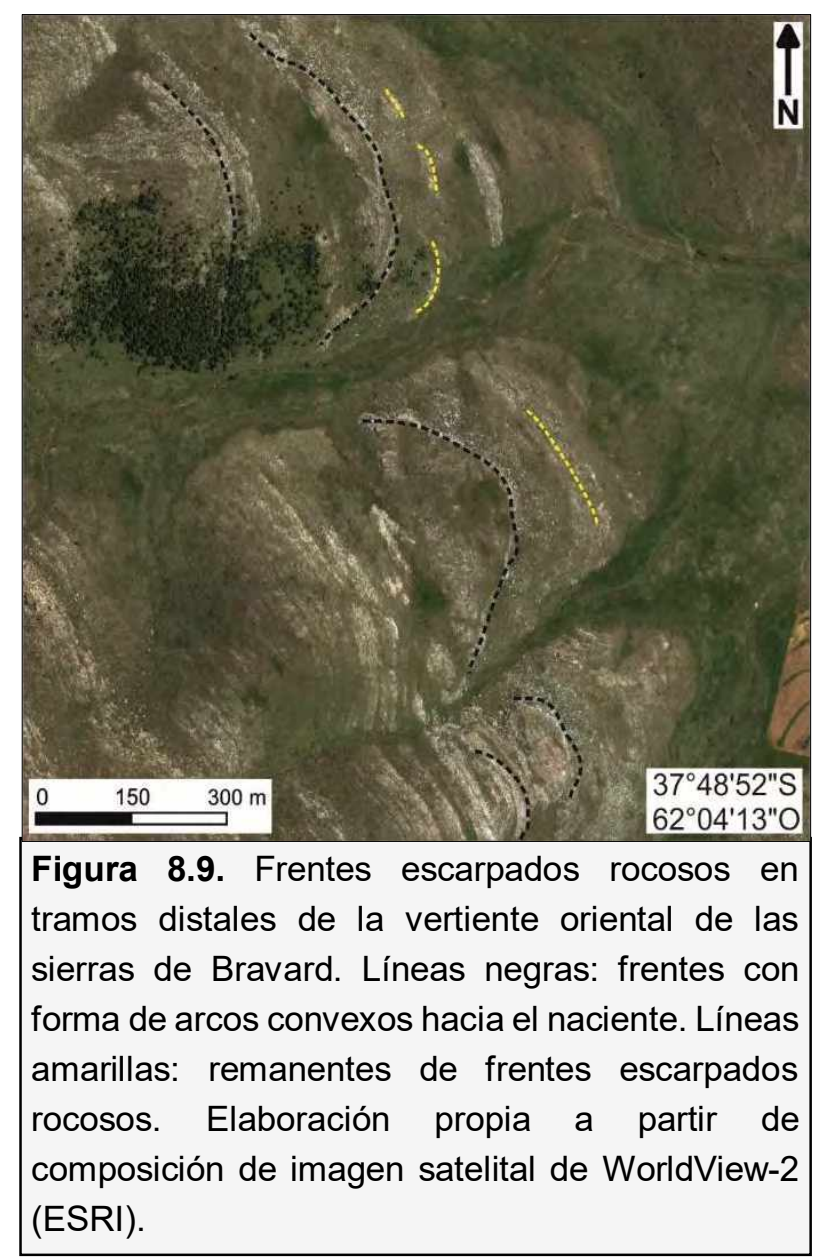


Movimientos en masa en las sierras de Bravard y Curamalal,

Sierras Australes de la Provincia de Buenos Aires.

Juan Manuel Susena

\subsubsection{Frentes escarpados en las Sierras de Curamalal}

Las Sierras de Curamalal presentan, respecto a las divisorias principales, un patrón asimétrico en el desarrollo de los frentes escarpados rocosos. Esta generalidad se aplica a todo el conjunto serrano, observable en imágenes satelitales y fotos aéreas.

Los faldeos orientales presentan un relieve escalonado muy conspicuo con frentes de poca altura, intercalados en menor medida con frentes más prominentes, llegando en conjunto a ocupar todo el perfil serrano, como ocurre en el Cerro Curamalal Grande, el más alto del área de estudio (Figura 8.3.B más arriba en este capítulo). Dicho relieve, muy característico en los sectores central y septentrional del área estudiada, responde a la disposición buzante hacia el oeste-suroeste de la Fm. Trocadero principalmente (Gr. Curamalal), con sistemas de diaclasas de rumbo NNE-SSO que condicionan el desarrollo de los frentes. El buzamiento se debe a la existencia de pliegues volcados hacia el NE. Los núcleos anticlinales favorecen el desarrollo de aleros y cuevas, mientras que a los sinclinales se asocian canaletas con frentes escarpados de gran altura, como ocurre en los valles intraserranos del cordón Lehmann (Figura 8.10). En el sector austral del área de estudio la vertiente oriental alterna entre un relieve escalonado orientado al este y frentes continuos orientados al oeste, los últimos coincidentes con planos de estratificación en valles intraserranos.

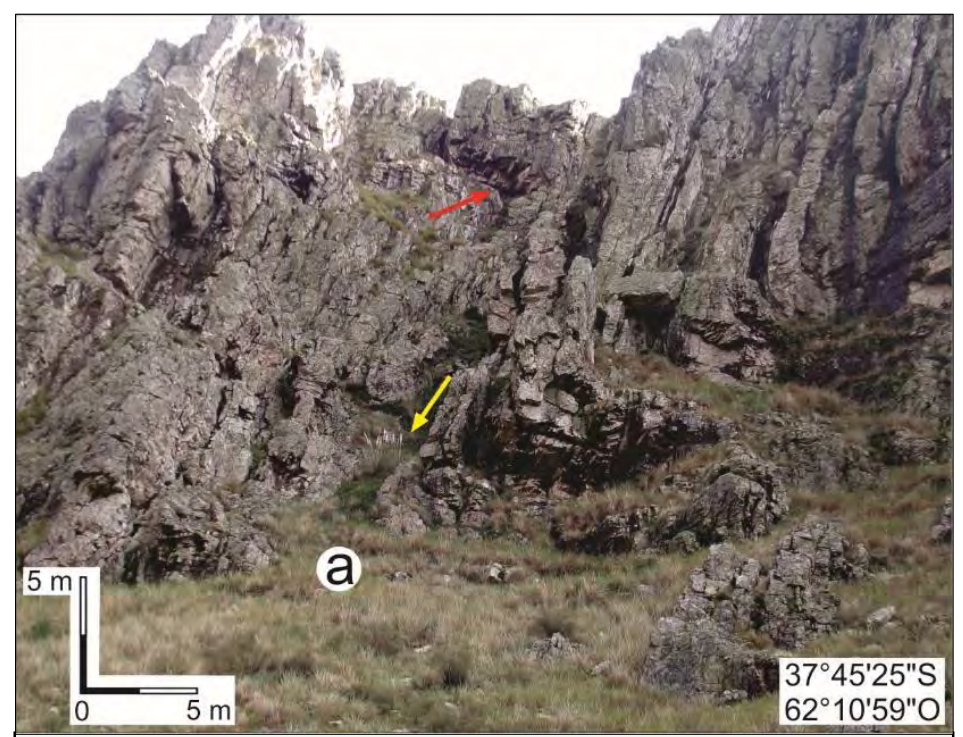

Figura 8.10. Aleros (flecha roja) asociados a anticlinales y canaletas (flecha amarilla) asociadas a sinclinales en un valle intraserrano del Cdón. Lehmann, Sierras de Curamalal (subzona 2). a: pequeño cono de detritos. Foto: Juan M. Susena.

Los frentes de la vertiente occidental están fuertemente condicionados por la presencia de pliegues más o menos apretados, donde frentes de más de $10 \mathrm{~m}$ conforman laderas de valles rocosos muy encajados. La disposición de estos frentes puede ser recta subparalela, o quebrada vista en planta (Figura 8.11). Al igual que en las Sierras de Bravard, en secuencias homoclinales se generan anfiteatros. En los cerros principales (cordones Hinojo Grande y Lehmann y cerros Curamalal Grande y Agua Blanca) es conspicua la posición retirada de los frentes hacia las divisorias, con un gran desarrollo de laderas de 
detritos a su pie. Esta característica coincide con las cabeceras de los cursos de agua principales (arroyos Alfalfa, Cochenleufú Chico, Agua Blanca y Cochenleufú Grande), pudiendo tratarse de los valles serranos más antiguos o desarrollados del área. Los sectores topográficamente intermedios y bajos presentan frentes escarpados rocosos en diversas direcciones. Dominan los frentes de gran altura y escasa longitud, desarrollados en valles intraserranos de primer o segundo orden.

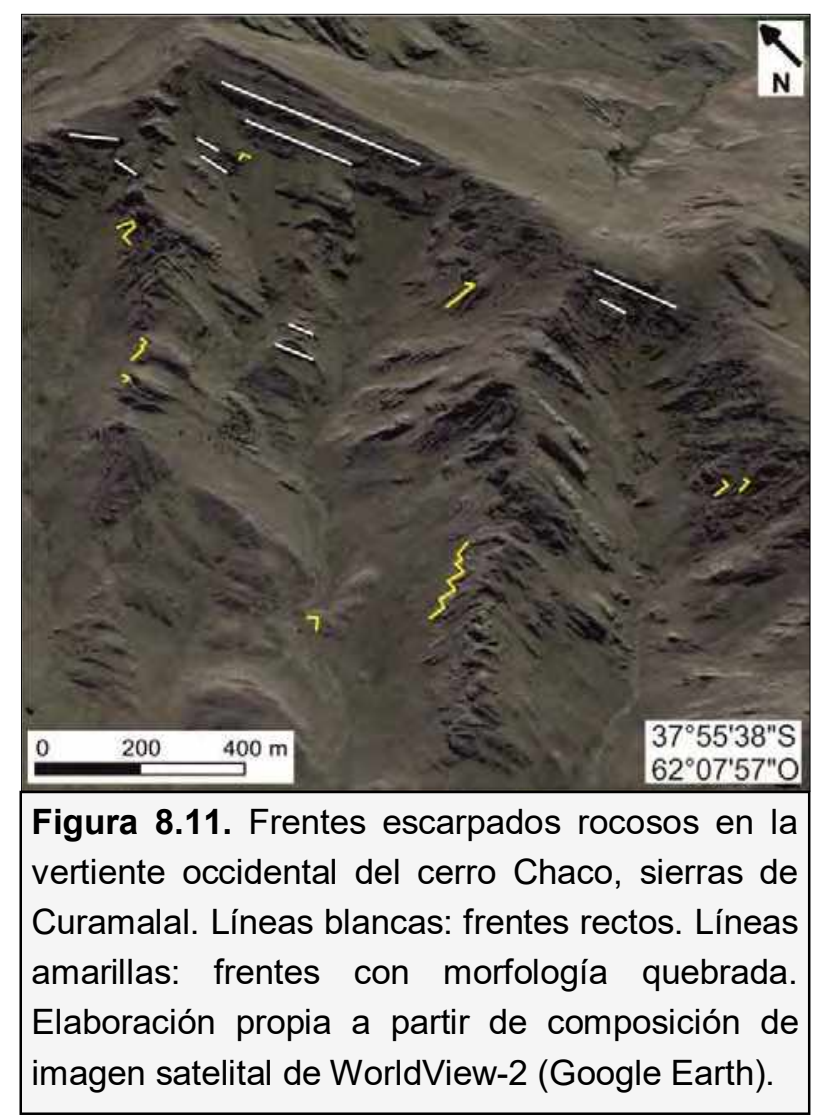

\subsubsection{Frentes escarpados en cerros aislados}

En el área estudiada los cerros aislados se ubican en el sector occidental y sur y sus frentes están modelados en las rocas del basamento y las Fms. La Lola (conglomerados) y Mascota (cuarcitas). Se tratan también -aunque no sean cerros- los frentes asociados a la unidad geomorfológica Piedemonte Aluvial Antiguo, desarrollados en la Brecha Cerro Colorado, ya que algunos de ellos se comportan de manera similar a los frentes de los cerros aislados. Salvo la Fm. Mascota, las demás unidades presentan estructuras geomorfológicas significativamente diferentes a las predominantes en las sierras de Bravard y de Curamalal. En este sentido, los frentes escarpados desarrollados presentan algunas particularidades.

- Salvo en el basamento, el relieve escalonado es raro, característica muy conspicua en los cordones serranos. El escaso relieve escalonado, desarrollado en basamento, es lateralmente mucho más discontinuo que el de las sierras, no superando los $10 \mathrm{~m}$.

- Los frentes más comunes del basamento se presentan como crestas de hasta 3-4 $\mathrm{m}$ de altura con buzamiento variable hacia el oeste y una marcada discontinuidad lateral, como es el caso de las unidades geomorfológicas Relieve de Crestas y Depresiones Pronunciadas (Figura 6.7 en el Capítulo 6 Geomorfología general del área). La inclinación de las crestas coincide con foliaciones que funcionan como superficies de 
Movimientos en masa en las sierras de Bravard y Curamalal,

Sierras Australes de la Provincia de Buenos Aires.

Juan Manuel Susena

debilidad. Otras discontinuidades están rellenas por pequeñas venas de cuarzo, y no tienen un diaclasamiento conspicuo.

- Los frentes de la Fm. La Lola presentan marcadas irregularidades decimétricas, sobre todo en los tramos inferiores, vinculadas a la presencia tafonis y de clastos redondeados de hasta $50 \mathrm{~cm}$ de eje mayor que sobresalen de la matriz.

- El Conglomerado La Lola y la Brecha Cerro Colorado presentan fracturas con superficies más irregulares que en las demás unidades rocosas. En la Fm. La Lola presentan separaciones de 2-3 $\mathrm{m}$, se disponen ortogonalmente buzando unos $70^{\circ}$ y son penetrativas. En la Brecha Cerro Colorado las fracturas son sub-verticales con espaciados decimétricos a métricos y no penetrativas; afectan sólo a los sectores más superficiales, como ocurre en el Valle de Las Grutas (Figura 8.12).

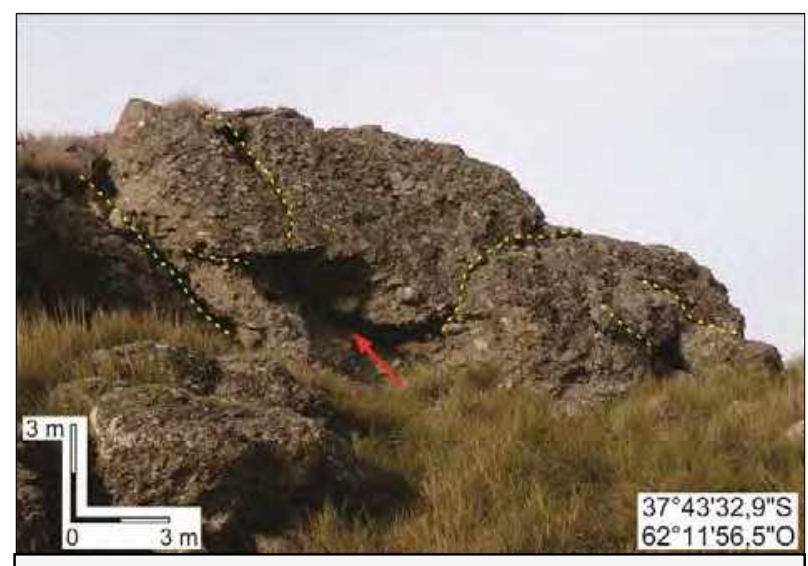

Figura 8.12. Fracturas no penetrativas (líneas amarillas) en un frente escarpado rocoso modelado en la Brecha Cerro Colorado en el Valle de las Grutas (subzona 2). Flecha: cueva. Foto: Juan M. Susena.

\subsection{Movimientos en masa}

Se reconocieron tres tipos cinemáticos de movimientos en masa desarrollados a partir de frentes escarpados rocosos: caídas, vuelcos y deslizamientos. El desplazamiento de los bloques puede ser grande en relación con las dimensiones de las laderas (varias decenas a más de cien metros) debido a la altura de los frentes y el alto ángulo de las laderas ubicadas al pie. En los bloques que experimentaron mayor recorrido, a veces resulta difícil encontrar el sitio exacto de procedencia (el "hueco" dejado en el frente escarpado rocoso), aunque muchos bloques tengan características de movimientos juveniles. Por ello, las caracterizaciones presentadas a continuación se refieren a movimientos de menor desplazamiento, o donde la fase principal del movimiento aún no se produjo, pero se puede identificar de qué tipo cinemático se trata -o se tratará- debido a los rasgos morfológicos. Un ejemplo del último criterio adoptado es la fotografía de un "vuelco de rocas" en el libro Geomorfología (Gutiérrez, 2008) donde, aunque aún no se produjo el movimiento, se aprecia la separación del conjunto rocoso y como tal, constituye un ejemplo didáctico de un posible vuelco de rocas. 


\subsubsection{Caídas}

Las caídas de rocas predominan en sectores de los frentes con pendientes extraplomadas. Su ocurrencia requiere estructuras horizontales $\mathrm{O}$ subhorizontales en las rocas, como diaclasas y estratificación. Los bloques desplazados son muy variados en cuanto a dimensiones y morfología, aunque algunos aspectos son generalizables:

1. En los frentes escarpados rocosos rectos, como los faldeos occidentales de las Sierras de Bravard u orientales del cerro Pan de Azúcar, entre otros, los bloques presentan morfologías preferentemente equidimensionales (= ecuantes), mayores a $30 \mathrm{~cm}$ de lado, pudiendo alcanzar incluso 2 o 3 $\mathrm{m}$, en cuyo caso son visibles desde

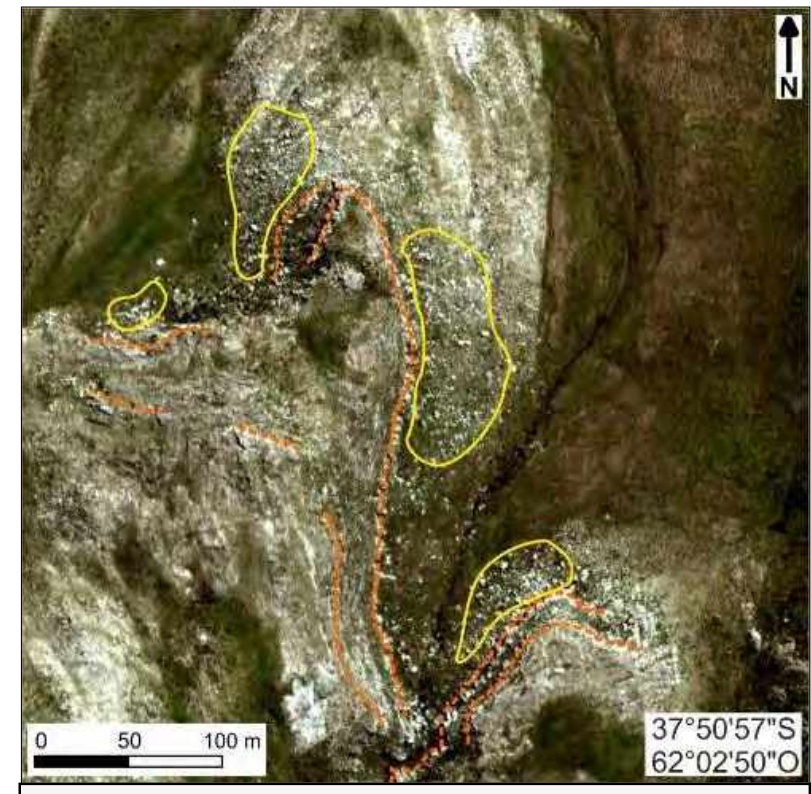

Figura 8.13. Sectores con abundantes caídas de bloques rocosos (amarillo) en los faldeos orientales de las sierras de Bravard. Líneas naranjas: frentes escarpados rocosos. Elaboración propia a partir de composición de imagen satelital de World View-2 (ESRI).

fotografías aéreas o imágenes satelitales (Figura 8.13). En general, tales dimensiones se relacionan con los espaciamientos de los sistemas de diaclasas, habiendo poca fragmentación de los bloques durante el movimiento. La distribución de los bloques desplazados es muy particular: por un lado, se desarrolla una gran concentración de bloques inmediatamente al pie de los frentes escarpados, donde se traban unos con otros, evidenciando una influencia negativa de la angularidad sobre la continuidad del movimiento. Estas acumulaciones se extienden al pie de los frentes, alcanzando anchos de 5-6 $\mathrm{m}$ y espesores de hasta 2 metros. Por otra parte, se encuentran grandes bloques dispersos a distancias variables del frente escarpado en las laderas o incluso más allá de las mismas, sobre planicies de inundación, sin un patrón de distribución característico. La diversidad de posiciones respecto al frente escarpado puede deberse a diferencias en la energía potencial de los distintos bloques, dependiente del tamaño y la posición topográfica, y/o a disminuciones diferenciales de la energía cinética, según el grado de interacción con rasgos de las laderas que funcionen como obstáculos topográficos, tales como zonas de hundimiento y de acumulación de deslizamientos. Suriano y Limarino (2009) describen, en el sistema pedemontano de 
Movimientos en masa en las sierras de Bravard y Curamalal,

Sierras Australes de la Provincia de Buenos Aires.

Juan Manuel Susena

un valle intermontano de la Precordillera argentina, una distribución similar, de clastos aislados, definiéndola como litofacies de aglomerados clasto-soportados, con fábrica caótica y exiguo contenido de matriz, asociándola a caídas de rocas (sensu Bilkra y Nemec, 1998).

2. En los valles intraserranos de las sierras de Bravard y de Curamalal, la presencia de numerosísimos pliegues apretados, la mayoría volcados, y la orientación de diaclasas maestras y menores, propicia una enorme variedad de bloques rocosos con diversas morfologías. Las formas son más variadas que en el caso anterior, pueden ser equidimensionales, discoidales o proladas, y angulosas a sub-angulosas, con tamaños variantes entre 0,1 y $3 \mathrm{~m}$ de eje mayor. Los bloques menores muchas veces son el resultado de la fragmentación de los mayores durante el movimiento (Figura 8.14). Se asocian mayormente a culminaciones de pliegues anticlinales y a sus flancos inmediatos, y en menor medida a relieve escalonado en los flancos. Una característica muy llamativa de las caídas en estos ámbitos es que algunos bloques caídos son retenidos entre afloramientos inclinados que constituyen paredes de valle o entrantes en los frentes escarpados rocosos (Figura 8.15). Algunos de estos bloques, pese a que parecen inestables, tienen características indicadoras de una relativa antigüedad en su sitio o posición.

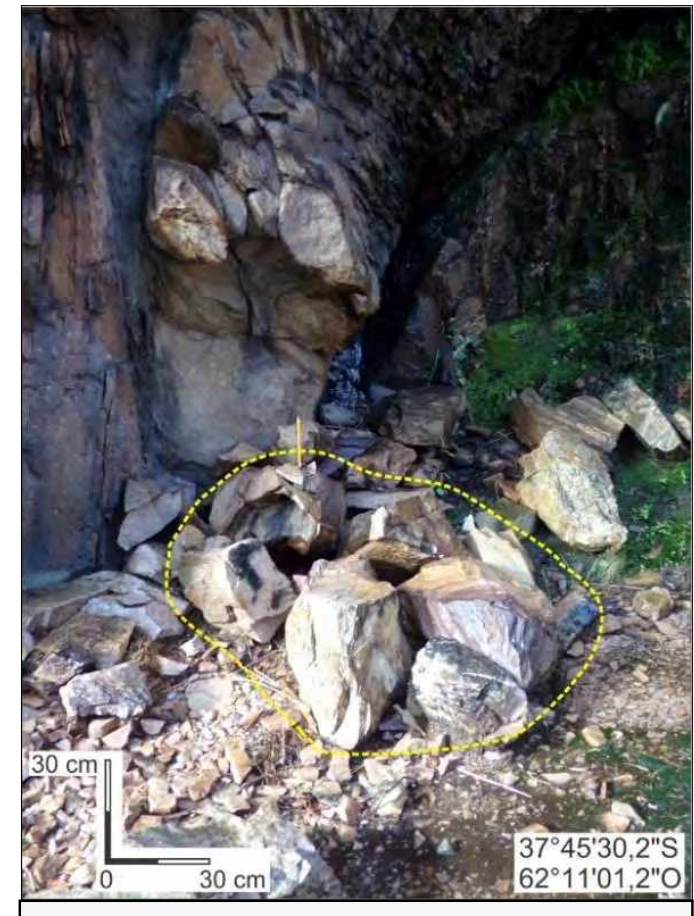

Figura 8.14. Bloques rocosos menores (línea amarilla) como resultado de la fragmentación de un bloque mayor tras una caída en un valle intraserrano del Cdón. Lehmann-Hinojo Grande (subzona 2). Foto: Juan M. Susena.

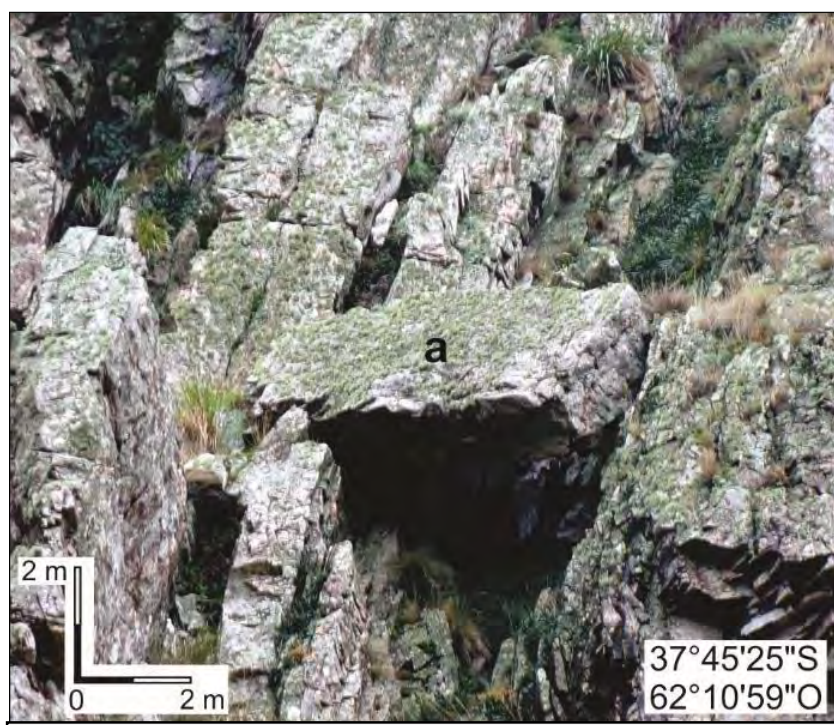

Figura 8.15. Bloque rocoso (a) trabado entre afloramientos en un valle interserrano de la vertiente oriental del Cdón. Lehmann (subzona 2). La presencia de vegetación en la cara de solana del bloque indica cierta antigüedad de éste en esa posición. Foto: Juan M. Susena. 


\subsubsection{Vuelcos}

Los vuelcos de roca presentan una distribución espacial más amplia que las caídas. Mientras que para las caídas se requiere la ausencia de materiales subyacentes, para lo cual se necesitan discontinuidades sub-verticales individualizando un bloque rocoso y subhorizontales que posibiliten la remoción del material subyacente, para los vuelcos, en cambio, es suficiente la presencia de discontinuidades sub-verticales que individualicen los bloques. Se diferencian dos tipos de morfologías de los materiales involucrados en los vuelcos: de bloques (Figura 8.16.A) y de lajas (Figura 8.16.B).

Debe hacerse notar que esta distinción es puramente morfológica, y que ambos corresponden al tipo cinemático vuelcos en bloque, aunque la separación entre discontinuidades varíe respecto a la definición original (ver Capítulo 1 Introducción al objeto de estudio). Dado que estas morfologías dependen de los distintos tipos de estructuras geológicas, como se explicará a continuación, no existe una gradación entre ambos tipos, sino que son claramente diferenciables.

Los vuelcos de bloques se vinculan estrechamente con el desarrollo de diaclasas y estructuras sedimentológicas, dependiendo sus dimensiones de la separación entre las mismas. Se encontraron bloques susceptibles a vuelcos de hasta $2 \mathrm{~m}$ de ancho y más de 3 de altura, como se muestra en la Figura 8.17. En dicho caso, el movimiento podría producirse hacia el frente escarpado, y no hacia fuera, siendo una excepción a la definición típica de vuelcos (en la cual el material se mueve hacia fuera de la ladera), como también se ha observado en sectores de Tandilia (Gentile, 2011). 


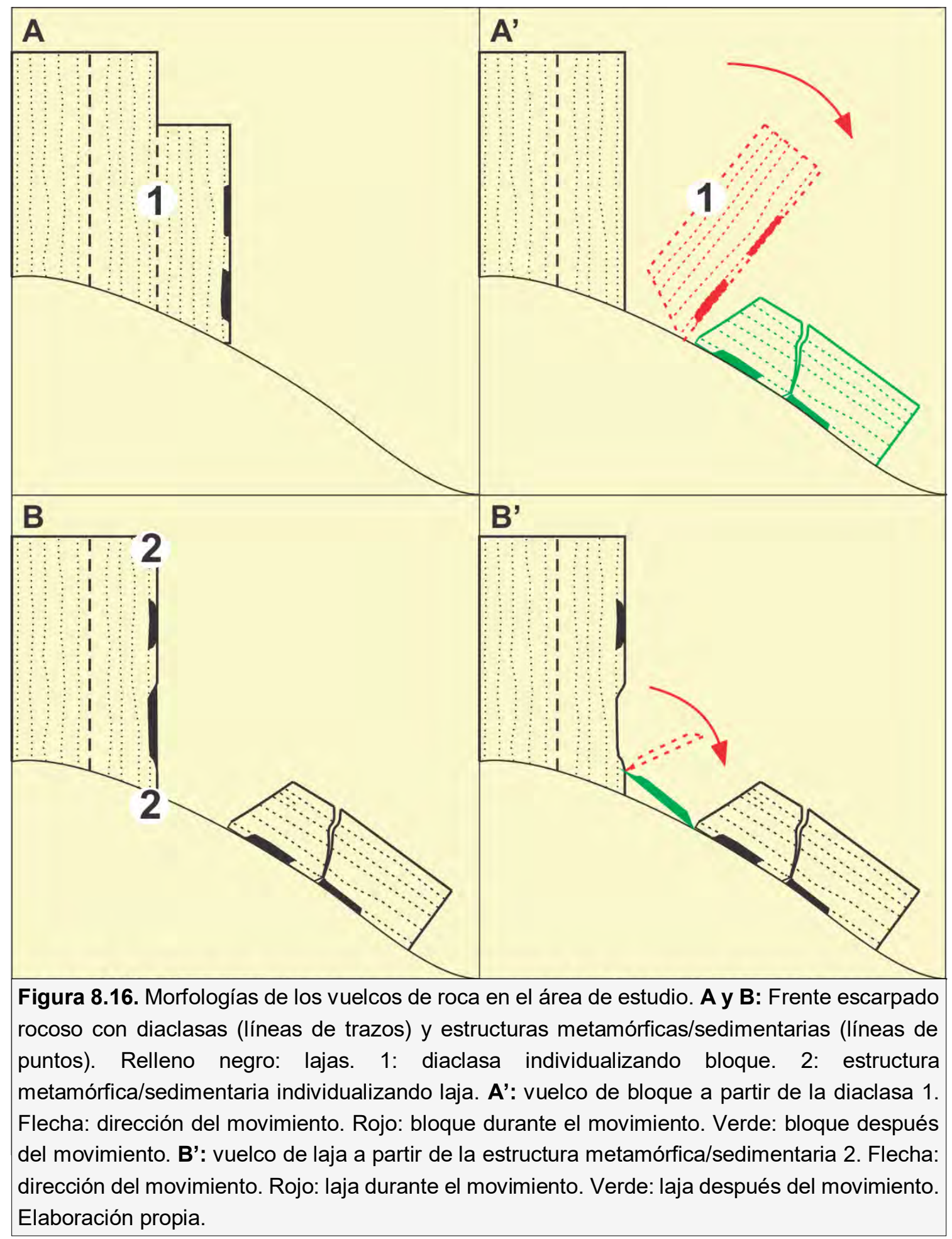




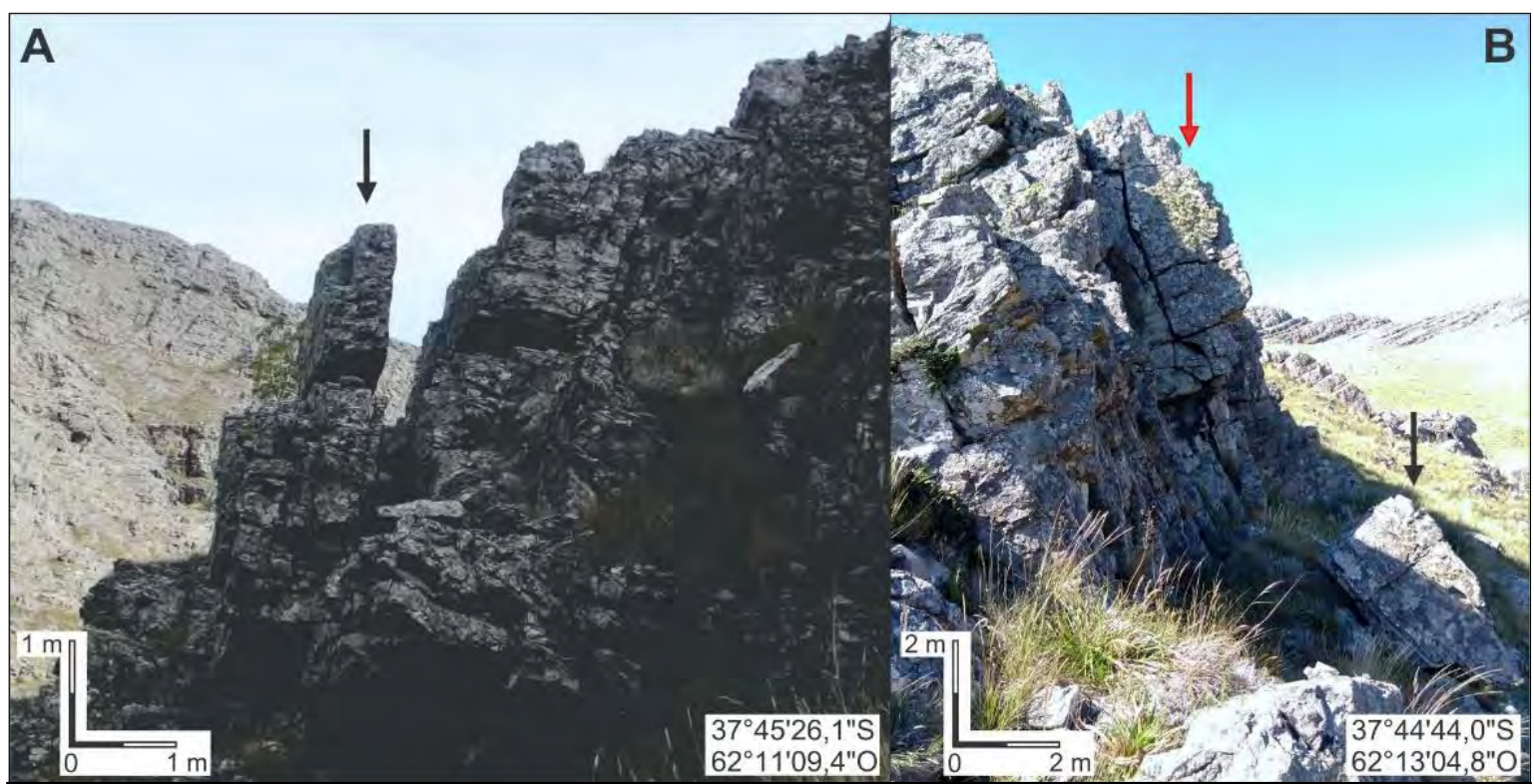

Figura 8.17. Vuelcos en bloque en la subzona 2. A. Bloque susceptible a vuelco (flecha) en un valle intraserrano en la vertiente oriental de las Sierras de Curamalal. B. Bloque volcado o caído y luego volcado (flecha negra) en un valle intraserrano de la vertiente occidental de las Sierras de Curamalal. Flecha roja: bloque aún no desplazado con una posición similar a la que habría tenido el bloque volcado. Fotos: Juan M. Susena.

Los vuelcos de lajas son de escasas dimensiones, de orden decimétrico y espesores de pocos centímetros, aunque en algunas ocasiones pueden alcanzar dimensiones mayores, según el tipo litológico. En general, en las metavulcanitas del basamento se producen lajas más grandes. Se asocian a discontinuidades sedimentológicas, metamórficas o cambios mineralógicos dentro de las mismas litologías, que favorecen una meteorización localizada y la consecuente individualización de las lajas. Son comunes en las unidades Relieve de Crestas y Depresiones Pronunciadas, afectando al basamento, donde la foliación inclinada subverticalmente posibilita la diferenciación de lajas (Figura 8.18). Los sistemas de diaclasas, si bien no individualizan lajas,

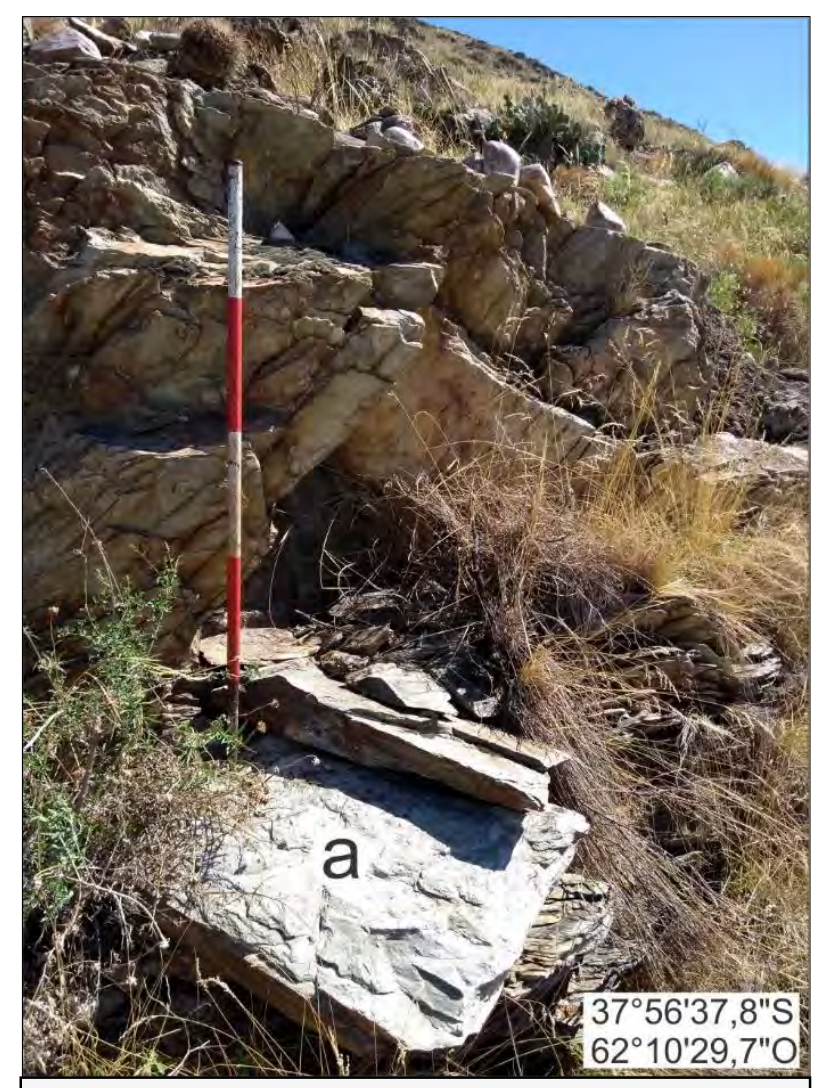

Figura 8.18. Vuelco de laja del basamento en el faldeo oriental del cerro Pan de Azúcar (subzona 3). a: laja desplazada. El jalón sive como escala, mide $1 \mathrm{~m}$ de altura. Foto: Juan M. Susena. 
Movimientos en masa en las sierras de Bravard y Curamalal,

Sierras Australes de la Provincia de Buenos Aires.

Juan Manuel Susena

participan en la individualización de bloques rocosos, exponiendo las caras de éstos a la meteorización y conformación de lajas.

\subsubsection{Deslizamientos en rocas}

Los deslizamientos producidos a partir de frentes escarpados rocosos son de tipo planar y en cuña. Cuando los planos sobre los que se produce el movimiento están muy inclinados, la masa puede destruirse y/o comenzar a rotar, y el movimiento puede transformarse en una caída. La diferencia con las caídas ya descriptas es que aquellas se producen principalmente a partir de aleros, con escasa o ninguna componente de deslizamiento. Los deslizamientos planares se vinculan a foliaciones (Figura 8.19.A), planos de estratificación (Figura 8.19.B), diaclasas (Figura 8.19.C) y superficies de meteorización o fracturas más o menos regulares (Figura 8.19.D). Estos movimientos son frecuentes en valles intraserranos, desplazándose bloques de más de $10 \mathrm{~m}^{3}$. Son comunes en frentes escarpados rocosos con inclinaciones algo menores que los típicos verticales, y en laderas rocosas.

Los deslizamientos en cuña se asocian a la conjunción de dos planos de discontinuidades, siendo las diaclasas los casos más comunes. La masa desplazada se encuentra siempre disgregada, ocupando volúmenes de $20-30 \mathrm{~m}^{3}$. La masa de algunos deslizamientos planares puede estar delimitada por dos planos de diaclasas (Figura 8.20.A). En dichos casos, los deslizamientos en cuña se diferencian de los deslizamientos planares en que el movimiento de los primeros se desarrolla a lo largo de ambos planos, los cuales tienen fuerte inclinación (Figuras 8.20.B y 8.20.C), mientras que en los planares la masa de desplaza sobre un tercer plano.

A pesar de la presencia de innumerables diaclasas y planos de estratificación en el área de estudio, muchos de los cuales podrían favorecer -o haber favorecido- el desarrollo de deslizamientos planares o en cuña, es llamativa la escasa representación de deslizamientos asociados a estas estructuras geológicas. Esto podría deberse a al menos dos razones, una intrínseca a la génesis de los movimientos, y otra vinculada a la dificultad en su reconocimiento. Por un lado, los frentes escarpados con cierta continuidad vertical, característica que permitiría en parte el desarrollo de deslizamientos, se ubican en sectores críticos en cuanto a la deformación dúctil o frágil, coincidiendo con foliaciones o intenso diaclasado, en zonas de cizalla y proximidades a charnelas de pliegues, respectivamente. Estas estructuras tienden a diferenciar bloques menores que van cayendo y modelando los frentes, antes que puedan desarrollarse las condiciones necesarias para los deslizamientos. En sitios aledaños a charnelas de pliegues, la alta densidad del diaclasado 


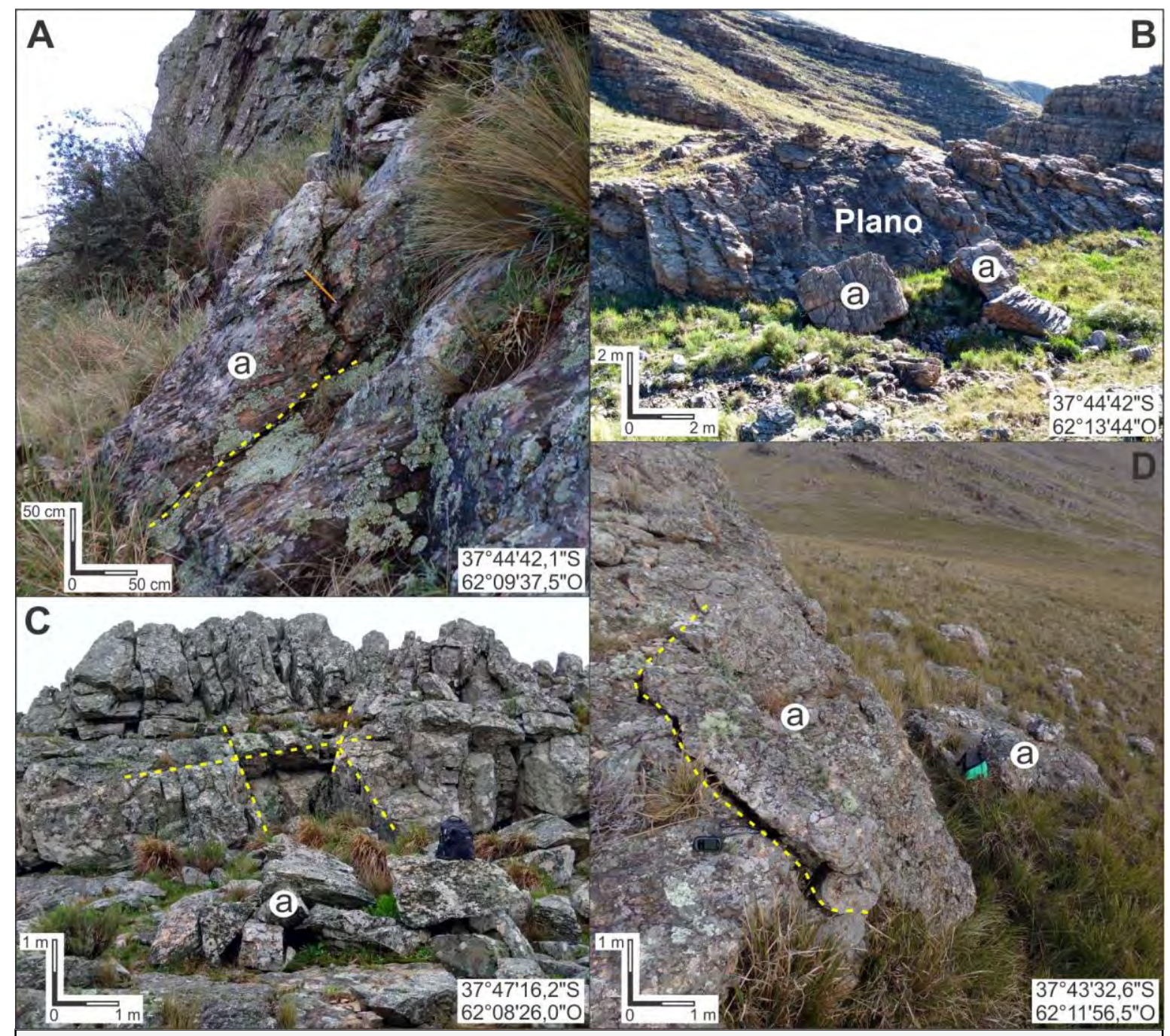

Figura 8.19. Deslizamientos planares en rocas. a: bloques desplazados. Líneas amarillas: discontinuidades que individualizan bloques rocosos. A. Frente escarpado occidental de las sierras de Bravard (subzona 2). La discontinuidad es un plano de foliación. El bloque se ha desplazado unos pocos centímetros, se observa la superficie de separación donde está el lápiz. B. Varios bloques deslizados y rotados (caídos) en un valle intraserrano occidental del Cdón. Lehmann/Hinojo Grande (sierras de Curamalal, subzona 2). El plano corresponde a la estratificación. C. Bloque rocoso deslizado y fragmentado a partir de diaclasas en los faldeos orientales del Cdón. Hinojo Grande (subzona 2). D. Bloques de la Brecha Cerro Colorado (Valle de las Grutas, subzona 2) desplazado unos pocos centímetros sobre una discontinuidad irregular asociada a meteorización. Fotos: Juan M. Susena.

impide la individualización de planos lo suficientemente continuos para que se generen deslizamientos. En contraste, la intersección de los juegos de diaclasas favorece el desarrollo de caídas y vuelcos, mediante la constitución de aleros. Por otra parte, la abundancia de discontinuidades en el macizo rocoso puede repercutir en el fracturamiento de la masa desplazada durante los deslizamientos, pudiendo confundirse, cuando son antiguos, con caídas/vuelcos de actividad múltiple. Un criterio útil para el reconocimiento de deslizamientos es la homogeneidad de los indicadores de edad relativa en la superficie 
Movimientos en masa en las sierras de Bravard y Curamalal,

Sierras Australes de la Provincia de Buenos Aires.

Juan Manuel Susena

de ruptura, por ejemplo, igual desarrollo de las colonias de líquenes en todo el plano; si se tratara de caídas múltiples, sería esperable que el desarrollo de líquenes sea desigual.

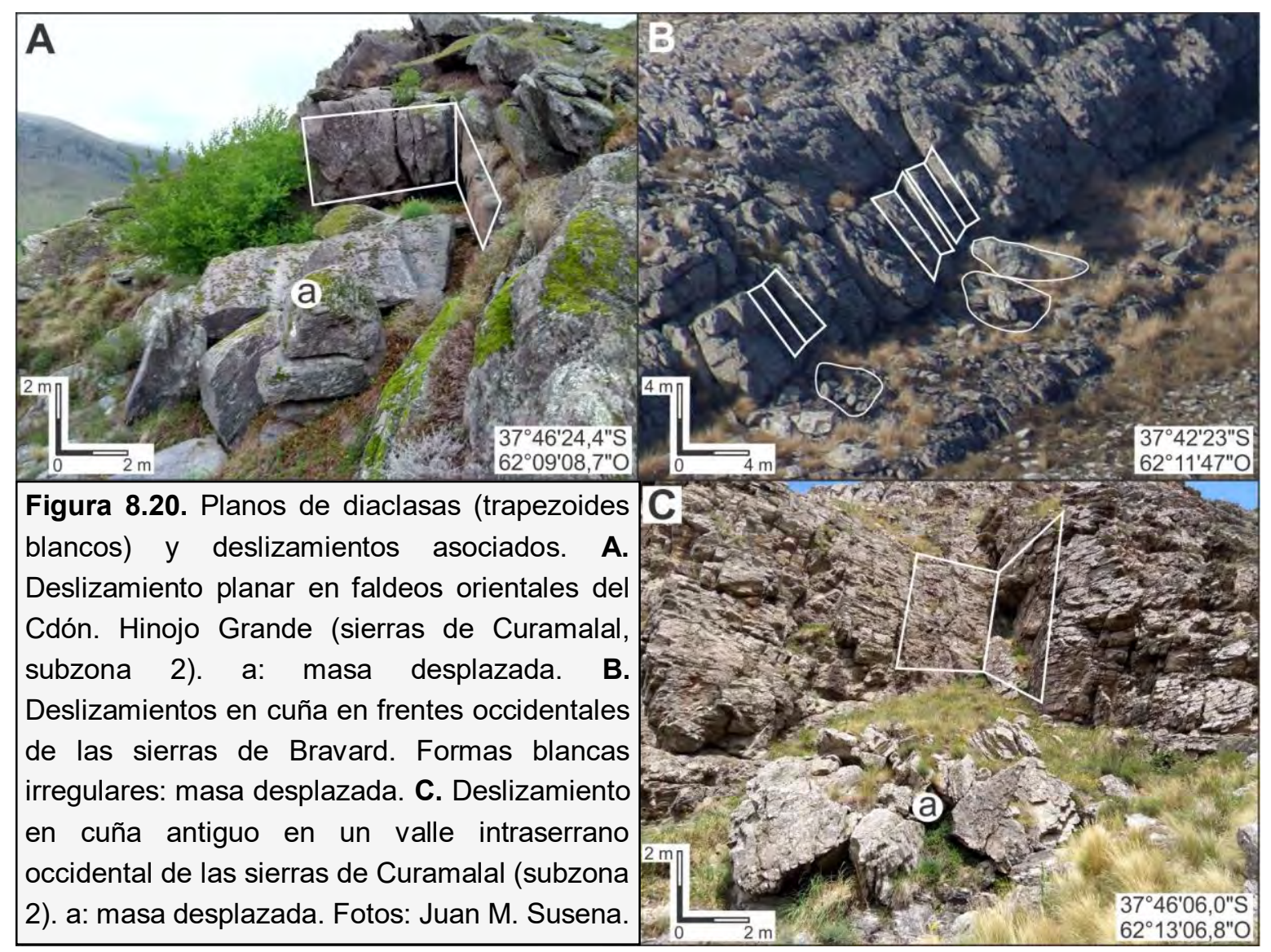

\subsection{Consideraciones prácticas}

Los movimientos en masa que ocurren desde los frentes escarpados pueden implicar un riesgo importante para los transeúntes del área, debido al carácter repentino, y a que son movimientos muy rápidos o extremadamente rápidos. La presencia de grandes bloques caídos en las laderas e incluso más allá de ellas sobre las planicies de inundación, denotan que los bloques pueden tener recorridos de varias decenas o incluso más de cien metros. Resulta práctico identificar posibles sectores con actividad frecuente de estos movimientos, para que el tránsito al pie de los frentes escarpados rocosos sea seguro. En este sentido, no es necesario diferenciar caídas, vuelcos y deslizamientos de rocas, dado que los tipos cinemáticos pueden variar durante el movimiento, siendo tendientes a desarrollarse caídas de rocas en última instancia. Podrían, en principio, delimitarse zonas de amenaza por movimientos en masa o Landslides Hazard Zones (Cardinali et al., 2002), cartografiando el área existente entre los frentes escarpados rocosos y la posición de los bloques más distales encontrados. Otra aproximación a la cartografía de susceptibilidad por estos 
movimientos podría consistir en calcular de manera idealizada (simplificada) la distancia máxima que pudiera recorrer un bloque rocoso, conforme a la altura de los frentes escarpados rocosos, la pendiente de la ladera aledaña y el tamaño máximo posible de los bloques rocosos según el espaciamiento de las discontinuidades. Los posibles resultados, asignados a los distintos tramos de los frentes escarpados, pueden dar una idea de la susceptibilidad de cada frente, y las distancias potenciales de los movimientos pueden utilizarse para delimitar "zonas de amenaza". Dado que tal tarea requiere un trabajo de campo a escala de detalle y que aun así existen incertidumbres difícilmente abordables por razones de tiempo y económicas (como las vinculadas a la edad relativa y actividad de los movimientos), resulta conveniente que los sectores más peligrosos sean identificados directamente por los transeúntes de la zona de manera cualitativa. Esto implica tareas de educación de tránsito en el ambiente serrano, enseñando los criterios de reconocimiento de los movimientos en masa y su actividad (ver capítulo anterior).

Para ello, se establece a continuación una serie de criterios morfológicos que indican sitios relativamente más seguros que otros, cuya aplicación se ilustra para algunos casos en la Figura 8.21 y en la Tabla 8.1, la última referida a figuras anteriores de este capítulo. Mientras se transita, debe prestarse atención a los bloques sueltos en superficie, e identificar si se los ve con características recientes (ver capítulo anterior), para tener una idea de la actividad de los movimientos. Este mismo criterio de observación puede aplicarse a los frentes escarpados rocosos, para reconocer dónde conviene transitar o parar, según los indicios de estabilidad que tengan los frentes. Recomendaciones de este tipo fueron referidas por Susena y Gentile (2018). Algunos de los elementos que denotan estabilidad de los frentes escarpados rocosos son la presencia de colonias de líquenes en todo el frente, fracturas rellenas, ausencia de agua, ausencia de raíces penetrando fracturas laterales (observar también que no haya árboles en la cima de los frentes), y signos de antigüedad de los bloques al pie, como presencia de matriz eólica en el talud, colonias de líquenes en los bloques, rasgos de meteorización con disposiciones coherentes con su génesis, como gnammas en posición horizontal y lajamiento en las caras de solana, y vegetación abundante no sepultada por bloques rocosos. Los elementos que denotan actividad de los movimientos son la ausencia de colonias de líquenes en los frentes o en los bloques al pie, la presencia de grandes bloques rocosos en las laderas, que no se vean enterrados en la matriz eólica (puesto que la matriz eólica es muy antigua), la presencia de bordes filosos en los bloques, los amontonamientos de detritos, y debe observarse también si hay agua brotando de los frentes, ya que esto indica que podrían estar individualizándose bloques susceptibles de desplazarse. 


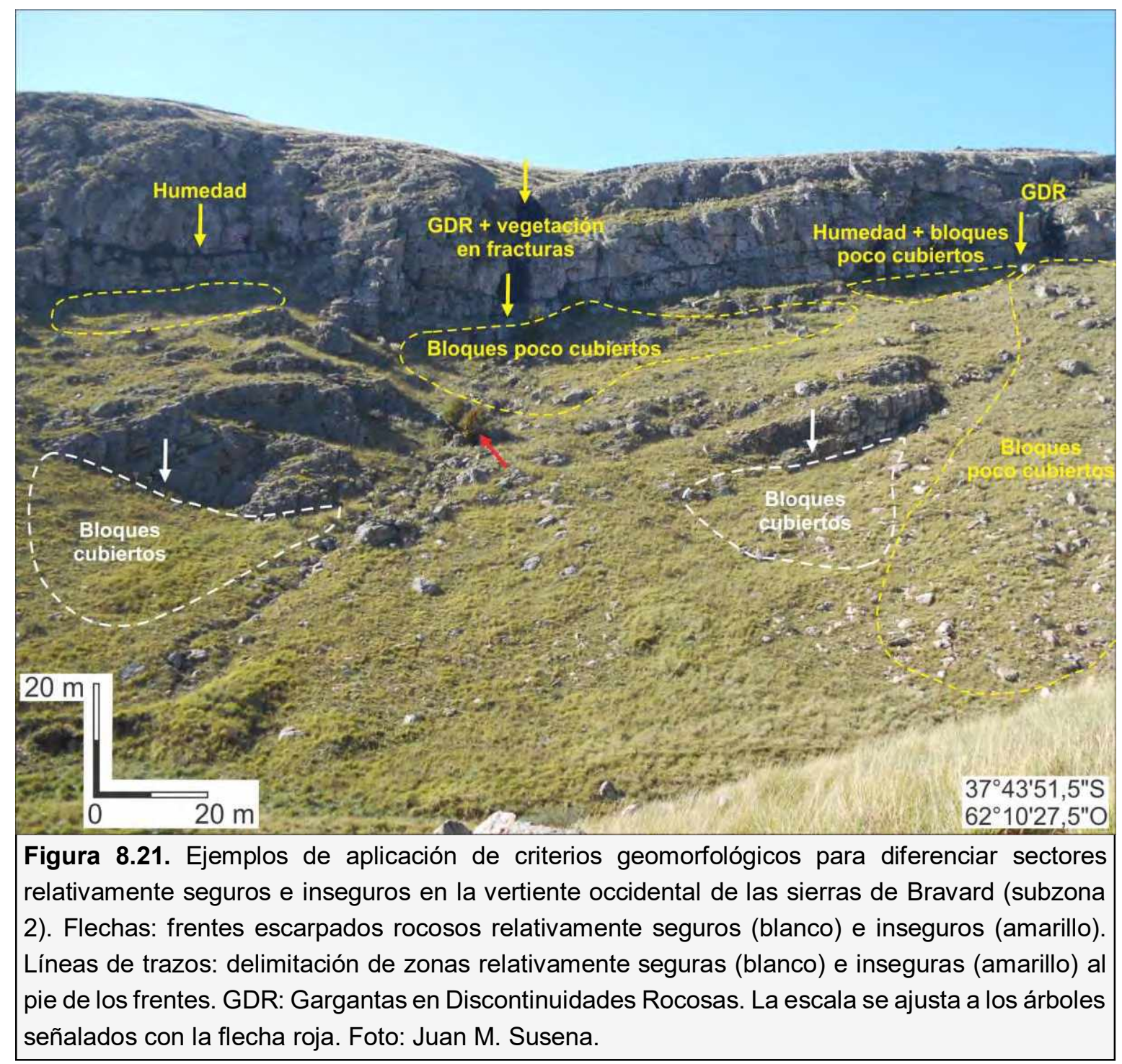

En el caso de las unidades geomorfológicas Gargantas en Discontinuidades Rocosas, debe observarse el estado de los frentes laterales antes de su ascenso, así como los indicadores de edad relativa de los bloques. No debe olvidarse que las gargantas del área se desarrollan principalmente por caídas de rocas, siendo uno de los procesos más comunes, y por lo tanto frecuentes. Se recomienda en este sentido que los ascensos a los cerros se realicen aprovechando entrantes suavizadas de los frentes, sitios en los cuales los frentes han sido destruidos y los afloramientos fueron ahogados por sus propios detritos. 


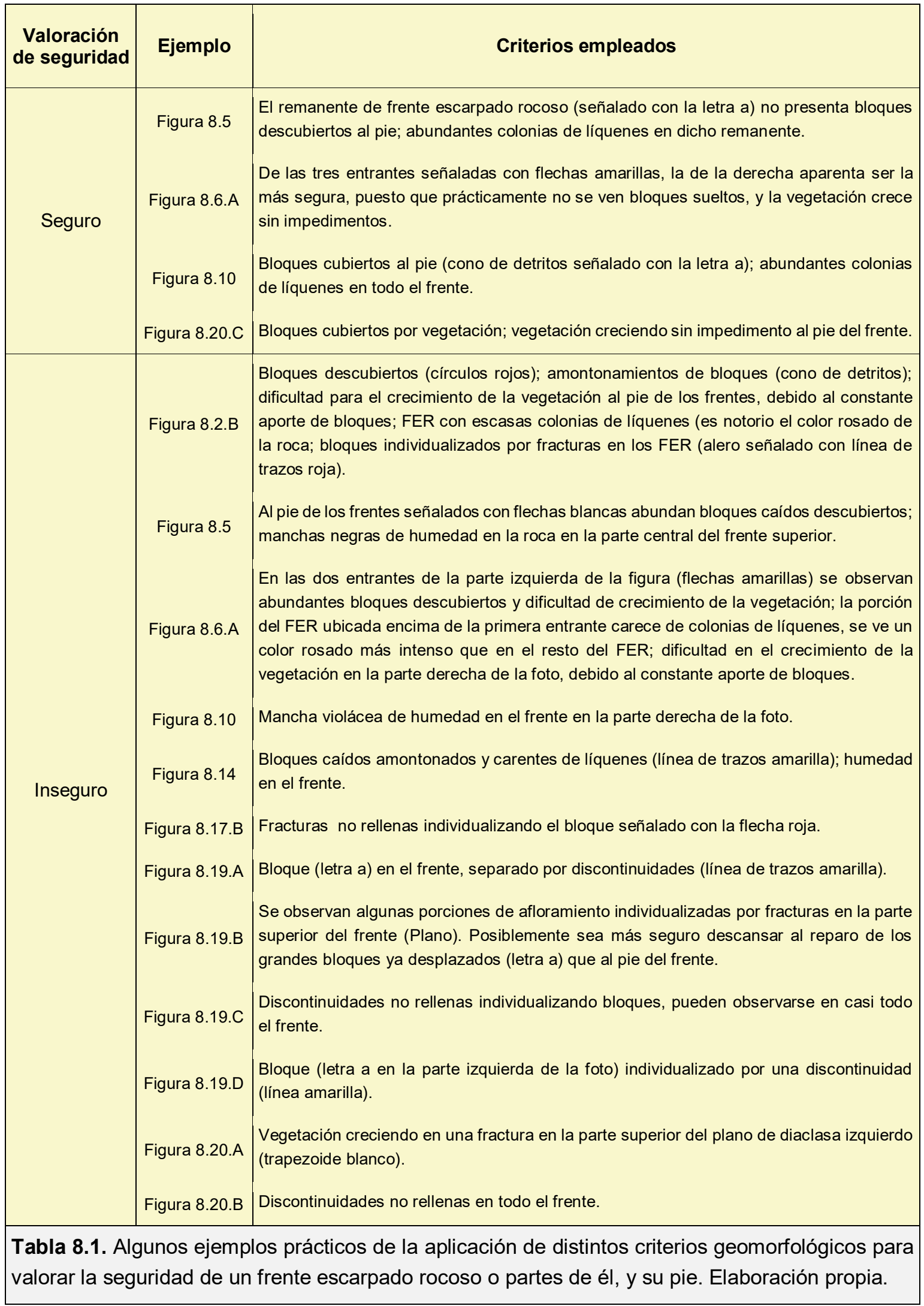


Movimientos en masa en las sierras de Bravard y Curamalal, Sierras Australes de la Provincia de Buenos Aires.

Juan Manuel Susena 


\section{Capítulo 9}

\section{Movimientos en masa en laderas}

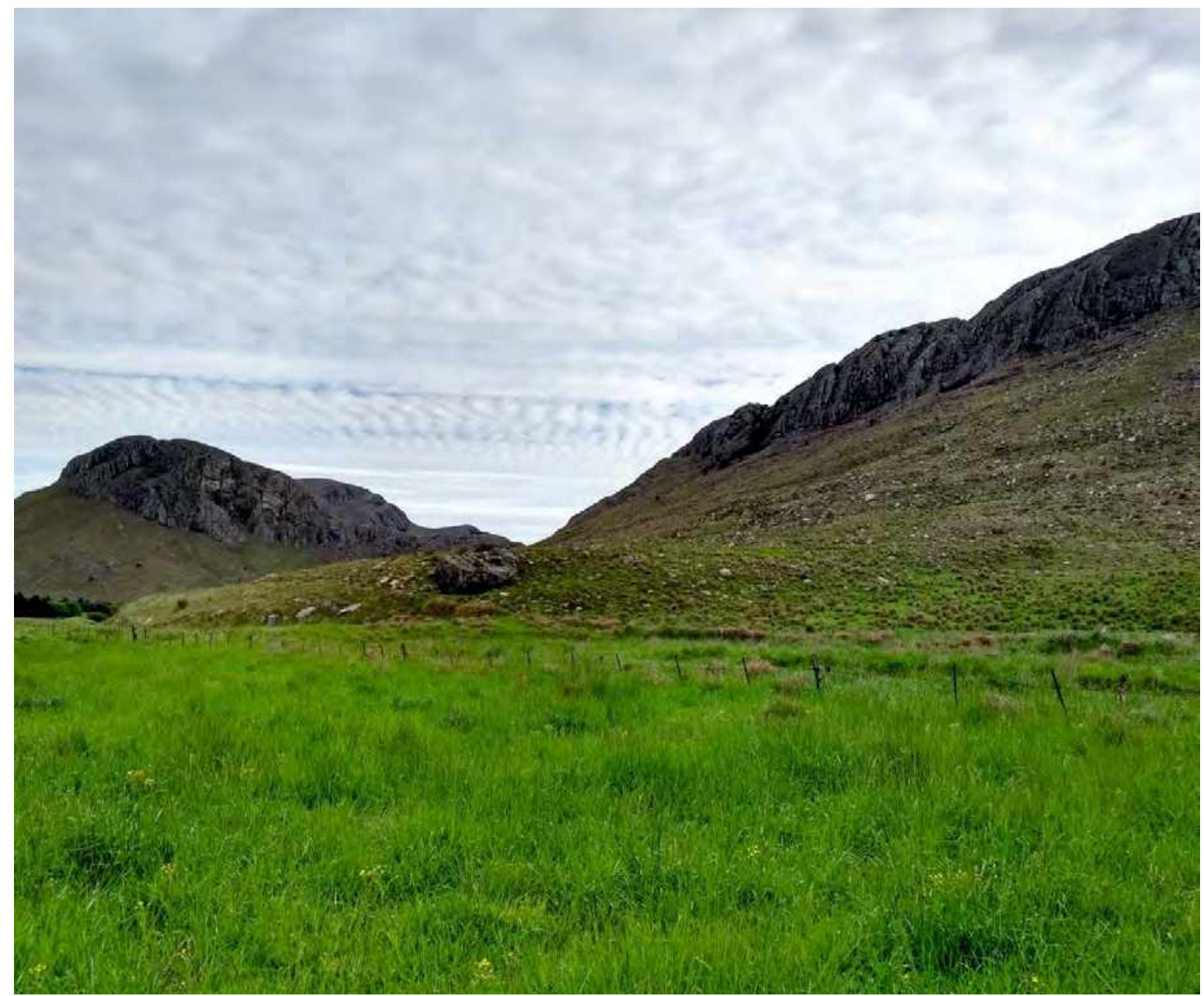

"El bloque durmiente" Un enorme bloque rocoso descansa sin problemas, al lado de un camino, a pesar de haber sido arrastrado por un deslizamiento.

Foto tomada durante una de las últimas campañas. 
Movimientos en masa en las sierras de Bravard y Curamalal, Sierras Australes de la Provincia de Buenos Aires.

Juan Manuel Susena 


\subsection{Objetivos y ordenamiento del capítulo}

Se tratan aquí, de una manera esencialmente descriptiva, los movimientos en masa desarrollados en las laderas. En este capítulo, el término laderas tiene una implicancia fisiográfica, pudiendo ser sinónimo de faldeos; no se relaciona con una unidad geomorfológica concreta, sino con un conjunto de ellas, e involucran la transición entre: 1. Cimas Planas y Divisorias Principales, Frentes Escarpados Rocosos, o localmente Collados y 2. Fajas Aluviales, Incisiones Fluviales o unidades pedemontanas. Los movimientos en masa desarrollados se agrupan según las unidades geomorfológicas más comunes en las laderas: Laderas de Detritos, Laderas Compuestas y Bajada Coluvial Fina. Tipos de movimientos en otras unidades que incluyen roca, como Relieve de Crestas y Depresiones (Suaves o Pronunciadas), ya se trataron en el capítulo anterior. Se incluyen también algunos aspectos relacionados con el reconocimiento de reactivaciones y nuevos movimientos en situaciones concretas. Como se explicó en el Capítulo 3 Metodología, aunque debido a la discontinuidad del registro de las fotos aéreas no se pueda realizar un análisis multi-temporal detallado, las fotos disponibles se utilizaron como un complemento descriptivo de la actividad en localidades concretas.

\subsection{Tipos de laderas en el área estudiada}

Las laderas pueden contener varias unidades y componentes geomorfológicos (Figura 9.1). Siguiendo el modelo de 9 tramos de ladera de Dalrymple et al. (1968), las laderas del área presentan diferentes combinaciones de tramos con presencia de distintas unidades geomorfológicas, donde dominan unos procesos geomorfológicos sobre otros (Figura 9.2 y Tabla 9.1). Los procesos comunes en cada unidad se detallaron en los capítulos previos. Cabe aclarar que en los modelos de ladera se incluyen los taludes, aunque sean componentes geomorfológicos menores, dada su importancia en la interpretación de la dinámica de los movimientos en masa, ya que estos taludes son producidos esencialmente por caídas y vuelcos de roca (véase Capítulo 7 Criterios de reconocimiento de los movimientos en masa y su actividad). 


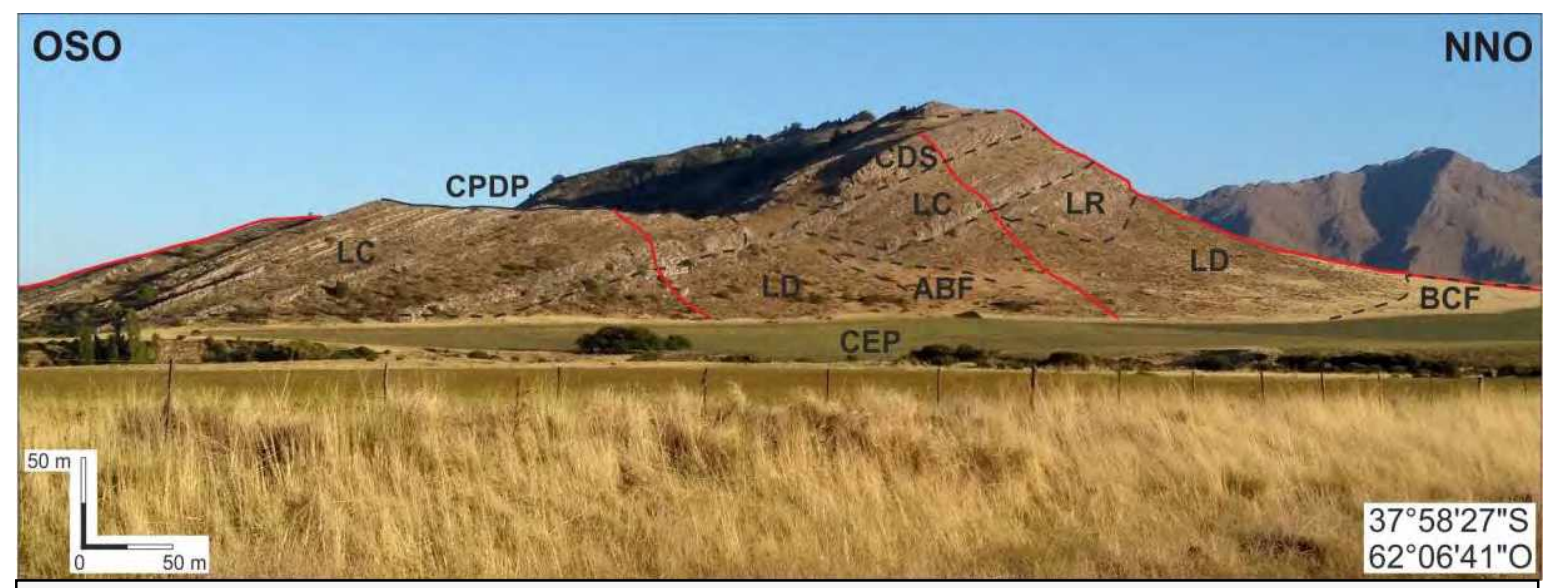

Figura 9.1. Vista al NO, cerro sin nombre ubicado al sur del Río Sauce Chico. Nótese cómo hay distintos tipos de perfiles de ladera (líneas rojas), en una misma secuencia rocosa homoclinal buzante al OSO. ABF: Abanico Aluvial Fino. BCF: Bajada Coluvial Fina. CDS: Relieve de Crestas y Depresiones Suaves. CEP: Cubierta Eólica Periserrana. CPDP: Cimas Planas y Divisorias Principales. LC: Laderas Compuestas. LD: Laderas de Detritos. LR: Ladera Rocosa. La escala y las coordenadas se ajustan al centro de la foto. Foto: Juan M. Susena.

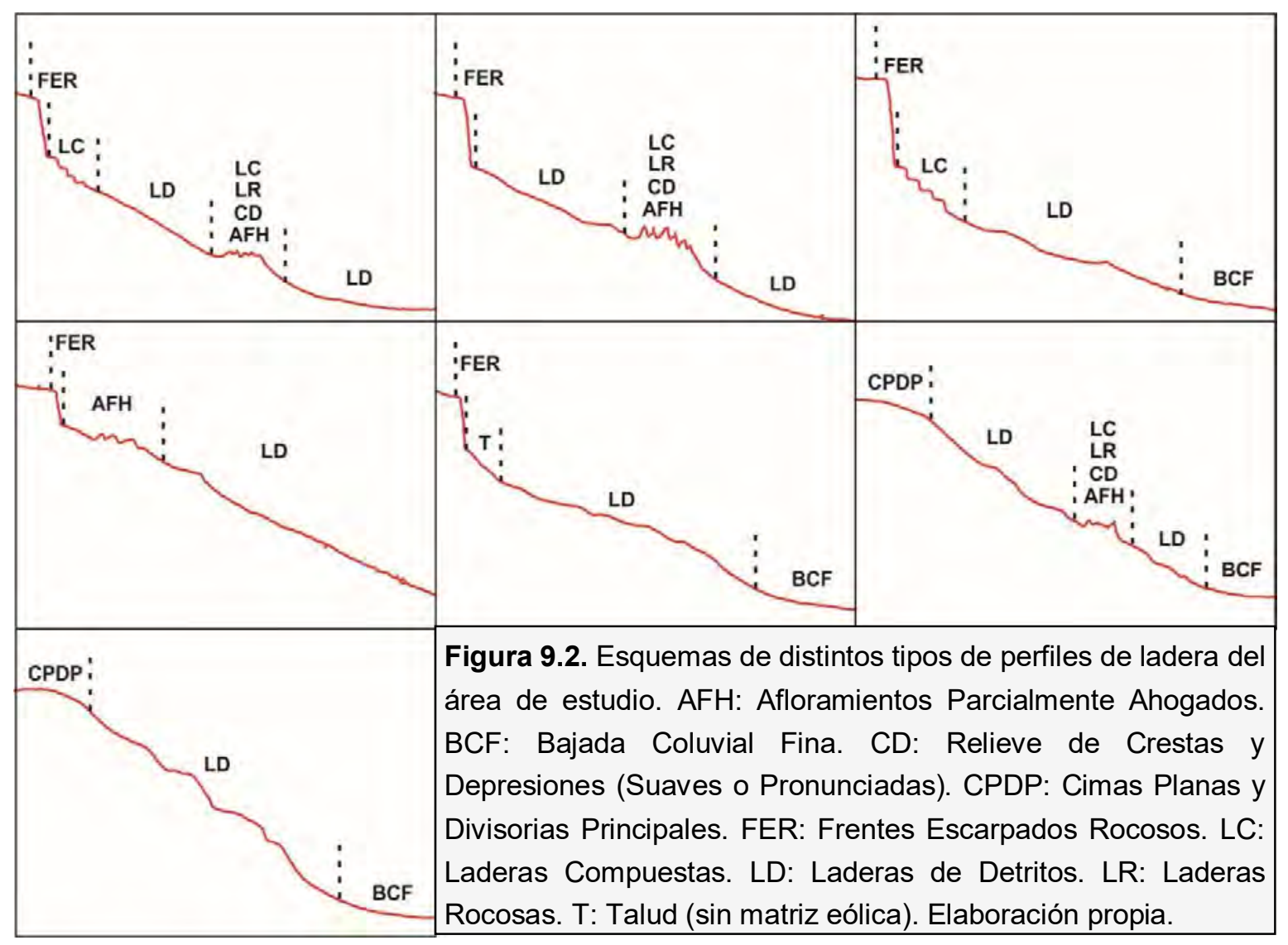




\begin{tabular}{|c|c|c|c|c|c|c|c|c|c|}
\hline Segmento & Materiales & Espesor & \multicolumn{2}{|c|}{ Pendiente } & $\mathrm{C} / \mathrm{V}$ & DESL & FLD & FLT & $\begin{array}{c}\text { Situación } \\
\text { sedimentológica } \\
\text { de la matriz }\end{array}$ \\
\hline $\mathbf{T}$ & Gruesos & ** & \multicolumn{2}{|c|}{$* * *$} & $* * *$ & - & - & - & - \\
\hline LC & $\begin{array}{l}\text { Roca y } \\
\text { Gruesos } \\
\text { >> Finos }\end{array}$ & * & $* * * *$ & * & $* * *$ & * & - & - & Lavaje \\
\hline LD & $\begin{array}{l}\text { Finos y } \\
\text { Gruesos }\end{array}$ & $\star * *$ & \multicolumn{2}{|c|}{ ** } & * & $\star \star * *$ & $* *$ & * & $\begin{array}{c}\text { Transporte y } \\
\text { lavaje }\end{array}$ \\
\hline AFH & $\begin{array}{l}\text { Gruesos y } \\
\text { Roca }\end{array}$ & * & \multicolumn{2}{|l|}{ * } & * & * & - & - & $\begin{array}{l}\text { Depositación y } \\
\text { lavaje }\end{array}$ \\
\hline BCF & $\begin{array}{l}\text { Finos }>> \\
\text { Gruesos }\end{array}$ & $* * *$ & \multicolumn{2}{|l|}{ * } & - & * & - & $* * *$ & $\begin{array}{l}\text { Depositación y } \\
\text { transporte }\end{array}$ \\
\hline
\end{tabular}

Tabla 9.1. Segmentos de ladera típicos y aspectos morfológicos, sedimentológicos y tipos de movimientos. T: Taludes. LC: Laderas Compuestas. LD: Laderas de Detritos. AFH: Afloramientos Parcialmente Ahogados. BCF: Bajadas Coluviales Finas. C/V: caídas y vuelcos de roca. DESL: deslizamientos. FLD: flujos de detritos. FLT: flujos de tierra. La cantidad de asteriscos $\left(^{*}\right)$ indica el desarrollo relativo de cada aspecto considerado. ${ }^{*}: 0-\mathrm{dm},<30^{\circ}$, escasos movimientos en masa. ${ }^{* *}$ : $\mathrm{dm}-\mathrm{m} ; 20-30^{\circ}$, movimientos en masa habituales. ${ }^{* * *}$ : $\mathrm{dm}-\mathrm{m},>40^{\circ}$, abundantes movimientos. ${ }^{* * * *}$ : laderas sub-verticales. Elaboración propia.

\subsection{Movimientos en masa en las unidades Laderas de Detritos y Laderas Compuestas}

En Laderas de Detritos y Laderas Compuestas, el tipo de movimiento en masa está condicionado por el espesor de los detritos, la profundidad del contacto con la roca o las calcretas, y en algunos casos la presencia de un horizonte arcilloso bien desarrollado. La abundancia relativa de los movimientos y su expresión morfológica son en parte influenciados por la orientación de las laderas (véase Capítulo 14 Análisis de susceptibilidad). Los movimientos allí desarrollados son principalmente deslizamientos rotacionales y traslacionales, flujos de detritos, caídas de rocas y reptación. La superficie de los deslizamientos y flujos suele ser del orden de cientos o miles de metros cuadrados, incluso pueden superar los $30.000 \mathrm{~m}^{2}$; asimismo, las terracettes pueden ocupar decenas a centenas de metros (Susena y Gentile, 2017). Estos rasgos son reconocibles en imágenes satelitales y fotos aéreas, mientras que otros sólo pueden identificarse a escala mesoscópica, como la gran mayoría de los depósitos producidos por caídas de rocas. Todos estos movimientos pueden estar aislados, pero generalmente aparecen en conjunto, dando a las laderas una topografía irregular de montículos y depresiones (hummocky, véase Figura 7.6 en el Capítulo 7 Criterios de reconocimiento de movimientos en masa y 
Movimientos en masa en las sierras de Bravard y Curamalal,

Sierras Australes de la Provincia de Buenos Aires.

Juan Manuel Susena

su actividad). En el caso de las caídas de rocas, pueden reconocerse sectores con mayor actividad de caídas que otros, evidenciados por modificaciones en la vegetación.

\subsubsection{Deslizamientos rotacionales}

Este tipo de movimientos se reconoce en el área principalmente en laderas de umbría y en sectores con espesores de detritos superiores a unos $3 \mathrm{~m}$. Son más comunes en los tramos medios de las laderas, a cierta distancia ladera abajo de los afloramientos rocosos, indicando que para su producción se requiere cierto espesor de detritos (Figuras 9.3 y 9.4). No obstante, algunos deslizamientos se encontraron a menos de $10 \mathrm{~m}$ de los afloramientos, pudiendo relacionarse a grandes espesores de detritos contiguos a frentes escarpados rocosos ahogados, o tratarse de movimientos que afectan a los afloramientos. De cualquier manera, son poco frecuentes más allá de los $125 \mathrm{~m}$ de los afloramientos, donde el espesor de las laderas decrece, desarrollándose Bajadas Coluviales Finas.

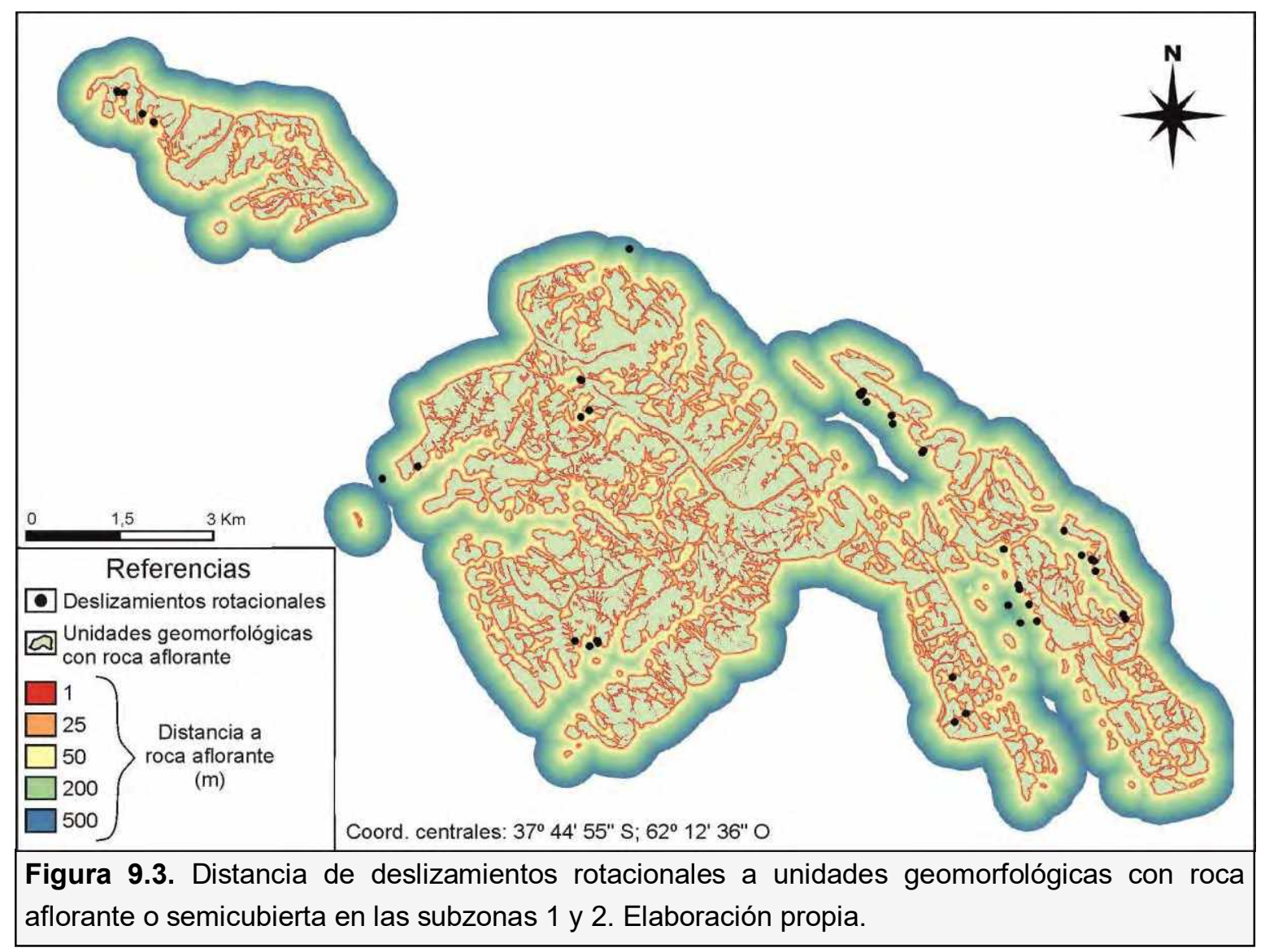




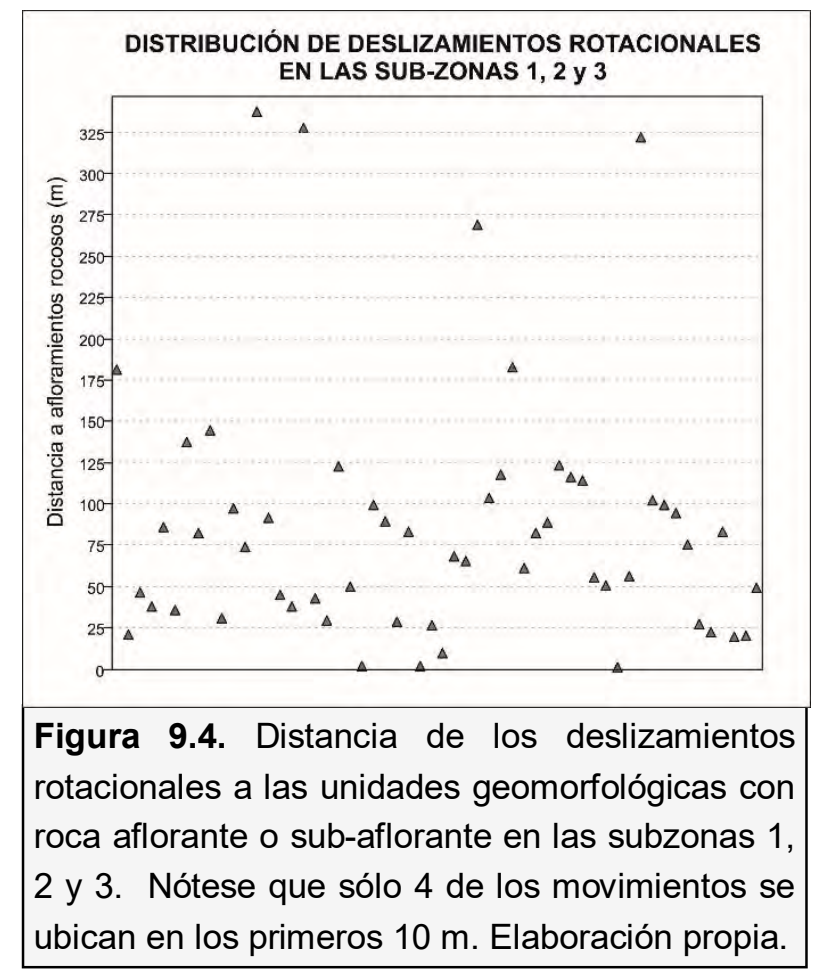

Las escarpas en general son subverticales, con desarrollo de terracettes y a veces degradadas por pequeños deslizamientos rotacionales. Los últimos pueden carecer de matriz, como respuesta a un lavaje intenso en la transición entre el terreno no afectado y la escarpa. De cualquier manera, estos deslizamientos rotacionales menores son más comunes en la zona proximal de la superficie de ruptura (Figura 9.5 en la página siguiente). Las zonas de hundimiento superan muchas veces los $3 \mathrm{~m}$ de profundidad, y suelen tener inclinaciones menores que las del terreno no afectado. Esta característica, junto a la presencia de la acumulación inmediatamente por debajo, a veces inclinada en contrapendiente, propicia la acumulación de agua. Se encontraron allí cuerpos de agua estancos en invierno y vegetación más verde que el entorno en verano, mostrando que localmente estas superficies cóncavas favorecen la concentración de agua. Una característica común allí es que los detritos están sepultados por una cobertura de material fino, proveniente del lavaje de la superficie de ruptura. Al respecto, las superficies de ruptura lavadas suelen mostrar concentraciones de carbonato de calcio diseminado en la masa y suelos arcillosos, siendo esto evidencia de un control geohidrológico en cuanto a la concentración de agua en sub-superficie, que contribuye al desarrollo de estos movimientos (véase Capítulo 11 Interacciones entre movimientos en masa y escurrimiento superficial/sub-superficial).

De una manera similar, deslizamientos rotacionales se encontraron en las partes altas de laderas modeladas a partir de remanentes de la Brecha Cerro Colorado, en sectores donde esta unidad aflora alternadamente en superficie, de una manera similar a las Laderas 


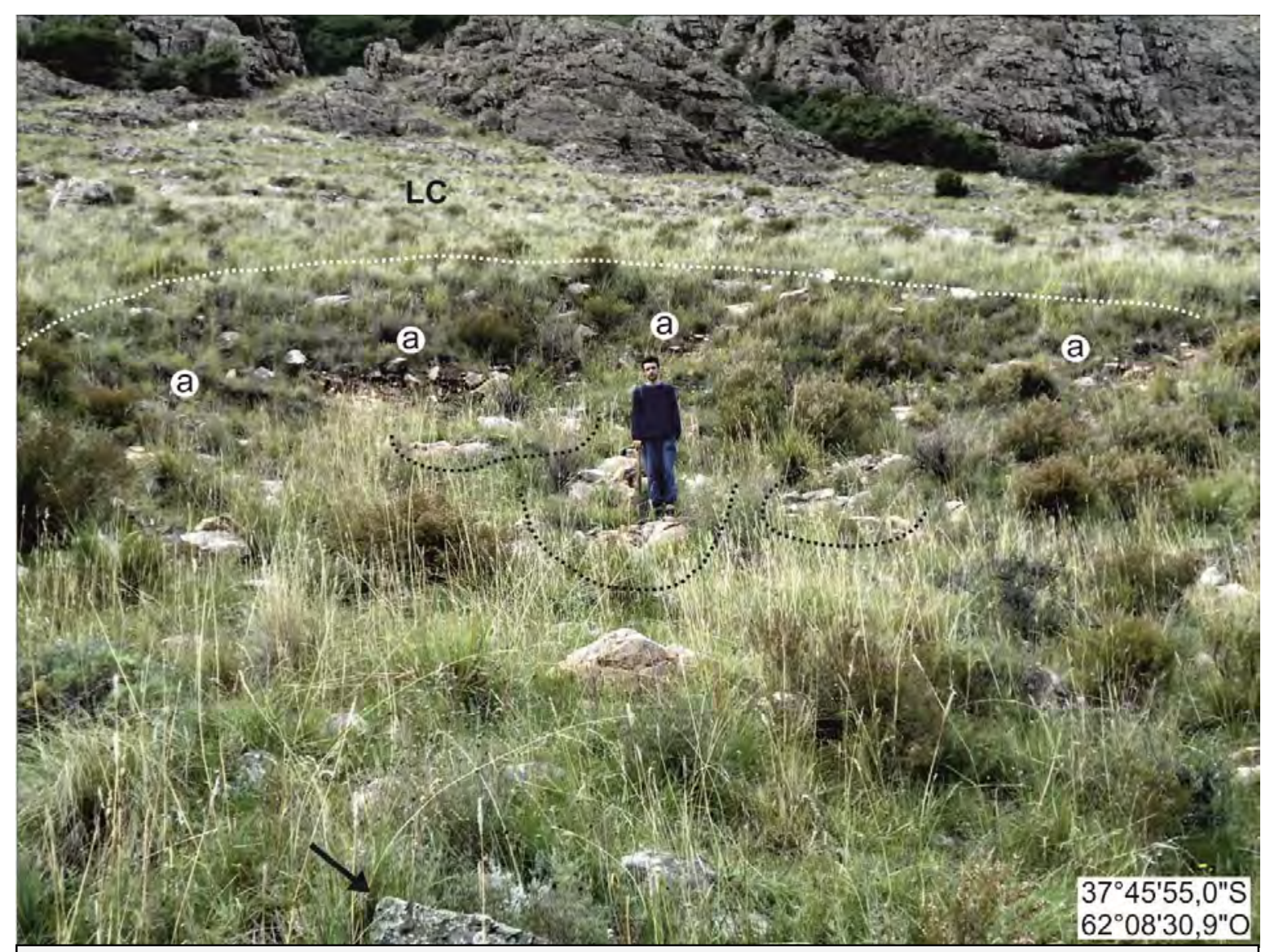

Figura 9.5. Deslizamiento rotacional en Ladera de Detritos occidental de las sierras de Bravard, subzona 2, producido antes del 25/02/1967. a: escarpa degradada del deslizamiento; en lugares concretos, la vegetación no puede crecer debido al lavaje de la matriz. Línea de puntos blanca: corona principal. Líneas de puntos negras: deslizamientos rotacionales menores en la superficie de ruptura del deslizamiento mayor. Flecha: bloque rocoso con colonias de líquenes en la zona de acumulación (sólo se ve una pequeña parte de la acumulación en la foto); la inmensa mayoría de los bloques de la acumulación comparten esta característica, indicando antigüedad del movimiento. LC: Ladera Compuesta. Foto: Juan M. Susena y Rodolfo O. Gentile.

Compuestas, pero dominada por Detritos de Ladera. En la ladera sur del remanente de una paleosuperficie ubicada en los faldeos orientales del cerro Guanaco, un deslizamiento de unos $45 \mathrm{~m}$ de longitud y una profundidad de la zona de hundimiento de unos $2,5 \mathrm{~m}$, afectó a estos afloramientos. La presencia de afloramientos en la corona podría indicar que la roca controla el desarrollo del deslizamiento, sea por la concentración de agua en el contacto entre la roca y los detritos o por la mayor resistencia mecánica de la roca que podría poner término al movimiento (Figura 9.6 en la página siguiente). 


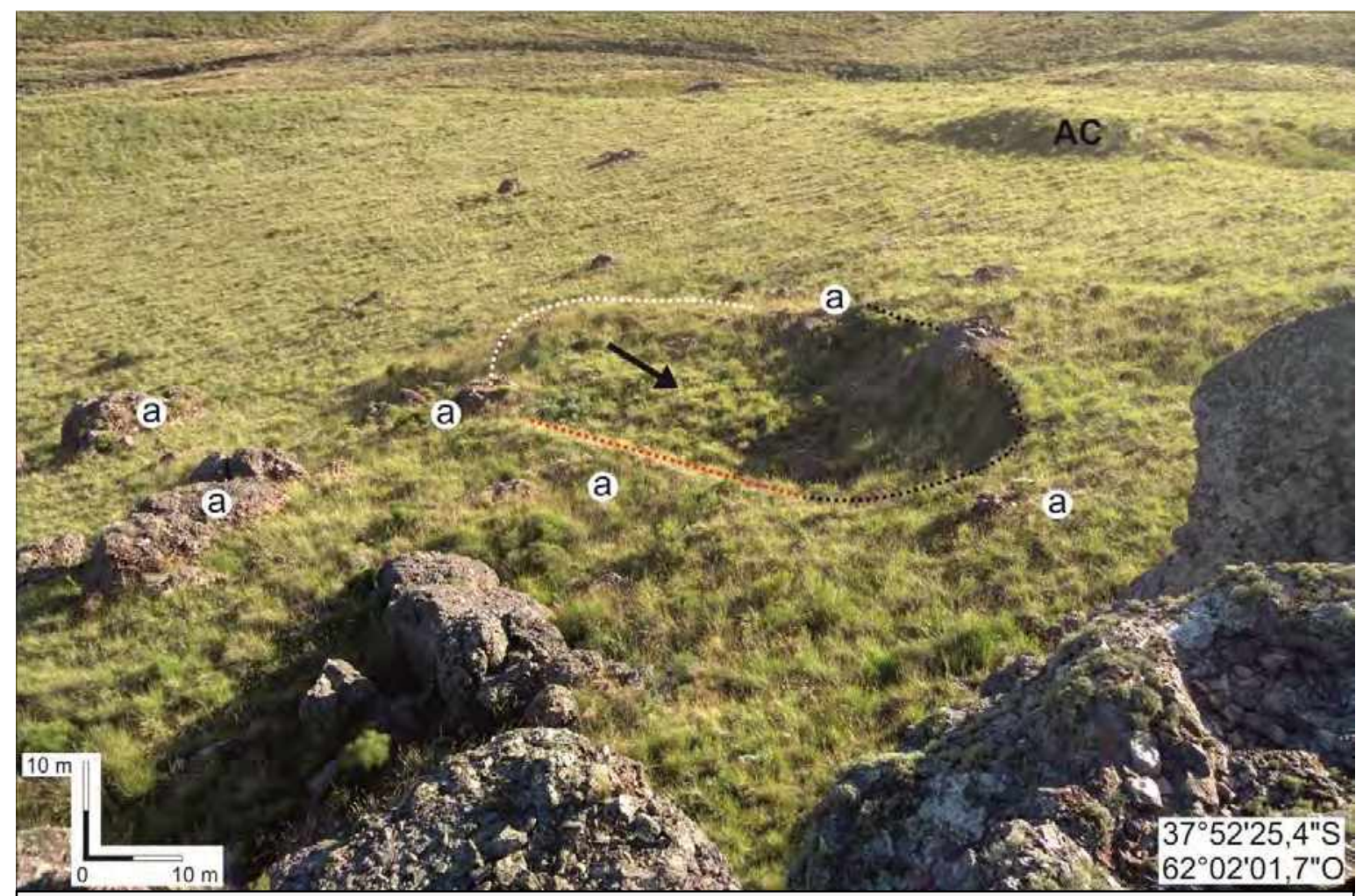

Figura 9.6. Deslizamiento rotacional en ladera de Piedemonte Aluvial Antiguo en la vertiente oriental del cerro Guanaco, sierras de Bravard. a: afloramientos rocosos. Línea de puntos negra: corona y flanco derecho del deslizamiento. Línea de puntos roja: el flanco izquierdo es rectilíneo, asociado a un afloramiento rocoso. Línea de puntos blanca: acumulación. Flecha: parte de la acumulación inclina en sentido opuesto a la pendiente de la ladera, indicando rotación de la masa. AC: acumulación de deslizamiento traslacional. Ambos movimientos son los representados en la Figura 9.7. Foto: Juan M. Susena.

\subsubsection{Deslizamientos traslacionales}

Se desarrollan tanto cerca como lejos de los afloramientos rocosos, en distintos tramos de las laderas y con altas o bajas pendientes. Se caracterizan por tener un eje mayor longitudinal a la pendiente y uno menor, transversal a la misma, y el ángulo de la superficie de la masa desplazada es similar al del terreno no afectado, salvo en la punta, donde el ángulo es mayor. El desplazamiento de la masa en general es mayor que en los deslizamientos rotacionales. Las acumulaciones pueden presentar una forma de $\mathrm{V}$ característica en sectores de altas pendientes, dando la apariencia de flujos de detritos, pero no presentan albardones laterales como los flujos. Las zonas de hundimiento son, en relación con las dimensiones generales del movimiento, menos profundas que en los deslizamientos rotacionales, por lo cual los cuerpos de agua en la zona de hundimiento son poco frecuentes. Las superficies de ruptura se ubican en el contacto con la roca o con 
Movimientos en masa en las sierras de Bravard y Curamalal,

Sierras Australes de la Provincia de Buenos Aires.

Juan Manuel Susena

un horizonte arcilloso. Su desarrollo se vincula a cambios en la consistencia o comportamiento hidrológico del material.

En Laderas de Detritos aledañas al Piedemonte Aluvial Antiguo mencionado en la sección anterior, un deslizamiento traslacional de unos $80 \mathrm{~m}$ de longitud y una zona de hundimiento de unos $4 \mathrm{~m}$ es muy conspicuo en la ladera (Figura 9.7). La Brecha Cerro Colorado no aflora en las cercanías del movimiento, pero se encontraron fragmentos de esta unidad en la zona de hundimiento, indicando que los afloramientos están en sub-superficie, cerca de la superficie de ruptura. La presencia de esta unidad rocosa cerca de la superficie condicionaría el flujo subsuperficial de agua, aumentando la presión poral de la masa suprayacente, propiciando el movimiento. El hecho de que estos movimientos sólo aparezcan en

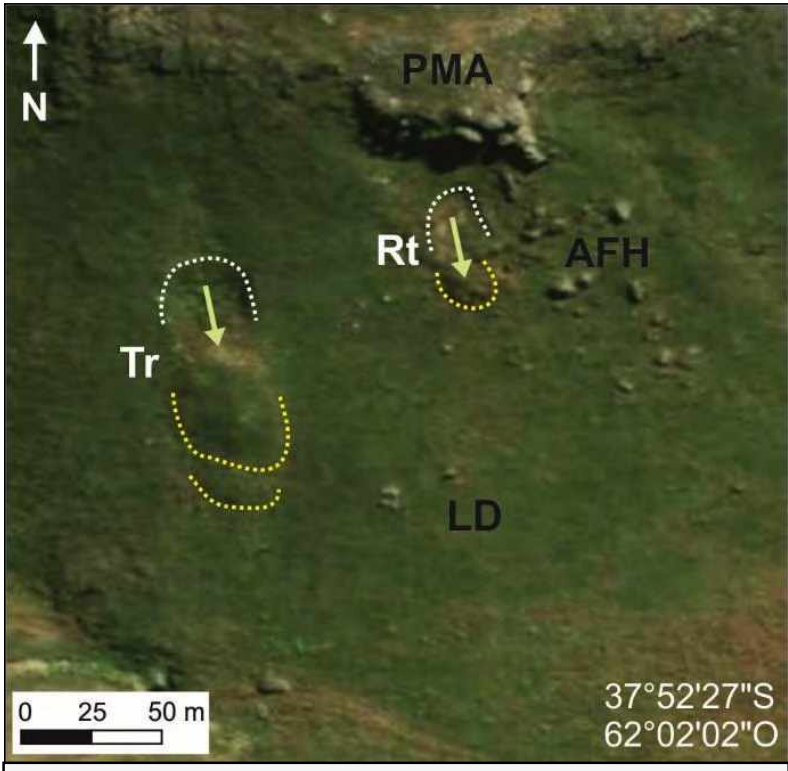

Figura 9.7. Deslizamientos en la Ladera de Detritos (LD) aledaña a Piedemonte Aluvial Antiguo (PMA), en la vertiente oriental del cerro Guanaco (sierras de Bravard). Rt: deslizamiento rotacional representado en la Figura 9.6. Tr: deslizamiento traslacional. Líneas blancas: escarpa. Líneas amarillas: acumulaciones. Flechas: dirección del movimiento. AFH: Afloramientos Parcialmente Ahogados. Elaboración propia a partir de composición de imagen satelital de World View-2 (ESRI).

las cercanías de la roca aflorante o sub-aflorante es otro elemento que permite considerar que el contraste geohidrológico de los materiales controla la profundidad de los deslizamientos traslacionales.

Los grandes deslizamientos traslacionales se producen en sectores con gran espesor de detritos con pendientes bajas o altas, o en sectores con menor espesor, pero de mucha pendiente. Las escarpas muchas veces son rocosas y se observa allí surgencia de agua (manantiales), pudiendo tratarse de antiguos frentes escarpados rocosos que estaban sepultados por detritos, ahora nuevamente expuestos por el desarrollo de los movimientos. Esto se vio en las laderas suroccidentales de un valle intraserrano en las sierras de Bravard, cerca del cerro Puntudo, donde grandes deslizamientos traslacionales dejaron al descubierto escarpas rocosas con diaclasas abiertas por las cuales circula agua. En el cerro Pan de Azúcar se encontró algo similar, en relación con el Mb. Cementado de los Detritos de Ladera. Un deslizamiento traslacional se produjo dejando al descubierto las calcretas; la escasez de bloques de esta unidad en la zona de hundimiento (de unos $4 \mathrm{~m}$ de profundidad) permite intuir que las calcretas son discontinuas y que la escarpa 
actualmente expuesta era el límite "roca"-regolito. Una reactivación lateral (ensanchante) de este movimiento, actualmente en una etapa incipiente, muestra una discontinuidad neta del Mb. Cementado en la superficie de separación, y la ausencia de éste en la masa desplazada, como si fuera un frente escarpado rocoso (Figura 9.8). La superficie de separación, de apenas unos $50 \mathrm{~cm}$ de ancho y unos $25 \mathrm{~m}$ de longitud, está situada a más de dos metros por debajo de la masa desplazada, y más de 4 por debajo de la superficie original del terreno. El agua caída en esta grieta puede llegar rápidamente a una profundidad considerable dentro de los Detritos de Ladera, aumentando la presión de poros de la parte profunda de la masa, manteniéndose relativamente seca la parte superficial.

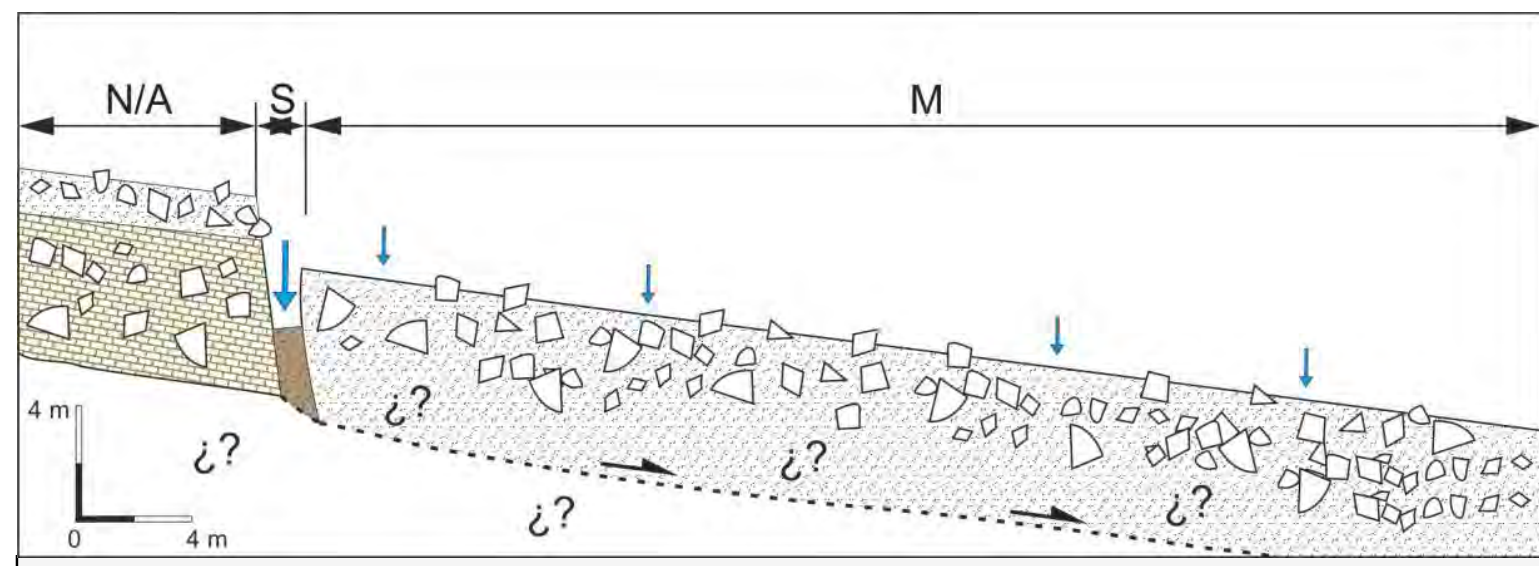

Figura 9.8. Perfil esquemático de deslizamiento traslacional en Ladera de Detritos occidental del cerro Pan de Azúcar (subzona 3, 3756’28,9” S; 62¹0’54,8” O). Traza gris: Detritos de Ladera, Mb. Suelto. Traza amarilla: Detritos de Ladera, Mb. Cementado. ¿?: incertidumbre sobre el material sub-superficial, aparente ausencia del Mb. Cementado. Traza castaña: material fino acumulado en la superficie de separación (S). N/A: terreno no afectado. M: masa desplazada. Línea de trazos: ubicación inferida de la superficie de ruptura. Flechas negras: dirección del movimiento. El tamaño de las flechas azules indica que el agua alcanza más rápido la superficie de ruptura en el sector de la superficie de separación. Elaboración propia.

Este tipo de movimiento es común también en las cercanías de cursos de agua, en contacto con planicies de inundación o directamente afectando las barrancas (ver capítulo siguiente). En estos casos, la superficie de ruptura es triangular con el ápice ladera arriba, morfología que se produce cuando el movimiento se origina por la remoción del soporte subyacente. En casos de actividad múltiple, la unión lateral de las escarpas resulta en una morfología vista en planta cóncavo-convexa respecto a la pendiente (Figura 9.9 y 10.9 en el siguiente capítulo); esta morfología sólo se observó en deslizamientos traslacionales en contacto con las Unidades Aluviales. 


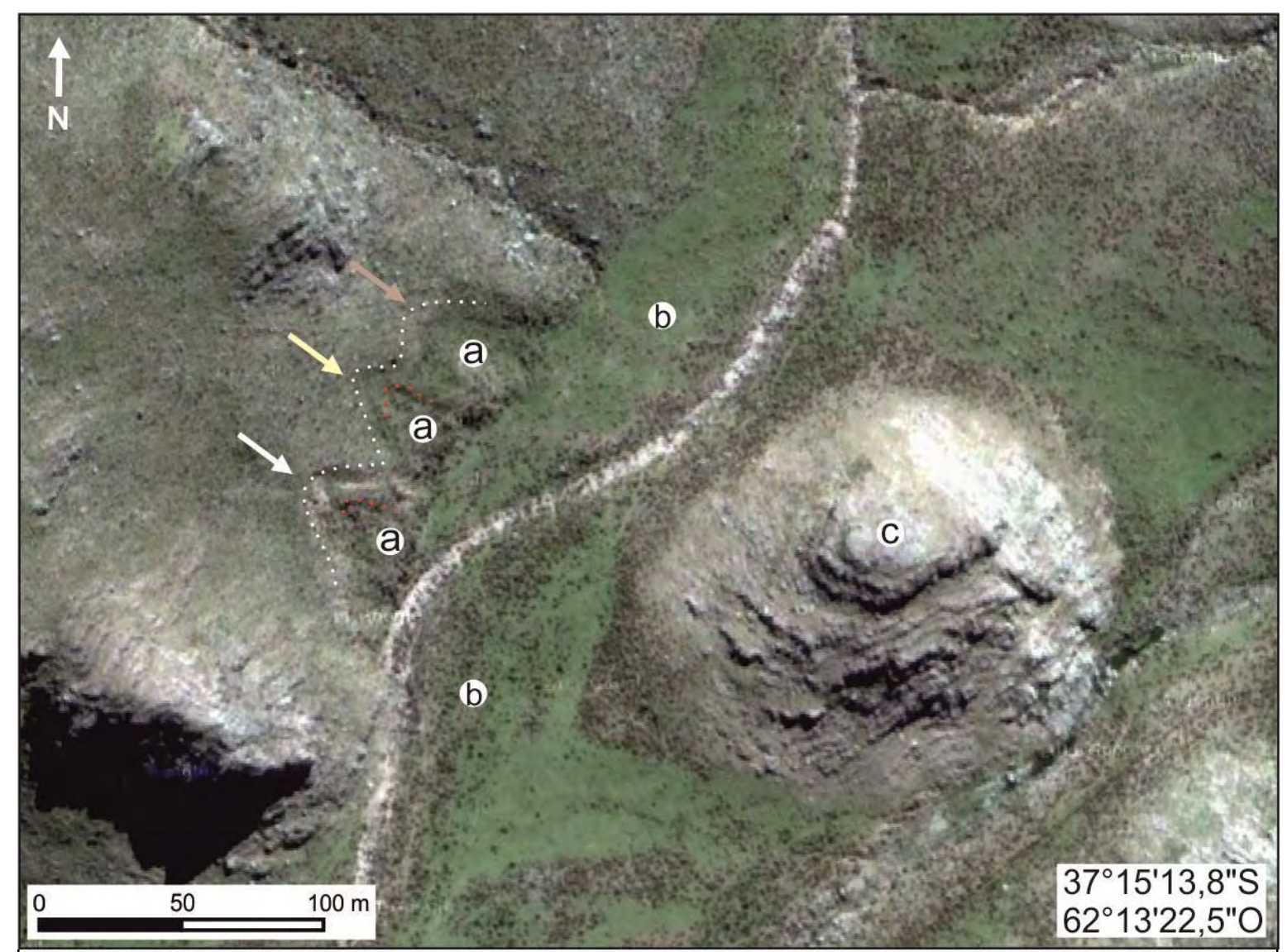

Figura 9.9. Deslizamientos traslacionales múltiples en las laderas de un valle intraserrano, en los faldeos occidentales del Cdón Lehmann-Hinojo Grande (subzona 2). a: masa desplazada. Línea punteada blanca: escarpas unidas, desarrollando una morfología vista en planta cóncavo-convexa respecto a la pendiente. Flechas: la antigüedad de los movimientos aumenta hacia el NE. Línea de puntos roja: movimientos menores. b: planicie de inundación/terrazas bajas. c: mogote (20-25 $\mathrm{m}$ topográficamente por encima de la planicie). Elaboración propia a partir de una composición de imagen satelital de World View-2 (Google Earth).

\subsubsection{Flujos de detritos}

Los flujos de detritos de las laderas se encuentran tanto en sectores de altas pendientes como de pendientes intermedias, y generalmente en tramos medios a distales. Pueden encontrarse en laderas con mucho o poco espesor de detritos, y tienen una morfología diversa. Cabe destacar que estos movimientos tienen algunas diferencias con flujos de detritos típicos en la bibliografía, por encontrarse en laderas donde la concentración de agua es incipiente; no obstante, se los clasifica como tales porque tienen rasgos morfológicos similares, y su desarrollo se asocia a un mayor contenido de agua en la masa, que permite una deformación interna en todo el material. Los flujos del área son más largos que anchos y la zona de hundimiento es poco profunda. El principal rasgo característico de muchos de estos movimientos es la presencia de albardones laterales más elevados que 
el terreno no afectado, y una depresión entre ambos albardones, que concluye con una acumulación de morfología lobada. Los albardones y la punta están conectados entre sí, presentando una morfología de "V", indicadora de una mayor velocidad del movimiento en la punta que en los laterales. En casos concretos, puede desarrollarse sólo un albardón. Los albardones pueden tener materiales finos o prescindir de ellos; la ausencia de materiales finos en este caso no implica necesariamente degradación de los albardones, por lo cual no puede utilizarse como criterio de antigüedad. La vegetación de los albardones, cuando está presente, es arbustiva, elemento que permite diferenciarlos de la zona de hundimiento, donde es más frecuente el pastizal, debido a un mayor contenido de humedad (Figura 9.10). Cuando los albardones son bajos y la vegetación de la zona de hundimiento es muy alta, resulta difícil percibir en el campo la diferencia altimétrica, por lo

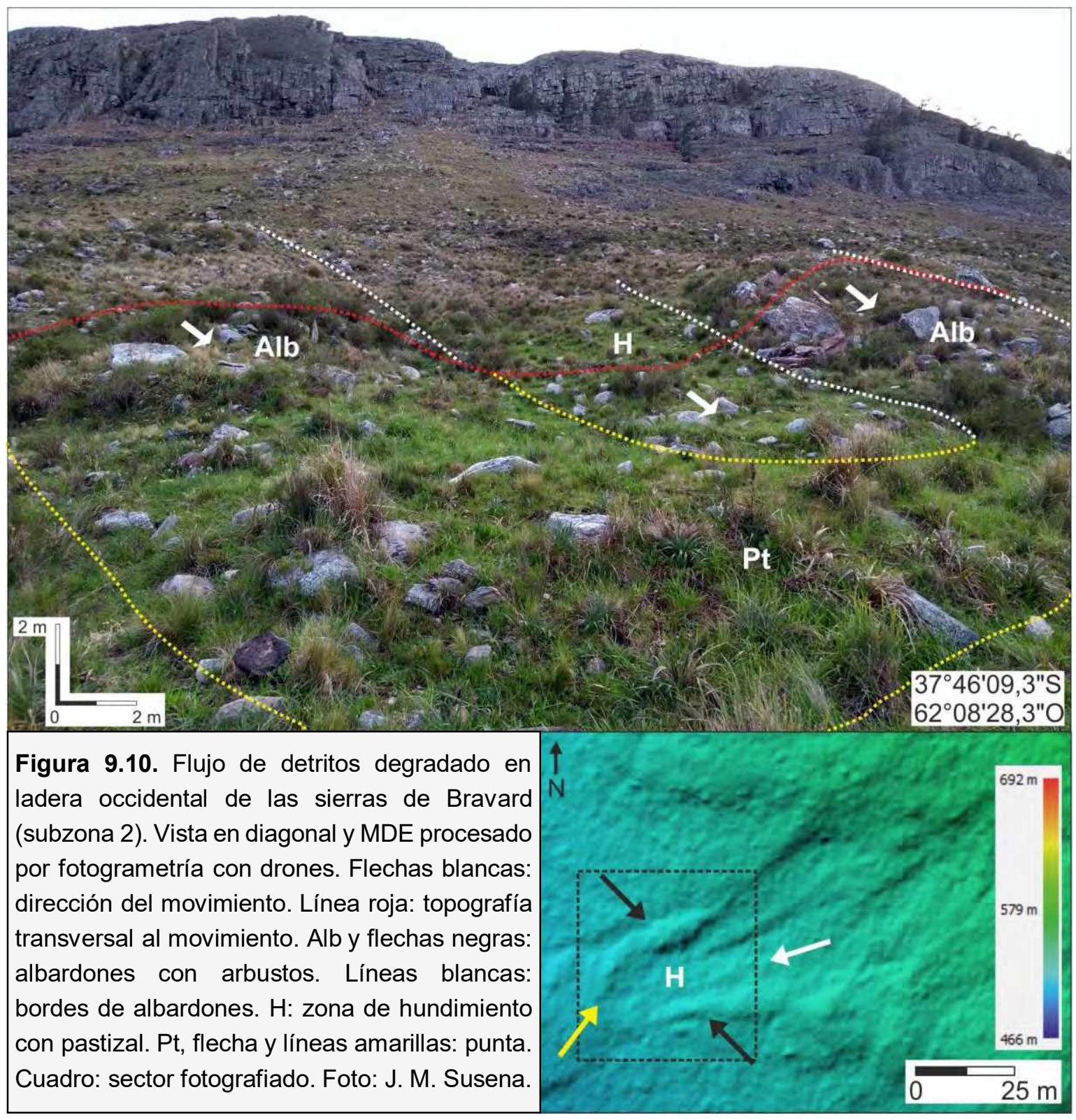


Movimientos en masa en las sierras de Bravard y Curamalal,

Sierras Australes de la Provincia de Buenos Aires.

Juan Manuel Susena

cual es necesario "caminarlos" para identificarlos. En las laderas occidentales de las sierras de Bravard en las cercanías del abra de Hinojo, los flujos se identificaron a partir de fotogrametría de detalle con drones, pasando desapercibidos en el campo; en el terreno sólo pudieron reconocerse con el pasto corto, en una temporada en que el ganado estuvo pastando en dicho sector.

Los flujos del área se relacionan con canalizaciones incipientes en las laderas - con depresiones locales. Se los encuentra rodeados por acumulaciones de deslizamientos, las cuales contribuyen a la concentración del agua en el terreno no afectado antes del desarrollo del flujo. En sectores de altas pendientes, los flujos aparecen cerca del límite entre los detritos $y$ frentes escarpados rocosos laterales (como Relieve de Crestas y Depresiones Pronunciadas o Laderas Rocosas), pudiendo los frentes escarpados y sus entrantes influir en la concentración del escurrimiento no encauzado en las

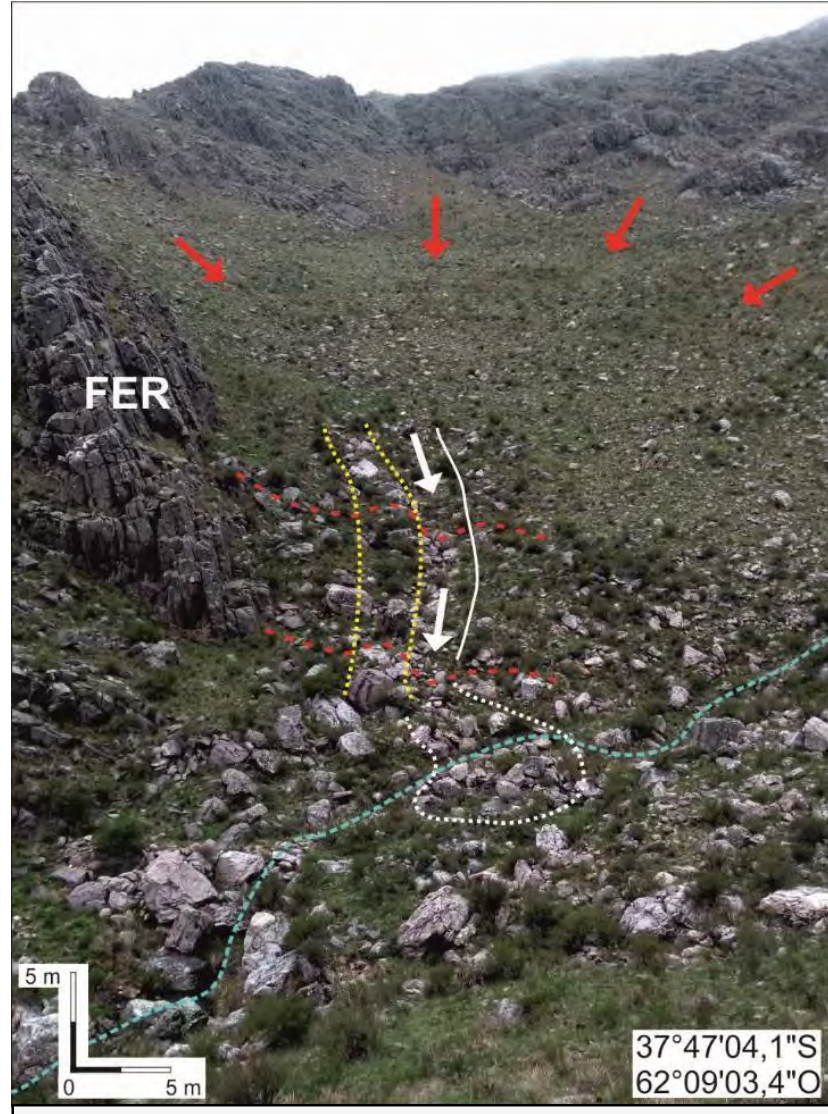

Figura 9.11. Flujo de detritos degradado en ladera de un valle intraserrano oriental del Cdón. Hinojo Grande (subzona 2). Línea blanca: límite con el terreno no afectado. Línea punteada blanca: acumulación (parte de los bloques pudieron ser agregados por caídas). Líneas amarillas: albardón. Flechas: dirección del flujo. Líneas rojas: refuerzo visual del perfil transversal al movimiento. Línea celeste: curso de agua. FER: Frente Escarpado Rocoso. Flechas rojas: concentración del escurrimiento superficial debido a la presencia de entrantes en la roca. Foto: Juan M. Susena. laderas durante lluvias intensas (Figura 9.11).

\subsubsection{Flujos de tierra}

Otro tipo de movimientos en Laderas de Detritos son los flujos de tierra. Se desarrollan tanto en tramos de ladera proximales, como medios y distales, con pendientes de $20-25^{\circ}$, en sectores donde pueda concentrarse agua, preferentemente de umbría. Presentan una morfología variable, y pueden tener escarpas afines a las de deslizamientos rotacionales, aunque algo más irregulares. Si bien para algunos autores estos movimientos podrían 
clasificarse como deslizamientos traslacionales, en esta tesis se incluyen entre los flujos de tierra, en el sentido de que la deformación se distribuye en toda la masa y no sólo en un plano concreto como sucede en los deslizamientos. El movimiento de la masa es recto en la dirección de la pendiente y de escaso recorrido (Figura 9.12). La masa presenta una deformación notable, expresada en un estrangulamiento en la parte proximal o central de la masa y una punta de forma lobulada, o la presencia de irregularidades en toda la masa, similar a una topografía hummocky de escasas dimensiones (Figuras 9.13 y 9.14).

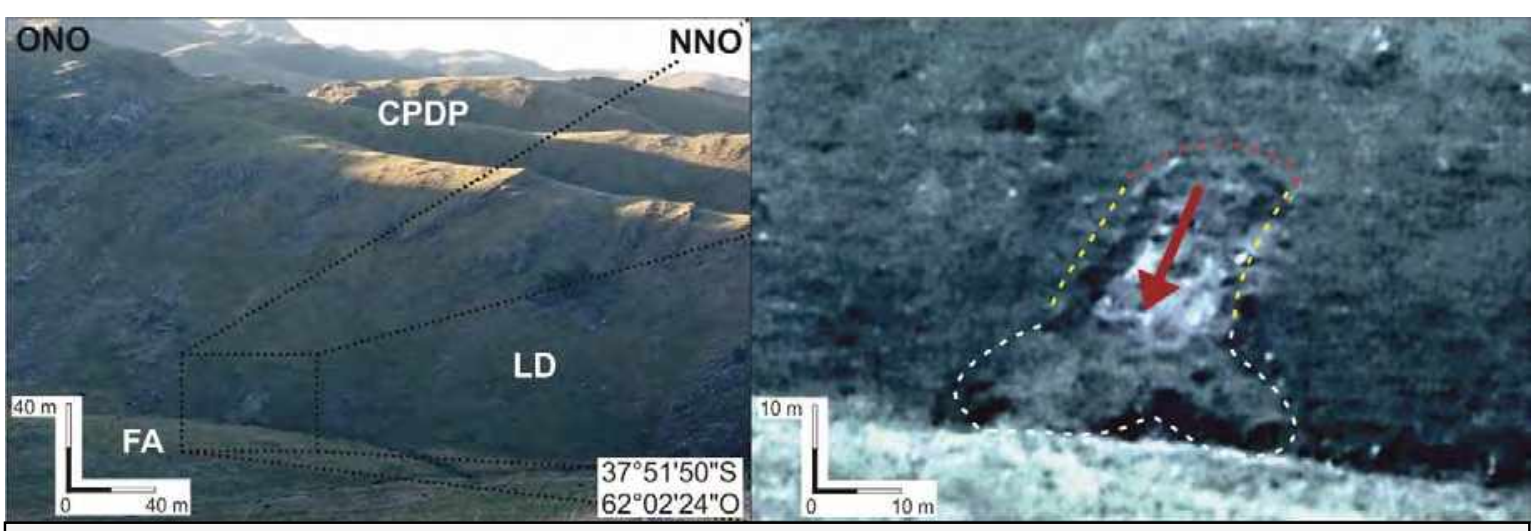

Figura 9.12. Vista al NO de un flujo de tierra en Ladera de Detritos (LD) de un valle oriental del cerro Guanaco, Sierras de Bravard. Línea roja: escarpa. Líneas amarillas: flancos. Línea blanca: acumulación. Flecha: dirección del movimiento. CPDP: Cimas Planas y Divisorias Principales. FA: Faja Aluvial. Fotos: Juan M. Susena. 


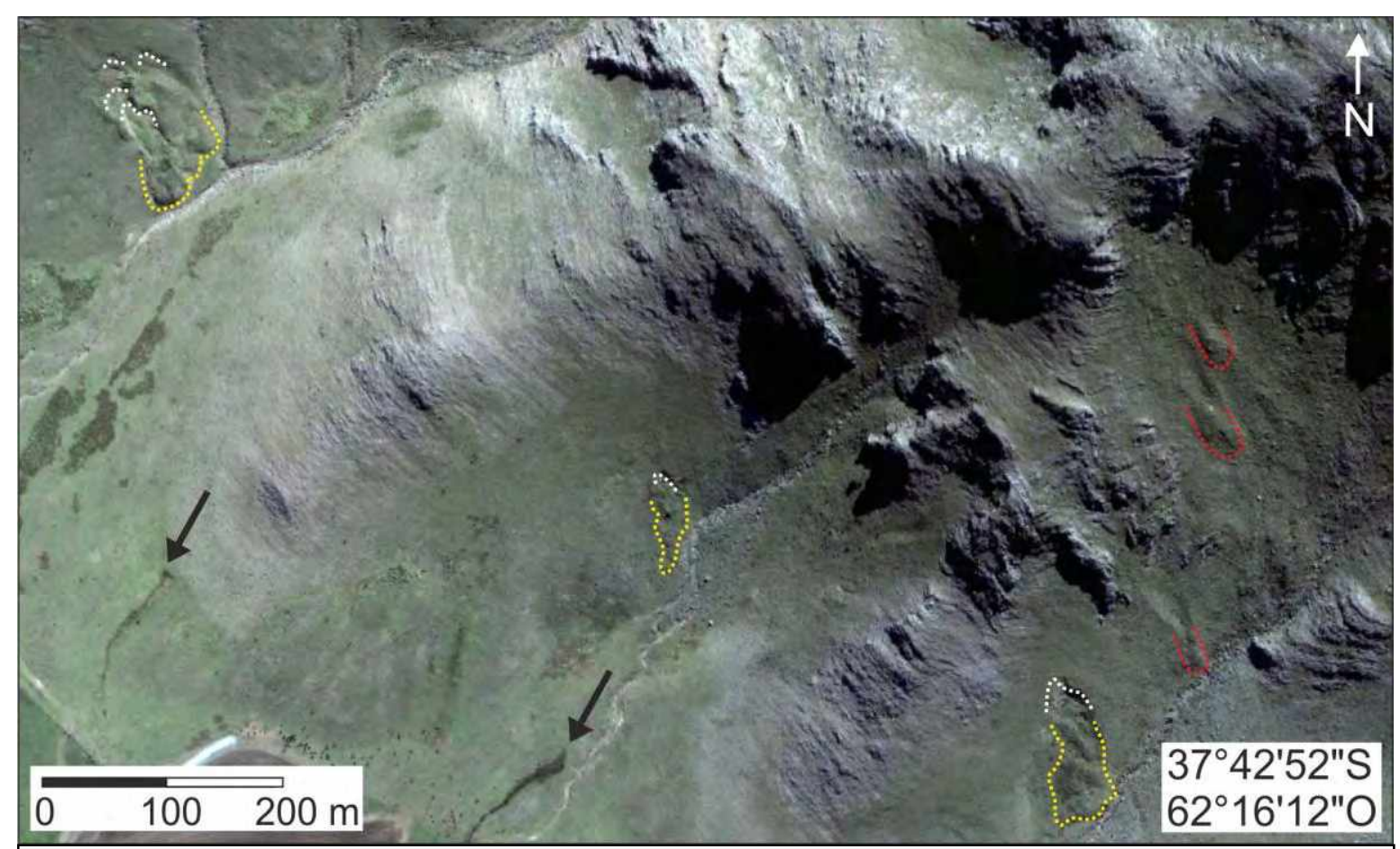

Figura 9.13. Distintas morfologías de flujos de tierra en la vertiente occidental del cerro Curamalal Chico. Líneas amarillas: acumulaciones con morfología variable. Líneas blancas: escarpas cóncavas hacia abajo a irregulares. Líneas rojas: acumulaciones de deslizamientos traslacionales, nótese que la morfología de la masa desplazada es más regular que en los flujos de tierra. Flechas: flujos de tierra en Bajada Coluvial Fina asociados a manantiales (descriptos más adelante en este capítulo). Elaboración propia a partir de composición de imagen satelital de World View-2 (Google Earth). 


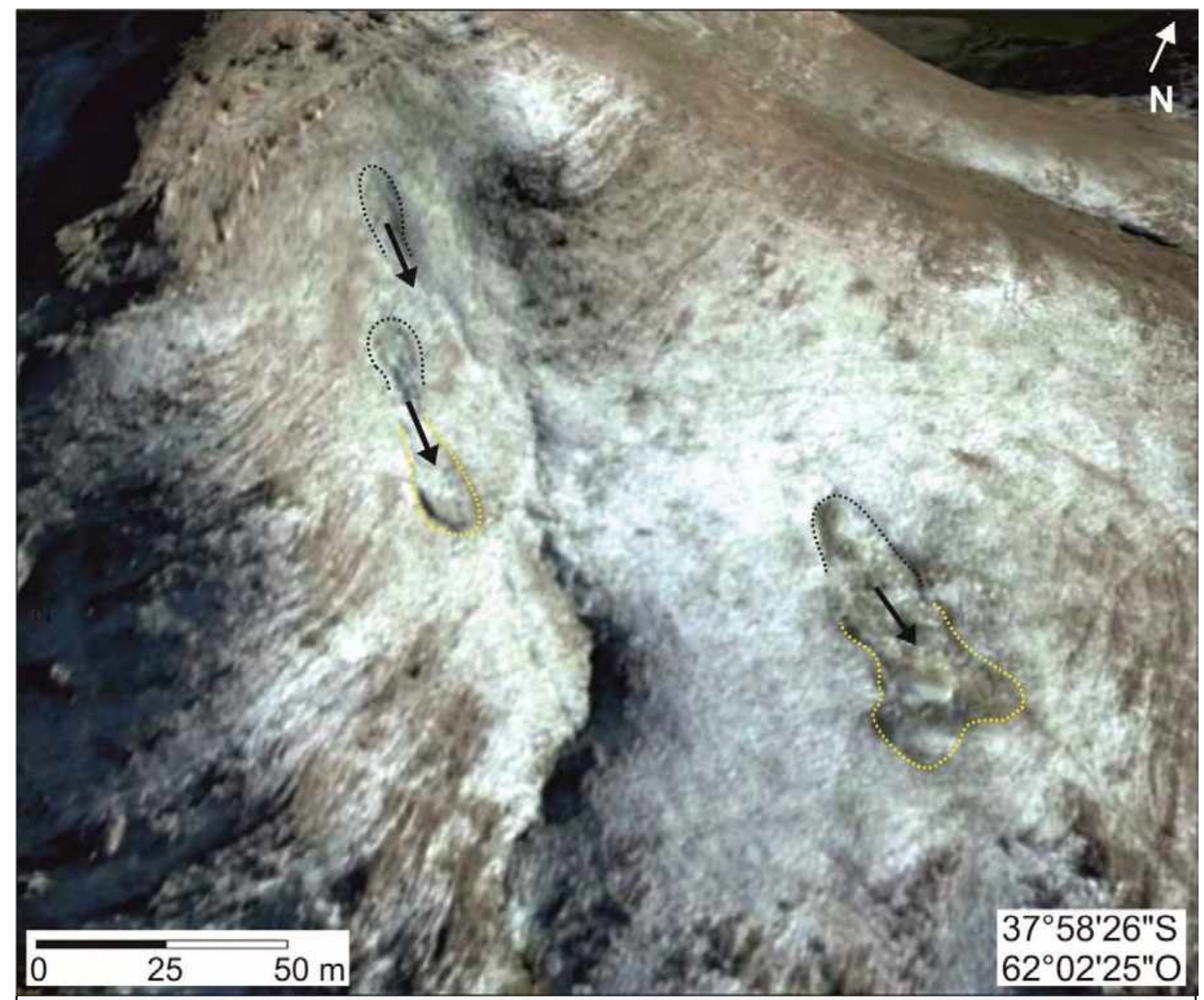

Figura 9.14. Flujos de tierra en faldeos orientales de la sierra Negra (extremo sureste del área de estudio). Líneas amarillas: acumulaciones; puede observarse un estrangulamiento en la parte proximal o central de la masa y una forma lobulada en la punta. Líneas negras: coronas. Flechas: dirección del movimiento. Los dos movimientos de la izquierda se ubican en una Ladera de Detritos, mientras que el de la derecha corresponde a una Bajada Coluvial Fina. Elaboración propia a partir de vista tridimensional de una composición de imagen satelital de World View-2 (Google Earth).

\subsubsection{Caídas de rocas}

En las laderas participan dos tipos de caídas de rocas: las procedentes de las unidades rocosas y las netamente producidas en las laderas. En el primer caso, los factores que condicionan el desarrollo de caídas se trataron en el capítulo anterior. Las caídas producidas netamente en las laderas consisten principalmente en rodaduras y rebotes y se relacionan con la removilización de bloques sueltos en superficie, o la liberación de bloques por lavaje de la matriz en sectores empinados. 
Movimientos en masa en las sierras de Bravard y Curamalal,

Sierras Australes de la Provincia de Buenos Aires.

Juan Manuel Susena

Las rocas puestas en movimiento se desplazan por las laderas hasta decenas de metros mediante rebotes y rodaduras, siendo los más propensos a rodar y rebotar los bloques equidimensionales, redondeados o sub-angulosos (Susena y Gentile, 2018). Diferentes obstáculos o una serie de ellos disminuyen la energía cinética hasta que el movimiento se detiene; los obstáculos comunes en el área son árboles, vegetación arbustiva, afloramientos y bloques rocosos mayores, o irregularidades topográficas, como zonas de hundimiento, segmentos cóncavos distales de las laderas, y otros sectores con pendientes menores que el entorno. Los bloques desplazados pueden partirse durante el movimiento; en sectores donde no hay un desarrollo conspicuo de la crioclastia u otros procesos de meteorización que tiendan a fragmentar los bloques, los bordes filosos de los fragmentos permiten reconocer el carácter reciente de los movimientos (Figura 9.15).

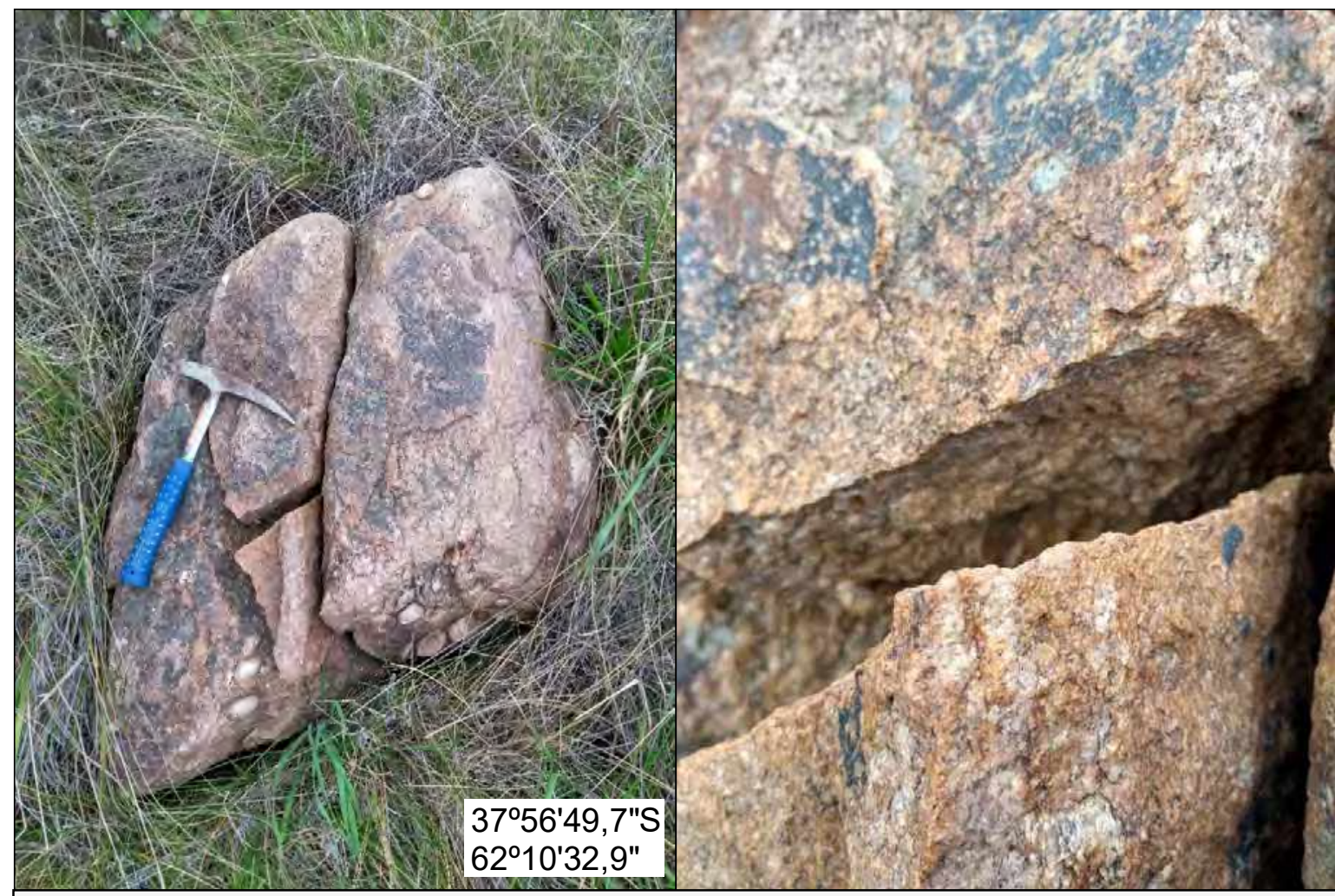

Figura 9.15. Bloque partido en sector de caídas de roca en Ladera de Detritos occidental del cerro Pan de Azúcar (subzona 3). En la foto de detalle puede verse el filo en el borde del fragmento inferior, indicando el carácter reciente de la caída. Fotos: Juan M. Susena.

Los bloques sueltos en superficie pueden desplazarse por la acción de animales (ver Capítulo 12 Movimientos en masa y actividad antropo y zoogeomorfológica). En los amontonamientos de detritos, el desplazamiento del material subyacente puede poner en movimiento a los bloques amontonados encima; este desplazamiento puede producirse por lavaje de la matriz subyacente, empuje por el impacto de otra roca, o acción de animales. El lavaje de la matriz de los Detritos de Ladera también puede ocasionar caídas 
en sectores de altas pendientes, sea en terreno no afectado por movimientos en masa, en escarpas o en acumulaciones de movimientos en masa. Otras caídas se producen cuando los bloques movilizados lentamente por acción del escurrimiento superficial no encauzado alcanzan escarpas de deslizamientos, cayendo por estas hacia la zona de hundimiento.

\subsubsection{Reptación}

La reptación de suelo se identifica en el área principalmente por la presencia de terracettes. Pereyra y Ferrer (1995) mencionan a la reptación como un proceso generalizado en toda la zona. No obstante, la reptación es más evidente en sectores localizados de las laderas. En primer lugar, las terracettes con mayor expresión morfológica están en laderas de umbría, como las occidentales de las sierras de Bravard y sur de las de Curamalal. Se encuentran allí sectores de las laderas dominados por un relieve escalonado que puede extenderse decenas de metros en dirección transversal a la pendiente, y más de $100 \mathrm{~m}$ en la dirección de la pendiente. La presencia de terracettes es más conspicua en los tramos medios a distales de las laderas. Podría pensarse por esto que para su desarrollo es necesario cierto espesor de los detritos, pero también se encontraron estos rasgos en suelos de menos de $30 \mathrm{~cm}$ de espesor, por lo cual la condición más importante en su desarrollo es el contenido de humedad.

Existen dos tipos de patrones de terracettes en las laderas del área de estudio: terracettes paralelas y terracettes en zig-zag. Las primeras (Figura 9.16.A), se desarrollan en laderas con pendiente variable, y la relación base/altura puede ser mucho menor a 1 , especialmente en zonas de alta pendiente. Pueden tener algunos tramos en diagonal, pero son minoritarios, insuficientes para imprimir un patrón en zig-zag a todo el sector con reptación. Los "corredores" (base de los terracettes, superficies transitables) son preferentemente horizontales, nivelados, y se puede caminar perfectamente sobre ellos. Se desarrollan en tramos distales, medios o proximales de las laderas, en el último caso, particularmente en conos de detritos, alcanzando el ápice de los conos. Las terracettes en zig-zag (Figuras 9.16.B y 9.16.C), tienen una distribución más limitada, próxima a cursos de agua y caminos o huellas rurales. Si bien los sectores con terracettes en zig-zag son más comunes en tramos de escasa pendiente, tienen una mayor expresión morfológica en sectores de pendientes mayores, debido a una mayor densidad de estos rasgos. Los corredores tienen pendientes menores que la ladera en esa zona, pero no están nivelados (transitar sobre ellos es más sencillo que ascender en la dirección de la pendiente, pero es igualmente agotador). Estos rasgos son comunes también en cursos de agua (ver el 
Movimientos en masa en las sierras de Bravard y Curamalal,

Sierras Australes de la Provincia de Buenos Aires.

Juan Manuel Susena

capítulo siguiente) y se relacionan con el tránsito del ganado, generándose por sobrecarga (véase Capítulo 12 Movimientos en masa y actividad antropo y zoogeomorfológica).

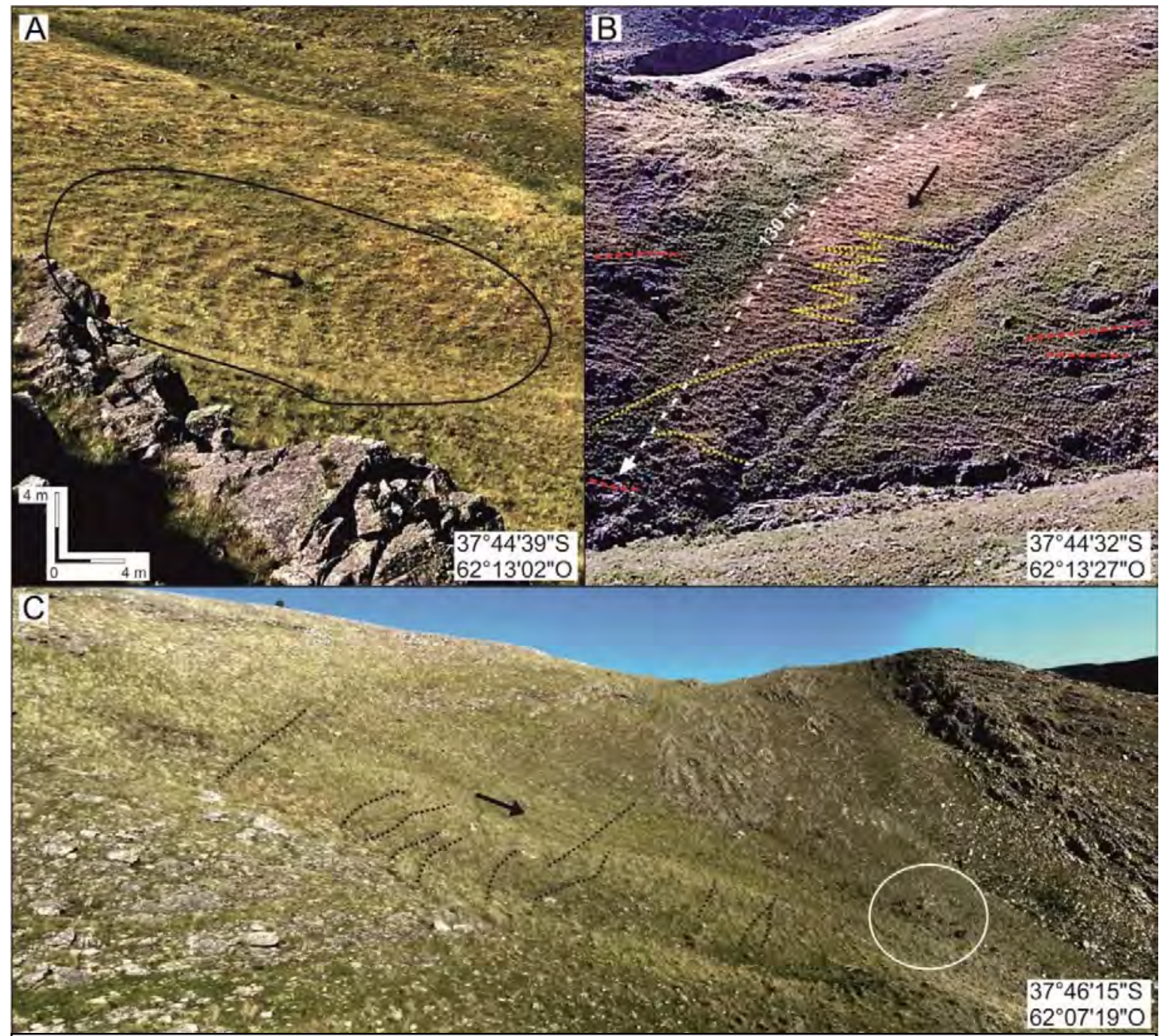

Figura 9.16. Reptación en Laderas de Detritos de valles intraserranos en la subzona 2. Flechas: dirección de la pendiente. A. Terracettes paralelas cóncavas (sector encerrado con la línea negra). B. Líneas amarillas: terracettes en zig-zag. Líneas rojas: discontinuidades en los cuerpos rocosos. C. Líneas negras: terracettes diagonales y en zig-zag. Las vacas (círculo) sirven como escala. Todas las fotos fueron tomas por Juan M. Susena. La Figura B fue modificada de Susena y Gentile (2019b).

\subsection{Movimientos en masa en la unidad Bajada Coluvial Fina}

Esta unidad, integrante de la parte distal de las laderas, se caracteriza por la abundancia de materiales finos procedentes del lavaje de los tramos proximales y medios de las laderas. Esta unidad se caracteriza por estar saturada en agua o tener un alto contenido de humedad durante gran parte del año, debido a que es común la surgencia del agua subsuperficial que se desplaza dentro de las Laderas de Detritos ubicadas topográficamente 
por encima. A pesar de la presencia de agua en las Bajadas Coluviales Finas, el escurrimiento encauzado es muy poco frecuente, dado que las pendientes son bajas y que existe una constante reposición de materiales finos.

Los movimientos desarrollados en esta unidad pueden variar según la consistencia del material, la cual depende del contenido de materia orgánica o la proporción de la fracción arcilla y el estado de humedad del material en el momento del movimiento. Se identificaron deslizamientos, flujos de tierra y reptación.

\subsubsection{Deslizamientos}

Los deslizamientos ocurren en la transición entre Laderas de Detritos y Bajadas Coluviales Finas. Se los reconoce por la presencia de pequeños escarpes y zonas de hundimiento generalmente menores a $1 \mathrm{~m}$ de altura; las dimensiones de estos movimientos en general son métricas. Las formas desarrolladas son muy degradables, dada la escasa consistencia de los materiales (limos) y el alto contenido de humedad en la estación lluviosa, por lo cual muchas veces sólo se encuentran las escarpas, siendo diferenciables los rotacionales de los traslacionales en circunstancias excepcionales (Figura 9.17).

Se acumula agua en las zonas de hundimiento y ésta es aprovechada por los animales, convirtiéndose en abrevaderos naturales, y pueden asociarse pequeños cauces a la zona de hundimiento. Es difícil precisar si la concentración de agua en zonas de hundimiento es la condición inicial para el desarrollo de pequeños cauces, o si los deslizamientos son simplemente un mecanismo de erosión retrocedente de pequeños cauces. De cualquier manera, es evidente la acción del agua en el

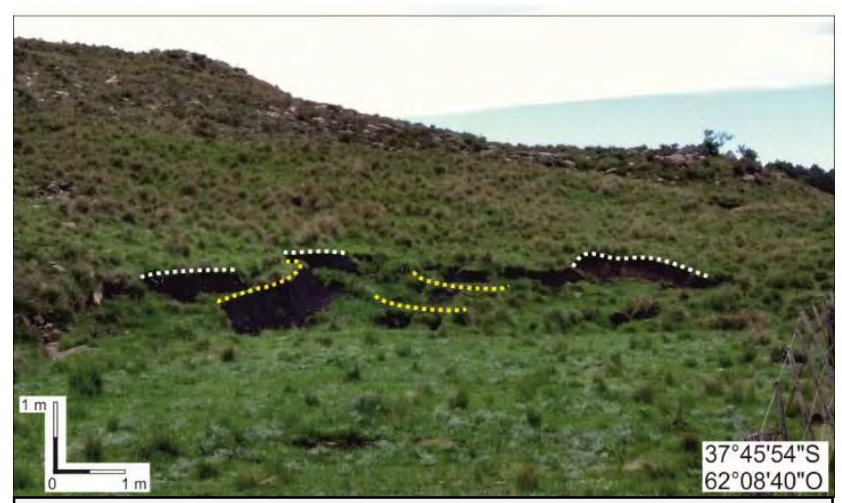

Figura 9.17. Deslizamientos rotacionales en Bajada Coluvial Fina aledaña al abra del arroyo Hinojo Grande (subzona 2). Líneas blancas: escarpes. Líneas amarillas: bloques desplazados. Foto: Juan M. Susena. desarrollo de deslizamientos.

\subsubsection{Flujos de tierra}

Existen en esta unidad dos variedades de movimientos que se clasificaron en esta tesis como flujos de tierra. Ambos se asemejan en que existe una escarpa, una superficie de ruptura y flancos bien definidos, y en que el material presenta una deformación total 
Movimientos en masa en las sierras de Bravard y Curamalal,

Sierras Australes de la Provincia de Buenos Aires.

Juan Manuel Susena

expresada en lóbulos o microirregularidades. La litología involucrada en ambos tipos son los Detritos de Ladera, variando la proporción de la fracción fina (limos y arcillas). El primer tipo de flujos alcanza dimensiones de unos $50 \mathrm{~m}$ de largo, la relación largo/ancho puede ser variable, y presentan acumulaciones con forma lobulada, similares a los desarrollados en Laderas de Detritos, descriptos más arriba (Figuras 9.13 y 9.14). El segundo tipo de flujos de tierra alcanza dimensiones mayores a $100 \mathrm{~m}$, siendo un orden de magnitud más largos que anchos, y sus acumulaciones son más bien rectas. Estos movimientos se desarrollan en tramos distales de Laderas de Detritos y en Bajadas Coluviales Finas, con pendientes generalmente menores a $20^{\circ}$, y el movimiento puede tener una trayectoria sinusoidal. Este segundo tipo de flujos de tierra se desarrolla particularmente donde el agua proveniente de tramos proximales y medios de las laderas impregna los materiales distales, siendo rápidamente saturados durante la estación lluviosa. La presencia de escarpas debido a la ocurrencia de flujos de tierra favorece la surgencia del agua sub-superficial cercana a la superficie, formándose manantiales que contribuyen al lavaje de las acumulaciones. Así, la morfología característica de estos procesos (Figuras 9.18 y 9.19) consiste en:

1. Una escarpa más o menos desarrollada y una zona de hundimiento, a veces con intensa compactación por pisoteo, donde generalmente se encuentran encharcamientos;

2. Un umbral topográfico menor producido por el propio material acumulado;

3. La acumulación propiamente dicha, elongada en la dirección de la pendiente, a veces rodeada por microcanales por los cuales circula el agua. Estos rasgos a veces están apenas por debajo (topográficamente) de la superficie no afectada, conformando un pseudo-canal de flujo (flow path);

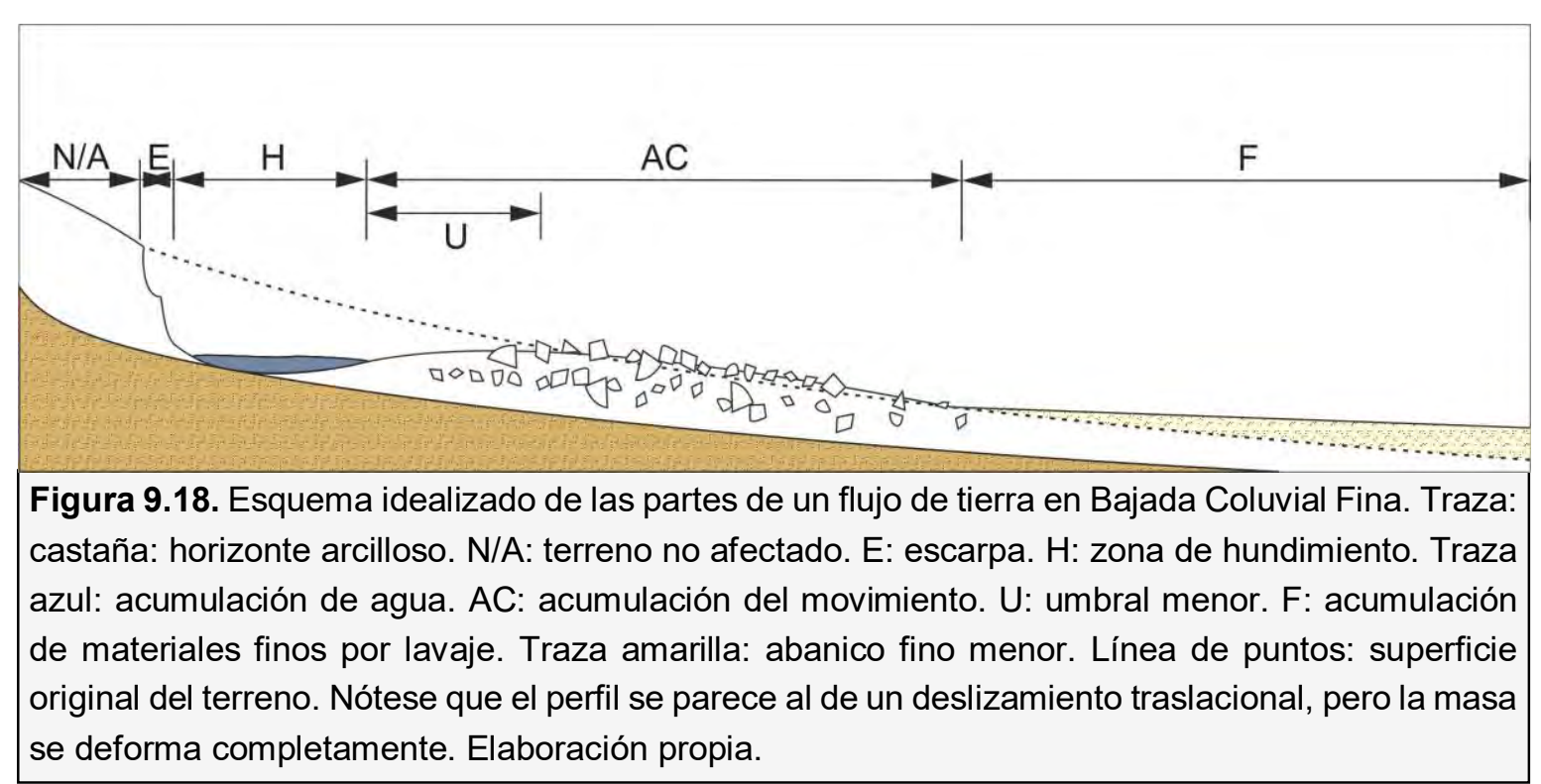


4. Acumulación de materiales finos movilizados por acción del escurrimiento superficial, que a veces pueden desarrollar pequeños abanicos finos.

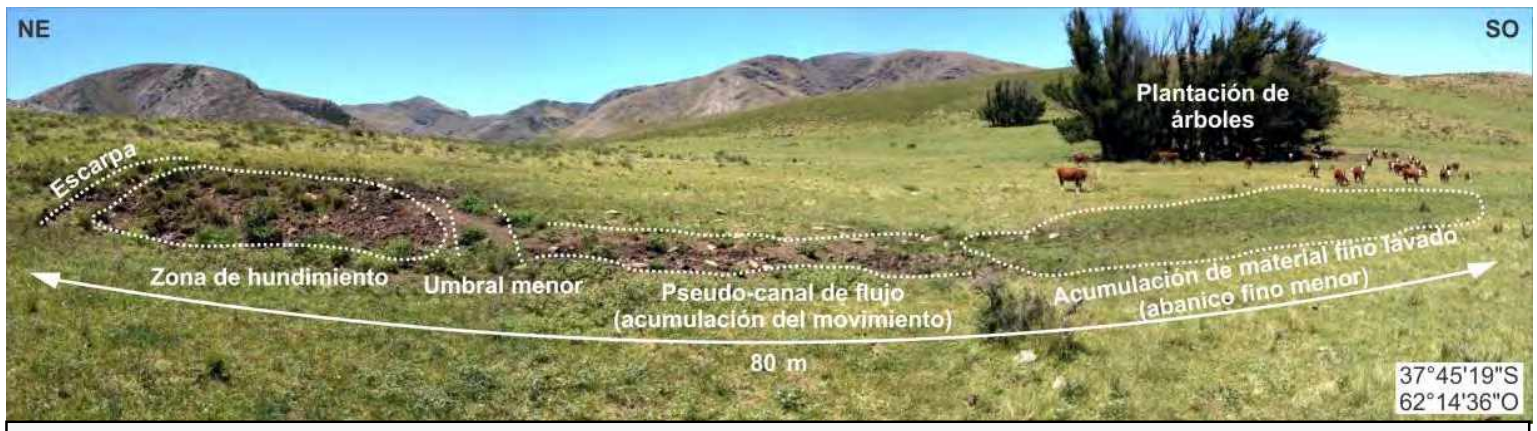

Figura 9.19. Partes de un flujo de tierra en Bajada Coluvial Fina, en el piedemonte occidental proximal de las sierras de Curamalal (subzona 2). La vista tiene cierta deformación por tratarse de una foto panorámica. El ganado sirve como escala. Foto: Juan M. Susena.

En condiciones previas al movimiento, pequeñas irregularidades del terreno pueden favorecer la acumulación de agua, siendo aprovechadas por el ganado como abrevaderos naturales. Los horizontes sub-superficiales de suelos cumúlicos limo-arcillosos allí presentes son compactados por el pisoteo, proceso que dificulta la infiltración y el escurrimiento sub-superficial; como consecuencia se saturan los materiales superficiales, desarrollándose flujos de tierra. Se encontraron grietas de $2 \mathrm{~cm}$ de ancho en el terreno no afectado inmediato a los flujos, indicando la presencia de material expansivo. Ensayos de expansión libre en muestras de la matriz en dichos sectores arrojaron coeficientes de expansión libre de 90 (los materiales saturados con agua se hinchan un $90 \%$ respecto al volumen seco), considerada alta respecto a otras muestras del área de estudio (el promedio de todas las muestras analizadas es 50). Schulz et al. (2018) demostraron que el material arcilloso expansivo puede actuar como un mecanismo resistente al desarrollo de los movimientos, por lo cual debería esperarse cierta estabilidad en la zona. No obstante, el pisoteo podría reducir el efecto estabilizante de los materiales expansivos. Posiblemente los materiales se encuentran en un equilibrio meta-estable pero que sólo puede romperse por una compactación intensa, y por eso no se encuentra este tipo de movimiento en otras Bajadas Coluviales Finas, a pesar de tener los mismos tipos de materiales y posiciones topográficas.

\subsubsection{Reptación}

La reptación en esta unidad se evidencia en el desarrollo de terracettes. Estos rasgos tienen escasa expresión morfológica debido a las bajas pendientes, siendo en general más anchos que altos, y presentando un patrón sub-paralelamente alineado. Los resaltos entre 
Movimientos en masa en las sierras de Bravard y Curamalal,

Sierras Australes de la Provincia de Buenos Aires.

Juan Manuel Susena

"corredores" son de unos pocos centímetros. Debido a que se desarrollan en sectores con alto contenido de humedad, en general están muy vegetados, siendo difícil su reconocimiento a distancia (Figura 9.20), pero pueden ocupar decenas de metros y asociarse a flujos de tierra en etapas incipientes.

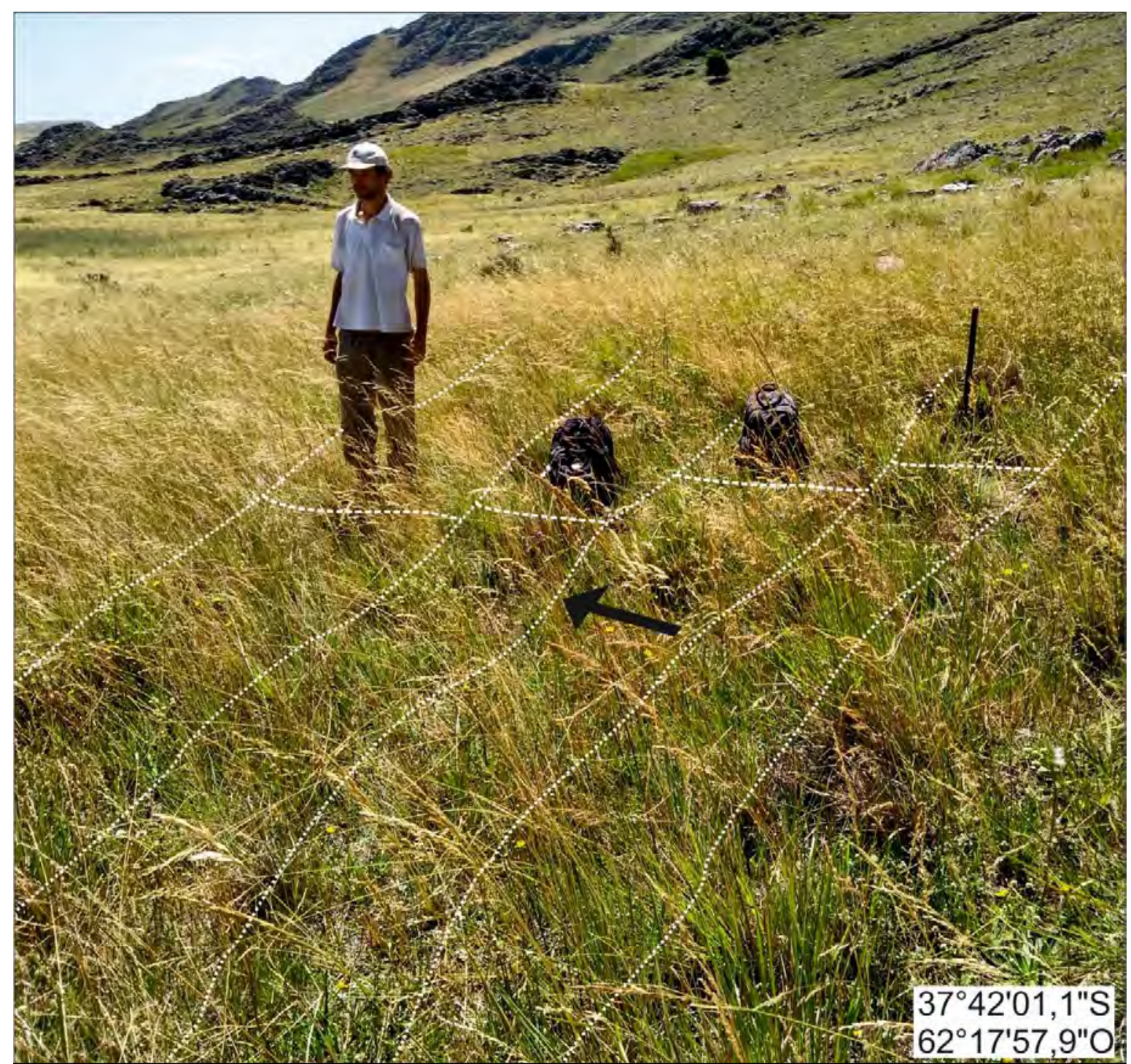

Figura 9.20. Terracettes en una Bajada Coluvial Fina del piedemonte occidental de las sierras de Curamalal (subzona 1). La expresión morfológica es mínima debido al crecimiento de la vegetación. Líneas: refuerzo visual de los corredores. Sobre los corredores la vegetación es levemente más verde que en las cornisas. La persona y los objetos de referencia se ubican en distintos corredores. Foto: Juan M. Susena y Andrea E. Cáceres. 


\section{Capítulo 10}

\section{Movimientos en masa en cursos de agua}

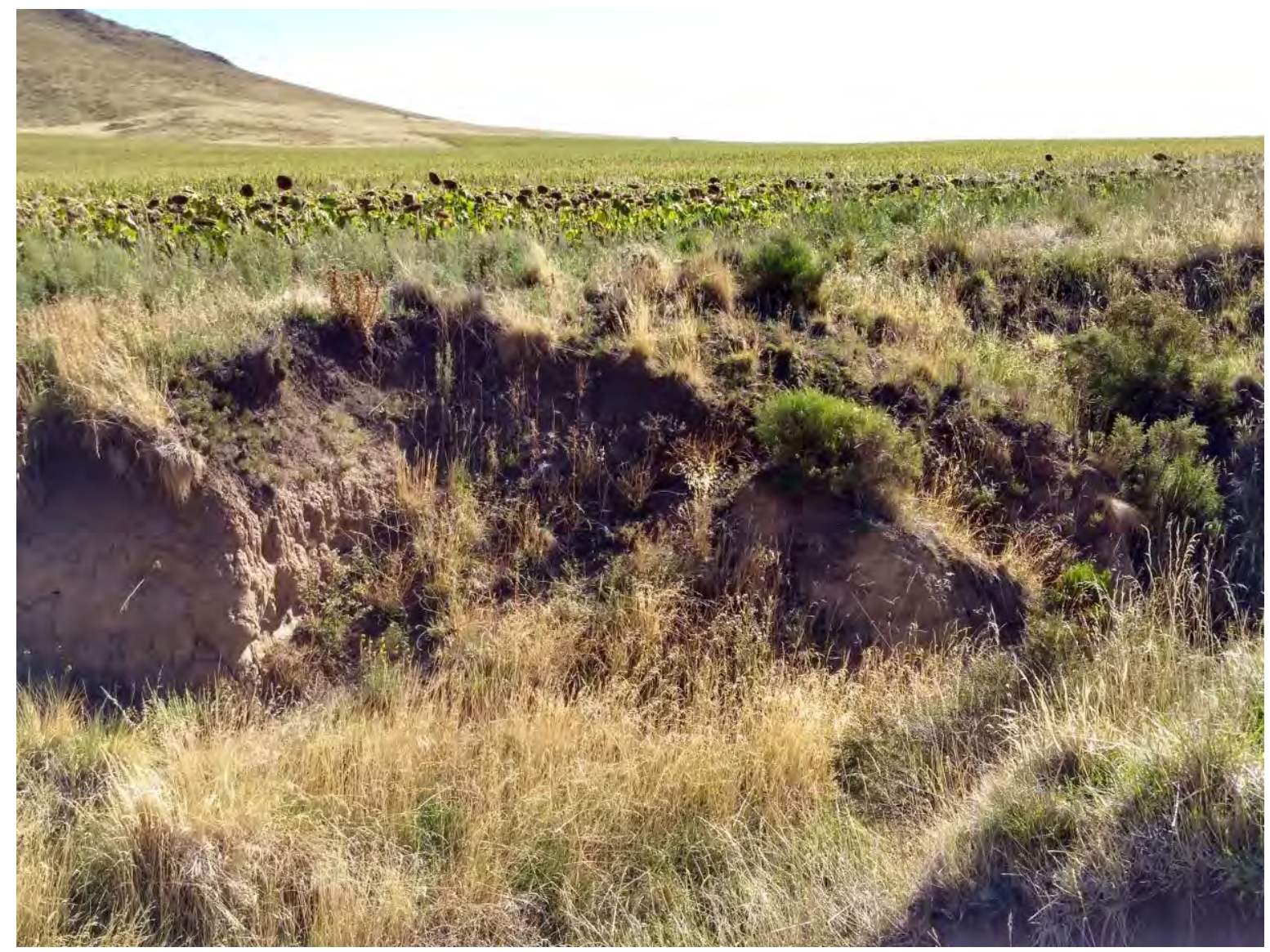

"El arbustillo del cadáver"

Remanente de un deslizamiento degradado en un pequeño arroyo.

Fotografía tomada en el Abra de Mayer, al suroeste de las Sierras de Curamalal. 
Movimientos en masa en las sierras de Bravard y Curamalal, Sierras Australes de la Provincia de Buenos Aires.

Juan Manuel Susena 


\subsection{Justificación y ordenamiento del capítulo}

Es conocido que los movimientos en masa participan activamente en el modelado de los cursos de agua mediante el ensanchamiento, alargamiento en cabeceras y aporte de materiales (Thornbury, 1960; Summerfield, 1991). Los movimientos en masa en dicho contexto geomorfológico suelen tratarse, debido a las pequeñas dimensiones que desarrollan (a veces centimétricas), entre los procesos fluviales erosivos como "erosión de banco" (Hooke, 1979, entre otros) o erosión lateral (Gutiérrez, 2008). Sin embargo, dado que en esta tesis se tratan los movimientos desde varios aspectos, como su participación en la evolución geomorfológica de los cursos de agua, serán aquí segregados de los demás procesos fluviales erosivos (como la abrasión y la acción hidráulica), independientemente de sus dimensiones. El socavamiento basal es entendido en este sentido como un mecanismo preparador y/o desencadenante de movimientos en masa (Varnes, 1958; 1978; Summerfield, 1991; Lacoste et al., 2009).

\begin{tabular}{|c|c|c|c|}
\hline $\begin{array}{c}\text { Contextos } \\
\text { geomorfológicos }\end{array}$ & $\begin{array}{l}\text { Cursos de agua en } \\
\text { Fajas Aluviales } \\
\text { aledañas a Laderas } \\
\text { de Detritos }\end{array}$ & $\begin{array}{c}\text { Cursos de agua en } \\
\text { Fajas Aluviales no } \\
\text { aledañas a Laderas } \\
\text { de Detritos }\end{array}$ & $\begin{array}{l}\text { Cursos de agua en } \\
\text { valles intraserranos }\end{array}$ \\
\hline $\begin{array}{c}\text { Principales litologías } \\
\text { cortadas }\end{array}$ & $\begin{array}{l}\text { Fm. Saavedra, Aluvio } \\
\text { y Detritos de Ladera. }\end{array}$ & $\begin{array}{l}\text { Fms. Las Malvinas, La } \\
\text { Norma, Del Águila, } \\
\text { Saavedra y Agua } \\
\text { Blanca y Aluvio. }\end{array}$ & $\begin{array}{l}\text { Rocas pre-paleocenas, } \\
\text { Fms. Agua Blanca y } \\
\text { Saavedra, Aluvio y } \\
\text { Detritos de Ladera. }\end{array}$ \\
\hline $\begin{array}{l}\text { Escarpas erosivas } \\
\text { (barrancas) }\end{array}$ & $\begin{array}{l}\text { Verticales a sub- } \\
\text { verticales, con alturas } \\
\text { entre } 1 \text { y } 3 \mathrm{~m} .\end{array}$ & $\begin{array}{l}\text { Sub-verticales con } \\
\text { alturas entre } 0,5 \text { y } 3 \mathrm{~m} \text {. }\end{array}$ & $\begin{array}{l}\text { De pendientes bajas a } \\
\text { moderadas o } \\
\text { inexistentes. Alturas } \\
\text { máximas de } 2 \mathrm{~m} \text {. }\end{array}$ \\
\hline $\begin{array}{l}\text { Multiplicidad del } \\
\text { canal }\end{array}$ & Simples & Simples a múltiples & Simples a múltiples \\
\hline Orden de cuenca & $\geq 1$ & $>2$ & $1-2$ \\
\hline $\begin{array}{l}\text { Unidades } \\
\text { geomorfológicas } \\
\text { relacionadas }\end{array}$ & $\begin{array}{l}\text { Laderas de Detritos, } \\
\text { Piedemonte Aluvial } \\
\text { Antiguo, Piedemonte } \\
\text { Inactivo Moderno } \\
\text { Indiferenciado, } \\
\text { Piedemonte Activo } \\
\text { Moderno } \\
\text { Indiferenciado. }\end{array}$ & $\begin{array}{c}\text { Cubierta Eólica } \\
\text { Periserrana, } \\
\text { Piedemonte Aluvial } \\
\text { Antiguo, Piedemonte } \\
\text { Inactivo Moderno } \\
\text { Indiferenciado, } \\
\text { Piedemonte Activo } \\
\text { Moderno } \\
\text { Indiferenciado. }\end{array}$ & $\begin{array}{l}\text { Laderas de Detritos, } \\
\text { Laderas Compuestas, } \\
\text { Laderas Rocosas, } \\
\text { Cuerpos Rocosos } \\
\text { Prominentes, } \\
\text { Piedemonte antiguo. }\end{array}$ \\
\hline Laderas confinantes & Una & Ninguna & Una o dos \\
\hline
\end{tabular}


Movimientos en masa en las sierras de Bravard y Curamalal,

Sierras Australes de la Provincia de Buenos Aires.

Juan Manuel Susena

En este capítulo se tratarán por separado los movimientos que afectan cursos de agua en Fajas Aluviales, de los desarrollados en valles intraserranos, debido a diferencias en sus canales y entorno inmediato (Tabla 10.1).

\subsection{Cursos de agua en Fajas Aluviales}

La red de drenaje caracterizada dentro de la unidad geomorfológica Fajas Aluviales (véase Capítulo 6 Geomorfología general de área), es modelada en depósitos de niveles pedemontanos antiguos (Fm. Malvinas) y modernos (Fm. Agua Blanca), en eólicos de Fm. Saavedra y en Aluvio. Los movimientos en masa que allí se desarrollan, lo hacen a partir de las barrancas de los cursos de agua. Se asocian tanto a las márgenes externas de dichos cursos (de máxima energía hidráulica), como a las márgenes internas (de menor energía hidráulica), y son frecuentes también en tramos rectos (Figura 10.1.A).

Estos movimientos tienen participación activa en el modelado de las fajas aluviales, y pueden observarse cambios a escala anual, como se verá más adelante. Se han reconocido vuelcos y caídas de suelo, deslizamientos, flujos de barro y reptación. Es necesario hacer notar que los vuelcos y caídas de suelo, al responder a procesos similares, y al transformarse unos en otros durante su recorrido, complicándose a veces su

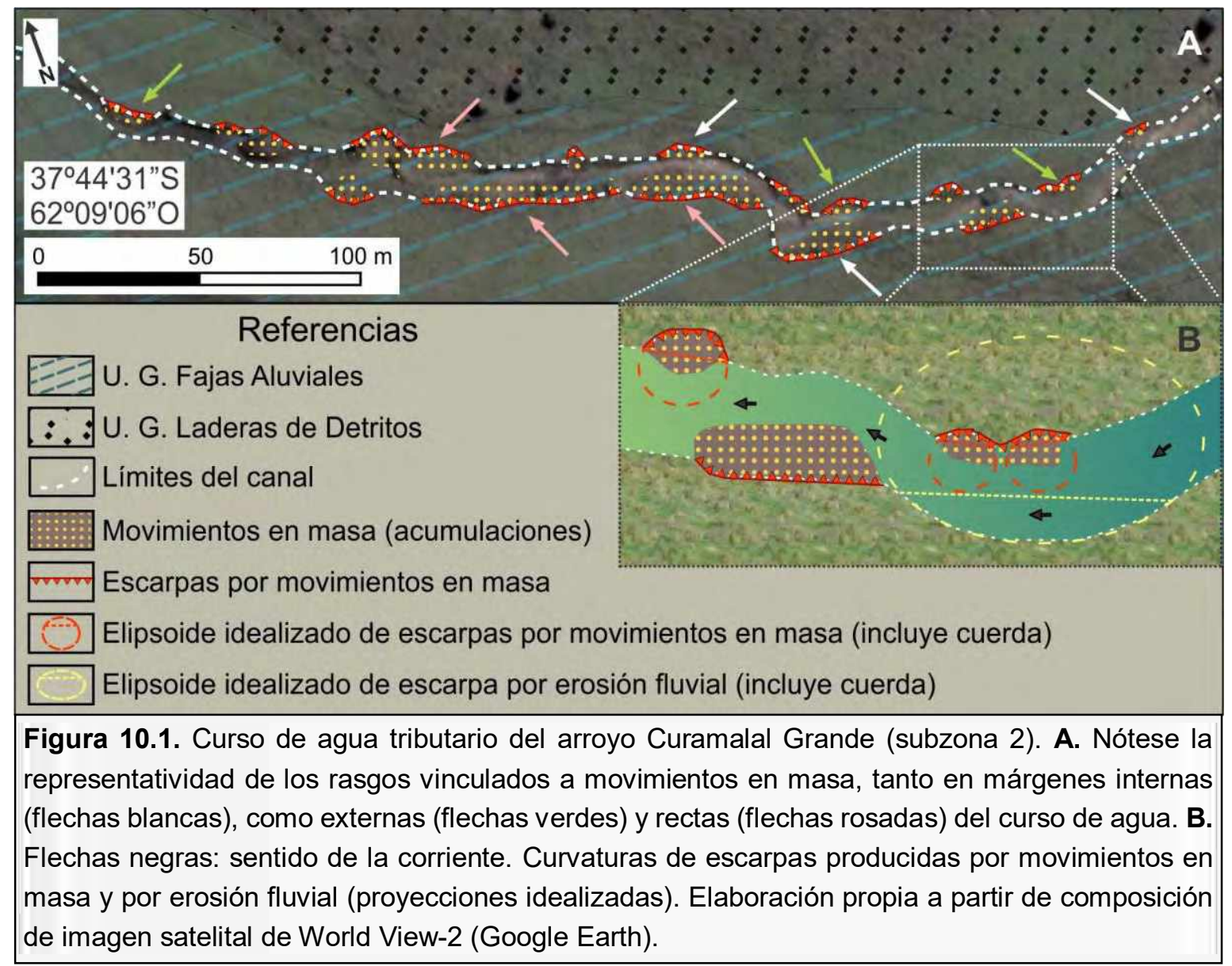


diferenciación, podrían tratarse conjuntamente (Susena y Gentile, 2018). En esta tesis, se los describirá por separado, destacando las morfologías características de unos y otros, con base en ejemplos representativos.

Vuelcos de suelo: afectan a las barrancas de los cursos de agua. Como resultado, las escarpas producidas tienen morfologías, vistas en planta, cóncavas hacia el canal, a rectas. Cuando estas escarpas son cóncavas, su grado de curvatura y dimensiones difieren considerablemente respecto a aquellas cóncavas originadas por erosión fluvial lateral, generando "entrantes" en las márgenes de los cursos de agua; esta situación puede generalizarse también para las escarpas cóncavas desarrolladas por caídas y deslizamientos rotacionales. Si en una vista en planta se proyectaran ambos tipos de escarpas, respetando su grado de curvatura hasta cerrar una figura idealizada, las escarpas por movimientos en masa generarían geometrías sub-circulares, mientras que aquellas generadas por erosión fluvial lateral serían más bien elipsoidales (Figura 10.1.B). Las escarpas por movimientos con formas rectas, por otra parte, presentan paredes laterales que las confinan respecto a las márgenes, generando formas vistas en planta similares a corchetes o trapecios sin base, con puntos de quiebre claramente visibles. Éstas, comunes en cárcavas modeladas en la Fm. Saavedra, suelen desarrollarse en coincidencia con rasgos lineales asociados a actividad antrópica, como caminos o líneas de arado (Figura 10.2). Los bloques volcados, cuando se encuentran, por lo general yacen inclinados hacia el canal, en mayor o menor medida sobre éste, y en parte apoyados sobre la barranca (Figura $\mathbf{1 0 . 3}$ en la página siguiente). En el caso ejemplificado, así como en otros que se ven más adelante, puede diferenciarse de un deslizamiento en que las

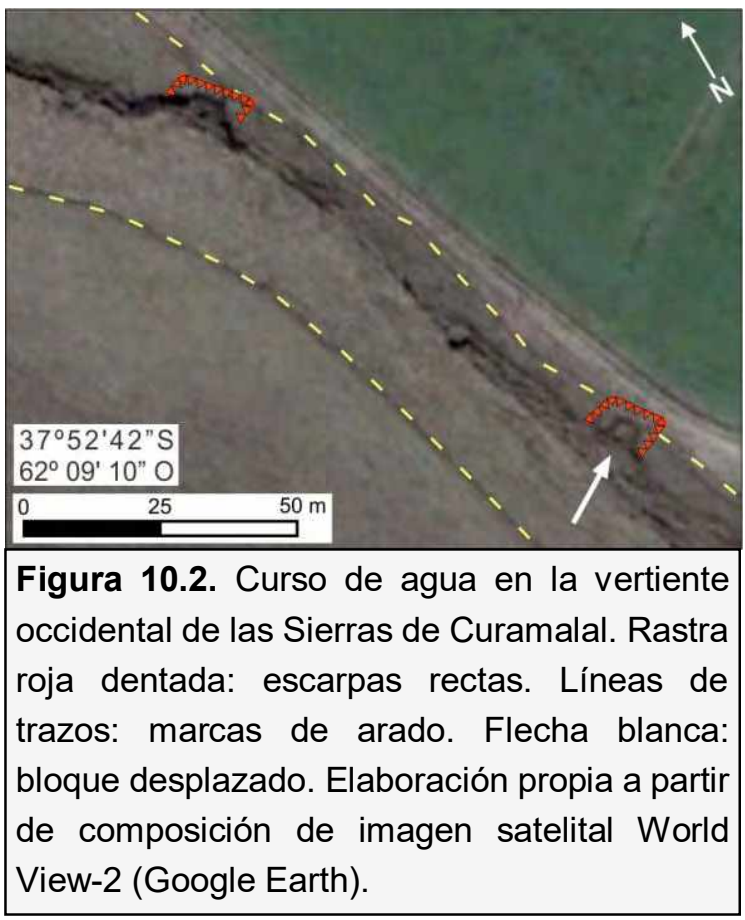

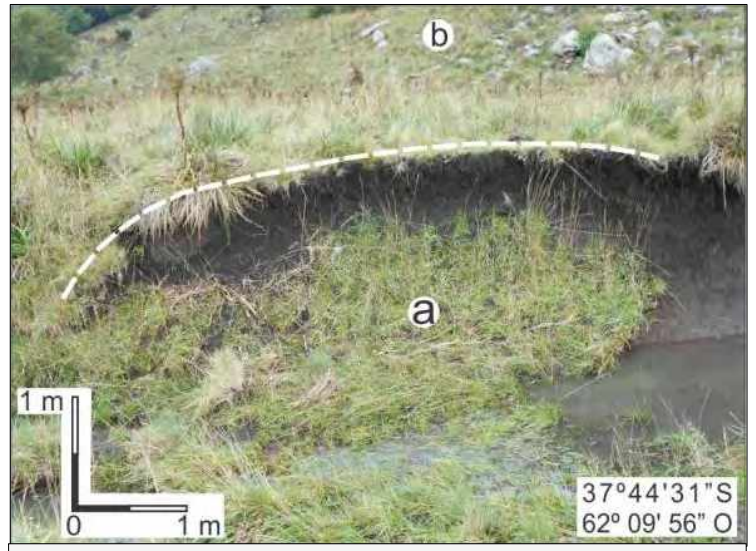

Figura 10.3. Vuelco de suelo en la margen derecha de un canal en el Valle de Las Grutas (subzona 2). Línea de trazos: límite de la escarpa. a: bloque volcado. b: lomada distal alcanzando la planicie de inundación. Foto: Juan M. Susena. Modificado de Susena y Gentile (2017). 
Movimientos en masa en las sierras de Bravard y Curamalal,

Sierras Australes de la Provincia de Buenos Aires.

Juan Manuel Susena

barrancas no tienen un plano con una inclinación semejante a la del bloque desplazado, que pudiera funcionar como superficie de ruptura: la única manera de que el bloque originalmente horizontal (como el resto del terreno no afectado) quedara inclinado, es mediante la producción de un vuelco.

Los bloques pueden presentar diferentes morfologías y dimensiones; se han reconocido dos situaciones extremas, entre las cuales existe cierto grado de variabilidad: morfologías equidimensionales a tabulares con orientación horizontal o sub-horizontal, y formas tabulares a prismáticas orientadas vertical o sub-verticalmente (Tabla 10.2). Estas morfologías podrían responder a la estructura del suelo, tendiendo a desarrollarse bloques tabulares a prismáticos orientados verticalmente, cuando el solum presenta estructuras prismáticas bien definidas. Por otra parte, el grado relativo de participación de ciertos

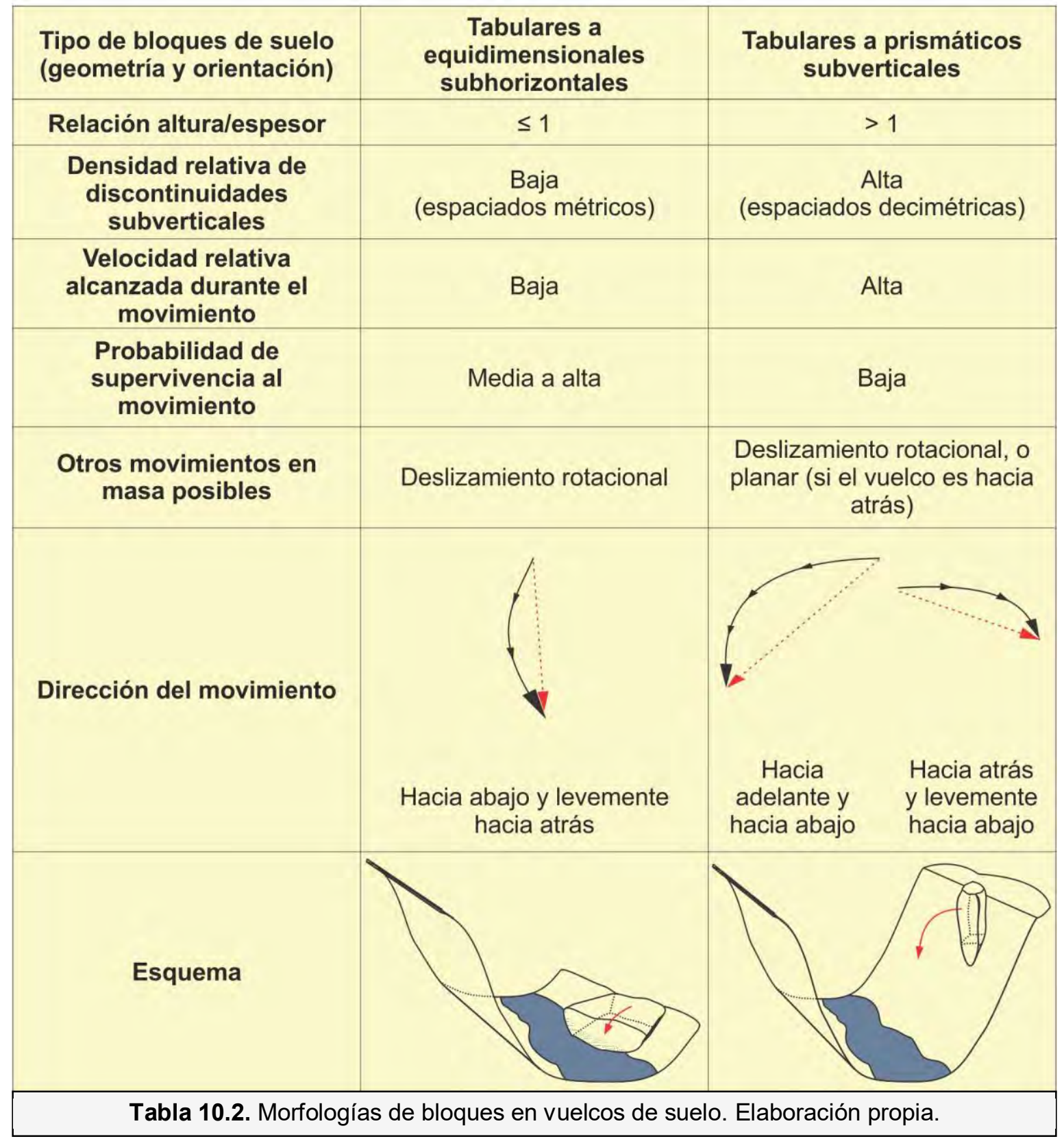


procesos conforma otro factor influyente: mayores tasas de socavamiento basal respecto a las de erosión pluvial o de escurrimiento superficial no encauzado, pueden favorecer, previamente al vuelco, morfologías tabulares sub-horizontales, mientras que un predominio de la erosión fluvial, y de la reptación de los bloques de suelo parcialmente separados por fracturas, propiciarán la generación de bloques subverticales. Los últimos, tienden a destruirse tras el impacto posterior al vuelco; consecuentemente, se encuentran mejor representados los bloques volcados del tipo tabular sub-horizontal. Las dimensiones de los bloques pueden alcanzar los 5-6 $\mathrm{m}^{3}$, siendo los tabulares a equidimensionales sub-horizontales (Figura 10.4) mayores que los tabulares a prismáticos subverticales (Figura 10.5). La superficie de los bloques que una vez volcados yacen en los canales varía aproximadamente entre 20 y $40^{\circ}$, y su espesor suele ser menor que la altura de la barranca. Esta última característica se debe a la ausencia de parte del material que conformaba la base del bloque (Figura 10.4), lo cual podría indicar que existe un importante socavamiento basal previo al movimiento, permitiendo interpretar dicho proceso como uno de los mecanismos desencadenantes

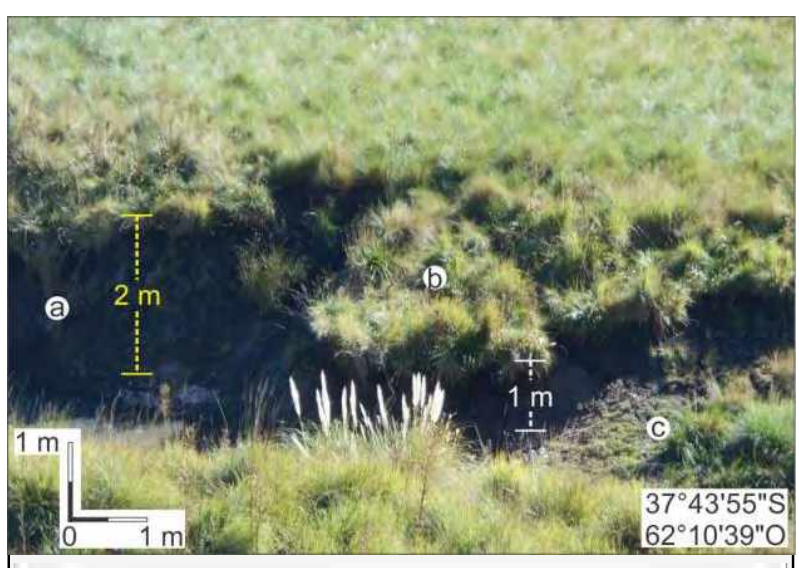

Figura 10.4. Vuelco de suelo en la margen izquierda de un arroyo del Valle de Las Grutas (subzona 2). a: barranca. b: bloque volcado. c: canal. Cota amarilla: espesor de la barranca. Cota blanca: espesor del bloque volcado. Foto: Juan M. Susena.

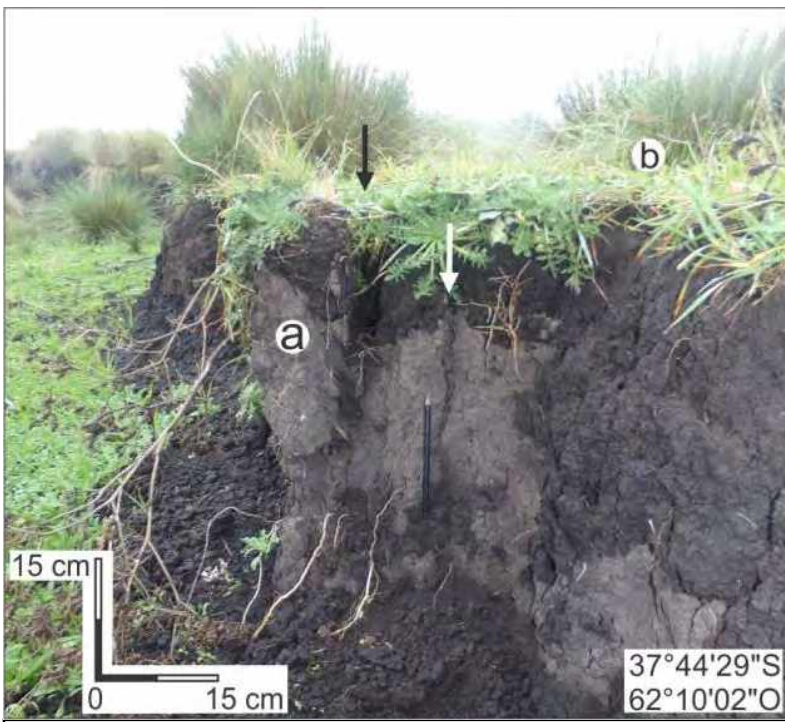

Figura 10.5. Bloque sub-vertical de suelo (a) en la margen izquierda de un arroyo del Valle de Las Grutas (subzona 2). b: planicie de inundación. Flecha negra: fractura individualizando el bloque. Flecha blanca: fractura que individualizaría un nuevo bloque. Foto: Juan M. Susena. (Varnes, 1978; Gutiérrez, 2008).

En los bloques volcados, la vegetación previa al vuelco puede sobrevivir cuando son inundados parcial o totalmente con corta duración. Por tanto, la existencia de vegetación viva sobre los bloques no puede ser considerada como un indicador de juventud del movimiento. No obstante, la vegetación muerta sí puede utilizarse como indicador de antigüedad de vuelcos, exceptuando los casos en que se vinculen a períodos lluviosos inmediatos a grandes sequías, entonces la vegetación podría haberse marchitado con 
anterioridad al movimiento. En este sentido, la calidad de la información que pueda obtenerse de este indicador depende estrechamente del conocimiento sobre el comportamiento de la vegetación de la zona, y su conjunción con datos meteorológicos.

Las acumulaciones pueden permanecer en el canal, o ser erosionadas parcial o completamente. En el último caso, este tipo de movimiento sólo puede identificarse a partir de la configuración de las paredes del canal. Los bloques volcados pueden obstaculizar el escurrimiento superficial, acumulándose agua en la parte trasera (proximal). De la misma manera, pueden

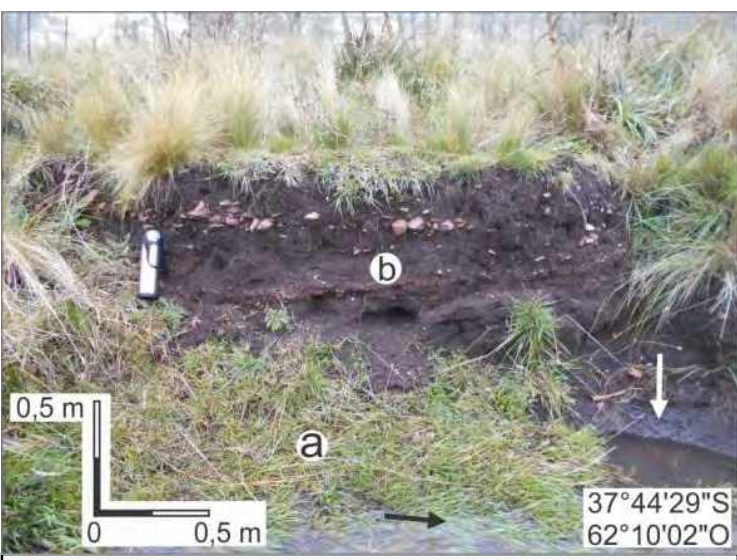

Figura 10.6. Vuelco de suelo en la margen izquierda de un arroyo del Valle de Las Grutas (subzona 2). a: remanente de bloque volcado. b: barranca. Nótese que la ausencia de un plano de deslizamiento permite diferenciar el vuelco de tal tipo de movimiento. Flecha blanca: remanso. Flecha negra: sentido del escurrimiento superficial. Foto: J. M. Susena. moderar/refrenar lateralmente el escurrimiento, protegiendo a las barrancas de la acción erosiva de las aguas, y permitiendo la generación de pequeños "remansos" aguas abajo (Figura 10.6). En algunos casos la erosión de la porción proximal separa a los bloques de su escarpa de origen, pudiendo convertirse en obstáculos aproximadamente centrales en el canal. Cuando la erosión de los bloques es avanzada, queda una alfombra de pastizal en la base del canal, que difiere de la vegetación típica de dicha posición.

Caídas de suelo: afectan la superficie de la planicie de inundación más próxima al canal, tramos de las barrancas y sectores de los canales que conforman "saltos de agua" (knickpoints). Se asocian también a entrantes de los canales por donde circula el ganado. Se evidencian por pequeños bloques de suelo sobre el lecho del canal, a diferentes distancias del pie de las barrancas, con formas aproximadamente esféricas a obladas con diámetros no mayores a $0,5 \mathrm{~m}$, y se los suele encontrar con vegetación (Figura 10.7). Estas dimensiones son las

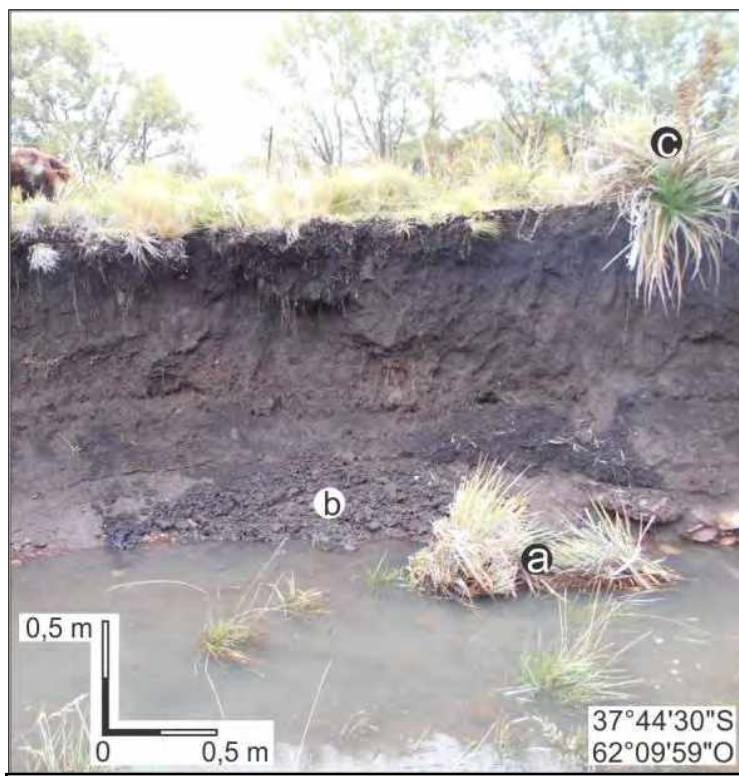

Figura 10.7. Caída de suelo en la margen izquierda de un arroyo del Valle de Las Grutas (subzona 2). a: bloque de horizonte superficial caído con vegetación muerta en una posición inclinada. b: remanente de bloque de horizonte sub-superficial caído o volcado. c: bloque colgante. Foto: Juan M. Susena. 
típicas de los bloques que caen de los horizontes de suelo superficiales y experimentan poca o ninguna fragmentación, mientras que en horizontes sub-superficiales, los cuales carecen de vegetación, los bloques pueden superar el metro, pero suelen destruirse tras la caída. La antigua cara superior de los bloques, representada por la presencia de vegetación viva o muerta, puede encontrarse apuntando hacia arriba o inclinada en cualquier dirección, incluso apuntando hacia abajo, pudiendo significar rodaduras durante la caída, o transporte posterior dentro del canal. Los bloques caídos pueden sobrevivir durante algún tiempo, constituyendo obstáculos que favorecen la depositación de la carga de lecho. Estas características fueron abordadas en el Capítulo 7 Criterios de reconocimiento de los movimientos en masa y su actividad. Son comunes en las barrancas, bloques colgantes susceptibles a caídas, apenas sostenidos por la vegetación, la cual ofrece la última resistencia al movimiento (Susena y Gentile, 2018).

Pequeños flujos de barro: sus representantes son muy escasos y de muy poco desarrollo. Se los encuentra al pie de las barrancas, a partir de las cuales se desarrollan, luego de las precipitaciones (Figura 10.8.A). También se los encuentra en la intersección entre galerías excavadas por animales y paredes laterales o lechos de los cursos de agua (Figura 10.8.B). Presentan morfologías lobadas de no más de $60 \mathrm{~cm}$ de longitud, con un pie o punta bien desarrollado y una relación largo/espesor cercana a 4. Presentan una erodabilidad relativamente alta, debido a la inconsistencia del material (predominancia de limos loéssicos o loessoides, ver Capítulo 5 Geología: generalidades), su pequeño tamaño, la saturación de poros, y la ausencia de vegetación. Estas características, sumadas a la elevada exposición a la erosión fluvial por su posición en el canal, podrían ser las

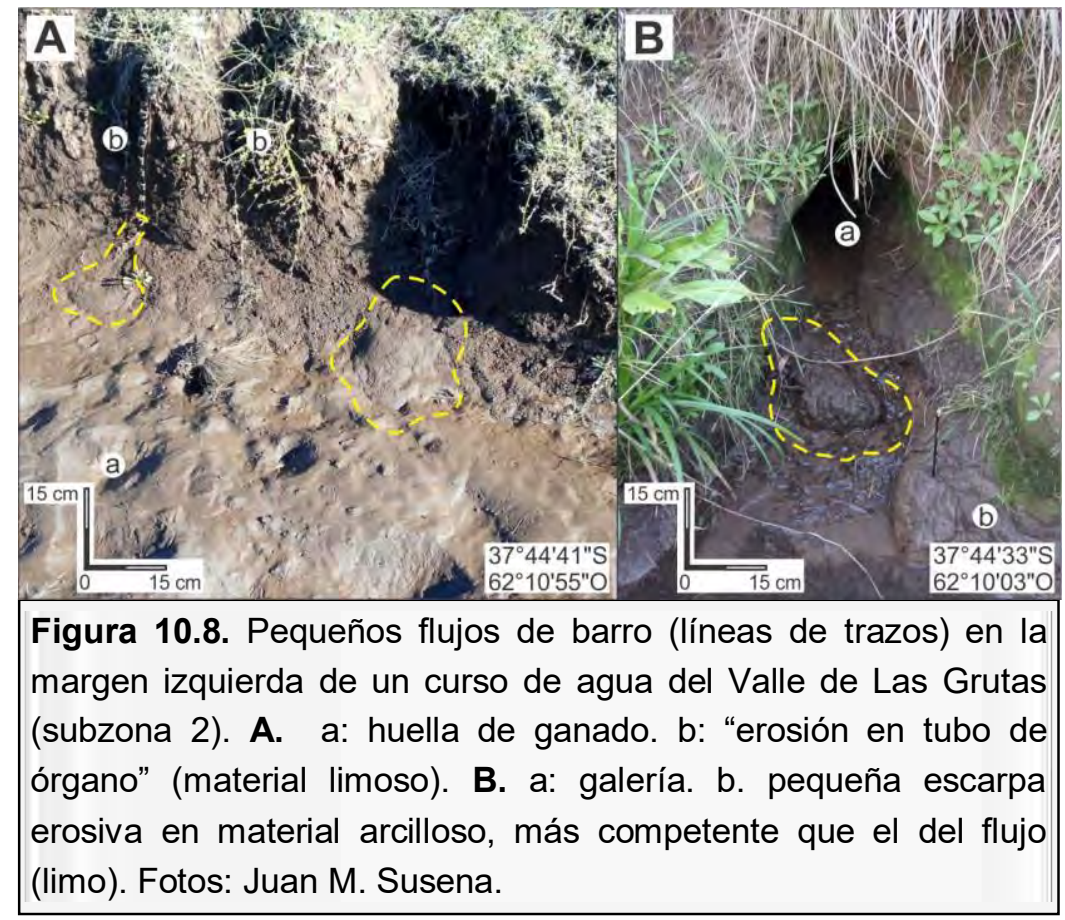


Movimientos en masa en las sierras de Bravard y Curamalal,

Sierras Australes de la Provincia de Buenos Aires.

Juan Manuel Susena

principales causas de la escasa representación de estos movimientos en el paisaje.

Deslizamientos: se ubican generalmente en las márgenes externas de los cursos de agua, afectando sólo tramos de éstas, o a veces también a parte de la planicie de inundación. En algunos sectores, se observaron deslizamientos en diferentes etapas de desarrollo, afectando significativamente ambas márgenes de los cursos de agua. Son más abundantes en las márgenes de cursos que atraviesan el valle intermontano, afectando depósitos de antiguos niveles de piedemonte (Fms. Malvinas o Agua Blanca) y/o su cubierta eólica (Fm. Saavedra). Por lo general presentan masas de entre 0,5 y $3 \mathrm{~m}$ de ancho, las cuales pueden ser simples (Figura 10.9) o múltiples (Figura 10.10). En casos de bloques múltiples, no hay grandes variaciones en cuanto a su tamaño. El desplazamiento no supera el metro de longitud, generalmente ronda los $0,5 \mathrm{~m}$, y suele estar condicionado por la profundidad del contacto entre las litologías previamente mencionadas. Los deslizamientos pueden asociarse a vuelcos, pero se diferencian en la rotación (los vuelcos rotan en general hacia adelante y los deslizamientos rotacionales hacia atrás, mientras que en los deslizamientos

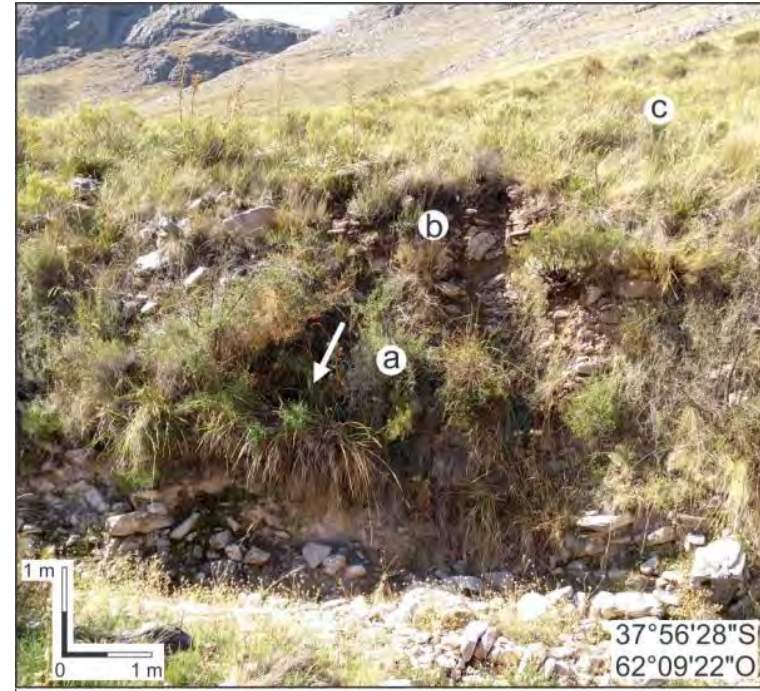

Figura 10.9. Deslizamiento de suelo en la margen izquierda de un arroyo al pie del Cerro Chaco (subzona 3). a: masa desplazada. b: superficie de ruptura. c: ladera de detritos. Flecha: dirección del movimiento. Foto: Juan M. Susena.

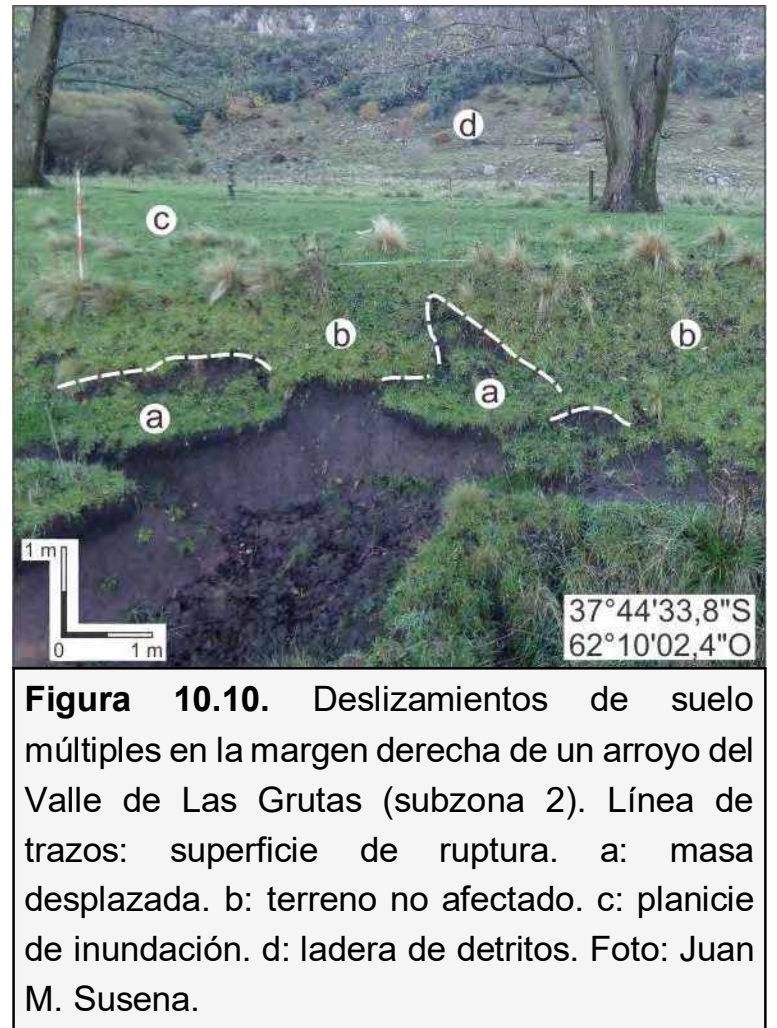

traslacionales no hay rotación). No obstante, cuando la masa y la superficie de ruptura o la escarpa están degradadas, resulta difícil discriminar entre bloques deslizados y bloques volcados (Figura 10.11). Debido al escaso desplazamiento, es difícil también diferenciar deslizamientos traslacionales de rotacionales; los últimos son reconocibles cuando las superficies de ruptura son cóncavas hacia el canal vistas en planta, y cóncavas hacia arriba vistas en perfil, así como signos claros de rotación en la masa desplazada. El lavaje 
superficial de la escarpa también puede modelar un perfil similar (equifinalidad), por lo cual esta característica sólo puede interpretarse con cierta confiabilidad cuando el movimiento es muy reciente, o si se ubica en la parte superior de la barranca, condiciones en las cuales el perfil respondería preponderantemente

movimientos en masa. La acumulación de agua en la "zona de hundimiento" o en la base de los "flancos", y el consiguiente aumento de la presión poral de toda la masa pueden favorecer el

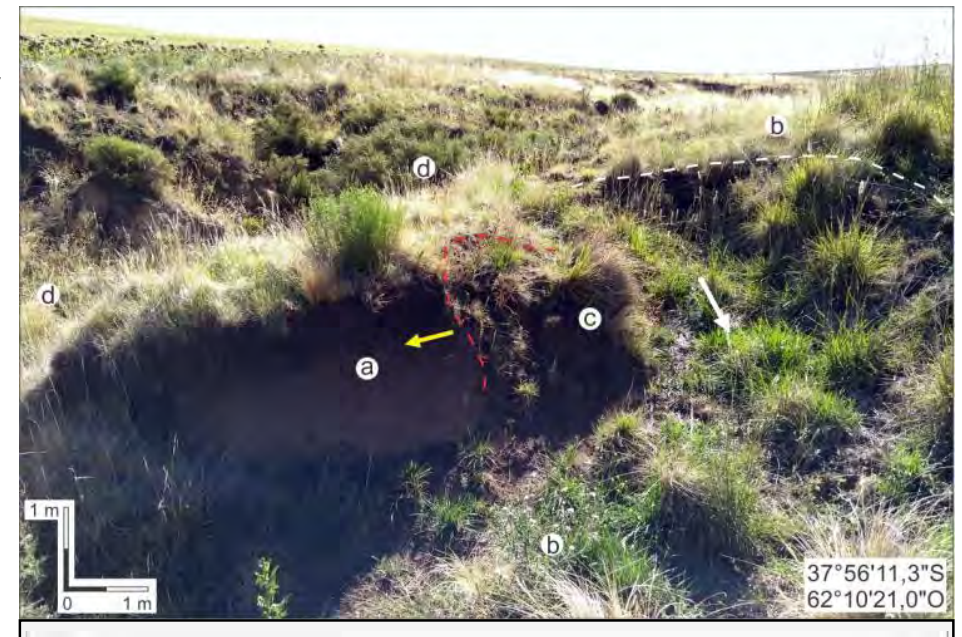

Figura 10.11. Deslizamiento y/o vuelco de suelo degradado en la margen izquierda de un curso de agua al pie del cerro del Corral (subzona 3). Línea de trazos blanca: superficie de ruptura. a: bloque desplazado; nótese la inclinación del límite de horizontes de suelo (flecha amarilla). b: terreno no afectado. Flecha blanca: pendiente local de escotadura generada a partir de la zona de arranque. Línea de trazos roja: superficie de ruptura afectando al bloque a. c: bloque desplazado. d: cauce. Foto: Juan M. Susena.

desarrollo de pequeños movimientos de tipo flujo en la parte inferior de los bloques.

Reptación: las márgenes cortadas en laderas de detritos presentan morfologías aterrazadas, con escalones de unos 0,3-0,5 $\mathrm{m}$ de altura y $1 \mathrm{~m}$ de ancho, a veces dispuestos en zig-zag (Figura 10.12). Muchas de estas terracettes presentan bloques rocosos sueltos en superficie cuyas caras más desarrolladas inclinan en la dirección de la pendiente y con el mismo ángulo. La inclinación de los bloques que están inmersos en la matriz de los Detritos de Ladera allí presentes es menor que la de la de los bloques sueltos, elemento que permite descartar que la disposición de los últimos se relacione con su

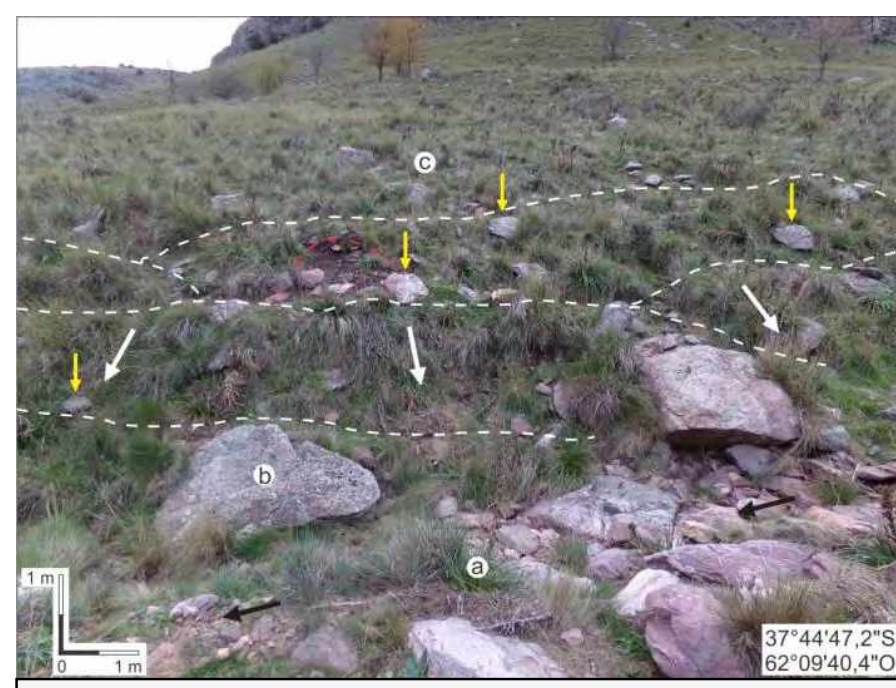

Figura 10.12. Morfología asociada a reptación aledaña a un curso de agua en el Valle de Las Grutas (subzona 2). Líneas de trazos blancas: terracettes. Flechas blancas: dirección de la pendiente local. a: cauce fluvial. Flechas negras: dirección de escurrimiento. b y flechas amarillas: bloques movilizados desde la ladera de detritos, note su inclinación a favor de la pendiente. Línea de trazos roja: superficie de ruptura de deslizamiento pequeño. Foto: Juan M. Susena. 
Movimientos en masa en las sierras de Bravard y Curamalal,

Sierras Australes de la Provincia de Buenos Aires.

Juan Manuel Susena

posición original. Estos bloques sueltos pueden movilizarse lentamente por la acción de la gravedad y el lavaje del material fino subyacente, tratándose de reptación de detritos, o bien ser transportados por acción de la fauna (remoción de materiales en sentido amplio). Cabe hacer notar que no se han encontrado morfologías similares a terracettes en las márgenes de los cursos que atraviesan sedimentos más finos (Fm. Saavedra y litologías afines) donde, probablemente el predominio de materiales limo-arcillosos con escasos porcentajes de clastos/bloques (Fs. Saavedra y Aluvio), condicione un comportamiento geomecánico diferente al de los materiales con mayor proporción de elementos gruesos.

Rasgos confundibles con movimientos en masa: es común encontrar rasgos similares a productos de movimientos en masa, cuyas características no son suficientes para poder clasificarlos, si acaso se los pudiese definir como tales. Se han encontrado taludes al pie de las barrancas, conformados por materiales limosos y limo-arcillosos, con ángulos de reposo de unos $30^{\circ}$, como se ejemplifica en la Figura 10.13. Podrían corresponder a caídas, vuelcos o deslizamientos de materiales inconsolidados o de bloques de suelo relativamente compactos (delimitados por superficies bien desarrolladas), que se destruirían durante o después del movimiento, o bien ser originados por acción de animales excavadores. Cuando crece la vegetación en estos materiales pueden confundirse fácilmente con bloques de suelo volcados, por lo cual es determinante la observación de la composición y orientación de la cobertura vegetal, y del entorno inmediato a las acumulaciones. Otro rasgo común, confundible con bloques de suelo caídos, son los remanentes de sedimentos en posiciones centrales de los canales, los cuales suelen encontrarse vegetados, como el indicado en la Figura 10.14. Estos remanentes se deben a la baja erodabilidad (respecto a los limos loessoides) de algunos niveles arcillosos

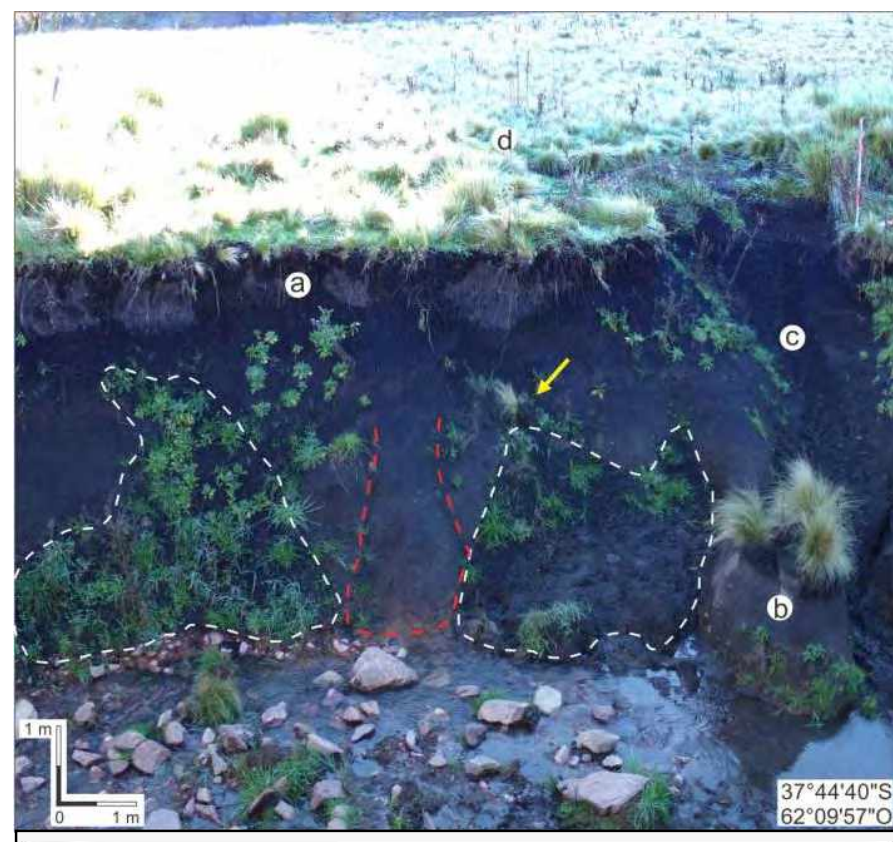

Figura 10.13. Talud limo-arcilloso en la margen derecha de un arroyo del Valle de Las Grutas (subzona 2). Líneas de trazos blancas: sectores vegetados, confundibles con materiales desplazados por movimientos en masa. Línea de trazos roja: posible flujo de barro. a: tramo vertical de la barranca. b: remanente de erosión fluvial o remanente de bloque deslizado. c: escotadura vinculada a acción del ganado. d: planicie de inundación. Flecha amarilla: pequeño bloque caído, nótese la orientación de la vegetación. Foto: Juan M. Susena. 
parcialmente calcificados. Se diferencian de las caídas de suelo por su coloración castaño rojiza, contrastante con el castaño oscuro característico de los horizontes superficiales de suelos que caen a los cursos. Este elemento, más la posición horizontal de lentes sabulíticas en dichos remanentes permiten en conjunto diferenciar, con cierta confianza, que se trata de remanentes de erosión in situ y no de bloques desplazados por movimientos en masa.

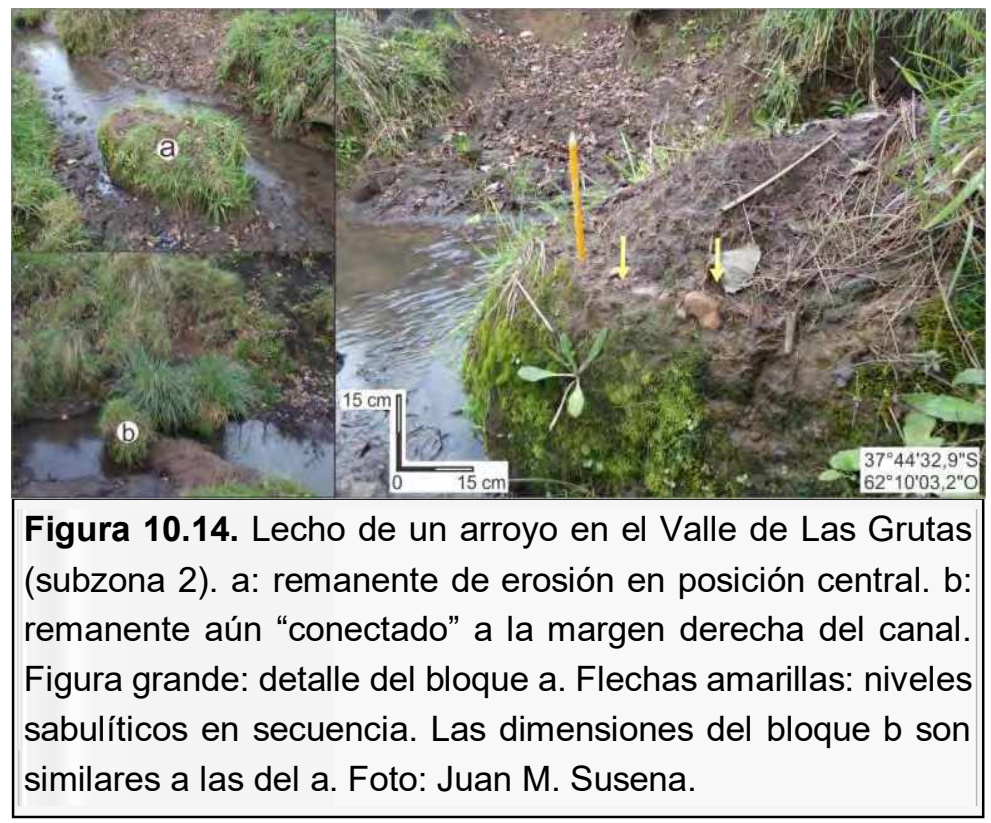

\subsection{Cursos de agua de valles intraserranos}

Los cursos de agua desarrollados en valles intraserranos corresponden principalmente a la unidad geomorfológica Incisiones Fluviales y atraviesan litologías generalmente más resistentes que los de la categoría anterior (Tabla 10.1). En general no se desarrollan barrancas, habiendo más bien una zona de transición entre las laderas y el cauce, con una pendiente mayor que las laderas, pero sin alcanzar el carácter vertical o sub-vertical de una barranca. En algunos casos se desarrollan barrancas, pero con superficies muy irregulares, siendo los movimientos en masa generados a expensas de las últimas más difíciles de clasificar. Se reconocieron caídas de roca/detritos, vuelcos de roca, deslizamientos de detritos, flujos de detritos y reptación.

Caídas de roca/detritos: son comunes y bien representadas en los cursos de agua que atraviesan las secuencias cuarcíticas de los Grupos Curamalal y Ventana, aunque también afectan a bloques de las Fms. Las Malvinas y Agua Blanca, el Aluvio y los Detritos de Ladera. Las caídas desde afloramientos de las secuencias cuarcíticas se vinculan a frentes escarpados verticales, sub-verticales y con aleros (ver Capítulo 8 Movimientos en masa desde frentes escarpados rocosos), contiguos o no a las fajas aluviales que integran los cursos. De cualquier manera, aportan materiales a los cursos de agua, representados por bloques de hasta $10 \mathrm{~m}$ de eje mayor. El tamaño de los bloques caídos y las estructuras de los frentes que los generan determinan la permanencia y su transporte aguas abajo (Figura 10.15). Así, cuando el tamaño de los bloques supera la competencia del agente fluvial, 
pueden constituir obstáculos que afectan al escurrimiento encauzado de diversas maneras (véase Capítulo 11 Interacciones

movimientos en masa $y$ escurrimiento superficial/subsuperficial). Por otra parte, las caídas de bloques integrantes de las Fms. Malvinas, Agua Blanca, Aluvio y Detritos de ladera, por lo general se circunscriben a las barrancas, y su producción se vincula al socavamiento basal, que

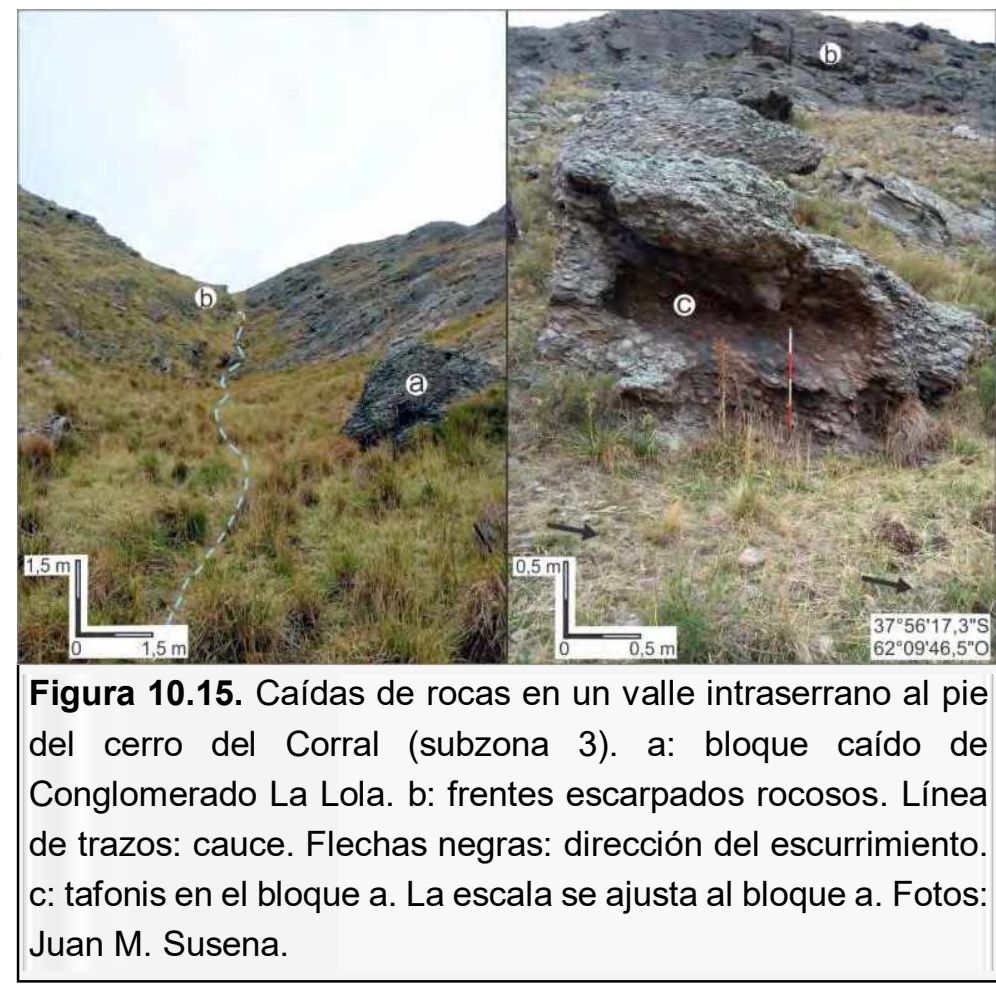
genera bloques colgados, y al lavado de la matriz de dichos depósitos. La similitud entre los bloques caídos y los depósitos de las fajas aluviales donde caen hace difícil la identificación de estos movimientos, por lo cual resulta indispensable constatar la existencia de los procesos mencionados, ya que actúan como mecanismos preparadores o disparadores de los movimientos. La ausencia de los materiales en las barrancas es otro elemento útil para identificar la ocurrencia de estos movimientos.

Vuelcos de roca: se vinculan a los frentes escarpados rocosos que limitan los valles intraserranos en sus cabeceras y en la transición entre estos y el piedemonte. En el primero de los casos, los cursos de agua se presentan como canaletas angostas de altas pendientes (Incisiones Fluviales), limitadas a una o ambas márgenes por afloramientos, donde los vuelcos generados producen bloques que, cuando yacen en las canaletas, pueden ser reconocidos por su morfología tabular característica (véase Capítulo 8 Movimientos en masa desde frentes escarpados rocosos). Ésta, se vincula estrechamente con la estructura geológica de los frentes de los cuales proceden, y cuando el transporte es escaso puede incluso reconocerse el hueco en el macizo rocoso en el cual se encontraba el bloque. Estos vuelcos, a diferencia de los desarrollados en Fajas Aluviales, raramente se vinculan al socavamiento basal por acción fluvial; se relacionan más bien con superficies de debilidad de los frentes escarpados, donde se produce un empuje hacia afuera por relleno de grietas y/o presión hidráulica. En las salidas de los valles hacia el piedemonte los vuelcos suelen producirse por socavamiento basal que genera sectores extraplomados. 
Deslizamientos de detritos: afectan al Aluvio y unidades afines que conforman las escarpas erosivas (= barrancas) de los cursos principales y sus tributarios, especialmente en las salidas de los valles hacia el piedemonte. Allí, las barrancas son verticales a subverticales con superficies irregulares, y suelen encontrarse superficies de ruptura de materiales, con o $\sin$ acumulaciones al pie. Las superficies de ruptura se asocian preferentemente a las barrancas de cursos tanto principales (a escala del valle) como tributarios, que afectan abanicos aluviales; las últimas, pueden tener hasta $2 \mathrm{~m}$ de altura, y pendientes superiores a $60^{\circ}$ (Figura 7.21 e $\mathrm{n}$ el Capítulo 7 Criterios de reconocimiento de los movimientos en masa y su actividad). Generalmente los deslizamientos que conservan las acumulaciones denotan antigüedad, con características tales como ausencia de material fino por lavado en las acumulaciones, y cubierta vegetal abundante en las escarpas, además de presencia de cortezas de líquenes en los bloques movilizados (Figura 10.16). La persistencia de estos rasgos en las fajas aluviales es factible principalmente cuando las acumulaciones se ubican en planicies de inundaciones excepcionales (o terrazas bajas), o cuando el tamaño de los bloques movilizados excede la capacidad de transporte fluvial en esos sectores.

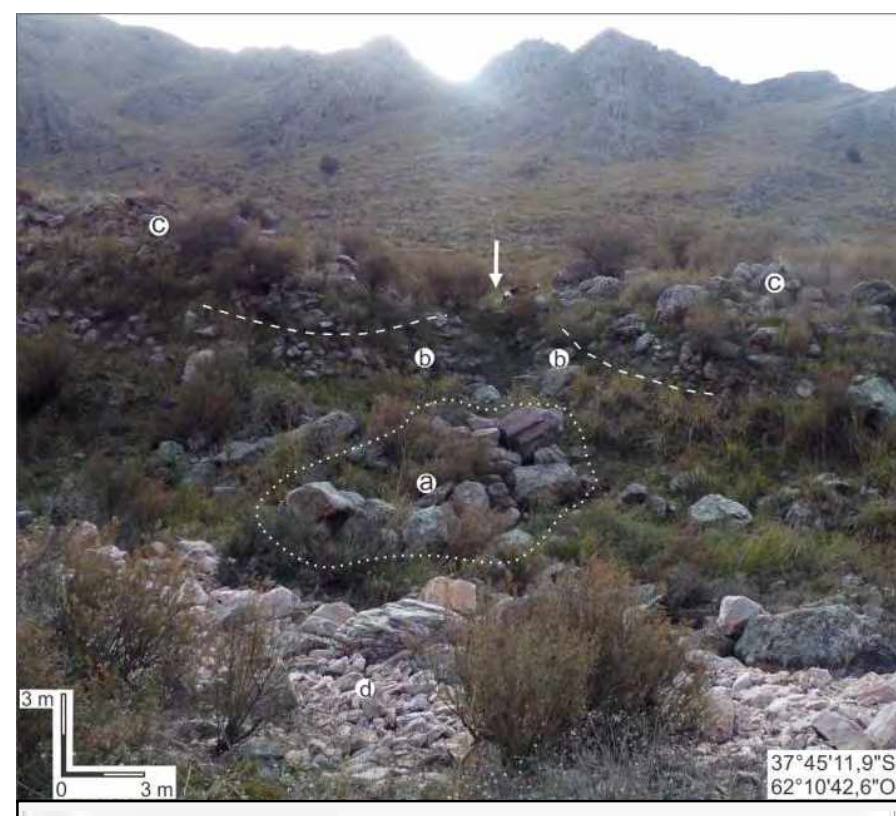

Figura 10.16. Deslizamiento de detritos afectando a un nivel pedemontano en un valle intraserrano de la vertiente oriental del Cdón. Lehmann (Sierras de Curamalal, subzona 2). a: acumulación; la ausencia de material fino y la abundancia de colonias de líquenes indican antigüedad del movimiento. b: flancos (las líneas de trazos refuerzan su visualización). Flecha blanca: escarpa; el perro está parado en la corona. c: terreno no afectado. d: cauce fluvial; la escasez de clastos con líquenes es contrastante con la acumulación del deslizamiento. Foto: J. M. Susena y Georgina Scarponi.

Los deslizamientos de detritos también se desarrollan en las zonas de transición entre Laderas de Detritos y los cauces, afectando a los Detritos de Ladera. En estos casos, el contenido de matriz es algo mayor que en el Aluvio y unidades afines. Los deslizamientos desarrollados se reconocen a partir de las superficies de ruptura (cicatrices), y es muy difícil encontrar las acumulaciones, debido a la erodabilidad de su matriz. Las coronas tienen una morfología cóncava hacia el cauce; cuando la actividad es múltiple en sentido lateral, se generan cicatrices cóncavo-convexas vistas en planta (Figura 10.17). Algunas presentan 
Movimientos en masa en las sierras de Bravard y Curamalal, Sierras Australes de la Provincia de Buenos Aires.

Juan Manuel Susena

signos de escurrimiento superficial no encauzado, perdiéndose los materiales finos por lavado, a favor de la concentración de materiales sabulíticos o mayores. Cuando se encuentran vegetadas, estas superficies continúan siendo diferenciables del entorno debido a sus mayores pendientes.

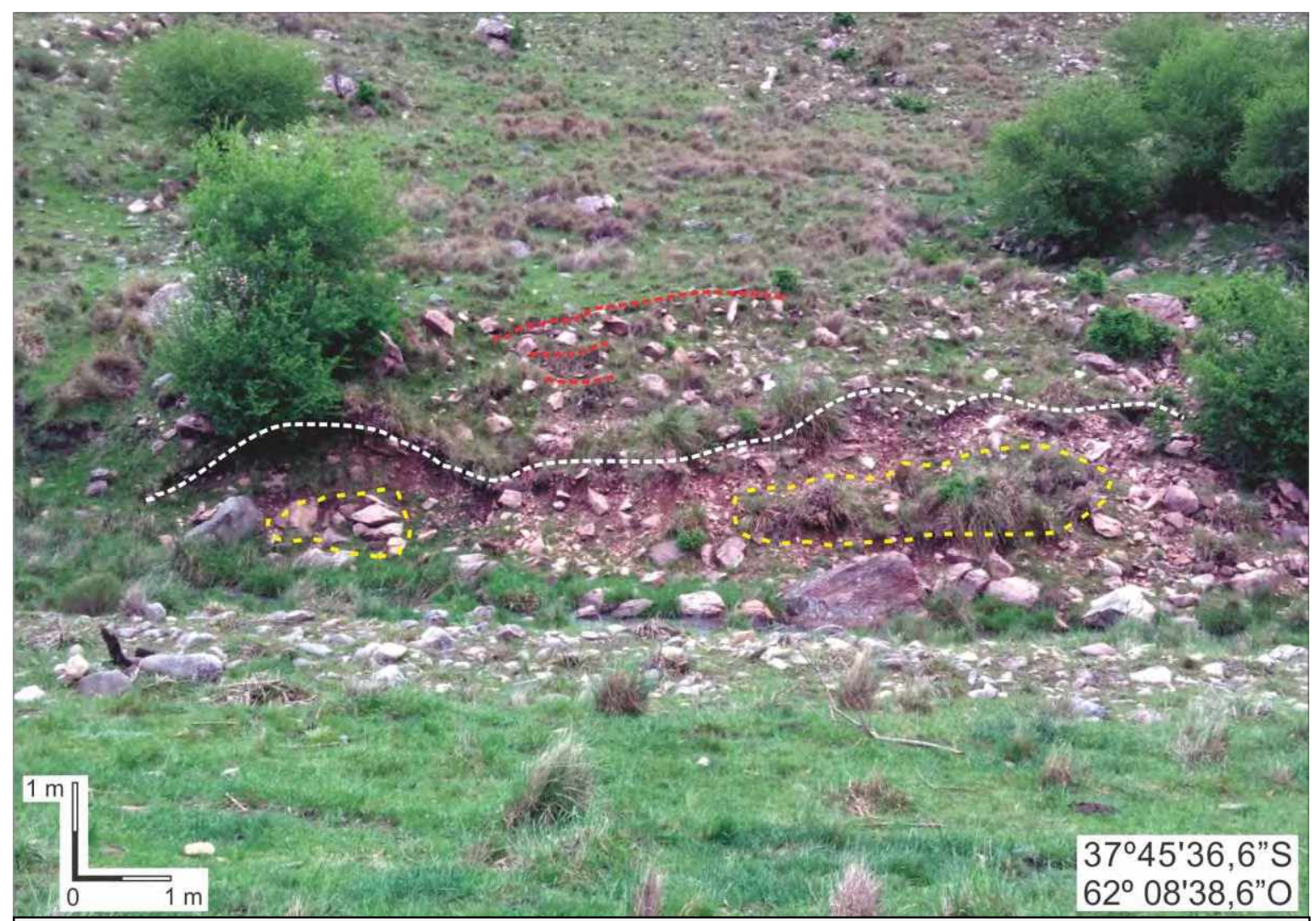

Figura 10.17. Deslizamientos de detritos en el arroyo Hinojo Grande (subzona 2). Línea blanca: escarpa de uno o más deslizamientos con una morfología cóncavo-convexa. Líneas amarillas: acumulaciones por deslizamientos. Líneas rojas: pequeñas escarpas en sector con intensa actividad de animales. Foto: Juan M. Susena. 
Flujos de detritos: los flujos de detritos fueron citados como un rasgo común en las sierras de Bravard y Curamalal (Pereyra y Ferrer, 1995). En los valles, los depósitos se asemejan morfológicamente a los fluviales, en parte por su carácter elongado, pero las dimensiones de los depósitos (especialmente su altura) y la fábrica caótica de los flujos de detritos difiere del ordenamiento imbricado y la escasa altura (por lo general menos de $1 \mathrm{~m}$ ) de las barras fluviales. En los valles intraserranos de las Sierras de Curamalal se encontraron depósitos con fábrica caótica integrados por bloques que superan el metro de eje mayor, con o sin matriz, como el que se muestra en la Figura 7.16 (en el Capítulo 7 Criterios de reconocimiento de los movimientos en masa y su actividad). Estos depósitos son alargados, pueden superar los $10 \mathrm{~m}$ de longitud y los $3 \mathrm{~m}$ de altura, presentando perfiles transversales convexos y frentes abruptos. Aparecen en el fondo de los valles, tanto en el centro como en las márgenes, siendo bordeados por el cauce. Las dimensiones considerablemente mayores del depósito respecto a las del cauce aledaño y su carga de lecho permiten descartar la posibilidad de que se trate de una antigua faja aluvial y que el cauce simplemente migró. Las cuencas donde se encuentran son de orden 1 o 2 y de escasa superficie, lo cual también induce a descartar una génesis netamente fluvial de estos depósitos. Las acumulaciones pueden obstruir la transición entre las Laderas de Detritos y las Incisiones Fluviales, desarrollándose una pequeña bajada coluvial fina al pie de las laderas (Figura 10.18).

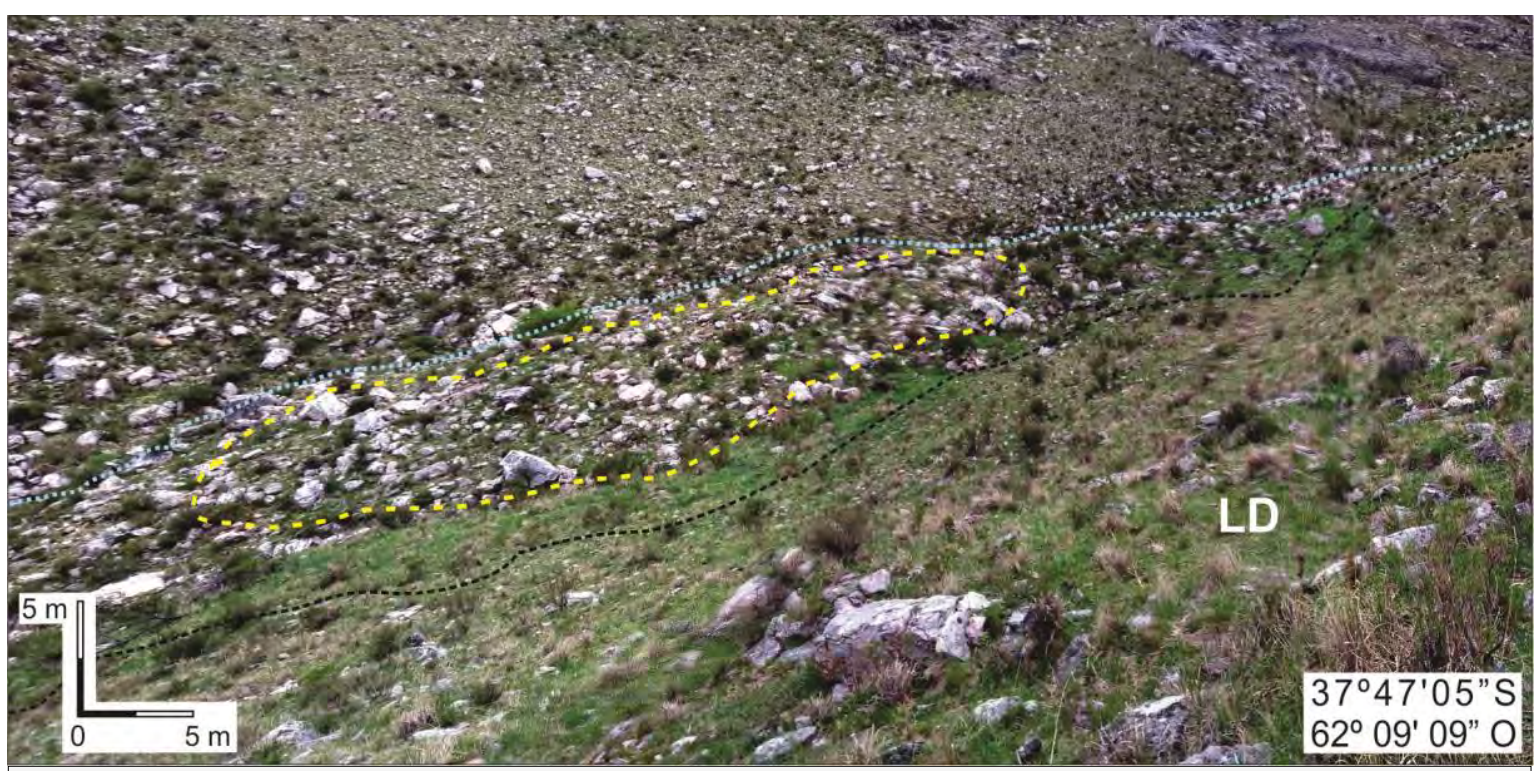

Figura 10.18. Flujo de detritos en un valle intraserrano de la vertiente oriental del Cdón. Hinojo Grande (subzona 2). En amarillo se encierra el depósito del flujo, el cual tiene unos $2 \mathrm{~m}$ de altura. La incisión fluvial (línea celeste) se ubica unos $3 \mathrm{~m}$ topográficamente por debajo del depósito. Línea negra: zona de contacto entre la Ladera de Detritos (LD) y una bajada coluvial fina de escasa pendiente. Foto: Juan M. Susena. 
Reptación: en las márgenes de cursos de agua labradas en Aluvio y afines, se han encontrado terracettes de unos $0,5-1,0 \mathrm{~m}$ de altura por $0,4 \mathrm{~m}$ de ancho, asociadas y no asociadas a zonas de arranque de materiales. Parte de ellas se relacionan con caminos de animales entrantes hacia los cursos agua, con presencia de huellas y excrementos, aunque no es siempre observable la orientación en zig-zag de los escalones, característica en dichas situaciones. Sus pendientes son sometidas a escurrimiento superficial no encauzado con lavado de los materiales más finos, generando rasgos similares a los mencionados en cicatrices de deslizamientos de suelo (Figura 10.19).

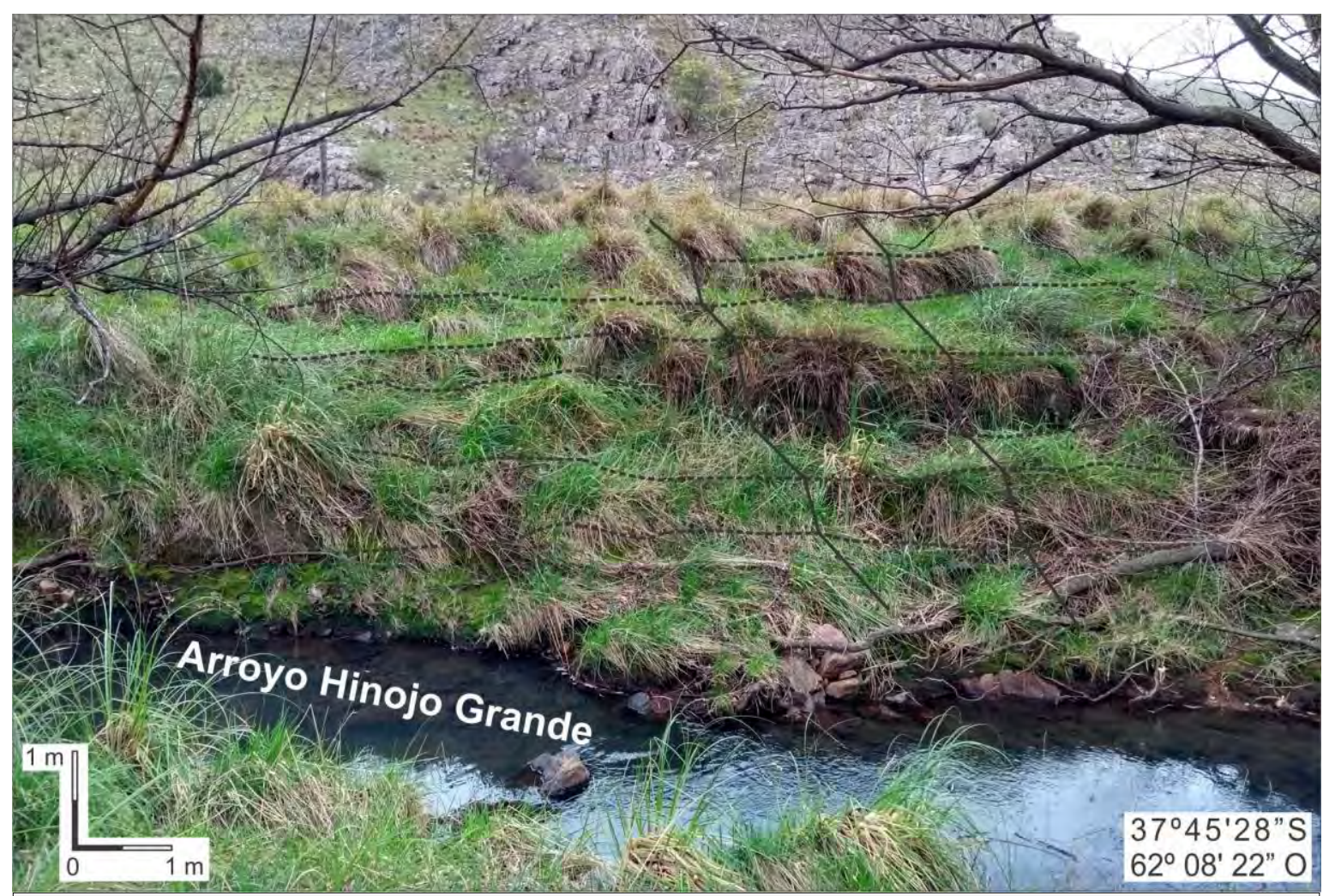

Figura 10.19. Reptación en la margen izquierda del arroyo Hinojo Grande (subzona 2). Las terracettes desarrolladas se refuerzan visualmente con líneas de puntos. Las líneas continuas representan la topografía. Foto: Juan M. Susena. 


\section{Capítulo 11}

\section{Interacciones entre movimientos en masa y escurrimiento superficial/sub-superficial}

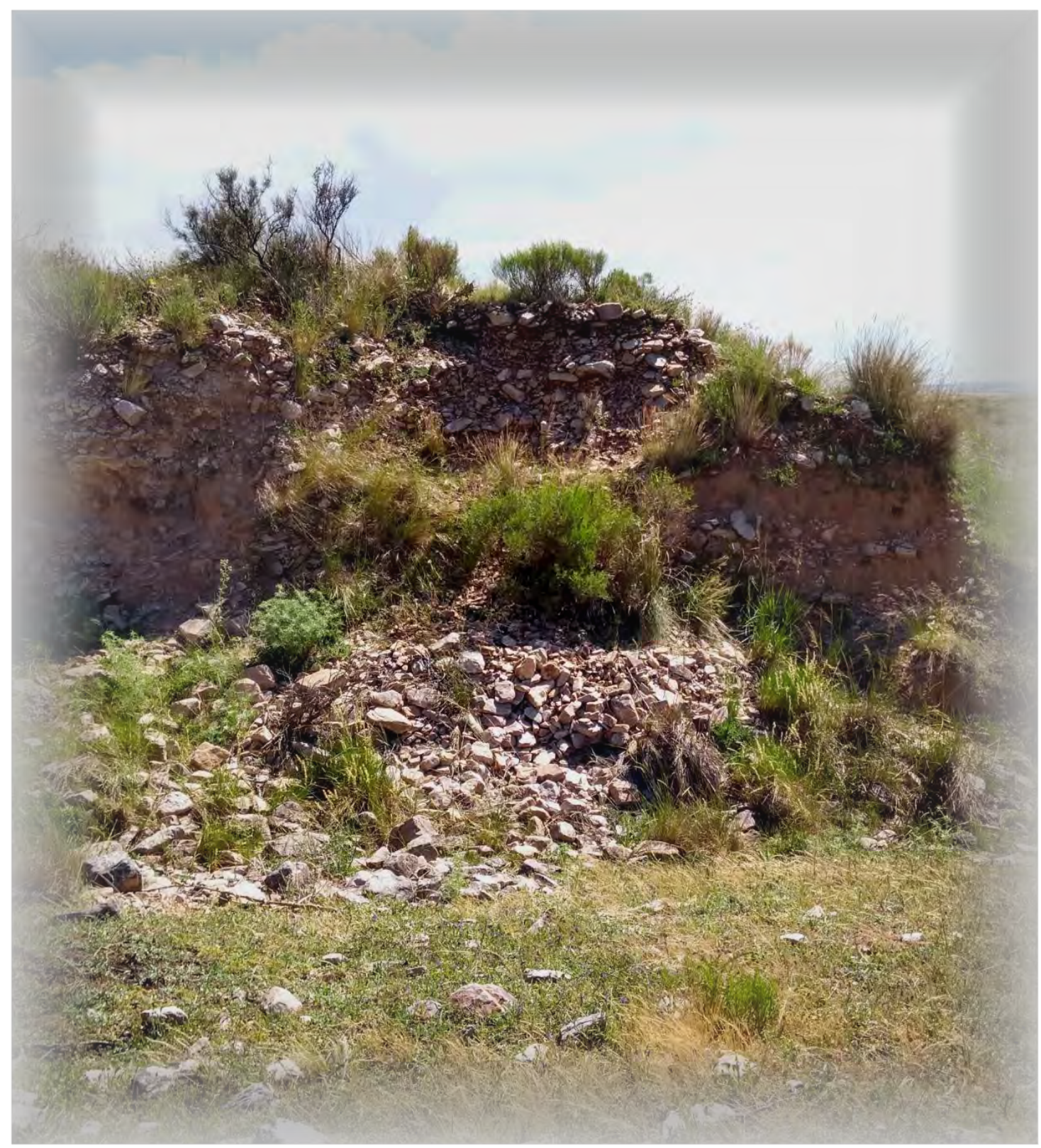

"Sin escrúpulos"

Insatisfecho con destruir los depósitos aluviales, intentó sepultar la planicie de inundación.

Foto de campo tomada en la penúltima campaña. 
Movimientos en masa en las sierras de Bravard y Curamalal,

Sierras Australes de la Provincia de Buenos Aires.

Juan Manuel Susena 


\subsection{Objeto de estudio y organización del capítulo}

En el presente capítulo se describen las interacciones entre las geoformas producidas por movimientos en masa, y la actividad hidrológica en superficie y sub-superficie. Se incluyen dentro de estas interacciones a las modificaciones del escurrimiento superficial por la presencia de movimientos en masa (geoformas), y la acción del agua en la modificación de tales geoformas. En este capítulo, la acepción "movimientos en masa" se referirá a las geoformas, mientras que se llamará "procesos de remoción en masa" a los procesos que las originan.

La acción del agua como mecanismo preparador y desencadenante de los procesos de remoción en masa es objeto de otros apartados de esta tesis (ver Capítulo 13 Causas de los movimientos en masa).

La Figura 11.1 esquematiza el ordenamiento de este capítulo. Se diferencian

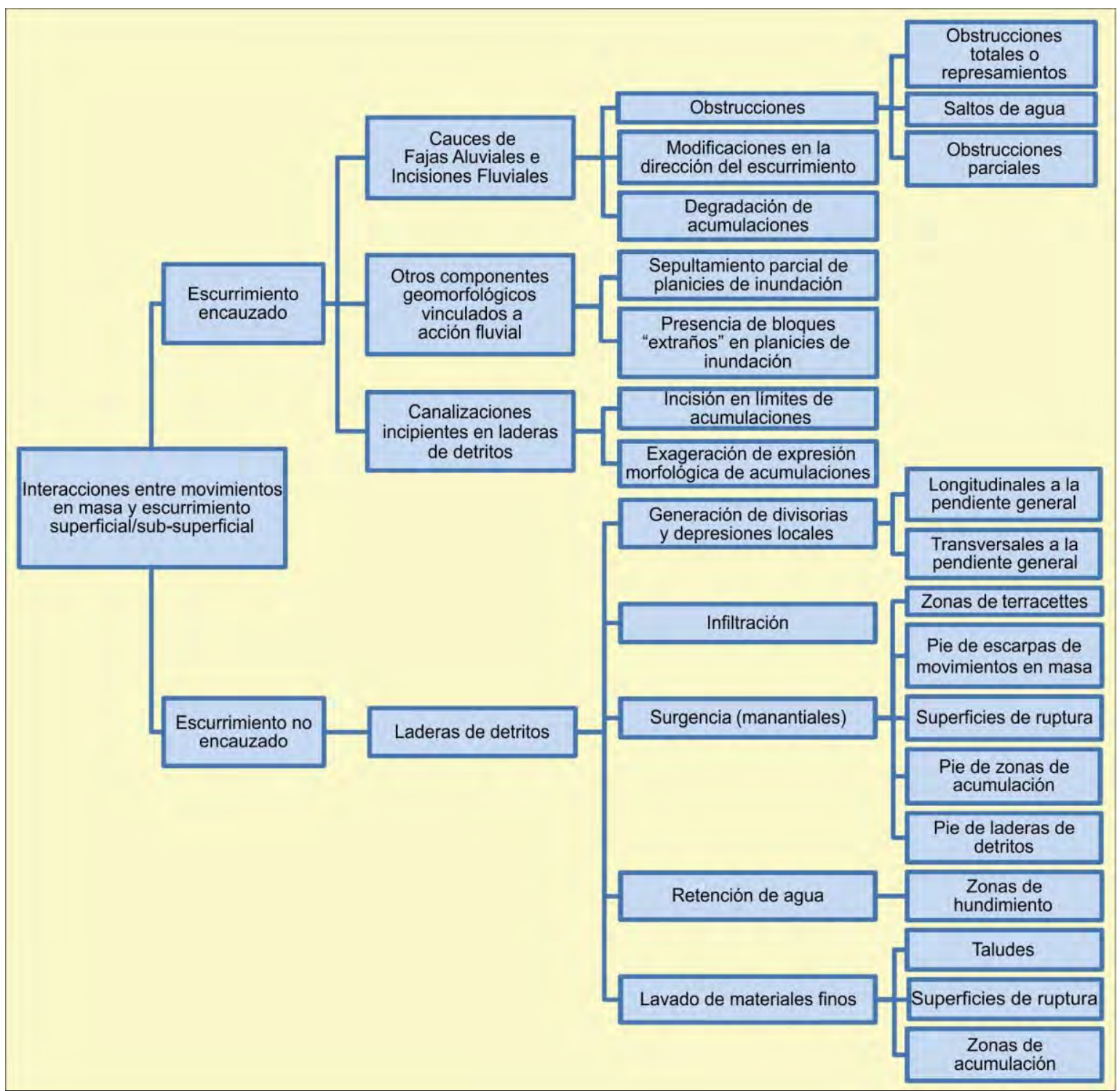

Figura 11.1. Esquema guía del ordenamiento del capítulo 11. Elaboración propia. 
primeramente las interacciones en base a las características del escurrimiento superficial (encauzado o no encauzado). Cabe aclarar que, si bien algunos autores consideran a la concentración incipiente del escurrimiento como arroyada difusa, se incluirá aquí a las canalizaciones incipientes de las laderas de detritos como escurrimiento encauzado, puesto que interactúan con los movimientos en masa de manera similar a tal tipo de escurrimiento. Una segunda diferenciación se hizo conforme a los componentes del paisaje principales donde existen las interacciones estudiadas. Finalmente, se discrimina entre distintos tipos de interacciones, y cuando resulta conveniente, estas se caracterizan en relación a diferentes modos de expresión de la interacción o relaciones con componentes geomorfológicos menores, como lo son las distintas partes de un movimiento en masa.

\subsection{Interacciones con el escurrimiento superficial encauzado}

\subsubsection{Interacciones en cauces de Fajas Aluviales e Incisiones Fluviales}

En el contexto de caracterización de los movimientos en masa, se mencionó en el capítulo anterior la relación entre algunos movimientos en masa que afectan a las escarpas erosivas de los canales, y el escurrimiento superficial encauzado. Existen además otros movimientos en masa, desarrollados en componentes del paisaje contiguos a los cursos de agua, o que los incluyen (laderas de detritos, valles intraserranos, etc.; Tabla 10.1 en el capítulo anterior), y que afectan a la red de drenaje de diferentes maneras; las relaciones de ambos casos se tratan juntamente a continuación.

\section{Obstrucciones}

En valles intraserranos, los movimientos en masa (deslizamientos, flujos, caídas y vuelcos) en sus laderas pueden alcanzar los canales del sistema de drenaje, obstruyendo parcial o totalmente el escurrimiento superficial y generando saltos de agua en contextos particulares. La posibilidad de que se desarrolle una obstrucción a partir de un movimiento en masa de una ladera dependerá de las relaciones espaciales (cercanía) entre las laderas y los cauces. Los valles pueden ser "confinados" por laderas de detritos contiguas, sin desarrollo de una planicie de inundación, o pueden ser "abiertos", donde existen planicies de inundación bien desarrolladas, y las laderas confinantes no se relacionan entre sí (Figura 11.2).

En los valles "confinados", las laderas rocosas y frentes escarpados asociados aportan materiales principalmente por caídas, vuelcos y deslizamientos planares, de roca, en sectores donde las pendientes superan los $45^{\circ}$-aunque algunos deslizamientos planares 


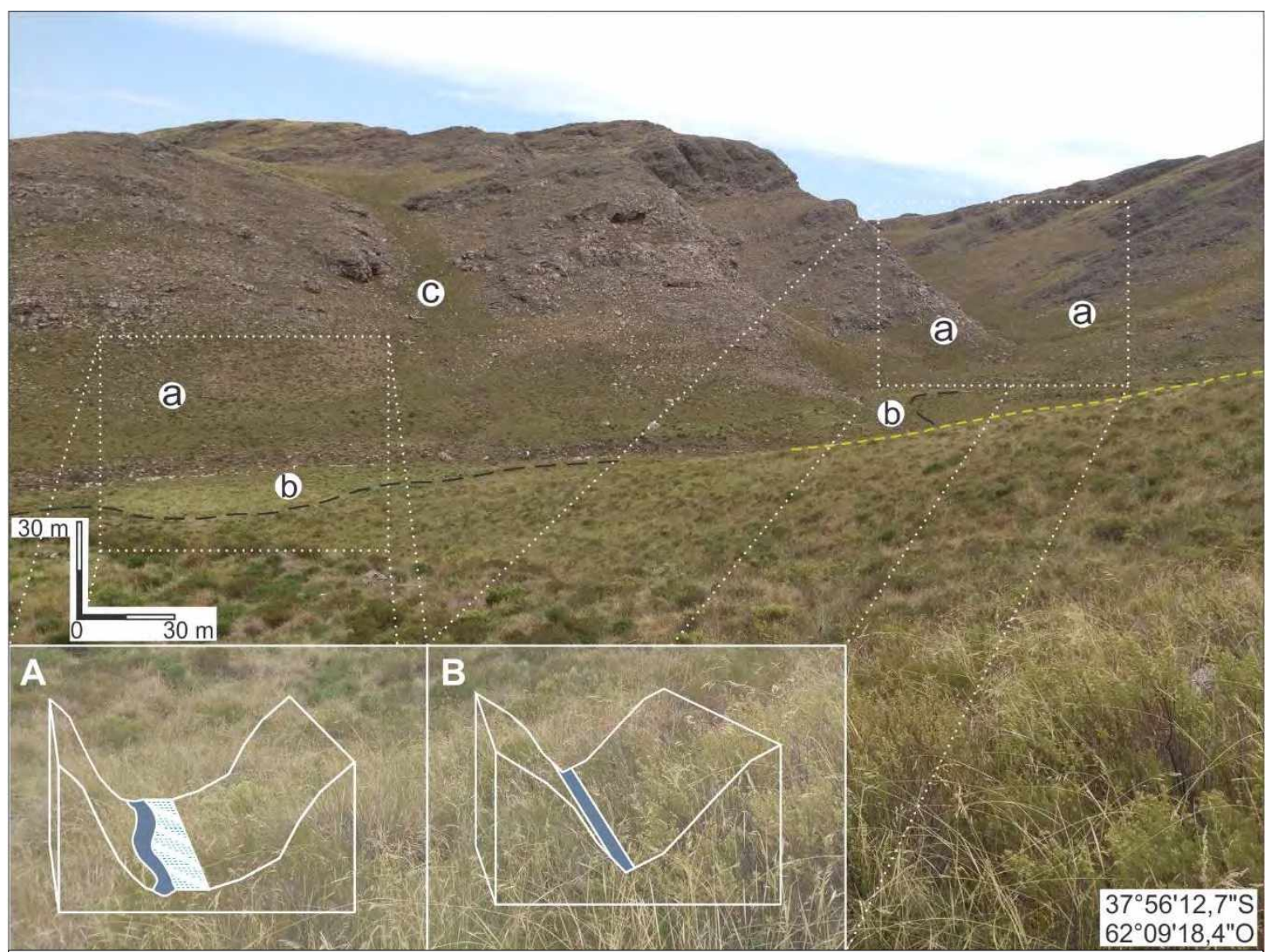

Figura 11.2. Valles intraserranos en el Cerro Del Corral (subzona 3). A: Valles "abiertos". B: Valles "confinados". a: laderas de detritos. b: planicies de inundación. c: pequeño valle asimétrico. Línea de trazos amarilla: refuerzo visual del perfil de la pendiente (divisoria de aguas local) próxima al observador. La escala se ajusta al valle c. Foto: Juan M. Susena. Esquemas: elaboración propia.

se desarrollan en pendientes algo menores-, así como en sub-verticales y extraplomadas (ver Capítulo 8 Movimientos en masa desde frentes escarpados rocosos). La disposición de los estratos y diaclasas favorece dicha situación, y se desarrolla tanto en las Sierras de Bravard como en las de Curamalal, preferentemente en valles perpendiculares al rumbo de las sierras, tales como las "abras" de la Ea. Cerro Áspero (Figura 11.3), y los valles del Co. del Corral en la Ea. Sauce Chico (Figura 11.4).

En los valles "abiertos" los materiales también pueden ser aportados desde las laderas -e incluso desde niveles pedemontanos disectados- por procesos de remoción en masa. Otros valles "abiertos" son limitados a un lado por Laderas de Detritos, y al otro por unidades que agrupan el piedemonte inactivo o algunas unidades aluviales activas. En ellos, se identificaron deslizamientos y caídas. Los deslizamientos se desarrollan preferentemente en escarpas erosivas de piedemontes aluviales o coluviales antiguos, disectados (Figura 11.5.A); las caídas, por lo general desde entrantes en frentes escarpados contiguos, a partir de las cuales se desarrollan conos de detritos (Figura 11.5.B). Esta situación es también la de muchos cursos de agua integrantes de la unidad geomorfológica Fajas Aluviales. 
Movimientos en masa en las sierras de Bravard y Curamalal,

Sierras Australes de la Provincia de Buenos Aires.

Juan Manuel Susena

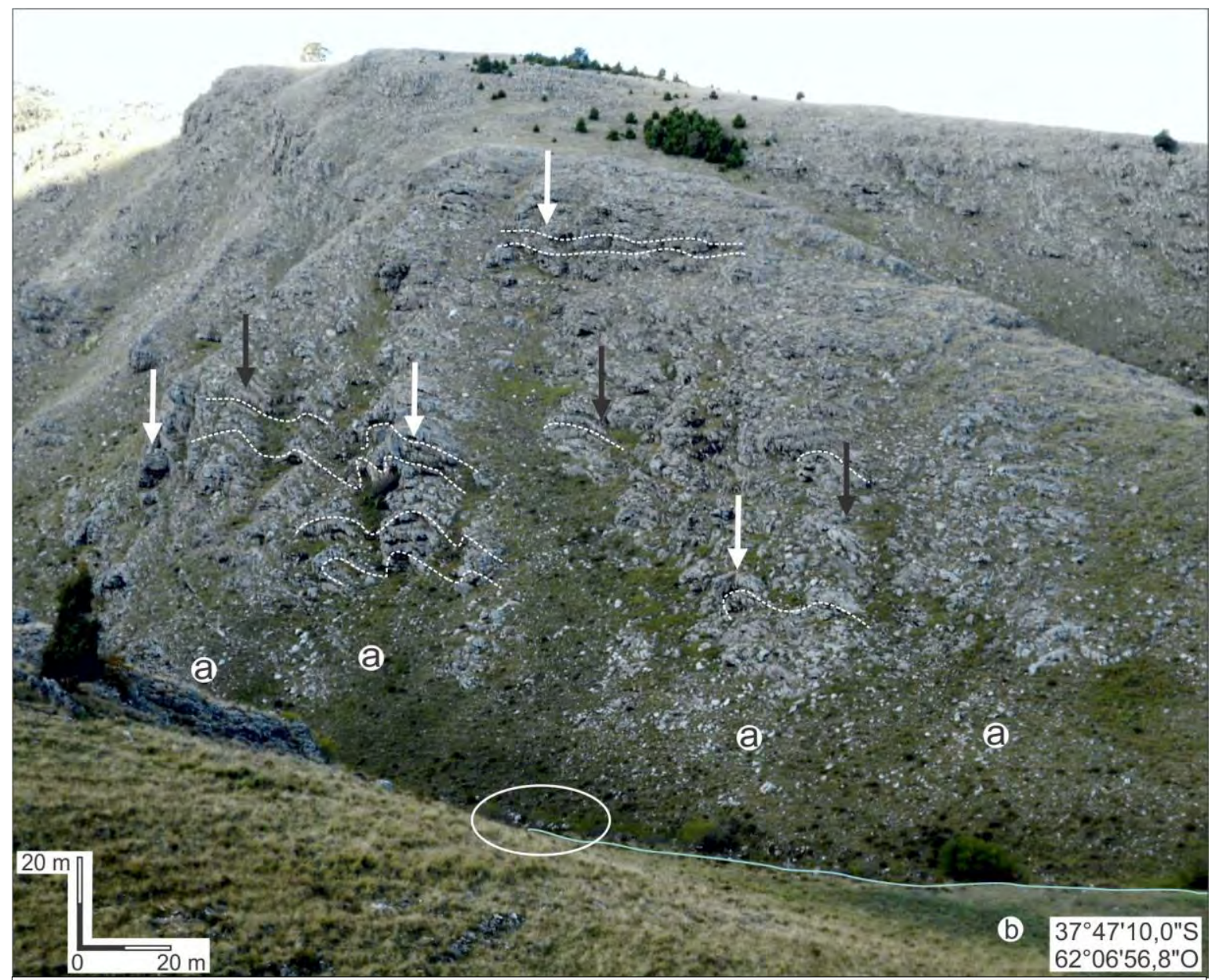

Figura 11.3. Valle intraserrano en el Cerro Barrancoso (Sierras de Bravard, subzona 2), "confinado" en la parte izquierda de la foto y "abierto" en la parte derecha de la foto. Línea celeste: cauce. Elipse: bloques rocosos alcanzando el cauce. a. campos de bloques desplazados. b: faja aluvial disectada. Flechas blancas: sectores de pendientes sub-verticales a extraplomadas. Flechas negras: sectores de pendientes cercanas a $45^{\circ}$. Líneas de trazos: refuerzo visual de la estructura de plegamiento. La escala se ajusta al centro de la imagen. Foto: Juan M. Susena. 


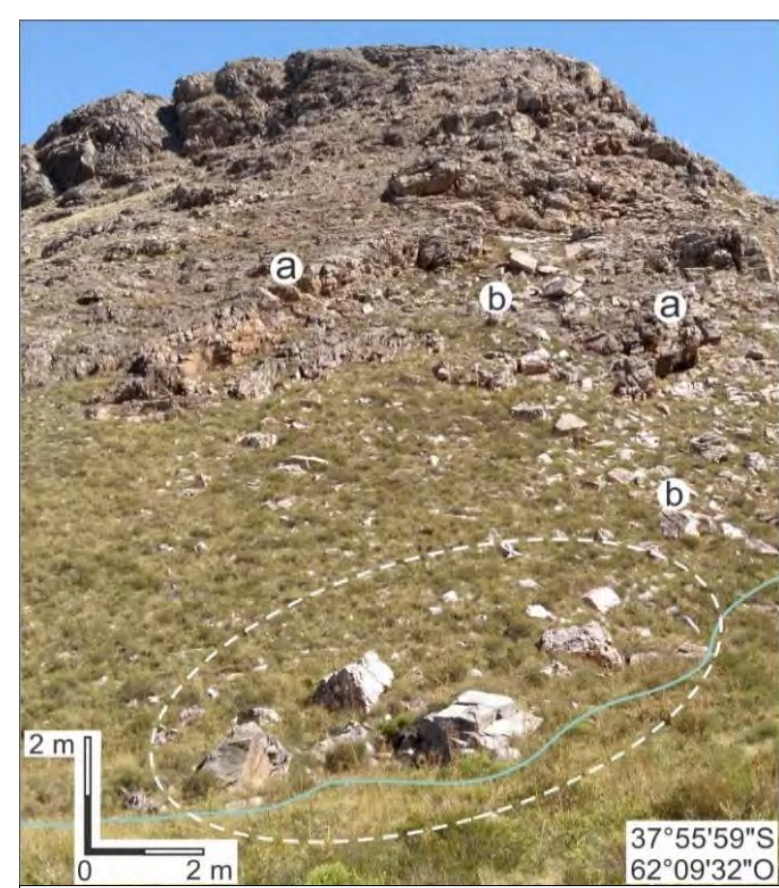

Figura 11.4. Ladera derecha de valle intraserrano "confinado" en la Ea. Sauce Chico, cerca del Cerro Chaco (Sierras de Curamalal, subzona 3). a: frentes escarpados rocosos. b: campo de bloques desplazados. Elipse: bloques distales. Línea: curso de agua. La escala se ajusta a los bloques distales. Foto: J. M. Susena.

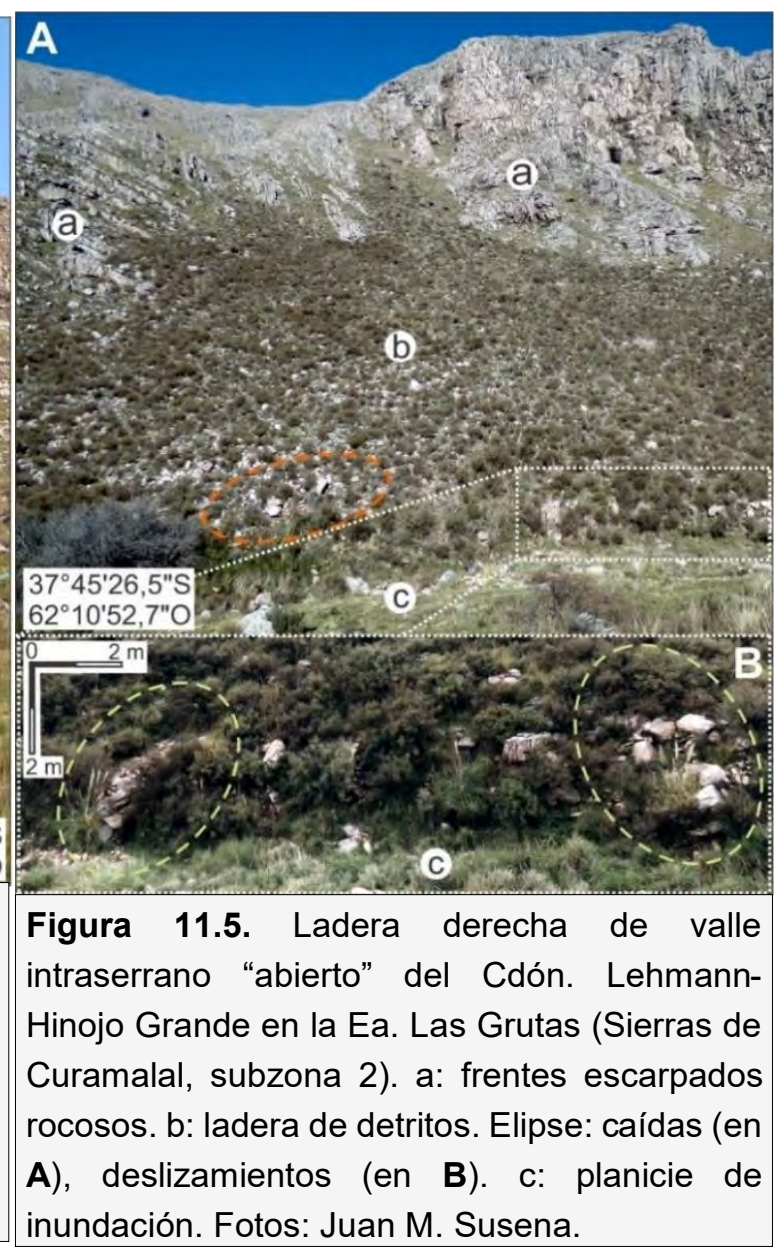

Los movimientos en masa, muchas veces constituidos por bloques de hasta 2-3 metros,

\section{pueden generar obstrucciones}

totales en los cursos de agua, constituyendo pequeños represamientos aguas arriba, de hasta $5 \mathrm{~m}$ de diámetro y $1,5 \mathrm{~m}$ de profundidad. Generalmente estos materiales provienen de caídas desde frentes escarpados próximos, o de deslizamientos 0 flujos desde las laderas de detritos. Esta situación ocurre en cuencas de primer o segundo orden con pendientes relativamente bajas en los cauces (Figura 11.6). Allí, el agua alcanza el canal

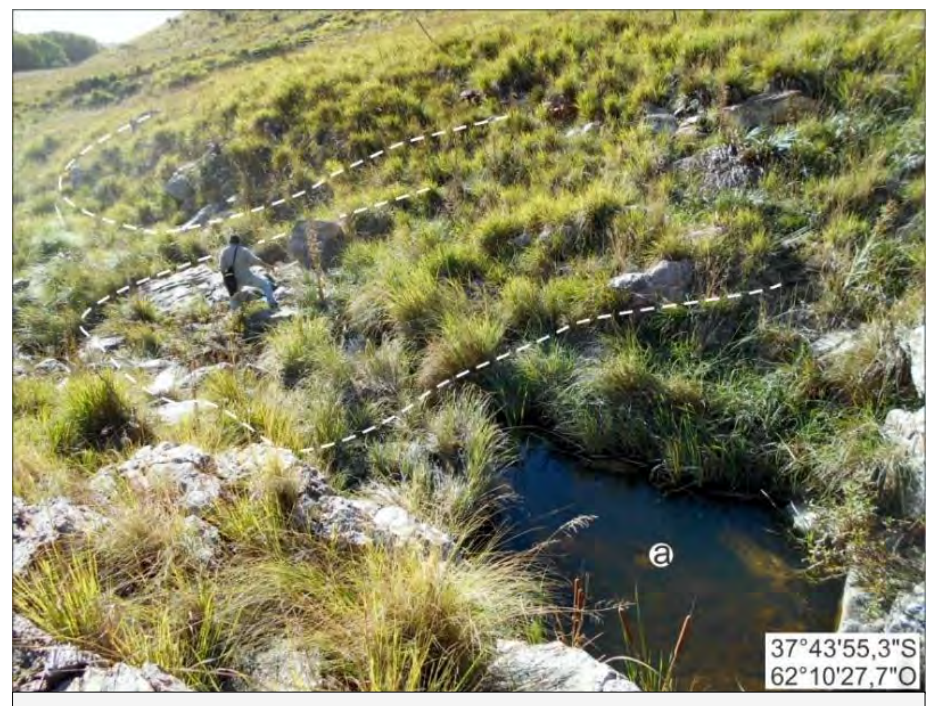

Figura 11.6. Valle intraserrano en la Ea. Las Grutas (Sierras de Bravard, subzona 2). Represamiento a: cuerpo de agua. Línea de trazos: movimientos en masa (zona de acumulación). La persona -utilícese como escala- se sitúa sobre el movimiento que produjo el represamiento. Foto: Juan M. Susena y Rodolfo O. Gentile. 
principalmente por escurrimiento superficial no encauzado, careciendo de energía suficiente para remover el obstáculo. Filtrándose por los espacios entre bloques, el agua escurre lentamente, removiendo los materiales finos, y los cuerpos de agua se vacían unos días después de las lluvias. También ocurren represamientos en cabeceras de pendientes mayores, desarrollándose cuerpos de agua de 2 o $3 \mathrm{~m}$ de diámetro y hasta $0,5 \mathrm{~m}$ de profundidad -aunque algunos alcanzan dimensiones mayores- ocasionados por bloques caídos. Estos pueden desplazarse desde frentes escarpados cercanos, recorriendo las laderas y alcanzando el canal, o desde frentes que generan "saltos de agua" en canales de lecho rocoso (quiebres en el perfil longitudinal de los cursos). En los últimos, los represamientos ocasionados por caídas de bloques, árboles y materiales aluviales o coluviales alcanzan dimensiones de 5 metros de diámetro y más de $1,5 \mathrm{~m}$ de profundidad.

Ocasionalmente se originan saltos de agua asociados a los represamientos. Cuando los bloques, acompañados en mayor o menor medida por troncos de árboles caídos, obstruyen un cauce labrado en laderas de detritos, la altura de los saltos depende el tamaño de dichos bloques, y alcanzan unos pocos metros (Figura 11.7). Saltos mayores pueden generarse cuando los materiales caídos $-y$ en parte los transportados por el agua- se ubican aguas arriba de algún afloramiento rocoso, y obstruyen el cauce. Así, se generan represamientos más amplios y profundos, y saltos de agua de mayor altura, otrora más pequeños, cuando el salto se producía desde el lecho rocoso.

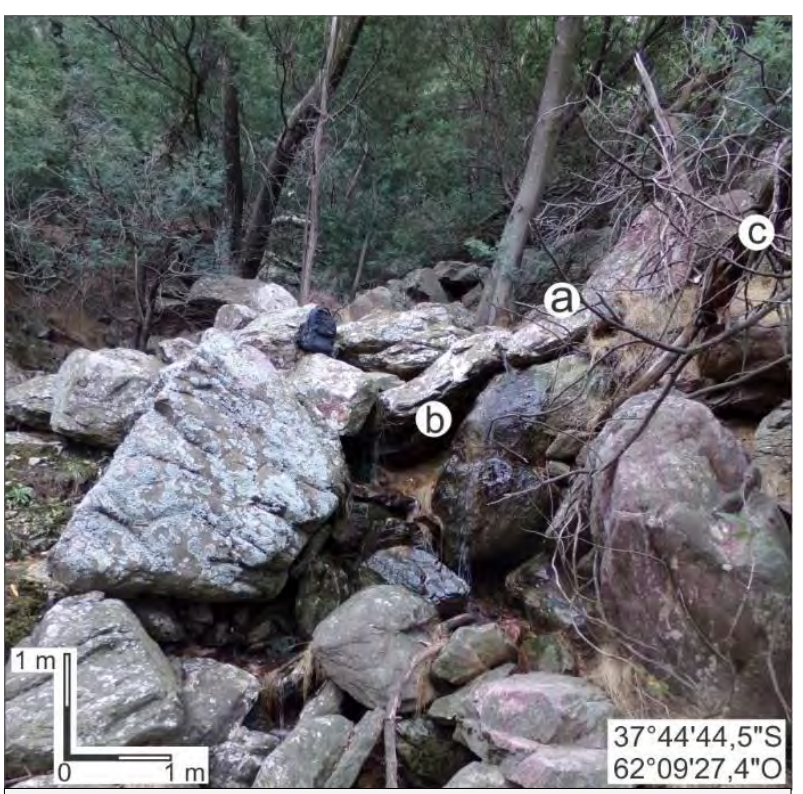

Figura 11.7. Pequeño salto de agua en valle intraserrano de la Ea. Las Grutas (Sierras de Bravard, subzona 2). a: ubicación del represamiento (detrás de los bloques, no visible en la imagen). b: pequeño salto de agua. c: árbol caído. Foto: Juan M. Susena.

Las obstrucciones parciales se producen en valles con vegetación arbórea, donde los troncos pueden ser quebrados por caídas de bloques o vientos fuertes, y caer en los cursos de agua, obstruyéndolos total o parcialmente. Se identificaron "alineaciones" de árboles caídos y bloques, verdaderamente intransitables, asociados a canalizaciones incipientes en laderas de valle (Figura 11.8). Otros casos de obstrucciones parciales consisten en bloques rocosos o de suelo, que caen, vuelcan o se deslizan hacia los cauces desde laderas de detritos o niveles de piedemonte antiguos, como lo son los bloques topográficamente inferiores de la Figura 11.4. Estas situaciones generan remansos en los cursos de agua, y las acumulaciones pueden perder progresivamente su expresión (ver 
Capítulo 7 Criterios de reconocimiento de los movimientos en masa y su actividad). Generan núcleos de acreción fluvial, e incluso forman parte de represamientos, produciéndose estanques aguas arriba.

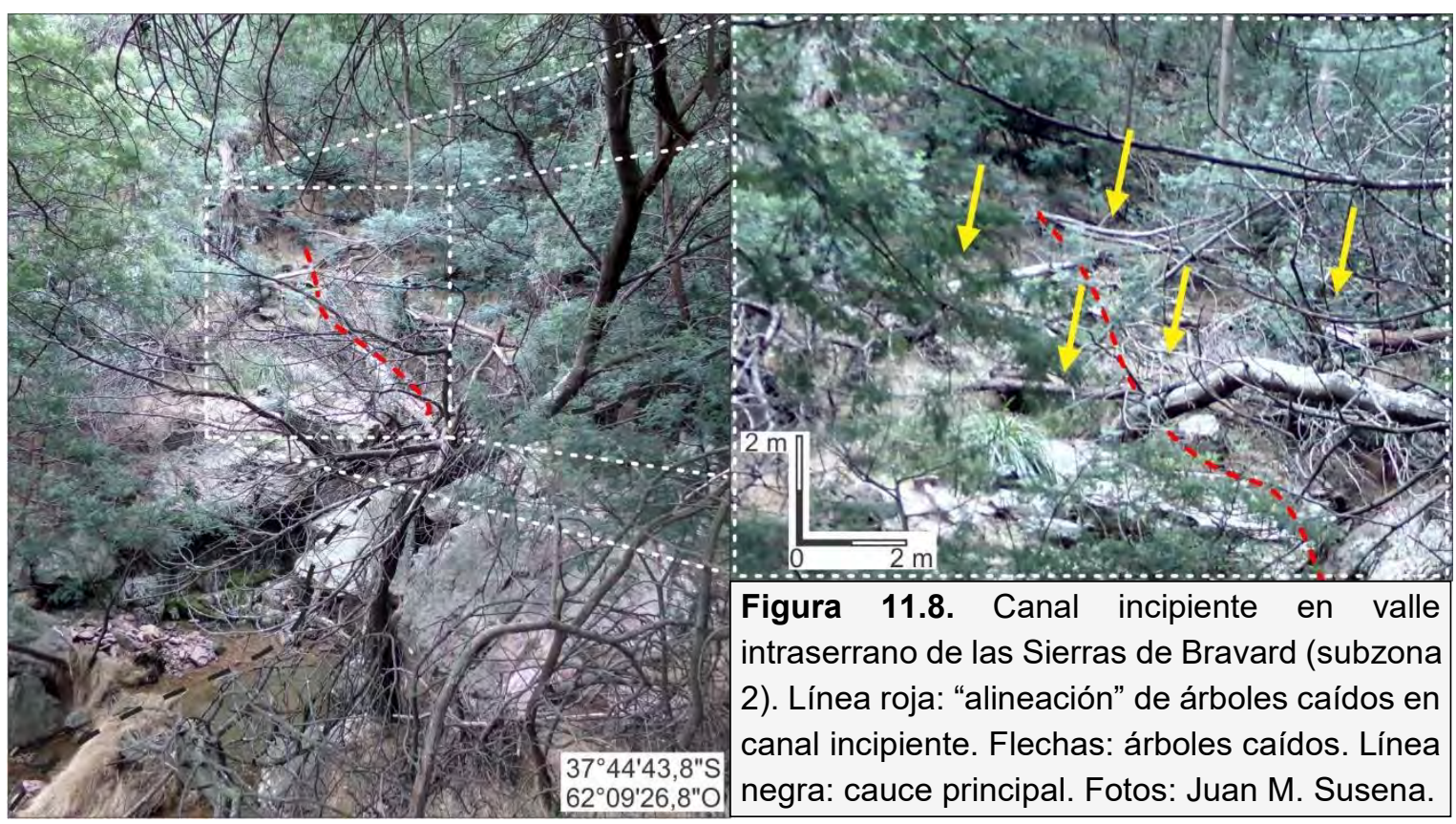

\section{Modificación en la dirección de drenaje}

Tanto en Fajas Aluviales como en Incisiones Fluviales, en el caso de deslizamientos y flujos que alcanzan los canales, puede observarse una relación entre la forma de la lomada y la dirección del curso, sugiriendo que el último ha sido desviado por las acumulaciones (Figura 11.9). Dicha situación es más evidente en los cursos que cortan pequeños espesores de la Fm. Saavedra (material eólico). En los cauces se observa una disparidad entre los bloques que yacen en el canal producto de movimientos en masa y la competencia del agente fluvial, siendo mayores los primeros. Este tipo de relación puede observarse en el campo y a veces en fotografías aéreas o imágenes satelitales.

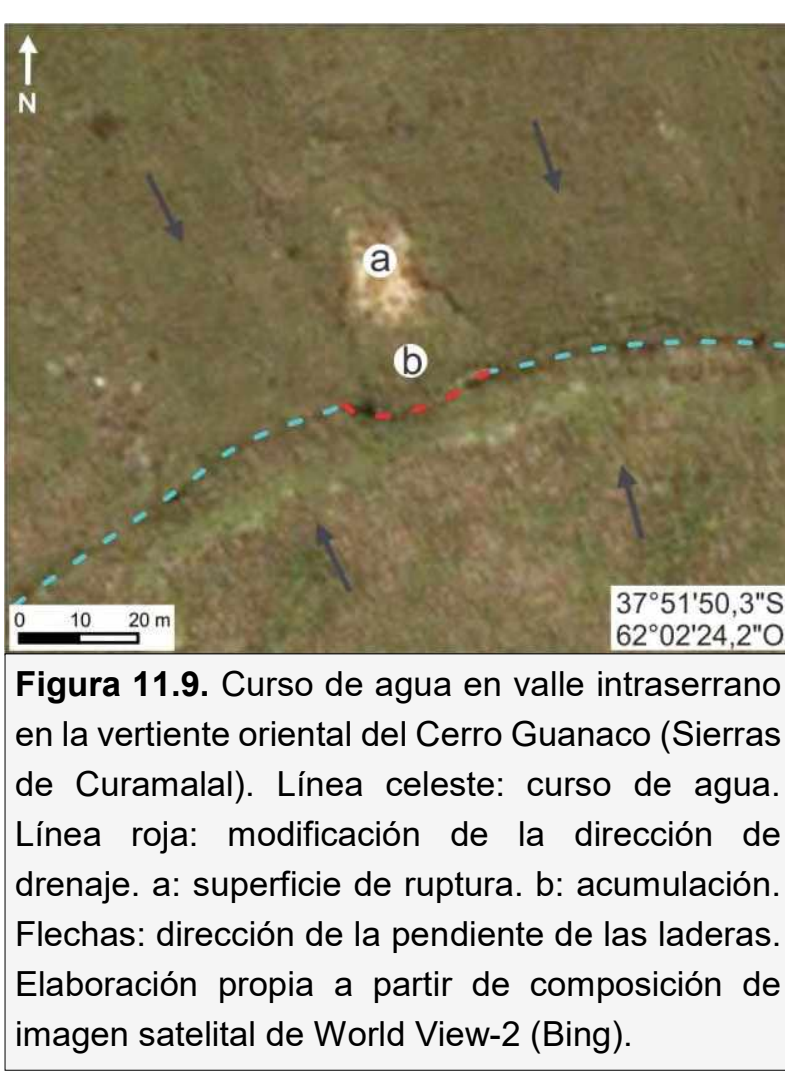

imagen satelital de World View-2 (Bing). 


\section{Degradación de acumulaciones}

Como contraparte a lo expresado en el párrafo anterior, en los cursos de agua -o sectores de ellos- con mayor energía, es difícil observar el aporte de materiales desde las laderas, debido a la erosividad y competencia del agente, y debe inferirse a partir de superficies de ruptura en las últimas, contiguas a los canales (Figura 11.10). Desde fotografías aéreas e imágenes de satélite se pueden observar relaciones de "corte", en las cuales los cursos de agua generaron escarpas en los frentes de las acumulaciones (= lomadas), cuyas pendientes superan el ángulo de reposo de los materiales que las constituyen, como se muestra en el sector derecho de la Figura 11.10.

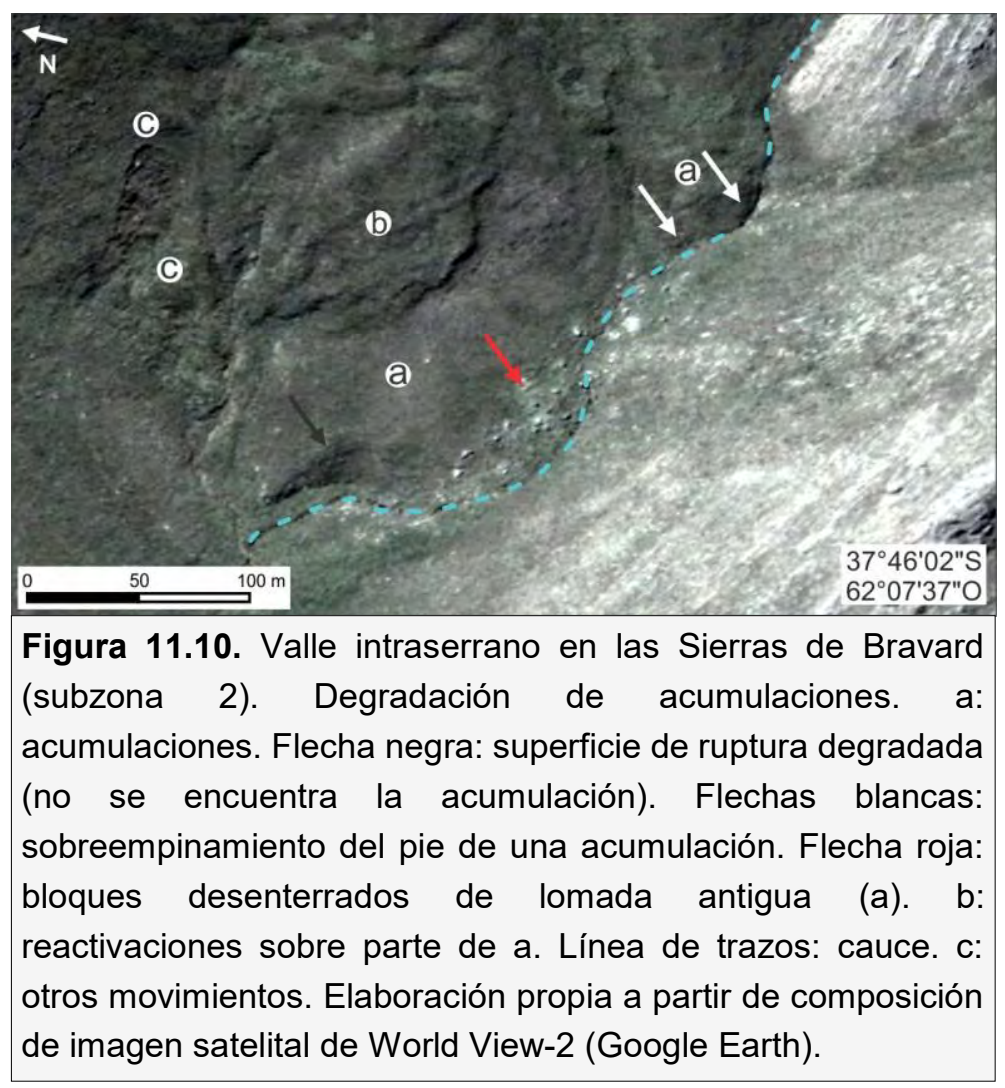

\subsubsection{Interacciones en otros componentes geomorfológicos vinculados a acción fluvial}

A continuación, se mencionan interacciones con componentes geomorfológicos que no se relacionan con los movimientos en masa de la misma manera que los cauces, a pesar de ser producto de la acción fluvial. Se presenta aquí a estas interacciones más bien por una cuestión de contexto espacio-temporal, y porque permiten hacer una cronología relativa entre los movimientos en masa y dichos componentes. 


\section{Sepultamiento parcial de planicies de inundación}

Las zonas de acumulación de deslizamientos y flujos alcanzan muchas veces las planicies de inundación de los cursos de agua. Cuando los movimientos son relativamente recientes, sus pies o puntas yacen sobre las planicies (Figuras 11.11 y 11.12.A). En los casos de movimientos antiguos, se requerirían estudios estratigráficos para diferenciar este tipo de relación, respecto a las de confinamiento de

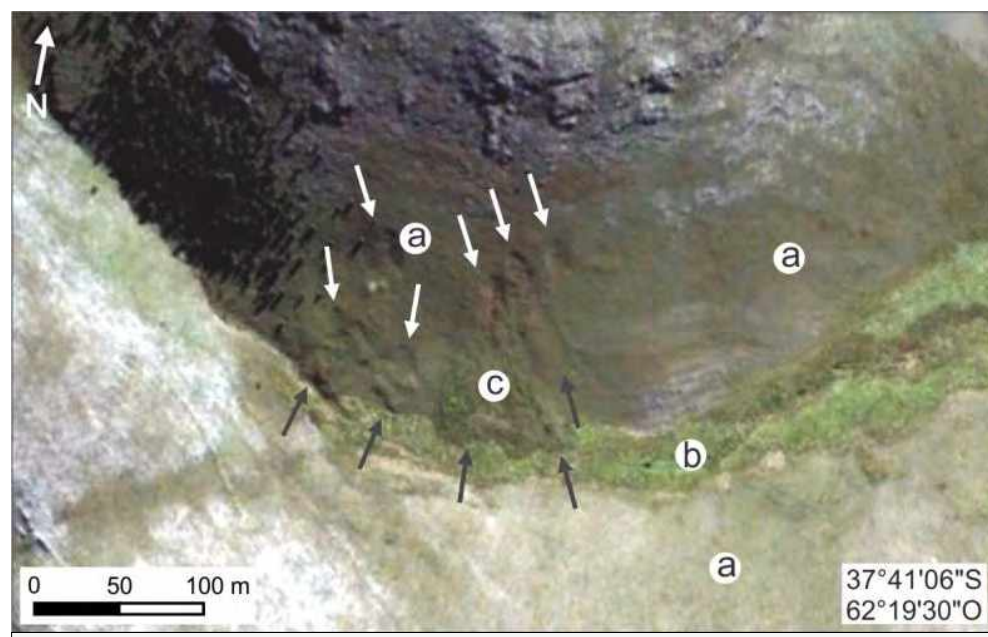

Figura 11.11. Valle intraserrano en la vertiente oriental del Cerro Curamalal Chico (Sierras de Curamalal). Sepultamiento parcial de planicie de inundación por movimientos en masa. a: ladera de detritos. b: planicie de inundación. Flechas blancas: superficies de ruptura. Flechas de grises: acumulaciones. c: acumulación sepultando la planicie. Elaboración propia a partir de composición de imagen satelital de World View-2 (Google planicies de inundación Earth).

(Figura 11.12.B). No obstante, otras relaciones con el escurrimiento superficial pueden servir como herramientas de reconocimiento de antigüedad relativa (ver apartado 11.3.1).

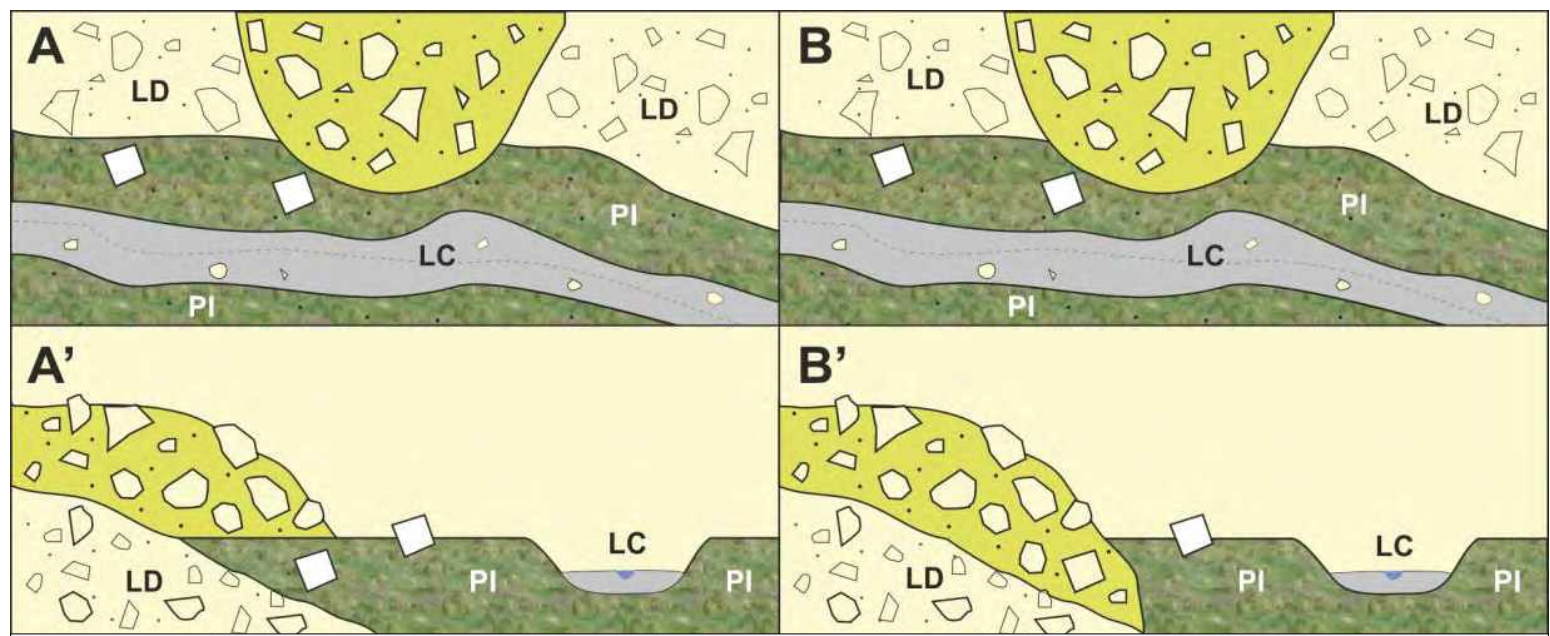

Figura 11.12. Esquema comparativo entre un movimiento en masa afectando (sepultando) a la planicie de inundación (A y $\mathbf{A}^{\prime}$ ) y un movimiento en masa anterior a la planicie de inundación, limitando su desarrollo (B y B'). A y B son representaciones en planta, con sus respectivos perfiles transversales A' y B'. Nótese que las representaciones en planta son exactamente iguales. Relleno verde: movimiento en masa. LD: ladera de detritos no afectada por el movimiento en masa. PI: planicie de inundación. Relleno blanco: bloques "extraños" en planicie de inundación. LC: lecho de canal. Elaboración propia. 


\section{Presencia de bloques "extraños" en planicies de inundación}

Bloques aislados de dimensiones considerablemente mayores a las de la competencia de los cursos de agua, suelen encontrarse en las planicies de inundación. Se idearon tres hipótesis sobre la procedencia de estos bloques:

a) caídos desde frentes escarpados proximales en tiempos recientes: algunas veces fue posible reconocer el "hueco" en los frentes escarpados rocosos de los cuales proceden;

b) caídos desde frentes escarpados antiguos proximales, yaciendo en superficie desde entonces: menos probable debido a la ausencia de gnammas, geoformas abundantes en el área de estudio, indicadores de yacencia longeva en la superficie (ver Capítulo 7 Criterios de reconocimiento de los movimientos en masa y su actividad);

c) caídos o deslizados que formaron parte de una ladera de detritos recientemente denudada: cuando no se encuentra el "hueco" del cual proceden los bloques, esta hipótesis podría explicar la ausencia de gnammas. Por otra parte, algunas lomadas distales actuales presentan escasísimos bloques considerablemente más grandes (tres veces mayores o más) que los restantes (Figura 11.13); si dichas lomadas fueran sometidas a acción fluvial (Figura 11.14), los bloques "extraños" podrían corresponder a remanentes de las mismas

\section{(Figura 11.15).}

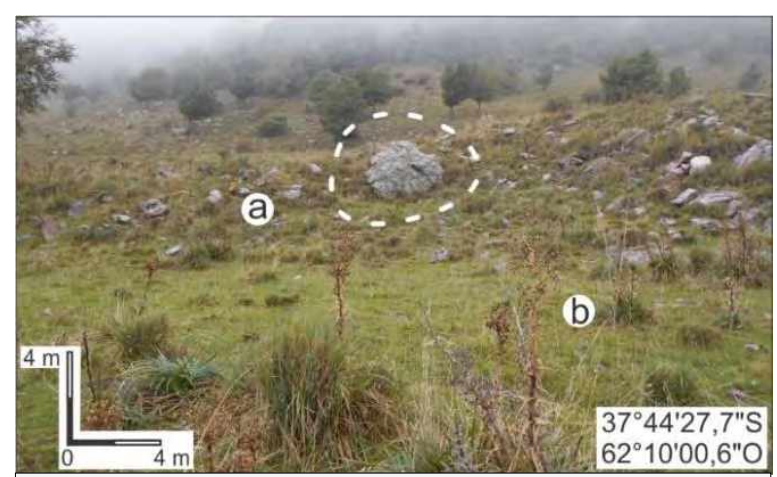

Figura 11.13. Ladera de Detritos en el Valle de Las Grutas (Sierras de Bravard, subzona 2). a: acumulación distal. b: planicie de inundación. Círculo: bloque de gran tamaño. Foto: Juan M. Susena.

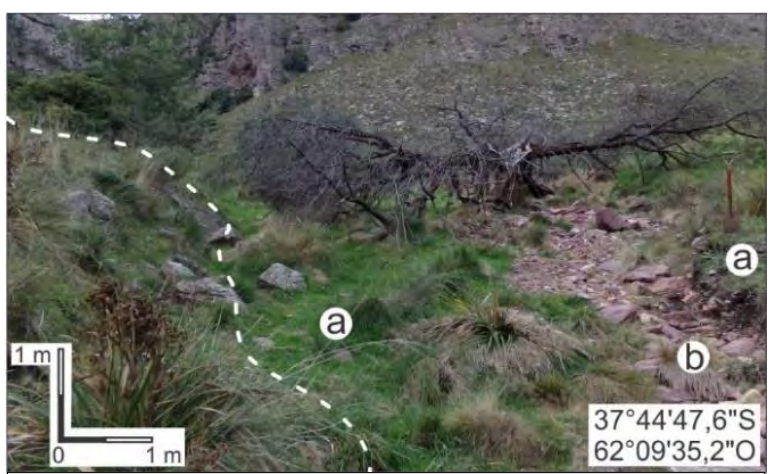

Figura 11.14. Ladera de Detritos en el Valle de Las Grutas (Sierras de Bravard, subzona 2). Línea de trazos: límite de acumulación distal. a: planicie de inundación. b: cauce. Foto: Juan M. Susena. 


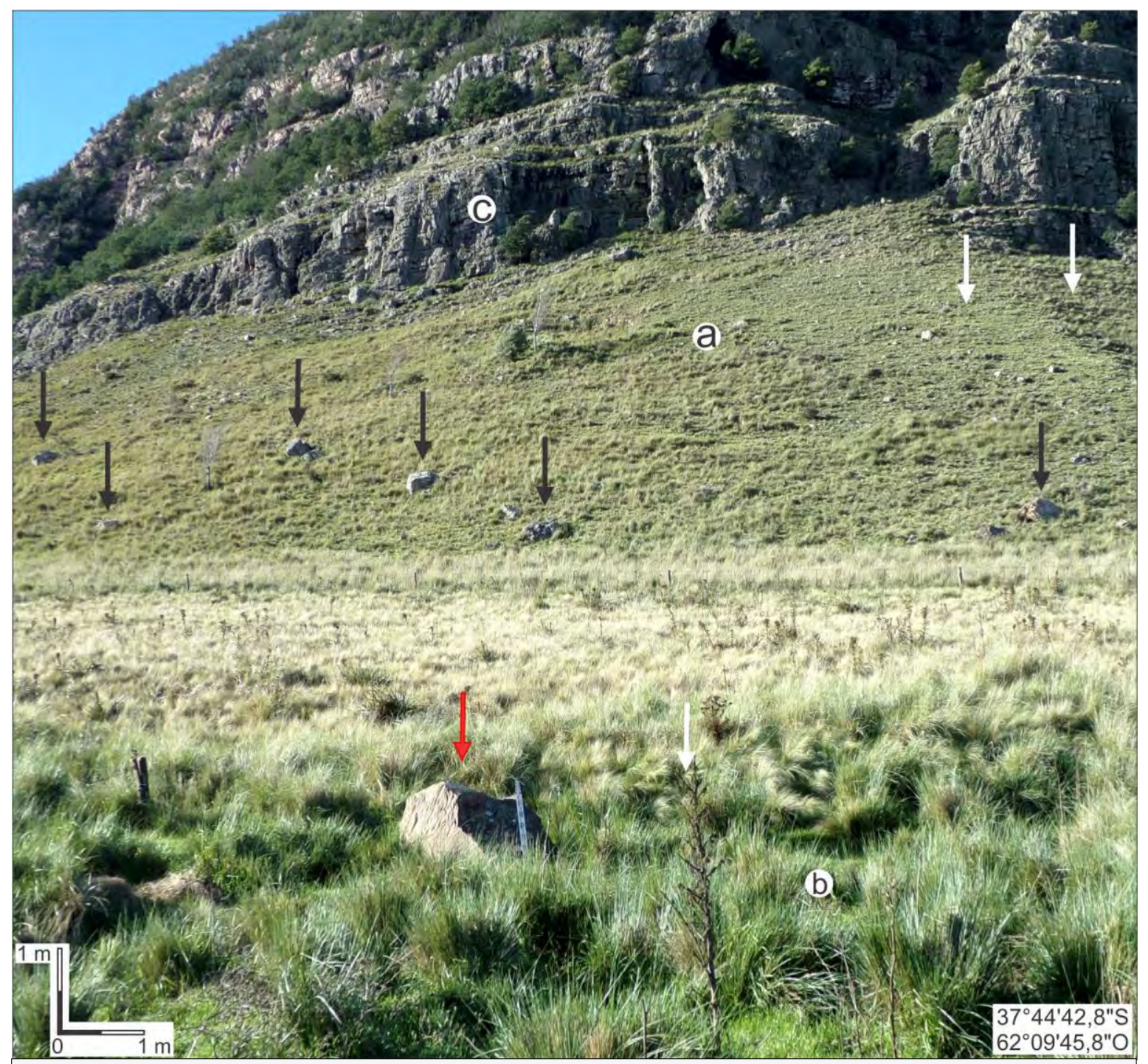

Figura 11.15. Faja Aluvial en el Valle de Las Grutas (subzona 2). Flecha roja: bloque "extraño" sobre planicie de inundación. a: Ladera de Detritos. b: planicie de inundación. c: Frente Escarpado Rocoso. Flechas negras: bloques de gran tamaño en la ladera. Flechas blancas: terracettes. La escala se ajusta al bloque indicado con la flecha roja. Foto: Juan M. Susena.

\subsubsection{Interacciones en canalizaciones incipientes en laderas de detritos}

\section{Incisión en límites de acumulaciones}

Los límites laterales de las lomadas de deslizamientos/flujos constituyen un control para el escurrimiento superficial no encauzado, limitando su migración lateral y favoreciendo así la incisión. Con menor influencia, se suma la acción del agua que escurre por las superficies laterales de las lomadas tangencialmente a la pendiente general y que alcanza el pie lateral (Figura 11.16.B). Así, con un aumento localizado del caudal, controlado por la existencia de las lomadas (pendientes locales), los materiales finos pueden ser lavados, generándose canalizaciones incipientes (Figura 11.16.C). A medida que los canalículos profundizan, el 
terreno contiguo no afectado por procesos de remoción en masa va adquiriendo una pendiente local hacia ellos (Figura 11.16.D). Así, los movimientos en masa favorecen el encauzamiento en las laderas y su consiguiente erosión, constituyéndose un mecanismo de retroalimentación positiva sensu Huggett (2007).

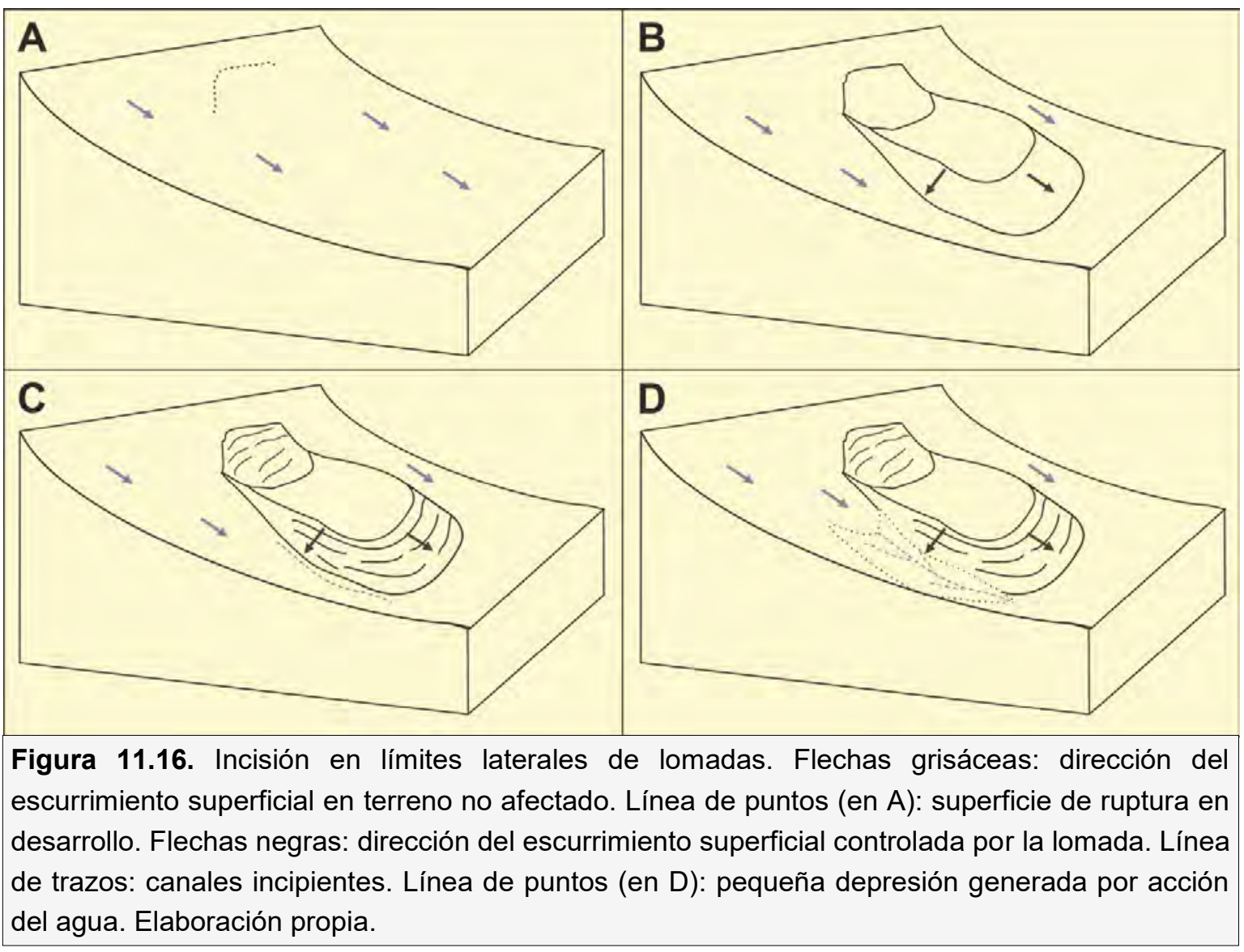

\section{Exageración de expresión morfológica de acumulaciones}

La incisión en límites de lomadas ocasiona un enriquecimiento residual del material sabulítico, evidenciando el lavaje del material fino, y por consiguiente, una relativa longevidad del rasgo. En fotografías aéreas e imágenes de satélite, en cambio, la profundización de tales límites da a los movimientos una falsa apariencia reciente o juvenil, constituyendo una dificultad a la hora establecer una cronología relativa a partir de su observación. Asimismo, la incisión sobredimensiona los movimientos en masa, pudiendo inducir a una sobreestimación de los procesos o condiciones que los originaron. Al respecto, la observación de campo es determinante para no arribar a tal error, como se ejemplifica en la Figura 11.17. 


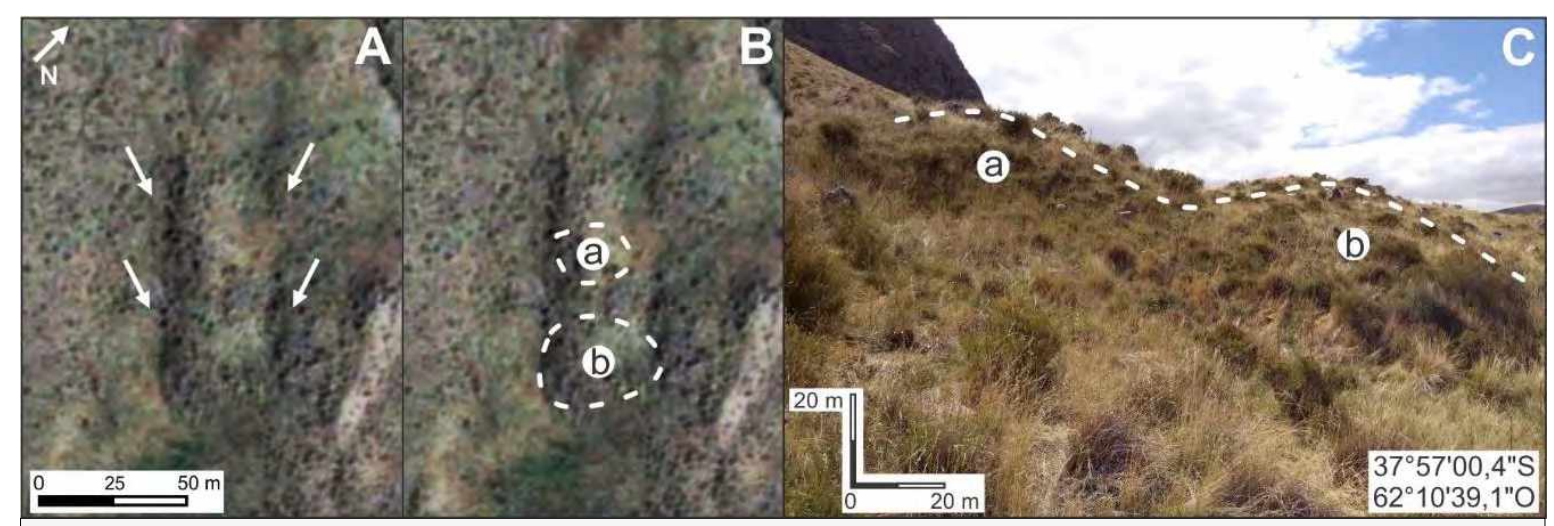

Figura 11.17. Ladera oriental del Co. Pan de Azúcar (subzona 3). A: acumulación "aparente" de unos $50 \mathrm{~m}$ de largo, delimitada por canalículos (flechas blancas). B y C: acumulaciones "reales" ( $a$ y b), reforzadas visualmente con líneas de trazos. Elaboración propia a partir de composición de imagen satelital de World View-2 (Google Earth). Foto: Juan M. Susena.

\subsection{Interacciones con el escurrimiento superficial no encauzado}

\subsubsection{Interacciones en laderas de detritos}

En laderas de detritos, el escurrimiento superficial es principalmente no encauzado. Durante las lluvias una delgada lámina de agua escurre sobre la superficie cuando la tasa de infiltración es superada por el caudal precipitado, o cuando los materiales han alcanzado la episaturación. En los sectores no afectados por movimientos en masa de tipo flujo o deslizamiento, este escurrimiento superficial se desarrolla en el sentido de la pendiente general de las laderas, sin perturbaciones significativas, como un manto continuo de espesor milimétrico, que copia la superficie del terreno. Este proceso ha sido denominado por diversos autores como escurrimiento (flujo) en manto (sheetflow en Jutson, 1919), erosión en manto (sheet erosion en Cotton, 1958), flujo superficial (overland flow en Leopold et al., 1964), lavaje disperso o arroyada difusa (dispersed wash en Peel, 1975), entre otros, entendidos y utilizados generalmente como equivalentes (Fairbridge, 1968; Hogg, 1982). Este tipo de escurrimiento interactúa con los movimientos en masa existentes en laderas de detritos de diferentes maneras, como se expone a continuación. 
Movimientos en masa en las sierras de Bravard y Curamalal,

Sierras Australes de la Provincia de Buenos Aires.

Juan Manuel Susena

\section{Generación de divisorias y depresiones locales}

Las zonas de acumulación (lomadas) de movimientos en masa, constituyen divisorias de jerarquía menor (respecto a las de cerros y niveles de piedemonte antiguos), que pueden aumentar o disminuir las pendientes originales de los perfiles transversales de las laderas (Figura 11.18). Pendientes del terreno no afectado por movimientos en masa, que rondan los $20^{\circ}$, pueden ser reducidas en las partes traseras (ladera arriba) de las lomadas a pocos grados, o incluso inclinar en contrapendiente. Allí, el escurrimiento superficial puede desviarse hacia los laterales de las acumulaciones, para alcanzar el terreno no afectado, o bien disminuir su velocidad, favoreciendo la infiltración o la retención del agua. Según las lomadas sean longitudinales o transversales a la pendiente general de las laderas, las relaciones con el escurrimiento superficial difieren.

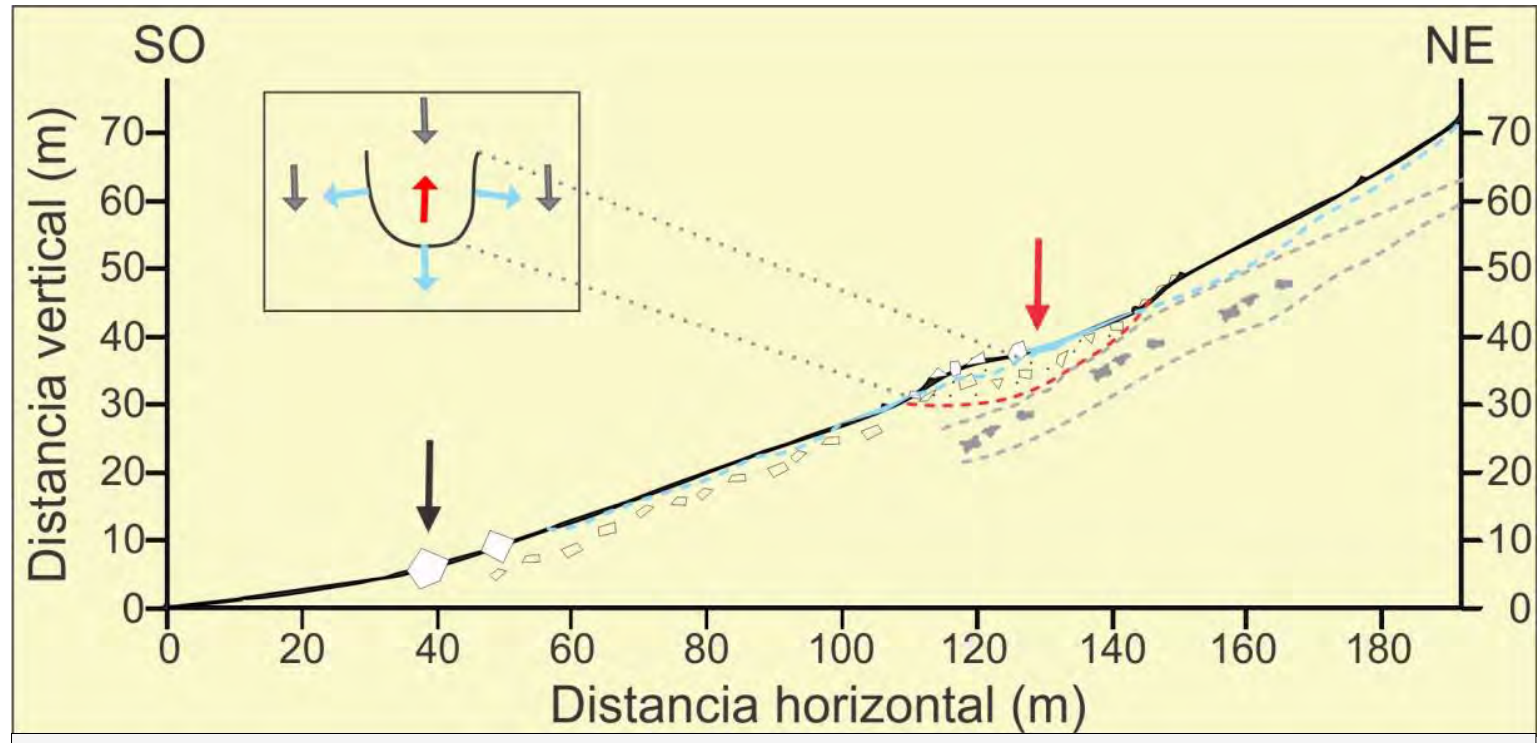

Figura 11.18. Perfil transversal de ladera de detritos occidental de las Sierras de Bravard en la Ea. Las Grutas ( $37^{\circ} 44^{\prime} 45^{\prime \prime}$ S; $62^{\circ} 09^{\prime} 39^{\prime \prime}$ O, subzona 2). Flecha roja: concentración de agua en la parte trasera de una zona de acumulación (lomada). Línea de trazos roja: ubicación inferida de la superficie de ruptura. Líneas de trazos celestes: escurrimiento sub-superficial (posición inferida). Líneas de trazos grises: Miembro Cementado de los Detritos de Ladera (extensión y espesor inferidos). Recuadro: esquema en planta de la lomada, indicando direccionales del escurrimiento superficial en el terreno no afectado (flechas grises) y el escurrimiento controlado por la lomada, siendo retrasado (flecha roja) o acelerado (flechas celestes). Elaboración propia a partir de un perfil geomorfológico levantado en el campo.

Los movimientos de tipo flujo, deslizamiento traslacional y complejo presentan generalmente lomadas alargadas en el sentido de la pendiente, comportándose como divisorias longitudinales a la pendiente general. La línea de contacto entre la pendiente y las lomadas es mayor en el sector lateral, que en la parte proximal o anterior de las mismas. Cuando el escurrimiento superficial en manto alcanza el límite con la parte anterior de las acumulaciones es desviado hacia los sectores laterales de estas, pudiendo desarrollarse pequeños canales, como se mencionó más arriba (Figura 11.16). 
Las divisorias transversales a la pendiente general se asocian a los deslizamientos rotacionales que tienen lomadas con su eje mayor transversal a la pendiente del terreno no afectado. La línea de contacto con el terreno no afectado es mayor en la parte proximal que en los laterales de las lomadas. Cuando el escurrimiento superficial alcanza el contacto proximal, difícilmente puede ser desviado hacia los laterales, perdiendo energía y quedando estancado, o infiltrándose (Figura 11.18, flecha roja).

\section{Infiltración}

La disminución en la velocidad del escurrimiento o su cese cuando alcanza zonas de acumulación de movimientos en masa posibilita la infiltración en los materiales de las acumulaciones. Esta situación es particularmente notable en el caso de lomadas relativamente antiguas, cuyos materiales finos fueron parcial o totalmente lavados. Pueden observarse diferencias entre la vegetación de la superficie de las lomadas y la del terreno no afectado, evidenciando pérdidas locales de humedad, como se muestra en la Figura 11.19. También es notoria la infiltración al pie de los frentes escarpados donde el contenido de material fino es escaso. El agua que escurre desde las cimas de las sierras, que surge de las fracturas de los frentes escarpados, o que escurre en canaletas asociadas a fracturas ensanchadas, al encontrarse con los depósitos de caídas y vuelcos al pie de los frentes escarpados (o salidas de canaletas), se insume en el terreno.

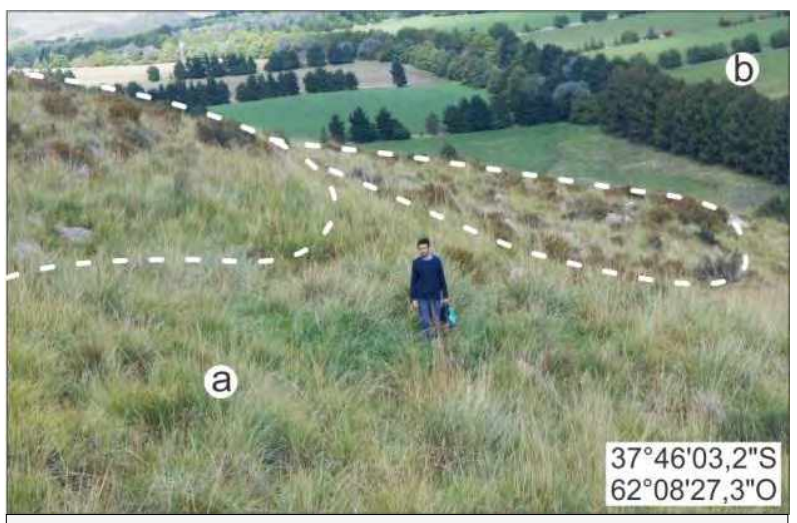

Figura 11.19. Ladera de Detritos occidental en las Sierras de Bravard (subzona 2). a: terreno no afectado, con pastizales verdes. Línea de trazos: zona de acumulación (lomadas) con predominio de vegetación arbustiva y pastizales amarillos. b: Valle Intermontano o Valle de Las Grutas/27 de Diciembre. La persona sirve como escala. Foto: Juan M. Susena y Rodolfo O. Gentile. 


\section{Surgencia}

El agua movilizada sub-superficialmente en las laderas de detritos puede surgir en la superficie, generándose manantiales. Se asocian a discontinuidades topográficas, como un aumento abrupto en la pendiente, o geohidrológicas (litológicas, estratigráficas o pedológicas), existen en sub-superficie cambios en la inclinación de los estratos u horizontes de suelo (Figura 11.20). Estas alteraciones en el terreno, que posibilitan la surgencia del agua en superficie, se relacionan con la presencia de movimientos en masa previos, como se verá a continuación.

Existen manantiales en zonas de terracettes, que suelen ubicarse en las cercanías de ápices de conos de detritos, o al pie de las laderas de detritos. En el último caso, es más evidente la acción de los animales, con encharcamientos pequeños asociados a marcas de pisoteo. La presencia de manantiales en terracettes puede deberse a compactaciones locales en sus superficies de menor pendiente, debido al pisoteo (Greenwood et al., 2015). Se desarrollan también manantiales al pie de escarpas de movimientos en masa. La escarpa principal constituye un rasgo topográfico favorable para el desarrollo de manantiales (Figura 11.20, flecha negra).

Generalmente el agua surge en el contacto entre horizontes $\mathrm{A}$ y $\mathrm{B}$, indicando la escasa profundidad del escurrimiento subsuperficial, asociada a una reducción de la permeabilidad hacia el horizonte $B$.

\section{Los manantiales en superficies de} ruptura se desarrollan en aquellas con presencia de horizontes arcillosos. Allí puede observarse lavaje localizado de los materiales finos y vegetación indicadora de condiciones ácuicas (colas de zorro), como se muestra en la Figura 11.21.
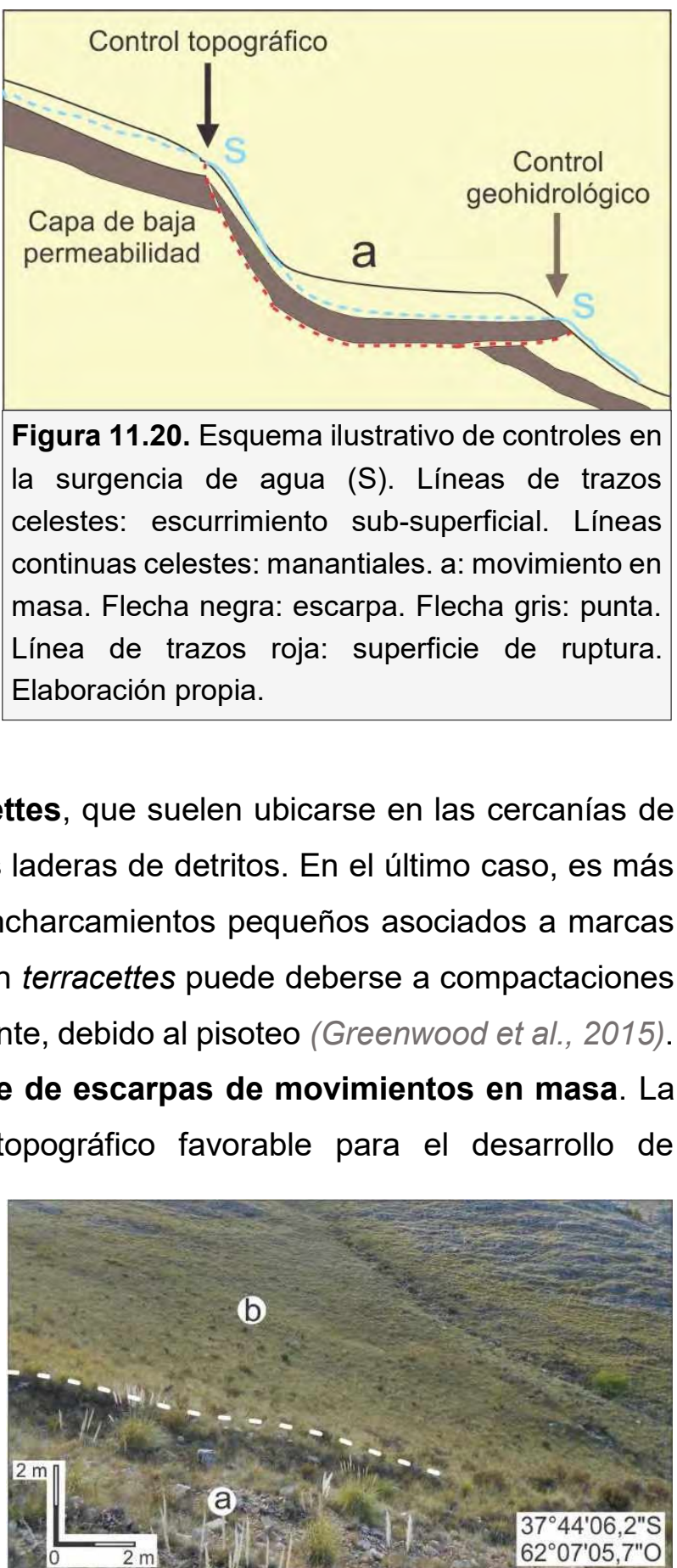

Figura 11.21. Ladera de detritos en valle intraserrano del Cerro Puntudo (Sierras de Bravard, subzona 2). Línea de trazos: flanco izquierdo de deslizamiento traslacional. a: superficie de ruptura con lavaje de materiales finos y vegetación hidrófila. b: terreno no afectado. Foto: Juan M. Susena. 
El agua de lluvia caída sobre la superficie de las acumulaciones de movimientos en masa y el agua que las alcanza por escurrimiento superficial en manto puede infiltrarse hacia su interior, y aflorar desarrollándose manantiales al pie de las zonas de acumulación (Figura 11.22). La surgencia ocurre en la parte media de la superficie terminal de las lomadas y en el pie/punta, siendo más evidente el primer caso, donde se presentan signos de degradación de la geoforma, como el lavaje de materiales finos, con caídas de bloques asociadas.

Por último, se encuentran también manantiales al pie de laderas de detritos en la zona de transición entre éstas y las planicies de inundación contiguas, donde existen cambios bruscos tanto en la granulometría de los depósitos -y consecuentemente su permeabilidadcomo en las pendientes, las cuales cambian de unos $20^{\circ}$ a menos de $10^{\circ}$. Estas variaciones posibilitan la surgencia del agua sub-superficial que alcanzan el pie de las laderas de detritos. En algunos lugares, la presencia de albardones aluviales en las márgenes de los cursos de agua, imposibilitan el drenaje del agua que alcanza las planicies de inundación desde las laderas, produciéndose estancamientos prolongados o encharcamientos de morfología elongada en dirección perpendicular a la pendiente, que pueden alcanzar los $30 \mathrm{~m}$ de ancho y más de $100 \mathrm{~m}$ de largo. En dichos sectores, es notorio el cambio de vegetación.

\section{Retención de agua en zonas de hundimiento}

En deslizamientos rotacionales, que constituyen divisorias transversales a la pendiente general, la zona de hundimiento constituye un relieve deprimido local, donde suele acumularse agua, que puede ser de lluvia, proveniente de las partes más altas de la ladera, agua sub-superficial que aflora localmente o una combinación de ellas. Los cuerpos de agua generados alcanzan los $5 \mathrm{~m}$ de ancho y unos $20 \mathrm{~m}$ de longitud en dirección perpendicular a la pendiente, y el agua puede permanecer varios días (Figura 11.23.A). La presencia de vegetación más verde en laderas de detritos dominadas por vegetación amarilla, es un muy buen indicador tanto en campo, como en imágenes satelitales, de la presencia de estos rasgos y por ende de los movimientos asociados (Figura 11.23.B). 


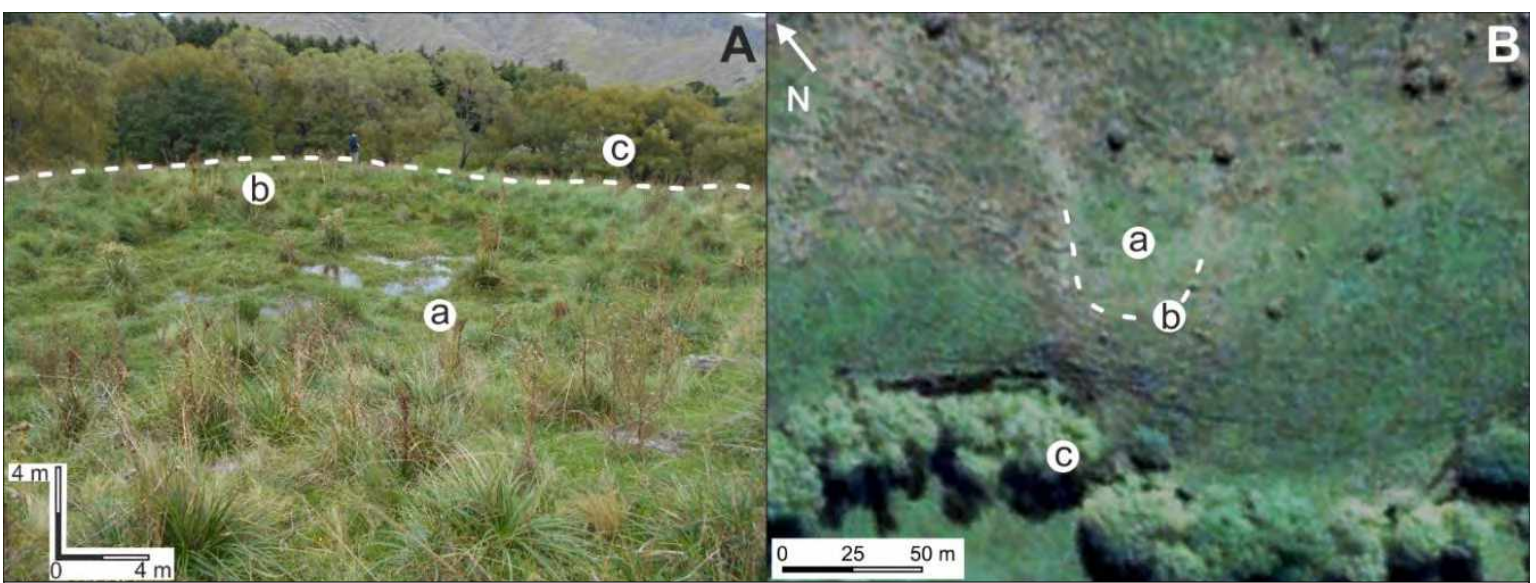

Figura 11.23. Ladera de Detritos occidental de las Sierras de Bravard en la Ea. Las Grutas $\left(37^{\circ}\right.$ 44' 19,1" S; $62^{\circ}$ 10' 16,5" O, subzona 2). Deslizamiento rotacional. A: fotografía tomada en el campo. B: imagen satelital. a: cuerpo de agua en zona de hundimiento. b: zona de acumulación. c: árboles ubicados sobre la planicie de inundación de un arroyo. Modificado de Susena y Gentile (2017).

\section{Lavaje de materiales finos}

La ausencia o escasez de materiales finos en los depósitos de caídas/vuelcos al pie de frentes escarpados rocosos puede deberse al lavaje o su no depositación. En el primer caso, aquí concerniente, el lavaje en taludes se expresa en el desarrollo de pequeñas concentraciones del escurrimiento, "senderos de detritos" peligrosos para el tránsito-, con escasa o ninguna presencia de materiales finos (Figura 11.24). Los criterios aquí utilizados para no vincular la génesis de estos senderos a una deposición de materiales por escurrimiento encauzado son la ausencia de incisión y de una fábrica de deposición vinculada a la acción del agua. En tramos medios y distales de las laderas, el lavaje produce pavimentos de erosión (Shaw, 1929).

El lavaje en superficies de ruptura es el

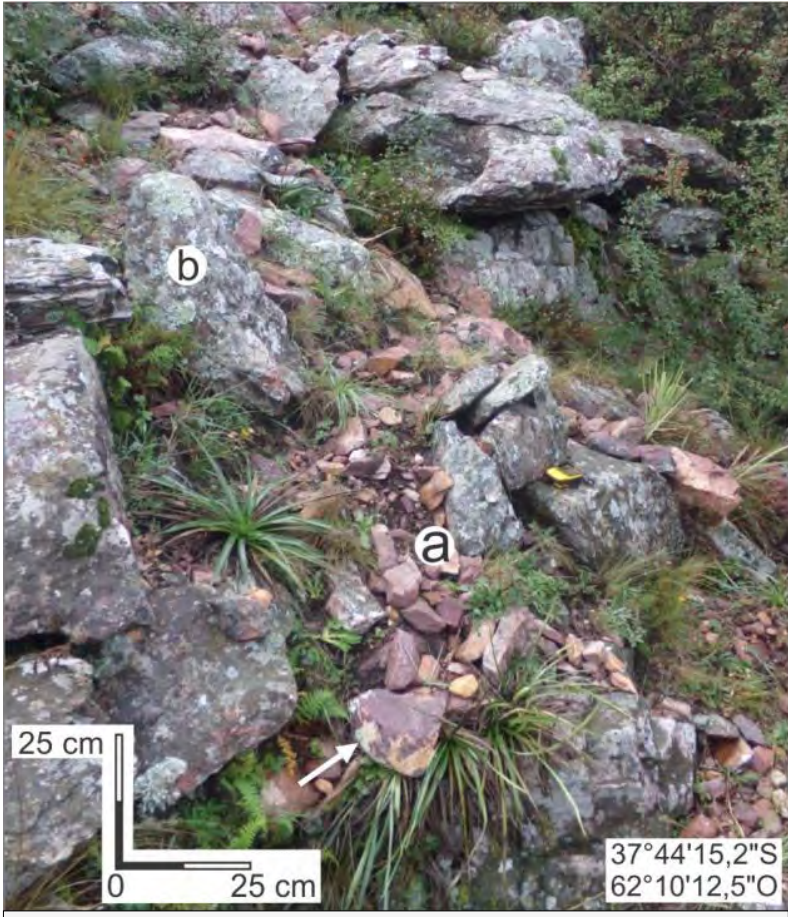

Figura 11.24. Ladera Compuesta occidental de las Sierras de Bravard en la Ea. Las Grutas (subzona 2). a: "sendero de detritos", nótese la escasez de materiales finos. b: bloque caído. Flecha: bloque recientemente caído sobre la vegetación, con colonias de líquenes en la cara inferior. Foto: Juan M. Susena.

más manifiesto en cuanto a partes de deslizamientos se refiere. Naturalmente, dada su 
condición de resalte (en el caso de deslizamientos rotacionales) o deprimida (en deslizamientos traslacionales) en el relieve local propicia una mayor exposición a la acción del agua con respecto a sus inmediaciones. A veces, en sectores concretos de las superficies de ruptura los detritos están trabados entre sí en ausencia de materiales finos, evidenciando un lavaje aún más acentuado que el resto del rasgo. En los deslizamientos traslacionales el lavaje generalmente se extiende a toda la superficie de ruptura, sobre la cual el agua circula y abandona el sector, mientras que en los rotacionales se restringe a la parte más proximal y pierde intensidad hacia el centro. Lo último se debe a que, dada la morfología cóncava de las superficies de ruptura de los deslizamientos rotacionales, el agua pierde velocidad hacia la parte media de las mismas, disminuyendo la erosividad, e incluso se desarrollan cuerpos de agua, como se mencionó anteriormente. Así, en superficies de ruptura de deslizamientos traslacionales es favorecido el lavaje prácticamente en toda su extensión, mientras que en los rotacionales sólo se desarrolla de manera conspicua en la parte más próxima al escarpe principal (Figura 11.25).

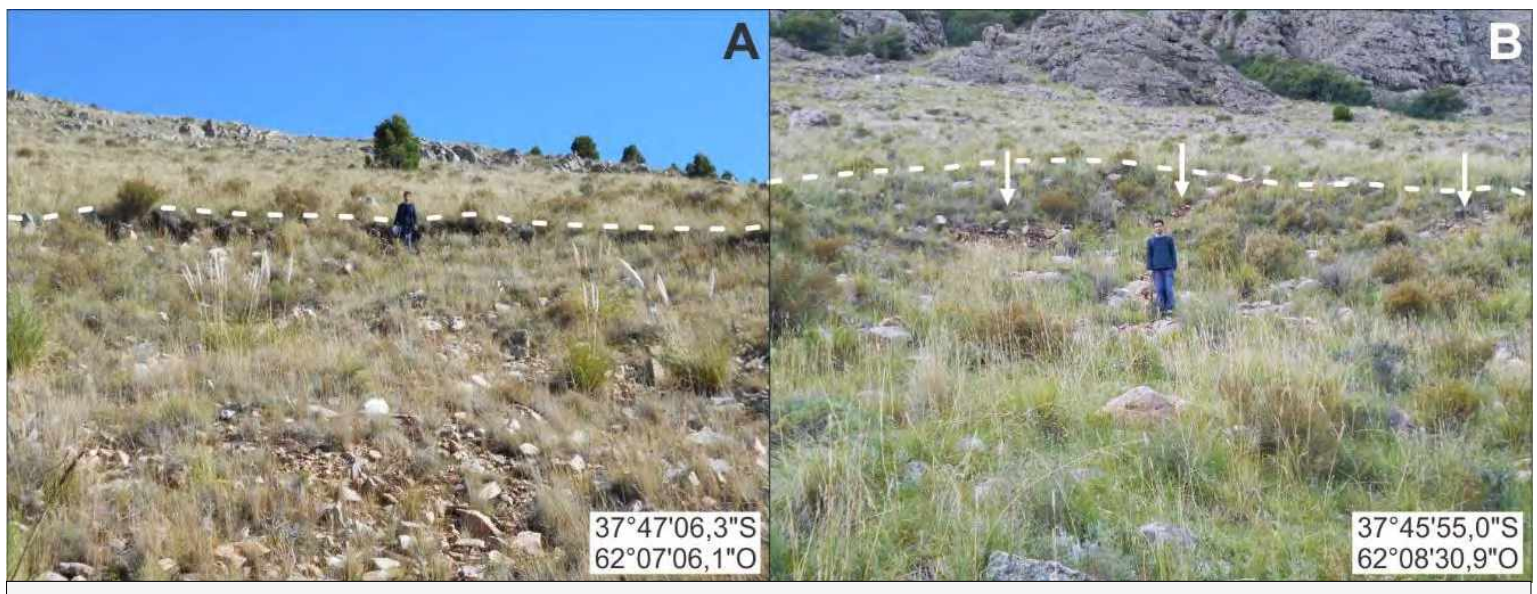

Figura 11.25. Lavaje de materiales finos en superficies de rupturas. Comparación entre deslizamiento rotacional en $\mathbf{A}$ y traslacional en B, ambos en las Sierras de Bravard (subzona 2). Líneas de trazos: corona. Nótese como en A el lavaje afecta a toda la superficie de ruptura, mientras que en $\mathbf{B}$ la expresión del lavaje se restringe a los sectores indicados con flechas blancas. La persona sirve como escala. Fotos: Juan M. Susena y Rodolfo O. Gentile.

El lavaje en zonas de acumulación se manifiesta en la ausencia de los materiales limosos-arcillosos, en favor de un aumento en la proporción de los materiales gruesos, los cuales aparecen trabados entre sí como gravas o brechas abiertas. Esta característica textural es más notoria en los tramos medios de las laderas, y principalmente en los sectores laterales o frontales de las lomadas. Pueden observarse bloques parcialmente desenterrados, identificados por cambios netos en el desarrollo de colonias de líquenes de su superficie, mostrándose una disminución notoria o ausencia de estas en la parte inferior. Cabe mencionar que el relieve positivo de las lomadas impide la acción del agua 
Movimientos en masa en las sierras de Bravard y Curamalal,

Sierras Australes de la Provincia de Buenos Aires.

Juan Manuel Susena

proveniente de las laderas, por lo cual el lavaje se debe fundamentalmente a la acción del agua de lluvia y en una pequeñísima proporción a la surgente del interior de las lomadas. 


\section{Capítulo 12}

\section{Movimientos en masa y actividad antropo y zoogeomorfológica}

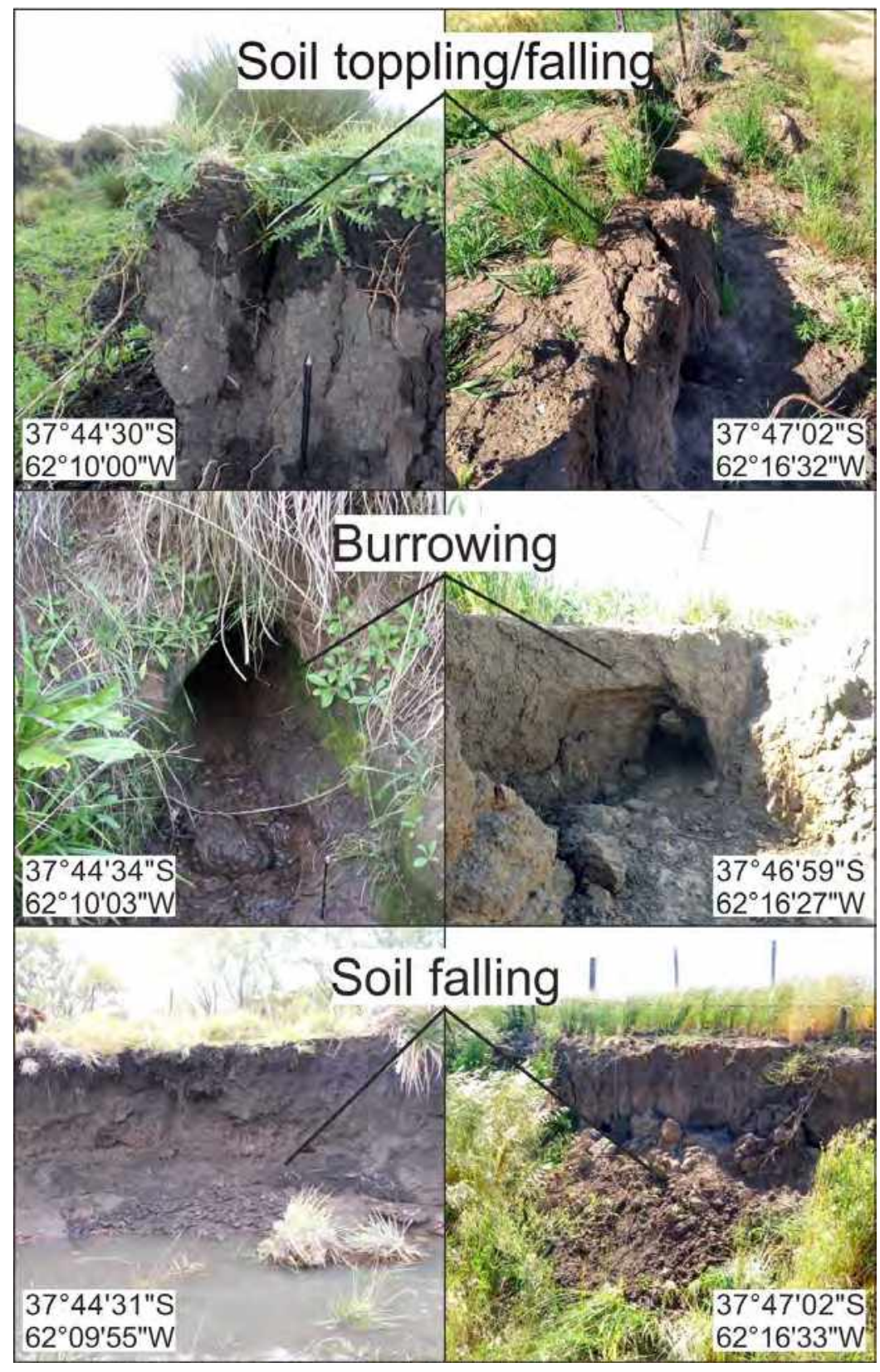

"Arroyos vs. Caminos"

Figura que se utilizó en un póster inédito en la Regional Conference on Geomorphology (Atenas, 2019), indicando que algunos movimientos y otros procesos erosivos se producen tanto en contextos naturales como antrópicos. 
Movimientos en masa en las sierras de Bravard y Curamalal, Sierras Australes de la Provincia de Buenos Aires.

Juan Manuel Susena 


\subsection{Objetivos y ordenamiento del capítulo}

En este capítulo se tratan las relaciones entre geoformas, entre procesos, o entre geoformas y procesos, que se vinculan a la actividad humana y faunística y los movimientos en masa. La actividad antrópica y faunística del área es conspicua y se pudieron identificar geoformas y procesos, e interacciones entre ellos con diferentes grados de expresión geomorfológica. Se presenta una breve introducción sobre las disciplinas que estudian este tipo de relaciones con un encuadre teórico global, así como la influencia de la actividad antrópica sobre la faunística o zoogeomorfológica. Es necesario, previo a la caracterización de los movimientos en masa ocurridos, definir las geoformas y procesos que se relacionan en distinta medida con los movimientos, a lo cual se dedica la primera parte del capítulo, dando una idea de su representatividad en el sistema geomorfológico del área estudiada. En la segunda parte del capítulo se caracterizan los movimientos en masa desde la perspectiva de la interacción con los procesos y geoformas antrópicos y zoogeomorfológicos. Se concluye con una síntesis del rol de la acción humana y faunística como mecanismos preparadores y desencadenantes de los movimientos en masa.

\subsection{Antropogeomorfología}

Una de las líneas de estudio de la geomorfología moderna es la vinculada a la acción antrópica (Li et al., 2017). Ya no hay discusión sobre la influencia del hombre en el cambio climático y según estos autores (y trabajos allí citados), es también indudable su rol como agente geomorfológico, influyendo además en el accionar de los procesos geomorfológicos naturales. La ocupación humana y el desarrollo de diferentes actividades puede ocasionar, en determinados contextos serranos o de montaña, un aumento en la frecuencia o amenaza de procesos erosivos, tales como los movimientos en masa (Cendrero et al., 2006a; 2006b) pudiendo representar una manifestación del "cambio geomorfológico global" (Remondo et al., 2005; Bonachea et al., 2010) definido por Cendrero y Douglas (1996). Cambios que afectan a formas y procesos geomorfológicos han sido destacados por numerosos autores (Ter-Stepanian, 1988; Slaymaker et al., 2009; Syvitski et al., 2005; Syvitski \& Kettner, 2011; Forte, 2017). Cendrero et al. (2020) han encontrado un marcado incremento de las tasas de sedimentación y los desastres naturales a escala global, especialmente desde mitad del Siglo XX. Sus resultados indican que la intensificación de los procesos geomorfológicos se explica mejor por cambios en los usos del suelo que por el cambio climático. Los autores señalan que sus conclusiones deben ser contrastadas con otros tipos de datos y aproximaciones. En este sentido, es necesario considerar al hombre 
Movimientos en masa en las sierras de Bravard y Curamalal,

Sierras Australes de la Provincia de Buenos Aires.

Juan Manuel Susena

como un agente geomorfológico y que su accionar impulsa el desarrollo de determinados procesos y geoformas, debiendo entenderse a los paisajes antropizados en mayor o menor medida como nuevos escenarios o sistemas geomorfológicos.

El desarrollo de actividades humanas produce diferentes tipos de impactos en el paisaje. Desde la perspectiva ambiental, estos impactos pueden ser positivos o negativos. En geomorfología, los impactos humanos pueden estudiarse en base a su aporte al desarrollo de diferentes sistemas geomorfológicos, dividiéndose en efectos/impactos directos o intencionados, e indirectos o no intencionados (Cendrero et al., 2006a).

Cuando las actividades humanas modifican las formas del paisaje, creando nuevos rasgos y/o modificando o destruyendo rasgos preexistentes, puede entenderse al hombre como un agente geomorfológico prácticamente exclusivo o completamente esencial en el desarrollo de tales modificaciones. Así, la construcción de obras civiles y edificios, la creación de cavas y galerías para la extracción de materiales, el aplanamiento de lomas bajas y el rellenado de depresiones, por ejemplo, son actividades que movilizan materiales, por lo cual pueden entenderse como efectos o impactos directos.

Los efectos indirectos de las actividades humanas son relaciones que se producen entre componentes geomorfológicos creados/modificados antrópicamente, procesos antrópicos, y procesos naturales. Estas relaciones pueden tender a la creación o a la destrucción de formas del paisaje, y comúnmente no son intencionales, sino simplemente consecuencias de la actividad antrópica. Como ejemplos de algunos efectos indirectos de actividades antrópicas en la geomorfología de las cuencas hidrográficas, pueden mencionarse, entre muchos otros, el aumento en las tasas de erosión en un sector cultivado, en un camino de tierra (MacDonald y Coe, 2008) o en una ladera deforestada (Bruschi et al., 2013 y trabajos allí citados), el aumento de susceptibilidad de erosión hídrica y degradación ambiental en general por cambios de uso del suelo (Gaspari y Bruno, 2003; Ángeles y Gil, 2006), los ajustes geomorfológicos de sistemas de drenaje y el deterioro de la calidad ambiental de humedales debido a integraciones antrópicas de la red por canalizaciones y trasvases de cuencas (Degiovanni et al., 2014), y el desarrollo de asentamientos diferenciales y colapsos vinculados a antiguas galerías mineras (Gentile y Villalba, 2008; Gentile y Susena, 2019). Por otra parte, un concepto relacionado con la contribución de la acción del hombre al modelado del paisaje es el de huella geomorfológica humana (Rivas et al., 2006). Estrictamente, es una expresión cuantitativa del cambio geomorfológico global, refiriéndose a la contribución per cápita a la creación de nuevas geoformas (construcciones, excavaciones, acumulaciones) y movilización de materiales terrestres,

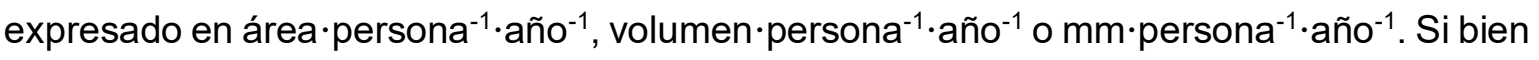
este concepto es cuantitativo por definición, la observación cualitativa del desarrollo de 
geoformas y procesos antropogénicos y su interacción con otros procesos geomorfológicos en distintos ambientes podría dar una idea aproximada del desarrollo de esta huella a escala local. Desde dicho planteo (cualitativo) se analiza en esta tesis la contribución de la actividad antrópica al desarrollo de movimientos en masa.

\subsection{Actividad antrópica en el área de estudio}

La actividad antrópica en el área de estudio implica la creación de nuevos rasgos del paisaje y la modificación o destrucción de rasgos preexistentes. A continuación, se describen los principales componentes antropogénicos del área estudiada y los procesos geomorfológicos más conspicuos que en ellos se desarrollan.

Caminos: exceptuando las ciudades y algunas rutas pavimentadas en el piedemonte distal, hay en la zona tres tipos de caminos no pavimentados bien diferenciables. El primer tipo, los caminos vecinales, se encuentran en el piedemonte $y$ el valle intermontano (aunque muy localizadamente pueden ocupar laderas de detritos distales y atravesar fajas aluviales) y tienen un desarrollo conspicuo en el área estudiada (Figura 12.1). Unos $470 \mathrm{Km}$ lineales y $11.300 \mathrm{Km}^{2}$ son ocupados por este tipo de obras, superando a los aproximadamente $380 \mathrm{Km}$ lineales y $6.100 \mathrm{Km}^{2}$ donde se desarrollan cursos de agua (Susena et al., 2019a). Estos caminos fueron construidos principalmente sobre sedimentos eólicos de la Fm. Saavedra y afines (Figura 12.2.A) y sobre depósitos con calcretas como las Fms. La Norma, Las Malvinas y Del Águila (Figura 12.2.B); ocasionalmente atraviesan Detritos de Ladera y Aluvio. Pueden tener

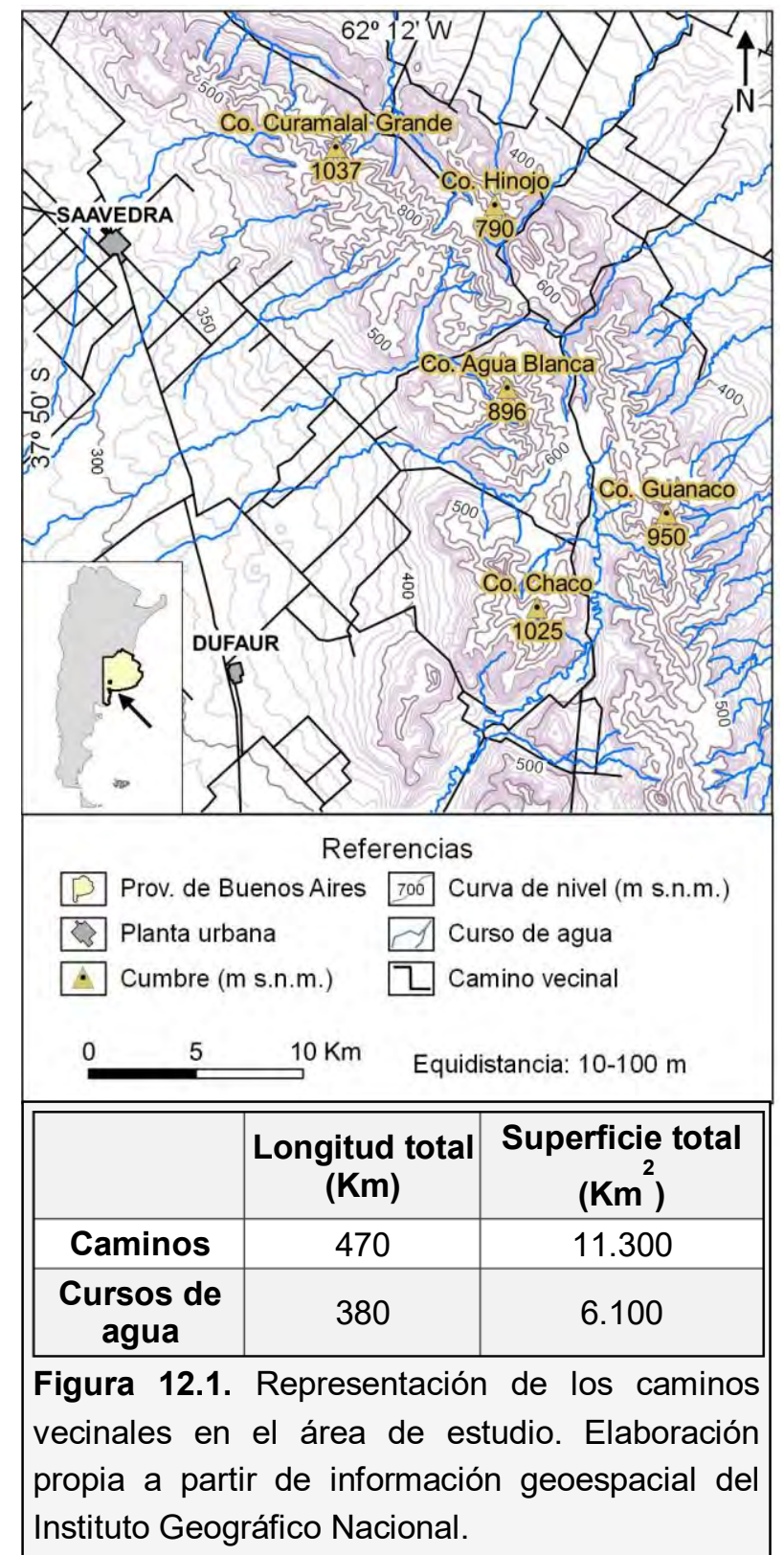


Movimientos en masa en las sierras de Bravard y Curamalal,

Sierras Australes de la Provincia de Buenos Aires.

Juan Manuel Susena

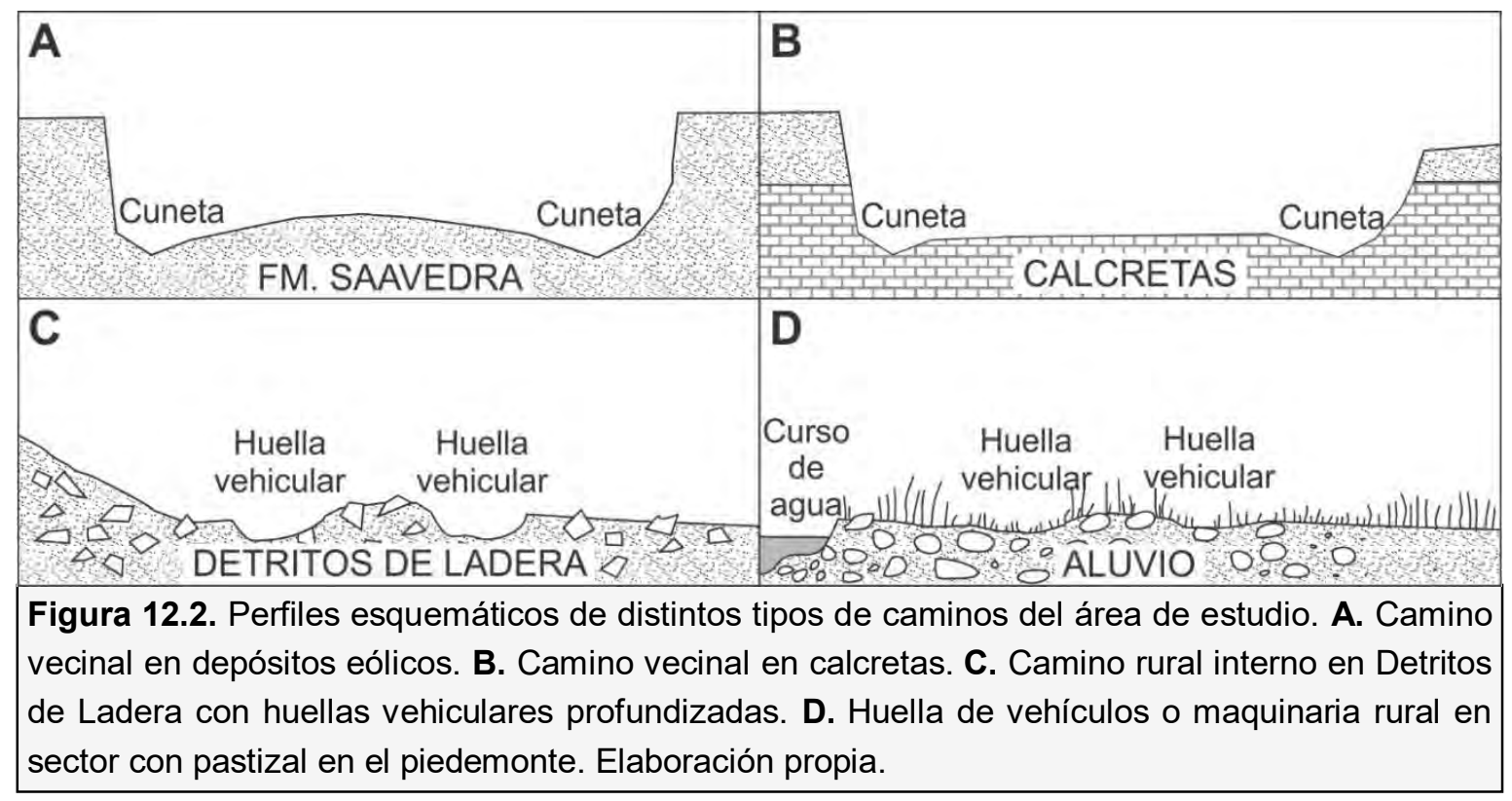

cunetas a sus lados generalmente pequeñas y en particular los tramos labrados en sedimentos friables tienen un perfil transversal inicialmente convexo (por diseño y mantenimiento vial). El lavaje en dirección transversal al eje del camino modifica este perfil, acentuándolo, ya que es más intenso en la parte distal del perfil, donde el material está menos compactado por la menor frecuencia de tránsito, y la evacuación de los materiales a través de las cunetas evita la acumulación y consiguiente evolución a un perfil cóncavo. La erosión pluvial/aluvial en este tipo de caminos puede ser muy manifiesta, debido a la ausencia de vegetación y al carácter friable en muchos casos, de los sedimentos presentes, generándose rasgos peligrosos para el tránsito, como canalículos transversales al eje del camino (Susena y Gentile, 2019). Como ejemplo de lo antedicho, durante una Iluvia torrencial de $155 \mathrm{~mm}$ el 18 de febrero de 1992, al menos $26.000 \mathrm{~m}^{3}$ de suelo fueron erosionados en un camino del piedemonte occidental, descendiendo la superficie del camino $1,5 \mathrm{~m}$ respecto a su cota original, en un tramo lineal de al menos $700 \mathrm{~m}$ (Figura 12.3). Uno de los vecinos del camino tuvo que reconstruir el alambrado $1,5 \mathrm{~m}$ campo adentro, perdiendo $1050 \mathrm{~m}^{2}$ de suelo útil, y tuvo que abrirse un camino alternativo para poder salir del campo; en la portada del Capítulo 2 Planteamiento del problema $y$ objetivos pueden observarse los restos del antiguo alambrado, previo al evento mencionado.

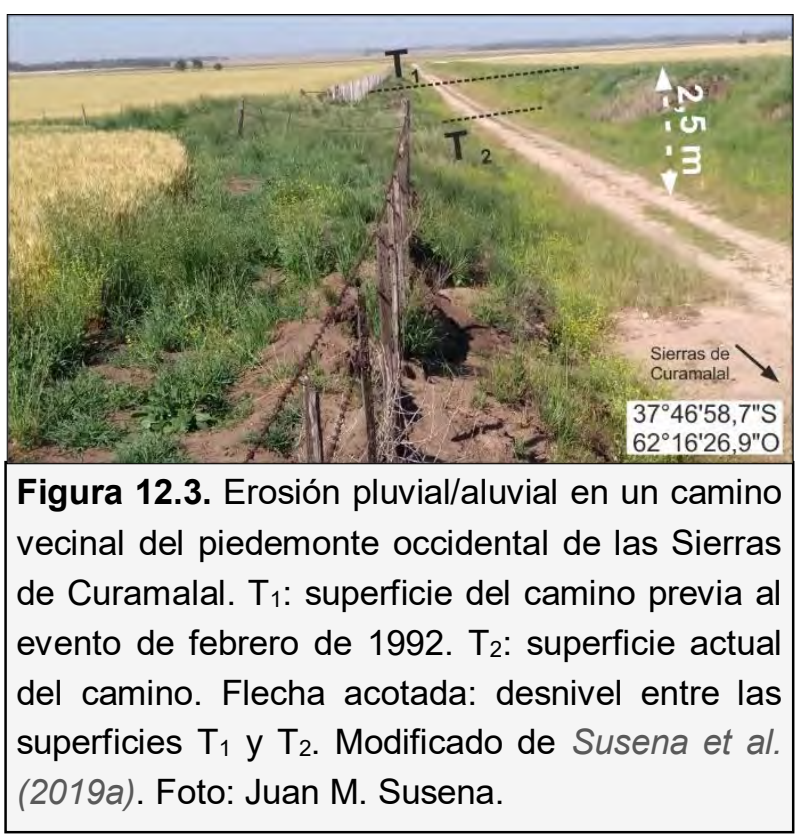


La erosión eólica en estos caminos es también conspicua y los materiales transportados se acumulan en sus inmediaciones, desarrollándose rasgos lineales que estarían relacionados con el advenimiento del automóvil a principios del Siglo XX (Bidart, 1992b). La erosión eólica no es un proceso ubicuo en el área estudiada, sino que se produce especialmente por el aumento de la susceptibilidad debido a la acción antrópica (Susena et al., 2019a).

Los caminos rurales internos se ubican en el interior de los campos, y se desarrollan sobre las mismas litologías que los vecinales, con una mayor participación en Detritos de Ladera en el sector serrano (Figura 12.2.C). Se caracterizan por tener mayor pedregosidad y menos mantenimiento que los antedichos. La falta de mantenimiento resulta en el desarrollo de canalículos de 5-25 cm de profundidad, generados por la concentración del escurrimiento superficial en huellas vehiculares. Su perfil transversal suele ser irregular y no tienen cunetas a sus lados.

Un tercer tipo de camino es representado por huellas de maquinaria y vehículos rurales, ocupando principalmente el piedemonte y las laderas de detritos. La principal característica de las huellas es la presencia de vegetación, y algunas están levemente deprimidas con respecto al terreno circundante, por lo cual puede concentrarse agua (Figura 12.2.D). Por lo general no presentan rasgos de erosión evidentes.

Canalizaciones: las canalizaciones se desarrollan localmente en algunos campos, y al lado de caminos vecinales. Por lo general los canales fueron construidos en Fm. Saavedra o Aluvio, son aproximadamente rectilíneos, no alcanzan los $20 \mathrm{~m}$ de ancho, sus longitudes pueden superar los $300 \mathrm{~m}$ y pueden tener hasta $3 \mathrm{~m}$ de profundidad. El lecho no es pavimentado, pero en algunos casos es firme debido a la presencia de materiales arcillosos. Si bien su representatividad espacial no es importante, desde el punto de vista hidrológico los canales permiten encauzar estancamientos de agua o dirigir el agua hacia reservorios artificiales, e incluso reintegrar redes de drenaje obliteradas por materiales eólicos.

Líneas de arado: en la zona se encuentran varios patrones de arado superpuestos, identificables desde imágenes satelitales. Existen tanto patrones según las curvas de nivel, con baja pendiente, como patrones más bien aleatorios o sub-paralelos a las pendientes (Figura 12.4). La mayoría de estos patrones son difíciles de identificar en el campo, siendo la teledetección una herramienta muy útil para su reconocimiento, principalmente en el caso de patrones antiguos con líneas de arado actuales superpuestas. Las prácticas de arado se encuentran tanto en suelos profundos como superficiales, en niveles de 
Movimientos en masa en las sierras de Bravard y Curamalal,

Sierras Australes de la Provincia de Buenos Aires.

Juan Manuel Susena

piedemonte antiguos, en el piedemonte moderno y en laderas de detritos distales.

En el caso del piedemonte, se encontraron diseños de las barrancas afines a los de las líneas de arado actuales y antiguas (Figura 12.5). En este aspecto, las líneas de arado constituyen discontinuidades en los suelos, en las cuales la erosión fluvial o los movimientos en masa que modelan las barrancas alcanzan un mayor desarrollo. En muchos casos, la pedregosidad de estas unidades fue reducida antrópicamente para extender el área cultivable, modificando el comportamiento hidrológico y reduciendo la resistencia mecánica de los materiales, ya que fueron transformados de conglomerados o brechas matriz sostén a

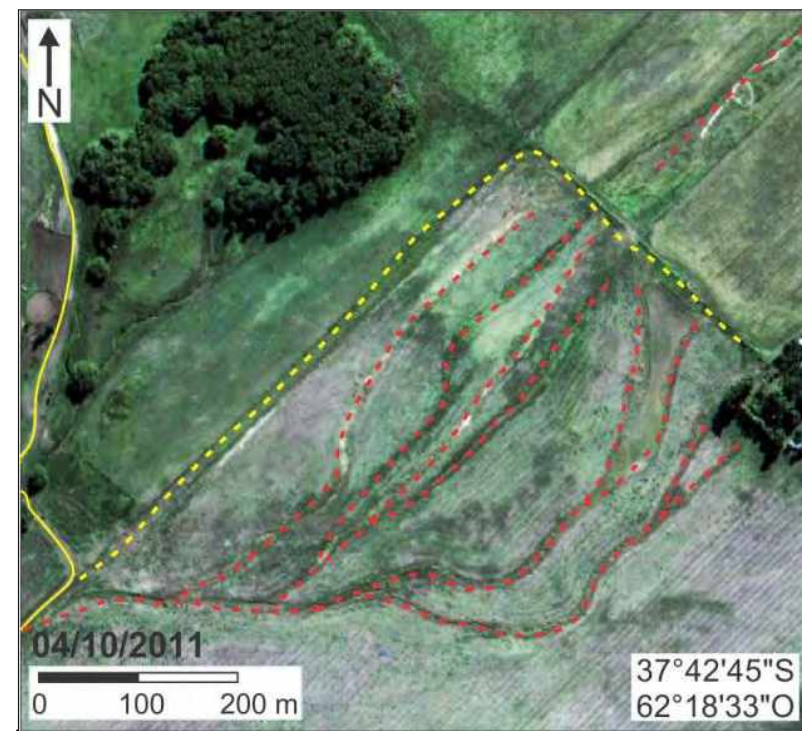

Figura 12.4. Erosión fluvial en líneas de arado con patrón sub-paralelo (líneas rojas) en el piedemonte occidental de las Sierras de Curamalal. Línea amarilla continua: camino rural interno. Línea amarilla discontinua: huella vehicular. Elaboración propia a partir de composición de imagen satelital de World View-2 (Google Earth). limos loessoides.

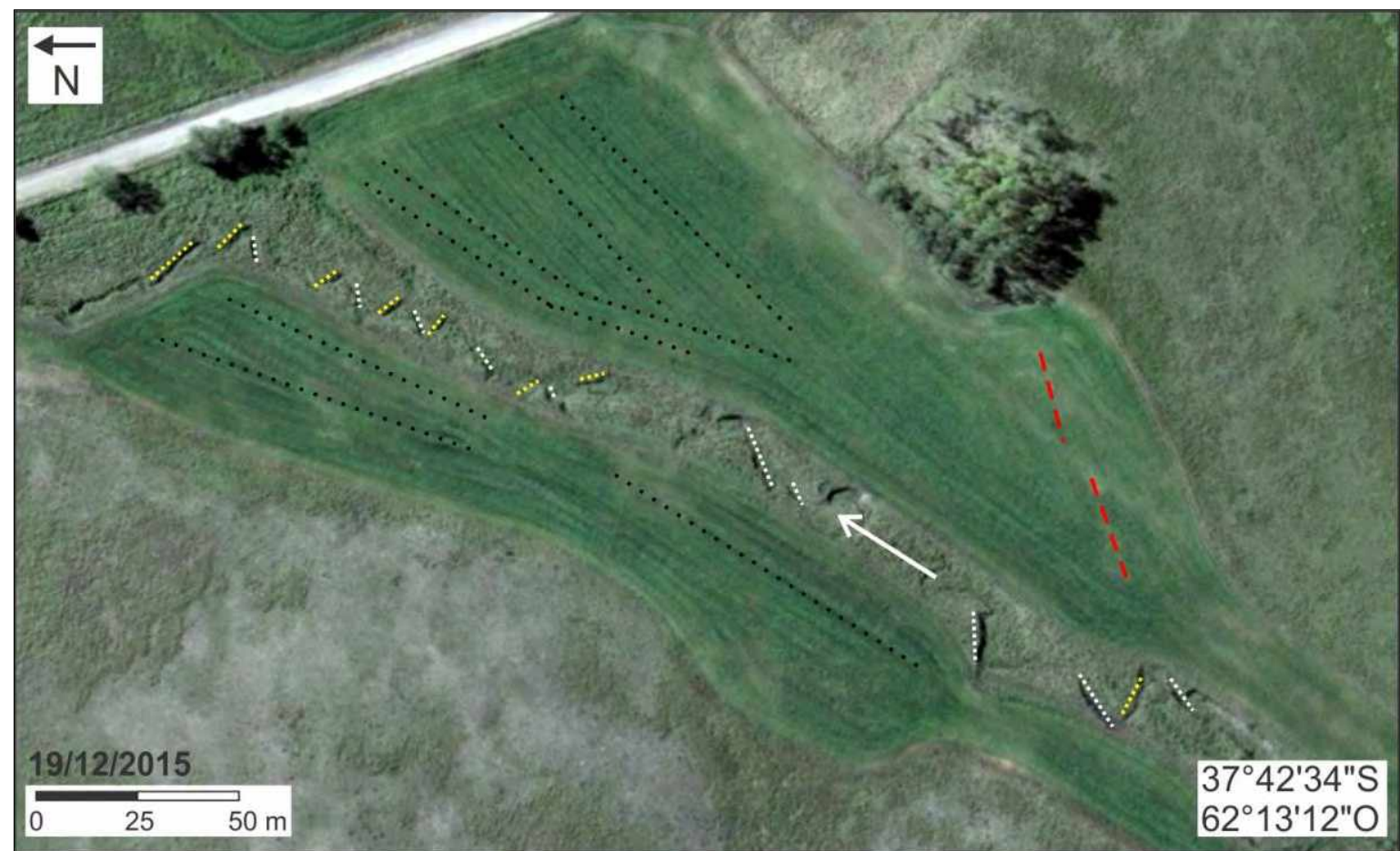

Figura 12.5. Diseño reticulado de las barrancas de un curso de agua (líneas punteadas blancas y amarillas) en el Valle de Las Grutas (subzona 2). Líneas punteadas negras (líneas de arado actuales). Líneas de guiones rojas: antiguas líneas de arado coincidentes en parte con la dirección de las líneas punteadas blancas. Modificado de Susena y Gentile (2019). 
Alambrados: los alambrados son utilizados principalmente para delimitar propiedades y cuadros ganaderos. El sistema de alambrado es el tradicional, con aproximadamente 7 hilos y postes enterrados separados cada unos 15-20 m, con varias varillas entre postes. Los alambrados que demarcan propiedades se extienden hasta las cimas de las sierras, mientras que los delimitan la actividad ganadera llegan a laderas de detritos y cimas menores, pero en general pierden continuidad en el piedemonte proximal. Los patrones de los alambrados se distribuyen, en general, independientemente de la disposición de los componentes naturales del paisaje.

Construcciones: se agrupan aquí elementos antrópicos de distribución puntual: edificios rurales, abrevaderos y elementos asociados, corrales y puentes.

Entre los edificios de los establecimientos rurales se encuentran viviendas, galpones (= naves), silos, establos, gallineros, etc. Por lo general se agrupan en un sector particular del terreno con escasas pendientes, y más o menos cerca de algún curso de agua. La impermeabilización de la superficie debido a las construcciones se reduce prácticamente a la extensión de los edificios, ya que sus contornos por lo general tienen superficies de tierra.

Los abrevaderos artificiales se ubican cerca de cursos de agua y sus aguas son cargadas con molinos de viento. Tanques australianos funcionan como reservorios de agua y localmente constituyen puntos elevados unos $2 \mathrm{~m}$ sobre el terreno circundante. Muchas de estas estructuras se encuentran abandonadas debido al deterioro de los molinos. Se ubican en el piedemonte medio y proximal, y a veces son reemplazados o complementados con pequeños embalses decamétricos, naturales o artificiales.

Los corrales se ubican cerca de las viviendas rurales, para guarecer cerdos, ovejas, vacas y caballos, los últimos, menos frecuentes. Se caracterizan por la ausencia de vegetación, una superficie limo-arcillosa expansiva, con grietas de desecación durante la estación seca y anegamientos durante la estación húmeda. Se encuentran topográficamente por debajo del terreno adyacente, a veces más de 0,5 m, indicando compactación y/o denudación.

Los puentes se ubican tanto en caminos vecinales como en caminos rurales internos. En su mayoría son de concreto y la luz (= abertura) se restringe al cauce actual. En general, no superan los $3 \mathrm{~m}$ de altura, y algunos de ellos son inundados o destruidos en eventos de precipitaciones excepcionales.

Forestaciones: como se mencionó en el Capítulo 4 Introducción al área de estudio, existen en la zona muchos bosques artificiales plantados en distintos sectores de las sierras, para protección y descanso del ganado. Los bosques más comunes del área son de pinos y aromos (acacias), y han crecido notablemente en el área de estudio, como se muestra en 
Movimientos en masa en las sierras de Bravard y Curamalal,

Sierras Australes de la Provincia de Buenos Aires.

Juan Manuel Susena

la Figura 4.13 del Capítulo 4. El desarrollo de bosques en la zona ha influido en la dinámica del escurrimiento superficial debido a la ausencia de pastizal debajo de la arboleda. En varios bosques en Laderas de Detritos se observaron concentraciones del escurrimiento superficial en canalículos de más de $30 \mathrm{~cm}$ de ancho y unos $10 \mathrm{~cm}$ de profundidad. En ausencia de bosques, la concentración del escurrimiento en las laderas es rara, limitada prácticamente a los bordes de acumulaciones de los deslizamientos o flujos de detritos (ver capítulo anterior).

\subsection{La Zoogeomorfología y su relación con la actividad antrópica en el área de estudio}

En las últimas décadas se ha desarrollado una disciplina que trata la acción geomorfológica de la fauna en contextos diversos: la zoogeomorfología (Butler, 1995). Existen animales con gran capacidad de modificar el paisaje, creando y destruyendo rasgos, y promoviendo o retrasando la acción de otros agentes geomorfológicos; a este tipo de animales, se los definió como zoogeomorfológicamente activos (Butler, 2012). Según este autor, la actividad humana influenció el comportamiento y la dinámica poblacional de varias especies de animales zoogeomorfológicamente activos en distintas partes del mundo, como castores, osos pardos, bisontes, perros de pradera, conejos, burros, cerdos y caballos, y esto se evidenció en grandes volúmenes de materiales desplazados (Butler, 2006).

Con respecto al área de estudio, a partir del siglo XVII, la introducción de ganado europeo en la región Pampeana (donde se incluye el área de estudio) produjo cambios en las actividades de los pueblos originarios, desarrollándose en la zona un espacio de movilización del ganado. Basta con decir que Curamalal (o Curá-Malal) significa "corral de piedra" en el idioma mapuche. Dicho espacio ha evolucionado paulatinamente durante el período de contacto "Hispano-Indígena" hasta la conformación definitiva de un núcleo ganadero a mediados del siglo XIX. Estos cambios ya eran evidentes en el paisaje al menos desde principios del siglo XIX (Panizza, 2015 y bibliografía allí citada). Desde entonces no cesó la presencia de animales de gran porte en la región, ejerciendo influencia sobre la diversidad florística y su abundancia relativa (Loydi y Distel, 2010; de Villalobos, 2016). De acuerdo con los últimos autores, la proliferación de animales introducidos de gran porte, como los caballos cimarrones y el ganado vacuno, ha dejado improntas en el paisaje, afectando la variedad de especies de vegetación y aumentando la superficie con suelo descubierto, efectos de degradación potencialmente irreversibles. Aunque en la región esta clase de estudios ecológicos se enfocaron en la acción de los caballos cimarrones, desde 
el punto de vista geomorfológico se destaca el ganado vacuno, por ser la especie introducida más abundante y probablemente la que mayor trabajo geomorfológico ejerce, dada su representatividad y su porte.

Por otra parte, recientemente ha aumentado la población de jabalíes en el área de estudio, mamíferos zoogeomorfológicamente activos. Según los habitantes de la zona, parte de ello se debe a la falta del control de la población de estos animales, debido a que se crían en campos abandonados o descuidados. Los pumas, únicos depredadores naturales potenciales de los jabalíes, escasean en la zona debido a la caza histórica de dichos animales, y los que quedan se alimentan preferentemente del ganado ovino. Adicionalmente, el desarrollo de cultivos de maíz y nogales en la zona representa un aumento en la disponibilidad de alimento para los jabalíes. Así, la dinámica poblacional de jabalíes se ve en gran medida afectada positivamente por la actividad antrópica, mediante la neutralización de sus depredadores y el aumento en la disponibilidad de alimento.

\subsection{Actividad zoogeomorfológica en el área de estudio}

Entre los animales zoogeomorfológicamente activos del área hay silvestres y domesticados. Los animales silvestres son jabalíes (también denominados en la zona "chanchos salvajes"), ciervos colorados, caballos cimarrones, pumas, guanacos, avestruces, antílopes, zorros, loros barranqueros y animales excavadores como liebres, cuises, peludos y vizcachas. Entre los animales domesticados se destacan vacas, ovejas, caballos y perros. Existen más especies en la zona (ver Capítulo 4 Introducción al área de estudio), pero los de mayor potencial para modificar el paisaje son los aquí mencionados, sea por su porte o su etología.

A continuación, se describen los principales componentes del paisaje del área de estudio construidos o modificados por la acción zoogeomorfológica y así como los procesos que participan en su desarrollo.

Caminos de "vaca": estos rasgos son ubicuos en el área estudiada, tanto en el piedemonte como en el ámbito serrano. Son rasgos lineales que pueden superar el kilómetro de longitud, su ancho no supera en general los $50 \mathrm{~cm}$ y su trayectoria puede ser rectilínea o escasamente curvada. En el piedemonte estos rasgos se desarrollan bordeando a los alambrados o aledañamente a los cursos de agua, bordeándolos y atravesándolos. En algunos casos presentan un diseño radial a estructuras de servicio para el ganado, como bosques y abrevaderos artificiales (Susena et al., 2019b), como se muestra en la Figura 12.6. 
Movimientos en masa en las sierras de Bravard y Curamalal,

Sierras Australes de la Provincia de Buenos Aires.

Juan Manuel Susena

Se encontraron distintos grados de erosión hídrica en estos caminos, evolucionando desde simples huellas con presencia de vegetación hasta cárcavas (Figura 12.7).

El carcavamiento es más común en la Cubierta Eólica Periserrana que yace sobre niveles pedemontanos previos al actual, preferentemente de manera transversal a la divisoria de los niveles de piedemonte. Contribuyen al carcavamiento (= acarcavamiento) los efectos de la pendiente, el carácter friable de los limos de la Fm. Saavedra (material eólico) y la ausencia de vegetación debido al pisoteo. En menor medida, el carcavamiento también se produce en las Fajas Aluviales,

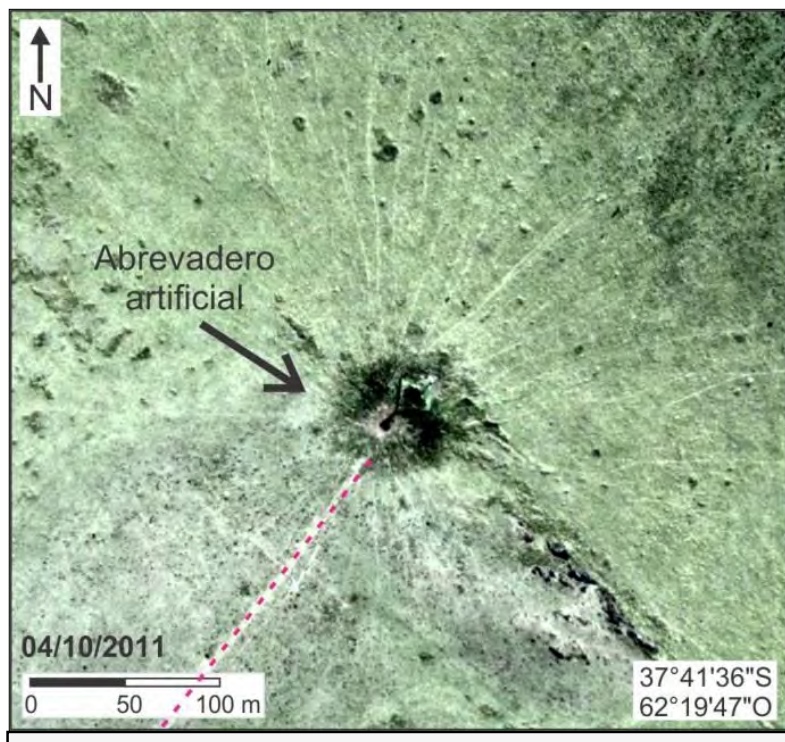

Figura 12.6. Caminos de vaca dispuestos radialmente en torno a un abrevadero artificial en el piedemonte occidental de las Sierras de Curamalal. Línea roja: camino rural interno. Elaboración propia a partir de composición de imagen satelital de World View-2 (Google Earth). paralelamente a la dirección del escurrimiento, afectando caminos por los cuales los animales descienden de la planicie de inundación al cauce.

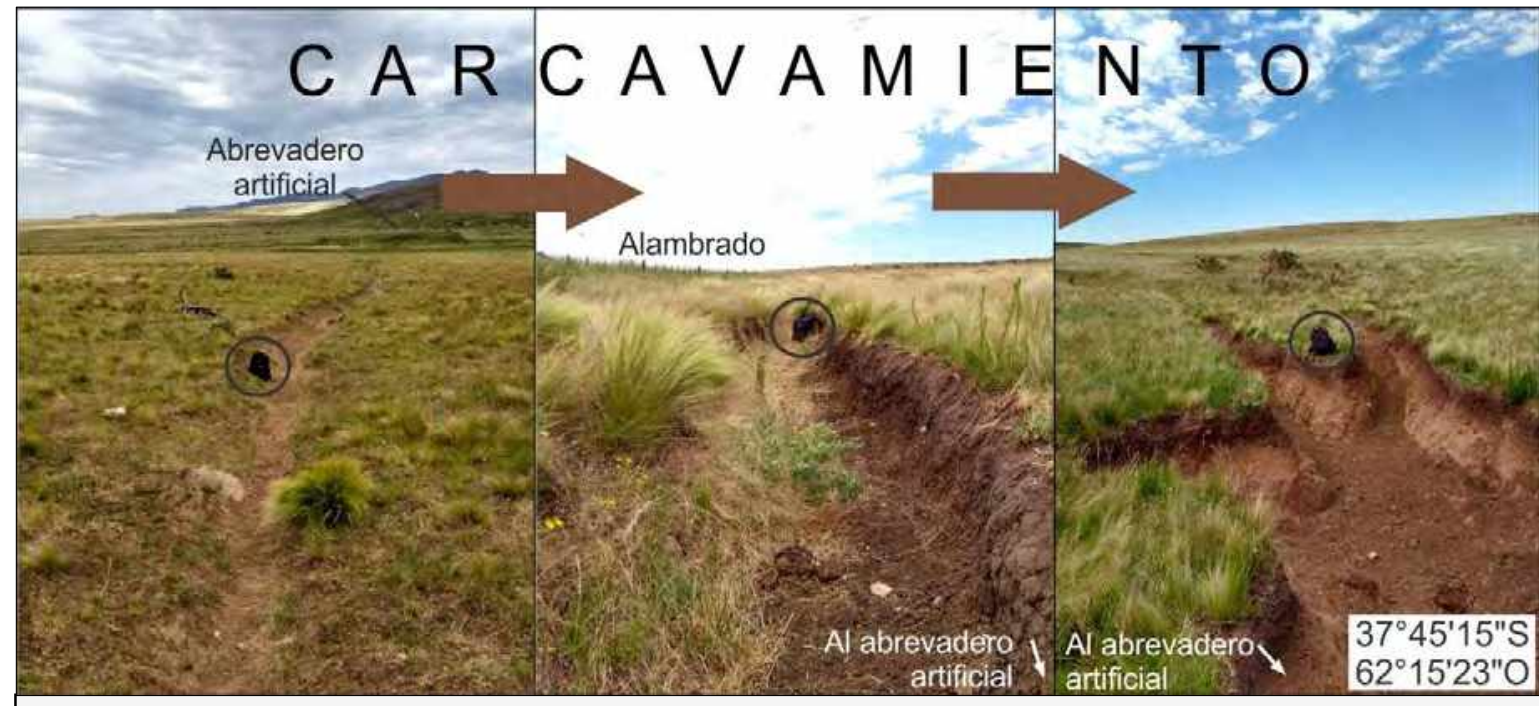

Figura 12.7. Distintos estados de la erosión hídrica en caminos de vaca en torno a un abrevadero en el piedemonte occidental de las Sierras de Curamalal (subzona 2). Los tres caminos son del mismo sector, separados entre sí por unas pocas decenas de metros. La mochila (círculos) sirve como escala. Fotos: Juan M. Susena.

Terracettes: el patrón en zig-zag de las terracettes, descripto en el Capítulo 9 Movimientos en masa en laderas, se asocia típicamente a la actividad del ganado, que asciende o desciende en diagonal a la pendiente de las laderas. Estos rasgos se desarrollan en 
sectores de pendientes mayores a $30^{\circ}$, mientras que, en zonas con pendientes menores, las terracettes son más bien paralelas. En dichos casos, la influencia del ganado en el sector se identifica por su interacción con los detritos, como se explicará en la siguiente sección. De la misma manera, se encontró un mayor desarrollo de estas formas en sectores con mayor carga ganadera.

En un trabajo reciente (Susena y Gentile, 2019) se levantaron perfiles de terracettes en Laderas de Detritos de umbría próximas entre sí y se encontró una relación inversamente proporcional entre la pendiente general de las laderas y la relación ancho/alto de las terracettes (Figura 12.8). El hecho de que la anchura tenga mayor participación en la morfología de las terracettes en zonas de menor pendiente, podría deberse a que en estas zonas el ganado permanece más tiempo pastando que en los sectores de pendientes mayores, ejerciendo trabajo geomorfológico relativamente mayor (mayor sobrecarga). La compactación del suelo y la reducción de la cobertura vegetal en estos sectores de menor pendiente promueve una mayor acción del escurrimiento superficial no encauzado, aumentando el lavaje de los materiales finos aún no compactados (Figura 12.9). El lavaje impide a su vez el crecimiento de nueva vegetación, produciéndose así una retroalimentación positiva en la erosión de los suelos de las laderas.

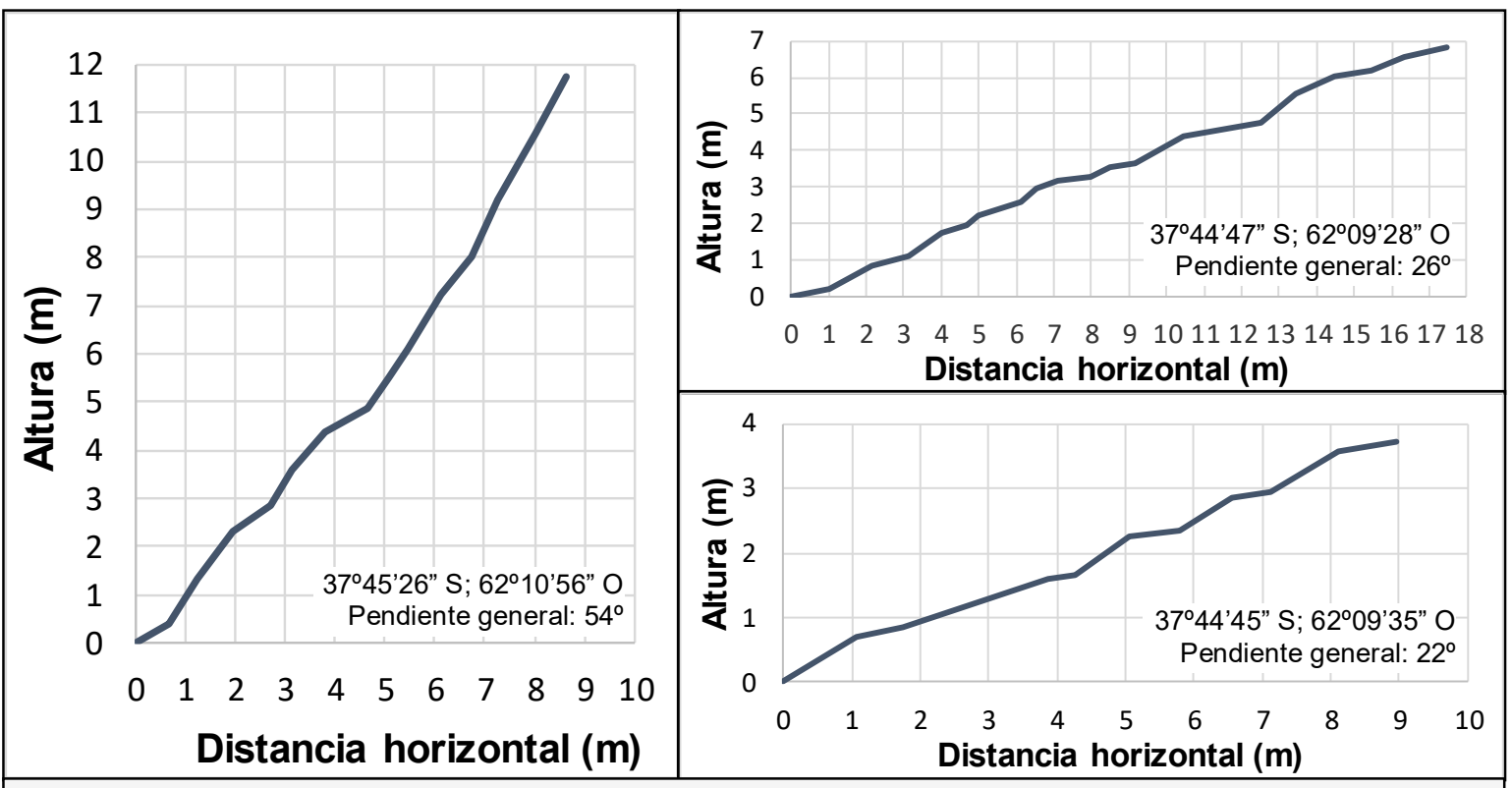

Figura 12.8. Perfiles de laderas con terracettes. Cuanto menor es la pendiente, más anchas son las terracettes. Tomado de Susena y Gentile (2019).

En laderas de solana, donde la vegetación crece con mayor lentitud debido a la menor humedad, el lavaje de la matriz de los Detritos de Ladera está muy desarrollado, quedando en superficie una delgada capa de gravilla sobre un suelo compactado. Por otra parte, los sectores de mayor pendiente son típicamente de tránsito, razón por la cual, además de un 


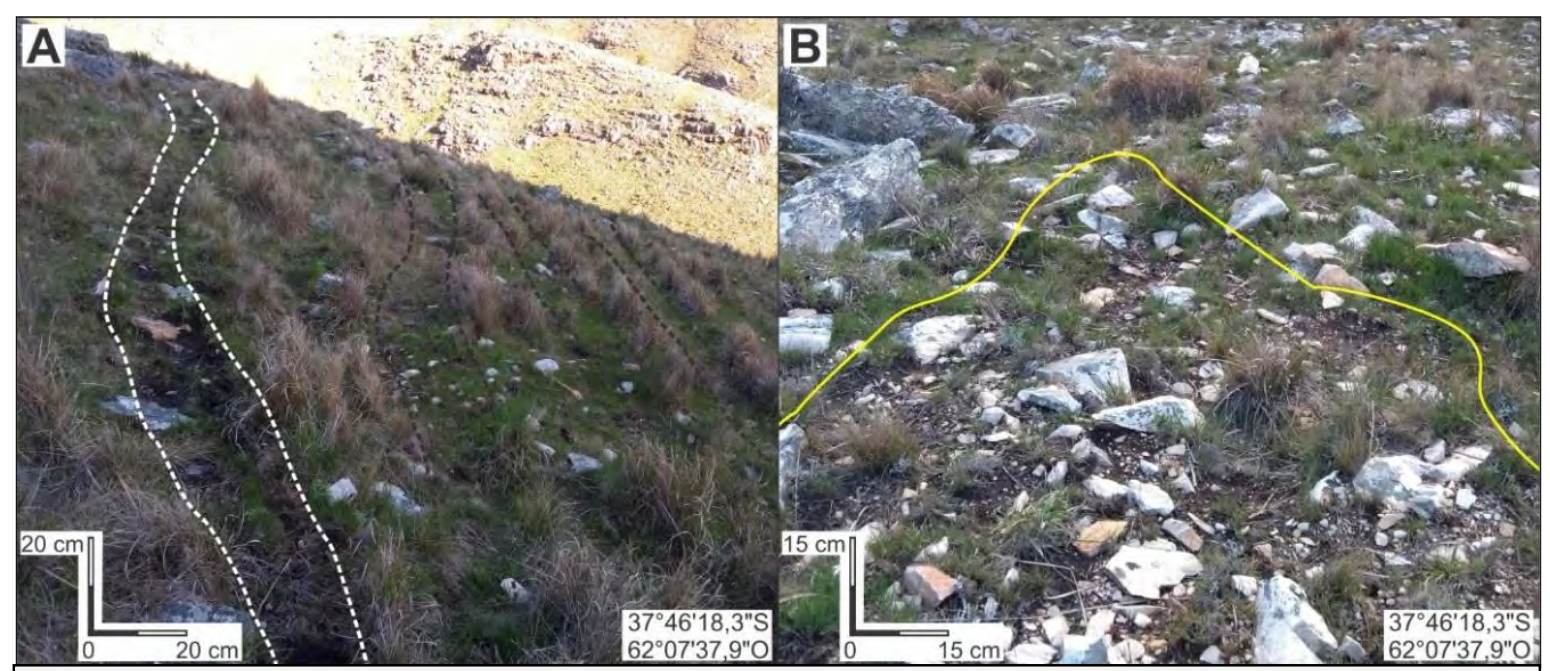

Figura 12.9. Efectos del pisoteo de animales en una ladera de un valle intraserrano de las Sierras de Bravard (subzona 2). A. Desarrollo de terracettes (líneas de trazos negras) y eliminación de la cobertura vegetal en una de ellas (líneas de trazos blancas). Pueden apreciarse los detritos rocosos más grandes hincados en la matriz (no sobresalen). B. Sector con lavaje intenso de la matriz de los depósitos, quedando una fina capa de gravilla en superficie. Se observan también detritos volteados y partidos por el tránsito animal. Fotos: Juan M. Susena.

menor desarrollo de los corredores de las terracettes, también se observa mayor presencia de cobertura vegetal.

Las terracettes se presentan también en los cursos de agua, modelando la transición entre las planicies de inundación o terrazas y los cauces, procesos observados también en otros sectores de las Sierras Australes.

Cornisas y pavimentos de detritos: estos rasgos se desarrollan en Laderas de Detritos,

y se asocian a la actividad de animales de gran porte (Susena et al, 2019a). Las cornisas de detritos son acumulaciones lineales de detritos en las terracettes, en los bordes de los corredores (zonas de menor pendiente), como se aprecia en la Figura 12.10. Es notorio cómo en los corredores escasean los detritos sueltos en superficie cuando se observan las cornisas de detritos. La

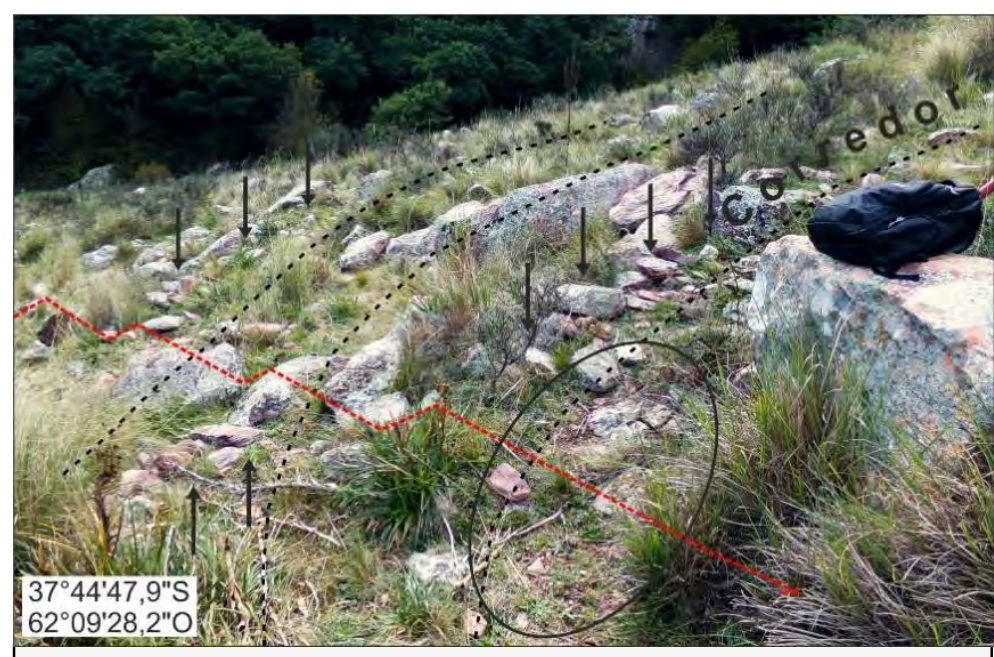
Figura 12.10. Terracettes en una ladera occidental de las Sierras de Bravard (subzona 2). Líneas negras: corredores. Línea roja: refuerzo visual de la topografía. Flechas: cornisas de detritos. Elipse: pavimento de detritos hincados en la matriz. Modificado de Susena et al. (2019a). Foto: Juan M. Susena. 
asociación de estos rasgos con heces de ganado y signos de volteo de clastos (ver Capítulo 7 Criterios de reconocimiento de los movimientos en masa y su actividad) son indicadores de la actividad zoogeomorfológica en el desarrollo de estas formas. Los animales patean los detritos hacia fuera de la ladera mientras caminan por los corredores; algunos detritos caen por la ladera mediante rebotes y rodaduras, mientras otros quedan retenidos por la vegetación u otros clastos en los bordes de los corredores, conformándose las cornisas de detritos. Los pavimentos de detritos se asocian también a corredores de terracettes, y consisten en superficies con los detritos hincados en la matriz eólica, resultando en una textura lisa similar a la de un camino de tierra compactado por el tránsito vehicular (Figuras 12.9.A y 12.10). La compactación impide el crecimiento de la vegetación, restringiéndose ésta a las cornisas y las partes empinadas de las terracettes.

Abrevaderos y revolcaderos naturales: existen sectores de las laderas donde se encuentra agua en superficie, como las Bajadas Coluviales Finas y las zonas de hundimiento de deslizamientos. Muchas veces el ganado vacuno y los jabalíes silvestres se concentran allí, desarrollándose abrevaderos y revolcaderos. En general se trata de zonas con materiales limosos y escasa pedregosidad, donde el agua aparece en superficie por cambios locales de las condiciones hidrogeológicas (reducción del gradiente hidráulico por cambios en la topografía, o reducción de la permeabilidad de los horizontes subsuperficiales por la presencia de arcillas), desarrollándose manantiales en las Bajadas Coluviales Finas, o cuerpos de agua estancos en las Laderas de Detritos. En Bajadas Coluviales Finas y algunos sectores de Piedemontes Coluviales Antiguos, se desarrollan depresiones de $0,5 \mathrm{~m}$ de profundidad, hasta $5 \mathrm{~m}$ de ancho y más de $10 \mathrm{~m}$ de longitud, donde el lavaje localizado y la reptación se asocian a la tendencia al hinchamiento y compactación del suelo por humedecimiento-secado y pisoteo de los animales (Susena y Gentile, 2019). Según estos autores, la presencia de huellas como microirregularidades favorece la concentración del agua, como se muestra en la Figura 12.11.A. Estas características se observaron también en zonas de hundimiento o partes anteriores de acumulaciones de deslizamientos donde se acumula agua (Figura 12.11.B). La conjunción de todos estos mecanismos contribuye al desarrollo del lavaje, produciéndose una retroalimentación que favorece su desarrollo. Si las tasas de reposición de material fino desde los tramos proximales y medios de las laderas son menores que las del lavaje, el desarrollo de abrevaderos naturales en demasía podría provocar una erosión importante de las Bajadas Coluviales Finas. 


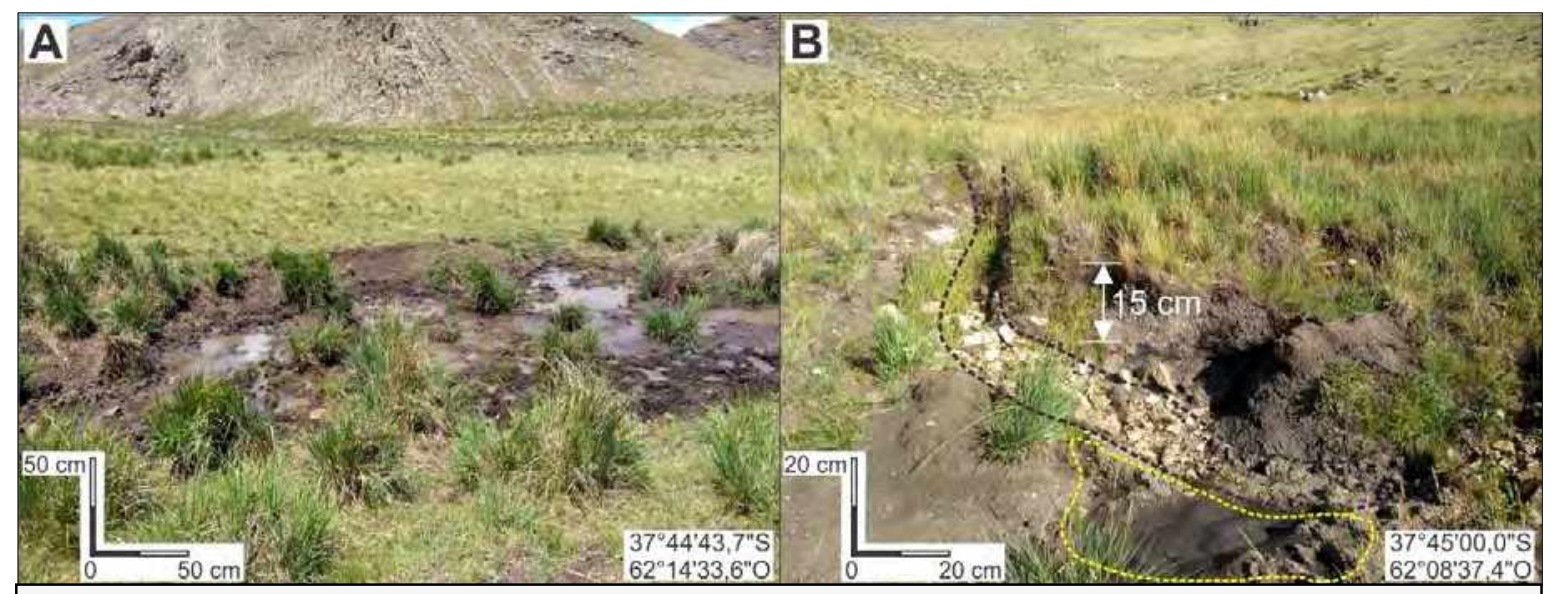

Figura 12.11. Abrevaderos naturales en la subzona 2. A. Abrevadero en una Bajada Coluvial Fina de la vertiente occidental de las Sierras de Curamalal, asociado a un flujo de tierra activo. Puede observarse cómo el agua se concentra en las huellas de los animales. B. Abrevadero en la parte trasera de la acumulación de un deslizamiento en una Ladera de Detritos del Cerro Hinojo (Sierras de Bravard). Líneas negras: lavaje intenso de la matriz en un camino de vaca levemente más deprimido que sus alrededores. La línea amarilla encierra un sector con concentración de agua en huellas de animales. Fotos: Juan M. Susena.

Rascaderos: distintos elementos del paisaje como árboles, afloramientos rocosos o bloques de gran tamaño son utilizados por los animales como rascaderos. La presencia de árboles y bloques rocosos con superficies muy pulidas indica este tipo de actividad zoogeomorfológica (Figuras 12.12.A y B). Si bien se observaron grupos de vacas rascándose contra bloques rocosos, esta actividad podría vincularse también a animales silvestres como los guanacos, aunque los etogramas de tal especie (Lama guanicoe) no indican que tengan el hábito de rascarse contra objetos; en todo caso, si así fuera, estos rasgos podrían ser más antiguos, dado que los guanacos habitan la zona con anterioridad al ganado vacuno. De cualquier manera, la concentración de animales en torno a un objeto único como puede ser un bloque rocoso o un afloramiento incrementa localmente la degradación del suelo debido a la compactación, acumulación de agua, destrucción de la vegetación e impedimento de su crecimiento y lavaje (Figuras 12.12.C y D). 


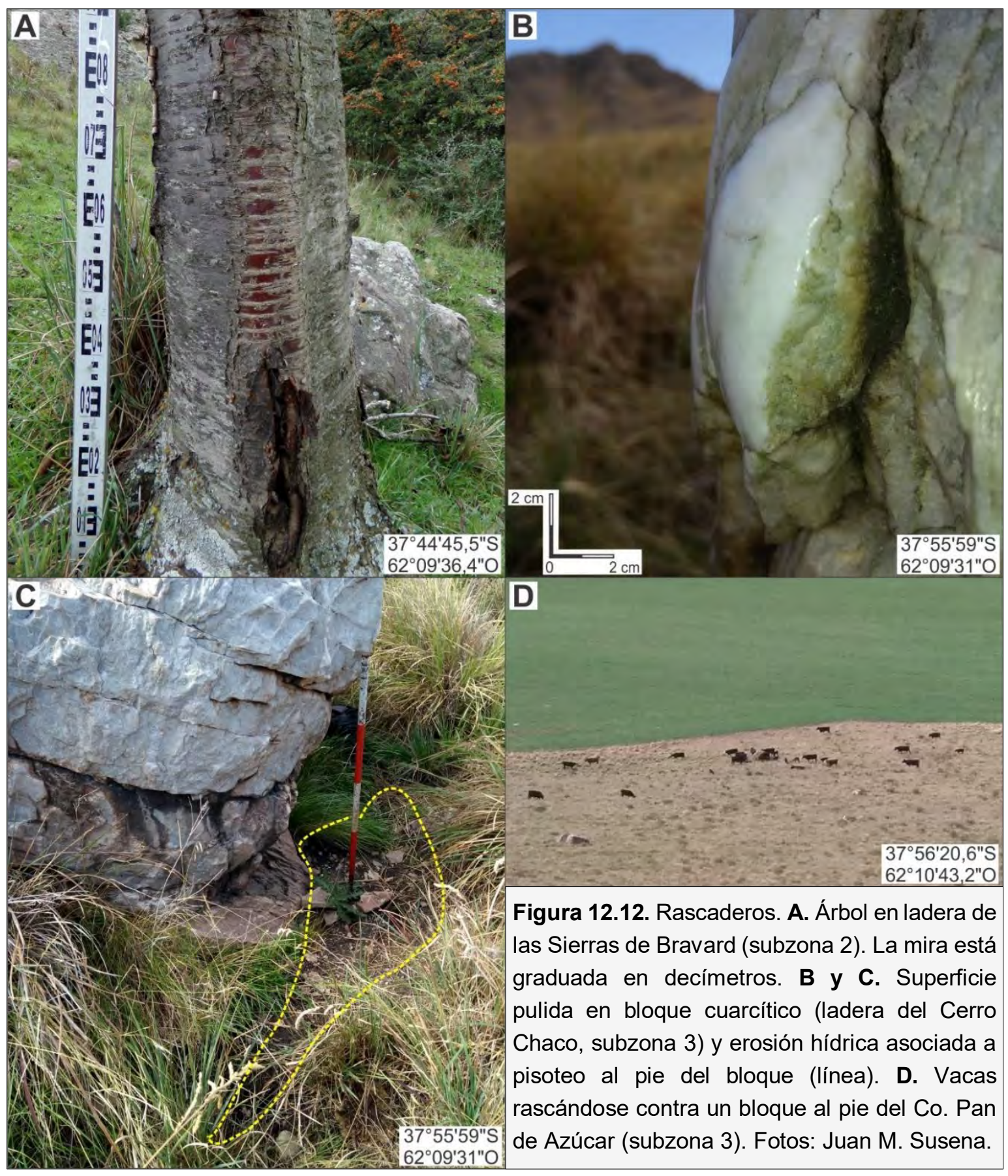

Hozaduras: la acción de hozar es un modo de búsqueda de alimento de los jabalíes del área, mediante el cual remueven el suelo con sus hocicos. En tramos medios y distales de las laderas con escasa proporción de materiales gruesos, las hozaduras pueden alcanzar superficies de unos $9 \mathrm{~m}^{2}$, dejando suelto el material fino (Figura 12.13), aumentando la susceptibilidad a la erosión hídrica. Muchas veces se encuentran bloques volteados y desenterrados por esta misma acción de hozar, e incluso bloques o detritos partidos y volteados. No se encontraron mayores consecuencias del desarrollo de hozaduras en el área, pero puede entenderse que localmente podría aumentar la capacidad de concentración del agua debido a las pequeñas irregularidades ocasionadas en el terreno 
Movimientos en masa en las sierras de Bravard y Curamalal,

Sierras Australes de la Provincia de Buenos Aires.

Juan Manuel Susena

por la mezcla y remoción del suelo y favorecer el desarrollo de pequeños flujos de barro o de tierra, o deslizamientos de tierra, desplazando estos materiales.

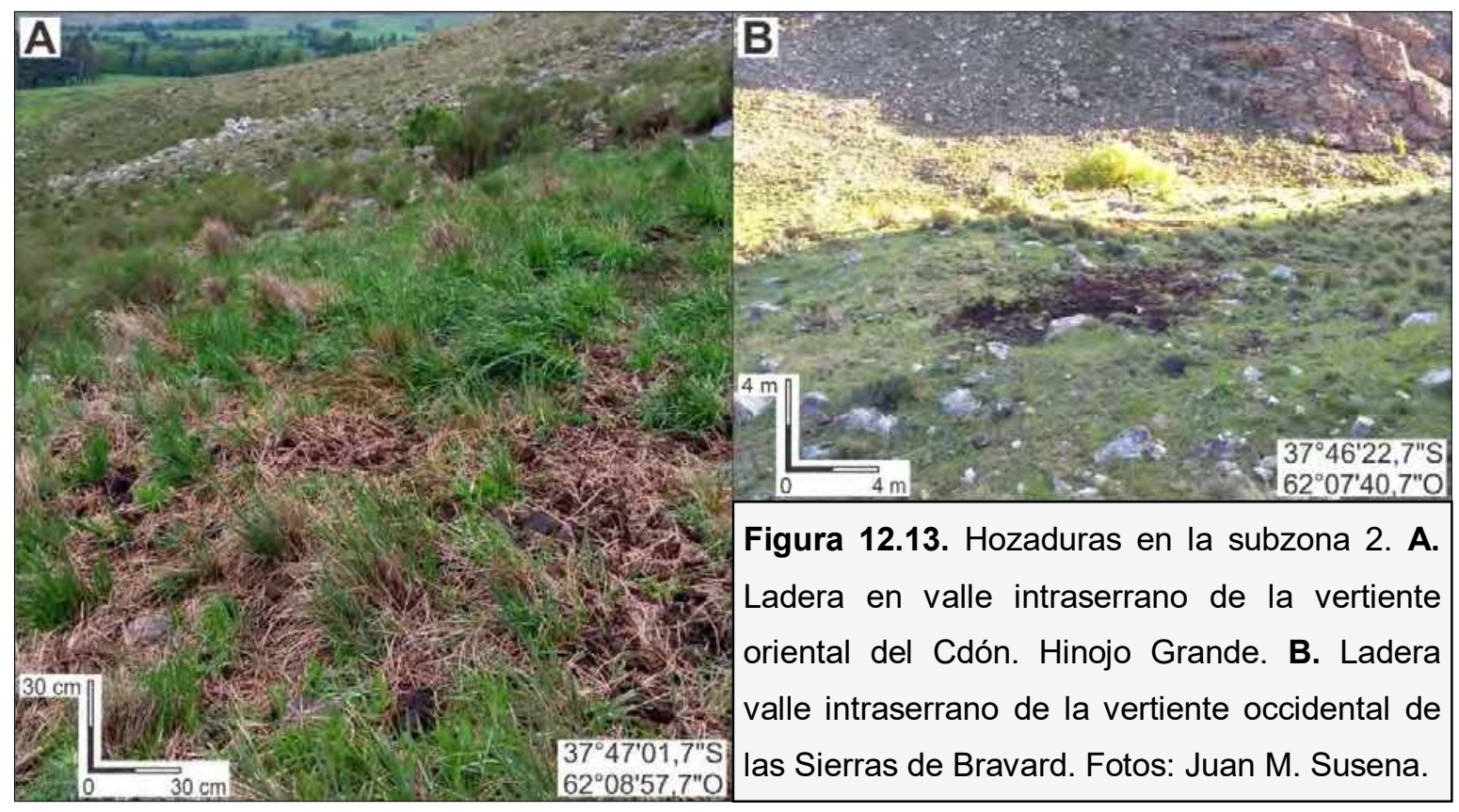

Indentaciones: las barrancas de los cursos de agua presentan interrupciones a modo de entrantes con forma generalmente triangular vista en planta, cuyo ápice apunta indistintamente aguas arriba o aguas abajo (Figura 12.14), denominadas indentaciones (Susena et al., 2019a). La pendiente de estas formas puede tener o no tener coherencia hidrológica respecto al curso de agua; la ausencia de coherencia hidrológica es un elemento que permite desvincular su génesis de un origen netamente por erosión hídrica. Las indentaciones son generadas por los animales que ascienden y descienden por las barrancas, modelando la transición entre las planicies de inundación o terrazas aluviales y los cauces. Formas similares son parte de las denominadas escotaduras menores (Gentile, 2005), comunes en el ámbito serrano y pedemontano de la Provincia de Buenos Aires. Las indentaciones son más comunes en sectores del terreno utilizados para ganadería, como es el piedemonte proximal y medio. Allí puede verse una estrecha relación entre los caminos de vaca y las indentaciones: los ápices de muchas indentaciones apuntan hacia los caminos de vaca o están en contacto con ellos. Como muestra la Figura 12.14, estos rasgos pueden ocupar una buena parte de las barrancas, modificando su morfología. 


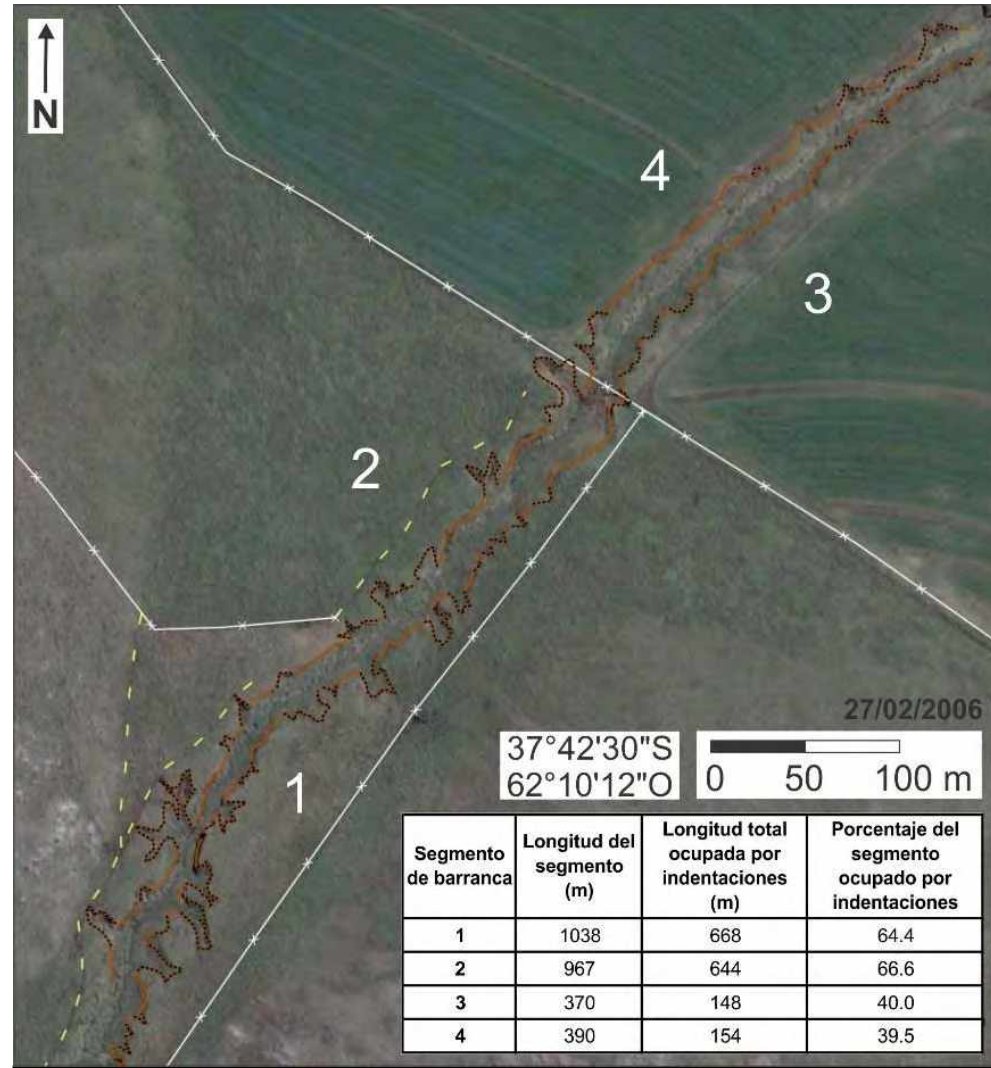

Figura 12.14. Indentaciones (líneas negras) en las barrancas (líneas castañas) de una faja aluvial del piedemonte oriental de las Sierras de Bravard. El curso discurre hacia el NE. Líneas de trazos amarillas: "caminos de vaca". Líneas blancas: alambrados. Números: los segmentos 3 y 4 son diferenciados respectivamente de los 1 y 2 por el alambrado de dirección NO$\mathrm{SE}$. Nótese que las indentaciones pueden tener o carecer de coherencia hidrológica con los cursos de agua, y que están más desarrolladas en el sector suroccidental, destinado a la ganadería, y que los ápices de algunas coinciden con los caminos de vaca. Modificado de Susena y Gentile (2019).

\subsection{Relaciones entre movimientos en masa y componentes antropogénicos}

\subsubsection{Movimientos asociados a caminos y canales antrópicos}

Como se mencionó más arriba, los caminos vecinales realizados en los sedimentos eólicos de la Fm. Saavedra generalmente se ubican topográficamente por debajo del terreno aledaño (Figura 12.2.A), con profundidades relativas máximas de unos $2,5 \mathrm{~m}$. Existen allí numerosas evidencias de movimientos en masa asociados a escarpas generadas por obras de ensanchamiento o reparación de dichos caminos. Estas tareas se hacen periódicamente debido que, dada la poca cohesión de los materiales, durante épocas 
Movimientos en masa en las sierras de Bravard y Curamalal,

Sierras Australes de la Provincia de Buenos Aires.

Juan Manuel Susena

lluviosas se generan verdaderos barreales que dificultan el tránsito. Se generan principalmente pequeños deslizamientos y vuelcos de suelo. Los deslizamientos traslacionales desplazan poco más de $1 \mathrm{~m}^{3}$, y presentan superficies de ruptura de alto ángulo. La masa puede conservarse relativamente entera o disgregarse, según disminuye el contenido de humedad, siendo difícil diferenciar deslizamientos de caídas o vuelcos (Figuras 12.15.A y B). No se encontraron deslizamientos rotacionales en los caminos recorridos, pero dada la homogeneidad de los materiales, no se descarta su posible desarrollo. Los vuelcos de suelo, generalmente de dimensiones sub-métricas, son muy

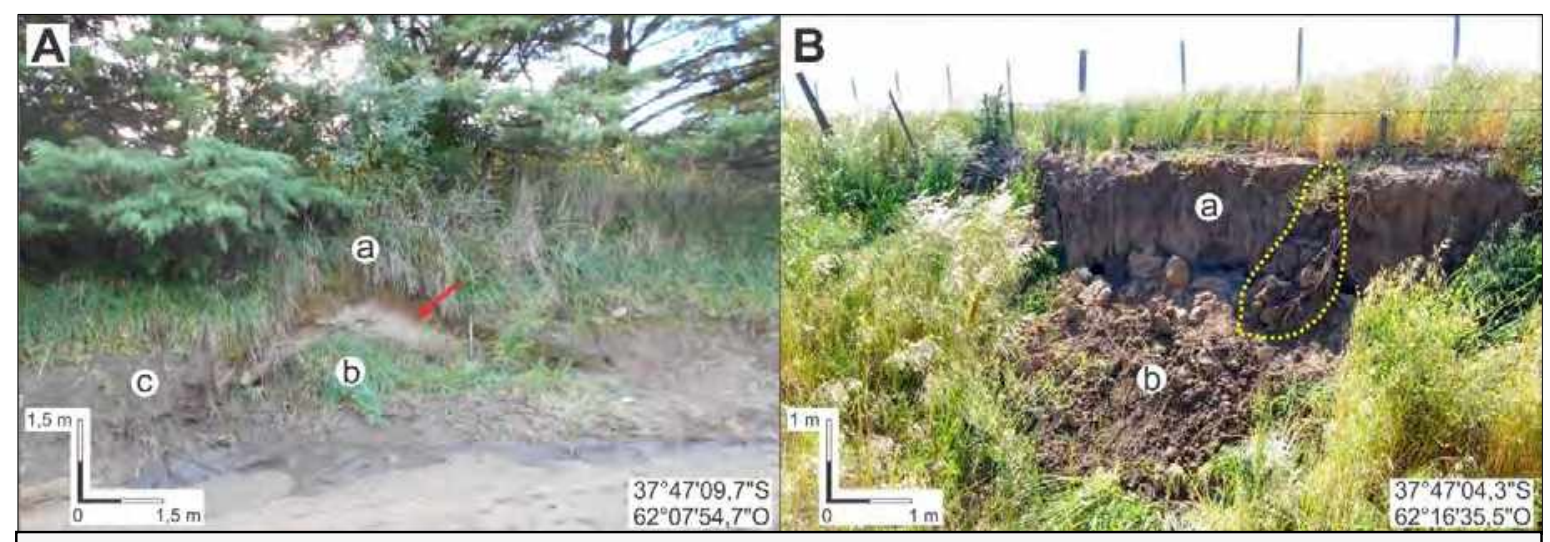

Figura 12.15. Pequeños movimientos en masa en caminos vecinales. A. Deslizamiento en el camino del Valle de Las Grutas-Abra de Hinojo (subzona 2). a: escarpa. b: material desplazado obstruyendo una pequeña cuneta. c: corte verticalizado por obras de mantenimiento. Flecha: la parte sub-superficial del suelo aún está seca, indicando que su exposición por causa del movimiento se habría producido recientemente. B: Deslizamiento/caída/vuelco de suelo con disgregación de la masa desplazada en un camino del piedemonte occidental de las Sierras de Curamalal. a: escarpa. b: masa desplazada. La línea de puntos encierra un pequeño bloque deslizado y su superficie de ruptura sub-vertical. Fotos: Juan M. Susena.

frecuentes. Las discontinuidades que individualizan bloques de suelo pueden relacionarse con grietas por contracción, conductos excavados por animales, desarrollo de raíces o instalación de postes. En algunos casos, los bloques de suelo individualizados pivotan levemente hacia fuera, y la introducción de agua en la superficie de separación hace que estos bloques se deslicen manteniendo su disposición vertical, constituyéndose movimientos con componentes de vuelco y de deslizamiento (Figura 12.16).

La acción antrópica funciona como un mecanismo preparador en dos aspectos: por un lado, se remueve la vegetación que funciona como anclaje, y por otro, se generan frentes escarpados artificiales sub-verticales, superando el ángulo de reposo de los materiales involucrados.

Los movimientos en masa desarrollados en los canales son similares a los que se producen en cursos de agua: deslizamientos, caídas y vuelcos de suelo, flujos de barro muy 
pequeños y reptación. Estos tipos de movimientos se describieron en el Capítulo 10 Movimientos en masa en cursos de agua.

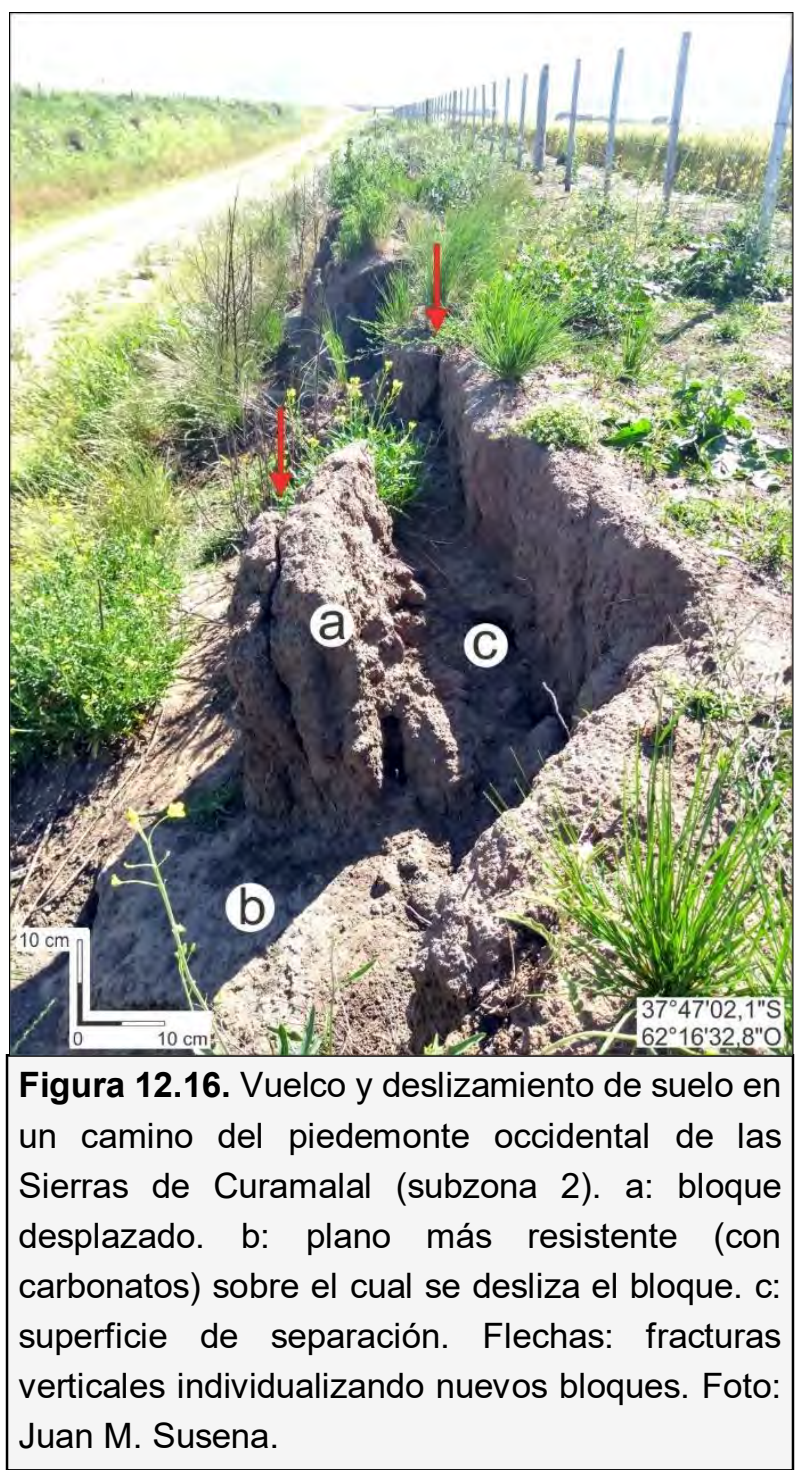

\subsubsection{Movimientos asociados a forestaciones}

En las partes proximales de las Laderas de Detritos y en las Gargantas en Discontinuidades Rocosas, las frecuentes caídas de bloques rocosos desde los frentes escarpados o desde las mismas laderas interactúan con los árboles allí desarrollados, como se mencionó en el Capítulo 7 Criterios de reconocimiento de los movimientos en masa y su actividad. El funcionamiento de los árboles como obstáculos para las caídas de rocas modifica parcialmente la fábrica original de los taludes. En ausencia de árboles y otros obstáculos, los bloques mayores en general son más frecuentes ladera abajo, pero en presencia de árboles, los bloques mayores pueden quedar retenidos ladera arriba. Esto debe tenerse en cuenta si se planifica una deforestación (por ejemplo, para control de plaga de ciertas 
Movimientos en masa en las sierras de Bravard y Curamalal,

Sierras Australes de la Provincia de Buenos Aires.

Juan Manuel Susena

especies de árboles), puesto que en las laderas los bloques trabados por árboles son potencialmente inestables. Asimismo, si los árboles se descomponen con el tiempo, los bloques trabados pueden desplazarse ladera abajo.

Muchos bloques rocosos se apoyan sobre la superficie, no trabados con ningún obstáculo. El aumento en la erosión por arroyada difusa bajo las arboledas debido a la ausencia de pastizal promueve la remoción del sedimento que sustenta los bloques, siendo estos potencialmente más inestables que los que yacen en laderas no arboladas, donde el abundante pastizal protege al suelo de la erosión hídrica.

En algunas incisiones fluviales arboladas en las laderas, se encontraron sectores con abundantes árboles caídos y quebrados por caídas de rocas, denominados aquí "alineaciones de árboles partidos" (Figura

12.17). Estas alineaciones son prácticamente intransitables y potencialmente peligrosas, dado que la escasa visibilidad no permite percibir un bloque cayendo, y que los rebotes contra los árboles pueden cambiar impredeciblemente la trayectoria.

Durante una de las campañas, al otro día de una lluvia de unos $20 \mathrm{~mm}$ (según los pobladores de la zona), dos veces se escucharon bloques rocosos cayendo en un sector de arboleda en las laderas. Esta apreciación, sumada a la observación de las quebraduras recientes de árboles, algunos reteniendo bloques o siendo sepultados por ellos, indican que las arboledas en laderas son sectores que siguen siendo activos en cuanto a caídas de rocas.

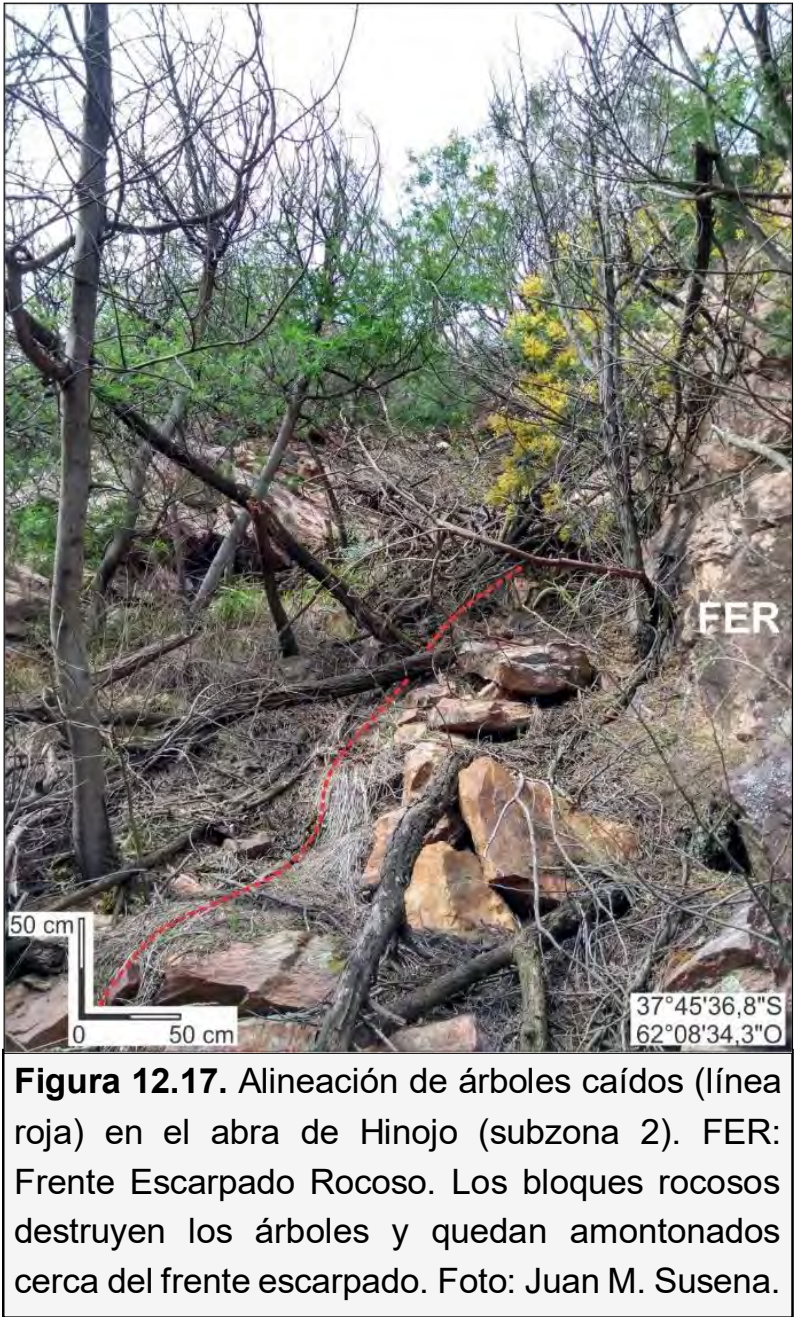




\subsection{Relaciones entre movimientos en masa y actividad zoogeomorfológica}

\subsubsection{Caídas, vuelcos, deslizamientos y reptación de suelo en torno a cursos de agua y caminos}

Caídas, vuelcos y deslizamientos decimétricos son impulsados por actividad de los animales. Estos tipos de movimientos en general se desarrollan en las barrancas de los cursos de agua. En sectores donde los caminos de animales son aledaños a las barrancas se observaron bloques de suelo con desplazamientos decimétricos por deslizamiento y también bloques de suelo caídos. Asimismo, se encontraron pequeños bloques de suelo susceptibles a vuelcos y caídas, apenas arraigados a las barrancas por las raíces del pastizal, propensos a caer ante cualquier pisoteo $o$ pateadura. Estos rasgos se encuentran también en los bordes de las indentaciones descriptas más arriba, pudiendo las caídas, vuelcos y deslizamientos de suelo tomar parte en el modelado de las indentaciones (Figura

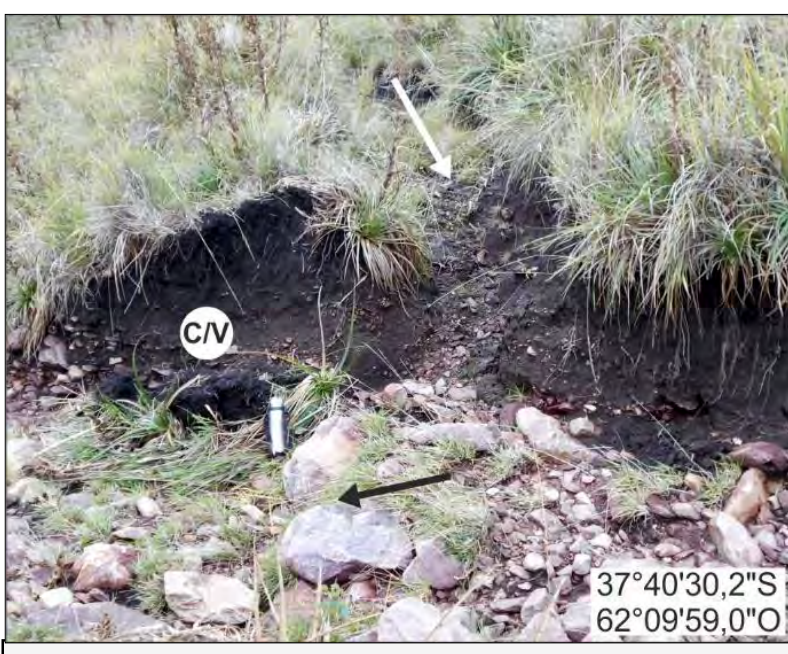

Figura 12.18. Caída/vuelco de suelo (C/V) asociado a una indentación (flecha blanca) en un curso de agua del Valle de Las Grutas (subzona 2). Flecha negra: dirección del escurrimiento; nótese que la indentación apunta en contra de la dirección del cauce. El termo al lado del bloque caído sirve como escala. Foto: Juan M. Susena. Modificado de Susena y Gentile (2019). 12.18).

La morfología de las márgenes de los cursos es modelada por reptación asociada al pisoteo, desarrollándose terracettes en diagonal, muy características en zonas con intensa carga ganadera (Figura 12.19.A). Este proceso se desarrolla especialmente en las facies matriz sostén del Aluvio, la Fm. Agua Blanca, la Fm. Saavedra y los Detritos de Ladera que constituyen las márgenes de los cursos de agua. No se observaron estas formas en otras litologías atravesadas por los cursos de agua, como las calcretas y silcretas, ni en las facies clasto sostén de unidades fluviales, como parte de la Fm. Agua Blanca y el Aluvio. La reptación asociada con la actividad zoogeomorfológica, principalmente del ganado, es extensiva a todo el ámbito de las Sierras Australes de la Provincia de Buenos Aires, incluyendo sectores ubicados fuera del área de esta tesis (Figura 12.19.B).

Algunos movimientos en masa responden a inestabilidades generadas por animales excavadores. Las galerías creadas por vizcachas, peludos y mulitas sufren colapsos del 
Movimientos en masa en las sierras de Bravard y Curamalal,

Sierras Australes de la Provincia de Buenos Aires.

Juan Manuel Susena

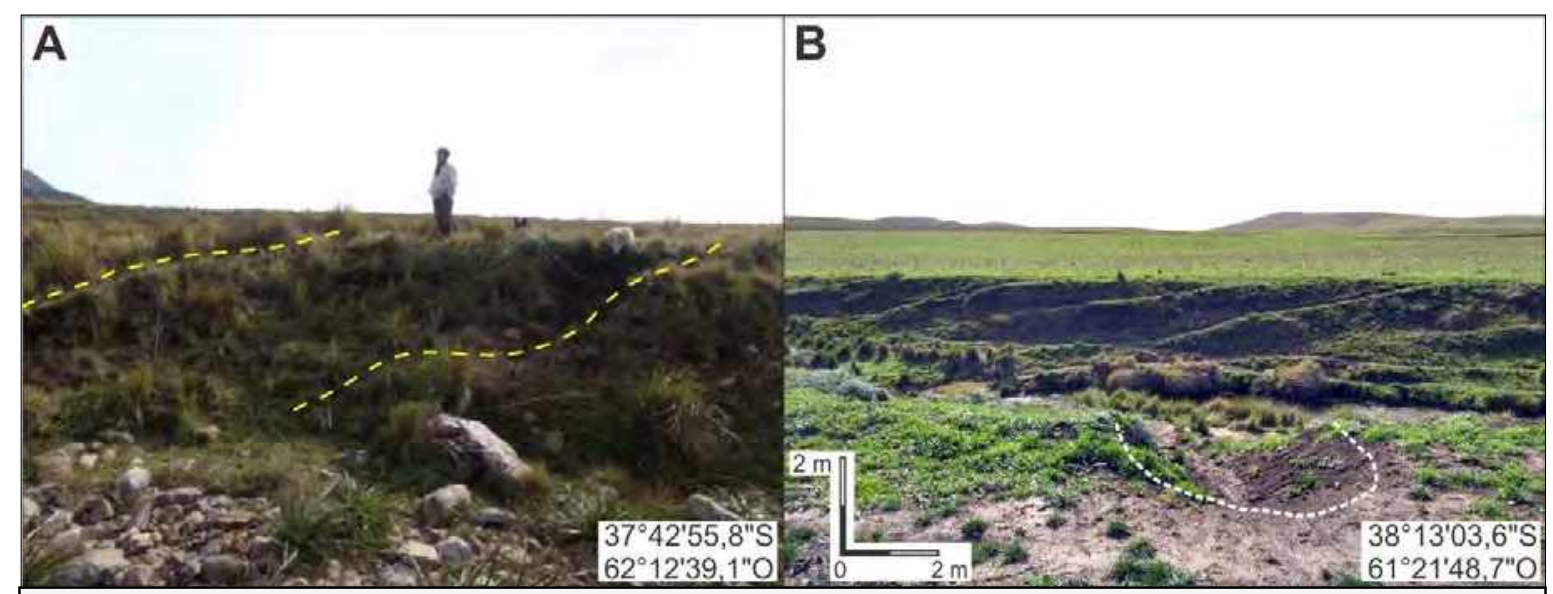

Figura 12.19. Terracettes en diagonal en cursos de agua. A. Margen izquierda de curso de agua en el Valle de Las Grutas (subzona 2). Líneas de trazos amarilla: terracettes en diagonal. La persona sirve como escala. Foto: Juan M. Susena y Georgina Scarponi. B. Margen izquierda de un curso de agua en el piedemonte oriental de las Sierras de las Tunas (fuera del área estudiada). Las terracettes en diagonal tienen más expresión morfológica. La estancia de $\mathbf{B}$. ha tenido históricamente mayor carga ganadera que la de A. Línea de trazos blanca: indentación. Foto: Juan M. Susena.

techo, generándose cavidades mayores. Generalmente son de diámetros decimétricos, lo cual se relaciona con el tamaño de los animales que excavan las galerías, y se desarrollan preferentemente en las cercanías de cursos de agua y en caminos que atraviesan sedimentos loéssicos o loessoides. Cuando las galerías son excavadas cerca de barrancas o en cortes de caminos, las depresiones generadas por su colapso pueden constituir discontinuidades a partir de las cuales se desarrollan superficies de separación de deslizamientos y vuelcos de suelo. Esto se observa en sectores donde la actividad de los animales excavadores es muy conspicua, desarrollándose sistemas de galerías (Figura 12.20). Las galerías que terminan en barrancas o en cortes de caminos pueden contribuir al desarrollo de movimientos tipo caídas, ya que funcionan como conductos (pipes), donde se concentra la erosión hídrica en épocas lluviosas, quitando el sustento a los

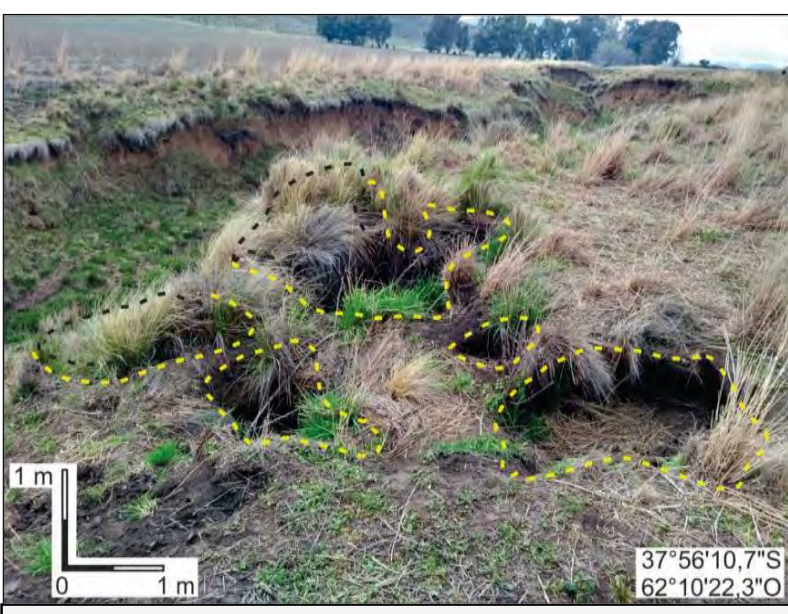

Figura 12.20. Galerías colapsadas (líneas de trazos amarillas) en un curso de agua al pie del Cerro del Corral (subzona 3). Líneas de trazos negras: bloques deslizados hacia el cauce; las galerías funcionan como superficies de separación entre la masa desplazada y el terreno no afectado por los movimientos. Foto: Juan M. Susena. 
materiales suprayacentes y también produciéndose pequeños flujos de barro (ver Figura 10.8.B en el Capítulo 10 Movimientos en masa en cursos de agua).

\subsubsection{Movimientos de detritos en laderas}

Muchos sectores de las laderas presentan una gran cantidad de detritos movilizados por los animales, como puede observarse en las Figuras 12.21 y 12.9 (más arriba). En general son sectores con detritos partidos con bordes filosos y volteados con disposiciones extrañas de las colonias de líquenes (ver Capítulo 7 Criterios de reconocimiento de los movimientos en masa y su actividad). Estos elementos indican actividad relativamente reciente de la acción zoogeomorfológica en la zona; incluso muchas veces se encuentran heces frescas y el pasto muy corto, indicando que los animales estuvieron hace poco tiempo. También es conocido en la zona que los jabalíes atraviesan las laderas para alimentarse en los valles durante las noches, pudiendo patear y poner en movimiento bloques rocosos (Susena y Gentile, 2018). El desplazamiento en piaras de estos animales puede poner en movimiento muchos bloques rocosos en

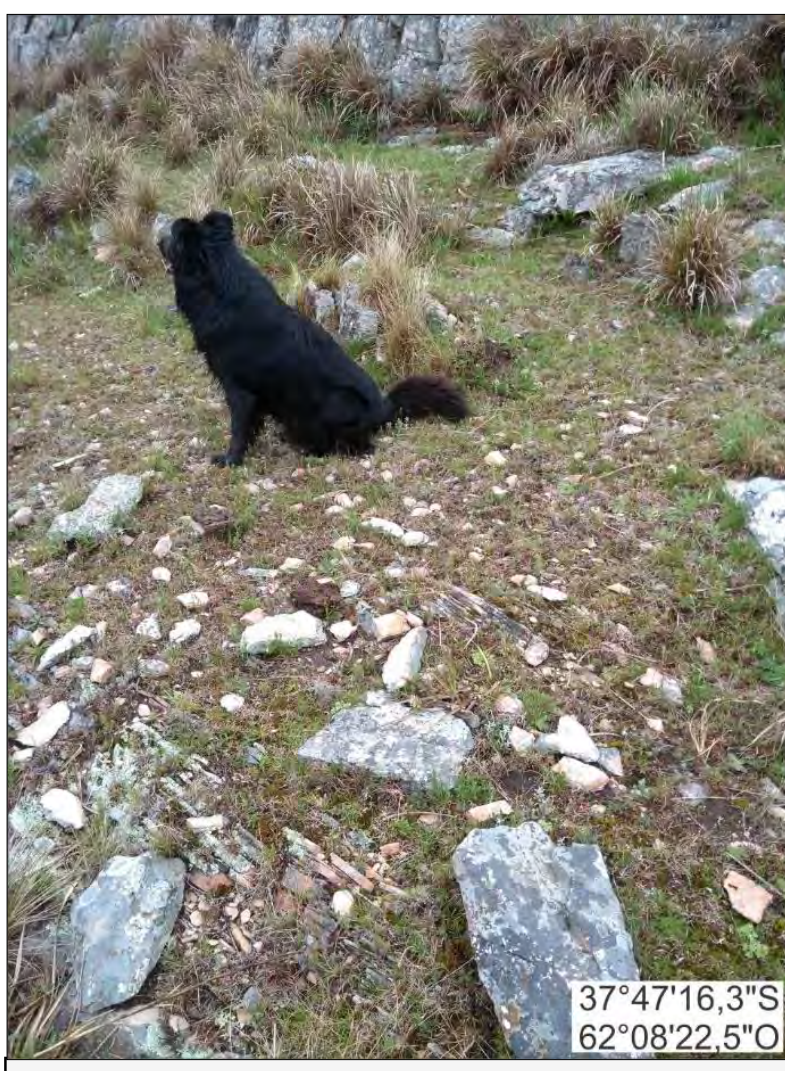
Figura 12.21. Sector con bloques volteados y partidos en una Ladera Compuesta en el área oriental del Cdón Hinojo Grande (subzona 2). Es notorio el contraste entre las superficies "frescas" de los bloques volteados por los animales, sin líquenes, y las de los bloques mayores que los animales no pueden voltear fácilmente, con líquenes. El perro sirve como escala. Foto: Juan M. Susena.

un corto período de tiempo (minutos o segundos), por lo cual en condiciones de escasa visibilidad este fenómeno puede representar un riesgo para los transeúntes (Susena y Gentile, 2018). Otros animales de mediando a gran porte -e incluso el hombre- pueden generar los mismos procesos, aunque su actividad no es tan evidente. En sectores con otros rasgos producidos por actividad zoogeomorfológica como pavimentos y cornisas de detritos, los amontonamientos de detritos son frecuentes, indicando cierta contribución del efecto de la fauna al desplazamiento de los bloques rocosos. 
Movimientos en masa en las sierras de Bravard y Curamalal,

Sierras Australes de la Provincia de Buenos Aires.

Juan Manuel Susena

El recorrido de los bloques pateados o volteados puede ser de unos pocos centímetros, pero en sectores de pendientes moderadas a altas pueden desplazarse metros o decenas de metros por rebotes y/o rodaduras. Los bloques más propensos a rodar y rebotar son los equidimensionales redondeados a sub-redondeados. Cabe recordar que las pendientes de las laderas son en general de $22-25^{\circ}$, aunque puede haber sectores de mayor pendiente, relacionados con distintos factores, como la presencia de escarpas por movimientos en masa. En estos casos, la acción de los animales puede entenderse como un mecanismo disparador, ya que proporciona a los bloques el impulso necesario para que continúen desplazándose como caídas (rebotes y/o rodaduras).

En el caso de grandes bloques rocosos utilizados como rascaderos, la erosión del material que subyace a los bloques podría permitir la caída de estos por las laderas, entendiendo a la acción zoogeomorfológica como un mecanismo preparador de movimientos de grandes bloques rocosos.

\subsubsection{Flujos de tierra en tramos distales de las laderas}

Los flujos de tierra desarrollados en los tramos distales de las laderas se asocian muchas veces a la acción de los animales. Se ubican en general cerca de elementos antrópicos que confinan o concentran la actividad del ganado, tales como alambrados, arboledas para reparo y abrevaderos artificiales. En muchos casos, los flujos de tierra se asocian a caminos de animales (Figura 12.22), desarrollándose a veces con posterioridad a los últimos (Figura 12.23). La concentración de humedad en los tramos distales de las laderas permite el crecimiento de vegetación más palatable para el ganado, especialmente en la época de déficit hídrico, concentrándose el ganado en dichos sectores. La compactación por pisoteo reduce la permeabilidad de los materiales, tendiendo el agua a permanecer en superficie. Adicionalmente, las huellas de los animales en los materiales limosos que integran estos sectores de las laderas constituyen pequeñas irregularidades capaces de contener el agua varios días después de las lluvias. Este efecto contribuye a que los materiales retengan localmente la humedad durante más tiempo que los sectores aledaños, estando su contenido de humedad más cerca del límite líquido y por lo tanto siendo más susceptibles al desarrollo de flujos de tierra. 


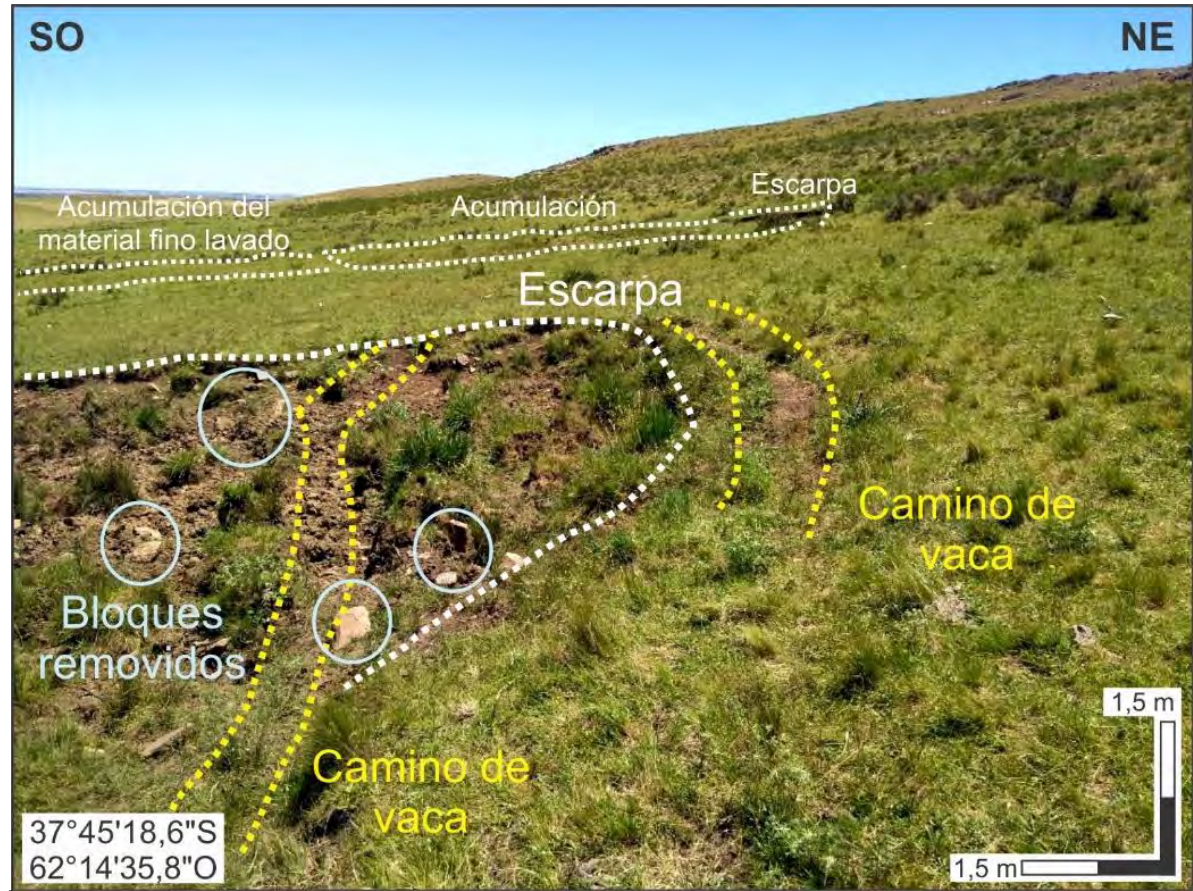

Figura 12.22. Caminos de vaca asociados a las cabeceras de un flujo de tierra en desarrollo en una Bajada Coluvial Fina de la vertiente occidental del Cdón. Lehmann-Hinojo Grande (subzona 2). Atrás se encuentra otro flujo de tierra con una escarpa más desarrollada. Foto: Juan M. Susena.

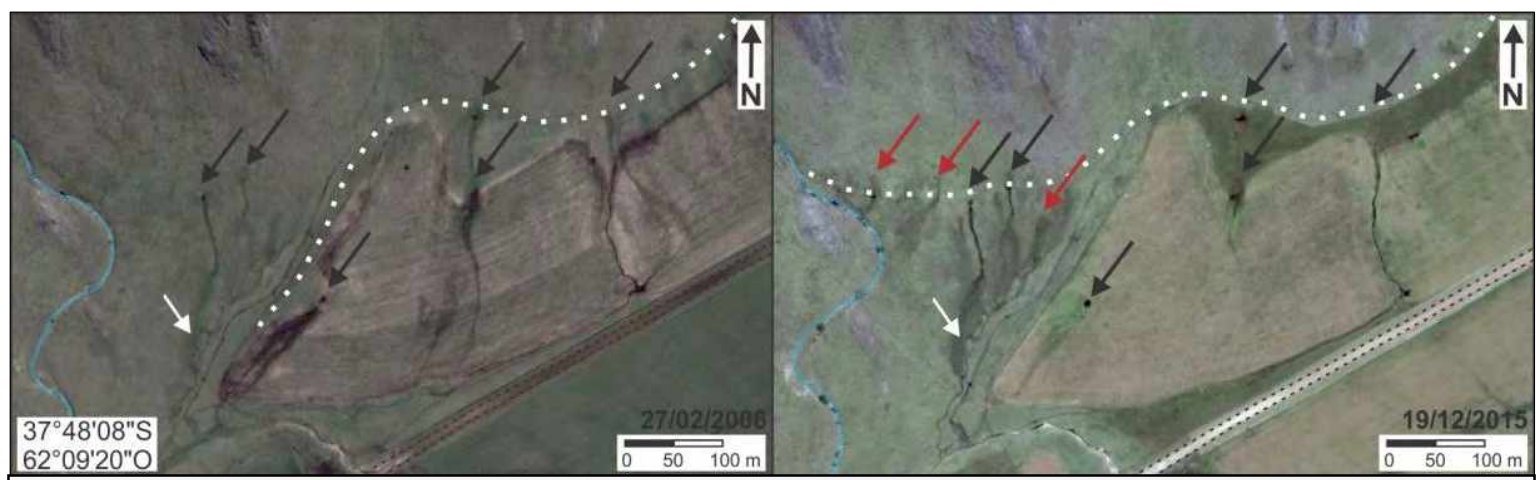

Figura 12.23. Flujos de tierra en dos fechas diferentes en la vertiente occidental del Cdón Hinojo Grande. Flechas negras: flujos que aparecen en ambas imágenes. Flechas rojas: flujos que aparecen en la imagen más reciente. Línea de puntos blanca: cambio de rumbo de un camino de vaca, nótese que los flujos "nuevos" están vinculados espacialmente al camino de vaca. Flecha blanca: indentaciones en una cárcava. Línea celeste: curso de agua. Línea de puntos negra: camino vecinal. Modificado de Susena y Gentile (2019).

Una vez producidos los flujos, el aporte de más material fino desde las laderas aumenta la disponibilidad de material para la propagación del movimiento. Del mismo modo, la existencia de un quiebre de pendiente coincidente con la escarpa vinculada al movimiento, propicia el afloramiento de agua sub-superficial muy cercana a la superficie que discurre desde los tramos medios de las laderas. El agua aumenta el límite plástico y líquido del material ("lo ablanda"), y el pisoteo intensivo puede aumentar la expresión morfológica de la "zona de hundimiento" (superficie por debajo del terreno no afectado por el movimiento), 
Movimientos en masa en las sierras de Bravard y Curamalal,

Sierras Australes de la Provincia de Buenos Aires.

Juan Manuel Susena

constituyéndose encharcamientos. Todo este conjunto de mecanismos se retroalimenta positivamente, contribuyendo a la propagación estacional de los flujos de tierra.

\subsection{Conclusiones preliminares sobre los movimientos en relación con la actividad antropo y zoogeomorfológica}

Tanto la acción antrópica como la zoogeomorfológica contribuyen al desarrollo de los movimientos en masa del área.

La acción antrópica es un mecanismo principalmente preparador de los movimientos. Hay un aumento de la susceptibilidad de movimientos en masa, debido a la construcción o modificación de rasgos susceptibles. Se destaca la construcción de caminos, especialmente en depósitos eólicos de la Fm. Saavedra, donde se generan deslizamientos y caídas desde los cortes verticales. Otros mecanismos preparadores consisten en el cambio de la fábrica de los depósitos pedemontanos, mediante la retirada (quitado) de los bloques rocosos y el desarrollo de estructuras de debilidad como las líneas de arado. En el primer caso, es posible que se desarrollen flujos de tierra como consecuencia directa del cambio del comportamiento geomecánico, mientras que las líneas de arado contribuyen de una manera más indirecta al desarrollo de vuelcos, caídas y deslizamientos, cuando éstas evolucionan a cárcavas. La instalación de postes también contribuye al desarrollo de discontinuidades en los suelos que pueden favorecer caídas o vuelcos.

La influencia humana en la actividad zoogeomorfológica puede considerarse también como una causa de los movimientos en masa, aunque de una manera más indirecta que la acción zoogeomorfológica en sí. Dicha influencia incluye el agregado de carga ganadera a la zona, la construcción de estructuras que concentran o confinan la actividad del ganado, y la influencia en la dinámica poblacional de animales silvestres, como los jabalíes.

En cuanto a la acción zoogeomorfológica, se reconocieron mecanismos preparadores y desencadenantes de los movimientos. La excavación de galerías puede funcionar al mismo tiempo como mecanismo preparador o disparador de caídas y pequeños flujos de barro. Algunas galerías, al colapsar pueden evolucionar a discontinuidades a partir de las cuales se producen vuelcos y deslizamientos.

La sobrecarga generada por el ganado en sitios concretos funciona como mecanismo preparador de movimientos en masa, en conjunción con la acción del agua, como es el caso de los flujos de tierra. En cuanto a las caídas, tanto el ganado como otros animales de medio a gran porte como los jabalíes y caballos cimarrones operan como disparadores, principalmente en laderas. Asimismo, contribuyen al desarrollo de la reptación en laderas y márgenes de cursos de agua. 


\section{UNIDAD IV}

El por qué... 



\section{Capítulo 13}

\section{Causas de los movimientos en masa}

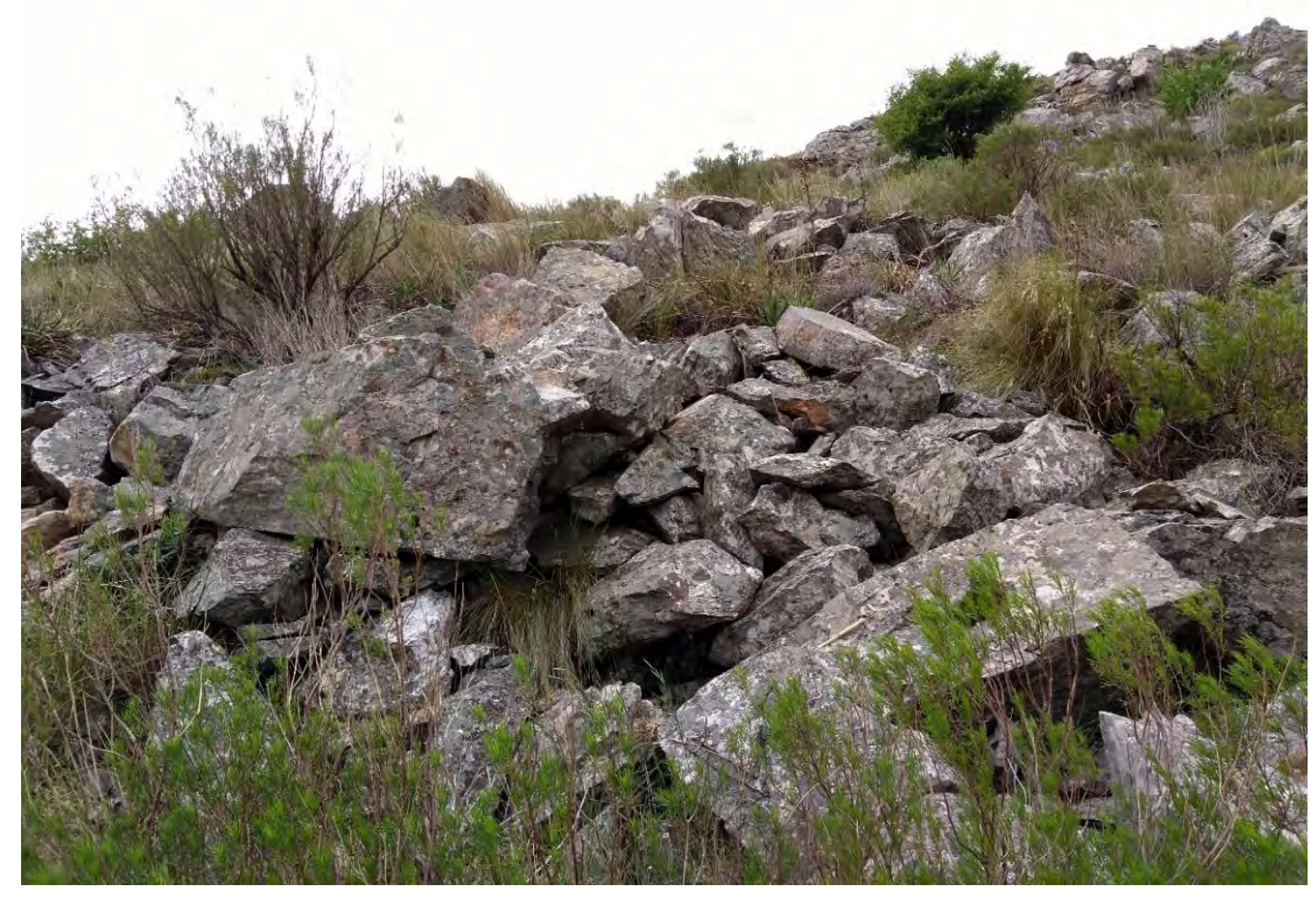

"Insostenible"

Estos bloques perdieron su matriz y están pobremente trabados entre sí, hasta que una fuerte lluvia los desplace. Foto tomada en el campo durante una de las últimas campañas. 
Movimientos en masa en las sierras de Bravard y Curamalal, Sierras Australes de la Provincia de Buenos Aires.

Juan Manuel Susena 


\subsection{Objetivos y ordenamiento del capítulo}

Se analizan aquí las causas de los movimientos tratados en los capítulos anteriores. La intención es identificar las variables influyentes en el desarrollo de los movimientos, reservando su representación cartográfica y análisis conjunto para el capítulo siguiente. Algunos aspectos, factores o mecanismos preparadores 0 desencadenantes se mencionaron previamente, presentándose aquí de forma ordenada. Se incluyen además análisis de los materiales con énfasis en el comportamiento geomecánico e hidrogeológico, así como sobre las condiciones climáticas. Se sigue el ordenamiento de las causas presentado en el Capítulo 1 Introducción al objeto de estudio, tratando primeramente los factores que contribuyen a una baja resistencia al movimiento o a reducir la resistencia al movimiento, y luego los procesos que favorecen la inestabilidad.

\subsection{Factores que contribuyen a una baja resistencia o a reducirla}

Entre estos factores pueden mencionarse propiedades intrínsecas de los materiales, como la textura, la mineralogía y la fábrica, los cuales influyen en el comportamiento geomecánico y geohidrológico. Otros factores pueden ser epigenéticos, como el desarrollo de discontinuidades en la roca, estructuras de debilidad generadas por procesos de meteorización y erosión, y alteración de la fábrica original en el caso de los depósitos.

Para estudiar algunos de estos factores se analizaron 11 localidades en distintos componentes del paisaje (Tabla 13.1), tomándose en ellas un total de 24 muestras de la matriz de los sedimentos, de las cuales algunas son superficiales y otras, subsuperficiales (Tabla 13.2). Aunque el número de muestras pudiera parecer escaso en una primera impresión, se observó que los procesos y la morfología de cada componente del paisaje analizado son bastante homogéneos comparando distintas localidades. Es por esto que puede considerarse que escasas muestras por componente geomorfológico son representativas del área estudiada. 
Movimientos en masa en las sierras de Bravard y Curamalal, Sierras Australes de la Provincia de Buenos Aires.

Juan Manuel Susena

\begin{tabular}{|c|c|c|c|c|c|}
\hline Localidad & $\begin{array}{l}\text { Coordenadas } \\
\text { (lat.; long.) }\end{array}$ & $\begin{array}{c}\text { Cota } \\
\text { (m s.n.m.) }\end{array}$ & $\begin{array}{c}\text { Unidad } \\
\text { Geomorfológica }\end{array}$ & $\begin{array}{l}\text { Unidad } \\
\text { Litológica }\end{array}$ & $\begin{array}{l}\text { Tramo de } \\
\text { ladera }\end{array}$ \\
\hline 158 & $\begin{array}{l}37^{\circ} 44^{\prime} 41,9^{\prime \prime} \mathrm{S} ; \\
62^{\circ} 09^{\prime} 53,7^{\prime \prime} \mathrm{O}\end{array}$ & 515 & Fajas Aluviales & Fm. Agua Blanca & $\begin{array}{c}\text { No } \\
\text { corresponde }\end{array}$ \\
\hline 160 & $\begin{array}{l}37^{\circ} 44^{\circ} 41,9^{\prime \prime} \mathrm{S} ; \\
62^{\circ} 09^{\prime} 44,7^{\prime \prime} \mathrm{O}\end{array}$ & 535 & Laderas de Detritos & $\begin{array}{l}\text { Detritos de } \\
\text { Ladera (Mb. } \\
\text { Suelto) }\end{array}$ & Medio \\
\hline CASP-1 & $\begin{array}{l}37^{\circ} 47^{\prime} 06,4^{\prime \prime} \mathrm{S} ; \\
62^{\circ} 07^{\prime} 06,6^{\prime \prime} \mathrm{O}\end{array}$ & 572 & Laderas de Detritos & $\begin{array}{l}\text { Detritos de } \\
\text { Ladera (Mb. } \\
\text { Suelto) }\end{array}$ & $\begin{array}{l}\text { Proximal - } \\
\text { Medio }\end{array}$ \\
\hline CASP-303 & $\begin{array}{l}37^{\circ} 46^{\prime} 05,4^{\prime \prime} \mathrm{S} ; \\
62^{\circ} 08^{\prime} 38,4^{\prime \prime} \mathrm{O}\end{array}$ & 473 & Bajada Coluvial Fina & $\begin{array}{l}\text { Detritos de } \\
\text { Ladera (Mb. } \\
\text { Suelto) }\end{array}$ & Distal \\
\hline CUR-19 & $\begin{array}{l}37^{\circ} 45^{\prime} 25,4^{\prime \prime} \mathrm{S} ; \\
62^{\circ} 10^{\prime} 56,0^{\prime \prime} \mathrm{O}\end{array}$ & 582 & Laderas de Detritos & $\begin{array}{l}\text { Detritos de } \\
\text { ladera (Mb. } \\
\text { Suelto) }\end{array}$ & Proximal \\
\hline CURCO-04 & $\begin{array}{l}37^{\circ} 47^{\prime} 02,1^{\prime \prime} \mathrm{S} ; \\
62^{\circ} 12^{\prime} 32,8^{\prime \prime} \mathrm{O}\end{array}$ & 402 & $\begin{array}{l}\text { Cubierta Eólica } \\
\text { Periserrana }\end{array}$ & Fm. Saavedra & $\begin{array}{c}\text { No } \\
\text { corresponde }\end{array}$ \\
\hline CURCO-27 & $\begin{array}{l}37^{\circ} 46^{\prime} 46,7^{\prime \prime} \mathrm{S} ; \\
62^{\circ} 13^{\prime} 22,9^{\prime \prime} \mathrm{O}\end{array}$ & 481 & Bajada Coluvial Fina & Fm. Saavedra & Distal \\
\hline CURCO-30 & $\begin{array}{l}37^{\circ} 46^{\prime} 31,6^{\prime \prime} \mathrm{S} \\
62^{\circ} 13^{\prime} 02,9^{\prime \prime} \mathrm{O}\end{array}$ & 499 & Bajada Coluvial Fina & $\begin{array}{l}\text { Detritos de } \\
\text { Ladera (Mb. } \\
\text { Suelto) }\end{array}$ & Distal \\
\hline G-420 & $\begin{array}{l}37^{\circ} 44^{\prime} 13,9^{\prime \prime} \mathrm{S} ; \\
62^{\circ} 10^{\prime} 08,7^{\prime \prime} \mathrm{O}\end{array}$ & 514 & Laderas de Detritos & $\begin{array}{l}\text { Detritos de } \\
\text { ladera (Mb. } \\
\text { Suelto) }\end{array}$ & Medio \\
\hline MALV & $\begin{array}{l}37^{\circ} 43^{\prime} 02,9^{\prime \prime} \mathrm{S} ; \\
62^{\circ} 19^{\prime} 49,1^{\prime \prime} \mathrm{O}\end{array}$ & 452 & $\begin{array}{c}\text { Piedemonte Aluvial } \\
\text { Antiguo con Depósitos } \\
\text { Cementados }\end{array}$ & $\begin{array}{l}\text { Fm. Las } \\
\text { Malvinas }\end{array}$ & $\begin{array}{c}\text { No } \\
\text { corresponde }\end{array}$ \\
\hline $\mathrm{SCH}$ & $\begin{array}{l}37^{\circ} 56^{\prime} 28,9 \text { " S; } \\
62^{\circ} 10^{\prime} 54,8^{\prime \prime} \mathrm{O}\end{array}$ & 558 & Laderas de Detritos & $\begin{array}{l}\text { Detritos de } \\
\text { ladera }(\mathrm{Mb} . \\
\text { Suelto }+\mathrm{Mb} \text {. } \\
\text { Cementado) }\end{array}$ & Medio \\
\hline
\end{tabular}




\begin{tabular}{|c|c|c|}
\hline \multicolumn{3}{|r|}{ MUESTRAS SUPERFICIALES } \\
\hline $\begin{array}{l}\text { Tramo de } \\
\text { Ladera }\end{array}$ & Muestra & Información sedimentológica \\
\hline Proximal & CASP-1 & Horizonte A en limos loéssicos post-Pampeanos \\
\hline \multirow{4}{*}{ Medio } & CUR-19A* & Matriz loéssica integrante de coluvio \\
\hline & $160 \mathrm{~A}$ & Matriz loéssica integrante de coluvio \\
\hline & $\mathrm{SCH} 4$ & Matriz loéssica integrante de coluvio \\
\hline & G-420A & Matriz loéssica integrante de coluvio \\
\hline \multirow{3}{*}{ Distal } & CASP-303A & Horizonte A en limos loéssicos post-Pampeanos \\
\hline & CURCO-27 & Suelo mezclado en limos loessoides post-Pampeanos \\
\hline & CURCO-30 & Suelo mezclado en limos loessoides post-Pampeanos \\
\hline \multirow{4}{*}{$\begin{array}{l}\text { No corresponde } \\
\text { (se ubican fuera } \\
\text { de las laderas) }\end{array}$} & 158A1 & Limos loessoides edafizados \\
\hline & 158A2 & Limos loessoides edafizados \\
\hline & CURCO-04 & Horizonte B en limos loéssicos post-Pampeanos \\
\hline & MALV-AC & $\begin{array}{l}\text { Horizonte AC con abundante carbonato de calcio. Conglomerados con } \\
\text { matriz dominantemente arenosa, cuarzo-feldespática }\end{array}$ \\
\hline \multicolumn{3}{|r|}{ MUESTRAS SUB-SUPERFICIALES } \\
\hline Proximal & CASP-1B & Horizonte B en limos loéssicos post-Pampeanos \\
\hline \multirow{5}{*}{ Medio } & CUR-19B* & $\begin{array}{c}\text { Matriz de coluvio (suelos cumúlicos) por retrabajamiento de limos } \\
\text { loéssicos }\end{array}$ \\
\hline & $160 B$ & $\begin{array}{l}\text { Matriz loéssica integrante del coluvio, con un leve incremento de arcilla, } \\
\text { aunque no alcanza a formarse un horizonte B }\end{array}$ \\
\hline & G-420B & $\begin{array}{c}\text { Matriz loéssica integrante de coluvio, con un leve incremento de arcilla, } \\
\text { aunque no alcanza a formarse un horizonte B }\end{array}$ \\
\hline & $\mathrm{SCH} 3$ & $\begin{array}{l}\text { Depósitos coluviales gruesos con matriz loéssica retrabajada por } \\
\text { escurrimiento laminar, con carbonato de calcio impregnando toda la masa, } \\
\text { recubriendo los clastos, y en venillas }\end{array}$ \\
\hline & $\mathrm{SCH} 1$ & $\begin{array}{l}\text { Depósitos coluviales gruesos con matriz loéssica, con carbonato de calcio } \\
\text { pulverulento, en venillas y en canalículos }\end{array}$ \\
\hline \multirow[b]{2}{*}{ Distal } & CASP-303Bt & Horizonte B en limos loéssicos post-Pampeanos \\
\hline & $\begin{array}{l}\text { CASP- } \\
\text { 303BC }\end{array}$ & Limos loéssicos post-Pampeanos \\
\hline \multirow{4}{*}{$\begin{array}{l}\text { No corresponde } \\
\text { (se ubican fuera } \\
\text { de las laderas) }\end{array}$} & 158B & Limos loessoides edafizados \\
\hline & $158 \mathrm{C} 1$ & Matriz limo-arenosa de conglomerados fluviales \\
\hline & $158 \mathrm{C} 2$ & Matriz limo-arenosa de conglomerados fluviales \\
\hline & MALV-C & $\begin{array}{l}\text { Horizonte } \mathrm{C} \text { con abundante carbonato de calcio, más que en el AC. } \\
\text { Conglomerados con matriz dominantemente arenosa, cuarzo-feldespática }\end{array}$ \\
\hline \multicolumn{3}{|c|}{$\begin{array}{c}\text { Tabla 13.2. Muestras analizadas, discriminando las superficiales de las sub-superficiales. } \\
\text { *Las muestras CUR-19A y CUR-19B se ubican en tramos proximales a medios; se analizan como } \\
\text { tramos medios debido a que los movimientos allí desarrollados son afines con los de dichos } \\
\text { tramos. Elaboración propia. }\end{array}$} \\
\hline
\end{tabular}


Movimientos en masa en las sierras de Bravard y Curamalal,

Sierras Australes de la Provincia de Buenos Aires.

Juan Manuel Susena

\subsubsection{Fábrica de los Detritos de Ladera}

Como se explicó en el Capítulo 5 Geología: generalidades, los materiales que constituyen las laderas tienen una génesis mixta, con un esqueleto de detritos rocosos generados por meteorización y movimientos de rocas desde los afloramientos rocosos, y una matriz principalmente alóctona, eólica. Estos materiales fueron $y / o$ son afectados por procesos pedogenéticos, como melanización, carbonatación y argiluviación, alterándose en distinta medida las características estructurales, texturales y mineralógicas originales.

Por otra parte, el escurrimiento superficial retransporta la matriz desde las zonas proximales hacia las distales de las laderas, siendo modificada la fábrica original de los Detritos de Ladera (Figura 13.1). Esto resulta en un relativo vaciamiento de la matriz en los tramos proximales, llegando a encontrarse, en su máxima expresión, gravas abiertas, es decir, solamente esqueleto en superficie. Los taludes actuales también tienen características similares, pero en este caso, por ser posteriores a la depositación del material eólico. Como contrapartida, en las unidades geomorfológicas Bajadas Coluviales Finas (tramos distales de las laderas), prepondera la depositación de materiales y la pedogénesis no alcanza a diferenciar

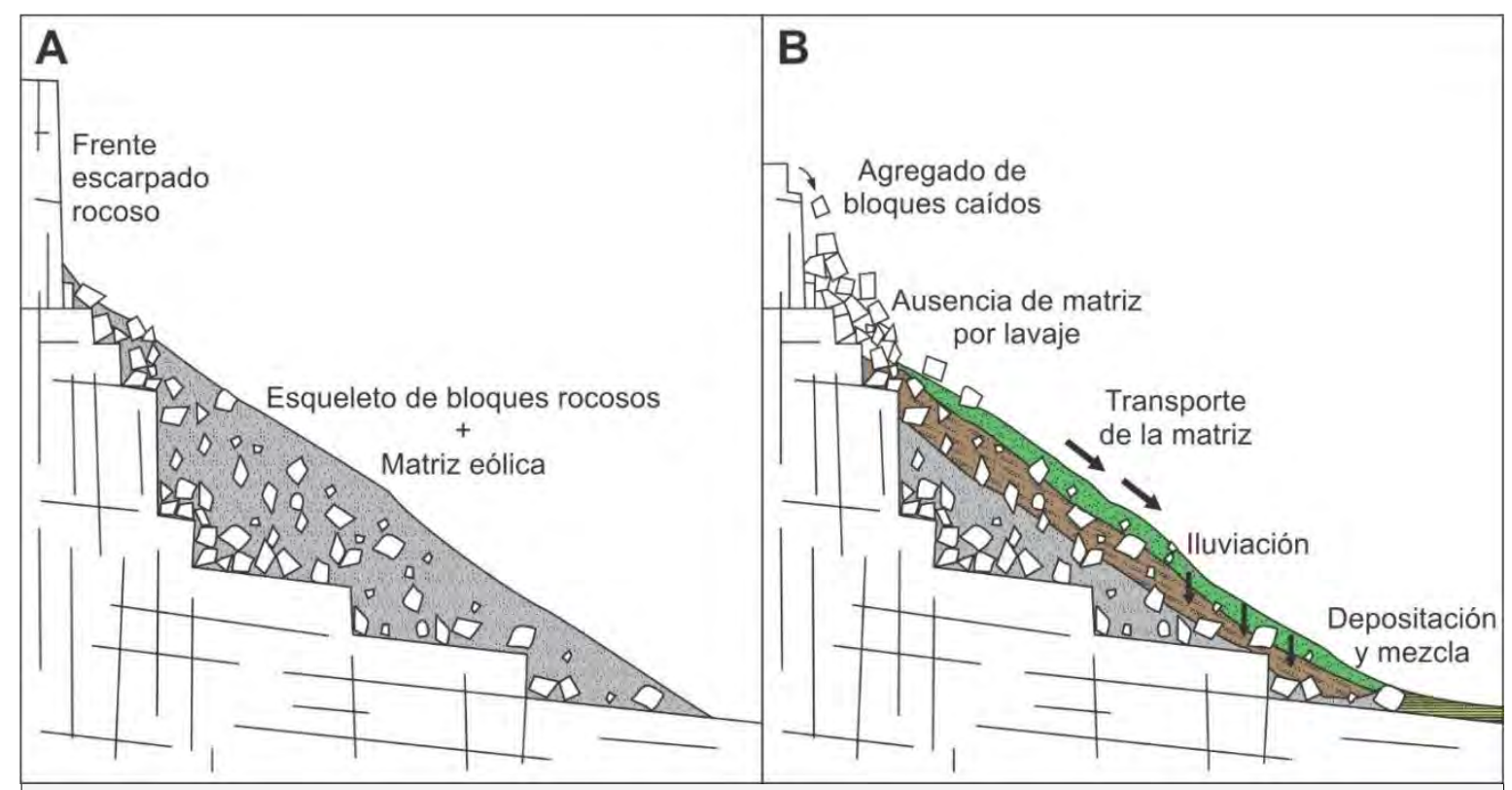

Figura 13.1. Perfiles esquemáticos ideales indicando distintos procesos que modifican la fábrica de los Detritos de Ladera. A. Fábrica original. B. Fábrica modificada y procesos que intervienen. Blanco con líneas rectas: roca con diaclasas. Polígonos: bloques rocosos. Gris: matriz eólica. Castaño: horizonte B. Verde con puntos: horizonte A. Verde con líneas: suelo mezclado. Elaboración propia. 
horizontes netos de suelo, formándose suelos mezclados. Los tramos medios de las laderas, por su parte, funcionan como una zona de transporte del material, y el desarrollo local de suelos mezclados se vincula a procesos de remoción en masa y acción zoogeomorfológica. En tramos medios de las laderas que no son afectados por los procesos antedichos se encuentran contactos netos entre horizontes, lo cual también ocurre en sectores de divisorias y de valles aluviales. Este conjunto de procesos pedogenéticos y acción del escurrimiento superficial resulta en la modificación de la fábrica y textura de los sedimentos y, consecuentemente, su comportamiento hidrogeológico y resistencia mecánica.

La diferenciación de horizontes arcillosos influye en el escurrimiento sub-superficial dificultando la infiltración. Como resultado, aumenta la presión poral de los horizontes superficiales y su inestabilidad, favoreciendo el desarrollo de deslizamientos traslacionales en los tramos medios (unidad geomorfológica Laderas de Detritos). En la parte distal (unidad Bajadas Coluviales Finas), la compactación localizada de los suelos mezclados debido a la actividad zoogeomorfológica puede ocasionar un efecto similar, contribuyendo al desarrollo de flujos de tierra. En ambos casos, el contacto entre materiales con distinto comportamiento hidrogeológico, sea por diferenciación de horizontes o por compactación, constituye la superficie sobre sobre la que se desplazan los materiales.

\subsubsection{Textura}

Para comparar el grado de retrabajamiento de los materiales de los Detritos de Ladera, se analizaron cuantitativamente muestras de la matriz eólica en tramos proximales, medios y distales. Se incluyeron además muestras de niveles pedemontanos antiguos y terrazas, donde prepondera la translocación (movimiento vertical dentro del perfil sedimentológico/pedológico) de los materiales, expresada en la diferenciación de horizontes de suelo. Teniendo en cuenta que los materiales de la matriz de todos estos sedimentos son, en origen, texturalmente similares (limos loéssicos o loessoides), los depósitos del piedemonte sirvieron como punto de referencia para estudiar el grado de influencia de los procesos de ladera en la textura de la matriz de las laderas. 
Movimientos en masa en las sierras de Bravard y Curamalal,

Sierras Australes de la Provincia de Buenos Aires.

Juan Manuel Susena

Se encontraron diferencias en la textura de la matriz de los depósitos de las laderas

(Figura 13.2). En las tres fracciones granulométricas puede observarse que la dispersión de los valores es alta en los tramos medios, mientras que en los distales es baja. La fracción arcilla presenta un incremento hacia los tramos distales. Las fracciones arena y limo, en cambio, no presentan grandes variaciones.

Comparando los horizontes superficiales con los sub-superficiales en cada muestra, se aprecia que el contenido de arcilla es mayor en sub-superficie sólo en los tramos medios. En estos tramos, la presencia de barnices arcillosos observados en algunos perfiles de suelo indica el movimiento vertical (iluviación) de la fracción arcillosa. La proporción de limo es mucho mayor en sub-superficie en la muestra del tramo proximal, mientras que en los otros tramos no hay diferencias claras. El aumento de limo en sub-superficie en el tramo proximal es consistente con el alto

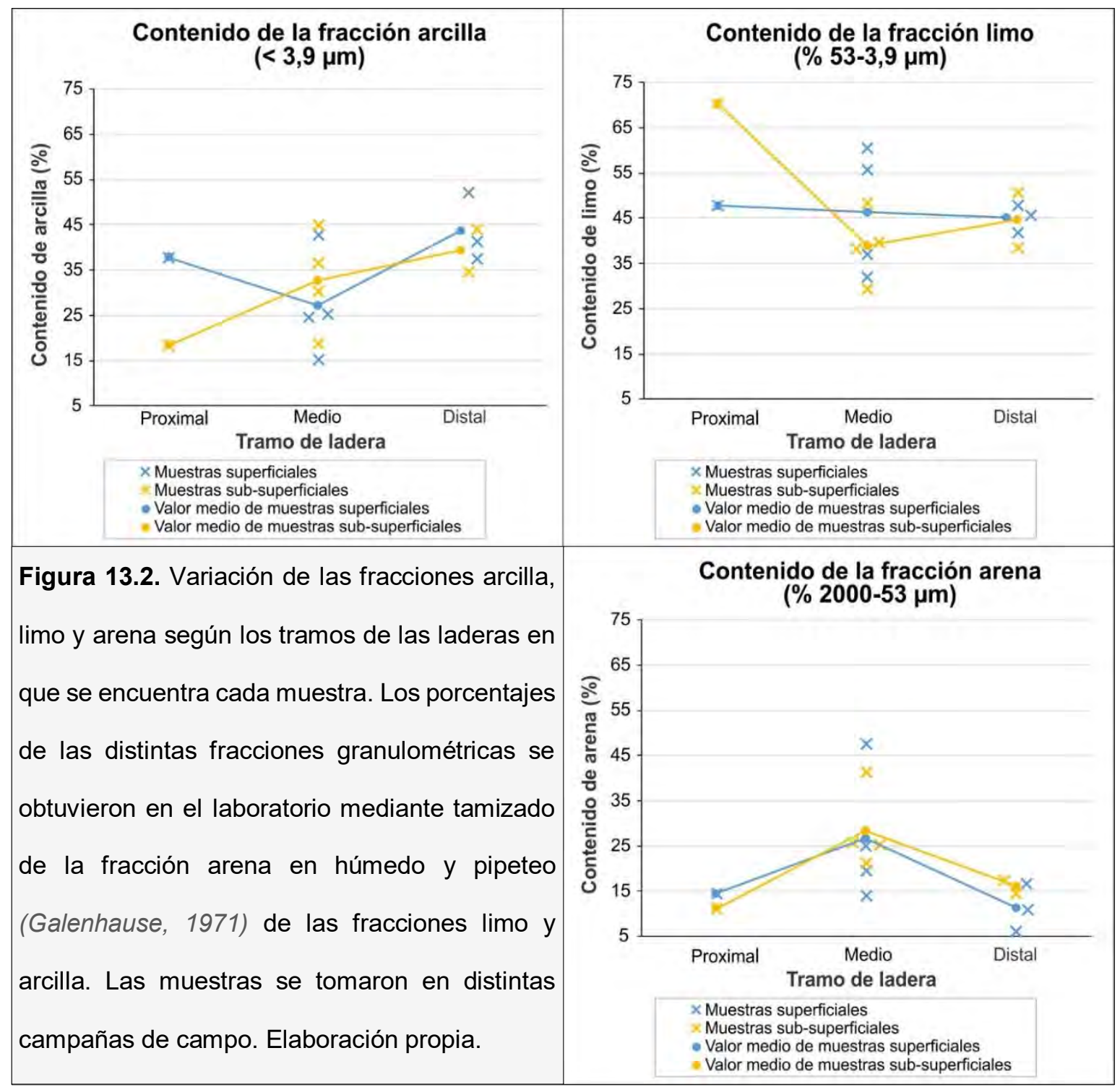


grado de erosión hídrica que experimenta la matriz en superficie, siendo la fracción limosa la más susceptible de ser eliminada; en concordancia con esto, se ve un aumento en las proporciones de arcilla y arena en superficie. Por otra parte, la fracción arena tiene escasa variabilidad con la profundidad, siendo relativamente algo mayor en sub-superficie en los tramos medio y distal.

De las descripciones de los dos párrafos previos, al menos preliminarmente y con las debidas cautelas, se desprende lo siguiente:

1. La fracción limo estaría sometida a lavaje superficial en los tramos proximales de las laderas, probablemente preservándose mejor en sub-superficie. Los tramos medios serían una zona típicamente de transporte del limo, estando más representado en los horizontes superficiales. Los tramos distales serían una zona de acumulación y mezcla de la fracción limosa.

2. La fracción arcilla tiende a ser más escasa en sub-superficie en los tramos proximales, incrementando su proporción hacia los tramos medios. Allí, el contenido sería mayor que en superficie, indicando argiluviación. En los tramos distales el contenido de arcilla sería aproximadamente el mismo en superficie que en subsuperficie, debiéndose a la mezcla de suelos.

3. En los tramos medios de las laderas la textura es mucho más variable que en los tramos distales. Esto podría deberse a la presencia de irregularidades del terreno que tienden a aumentar o disminuir la relación entre el escurrimiento superficial y la infiltración, los cuales inciden en los movimientos horizontales (erosión y depositación) o verticales (eluviación-iluviación) de las distintas fracciones de los sedimentos. Una explicación alternativa es que el lavaje de los tramos proximales y medios varíe de una ladera a otra, así como el grado de acumulación en los tramos medios. Así, el error (dispersión) de los datos de los tramos medios podría ser alto por acumulación de errores de los tramos proximales y distales que interactúan con los tramos medios.

En la Figura 13.3 se puede comparar la textura de los diferentes tramos de ladera con la de las muestras ubicadas fuera de las laderas. En comparación con las muestras ubicadas fuera de las laderas, las texturas de los tramos proximales son más arcillosas en superficie, y menos arenosas tanto en superficie como en subsuperficie. La menor proporción de arena podría deberse a que la altitud limita el transporte eólico de las fracciones más gruesas, depositándose en las partes bajas. El relativamente alto contenido de arcilla en superficie podría deberse a una 


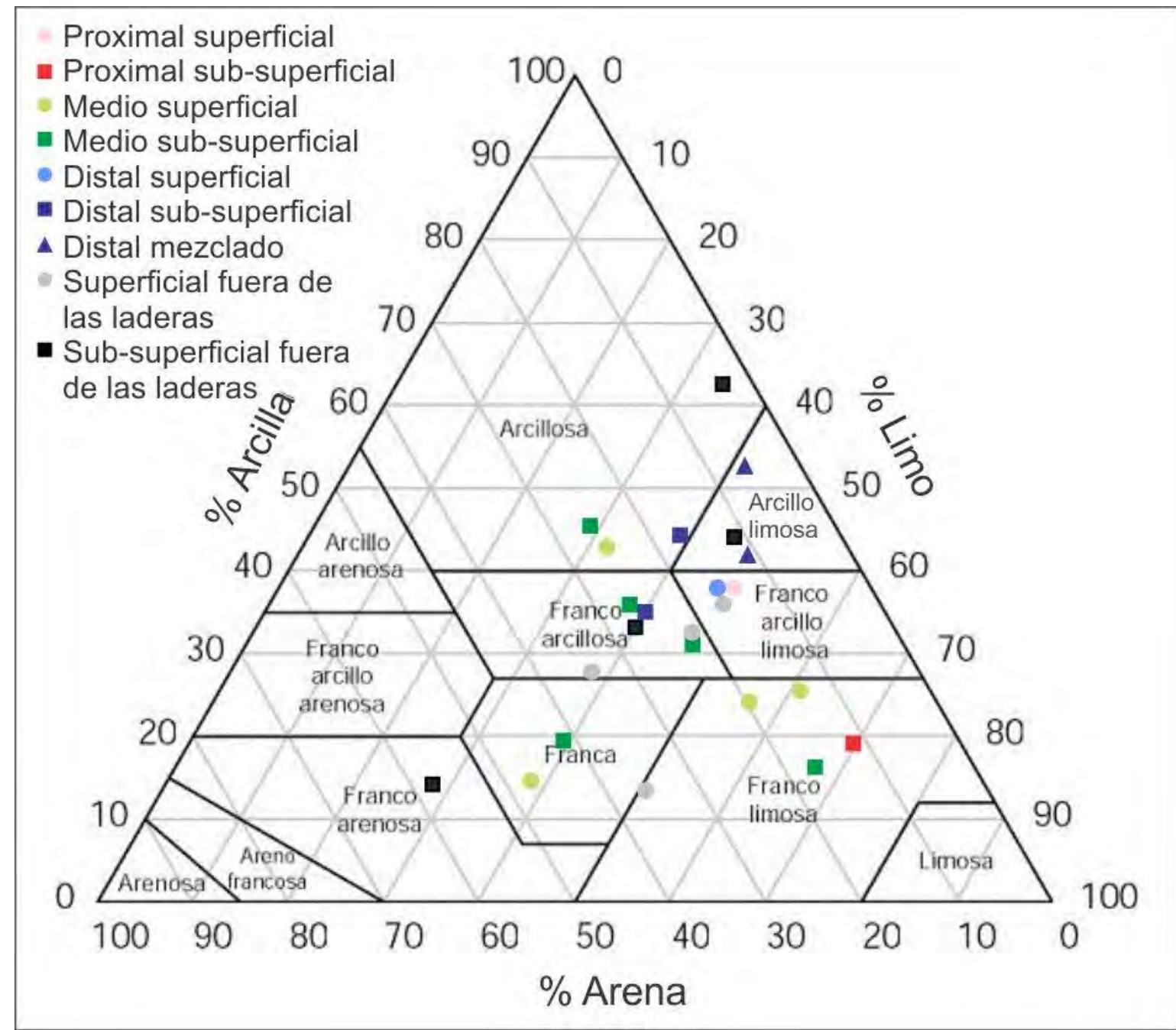

Figura 13.3. Textura de muestras de la matriz de sedimentos en distintos tramos de ladera y sectores ubicados fuera de estas, graficadas en el triángulo textural USDA. Las distintas fracciones granulométricas se determinaron por tamizado de la fracción arena en húmedo y pipeteo (Galenhause, 1971) de las fracciones limo y arcilla. Elaboración propia.

concentración residual por lavaje del material limoso. Aunque se tiene sólo una muestra de los tramos proximales, estas diferencias se observaron cualitativamente en el campo en numerosas ocasiones. La matriz de los tramos medios de las laderas es bastante similar a la de las muestras ubicadas fuera de las laderas, siendo algo más limosos los horizontes superficiales de los tramos medios. La matriz en los tramos distales de las laderas es en general más arcillosa que en las muestras superficiales ubicadas fuera de ellas, asemejándose más bien a las muestras sub-superficiales.

Las muestras sub-superficiales de los tramos medios y distales tienen contenidos de arcilla más o menos similares a los de las ubicadas fuera de las laderas. 
En las fajas aluviales y el piedemonte el movimiento vertical del agua en el perfil del suelo favorece la argiluviación. En las laderas, el movimiento percolativo del agua y la translocación de arcilla en dirección sub-paralela a la pendiente podría generar un efecto similar: el agua infiltrada en los tramos proximales, más permeables por las altas proporciones de limo y arena, percolaría subparalelamente a la superficie de las laderas sobre el contacto con la roca, las calcretas u horizontes sub-superficiales más arcillosos, desplazando la fracción arcillosa hacia los tramos medios. Como apoyo empírico de esta hipótesis, se encontraron estructuras de flujo laminar sub-paralelo a la superficie en cortes estratigráficos de los tramos medios de las laderas, evidentes incluso en bancos centimétricos de calcretas.

Los contrastes texturales entre distintos segmentos de ladera y también dentro de cada perfil, originados por acción del agua en superficie y en sub-superficie, condicionarían la acción del agua como mecanismo desencadenante. En los tramos proximales prevalece la infiltración y la percolación hacia los tramos medios. Para que se desarrollen movimientos en los tramos proximales, es necesario un aporte brusco de agua desde alguna garganta $u$ otro tipo de entrante en el frente escarpado rocoso, o la presencia de la roca a escasa profundidad, que dificulte la infiltración. En los tramos medios, la presencia de un horizonte arcilloso dificulta la infiltración, favoreciendo la saturación de los horizontes superficiales y el desarrollo de deslizamientos traslacionales. En sectores de los tramos medios donde los horizontes sub-superficiales no son considerablemente más arcillosos que los superficiales, la lámina de agua suele situarse a mayor profundidad, desarrollándose deslizamientos rotacionales. En los tramos distales, la gran proporción de materiales finos favorece el encharcamiento y la producción de flujos de tierra.

\subsubsection{Propiedades geomecánicas y mineralogía}

Los dos parámetros geomecánicos que se determinaron sobre muestras de la matriz de los materiales de las laderas son la expansión libre y el límite líquido.

La Figura 13.4 muestra los coeficientes de expansión libre en muestras superficiales y sub-superficiales de los distintos tramos de las laderas. En general, y teniendo en cuenta que se dispone de pocas muestras, se observa un incremento 
Movimientos en masa en las sierras de Bravard y Curamalal,

Sierras Australes de la Provincia de Buenos Aires.

Juan Manuel Susena

de la expansión libre hacia los tramos distales, y una mayor dispersión de los datos en los tramos medios. En cuanto a la variación con la profundidad en cada tramo, en la muestra proximal la expansión libre no varía, en los tramos medios es mayor en sub-superficie, y en los tramos distales lo es en el material más superficial. Excepcionalmente, las muestras CASP 1 (superficial) y CASP 1B (subsuperficial), ubicadas en un tramo de ladera proximal a medio en un valle intraserrano de las sierras de Bravard, tienen valores mucho más altos que el resto de las muestras.

Esta variación parece no relacionarse con la proporción de arcilla de las

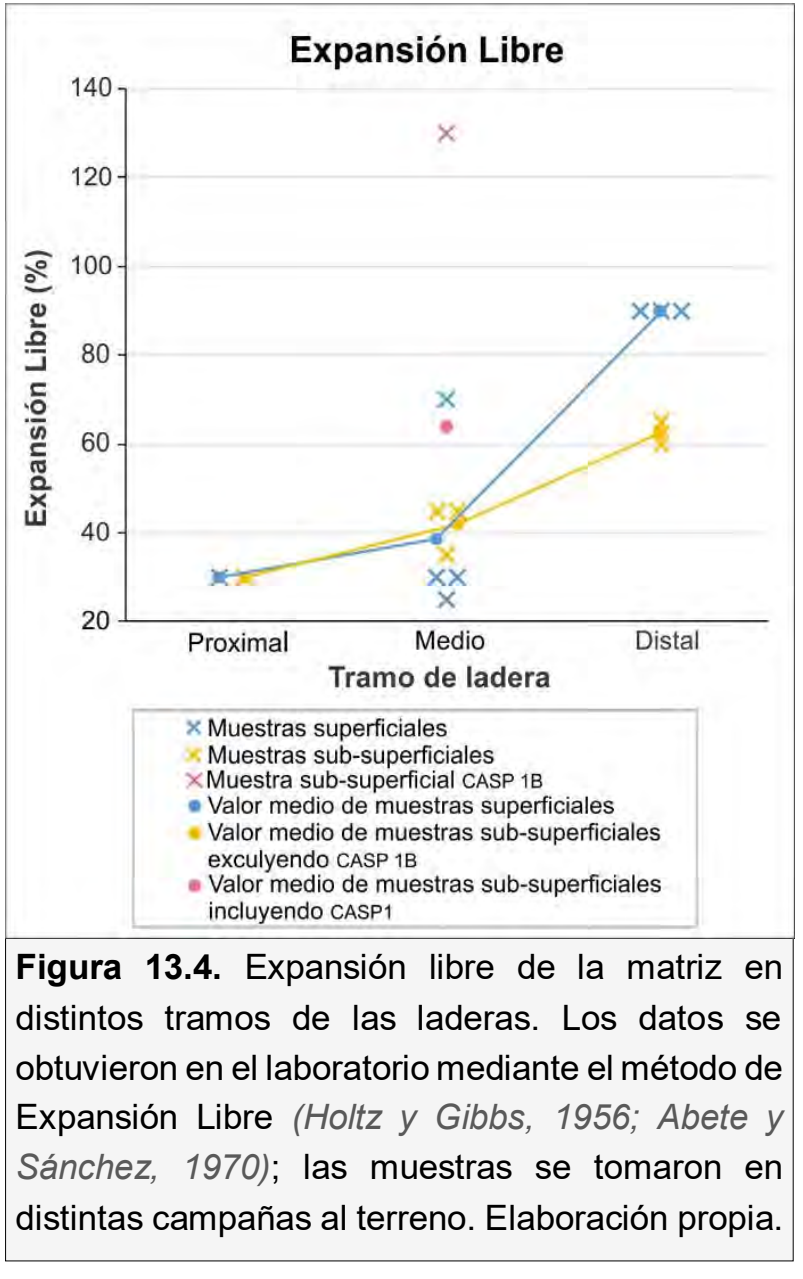
muestras, sino más bien con el tipo de arcilla, ya que se encontró illita/esmectita (alta expansividad) en las muestras superficiales CASP 303A y CASP 303Bt, no determinada en la sub-superficial CASP 303BC. Las muestras CURCO DIC27 y CURCO DIC30 presentan grietas de expansión/contracción, aunque mediante Difracción de Rayos X (DRX) no se identificó illita/esmectita claramente; podría haber una escasa proporción de estos minerales (si hay menos de un $15 \%$ su identificación es difícil en los difractogramas). En otros sectores de la Provincia de Buenos Aires con proporciones similares y aún menores de montmorillonita y/o interestratificados expansivos, se desarrollaron rasgos vérticos moderados en los suelos (Hurtado et al., 2006). Asimismo, la materia orgánica presente especialmente en los tramos distales, puede favorecer los fenómenos de expansión-contracción (Madsen y Mitchell, 1989).

Los ensayos de límite líquido (Figura 13.5) muestran que las muestras proximales de las laderas necesitan una gran cantidad de agua para comportarse mecánicamente como un líquido. Esto parece concordar con el hecho de que no se 
hayan encontrado movimientos de tipo flujo en los sectores proximales, sino más bien

deslizamientos principalmente rotacionales. Los últimos, no responderían tanto al límite líquido de la matriz, sino más bien a contrastes hidrogeológicos por la presencia de afloramientos en subsuperficie y escasa matriz en superficie, permitiendo la infiltración. En los tramos medios, el límite líquido tiene un alto grado de dispersión en los datos, y es menor en profundidad. Si los datos son correctos, resultaría entonces lógico pensar que los flujos

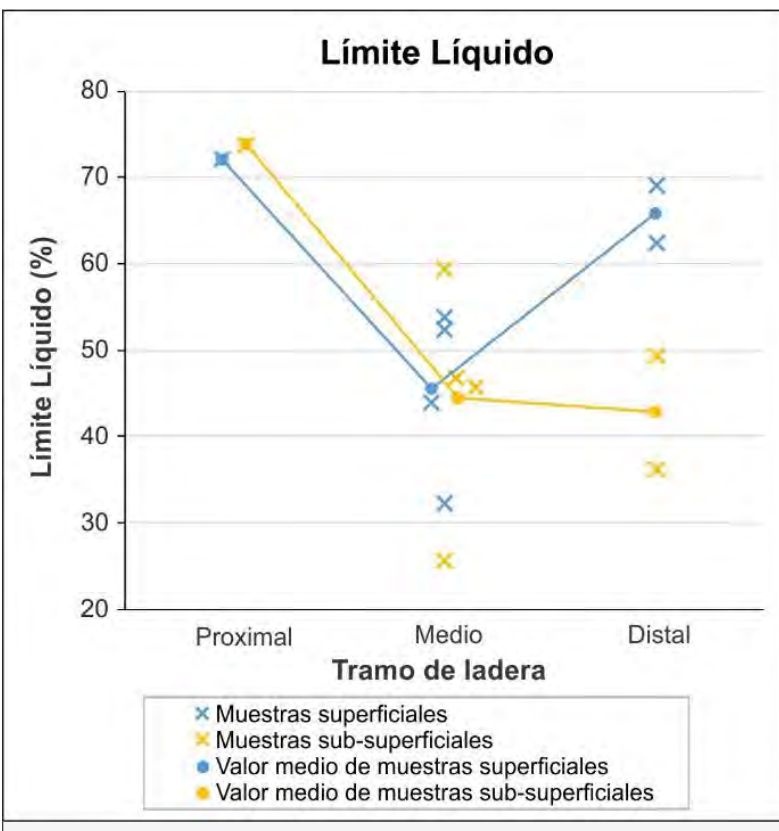

Figura 13.5. Límite líquido de la matriz de distintos tramos de las laderas. Los datos se obtuvieron en el laboratorio con el aparato de Casagrande (1932); las muestras se tomaron en distintas campañas al terreno. Elaboración propia. estén restringidos a sectores de mucha concentración de agua, como los aledaños a frentes escarpados rocosos laterales y entrantes en los frentes (ver Capítulo 10 Movimientos en masa en laderas), mientras que los deslizamientos traslacionales se desarrollan preferentemente en los tramos medios en el límite entre los horizontes superficiales con mayor límite líquido y los sub-superficiales con menor límite líquido. En el último caso, la deformación se concentraría sobre dicho límite, y la masa no sufriría una deformación notable. Dos localidades con deslizamientos de grandes dimensiones (mayores a $100 \mathrm{~m}$ de largo) presentan ciertas particularidades respecto al límite líquido. Por un lado, en la localidad CASP 1 el límite líquido es mucho menor (casi la mitad) en superficie que en sub-superficie; dicho contraste podría favorecer el desarrollo de flujos de detritos en condiciones de precipitaciones intensas, sin embargo, el movimiento allí presente es un deslizamiento traslacional. Se combinan en este caso varios factores: la textura superficial de la muestra CASP 1 es franca, siendo bastante permeable; el alto coeficiente de expansión libre de la muestra subsuperficial CASP 1B indica su capacidad para absorber el agua, hinchándose el material de una manera relativamente homogénea (no deformándose la masa a modo de flujo); y la presencia de un horizonte carbonático debajo de la muestra CASP 1B constituiría la superficie de contraste hidrogeológico sobre la cual se 
produciría el deslizamiento. Por otra parte, la localidad $\mathrm{SCH}$ presenta una relación invertida del límite líquido: las muestras sub-superficiales tienen menor límite líquido que las superficiales. Esto se vincula a la presencia de una discontinuidad litológica, encontrándose una parte del Mb. Cementado de los Detritos de Ladera en subsuperficie, y el Mb. Suelto en superficie. El Mb. Cementado tiene una textura franca en esta localidad. Tanto allí como en otros sectores de la misma ladera (Cerro Pan de Azúcar) con grandes movimientos, la permeabilidad de la matriz ha permitido que el carbonato se disolviera en la base, o que la cementación haya sido originalmente más débil. En este sentido, la base del perfil tendría mayor actividad del agua, como lo muestra el desarrollo de oquedades en la Figura 5.17.B del Capítulo 5 Geología: generalidades. La saturación de dicho sector pudo haber causado el desarrollo del movimiento de la localidad SCH y otras localidades donde la masa tiene una intensa deformación, como se muestra en la Figura 13.6. Volviendo a las generalidades, en los tramos distales el límite líquido es mucho mayor en los suelos mezclados superficiales que en los horizontes sub-superficiales, lo cual podría tener ciertas implicancias en el desarrollo de los flujos de tierra: por un lado, los flujos de tierra en sectores donde hay horizontes diferenciados podrían iniciarse desde los horizontes subsuperficiales por endosaturación. Por otra parte, los flujos de tierra en suelos mezclados requieren una gran cantidad de agua, debiendo desarrollarse en la estación húmeda con una saturación lenta y progresiva de los poros; una componente del desplazamiento podría deberse a efectos de expansión-contracción que se suma a la acción de la gravedad.

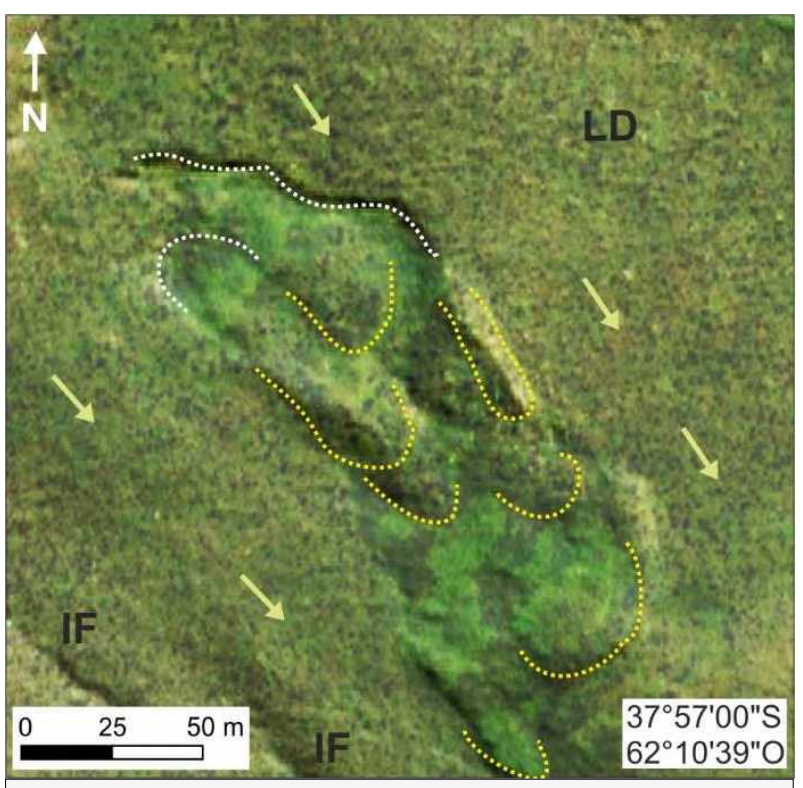

Figura 13.6. Movimientos múltiples con una superficie de ruptura mayor en la ladera oriental del Cerro Pan de Azúcar (subzona 3). Líneas blancas: escarpas. Líneas amarillas: acumulaciones. Flechas: dirección de la pendiente. LD: Ladera de Detritos. IF: Incisiones Fluviales. Elaboración propia a partir de la combinación de una composición de imagen satelital de World View-2 (Bing) y un MDE generado con fotogrametría de imágenes capturadas con un dron en el terreno. 
Respecto a la mineralogía, interesa especialmente la composición de la fracción arcillosa. Es notorio el contraste entre muestras de niveles de piedemontes del PlioPleistoceno y de muestras de la matriz eólica holocena de las laderas (Figura 13.7), donde los argilominerales de las últimas tienen menor cristalinidad. A pesar de la dificultad que esto implica para la determinación de los argilominerales,

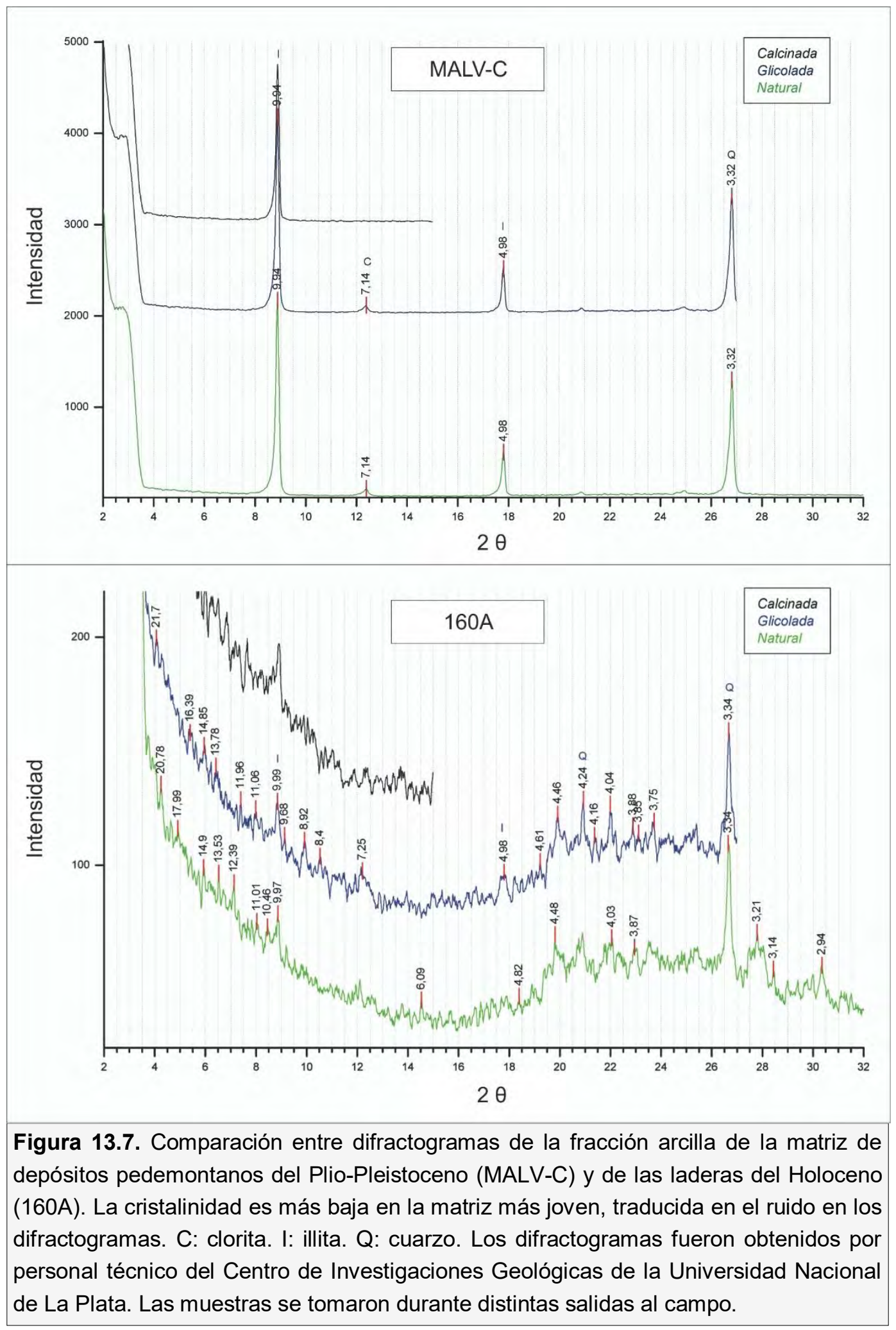


Movimientos en masa en las sierras de Bravard y Curamalal,

Sierras Australes de la Provincia de Buenos Aires.

Juan Manuel Susena

complementando la información de los difractogramas con observaciones de campo se pueden establecer algunas hipótesis sobre el significado de la presencia de ciertos minerales en el compartimiento de las laderas.

El argilomineral mejor representado (identificado) en los difractogramas es la illita, presente en todos los depósitos de ladera, y solamente ausente en un horizonte eluvial superficial y parte de un paleosuelo enterrado, ambos en la localidad 158 (planicie de inundación). Se identificaron interestratificados illita/esmectita en la localidad CASP- 303 (tramo distal de ladera); en dicho sector, se encontraron rasgos asociados a expansión/contracción en superficie, tales como grietas poligonales. No obstante, en sub-superficie no se encontraron rasgos vérticos de escala mesoscópica, concordando esto con la ausencia -o al menos su no identificación por DRX- de argilominerales expansivos en el horizonte subsuperficial. También se encontraron grietas superficiales en las localidades CURCO-27 y CURCO-30 (tramos distales de ladera), aunque allí no se pudo determinar la presencia de argilominerales expansivos; esto podría deberse a la baja cristalinidad o escasa proporción de estos minerales.

Si bien los minerales del grupo de la montmorillonita (arcillas expansivas) son los expansivos por excelencia, debe considerarse también que otros argilominerales también lo son. El concepto de actividad (Skempton 1948; 1953) indica, entre otras cosas, la capacidad de las arcillas para absorber agua y cómo varía el volumen con el agregado de agua. Las arcillas activas son más expansivas que las inactivas (Tabla 13.3). En las muestras con illita, la actividad es normal, implicando que hay cierto grado de absorción de agua y expansión. En tales casos, podrían desarrollarse movimientos con cierta deformación interna de la masa, como los flujos. Si los datos de textura descriptos más arriba (especialmente la fracción arcillosa) son consistentes y si se confirman con un mayor número de muestras, esto podría explicar el desarrollo de flujos de detritos en laderas, o deslizamientos con abundante deformación interna que desarrollan acumulaciones en forma de $\mathrm{V}$. No hay una relación clara con el desarrollo de los deslizamientos, debiendo buscarse explicaciones de otra índole, como cambios del comportamiento hidrogeológico o geomecánico por modificaciones locales en la fábrica, la compactación o la presencia de la roca a poca profundidad. 


\begin{tabular}{|c|c|c|c|}
\hline Mineral & Actividad & Referencia bibliográfica & $\begin{array}{c}\text { Clasificación de } \\
\text { actividad }\end{array}$ \\
\hline Cuarzo & 0,0 & von Moos (1938) & Inactiva \\
\hline Calcita & 0,18 & von Moos (1938) & Inactiva \\
\hline Muscovita & 0,23 & von Moos (1938) & Inactiva \\
\hline Caolinita & $0,33-0,46$ & $\begin{array}{c}\text { Northey (1950) - Samuels } \\
(1950)\end{array}$ & Inactiva \\
\hline Illita & 0,90 & Northey (1950) & Normal \\
\hline Montmorillonita cálcica & 1,5 & Samuels (1950) & Activa \\
\hline Montmorillonita sódica & 7,2 & Samuels (1950) & Activa \\
\hline
\end{tabular}

\subsubsection{Discontinuidades en roca}

Dada la gran complejidad estructural del área de estudio, extensiva a todo el ámbito de las Sierras Australes de la Provincia de Buenos Aires, este aspecto es difícil de estudiar a escala de laderas, así como también su generalización a escala regional. Las orientaciones de las estructuras de la roca son tan diversas, debido a la existencia de numerosos eventos tectónicos, que resulta inviable un estudio exhaustivo a escala de ladera para un área tan grande como la aquí considerada. Por esta razón se abordó dicho aspecto de una manera cualitativa, observando las relaciones entre tipos de estructuras y los movimientos en masa.

Las discontinuidades que promueven movimientos en roca son de distinta índole: planos de estratificación $S_{0}$, foliaciones $\left(S_{1}, S_{2}\right)$ y fracturas (diaclasas y fallas). Según dominen en los macizos rocosos un tipo u otro de discontinuidades, y según cómo se relacionen con la pendiente del terreno, tienden a desarrollarse distintos tipos de movimientos. El ángulo y espaciado entre los distintos grupos de discontinuidades es variable, delimitando desde bloques rocosos de forma prismática con más de $10 \mathrm{~m}$ de eje mayor y bloques equidimensionales métricos, hasta bloques decimétricos con morfología romboidal y pequeñas lajas de espesores milimétricos.

Los planos de estratificación $S_{0}$ favorecen el desarrollo de deslizamientos planares, sean de bajo o alto ángulo. Puede desplazarse toda una masa coherente sobre el plano de estratificación, destruyéndose durante el movimiento según otros planos 
Movimientos en masa en las sierras de Bravard y Curamalal,

Sierras Australes de la Provincia de Buenos Aires.

Juan Manuel Susena

de debilidad, o excepcionalmente conservándose entera. En algunos casos, la conjunción de un plano de estratificación inclinado en la dirección de la pendiente y otros planos de discontinuidad como fracturas o diaclasas pueden ocasionar la individualización de bloques rocosos que se deslizan sobre el plano de estratificación, tal como se muestra en la Figura 8.17 del Capítulo 8 Movimientos en masa desde frentes escarpados rocosos. La velocidad del movimiento dependerá en parte de la inclinación de los estratos, siendo mayor cuanto más cercanos a la vertical se encuentren.

En el área estudiada, la densidad de los planos de esquistosidad $\left(\mathrm{S}_{1}, \mathrm{~S}_{2}\right)$ varía según el tipo de roca. En el basamento estos planos delimitan lajas con espesores decimétricos que experimentan vuelcos en sectores con relieve de crestas y depresiones, como los descriptos en el Capítulo 8 (por ejemplo, ver Figura 8.16). En las rocas sedimentarias la foliación tiene mayor densidad, por lo cual este tipo de discontinuidad favorece el desarrollo de movimientos muy pequeños (Figura 13.8).

Las diaclasas y fracturas delimitan bloques susceptibles de caídas. Existen sectores donde el espaciamiento entre planos es denso, diferenciándose bloques centimétricos, y otros casos donde los bloques son métricos. Los bloques mayores son más comunes en rocas con pocos planos de diaclasas y más planos de fracturas de superficie irregular, como lo son el Conglomerado La Lola y la Brecha Cerro Colorado. Las fracturas irregulares en la roca pueden generarse o ampliarse por meteorización, siendo este proceso más común en sedimentitas con menor contenido de cuarzo, como la Fm. Bravard (Figura 13.9). En el caso de las fracturas sub-verticales, su ampliación por meteorización tendrá casi siempre la tendencia a diferenciar bloques que materializan vuelcos o caídas.

Desde otra perspectiva, la densidad y el estado de las discontinuidades (rellenas o abiertas) influyen en el desarrollo de entrantes en los frentes escarpados rocosos y gargantas en discontinuidades rocosas. Estos componentes del paisaje concentran el agua, lo cual implica que las porciones de las laderas ubicadas al pie tengan una mayor tendencia a la producción de deslizamientos y flujos. Como ejemplo, una de las mayores expresiones de movimientos en masa del área estudiada, que se ubica en la ladera occidental del Cerro Pan de Azúcar (subzona 3), tiene su zona de agotamiento al pie de una garganta desarrollada a partir de la conjunción de dos 


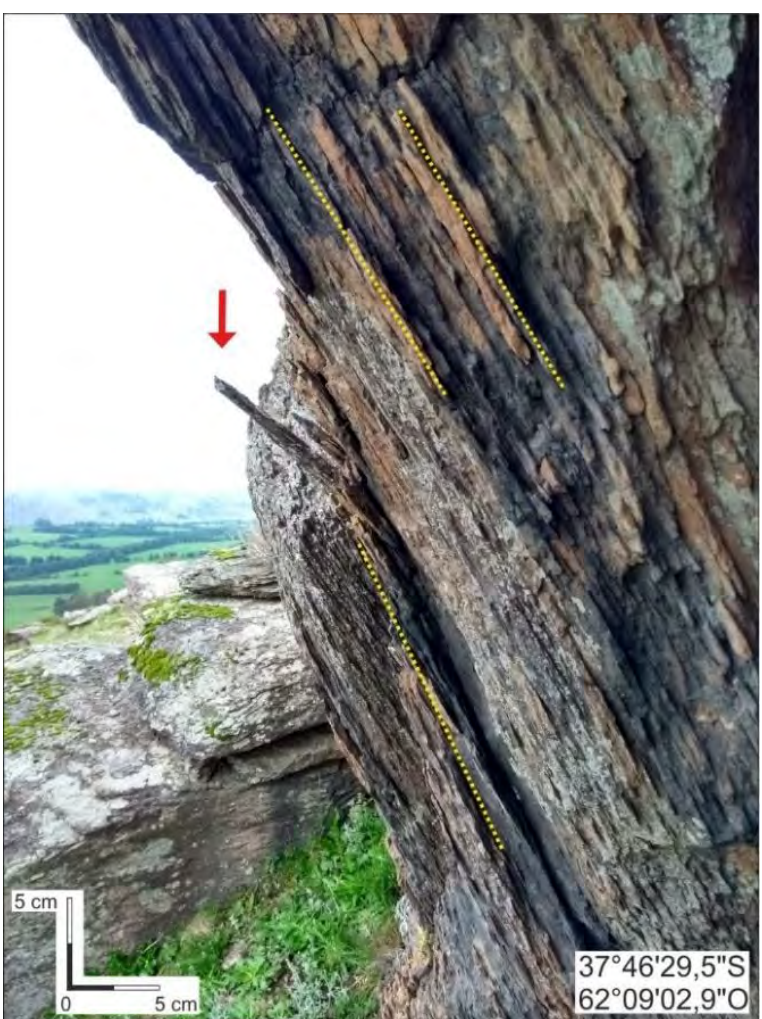

Figura 13.8. Vuelco de una laja centimétrica (flecha) delimitada por planos de foliación de alta densidad (líneas amarillas) en sedimentitas metamorfizadas de la Fm. Hinojo del Gr. Curamalal (ladera oriental del Cdón Hinojo Grande, subzona 2). Foto: Juan M. Susena.

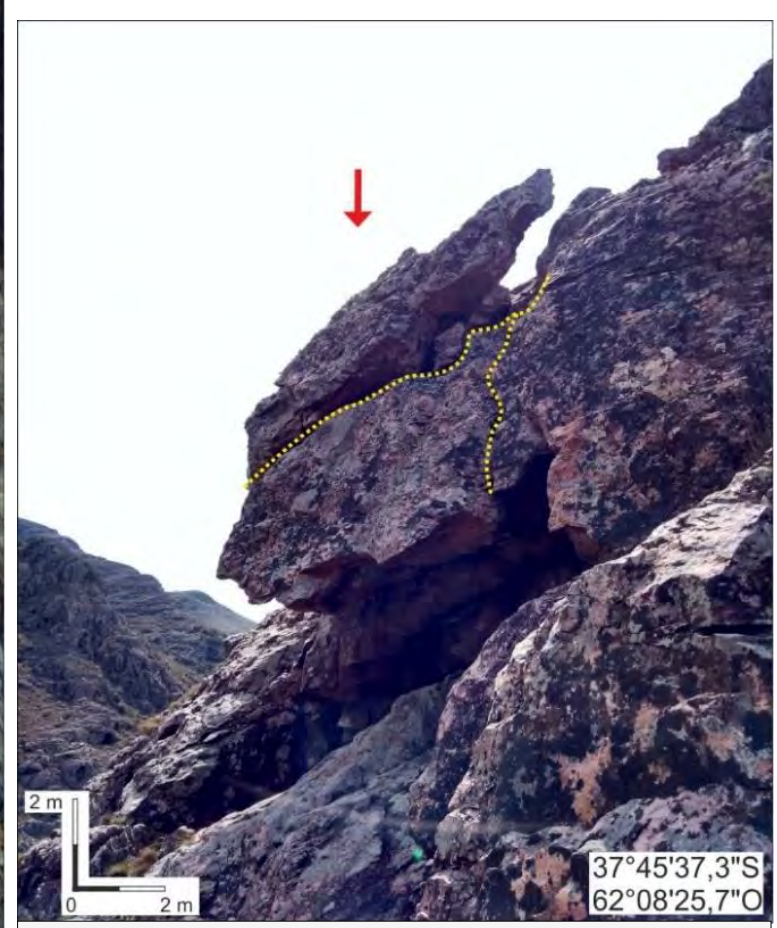

Figura 13.9. Bloque rocoso susceptible a vuelco o caída (flecha roja) diferenciado por fracturas irregulares ensanchadas por meteorización (líneas amarillas) en sedimentitas de la Fm. Bravard del Gr. Ventana (Sierras de Bravard en el Abra de Hinojo, subzona 2). Foto: Juan M. Susena.

planos de diaclasas (Figura 13.10). El movimiento principal desarrollado presenta remanentes de albardones laterales y una acumulación de forma lobada, indicando que se trata de un flujo de detritos, lo cual requiere un gran aporte de agua en relativamente poco tiempo. 


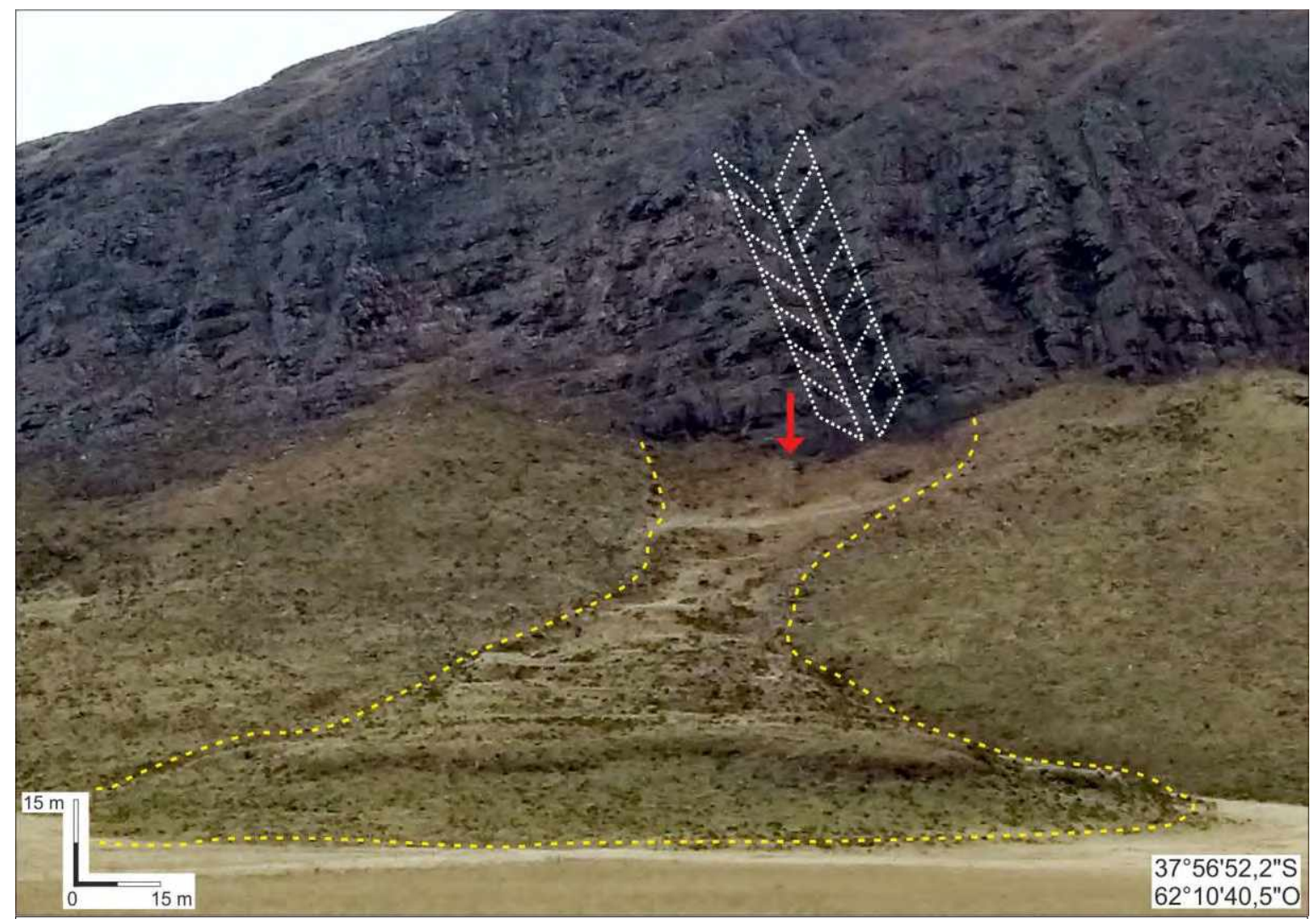

Figura 13.10. Ladera oriental del Cerro Pan de Azúcar (subzona 3). Una garganta desarrollada en la intersección de dos planos de diaclasas (líneas blancas) concentra el agua al pie de la ladera, donde se encuentra la zona de hundimiento (flecha) de parte de un gran conjunto de movimientos en masa (delimitado por líneas amarillas). La distancia entre esta zona de hundimiento y la punta es de unos $400 \mathrm{~m}$, sobrepasando la longitud de la ladera en el terreno no afectado. El ancho de la parte alta de la punta es de unos $150 \mathrm{~m}$. El conjunto tiene varias zonas de hundimiento dentro de la masa desplazada, pudiendo representar avances sucesivos hasta alcanzar la forma final. La escala se adapta a la zona indicada con la flecha. Foto: Juan M. Susena.

\subsubsection{Morfología del terreno}

Las características geomorfológicas son muy variadas, como puede observarse en los mapas geomorfológicos del Anexo. Distintas características del terreno, como la pendiente, la curvatura y la orientación de la pendiente, influyen en el contenido de humedad, la acción del agua y la fuerza de la gravedad, entre otros factores. Estas características del terreno podrían resultar de la estructura geológica, los tipos litológicos y la variación de las condiciones climáticas y tectónicas a largo término, es decir, son la expresión actual de la historia geomorfológica del lugar. Las características del terreno, expresadas en la cartografía geomorfológica y variables obtenidas mediante teledetección, su significado geomorfológico y su 
relación con los movimientos en masa se analizan en el siguiente capítulo de manera sistemática y detallada.

\subsection{Procesos que favorecen la inestabilidad}

Los procesos que aumentan la inestabilidad de las laderas pueden actuar a corto 0 largo término. Los procesos a corto plazo son los que se tratan aquí, y son principalmente la acción del agua, la actividad sísmica y la actividad antrópica y zoogeomorfológica. De éstos, se tratan aquí los dos primeros, ya que la actividad antropo y zoogeomorfológica como mecanismos preparadores y desencadenantes se explicó en el capítulo anterior. Entre los procesos a largo término pueden mencionarse, entre otros, los cambios climáticos, la tectónica y la meteorización; las consecuencias de dichos procesos son el desarrollo de las características geomorfológicas, texturales, mineralógicas, pedológicas, etc., que ya se explicaron como factores que tienden a una baja resistencia o a reducirla.

\subsubsection{Acción del agua}

En el área estudiada la acción del agua como mecanismo desencadenante de movimientos en masa se manifiesta de varias maneras.

El agua superficial se infiltra en determinados sectores de las laderas, aumentando la presión poral en toda la masa o en parte de ella, condicionada por variaciones de las propiedades hidrogeológicas de los materiales (permeabilidad especialmente). Desde otoño hasta primavera, el suelo puede tener un contenido de humedad relativamente alto, próximo a las condiciones de saturación. En campañas realizadas entre marzo y septiembre, los materiales se encontraban saturados en sectores localizados de las laderas, como los distales y algunas partes de los proximales. En los tramos medios de las laderas se observó agua brotando al pie de escarpas producidas por movimientos en masa, así como al pie de las puntas de algunos deslizamientos. En los tramos proximales, donde los afloramientos rocosos tienen una disposición escalonada y están en parte cubiertos por detritos (unidad geomorfológica Laderas Compuestas) el agua brota de los afloramientos rocosos, insinuando el carácter interconectado de los juegos de 
Movimientos en masa en las sierras de Bravard y Curamalal,

Sierras Australes de la Provincia de Buenos Aires.

Juan Manuel Susena

diaclasas (porosidad por fracturación). Cuando la saturación se produce durante la estación húmeda, la presión de poros aumenta y disminuye bruscamente la resistencia a la rotura, produciéndose los movimientos, especialmente deslizamientos y flujos. La cercanía entre las superficies de ruptura de muchos deslizamientos y las Laderas Compuestas es otro elemento que permite pensar en una saturación repentina de los detritos, favorecida por el contraste hidrológico entre la roca y los detritos, y por la carencia de matriz en los tramos proximales (Foto de portada de este capítulo); el agua de lluvia infiltra rápidamente hacia el contacto roca-detritos y se produce la saturación.

Otros modos en que el agua actúa como mecanismo disparador son el socavamiento basal en cursos de agua y el pipping, sea en cursos de agua o cortes de caminos. En cursos de agua, el socavamiento basal puede producir aleros a partir de los cuales se desarrollan caídas y vuelcos, especialmente en depósitos más o menos cementados, como son las calcretas (Figura 13.11). De la misma manera, en sectores de contacto entre las laderas y los cursos de agua, la remoción de la base de las laderas por erosión hídrica desencadena deslizamientos traslacionales (ver como ejemplo la Figura 10.9 en el Capítulo 9 Movimientos en masa en cursos de agua). En cuanto al pipping, pueden producirse caídas y deslizamientos por la acción hídrica localizada en galerías construidas por los animales o en galerías generadas por disolución del carbonato de calcio (en mucha menor medida). En el área de estudio, el pipping es un proceso común en el modelado de las cabeceras de las incisiones fluviales, y también se

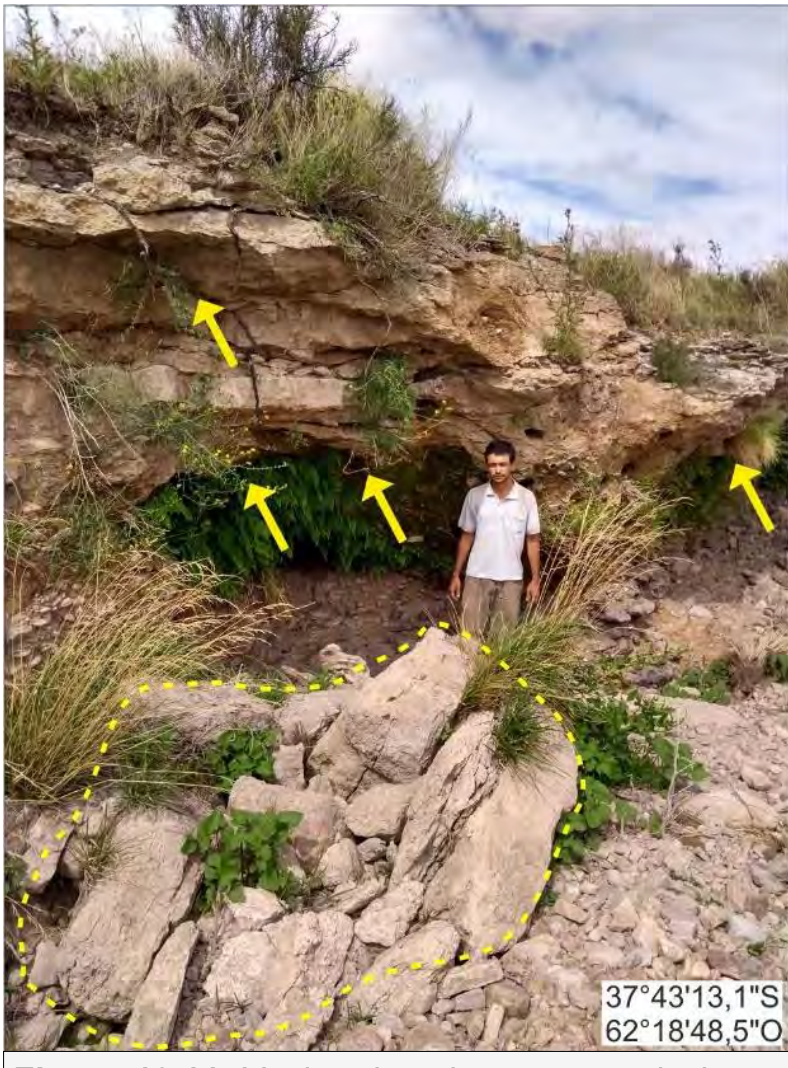

Figura 13.11. Vuelco de calcretas a partir de un alero generado por socavamiento basal en el Arroyo Alfalfa. Flechas: aleros. Línea de trazos: acumulación de bloques caídos; parte de los bloques más pequeños fueron aportados por el curso de agua. Foto: Juan M. Susena y Martín A. Hurtado. 
manifiesta en sectores localizados de las laderas en el contacto entre la roca (incluyendo las calcretas) y el regolito.

Como se mencionó varias veces en esta tesis, la poca disponibilidad de fotos aéreas e imágenes satelitales de alta resolución hace difícil un estudio multitemporal detallado de los movimientos en masa. Por tanto, se estimó conveniente identificar los eventos con precipitaciones intensas por un lado, y las fechas de observación de los movimientos con características juveniles, por otro. El movimiento mejor acotado en el tiempo se produjo entre diciembre de 1987 y diciembre de 1988 (Figura 13.12). La única tormenta intensa en dicho lapso se produjo en septiembre de 1988, habiendo precipitado $167 \mathrm{~mm}$ en 4 días. El día más lluvioso de esa tormenta cayeron 86 mm, y el par de días más lluvioso suma 135 $\mathrm{mm}$. Como no se sabe en qué día exactamente pudo haber ocurrido el movimiento,

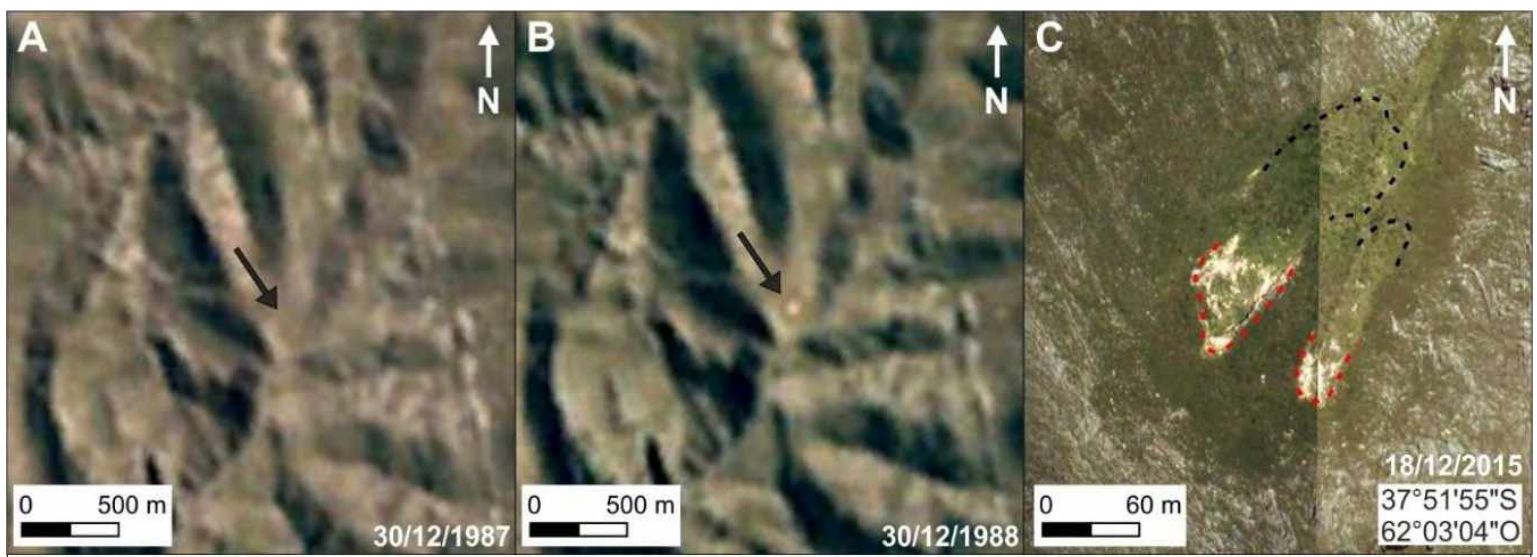

Figura 13.12. Movimiento en los faldeos orientales de las Sierras de Bravard. A. El movimiento aún no se había producido al 30/12/1987, la flecha negra indica la localidad. B. El movimiento se observa ya el 30/12/1988 en la localidad indicada con la flecha negra. C. En la composición de imagen satelital de alta resolución (World View-2) se observan las superficies de ruptura de dos movimientos (líneas rojas) y sus acumulaciones (líneas negras). Elaboración propia a partir de imágenes de baja resolución Landsat $(A$ y $B$ ) e imagen de alta resolución World View-2 del servidor Bing (C).

o si se desarrolló lentamente durante el período de tormenta, se estima como umbral de precipitación desencadenante orientativo a aquella en la cual caen al menos $160 \mathrm{~mm}$ en 4 días, $120 \mathrm{~mm}$ en 2 días, o más de $80 \mathrm{~mm}$ en 1 día. La Figura 13.13 muestra que en el área de estudio y sus alrededores tales eventos de precipitación son frecuentes, y que los movimientos en masa con características juveniles se encuentran temporalmente muy próximos a ellos. Se reconocieron 252 localidades con movimientos en masa desarrollados entre el año 1967 y el año 2019, es decir, en un lapso de aproximadamente 52 años. Esto pudo hacerse con cierta parcialidad espacial debido a que no se disponía de un registro de fotos 


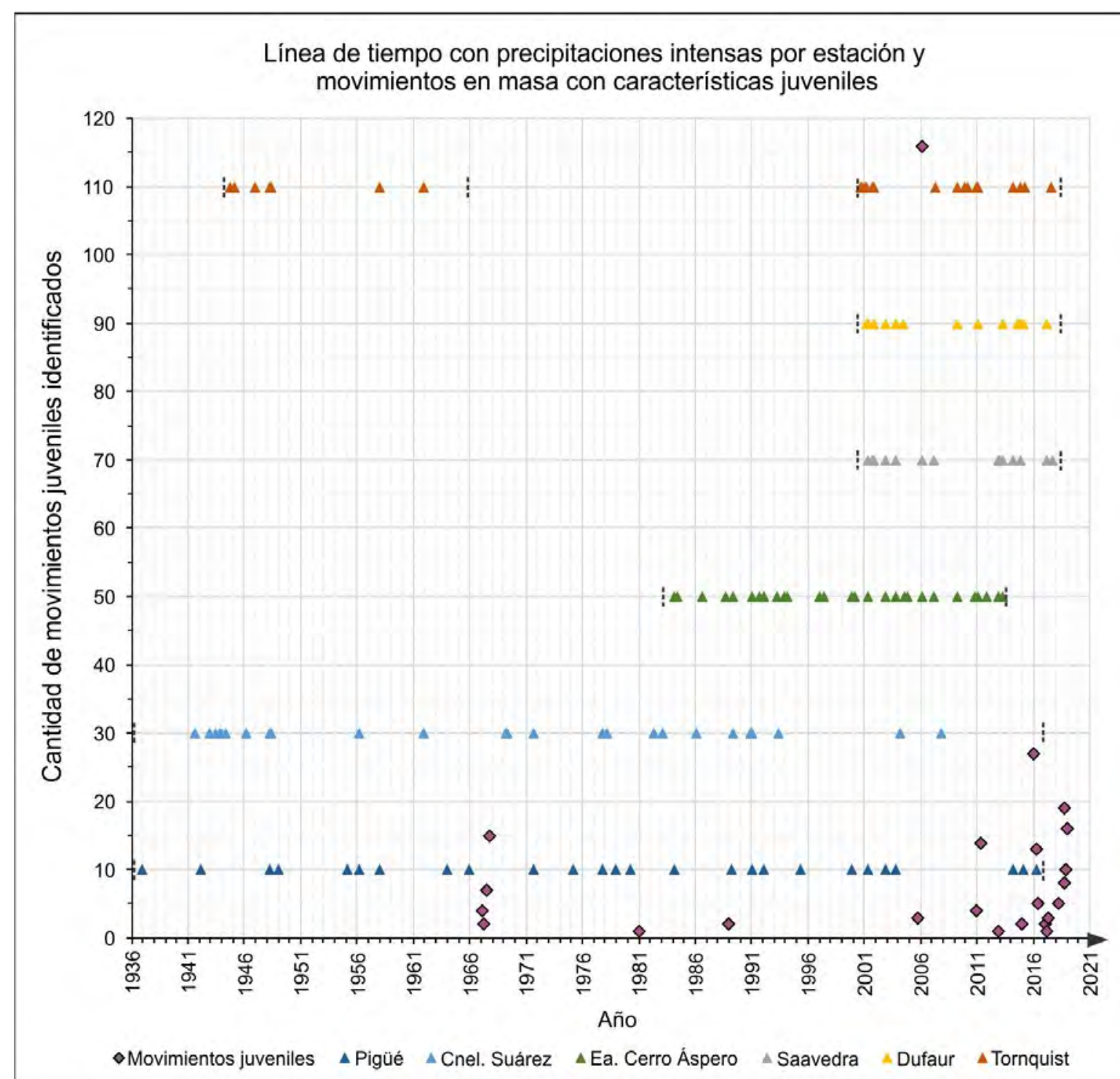

Figura 13.13. Línea de tiempo mostrando los eventos de precipitaciones intensas en las diferentes estaciones (triángulos) y las fechas en que los movimientos en masa se identificaron con características juveniles (rombos). Se identificaron 287 localidades con movimientos de características juveniles, de las cuales 35 se registraron en fotos aéreas del año 1967, y 252 con posterioridad a éstas. Las últimas incluyen movimientos reconocidos como posteriores al año 1967 por no encontrarse aún en las fotos aéreas de ese año, y otros con características juveniles en imágenes/fotos aéreas u observaciones de campo posteriores al año 1967, en localidades donde no se disponía de las fotos de 1967, o donde se produjeron reactivaciones. Las líneas de puntos negras acotan la fecha de los datos de precipitaciones disponibles para cada estación. Nótese que hay un lapso de casi 40 años entre fechas con frecuencias de movimientos juveniles relativamente altas (años 1967 y 2006), lo cual puede deberse a la discontinuidad del registro de imágenes, más que a la ausencia de eventos de precipitaciones intensas. La ubicación de las estaciones meteorológicas puede revisarse en la Figura 3.2 del Capítulo 3 Metodología. Elaboración propia a partir de los registros de precipitaciones diarios, fotointerpretación de fotografías aéreas e imágenes satelitales de baja y alta resolución espacial y trabajo de campo.

aéreas de toda el área de estudio, y a que tampoco se puedo acceder a todas las estancias ubicadas en dicha área. Si se dispusiese de un registro multi-temporal 
más detallado de los movimientos, podrían relacionarse los movimientos con diferentes intensidades de las precipitaciones, al poder acotar a qué evento se relaciona cada movimiento, y replantear el límite establecido para considerar como intenso a un evento de precipitación.

\subsubsection{Sismos}

El desarrollo de sismos puede contribuir a la producción de algunos movimientos en masa particulares. De acuerdo con Keefer (1984), para que se produzcan movimientos en masa de dimensiones considerables se requieren sismos con una magnitud superior a 4 en la escala de Richter, aunque valores algo menores pueden ser suficientes para que produzcan caídas de rocas. En el área estudiada existen bloques rocosos en equilibrio metaestable, susceptibles de caer, como el indicado en la Figura 13.9, más arriba en este capítulo. Los sismos más cercanos registrados por el Instituto Nacional de Prevención Sísmica desde el año 2009, tienen sus epicentros al menos a $100 \mathrm{Km}$ del área de estudio, y rara vez alcanzan los 4 grados de magnitud (Figura 13.14). Esta distancia no es lo suficientemente grande como para descartar la sismicidad como mecanismo desencadenante. Incluso, posiblemente se hayan desencadenado sismos más cercanos o con mayor

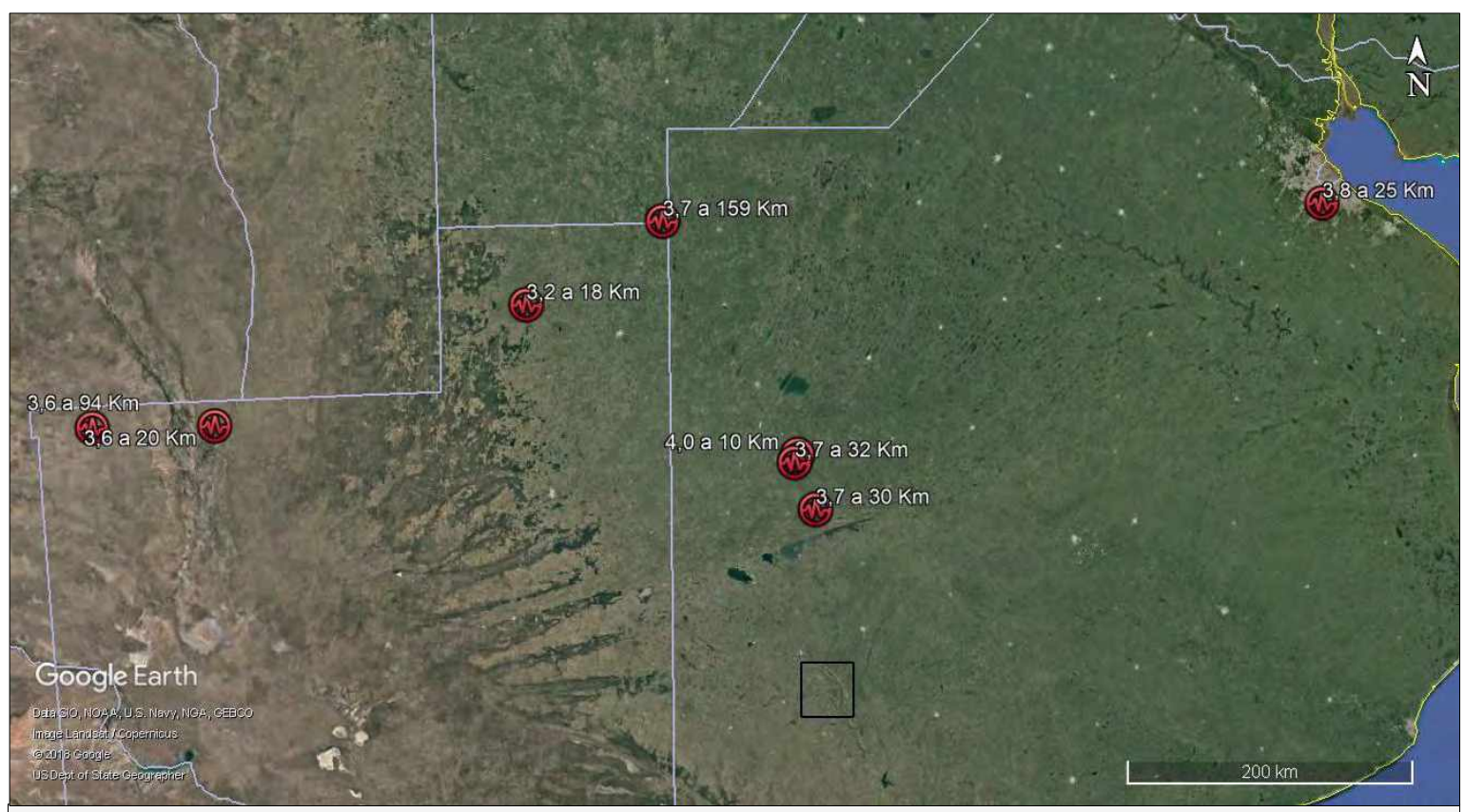

Figura 13.14. Sismos cercanos al área estudiada (indicada con el rectángulo negro) entre los años 2009 y 2019. Las etiquetas de cada evento indican la magnitud en la escala de Richter y la profundidad del epicentro. Elaboración propia a partir de datos del Instituto Nacional de Prevención Sísmica. 
Movimientos en masa en las sierras de Bravard y Curamalal,

Sierras Australes de la Provincia de Buenos Aires.

Juan Manuel Susena

magnitud considerando intervalos mayores, por lo cual es necesaria una serie temporal mayor para extraer conclusiones más confiables. Quatrocchio et al. (1994) mencionan la posibilidad de neotectónica en base a estudios del subsuelo e identificación de deformaciones en las barrancas del Río Sauce Chico al sur del área estudiada. Si bien no es definitorio, no debe descartarse la posibilidad de que algunos sismos cercanos pudieran desencadenar caídas de rocas.

De todo lo expresado en este capítulo y en parte en los anteriores, en lo tocante a las condiciones causales de los movimientos en masa, puede concluirse que una buena parte de las causas se relacionan con las propiedades intrínsecas del terreno, las cuales resultan de su historia geológica y geomorfológica. Entre ellas se encuentran las estructuras geológicas y tipos litológicos y las características texturales y mineralógicas de la matriz de los sedimentos no consolidados, así como la profundidad del sustrato rocoso. Estas características influyen en la permeabilidad y consiguientemente en la tendencia a la saturación que puedan tener los diferentes sectores del área estudiada, y pueden analizarse integrando la cartografía litológica y la geomorfológica. Otras causas de los movimientos, como el accionar del agua, se relacionan con la presencia de cursos de agua, los cuales son cartografiables. En el caso de las precipitaciones, dado el gran distanciamiento entre estaciones pluviométricas y la influencia de las sierras -como barreras topográficas- sobre los montos de precipitación, resulta de interés orientar el análisis de la acción del agua hacia la identificación de sectores con diferente potencial de acumulación de humedad, dependientes de la orientación y la morfología de las laderas; dichas variables pueden obtenerse mediante el procesamiento de modelos de elevación digital. La acción antropo y zoogeomorfológica y sus efectos en el desarrollo de movimientos pueden expresarse, al menos parcialmente, en cartografía de elementos antrópicos utilizados tanto por los humanos como por los animales y que concentran su actividad, como pueden ser los caminos y huellas rurales. En el capítulo siguiente se entrará más en detalle sobre la distribución espacial de estas variables que expresan las causas de los movimientos en masa. 


\section{Capítulo 14}

\section{Análisis de susceptibilidad}

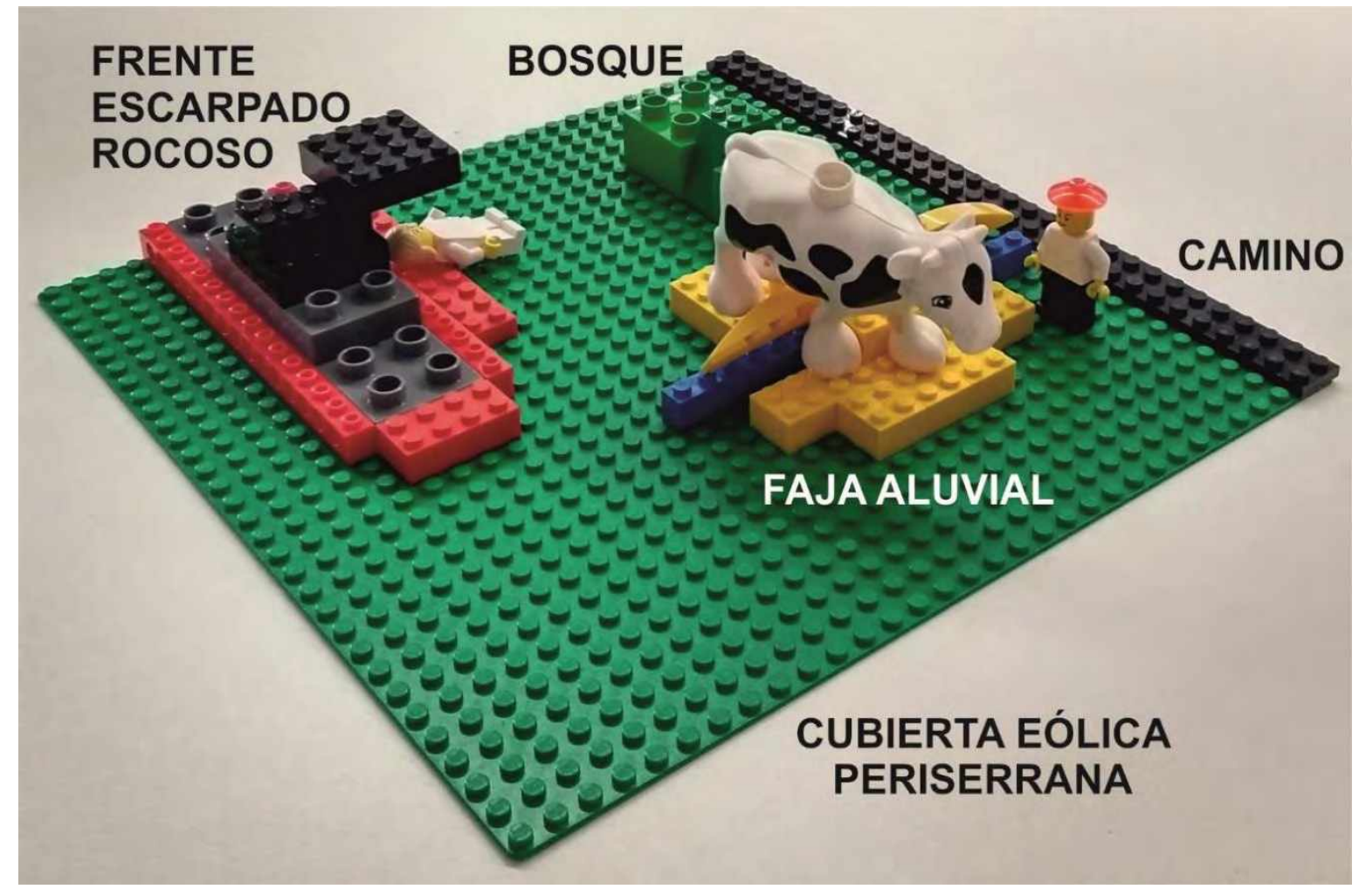

"Formas de expresión" Maqueta armada durante un curso de Formación Transversal de la Escuela de Doctorado de la Universidad de Cantabria, para expresar la utilidad de los modelos de susceptibilidad. Los colores indican susceptibilidad baja (verde), media (amarillo) y alta (rojo). Una vaca corre riesgo de caer por las barrancas y una turista descansa bajo un alero rocoso susceptible a caídas. 
Movimientos en masa en las sierras de Bravard y Curamalal, Sierras Australes de la Provincia de Buenos Aires.

Juan Manuel Susena 


\subsection{Justificación y ordenamiento del capítulo}

La susceptibilidad de movimientos en masa es la propensión (grado de probabilidad en el espacio) a la ocurrencia de un determinado tipo y magnitud de movimiento en masa, en relación a las condiciones locales del terreno (Brabb, 1984). Responde a la pregunta ¿qué lugares son más proclives a que ocurra un movimiento con determinadas características? Muchas veces este concepto suele confundirse con el de amenaza (Fell et al., 2008), pero el último implica además la dimensión temporal (Varnes, 1984), para cuyo estudio se necesitan además registros históricos para establecer la frecuencia de estos procesos y/o la distribución e intensidad de los procesos desencadenantes, como las precipitaciones (Guzzetti et al., 1999).

Debido a la insuficiencia de registros multi-temporales de movimientos en masa en el área de tesis, en este capítulo (y en esta tesis) se aborda sólo el análisis de susceptibilidad. Se espera que en los próximos años, el avance de las tecnologías de percepción remota u otros métodos de recolección de datos propicien la creación de una base de datos con una resolución espacio-temporal adecuada para analizar la amenaza de una manera fidedigna.

Como se deriva de lo escrito más arriba, un análisis de susceptibilidad a movimientos en masa implica un estudio de variables intrínsecas del terreno. Algunas de estas variables son relativamente constantes en el rango temporal de análisis (Siglos XX y XXI), como la litología pre-Holoceno, las pendientes y su orientación y la distancia de las laderas a los cursos de agua. Otras variables, como la estructura del suelo en terrenos labrados, la cobertura vegetal y el desarrollo de geoformas antrópicas, tienen un ritmo de cambio mucho más acelerado, registrable en el intervalo temporal considerado.

Para un análisis geoestadístico y de susceptibilidad a movimientos en masa, los Sistemas de Información Geográfica (SIG) se han vuelto una herramienta muy útil (Fell et al., 2008; Remondo y Oguchi, 2009). En este capítulo se tratará la metodología empleada para el análisis de susceptibilidad, se describirán las variables empleadas y su modo de obtención, y se mostrarán los resultados y conclusiones obtenidos, respecto al análisis e integración de variables. Se explicará, con un estilo de flujo de trabajo, la metodología y los resultados de cada 
Movimientos en masa en las sierras de Bravard y Curamalal,

Sierras Australes de la Provincia de Buenos Aires.

Juan Manuel Susena

etapa. Se analizarán las variables numéricas para descartar aquellas que se relacionan poco con los movimientos, o cuyas relaciones no sean a priori claras. Luego se explicarán los parámetros y funciones utilizados para el análisis de susceptibilidad y los arreglos que se hicieron a algunas de las variables. Se expondrán los resultados de los diferentes modelos de susceptibilidad desarrollados y su validación, y finalmente se explicarán las conclusiones obtenidas de todo el análisis, desde las perspectivas geomorfológica y metodológica.

\subsection{Algunas metodologías comunes de análisis de susceptibilidad}

Numerosos enfoques metodológicos fueron planteados en el estudio de susceptibilidad y amenaza de movimientos en masa desde la perspectiva de su ocurrencia, entre los cuales pueden mencionarse tres tipos de aproximaciones comunes: heurística (o de criterio experto), determinística, y probabilística o estadística, (Castellanos Abella y Van Westen, 2008; Fell et al., 2008; Corominas et al., 2014; Reichencbach et al., 2018). La primera puede ser de carácter cualitativo o semi-cuantitativo, mientas que las otras dos son cuantitativas.

La aproximación heurística combina el mapeo de los movimientos en masa y su entorno geomorfológico como variables principales (Soeters y Van Westen, 1996). La zonación de susceptibilidad puede ser directa, a partir de la observación de campo (aproximación geomorfológica). Esto ha sido criticado, entre otros aspectos, debido a la subjetividad del análisis y dificultad en la estandarización. En la aproximación heurística indirecta, el experto pondera la importancia de cada variable que considera influyente en el desarrollo de movimientos en masa, y puede acudir al uso de SIG para asistir esta tarea (Hansen et al., 1995; Guzzetti et al., 2005; Reichenbach et al., 2018).

La aproximación determinística, útil para estudios locales, se basa en modelos de estabilidad de laderas o taludes ingenieriles, y consiste en el cálculo de valores cuantitativos de estabilidad (por ejemplo, el factor de seguridad), mediante la aplicación de diferentes modelos de estabilidad de laderas (Montgomery y Dietrich, 1994; Zhou et al., 2003; Savage et al., 2004). El problema o punto débil de este tipo de aproximación, además de no poder aplicarse a áreas grandes o con una 
distribución heterogénea de variables, es la generalización de los valores de variables (Soeters y Van Westen, 1996).

La aproximación probabilística o estadística se basa en el análisis de las relaciones estadísticas entre los movimientos en masa y distintos factores (= variables) que influirían en el desarrollo de estos procesos. Toda esta información se analiza en un SIG. Se supone que las variables utilizadas son independientes, y que se utiliza una muestra aleatoria de la población de movimientos existentes. Siempre debe tenerse en cuenta que los movimientos utilizados en el análisis ya ocurrieron, y que se asume una postura uniformitarista o actualista: se supone que en el futuro ocurrirán movimientos del mismo tipo y magnitud, y que prevalecerían los factores que produjeron los movimientos pasados (Varnes, 1984; Carrara et al., 1991; Hutchinson, 1995). Asimismo, se supone que se conocen los principales factores que contribuyen al desarrollo de los movimientos analizados. Para aplicar estos supuestos, debe tenerse en cuenta la posible existencia de movimientos muy antiguos que pudieran haberse producido bajo condiciones climáticas diferentes a las actuales, para descartarlos del análisis. Por otra parte, debe conocerse bien la zona estudiada y las limitaciones de las herramientas y metodologías utilizadas para la obtención de las variables, y considerar qué variables del terreno podrían cambiar con el tiempo, considerando tanto el pasado, como el futuro (dentro de lo posible). La principal ventaja del método estadístico es su aplicabilidad a escala regional, y la posibilidad de establecer una zonación de susceptibilidad en áreas con escasez de datos, debido a que muchas variables pueden extraerse automáticamente de un MDE y que se dispone de nuevas tecnologías para la obtención de variables (Guzzeti et al., 2012).

Diferentes estudios se enfocaron en la determinación del peso (importancia relativa) de las variables utilizadas en estudios de movimientos en masa mediante procedimientos estadísticos (Costanzo et al., 2012; Alkhasawneh et al., 2013; Dou et al., 2015b).

La aproximación utilizada en este trabajo es la estadística. Existen en la bibliografía numerosísimos casos de aplicación de aproximaciones estadísticas a la susceptibilidad de movimientos en masa, entre las cuales pueden mencionarse Estadística Multivariada convencional (Multivariate Statistics, Lee et al., 2008), $W_{i}$ Statistical Index Method (Van Westen, 1997); WLC - Weighted Linear Combination (Voogd, 1982; Ayalew et al., 2004); AHP - Analytical Hierarchy Process (Saaty, 
Movimientos en masa en las sierras de Bravard y Curamalal,

Sierras Australes de la Provincia de Buenos Aires.

Juan Manuel Susena

1980; Barredo et al., 2000), FC - Factor de Certidumbre (CF - Certainity Factor Method, Binaghi et al., 1998; Lan et al., 2004; Sujatha et al., 2012); Regresión Logística (LR - Logistic Regression, Dai \& Lee, 2003; Duman et al., 2006; Nefeslioglu et al., 2008; Chauhan et al., 2010; Akgun, 2012); WOE - Weight of Evidence Model (Lee et al., 2004; Dahal et al., 2008; Tangestani, 2009; Park, 2011; Armaş, 2012; Neuhäuser et al., 2012; Thiery et al., 2014; Saponaro et al., 2015; Ilia \& Tsangaratos, 2016); Frecuencia Relativa (Frequency Ratio, Lee y Pradhan, 2006; 2007; Yilmaz, 2010; Akinci et al., 2011; Reis et al., 2012; Umar et al., 2014; Wu et al., 2016), entre muchísimos otros.

En esta tesis se utilizaron las Funciones de Favorabilidad (Chung y Fabbri, 1993), metodología explicada en detalle más adelante en este capítulo. Cabe recordar que el objetivo del análisis de susceptibilidad aquí presentado es complementar las observaciones e interpretación de la geomorfología del área, tareas realizadas principalmente en el campo. No se considera a estos análisis como un objetivo final, sino como una herramienta más para comprender y explicar la dinámica de los movimientos en masa en el área de estudio (Figura 3.1 en Capítulo 3). Por lo antedicho, se utilizaron las Funciones de Favorabilidad por tratarse de una metodología que permite analizar variables de obtención rápida con tratamientos relativamente sencillos, y que pueden validarse, compararse, criticarse e interpretarse geomorfológicamente, tomando como referencia lo que se vio en el campo. Se considera que un análisis más profundo de variables, su comparación, modos de obtención, expresión, tratamiento e interpretación como objetivo per se, sería un trabajo para realizar "una tesis aparte".

\subsection{Variables analizadas}

Como se dijo en el apartado anterior, se supone que se conocen los factores que contribuyen al desarrollo de los movimientos en masa. Como se indicó en el capítulo anterior, los factores varían según el tipo de movimiento. En el análisis presentado a continuación, se tratan movimientos cartografiados a escala 1:5.000 de tipo deslizamiento de detritos, deslizamiento de detritos con alguna componente de flujo (flujos deslizantes), flujos de tierra dinámicamente afines a los flujos deslizantes (con escasa deformación relativa de la masa). Los principales factores 
que contribuyen al desarrollo de estos movimientos son los correspondientes al material (presencia o ausencia de matriz, espesor de detritos, cohesión de la matriz, permeabilidad, grado de compactación, cementación, meteorización, etc.), el contenido de humedad, la pendiente y la interacción con la acción hídrica, antropo y zoogeomorfológica y el escurrimiento sub-superficial. Teniendo esto en cuenta, un análisis de susceptibilidad debe incluir esta información, expresada en variables cuantificables o ponderables. Dado que es inviable obtener directamente toda esta información para toda el área de estudio de manera sistemática, se obtuvieron variables que expresen indirectamente esta información. La Tabla 14.1 muestra las variables que se obtuvieron y la información que contiene respecto a los factores que contribuyen al desarrollo de este tipo de movimientos en masa.

Se considera en principio que estas variables, expresadas adecuadamente, explican satisfactoriamente la existencia de los movimientos en masa que se pretenden analizar, y que su potencial explicativo depende de la fidelidad con que representan a los factores que contribuyen al desarrollo de movimientos. Esta fidelidad depende en gran medida de la distribución espacial y densidad de la información original, el grado de objetividad o subjetividad de su obtención, y el nivel de generalización que tengan a la hora de analizarlas en conjunto.

Para el análisis se seleccionó la subzona 1, sobre la cual se trabajó remotamente y en el terreno (Figura 14.1; ver también la Figura 4.2 del Capítulo 4 Introducción al área de estudio). Se eligió esta subzona porque se pudo acceder a ella y complementar el trabajo de gabinete con el de campo, y porque los movimientos allí desarrollados son en gran parte identificables por teledetección, son relativamente recientes (no relictos), tienen una magnitud representativa de los

\begin{tabular}{|c|c|}
\hline Variable & Información sobre factores que contribuyen a los movimientos en masa \\
\hline $\begin{array}{l}\text { Inventario de movimientos } \\
\text { en masa }\end{array}$ & Evidencias de inestabilidades pasadas \\
\hline MDE y sus derivados & $\begin{array}{c}\text { Morfología del terreno, esfuerzo de corte, contenido de humedad, acción } \\
\text { hídrica, meteorización }\end{array}$ \\
\hline $\begin{array}{l}\text { Distancia a cursos de } \\
\text { agua }\end{array}$ & Acción hídrica \\
\hline Distancia a caminos & Acción antropo y zoogeomorfológica \\
\hline Litología & Características del material, comportamiento geomecánico e hidrogeológico \\
\hline Geomorfología & Espesor de regolito, estructuras geológicas, procesos geomorfológicos \\
\hline Vegetación & Acción hídrica, infiltración de agua, retención del material \\
\hline \multicolumn{2}{|c|}{$\begin{array}{l}\text { Tabla 14.1. Variables e información que aportan sobre los factores que influyen en el desarrollo de } \\
\text { movimientos en masa. }\end{array}$} \\
\hline
\end{tabular}




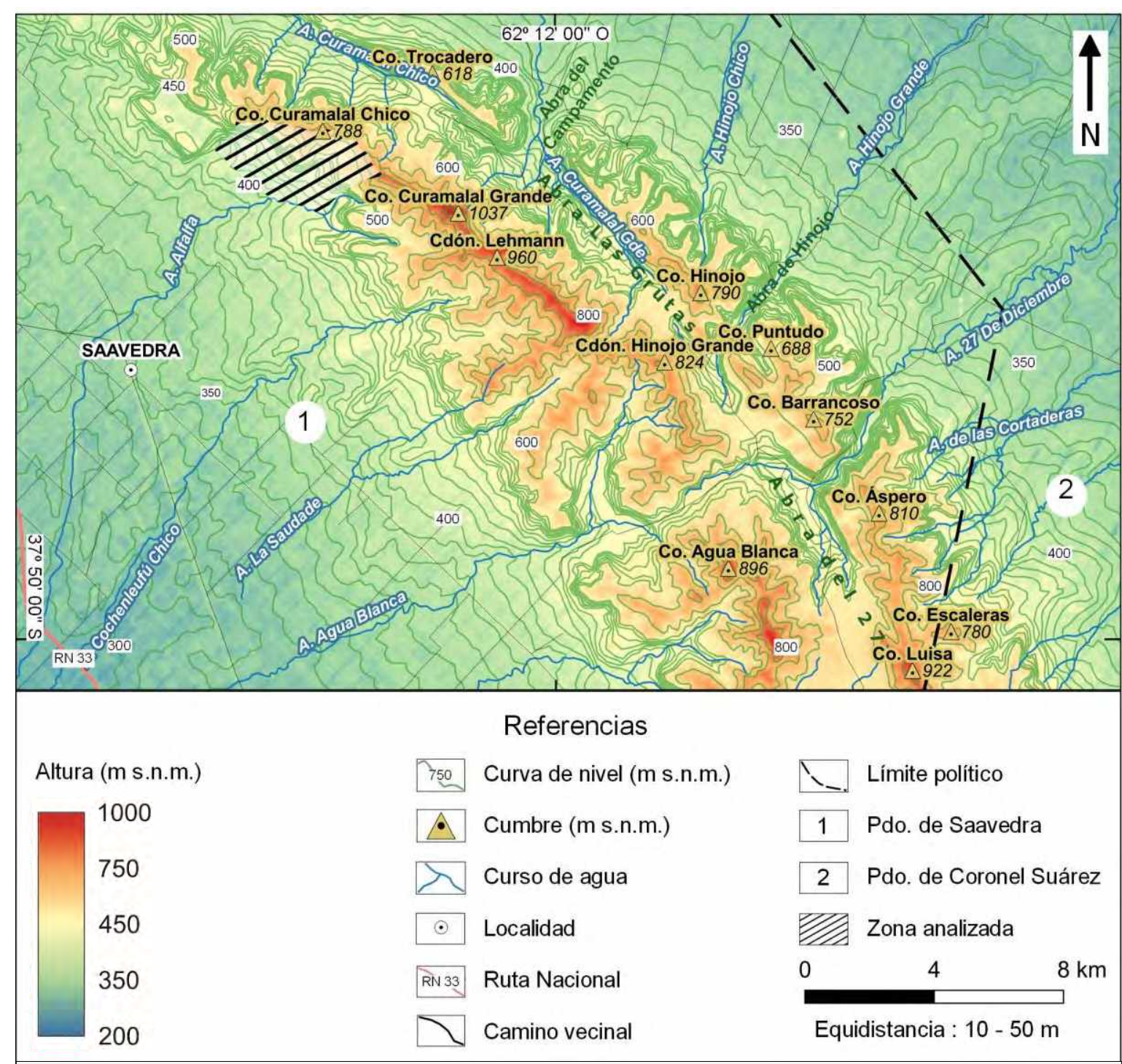

Figura 14.1. Mapa mostrando la ubicación de la zona seleccionada para el análisis de susceptibilidad. Para un contexto más general dentro del área estudiada, ver la Figura 4.2 en el Capítulo 4 Introducción al área de estudio. Elaboración propia.

movimientos de toda el área de estudio. En adición a esto, prácticamente todas las unidades geomorfológicas y tipos litológicos a grandes rasgos (roca, calcretes, depósitos aluviales, coluviales y eólicos) están representados, lo cual permite analizar el grado de contribución relativa de estas variables -consideradas, en principio, significativas- al desarrollo de los movimientos. Podría ser motivo de estudios posteriores a esta tesis, el análisis de las subzonas 2 y 3 (Figura 4.2 del Capítulo 4 Introducción al área de estudio).

La subzona 1 se ubica en el flanco occidental de las sierras de Curamalal, involucrando el ámbito serrano y el pedemontano, y ocupa unas 927 hectáreas $\left(9,27 \mathrm{Km}^{2}\right)$. En este sector se ubican casi todas las unidades geomorfológicas (excepto Gargantas en Discontinuidades Rocosas y Piedemonte Aluvial Activo 


\begin{tabular}{|c|c|c|}
\hline Aspecto & Variable / Mapa & Clases / Categorias \\
\hline \multirow{4}{*}{ Geología } & \multirow{4}{*}{ Unidad litológica } & Basamento \\
\hline & & Gr. Curamalal principalmente cubierto \\
\hline & & $(\ldots)$ \\
\hline & & Detritos de Ladera \\
\hline \multirow{6}{*}{ Geomorfologia } & \multirow{4}{*}{ Unidad geomorfológica } & Fajas Aluviales \\
\hline & & Laderas de Detritos \\
\hline & & $(\ldots)$ \\
\hline & & Frentes Escarpados Rocosos \\
\hline & \multirow{2}{*}{ Movimientos en masa } & Con movimientos (1) \\
\hline & & Sin Movimientos (0) \\
\hline \multirow{7}{*}{ Relieve } & \multirow{3}{*}{ Curvatura general de la pendiente } & Convexa \\
\hline & & Plana \\
\hline & & Cóncava \\
\hline & \multirow{4}{*}{ Orientación de la superficie } & Superficie sub-horizontal \\
\hline & & $\mathrm{N}$ \\
\hline & & $(\ldots)$ \\
\hline & & so \\
\hline \multicolumn{3}{|c|}{$\begin{array}{l}\text { Tabla 14.2. Ejemplo ilustrativo de la estructura jerárquica de algunas de las variables utilizadas. } \\
\text { Sólo se muestran algunas variables de los aspectos. Los puntos suspensivos (...) significan que } \\
\text { hay más clases dentro de la variable. }\end{array}$} \\
\hline
\end{tabular}

Indiferenciado), y hay tanto roca como regolito con diferente grado de consolidación. Las actividades desarrolladas en el sector son agricultura en el piedemonte y ganadería en el ámbito serrano y pedemontano proximal.

Todas las variables del terreno obtenidas, tanto a partir del trabajo de campo, como a partir de teledetección, se georreferenciaron en marco geoespacial en común (sistema de referencia de coordenadas POSGAR 1994 Faja 4, mismas coordenadas extremas y mismo tamaño de píxel), y se construyeron matrices (rasters), cuyos píxeles tienen una resolución espacial de 12,5 x 12,5 m (156,25 m² de superficie cartográfica cada píxel). Esta medida corresponde a la resolución espacial (horizontal) del MDE empleado, en principio apropiada para representar en la zona estudiada algunas características de la geometría del terreno como pendiente, curvatura, orientación, etc. Rasgos menores del paisaje que no pueden diferenciarse debido a su relieve abrupto o escasa representación en planta, por 
Movimientos en masa en las sierras de Bravard y Curamalal,

Sierras Australes de la Provincia de Buenos Aires.

Juan Manuel Susena

ejemplo barrancas de cursos labrados en sedimentos loessoides, frentes escarpados rocosos menores, y crestas y depresiones en laderas (véase Capítulo 6 Geomorfología general del área), están representados en otras variables (por ejemplo la geomorfología) generadas por interpretación visual de composiciones de imágenes satelitales de alta resolución de World View-2 (obtenidas de los servidores Google Earth y Bing).

La estructura de los datos utilizados para analizar la susceptibilidad a movimientos en masa es jerárquica, con aspectos, variables y clases (Tabla14.2). De éstos, solamente se introducen en un SIG las variables y sus clases.

Se utilizaron variables espacialmente continuas tanto cuantitativas (como el MDE y sus derivadas) como categóricas (litología, geomorfología y vegetación), así como variables espacialmente discretas (movimientos en masa, caminos y cursos de agua). Las variables continuas categóricas y las variables discretas se obtuvieron mayormente por digitalización con el software QGIS. Las variables "automáticas", derivadas del MDE (pendiente, curvatura, orientación, etc.) se obtuvieron con los programas QGIS y SAGA, aplicando el método de Zevenbergen y Thorne (1987).

Cabe aclarar que la resolución vertical del MDE es de $1 \mathrm{~m}$, y que muchas variables derivadas del MDE, por su modo de expresión numérica (por ejemplo, de $-1 \mathrm{a}+1$ en el caso de la curvatura), tienen decimales. En dichos casos, la presencia de decimales no supone una mejora en la precisión respecto al MDE de origen, pero se los ha conservado para mantener la identidad de los valores resultantes. Esto no implica sesgos en el análisis, ya que posteriormente se establecen categorías para agrupar estos valores, pero se aclara que este "artefacto" se tuvo en cuenta a la hora de interpretar las variables derivadas.

Para cada variable se analizó la frecuencia relativa de movimientos en las distintas clases, conforme a la siguiente ecuación:

$$
\text { Frecrel } l_{C l}=\frac{\hat{A} r e a_{M C l}}{\text { Área } e a_{C l}}
$$

Donde Frecrel $\mathrm{C}_{\mathbf{c}}$ es la frecuencia relativa de movimientos en la clase, Área $\mathbf{M c ı}_{\mathrm{c}}$ es el área de la clase ocupada por movimientos en masa, y Áreacı es el área de la clase. Esto proporciona una estimación del grado de propensión (probabilidad, 
susceptibilidad, favorabilidad) relativa de cada clase de una variable al desarrollo de movimientos en masa, pudiendo esta información servir de base para integrar simultáneamente variables de distinta naturaleza (de valores cuantitativos y categóricos, y de distribución espacial continua y discreta) a la hora de elaborar modelos de susceptibilidad (Chung y Fabbri, 1993).

Dado que en la zona estudiada la relación entre la superficie con movimientos en masa es muy escasa ( $1,84 \%$ de la zona), y que muchas de las variables continuas tienen más de 100 -y hasta más de 50.000- valores únicos, su utilización para el análisis resultaría en principio vana, porque no se podrían calcular los valores de favorabilidad para todas las clases de la variable. Por ello, las variables continuas (altitud, pendiente, curvatura, distancia a caminos, etc.) se reclasificaron, en clases con rangos de valor establecidos desde la perspectiva de los procesos geomorfológicos. Como ejemplo puede citarse la altitud, cuyos límites de rangos de valor coinciden aproximadamente con las altitudes de los diferentes niveles pedemontanos y paleosuperficies, para discriminar, por ejemplo, los rangos de altitud en los cuales prácticamente no hay laderas de detritos.

A continuación, se define cada variable y su modo de obtención.

Inventario de movimientos en masa: polígonos mapeados a escala 1:5.000 a partir del reconocimiento en composiciones de imágenes satelitales de World View2 (Google Earth, Bing y ESRI), fotografías aéreas del INTA (1967) y del ex-MOSP (1981), y relevamiento de campo. Los movimientos mapeados son de tipo deslizamiento, algunos con una componente de flujo, similares a flujos deslizantes. También se incluyen flujos de tierra, dado que en el área éstos se producen sobre un plano definido (horizonte de suelo arcilloso), de manera similar a los flujos deslizantes. Cabe aclarar que los flujos de detritos producidos en cauces no se incluyen, por tener una morfología y mecanismos de movimiento diferentes a los de los movimientos previamente mencionados. En casos de movimientos múltiples, se mapeó todo el conjunto, dada la dificultad en diferenciar cada movimiento individual. Los conjuntos de movimientos no se utilizaron para el análisis, sino para la validación. Se mapearon tanto las superficies de ruptura como las acumulaciones, por tratarse de movimientos superficiales (no involucran roca) y de poco recorrido, en general no más de 100 m; teniendo en cuenta la resolución espacial de las variables, si se mapearan sólo las superficies de ruptura, cada movimiento estaría 
representado por muy pocas celdas (píxeles), pudiendo ser inviable el análisis. Por otra parte, se encontraron en el área de estudio movimientos muy degradados, posiblemente relictos (antiguos), pero no se incluyeron en el análisis, para mantener el supuesto uniformitarista o actualista mencionado más arriba. Este tipo de movimientos se diferencian del resto por su escasa expresión morfológica y otros signos de degradación (ver Capítulo 7 Características geomorfológicas de los movimientos en masa). Si bien en el inventario se consignó información de aspectos diversos (Tabla 14.3), para el análisis en SIG se utilizó una codificación booleana, donde $0=$ superficie no afectada por movimientos en masa, y $1=$ superficie afectada por movimientos en masa. 


\begin{tabular}{|c|c|c|c|}
\hline CAMPO & DESCRIPCIÓN & CODIFICACIÓN & VALORES POSIBLES \\
\hline \multirow{14}{*}{ TIPO } & \multirow{14}{*}{ Tipo de movimiento en masa } & \multirow{14}{*}{ Texto } & Caída de suelo \\
\hline & & & $\begin{array}{c}\text { Caídas de roca (sector con } \\
\text { caídas) }\end{array}$ \\
\hline & & & Complejo \\
\hline & & & Deslizamiento (genérico) \\
\hline & & & Deslizamiento en cuña \\
\hline & & & Deslizamiento rotacional \\
\hline & & & $\frac{\text { Deslizamiento }}{\text { traslacional }}$ \\
\hline & & & Flujo o deslizamiento \\
\hline & & & Flujo de detritos \\
\hline & & & Flujo de tierra \\
\hline & & & $\begin{array}{l}\text { Movimientos menores } \\
\text { asociados a pipping }\end{array}$ \\
\hline & & & $\begin{array}{l}\text { Vuelcos de rocas (sector } \\
\text { con vuelcos) }\end{array}$ \\
\hline & & & Vuelco de suelo \\
\hline & & & $\begin{array}{c}\text { Desconocido } \\
\text { (deslizamiento o flujo muy } \\
\text { degradado) }\end{array}$ \\
\hline \multirow{5}{*}{ ESTADO } & \multirow{5}{*}{$\begin{array}{l}\text { Expresión morfológica del } \\
\text { movimiento, que da indirectamente } \\
\text { una idea de su actividad o edad } \\
\text { relativa (criterio subjetivo) }\end{array}$} & \multirow{5}{*}{ Texto } & Actual \\
\hline & & & Juvenil \\
\hline & & & Degradado \\
\hline & & & $\begin{array}{l}\text { Variable (según las partes } \\
\text { del movimiento) }\end{array}$ \\
\hline & & & Indefinido \\
\hline $\begin{array}{l}\text { FECHA DE } \\
\text { OBSERVACIÓN }\end{array}$ & $\begin{array}{c}\text { Fecha de observación en el campo o } \\
\text { fecha de la imagen. En casos de } \\
\text { varias fechas de observación en } \\
\text { imágenes, se consigna la de mejor } \\
\text { visualización del movimiento }\end{array}$ & Texto & AAAA/MM/DD \\
\hline \multirow{2}{*}{$\begin{array}{l}\text { EDAD } \\
\text { RELATIVA }\end{array}$} & \multirow{2}{*}{$\begin{array}{c}\text { Edad del movimiento con respecto a } \\
\text { la fecha/s de observación. }\end{array}$} & \multirow{2}{*}{ Texto } & Previo al AAAA/MM/DD \\
\hline & & & $\begin{array}{c}\text { Entre el AAAA/MM/DD y el } \\
\text { AAAA/MM/DD }\end{array}$ \\
\hline DESCRIPCIÓN & $\begin{array}{l}\text { Breve descripción de características } \\
\text { sobresalientes del movimiento, } \\
\text { actividad y relación con otros } \\
\text { componentes del paisaje. }\end{array}$ & Texto & $\begin{array}{l}\text { Las descripciones varían } \\
\text { según el tipo de } \\
\text { movimiento }\end{array}$ \\
\hline \multirow{2}{*}{ ESCALA_OBS } & \multirow{2}{*}{$\begin{array}{l}\text { Escala de observación del } \\
\text { movimiento }\end{array}$} & \multirow{2}{*}{ Texto } & CAMPO \\
\hline & & & IMAGEN \\
\hline \multirow{3}{*}{ IMAGEN } & \multirow{3}{*}{$\begin{array}{l}\text { Reseña a fotografía de campo, } \\
\text { imagen satelital (servidor del cual se } \\
\text { obtuvo) o foto aérea donde se } \\
\text { encuentra el movimiento }\end{array}$} & \multirow{3}{*}{ Texto } & $\begin{array}{c}\text { CAMP } 7 \text { - Foto DSCN- } \\
4375\end{array}$ \\
\hline & & & II-RH-650-67 \\
\hline & & & Google Earth \\
\hline
\end{tabular}


Movimientos en masa en las sierras de Bravard y Curamalal,

Sierras Australes de la Provincia de Buenos Aires.

Juan Manuel Susena

Altitud: datos de elevación relativa al nivel del mar, con precisión vertical de $1 \mathrm{~m}$ (variable continua), obtenida del MDE ALOS PALSAR. La importancia de esta variable radica en que se relaciona con las condiciones meteorológicas (temperatura, heladas, viento), e indirectamente con la acción biológica (puede condicionar el desarrollo de diferentes especies), y de ella derivan muchas otras variables quizá más influyentes en el desarrollo de movimientos en masa (Carrara, 1983; Crozier, 1984; Catani et al., 2013).

En la zona seleccionada (Figura 14.2), hay una gran representatividad del piedemonte, que se evidencia en la distribución de los valores de altitud (moda = 435 m s.n.m.). La mayor proporción de la superficie se ubica entre los 420 y 500 m S.n.m. aproximadamente.

Para estudiar la frecuencia relativa de movimientos en masa, los datos de altitud se reclasificaron en intervalos de $5 \mathrm{~m}$. Como se muestra en el histograma, con una perspectiva general, la distribución de la frecuencia relativa es relativamente normal. Todos los valores superiores a $4 \%$ se ubican entre los 495 y los 595 m s.n.m. Algunos movimientos en concreto determinan que haya picos menores tanto a elevaciones más bajas (470-485 m s.n.m.) como a mayor altitud (710-715 m s.n.m.).

Valor mínimo: $412 . \quad$ Rango de valores: $446 . \quad$ Valor medio: 628.

Valor máximo: $858 . \quad$ Valor modal: $435 . \quad$ Desviación estándar: 126.

Pendiente: derivada del procesamiento del MDE, corresponde a la pendiente topográfica, es decir, el ángulo entre la superficie del terreno y el plano horizontal, expresado en grados. Es una variable continua que depende de las derivadas de primer grado de la altitud, se expresa en grados, con una "falsa precisión" de 2 decimales y varía de $0^{\circ}$ (horizontal) a $90^{\circ}$ (vertical). La pendiente es una variable importante en cuanto a la estabilidad de las laderas, así como en la acción hídrica (Brand y Hudson, 1982; Crozier, 1984; Mulder, 1991; Remondo, 2001). En menor medida, la pendiente puede influir indirectamente en la humedad. Para la caracterización de la frecuencia relativa de movimientos en masa, los valores de pendiente se reclasificaron en intervalos de $2^{\circ}$. 


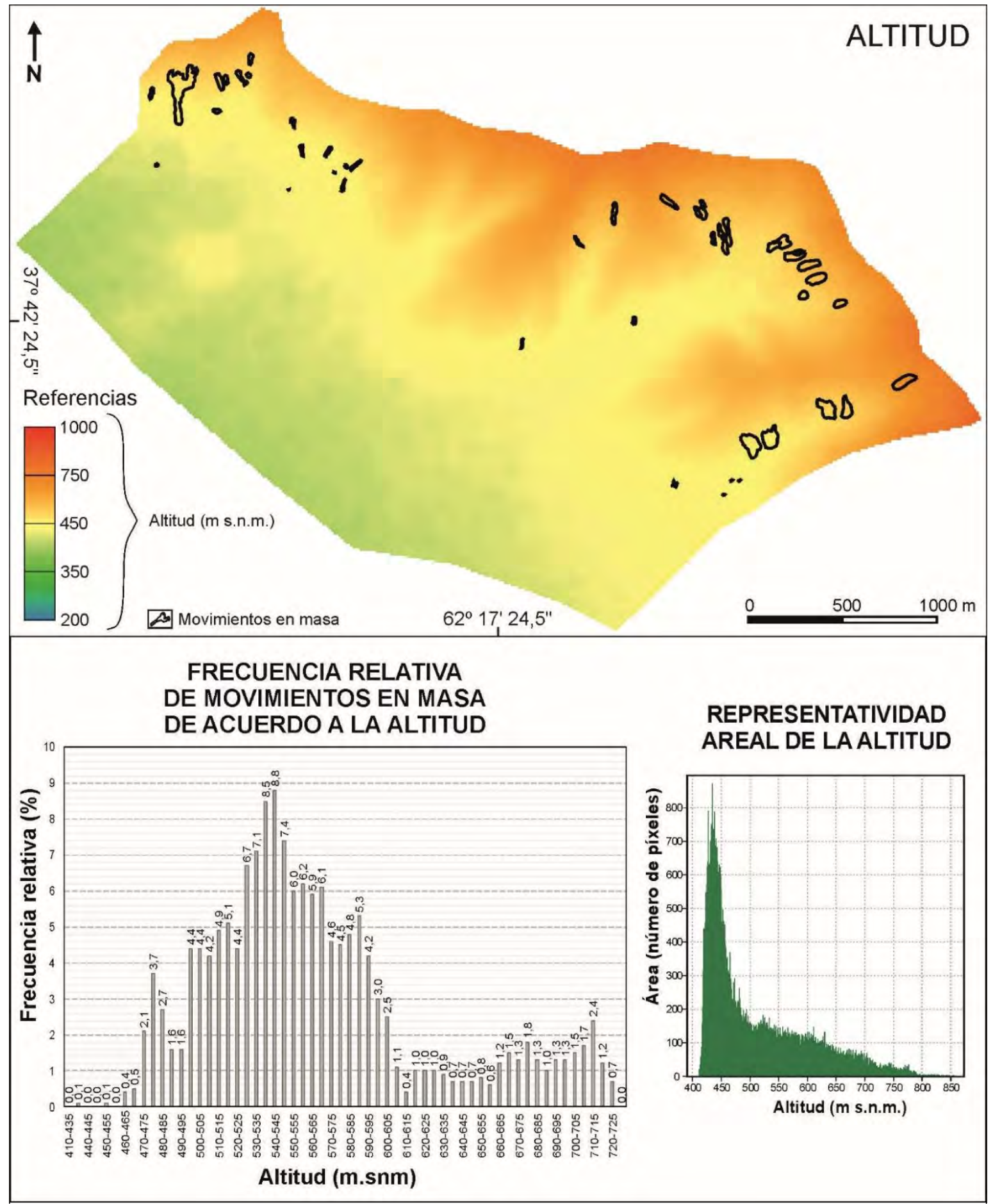

Figura 14.2. Variable ALTITUD.

El área analizada presenta dos picos en la distribución de esta variable (Figura 14.3). El más acusado es el de menores pendientes $\left(0-6^{\circ}\right)$ y coincide con el piedemonte, los pisos de valles intraserranos y las paleosuperficies más elevadas. El pico más suave, situado aproximadamente entre 16 y $28^{\circ}$ corresponde a gran parte de las laderas, tanto rocosas como de detritos y compuestas. 


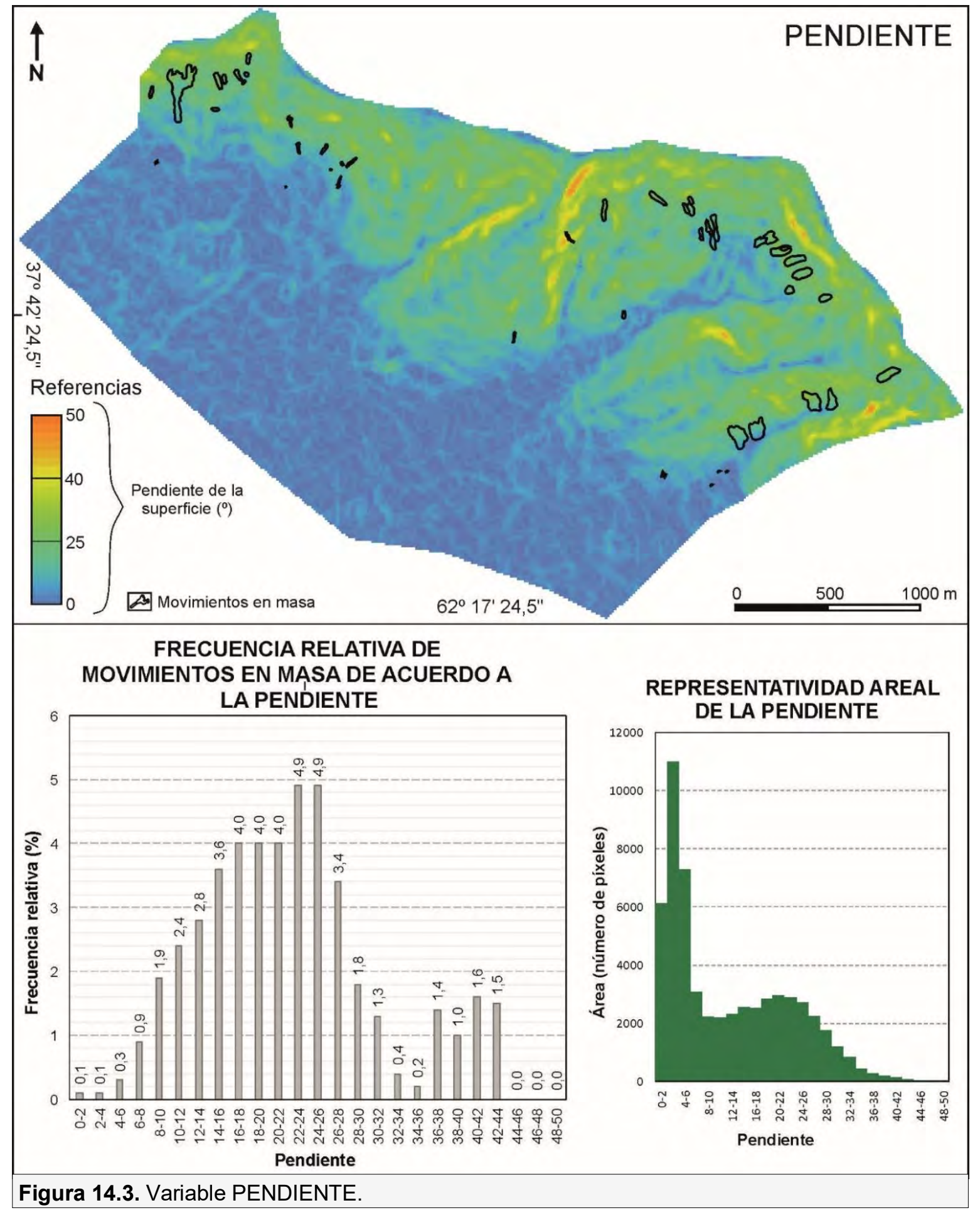

En cuanto a la frecuencia relativa, sus valores más altos coinciden con los últimos valores de pendiente mencionados, y decrecen paulatinamente al aumentar o disminuir la pendiente. Un segundo pico menos acusado se ubica entre los 36 y $44^{\circ}$ de pendiente. 
Valor mínimo: 0.

Valor máximo: 48,81.
Rango de valores: 48,81.

Valor modal: 2,29.
Valor medio: 29,11.

Desviación estándar: 10,32.

Orientación de la superficie: derivada del MDE, el valor de cada celda depende de las derivadas de primer grado de la altitud, y expresa el rumbo de la pendiente respecto al norte geográfico, esto es, el ángulo entre el norte geográfico y la componente horizontal del vector de la máxima pendiente en la unidad del terreno considerada. El algoritmo utilizado en QGIS arroja valores con una precisión de 2 decimales y varían desde $>0^{\circ}$ hasta $360^{\circ}$ con respecto al este, en sentido antihorario, reservándose el valor 0 para las celdas "horizontales" (superficies con pendientes menores a $5^{\circ}$, valor asignado por el operario para eliminar el "ruido" de las superficies de escasa pendiente del piedemonte). Para el análisis, esta variable continua se reclasificó en categorías (rosa de los vientos), como se muestra en la Figura 14.4. La orientación proporciona una medida indirecta de la insolación y consecuentemente el contenido de humedad relativo de una ladera, lo cual puede repercutir en la estabilidad (Remondo, 2001; Dai y Lee, 2002), así como la velocidad potencial relativa de la fusión de nieve, y la exposición a los vientos y frentes de tormenta, el tipo de vegetación, etc.

Como muestra el gráfico de torta, de las superficies inclinadas, las orientadas al $\mathrm{S}$ y SO son las más habituales. La distribución de la frecuencia relativa de movimientos en masa presenta como más propensa a la orientación S (SSE y SSO). Es notorio que en la superficie NO, a pesar de ser tan común en la zona como la SE, la frecuencia relativa es prácticamente nula, fenómeno también apreciable en la superficie horizontal, la más representada en el área.

Valor modal: superficie horizontal (38,22\% de los píxeles).

Valor modal de las superficies inclinadas: $\mathrm{S}$ (18,86\% de los píxeles).

Valor menos frecuente: NE $(0,26 \%$ de los píxeles).

Desviación estándar (\% del número de píxeles): 12,12.

Insolación (radiación solar potencial): matriz de datos relativos del grado de iluminación recibida directamente del sol en ausencia de nubosidad. Esta variable, expresada originalmente en $\mathrm{KWh} / \mathrm{m}^{2}$, deriva del procesamiento del MDE con el software SAGA, teniendo en cuenta el ocultamiento topográfico y se incluyen 


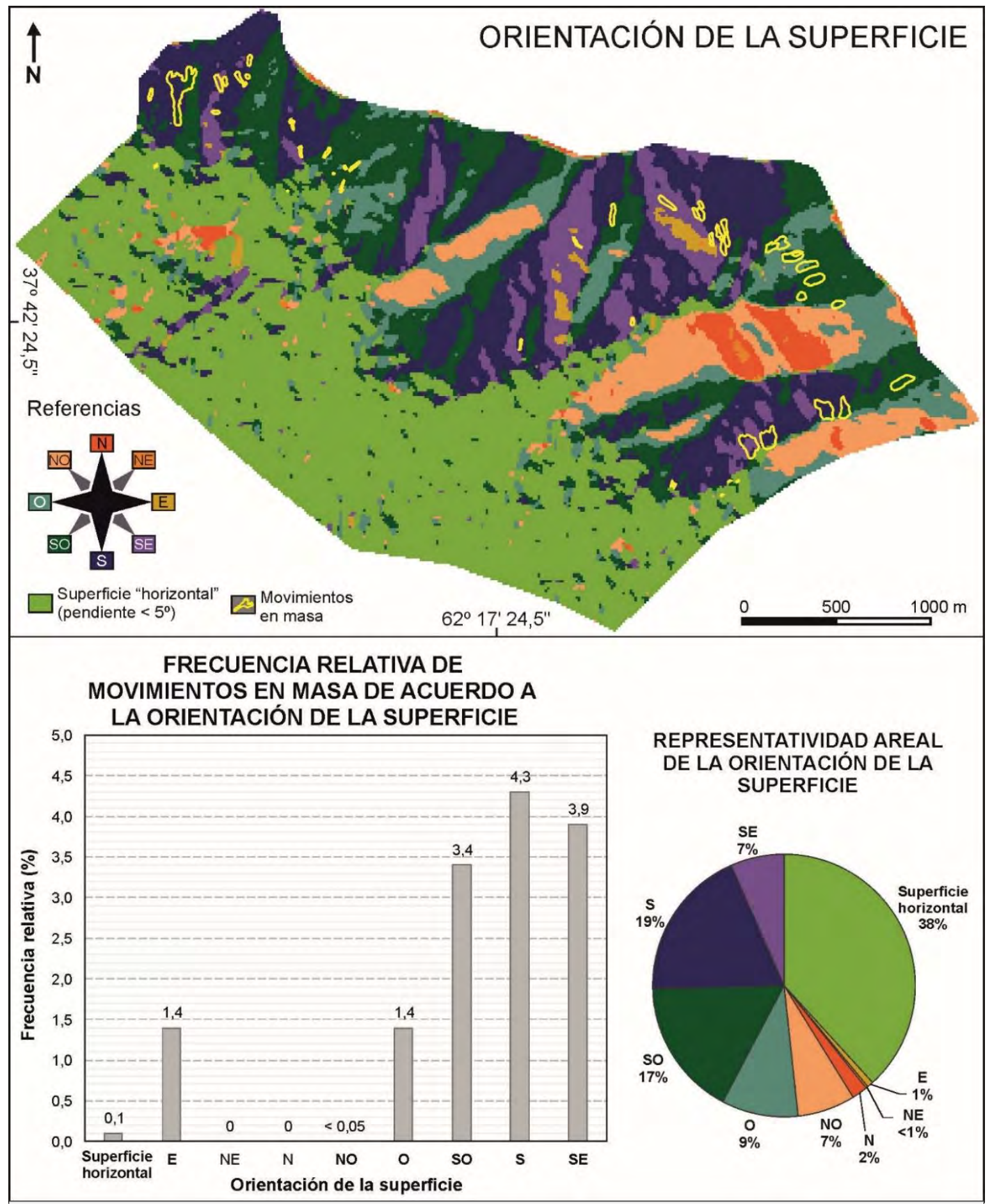

Figura 14.4. Variable ORIENTACIÓN DE LA SUPERFICIE.

parámetros como una constante solar, la declinación solar que depende de la latitud y del día del año para el cual se hace el cómputo, las horas de sol y coeficientes estandarizados relacionados con las condiciones atmosféricas (Boehner y Antonic, 2009). Se calculó en concreto la insolación para el 23 de diciembre, día más largo del año en el área de estudio, como la sumatoria de la insolación calculada cada 15 minutos, desde las 5:45 a.m. hasta las 20:30 p.m. En realidad, lo que interesa 
de esta variable es el grado de insolación relativo (entre celdas), por lo cual los valores se reclasificaron de 0 a 255 (clases de igual intervalo de valor). Con este carácter adimensional de la variable, los datos sólo se refirieren a la exposición al sol, que es lo que interesa en este estudio. Esta variable es indicadora de laderas de umbría y de solana, lo cual determina variaciones en su contenido de humedad, siendo más húmedas las de umbría (Neuland, 1976; Carrara, 1983). La insolación puede influir también en la distribución y grado de desarrollo de la vegetación y en los usos del suelo, pero a la escala de trabajo empleada en esta tesis, dicha influencia no es evidente en el área estudiada.

En el área estudiada, la insolación presenta un pico muy acusado en la distribución, con los mayores valores en el piedemonte (Figura 14.5). La variación de la insolación respecto al área es aproximadamente exponencial. En el mapa puede observarse en color azul, una pequeña concentración de los valores más bajos de insolación en las laderas centrales del área que miran al este, en los tramos proximales.

La frecuencia relativa de movimientos en masa presenta una distribución con dos picos. El primero, muy acentuado, está integrado por los rangos de insolación 4050 y $50-60$, siendo la frecuencia relativa del primero $(20,0)$ más del doble que el segundo $(8,0)$. Ya fuera de este pico, el tercer valor más alto $(5,6)$, correspondiente al intervalo de insolación 180-190, ocupa el centro del segundo pico, mucho más suave que el primero. Cabe destacar que los valores de insolación con mayor frecuencia relativa de movimientos (insolación entre 40 y 60) ocupan una escasa proporción del área estudiada. El segundo pico de frecuencia relativa (el más suave), ocupa un rango muy variado de valores de insolación y se ubica en valores de insolación intermedios a elevados. Por otra parte, valores extremos de insolación, tanto de solana como de umbría, no tienen movimientos en masa registrados. En particular, los valores más bajos de insolación se ubican a la sombra de un frente escarpado rocoso con afloramientos al pie, donde no se desarrollan movimientos cartografiables debido al poco o nulo espesor de detritos. Lo antedicho pone de manifiesto que, salvo en circunstancias particulares donde hay una fuerte influencia de la litología o la geomorfología (caso de los afloramientos rocosos al pie de los frentes escarpados), la insolación muestra una relación con los movimientos en masa: a menor insolación, mayor probabilidad de encontrar movimientos. 
Movimientos en masa en las sierras de Bravard y Curamalal,

Sierras Australes de la Provincia de Buenos Aires.

Juan Manuel Susena

Valor mínimo: 0,0.

Rango de valores: 255.

Valor medio: 214.

Valor máximo: 255.

Valor modal: 245.

Desviación estándar: 36.

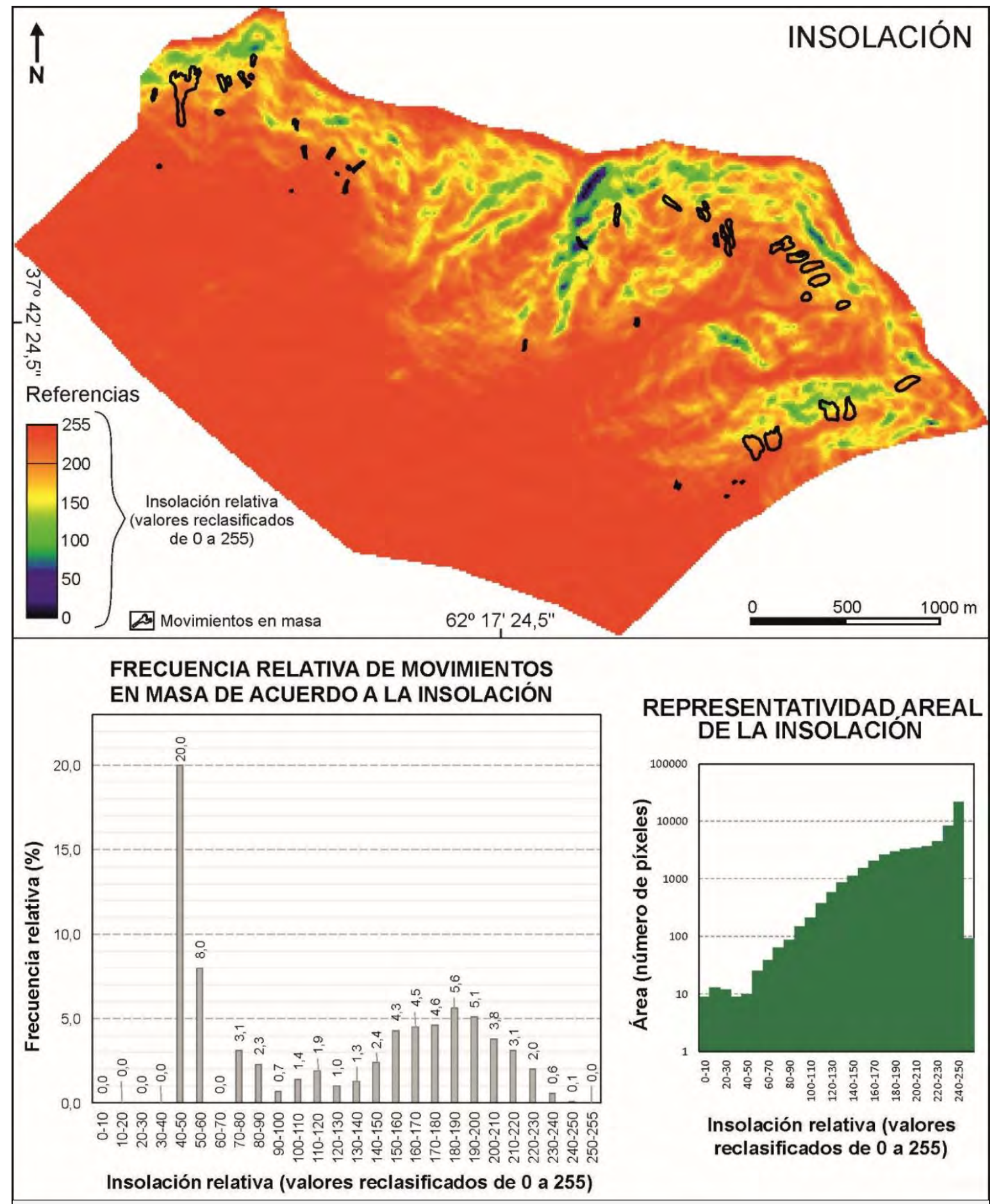

Figura 14.5. Variable INSOLACIÓN. La distribución espacial de la variable (histograma verde) está representada en escala semi-logarítmica. 


\section{Irregularidad (Índice de irregularidad del terreno o Terrain Ruggedness}

Index): matriz donde el valor de cada celda es la suma de los módulos de las diferencias de altura con las celdas vecinas (Riley et al., 1999). El algoritmo utilizado para su cálculo divide este valor por 8 , dando una idea del gradiente promedio entre la celda central y las vecinas, y que Nuun y Puga (2012) denominaron pendiente media. Su precisión es de 3 decimales (falsa precisión), siendo una variable continua. Este índice es una medida de la irregularidad de la superficie, muy sensible a la resolución espacial del MDE y al tamaño de los rasgos del terreno. En el área de estudio, teniendo en cuenta que la resolución del MDE es de 12,5 m, valores medios a altos de irregularidad representan topografía de crestas y depresiones, frentes escarpados rocosos, cuerpos rocosos prominentes, laderas compuestas, afloramientos parcialmente ahogados, laderas de detritos con muchos movimientos en masa (relieve hummocky), y en menor medida bordes de niveles de piedemonte antiguo disectados, barrancas de cursos de agua tipo braided (planicies aluviales de más de $15 \mathrm{~m}$ ), etc.

La distribución espacial de esta variable es similar a la de la pendiente: los valores más frecuentes $(0,0-1,0)$ se ubican en el piedemonte, mientras un segundo pico con una frecuencia bastante menor $(3,0-4,5)$ se asocia a la mayor parte del ambiente serrano (Figura 14.6). Al aumentar la irregularidad, la frecuencia decrece. En el mapa pueden observarse cambios netos en los valores de esta variable, lo cual está relacionado con la morfología de ciertos rasgos del paisaje, como frentes escarpados rocosos (verde y anaranjado en el centro-norte del mapa) y las paleosuperficies (azul, entre los frentes antedichos).

Para la caracterización de la frecuencia relativa de movimientos en masa, los valores se reclasificaron en intervalos de igual valor de 0,5 . Un pico se destaca entre los valores de irregularidad 1,5 y 5,5 , con su frecuencia relativa máxima en torno al valor 4,0. Un pico menor aparece asociado a índices de irregularidad mayores $(7,0$ a 8,5$)$, pero por encima de este umbral no se registraron movimientos en masa. Los valores intermedios de irregularidad, donde hay mayor frecuencia relativa de movimientos en masa, corresponden a tramos proximales a medios de las laderas. En el caso en que estos valores coinciden con tramos medios de las laderas, la irregularidad puede relacionarse con la morfología de los movimientos más grandes, como el más grande en extremo noroccidental del mapa (Figura 14.7). 
Movimientos en masa en las sierras de Bravard y Curamalal, Sierras Australes de la Provincia de Buenos Aires.

Juan Manuel Susena

Valor mínimo: 0,000.

Valor máximo: 11,000.
Rango de valores: 11,000 .

Valor modal: 0,375 .
Valor medio: 5,266.

Desviación estándar: 10,32.

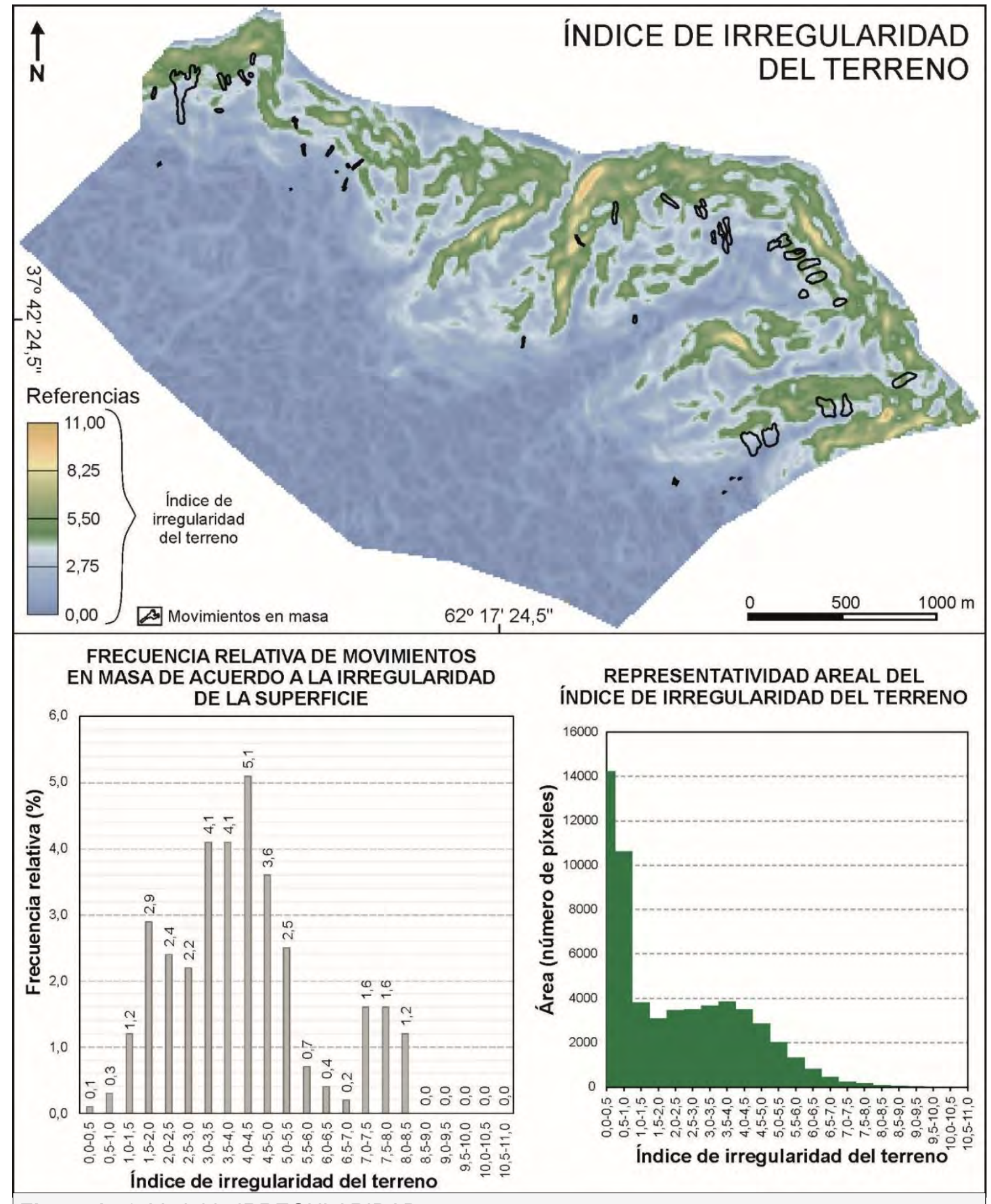

Figura 14.6. Variable IRREGULARIDAD. 


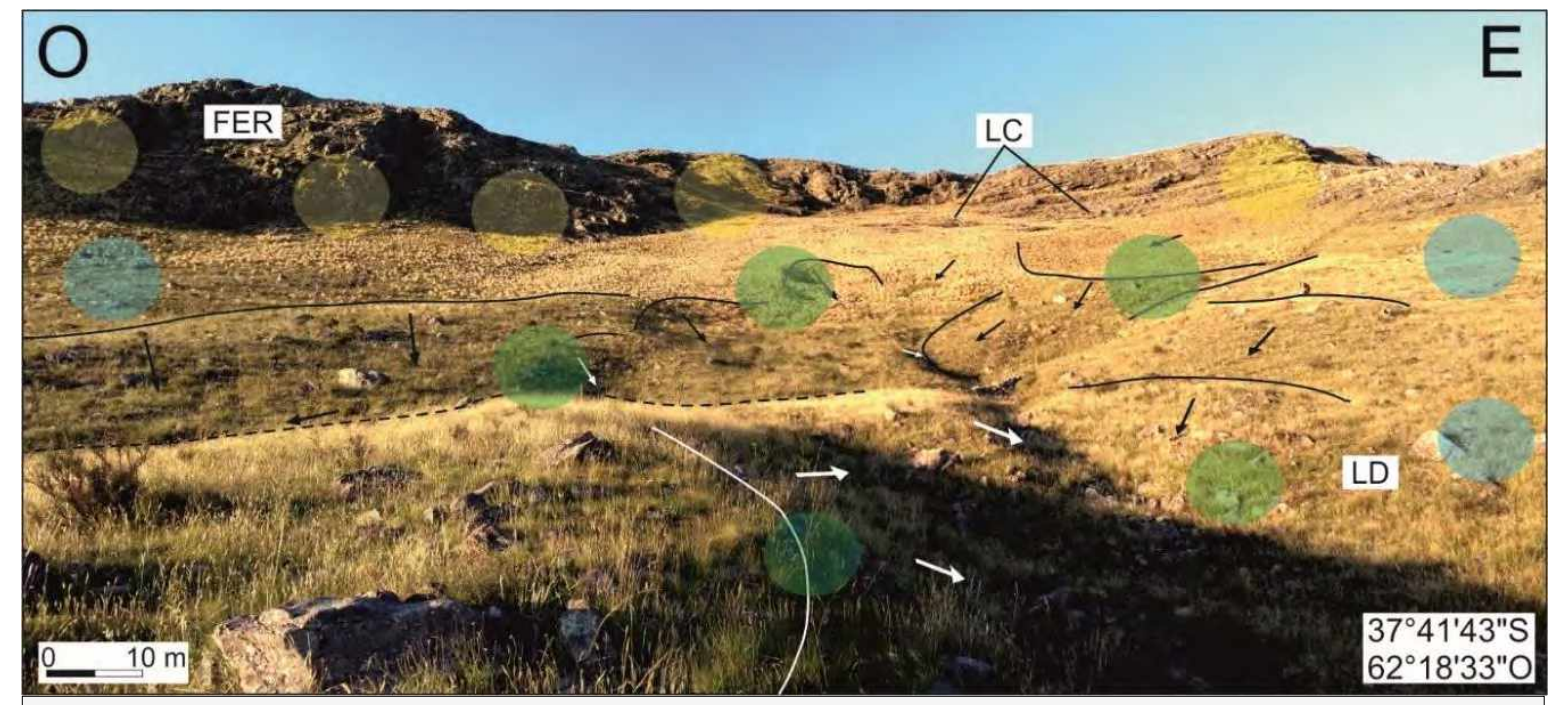

Figura 14.7. Foto panorámica de una ladera con un gran movimiento en masa (y reactivaciones). Círculos: valores relativos del índice de irregularidad (azul $=$ baja; verde $=$ media; amarillo $=$ alta). Líneas continuas: quiebres de pendiente. Flechas: dirección de la pendiente. Los tamaños y colores cumplen la sola función de resaltar los rasgos. Línea discontinua: borde de una lomada que oculta los rasgos ubicados al otro lado. FER: Frente Escarpado Rocoso. LC: Ladera Compuesta. LD: Ladera de Detritos. La escala se ajusta al centro de la foto; la distancia a LC es de unos $250 \mathrm{~m}$.

Curvatura: sus datos representan el grado de concavidad o convexidad de una superficie, y dependen de las derivadas de segundo grado de la altitud (MDE). Los valores obtenidos tienen una precisión de 3 decimales y varían idealmente de -1 (pendientes cóncavas) a 1 (pendientes convexas). Los valores entre -0,001 y 0,001 se clasificaron como pendientes planas. La curvatura refleja la capacidad de la superficie para concentrar o esparcir (dispersar) agua, siendo las superficies cóncavas concentradoras de agua, y las convexas, esparcidoras. Las superficies cóncavas son muy eficientes en la captación del agua de lluvia, posibilitando la generación de movimientos en masa superficiales (Carrara, 1983; Oyagi, 1984; Smith 1988; Reneau et al., 1990; Gao 1993). Se utilizaron tres tipos de curvatura:

- Curvatura general o estándar: es la curvatura tridimensional, es decir, la curvatura de una unidad del terreno (píxel) respecto a su entorno. Como ejemplo, el píxel del centro de una cubeta tendría valores de curvatura cercanos a -1 (cóncava), mientras que el ubicado en el centro de un domo estaría representado por valores próximos a 1 (convexo). La Figura 14.8 muestra la distribución de esta variable en la zona analizada. 
Movimientos en masa en las sierras de Bravard y Curamalal,

Sierras Australes de la Provincia de Buenos Aires.

Juan Manuel Susena

Valor mínimo: $-0,128$. Rango de valores: 0,256. Valor modal: 0,000.

Valor máximo: 0,128. Valor medio: - $-0,005 . \quad$ Desviación estándar: 0,075.

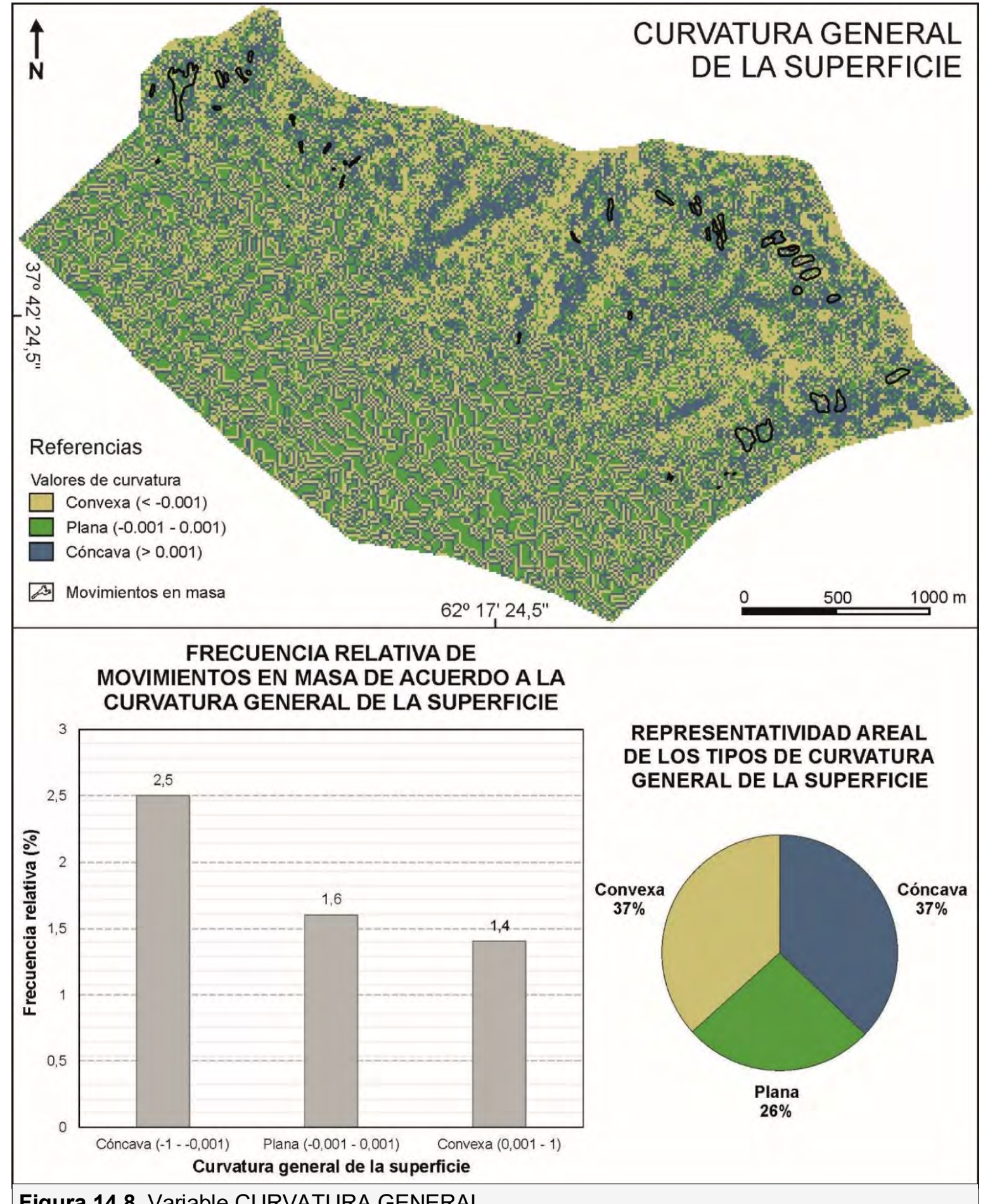

Figura 14.8. Variable CURVATURA GENERAL.

- Curvatura en el sentido de la pendiente o paralela: corresponde a la curvatura medida en el sentido de la pendiente, medida en la dirección de su pendiente. Representa el grado de concavidad-convexidad del terreno en la dirección de la pendiente. De alguna manera, este tipo de curvatura sirve para detectar sectores 
donde el escurrimiento superficial podría, si fuera cóncava, retardarse (eventualmente detenerse) o, si fuera convexa, acelerarse, favoreciendo en el primer caso la infiltración y aumento de la presión poral en las laderas (contribuyendo a la inestabilidad), y en el segundo caso la erosión hídrica. En este sentido, la curvatura paralela también puede reflejar las contrapendientes relacionadas a los deslizamientos rotacionales, e influye en las tasas de erosión y acumulación y consecuentemente en el espesor del regolito (Remondo, 2001; Dai y Lee, 2002; Goetz et al., 2011). La Figura 14.9 muestra la distribución de esta variable en la zona analizada.

Valor mínimo: $-0,032$. Rango de valores: 0,057 . Valor medio: $-0,000$.

Valor máximo: 0,025. Valor modal: 0,005. Desviación estándar: 0,000.

- Curvatura transversal a la pendiente: corresponde curvatura del terreno medida en dirección transversal a la pendiente. Representa el grado de concavidad-convexidad del terreno en la "dirección de las curvas de nivel", y puede indicar, a escala de ladera, la presencia de interfluvios o concentraciones locales del escurrimiento superficial. La Figura 14.10 muestra la distribución de esta variable en la zona analizada.

Valor mínimo: -0,029. Rango de valores: 0,059. Valor medio: 0,000.

Valor máximo: $0,030 . \quad$ Valor modal: 0,000 Desviación estándar: 0,006.

En cuanto a la proporción de las curvaturas, la plana es en los tres casos la minoritaria, pero no irrelevante, ya que ocupa aproximadamente $1 / 4$ de la superficie de la zona analizada. La curvatura plana es más frecuente en el piedemonte, indicando el suavizado del piedemonte debido a la depositación de la cubierta eólica periserrana. La curvatura plana paralela a la pendiente tiene alguna participación en los tramos de las laderas próximos a las cimas o a afloramientos topográficamente más bajos, evidenciando posiblemente poco espesor de los detritos (poca posibilidad de modelado aluvial/fluvial o coluvial). Las superficies convexas son comunes en las cimas planas y divisorias principales, para los tres tipos de curvatura. Asimismo, este tipo de curvatura indica muy bien en la zona la presencia de roca aflorante o a escasa profundidad en las laderas. La curvatura 


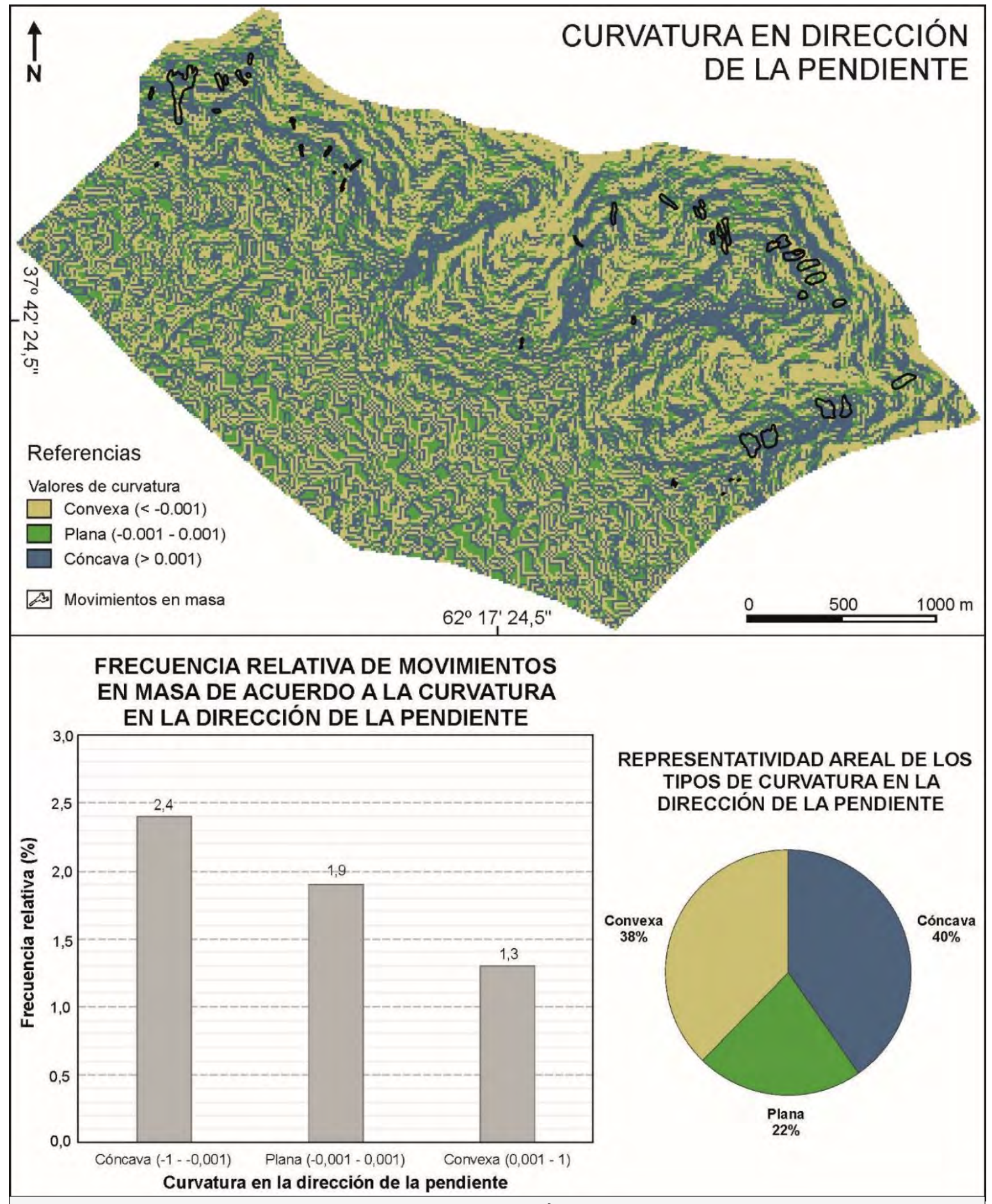

Figura 14.9. Variable CURVATURA EN LA DIRECCIÓN DE LA PENDIENTE O PARALELA.

convexa en la dirección de la pendiente, en cambio, tiene una participación, respecto a la transversal, más reducida y discontinua el ambiente serrano. Se encuentra muy restringida a las cimas planas y divisorias principales. En las laderas, puede observarse una llamativa alternancia de bandas cóncavo-convexas en la curvatura paralela, con un aspecto "aterrazado". Para descartar la posibilidad de que se trate de algún efecto provocado por el algoritmo de procesamiento, se 


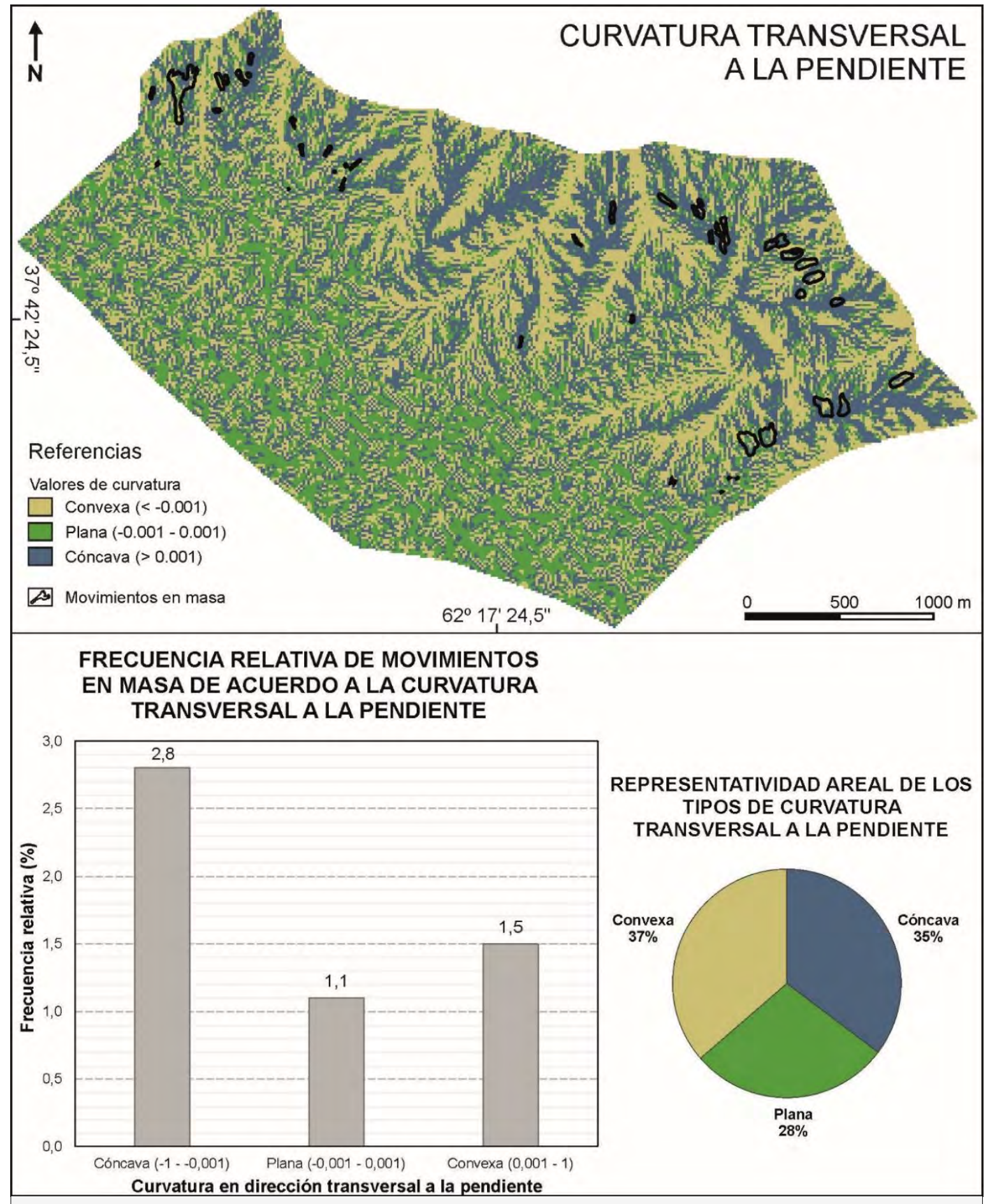

Figura 14.10. Variable CURVATURA TRANSVERSAL A LA PENDIENTE.

remuestreó el DEM a tamaños de celda de $25 \times 25 \mathrm{~m}$ y de 50 × $50 \mathrm{~m}$ y se volvió a calcular la curvatura, observándose un suavizado general de la curvatura, pero una permanencia de esta alternancia cóncavo-convexa. Dicha alternancia podría indicar, dada su regularidad y paralelismo, cierta influencia de la estructura geológica en sub-superficie; de hecho, los segmentos convexos en general coinciden con Afloramientos Parcialmente Ahogados o Laderas Compuestas. La 
Movimientos en masa en las sierras de Bravard y Curamalal,

Sierras Australes de la Provincia de Buenos Aires.

Juan Manuel Susena

pérdida de expresión al aumentar la distancia a los afloramientos es otro elemento que refuerza este argumento, siendo más acusadas las curvaturas paralelas cóncavas en torno a cursos de agua (o en todo caso en la transición entre Bajadas Coluviales Finas o Laderas de Detritos, y la Cubierta Eólica Periserrana o Piedemonte Aluvial Inactivo Moderno), y convexas en sectores de divisorias. La leve dominancia de laderas convexas en el sentido de la pendiente de las unidades coluviales activas, indicaría un dominio (aunque no muy acentuado) de los procesos coluviales por sobre la acción del escurrimiento superficial, o un carácter de inmaduro o juvenil de las laderas desde la perspectiva de la evolución a largo término. Estas acepciones se toman teniendo en cuenta el contexto geomorfológico ya desarrollado en capítulos anteriores; sería difícil arribar a estas conclusiones solamente teniendo en cuenta la curvatura.

La frecuencia relativa de movimientos en masa es mayor en la curvatura cóncava para los tres tipos de curvatura, siendo la diferencia más acentuada en el caso de la curvatura transversal a la pendiente. Puede interpretarse que los movimientos se ubican preferentemente en sectores con mayor tendencia a la concentración del agua superficial, aunque localmente la morfología cóncava podría representar la zona de agotamiento de los movimientos mayores. La curvatura convexa ocupa el segundo lugar sólo en el caso de la curvatura transversal a la pendiente, pudiendo indicar que los movimientos se producen en sectores con escasa cobertura de detritos (afloramientos en sub-superficie influenciando la morfología convexa), o bien que la curvatura convexa responde a la expresión morfológica de los movimientos.

Distancia a cursos de agua: matriz cuyos valores indican la distancia cartográfica al curso de agua más cercano, expresada en $\mathrm{m}$. Los cursos de agua son matrices booleanas generadas a partir de datos vectoriales de líneas correspondientes a cursos de agua y canales artificiales. Se obtuvieron de la base de datos de acceso libre del Programa SIG 250 del IGN, digitalización de la base cartográfica del IGMIGN a escala 1:50.000. A esta información se le agregaron líneas derivadas del MDE, ajustadas mediante fotointerpretación de composiciones de imágenes satelitales de World View-2 (Google Earth y Bing), a escala de observación 1:5000. Los valores así obtenidos se reclasificaron en clases de igual rango de valor, con 
intervalos de $25 \mathrm{~m}$. La proximidad a cursos de agua podría contribuir al desarrollo de movimientos en masa, debido a que los procesos erosivos fluviales remueven el material subyacente, aumentando la inestabilidad (Dai y Lee, 2002; Bonachea, 2006).

Podría decirse que en el área analizada "casi siempre hay un arroyo cerca" (Figura 14.11). La distribución de la frecuencia de distancia a los cursos de agua es decreciente. El valor modal está en la clase 0-25 m. Los valores de mayor distancia

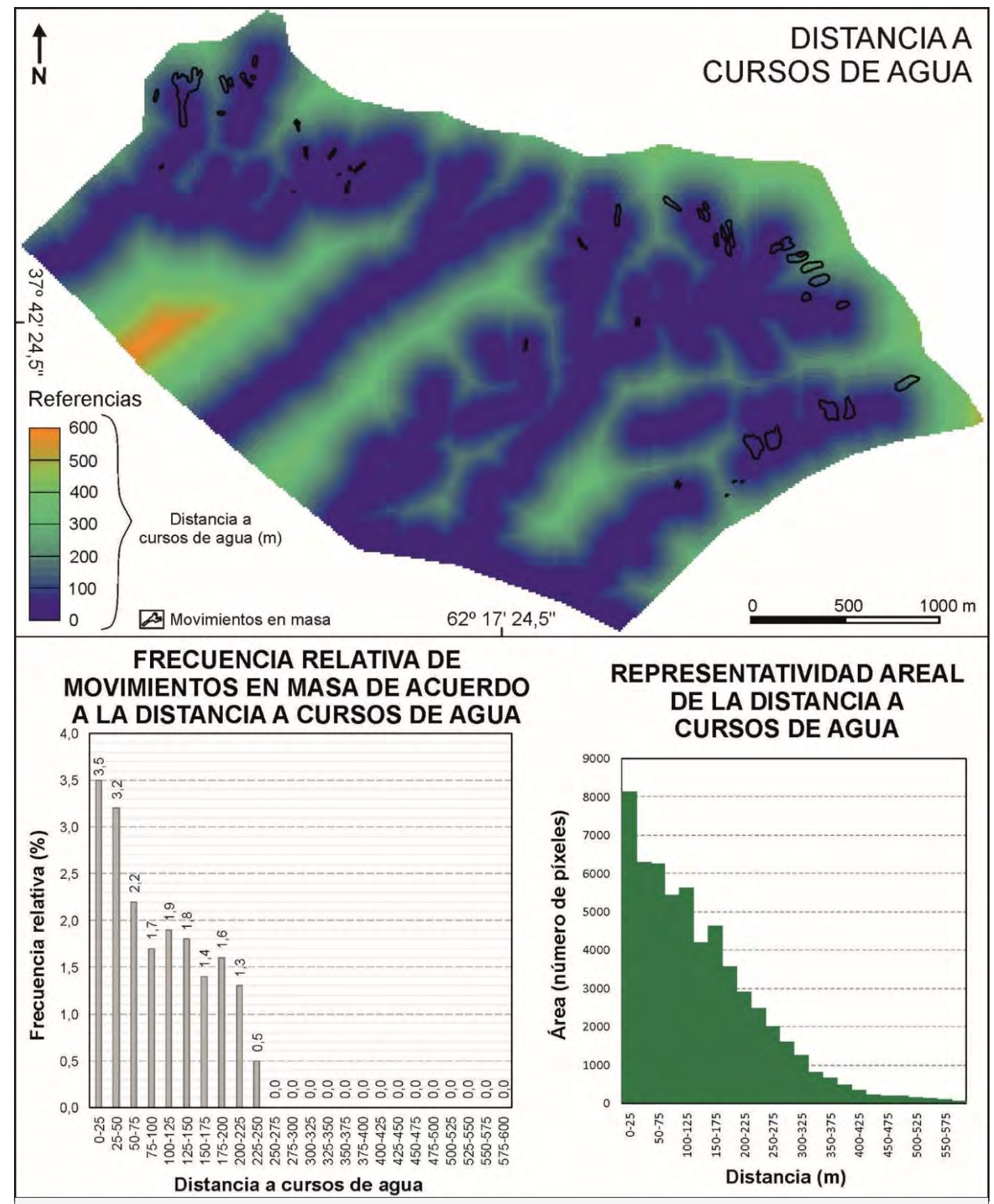

Figura 14.11. Variable DISTANCIA A CURSOS DE AGUA. 
Movimientos en masa en las sierras de Bravard y Curamalal,

Sierras Australes de la Provincia de Buenos Aires.

Juan Manuel Susena

a los cursos se ubican en el piedemonte y en las cimas planas y divisorias principales.

La frecuencia relativa de movimientos en masa presenta una tendencia decreciente hasta los $250 \mathrm{~m}$. Más allá de los $250 \mathrm{~m}$ de los cursos de agua, no se registraron movimientos. El pico principal indica una fuerte relación con los cursos de agua en el entorno inmediato a Fajas Aluviales o Incisiones Fluviales, las últimas, más comunes en el ambiente serrano.

Valor mínimo: 0 .

Rango de valores: 593.

Valor medio: 365.

Valor máximo: 593.

Valor modal: 13.

Desviación estándar: 143.

Distancia a caminos: matriz cuyos valores indican la distancia cartográfica al camino más cercano. Los caminos son líneas correspondientes a caminos asfaltados y de tierra que conectan poblados y establecimientos rurales, obtenidos de la base de datos de acceso libre del Programa SIG 250 del IGN. Se agregaron huellas rurales de vehículos o tránsito constante de animales, identificadas a escala 1:5.000 a partir de composiciones de imágenes satelitales de World View-2 (Google Earth y Bing). La distancia a caminos es una variable continua, expresada en $\mathrm{m}$. Los valores se reclasificaron en clases con distinto rango de valor, acordes a la intensidad de tránsito animal o humano esperada (expresada en la acción antropo y zoogeomorfológica). Además de su influencia sobre la acción antropo y zoogeomorfológica, la presencia de caminos puede modificar la geometría y el comportamiento hidrológico de las laderas (Devkota et al., 2013; Demir et al., 2013). La mayor parte del área analizada se ubica a más de $100 \mathrm{~m}$ de caminos o trazas de huellas principales, encontrándose dichos sectores en los tramos medios o proximales de las laderas, y en las cimas planas y divisorias principales (Figura 14.12).

En cuanto a la frecuencia relativa de movimientos en masa, los sectores más distales son los más afectados por movimientos. Entre los 0 y los $300 \mathrm{~m}$, no hay una tendencia clara de la frecuencia de movimientos respecto a la distancia a caminos, pero luego se ve un incremento al aumentar la distancia, encontrándose la frecuencia relativa máxima a distancias mayores a $500 \mathrm{~m}$. Puede interpretarse que la presencia de caminos no tiene una influencia clara en la distribución de los 


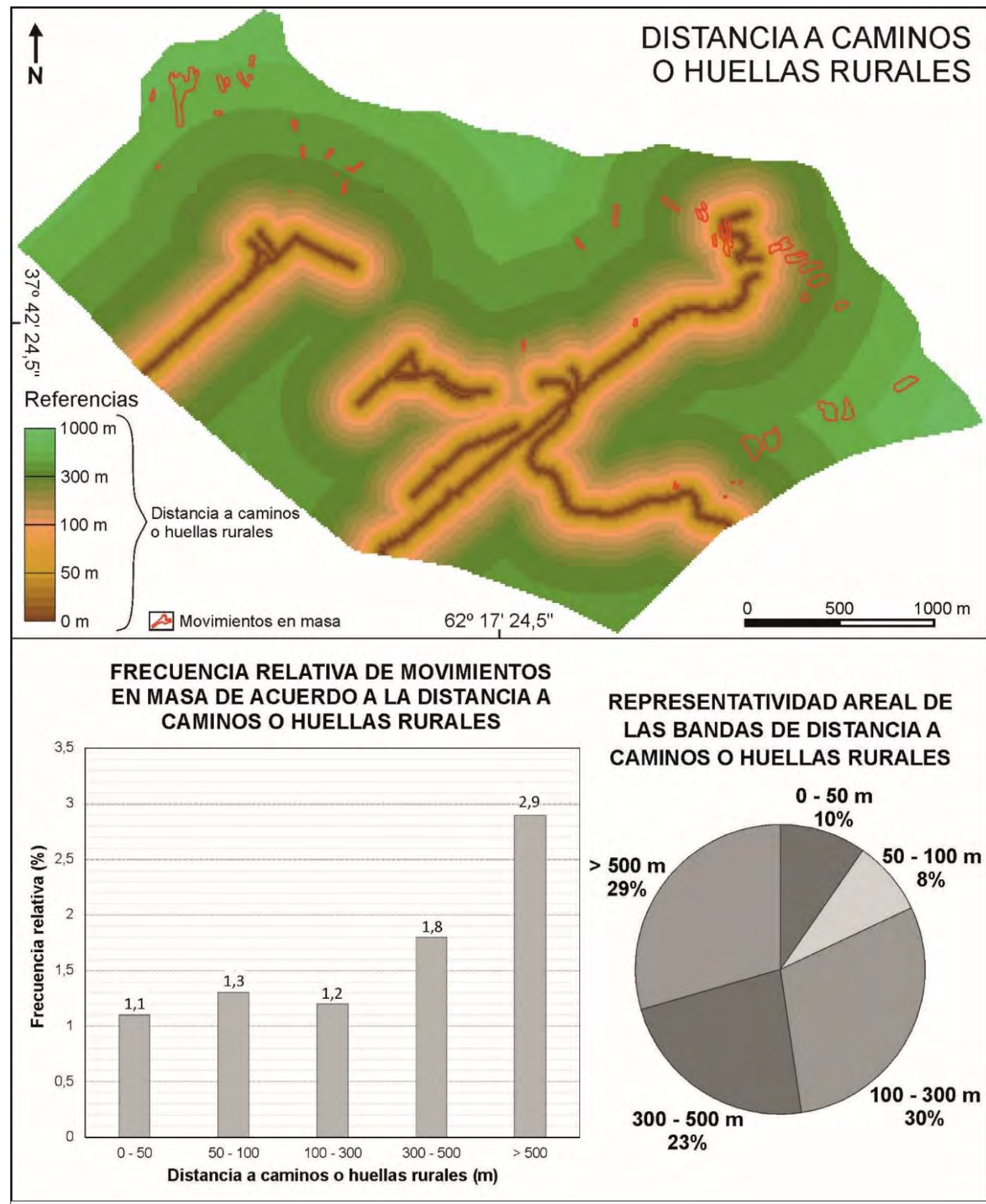

Figura 14.12. Variable DISTANCIA A CAMINOS O HUELLAS RURALES.

movimientos en masa -al menos en un conjunto no clasificado por tipos cinemáticos-, así como que los caminos se construyen en componentes del paisaje de tránsito sencillo (fajas aluviales y niveles de piedemonte), evitando los sectores con más movimientos (ver más adelante). Al respecto, solamente un camino llega hasta la parte más proximal del ambiente serrano y recorre parte de una ladera de 
Movimientos en masa en las sierras de Bravard y Curamalal,

Sierras Australes de la Provincia de Buenos Aires.

Juan Manuel Susena

detritos, resultando difícil interpretar si "el camino se acercó a los movimientos" o si "los movimientos se acercaron al camino".

Valor mínimo: 0.

Rango de valores: 1418.

Valor medio: 784 .

Valor máximo: 1418.

Valor modal: 13.

Desviación estándar: 309.

Litología: matriz de valores que representan el tipo de roca o sedimento inconsolidado, clasificados en 12 categorías (Tabla 14.4). Como una primera aproximación se utilizaron mapas geológicos y geomorfológicos preexistentes a escala 1:200.000, 1:75.000 y 1:50.000 (Harrington, 1947; De Francesco, 1992a; Pereyra y Ferrer, 1995). Se mapearon luego polígonos a escala 1:5.000 ajustando dicha cartografía (añadiendo/agrupando unidades y modificando límites de unidades)

\begin{tabular}{|c|c|c|c|}
\hline Categoría & Código & Litología & $\begin{array}{c}\text { \% ocupado en } \\
\text { la zona } \\
\text { analizada }\end{array}$ \\
\hline 1 & BAS AFL & $\begin{array}{l}\text { Basamento principalmente aflorante (rocas ígneo- } \\
\text { metamórficas) }\end{array}$ & 0,00 \\
\hline 2 & BAS CUB & Basamento principalmente cubierto (por detritos) & 0,00 \\
\hline 3 & CML AFL & $\begin{array}{l}\text { Gr. Curamalal principalmente aflorante (cuarcitas con } \\
\text { conglomerados y limolitas subordinados) }\end{array}$ & 25,84 \\
\hline 4 & CML CUB & Gr. Curamalal principalmente cubierto (por detritos) & 6,83 \\
\hline 5 & VNT AFL & Gr. Ventana principalmente aflorante (cuarcitas) & 0,00 \\
\hline 6 & VNT CUB & Gr. Ventana principalmente cubierto (por detritos) & 0,00 \\
\hline 7 & BCC & Brecha Cerro Colorado (brechas silicificadas) & 0,80 \\
\hline 8 & MALV & Fm. Las Malvinas (calcretas psefíticas) & 0,00 \\
\hline 9 & CALC & Unidades con calcretas notables no diferenciadas & 0,00 \\
\hline 10 & ALUV & Depósitos aluviales (Fm. Agua Blanca y Aluvio) & 8,55 \\
\hline 11 & SAAV & $\begin{array}{l}\text { Fm. Saavedra y similares debido a modificación antrópica } \\
\text { (depósitos eólicos) }\end{array}$ & 28,20 \\
\hline 12 & DETR & Detritos de Ladera y Aluvio subordinado & 29,78 \\
\hline
\end{tabular}


Mediante interpretación visual de composiciones de imágenes satelitales de World View-2 (Google Earth y Bing) y relevamiento de campo. La litología es un parámetro muy utilizado en el análisis de movimientos en masa, y debe tenerse en cuenta porque su inclusión mejora los modelos de susceptibilidad (Felicísimo et al., 2013), ya que indica el comportamiento geomecánico (resistencia al corte, cohesión, susceptibilidad a la meteorización) e hidrológico (permeabilidad), influyentes en los tipos de movimientos que se pudieran desarrollar (deslizamientos, flujos, etc.).

Los tipos litológicos principales en el área analizada son los Detritos de Ladera y Aluvio subordinado y Fm. Saavedra y similares debido a modificación antrópica, ambas unidades son regolito y ocupan en conjunto más de la mitad del área analizada (Figura 14.13). El Gr. Curamalal principalmente aflorante (roca) sigue en importancia, ocupando un cuarto de la zona. Los depósitos aluviales ocupan menos del $10 \%$ del área, lo mismo que el $\mathrm{Gr}$. Curamalal principalmente cubierto (alternancia aflorante/sub-aflorante).

La mayor frecuencia relativa de movimientos en masa corresponde a los Detritos de Ladera (5,9\%), seguido por los depósitos aluviales, con una frecuencia casi 9 veces menor $(0,7 \%)$. Es de destacar la escasa frecuencia de movimientos en roca (Gr. Curamalal tanto aflorante como cubierto), y en Fm. Saavedra y unidades similares, a pesar de que ocupan una gran proporción del área analizada. Esto se debe a que la roca o los depósitos loessoides tienden a generar movimientos menores no mapeables a escala 1:5.000 (en el campo sí se vieron movimientos afectando a estas unidades), o a que se asocian a componentes geomorfológicos o partes de componentes geomorfológicos más estables.

Valor modal: Detritos de Ladera (29,78\% de las celdas).

Valor menos frecuente: Brecha Cerro Colorado (0,42\% de las celdas).

Desviación estándar (\% del número de píxeles): 12,68.

Geomorfología: polígonos de igual unidad o componente geomorfológico, agrupados en 22 categorías (Tabla 14.5). Se generaron mediante el mapeo a escala 1:5.000 a partir de composiciones de imágenes satelitales de World View-2 (Google Earth y Bing y ESRI), fotografías aéreas del INTA y el ex-MOSP, y relevamiento de campo. Los componentes antrópicos existentes en el área (alambrados, tranqueras, molinos, tanques australianos y abrevaderos) no se 


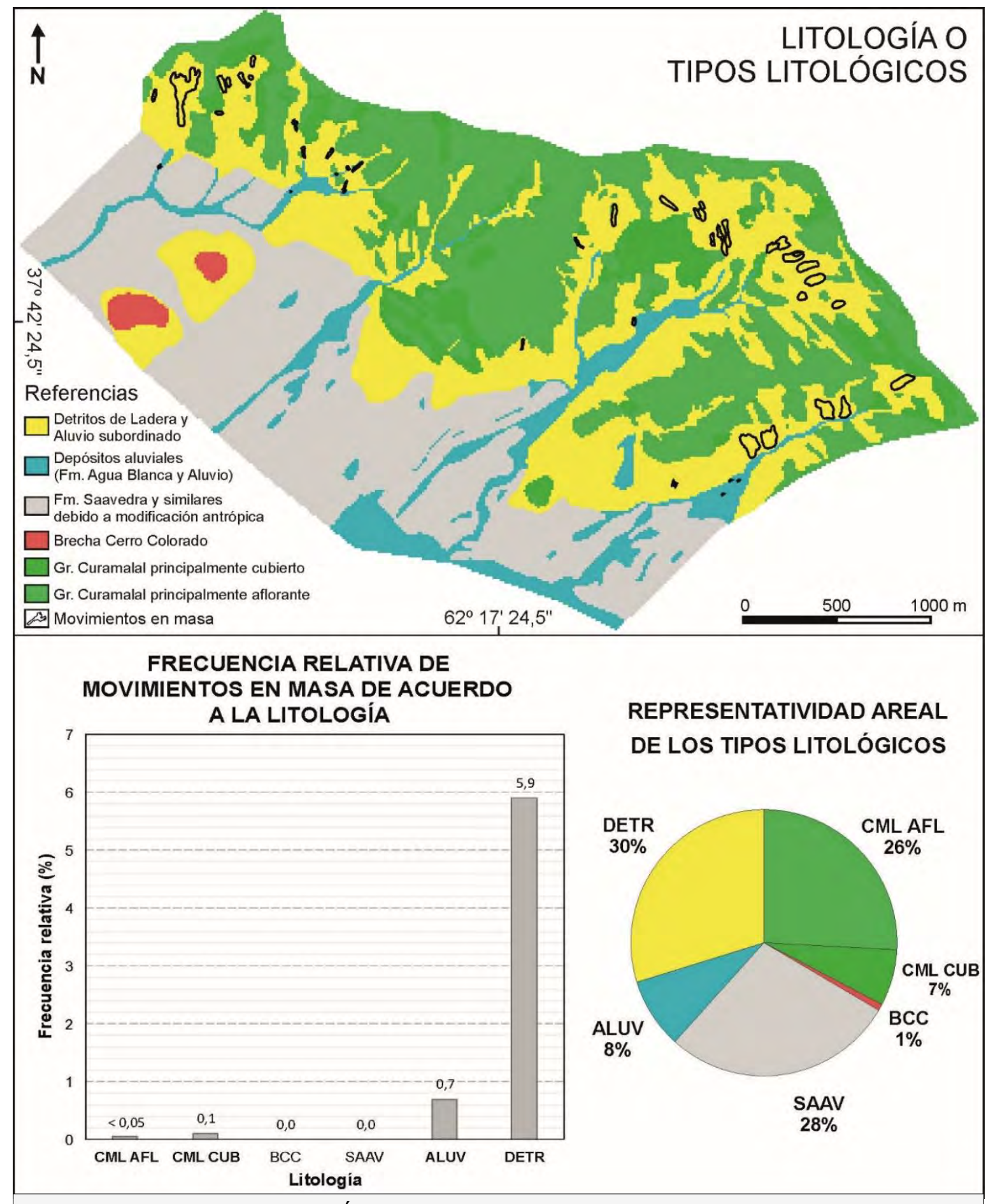

Figura 14.13. Variable LITOLOGÍA.

tuvieron en cuenta en el mapeo, dada su distribución discontinua y escasa representatividad en el mapa, siendo entendidos como geoformas menores.

Aunque la geomorfología se relaciona con otras variables morfométricas (curvatura, rugosidad, etc.), se considera de utilidad para el análisis de susceptibilidad a movimientos en masa (entre otros, Remondo et al., 2008; Galve et al., 2011). La cartografía geomorfológica aporta el criterio de campo al análisis, ya que discrimina 
superficies con dominancia de unos procesos geomórficos sobre otros, tales como la meteorización, la acción del escurrimiento difuso y el escurrimiento encauzado, la relación erosión/acumulación, etc., información importante y difícil de obtener y representar adecuadamente mediante las variables automáticas con que se dispone.

La Tabla 14.5 resume los componentes geomorfológicos del área y su abundancia relativa. La Cubierta Eólica Periserrana y las Laderas de Detritos son los dos componentes más abundantes de la zona (27,84\% y $24,27 \%$, respectivamente), seguidos en menor proporción por las Laderas Compuestas $(12,00 \%)$, Laderas Rocosas $(8,80 \%)$ y Fajas Aluviales $(5,69 \%)$. El resto representa individualmente

\begin{tabular}{|c|c|c|}
\hline Categoría & Geomorfología & $\begin{array}{l}\% \text { ocupado en la } \\
\text { zona analizada }\end{array}$ \\
\hline $\mathrm{ABF}$ & Abanicos aluviales finos & 0,32 \\
\hline$A B G$ & Abanicos aluviales de materiales gruesos & 0,04 \\
\hline $\mathrm{AFH}$ & Afloramientos parcialmente ahogados & 0,72 \\
\hline ALVA & Piedemonte aluvial activo indiferenciado & 0,00 \\
\hline ALVI & Piedemonte aluvial inactivo moderno indiferenciado & 2,81 \\
\hline $\mathrm{BCF}$ & Bajada coluvial fina & 0,60 \\
\hline CDP & Relieve de crestas y depresiones pronunciadas & 0,50 \\
\hline CDS & Relieve de crestas y depresiones suaves & 0,09 \\
\hline CEP & Cubierta eólica periserrana & 27,89 \\
\hline $\mathrm{CO}$ & Collados & 0,20 \\
\hline CPDP & Cimas planas y divisorias principales & 3,52 \\
\hline CRP & Cuerpos rocosos prominentes & 2,02 \\
\hline FA & Fajas aluviales & 5,69 \\
\hline FER & Frentes escarpados rocosos & 4,02 \\
\hline GDR & Gargantas en discontinuidades rocosas & 0,00 \\
\hline IF & Incisiones fluviales & 0,77 \\
\hline LC & Laderas compuestas & 12,00 \\
\hline LD & Laderas de detritos & 24,27 \\
\hline LR & Laderas rocosas & 8,80 \\
\hline PMA & Piedemonte aluvial antiguo & 3,17 \\
\hline PMCA & Piedemonte coluvial antiguo & 1,98 \\
\hline RFER & Remanentes de frentes escarpados rocosos & 0,61 \\
\hline
\end{tabular}


Movimientos en masa en las sierras de Bravard y Curamalal,

Sierras Australes de la Provincia de Buenos Aires.

Juan Manuel Susena

menos del $5 \%$ del área analizada (Figura 14.14). Es notoria y merece ser comentada la similitud entre la Cubierta Eólica Periserrana (CEP) y los depósitos eólicos (SAAV, unidad litológica), puesto que ambas unidades son aparentemente idénticas, pero no coinciden exactamente. La superficie ocupada por CEP es un $27,89 \%$ del área estudiada, mientras que SAAV ocupa un $28,20 \%$; esta diferencia de $0,31 \%$, es semejante o mayor que la superficie relativa de algunas unidades

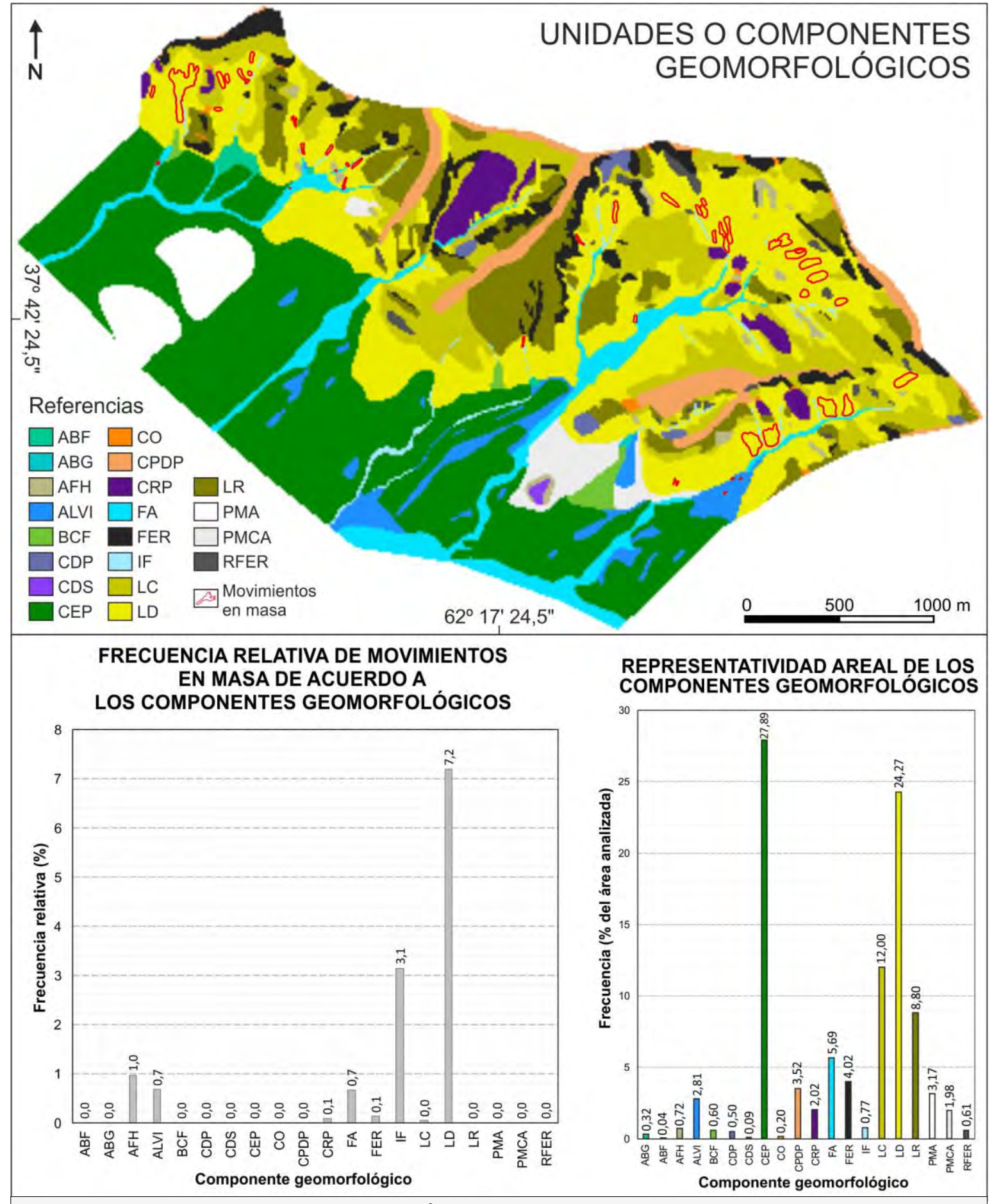

Figura 14.14. Variable GEOMORFOLOGÍA. 
geomorfológicas, como Abanicos aluviales finos (0,32\%), Abanicos aluviales de materiales gruesos $(0,04 \%)$, Relieve de crestas y depresiones suaves $(0,09 \%)$ y Collados (0,20\%). Dicha diferencia radica en que SAAV (unidad litológica) puede coincidir con las unidades geomorfológicas CEP o con Incisiones Fluviales (IF). Siendo una unidad geomorfológica erosiva, IF estrictamente no puede ser mapeada como unidad litológica (por ejemplo, depósitos aluviales).

Las Laderas de Detritos (LD) y las Incisiones Fluviales (IF) son los dos componentes con mayor frecuencia relativa de movimientos en masa $(7,2$ y 3,1 , respectivamente).

Las Laderas de Detritos son la unidad geomorfológica preferencial para el desarrollo de grandes movimientos, dado el espesor de detritos y las pendientes. Observando el mapa puede verse también que las LD se intercalan con unidades con influencia de la estructura de la roca, como Laderas Compuestas (LC) y Cuerpos Rocosos Prominentes (CRP), pero éstas tienen escasos movimientos cartografiables, indicando que su desarrollo o propagación son muy limitados. En el campo se comprobó, que estas unidades, así como otras influenciadas por la estructura geológica son activas en cuanto a movimientos de tipo caídas, vuelcos y deslizamientos de rocas.

Los Afloramientos Parcialmente Ahogados (AFH) muestran una frecuencia relativa menor $(1,0)$ relacionándose con movimientos superficiales de escaso espesor de regolito. Por otra parte, es notorio que las IF, a pesar de estar poco representadas en la zona analizada $(0,77 \%)$ son unidades muy afectadas. Las IF se ubican en el contacto entre dos laderas de valle (generalmente LD) y no desarrollan planicies de inundación como las Fajas Aluviales (FA); dado su escaso desarrollo y su contacto con LD, su morfología puede verse muy afectada por los movimientos en masa, pudiendo los cauces ser sepultados o desviados (véase Capítulo 12 Relación entre movimientos en masa y escurrimiento superficial/sub-superficial). Otras dos de las unidades aluviales (FA y Piedemonte Aluvial Inactivo Moderno Indiferenciado ALVI) tienen frecuencias relativas similares, bajas. Aunque los movimientos en masa son importantes en el modelado de estas unidades (ver Capítulo 10 Movimientos en masa en cursos de agua), las geoformas originadas tienen poca persistencia en el paisaje, por lo cual están poco expresadas a la escala analizada. En el resto de las unidades de la zona analizada no se registraron movimientos cartografiables, aunque debe recordarse que muchas de las unidades tienen movimientos menores, 
Movimientos en masa en las sierras de Bravard y Curamalal,

Sierras Australes de la Provincia de Buenos Aires.

Juan Manuel Susena

ya descriptos en los capítulos anteriores de esta tesis, como la Cubierta Eólica Periserrana (movimientos en caminos), las Bajadas Coluviales Finas y Abanicos Aluviales Finos (flujos de tierra), el Relieve de Crestas y Depresiones Suaves y Pronunciadas (caídas y vuelcos de rocas), los Frentes Escarpados Rocosos (caídas, vuelcos y deslizamientos de rocas), etc.

Valor modal: Cubierta Eólica Periserrana (27,89\% de las celdas).

Valor menos frecuente: Abanico Aluvial de Materiales Gruesos (0,04\% de las celdas).

Desviación estándar (\% del número de píxeles): 7,87.

Vegetación: representa tipos o dominancia de tipos de vegetación y/o su proporción respecto al suelo descubierto. Se generaron a partir de fotointerpretación a escala 1:5.000 de composiciones de imágenes satelitales de World View-2 (Google Earth y Bing y ESRI), y observaciones de campo. Las observaciones de campo consistieron en identificar cualitativamente la proporción y tipos de vegetación en cada componente geomorfológico, asociándose los tipos de vegetación con los diferentes componentes. En este aspecto, el mapa de vegetación es en gran medida derivado del geomorfológico, corregido por fotointerpretación en sectores puntuales de crecimiento de bosques, desarrollo de caminos, erosión hídrica, etc.

La Tabla 14.6 y la Figura 14.15 muestran la distribución espacial de las unidades de vegetación, con un claro dominio de superficies con pastizal $(28,68 \%$ ) y superficies cultivadas $(27,67 \%)$. El roquedal tiene también una participación notable.

\begin{tabular}{|cc|c|}
\hline Categoría & Tipo de vegetación & $\begin{array}{c}\text { \% ocupado en la } \\
\text { zona analizada }\end{array}$ \\
\hline ARBOL & Arboleda & 1,00 \\
ESC COB & Escasa cobertura arbustiva y de pastizal & 9,93 \\
PAST & Pastizal & 28,68 \\
PAST > ROQ & Pastizal dominante sobre roquedal & 1,21 \\
ROQ $>$ PAST & Roquedal dominante sobre pastizal & 15,42 \\
ROQ & Roquedal & 15,26 \\
DESCUB & Suelo descubierto & 0,83 \\
CULT & Cultivo & 27,67 \\
\hline Tabla 14.6. Unidades de vegetación. & & \\
\hline
\end{tabular}




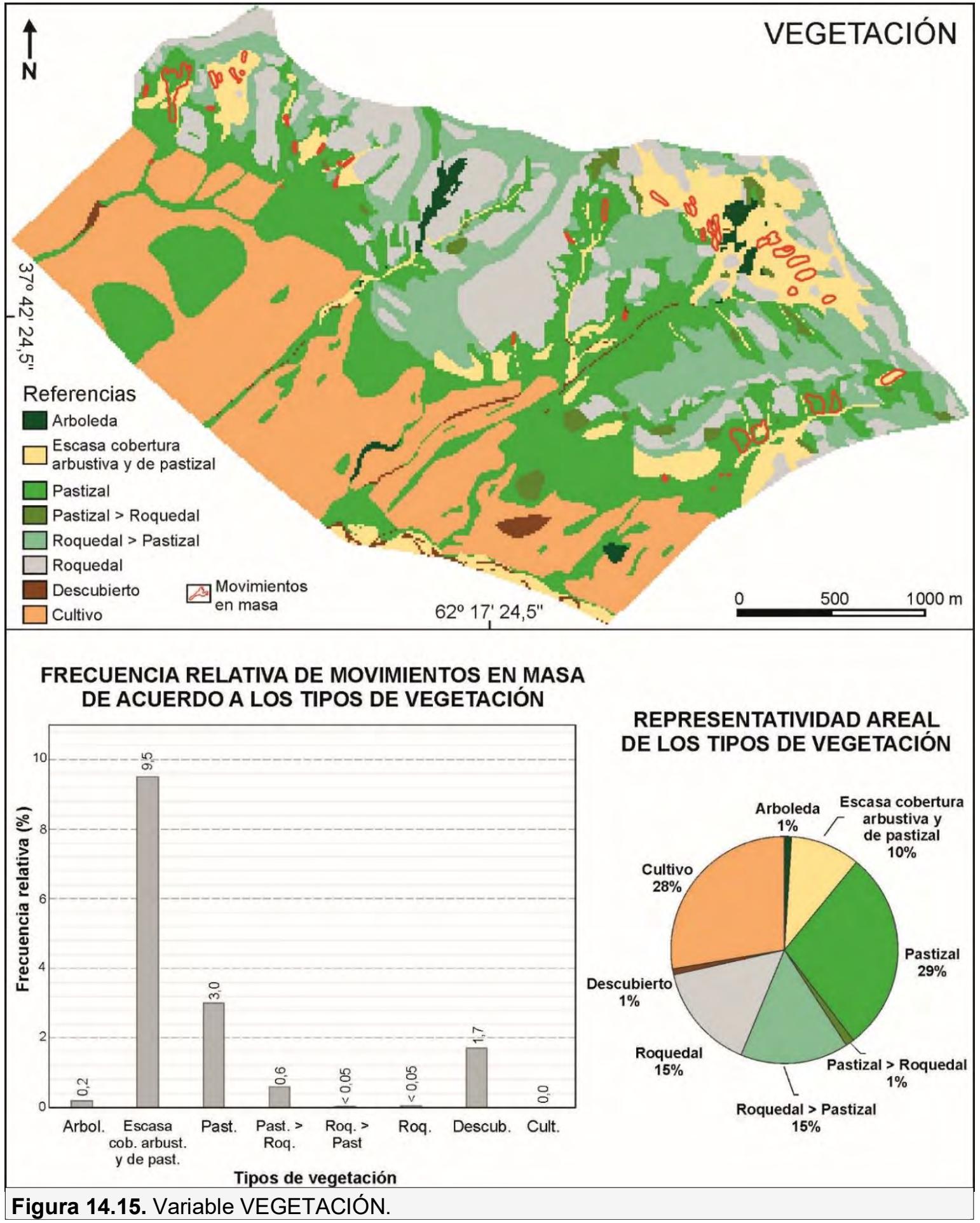

La clase de vegetación con mayor frecuencia relativa de movimientos en masa es la de escasa cobertura arbustiva y de pastizal $(9,5)$, seguida por el pastizal $(3,0)$ y el suelo descubierto $(1,7)$. No se registraron movimientos mapeables en las superficies con cultivos, y en el resto de las unidades la frecuencia relativa es inferior a 1. La asociación de la escasa cobertura arbustiva y de pastizal con los movimientos en masa podría estar indicando una relación de causalidad debido a 
Movimientos en masa en las sierras de Bravard y Curamalal,

Sierras Australes de la Provincia de Buenos Aires.

Juan Manuel Susena

una menor protección del suelo respecto a otras superficies, así como una respuesta a procesos que podrían contribuir al desarrollo de ambas características (poca vegetación y movimientos en masa), como el lavaje de los materiales finos en los tramos proximales o medios de las laderas. Es de destacar que en las laderas, la vegetación es una variable discriminante de la proporción de material fino y las condiciones hidrológicas.

Particularmente la escasa cobertura arbustiva y de pastizal indica sectores de lavaje de la matriz y materiales permeables, condiciones favorables para el desarrollo de deslizamientos. Por otro lado, en el mapa puede observarse que una buena parte de los movimientos se vincula a áreas con abundante pastizal; sin embargo, la frecuencia relativa es baja, dada la importante extensión de esta unidad. El pastizal puede desarrollarse con relativa rapidez en las zonas de agotamiento y superficies de ruptura, donde hay mayor contenido de humedad, tendiendo a "sanar las heridas" producidas por los movimientos. En este sentido, el pastizal puede ubicarse en inestabilidades pasadas, pero no necesariamente indica condiciones de inestabilidad, como lo muestra su baja frecuencia relativa de movimientos en masa.

Valor modal: Pastizal $(28,68 \%$ de las celdas)

Valor menos frecuente: Suelo descubierto $(0,83 \%$ de las celdas $)$

Desviación estándar (\% del número de píxeles): 11,41

\subsection{Consideraciones geomorfológicas sobre las variables}

A continuación se presenta, a modo de recapitulación, una serie de conclusiones sobre el significado geomorfológico de las variables y su relación con los movimientos en masa, a partir del análisis de la frecuencia relativa. En los siguientes apartados se complementan estas observaciones con análisis estadísticos, los modelos de susceptibilidad y análisis de sensibilidad de las variables.

Todas las variables analizadas muestran diferencias significativas de frecuencia relativa entre sus respectivas clases. En algunas, sólo una o dos clases sobrepasan ampliamente a las demás (orientación, insolación, litología, geomorfología y 
vegetación), mientras que en otras, las diferencias son más graduales entre un rango continuo de categorías (altitud, pendiente, curvaturas, rugosidad, distancia a caminos y distancia a cursos de agua). Como fuera expresado en la explicación de cada variable, en algunos casos, altas frecuencias relativas de movimientos en masa no indican necesariamente una relación de causalidad, como se vio en la distancia a caminos y la presencia de abundante pastizal, pero en general se pudo entender el significado geomorfológico de cada variable y relacionarlo con la existencia de movimientos en masa.

Entre las variables "automáticas", particularmente las curvaturas explican la relación de los movimientos con la concentración de agua en la superficie, lo cual se vio en el campo. La variable altitud indica en cierta manera la ubicación de los movimientos y de los componentes geomorfológicos donde estos se desarrollan. Considerando la existencia de cimas planas, valles muy encajados de fondo plano y laderas entre estos dos elementos, el espesor de detritos es una variable bastante regular que, en las laderas depende de su posición topográfica (distancia a los afloramientos), pudiendo la altitud indicar indirectamente esta relación. La pendiente es otra variable que explica el desarrollo de movimientos, no sólo por indicar situaciones de alto esfuerzo cortante, sino también porque dentro de una misma ladera la pendiente discrimina, por un lado, los sectores donde los materiales se mueven por caídas y por tanto hay poco espesor de detritos, y por otra parte los tramos donde puede acumularse un espesor que posibilite el desarrollo de movimientos cartografiables (los aquí analizados). La orientación y la insolación proporcionan información sobre el contenido de humedad de las laderas, explicando la causalidad de una manera bastante neta. La relación no lineal entre la insolación y los movimientos en masa, indica que entre esta variable y la orientación, parece más satisfactoria la orientación, ya que no está tan influenciada por componentes geomorfológicos como los Frentes Escarpados Rocosos, como se indicó en la explicación de la variable insolación. La irregularidad, por su parte, discrimina los tramos de ladera medios, donde la topografía hummocky se vincula preferentemente a la existencia de movimientos en masa pretéritos. La presencia de reactivaciones de movimientos en la zona estudiada alienta a considerar esta variable, ya que la presencia de movimientos previos implica cierta probabilidad de ocurrencia de movimientos nuevos a partir de ellos. 
Movimientos en masa en las sierras de Bravard y Curamalal,

Sierras Australes de la Provincia de Buenos Aires.

Juan Manuel Susena

La litología, la geomorfología y la vegetación son variables con tendencias muy claras. La litología pone de manifiesto que hay dos materiales donde los movimientos se desarrollan preferentemente: los Detritos de Ladera y los depósitos aluviales. En la zona hay materiales geomecánicamente más débiles, como los depósitos eólicos, sin embargo su frecuencia relativa de movimientos es baja. Esto indica que la litología por sí sola no indica una relación con los movimientos basada exclusivamente en el comportamiento de los materiales, sino que su distribución espacial tiene especial importancia, ya que ésta refleja las condiciones del paisaje que propician los movimientos, como zonas de generación, de transporte y de depositación de regolito.

La geomorfología muestra claramente que los movimientos en masa se producen en unidades coluviales activas y unidades aluviales, tal como se vio en el terreno y se expresó en capítulos anteriores. Las unidades dominadas por la estructura de la roca tienen poca relevancia en el desarrollo de estos movimientos, así como la cubierta eólica y las paleosuperficies. Esta discriminación pareciera similar a la que hace la litología, pero la geomorfología diferencia distintas unidades y procesos geomorfológicos dentro de una misma categoría de litología, ofreciendo un mejor ajuste de la frecuencia relativa de las clases con movimientos, al delimitarlas de una manera más precisa que la litología.

En cuanto a la vegetación, si bien las diferencias de frecuencia relativa son notables entre las clases de las variables, parece que solamente la escasa cobertura arbustiva y de pastizal pudiera significar alguna causa del desarrollo de movimientos. La presencia de esta unidad de vegetación implica la existencia de materiales permeables, con un escaso a medio contenido relativo de materiales finos, condiciones que pudieran favorecer la infiltración del agua de lluvia y desarrollo de movimientos. Sin embargo, como se deriva de lo expresado al analizar esta variable, la presencia de pastizal puede introducir ruido al análisis.

\subsection{Análisis para la selección de variables}

Un supuesto importante para un análisis de susceptibilidad es la independencia de las variables. Es necesario evitar información redundante para no sobrevalorar cierta información del terreno en detrimento de otra, ya que la redundancia de 
información en estos modelos podría conducir a sesgos, tanto sobreestimaciones como subestimaciones de la susceptibilidad al desarrollo de movimientos en masa. Si bien el criterio experto es de utilidad para la selección de variables, existen métodos estadísticos que pueden aplicarse para estudiar las relaciones entre variables y elegir las que deben incluirse en el análisis de susceptibilidad. Para las variables continuas de las que se dispone, se asistió la selección de variables con dos análisis estadísticos que se interpretaron en conjunto, detallados a continuación. En todo caso, un análisis de susceptibilidad consistente en análisis y validación independiente determinará, a la postre, qué variables son las más predictivas.

\subsubsection{Matriz de correlación}

La matriz de correlación indica el grado de interdependencia de un conjunto de variables, analizadas por pares, por lo cual en principio es una herramienta útil para reconocer variables que puedan estar muy correlacionadas (dependientes entre sí). Para generar la matriz de correlación se utilizaron sólo las variables continuas, reclasificándose sus valores en un rango de 0 a 255 (clases de igual intervalo de valor). Si bien esta reclasificación no es estrictamente necesaria, en este caso los resultados obtenidos no están tan influenciados por las diferencias en los rangos de valores.

De la matriz de correlación de las variables de la zona analizada (Tabla 14.7), se identificó una similitud muy grande entre la irregularidad y la pendiente (correlación $r=1,00$ ), y entre éstas y la insolación (respectivamente $-0,95$ y -0,94). La pendiente y la irregularidad también se correlacionan con la altitud $(0,78)$. Asimismo, las curvaturas en el sentido de la pendiente y transversal a la pendiente, aunque la correlación entre ellas es pobre $(0,38)$, presentan cierta correlación con la curvatura general $(0,79$ y 0,78 respectivamente). El resto de los pares de variables tienen correlaciones bajas.

De las variables categóricas litología, geomorfología y vegetación, podría decirse que se relacionan mucho, ya que la geomorfología depende a largo término de la litología, y la vegetación crece en respuesta a las condiciones hidrológicas, climáticas y del suelo (los cuales dependen de la geomorfología y la litología). Sin embargo, su distribución espacial no es idéntica, y en particular en la 
Movimientos en masa en las sierras de Bravard y Curamalal,

Sierras Australes de la Provincia de Buenos Aires.

Juan Manuel Susena

geomorfología, hay más clases que en la vegetación y la litología. Esta variable presenta un nivel de más detalle que las otras dos, discriminando unidades con distinto comportamiento geomorfológico, aunque tengan los mismos materiales o el mismo tipo de vegetación. La vegetación y la litología son también diferentes, puesto que algunos tipos de vegetación no dependen sólo de los materiales sobre los que crece, sino también de las condiciones del terreno (orientación, pendientes, etc.), mientras que otros tipos de vegetación trascienden a las condiciones del terreno, como la arboleda, que puede crecer en roca, detritos, depósitos aluviales y eólicos.

\begin{tabular}{|c|c|c|c|c|c|c|c|c|}
\hline \multicolumn{9}{|c|}{ MATRIZ DE CORRELACIÓN } \\
\hline \multicolumn{9}{|c|}{ Valor medio de cada variable } \\
\hline 67,6 & 127,57 & 141,78 & 125,38 & $69,27215,83$ & 99,43 & 64,77 & 58,07 & 51,33 \\
\hline \multicolumn{9}{|c|}{ Desviación estándar de cada variable } \\
\hline 50,83 & 20,57 & 18,96 & 18,98 & $65,74 \quad 35,4$ & 84,92 & 53,58 & 46,03 & 44,09 \\
\hline
\end{tabular}

\begin{tabular}{|c|ccccccccccc|}
\hline & $\begin{array}{c}\text { DIST } \\
\text { CAMINOS }\end{array}$ & $\begin{array}{c}\text { CURV } \\
\text { GEN }\end{array}$ & $\begin{array}{c}\text { CURV } \\
\text { PARAL }\end{array}$ & $\begin{array}{c}\text { CURV } \\
\text { PRANSV }\end{array}$ & ALT & INSOL & ORIENT PEND & $\begin{array}{c}\text { DIST } \\
\text { CURSOS }\end{array}$ & IRREG \\
\hline DIST CAMINOS & 1,00 & 0,03 & 0,08 & $-0,01$ & 0,57 & $-0,45$ & 0,29 & 0,49 & 0,02 & 0,49 \\
CURVGEN & 0,03 & 1,00 & 0,79 & 0,78 & 0,09 & 0,04 & 0,00 & 0,00 & 0,11 & 0,00 \\
CURV PARAL & 0,08 & 0,79 & 1,00 & 0,38 & 0,15 & 0,02 & 0,00 & 0,02 & 0,13 & 0,02 \\
CURV TRANSV & $-0,01$ & 0,78 & 0,38 & 1,00 & 0,06 & 0,06 & 0,01 & $-0,01$ & 0,11 & $-0,01$ \\
ALT & 0,57 & 0,09 & 0,15 & 0,06 & 1,00 & $-0,69$ & 0,58 & 0,78 & 0,18 & 0,78 \\
INSOL & $-0,45$ & 0,04 & 0,02 & 0,06 & $-0,69$ & 1,00 & $-0,64$ & $-0,94$ & 0,04 & $-0,95$ \\
ORIENT & 0,29 & 0,00 & 0,00 & 0,01 & 0,58 & $-0,64$ & 1,00 & 0,70 & $-0,01$ & 0,68 \\
PEND & 0,49 & 0,00 & 0,02 & $-0,01$ & 0,78 & $-0,94$ & 0,70 & 1,00 & $-0,01$ & 1,00 \\
DIST CURSOS & 0,02 & 0,11 & 0,13 & 0,11 & 0,18 & 0,04 & $-0,01$ & $-0,01$ & 1,00 & $-0,01$ \\
IRREG & 0,49 & 0,00 & 0,02 & $-0,01$ & 0,78 & $-0,95$ & 0,68 & 1,00 & $-0,01$ & 1,00 \\
\hline
\end{tabular}

Tabla 14.7. Matriz de correlación de las variables de la zona 1. Gris: diagonal de la matriz. Amarillo: correlación alta. Anaranjado: correlación muy alta.

\subsubsection{Análisis factorial}

El análisis factorial (Koch y Link, 1971; Klovan, 1975; Davis, 1986) es una técnica estadística de reducción de datos. Consiste en la construcción de factores (nuevas variables) obtenidos por combinación lineal de las variables originales. Los coeficientes se obtienen de la transformación de los autovectores (vectores propios o eigenvectors) y autovalores (valores propios o eigenvalues) de la matriz de correlación. Cada factor representa en distintas proporciones las variables originales, y explica en mayor o menor medida la varianza del conjunto de datos. 
No obstante, los factores así obtenidos hacen difícil interpretar su sentido físico, por lo cual esta técnica solo se utilizó para reducir el número de variables explicativas originales.

La Tabla 14.8 muestra el análisis factorial de las variables. Los primeros 7 factores explican el $98,77 \%$ de la varianza, por lo cual se descartaron los últimos 3 . El primer y segundo factor explican un $68,09 \%$ de la varianza, pero no se correlacionan particularmente con ninguna variable, por lo cual no ofrecen ningún criterio para descartar variables. En consecuencia, dada su importancia para explicar el conjunto de datos, no se descartó por este criterio ninguna variable. Los demás factores (excepto el factor 5) están muy relacionados con algunas de las variables, lo que indica la capacidad explicativa, por lo cual resulta plausible, en principio, considerarlas.

\begin{tabular}{|ccccccccccc|}
\hline \multicolumn{10}{|c|}{ ANÁLISIS FACTORIAL } \\
\hline \multicolumn{10}{|c|}{ Varianza de cada factor } \\
4,44 & 2,37 & 1,01 & 0,78 & 0,59 & 0,42 & 0,26 & 0,06 & 0,06 & 0 \\
& Porcentaje de la varianza total por factor y & porcentaje acumulado & \\
44,38 & 23,71 & 10,12 & 7,81 & 5,94 & 4,22 & 2,59 & 0,62 & 0,59 & 0,02 \\
44,38 & 68,09 & 78,21 & 86,02 & 91,96 & 96,18 & 98,77 & 99,39 & 99,98 & 100 \\
\hline
\end{tabular}

\begin{tabular}{|c|c|c|c|c|c|c|c|c|c|c|}
\hline & $\begin{array}{c}\text { DIST } \\
\text { CAMINOS }\end{array}$ & $\begin{array}{l}\text { CURV } \\
\text { GEN }\end{array}$ & $\begin{array}{c}\text { CURV } \\
\text { PARAL }\end{array}$ & $\begin{array}{c}\text { CURV } \\
\text { TRANSV }\end{array}$ & LT & VSOL & DRIENT & PEND & $\begin{array}{c}\text { DIST } \\
\text { cURSOS }\end{array}$ & \\
\hline F1 & 0,289 & 0,016 & 0,030 & 0,004 & 0,408 & 439 & 36 & 0,462 & 0,015 & 0,460 \\
\hline F2 & & 0,631 & 0,535 & & & & & & & $-0,032$ \\
\hline F3 & ,130 & 137 & 0,030 & 13 & $-0,203$ & $-0,093$ & ,097 & 06 & $-0,937$ & 0,059 \\
\hline F4 & 0,796 & $-0,015$ & 0,230 & $-0,250$ & 0,12 & 0 & $-0,380$ & $-0,108$ & $-0,234$ & $-0,098$ \\
\hline F5 & $-0,34$ & 0,020 & 661 & $-0, \epsilon$ & -0, & 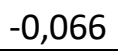 & & & $-0,002$ & 0,034 \\
\hline F6 & 0 , & 0,0 & 0,036 & $-0,0$ & & & & & 7 & 76 \\
\hline F7 & 0,312 & 0,073 & 0,045 & $-0,0$ & -0 & $-c$ & 0,159 & 0,061 & 03 & 078 \\
\hline F8 & 0,009 & $-0,475$ & 0,297 & 0,261 & $-0,1 \varepsilon$ & 0,571 & $-0,0$ & 0 & 0,002 & 0,328 \\
\hline$F$ & $-0,00$ & $-0,593$ & 0,360 & 0,3 & 0,0 & $-0,4$ & 8 & -0, & $-0,021$ & $-0,241$ \\
\hline F1 & $-0,001$ & 004 & 0,003 & $-0,004$ & 0,001 & 0,000 & $0,0<1$ & $-0,686$ & $-0,002$ & 0,725 \\
\hline
\end{tabular}

Tabla 14.8. Matriz del análisis factorial de las variables de la zona 1. Verde: factores seleccionados (1 al 7). Amarillo: correlación alta. Anaranjado: correlación muy alta.

\subsubsection{Variables seleccionadas}

Como resultado del análisis de ambas matrices, se optó por descartar la variable irregularidad, por su alta correlación con la pendiente, siendo la última más utilizada en la literatura y más intuitiva. Aunque la pendiente no se correlacione 
Movimientos en masa en las sierras de Bravard y Curamalal,

Sierras Australes de la Provincia de Buenos Aires.

Juan Manuel Susena

significativamente con alguno de los factores más importantes, se la tendrá en cuenta porque dentro del factor 1 , el más explicativo, la pendiente es la variable con mayor correlación. Al respecto, de acuerdo a Alkhasawneh et al. (2013), la pendiente es el factor topográfico más determinante en el desarrollo de movimientos en masa. Se descartó también la insolación, dada su estrecha relación con la pendiente (en el área de estudio hay una gran extensión de piedemonte, donde las bajas pendientes determinan la máxima insolación). En cuanto a las curvaturas, en un primer análisis de susceptibilidad no se utilizó la curvatura general de la pendiente, puesto que se correlaciona con las otras dos curvaturas, las cuales a su vez difieren entre sí y que además son importantes en el factor 5 , que explica el $5,94 \%$ de la varianza; adicionalmente, las curvaturas paralela y transversal a la pendiente tienen una expresión morfológica (en el mapa) más clara que la curvatura general. De todas formas, posteriormente sí se utilizó la curvatura general en modelos alternativos, para que, analizando la sensibilidad de las variables (ver más adelante), se esclarezca si la curvatura tiene alguna importancia en la susceptibilidad como variable.

En resumen, del conjunto de variables iniciales, las que a priori se utilizarán en el análisis de susceptibilidad son 7: altitud, pendiente, orientación, las tres curvaturas, distancia a caminos y distancia a cursos de agua. A estas se agregan las variables litología, geomorfología y vegetación, sumando un total de 10 variables.

\subsection{Funciones de Favorabilidad}

Los modelos de susceptibilidad se crearon utilizando el método de las Funciones de Favorabilidad (Chung y Fabbri, 1993). Se trata de un método para construir modelos predictivos (en este caso, modelos de susceptibilidad de movimientos en masa) a partir de una serie de variables causales, típicamente denominadas variables independientes. Estas variables pueden ser de distinta naturaleza (cuantitativas o categóricas en cuanto a valor, y espacialmente continuas u objetos aislados en el espacio). Para integrar todas estas variables en un modelo predictivo se pueden transformar, mediante una función, en valores que expresen favorabilidad, de aquí su nombre. Los valores de favorabilidad se pueden entender en términos de probabilidad, certidumbre, pertenencia difusa, etc., en función del 
marco matemático en el cual se trabaje, por ejemplo teoría de probabilidades o teoría de los conjuntos difusos (Chung y Fabbri, 1998). En este trabajo los valores de favorabilidad se interpretaron en el marco de la teoría de probabilidades, como factor de certidumbre, lo cual se explica más adelante. Una vez obtenidos los factores de certidumbre para cada variable, se integran de acuerdo a una serie de reglas de integración. Como procedimiento, las Funciones de Favorabilidad se concibieron para desarrollar modelos predictivos de una manera "automática", si bien es posible introducir el criterio experto en el análisis.

Desde el punto de vista operativo:

1. Primero se debe disponer de dos muestras independientes de movimientos en masa: una para el análisis y otra para la validación.

2. Cruzando los movimientos de análisis con cada una de las variables se obtienen los valores de favorabilidad, expresados en términos de probabilidad.

3. Los valores de favorabilidad se transforman en factores de certidumbre.

4. Se integran todas las variables expresadas en un factor de certidumbre final.

5. El modelo resultante se compara con los movimientos reservados para la validación.

Para obtener los valores de favorabilidad de cada clase, se compara la frecuencia relativa de movimientos en la clase (área de la clase afectada por movimientos) con la probabilidad a priori de ocurrencia de movimientos.

La probabilidad a priori Prob $_{\mathbf{M}}$ se calcula de la siguiente manera:

$$
\operatorname{Pr} o b_{M}=\frac{\hat{A} r e a_{M}}{\text { Ár } e a_{T}}
$$

Área ${ }_{\mathbf{M}}$ es el área ocupada por movimientos en masa, y Área ${ }_{\mathrm{T}}$ es el área de la zona analizada. Esta probabilidad a priori de que en un píxel del área estudiada se produzca un movimiento en masa es $\operatorname{Prob}_{\mathbf{M}}=0,00375(0,375 \%)$. Esta es la probabilidad calculada con una muestra aleatoria de la población de movimientos, que se empleó en el análisis. Cabe aclarar que, si se incluyeran absolutamente todos los movimientos cartografiados, es decir, la muestra de análisis más la muestra de validación, la probabilidad sería mayor. 
Luego se calculó la probabilidad de que se produzca un movimiento, en función de la clase, para las diferentes clases de cada variable, según la siguiente ecuación:

$$
\operatorname{Prob}_{C l}=1-\left(1-\frac{1}{A_{C l}}\right)^{A_{M C l}}
$$

Prob $_{c ı}$ es la favorabilidad de la clase, $A_{c l}$ es el área que ocupa la clase en el mapa, y $A_{M c l}$ es el área de la clase coincidente con movimientos en masa. Esta ecuación es similar a la ecuación (1), utilizada para estimar la frecuencia relativa; se utiliza ésta siguiendo a Chung y Fabbri (1993), quienes indican que esta función es apropiada cuando el área movilizada es mucho más pequeña que el área total (probabilidad a priori muy baja).

Los valores de probabilidad Probcı de cada clase se transformaron para obtener el factor de certidumbre FC de la variable, de acuerdo con las siguientes expresiones:

$$
\begin{array}{ll}
\text { Si } \operatorname{Pr} o b_{C l} \geq \operatorname{Prob}_{M} & F C=\frac{\operatorname{Prob}_{C l}-\operatorname{Pr} o b_{M}}{\operatorname{Prob}_{C l}\left(1-\operatorname{Pr} o b_{M}\right)} \\
\text { Si }{\operatorname{Pr} o b_{C l}<\operatorname{Prob}_{M}}_{F C}=\frac{\operatorname{Prob}_{C l}-\operatorname{Pr} o b_{M}}{\operatorname{Prob}\left(1-\operatorname{Pr} o b_{C l}\right)}
\end{array}
$$

FC es el factor de certidumbre de la variable en la unidad del terreno analizada. El FC expresa la certeza de ocurrencia o no ocurrencia de un movimiento, en una escala de -1 (certidumbre de no ocurrencia) a 1 (certidumbre de ocurrencia), donde el valor 0 expresa incertidumbre.

Puesto que la probabilidad a priori Prob $_{\mathbf{M}}$ es muy pequeña, hay que tratar de encontrar un equilibrio entre el número de clases (a mayor número de clases, mayor resolución) de las variables, y la significación estadística del área afectada por movimientos en las clases (improbabilidad de que el valor obtenido haya sido debido al azar). Por ello se reclasificaron los valores de algunas variables, disminuyendo el número inicial de clases mostrado en los apartados anteriores. 
La Figura 14.16 muestra el FC de la variable altitud, donde puede apreciarse una banda de alta certidumbre de no ocurrencia (verde), entre bandas con certidumbre de ocurrencia (anaranjado), a pesar de que hay un gradiente de aumento de la altitud creciente hacia el NO (ver Figura 14.2). Esto se debe al escaso número de movimientos en relación con las unidades de la variable, lo que produce artefactos. Como consecuencia se obtienen valores anómalos, en este caso de certidumbre, tal como se ha mencionado y puede observarse en la Figura 14.16, en la que algunos movimientos de la muestra de validación ocurren en la banda verde. Esto ocurrió en concreto en las variables Altitud, Pendiente, Distancia a Cursos de Agua y Distancia a Caminos.

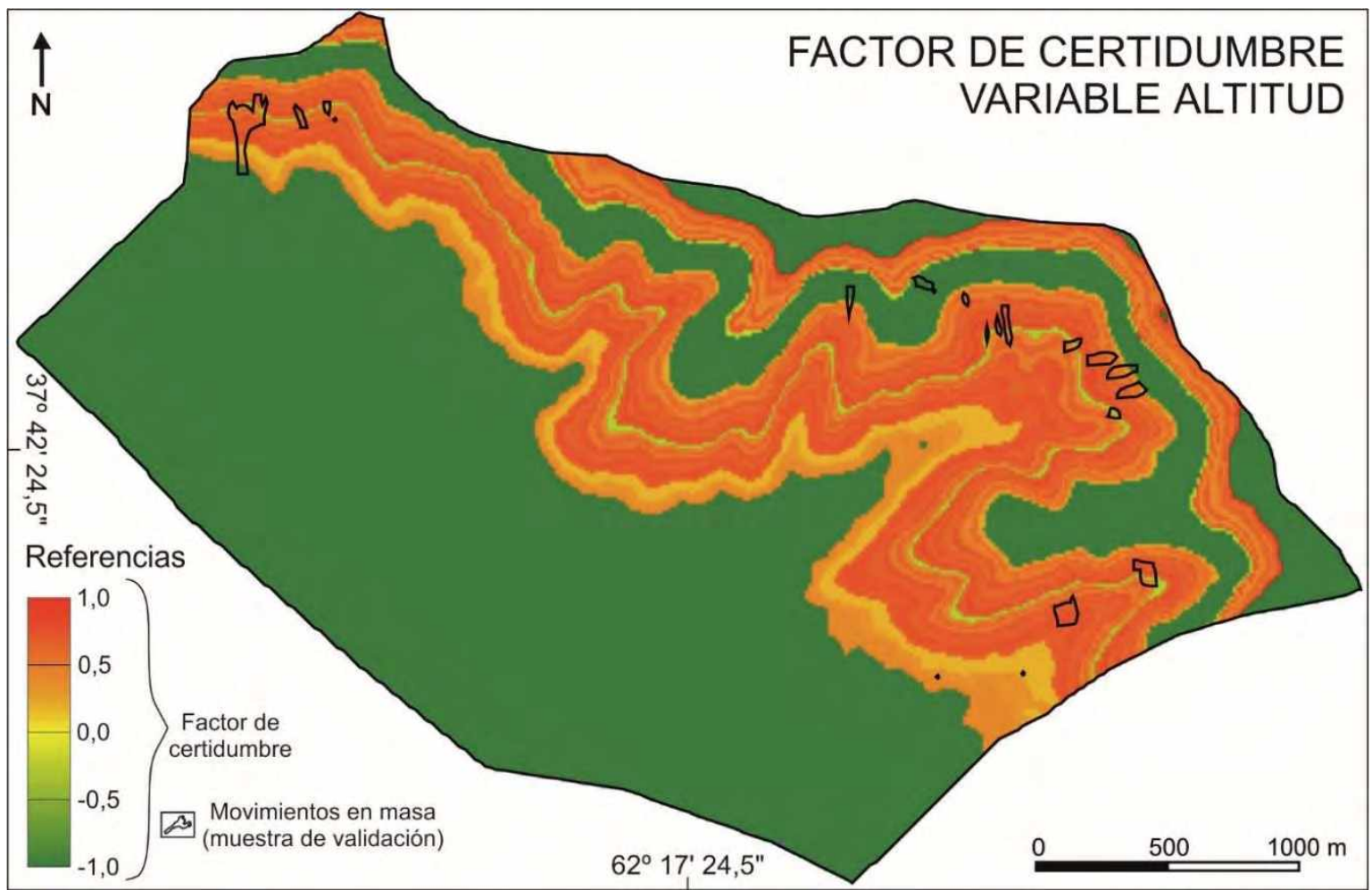

Figura 14.16. Patrón "extraño" del factor de certidumbre en la variable ALTITUD. Compárese con la Figura 14.17 en la cual se reclasificó la variable.

Para solucionar esto, se reclasificaron los rangos de valores de estas variables, creando menos clases de valor, como lo resume la Tabla 14.9; la Figura 14.17 ilustra una disminución de la certidumbre respecto a la figura anterior, en favor de que los movimientos sean correctamente predichos. Aunque la máxima certidumbre de ocurrencia en el mapa disminuya, se prefiere sacrificar certidumbre de ocurrencia antes que aumentar la posibilidad de cometer errores. De todas maneras, no hay que basarse sólo en la certidumbre variable a variable, sino en la resultante de la combinación de todas las variables, en cuya integración los errores 
Movimientos en masa en las sierras de Bravard y Curamalal,

Sierras Australes de la Provincia de Buenos Aires.

Juan Manuel Susena

se propagan.

\begin{tabular}{|c|c|c|c|c|}
\hline Variable & Rangos de valor previos & $\begin{array}{c}\mathrm{N}^{\circ} \mathrm{de} \\
\text { clases } \\
\text { previas }\end{array}$ & $\begin{array}{l}\text { Rangos de valor } \\
\text { reclasificados }\end{array}$ & $\begin{array}{c}\mathbf{N}^{0} \text { de nuevas } \\
\text { clases }\end{array}$ \\
\hline ALTI & $\begin{array}{c}5 \mathrm{~m} \text { excepto los valores } \\
\text { extremos }(<435 \mathrm{~m} \text { y }>725 \mathrm{~m})\end{array}$ & 60 & $\begin{array}{c}100 \mathrm{~m} \text { excepto valores } \\
\text { extremos }(<450 \mathrm{~m} \text { y }>850 \mathrm{~m})\end{array}$ & 6 \\
\hline PEND & $2^{\circ}$ & 25 & $\begin{array}{c}10^{\circ} \text { excepto valores extremos } \\
\left(<5^{\circ} \mathrm{y}>45^{\circ}\right)\end{array}$ & 6 \\
\hline CURSOS_DIST & $25 \mathrm{~m}$ & 24 & $\begin{array}{c}\text { Rangos irregulares } \\
0-50 \mathrm{~m} \\
50-150 \mathrm{~m} \\
150-300 \mathrm{~m} \\
300-500 \mathrm{~m} \\
>500 \mathrm{~m}\end{array}$ & 5 \\
\hline CAMINOS_DIST & $\begin{array}{c}\text { Rangos irregulares } \\
0-50 \mathrm{~m} \\
50-100 \mathrm{~m} \\
100-300 \mathrm{~m} \\
300-500 \mathrm{~m} \\
>500 \mathrm{~m}\end{array}$ & 5 & $\begin{array}{c}\text { Rangos irregulares } \\
0-50 \mathrm{~m} \\
50-150 \mathrm{~m} \\
150-500 \mathrm{~m} \\
>500 \mathrm{~m}\end{array}$ & 4 \\
\hline
\end{tabular}

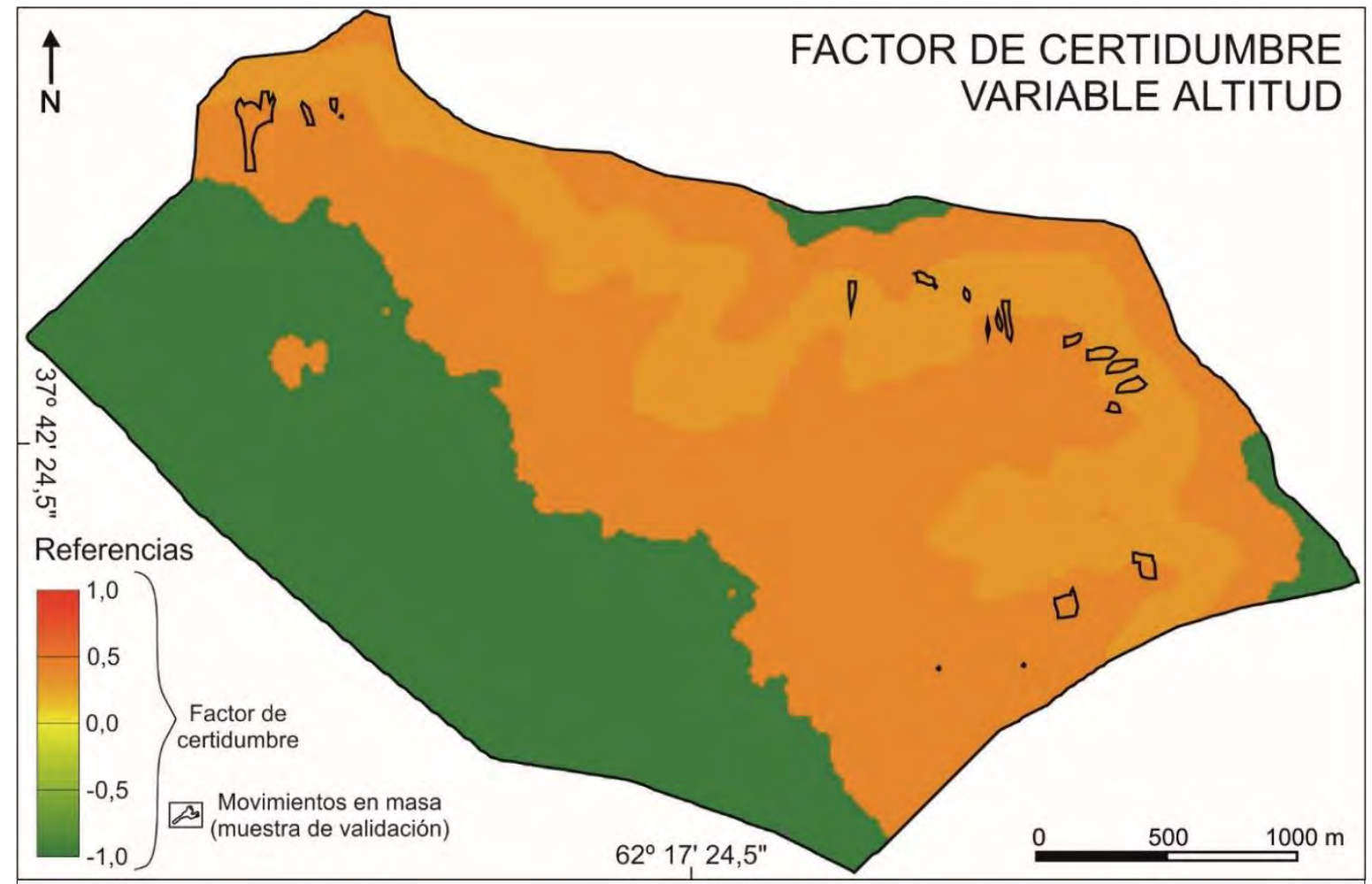

Figura 14.17. Factor de certidumbre de la variable ALTITUD luego reclasificar las clases de valor. Nótese la disminución de la certidumbre de ocurrencia y la desaparición del patrón "extraño".

El índice de susceptibilidad de cada unidad del terreno se obtuvo integrando (combinando) los valores de FC de a pares y progresivamente: el resultado de integrar $F_{1}$ con $F_{2}\left(Z_{1-2}\right)$, se combinó con $F_{3}$ para generar $Z_{1-2-3}$ y así sucesivamente, hasta integrar todas las variables, generando un factor de certidumbre $Z_{1-2-3-\ldots-n}$. Las reglas de integración son las siguientes (Luzi y Fabbri, 
Si $F C_{1}$ y $F C_{2}$

son de si gnoopuesto

$$
Z_{1,2}=\frac{F C_{1}+F C_{2}}{1-\min \left(a b s F C_{1}, a b s F C_{2}\right)}
$$

Todas estas operaciones, de naturaleza matricial, se realizaron con el software ILWIS, y los resultados se plasmaron en mapas de zonificación de susceptibilidad (Brabb et al., 1972). Los valores de susceptibilidad se clasificaron en rangos de susceptibilidad relativa (relative ranks, sensu Chung y Fabbri, 1999), creando 200 clases de igual área, mediante la operación de ecualización de histograma.

Respetando la selección de variables realizada mediante el análisis factorial y de la matriz de correlación, se creó en primera instancia un modelo de susceptibilidad con todas las variables seleccionadas. Posteriormente se realizaron 19 modelos alternativos, para complementar la interpretación del potencial predictivo de las diferentes variables. El objetivo de los modelos alternativos tiene dos aspectos: uno geomorfológico, complementando el criterio de campo y el estudio de variables expresado en el capítulo anterior, para entender el significado físico de cada variable; el otro objetivo es metodológico, buscando optimizar la relación calidad predictiva del modelo-tiempo de trabajo, expresado el último aspecto en el número de variables utilizadas y su tiempo de obtención.

Entre los modelos alternativos, se hicieron dos grupos de modelos con fines concretos: modelos de las "variables automáticas", y modelos de "variables automáticas y manuales". Los modelos de variables automáticas incluyen el MDE (altitud) y/o sus derivados; el objetivo concreto fue analizar si la altitud y la orientación mejoraban las predicciones, y si la curvatura general daba resultados similares al conjunto de las curvaturas longitudinal y transversal a la pendiente. El objetivo de este análisis es reducir el número de variables útiles para el modelo. Para los modelos de variables automáticas y manuales, se utilizaron las mejores 
Movimientos en masa en las sierras de Bravard y Curamalal,

Sierras Australes de la Provincia de Buenos Aires.

Juan Manuel Susena

combinaciones de las automáticas, y se agregaron las variables obtenidas mediante un trabajo más exhaustivo de campo y fotointerpretación (litología, geomorfología y vegetación), para analizar si hay mejoras con el agregado de estas variables, y si son necesarias todas ellas, o si hay redundancia a la escala de trabajo considerada.

La Figura 14.18 muestra la superposición de los movimientos de validación con uno de los mapas de susceptibilidad. Puede comprobarse de manera visual que el modelo tiene una buena capacidad predictiva, observando que los movimientos del grupo de validación coinciden con las clases de mayor susceptibilidad.

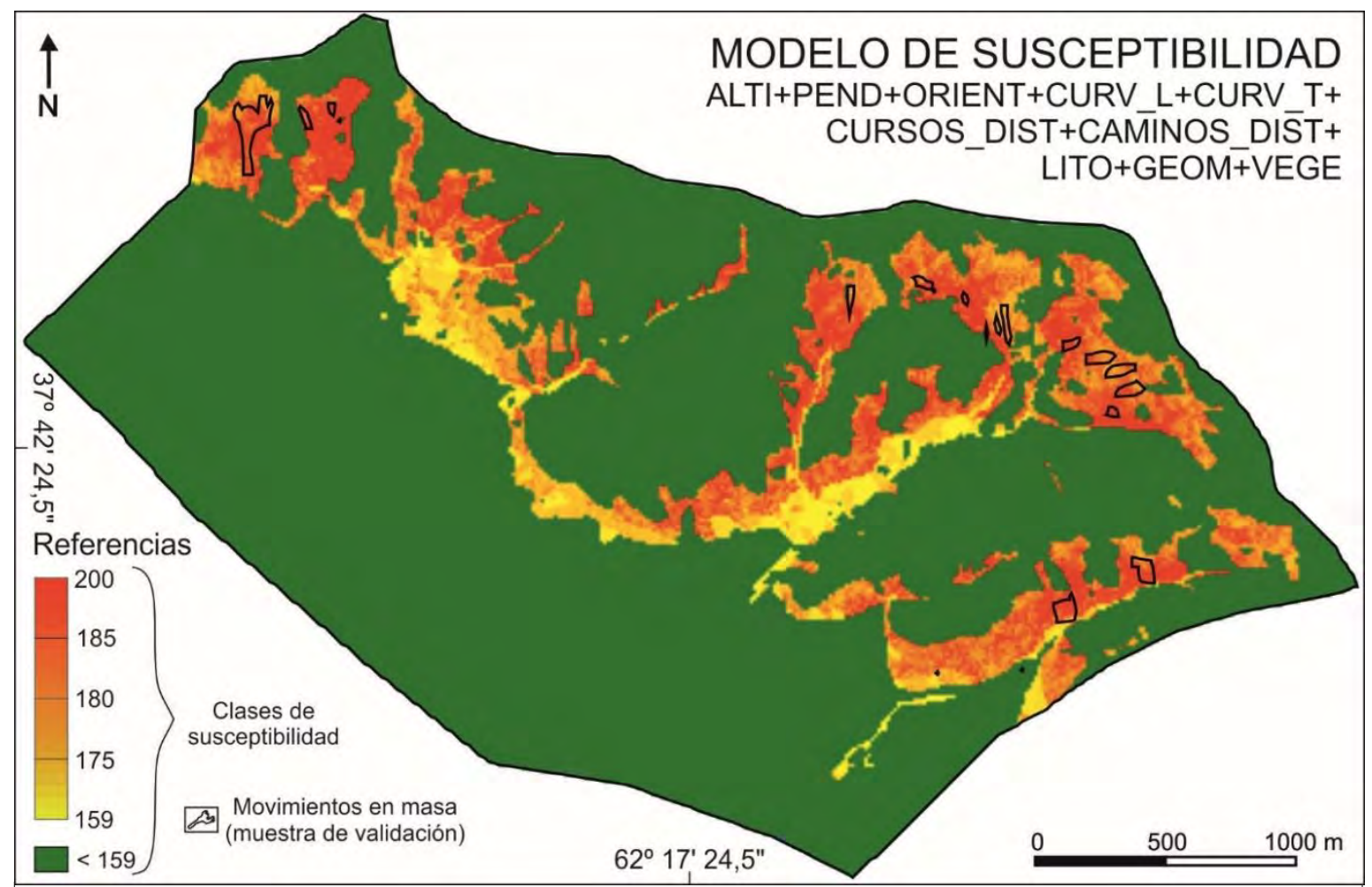

Figura 14.18. Modelo de susceptibilidad de movimientos en masa, empleando las diez variables. Las clases de susceptibilidad corresponden a una reclasificación de los valores de índice de susceptibilidad en 200 clases de igual área (relative ranks, sensu Chung y Fabbri, 1999). La clase 200 es la clase más susceptible. Las clases 1 a 158 han sido etiquetadas conjuntamente, por poseer los mismos valores de índice de susceptibilidad.

\subsection{Validación}

Para la evaluación de los modelos obtenidos se utilizó una estrategia aleatoria: previo a la elaboración del modelo de susceptibilidad, se excluyó aleatoriamente una muestra de movimientos en masa, y se la reservó para la validación (Chung et al., 1995). Aunque posiblemente la estrategia más adecuada sería utilizar una 
población de movimientos posterior a la de aquellos en los que se basaron los modelos de susceptibilidad (Remondo et al., 2003; Galve et al., 2009), la falta de un registro completo de imágenes satelitales/fotografías aéreas dificulta la realización de un inventario multi-temporal, por lo que esta alternativa no fue factible.

Para la validación se elaboró una curva de predicción, la cual representa la tasa acumulada de éxito (coincidencia) de los movimientos en masa con cada clase de susceptibilidad del mapa (relative ranks, sensu Chung y Fabbri, 1999, como se mencionó en la sección anterior). En el eje de las abscisas se ubica la superficie acumulada de las clases de susceptibilidad en orden de susceptibilidad decreciente, y en el eje de las ordenadas se representa la superficie acumulada de los movimientos en masa de esas clases de susceptibilidad (Figura 14.19). La forma de la curva resultante muestra la capacidad predictiva o bondad del modelo (Fabbri et al., 2002). Cuanto más se aleje la curva de la diagonal, y cuanto mayor

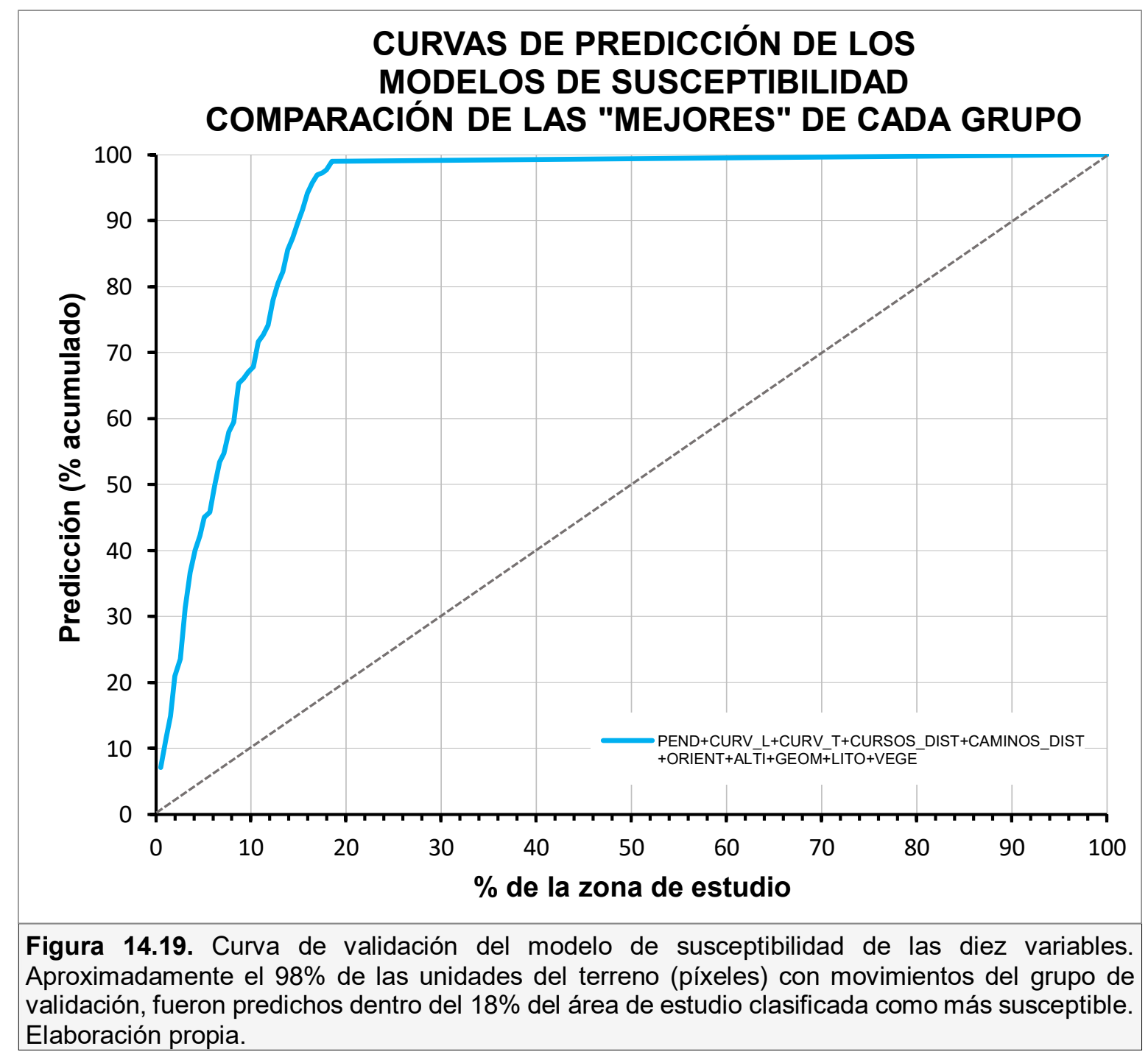


Movimientos en masa en las sierras de Bravard y Curamalal,

Sierras Australes de la Provincia de Buenos Aires.

Juan Manuel Susena

sea la pendiente en el tramo más cercano al origen, mayor será el potencial predictivo del mapa de susceptibilidad (Remondo, 2001). Si se dan estas condiciones, significaría que la porción del área de estudio más susceptible (cuanto más pequeña, mejor), explicaría un alto porcentaje de los movimientos validados, indicando -dicho de otra forma- una alta probabilidad/certidumbre de que los futuros movimientos ocurran en esa/s clase/s de susceptibilidad expresada/s en el mapa, y una baja probabilidad de que ocurran fuera de esa/s clase/s de susceptibilidad.

\subsubsection{Análisis de sensibilidad}

La curva de validación sirve además -y especialmente- para comparar diferentes modelos desarrollados en la zona analizada. Pueden compararse modelos que se diferencien en el agregado o quitado de una variable específica, para comprobar si dicha variable mejora la capacidad predictiva o bondad. Las diferencias de bondad de estos modelos dan una idea de la sensibilidad de las variables empleadas.

Las curvas de validación de los modelos de las "variables automáticas" se muestran en la Figura 14.20. Puede observarse que los mejores modelos obtenidos incluyen la altitud, la orientación de las laderas, la pendiente, la distancia a cursos de agua y las curvaturas longitudinal y transversal a la pendiente, o la curvatura general. En éstos, aproximadamente el $98 \%$ de los movimientos del grupo de validación aparecen entre el entre el 35 y el $45 \%$ del área de estudio más susceptible. De la comparación entre la curva gris, el grupo de coloreadas suaves y el grupo de coloreadas fuertes, puede verse que el agregado de la orientación y la altitud mejoran notoriamente la capacidad predictiva de los modelos. La similitud entre las curvas coloreadas de cada grupo muestra que las variables de curvatura tienen cierta redundancia, o que no tienen un potencial predictivo que justifique su uso. La curva negra muestra que el quitado de las curvaturas no afecta negativamente la sensibilidad de los modelos.

Las curvas de validación de las "variables automáticas y manuales" muestran una notable mejora: aproximadamente el 18\% más susceptible del área de estudio explica casi el 100\% de los movimientos del grupo de validación (Figuras 14.19 y 14.21). 


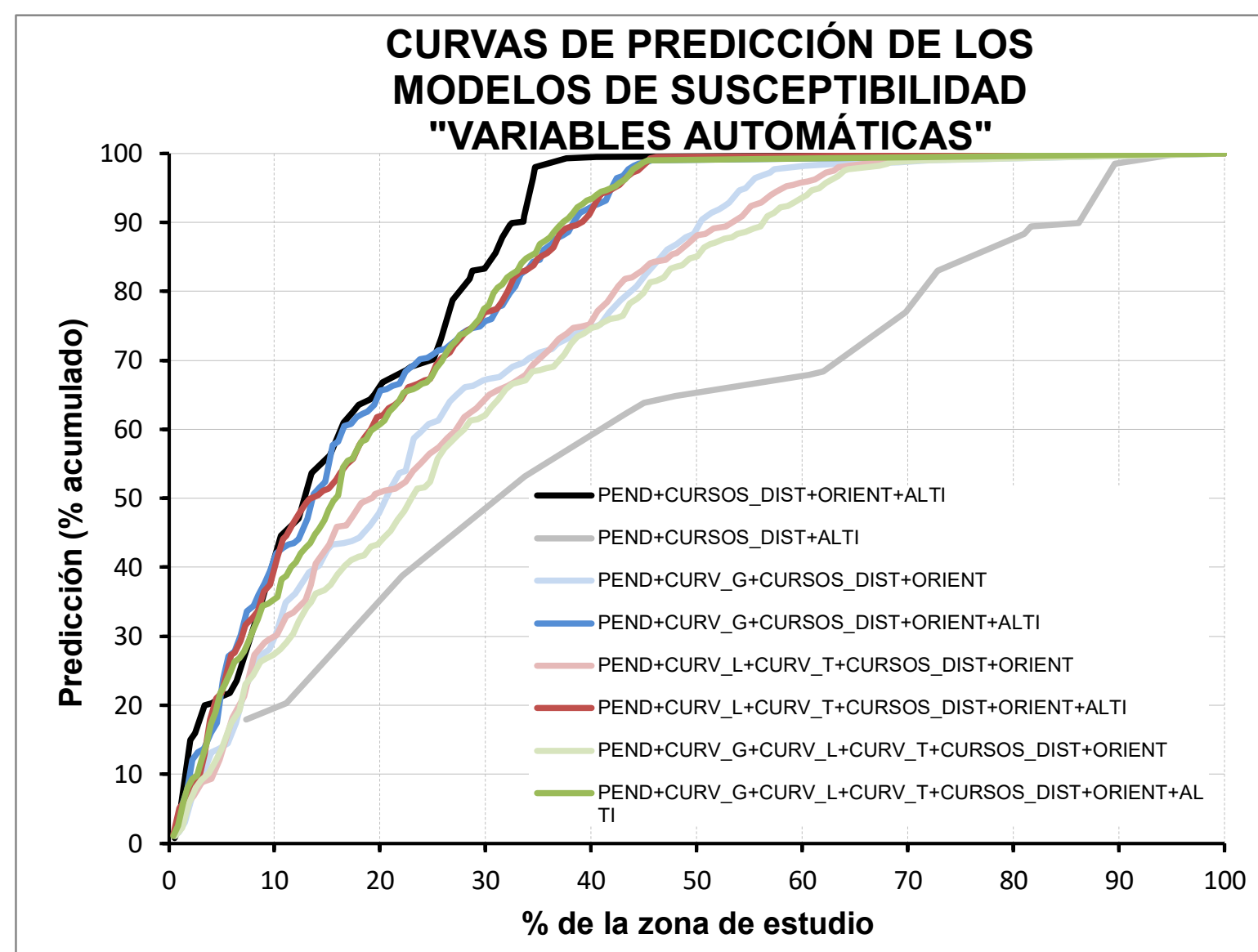

Figura 14.20. Curva de validación de los modelos de "variables automáticas". En el mejor de los modelos, aproximadamente $99 \%$ de las unidades del terreno (píxeles) con movimientos del grupo de validación, fueron predichos dentro del $37 \%$ del área de estudio clasificada como más susceptible. Ver explicación detallada en el texto. Elaboración propia. 


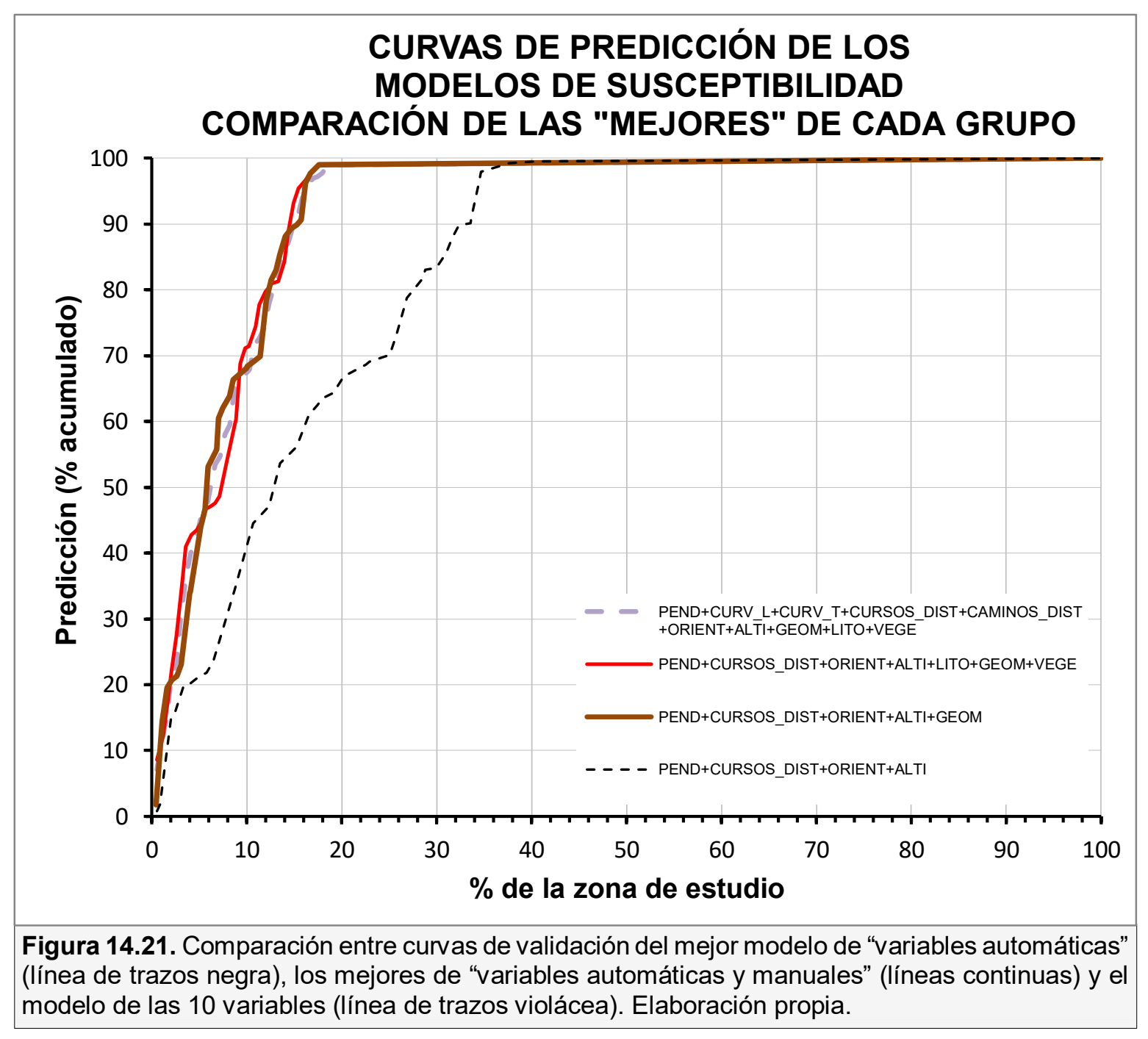

Se compararon en detalle distintas combinaciones de litología, geomorfología y vegetación (más las variables automáticas), con o sin la curvatura, y con o sin la distancia a cursos de agua (Figura 14.22). Se encontraron diferencias muy leves, que se apuntan a continuación:

- a grandes rasgos puede observarse que el agregado de la curvatura (curvas con líneas de trazos finas) empeora la sensibilidad de los modelos;

- de las variables manuales, la que más aporta por sí sola a la sensibilidad de los modelos es la geomorfología (línea continua castaña), y la que menos aporta es la vegetación (línea continua verde);

- la mejor combinación de variables manuales es geomorfología-vegetación (línea continua roja); 
- el único modelo sin la distancia a los cursos de agua (línea continua negra) es algo peor que su análogo con esta variable incluida (línea continua castaña)

- la utilización de las 10 variables iniciales (línea de trazos gruesa violácea) no mejora sensiblemente la predicción, un modelo con sólo 4 variables (línea continua negra) da resultados similares.

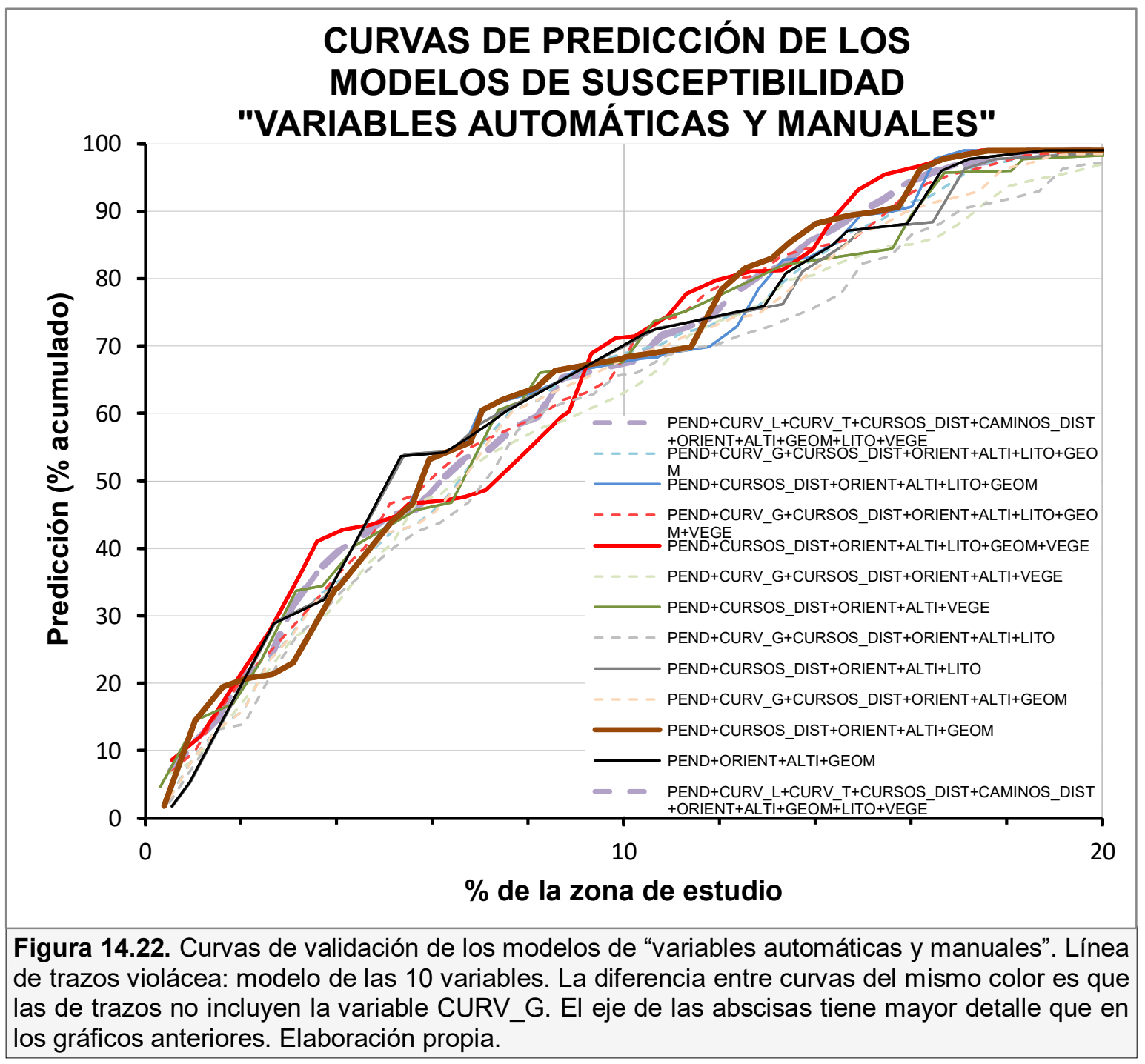

Un análisis más exhaustivo, considerando otras muestras independientes de validación y/o otras subzonas de estudio, permitirian reforzar el análisis de sensibilidad. 


\subsection{Conclusiones sobre el potencial de las variables utilizadas para analizar la susceptibilidad}

De los análisis de susceptibilidad realizados y su validación, surgen una serie de conclusiones geomorfológicas (parte de ellas se comentaron en apartados anteriores) y metodológicas. Cabe aclarar que las conclusiones aquí presentadas son preliminares, reflejan la casuística analizada, y deberían ser comprobadas con estudios posteriores.

Hay variables cuya obtención no es necesaria para la elaboración de modelos confiables, como la rugosidad, la insolación (debido a que tiene una información similar a la orientación de las laderas), las curvaturas y la distancia a caminos.

El hecho de que la insolación se correlacione tanto con la orientación, puede estar significando que el efecto del ocultamiento topográfico en la zona es mucho menor que el de la orientación por sí sola. Esto no tiene por qué ser estrictamente cierto en toda el área estudiada en la tesis, dado que hay sectores muy sombríos durante gran parte del día, especialmente en los valles intraserranos de laderas rocosas, como en la vertiente occidental de las sierras de Curamalal, por lo cual esta variable podría reemplazar a la orientación en determinadas zonas.

En el caso de la rugosidad y las curvaturas, puede que se trate de información redundante con otras variables, como la altitud, ya que derivan de ésta. No obstante, no hay que descartar la posibilidad de que su poca capacidad predictiva pudiera relacionarse con la calidad del MDE del cual derivan; el hecho de que el potencial predictivo decrezca considerablemente con el quitado de las variables obtenidas mediante fotointerpretación y criterio de campo, parece apoyar esta idea de "insuficiencia" de estas variables automáticas. De cualquier manera, hay variables que son muy sensibles al desarrollo de movimientos en masa en la zona, y que aparentemente no tienen problemas respecto a la calidad del MDE: la orientación, la pendiente y la altitud. Pudo observarse que si no se utilizan estas variables, los modelos tienen muy poco potencial predictivo.

De la litología, la geomorfología y la vegetación, la geomorfología da resultados algo mejores. La litología se cartografió discriminando, en el caso de la roca, los sectores donde dominan los afloramientos, y los sectores donde se la encuentra principalmente cubierta. Probablemente si no se hubiera hecho esta discriminación, 
las predicciones mediante la litología sin incluir la geomorfología ni la vegetación empeorarían, dado que el contraste geohidrológico entre los detritos y la roca subaflorante -causa del desarrollo de muchos movimientos- no se introduciría en el análisis si no se aplicara este criterio cartográfico. La variable litología tampoco contempla de manera estricta aquellos sectores en que sus unidades son afectadas por rasgos erosivos con morfologías susceptibles de que se produzcan movimientos en masa, como en el caso de los depósitos eólicos, que pueden incluir una unidad geomorfológica poco susceptible, como lo es la Cubierta Eólica Periserrana, y al mismo tiempo tener una unidad más susceptible, como las Incisiones Fluviales. Si bien por un problema de escala, en el inventario usado para el análisis de susceptibilidad no pudieron incorporarse los movimientos producidos en Incisiones Fluviales que afectan a los depósitos eólicos, puede entenderse por razonamiento lógico y por lo que se observó en el terreno y explicó en los capítulos anteriores (especialmente en el Capítulo 6 Geomorfología general del área), los movimientos en masa se producen en unidades o rasgos geomorfológicos erosivos que afectan al material eólico. Estas diferencias de sensibilidad entre las variables litología y geomorfología, pueden ser también una característica intrínseca de la zona. En las Sierras Australes, no existe aún un perfecto ajuste entre la litología y la geomorfología, dado el estado juvenil del paisaje en términos de ciclo sedimentológico. Esto es evidente en los perfiles de las laderas (ver Capítulo 10 Movimientos en masa en laderas) y en que hay demasiados rasgos del paisaje con el mismo tipo litológico, los cuales, aún con la misma litología, presentan diferencias de pendiente, curvatura, relación hidrológica con el medio circundante, espacio de acomodación de los materiales, etc., que se relacionan con el desarrollo de los movimientos. Algunas de estas características son extraíbles del MDE, pero otras, como el espesor de detritos y la proporción de materiales finos y gruesos, requieren otras variables para su expresión, como los son, indirectamente, las unidades geomorfológicas. En este sentido y volviendo al caso de la Cubierta Eólica Periserrana, es válido y especialmente útil a medio o largo término, pensar en dicha unidad como susceptible a movimientos porque, aunque en el presente no lo sea (como se explicó antes), en el futuro se convertirá en otras unidades, como las Incisiones Fluviales, que sí lo serán. El desafío en dicho caso será definir dónde se producirían estos cambios de unidad. 
La vegetación, por su parte, tiene una sensibilidad algo menor que la geomorfología y la litología. Esto es importante, ya que modelos muy parecidos pueden obtenerse usando ésta o aquellas. La vegetación es una variable que puede obtenerse de manera automática a partir de imágenes satelitales, por lo cual consignando la proporción de la cobertura vegetal, diferenciando las zonas con roquedal, y las zonas con pastizal, y estableciendo determinados umbrales que identifiquen la preponderancia de unos tipos sobre otros, pueden obtenerse modelos con una relación costo-beneficio muy favorable. La vegetación responde a condiciones del terreno muy relacionadas con movimientos en masa, como el contenido de humedad y el espesor de regolito. En este sentido, es una variable que se relaciona con los movimientos por ser indicadora de dichas condiciones, pero debe tenerse en cuenta que no es especialmente una variable causal, dado que algunos tipos de vegetación, como el pastizal abundante, se asocian tanto a condiciones de inestabilidad como de estabilidad del terreno. Por otra parte, el crecimiento de arboleda en la zona podría introducir un sesgo, ya que muchas veces los árboles crecen en grietas entre las rocas en los límites entre unidades de roca y de regolito, enmascarando los límites entre unidades litológicas y/o geomorfológicas, por lo cual debería considerarse la posibilidad de excluir tales zonas del análisis general y estudiarlas particularmente. 
CONCLUSIONES Y

CONSIDERACIONES FINALES 
Movimientos en masa en las sierras de Bravard y Curamalal, Sierras Australes de la Provincia de Buenos Aires.

Juan Manuel Susena 
Para ordenar las conclusiones de esta tesis y evidenciar el cumplimiento de los objetivos propuestos, se presentará primeramente y a modo de síntesis, la lista de tareas generales (ver Capítulo 2 Planteamiento del problema y objetivos) y los resultados obtenidos de dichas tareas. La siguiente figura recuerda cómo las tareas se relacionan con los distintos objetivos específicos. Posteriormente, se detallarán las conclusiones obtenidas, de acuerdo a los objetivos planteados, se establecerá una serie de consideraciones finales y líneas de trabajo futuro.

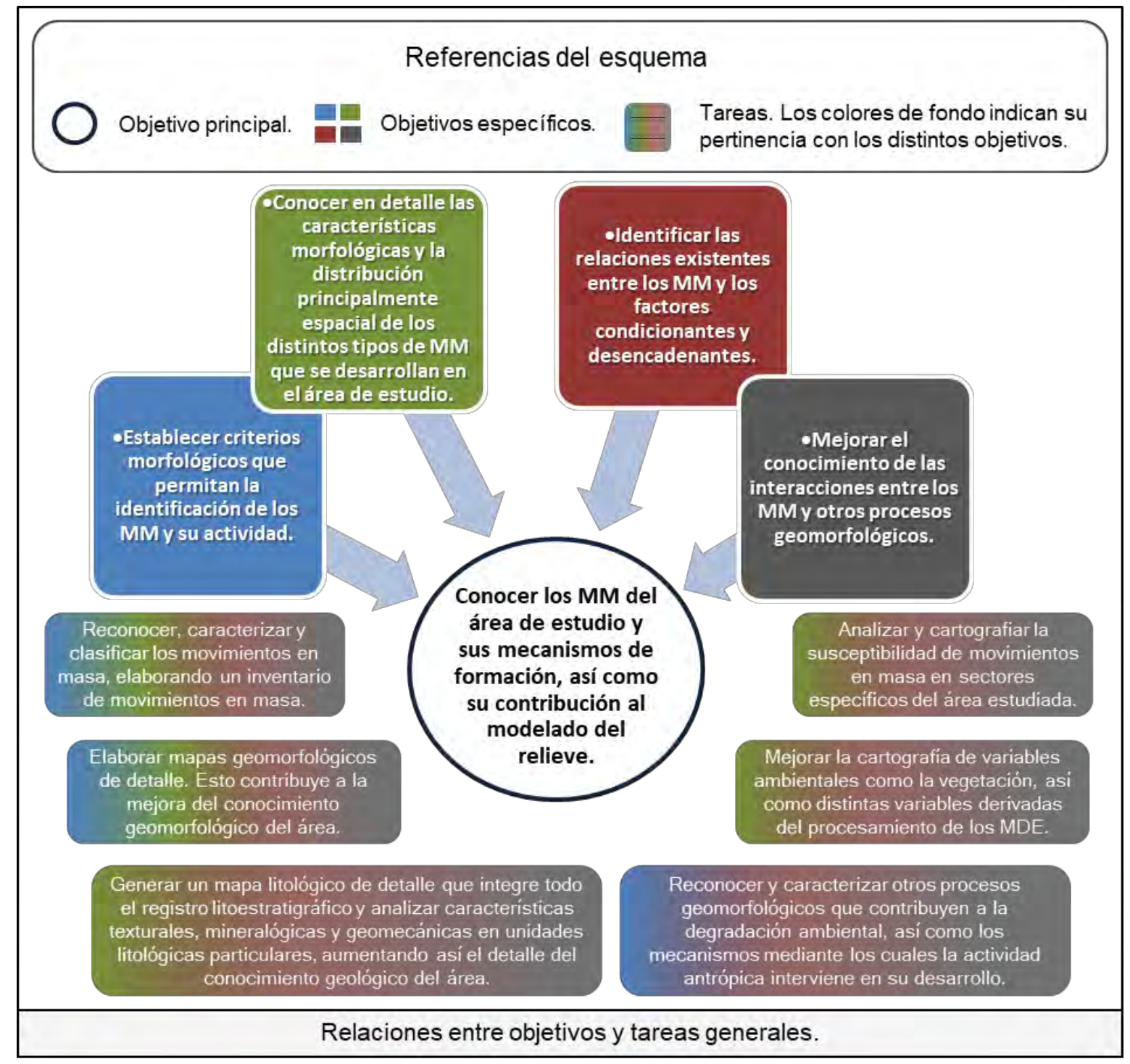


Movimientos en masa en las sierras de Bravard y Curamalal,

Sierras Australes de la Provincia de Buenos Aires.

Juan Manuel Susena

\section{Tareas generales y sus resultados}

\section{Reconocer, caracterizar y clasificar los movimientos en masa, elaborando un} inventario de movimientos en masa. Se estableció una serie de criterios o indicadores geomorfológicos de campo y de teledetección útiles para reconocer movimientos en masa y caracterizar el estado su actividad (edad relativa). Los rasgos vinculados a caídas, vuelcos y deslizamientos de rocas son la presencia de taludes y laderas, conos de talud o conos de detritos y amontonamientos de detritos; los deslizamientos y flujos son reconocidos por las irregularidades en la morfología de las laderas (topografía hummocky); otros tipos de movimientos también pueden ser identificados por la presencia de discontinuidades producidas en superficies verticales en materiales no consolidados (por ejemplo, concavidades que interrumpen la continuidad longitudinal de las barrancas), y modificaciones en la distribución y morfología de la vegetación. Los indicadores de edad relativa se clasificaron en indicadores de antigüedad y de juventud. Los indicadores de antigüedad son: vegetación muerta o viva (según el rasgo que se esté observando), desarrollo de colonias de líquenes, lavaje y acumulación de materiales finos (dependiendo del rasgo analizado), reactivaciones de movimientos en masa, incisión fluvial en torno a rasgos producidos por movimientos en masa, degradación de la forma de las acumulaciones, meteorización de detritos movilizados y degradación de escarpas de movimientos en masa. Los indicadores de juventud de movimientos son: vegetación con disposición extraña y signos de daños recientes, ausencia de vegetación, ausencia y disposición extraña de colonias liquénicas y morfologías en desequilibrio con el drenaje superficial. Este conjunto de indicadores ha servido para desarrollar un inventario de movimientos en masa. Se han reconocido 14 tipos de movimientos en masa: caídas y vuelcos de rocas/detritos, caídas y vuelcos de tierra/suelo, flujos de tierra, de barro y de detritos, deslizamientos rotacionales y traslacionales de detritos y de tierra/suelo, deslizamientos planares y en cuña en roca, y reptación de suelo/detritos. Exceptuando a la reptación, se han inventariado 460 localidades con movimientos en masa de los distintos tipos en las tres subzonas estudiadas; 296 de estas localidades corresponden a movimientos cartografiables a escala 1:5.000, mientras que las 164 restantes consisten en movimientos menores, no cartografiables a dicha escala. El inventario consigna fecha de observación o de la imagen observada, tipo de movimiento, estado (juvenil o degradado), edad relativa, una descripción, escala de observación más detallada (teledetección y/o campo), fuente de la observación (nombre de la aerofoto o servidor de imagen satelital), y coordenadas. Los movimientos cartografiados se han representado en los tres mapas geomorfológicos de las distintas subzonas y han servido como insumo 
para evaluar la relación de los movimientos con distintas variables que representan condiciones del terreno. Se han estudiado en detalle las características geomorfológicas de los distintos tipos de movimientos y se las ha descripto de manera sistemática de acuerdo a tres contextos geomorfológicos principales y claramente diferenciables: frentes escarpados rocosos, laderas y cursos de agua. Para los tres contextos se muestran estudios multiescala, con aspectos puntuales, como orientaciones de diaclasas, detritos y pendientes locales, descripciones de tipos de materiales, rasgos de meteorización y relación con otros procesos, así como también a escala de ladera, con levantamiento de perfiles geomorfológicos, teledetección satelital y aerofotogrametría con drones, y obtención de datos de distribución de los movimientos mediante aplicación de técnicas estadísticas sencillas en entornos SIG, y a escala regional, como el análisis de datos de posibles factores desencadenantes, como las precipitaciones y los sismos.

\section{Elaborar mapas geomorfológicos de detalle. Esto contribuye a la mejora del} conocimiento geomorfológico del área. En las tres subzonas seleccionadas se diferenciaron, caracterizaron y cartografiaron a escala 1:5.000, 22 unidades geomorfológicas, agrupadas en 6 categorías, de acuerdo a los materiales y procesos involucrados: unidades influenciadas por la estructura geológica, cimas planas y divisorias principales, piedemonte inactivo, unidades aluviales activas, unidades coluviales activas y cubierta eólica periserrana. Se describió en detalle la morfología y los procesos geomorfológicos que se desarrollan en cada una de estas unidades, incluyendo aquellos rasgos menores, no cartografiables a escala 1:5.000. En unidades especialmente relacionadas con el desarrollo de movimientos en masa, se incluyen datos de laboratorio relacionados con el comportamiento geohidrológico y geomecánico, perfiles geomorfológicos levantados con técnicas cartográficas especiales, complementando observaciones de campo y técnicas de teledetección modernas, como lo es la generación de MDEs de detalle a partir de fotogrametría con drones. Se analizaron, tanto cualitativa o semi-cuantitativamente en el campo, como cuantitativamente en una aproximación telemática, las interacciones entre los distintos componentes y procesos geomorfológicos en general y el desarrollo de los movimientos en masa y sus formas asociadas, desde una perspectiva de procesos. Se identificaron así los mecanismos mediante los cuales las propiedades hidrológicas y geomecánicas de los distintos materiales, las estructuras, formas del paisaje y procesos geomorfológicos, como la acción hídrica y la actividad antrópica y zoogeomorfológica, influyen en la dinámica de producción y/o degradación de movimientos en masa.

Generar un mapa litológico de detalle que integre todo el registro litoestratigráfico y analizar características texturales, mineralógicas y geomecánicas en unidades 
Movimientos en masa en las sierras de Bravard y Curamalal,

Sierras Australes de la Provincia de Buenos Aires.

Juan Manuel Susena

litológicas particulares, aumentando así el detalle del conocimiento geológico del área. Se elaboró un mapa litológico a escala 1:20.000, partiendo de un estudio crítico y detallado de trabajos y cartografía preexistentes que cubrían parcialmente el área estudiada, o que no eran aptos para los objetivos de esta tesis. Se aplicaron técnicas de teledetección incluyendo el procesamiento digital de imágenes satelitales y reconocimiento en el campo, y el mapa así elaborado responde a los objetivos de esta tesis, ya que las unidades aflorantes han sido agrupadas de acuerdo a la escala de observación y al comportamiento mecánico de los materiales, respetando a su vez las denominaciones formales de unidades litoestratigráficas. Se incluyen descripciones de campo, mediciones y datos de laboratorio de las distintas unidades, aplicados al estudio de movimientos en masa: orientaciones de discontinuidades, fábrica de los depósitos, datos granulométricos y geomecánicos. Cabe destacar que se cartografió y describió en detalle una unidad informal aquí denominada Detritos de Ladera, la cual no ha sido jerarquizada por otros autores como unidad litológica en los mapas locales por razones de escala u objetivos de sus respectivos trabajos. En esta tesis se hace evidente la relevancia de esta unidad en la dinámica geomorfológica de la región.

Mejorar la cartografía de variables ambientales como la vegetación, así como distintas variables derivadas del procesamiento de los MDE. Se desarrolló una serie de mapas a escala 1:5.000 de variables en la subzona 1, que representan distintos aspectos del área estudiada: litología (características del material, comportamiento geomecánico e hidrogeológico), geomorfología (espesor de regolito, estructuras geológicas, procesos geomorfológicos), vegetación (acción hídrica, infiltración de agua, retención del material), distancia a caminos o huellas rurales (acción antropo y zoogeomorfológica), distancia a cursos de agua (acción hídrica) y variables derivadas del procesamiento de Modelos Digitales de Elevación (morfología del terreno, esfuerzo de corte, contenido de humedad, acción hídrica, meteorización). Se indicó la representatividad areal de las distintas clases de cada una de estas variables y se las interpretó de manera crítica en cuanto a su significado geomorfológico y su escala de representación.

\section{Analizar y cartografiar la susceptibilidad de movimientos en masa en sectores} específicos del área estudiada. Con las variables mencionadas en el párrafo anterior y el inventario de movimientos en masa, se analizó en un entorno SIG y con técnicas estadísticas relativamente sencillas (Frecuencia Relativa), el significado de cada variable en cuanto al desarrollo de movimientos en masa. Para elegir qué variables a priori 
contribuirían al desarrollo de movimientos en masa, se hizo y presentó un análisis de las causas de los movimientos en masa, con datos cualitativos propios de distintas características y procesos geomorfológicos observados y/o medidos en el terreno o mediante teledetección, y datos sistemáticos sobre factores condicionantes obtenidos en laboratorio y desencadenantes como las precipitaciones y los sismos, tanto editados como inéditos. A partir de un conjunto inicial de variables, realizando análisis factorial y de correlación de variables, se detectaron y descartaron aquellas derivadas de los MDE que tenían significados estadísticos -y geomorfológicos- similares, evitando sesgos por redundancia de información. Con las variables restantes (altitud, pendiente, orientación de la pendiente, curvaturas longitudinal y transversal a la pendiente, distancia a cursos de agua, distancia a caminos y huellas rurales, litología, geomorfología y vegetación), se elaboraron 20 modelos de susceptibilidad de movimientos en masa utilizando Funciones de Favorabilidad y Factor de Certidumbre con distintas combinaciones de las variables seleccionadas, y se elaboró un mapa de susceptibilidad a partir de uno de ellos. Se realizaron análisis de bondad de estos modelos mediante validaciones independientes y se analizó la sensibilidad y el potencial de las variables empleadas para explicar el desarrollo de movimientos en masa.

Reconocer y caracterizar otros procesos geomorfológicos que contribuyen a la degradación ambiental, así como los mecanismos mediante los cuales la actividad antrópica interviene en su desarrollo. Se describieron e interpretaron en instancia de campo y de gabinete (incluyendo análisis de datos de precipitaciones) distintos procesos de degradación ambiental, como la erosión hídrica, la acción eólica localizada y la pérdida permanente de cobertura vegetal. Se presentan numerosos casos de estudio locales donde se evidencian las interacciones entre la actividad antrópica y zoogeomorfológica y sus rasgos asociados, y los distintos procesos de degradación, con énfasis en los movimientos en masa, tanto desde un enfoque cualitativo de campo, como semi-cuantitativo mediante técnicas de SIG. Estas interacciones se analizaron desde un enfoque sistémico, identificándose casos de retroalimentación positiva entre acción antrópica y/o zoogeomorfológica, pérdida de cobertura vegetal y procesos erosivos. 


\section{Conclusiones según los objetivos planteados}

\section{Objetivo específico: Establecer criterios morfológicos que permitan la identificación de los movimientos en masa y su actividad.}

Se estableció una serie de criterios y rasgos morfológicos útiles para identificar movimientos en masa de distintos tipos y reconocer su actividad. Se trata de una serie de rasgos indicadores, reconocibles especialmente en el campo, aplicables a la caracterización de movimientos de roca (caídas, vuelcos y deslizamientos), o de movimientos que afectan al regolito (deslizamientos y flujos). Otros de estos indicadores son aplicables a varios tipos de movimientos de una manera genérica, como los relacionados con la vegetación y la meteorización de los bloques rocosos. Cada indicador tiene un potencial interpretativo particular y su utilización permitió clasificar a los movimientos según el estado de su actividad, en antiguos y jóvenes. Estos indicadores pueden ser de gran utilidad para mejorar la percepción de riesgo de los transeúntes, ya que las caídas de rocas desde frentes escarpados rocosos y en laderas, así como los vuelcos y caídas de suelo en fajas aluviales, suponen un riesgo para la actividad turística.

\section{Objetivo específico: conocer en detalle las características morfológicas y la} distribución principalmente espacial de los distintos tipos de movimientos en masa que se desarrollan en el área de estudio.

Se reconocieron, clasificaron y describieron de manera sistematizada los movimientos en masa de las sierras de Bravard y Curamalal. Se han diferenciado 14 tipos de movimientos en masa, de los cuales los más conspicuos son los deslizamientos rotacionales y traslacionales de detritos, los vuelcos de suelo, las caídas y vuelcos de rocas/detritos y la reptación. La distribución de los distintos tipos de movimientos varía según el contexto geomorfológico. Los movimientos comunes en la unidad geomorfológica Frentes Escarpados Rocosos son las caídas y vuelcos de roca, y en menor medida los deslizamientos planares y en cuña. En laderas (unidades geomorfológicas Laderas de Detritos, Laderas Compuestas, Afloramientos Ahogados, y Bajada Coluvial Fina, entre otras) dominan los deslizamientos y flujos de detritos, flujos de tierra, caídas de rocas y reptación. En las unidades geomorfológicas relacionadas con cursos de agua (Fajas Aluviales, Incisiones Fluviales, y otras unidades aluviales antiguas o modernas) se desarrollan principalmente caídas y vuelcos de suelo, deslizamientos de suelo y de detritos, y reptación. El inventario de movimientos en masa proporciona información de los movimientos desarrollados en tres subzonas del área estudiada. Mediante este inventario se estudiaron aspectos de la distribución de los movimientos, su 
asociación con distintos componentes geomorfológicos y otras variables del terreno, y fue una pieza fundamental para la elaboración de modelos de susceptibilidad. Con una perspectiva más amplia, el inventario desarrollado sirve además como base para analizar a posteriori estos procesos desde una perspectiva multi-temporal; podrán agregarse a este registro los movimientos que se produzcan en el futuro.

Se mejoró la comprensión del papel de los movimientos en masa en el modelado del relieve, siendo especialmente influyentes en el desarrollo de las laderas de detritos y los cursos de agua. Las caídas de roca tienen especial importancia en determinados sectores de los frentes escarpados rocosos, contribuyendo al modelado de gargantas, pequeñas cuencas rocosas, taludes y conos de detritos. Si bien la reptación es un proceso generalizado en el área, los deslizamientos son los principales movimientos que modelan las laderas, imprimiendo una topografía hummocky muy característica, mientras los flujos de detritos tienen menor participación.

\section{Objetivo específico: Identificar las relaciones existentes entre los movimientos en masa y los factores condicionantes y desencadenantes.}

Los principales mecanismos preparadores y desencadenantes de los movimientos son la acción del agua (precipitaciones, lavaje de la matriz de los depósitos, socavamiento basal en cursos de agua y pipping), y la acción antro y zoogeomorfológica (puesta en movimiento de rocas, sobrecarga en el terreno, creación de componentes de paisaje susceptibles a movimientos y aumento en la susceptibilidad de geoformas preexistentes por alteración de las propiedades geomecánicas y geohidrológicas o la fábrica de los depósitos). El agua es el principal mecanismo desencadenante de movimientos mediante saturación de poros en las laderas, especialmente las de umbría, el lavaje de la matriz vinculado a manantiales en el contacto roca-detritos, el socavamiento basal por pipping y la erosión hídrica en cursos de agua. Otros mecanismos secundarios condicionantes y desencadenantes son la acción antropo y zoogeomorfológica. La primera, opera a través de la construcción de cortes de caminos, reducción de la resistencia mecánica del material por prácticas agrotécnicas, e indirectamente la contribución al desarrollo de incisiones fluviales donde se producen movimientos. La acción zoogeomorfológica actúa mediante la generación de sobrecargas, puesta en movimiento de detritos, excavaciones e indirectamente modificaciones en el comportamiento hidrológico del material.

Los principales factores condicionantes y desencadenantes de los distintos tipos de movimientos se expresaron en cartografía temática de utilidad para diversos tipos de análisis (susceptibilidad, amenaza, riesgo). Dicha cartografía agrupa información obtenida en el campo y mediante fotointerpretación, como la litología, la geomorfología y la vegetación, y variables del terreno obtenidas automáticamente mediante el 
Movimientos en masa en las sierras de Bravard y Curamalal,

Sierras Australes de la Provincia de Buenos Aires.

Juan Manuel Susena

procesamiento de un modelo digital de elevaciones. Del análisis individual y conjunto de la contribución de estas variables al desarrollo de movimientos en masa, se identificaron las variables más representativas y factibles para la obtención de modelos de susceptibilidad confiables. Se comprobó que el grado de detalle de la cartografía (número de clases de las variables) de la litología, la geomorfología y la vegetación, permite generar predicciones aceptables, estableciendo un esquema cartográfico para la obtención sistemática de estas variables en otras zonas de las Sierras Australes de la Provincia de Buenos Aires. Se encontraron así las combinaciones de variables más adecuadas para establecer de manera aceptable las áreas más susceptibles al desarrollo de estos procesos. La mejor combinación de variables incluye la geomorfología, la pendiente, la orientación, la altitud y la distancia a cursos de agua. Lo expresado en este párrafo es una actividad sin precedentes en el ámbito serrano del suroeste bonaerense y establece una base para analizar otras zonas de estas sierras.

\section{Objetivo especifico: Mejorar el conocimiento de las interacciones entre los movimientos en masa y otros procesos geomorfológicos.}

Se analizaron las diferentes interacciones entre los movimientos en masa y otros procesos geomorfológicos. Se reconoció que los movimientos en masa alteran el funcionamiento de otros procesos geomorfológicos, como el escurrimiento superficial y sub-superficial. La creación de convexidades y concavidades en las laderas debido a los movimientos en masa favorece, respectivamente, la aceleración o desaceleración del escurrimiento superficial, y consecuentemente la erosión de la matriz de los depósitos o el estancamiento de agua y depositación de materiales finos. Asimismo, los quiebres de pendiente en escarpas de movimientos en masa permiten la surgencia del agua subsuperficial, formándose manantiales. Los rasgos producto de movimientos en masa pueden también concentrar la actividad zoogeomorfológica, por concentración local de agua o presencia de bloques que sirven como rascaderos. Como consecuencia, puede aumentar localizadamente la compactación y la pérdida permanente de cobertura vegetal. Los movimientos contribuyen además a la degradación del piedemonte, especialmente mediante el ensanchamiento y retroceso de cárcavas y la destrucción de taludes en caminos. Así, el desarrollo de estos procesos reduce la superficie del piedemonte disponible para la explotación agropecuaria.

De esta manera, se alcanzó el objetivo general de esta tesis: Conocer los movimientos en masa del área de estudio y sus mecanismos de formación, así como su 
contribución al modelado del relieve. Los resultados presentados en esta tesis contribuyeron a mejorar el conocimiento de los movimientos en masa del ámbito serrano del suroeste bonaerense, mediante la caracterización de los diferentes tipos de movimientos, su relación con los componentes geológicos y geomorfológicos, su interacción con otros procesos, como la acción del escurrimiento superficial y subsuperficial y la acción antropo-faunística, y el análisis de susceptibilidad de los movimientos, así como la amenaza y riesgo que suponen y los cambios que producen en el paisaje.

Esta tesis no sólo aportó información para alcanzar los objetivos planteados, sino que comprende además una serie de aportes al conocimiento del área estudiada, que son de interés para otros ámbitos de las ciencias ambientales:

- Se mejoró el conocimiento geomorfológico del área, mediante la identificación de unidades geomorfológicas de detalle y la caracterización de sus procesos actuantes y geoformas más comunes, y su representación en mapas geomorfológicos.

- Se aportó información sobre procesos geomorfológicos naturales y antrópicos que contribuyen a la degradación ambiental, así como criterios para su identificación en etapas tempranas.

- Se obtuvo un mapa litológico integral del área de estudio, contemplando todo el registro litoestratigráfico aflorante, con especial énfasis en las unidades del Cenozoico.

- Se mejoró la cartografía de variables ambientales, como la vegetación, la hidrografía y otras variables derivadas del procesamiento de los MDE. 
Movimientos en masa en las sierras de Bravard y Curamalal,

Sierras Australes de la Provincia de Buenos Aires.

Juan Manuel Susena

\section{Otras consideraciones}

\section{Sobre las terminologías aplicadas}

Es de utilidad diferenciar los tipos cinemáticos, ya que su distribución se vincula a determinadas condiciones de las laderas (hidrológicas, tipos de material, relación con los materiales sub-superficiales). Algunos aspectos de las clasificaciones convencionales son de difícil obtención, como el estado de la actividad, ya que no se dispone de registros (inventarios) anuales de los movimientos. Por esta razón, dichos aspectos deben redefinirse de acuerdo a la información disponible (en este caso indicadores de edad relativa), o no utilizarse. En la comunicación profesional, algunos tipos de movimientos, como los flujos de tierra y los flujos de detritos, se asocian inevitablemente a ejemplos de cierta fama a nivel mundial, lo cual condiciona que la clasificación se centre estrictamente en el mecanismo de movimiento. En el caso del área de estudio, los flujos de tierra menores no se parecen a los ejemplos comunes en la bibliografía, pero los materiales involucrados y las características morfológicas esenciales vinculadas al mecanismo de movimiento permiten clasificarlos como tales. Nunca debe olvidarse que, siendo construcciones humanas, estas clasificaciones proponen los extremos más conspicuos y fáciles de identificar, habiendo entre ellos una gradación continua de procesos y morfologías resultantes, producto en este caso de la proporción de agua y de los materiales involucrados. En este sentido, quizá no siempre sea estrictamente necesario clasificar todos los movimientos e inventar clases nuevas porque lo observado no encaja en ningún extremo, sino que puede ser más expeditivo asociar lo observado al tipo de movimiento más parecido de los definidos en la literatura.

\section{Sobre la metodología}

Durante la elaboración de esta tesis existió una retroalimentación constante entre el criterio de campo y la fotointerpretación y la utilización de variables automáticas. Lo que se observa en el campo puede, por razones de escala, complementar o afinar lo identificado en las imágenes y mejorar la cartografía de las variables como la geomorfología y la litología. También implica mejoras en el inventario, ya que se pueden discriminar tipos de movimientos aparentemente similares en las imágenes, o sectores con abundantes caídas y movimientos menores no detectables con imágenes medianamente asequibles. La inclusión de las variables obtenidas en el campo permite asimismo mejorar la predicción de los modelos de susceptibilidad. 
En ausencia de información multi-temporal sistemática, la identificación de indicadores morfológicos de antigüedad o juventud, son un elemento de campo útil a la hora de realizar modelos de susceptibilidad, permitiendo descartar aquellos movimientos demasiado antiguos, donde se pudiera presuponer un carácter relíctico (desarrollados bajo condiciones ambientales diferentes a las actuales). Cabe destacar que el aporte de información de pobladores de la zona sobre eventos climáticos extremos y procesos hidrogeomorfológicos asociados, ha mejorado la perspectiva de la intensidad de algunos procesos, como la erosión hídrica y los movimientos de tipo flujo en eventos de lluvias intensas, no detectables de otra manera por falta de información multitemporal.

Por su parte, el análisis de modelos digitales del terreno aporta información no obtenida en el campo, sea por falta de expresión morfológica o por la dificultad de obtener sistemáticamente dicha información. En todo caso, este tipo de modelos ofrecen información complementaria de gran utilidad.

\section{Líneas de trabajo futuro}

La información aportada en esta tesis abre el campo a nuevas líneas de trabajo, susceptibles de llevarse a cabo con la información disponible y añadiendo más datos obtenidos en el campo, así como mediante otros recursos. El desarrollo de estas nuevas líneas de investigación contribuiría a acrecentar el conocimiento geomorfológico de la región, a mejorar la gestión de uso del territorio y potenciar o impulsar actividades económicas.

Líneas vinculadas al conocimiento geomorfológico:

- Cartografiar la distribución en el subsuelo del Mb. Cementado de los Detritos de Ladera para conocer mejor su génesis e influencia sobre el desarrollo de los movimientos actuales.

- Datar los movimientos mayores del área estudiada, así como otros grandes movimientos de las Sierras Australes, para saber si pueden vincularse a condiciones climáticas afines a las actuales y estudiar la evolución de las laderas desde una perspectiva a largo término. 
- Cuantificar el aporte relativo de los movimientos en masa a la pérdida de material eólico en cursos de agua y caminos, ya los suelos desarrollados en dicho material son el principal recurso económico de la región.

- Analizar la mecánica de los flujos de tierra vinculados a la acción faunística para detectar los períodos del año con mayor susceptibilidad y programar la distribución de la carga ganadera para reducir la degradación del suelo.

- Abordar un análisis cuantitativo o semi-cuantitativo mediante indicadores, de los efectos de la acción antrópica y zoogeomorfológica en el paisaje, en relación con los debidos a agentes o procesos naturales.

Líneas relacionadas con la susceptibilidad, amenaza y riesgo por movimientos en masa:

- Reproducir sistemáticamente la metodología llevada a cabo en esta tesis en otros sectores de las Sierras Australes de la Provincia de Buenos Aires hasta lograr una cartografía de susceptibilidad completa de la región.

- Ajustar los modelos a escala de ladera en otros sectores de Ventania, mediante un levantamiento sistemático de MDE más detallados y obtención de sus derivados, e incorporación de variables geomecánicas. Esto debería hacerse especialmente en sitios potencialmente residenciales, comerciales o industriales y zonas de tránsito frecuente, como las rutas, a corto y mediano plazo.

- Delimitar sistemáticamente los sectores más susceptibles de caídas y vuelcos de roca, así como las condiciones más favorables para su producción, para organizar el tránsito. 
- Sistematizar un análisis multi-temporal mediante un relevamiento fotogramétrico regular, para poder avanzar hacia la detección sistemática de reactivaciones de movimientos en masa.

- Refinar la metodología de análisis de la susceptibilidad (variables continuas, mejorar las funciones a aplicar, mejorar el análisis de selección de variables, utilizar otras estrategias de validación, etc.).

- Analizar la frecuencia temporal de movimientos en el pasado reciente en algún sector favorable con mayor precisión de datos, correlacionando la ocurrencia de movimientos con series de datos climáticos. Esto ayudaría a establecer la periodicidad esperable y a hacer una estimación inicial de peligrosidad/amenaza (probabilidad espacio-temporal).

- Concientizar a los residentes del área sobre el riesgo potencial de los movimientos en masa y enseñar los criterios de reconocimiento de su actividad, incentivando a la creación de un inventario colaborativo de los movimientos de la zona, del cual puedan disponer los municipios.

- Analizar la evolución geomorfológica reciente considerando escenarios de cambio climático e intensificación de la actividad antrópica. Proyectar posibles tendencias futuras de implicaciones en los procesos y riesgos asociados.

Líneas concernientes al patrimonio y la actividad turística:

- Establecer la contribución de los movimientos en masa a la destrucción de sitios de posible interés geológico, arqueológico, paleontológico, etc., así como medidas para su mitigación y preservación del patrimonio.

- Dada la rareza de los grandes de los grandes movimientos del área, descifrar su historia geológica y ponerlos en valor como patrimonio geológico, podría representar una oportunidad para el desarrollo turístico de la región. 
Movimientos en masa en las sierras de Bravard y Curamalal, Sierras Australes de la Provincia de Buenos Aires.

Juan Manuel Susena 


\section{AGRADECIMIENTOS}

He hecho el esfuerzo de no olvidar a nadie, pero tengo la tranquilidad de que cada persona sabe cuánto ha contribuido directa o indirectamente a la realización de este trabajo y a hacer más ameno mi tránsito por esta etapa de mi vida.

En lo personal doy primeramente gracias a Dios, porque me sostuvo en los mejores y peores momentos; pensar que la posibilidad de hacer este trabajo vino de Él es una de las principales causas que me han enfocado para no claudicar. En segundo lugar, agradezco a mi esposa Georgina, por acompañarme en esta etapa con sus palabras y cariño incondicional y sus ayudas de incalculable valor, tanto en ámbito doméstico como en el laboral. Doy gracias también a mi familia de sangre, por haberme ayudado en los inicios de mi carrera, por alentarme y estar pendientes de mi estado de salud y de ánimo, a mis hermanos en la fe por su apoyo, a mis amigos y colegas que muchísimas veces me han dado ánimo y valiosos consejos.

En lo profesional doy gracias en primer lugar a mi director Osvaldo Gentile, por estar siempre dispuesto desde el primero hasta el último día (e incluso antes) de este largo trabajo, y también por su dedicación y preocupación por mi formación y mi futuro profesional. Doy gracias también a Nauris Dangavs y a Enrique Fucks, que no han dudado en ofrecerme una mano en todo momento en que la necesité. Agradezco asimismo a Martín Hurtado, director del Instituto de Geomorfología y Suelos de la Universidad Nacional de La Plata por permitirme integrarme al grupo de trabajo, y por su fiel amistad y compañía durante estos cinco años. Todo el personal de dicha institución me ha apoyado y animado sin cesar, lo cual también agradezco profundamente. Imposible olvidar a mi director Juan Remondo, por sus invaluables aportes a la realización de esta tesis, por sus enseñanzas y las largas horas que me ha dedicado, y por su compañerismo tanto en lo profesional como en lo humano. Extiendo el agradecimiento a Antonio Cendrero por haberme incentivado a realizar la tesis en régimen de cotutela, por ser solícito en todo momento, tanto en Argentina como en España, por sus consejos profesionales y también por su apertura hacia mi persona. Agradezco asimismo a Jesús Rodríguez, director del Departamento de Ciencias de la Tierra y Física de la Materia Condensada de la Universidad de Cantabria, así como al resto del personal, por recibirme y hacer muy amena mi estancia en dicha institución. Gracias al Personal de Apoyo del Instituto de Geomorfología y Suelos y del Centro de Investigaciones Geológicas (Universidad Nacional de La Plata) por la respectiva realización de algunos de los análisis de textura y de los análisis de difracción de rayos $\mathrm{X}$. 
Agradezco a Rubén Godagnone del INTA de Castelar y al Departamento de Metodología Valuatoria Rural de ARBA por haberme permitido acceder a su juego de fotos aéreas del área de estudio, así como a Eduardo Campi del INTA Bordenave, por brindarme los datos de precipitaciones de varias estaciones meteorológicas.

Quiero agradecer también a los jurados Antonio Cendrero, Yolanda Aguilera y Stella Moreiras, que accedieron a evaluar mi tesis, en un momento tan complicado como lo es esta situación de pandemia y trabajo en el hogar, valoro sinceramente su esfuerzo y tiempo dedicado. Sus correcciones y comentarios, tan críticos como constructivos, tanto formales como informales, han mejorado no sólo la calidad de este trabajo, sino también mi formación profesional.

Muchas gracias a la administración de las Estancias Las Grutas, Cerro Áspero, Cura-Có, La Ermita, Don José, Lolén y Sauce Chico por permitirme acceder a los establecimientos para realizar las tareas de campo. Agradezco especialmente a "Negrita" y familia (Estancia Las Grutas) y a Carlos Eckardt y familia (Estancia Cerro Áspero) por su solicitud y buena disposición para contactarme con la administración de las demás estancias, y por brindarme información de gran valor para la realización de esta tesis. También doy gracias a mis colegas Lucas Misseri y Andrea Cáceres, por haber colaborado con ciertas tareas de campo y a las Cátedras de Geología Argentina, Ecología de Pastizales, Ecología de Comunidades, Herpetología y Parasitología, por haberme incluido en sus salidas al campo.

Doy gracias también a la Escuela de Doctorado de la Universidad de Cantabria por permitir mi inscripción a la Carrera del Doctorado en Ciencia y Tecnología. Gracias al Consejo Nacional de Investigaciones Científicas y Técnicas (CONICET) de Argentina por otorgarme la Beca Doctoral, brindándome la posibilidad de dedicarme a tiempo completo al trabajo de tesis. Por último, pero con énfasis, agradezco a la Facultad de Ciencias Naturales y Museo por la formación que me ha dado desde que ingresé a la Licenciatura en Geología en el año 2008 hasta el presente, y a la Nación Argentina, ya que, si la Universidad no fuera pública y "gratuita", posiblemente no estaría escribiendo esto. 


\section{BIBLIOGRAFÍA CITADA}

ABETE, L. A. y SÁNCHEZ, M. 1970. Relación entre las constantes de Atterberg y su estimación rápida mediante el ensayo de expansión libre. Memoria de la Primera Reunión Argentina de Mecánica de Suelos e Ingeniería de Fundaciones, pp. 241-250. La Plata.

AGUIRRE, E. 1891. La Sierra de la Ventana. Anales Sociedad Científica Argentina, 32: 20-33.

AKGUN, A. 2012. A comparison of landslide susceptibility maps produced by logistic regression, multi-criteria decision, and likelihood ratio methods: a case study at Izmir, Turkey. Landslides, 9: 93-106. https://doi.org/10.1007/s10346-011-0283-7

AKINCI, H., DOĞAN, S., KILICOĞLU, C. y TEMIZ, M. S. 2011. Production of landslide susceptibility map of Samsun (Turkey) City Center by using frequency ratio method. International Journal of the Physical Sciences, 6 (5): 1015-1025.

ALCÁNTARA-AYALA, I. 2000. Landslides: ¿deslizamientos o movimientos del terreno? Definición, clasificaciones y terminología. Investigaciones Geográficas, Boletín del Instituto de Geografía, UNAM, 41: 7-25.

ALESSANDRETTI, L., PHILIPP, R. P., CHEMALE Jr, F., BRÜCKMANN, M. P., ZVIRTES, G., MATTÉ, V. y RAMOS, V. A. 2013. Provenance, volcanic record, and tectonic setting of the Paleozoic Ventania Fold Belt and the Claromecó Foreland Basin: Implications on sedimentation and volcanism along the southwestern Gondwana margin. Journal of South American Earth Sciences, 47: 12-31.

ALKHASAWNEH, M. S., NGAH, U. K., TAY, L. T., MAT ISA, N. A. y AL-BATAH, M. S. 2013. Determination of important topographic factors for landslide mapping analysis using MLP network. The Scientific World Journal, Volume 2013, ID 415023, 12 pp. DOI:10.1155/2013/415023.

ANDREIS, R. 1965. Petrografía de las sedimentitas psefíticas paleozoicas de las Sierras Australes Bonaerenses. Anales CIC, Provincia de Buenos Aires, pp. 9-63.

ANDREIS, R. y LÓPEZ GAMUNDÍ, O. R. 1985. Interpretación paleoambiental de la secuencia paleozoica del cerro Pan de Azúcar, Sierras Australes, provincia de Buenos Aires. Resúmenes de las $1^{\circ}$ Jornadas de Geología Bonaerenses, 241. La Plata.

ANDREIS, R. y TORRES RIBEIRO, M. 2003. Estratigrafía, facies y evolución depositacional de la Formación Sauce Grande (Carbonífero Superior), Cuenca Sauce Grande, Sierras Australes, Buenos Aires, Argentina. Revista de la Asociación Geológica Argentina, 58: 137-165.

ANDREIS, R., SPALLETTI, L. y MAZZONI, M. 1971. Sedimentología de la Brecha Cerro Colorado, Sierras Australes de la provincia de Buenos Aires. Resúmenes de la Reunión sobre Geología Sierras Australes Bonaerenses, pp. 65-96.

ANDREIS, R., IÑIGUEZ, A. M., LLUCH, J. y RODRíGUEZ, S. 1989. Cuenca paleozoica de Ventania, Sierras Australes, provincia de Buenos Aires. En: Chebli, G. y Spalletti, L. A. (Eds.): Cuencas Sedimentarias de Argentina. Instituto Superior de Correlación Geológica, Universidad Nacional de Tucumán, San Miguel de Tucumán, 6: 265-298.

ÁNGELES, G. R. y GIL, V. 2006. Identificación del grado de transformación antrópica y riesgo ambiental en cuencas fluviales serranas. El caso de la cuenca del arroyo El Belisario (Argentina). GeoFocus, 6: 138-151.

ANGELIS, P. 1836. Colección de obras y documentos relativos a la historia antigua y moderna de las Provincias del Río de la Plata. Imprenta del Estado. Buenos Aires.

ANTONIOLI, J. 1969. Fanglomerado Cerro Colorado. Trabajo inédito.

ARMAŞ, I. 2012. Weights of evidence method for landslide susceptibility mapping. Prahova Subcarpathians, Romania. Natural Hazards, 60 (3): 937-950. DOI: 10.1007/s11069-011-9879-4.

ATTERBERG, A. 1911. Die plastizität der tone. Internationale Mitteilungen für Bodenkunde, 1: 1043.

AYALEW, L., YAMAGISHI, H. y UGAWA, N. 2004. Landslide susceptibility mapping using GISbased weighted linear combination, the case in Tsugawa area of Agano River, Niigata Prefecture, Japan. Landslides 1: 73-81. 
BALDO, M., BICOCCHI, C., CHIOCCHINI, U., GIORDAN, D. y LOLLINO, G. 2009. LIDAR monitoring of mass wasting processes: The Radicofani landslide, Province of Siena, Central Italy. Geomorphology, 105: 193-201.

BALLIVIÁN JUSTINIANO, C. A. 2016. Geología y aspectos estructurales del área Cerro Pan De Azúcar - Cerro Del Corral. Procesos petrogenéticos/geoquímica del skarn Loma Marcelo, Sierras Australes de Buenos Aires. Tesis Doctoral, Facultad de Ciencias Naturales y Museo, Universidad Nacional de La Plata. $456 \mathrm{pp}$.

BANCHIG, A. L., MOREIRAS, S. y BANCHING, P. N. 2008. Eventos de deslizamientos endicamientos reiterados de ocurrencia histórica. Cuenca del Río Villavil, Sierra de Aconquija, Andalgalá, Catamarca. Actas del XVII Congreso Geológico Argentino. Jujuy. 1: 257-258.

BARREDO, J. I., BENAVIDES, A., HERVAS, J. y VAN WESTEN, C. J. 2000. Comparing heuristic landslide hazard assessment techniques using GIS in the Tirajana basin, Gran Canaria Island, Spain. International Journal of Applied Earth Observation and Geoinformation, 2: 9-23.

BEAUMONT, A. 1806. Description des Alpes Grecques et Cottiennes ou tableau historique et statistique de la Savoie. Vol. 2: 659 pp. París.

BELL, R., PETSCHKO, H., RÖHRS, M. y DIX, A. 2012. Assessment of landslide age, landslide persistence and human impact using airborne laser scanning digital terrain models. Geografiska Annaler: Series A, Physical Geography. 94: 135-156.

BENDA, L., VELDHUISEN, C. y BLACK, J. 2003. Debris flows as agents of morphological heterogeneity at low-order confluences, Olympic Mountains, Washington. GSA Bulletin, 115 (9): 1110-1121.

BERTRAND, M. E. 1757. Mémoires historiques et phisiques sur les tremblements de terre, La Haye. $328 \mathrm{pp}$.

BIDART, S. 1992a. Clasificación de los sedimentos eólicos del Pleistoceno tardío-Holoceno del sur bonaerense. Una Propuesta. IV Reunión Argentina de Sedimentología, Actas II, pp. 159-166.

BIDART, S. 1992b. Depósitos de "polvo vial" en la cuenca del Río Sauce Grande, Provincia de Buenos Aires. Connotación estratigráfica. Actas de las III Jornadas Geológicas Bonaerenses, pp. 91-96.

BIDART, S. 1993. Textural characterization and stratigraphic aspects of the late PleistoceneHolocene eolian sediments in the Sierra de la Ventana area, Buenos Aires Province, Argentina. Quaternary International, 17: 39-47.

BIDART, S. 1996. Sedimentological study of aeolian soil parent materials in the Río Sauce Grande basin, Buenos Aires province, Argentina. Catena 3-4: 191-207.

BILKRA L. H. y NEMEC, W. 1998. Postglacial colluvium in western Norway: depositional process, facies and paleoclimatic record. Sedimentology, 45: 909-959.

BINAGHI, E., LUZI, L., MADELLA, P., PERGALANI, F. y RAMPINI, A. 1998. Slope Instability Zonation: a Comparison Between Certainty Factor and Fuzzy Dempster-Shafer Approaches. Natural Hazards, 17: 77-97. https://doi.org/10.1023/A:1008001724538

BLANCO, M. del C., SANCHEZ, L. F., VERA, M. y AGUILAR RUIZ, J. 1997. Mineralogía y micromorfología de suelos loéssicos con desarrollo moderado en la Llanura Subventánica Occidental Bonaerense, Argentina. Edafología. Revista de la Sociedad Española de la Ciencia del Suelo, 2: 215-219.

BLOOM, A. L. 1978. Geomorphology. Prentice Hall, 510 pp. New Jersey.

BLOOM, A. L. 1991. Geomorphology: A Systematic Analysis of Late Cenozoic Landforms. Prentice Hall, Englewood Cliffs, 2da. Edición, 531 pp. New York.

BOEHNER, J. y ANTONIC, O. 2009. Land-surface parameters specific to topo-climatology. En: Hengl, T. y Reuter, H. (Eds.): Geomorphometry - Concepts, Software, Applications. Developments in Soil Science, 33: 195-226, Elsevier. ScienceDirect.

BONACHEA, J. 2006. Desarrollo, aplicación y validación de procedimientos y modelos para la evaluación de amenazas, vulnerabilidad y riesgo debidos a procesos geomorfológicos. Tesis Doctoral, Universidad de Cantabria. 356 pp.

BONACHEA, J., BRUSCHI, V., HURTADO, M., FORTE, L., DA SILVA, M., ETCHEVERRY, R., CAVALlOTTO, J., DANTAS, M., PEJON, O., ZUQUETTE, L., DE, O., BEZERRA, M., REMONDO, J., RIVAS, V., GÓMEZ-AROZAMENA, J., FERNÁNDEZ, G. y CENDRERO, A. 
2010. Natural and human forcing in recent geomorphic change; case studies in the Rio de la Plata basin. Science of the Total Environment, 408: 2674-2695.

BOUYOUCOS, G. J. 1962. Hydrometer method improved for making particle size analysis of soils. Agronomy Journal 43: 464-465.

BRABB, E. E. 1984. Innovative approaches to landslide hazard mapping. Proceedings of the IV International Symposium of Landslides, 1: 307-324. Toronto.

BRABB, E. E., PAMPEYAN, E. H. y BONILLA, M. G. 1972. Landslide susceptibility in San Mateo County, California. U.S. Geological Survey Miscellaneous Field Studies Map, MF360 (scale 1:62.500).

BRAND, E. W. y HUDSON, R. R. 1982. CHASE-An empirical approach to the design of cut slopes in Hong-Kong soils. Proceedings $7^{\circ}$ Southeast Asian geotechnical Conference, 1: 1-16. HongKong.

BRESSAN, D. 2010. Landslides in the Alps: Introduction and History of research. Recuperado de: http://historyofgeology.fieldofscience.com/2010/07/landslides-in-alps-introduction-and.html

BRUNSDEN, D. 1979. Mass movements. En: Embleton, C. E. y Thornes, J. B. (Eds.): Progress in Geomorphology, Arnold, pp. 130-186.

BRUSCHI, V. M., BONACHEA, J., REMONDO, J., GÓMEZ-AROZAMENA, J., RIVAS, V., BARBIERI, M., CAPOCCHI, S., SOLDATI, M. y CENDRERO, A. 2013. Land Management Versus Natural Factors in Land Instability: Some Examples in Northern Spain. Environmental Management, 52: 398-416.

BUGGISCH, W. 1987. Stratigraphy and very low grade metamorphism of the Sierras Australes de la Provincia de Buenos Aires (Argentina) and implications in Gondwana correlation. Zentralblatt Mineralogie Geologie Paläontologie, 1: 819-837.

BURCKHARDT, C., 1900. Profils géologiques transversaux de la cordillére argentino-chilienne. Stratigraphie et Tectonique. Anales del Museo de La Plata, Sección Mineralogía y Geología, 1 (2): 1-136.

BUSCHIAZZO, D. 1986. Estudio sobre la tosca. Parte 1: Evidencias de un movimiento descendente del carbonato en base a la interpretación de características macro y geomorfológicas. Ciencia del Suelo, 4: 55-65.

BUTLER, D. R. 1995. Zoogeomorphology: Animals as Geomorphic Agents. Cambridge University Press, $231 \mathrm{pp}$.

BUTLER, D. R. 2006. Human-induced changes in animal populations and distributions, and the subsequent effects on fluvial systems. Geomorphology, 79: 448-459.

BUTLER, D. R. 2012. The impact of climate change on patterns of zoogeomorphological influence: examples from the Rocky Mountains of the western U.S.A. Geomorphology, 157-158: 183-191.

CABRERA, A. L. 1953. Esquema fitogeográfico de la República Argentina. Revista del Museo Eva Perón, Botánica, 8: 87-168.

CABRERA, A. L. 1968. Flora de la Provincia de Buenos Aires. Colección Científica del INTA, Buenos Aires. pp. 33-101.

CAMPO, A. M., RAMOS, M. B. y ZAPPERI, P. A. 2009. Análisis de las variaciones anuales de precipitación en el suroeste bonaerense, Argentina. XII Encuentro de Geógrafos de América Latina. Montevideo. Actas del $12^{\circ}$ Encuentro de Geógrafos de América Latina. Montevideo. Disponible en: http://egal2009.easyplanners.info/area07/7085_campo_alicia_m_.pdf ISBN 9789974-0-5

CAPPANNINI, D. A., SCOPPA, C. O. y VARGAS GIL, J. R. 1974. Suelos de las Sierras Australes de la Provincia de Buenos Aires. Actas de la Reunión sobre la Geología de las Sierras Australes Bonaerenses (año 1970), pp. 203-234.

CARDINALI, A., REICHENBACH, P., GUZZETTI, F., ARDIZZONE, G., GALLI, M., CACCIANO, M., CASTELLANI, M. y SALVATI, P. 2002. A geomorphological approach to the estimation of landslide hazards and risks in Umbria, Central Italy. Natural Hazards and Earth System Sciences, 2: $57-72$.

CARRARA, A. 1983. Multivariate models for landslide hazard evaluation. Mathematical Geology, 15: $403-426$. 
CARRARA A., CARDINALLI, M., DETTI, R., GUZZETTI, F., PASQUI, V. y REICHENBACH, P. 1991. GIS techniques and statistical models in evaluating landslide hazard. Earth Surface Processes and landforms 16 (5): 427-445.

CARRASCAL, C. C., DENEGRI, G. A. y DELGADO, M. I. 2013. Costos mínimos de compensación y cuantificación de la oferta hídrica en la Cuenca del río Sauce Grande, Argentina. Investigaciones Geográficas, Boletín del Instituto de Geografía, UNAM, 80: 55-70.

CASAGRANDE, A. 1932. Research non the Atterberg Limits of soils. Public Roads, 13: 121-136.

CASTELLANOS ABELLA, E. A. y VAN WESTEN, C. J. 2008. Qualitative landslide susceptibility assessment by multicriteria analysis: A case study from San Antonio del Sur, Guantánamo, Cuba. Geomorphology, 94: 453-466.

CATANI, F., LAGOMARSINO, D., SEGONI, S. y TOFANI, V. 2013. Landslide susceptibility estimation by random forests technique: sensitivity and scaling issues. Natural Hazards and Earth System Sciences, 13: 2815-2831.

CENDRERO, A. y DOUGLAS, I. 1996. Earth surface processes, materials use and urban development; project aims and methodological approach. Abstracts with programs, GSA Annual Meeting, Denver: A-79.

CENDRERO, A. y DRAMIS, F. 1996. The contribution of landslides to landscape evolution in Europe. Geomorphology, 15: 191-211.

CENDRERO, A., FRANCÉS, E. y DÍAZ DE TERÁN, J.R. 1992. Geoenvironmental Units as a Basis for the Assessment, Regulation and Management of the Earth's Surface. En: Cendrero, A., Lüttig, G. y Wolff, F.C. (Eds.): Planning the Use of the Earth's Surface. Lecture Notes in Earth Sciences, pp. 199-234. Springer-Verlag. Berlín.

CENDRERO, A., REMONDO, J., BONACHEA, J., RIVAS, V. y SOTO, J. 2006a. Sensitivity of landscape evolution and geomorphic processes to direct and indirect human influence. Geografia Fisica e Geodinamica Quaternaria, 29 (2): 125-137.

CENDRERO, A., REMONDO, J., BONACHEA, J., RIVAS, V. y SOTO, J. 2006b. Acción humana y procesos geológicos superficiales ¿qué le estamos haciendo a la faz de la Tierra? Revista de la Real Academia de Ciencias Exactas, Físicas y Naturales, 100 (1): 187-209.

CENDRERO, A., FORTE, L. M., REMONDO, J. y CUESTA-ALBERTOS, J. A. 2020. Anthropocene Geomorphic Change. Climate or Human Activities? Earth's Future, 8 (5). DOI: 10.1029/2019EF001305.

CHARLTON, R. J. 2007. Fundamentals of Fluvial Geomorphology. 280 pp. Routledge, London.

CHAUHAN, S., SHARMA, M. y ARORA, M. K. 2010. Landslide susceptibility zonation of the Chamoli region, Garhwal Himalayas, using logistic regression model. Landslides, 7: 411-423. https://doi.org/10.1007/s10346-010-0202-3

CHUNG, C. F. y FABBRI, A. 1993. The Representation of Geoscience Information for Data Integration. Non-renewable Resources, 2 (2): 122-139.

CHUNG, C. F. y FABBRI, A. G. 1998. Three Bayesian prediction models for landslide hazard. En: Bucciantti, A. (Ed.): Proceedings of International Association for Mathematical Geology Annual Meeting (IAMG'98), pp. 204-211. Ischia, Italia.

CHUNG, C. F. y FABBRI, A. 1999. Probabilistic prediction models for landslide hazard mapping. Photogrammetric Engineering \& Remote Sensing, 65 (12): 1389-1399.

CHUNG, C. F., FABBRI, A. y VAN WESTEN, C. J. 1995. Multivariate regression analysis for landslide hazard zonation. En: Carrara, A. y Guzzetti, F. (Eds.): Geographical Information Systems in Assessing Natural Hazards, Kluwer Academic Publishers, the Netherlands, pp. 107133.

CINGOLANI, C. A. 2005. Unidades morfoestructurales (y estructuras menores) de la Provincia de Buenos Aires. En: de Barrio, R., Etcheverry, R., Caballé, M y LLambías, E. (Eds.): Geología y Recursos Minerales de la Provincia de Buenos Aires. Relatorio del XVI Congreso Geológico Argentino, II: 21-30. La Plata.

CLAYTON, R. W. 1956. Linear depressions (Bergfussniederungen) in savannah landscapes. Geographical Studies, 3: 102-126.

COBBOLD, P. R., MASSABIE, A. C. y ROSSELLO, E. A. 1986. Hercynian wrenching and thrusting in the Sierras Australes Foldbelt, Argentina. Hercynica, 2 (2): 135-148. 
COBBOLD, P. R., GAPAIS, D. y ROSSELLO, E. A. 1991. Partitioning of transpressive motions within a sigmoidal foldbelt: the Variscan Sierras Australes, Argentina. Journal of Structural Geology, 13 (7): 743-758.

COBBOLD, P. R., GAPAIS, D., ROSSELlO, E. A., MILANI, E. y SZATMARI, P. 1992. PermoTriassic intracontinental deformation in SW Gondwana. En: Wit, J. y Ransome, N. (Eds.): Inversion Tectonics of the Cape Fold Belt, Karoo and Cretaceous Basins of Southern Africa. Balkema, pp. 23-26, Rotterdam.

COROMINAS, J. 1989. Clasificación y reconocimiento de los movimientos de ladera. En: Corominas, J. (Ed.): Estabilidad de taludes y laderas naturales. Monografía nº3. Sociedad Española de Geomorfología, pp. 1-30. Barcelona.

COROMINAS, J., VAN WESTEN, C., FRATTINI, P., CASCINI, L., MALET, J. P., FOTOPOULOU, S., CATANI, F., VAN DEN EECKHAUT, M., MAVROULI, O., AGLIARDO, F., PITILASKIS, K., WINTER, M. G., PASTOR, M., FERLISI, S., TOFANI, V., HERVÁS, J. y SMITH, J. T. 2014. Recommendations for the quantitative analysis of landslide risk. Bulletin of Engineering Geology and the Environment, 73 (2): 209-263.

COROMINAS DULCET, J. y GARCÍA-YAGÜÉ, A. 1997. Terminología de los movimientos de ladera. Memoria del IV Simposio nacional sobre taludes y laderas inestables, pp. 1051-1072. Granada.

CORTE, A. E. y RODRIGUEZ, N. R. 1971. Mediciones de transporte en masa en taludes. Parte I: Sierra de la Ventana. Actas Reunión sobre la Geología de las Sierras Australes Bonaerenses, Bahía Blanca. CIC de la Provincia de Buenos Aires, pp: 97-101. La Plata.

COSTANZO, D., ROTIGLIANO, E., IRIGARAY, C., JIMÉNEZ-PERÁLVAREZ, J. D. y CHACÓN, J. 2012. Factors selection in landslide susceptibility modelling on large scale following the gis matrix method: application to the river Beiro basin (Spain). Natural Hazards and Earth System Sciences, 12: 327-340.

COTTON, C. A. 1958. Geomorphology, an Introduction to the Study of Landforms. 7th ed., 508 pp. Whitcombe and Tombs, Wellington, N.A.

CROZIER, M. J. 1984. Field assessment of slope instability. En: Brunsden, D. y Prior, D. B. (Eds.): Slope Instability, pp. 103-142. Wiley, New York.

CROZIER, M. J. 2009. Landslide Geomorphology: An argument for recognition. Geomorphology, DOI: 10.1016/j.geomorph.2009.09.010.

CROZIER, M. J. 2010. Deciphering the effect of climate change on landslide activity: A review. Geomorphology, 124 (3): 260-267.

CRUDEN, D. M. 1991. A simple definition of a landslide. Bulletin International Association for Engineering Geology, 43: 27-29.

CRUDEN, D. M., HU, Z. Q. y LU, Z. Y. 1993. Rock topples in the highway cut west of Clairvivaux, Creek, Jasper, Alberta. Canadian Geotechnical Journal, 30 (6): 1016-1023.

CRUDEN, D. M. y VARNES, D. J. 1993. Landslides: investigation and mitigation. Chapter 3: Landslide types and processes. Transportation Research Board, National Academy of Science, Special Report, 247: 36-75.

CRUDEN, D. M. y VARNES, D. J. 1996. Landslide types and processes. En: Turner, A. K. y Schuster, R. L. (Eds.): Landslides investigation and mitigation. National Research Council, Washington D.C. Special Report 247.

CUCCI, R. 1966. Petrofábrica del conglomerado de la Formación La Lola, Sierras Australes de la Provincia de Buenos Aires. Revista de la Asociación Geológica Argentina, 21: 71-106.

CUERDA, A. J., CINGOLANNI, C. A. y BARRANQUERO, H. R. 1975. Estratigrafía del basamento precámbrico en la comarca de los cerros Pan de Azúcar-del Corral, Sierras Australes (provincia de Buenos Aires). Actas del II Congreso Iberoamericano de Geología Económica, 1: 57-63.

DAHAL, R. K., HASEGAWA, S., NONOMURA, A., YAMANAKA, M., DHAKAL, S., y PAUDYAL, P. 2008. Predictive modelling of rainfall-induced landslide hazard in the Lesser Himalaya of Nepal based on weights-of-evidence. Geomorphology, 102 (3-4): 496-510. DOI: 10.1016/j.geomorph.2008.05.041

DAI, F. C. y LEE, C. F. 2002. Landslide characteristics and slope instability modeling using GIS, Lantau Island, Hong Kong. Geomorphology, 42: 213-228. 
DAI, F. C. y LEE, C. F. 2003. A spatiotemporal probabilistic modelling of storm-induced shallow landsliding using aerial photographs and logistic regression. Earth Surface Processes and Landforms, 28 (5): 527-545. https://doi.org/10.1002/esp.456

DALRYMPLE, J. B., BLONG, R. J. y CONACHER, A. J. 1968. A hypothetical nine-unit landsurface model. Zeitschrift für Geomorphologie, 12: 60-76.

DAVIS, J. C. 1986. Statistics and data analysis in geology. 646 pp. John Wiley \& Sons, Inc., New York.

DE BARRIO, R. E., LANFRANCHINI, M. E., ETCHEVERRY, R. O., MARTÍN-IZARD, A., TESSONE, M. y CORIALE, N. G. 2008. Geología y geoquímica mineral del skarn Loma Marcelo, Sierras Australes de Buenos Aires, Argentina. Actas del XVII Congreso Geológico Argentino, 2: 537-538, San Salvador de Jujuy.

DE FRANCESCO, F. 1970. Geología del Cenozoico Superior Pedemontano del Flanco Sudoccidental de las Sierras de Curamalal y Ventana. Relatorio del VI Congreso Geológico Argentino, pp. 103-138, Bahía Blanca.

DE FRANCESCO, F. 1971. Geología superficial en el área pedemontana del flanco sudoccidental de la sierra de la Ventana, provincia de Buenos Aires. Informe inédito, Comisión de Investigaciones Científicas, La Plata.

DE FRANCESCO, F. 1992a. Estratigrafía del Cenozoico en el flanco occidental de las Sierras de Curamalal, Sierras Australes Bonaerenses. Actas de las III Jornadas Geológicas Bonaerenses, pp. 3-12. La Plata.

DE FRANCESCO, F. 1992b. Formación del Águila: depósitos pedemontanos en el sector occidental de Sierras Australes. Actas de las III Jornadas Geológicas Bonaerenses, pp. 13-16. La Plata.

DE FRANCESCO, F. y NUCETELLI, G. A. 1990. Sedimentos loessicos del Terciario en el sector occidental de las Sierras Australes Bonaerenses, Argentina. Resúmenes expandidos del Simposio Internacional sobre Loess, pp. 96-101. Mar del Plata.

DE FREITAS, M. H. y WATERS, R. J. 1973. Some field examples of toppling failure. Geotechnique, 23: 495-514.

DEGIOVANNI, S., ECHEVARRÍA, K., ANDREAZZINI, J. y DOFFO, N. 2014. Los sistemas fluviales del sur de Córdoba: alteraciones históricas, procesos de ajuste y consecuencias ambientales. Actas digitales del XIX Congreso Geológico Argentino, 2 pp. Córdoba.

DE HAAS, T., VENTRA, D., CARBONNEAU, P. E. y KLEINHANS, M. G. 2014. Debris-flow dominance of alluvial fans masked by runoff reworking and weathering. Geomorphology, 217: 165-181.

DELGADO, M. I., SENISTERRA, G. E., GASPARI, F. J., RODRÍGUEZ VAGARÍA, A. y BESTEIRO, S. 2009. Variación del Régimen Pluviométrico en el Sistema de Serrano del Suroeste Bonaerense, Argentina. Revista Electrónica de la Red Latinoamericana de Cooperación Técnica en Manejo de Cuencas Hidrográficas, 1: 67-74.

DELGADO, M. I., GASPARI, F. J. y SENISTERRA, G. E. 2013. Tendencia de cambio espaciotemporal del escurrimiento superficial en una cuenca serrana. Argentina. Medio Ambiente y Desarrollo Sustentable, 2 (VII): 99-109.

DEMIR, G., AYTEKIN, M., AKGÜN, A., IKIZLER, S. B. y TATAR, O. 2013. A comparison of landslide susceptibility mapping of the eastern part of the North Anatolian Fault Zone (Turkey) by likelihood-frequency ratio and analytic hierarchy process methods. Natural Hazards, 65 (3): 14851506.

DEMOULIN, A., ZÁRATE, M. A. y RABASSA, J. 2005. Long-term landscape development: a perspective from the southern Buenos Aires ranges of east central Argentina. Journal of South American Earth Sciences. 19: 193-204.

DE VILLALOBOS, A. E. 2016. Efectos de los caballos cimarrones sobre la composición florística y la estructura de los pastizales naturales en las Sierras Australes Bonaerenses. Ecología Austral, 26: 264-274.

DEVKOTA, K. C., REGMI, A. D., POURGHASEMI, H. R., YOSHIDA, K., PRADHAN, B., RYU, I., DHITAL, M. R. y ALTHUWAYNEE, O. 2013. Landslide susceptibility mapping using certainty factor, index of entropy and logistic regression models in GIS and their comparison at MuglingNarayanghat road section in Nepal Himalaya. Natural Hazards, 65 (1): 135-165.

DIKAU, R., BRUNSDEN, D., SCHROTT L. y IBSEN, M. L. (Eds.). 1996. Landslide Recognition: Identification, Movement and Causes. 274 pp., Wiley, Chichester. 
DIMIERI, L. V., DELPINO, S. y TURIENZO, M. 2005. Estructura de las Sierras Australes de Buenos Aires En: de Barrio, R., Etcheverry, R., Caballé, M y LLambías, E. (Eds.): Geología y Recursos Minerales de la Provincia de Buenos Aires. Relatorio del XVI Congreso Geológico Argentino, VII: 101-118. La Plata.

DI NARDO, L. R. y DIMIERI, L. V. 1988. Mesoestructuras formadas en el campo de comportamiento rígido, Abra de La Ventada, Sierras Australes de Buenos Aires. Revista de la Asociación Geológica Argentina, 43: 140-152.

D'ODORICO, P., PÉREZ, D. y SEQUEIRA, N. 2008. El represamiento del río Santa Cruz, Cordillera Principal y Frontal $\left(31^{\circ} 45^{\prime} \mathrm{LS}\right)$, Provincia de San Juan, Argentina. Actas del XVII Congreso Geológico Argentino, pp. 270-271. Jujuy.

DOU, J., PAUDEL, U., OGUCHI, T., UCHIYAMA, S. y HAYAKAWA, Y. S. 2015a. Shallow and Deep-Seated Landslide Differentiation Using Support Vector Machines: A Case Study of the Chuetsu Area, Japan. Terrestrial, Atmospheric and Oceanic Sciences, 26 (2): 227-239.

DOU, J., TIEN BUI, D., YUNUS, A. P., JIA, K., SONG, X., REVHAUG, I., XIA, H. y ZHU, Z. 2015b. Optimization of causative factors for landslide susceptibility evaluation using remote sensing and GIS Data in parts of Niigata, Japan. DOI: 10.1371/journal.pone.0133262.

DUMAN, T. Y., CAN, T., GOKCEOGLU, C., NEFESLIOGLU, H. A y SNMEZ, H. 2006. Application of logistic regression for landslide susceptibility zoning of Cekmece Area, Istanbul, Turkey. Environmental Geology, 51: 241-256. https://doi.org/10.1007/s00254-006-0322-1

DU TOIT, A. L. 1927. A Geological Comparison of South America with South Africa. With a paleontological contribution by F. Cowper Reed. Carnegie Institution. Publ. 381, 157 pp. Washington.

DUYMOVICH, O. A. y MONEDA, C. P. 1965. Cavernas de la Provincia de Buenos Aires. Anales de la Comisión de Investigaciones Científicas de la Provincia de Buenos Aires, pp. 111-150.

ESCHER, H. C. 1807. Über Bergstürze in der Schweiz. Neujahrsblatt d. Naturf. Ges., 1-8 pp. Zürich.

FABBRI A. G., CHUNG C. F., NAPOLITANO P., REMONDO J. y ZEZERE J. L. 2002. Prediction rate functions of landslide susceptibility applied in the Iberian Peninsula. En: Brebbia C. A. (Ed.): Risk Analysis III. Southampton, Boston, WIT Press, pp. 703-718.

FAIRBRIDGE, R. W. 1968. The Encyclopedia of Geomorphology. Encyclopedia of Earth Sciences Series, Volume III. 1295 pp. Dowden, Hutchinson \& Ross, Inc. Stroudsburg, Pennsylvania.

FAUQUÉ, L. E. y TCHILINGUIRIAN, P. 2002. Villavil rockslide, Catamarca province, Argentina. En: Evans, S. G. y DeGraff, J. V. (Eds.): Catastrophic Landslides: Effects, Occurrence, and Mechanisms. Geological Society of America Reviews in Engineering Geology, 15: 303-324.

FAUQUÉ L. E., CORTÉS, J. M., FOLGUERA, A. y ETCHEVERRÍA, M. 2000. Avalanchas de rocas asociadas a Neotectónica en el valle del río Mendoza, al sur de Uspallata. Revista de la Asociación Geológica Argentina, 55 (4): 419-423.

FELICÍSIMO, A., CUARTERO, A., REMONDO, J. y QUIRÓS, E. 2013. Mapping landslide susceptibility with logistic regression, multiple adaptive regression splines, classification and regression trees, and maximum entropy methods: a comparative study. Landslides, 10: 178-189.

FELL, R., COROMINAS, J., BONNARD, C., CASCINI, L., LEROI, E. y SAVAGE, W. 2008. Guidelines for landslide susceptibility, hazard and risk zoning for land-use planning. Engineering Geology, 102: 99-111.

FERNÁNDEZ LONG, M. E., BARNATÁN, I. E., SPESCHA, L., HURTADO, R. y MURPHY, G. 2005. Caracterización de las heladas en la Región Pampeana y su variabilidad en los últimos 10 años. Revista de la Facultad de Agronomía Universidad de Buenos Aires, 25 (3): 247-257.

FIDALGO, F., DE FRANCESCO, F. O. y PASCUAL, R. 1975. Geología Superficial de la Llanura Bonaerense. Relatorio del VI Congreso Geológico Argentino, pp. 103-138. Bahía Blanca.

FIGINI, A., RABASSA, L., TONNI, E., HUARTE, R., GÓMEZ, O., CARBONARI, J. L. y ZUBIAGA, A. 1985. Datación radiocarbónica de gasterópodos terrestres en sedimentos del Pleistoceno superior y Holoceno del valle del Río Sauce Grande, provincia de Buenos Aires. Resúmenes de las I Jornadas Geológicas Bonaerenses, pp. 131-132.

FIGUEROA, L. 1968. Informe preliminar sobre algunas acumulaciones de bloques en el área del Abra de la Ventana (provincia de Buenos Aires). Actas de la III Jornada Geológica Argentina, II: 43-66. Buenos Aires. 
FOLGUERA, A. y ZÁRATE, M. 2009. La sedimentación neógena continental en el sector extraandino de Argentina central. Revista de la Asociación Geológica Argentina 64: 692-712.

FRENGUELLI, J. 1950. Rasgos generales de la morfología y geología de la Provincia de Buenos Aires. LEMIT, Serie II, $33 \mathrm{pp}$.

FORTE, L. M. 2017. Análisis de las variaciones espacio-temporales de los procesos geomorfológicos y los riesgos naturales asociados. Tesis Doctoral, Universidad de Cantabria. $466 \mathrm{pp}$.

FURQUE, G. 1967. Estratigrafía de la Región de Pillahuincó. Acta Geológica Lilloana, 9: 79-114. San Miguel de Tucumán.

FURQUE, G. 1973. Descripción geológica de la Hoja 34n, Sierra de Pillahuincó, provincia de Buenos Aires. Servicio Nacional de Minería y Geología, Boletín 141, 70 pp. Buenos Aires.

FURQUE, G. 1974. Sistema de terrazas aluviales en los aledaños de Saldungaray, provincia de Buenos Aires. LEMIT, Serie II (265): 103-112. La Plata.

GALENHAUSE, J. 1971. Sedimentation analysis. En: Carver, R. (Ed.): Procedures in sedimentary petrology, Wiley-Interscience, pp. 65-94. New York.

GALVE, J. P., GUTIERREZ, F., LUCHA, P., GUERRERO, J., BONACHEA, J., REMONDO, J. y CENDRERO, A. 2009. Probabilistic sinkhole modelling for hazard assessment. Earth Surface Processes and Landforms, 34: 437-452.

GALVE, J. P., REMONDO, J. y GUTIÉRREZ, F. 2011. Improving sinkhole hazard models incorporating magnitude-frequency relationships and nearest neighbor analysis. Geomorphology, 134 (1-2): 157-170.

GALVE, J. P., CEVASCO, A., BRANDOLINI, P. y SOLDATI, M. 2015. Assessment of shallow landslide risk mitigation measures based on land use planning through probabilistic modelling. Landslide, 12 (1): 101-114.

GAO, J. 1993. Identification of topographic settings conductive to landsliding from DEM (digital elevation model) in Nelson County, Virginia (USA). Earth Surface Processes and Landform, 8: 579-591.

GARCÍA MARTÍNEZ, B., GIL, V., CARBONE, M. E. y POSADA SIMEÓN, C. 2016. Caracterización del patrón hidromorfológico del Arroyo de la Ventana en su tramo medio alto (Buenos Aires, Argentina). Estudios Geográficos, LXXVII (281): 521-541.

GASPARI, F. J. y BRUNO, J. E. 2003. Diagnóstico de degradación ambiental por erosión hídrica en la cuenca del arroyo Napostá Grande. Ecología Austral, 13: 109-120.

GASPARI, F. J., RODRígUEZ VAGARÍA, A. M., SENISTERRA, G. E. y DELGADO, M. I. 2008. Determinación espacio-temporal del índice de agresividad de precipitaciones en el sistema serrano de Ventania. Provincia de Buenos Aires-Argentina. Revista Geográfica Venezolana, I (49): 57-66.

GASPARI, F. J., RODRIGUEZ VAGARÍA, A. M., DELGADO, M. I., SENISTERRA, G. E. y DENEGRI, G. A. 2011. Vulnerabilidad ambiental en cuencas hidrográficas serranas mediante SIG. Multequina, 20: 3-13.

GENTILE, R. O. 2005. Procesos de remoción en masa en el extremo sur del Partido de Tandil (Provincia de Buenos Aires). Tesis de Maestría, Facultad de Ciencias Agrarias y Forestales, Universidad Nacional de La Plata. 197 pp.

GENTILE, R. O. 2006. Movimientos en masa en laderas del sur del Partido de Tandil (Provincia de Buenos Aires). Actas del III Congreso Argentino de Cuaternario y Geomorfología, I: 405-415. Córdoba.

GENTILE, R. O. 2008a. Movimientos en masa en Cuchilla de las Águilas, Cerro Gruta de Oro y aledaños (Partido de Benito Juárez, Provincia de Bs. As.). Actas del XVII Congreso Geológico Argentino, pp. 1216-1217. San Salvador de Jujuy.

GENTILE, R. O. 2008b. Movimientos en masa en sectores del Partido de Tandil (Provincia de Buenos Aires). Actas del XVII Congreso Geológico Argentino, pp. 1214-1215. San Salvador de Jujuy.

GENTILE, R. O. 2009a. Patrimonio geológico de los partidos de Tandil, Olavarría y Azul (Provincia de Buenos Aires). En: Endere, M. L. y Prado, J. L. (Eds.): Patrimonio, ciencia y comunidad. Su abordaje en los partidos de Azul, Olavarría y Tandil, pp: 77-100. INCUAPA, UNICEN. Municipalidad de Olavarría. 
GENTILE, R. O. 2009b. Deslizamientos en el área de Sierra La Juanita y aledaños (Partidos de Tandil y Benito Juárez). $9^{\circ}$ Simposio de Geología Aplicada a la Ingeniería y al Ambiente. 2 páginas. Versión CD. Mar del Plata.

GENTILE, R. O. 2009c. Geoformas en rocas del basamento cristalino en cerros del área de la Cantera Tartagal y aledaños (Tandil, Provincia de Buenos Aires). Resúmenes del IV Congreso Argentino de Cuaternario y Geomorfología, pag.10. La Plata.

GENTILE, R. O. 2011. Movimientos en masa en sectores de cabeceras de las cuencas del Río Quequén Grande y arroyos Chapaleofú y Napaleofú (vertientes sur y norte de Tandilia). Provincia de Buenos Aires. Tesis Doctoral, Facultad de Ciencias Naturales y Museo, Universidad Nacional de La Plata, 289 pp.

GENTILE, R. O. y VILLALBA, H. A. 2003a. Deslizamientos recientes en el extremo sur del Partido de Tandil (provincia de Buenos Aires). Actas del II Congreso Argentino del Cuaternario, pp. 275182. San Miguel de Tucumán.

GENTILE, R. O. y VILLALBA, H. A. 2003b. Deslizamientos y rasgos asociados producidos en el año 2001 en un sector de las Sierras Septentrionales (Provincia de Buenos Aires). Revista de Geología Aplicada a la Ingeniería y al Ambiente (ASAGAI), 19: 31-44.

GENTILE, R. O. y VILLALBA, H. A. 2008. Antiguas "minas de arena" y daños en obras (Tandil, Provincia de Buenos Aires). Revista de Geología Aplicada a la Ingeniería y al Ambiente (ASAGAI), 22: 13-30.

GENTILE, R. O. y SUSENA, J. M. 2018. Recurrencia de movimientos en masa (Partido de Tandil, Provincia de Buenos Aires). Actas electrónicas de las II Jornadas Internacionales y IV Jornadas Nacionales de Ambiente, pp. 659-662. Tandil.

GENTILE, R. O. Y SUSENA, J. M. 2019. Procesos de remoción en masa e implicaciones ambientales (Partido de Tandil, Provincia de Buenos Aires). Actas digitales del VII Congreso Nacional de Geografía de Universidades Públicas y XXI Jornadas de Geografía de la UNLP. http://www.memoria.fahce.unlp.edu.ar/trab_eventos/ev.13559/ev.13559.pdf

GENTILI, J. O. y GIL, V. 2013. Variabilidad temporal de las precipitaciones en vertientes opuestas del Sistema de Ventania, Buenos Aires, Argentina. Revista Universitaria de Geografía, 22 (1-2): 147-166.

GENTILI, J. O., CAMPO, A. M. y GIL, V. 2011. Distribución espacial y temporal de las precipitaciones en la cuenca alta del arroyo Sauce Corto, Sistema de Ventania. En: GAEA. Actas Científicas CNG $72^{\circ}$ Semana de Geografía, GAEA, pp. 115-126. Mar del Plata.

GIL, V. 2009. Hidrogeomorfología de la cuenca alta del río Sauce Grande aplicada al peligro de Crecidas. Tesis Doctoral, Departamento de Geografía y Turismo, Universidad Nacional de Sur. $262 \mathrm{pp}$.

GIL, V. 2011. Variabilidad espacial y temporal de las precipitaciones. Cuenca Alta del río Sauce Grande, Sistema de Ventania. En: GAEA. Actas Científicas CNG $72^{\circ}$ Semana de Geografía. Mar del Plata, GAEA, pp. 127-139.

GIL, V. y CAMPO DE FERRERAS, A. 2006. Procesos de Vertientes en el área del Abra de la Ventana. Partido de Tornquist, provincia de Buenos Aires. Actas de las VI Jornadas Nacionales de Geografía Física, pp. 59-65. Río Gallegos.

GIL, V. y CAMPO, A. M. 2012. Geomorfología y procesos de vertiente. Cuenca alta del río Sauce Grande (Buenos Aires, Argentina). Cuaternario y Geomorfología, 26 (1-2): 133-150.

GIL, V., GENTILI, J. O. y CAMPO, A. M. 2009. Influencia de la litología en la variación de los parámetros morfométricos, Sistema de Ventania, Argentina. Papeles de Geografía, 49-50: 5568.

GIL, V. N., GIL, V. y CAMPO, A. M. 2014. Capacidad de carga turística en el sendero del Cerro Ventana. Parque Provincial Ernesto Tornquist, Argentina. Estudios y Perspectivas en Turismo, 23: 362-375.

GOETZ, J. N., GUTHRIE, R. H. y BRENNING, A. 2011. Integrating physical and empirical landslide susceptibility models using generalized additive models. Geomorphology, 129: 376-386.

GONZÁLEZ, P. D., PÁEZ, G. N., CERVERA, F. M. e IRIBARNE, M. 2004. Texturas relícticas en las metaignimbritas neoproterozoicas del basamento del cerro del Corral, Sierras Australes de Buenos Aires. Revista de la Asociación Geológica Argentina, 59 (1): 103-112. 
GONZÁLEZ DÍAZ, E. F. 1973. La participación del proceso de remoción en masa (mass-wasting) en el llamado aluvión de Chumbicha (sede de la Provincia de Catamarca). Actas del V Congreso Geológico Argentino, V: 101-122.

GONZÁLEZ DíAZ, E. F. 2009. Deslizamientos al norte de la población de Tricao Malal. Revista de la Asociación Geológica Argentina, 65 (3): 545-550.

GONZÁLEZ DíAZ, E. F. y MALAGNINO, E. C. 1990. El proceso de la remoción en masa: su incidencia como riesgo geológico natural en el fenómeno del 29-3-84, en el SE de la sierra de Aguarague, Salta República Argentina. Actas del $3^{\circ}$ Simposio de Geología Aplicada, Asociación Argentina de Geología Aplicada a la Ingeniería, 5: 7-18. Buenos Aires.

GONZÁLEZ DÍAZ, E. F. y MON, R. 1996. El origen de las Lagunas de Yala, Provincia de Jujuy $24^{\circ}$ $05^{\prime}$ de latitud sur y $65^{\circ} 28^{\prime}$ de longitud oeste. Actas del XIII Congreso Geológico Argentino Buenos Aires, 4: 209-217. Buenos Aires.

GONZÁLEZ DÍAZ, E. F., FAUQUÉ, L., GIACCARDI, A. D. y COSTA, C. H. 2000. Las lagunas de Varvarco Campos y Varvarco Tapia ( $N$ del Neuquén, Argentina): su relación con avalanchas de rocas. Revista de la Asociación Geológica Argentina, 55 (3): 147-164.

GONZÁLEZ DíEZ, A., FERNÁNDEZ-MAROTO, G., DOUGHTY, M. W., DÍAZ DE TERÁN, J. R., BRUSCHI, V., CARDENAL, J., PÉREZ, J. L., MATA, E. y DELGADO, J. 2014. Development of a methodological approach for the accurate measurement of slope changes due to landslides, using digital photogrammetry. Landslides, 11: 615-628.

GONZÁLEZ URIARTE, M. 1984. Características geomorfológicas de la porción continental que rodea la Bahía Blanca, Provincia de Buenos Aires. Actas del IX Congreso Argentino de Geología, pp. 556-576. Bariloche.

GONZÁLEZ URIARTE, M., CARBALLO, O., ALDACOUR, A., CALMELS, A. 1988. Geomorfología de la sierra de Bravard y su piedemonte (Provincia de Buenos Aires). Actas de las II Jornadas Geológicas Bonaerenses, pp. 173-185. Bahía Blanca.

GOODMAN, R. E. y BRAY, J. W. 1976. Toppling of rock slopes. Memorias de Specialty Conference on Rock Engineering for Foundations and slopes, Boulder, Colorado, pp. 201-234.

GREENWOOD, P., KUONEN, S., FISTER, W. y KUHN, N. L. 2015. The influence of terracettes on the surface hydrology of steep-sloping and subalpine environments: some preliminary findings. Geographica Helvetica, 70: 63-73.

GROEBER, P. 1916. Informe sobre las causas que han producido las crecientes del río Colorado (Territorios del Neuquén y La Pampa) en 1914. Dirección General de Minas, Geología e Hidrogeología, Boletín 11 (Serie B, Geología): 1-29. Buenos Aires.

GUTHRIE, R. H. y EVANS, S. G. 2007. Work, persistence, and formative events: The geomorphic impact of landslides. Geomorphology, 88: 266-275.

GUTIÉRREZ, M. 2008. Geomorfología. 920 pp. Pearson/Prentice-Hall, Madrid.

GUZZETTI, F., CARRARA, A., CARDINALI, M. y REICHENBACH, P. 1999. Landslide hazard evaluation: a review of current techniques and their application in a multi-scale study, Central Italy. Geomorphology, 31: 181-216.

GUZZETTI, F., REICHENBACH, P., CARDINALI, M., GALLI, M. y ARDIZZONE, F. 2005. Probabilistic landslide hazard assessment at the basin scale. Geomorphology, 72: 272-299.

GUZZETTI, F., MONDINI, A. C., CARDINALI, M., FIORUCCI, F., SANTANGELO, M. y CHANG, K. T. 2012. Landslide inventory maps: New tools for an old problem. Earth-Science Reviews, 112: 42-66.

HACKER, D. B., BIEK, R. F. y ROWLEY, P. D. 2014. Catastrophic emplacement of the gigantic Markagunt gravity slide, southwest Utah (USA): Implications for hazards associated with sector collapse of volcanic fields. Geology, 42 (11): 943-946.

HANSEN, A. 1984. Landslide Hazard Analysis. En: Brunsden, D. y Prior, D.B. (Eds.): Slope Instability, Wiley, Interscience, Chichester, pp. 523-602.

HANSEN, A., FRANKS, C. A. M., KIRK, P. A., BRIMICOMBE, A. J. y TUNG, F. 1995. Application of GIS to hazard assessment, with particular reference to landslides in Hong Kong. En: Carrara, C. y Guzzetti, F. (Eds.): Geographical Information Systems in Assessing Natural Hazards, Kluwer Academic Publisher, Dordrecht, The Netherlands, pp. 135-175.

HARKER R. I. 1996. Curved tree trunks? Indicators of soil creep and other phenomena. The Journal of Geology 104:351-358. 
HARRINGTON, H. J. 1936. El Conglomerado Rojo de las Sierras Australes de Buenos Aires y sus relaciones con el relieve de montaña. Museo de La Plata, Obra del Cincuentenario, II: 145-184.

HARRINGTON, H. J. 1946. Las corrientes de barro ("Mud-Flows") de "El Volcán". Quebrada de Humahuaca, Jujuy. Revista de la Asociación Geológica Argentina, I (2): 149-165. Buenos Aires.

HARRINGTON, H. J. 1947. Explicación de las hojas geológicas $33 m$ y $34 m$, Sierras de Curamalal y de la Ventana, Provincia de Buenos Aires. Boletín de Dirección de Minas y Geología, 61: 1-43. Buenos Aires.

HARRINGTON, H. J. 1970. Las Sierras Australes de Buenos Aires, República Argentina: Cadena Aulacogénica. Revista de la Asociación Geológica Argentina, 25 (2): 151-181. Buenos Aires.

HARRINGTON, H. J. 1980. Sierras Australes de Buenos Aires. En: Leanza, A. F. (Ed.): Geología Regional Argentina (Academia Nacional de Ciencias de Córdoba): 967-983. Córdoba.

HEIM, A. 1882. Der Bergsturz von Elm. Zwitschrift der Deutschen Geologischen Gesellschaft, 34: 74-115.

HEIM, A. 1932. Bergsturz und Menschenleben. Fretz und Wasmuth, 218 pp. Zürich

HOEK, E. y BRAY, J. W. 1981. Rock slope engineering. $3^{\circ}$ Edición, Institution of Mining and Metallurgy, $358 \mathrm{pp}$. London.

HOFF, K. E. A. v. 1834. Geschichte der durch Überlieferung nachgewiesenen natürlichen Veränderungen der Erdoberfläche. III Theil, Gotha: 511.

HOGG, S. E. 1982. Sheetfloods, Sheetwash, Sheetflow, or ...? Earth-Science Reviews, 18: 59-76.

HOLTZ W. G. y GIBBS H. J. 1956. Engineering Properties of Expansive clays. Transactions of American Society of Civil Engineers, 121: 641-677.

HOOKE, J. 1979. An Analysis of the Processes of River Bank Erosion. Journal of Hydrology, 42 (1): 39-62.

HSÜ, K. J. 1975. On sturzstroms-catastrophic debris streams generated by rockfalls. Geological Society of America Bulletin, 86: 129-140.

HUGGETT, R. J., 2007. Fundamentals of Geomorphology. 465 pp. Routledge, London and New York.

HUNGR, O. 1997. Some methods of landslide hazard intensity mapping. En: Cruden, D. y Fell, R. (Eds.): Landslide risk assessment. Balkema, Rotterdam, pp. 215-226.

HUNGR, O, y EVANS, S. G. 1988. Engineering evaluation of fragmental rockfall hazards. Proceedings 5th International Symposium on Landslides, Lausanne, Switzerland, 1, 685-690.

HUNGR, O. y EVANS, S. G. 2004. The occurrence and classification of massive rock slope failure. Felsbau, Viena, 22:1-12

HUNGR, O., EVANS, S. G., BOVIS, M. J. y HUTCHINSON, J. N. 2001. A Review of the Classification of Landslides of the Flow Type. Environmental and Engineering Geoscience, VII (3): 221-238.

HUNGR, O., LEROUEIL, S. y PICARELLI, L. 2014. The Varnes classification of landslide types, an update. Landslides, 11:167-194.

HURTADO, M. A. y GIMÉNEZ, J. E. 1988. Entisoles de la Región Pampeana. Génesis, clasificación, cartografía y mineralogía. Relatos de las II Jornadas de Suelos de la Región Pampeana, pp. 79138. La Plata.

HURTADO, M. A., GIMÉNEZ, J. E. y CABRAL, M. 2006. Análisis ambiental del Partido de La Plata. Aportes al ordenamiento territorial. Consejo Federal de Inversiones, $124 \mathrm{pp}$. La Plata.

HUTCHINSON, J. N. 1968. Mass movement. En: Fairbridge, R. D. (Ed.): Encyclopedia of Geomorphology. Reinhold Book Corporation, pp. 688-695. Nueva York.

HUTCHINSON, J. N. 1988. Morphological and geotechnical parameters of landslides in relation to geology and hydrogeology. Proceedings 5th International Symposium on Landslides, Lausanne, Switzerland, 1: 3-36.

HUTCHINSON, J. N. 1995. Keynote paper: Landslide hazard assessment. International Symposium on Landslides, pp. 1805-1841. Rotterdam.

ILIA, I. y TSANGARATOS, P. Applying weight of evidence method and sensitivity analysis to produce a landslide susceptibility map. Landslides, 13: 379-397. https://doi.org/10.1007/s10346015-0576-3 
INTA (Instituto Nacional de Tecnología Agropecuaria). 1995. Carta de suelos de la República Argentina. Hoja 3763-35 "Saavedra".

JAPAS, M. S. 1987. Caracterización geométrico-estructural del Grupo Pillahuincó l. Perfil del Arroyo Atravesado, Sierra de las Tunas, Sierras Australes de la Provincia de Buenos Aires. Anales de la Academia Nacional de Ciencias Exactas, Físicas y Naturales, 38: 145-155, Buenos Aires.

JAPAS, M. S. 1988. Las bandas kink en las Sierras Australes de Buenos Aires: características geométricas e hipótesis acerca del origen de las mismas. Actas de la $\mathrm{V}$ Reunión de Microtectónica, 1: 90-95.

JAPAS, M. S. 1995. El arco noroccidental de las Sierras Australes de Buenos Aires: producto de megakinks extensionales durante el proceso de la deformación. Actas de las IV Jornadas Geológicas y Geofísicas Bonaerenses, pp. 257-263. Junin.

JAPAS, M. S. 1999. Revisión de las teorías acerca del origen del arco de las Sierras Australes de Buenos Aires. Revista de la Asociación Geológica Argentina, 54 (1): 9-22.

JENNY, H. J. 1941. Factors of soil formation: a system of quantitative pedology. McGraw-Hill, 281 pp. New York.

JOSHI, S., UPRETI, D. K., DAS, P. y NAYAKA, S. 2012. Lichenometry: A technique to date natural hazards. Sciences India, Popular Issue, V (II): 1-16.

JUTSON, J. T. 1919. Sheet flows, or sheet floods, and their associated phenomena in the Niagara district of sub-arid south-central Western Australia. American Journal of Science, 4 (48): 435-439.

KANTOR, M., 1916. El problema de las inundaciones en Andalgalá (prov. de Catamarca). Revista del Museo de la Plata, 23 (2): 257-269.

KEATON, J. R. y DeGRAFF, J. V. 1996. Surface observation and geologic mapping. En: Turner, A. K. y Schuster, R. L. (Eds.): Landslides, Investigation and Mitigation. Transportation Research Board Special Report 247: 178-230. Washington D.C.

KEEFER, D. K. 1984. Landslides caused by earthquakes. Geological Society of America Bulletin, 95 (4): 406-421.

KEEFER, D. K. y JOHNSON, A. M. 1983. Earth flows: Morphology, mobilization, and movement. United States Government Printing Office, 56 pp. Washington.

KEIDEL, J. 1916. La geología de las sierras de la provincia de Buenos Aires y sus relaciones con las montañas de Sud África y los Andes. Anales del Ministerio de Agricultura de la Nación, sección Geología, Mineralogía y Minería, 3 (XI): 5-77.

KIENHOLZ, H. 1978. Maps of Geomorphology and natural hazards of Grindelwald, Switzerland, scale 1:10.000. Artic and Alpine Research, 10: 169-184.

KILMURRAY, J. O. 1961. Petrografía de las rocas Ígneas de las Sierras Australes de la Provincia de Buenos Aires. Tesis Doctoral, Facultad de Ciencias Naturales y Museo, Universidad Nacional de La Plata.

KILMURRAY, J. O. 1965. Petrografía y petrofábrica de las psamitas deformadas de la Serie de Curamalal. Sierras Australes de la provincia de Buenos Aires. Actas de las II Jornadas Geológicas Argentinas (1963), II: 113-127.

KILMURRAY, J. O. 1968a. Petrografía de las rocas ígneas de las Sierras Australes de la Provincia de Buenos Aires. Revista Museo La Plata, sección Geología, VI (45): 155-188.

KILMURRAY, J. O. 1968b. Petrología de las rocas cataclásticas y el skarn del anticlinal del Cerro Pan de Azúcar (partido de Saavedra, provincia de Buenos Aires). Actas de las III Jornadas Geológicas Argentinas, III: 217-238. Buenos Aires.

KILMURRAY, J. O. 1975. Las Sierras Australes de la Provincia de Buenos Aires. Las Fases de deformación y nueva interpretación estratigráfica. Revista de la Asociación Geológica Argentina, 30 (4): 331-348. Buenos Aires.

KILMURRAY, J. O., LEGUIZAMÓN, M. A. y TERUGGI, M. E. 1985. Caracteres estructurales y petrológicos de la Formación Trocadero en las Abras de Agua Blanca, Abra de Hinojo y Sofía, Sierras Australes de la Provincia de Buenos Aires. Resúmenes de las $1^{\circ}$ Jornadas de Geología Bonaerenses, 1: 1011-1022. Tandil.

KLOVAN, J. E. 1975. R- and Q-mode factor analysis. En: McCammon, R. B. (Ed.): Concepts in geostatistics, 2: 22-61. New York, Springer-Verlag.

KNIGHTON, D. 1998. Fluvial forms and processes: a new perspective. Oxford University Press, 383 pp. New York. 
KOCH, G. S. y LINK, R. F. 1971. Statistical analysis of geologic data. New York, Dover Publishing, 2: $438 \mathrm{pp}$.

KORUP, O., DENSMORE, A.L. y SCHLUNEGGER, F. 2010. The role of landslides in mountain range evolution. Geomorphology, 120: 77-90.

KRISTENSEN, M. J. y FRANGI, J. L. 1996. Mesoclimas de roquedales de la Sierra de la Ventana. Ecología Austral 6: 115-122.

LACOSTE, A., LONCKE, L., CHANIER, F., BAILLEUL, J., VENDEVILLE, B.C. y MAHIEUX, G. 2009. Morphology and structure of a landslide complex in an active margin setting: The Waitawhiti complex, North Island, New Zealand. Geomorphology, 109: 184-196.

LAN, H. X., ZHOU, C. H., WANG, L. J., ZHANG, H. Y. y LI, R. H. 2004. Landslide hazard spatial analysis and prediction using GIS in the Xiaojiang watershed, Yunnan, China. Engineering Geology, 76:109-128. https://doi.org/10.1016/j.enggeo.2004.06.009

LATRUBESSE, E. M. 2010. Natural hazards and human-exacerbated disasters in Latin America. Special Volumes of Geomorphology. ELSEVIER, $510 \mathrm{pp}$.

LEGUIZAMÓN, M. A. y RODRÍGUEZ, S. G. 1988. Comportamiento de estratos de diferente litología ante la deformación. Sierras Australes Bonaerenses. Actas de las II Jornadas Geológicas Bonaerenses, pp. 373-382. Bahía Blanca.

LEGUIZAMÓN, M. A. y TERUGGI, M. E. 1985. Contribución al conocimiento petrológico-estructural de las rocas de la Formación Hinojo, Sierras Australes de la Provincia de Buenos Aires. Resumen de las $1^{\circ}$ Jornadas Geológicas Bonaerenses, 229. La Plata.

LEGUIZAMÓN, M. A. y TERUGGI, M. E. 1991. El metamorfismo de las Sierras Australes. Revista del Museo de La Plata (Nueva Serie), Sección Geología, X (92): 233-242. La Plata.

LEMOS, A. 1883. Apuntes de viaje a través de los Andes. London.

LEOPOLD, L. B., WOLMAN, M. G., y MILLER, J. P. 1964. Fluvial processes in geomorphology. 522 pp. W.H. Freeman and Company, San Francisco, California.

LEUNG, A. K. y NG, C. W. W. 2015. Field investigation of deformation characteristics and stress mobilization of a soil slope. Landslides, 13: 229-240.

LEE, S., RYU, J. H., WON, J. S. y PARK, H. J. 2004. Determination and application of the weights for landslide susceptibility mapping using an artificial neural network. Engineering Geology 71: 289-302. https://doi.org/10.1016/S0013-7952(03)00142-X

LEE, S. y PRADHAN, B. 2006. Probabilistic landslide hazards and risk mapping on Penang Island, Malaysia. Journal of Earth System Science, 115: 661-672. https://doi.org/10.1007/s12040-0060004-0

LEE, S. y PRADHAN, B. 2007. Landslide hazard mapping at Selangor, Malaysia using frequency ratio and logistic regression models. Landslides, 4: 33-41. https://doi.org/10.1007/s10346-0060047-y

LEE, C. T., HUANG, C. C., LEE, J. F., PAN, K. L., LIN, M. L., y DONG, J. J. 2008. Statistical approach to storm event-induced landslides susceptibility. Natural Hazards and Earth System Sciences, 8: 941-960. https://doi.org/10.5194/nhess-8-941-2008.

LI, J., YANG, L., PU, R. y LIU, Y. 2017. A review on anthropogenic geomorphology. Journal of Geographical Sciences, I (27): 109-128.

LLAMBíAS, E. J. 1975. Geología de la provincia de La Pampa y su aspecto minero. Dirección de Minas de la provincia de La Pampa. Informe inédito. Santa Rosa.

LLAMBÍAS, E. J. y PROZZI, C. R. 1975. Ventania. Relatorio VI Congreso Geológico Argentino, 1: 79-101. Bahía Blanca.

LONDE, P. 1965. Une methodé d' analyse à trois dimensions de la stabilité d' une rive rocheuse. Annales des Ponts et Chaussées, 1: 37-60.

LOTHARI, L., TOFFANI, M., GARRIDO, M., SOTO, C. y MIZERIT, I. 2017. Mapa de susceptibilidad geológica para procesos de remoción en masa generado mediante análisis bivariado en la región de laguna Varvarco. 10 pp. DOI: 10.13140/RG.2.2.20249.88166.

LOYDI, A. y DISTEL, R. A. 2010. Diversidad florística bajo diferentes intensidades de pastoreo por grandes herbívoros en pastizales serranos del Sistema de Ventania, Buenos Aires. Ecología Austral, 20: 281-291.

LUCKMAN, B. H. 2013. Talus Slopes. En: Elias S.A. (Ed.): The Encyclopedia of Quaternary Science, 3: 566-573. Elsevier, Amsterdam. 
LUZI, L. y FABBRI, A. G. 1995. Application of Favorability Modelling to Zoning of Landslide Hazard in the Fabriano Area, Central Italy. 1st. Joint European Conference and Exhibition on Geographical Information, 398-403. La Haya, Países Bajos.

LYELL, C. 1830-1833. Principles of Geology, Being an Attempt to Explain the Former Changes of the Earth's Surface, by Reference to Causes Now in Operation. Vol. 1. J. Murray, London.

MacDONALD, L. H. y COE, D. B. R. 2008. Road Sediment Production and delivery processes and management. Proceedings of the First World Landslide Forum. International Programme on Landslides and International Strategy for Disaster Reduction. United Nations University, 381-384. Tokio.

MADSEN, F. T. y MITCHELL, J. K. 1989. Chemical effects on clay fabric and hydraulic conductivity. En: Baccini, P. (Ed.): The Landfill. Lecture Notes in Earth Sciences, 20: 201-251. Springer, Berlín, Heidelberg.

MAENZA, R. A. y COMPAGNUCCI, R. H. 2010. Simulación de la Pequeña Edad de Hielo usando el modelo EdGCM. Geoacta, 35 (2): 78-91.

MARTíNEZ, G. A. 2001. Geomorfología y Geología del Cenozoico superior de las cuencas de los arroyos Los Cueros y Seco, vertiente nororiental de las Sierras Septentrionales, provincia de Buenos Aires. Tesis Doctoral, Universidad Nacional de Mar del Plata. 348 pp.

MASSABIE, A. C., ROSSELLO, E. A. y LÓPEZ GAMUNDí, O. R. 2005. Cubierta paleozoicamesozoica de las sierras Australes de la provincia de Buenos Aires. En: de Barrio, R. E., Etcheverry, R. O., Caballé, M. F. y Llambías, E. (Eds.): Geología y Recursos Minerales de la provincia de Buenos Aires. Relatorio del XVI Congreso Geológico Argentino, 6: 85-100, La Plata.

McCALPIN, J. P. 1984. Preliminary age classification of landslides for inventory mapping. Proc. 21st Annual Engineering Geology \& Soils Engineering Symposium, 99-120. Moscú.

MELOSH, H. J. 1987. The mechanics of large rock avalanches. En: Costa, J. E. y Wieczorek, G. F. (Eds.): Debris Flows/Avalanches: process, recognition and mitigation. Reviews of Engineering Geology, Geological Society of America, 7: 41-49.

MERGILI M., MARCHANT SANTIAGO, C. I. y MOREIRAS, S. M. 2015. Causas, características e impacto de los procesos de remoción en masa, en áreas contrastantes de la región Andina. Revista Colombiana de Geografía, 24 (2): 113-131.

MIDDLETON, G. V. y HAMPTON, M. A. 1973. Sediment gravity flows mechanisms of flow and deposition. En: Middleton, G. V. y Bouma, A. (Eds.): Turbidites and Depp Water Sedimentation. Society of Economic Paleontologist and Mineralogist. Pacific Section, Short Course, Anaheim, Tulsa, pp. 1-38.

MIKOŠ, M. 2017. Landslides: a top international journal in geological engineering and engineering geology? Landslides, 14 (5), 1827-1838.

MONSIEURS, E., JACOBS, L., MICHELLIER, C., BASIMIKE TCHANGABOBA, J., BAMULEZI GANZA, G., KERVYN, F., MAKI MATESO, J., MUGARUKA BIBENTYO, T., KALIKONE BUZERA, C., NAHIMANA, L., NDAYISENGA, A., NKURUNZIZA, P., THIERY, W., DEMOULIN, A., KERVYN, M. y DEWITTE, O. 2018. Landslide inventory for hazard assessment in a data-poor context: a regional-scale approach in a tropical African environment. Landslides, 15 (11): 21952209.

MONTGOMERY, D. R. y DIETRICH, W. E. 1994. A physically based model for the topographic control of shallow landsliding. Water Resour. Res., 30 (4): 1153-1171.

MOREIRAS, S. M. 2005. Landslide susceptibility zonation in the Rio Mendoza Valley, Argentina. Geomorphology, 66: 345-357.

MULDER, H. F. 1991. Assessment of landslide hazard. Ed. Faculty of Geographical Science, University of Utrecht, $150 \mathrm{pp}$.

MÜLLER, J. 1979. Josef Stini: Contributions to engineering geology and slope movement investigations. En: Voight, B. (Ed.): Rockslides and Avalanches, 2: 95-109. New York: Elsevier.

NEFESLIOGLU, H. A., GOKCEOGLU, C. y SONMEZ, H. 2008. An assessment on the use of logistic regression and artificial neural networks with different sampling strategies for the preparation of landslide susceptibility maps. Engineering Geology, 97 (3-4): 171-191. https://doi.org/10.1016/j.enggeo.2008.01.004

NEMČOK, A., PAŠEK, J. Y RYBÁŘ, J. 1972. Classification of landslides and other mass movements. Rock Mechanics, 4 (2): 71-78. 
NEUHÄUSER, B., DAMM, B. y TERHORST, B. 2012. GIS-based assessment of landslide susceptibility on the base of the weights of evidence model. Landslides 9: 511-528. https://doi.org/10.1007/s10346-011-0305-5

NEULAND, H. 1976. A prediction model of landslips. Catena, 3: 215-230.

NEWTON, A. A. y CINGOLANI, C. A. 1990. Aspectos estratigráficos y estructurales comparativos entre las secuencias siluro-devónicas de la Sierra de la Ventana (Argentina) y el Cinturón Plegado del Cabo (Sudáfrica). Revista Técnica de YPFB 11: 59-63.

NICHOL, S., HUNGR, O., y EVANS, S. G. 2002. Large scale brittle and ductile toppling of rock slopes. Canadian Geotechnical Journal, 39: 773-788.

NILSEN, T. H., WRIGHT, R. H., VLASIC, T. C. y SPANGLE, W. E., 1979. Relative slope stability and land-use planning in the San Francisco Bay region, California. U.S. Geological Survey Professional Paper, 944: 96.

NOLLER, J. S. y LOCKE, W. W. 2000. Lichenometry. En: Noller J. S., Sowers J. M. y Lettis W. R. (Eds.): Quaternary Geochronology. DOI: 10.1029/RF004p0261.

NUUN, N. y PUGA, D. 2012. Ruggedness: The blessing of bad geography in Africa. Review of Economics and Statistics, 94 (1): 20-36.

OYAGI, N. 1984. Landslides in weathered rocks and residual soils in Japan and surrounding areas: A state of the art report. Proceedings of the IV International Symposium on Landslides, 3: 1-31. Toronto.

PANEK, T. 2015. Recent progress in landslide dating: a global overview. Progress in Physical Geography, 39 (2): 168-198.

PANIZZA, M. G. 2015. El área de Ventania en la conformación de la línea de frontera durante el siglo XIX. Cambio y diversidad cultural en la apropiación del paisaje. Tefros, II (13): 83-107.

PARK, N. 2011. Application of Dempster-Shafer theory of evidence to GIS-based landslide susceptibility analysis. Environmental Earth Sciences, 62: 367-376. https://doi.org/10.1007/s12665-010-0531-5

PASCUAL, R. 1961. Un Nuevo Cardiomyinae (Rodentia, Caviidae) de la Formación Arroyo Chasicó (Plioceno inferior) de la provincia de Buenos Aires. Ameghiniana, 2 (4): 57-71.

PASUTO, A. y SOLDATI, M. 1999. The use of landslide units in geomorphological mapping an example in the Italian Dolomites. Geomorphology, 30: 53-64.

PEEL, R. F. 1975. Water action in desert landscapes. En: Peel, R.F., Chisholm, M. y Haggett, P. (Eds.): Processes in Physical and Human Geography, pp. 110-129. Heinemann Educational Books (Bristol Essays), London.

PEREYRA, F. X. 1996a. Caracterización geomórfica y evolución del paisaje de un sector de las Sierras Australes, Provincia de Buenos Aires. Revista de la Asociación Geológica Argentina, 51 (3): 248-260.

PEREYRA, F. X. 1996b. Geomorfología. En: Ramos, V. (Ed.): Geología de la región del Aconcagua. Anales de la Subsecretaría de Minería de la Nación-DNSG, 24 (25): 423-445. Buenos Aires.

PEREYRA, F. X. 2018. Geomorfología de la Provincia de Buenos Aires. Instituto de Geología y Recursos Minerales, SEGEMAR. Serie Contribuciones Técnicas - Ordenamiento territorial $\mathrm{N}^{\circ} 9$, $85 \mathrm{pp}$. Buenos Aires.

PEREYRA, F. X. y FERRER, J. A. 1995. Geomorfología del Flanco Nororiental de las Sierras australes, Provincia de Buenos Aires. Actas de las IV Jornadas geológicas y geofísicas Bonaerenses, pp. 239-348. Junín.

PEREYRA, F. X. y FERRER, J. A. 1997. El material originario de los molisoles de las Sierras Australes, Provincia de Buenos Aires, Argentina. Ciencia del Suelo, 15: 87-94.

PEREYRA, F. X. y GONZÁLEZ DÍAZ, E. F. 1993. Reinterpretación geomórfica de la llamada "morena" de Los Horcones, Puente del Inca, Provincia de Mendoza. Actas del XII Congreso Geológico Argentino, 4: 73-79. Mendoza.

PEREYRA, F. X., TCHILINGUIRIAN, P., COPOLECCHIA, M., CAVALLARO, S., FRATALOCCHI, C., BORELLO, L., MILANESE, J. B. y SURIANO, J. M. 2001. Carta de Línea de Base Ambiental 3763-IV Coronel Suárez. Instituto de Geología y Recursos Minerales, Servicio Geológico Minero Argentino. Boletín $\mathrm{N}^{\circ}$ 307. Buenos Aires. 
PMA-GCA (Proyecto Multinacional Andino: Geociencias para las Comunidades Andinas). 2007. Movimientos en Masa en la Región Andina: Una guía para la evaluación de amenazas. Servicio Nacional de Geología y Minería, Publicación Geológica Multinacional, 4: 432 pp.

POLANSKI, J. 1960. Cenoglomerado del Quemado (provincia de Mendoza). Revista de la Asociación Geológica Argentina, 15: 159-179.

QUATTROCCHIO, M. E., DESCHAMPS, C., ZAVALA, C., BORROMEI, A. M., GRILL, S. y GUERSTEIN, G. R. 1993. Cuaternario del sur de la Provincia de Buenos Aires. Estratigrafía e inferencias paleoambientales. En: Iriondo, M. (Ed.): El Holoceno en la Argentina, II: 22-34. CADINQUA, Paraná.

QUATTROCCHIO, M. E., KOSTADINOFF, J., MARTíNEZ, G. A. y PRIETO, A. R. 1994. Evidencias de neotectónica en el río Sauce Chico, Provincia de Buenos Aires. Revista de la Asociación Geológica de Argentina, 49 (3-4): 297-305.

RABASSA, J. 1989. Geología de los depósitos del Pleistoceno Superior y Holoceno en las cabeceras del río Sauce Grande, provincia de Buenos Aires. Actas de las Primeras Jornadas Geológicas Bonaerenses, pp. 765-790. Tandil.

RABASSA, J. y OLLIER, C. 2014. Gondwana Landscapes in southern South America. Springer Earth System Sciences, Monograph Series, 544 pp.

RABASSA, J., ZÁRATE, M.A., CAMILIÓN, M. C., PARTRIDGE, T. y MAUD, R. 1995. Relieves relictuales de Tandilia y Ventania. Actas de las IV Jornadas Geológicas Bonaerenses, pp. 249256. La Plata.

RABASSA, J., ZÁRATE, M. A., DEMOULIN, A., CAMILIÓN, M. C., PARTRIDGE, T. y MAUD, R. 1998. Superficies de erosión y morfogénesis de Tandilia y Ventania. Actas de las $\mathrm{V}$ Jornadas Geológicas Bonaerenses, pp. 111-118. Mar del Plata.

RABASSA., J., CORONATO, A. y SALEME, M. 2005. Chronology of the Late Cenozoic Patagonian glaciations and their correlation with biostratigraphic units of Pampean region. Journal of South American Earth Sciences 20: 81-103.

RAMOS, V. A. 1984. Patagonia: un continente paleozoico a la deriva? Actas del IV Congreso Geológico Argentino, II: 311-325.

RAMOS, V. A. 1988. The tectonics of the central Andes; $30^{\circ}$ to $33^{\circ} \mathrm{S}$ latitude. Geological Society of America, 218: 31-54.

RAMOS, V., CHEMALE, F., NAIPAUER, M. y PAZOS, P. 2013. A provenance study of the Paleozoic Ventania System (Argentina): Transient complex sources from Western and Eastern Gondwana. Gondwana Research, 26: 719-740.

RAPELA, C. W. y KOSTADINOFF, J. 2005. El basamento de Sierra de la Ventana: historia tectomagmática. En: de Barrio, R., Etcheverry, R., Caballé, M y LLambías, E. (Eds.): Geología y Recursos Minerales de la Provincia de Buenos Aires. Relatorio del XVI Congreso Geológico Argentino, pp. 69-84. La Plata.

REICHENBACH, P., ROSSI, M., MALAMUD, B. D., MIHIR, M. y GUZZETTI, F. 2018. A review of statistically-based landslide susceptibility models. Earth-Science Reviews, 180: 60-91.

REIG, O. 1975. Diagnosis previas sobre los marsupiales de la Formación Arroyo Chasicó. Ameghiniana, 1 (3): 27-31.

REIS, S., YALCIN, A., ATASOY, M., NISANCI, R., BAYRAK, T., ERDURAN, M., SANCAR, C. y EKERCIN, S. 2012. Remote sensing and GIS-based landslide susceptibility mapping using frequency ratio and analytical hierarchy methods in Rize province (NE Turkey). Environmental Earth Sciences, 66: 2063-2073. https://doi.org/10.1007/s12665-011-1432-y

REMONDO, J. 2001. Elaboración y validación de mapas de susceptibilidad de deslizamientos mediante técnicas de análisis espacial. Tesis Doctoral, Universidad de Oviedo. 404 pp.

REMONDO, J. y OGUCHI, T. 2009. GIS and SDA applications in geomorphology. Geomorphology, 111: 1-3.

REMONDO, J., GONZÁLEZ, A., DÍAZ DE TERÁN, J. R., CENDRERO, A., FABBRI, A. y CHUNG, C. J. 2003. Validation of landslide susceptibility maps; examples and applications from a case study in Northern Spain. Natural Hazards, 30: 437-449.

REMONDO, J., SOTO, J., GONZÁLEZ-DÍEZ, A., DÍAZ DE TERÁN, J.R. y CENDREO, A. 2005. Human impact on geomorphic processes and hazards in mountain areas in northern Spain. Geomorphology, 66: 69-84. 
REMONDO, J., BONACHEA, J. y CENDRERO, A. 2008. Quantitative landslide risk assessment and mapping on the basis of recent occurrences. Geomorphology, 94: 496-507.

RENEAU, S., DIETRICH, W., DONAHUE, D., JUIL, A. y RUBIN, M. 1990. Late Quaternary history of colluvial deposition and erosion in Hallows, Central California Coast Ranges. Geological Society of American Bulletin, 102 (V): 969-982.

RILEY, S. J., DE GLORIA, S. D. y ELLIOT, R. 1999. A Terrain Ruggedness that Quantifies Topographic Heterogeneity. Intermountain Journal of Science, 1-4 (5): 23-27.

RIVAS, V., CENDRERO, A., HURTADO, M., CABRAL, M., GIMÉNEZ, J., FORTE, L., DEL RíO, L., CANTÚ, M. y BECKER, A. 2006. Geomorphic consequences of urban development and mining activities; an analysis of study areas in Spain and Argentina. Geomorphology, 73 (3-4): 185-206.

ROLLERI, E. O. 1975. Provincias geológicas bonaerenses. Relatorio del VI Congreso Geológico Argentino, pp. 29-54. Bahía Blanca.

ROSELL, M. P. y ÁNGELES, G. R. 2012. Aplicación de un modelo de erosión de laderas para estudiar las características hidrodinámicas de la cuenca alta del Arroyo Pigüé, Buenos Aires, Argentina. Actas de las IX Jornadas Nacionales de Geografía Física, pp 152-170. Bahía Blanca.

ROSSELlO E., MASSABIE, A. C., LÓPEZ GAMUNDI, O. R., COBBOLD, P. R. Y GAPAIS, D. 1997. Late paleozoic transpession in Buenos Aires and Northeast Patagonia ranges, Argentina. Journal of South American Earth Sciences 10: 389-402.

RUIZ-CARULLA R., COROMINAS J., y MAVROULI O. 2017. A fractal fragmentation model for rockfalls. Landslides, 14 (3): 875-889.

SAATY, T. L. 1980. The Analytic Hierarchy Process. McGraw-Hill, New York. 296 pp.

SAPONARO, A., PILZ, M., WIELAND, M., BINDI, D., MOLDOBEKOV, B. y PAROLAI, S. 2015. Landslide susceptibility analysis in data-scarce regions: the case of Kyrgyzstan. Bulletin of Engineering Geology and the Environment, 74: 1117-1136. https://doi.org/10.1007/s10064-0140709-2

SASSA, K. 1999. Introduction. En: Sassa, K. (Ed.): Landslides of the world. Kyoto University Press, pp. 3-18.

SASSA, K. 2004. Preface. Landslides, 1:1-5.

SASSA, K. 2007. Landslide science as a new scientific discipline. En: Sassa, K., Fukuoka, H., Wang F. y Wang, G. (Eds.): Progress in Landslide Science, pp. 3-11. Springer, Berlin, Heidelberg.

SAVAGE, C. N. 1968. Mass wasting. En: Fairbridge, R. D. (Ed.): Encyclopedia of Geomorphology. Reinhold Book Corporation, pp. 696-700. Nueva York.

SAVAGE, W. Z., GODT, J. W. y BAUM, R. L. 2004. Modeling time-dependent area slope stability. Proceedings of IX International Symposium on Landslide, pp. 23-38. Río de Janeiro.

SCARPATI, O. E. y CAPRIOLO, A. D. 2013. Sequías e inundaciones en la provincia de Buenos Aires (Argentina) y su distribución espacio-temporal. Investigaciones Geográficas, Boletín del Instituto de Geografía, UNAM, 82: 38-51.

SCHILLER, W. 1930. Investigaciones geológicas en las montañas del sudoeste de la Provincia de Buenos Aires. Anales del Museo de la Plata, 4 (2): 9-101.

SCHILLER, W. 1942. Las antiguas montañas de la Provincia de Buenos Aires. Notas Museo de La Plata, Sección Geología, VII (22): 247-252.

SCHRODER, J. F. 1971. Landslides of Utah. Utah Geological and Mineralogical Survey, Bulletin 90. $50 \mathrm{pp}$.

SCHULZ, W. H., SMITH, J. B., WANG, G., JIANG, Y., y ROERING, J. J. 2018. Clayey landslide initiation and acceleration strongly modulated by soil swelling. Geophysical Research Letters, 45: 1888-1896.

SCHWERDTFEGER, W. y VASINO, C. 1954. La variación secular de las precipitaciones en el Este y Centro de la República Argentina. Meteoros, IV (3): 174-193.

SELLÉS-MARTíNEZ, J. 1989. The structure of Sierras Australes (Buenos Aires, Argentina). An example of folding in a transpressive environment. Journal of South America Earth Science, 2 (4): 317-329.

SELLÉS-MARTíNEZ, J. 2001. Geología de la Ventania (Provincia de Buenos Aires, Argentina). Journal of Iberian Geology, 27: 43-69. 
SELLÉS-MARTíNEZ, J. y QUENARDELLE, S. M. 1992. Evidencias microestructurales de deformación progresiva en la Formación Lolén (Devónico de Sierra de la Ventana. Provincia de Buenos Aires). VI Reunión sobre microtectónica. Monografías de la Academia Nacional de Ciencias Exactas, Físicas y Naturales, pp. 127-131. Buenos Aires.

SELBY, M. J. 1982. Controls on the stability and inclinations of hillslopes formed on hard rock. Earth Surf. Process. Landforms, 7: 449-467.

SEPÚLVEDA, S. A., MOREIRAS, S. M., LARA, M. y ALFARO, A. 2014. Debris flows in the Andean ranges of central Chile and Argentina triggered by 2013 summer storms: characteristics and consequences. Landslides, 12: 115-133.

SHANMUGAM, G. 2015. The landslide problem. Journal of Palaeogeography, 4 (2): 109-166.

SHARPE C. F. S. 1938. Landslides and related phenomena: a study of mass-movements of soil and rock. Columbia University Press, New York. 137 pp.

SHAW, C. F. 1929. Erosion pavement. Geographical Review, 19 (4): 638-641.

SHREVE, R. L. 1966. Sherman Landslide, Alaska. Science, 154: 1639-1643.

SKEMPTON, A. W. 1948. A possible relationship between true cohesion and the mineralogy of clays. Proceedings of the $2^{\text {nd }}$ International Conference on Soil Mechanics, 7: 45-46.

SKEMPTON, A. W. 1953. The colloidal "activity" of clays. Proceedings $3^{\text {rd }}$ International Conference on Soil Mechanics, 1: 57-61. Zurich.

SLAYMAKER, O., SPENCER, T., y EMBLETON-HAMANN, C. 2009. Geomorphology and global environmental change. Cambridge University Press, $434 \mathrm{pp}$.

SMITH T. C. 1988. A method for mapping relative susceptibility to debris flows with an example from San Mateo County. En: Ellen, S. D. \& Wieczorek G. F. (Eds.): Landslides, floods, and marine effects of the storm of January 3-5, 1982, in the San Francisco Bay Region, California. Washington: U.S. Geological Survey Professional Paper. 1434: 185-203.

SOETERS, R. y VAN WESTEN, C. J. 1996. Slope instability recognition, analysis, and zonation. En: Turner, A. K. y Schuster, R. L. (Eds.): Landslides: investigation and mitigation. National Research Council, Special report 247: 129-177. Washington, D.C.,

SOIL SCIENCE SOCIETY OF AMERICA. 2008. Glossary of Soil Science Terms. Soil Science Society of America, Inc., Madison, WI. 88 pp. DOI: 10.2136/2008.glossarysoilscienceterms

STRAHLER, A. 1952. Dynamic Basis of Geomorphology. Geological Society of America Bulletin, 63, 923-938.

STUMPF, A., MALET, J. P., ALLEMAND, P., PIERROT-DESEILLIGNY, M. y SKUPINSKI, G. 2014. Ground-based multi-view photogrammetry for the monitoring of landslide deformation and erosion. Geomorphology, 231: 130-145.

SUERO, T. 1972. Compilación geológica de las Sierras Australes de la Provincia de Buenos Aires. Ministerio de Obras Públicas, LEMIT, División Geología. Anales II, 216: 135-147. La Plata.

SUERO, T. 1973. Perfiles geológicos de las Sierras Australes de la provincia de Buenos Aires. Ministerio de Obras Públicas, LEMIT, División Geología. Anales II, 236: 1-63. La Plata.

SUJATHA, E. R., RAJAMANICKAM, G. V. y KUMARAVEL, P. 2012. Landslide susceptibility analysis using Probabilistic Certainty Factor Approach: A case study on Tevankarai stream watershed, India. Journal of Earth System Science, 121: 1337-1350. https://doi.org/10.1007/s12040-012-0230-6

SUMMERFIELD, M. A. 1991. Global Geomorphology: An introduction to the study of landforms. 537 pp. Longman, London.

SUSENA, J. M. y GENTILE, R. O. 2017. Movimientos en masa en sectores de la Sierra de Bravard y el Valle de las Grutas, Sierras Australes Bonaerenses (Partido de Saavedra, Provincia de Buenos Aires). Actas digitales del XX Congreso Geológico Argentino, pp. 432-439. San Miguel de Tucumán.

SUSENA, J. M., y GENTILE, R. O. 2018. Caídas y vuelcos de roca y suelo en un área turística de las Sierras Australes de la Provincia de Buenos Aires. Actas de las II Jornadas Internacionales y IV Jornadas Nacionales de Ambiente, pp. 663-666. Tandil.

SUSENA, J. M. y GENTILE, R. O. 2019. Interacciones entre procesos erosivos y actividad antropofaunística en las Sierras de Bravard y Curamalal y piedemontes aledaños, Provincia de Buenos Aires. Actas digitales del VII Congreso Nacional de Geografía de Universidades Públicas y XXI Jornadas de Geografía de la UNLP, 22 pp. La Plata. 
SUSENA, J. M., GENTILE, R. O. y REMONDO, J. 2019a. Cambios morfológicos en laderas de detritos y niveles pedemontanos pleistocenos y holocenos vinculados a actividades humanas, Sierras Australes de la Provincia de Buenos Aires, Argentina. Libro de Resúmenes de la XV Reunión Nacional de Cuaternario, pp. 103-106. Bilbao.

SUSENA, J. M., REMONDO, J. y GENTILE, R. O. 2019b. Interactions Between Human Activities and Geomorphic Processes in a Mountain and Piedmont Farming Context, Argentina. Abstract Book. IAG Regional Conference 2019: Geomorphology of Climatically and Tectonically Sensitive Areas, page 170. Atenas.

SURIANO, J. y LIMARINO, C. O. 2009. Sedimentación Pedemontana en las Nacientes del Río Jáchal y Pampa de Gualilán, Precordillera de San Juan. Revista de la Asociación Geológica Argentina, 65 (3): 516-532.

SYVITSKI, J., y KETTNER, A. 2011. Sediment flux and the Anthropocene. Philosophical Transactions of the Royal Society, 369 (A): 957-975.

SYVITSKI, J., VÖRÖSMARTY, C. J., KETTNER, A. J., y GREEN, P., 2005. Impacts of humans on the flux of terrestrial sediment to the global coastal ocean. Science, 308: 376-380.

TANGESTANI, M. H. 2009. A comparative study of Dempster-Shafer and fuzzy models for landslide susceptibility mapping using a GIS: an experience from Zagros Mountains, SW Iran. Journal of Asian Earth Sciences 35 (1): 66-73. https://doi.org/10.1016/j.jseaes.2009.01.002

TER-STEPANIAN, G. 1988. Beginning of the Technogene. Bulletin of the International Association of Engineering Geology, 38: 133-142.

TERZAGHI, K. 1950. Mechanics of Landslides. Geological Society of America, Berkey Volume, 83124. New York.

TERZAGHI, K. 1956. Varieties of submarine slope failures. Procedures of the $8^{\text {th }}$ Texas Conference on Soil Mechanics and Foundation Engineering, $41 \mathrm{pp}$.

THIERY, Y., MAQUAIRE, O. y FRESSARD, M. 2014. Application of expert rules in indirect approaches for landslide susceptibility assessment. Landslides, 11: 411-424. https://doi.org/10.1007/s10346-013-0390-8

THORNBURY, W. D. 1960. Principios de Geomorfología. Ed. Kapelusz. 627 pp.

THORNTHWAITE, C. W. 1948. An approach toward a rational classification of climate. The Geographical Review, 38: 55-94.

TOMCZYK, A. M. y EWERTOWSKI, M. W. 2017. Surface morphological types and spatial distribution of fan-shaped landforms in the periglacial high-Arctic environment of central Spitsbergen, Svalbard. Journal of Maps, 13 (2): 239-251.

TOMEZZOLI, R. N. 2001. Further Palaeomagnetic results from the Sierras Australes fold and thrust belt, Argentina. Geophysical Journal International, 147: 356-366.

TOMEZZOLI, R. N. y CRISTALLINI, E. O. 2004. Secciones estructurales de Las Sierras Australes de la provincia de Buenos Aires: Repetición de la secuencia estratigráfica a partir de fallas inversas? Revista de la Asociación Geológica Argentina, 59 (2): 330-340.

TORRERO, M. P. y CAMPO, A. 2008. Hidrogeomorfología de la cuenca del río Sauce Chico, Argentina. Revista Geográfica de Valparaíso, 41: 1-13.

TORRERO, M. P., CAMPO, A. M. y UBOLDI, J. 2010. Environmental assessment of the Sauce Chico river basin, Argentina derived from satellital images and use of geographic information systems. GeoFocus, 10: 18-53.

TROMBOTTO, D. 2008. Geocryology of Southern South America. Developments in Quaternary Sciences, 11: 255-268.

TWIDALE, C. R. 1962. Steepened margins of inselbergs from north-western Eyre Peninsula, South Australia. Zeitschrift für Geomorphologie, 6: 51-69.

TWIDALE, C. R. y CORBIN, E. M. 1963. Gnammas. Revue de Géomorphologie Dynamique, 14: 120.

UBOLDI, J., LAUCIRICA, J., MICHALIJOS, P. y MANCINO, M. 2011. Cambio climático, turismo y riesgo de incendios, de pasturas y de interfase, en el sudoeste bonaerense, su análisis con geotecnologías. Revista Geográfica de América Central, número especial EGAL, pp. 1-15.

UMAR, Z., PRADHAN, B., AHMAD, A., JEBUR, M. N. y TEHRANY, M. S. 2014. Earthquake induced landslide susceptibility mapping using an integrated ensemble frequency ratio and 
logistic regression models in West Sumatera Province, Indonesia. Catena, 118: 124-135. https://doi.org/10.1016/j.catena.2014.02.005

URIEN, C. M. y ZAMBRANO, J. J. 1973. Geology of the basins of the Argentine continental margin and Malvinas Plateau. En: Nairn, A. E. M. y Stehli, F. G. (Eds.): The ocean basins and margins. Plenum Publishing Co, I- The South Atlantic, 4: 135-170. New York.

VAN WESTEN, C.J. 1997. Statistical landslide hazard analysis. ILWIS 2.1 for Windows application guide. ITC Publication, 73-84. Enschede.

VARELA. R. 1978. Sierras Australes de la Provincia de Buenos Aires: Hipótesis de trabajo sobre su composición geológica y rasgos geotectónicos salientes. Revista de la Asociación Geológica Argentina, 33 (1): 52-62, Buenos Aires.

VARELA, R. y CINGOLANI, C. A. 1975. Nuevas edades radimétricas del basamento aflorante en el perfil del Cerro Pan de Azúcar-Cerro del Corral y consideraciones sobre la evolución geocronológica de las rocas ígneas de las Sierras Australes, provincia de Buenos Aires. Actas del VI Congreso Geológico Argentino, 1: 543-556. Bahía Blanca.

VARNES, D. J. 1958. Landslides types and processes. En: Eckel, E. B. (Ed.): Landslides and engineering practice. Special Report, 28: 20-47. Washington.

VARNES, D. J. 1978. Slope movement types and processes. En: Schuster, R. L. y Krizek, R. J. (Eds.): Landslides-Analysis and Control. Transportation Research Board Special Report, 176: 1133. Washington.

VARNES, D. J. 1984. Landslides Hazard Zonation: A Review of Principles and Practice. UNESCO, Paris, Natural Hazards, 3: 1-63.

VERSTAPPEN, H. 2011. Old and new trends in geomorphological and landform mapping. En: Smith, M. J., Paron, P. y Griffith, J. (Eds.): Geomorphological mapping: A handbook of techniques and applications, pp. 13-38. Elsevier, Amsterdam.

VIERA, V. O. y CENCETTI, C. 2008. Paleolago formado por flujos densos, río Toro, Salta, Argentina. Actas del XVII Congreso Geológico Argentino, pp. 320-321. Jujuy.

VON GOSEN, W., BUGGISCH, W. y KRUMM, S. 1991. Metamorphic and deformation mechanisms in the Sierras Australes fold thrust belt (Buenos Aires, Province, Argentina). Tectonophysics, 185: 335-356.

VOOGD, J. H. 1982. Multicriteria evaluation for urban and regional planning. Delftsche Uitgevers Maatschappij. 380 pp. https://doi.org/10.6100/IR102252

WANG, L. y LIU, H. 2006. An efficient method for identifying and filling surface depressions in digital elevation models for hydrologic analysis and modelling. International Journal of Geographical Information Science, 20 (2): 193-213.

WANG, B., PAUDEL, B. y LI, H. 2016. Behaviour of retrogressive thaw slumps in northern Canadathree-year monitoring results from 18 sites. Landslides, 13:1-8.

WARD, S. N. y DAY, S. 2006. A particulate kinematic model for large debris avalanches: Interpretation of debris avalanche deposits and landslide seismic signals of Mount St. Helens, May 18th, 1980. Geophysical Journal International, 167 (2): 991-1004.

WASHBURN, A. L. 1979. Geocryology. E. Arnold, 406 pp. London.

WIECKZOREK, G. F. y SNYDER, J. B. 2009. Monitoring slope movements. En: Young, R., y Norby, L. (Eds.): Geological Monitoring: Boulder, Colorado. Geological Society of America, pp. 245-271.

WP/WLI (International Geotechnical Societies' UNESCO Working Party on World Landslide Inventory). 1991. A Suggested Method for a Landslide Summary. Bulletin International Association for Engineering Geology, 43: 101-110.

WP/WLI. 1993a. A suggested method for describing the activity of a landslide. Bulletin International Association for Engineering Geology, 47: 53-57.

WP/WLI. 1993b. Multilingual landslide glossary. The Canadian Geotechnical Society. BiTech Publishers Ltd.

WU, Y., LI, W., WANG, Q., LIU, Q., YANG, D., XING, M., PEI, Y. y YAN, S. 2016. Landslide susceptibility assessment using frequency ratio, statistical index and certainty factor models for the Gangu County, China. Arabian Journal of Geosciences, 9: Artículo № 84. https://doi.org/10.1007/s12517-015-2112-0

YILMAZ, I. 2010. Comparison of landslide susceptibility mapping methodologies for Koyulhisar, Turkey: conditional probability, logistic regression, artificial neural networks, and support vector 
machine. Environmental Earth Sciences, 61: 821-836. https://doi.org/10.1007/s12665-009-03949

YRIGOYEN, M. R. 1975. Geología del subsuelo y plataforma continental. Geología de la Provincia de Buenos Aires. Relatorio del VI Congreso Geológico Argentino, pp. 139-168. Bahía Blanca.

ZAPPERI, P., RAMOS, M., GIL, V. y CAMPO, A. 2007. Caracterización de las precipitaciones estivales en el Suroeste bonaerense. Contribuciones Científicas GÆA. Buenos Aires: Sociedad Argentina de Estudios Geográficos, pp. 483-491.

ZAPPETTINI, E. 2008. Las Avalanchas de detritos del Volcán Llullaillaco, El Colapso de un Gigante. Anales del Servicio Geológico Minero Argentino (SEGEMAR), 46 (1): 1-47.

ZÁRATE, M. y RABASSA, J. 2005. Geomorfología de la Provincia de Buenos Aires. En: de Barrio, R., Etcheverry, R., Caballé, M y LLambías, E. (Eds.): Geología y Recursos Minerales de la Provincia de Buenos Aires. Relatorio del XVI Congreso Geológico Argentino, VIII: 119-138.

ZÁRATE, M., RABASSA, J., PARTRIDGE, T. C. y MAUD, R. 1995. La Brecha Cerro Colorado, es Miocena? Actas de las IV Jornadas Geológicas Bonaerenses, 1: 159-168. Junín.

ZÁRATE, M., RABASSA, J., MAUD, R. y PARTRIDGE, T. C. 1998. La silicificación de la Brecha Cerro Colorado: clasificación, génesis e implicancias ambientales. Actas de las $\mathrm{V}$ Jornadas Geológicas Bonaerenses, I: 165-173. Mar del Plata.

ZAVALA, C., AZÚA, G., FREIJE, R. H. y PONCE, J. J. 2000. Sistemas deltaicos dominados por avenidas fluviales en el Grupo Curamalal (Paleozoico inferior), Cuenca paleozoica de Ventania, Provincia de Buenos Aires, Argentina. Revista de la Asociación Geológica Argentina, 55 (3): 165178.

ZAY, K. 1807. Goldau und seine Gegend, wie sie war und wie sie geworden. 390 pp. Zürich.

ZEVENBERGEN, L. W. y THORNE, C. R. 1987. Quantitative analysis of land surface topography. Earth Surface Processes and Landforms, 12: 47-56.

ZÊZERE, J. L, TRIGO, R. M. y TRIGO, I. F. 2005. Shallow and deep landslides induced by rainfall in the Lisbon region (Portugal). Natural Hazards and Earth System Sciences, 5: 331-344.

ZHOU, G., ESAKI, T., MITANI, Y., XIE, M. y MORI, J. 2003. Spatial probabilistic modelling of slope failure using an integrated GIS Monte Carlo simulation approach. Engineering Geology, 68: 373386. 
ANEXO 
Movimientos en masa en las sierras de Bravard y Curamalal, Sierras Australes de la Provincia de Buenos Aires.

Juan Manuel Susena 


\begin{tabular}{|c|c|c|c|c|}
\hline Pico & Cordón serrano & Latitud & Longitud & $\begin{array}{c}\text { Cota } \\
\text { (m s.n.m.) }\end{array}$ \\
\hline Sa. Negra & Bravard-Ventana & $-37^{\circ} 59^{\prime} 45^{\prime \prime}$ & $-62^{\circ} 02^{\prime} 38^{\prime \prime}$ & 978 \\
\hline Co. Guanaco & Bravard & $-37^{\circ} 52^{\prime} 30^{\prime \prime}$ & $-62^{\circ} 03^{\prime} 26^{\prime \prime}$ & 950 \\
\hline Co. Luisa & Bravard & $-37^{\circ} 51^{\prime} 09^{\prime \prime}$ & $-62^{\circ} 04^{\prime} 43^{\prime \prime}$ & 922 \\
\hline Co. de la Providencia & Bravard & $-37^{\circ} 55^{\prime} 02^{\prime \prime}$ & $-62^{\circ} 03^{\prime} 27^{\prime \prime}$ & 914 \\
\hline Co. Áspero & Bravard & $-37^{\circ} 48^{\prime} 31^{\prime \prime}$ & $-62^{\circ} 05^{\prime} 21^{\prime \prime}$ & 810 \\
\hline Co. Hinojo & Bravard & $-37^{\circ} 44^{\prime} 45^{\prime \prime}$ & $-62^{\circ} 09^{\prime} 00^{\prime \prime}$ & 790 \\
\hline Co. Escaleras & Bravard & $-37^{\circ} 50^{\prime} 31^{\prime \prime}$ & $-62^{\circ} 03^{\prime} 53^{\prime \prime}$ & 780 \\
\hline Co. Barrancoso & Bravard & $-37^{\circ} 46^{\prime} 55^{\prime \prime}$ & $-62^{\circ} 06^{\prime} 41^{\prime \prime}$ & 752 \\
\hline Co. Puntudo & Bravard & $-37^{\circ} 45^{\prime} 43^{\prime \prime}$ & $-62^{\circ} 07^{\prime} 33^{\prime \prime}$ & 688 \\
\hline Co. Trocadero & Bravard & $-37^{\circ} 40^{\prime} 59^{\prime \prime}$ & $-62^{\circ} 14^{\prime} 32^{\prime \prime}$ & 618 \\
\hline Co. Curamalai Grande & Curamalal & $-37^{\circ} 43^{\prime} 20^{\prime \prime}$ & $-62^{\circ} 14^{\prime} 04^{\prime \prime}$ & 1037 \\
\hline Co. Chaco & Curamalal & $-37^{\circ} 54^{\prime} 54^{\prime \prime}$ & $-62^{\circ} 07^{\prime} 32^{\prime \prime}$ & 1025 \\
\hline Cdón. Lehmann & Curamalal & $-37^{\circ} 44^{\prime} 05^{\prime \prime}$ & $-62^{\circ} 13^{\prime} 16^{\prime \prime}$ & 960 \\
\hline Co. La Sofia & Curamalal & $-37^{\circ} 53^{\prime} 51^{\prime \prime}$ & $-62^{\circ} 08^{\prime} 40^{\prime \prime}$ & 959 \\
\hline Co. Agua Blanca & Curamalal & $-37^{\circ} 49^{\prime} 22^{\prime \prime}$ & $-62^{\circ} 08^{\prime} 33^{\prime \prime}$ & 896 \\
\hline Cdón. Hinojo Grande & Curamalal & $-37^{\circ} 45^{\prime} 54^{\prime \prime}$ & $-62^{\circ} 09^{\prime} 48^{\prime \prime}$ & 824 \\
\hline Co. Curamalal Chico & Curamalal & $-37^{\circ} 41^{\prime} 54^{\prime \prime}$ & $-62^{\circ} 16^{\prime} 52^{\prime \prime}$ & 788 \\
\hline Co. Pan de Azúcar & Aislado en elextremo SW & $-37^{\circ} 56^{\prime} 46^{\prime \prime}$ & $-62^{\circ} 10^{\prime} 47^{\prime \prime}$ & 715 \\
\hline Co. San Mario & Aislado en elextremo SW & $-37^{\circ} 57^{\prime} 47^{\prime \prime}$ & $-62^{\circ} 11^{\prime} 53^{\prime \prime}$ & 614 \\
\hline Co. del Corral & Aislado en elextremo SW & $-37^{\circ} 56^{\prime} 08^{\prime \prime}$ & $-62^{\circ} 09^{\prime} 52^{\prime \prime}$ & 567 \\
\hline Co. de los Terneros & Aislado en elextremo $\mathrm{S}$ & $-37^{\circ} 59^{\prime} 34^{\prime \prime}$ & $-62^{\circ} 07^{\prime} 53^{\prime \prime}$ & 629 \\
\hline
\end{tabular}


Movimientos en masa en las sierras de Bravard y Curamalal, Sierras Australes de la Provincia de Buenos Aires.

\begin{tabular}{|c|c|c|c|c|c|c|c|}
\hline \multicolumn{8}{|c|}{ Muestras tomadas y análisis de laboratorio efectuados } \\
\hline Muestra & $\begin{array}{c}\text { Coordenadas } \\
\text { (lat;Iong) }\end{array}$ & $\begin{array}{c}\text { Unidad } \\
\text { geomorfológica }\end{array}$ & Litología & Textura & $\begin{array}{c}\text { Expansión } \\
\text { libre }\end{array}$ & $\begin{array}{l}\text { Límite } \\
\text { líquido }\end{array}$ & DRX \\
\hline 158A1 & $\begin{array}{l}37^{\circ} 44^{\prime} 41,9^{\prime \prime} \mathrm{S} \\
62^{\circ} 09^{\prime} 53,7^{\prime \prime} \mathrm{O}\end{array}$ & $\begin{array}{c}\text { Fajas Aluviales } \\
\text { (= FA) }\end{array}$ & ALV & $x$ & $x$ & & \\
\hline $158 \mathrm{~A} 2$ & $=158 \mathrm{~A} 1$ & FA & ALV & $x$ & $X$ & & $X$ \\
\hline $158 B$ & $=158 \mathrm{~A} 1$ & FA & ALV & $x$ & $x$ & & $x$ \\
\hline $158 \mathrm{C} 1$ & $=158 \mathrm{~A} 1$ & FA & ALV & $x$ & $x$ & & $X$ \\
\hline $158 C 2$ & $=158 \mathrm{~A} 1$ & FA & ALV & $\mathrm{X}$ & $\mathrm{X}$ & & $X$ \\
\hline $160 A$ & $\begin{array}{l}37^{\circ} 47^{\prime} 06,4^{\prime \prime} \mathrm{S} ; \\
62^{\circ} 07^{\prime} 06,6^{\prime \prime} \mathrm{O}\end{array}$ & $\begin{array}{c}\text { Laderas de } \\
\text { Detritos (= LD) }\end{array}$ & DETR & $x$ & $x$ & $x$ & $X$ \\
\hline $160 B$ & $=160 \mathrm{~A}$ & LD & DETR & $x$ & $x$ & $x$ & $x$ \\
\hline CASP 1 & $\begin{array}{l}37^{\circ} 47^{\prime} 06,4^{\prime \prime} \mathrm{S} ; \\
62^{\circ} 07^{\prime} 06,6^{\prime \prime} \mathrm{O}\end{array}$ & LD & DETR & $x$ & $x$ & $x$ & $\mathrm{X}$ \\
\hline CASP 1B & $=$ CASP 1 & LD & DETR & $\mathrm{X}$ & $X$ & $x$ & $X$ \\
\hline CASP-303A & $\begin{array}{l}37^{\circ} 46^{\prime} 05,4^{\prime \prime} \mathrm{S} ; \\
62^{\circ} 08^{\prime} 38,4^{\prime \prime} \mathrm{O}\end{array}$ & $\begin{array}{c}\text { Bajada Coluvial } \\
\text { Fina }(=\mathrm{BCF})\end{array}$ & DETR & $x$ & $x$ & & $X$ \\
\hline CASP-303Bt & $\begin{array}{l}37^{\circ} 46^{\prime} 05,4^{\prime \prime} \mathrm{S} ; \\
62^{\circ} 08^{\prime} 38,4^{\prime \prime} \mathrm{O}\end{array}$ & $\mathrm{BCF}$ & DETR & $\mathrm{X}$ & $X$ & $X$ & $X$ \\
\hline CASP-303BC & $\begin{array}{l}37^{\circ} 46^{\prime} 05,4 " \mathrm{~S} \\
62^{\circ} 08^{\prime} 38,4^{\prime \prime} \mathrm{O}\end{array}$ & $\mathrm{BCF}$ & DETR & $x$ & $x$ & $x$ & $X$ \\
\hline CUR 19A & $\begin{array}{l}37^{\circ} 45^{\prime} 25,4^{\prime \prime} \mathrm{S} ; \\
62^{\circ} 10^{\prime} 56,0^{\prime \prime} \mathrm{O}\end{array}$ & LD & DETR & $x$ & $x$ & $x$ & $x$ \\
\hline CUR 19B & $=$ CUR 19A & LD & DETR & $x$ & $x$ & $x$ & $x$ \\
\hline CURCO-04 & $\begin{array}{l}37^{\circ} 47^{\prime} 02,1^{\prime \prime} \mathrm{S} ; \\
62^{\circ} 12^{\prime} 32,8^{\prime \prime} \mathrm{O}\end{array}$ & $\begin{array}{c}\text { Cubierta Eólica } \\
\text { Periserrana }(= \\
\text { CEP) }\end{array}$ & SAAV & $x$ & $x$ & $x$ & $x$ \\
\hline CURCO-27 & $\begin{array}{l}37^{\circ} 46^{\prime} 46,7^{\prime \prime} \mathrm{S} ; \\
62^{\circ} 13^{\prime} 22,9^{\prime \prime} \mathrm{O}\end{array}$ & $\mathrm{BCF}$ & SAAV & $x$ & $x$ & $x$ & $x$ \\
\hline CURCO-30 & $\begin{array}{l}37^{\circ} 46^{\prime} 31,6^{\prime \prime} \mathrm{S} ; \\
62^{\circ} 13^{\prime} 02,9^{\prime \prime} \mathrm{O}\end{array}$ & $\mathrm{BCF}$ & DETR & $x$ & $X$ & $X$ & $x$ \\
\hline G 420A & $\begin{array}{l}37^{\circ} 44^{\prime} 13,9 " \mathrm{~S} ; \\
62^{\circ} 10^{\prime} 08,7^{\prime \prime} \mathrm{O}\end{array}$ & LD & DETR & $x$ & $x$ & $x$ & $x$ \\
\hline G 420B & $=\mathrm{G} 420 \mathrm{~A}$ & LD & DETR & $x$ & $x$ & $x$ & $x$ \\
\hline MALV-AC & $\begin{array}{l}37^{\circ} 43^{\prime} 02,9^{\prime \prime} \mathrm{S} ; \\
62^{\circ} 19^{\prime} 49,1^{\prime \prime} \mathrm{O}\end{array}$ & $\begin{array}{c}\text { Piedemonte } \\
\text { Aluvial Antiguo } \\
\text { (= PMA) }\end{array}$ & MALV & $x$ & $x$ & & $x$ \\
\hline MALV-C & $=$ MALV-AC & PMA & MALV & $x$ & $x$ & & $x$ \\
\hline $\mathrm{SCH} 4$ & $\begin{array}{l}37^{\circ} 56^{\prime} 58,1^{\prime \prime} \mathrm{S} ; \\
62^{\circ} 10^{\prime} 41,0^{\prime \prime} \mathrm{O}\end{array}$ & LD & DETR & $X$ & $x$ & $x$ & $x$ \\
\hline $\mathrm{SCH} 3$ & $=\mathrm{SCH} 4$ & LD & DETR & $x$ & $x$ & $x$ & $x$ \\
\hline
\end{tabular}




\begin{tabular}{|c|c|c|c|c|c|c|}
\hline $\mathrm{SCH} 1$ & $=\mathrm{SCH} 4$ & LD & DETR & $x$ & $x$ & $x$ \\
\hline SCASP3-A & $\begin{array}{l}37^{\circ} 46^{\prime} 03,6^{\prime \prime} S \\
62^{\circ} 08^{\prime} 43,2^{\prime \prime O}\end{array}$ & CEP & SAAV & $\mathrm{X}^{*}$ & $x$ & \\
\hline SCASP3-Bt & $=$ SCASP3-A & CEP & SAAV & $\mathrm{X}^{*}$ & $x$ & \\
\hline SCASP3-C & $=$ SCASP3-A & CEP & SAAV & $X^{*}$ & $x$ & \\
\hline SGRT2-A & $\begin{array}{l}37^{\circ} 44^{\prime} 15,9 \mathrm{~S} ; \\
62^{\circ} 10^{\prime} 33,5^{\prime \prime O}\end{array}$ & FA & ALV & $X^{*}$ & $\mathrm{X}$ & \\
\hline SGRT2-AB & $=$ SGRT2-A & FA & ALV & $X^{*}$ & $x$ & \\
\hline SGRT2-Bw1 & = SGRT2-A & FA & ALV & $X^{*}$ & $x$ & \\
\hline SGRT2-Bw2 & = SGRT2-A & FA & ALV & $\mathrm{X}^{*}$ & $x$ & \\
\hline
\end{tabular}

Tabla A.2. Resumen de las muestras tomadas en el terreno y los análisis de laboratorio realizados. $X^{*}$ : análisis de textura expeditivos realizados con el método del hidrómetro (Bouyoucos, 1962). Elaboración propia.

\begin{tabular}{|c|c|c|c|c|c|c|c|c|c|}
\hline \multicolumn{10}{|c|}{ Resultados de los análisis de laboratorio efectuados } \\
\hline \multirow{3}{*}{$\begin{array}{c}\text { Muestra } \\
158 \mathrm{~A} 1\end{array}$} & \multirow{3}{*}{\begin{tabular}{|c|}
$\begin{array}{c}\text { Unidad } \\
\text { geomorfoló- } \\
\text { gica }\end{array}$ \\
$\begin{array}{c}\text { Fajas } \\
\text { Aluviales } \\
(=\mathrm{FA})\end{array}$ \\
\end{tabular}} & \multirow{3}{*}{$\begin{array}{c}\text { Litología } \\
\text { ALV }\end{array}$} & \multicolumn{4}{|c|}{ Textura } & \multirow{2}{*}{\multicolumn{2}{|c|}{ Expansión libre }} & \multirow{2}{*}{$\begin{array}{l}\text { Límite } \\
\text { líquido }\end{array}$} \\
\hline & & & $\%$ arcilla & $\%$ limo & $\%$ arena & Clase Textural & & & \\
\hline & & & 32,45 & 46,06 & 21,48 & Franco arcillosa & 20 & Baja & - \\
\hline 158A2 & FA & ALV & 36,65 & 48,23 & 15,12 & $\begin{array}{l}\text { Franco arcillo } \\
\text { limosa }\end{array}$ & 45 & Baja & - \\
\hline $158 \mathrm{~B}$ & FA & ALV & 32,70 & 39,77 & 27,52 & Franco arcillosa & 45 & Baja & - \\
\hline $158 \mathrm{C} 1$ & FA & ALV & 62,75 & 33,47 & 3,79 & Arcillosa & 25 & Baja & - \\
\hline $158 \mathrm{C} 2$ & FA & ALV & 44,62 & 43,59 & 11,79 & Arcillo limosa & 65 & Media & - \\
\hline $160 \mathrm{~A}$ & $\begin{array}{c}\text { Laderas de } \\
\text { Detritos } \\
(=\mathrm{LD})\end{array}$ & DETR & 25,32 & 60,56 & 14,12 & Franco limosa & 25 & Baja & 52,35 \\
\hline $160 \mathrm{~B}$ & LD & DETR & 36,57 & 38,23 & 25,20 & Franco arcillosa & 45 & Baja & 45,68 \\
\hline CASP 1 & LD & DETR & 15,35 & 37,01 & 47,64 & Franco & 70 & Media & 32,25 \\
\hline CASP 1B & LD & DETR & 30,47 & 48,41 & 21,12 & Franco arcillosa & 130 & Alta & 59,38 \\
\hline CASP-303A & $\begin{array}{c}\text { Bajada } \\
\text { Coluvial Fina } \\
(=\mathrm{BCF})\end{array}$ & DETR & 37,58 & 45,70 & 16,72 & $\begin{array}{l}\text { Franco arcillo } \\
\text { limosa }\end{array}$ & 60 & Media & - \\
\hline CASP-303Bt & $\mathrm{BCF}$ & DETR & 34,76 & 50,63 & 14,60 & $\begin{array}{c}\text { Franco arcillo } \\
\text { limosa }\end{array}$ & 90 & Alta & 49,35 \\
\hline CASP-303BC & $\mathrm{BCF}$ & DETR & 44,07 & 38,56 & 17,36 & Arcillosa & 65 & Media & 36,24 \\
\hline CUR 19A & LD & DETR & 37,82 & 47,77 & 14,41 & $\begin{array}{l}\text { Franco arcillo } \\
\text { limosa }\end{array}$ & 30 & Baja & 72,16 \\
\hline CUR 19B & LD & DETR & 18,40 & 70,36 & 11,24 & Franco limosa & 30 & Baja & 73,85 \\
\hline CURCO-04 & $\begin{array}{c}\text { Cubierta } \\
\text { Eólica } \\
\text { Periserrana } \\
(=\mathrm{CEP})\end{array}$ & SAAV & 28,37 & 37,49 & 34,14 & Franco arcillosa & 35 & Baja & 27,70 \\
\hline
\end{tabular}


Movimientos en masa en las sierras de Bravard y Curamalal, Sierras Australes de la Provincia de Buenos Aires.

Juan Manuel Susena

\begin{tabular}{|c|c|c|c|c|c|c|c|c|c|}
\hline CURCO-27 & $\mathrm{BCF}$ & SAAV & 41,28 & 47,80 & 10,92 & Arcillo limosa & 90 & Alta & 62,41 \\
\hline CURCO-30 & $\mathrm{BCF}$ & DETR & 52,22 & 41,78 & 6,01 & Arcillo limosa & 90 & Alta & 69,02 \\
\hline G 420A & LD & DETR & 42,78 & 32,09 & 25,13 & Arcillosa & 30 & Baja & 53,78 \\
\hline G 420B & LD & DETR & 44,92 & 29,37 & 25,71 & Arcillosa & 45 & Baja & 46,90 \\
\hline MALV-AC & $\begin{array}{c}\text { Piedemonte } \\
\text { Aluvial } \\
\text { Antiguo } \\
\text { (=PMA) }\end{array}$ & MALV & 13,53 & 51,42 & 35,05 & Franco limosa & 25 & Baja & - \\
\hline MALV-C & PMA & MALV & 13,76 & 27,52 & 58,73 & Franco arenosa & 0 & Baja & - \\
\hline $\mathrm{SCH} 4$ & LD & DETR & 24,68 & 55,79 & 19,53 & Franco limosa & 30 & Baja & 43,86 \\
\hline $\mathrm{SCH} 3$ & LD & DETR & 16,88 & 66,51 & 16,62 & Franco limosa & 40 & Baja & 31,15 \\
\hline $\mathrm{SCH} 1$ & LD & DETR & 18,95 & 39,61 & 41,44 & Franca & 35 & Baja & 25,64 \\
\hline SCASP3-A & CEP & SAAV & 10,51 & 40,03 & 49,47 & Franca* & 55 & Media & - \\
\hline SCASP3-Bt & CEP & SAAV & 22,51 & 36,02 & 41,47 & Franca* & 55 & Media & - \\
\hline SCASP3-C & CEP & SAAV & 25,52 & 33,02 & 41,46 & Franca* & 50 & Media & - \\
\hline SGRT2-A & FA & ALV & 11,51 & 44,02 & 44,47 & Franca* & 45 & Baja & - \\
\hline SGRT2-AB & FA & ALV & 41,03 & 38,03 & 20,94 & Arcillosa* & 45 & Baja & - \\
\hline SGRT2-Bw1 & FA & ALV & 39,04 & 44,04 & 16,92 & $\begin{array}{l}\text { Franco arcillo } \\
\text { limosa* }\end{array}$ & 70 & Media & - \\
\hline SGRT2-Bw2 & FA & ALV & 37,03 & 46,03 & 16,94 & $\begin{array}{l}\text { Franco arcillo } \\
\text { limosa* }\end{array}$ & 65 & Media & - \\
\hline
\end{tabular}

Tabla A.3. Resumen de los resultados de los análisis de laboratorio efectuados. *: análisis de textura expeditivos realizados con el método del hidrómetro (Bouyoucos, 1962). Elaboración propia. 


\section{DIFRACTOGRAMAS DE LA FRACCIÓN ARCILLA}
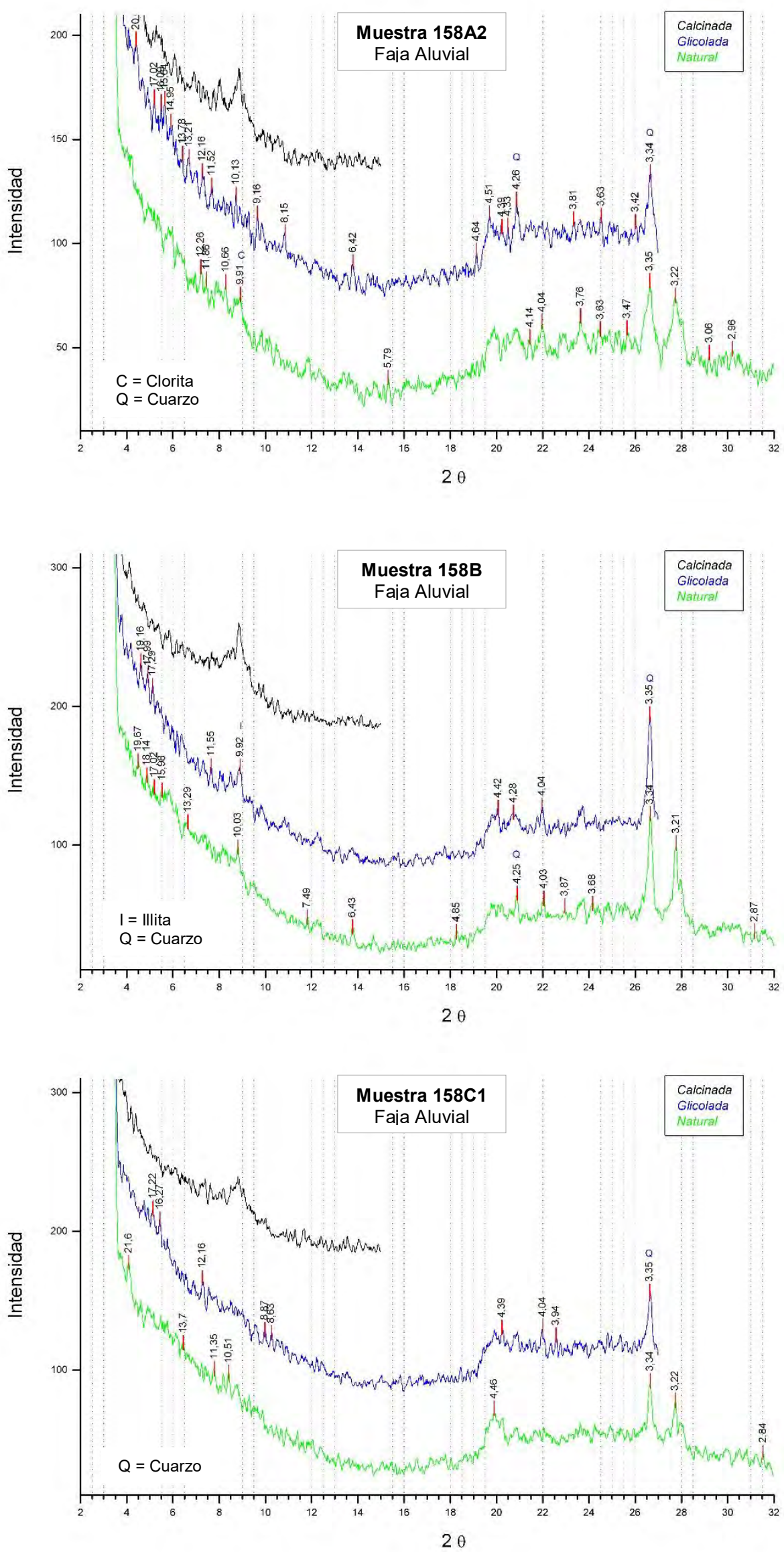
Movimientos en masa en las sierras de Bravard y Curamalal, Sierras Australes de la Provincia de Buenos Aires.

\section{DIFRACTOGRAMAS DE LA FRACCIÓN ARCILLA}
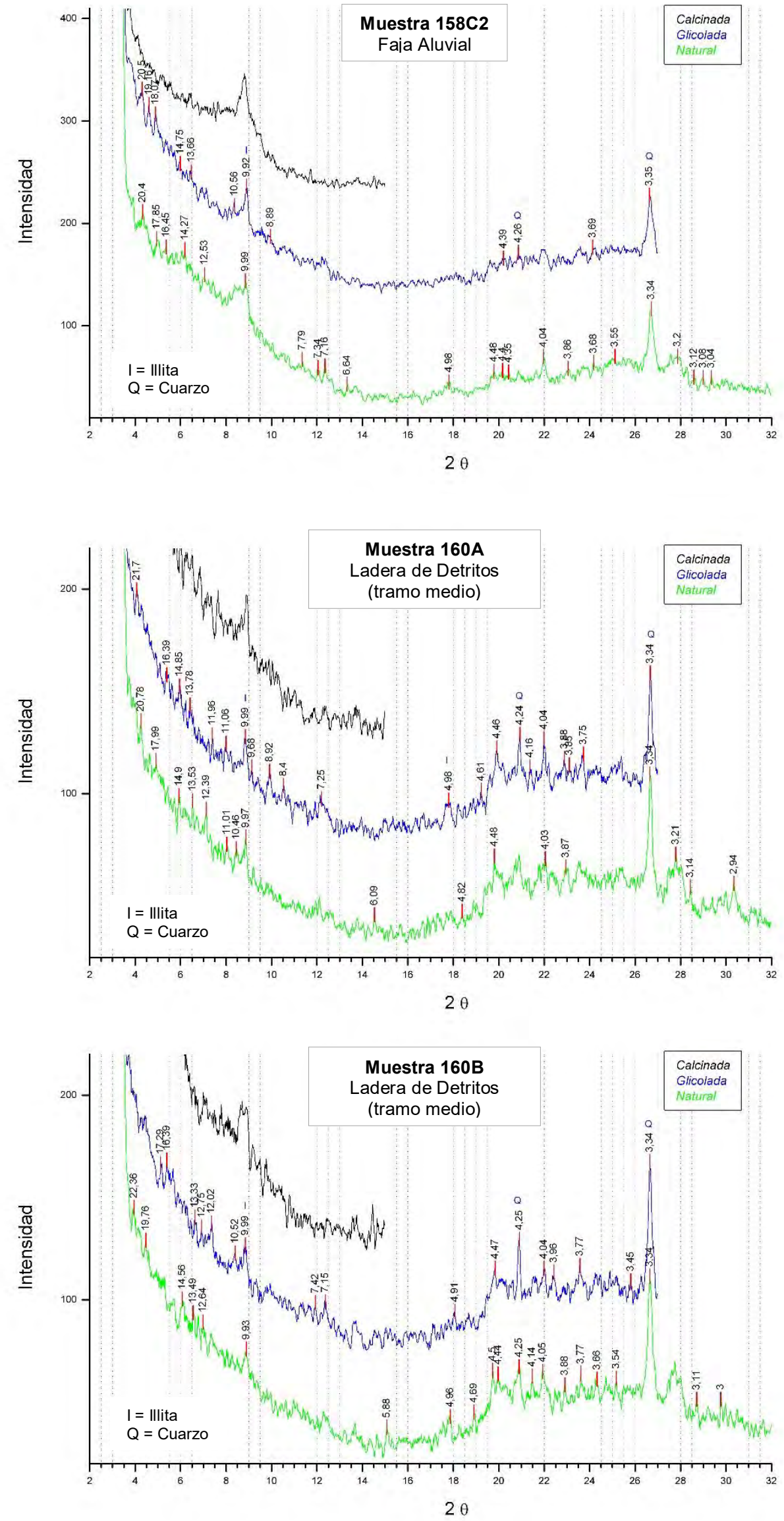

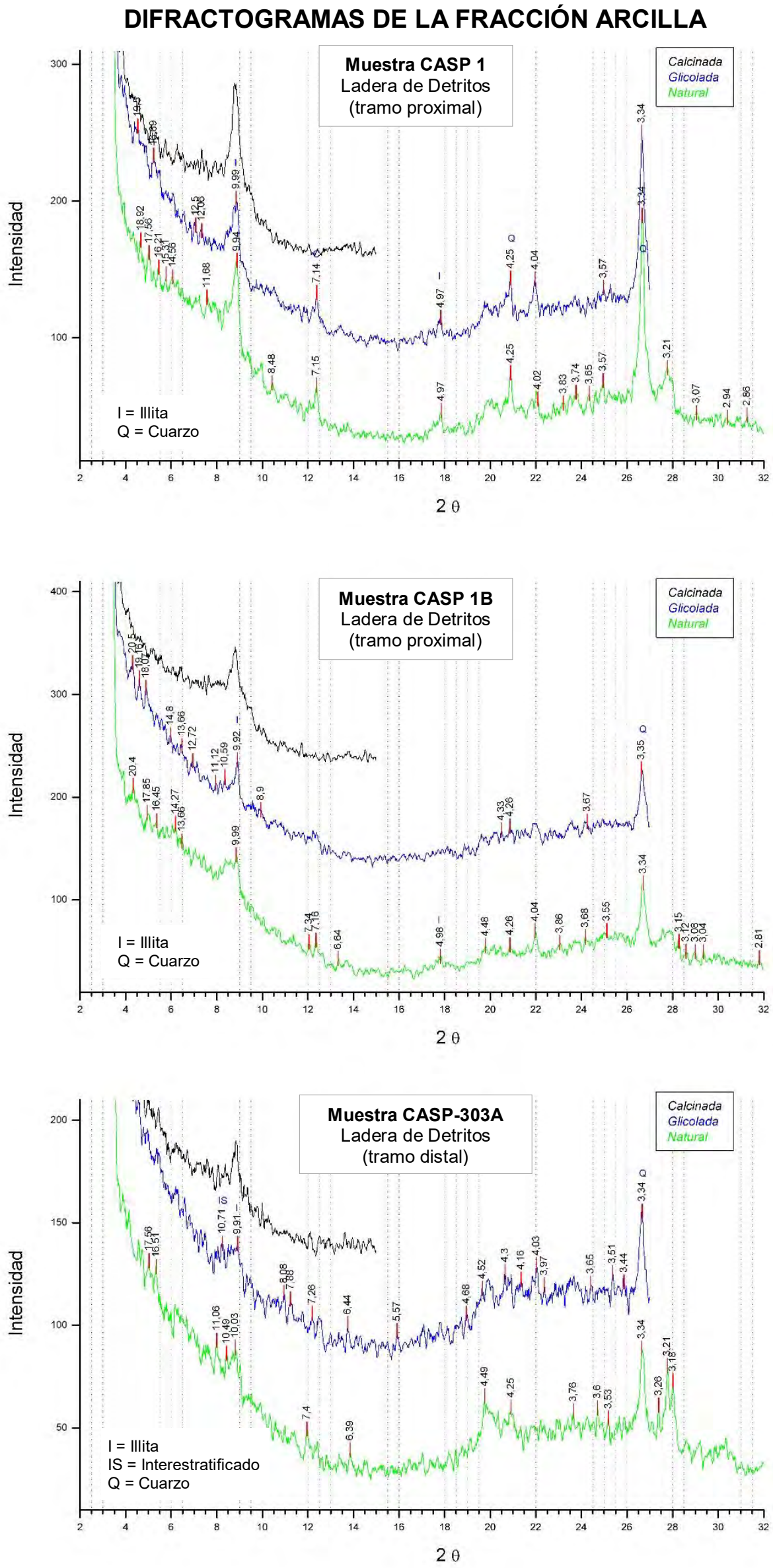
Movimientos en masa en las sierras de Bravard y Curamalal, Sierras Australes de la Provincia de Buenos Aires.

\section{DIFRACTOGRAMAS DE LA FRACCIÓN ARCILLA}
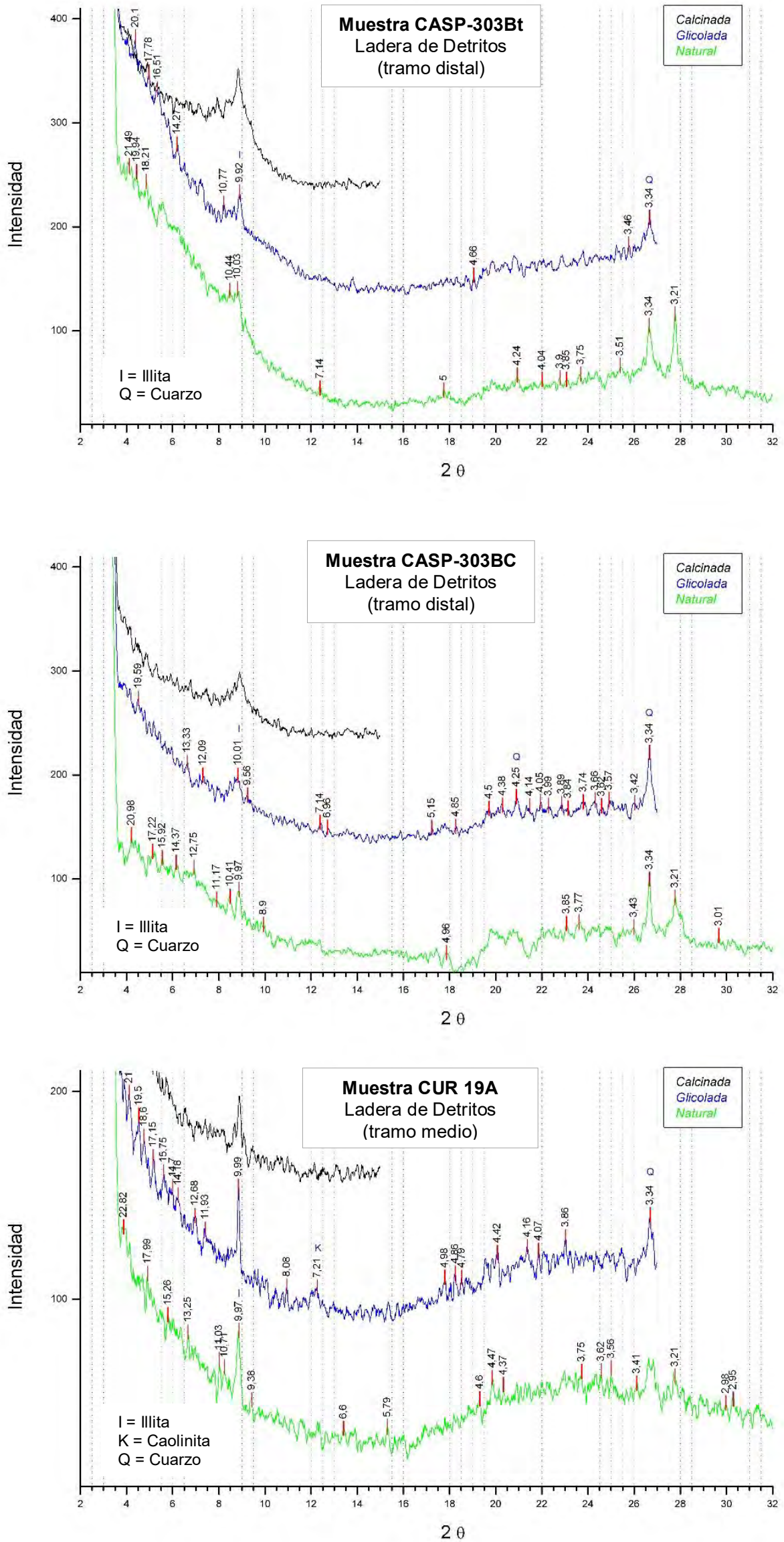


\section{DIFRACTOGRAMAS DE LA FRACCIÓN ARCILLA}
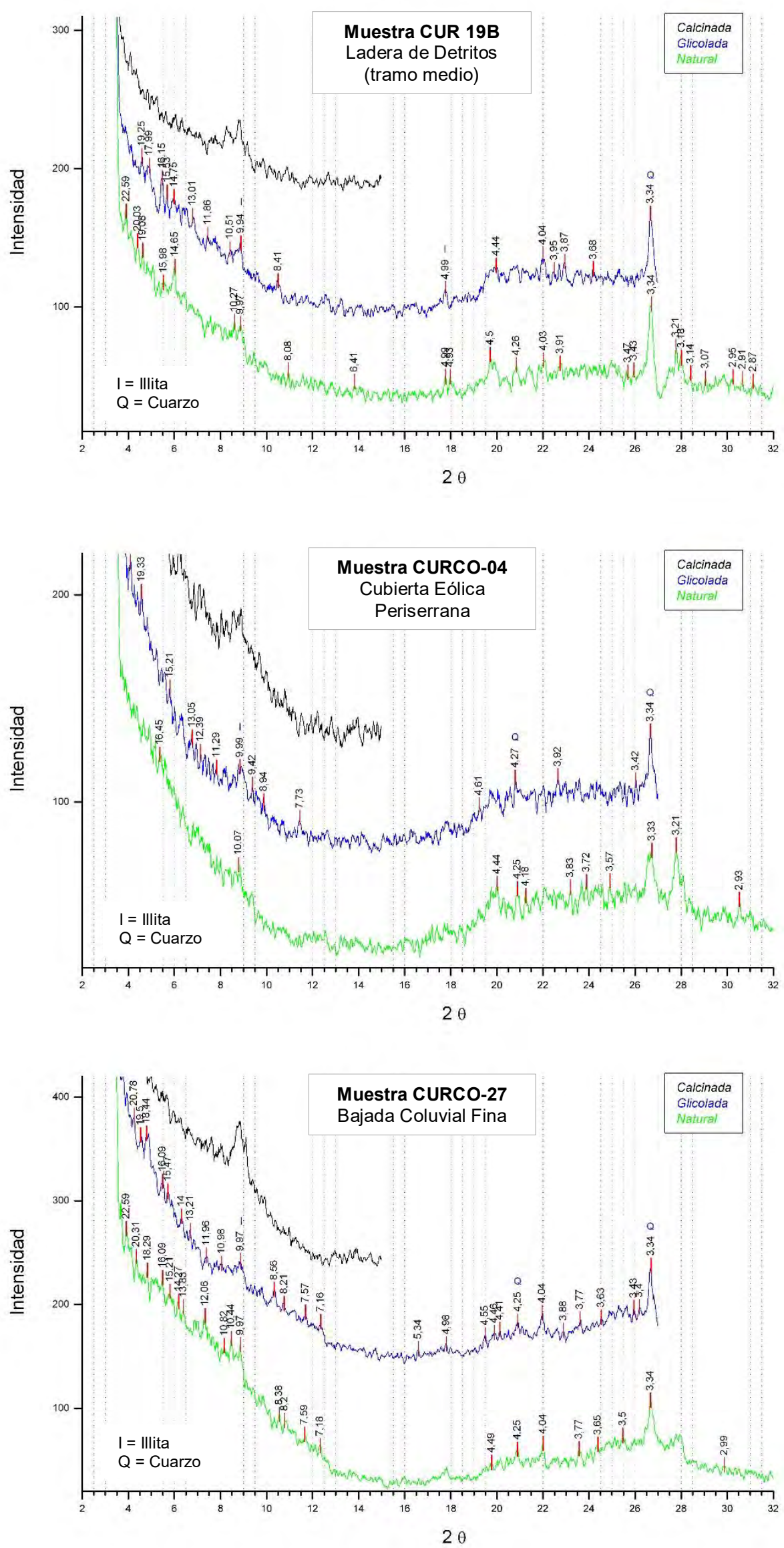
Movimientos en masa en las sierras de Bravard y Curamalal, Sierras Australes de la Provincia de Buenos Aires.

\section{DIFRACTOGRAMAS DE LA FRACCIÓN ARCILLA}
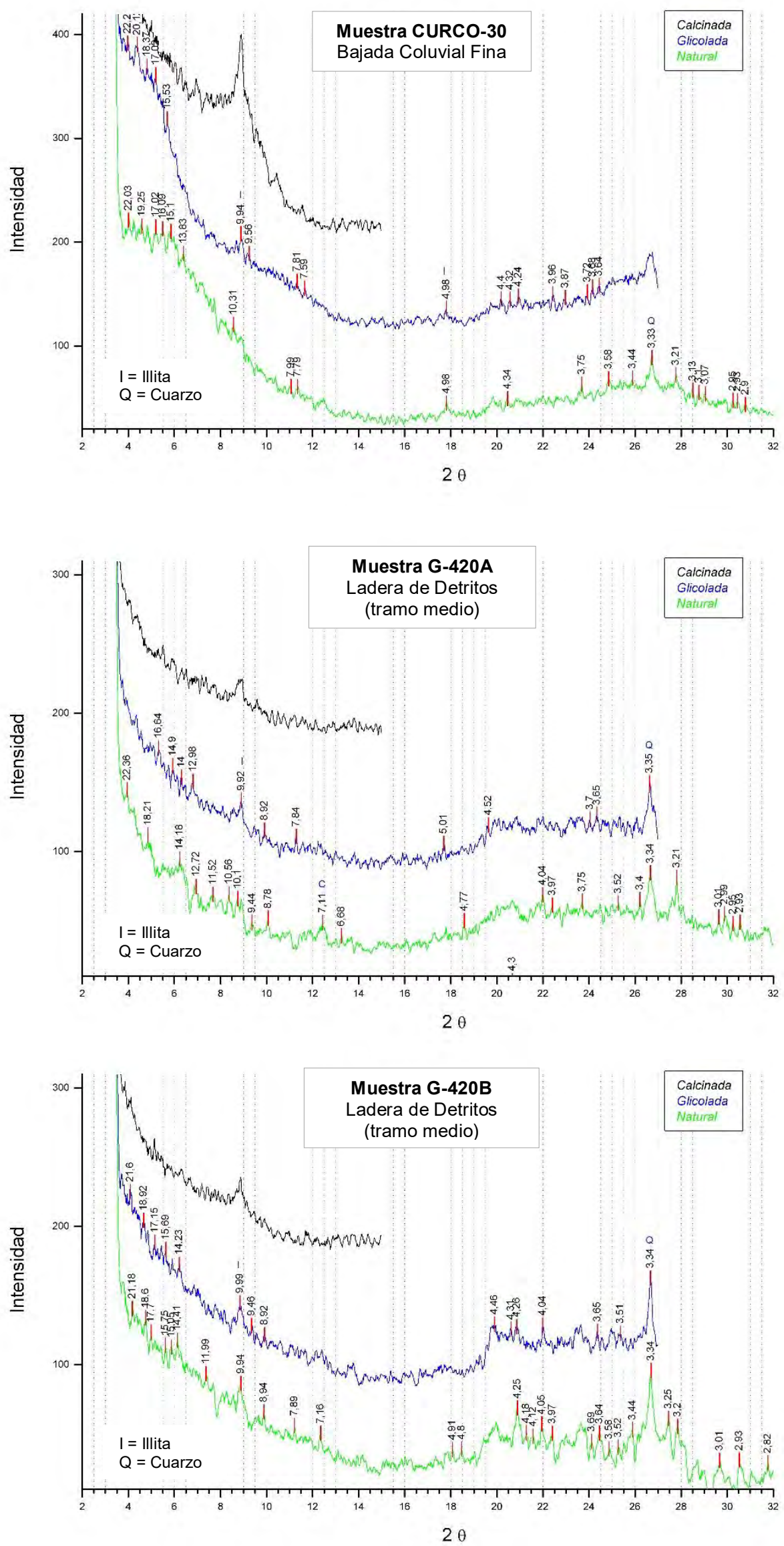


\section{DIFRACTOGRAMAS DE LA FRACCIÓN ARCILLA}
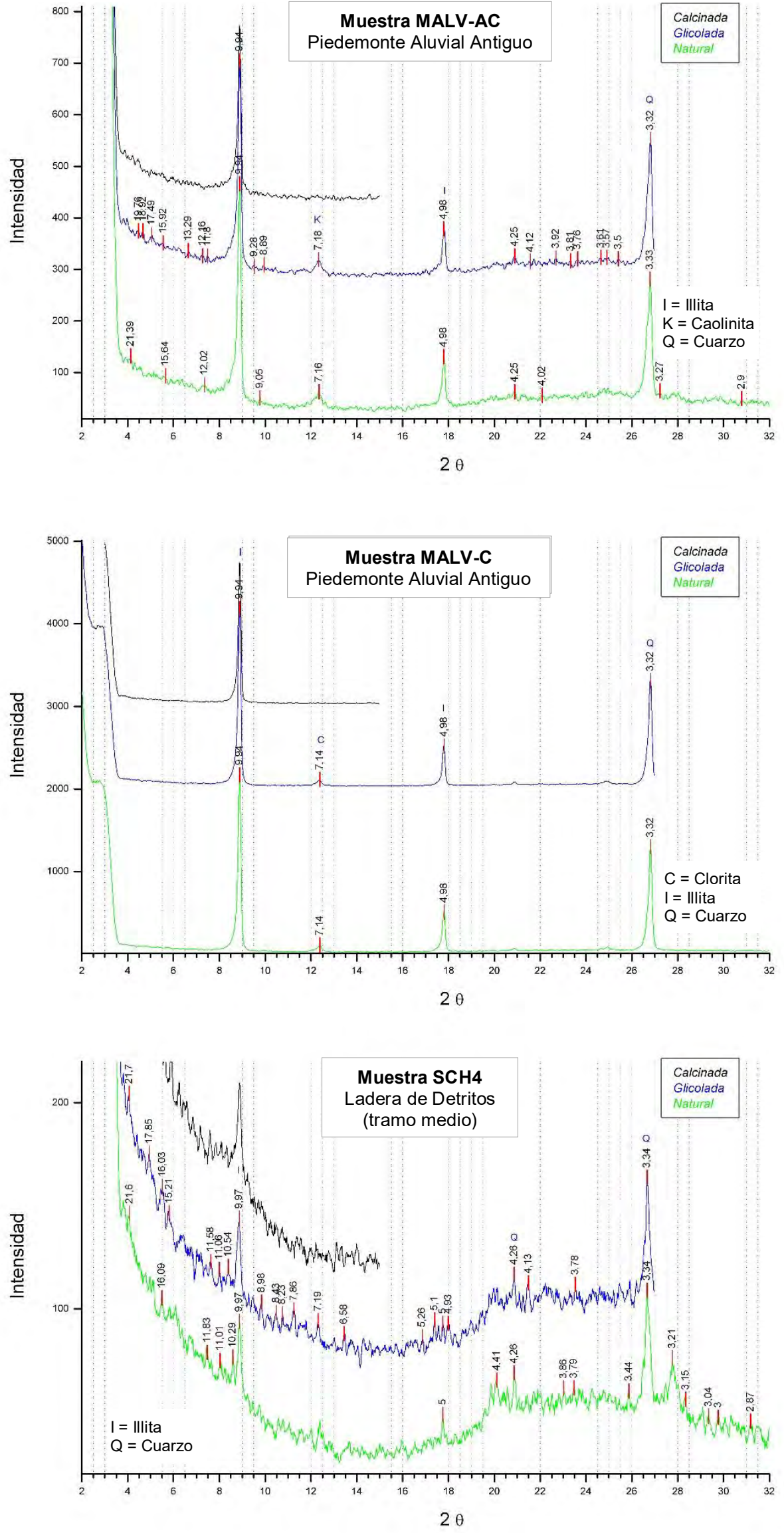
Movimientos en masa en las sierras de Bravard y Curamalal, Sierras Australes de la Provincia de Buenos Aires.

Juan Manuel Susena

\section{DIFRACTOGRAMAS DE LA FRACCIÓN ARCILLA}
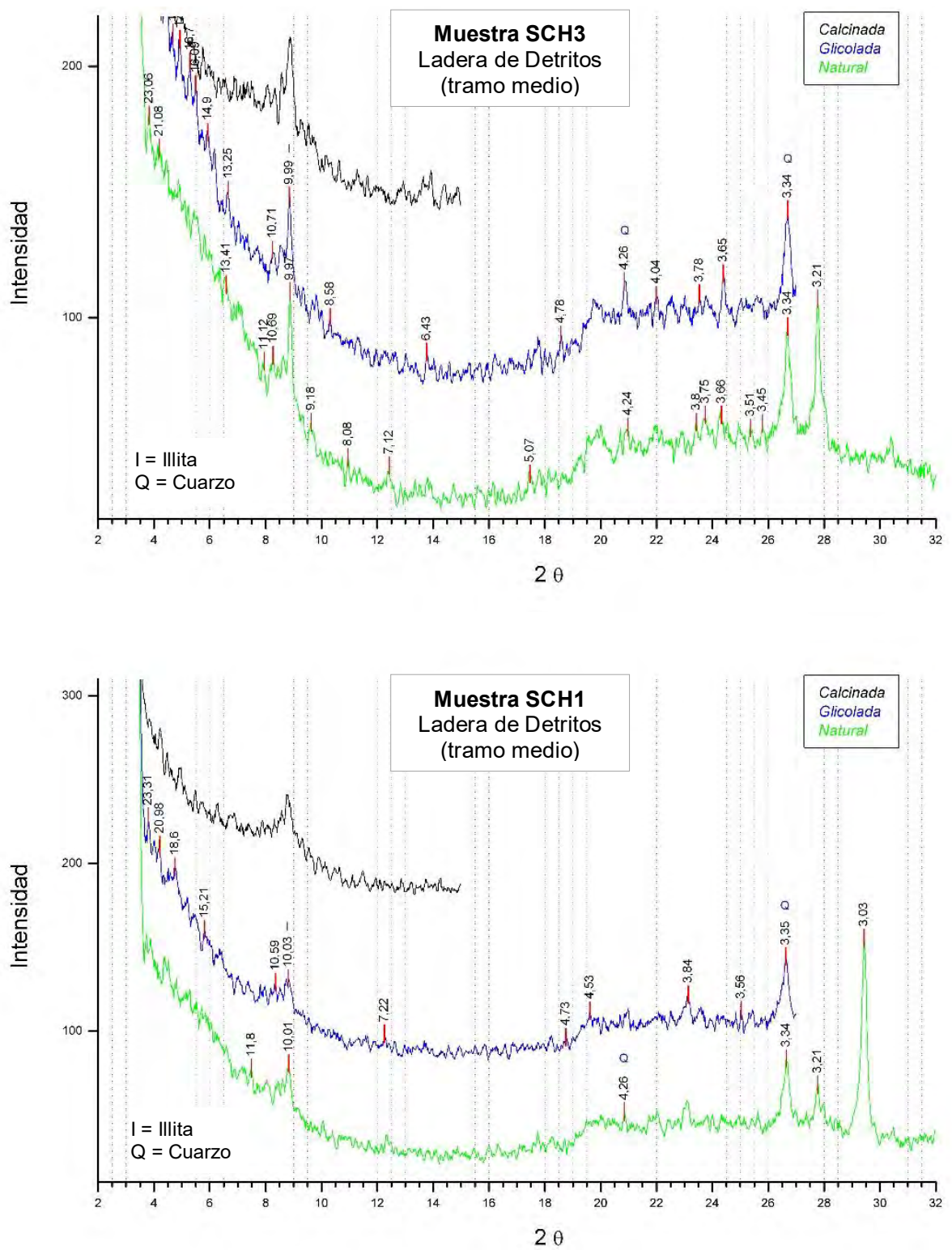
Precipitación mensual en Pigüé (mm)

\begin{tabular}{|c|c|c|c|c|c|c|c|c|c|c|c|c|c|}
\hline Año & Ene & Feb & Mar & Abr & May & Jun & Jul & go & ep & ct & Nov & Dic & $\begin{array}{l}\text { rec. } \\
\text { nual }\end{array}$ \\
\hline 35 & 26 & 5 & 0,4 & 2,2 & 14 & 0,5 & 50,2 & 32,6 & 5,3 & 39,5 & 40,4 & 158,1 & 434,2 \\
\hline 1936 & 12 & & 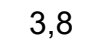 & & 19,4 & 2 & & & 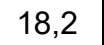 & 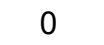 & & 17 & 72,5 \\
\hline 1937 & 2 & 39,3 & & 42,9 & 83,2 & 8 & 20,1 & & & & 1 & & 4,5 \\
\hline 1938 & 3,2 & 4,2 & 68,4 & 45,3 & 70 & 10 & 3,2 & 1 & 8 & 2,9 & 8,2 & & 81,1 \\
\hline 1939 & 65,2 & 173,5 & 55,2 & 15,8 & 98,3 & 108,3 & 20,2 & 4,8 & 1,6 & 95,4 & 8,7 & & 833,6 \\
\hline 1940 & 55 & 119,6 & 66,8 & 44,1 & 71,2 & 109,4 & 28,1 & 58,3 & 59,5 & 82,8 & 64,9 & 171,6 & 931,3 \\
\hline 1941 & 46,4 & 42,9 & 173,1 & 24,7 & 28,2 & 13,2 & 46,7 & 8,2 & 29 & 27,3 & 9,4 & 2,2 & 525,2 \\
\hline 1942 & 86,4 & 206,6 & 47,8 & 14,5 & 14,5 & 6,7 & 10,1 & 18 & 33 & 126,7 & 90,5 & 6,9 & 721,7 \\
\hline 1943 & 7,5 & 36,4 & 97,1 & 43,6 & 44,6 & 101 & 20 & , & 27,7 & & 4 & & 91,3 \\
\hline 1944 & 70,1 & 22,4 & 66,1 & 24,1 & 58,9 & 21,5 & 6,7 & 7,3 & 64,1 & 161,1 & 36,7 & , & 588,2 \\
\hline 1945 & 32,6 & 144,8 & 122,1 & 22 & 13 & 0,3 & 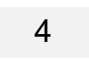 & ,4 & 101,1 & ,2 & 52,8 & 11,2 & 681,5 \\
\hline 1946 & 88,1 & 148,8 & 64,7 & 138,8 & 62,2 & 60,5 & 67,7 & 7,8 & 172,9 & 39,4 & 114 & 144,9 & 1149,8 \\
\hline 1947 & 26,9 & 48,2 & 154,1 & 60,7 & 14,7 & 35,7 & & 1,5 & 2 & 81 & $/ 4,5$ & & 612,8 \\
\hline 1948 & 75 & & 213,2 & 51 & 15 & & 24,4 & 1 & 169 & & & & 8,7 \\
\hline 1949 & 47 & 36,2 & 135,6 & 24,1 & 3 & 5,8 & 12,5 & 47 & & ,3 & 104,2 & & 83,7 \\
\hline 1950 & 8,8 & 86 & 54,7 & 106, & & & & . & 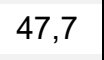 & & & & 51,3 \\
\hline 1951 & 34,3 & 98,3 & 25,9 & 31 & 63,1 & 59,3 & 9 & 25,4 & 15 & 6,7 & 85,4 & 109,6 & 555,1 \\
\hline 195 & & & & & & & & 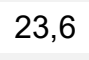 & & & & & 5 \\
\hline 1953 & 51. & 0 & 152,3 & 46,8 & 9 & 20,8 & 21 & 2 & 54,9 & 71 & 119,7 & 11 & 845,5 \\
\hline 1954 & & & & & & & & & & & & & \\
\hline 1955 & 80,7 & 179,2 & 112 & 42 & 68 , & 18,5 & 78,4 & 8 & 48 & 28, & 55,2 & 4 & 756,1 \\
\hline 1956 & & & 304,4 & & & & & & & & & & 866,8 \\
\hline 1957 & 104,7 & 26,3 & 62,9 & 80,6 & 66,8 & 83,3 & 26,3 & 2,2 & 44,5 & 80,8 & 103,9 & 21 & 897,3 \\
\hline 1958 & & & 104, & & & & & & 14 & & & & ,7 \\
\hline 1959 & 104,1 & 53 & 7 & 38, & & 23,1 & 2 & 5,1 & & 109,7 & 118,8 & & 30,4 \\
\hline 1960 & & 89,4 & 9 & & & & & & & & & & 6 \\
\hline 1961 & & 73 & 4 & 18 & 20 & 10 , & 23 & 4 & 36 & & 76 & 91 & 612,6 \\
\hline 196 & & & & & & & & & & & & & 358,8 \\
\hline 1963 & & & 126 & & & , & 13 & & & 115 & & 23 & 1006,2 \\
\hline 196 & & & 152,6 & . & 119,4 & & & 6 & & & & & 924,4 \\
\hline 1965 & 59,7 & & 15 & & & J), & & 37,4 & & & 135,8 & 要 & 660,6 \\
\hline 1966 & & & 3 & & & & & & & & 147,3 & & 9 \\
\hline 1967 & & & & & 43,4 & & & 10,0 & & $\angle 00,8$ & & 0 & 799 \\
\hline 1968 & 49,2 & 47,8 & 131,8 & 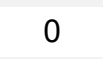 & 20 & 39 , & 23,6 & 10,1 & 50,2 & 75 & 97,2 & 158 & 684,9 \\
\hline 1969 & 34,5 & 84, & 255,8 & 00,0 & & 26 & 11, & 8,9 & 44 & 50,6 & 148,5 & & 24,7 \\
\hline 1970 & 80 & 3,5 & 109,3 & 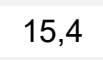 & & . & & 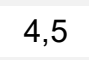 & 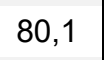 & 84,1 &, 8 & 8,8 & 0,5 \\
\hline 1971 & & & 134,8 & & & & 15 & 54,6 & & & & 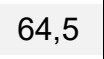 & 565,2 \\
\hline 1972 & & & 133,4 & 105,9 & 19,7 & 75,4 & 5,2 & 16 & $125, \subseteq$ & & & 39,2 & 781,7 \\
\hline 1973 & 13, & 54,3 & 133,7 & & 14 & 100,1 & 5 & 4,1 & 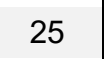 & 23 & 19 & 160 & 828,1 \\
\hline 1974 & 49,5 & 101 & 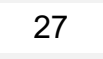 & 21,9 & 101 & 22,3 & 82,6 & & . & & 50,6 & & 611,3 \\
\hline 1975 & 91,1 & 102,7 & 125,9 & 143,3 & 67 , & 45,3 & 7,1 & & 43,4 & 44,9 & 24,3 & 50,7 & 749,6 \\
\hline 1976 & 46,1 & 192,4 & 56,9 & & 0,0 & $2 t$ & 7 & & & & 258,8 & 90 & 939,5 \\
\hline 1977 & 104 & 162,2 & 33,6 & 48,9 & 1,7 & 16,7 & 15,7 & 19,5 & 16,2 & 205,9 & 55,7 & 129 & 809,1 \\
\hline
\end{tabular}


Movimientos en masa en las sierras de Bravard y Curamalal,

Sierras Australes de la Provincia de Buenos Aires.

Juan Manuel Susena

\begin{tabular}{|c|c|c|c|c|c|c|c|c|c|c|c|c|c|}
\hline 1978 & 5,7 & 145 & 05,1 & 40,6 & 25,1 & 10,7 & 51,2 & 16,8 & 102,8 & 33,2 & 92,7 & 221,4 & 1000,3 \\
\hline 1979 & 22,3 & 20,9 & 87 & 0,7 & 5,4 & 3,6 & 5,9 & $2 C$ & 30 & 49,5 & 0,4 & 04,7 & 690,4 \\
\hline 1980 & ,9 & 34,7 & 68,9 & 58,8 & 24,9 & 7,4 & 1 & 2,7 & 28,7 & 12 & 70 & 2,5 & 43,6 \\
\hline 1981 & 72 & 74,1 & 4,5 & 69,9 & 0,3 & 19,5 & 3,1 & 1,3 & 2,7 & 99,1 & 74,5 & 6,8 & 752,8 \\
\hline 1982 & 6,5 & 102,3 & 38,3 & 218,2 & 79,4 & 20,2 & 26,1 & 5 & 57,9 & 58 & 58 & 88,1 & 828 \\
\hline 1983 & 6,7 & 12,1 & 168,8 & 62,9 & 79 & 2,1 & 4,9 & 61,9 & 40,7 & 69,2 & 101 & 127 & 796,3 \\
\hline 1984 & 27 & 72,7 & 44,6 & 30 & 38,4 & 13 & 5,7 & 9,1 & 80,7 & 37,7 & 99,2 & 73,5 & 861,6 \\
\hline 1985 & 99,6 & 94,1 & 58,6 & 85,2 & 6,3 & 11,2 & 84,6 & 2,4 & 91,3 & 230,7 & 131,6 & 186 & |181,6 \\
\hline 1986 & 5 & 2,7 & 89,3 & 78,8 & 3,2 & 20,8 & 3 & 66,3 & 9,4 & 1,8 & 1 & 7,9 &, 1 \\
\hline 1987 & 140,3 & 0 & 79,2 & 49 & 10,8 & 31 & 39,4 & 56,1 & 58,2 & 54,6 & 83,4 & 23,4 & 625,4 \\
\hline 1988 & 3,1 & 139,7 & 32,7 & 49,9 & 5 & 3 & 0,5 & 0,6 & 7,4 & 29,8 & 59,4 & 10,2 & 576,3 \\
\hline 1989 & 41,5 & 34,1 & 184,5 & 8,2 & 107,3 & 37,6 & 58,8 & 57,3 & 81 & 51 & 92,6 & 108,3 & 862,2 \\
\hline 1990 & 56,2 & 10,4 & 2,7 & 12,3 & 12,6 & 3 & 23 & 5,1 & 60,2 & 99,6 & 71 & 80,1 & 826,7 \\
\hline 1991 & 0,9 & 59,9 & 68,6 & 68,5 & 29,6 & 59,8 & 10,9 & 26,3 & 128,9 & 62,9 & 68,7 & 10,7 & 855,7 \\
\hline 1992 & 3,8 & 81,8 & 57,5 & 62 & 5,4 & 47,7 & 25,7 & 103 & 9,2 & 42 & 80 & 67,2 & 1105,3 \\
\hline 1993 & 103,5 & 51 & 73,2 & 67,3 & 96,1 & 23 & 0,2 & 0 & 36,7 & 67,3 & 155,7 & 49,7 & 823,7 \\
\hline 1994 & 62,6 & 98 & 85,6 & 25,9 & 87,5 & 42,4 & 42,2 & 59,2 & 10,2 & 64,2 & 47,5 & 123,1 & 748,4 \\
\hline 1995 & 55,7 & 39,5 & 127,6 & 166,5 & 5,9 & 4,9 & 0 & 4,5 & 8,4 & 51,7 & 110,9 & 83,5 & 669,1 \\
\hline 1996 & 80 & 118 & 65,2 & 66,2 & 24,4 & 8,5 & 14,7 & 52,5 & 19,9 & 43,8 & 94,7 & 177,2 & 765,1 \\
\hline 1997 & 1,2 &, 5 & 61,1 & 17 & 43 & 128,7 & 70,1 & 12 & 3,4 & 81 & 5 & 7,5 & 841,3 \\
\hline 1998 & 232 & 191,2 & 32,7 & 70,6 & 8,8 & 10,8 & 10 & 19 & 9,4 & 23 & 25,3 & 7,2 & \\
\hline 1999 & 7,9 & 79,9 & 34,5 & 62,2 & 20,2 & 13 & 5,9 & 23, & 3,7 & 3,9 & 164,8 & 1,9 & 811,1 \\
\hline 2000 & 8 & 188,5 & 91,1 & 14,9 & 6,6 & 17,1 & 10,2 & 86 , & 101,3 & 166,2 & 9 & 8 & 864,7 \\
\hline 2001 & 1,4 & 112 & 136 & 33,2 & 49 , & 48 & 0,1 & 79 & 138,9 & 228,4 & 118,8 & & 119 \\
\hline 2002 &, 5 & 130,3 & 71,4 & 9 & 3,8 & 14,6 & 38,7 & 9 & 0,9 & 157 & 187,5 & 127,7 & 99,3 \\
\hline 2003 & 3,8 & 76,6 & 46,2 & 36,6 & 25 , & 2 & 18,7 & 33 & & 81 & 76,5 & & 703,4 \\
\hline 2004 & 7,3 &, 7 & 93,2 & 89 & & 7, & 144 & 35 & 39,2 & 130,7 & 153 & 217,3 & 978,8 \\
\hline 2005 & 8,2 & , 5 & 51 & 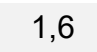 & 10,2 & 10 & 9,9 & 22 & 48,3 & 44,9 & 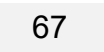 & 89,1 & 474,5 \\
\hline 2006 & 102,2 & 181,2 & 96,3 & 457 & & 6.4 & 14,8 & 17,3 & 44,3 & 178,8 & 14,8 & 96 & 797,8 \\
\hline 2007 & 01,2 & 168,5 & 39,4 & 51 , & 21 & 0 , & U, & & 172,1 & 136,1 & 6,4 & 31,1 & 879,5 \\
\hline 2008 & 109 & ,8 & 7,7 & 67 & 2 & 11,7 & 7,4 & 28 & 52 & 82,3 & 2 &, 9 & \\
\hline 2009 & 10 & & 63, & & & & & & 90,3 & $20, v$ & ז' & , L & \\
\hline 2010 & 11,7 & 6,7 & 119 & & ,4 & 28,9 & 22,7 & 0 & 7,2 & 4 & 9 & 2 & ,9 \\
\hline 2011 & 177,2 & 20,0 & 96, & & & $27, \varepsilon$ & 20,1 & & 1, & 48,5 & 152,5 & 3,1 & \\
\hline 2012 & & & & & & 8 & 0 & 97 & 58 & ,4 & 11 & 221,5 & 2,6 \\
\hline 2013 & 39,8 & 49,2 & 81,4 & & & & 77,3 & 0 , & 4,9 & 9 & 3 & 26 & 6 \\
\hline 2014 & 32 & & & 16 & 54 , & 17 & 100 & 66 & 0,3 & 237,6 & 4 & 2,9 & 1,4 \\
\hline 2015 & 112 & 243,9 & 58,7 & & 52,2 & 6,2 & 59,8 & 15 & 38,4 & 4 & 107,2 & 125,8 & 1067,1 \\
\hline 2 & 98,5 & 178,6 & 49,5 & 84, & 56,5 & 17,6 & 38,2 & & & 143,7 & 50,5 & 3,6 & 909,6 \\
\hline & 70,7 & 8 & 96 & 6 & 45,9 & 27 & $2 \varepsilon$ & 2 & 54,6 & 87,0 & 8 & ,8 & 756,1 \\
\hline $\begin{array}{c}\text { Prec.M } \\
\text { edia } \\
1981- \\
2010 \\
\end{array}$ & 92,5 & 92,6 & 92,8 & 68,4 & 42,8 & 21,7 & 26,1 & 34,4 & 63,7 & 92,8 & 88,6 & 90,8 & 807,2 \\
\hline
\end{tabular}

Tabla A.4. Valores mensuales de precipitación de la Estación Pigüé, calculados a partir de valores diarios del Servicio Meteorológico Nacional. Elaboración propia. 
Precipitación mensual en Coronel Suárez (mm)

\begin{tabular}{|c|c|c|c|c|c|c|c|c|c|c|c|c|c|}
\hline Año & Ene & Feb & Mar & Abr & May & Jun & Jul & Ago & Sep & Oct & Nov & Dic & \\
\hline $36^{*}$ & 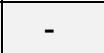 & 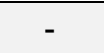 & - & 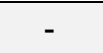 & - & - & 4,1 & 8,7 & 8,5 & 68,2 & 9,4 & 45,8 & 354,7 \\
\hline 1937 & 28,8 & 38,1 & 26,5 & 57,5 & 85,2 & 11,4 & 9 & 12,3 & 26,6 & 35,7 & 68 & 8,4 & 461,4 \\
\hline 1938 & 40,9 & 4,2 & 74,4 & 3,8 & 113,1 & 3,3 & 3,8 & 1,1 & 6,3 & 33,4 & 4 & 8,8 & 417,1 \\
\hline 1939 & 17,2 & 116,9 & 111,5 & 11,6 & 52,1 & 99,8 & 16,2 & 29,3 & 80,6 & 182,5 & 12,8 & 3,2 & 743,7 \\
\hline 1940 & 80,1 & 70 & 37,7 & 16 & 1,4 & 110,9 & 18,7 & 46,2 & 70,1 & 1,8 & 5,7 & 182 & 891,1 \\
\hline 1941 & 62,6 & 113,5 & 150,2 & 29 & 34,8 & 11,8 & 100,8 & 130,7 & 4,7 & 7,8 & 2 & o, & 736,0 \\
\hline 1942 & 74,5 & 163,1 & 74,5 & 14,3 & 6,3 & 2,9 & 9,3 & 58,2 & 38,7 & 140,2 & 45,3 & 212 & 764,8 \\
\hline 1943 & 17,4 & 12,5 & 126,0 & 38,6 & 111,9 & 107,0 & 24,9 & & 58,8 & 420,8 & 98,7 & 136,5 & 1161,7 \\
\hline 1944 & 83 & 21,7 & 66 & 151,4 & 73,6 & 25,5 & 8,6 & 38 & 52,7 & 177,1 & 28 & 54,1 & 779,7 \\
\hline 1945 & 71,4 & 90,6 & 76,7 & 68,2 & 8 & & 7,2 & c & 95,8 & & 57,6 & & 694,7 \\
\hline 1946 & 61,8 & 144,6 & 58,6 & 120,2 & 68,0 & 115,4 & 69,8 & 81,9 & 84,3 & 78,5 & 125,5 & 132,3 & 1140,9 \\
\hline 1947 & 4( & 7 & 47, & & 1 & & & & & & & & 2,8 \\
\hline 1948 & 81,8 & 41,7 & 171,2 & 56,2 & 233,5 & 51,2 & 20,0 & 19,6 & 125,6 & 37,6 & 32,0 & 164,5 & 1034,9 \\
\hline 1949 & 20,8 & 6 & & & 0,6 & & 2 & & & 42,4 & 1 & & 607,7 \\
\hline 1950 & 1,6 & 93,3 & 104,5 & 87,8 & 33 & 4,2 & 20 & 27,2 & 43,8 & 48,7 & 91,4 & 41, & 597,4 \\
\hline 1951 & 24,5 & 102 & 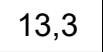 & 24 , & 2. & $2 \varepsilon$ & 1,6 & 1 & & 22 & & 143 & 561,7 \\
\hline 1952 & 13,1 & 19 & 105 & 16,3 &, 6 & 6 & 48,4 & 60,5 & 66,1 & 139,9 & 61,6 & & 662,1 \\
\hline 1953 & 69,2 & 20,7 & 146,6 & 107 & 75, & & 0,6 & & & 72 & 90,0 & 191 & 59,9 \\
\hline 1954 & 41,5 & 40 & 45,8 & 157,6 & 48,4 & 29,2 & 19 & 0,8 & 9,7 & 138 & 63,5 & 39,9 & 653,4 \\
\hline 1955 & 67,6 & 155 & 90, & 28 & 2 & 20,6 & 79,3 & & 30,5 & 35,5 & 94 & 31 & 663,0 \\
\hline 1956 & 94,5 & 19,8 & 379,3 & 66,3 & 32,9 & 22 & 35,1 & 50,4 & 26,7 & 101,8 & 91,6 & 39,7 & 960,2 \\
\hline 1957 & 101,4 & 2 & 39,6 & 95 & & 5 & 20 & & 2 & 12,5 & 147 & 112 & 316,9 \\
\hline 1958 & 70,4 & 5 & 5 & 59 & 4 & 24 & 3 & & 139,3 & 4,3 & & 60,9 & 94,8 \\
\hline 1959 & 144,4 & 5 & 167 & & 26 , & & & 1 & & 11,0 & ,9 & & 06,7 \\
\hline 1960 & 93,0 & 86,9 & 104,9 & 18,4 & 2,7 & 8 & 43,0 & & 1 & 40,8 & 5,9 & , & 67,7 \\
\hline 1961 & 88,5 & 65,5 & 7 & 15 & 69,0 & 7, & 36 & 64 & & 74 & 1 & & 748,7 \\
\hline 1962 & 92,3 & 5,7 & 36,7 & 49, & & & & 19 & 30 & 40 & 46 & & 351,1 \\
\hline 1963 & 42,8 & 06,5 & 57,8 & 34 & 51,8 & 73, & 66 & 0 & 104,6 & 143,7 & 118,1 & 86 & 1025,5 \\
\hline 1964 & 36,4 & 110,0 & 159,1 & 72 & 9 & 1 & 14 & 45, & 59, & 33,2 & 178,8 & 60 & 874,6 \\
\hline 1965 & 27,1 & 26,7 & 31,3 & 90,5 & 40,8 & 40,9 & 17,8 & 48,4 & 0,2 & 42,5 & 112,8 & OA & 573,6 \\
\hline 1966 & 22,9 & 60,4 & 53, & 78 , & 23,9 & 48,4 & 88,5 & 2 & 4, & 50,4 & 167,3 & 142 & 742,4 \\
\hline 1967 & 74,6 & 70,1 & 19,5 & 81,1 & 45,5 & 17 & 26,4 & 10 & 37,0 & 236,8 & 75,3 & 75,6 & 745,5 \\
\hline 1968 & 33,0 & 78,0 & 70,0 & & 1 & 47 & 26,4 & 38 & 74,0 & 98,0 & 73,0 & 116 & 663,6 \\
\hline 1969 & 35,0 & 129,0 & 279,0 & 58,0 & 110,0 & 83,0 & 9,0 & & 34,0 & 59,0 & 143,0 & 7,0 & 1010,0 \\
\hline 1970 & 114,0 & 61,0 & 173, & 14 & 48 & 67 & 2,0 & & 126,0 & 66,0 & 60,0 & & 790,0 \\
\hline 1971 & 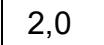 & 9 & 164,4 & 41,1 & 109,0 & 8 & 12,5 & , 3 & 12 & 3,2 & 1,8 & 08,6 & 60,9 \\
\hline 1972 & 38,0 & 1,9 & 100,8 & 48 & 25,0 & 102,3 & & 12,1 & 100,0 & 78,4 & 105,0 & 45 & 662,1 \\
\hline 1973 & 15,9 & 117,8 & 75,2 & 54,9 & 71 & 993 & 15, & & 18,8 & 199,4 & 20 & 120,7 & 750,3 \\
\hline 1974 & 98,2 & 173,3 & 29,5 & 30 & 83 & & 27,2 & & , I & 30,6 & 69,1 & 72,1 & 662,7 \\
\hline 1975 & 146,6 & 115,2 & 127,8 & 130,0 & 52,5 & 62,7 & 1,6 & 8,0 & 60,5 & 40,2 & 41,7 & 32,8 & 819,6 \\
\hline 1976 & 61,8 & 213 & 67,6 & 60 & 2 & 14 & 14 & 37 & 7, & 93,7 & 194,7 & 157,9 & 1025,6 \\
\hline 1977 & 52,7 & 199,0 & 69,4 & 68 & , & 22,2 & 10,5 & 11 & 7, & 201,9 & 87,6 & 185,1 & 917,1 \\
\hline 1978 & 83,9 & 290,8 & 177,8 & 70,5 & 22,5 & 8,6 & 60,2 & 22,3 & 121,3 & 32,1 & 98,6 & 177,9 & 1166,5 \\
\hline 1979 & 76,2 & 13,7 & 82,5 & 85,5 & 74,6 & 9,7 & 6,3 & 37,4 & 42,8 & 45,4 & 85,9 & 117,3 & 677,3 \\
\hline
\end{tabular}


Movimientos en masa en las sierras de Bravard y Curamalal, Sierras Australes de la Provincia de Buenos Aires.

Juan Manuel Susena

\begin{tabular}{|c|c|c|c|c|c|c|c|c|c|c|c|c|c|}
\hline 1980 & 90,1 & 28,4 & 124,1 & 205,6 & 114,8 & 13,5 & 34,8 & 1,2 & 36,0 & 33,9 & 96,5 & 129,2 & 908,1 \\
\hline 1981 & 86,0 & 68,3 & 73,1 & 159,3 & 53,1 & 16,9 & 4,8 & 4,8 & 17,4 & 76,3 & 60,1 & 24,9 & 645,0 \\
\hline 1982 & 59,4 & 85,2 & 90,0 & 292,7 & 64,8 & 25,0 & 56,5 & 3,5 & 105,9 & 99,5 & 40,9 & 68,0 & 991,4 \\
\hline 1983 & 176,2 & 27,8 & 163,5 & 95,6 & 79,5 & 5,2 & 3,3 & 104,3 & 20,5 & 121,0 & 13,4 & 84,7 & 895,0 \\
\hline 1984 & 104,1 & 160,8 & 50,2 & 74,2 & 96,2 & 36,0 & 33,8 & 51,2 & 62,4 & 133,2 & 111,5 & 75,1 & 988,7 \\
\hline 1985 & 209,0 & 65,7 & 43,8 & 98,6 & 18,3 & 7,4 & 128,4 & 0,5 & 99,2 & 247,4 & 216,2 & 88,0 & 1222,5 \\
\hline 1986 & 213,5 & 24,7 & 125,0 & 130,0 & 12,1 & 16,9 & 0,5 & 76,3 & 78,4 & 92,4 & 165,2 & 7,4 & 942,4 \\
\hline 1987 & 82,5 & 10,4 & 94,6 & 37,1 & 10,7 & 27,7 & 42,8 & 53,0 & 66,5 & 116,1 & 110,4 & 49,0 & 700,8 \\
\hline 1988 & 57,2 & 193,2 & 122,0 & 47,8 & 3,2 & 1,9 & 1,2 & 12,1 & 89,2 & 30,2 & 40,0 & 9,7 & 607,7 \\
\hline 1989 & 55,5 & 62,6 & 123,4 & 3,7 & 140,8 & 29,5 & 36,0 & 64,6 & 69,5 & 27,0 & 27,2 & 101,8 & 741,6 \\
\hline 1990 & 183,5 & 47,4 & 60,5 & 11,6 & 135,6 & 0,5 & 24,6 & 3,1 & 63,2 & 108,3 & 128,5 & 176,1 & 942,9 \\
\hline 1991 & 177,8 & 69,0 & 63,9 & 45,3 & 31,0 & 73,4 & 10,0 & 22,4 & 98,9 & 60,2 & 95,9 & 123,1 & 870,9 \\
\hline 1992 & 192,3 & 83,5 & 131,1 & 54,0 & 127,3 & 64,8 & 26,6 & 97,4 & 25,0 & 60,9 & 77,3 & 143,7 & 1083,9 \\
\hline 1993 & 140,1 & 30,7 & 65,2 & 184,4 & 140,7 & 32,4 & 0,5 & 0,0 & 61,6 & 86,8 & 126,6 & 35,8 & 904,8 \\
\hline 1994 & 125,4 & 51,4 & 171,3 & 26,5 & 112,6 & 21,2 & 44,0 & 61,1 & 12,9 & 61,9 & 35,8 & 100,2 & 824,3 \\
\hline 1995 & 73,0 & 40,6 & 93,0 & 107,0 & 2,7 & 5,8 & 0,1 & 4,9 & 10,7 & 55,0 & 91,8 & 42,3 & 526,9 \\
\hline 1996 & 73,0 & 112,2 & 89,7 & 119,7 & 25,7 & 9,0 & 33,7 & 27,1 & 16,8 & 124,4 & 94,0 & 161,9 & 887,2 \\
\hline 1997 & 85,4 & 76,2 & 161,0 & 17,6 & 23,5 & 114,1 & 46,3 & 18,6 & 46,1 & 101,7 & 57,9 & 31,7 & 780,1 \\
\hline 1998 & 161,7 & 189,4 & 19,6 & 144,8 & 1,2 & 5,6 & 14,3 & 18,0 & 82,7 & 16,1 & 86,2 & 59,2 & 798,8 \\
\hline 1999 & 41,9 & 53,0 & 138,5 & 39,9 & 11,0 & 6,8 & 17,0 & 28,0 & 52,1 & 24,8 & 79,5 & 66,4 & 558,9 \\
\hline 2000 & 133,1 & 143,0 & 78,8 & 17,5 & 55,2 & 14,4 & 2,4 & 44,1 & 48,3 & 172,1 & 16,2 & 46,5 & 771,6 \\
\hline 2001 & 123,7 & 94,4 & 146,4 & 94,0 & 8,6 & 24,4 & 7,6 & 52,4 & 106,6 & 165,1 & 100,8 & 53,0 & 977,0 \\
\hline 2002 & 160,0 & 49,0 & 159,7 & 62,1 & 68,8 & 13,5 & 59,0 & 99,4 & 61,3 & 118,1 & 65,6 & 106,7 & 1023,2 \\
\hline 2003 & 47,2 & 57,3 & 31,6 & 31,2 & 43,5 & 3,0 & 23,0 & 9,7 & 26,7 & 115,0 & 97,1 & 124,5 & 609,8 \\
\hline 2004 & 98,0 & 36,0 & 103,0 & 68,5 & 1,0 & 18,0 & 145,0 & 48,0 & 46,0 & 118,4 & 63,4 & 158,0 & 903,3 \\
\hline 2005 & 131,0 & 109,4 & 97,1 & 3,4 & 16,6 & 9,2 & 6,1 & 23,2 & 56,9 & 60,8 & 32,9 & 68,1 & 614,7 \\
\hline 2006 & 89,4 & 125,3 & 55,8 & 20,1 & 1,0 & 17,2 & 15,2 & 13,3 & 43,8 & 185,4 & 11,3 & 145,3 & 723,1 \\
\hline 2007 & 100,8 & 121,3 & 168,2 & 54,7 & 17,1 & 3,0 & 1,9 & 6,0 & 102,5 & 162,0 & 48,5 & 49,0 & 835,0 \\
\hline 2008 & 164,2 & 48,9 & 53,7 & 5,4 & 25,3 & 11,9 & 15,0 & 23,2 & 53,4 & 113,5 & 28,6 & 116,1 & 659,2 \\
\hline 2009 & 34,5 & 48,0 & 50,0 & 33,7 & 42,0 & 2,0 & 8,2 & 1,3 & 69,8 & 35,7 & 45,7 & 141,2 & 512,1 \\
\hline 2010 & 32,7 & 168,0 & 133,2 & 17,8 & 44,4 & 22,2 & 19,9 & 5,0 & 67,4 & 93,3 & 47,0 & 24,6 & 675,5 \\
\hline $2011^{*}$ & 246,0 & 39,2 & 80,4 & 53,3 & 33,1 & 21,4 & - & - & - & - & - & - & 473,4 \\
\hline $\begin{array}{l}\text { Prec. } \\
\text { Media }\end{array}$ & 83,9 & 81,2 & 101,6 & 64,5 & 50,8 & 31,9 & 27,9 & 29,7 & 54,5 & 92,9 & 79,9 & 89,1 & 787,8 \\
\hline $\begin{array}{l}\text { Prec. } \\
\text { Media } \\
1981- \\
2010 \\
\end{array}$ & 113,7 & 81,76 & 98,56 & 69,94 & 47,12 & 21,30 & 27,59 & 32,55 & 58,72 & 99,42 & 73,85 & 82,73 & 807,3 \\
\hline
\end{tabular}




\begin{tabular}{|c|c|c|c|c|c|c|c|c|c|c|c|c|c|}
\hline \multicolumn{14}{|c|}{ Precipitación mensual en Estancia Cerro Áspero (mm) } \\
\hline Año & Ene & Feb & Mar & Abr & May & Jun & Jul & Ago & Sep & Oct & Nov & Dic & $\begin{array}{l}\text { Prec. } \\
\text { anual }\end{array}$ \\
\hline 1983 & 93 & 0 & 189 & 99 & 66 & 40 & 18 & 30 & 28 & 58 & 0 & 39 & 660 \\
\hline 1984 & 76 & 207 & 59 & 134 & 157 & 46 & 37 & 53,5 & 99 & 118 & 155 & 74 & 1215,5 \\
\hline 1985 & 149 & 105 & 71 & 100,5 & 12 & 18 & 108,5 & 4 & 124 & 205 & 196 & 137,5 & 1230,5 \\
\hline 1986 & 187 & 46,5 & 89 & 184 & 6 & 21 & 3 & 86 & 70 & 72,5 & 111 & 3 & 879 \\
\hline 1987 & 69 & 11 & 162 & 13 & 61 & 31 & 43 & 90 & 56 & 97 & 79 & 42 & 754 \\
\hline 1988 & 124 & 133 & 197 & 21 & 11 & 4 & 4 & 17 & - & 29 & 51 & 16 & 607 \\
\hline 1989 & 46 & 28 & 129 & 14 & 133 & 31,5 & 69 & 127 & 99 & 38 & 75 & 149 & 938,5 \\
\hline 1990 & 152,5 & 44 & 110,5 & 42 & 146,5 & 2 & 50 & 19 & 131,5 & 155 & 86,5 & 123 & 1062,5 \\
\hline 1991 & 239 & 68 & 28 & 107 & 42 & 88 & 21,5 & 39 & 183 & 67,5 & 118 & 102 & 1103 \\
\hline 1992 & 233,5 & 239 & 227 & 94 & 108,5 & 110,5 & 67,5 & 113 & 73 & 55 & 110 & 173 & 1604 \\
\hline 1993 & 175,5 & 83 & 132 & 243 & 119 & 74 & 0 & 0 & 72 & 90,5 & 167,5 & 74 & 1230,5 \\
\hline 1994 & 97,5 & 95,5 & 171 & 54,5 & 84,5 & 35 & 76 & 81 & 10,5 & 73 & 66 & 147,5 & 992 \\
\hline 1995 & 77,5 & 81,5 & 148,5 & 149,5 & 5 & 0 & 0 & 24 & 8,5 & 86 & 108,5 & 67,5 & 756,5 \\
\hline 1996 & 64 & 86 & 49,5 & 75 & 49,5 & 12 & 40 & 48 & 15,5 & 76,5 & 92 & 283,5 & 891,5 \\
\hline 1997 & 70 & 72 & 124 & 43 & 42 & 259,5 & 82 & 21 & 83,5 & 114,5 & 94 & 25,5 & 1031 \\
\hline 1998 & 253,5 & 152,5 & 43 & 133,5 & 13 & 15 & 6 & 23 & 72,5 & 8 & 125 & 46,5 & 891,5 \\
\hline 1999 & 56 & 102 & 223 & 79 & 16 & 2,5 & 44 & 26 & 64 & 52 & 197,5 & 109 & 971 \\
\hline 2000 & 115,5 & 221,5 & 104 & 18,5 & 129 & 19,5 & 40 & 49 & 99,5 & 193,5 & 26,5 & 25,5 & 1042 \\
\hline 2001 & 105 & 80 & 183,5 & 181 & 30,5 & 28 & 13,5 & 76 & 222,5 & 194 & 161 & 30 & 1305 \\
\hline 2002 & 49 & 86,5 & 66 & 101 & 47,5 & 20 & 86,5 & 162,5 & 26,5 & 139,5 & 223 & 98 & 1106 \\
\hline 2003 & 53,5 & 86,5 & 37,5 & 21 & 75,5 & 12 & 17,5 & 35,5 & 48 & 197,5 & 68,5 & 160 & 813 \\
\hline 2004 & 92 & 41 & 113 & 109 & 3,5 & 21,5 & 219 & 29,5 & 68 & 172,5 & 85 & 238 & 1192 \\
\hline 2005 & 86,5 & 104,5 & 92,5 & 4 & 22 & 35 & 9 & 27 & 72,5 & 68 & 31 & 91 & 643 \\
\hline 2006 & 133,5 & 230,5 & 59 & 66 & 0 & 9 & 65,5 & 9,5 & 60 & - & 16,5 & 76,5 & 726 \\
\hline 2007 & 163 & 161 & 166,5 & 66 & 23 & 0 & 6,5 & 9 & 163,5 & 183,5 & 59,5 & 34 & 1035,5 \\
\hline 2008 & 181,5 & 101 & 58 & 7,5 & 20,5 & 23 & 48 & 22 & 150 & 93 & 40 & 82,5 & 827 \\
\hline 2009 & 37 & 24,5 & 154 & 13 & 32 & 2,5 & 80 & 4 & 54 & 27 & 65,5 & 93,5 & 587 \\
\hline 2010 & 57 & 156 & 104 & 6 & 51 & 51 & 54,5 & 0 & 111 & 127 & 42 & 25,5 & 785 \\
\hline 2011 & 355,5 & 50,5 & 105,5 & 72,5 & 41,5 & 42 & 27,5 & 36,5 & 2 & 91 & 201,5 & 21,5 & 1047,5 \\
\hline 2012 & 82 & 82 & 131 & 112 & 109,5 & 8,5 & 0 & 111 & 48 & 77,5 & 173 & 229 & 1163,5 \\
\hline 2013 & 18,5 & 38 & 110 & 192 & 29,5 & 9,5 & 131,5 & 0 & 87 & 59,5 & 55 & 70,5 & 801 \\
\hline $\begin{array}{l}\text { Prec. } \\
\text { Media }\end{array}$ & 119,1 & 97,3 & 117,3 & 82,4 & 54,4 & 34,6 & 47,4 & 44,3 & 77,5 & 97,4 & 99,4 & 93,1 & 964,2 \\
\hline
\end{tabular}


Movimientos en masa en las sierras de Bravard y Curamalal, Sierras Australes de la Provincia de Buenos Aires.

\begin{tabular}{|c|c|c|c|c|c|c|c|c|c|c|c|c|c|}
\hline \multicolumn{14}{|c|}{ Precipitación mensual en Saavedra (mm) } \\
\hline Año & Ene & Feb & Mar & Abr & May & Jun & Jul & Ago & Sep & Oct & Nov & Dic & $\begin{array}{l}\text { Prec. } \\
\text { anual }\end{array}$ \\
\hline 2000 & 86 & 168 & 76 & 5 & 55 & 9 & 0 & 67 & 60 & 91 & sd & sd & 616 \\
\hline 2001 & 141 & 78 & 132 & 132 & 9 & 15 & 12 & 47 & 89 & 122 & 135 & sd & 911 \\
\hline 2002 & 2 & 20 & 46 & 59 & 34 & 11 & 30 & 113 & 21 & 123 & 213 & 73 & 744 \\
\hline 2003 & 29 & 61 & 37 & 18 & 26 & 0 & 11 & 15 & 29 & 119 & 84 & 106 & 535 \\
\hline 2004 & 49 & 14 & 65 & 117 & 0 & 0 & 153 & 25 & 45 & 129 & 81 & 200 & 878 \\
\hline 2005 & 49 & 54 & 93 & 0 & 2 & 0 & 25 & 24 & 68 & 38 & 46 & 82 & 481 \\
\hline 2006 & 137 & 254 & 41 & 60 & 0 & 7 & 13 & 5 & 40 & 157 & 10 & 120 & 843 \\
\hline 2007 & 92 & 143 & 169 & 25 & 6 & 0 & 5 & 10 & 101 & 118 & 33 & 17 & 719 \\
\hline 2008 & 110 & 120 & 65 & 0 & 13 & 6 & 26 & 26 & 60 & 93 & 35 & 66 & 620 \\
\hline 2009 & 44 & 55 & 128 & 12 & 30 & 3 & 18 & 4 & 84 & 29 & 86 & 116 & 609 \\
\hline 2010 & 28 & 133 & 101 & 8 & 27 & 35 & 28 & 0 & 104 & 99 & 48 & 45 & 655 \\
\hline 2011 & 201 & 35 & 116 & 84 & 50 & 32 & 18 & 23 & 0 & 42 & 142 & 32 & 773 \\
\hline 2012 & 98 & 50 & 98 & 63 & 90 & 3 & 0 & 95 & 51 & 91 & 163 & 211 & 1012 \\
\hline 2013 & 45 & 34 & 77 & 157 & 16 & 6 & 80 & 0 & 67 & 58 & 45 & 24 & 609 \\
\hline 2014 & 38 & 60 & 192 & 142 & 69 & 21 & 132 & 79 & 60 & 221 & 89 & 122 & 1224 \\
\hline 2015 & 159 & 105 & 57 & 133 & 30 & 3 & 69 & 16 & 78 & 138 & 121 & 199 & 1108 \\
\hline 2016 & 116 & 125 & 28 & 110 & 56 & 18 & 27 & 2 & 39 & 136 & 45 & 36 & 737 \\
\hline 2017 & 60 & 216 & 77 & 93 & 99 & 109 & 28 & 55 & 123 & 52 & 53 & 44 & 1008 \\
\hline $\begin{array}{l}\text { Prec. } \\
\text { Media }\end{array}$ & 82 & 96 & 89 & 68 & 34 & 15 & 38 & 34 & 62 & 103 & 84 & 93 & 797 \\
\hline
\end{tabular}




\begin{tabular}{|c|c|c|c|c|c|c|c|c|c|c|c|c|c|}
\hline \multicolumn{14}{|c|}{ Precipitación mensual en Dufaur (mm) } \\
\hline Año & Ene & Feb & Mar & Abr & May & Jun & Jul & Ago & Sep & Oct & Nov & Dic & $\begin{array}{l}\text { Prec. } \\
\text { anual }\end{array}$ \\
\hline 2000 & sd & sd & 66 & 26 & 72 & 23 & 0 & 70 & 71 & 91 & sd & sd & 419 \\
\hline 2001 & 105 & 125 & 185 & 147 & 16 & 9 & 10 & 36 & 77 & 113 & 130 & sd & 952 \\
\hline 2002 & 87 & 10 & 48 & 42 & 36 & 13 & 35 & 101 & 24 & 87 & 212 & 99 & 793 \\
\hline 2003 & 34 & 78 & 34 & 50 & 15 & 0 & 10 & 10 & 28 & 169 & 63 & 73 & 564 \\
\hline 2004 & 81 & 20 & 76 & 84 & 0 & 3 & 201 & 15 & 24 & 90 & 57 & 200 & 851 \\
\hline 2005 & 61 & 48 & 90 & 0 & 2 & 0 & 33 & 56 & 55 & 30 & 56 & 71 & 501 \\
\hline 2006 & 100 & 181 & 63 & 57 & 0 & 9 & 45 & 4 & 43 & 126 & 12 & 119 & 757 \\
\hline 2007 & 160 & 146 & 94 & 21 & 9 & 0 & 9 & 10 & 119 & 83 & 19 & 16 & 685 \\
\hline 2008 & 91 & 77 & 65 & 0 & 17 & 7 & 18 & 18 & 51 & 57 & 26 & 47 & 474 \\
\hline 2009 & 35 & 31 & 155 & 5 & 25 & 5 & 5 & 7 & 81 & 26 & 63 & 102 & 540 \\
\hline 2010 & 45 & 107 & 92 & 7 & 16 & 35 & 33 & 0 & 94 & 92 & 64 & 65 & 649 \\
\hline 2011 & 255 & 27 & 80 & 39 & 27 & 18 & 12 & 13 & 0 & 35 & 65 & 23 & 594 \\
\hline 2012 & 101 & 78 & 87 & 54 & 84 & 2 & 0 & 83 & 48 & 54 & 100 & 191 & 882 \\
\hline 2013 & 53 & 2 & 55 & 125 & 10 & 0 & 83 & 0 & 70 & 46 & 38 & 26 & 508 \\
\hline 2014 & 50 & 74 & 86 & 111 & 79 & 29 & 124 & 114 & 42 & 257 & 80 & 83 & 1129 \\
\hline 2015 & 158 & 61 & 96 & 113 & 35 & 4 & 47 & 10 & 21 & 128 & 76 & 175 & 924 \\
\hline 2016 & 117 & 83 & 18 & 94 & 88 & 31 & 21 & 1 & 28 & 95 & 36 & 51 & 663 \\
\hline 2017 & 40 & 163 & 60 & 63 & 59 & 68 & 32 & 66 & 111 & 47 & 54 & 46 & 809 \\
\hline $\begin{array}{l}\text { Prec. } \\
\text { Media }\end{array}$ & 92 & 77 & 81 & 58 & 33 & 14 & 40 & 34 & 55 & 90 & 68 & 87 & 728 \\
\hline
\end{tabular}




\begin{tabular}{|c|c|c|c|c|c|c|c|c|c|c|c|c|c|}
\hline \multicolumn{14}{|c|}{ Precipitación mensual en Tornquist (mm) } \\
\hline Año & Ene & Feb & Mar & Abr & May & Jun & Jul & Ago & Sep & Oct & Nov & Dic & $\begin{array}{l}\text { Prec. } \\
\text { anual }\end{array}$ \\
\hline 1944 & - & - & - & - & - & - & - & - & 169,6 & 120 & 41,5 & 14 & 345,1 \\
\hline 1945 & 18 & 213,6 & 71,7 & 26,2 & 14,9 & 0 & 2,5 & 44,3 & 50,8 & 95,8 & 80,9 & 29,6 & 648,3 \\
\hline 1946 & 77,3 & 125,4 & 90,4 & 130,2 & 96,2 & 90,4 & 49,3 & 50,5 & 99,9 & 72,9 & 147,9 & 101,3 & 1131,7 \\
\hline 1947 & 76,4 & 78,8 & 70,2 & 19 & 31,1 & 18 & 37,2 & 8 & 47,5 & 85,4 & 77,9 & 22,6 & 572,1 \\
\hline 1948 & 63,9 & 36,2 & 184,8 & 59 & 196,3 & 24,1 & 29,2 & 3,4 & 260 & 53,1 & 15,1 & 144,5 & 1069,6 \\
\hline 1949 & 16,2 & 20,9 & 85,3 & 13,2 & 37,1 & 9,5 & 25,7 & 47,7 & 52,2 & 27,2 & 118,7 & 30,8 & 484,5 \\
\hline 1950 & 15,6 & 48,1 & 87 & 203,9 & 13,8 & 4,4 & 5,1 & 30,5 & 88,8 & 40,6 & 66,2 & 43,6 & 647,6 \\
\hline 1951 & 61,3 & 133,1 & 23 & 6,1 & 46,4 & 47,8 & 7,6 & 21,7 & 26,2 & 15,8 & 78,1 & 89,6 & 556,7 \\
\hline 1952 & 58,5 & 25,4 & 98,6 & 7,2 & 3,1 & 46,6 & 67,9 & 31,3 & 23,2 & 114,2 & 65,3 & 79,6 & 620,9 \\
\hline 1953 & 48,4 & 87,7 & 137,8 & 77,8 & 82 & 28,3 & 13,9 & 4,9 & 59,8 & 48 & 96,2 & 114,2 & 799 \\
\hline 1954 & 33,2 & 37,4 & 35 & 113,4 & 97,9 & 50,7 & 8 & 17,7 & 39,3 & 87,8 & 44,6 & 21,5 & 586,5 \\
\hline 1955 & 47,1 & 202 & 63,6 & 0 & 2,6 & 14,6 & 66,5 & 27,9 & 59,8 & 18,1 & 55 & 22,5 & 579,7 \\
\hline 1956 & 70,2 & 15,7 & 206,5 & 77 & 37 & 14 & 21,5 & 80 & 42,2 & 75 & 54,5 & 38,5 & 732,1 \\
\hline 1957 & 23,3 & 40,1 & 59,7 & 87,7 & 111,5 & 89 & 68 & 0,3 & 45,7 & 82,4 & 116,6 & 102 & 826,3 \\
\hline 1958 & 48,5 & 26,5 & 26,5 & 80,4 & 13,1 & 3 & 67 & 23 & 115 & 12 & 52,5 & 49,8 & 517,3 \\
\hline 1959 & 99,8 & 0 & 77,5 & 54 & 25 & 59,9 & 17,7 & 11 & 0 & 104,3 & 44 & 52 & 545,2 \\
\hline 1960 & 78 & 83 & 61,5 & 23 & 62,4 & 70 & 0 & 0 & 87,5 & 27,5 & 12,5 & 49,3 & 554,7 \\
\hline 1961 & 101,5 & 68,5 & 29 & 23 & 20,5 & 0 & 39 & 93,5 & 44 & 58 & 55 & 156 & 688 \\
\hline 1962 & 33,5 & 19,5 & 43,7 & 37 & 11,1 & 7,5 & 3 & 15 & 42,5 & 85,5 & 59,5 & 34 & 391,8 \\
\hline 1963 & 28 & 69 & 146 & 28,5 & 10 & 105,5 & 49 & 23 & 38,5 & 104 & 62,5 & 107 & 771 \\
\hline 1964 & 68 & 91 & 0 & 58 & 108 & 15 & 4,5 & 29 & 96 & 70,5 & 236,5 & 68 & 844,5 \\
\hline 1965 & 50,5 & 50 & 0 & 42,5 & 49 & 46 & 40,5 & 22,5 & - & - & - & - & 301 \\
\hline 2000 & 3 & 120 & 71 & 12 & 60 & 22 & 7 & 4 & 36 & 74 & sd & sd & 409 \\
\hline 2001 & 188 & 94 & 177 & 18 & 17 & 28 & sd & 73 & 98 & 141 & 75 & sd & 909 \\
\hline 2002 & 32 & 0 & 50 & 68 & 51 & sd & sd & sd & 9 & 80 & 201 & sd & 491 \\
\hline 2003 & sd & sd & sd & sd & sd & sd & sd & sd & sd & sd & sd & sd & - \\
\hline 2004 & sd & $s d$ & sd & sd & sd & sd & sd & sd & sd & sd & sd & sd & - \\
\hline 2005 & 66 & 54 & 67 & 9 & 4 & 2 & 37 & 36 & 37 & 15 & 60 & 107 & 494 \\
\hline 2006 & 75 & 119 & 48 & 49 & 0 & 1 & 56 & 43 & 38 & 144 & 17 & 65 & 655 \\
\hline 2007 & 124 & 155 & 64 & 157 & 30 & 0 & 15 & 15 & 117 & 74 & 64 & 24 & 839 \\
\hline 2008 & 132 & 115 & 65 & 0 & 23 & 9 & 15 & 8 & 64 & 92 & 20 & 55 & 598 \\
\hline 2009 & 30 & 36 & 127 & 0 & 41 & 4 & 19 & 4 & 60 & 22 & 107 & 202 & 652 \\
\hline 2010 & 30 & 204 & 164 & 12 & 8 & 21 & 20 & 0 & 91 & 74 & 40 & 90 & 754 \\
\hline 2011 & 250 & 39 & 82 & 39 & 30 & 12 & 34 & 25 & 0 & 64 & 174 & 4 & 753 \\
\hline 2012 & 65 & 125 & 78 & 14 & 130 & 0 & 0 & 110 & 31 & 58 & 70 & 42 & 723 \\
\hline 2013 & 31 & 0 & 76 & 167 & 18 & 0 & 89 & 0 & 88 & 124 & 21 & 30 & 644 \\
\hline 2014 & 62 & 86 & 120 & 179 & 96 & 24 & 88 & 140 & 95 & 215 & 98 & 14 & 1217 \\
\hline 2015 & 116 & 51 & 258 & 67 & 30 & 0 & 53 & 25 & 19 & 117 & 65 & 113 & 914 \\
\hline 2016 & 133 & 98 & 81 & 51 & 37 & 26 & 23 & 7 & 26 & 106 & 69 & 30 & 688 \\
\hline 2017 & 101 & 101 & 41 & 52 & 27 & 65 & 23 & 53 & 87 & 46 & 56 & 58 & 710 \\
\hline
\end{tabular}




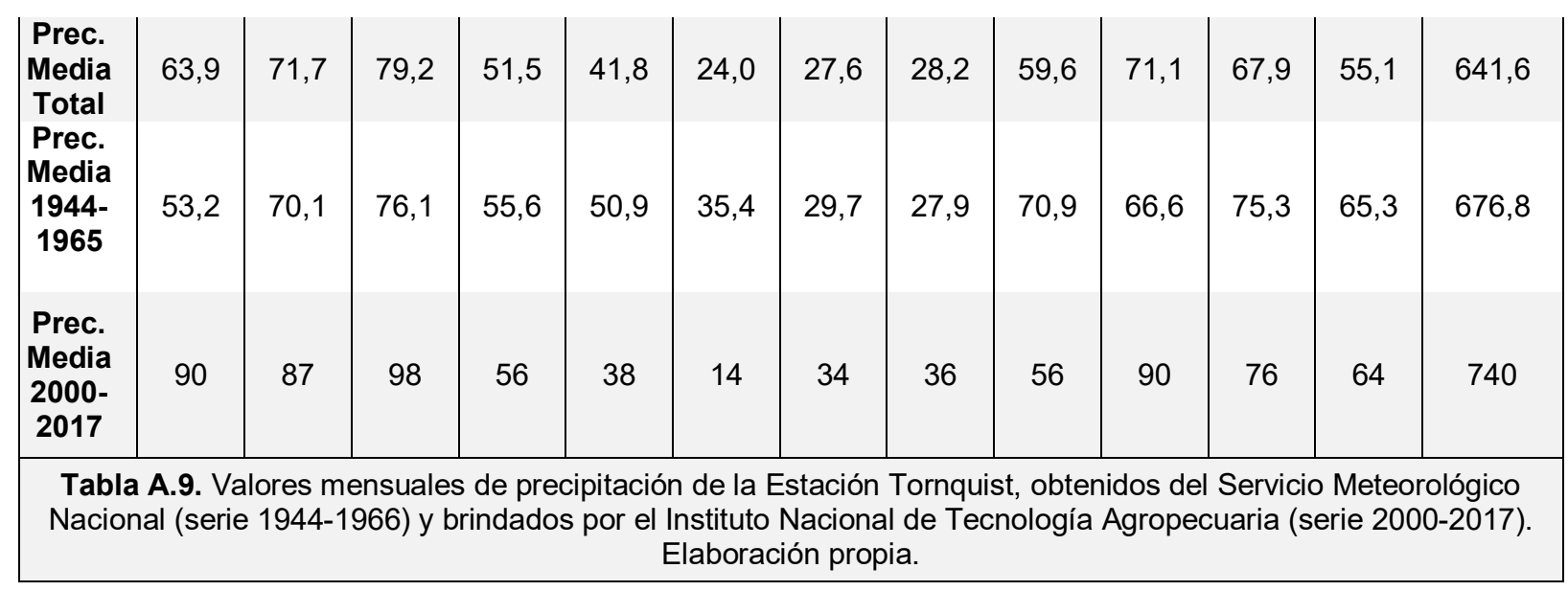

\begin{tabular}{|c|c|c|c|c|c|c|c|c|c|c|c|c|c|}
\hline \multicolumn{10}{|c|}{ Precipitación mensual en Tornquist (mm) } \\
\hline Año & Ene & Feb & Mar & Abr & May & Jun & Jul & Ago & Sep & Oct & Nov & Dic & $\begin{array}{c}\text { Prec. } \\
\text { anual }\end{array}$ \\
\hline $\mathbf{2 0 0 5}$ & 71 & 69 & 81 & 9 & 10 & 12 & 39 & 21 & 40 & 45 & 59 & 68 & 524 \\
$\mathbf{2 0 0 6}$ & 69 & 122 & 44 & 43 & 0 & 1 & 73 & 51 & 16 & 118 & 10 & 106 & 652 \\
$\mathbf{2 0 0 7}$ & 140 & 142 & 90 & 54 & 10 & 0 & 9 & 0 & 116 & 88 & 55 & 15 & 719 \\
$\mathbf{2 0 0 8}$ & 39 & 141 & 72 & 0 & 18 & 10 & 17 & 20 & 49 & 55 & 12 & 87 & 520 \\
$\mathbf{2 0 0 9}$ & 30 & 52 & 100 & 5 & 33 & 1 & 46 & 11 & 61 & 24 & 68 & 178 & 609 \\
$\mathbf{2 0 1 0}$ & 25 & 166 & 210 & 13 & 19 & 25 & 23 & 4 & 103 & 105 & 39 & 19 & 751 \\
$\mathbf{2 0 1 1}$ & 255 & 51 & 98 & 64 & 23 & 14 & 13 & 32 & 0 & 42 & 184 & 30 & 806 \\
$\mathbf{2 0 1 2}$ & 82 & 93 & 75 & 58 & 110 & 0 & 0 & 131 & 48 & 17 & 70 & 27 & 711 \\
$\mathbf{2 0 1 3}$ & 36 & 0 & 128 & 102 & 19 & 0 & 106 & 6 & 137 & 46 & 29 & 9 & 618 \\
$\mathbf{2 0 1 4}$ & 51 & 67 & 78 & 53 & 27 & 16 & 92 & 130 & 56 & 250 & 81 & 35 & 936 \\
$\mathbf{2 0 1 5}$ & 96 & 64 & 215 & 71 & 25 & 2 & 56 & 35 & 26 & 118 & 41 & 148 & 897 \\
$\mathbf{2 0 1 6}$ & 103 & 75 & 54 & 89 & 42 & 38 & 13,1 & 5 & 29 & 110 & sd & sd & 558 \\
$\mathbf{2 0 1 7}$ & 100 & 121 & 40 & 110,2 & 29,4 & 67 & 22 & 54 & 110 & 40 & 75 & 33,1 & 802 \\
&
\end{tabular}


Movimientos en masa en las sierras de Bravard y Curamalal, Sierras Australes de la Provincia de Buenos Aires.

Juan Manuel Susena

\begin{tabular}{|c|c|c|c|c|c|c|}
\hline \multicolumn{7}{|c|}{ EVENTOS DE PRECIPITACIONES EXTREMAS } \\
\hline \multirow[b]{2}{*}{$\begin{array}{l}\text { Fecha de } \\
\text { inicio }\end{array}$} & \multicolumn{6}{|c|}{ Milímetros registrados por estación (duración del evento en días) } \\
\hline & Pigüé & $\begin{array}{l}\text { Coronel } \\
\text { Suárez }\end{array}$ & $\begin{array}{c}\text { Estancia } \\
\text { Cerro } \\
\text { Áspero }\end{array}$ & Saavedra & Dufaur & Tornquist \\
\hline $1936 / 12 / 29$ & $82,8(1)$ & & & & & \\
\hline $1941 / 08 / 07$ & & $83,6(1)$ & & & & \\
\hline $1942 / 02 / 22$ & $\begin{array}{c}105,2(1) / \\
125,7(2)\end{array}$ & & & & & \\
\hline $\begin{array}{l}1942 / 12 / 07 \\
1943 / 05 / 03\end{array}$ & & $\begin{array}{c}176,2(1) \\
94,5(1)\end{array}$ & & & & \\
\hline $1943 / 10 / 17$ & & $\begin{array}{c}130,5(2) / \\
197,2(4)\end{array}$ & & & & \\
\hline $1943 / 12 / 14$ & & $87,0(1)$ & & & & \\
\hline $1944 / 04 / 06$ & & $\begin{array}{l}97,9(1) / \\
148,1(2)\end{array}$ & & & & \\
\hline $1944 / 09 / 28$ & & & & & & $102,3(1)$ \\
\hline $1945 / 02 / 03$ & & & & & & $\begin{array}{c}97,7(1) / \\
151,7(2) / \\
166,2(4)\end{array}$ \\
\hline $1946 / 02 / 02$ & & $97,8(1)$ & & & & \\
\hline $1946 / 11 / 13$ & & & & & & $90,1(1)$ \\
\hline $1948 / 03 / 20$ & $146,0(1)$ & $121,7(1)$ & & & & $128,3(1)$ \\
\hline $1948 / 05 / 12$ & & $\begin{array}{c}118,7(1) / \\
171,8(2)\end{array}$ & & & & \\
\hline $1948 / 05 / 13$ & & & & & & $93,7(1)$ \\
\hline $1948 / 12 / 07$ & $115,0(1)$ & & & & & \\
\hline $1955 / 02 / 13$ & $96,7(1)$ & & & & & \\
\hline $1956 / 03 / 09$ & $\begin{array}{c}121,2(1) / \\
173,0(2) / \\
208,4(4)\end{array}$ & $\begin{array}{c}209,3(1) / \\
285,3(2) / \\
310,7(4)\end{array}$ & & & & \\
\hline $1957 / 12 / 08$ & $108,6(1)$ & & & & & 90,0 (1) \\
\hline $1961 / 11 / 29$ & & 90,4 (1) & & & & \\
\hline $1961 / 12 / 06$ & & & & & & $105,0(1)$ \\
\hline $1963 / 12 / 24$ & $108,4(1)$ & & & & & \\
\hline $1965 / 12 / 02$ & $81,4(1)$ & & & & & \\
\hline $1969 / 03 / 15$ & & $85,0(1)$ & & & & \\
\hline $1969 / 05 / 16$ & & $100,0(1)$ & & & & \\
\hline $1971 / 09 / 10$ & $81,1(1)$ & 90,0 (1) & & & & \\
\hline $1975 / 03 / 13$ & 83,3 (1) & & & & & \\
\hline $1977 / 10 / 03$ & 84,1 (1) & $81,1(1)$ & & & & \\
\hline $1978 / 02 / 26$ & & $\begin{array}{c}207,0(1) / \\
228,5(2)\end{array}$ & & & & \\
\hline $1978 / 12 / 20$ & $\begin{array}{c}145,3(1) / \\
160,8(2) / \\
207,3(4)\end{array}$ & & & & & \\
\hline $1980 / 04 / 25$ & $\begin{array}{c}104,0(1) / \\
145,5(2) / \\
173,2(4)\end{array}$ & & & & & \\
\hline $1982 / 04 / 19$ & & $115,5(1)$ & & & & \\
\hline $1983 / 01 / 28$ & & 111,9 (1) & & & & \\
\hline $1984 / 02 / 03$ & 80,6 (1) & & & & & \\
\hline $1984 / 02 / 12$ & & & $86(1)$ & & & \\
\hline $1984 / 05 / 28$ & & & $\begin{array}{c}107 \text { (1) / } 122 \\
(2)\end{array}$ & & & \\
\hline $1986 / 01 / 25$ & & 92,7 (1) & & & & \\
\hline $1986 / 08 / 31$ & & & $82(1)$ & & & \\
\hline $1988 / 09 / 21$ & & & $\begin{array}{l}86(1) / 135 \\
(2) / 167(4)\end{array}$ & & & \\
\hline $1989 / 03 / 01$ & 82,7 (1) & & & & & \\
\hline $1989 / 05 / 13$ & & $\begin{array}{l}81,5(1) / \\
133,0(2)\end{array}$ & $\begin{array}{c}112 \text { (1) / } 133 \\
\text { (2) }\end{array}$ & & & \\
\hline 1990/11/12 & & $94,2(1)$ & & & & \\
\hline $1990 / 12 / 17$ & & 85,6 (1) & & & & \\
\hline $1991 / 01 / 29$ & $88,0(1)$ & $91,3(1)$ & $\begin{array}{c}143(1) / 146 \\
(2)\end{array}$ & & & \\
\hline
\end{tabular}




\begin{tabular}{|c|c|c|c|c|c|c|}
\hline $1991 / 09 / 05$ & & & $87(1)$ & & & \\
\hline $1992 / 01 / 01$ & & & $125(2)$ & & & \\
\hline 1992/02/18 & $\begin{array}{c}140,0(1) / \\
151,5(2)\end{array}$ & & & & & \\
\hline 1992/02/19 & & & $\begin{array}{c}155 \text { (1) / } 175 \\
\text { (1) }\end{array}$ & & & \\
\hline $1993 / 04 / 06$ & & & $130(1)$ & & & \\
\hline $1993 / 05 / 21$ & & $87,0(1)$ & & & & \\
\hline $1993 / 11 / 10$ & & & $80(1)$ & & & \\
\hline 1994/03/14 & & & 90 (1) & & & \\
\hline $1995 / 04 / 07$ & 83,0 (1) & & & & & \\
\hline $1996 / 12 / 10$ & & & 125,5 & & & \\
\hline $1997 / 06 / 13$ & & & $\begin{array}{c}93,5(1) / 150 \\
(2) / 172(4)\end{array}$ & & & \\
\hline 1999/11/01 & 99,4 (1) & & & & & \\
\hline $\begin{array}{l}1999 / 11 / 02 \\
2000 / 02 / 27\end{array}$ & & & $100(1)$ & & & \\
\hline $2001 / 01 / 16$ & & & $88(1)$ & & & $87(1)$ \\
\hline $2001 / 02 / 26$ & & & & & 81 (1) & 年 (11) \\
\hline $2001 / 02 / 28$ & & & & & & $89(1)$ \\
\hline 2001/04/13 & 88,0 (1) & & $110(1)$ & 90 (1) & $98(1)$ & \\
\hline $2001 / 09 / 23$ & & & & 85 (1) & & $98(1)$ \\
\hline 2001/10/08 & & & & 94 (1) & $86(1)$ & $87(1)$ \\
\hline $2002 / 11 / 08$ & $132,0(2)$ & & & & & \\
\hline 2002/11/09 & & & $\begin{array}{c}111(1) / 188 \\
\text { (2) }\end{array}$ & & $\begin{array}{c}83(1) / 163 \\
(2)\end{array}$ & \\
\hline $2002 / 11 / 10$ & & & & $\begin{array}{c}89(1) / 174 \\
\text { (2) }\end{array}$ & & \\
\hline $\begin{array}{l}2003 / 10 / 06 \\
2003 / 10 / 07\end{array}$ & $137,0(2)$ & & $162(1)$ & $82(1)$ & $135(1)$ & \\
\hline $2004 / 07 / 20$ & & & $\begin{array}{c}90(1) / 123 \\
\text { (2) }\end{array}$ & & & \\
\hline $2004 / 07 / 21$ & & & & & $181(4)$ & \\
\hline 2004/10/12 & & & $80(1)$ & & & \\
\hline $2006 / 02 / 21$ & & & $\begin{array}{c}134(1) / \\
149,5 \\
(2) 165,5(3) .\end{array}$ & $\begin{array}{c}121(1) / 172 \\
(2)\end{array}$ & & \\
\hline 2007/03/07 & & & $84(1)$ & $\begin{array}{c}120(1) / 129 \\
(2)\end{array}$ & & \\
\hline $\begin{array}{l}2007 / 04 / 19 \\
2007 / 10 / 01\end{array}$ & & & & & & $130(1)$ \\
\hline $2009 / 03 / 03$ & & $89(1)$ & 87 (1) & & $83(1)$ & $92(1)$ \\
\hline $2009 / 12 / 19$ & & & & & & 146 (1) \\
\hline $2010 / 03 / 21$ & & & & & & $82(1)$ \\
\hline 2010/10/29 & & & $90(1)$ & & & \\
\hline 2011/01/03 & & & $174(4)$ & & & $\begin{array}{c}120(1) / 180 \\
(2) / 219(4)\end{array}$ \\
\hline 2011/01/04 & & & & & $\begin{array}{c}124(2) / 189 \\
\text { (4) }\end{array}$ & \\
\hline $2011 / 11 / 03$ & & & $92(1)$ & & & \\
\hline 2012/11/09 & & & 94 (1) & $85(1)$ & & \\
\hline 2012/12/05 & & & & $85(1)$ & & \\
\hline 2013/04/01 & & & $80(1)$ & & & \\
\hline 2013/04/03 & & & & 90 (1) & $93(1)$ & \\
\hline $2014 / 03 / 13$ & $114,0(1)$ & & & $127(1)$ & & \\
\hline $2014 / 04 / 07$ & & & & & & $\begin{array}{c}88(1) / 125 \\
(2)\end{array}$ \\
\hline 2014/08/23 & & & & & $90(1)$ & \\
\hline $2014 / 10 / 26$ & & & & & & $150(2)$ \\
\hline $\begin{array}{l}2014 / 10 / 27 \\
2015 / 01 / 18\end{array}$ & & & & $\begin{array}{c}129(1) \\
82(1)\end{array}$ & 205 (1) & \\
\hline $2015 / 02 / 03$ & $\begin{array}{c}114,0(1) / \\
140,0(2)\end{array}$ & & & & & \\
\hline 2015/03/12 & & & & & & $126(1)$ \\
\hline 2016/03/31 & 84,0 (1) & & & & & \\
\hline 2017/02/04 & & & & & $82(1)$ & \\
\hline $2017 / 02 / 05$ & & & & $114(1)$ & & \\
\hline
\end{tabular}


Movimientos en masa en las sierras de Bravard y Curamalal,

Sierras Australes de la Provincia de Buenos Aires.

Juan Manuel Susena

$2017 / 08 / 28$

2017/09/10

$95(1)$

$90(1)$

Tabla A.10. Eventos de precipitaciones extremas registrados en diferentes estaciones. Se considera extremo a aquel evento en el cual caen al menos $160 \mathrm{~mm}$ en 4 días, $120 \mathrm{~mm}$ en 2 días u $80 \mathrm{~mm}$ en 1 día. Elaboración propia a partir de registros diarios de lluvia del Servicio Meteorológico Nacional, el Instituto Nacional de

Tecnología Agropecuaria y los dueños de la Estancia Cerro Áspero.

\begin{tabular}{|c|c|c|c|c|c|c|c|}
\hline \multicolumn{8}{|c|}{ Referencias del inventario de movimientos en masa } \\
\hline \multicolumn{2}{|c|}{ Tipo } & \multicolumn{2}{|c|}{ Estado } & \multicolumn{2}{|c|}{$\begin{array}{c}\text { Escala de } \\
\text { observación }\end{array}$} & \multicolumn{2}{|c|}{ Imagen } \\
\hline Caída_roc & $\begin{array}{c}\text { Sector con } \\
\text { caídas de roca }\end{array}$ & Degradado & $\begin{array}{l}\text { Movimiento con } \\
\text { características } \\
\text { indicadoras de } \\
\text { antigüedad }\end{array}$ & IMG & $\begin{array}{l}\text { Teledetección } \\
\text { (imágenes } \\
\text { satelitales o } \\
\text { fotografías } \\
\text { aéreas) }\end{array}$ & II-R657-55 & $\begin{array}{c}\text { Fotos aéreas de } \\
1967\end{array}$ \\
\hline Caída_suel & $\begin{array}{l}\text { Caída de } \\
\text { tierra/suelo }\end{array}$ & Juvenil & $\begin{array}{c}\text { Movimiento con } \\
\text { características } \\
\text { indicadoras de } \\
\text { juventud }\end{array}$ & CMP & $\begin{array}{l}\text { Observación } \\
\text { en el terreno }\end{array}$ & C-384-17 & $\begin{array}{c}\text { Fotos aéreas de } \\
1981\end{array}$ \\
\hline Desc & Desconocido & Indef & Indefinido & & & $\begin{array}{l}\text { CAMP8 } \\
20111211\end{array}$ & $\begin{array}{l}\text { Fotos de campo } \\
\text { indicando } \\
\text { número de } \\
\text { campaña (8) y } \\
\text { fecha (2011-12- } \\
11)\end{array}$ \\
\hline Desl_cuña & $\begin{array}{c}\text { Deslizamiento } \\
\text { en cuña (en } \\
\text { roca) }\end{array}$ & Variable & $\begin{array}{l}\text { Movimiento/s con } \\
\text { sectores que } \\
\text { indican juventud y } \\
\text { sectores que } \\
\text { indican } \\
\text { antigüedad }\end{array}$ & & & Campo & $\begin{array}{l}\text { Fotos de campo } \\
\text { sin diferenciar }\end{array}$ \\
\hline Desl_gen & $\begin{array}{l}\text { Deslizamiento } \\
\text { genérico (no } \\
\text { se diferencian } \\
\text { subtipos) }\end{array}$ & & & & & Dron & $\begin{array}{c}\text { Fotos tomadas } \\
\text { en el campo con } \\
\text { un dron }\end{array}$ \\
\hline Desl_rotac & $\begin{array}{c}\text { Deslizamiento } \\
\text { rotacional }\end{array}$ & & & & & $\begin{array}{c}\text { Google } \\
\text { Earth/Bing }\end{array}$ & $\begin{array}{l}\text { Composiciones } \\
\text { de imágenes } \\
\text { satelitales } \\
\text { (servidor del cual } \\
\text { se las obtuvo) }\end{array}$ \\
\hline Desl_suelo & $\begin{array}{c}\text { Deslizamiento } \\
\text { de suelo sin } \\
\text { diferenciar } \\
\text { subtipo }\end{array}$ & & & & & & \\
\hline DesI_trasl & $\begin{array}{c}\text { Deslizamiento } \\
\text { traslacional }\end{array}$ & & & & & & \\
\hline Flujo_detr & $\begin{array}{l}\text { Flujo de } \\
\text { detritos }\end{array}$ & & & & & & \\
\hline Flujo_tier & Flujo de tierra & & & & & & \\
\hline Flujo_desl & \begin{tabular}{|c|} 
Flujo o \\
deslizamiento \\
con flujo
\end{tabular} & & & & & & \\
\hline Pipping & $\begin{array}{l}\text { Movimientos } \\
\text { menores } \\
\text { asociados a } \\
\text { pipping }\end{array}$ & & & & & & \\
\hline Vuelco_roc & Vuelco de roca & & & & & & \\
\hline Vuelco_sue & $\begin{array}{l}\text { Vuelco de } \\
\text { tierra/suelo }\end{array}$ & & & & & & \\
\hline
\end{tabular}


INVENTARIO DE MOVIMIENTOS EN MASA CARTOGRAFIABLES A ESCALA 1:5.000

\begin{tabular}{|c|c|c|c|c|c|c|c|c|c|}
\hline \multicolumn{10}{|c|}{ INVENTARIO DE MOVIMIENTOS EN MASA CARTOGRAFIABLES A ESCALA 1:5.000 } \\
\hline Sub-zona & $\begin{array}{c}\text { Fecha de } \\
\text { Observación }\end{array}$ & Tipo & Estado & Edad relativa & Descripción & $\begin{array}{c}\text { Escala de } \\
\text { Observación }\end{array}$ & Imagen & Longitud & Latitud \\
\hline 1 & $2006-02-26$ & Complejo & Variable & Previo al 2006-02-26 & Sector de movimientos y reactivaciones & IMG & Google Earth & -62.269073 & -37.710575 \\
\hline 1 & 2006-02-26 & Complejo & Variable & Previo al 2006-02-26 & Sector de movimientos y reactivaciones & IMG & Google Earth & -62.270248 & -37.710587 \\
\hline 1 & 2006-02-26 & Desc & Degradado & Previo al 2006-02-26 & Superficie de ruptura de deslizamiento o flujo & IMG & Google Earth & -62.277803 & -37.700872 \\
\hline 1 & 2006-02-26 & Desc & Degradado & Previo al 2006-02-26 & Deslizamiento o flujo & IMG & Google Earth & -62.276300 & -37.702187 \\
\hline 1 & 2006-02-26 & Desc & Degradado & Previo al 2006-02-26 & Deslizamiento o flujo & IMG & Google Earth & -62.271423 & -37.703733 \\
\hline 1 & 2006-02-26 & Desc & Degradado & Previo al 2006-02-26 & Deslizamiento o flujo & IMG & Google Earth & -62.270932 & -37.704388 \\
\hline 1 & 2006-02-26 & Desc & Indef & Previo al 2006-02-26 & Caídas o deslizamientos rotacionales de suelo & IMG & Google Earth & -62.310573 & -37.699213 \\
\hline 1 & 2006-02-26 & Desl_gen & Degradado & Previo al 2006-02-26 & Zona de hundimiento próxima a los afloramientos. No se conserva la acumulación & IMG & Google Earth & -62.306987 & -37.696618 \\
\hline 1 & 2006-02-26 & Desl_gen & Degradado & Previo al 2006-02-26 & Se ve sólo la acumulación (observación de campo del 2018-01-20) & CMP & Google Earth & -62.305091 & -37.694897 \\
\hline 1 & 2006-02-26 & Desl_gen & Degradado & Previo al 2006-02-26 & Superficie de ruptura sepultada & IMG & Google Earth & -62.273538 & -37.702848 \\
\hline 1 & 2006-02-26 & Desl_gen & Degradado & Previo al 2006-02-26 & Se observa solo la lomada & IMG & Google Earth & -62.273626 & -37.712009 \\
\hline 1 & 2006-02-26 & Desl_gen & Degradado & Previo al 2006-02-26 & Se ven las acumulaciones y una depresión & IMG & Google Earth & -62.269527 & -37.705560 \\
\hline 1 & 2006-02-26 & Desl_gen & Juvenil & Previo al 2006-02-26 & Deslizamiento con flanco derecho condicionado por afloramiento, reactivación progresiva & IMG & Google Earth & -62.283100 & -37.701363 \\
\hline 1 & 2006-02-26 & Desl_gen & Juvenil & Previo al 2006-02-26 & Sepulta a uno más antiguo & IMG & Google Earth & -62.272914 & -37.702662 \\
\hline 1 & 2006-02-26 & Desl_gen & Juvenil & Previo al 2006-02-26 & Sepulta a uno más antiguo & IMG & Google Earth & -62.271994 & -37.703162 \\
\hline 1 & 2006-02-26 & Desl_gen & Juvenil & Previo al 2006-02-26 & Tiene una reactivación que sepulta parte de la zona de agotamiento & IMG & Google Earth & -62.272304 & -37.703318 \\
\hline 1 & 2006-02-26 & Desl_gen & Juvenil & Previo al 2006-02-26 & Sepulta a uno más antiguo & IMG & Google Earth & -62.271707 & -37.705192 \\
\hline 1 & 2006-02-26 & Desl_gen & Juvenil & Previo al 2006-02-26 & Varios deslizamientos chicos vinculados a curso de agua & IMG & Google Earth & -62.288564 & -37.707574 \\
\hline 1 & 2006-02-26 & Desl_rotac & Juvenil & Previo al 2006-02-26 & Rotacionales múltiples vinculados a cauce incipiente & IMG & Google Earth & -62.301879 & -37.698432 \\
\hline 1 & 2006-02-26 & Desl_rotac & Juvenil & Previo al 2006-02-26 & Varios deslizamientos alineados en depresión de curso de agua & IMG & Google Earth & -62.299352 & -37.700040 \\
\hline 1 & 2006-02-26 & Desi_trasl & Degradado & Previo al 2006-02-26 & Lomada bien expresada con bloques en la punta & IMG & Google Earth & -62.278093 & -37.701261 \\
\hline 1 & 2006-02-26 & DesI_trasl & Degradado & Previo al 2006-02-26 & $\begin{array}{c}\text { Lomada bien expresada con bloques en la punta. Superficie de ruptura sepultada por reactivación } \\
\text { progresiva }\end{array}$ & IMG & Google Earth & -62.277788 & -37.701315 \\
\hline 1 & 2006-02-26 & Desl_trasl & Degradado & Previo al 2006-02-26 & Sepulta al afloramiento & IMG & Google Earth & -62.265662 & -37.709264 \\
\hline 1 & $2006-02-26$ & Desl_trasl & Juvenil & Previo al 2006-02-26 & La acumulación obstruye el cauce. En el 2015-12-18 es atravesado por el curso de agua & IMG & $\begin{array}{l}\text { Google Earth y } \\
\text { Bing }\end{array}$ & -62.299191 & -37.699215 \\
\hline 1 & $2006-02-26$ & DesI_trasl & Juvenil & Previo al 2006-02-26 & $\begin{array}{c}\text { Acumulación elongada en la dirección de la pendiente, con buena expresión morfológica. Se } \\
\text { observan muchos detritos en la imagen }\end{array}$ & IMG & Google Earth & -62.276426 & -37.702873 \\
\hline 1 & 2006-02-26 & Desl_trasl & Juvenil & Previo al 2006-02-26 & Tiene una reactivación progresiva afectando la parte izquierda de la acumulación & IMG & Google Earth & -62.276702 & -37.702211 \\
\hline 1 & $2006-02-26$ & Desi_trasl & Variable & Previo al 2006-02-26 & Conjunto de deslizamientos traslacionales. Hay dos juveniles que desvían el curso de agua & IMG & Google Earth & -62.277198 & -37.702523 \\
\hline 1 & $2006-02-26$ & Desl_trasl & Juvenil & Previo al 2006-02-26 & $\begin{array}{l}\text { Dos movimientos con sus superficies de ruptura cóncavas hacia el cauce. De uno no se tiene la } \\
\text { acumulación, la cual debería estar en el cauce. El otro es incipiente, se está produciendo }\end{array}$ & IMG & Google Earth & -62.281854 & -37.706467 \\
\hline 1 & 2006-02-26 & Flujo_detr & Degradado & Previo al 2006-02-26 & Se observan los albardones pero no la superficie de ruptura & IMG & Google Earth & -62.279860 & -37.700771 \\
\hline 1 & 2006-02-26 & Flujo_detr & Juvenil & Previo al 2006-02-26 & $\begin{array}{c}\text { La superficie de ruptura es muy conspicua, se conserva una escarpa lateral y varios albardones } \\
\text { muy angostos }\end{array}$ & IMG & Google Earth & -62.285260 & -37.702718 \\
\hline 1 & 2006-02-26 & Flujo_tier & Juvenil & Previo al 2006-02-26 & Asociado a camino. En el 2015 se ven mejor las escarpas & IMG & Google Earth & -62.279264 & -37.714275 \\
\hline 1 & 2006-02-26 & Flujo_tier & Juvenil & Actual & Asociado a camino. En el 2015 se ven mejor las escarpas & IMG & Google Earth & -62.279429 & -37.714193 \\
\hline 1 & 2006-02-26 & Pipping & Juvenil & Previo al 2006-02-26 & Hay escarpas laterales posiblemente asociadas a caídas & IMG & Google Earth & -62.276412 & -37.714716 \\
\hline 1 & 2006-02-26 & Pipping & Juvenil & Previo al 2006-02-26 & Hay escarpas laterales posiblemente asociadas a caídas & IMG & Google Earth & -62.275959 & -37.714041 \\
\hline 1 & $2006-02-26$ & Pipping & Juvenil & Previo al 2006-02-26 & Hay escarpas laterales posiblemente asociadas a caídas & IMG & Google Earth & -62.275472 & -37.714043 \\
\hline 1 & 2011-04-10 & Flujo_desl & Juvenil & Previo al 2011-04-10 & $\begin{array}{l}\text { Movimiento elongado en la dirección de la pendiente con deformación de la masa. Tiene buena } \\
\text { expresión morfológica y se conserva parte de la escarpa. }\end{array}$ & IMG & Google Earth & -62.304982 & -37.694145 \\
\hline 1 & 2015-12-18 & Complejo & Juvenil & Previo al 2006-02-26 & Flujos y deslizamientos con reactivación entre el 2011-04-10 y el 2015-12-18 & IMG & Google Earth & -62.274780 & -37.712319 \\
\hline 1 & 2018-01-20 & Desl_rotac & Variable & Previo al 2018-01-20 & Rotacionales múltiples & CMP & Campo & -62.305258 & -37.695274 \\
\hline 1 & 2019-01-20 & Caída_suel & Juvenil & Actual & Bloque listo para caer, agarrado con raíces & CMP & Campo & -62.302647 & -37.700356 \\
\hline 1 & 2019-01-20 & Complejo & Variable & Previo al 2006-02-26 & Varios movimientos grandes, hay traslacionales y rotacionales, y se van afectando unos a otros & IMG & Google Earth & -62.309129 & -37.695560 \\
\hline 1 & 2019-01-20 & Desl_gen & Juvenil & Previo al 2011-04-10 & Deslizamientos múltiples que en la imagen se confunden con un flujo & CMP & Google Earth & -62.302346 & -37.697201 \\
\hline 1 & 2019-01-20 & Desl_gen & Juvenil & Previo al 2011-04-10 & Deslizamientos múltiples que en la imagen se confunden con un flujo & CMP & Google Earth & -62.302499 & -37.697024 \\
\hline 1 & 2019-01-20 & Desi_gen & Juvenil & Previo al 2006-02-26 & Deslizamientos múltiples en contacto entre bloques y afloramiento, un millón de fotos & CMP & Google Earth & -62.298647 & -37.699153 \\
\hline 1 & 2019-01-20 & DesI_rotac & Degradado & Previo al 2011-04-10 & $\begin{array}{c}\text { Se ve la depresión pero no escarpas, la parte de atrás de la loma esta algo en contrapendiente y } \\
\text { tiene muchos finos acumulados }\end{array}$ & CMP & Google Earth & -62.306448 & -37.695132 \\
\hline 1 & 2019-01-20 & Desl_rotac & Juvenil & Previo al 2019-01-20 & Obstruye cauce & CMP & Campo & -62.299890 & -37.699507 \\
\hline 1 & 2019-01-20 & Desi trasl & Degradado & Previo al 2011-04-10 & Tiene reactivaciones menores adentro, es antiguo & CMP & Google Earth & -62.300280 & -37.698504 \\
\hline
\end{tabular}




\begin{tabular}{|c|c|c|c|c|}
\hline Sub-zona & $\begin{array}{l}\text { Fecha de } \\
\text { Observación }\end{array}$ & Tipo & Estado & Edad relativa \\
\hline 1 & 2019-01-20 & DesI_trasl & Indef & Previo al 2011-04-10 \\
\hline 1 & 2019-01-20 & Desl_trasl & Juvenil & Previo al 2011_04_1C \\
\hline 1 & 2019-01-20 & Flujo_desl & Juvenil & Previo al 2011-04-10 \\
\hline 1 & 2019-01-20 & Flujo_tier & Juvenil & Actual \\
\hline 2 & $1967-02-25$ & Complejo & Degradado & Previo al $1967-02-25$ \\
\hline 2 & $1967-02-25$ & Complejo & Juvenil & Previo al $1967-02-25$ \\
\hline 2 & $1967-02-25$ & Complejo & Juvenil & Previo al $1967-02-25$ \\
\hline 2 & $1967-02-25$ & Complejo & Variable & Previo al $1967-02-25$ \\
\hline 2 & $1967-02-25$ & Complejo & Variable & Previo al $1967-02-25$ \\
\hline 2 & 1967-02-25 & Complejo & Variable & Previo al $1967-02-25$ \\
\hline 2 & $1967-02-25$ & Complejo & Variable & Previo al $1967-02-25$ \\
\hline 2 & $1967-02-25$ & Complejo & Variable & Previo al $1967-02-25$ \\
\hline 2 & $1967-02-25$ & Desc & Indef & Previo al $1967-02-25$ \\
\hline 2 & $1967-02-25$ & Desl_gen & Juvenil & Previo al 1967-02-25 \\
\hline 2 & $1967-02-25$ & Desl_rotac & Juvenil & Previo al $1967-02-25$ \\
\hline 2 & 1967-02-25 & DesI_trasl & Degradado & Previo al $1967-02-25$ \\
\hline 2 & 1967-02-25 & Flujo_tier & Juvenil & Previo al $1967-02-25$ \\
\hline 2 & 1981-01-12 & Flujo_detr & Degradado & Previo al 1981-01-12 \\
\hline 2 & 1981-01-12 & Flujo_detr & Juvenil & Previo al 1981-01-12 \\
\hline 2 & 2006-02-26 & Complejo & Degradado & Previo al 2006-02-26 \\
\hline 2 & 2006-02-26 & Complejo & Degradado & Previo al 2006-02-26 \\
\hline 2 & $2006-02-26$ & Complejo & Degradado & Previo al 2006-02-26 \\
\hline 2 & 2006-02-26 & Complejo & Degradado & Previo al 2006-02-26 \\
\hline 2 & $2006-02-26$ & Complejo & Degradado & Previo al 2006-02-26 \\
\hline 2 & 2006-02-26 & Complejo & Degradado & Previo al 2006-02-26 \\
\hline 2 & $2006-02-26$ & Complejo & Indef & Previo al 2006-02-26 \\
\hline 2 & 2006-02-26 & Complejo & Juvenil & Previo al 2006-02-26 \\
\hline 2 & $2006-02-26$ & Complejo & Juvenil & Previo al 2006-02-26 \\
\hline 2 & 2006-02-26 & Complejo & Variable & Previo al 2006-02-26 \\
\hline
\end{tabular}

Edad relativa

Deslizamiento traslacional aprovechando afloramiento Cercano a afloramiento

Flujo deslizante con forma de $V$. Esta el afloramiento abajo y tiene albardones laterales En desarrollo incipiente, se observan terracettes Deslizamiento rotacional que ocupa casi toda la ladera. Tiene reactivaciones y está erosionado
por acción del agua, desarrollándose un pequeño cauce (observación de campo del 2018-10-20) Deslizamiento afectado por muchas reactivaciones progresivas y algunas dentro de la superficie de ruptura. Actualmente tiene terracettes tanto en la escarpa como en la acumulación

Conjunto de deslizamientos con reactivaciones progresivas y retrogresivas. En las cabeceras
aflora tosca con una inclinación menor que la pendiente (observación de campo del 2016-05-18) Conjunto de deslizamientos y flujos de morfología y dimensiones variables. Es difícil separar un Conjunto de deslizamientos y flujos de morfología y dimensiones variables. Es difícil separar un
movimiento de otro, ya que se afectan entre sí. Hay reactivaciones juveniles y un sistema de drenaje en los contactos entre acumulaciones (obs. de campo)
dratimiento de

Conjunto de deslizamientos. Hay una gran superficie de ruptura sepultada por reactivaciones rotacionales (observación de campo). Hay reactivaciones juveniles afectando también los laterales de la acumulación y la punta

Conjunto de movimientos de tipo deslizamiento y flujo de detritos. Tres grandes acumulaciones argadas según la pendiente similares a deslizamientos traslacionales, tienen reactivaciones rotacionales en los laterales y las puntas

Deslizamiento con una componente de tipo flujo de tierra. La escarpa tiene terracettes y la zona de hundimiento tiene bloques con colonias de liquenes (observaciôn de campo del 2016-05-18). Actividad múltiple en la zona de acumulación

Conjunto de deslizamientos y flujos de detritos. Las acumulaciones tienen en general buen expresión, aunque las escarpas no se observan. Hay un curso de agua que fue desviado por un

Acumulación degradada en la imagen del 2006-02-26. No se ve bien en la foto de 1967. Hay una aspecto de juventud

Actualmente la acumulación se conserva pero la superficie de ruptura perdió expresión morfológica

Deslizamiento rotacional múltiple con flujo distal. Reactivaciones retrogresivas decrecientes, algunas se produjeron entre el 1967-02-25 y el 1981-01-12

Movimiento con parte de la escarpa sepultada. La zona de hundimiento tiene poca expresión La acumulación tiene terracettes y reactivaciones

Flujo que ocupa buena parte de la ladera. Actualmente tiene poca expresión morfológica, se lo pudo identificar a partir de las imágenes del dron

Albardones poco definidos, se conserva la acumulación. Hay reactivaciones con características juveniles

Albardones poco definidos con una acumulación ladera abajo. La morfologia es alargada en la dirección de la pendich y punta tiene forma levemente lobada. En la imagen del 2006-02-26 tiene menos expresión morfológica que en 1981

A cados por movimientos más jóvenes

Deslizamientos múltiples con iujo. Afectados por movimientos más jóvenes Aparentes deslizamientos con flujo, múltiples

Relieve de montículos y depresiones. No se observan escarpas pero sí zonas de agotamiento conspicuas y acumulaciones con expresion variable. Hay una acumulación menor sepultando a una mayor, más degradada

Flujo de detritos con deslizamientos rotacionales afectando la punta (observación de campo) traslacional. Se conserva la acumulación, acecta por reaclivaciones pequeñas. La zona de Zona con múltiples deslizamientos pequeños alineados en la dirección de la pendiente. La parte Deslizamientos múltiples con deformación de la masa Deslizamientos mútiples con flujo Conjunto de deslizamientos rotacionales y traslacionales, predominando los traslacionales. En
general están degradados y se afectan entre sí

\begin{tabular}{|c|c|c|c|}
\hline $\begin{array}{l}\text { Escala de } \\
\text { Observación }\end{array}$ & Imagen & Longitud & Latitud \\
\hline CMP & Google Earth & -62.305615 & -37.694934 \\
\hline IMG & Google Earth & -62.310914 & -37.695796 \\
\hline IMG & Google Earth & -62.306813 & -37.695218 \\
\hline CMP & Campo & -62.299398 & -37.700316 \\
\hline IMG & II-R657-55 & -62.132361 & -37.758950 \\
\hline IMG & $\begin{array}{l}\text { Il-R657-55 y } \\
\text { Google Earth }\end{array}$ & -62.142757 & -37.765930 \\
\hline IMG & II-R657-55 y dron & -62.143113 & -37.764995 \\
\hline IMG & II-R657-55 y dron & -62.144332 & -37.749358 \\
\hline IMG & II-R657-55 y dron & -62.124334 & -37.768402 \\
\hline IMG & $\begin{array}{l}\text { Google Earth y } \\
\text { dron }\end{array}$ & -62.125115 & -37.767035 \\
\hline IMG & II-R-657-55 y dron & -62.142592 & -37.765469 \\
\hline IMG & $\begin{array}{l}\text { II-R657-55 y } \\
\text { Google Earth }\end{array}$ & -62.122549 & -37.778826 \\
\hline IMG & $\begin{array}{l}\text { II-R657-55 y } \\
\text { Google Earth }\end{array}$ & -62.122843 & -37.779466 \\
\hline IMG & $\begin{array}{l}\text { II-R657-55 y } \\
\text { Google Earth }\end{array}$ & -62.129467 & -37.761090 \\
\hline IMG & $\begin{array}{l}\text { II-R657-55 y } \\
\text { C384-17 }\end{array}$ & -62.128543 & -37.763351 \\
\hline IMG & II-R657-55 & -62.143446 & -37.766422 \\
\hline IMG & II-R657-55 y dron & -62.127601 & -37.764934 \\
\hline IMG & C384-17 & -62.135699 & -37.762364 \\
\hline IMG & $\begin{array}{l}\text { C384-16 y Google } \\
\text { Earth }\end{array}$ & -62.143593 & -37.763549 \\
\hline IMG & Google Earth & -62. & 37.722069 \\
\hline IMG & Google E & & -37.721840 \\
\hline IMG & Google Earth & -62.231290 & -37.737588 \\
\hline IMG & $\begin{array}{c}\text { Google Earth y } \\
\text { Bing }\end{array}$ & -62.173055 & -37.735758 \\
\hline IMG & Google Earth & -62.130346 & -37.760748 \\
\hline IMG & $\begin{array}{c}\text { Google Earth y } \\
\text { dron }\end{array}$ & -62.141223 & -37.769496 \\
\hline IMG & Google Earth & -62.142553 & -37.767255 \\
\hline IMG & & & -37 \\
\hline IMG & Google Earth & -62.222783 & -37.722427 \\
\hline IMG & Google Earth & -62.223833 & -37.736620 \\
\hline
\end{tabular}




\begin{tabular}{|c|c|c|c|c|}
\hline Sub-zona & $\begin{array}{l}\text { Fecha de } \\
\text { Observación }\end{array}$ & Tipo & Estado & Edad relativa \\
\hline 2 & $2006-02-26$ & Complejo & Variable & Previo al 2006-02-26 \\
\hline 2 & $2006-02-26$ & Complejo & Variable & Previo al 2006-02-26 \\
\hline 2 & $2006-02-26$ & Complejo & Variable & Previo al 2006-02-26 \\
\hline 2 & $2006-02-26$ & Complejo & Variable & Previo al 2006-02-26 \\
\hline 2 & 2006-02-26 & Complejo & Variable & Previo al 2006-02-26 \\
\hline 2 & 2006-02-26 & Complejo & Variable & Previo al 2006-02-26 \\
\hline 2 & 2006-02-26 & Complejo & Variable & Previo al 2006-02-26 \\
\hline 2 & 2006-02-26 & Complejo & Variable & Previo al 2006-02-26 \\
\hline 2 & $2006-02-26$ & Complejo & Variable & $\begin{array}{l}\text { Entre el 1967-02-25 y } \\
\text { el 2006-02-26 }\end{array}$ \\
\hline 2 & 2006-02-26 & Complejo & Variable & Previo al 2006-02-26 \\
\hline 2 & 2006-02-26 & Complejo & Variable & Previo al 1967-02-25 \\
\hline 2 & 2006-02-26 & Complejo & Variable & $\begin{array}{l}\text { Entre el 1967-03-05 y } \\
\text { el 2006-02-26 }\end{array}$ \\
\hline 2 & $2006-02-26$ & Complejo & Variable & Previo al 2006-02-26 \\
\hline 2 & 2006-02-26 & Complejo & Variable & Previo al 2006-02-26 \\
\hline 2 & 2006-02-26 & Complejo & Variable & Previo al 2006-02-26 \\
\hline 2 & 2006-02-26 & Desc & Degradado & Previo al 2006-02-26 \\
\hline 2 & 2006-02-26 & Desc & Degradado & Previo al 2006-02-26 \\
\hline 2 & 2006-02-26 & Desc & Degradado & Previo al 2006-02-26 \\
\hline 2 & 2006-02-26 & Desc & Degradado & Previo al 2006-02-26 \\
\hline 2 & 2006-02-26 & Desc & Degradado & Previo al 2006-02-26 \\
\hline 2 & 2006-02-26 & Desc & Degradado & Previo al 2006-02-26 \\
\hline 2 & $2006-02-26$ & Desc & Degradado & Previo al 2006-02-26 \\
\hline 2 & 2006-02-26 & Desc & Degradado & Previo al 2006-02-26 \\
\hline 2 & $2006-02-26$ & Desc & Degradado & Previo al 2006-02-26 \\
\hline
\end{tabular}

Conjunto de deslizamientos traslacionales de pocos metros de longitud. Algunos tienen caracteristicas juveniles y otros están degradados (observación de campo). Uno de los movimientos juveniles se produjo entre el 2006-02-27 y el 2011-04-10 Varios deslizamientos. Hay movimientos elongados ladera arriba que se produjeron entre el 2006-
$02-26$ y el 2015-12-18 que sepultan las superficies de ruptura de movimientos más antiguos, previos al 2006-02-26

Conjunto de deslizamientos. Es dificil precisar los límites entre unos y otros, ya que se afectan tom nolaciones son notorios, evidenciando retención dela $\mathrm{h}$

Conjunto de deslizamientos rotacionales y traslacionales. Los mayores son los rotacionales. Es son retrogresivas y sepultan la zona de agotamiento previas

Deslizamiento rotacional de varias decenas de metros. Tiene un cuerpo de agua en la zona de agotamiento y una reactivación retrogresiva juvenil (observación de campo del 2017-05-20) Conjunto de movimientos, en general deslizamientos rotacionales de pocos metros, generándose un relieve escalonado proximal y una topografía de montículos y depresiones distal. Es difícil separar un movimiento de otro, ya que se afectan entre sí

Conjunto de movimientos conformando una topografía hummocky. No se observan las escarpas pero las zonas de hundimiento son notorias. Las acumulaciones tienen terracettes y deslizamientos menores

Flujo de detritos y deslizamiento que coalescen al pie. El flujo aún conserva la escarpa y la cumulación, y tiene una reactivación en la acumulación. Del deslizamiento se conserva la zona Deslizamien ro

Duperficie de ruptura. El movimiento mayor está degradado y tiene te la roca o tosca en la agotamiento Deslizamiento traslacional mayor con varias reactivaciones progresivas. Sepulta a la planicie de
inundación y es erosionado tanto en la punta como dentro de la acumulación por la acción del

agua

Deslizamientos rotacionales con flujos distales, hay reactivaciones retrogresivas (observación de
campo del 2018-10-12) Deslizamiento rotacional con reactivaciones en la acumulación (observación de fotos del dron). La
superficie de ruptura tiene terracettes

Flujo de detritos y deslizamientos. Los deslizamientos parecen haberse producido a partir de la zona de agotamiento o la escarpa de un gran movimiento previo. Hay también reactivaciones en as acumulaciones de este gran movimiento

Topografía hummocky con numerosísimos movimientos de tipo deslizamiento, ocupando casi tod la ladera. Hay reactivaciones retrogresivas y ensanchantes

Conjunto de deslizamientos que se superponen unos a otros. Los movimientos de las cabeceras tienen roca en la superficie de ruptura, y los ubicados ladera abajo tienen zonas de hundimiento conspicuas (observación de campo)

Aflora tosca en la superficie de ruptura y presenta una acumulación degradada de casi $1 \mathrm{~m}$ de Zona

Sector de la ladera con relieve de montículos y depresiones (hummocky). No se observan

Deslizamientos múltiples degradados. Lavaje de materiales finos, se ven sólo las escarpas de campo)

Zona de agotamiento de un movimiento antiguo. No se conserva la escarpa y la acumulación Jene poca expresión. La zona de agotamiento está sepultada parcialmente por una reactivación retrogresiva

Conjunto de acumulaciones de detritos con morfología lobulada. Carecen de superficies de ruptura, posiblemente se trate de lóbulos de solifluxión

Antiguos movimientos, presentan dos zonas de agotamiento y una de acumulación muy conspicuas, así como el contraste en la vegetación. La morfología original está alterada por el escurrimiento superficial y movimientos menores

Acumulaciones de morfología lobulada. No se observan superficies de ruptura y las zonas de gotamiento son pequeñas. Puede verse el contraste de vegetación delineando la punta de las

Supe ficie de ruptura de flujo o deslizmiaciones acumulaciones

\begin{tabular}{|c|c|c|c|}
\hline $\begin{array}{l}\text { Escala de } \\
\text { Observación }\end{array}$ & Imagen & Longitud & Latitud \\
\hline IMG & $\begin{array}{l}\text { Google Earth - } \\
\text { Bing }\end{array}$ & -62.222784 & -37.742107 \\
\hline IMG & Google Earth & -62.226994 & -37.781014 \\
\hline IMG & Google Earth & -62.174660 & -37.734807 \\
\hline IMG & $\begin{array}{l}\text { Google Earth y } \\
\text { Bing }\end{array}$ & -62.172242 & -37.736813 \\
\hline IMG & Google Earth & -62.171321 & -37.737932 \\
\hline IMG & Google Earth & -62.166335 & -37.740863 \\
\hline IMG & Google Earth & -62.161265 & -37.745892 \\
\hline IMG & Google Earth & -62.150749 & -37.752601 \\
\hline IMG & $\begin{array}{c}\text { Google Earth y II- } \\
\text { R657-55 }\end{array}$ & -62.144530 & -37.748403 \\
\hline IMG & Google Earth & -62.145020 & -37.759836 \\
\hline IMG & $\begin{array}{l}\text { Google Earth y II- } \\
\text { R657-55 }\end{array}$ & -62.132795 & -37.758511 \\
\hline IMG & $\begin{array}{l}\text { Google Earth y II- } \\
\text { R657-55 }\end{array}$ & -62.126438 & -37.766092 \\
\hline IMG & $\begin{array}{l}\text { Google Earth y } \\
\text { dron }\end{array}$ & -62.137888 & -37.772176 \\
\hline IMG & $\begin{array}{l}\text { Google Earth y } \\
\text { dron }\end{array}$ & -62.140755 & -37.770343 \\
\hline IMG & $\begin{array}{l}\text { Google Earth y } \\
\text { Bing }\end{array}$ & -62.154161 & -37.780838 \\
\hline IMG & Google Earth & -62.248703 & -37.752608 \\
\hline IMG & Google Earth & -62.252081 & -37.749160 \\
\hline IMG & Google Earth & -62.215322 & -37.743902 \\
\hline IMG & Google Earth & -62.228304 & -37.780515 \\
\hline IMG & Google Earth & -62.218701 & -37.774221 \\
\hline IMG & Google Earth & -62.216202 & -37.737677 \\
\hline IMG & Google Earth & -62.156642 & -37.751366 \\
\hline IMG & $\begin{array}{l}\text { Google Earth y } \\
\text { Bing }\end{array}$ & -62.141116 & -37.752726 \\
\hline IMG & rth & 31017 & -37. \\
\hline
\end{tabular}




\begin{tabular}{|c|c|c|c|c|}
\hline Sub-zona & $\begin{array}{l}\text { Fecha de } \\
\text { Observación }\end{array}$ & Tipo & Estado & Edad relativa \\
\hline 2 & 2006-02-26 & Desc & Degradado & Previo al 2006-02-26 \\
\hline 2 & $2006-02-26$ & Desc & Degradado & Previo al 2006-02-26 \\
\hline 2 & $2006-02-26$ & Desc & Degradado & Previo al 2006-02-26 \\
\hline 2 & $2006-02-26$ & Desc & Degradado & Previo al 2006-02-26 \\
\hline 2 & $2006-02-26$ & Desc & Degradado & Previo al 2006-02-26 \\
\hline 2 & $2006-02-26$ & Desc & Indef & Previo al 2006-02-26 \\
\hline 2 & 2006-02-26 & Desc & Indef & Previo al 2006-02-26 \\
\hline 2 & 2006-02-26 & Desc & Indef & Previo al 2006-02-26 \\
\hline 2 & 2006-02-26 & Desc & Juvenil & Previo al 2006-02-26 \\
\hline 2 & $2006-02-26$ & Desc & Juvenil & Previo al 2006-02-26 \\
\hline 2 & 2006-02-26 & Desc & Juvenil & Previo al 2006-02-26 \\
\hline 2 & 2006-02-26 & Desc & Juvenil & Previo al 2006-02-26 \\
\hline 2 & $2006-02-26$ & DesI_cuña & Degradado & Previo al 2006-02-26 \\
\hline 2 & 2006-02-26 & Desl_gen & Degradado & Previo al 2006-02-26 \\
\hline 2 & $2006-02-26$ & Desl_gen & Degradado & Previo al 2006-02-26 \\
\hline 2 & 2006-02-26 & Desl_gen & Degradado & Previo al 2006-02-26 \\
\hline 2 & 2006-02-26 & Desl_gen & Degradado & Previo al 2006-02-26 \\
\hline 2 & 2006-02-26 & Desl_gen & Degradado & Previo al 2006-02-26 \\
\hline 2 & 2006-02-26 & DesI_gen & Degradado & Previo al 2006-02-26 \\
\hline 2 & 2006-02-26 & Desl_gen & Degradado & Previo al 2006-02-26 \\
\hline 2 & $2006-02-26$ & Desl_gen & Degradado & $\begin{array}{l}\text { Entre el 1967-02-25 y } \\
\text { el 2006-02-26 }\end{array}$ \\
\hline 2 & 2006-02-26 & Desl_gen & Degradado & Previo al 2006-02-26 \\
\hline 2 & 2006-02-26 & Desl_gen & Indef & Previo al 2006-02-26 \\
\hline 2 & 2006-02-26 & Desl_gen & Juvenil & Previo al 2006-02-26 \\
\hline 2 & 2006-02-26 & Desl_gen & Juvenil & Previo al 2006-02-26 \\
\hline 2 & 2006-02-26 & Desl_gen & Juvenil & Previo al 2006-02-26 \\
\hline 2 & 2006-02-26 & Desl_gen & Juvenil & Previo al 2006-02-26 \\
\hline 2 & 2006-02-26 & Desl_gen & Juvenil & Actual \\
\hline 2 & $2006-02-26$ & Desl_rotac & Degradado & Previo al 2006-02-26 \\
\hline 2 & 2006-02-26 & Desl_rotac & Degradado & Previo al 2006-02-26 \\
\hline
\end{tabular}

Movimiento elongado. Tiene una zona de agotamiento y una acumulación con poca expresión. Superficie de ruptura donde aflora la roca y acumulación con poca expresión, similar a la de un Acuriones superestas No se obserion supefices

uperpuestas. No se observan superficies de ruptura, aunque si hay cambios de

Movimiento muy degradado, pero de bloques enormes, que contrastan con los del resto de la

Deslizamiento o flujo. Se conserva la acumulación. La superficie de ruptura está muy vegetada Movimiento de suelo afectando una barranca. Se vincula a un camino de animales y sólo se Movimiento de suelo afectando una barranca. Se vincula a un camino
conserva la escarpa, de morfología cóncava

Acumulaciones lobuladas. No se observa una zona de agotamiento y son similares a lóbulos de múltiples y se afectan unos a otros

Varias acumulaciones con forma de $\mathrm{V}$. No se observan zonas de hundimiento o escarpas conspicuas. Similares a lóbulos de solifluxión

\section{Superficie de ruptura de deslizamiento o flujo en zona de pendientes elevadas}

Superficie de ruptura de deslizamiento o flujo en zona de pendientes elevadas

Superficie de ruptura de deslizamiento o flujo en zona de pendientes elevadas.

Movimiento afectando la acumulación de un flujo de detritos previo

Deslizamiento de grandes bloques rocosos métricos. El depósito carece de matriz y el frente escarpado rocoso del cual provienen los materiales ha retrocedido (observación de campo) Acumulación con forma de $V$. No se observa la superficie de ruptura

La acumulación tiene forma de $\vee$ y la zona de agotamiento está vegetada. No se observa la escarpa ni la superficie de ruptura
Sólo se conserva la superficie de ruptura; la acumulación habría estado donde se encuentra la
planicie de inundación

Deslizamiento de grandes dimensiones, movilizando casi toda la ladera. La punta tiene reactivaciones y es cortada por un flujo de detritos en la parte izquierda

Zona de agotamiento con gran contenido de humedad y muy vegetada (observación de campo del 2016-02-27). La escarpa no se conserva pero la acumulación tiene buena expresión morfológica. Hay una reactivación afectando la acumulación

Sólo se conserva la acumulación de un deslizamiento rotacional o traslacional

Zona de hundimiento y flanco izquierdo bien conservados. La acumulación está degradada pero dirección de la pendiente

Deslizamiento afectando la acumulación de un flujo de tierra previo

Brota agua en toda la superficie de ruptura, donde también hay terracettes (observación de

Reactivación progresiva en la punta de un deslizamiento. Tiene terracettes en la superficie de en la acumulación

Deslizamientos pequeños. Las escarpas y acumulaciones tienen buena expresión morfológica Reactivación ensanchante de un flujo de detritos mayor. La acumulación tiene buena expresión

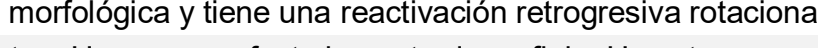

que se afectan escarpas bien delineadas

$$
\text { Reactivación de una acumulación más antigua }
$$
Deslizamientos de tierra múltiples asociados a terracettes y pisoteo (observación de campo del
2018-10-20). Las escarpas son muy conspicuas

La zona de agotamiento sólo se ve en el campo y tiene un pequeño relieve escalonado sobreimpuesto. La acumulación tiene poca expresión morfológica, pero se nota que sepulta oblicuamente la zona de agotamiento de otro movimiento (observación de campo)

La acumulación parece haber desviado el curso de agua; es muy notoria la disminución de la
pendiente del cauce en el tramo afectado por el movimiento (observación de campo 2018-12-12)

\begin{tabular}{|c|c|c|c|}
\hline $\begin{array}{l}\text { Escala de } \\
\text { Observación }\end{array}$ & Imagen & Longitud & Latitud \\
\hline IMG & Google Earth & -62.129963 & -37.762058 \\
\hline IMG & Google Earth & -62.122254 & -37.769311 \\
\hline IMG & Google Earth & -62.134254 & -37.774830 \\
\hline IMG & Google Earth & -62.139276 & -37.769487 \\
\hline IMG & Google Earth & -62.117839 & -37.784724 \\
\hline IMG & Google Earth & -62.166569 & -37.741567 \\
\hline IMG & $\begin{array}{l}\text { Google Earth y } \\
\text { dron }\end{array}$ & -62.146232 & -37.748557 \\
\hline IMG & Google Earth & -62.147670 & -37.760222 \\
\hline IMG & $\begin{array}{c}\text { Google Earth y } \\
\text { Bing }\end{array}$ & -62.188716 & -37.755582 \\
\hline IMG & $\begin{array}{l}\text { Google Earth y } \\
\text { Bing }\end{array}$ & -62.188518 & -37.754719 \\
\hline IMG & $\begin{array}{l}\text { Google Earth y } \\
\text { Bing }\end{array}$ & -62.187536 & -37.755732 \\
\hline IMG & Google Earth & -62.149362 & -37.753606 \\
\hline IMG & Google Earth & -62.218712 & -37.768444 \\
\hline IMG & Google Earth & -62.237345 & -37.736926 \\
\hline IMG & Google Earth & -62.237221 & -37.736700 \\
\hline IMG & Google Earth & -62.234165 & -37.754501 \\
\hline IMG & Google Earth & -62.216326 & -37.743564 \\
\hline IMG & Google Earth & -62.177256 & -37.751580 \\
\hline IMG & Google Earth & -62.169518 & -37.739100 \\
\hline IMG & $\begin{array}{l}\text { Google Earth y } \\
\text { dron }\end{array}$ & -62.146312 & -37.747858 \\
\hline IMG & $\begin{array}{l}\text { Google Earth y II- } \\
\text { R657-55 }\end{array}$ & -62.128593 & -37.765117 \\
\hline IMG & $\begin{array}{l}\text { Google Earth y } \\
\text { dron }\end{array}$ & -62.138283 & -37.771144 \\
\hline IMG & Google Earth & -62.144305 & -37.766362 \\
\hline IMG & $\mathrm{gg}$ & -62.121767 & -37.768850 \\
\hline IMG & $\begin{array}{l}\text { Google Earth y } \\
\text { dron }\end{array}$ & -62.140764 & -37.767982 \\
\hline IMG & $\begin{array}{l}\text { Google Earth y } \\
\text { dron }\end{array}$ & -62.143481 & -37.768615 \\
\hline IMG & $\begin{array}{l}\text { Google Earth y } \\
\text { dron }\end{array}$ & -62.142047 & -37.769308 \\
\hline IMG & $\begin{array}{l}\text { Google Earth y } \\
\text { campo }\end{array}$ & -62.141707 & -37.788862 \\
\hline IMG & Google Earth & -62.220221 & -37.740635 \\
\hline IMG & Google Earth & -62.222332 & -37.741531 \\
\hline
\end{tabular}




\begin{tabular}{|c|c|c|c|c|}
\hline Sub-zona & $\begin{array}{l}\text { Fecha de } \\
\text { Observación }\end{array}$ & Tipo & Estado & Edad relativa \\
\hline 2 & 2006-02-26 & Desl_rotac & Degradado & Previo al 2006-02-26 \\
\hline 2 & $2006-02-26$ & DesI_rotac & Degradado & Previo al 2006-02-26 \\
\hline 2 & $2006-02-26$ & DesI_rotac & Degradado & Previo al 2006-02-26 \\
\hline 2 & 2006-02-26 & Desl_rotac & Degradado & Previo al 2006-02-26 \\
\hline 2 & $2006-02-26$ & Desl_rotac & Juvenil & Previo al 2006-02-26 \\
\hline 2 & $2006-02-26$ & DesI_rotac & Juvenil & Previo al 2006-02-26 \\
\hline 2 & 2006-02-26 & Desl_rotac & Juvenil & Previo al 2006-02-26 \\
\hline 2 & $2006-02-26$ & DesI_rotac & Juvenil & Previo al 2006-02-26 \\
\hline 2 & $2006-02-26$ & DesI_rotac & Juvenil & Previo al 2006-02-26 \\
\hline 2 & $2006-02-26$ & DesI_rotac & Juvenil & Previo al 2006-02-26 \\
\hline 2 & $2006-02-26$ & DesI_rotac & Variable & Previo al 2006-02-26 \\
\hline 2 & $2006-02-26$ & Desl_trasl & Degradado & Previo al 2006-02-26 \\
\hline 2 & $2006-02-26$ & Desl_trasl & Degradado & Previo al 2006-02-26 \\
\hline 2 & $2006-02-26$ & Desl_trasl & Degradado & Previo al 2006-02-26 \\
\hline 2 & $2006-02-26$ & Desl_trasl & Degradado & Previo al 2006-02-26 \\
\hline 2 & $2006-02-26$ & Desl_trasl & Degradado & Previo al 2006-02-26 \\
\hline 2 & $2006-02-26$ & Desl_trasl & Degradado & Previo al 2006-02-26 \\
\hline 2 & $2006-02-26$ & Desl_trasl & Degradado & Previo al 2006-02-26 \\
\hline 2 & $2006-02-26$ & Desl_trasl & Degradado & Previo al 2006-02-26 \\
\hline 2 & $2006-02-26$ & Desl_trasl & Degradado & Previo al 2006-02-26 \\
\hline 2 & $2006-02-26$ & Desl_trasl & Degradado & Previo al 2006-02-26 \\
\hline 2 & $2006-02-26$ & Desl_trasl & Degradado & Previo al 2006-02-26 \\
\hline 2 & $2006-02-26$ & Desl_trasl & Degradado & Previo al 2006-02-26 \\
\hline 2 & $2006-02-26$ & Desl_trasl & Degradado & Previo al 2006-02-26 \\
\hline 2 & $2006-02-26$ & Desl_trasl & Degradado & Previo al 2006-02-26 \\
\hline 2 & $2006-02-26$ & Desl_trasl & Degradado & Previo al 2006-02-26 \\
\hline 2 & 2006-02-26 & Desl_trasl & Juvenil & Previo al 2006-02-26 \\
\hline 2 & $2006-02-26$ & Desl_trasl & Juvenil & Previo al 2006-02-26 \\
\hline 2 & 2006-02-26 & Desl_trasl & Juvenil & Previo al 2006-02-26 \\
\hline
\end{tabular}

Bloques enterrados en la parte posterior de la acumulación indicando antigüedad (observación de campo del 2016-04-16). No se encuentra la escarpa

Deslizamiento controlando al curso de agua. Tiene una reactivación progresiva cuyos materiales finos fueron lavados por el

La escarpa aún se conserva. Tiene reactivaciones y los bloques rocosos tienen cortezas de líquenes abundantes (observación de campo del 2018-10-20)

Deslizamiento de varias decenas de metros con mucho lavaje de materiales finos y muchas reactivaciones menores juveniles (observación de campo del 2018-10-22)

El sector tiene deslizamientos y caminos de animales. La tosca está unos $20 \mathrm{~cm}$ debajo de la superficie (observación de campo del 2018-10-23)

Deslizamientos rotacionales múttiples conformándose un relieve escalonado (observación de campo)

reactivación retrogresiva de un deslizamiento más antiguo, degradado

Reactivación retrogresiva de un movimiento complejo mayor

La escarpa presenta terracettes; tiene buena expresión morfológica todo el movimiento (observación de campo del 2018-10-22), por lo cual es posible que el movimiento esté activo Reactivación ensanchante de deslizamiento mayor

Tiene una zona de hundimiento muy notoria en el campo, y reactivaciones en la punta producidas entre el 2006-02-26 y el 2015-12-18 Deslizamiento elongado con una acumulación en forma de $V$. La escarpa y la superficie de
ruptura están degradadas, pero se observa la zona de agotamiento

Superficie de ruptura con tosca aflorante y acumulación degradada, menor a $1 \mathrm{~m}$ de altura (observación de campo)

Movimiento de varias decenas de metros, uno de los más grandes de la ladera. Tiene reactivaciones progresivas afectando la acumulación (observación de campo) Deslizamiento generado a partir de la acumulación de un deslizamiento previo Reactivación progresiva de un deslizamiento mayor. A su vez es afectado por reactivaciones retrogresivas de pocos metros producidas entre el 2006-02-26 y el 2011-04-10 La zona de agotamiento se ubica cerca de un afloramiento rocoso y la acumulación está
degradada por lavaje del material fino (observación de campo)

La acumulación está bien conservada y la superficie de ruptura tiene una inclinación menor que la del terreno no afectado (observación de campo)

Deslizamiento en forma de V. La acumulación tiene terracettes con buena expresión morfológica; las terracettes de la zona de agotamiento no tienen tan buena expresión como en el terreno no afectado (observación de campo)

Deslizamiento antiguo, se conserva la superficie de ruptura, pero no la escarpa, y la acumulación tiene poca expresión morfológica (observación de campo). Reactivación progresiva decreciente

Deslizamiento aparentemente más reciente que el vecino, la acumulación se apoya sobre la planicie de inundación. Tiene una reactivación progresiva previa al 2006-02-26 en la parte La superficie de ruptura está parcialmente sepultada por otro deslizamiento (observación de campo). La acumulación tiene bloques métricos

Dificil de identificar en la imagen debido a su grado de degradación. Brota as afloramiento ladera abajo (observación de campo del 2018-10-22)

Sólo se conserva la zona de agotamiento (observación de campo del 2018-10-27) Movimiento con buena expresión morfológica. Tiene reactivaciones retrogresivas de
deslizamientos rotacionales y desarrollo de terracettes en la escarpa. Hay reactivaciones en la

Deslizamiento con bloques rocosos enterrados (observación de campo del 2018-10-20). Tiene (a) es visible en el campo Reactivación progresiva lateral de un movimiento complejo

Deslizamiento elongado con afloramiento rocoso confinante en el flanco izquierdo y en la corona. (observación de campo)

El afloramiento rocoso queda expuesto en la superficie de ruptura. La morfología de los
afloramientos condiciona parcialmente la dirección del movimiento (observación de campo)

\begin{tabular}{|c|c|c|c|}
\hline $\begin{array}{l}\text { Escala de } \\
\text { Observación }\end{array}$ & Imagen & Longitud & Latitud \\
\hline IMG & Google Earth & -62.170174 & -37.738955 \\
\hline IMG & Google Earth & -62.159663 & -37.746226 \\
\hline IMG & Google Earth & -62.134207 & -37.757337 \\
\hline IMG & Google Earth & -62.128950 & -37.761590 \\
\hline IMG & Google Earth & -62.257813 & -37.750723 \\
\hline IMG & Google Earth & -62.251238 & -37.748908 \\
\hline IMG & Google Earth & -62.218646 & -37.773944 \\
\hline IMG & Google Earth & -62.122716 & -37.768406 \\
\hline IMG & Google Earth & -62.123338 & -37.769175 \\
\hline IMG & Google Earth & -62.142355 & -37.765232 \\
\hline IMG & $\begin{array}{l}\text { Google Earth y } \\
\text { Bing }\end{array}$ & -62.151457 & -37.784017 \\
\hline IMG & Google Earth & -62.224643 & -37.720998 \\
\hline IMG & Google Earth & -62.247908 & -37.751442 \\
\hline IMG & Google Earth & -62.220289 & -37.741175 \\
\hline IMG & Google Earth & -62.221415 & -37.741023 \\
\hline IMG & $\begin{array}{l}\text { Google Earth y } \\
\text { Bing }\end{array}$ & -62.221107 & -37.741714 \\
\hline IMG & Google Earth & -62.215570 & -37.741529 \\
\hline IMG & Google Earth & -62.215196 & -37.742064 \\
\hline IMG & Google Earth & -62.217291 & -37.744513 \\
\hline IMG & $\begin{array}{c}\text { Google Earth y } \\
\text { Bing }\end{array}$ & -62.223991 & -37.753731 \\
\hline IMG & Google Earth & -62.223758 & -37.753519 \\
\hline IMG & Google Earth & -62.213700 & -37.771652 \\
\hline IMG & Google Earth & -62.122872 & -37.769732 \\
\hline IMG & Google Earth & -62.129825 & -37.768269 \\
\hline IMG & Google Earth & -62.140650 & -37.768738 \\
\hline IMG & Google Earth & -62.153006 & -37.777511 \\
\hline IMG & Google Earth & -62.222610 & -37.722241 \\
\hline IMG & Google Earth & -62.219448 & -37.741712 \\
\hline IMG & Eart & -62.220868 & -37 \\
\hline
\end{tabular}




\begin{tabular}{|c|c|c|c|c|}
\hline Sub-zona & $\begin{array}{c}\text { Fecha de } \\
\text { Observación }\end{array}$ & Tipo & Estado & Edad relativa \\
\hline 2 & 2006-02-26 & DesI_trasl & Juvenil & Previo al 2006-02-26 \\
\hline 2 & 2006-02-26 & Desl_trasl & Juvenil & Previo al 2006-02-26 \\
\hline 2 & 2006-02-26 & Desl_trasl & Juvenil & Previo al 2006-02-26 \\
\hline 2 & 2006-02-26 & Desl_trasl & Juvenil & Actual \\
\hline 2 & 2006-02-26 & DesI_trasl & Juvenil & Previo al 2006-02-26 \\
\hline 2 & 2006-02-26 & Desl_trasl & Juvenil & Actual \\
\hline 2 & 2006-02-26 & DesI_trasl & Juvenil & $\begin{array}{l}\text { Entre el 1981-01-12 y } \\
\text { el 2006-02-26 }\end{array}$ \\
\hline 2 & 2006-02-26 & Flujo_desl & Degradado & Previo al 2006-02-26 \\
\hline 2 & $2006-02-26$ & Flujo_desl & Degradado & Previo al 2006-02-26 \\
\hline 2 & $2006-02-26$ & Flujo_desl & Degradado & Previo al 2006-02-26 \\
\hline 2 & 2006-02-26 & Flujo_desl & Degradado & Previo al 2006-02-26 \\
\hline 2 & $2006-02-26$ & Flujo_desl & Degradado & Previo al 2006-02-26 \\
\hline 2 & $2006-02-26$ & Flujo_desl & Degradado & Previo al 2006-02-26 \\
\hline 2 & 2006-02-26 & Flujo_desl & Indef & Previo al 2006-02-26 \\
\hline 2 & $2006-02-26$ & Flujo_desl & Juvenil & $\begin{array}{l}\text { Entre el 1981-01-12 y } \\
\text { el 2006-02-26 }\end{array}$ \\
\hline 2 & $2006-02-26$ & Flujo_desl & Juvenil & Previo al 2006-02-26 \\
\hline 2 & $2006-02-26$ & Flujo_desl & Juvenil & Previo al 2006-02-26 \\
\hline 2 & $2006-02-26$ & Flujo_detr & Degradado & Previo al 2006-02-26 \\
\hline 2 & $2006-02-26$ & Flujo_detr & Degradado & Previo al 2006-02-26 \\
\hline 2 & $2006-02-26$ & Flujo_detr & Degradado & Previo al 2006-02-26 \\
\hline 2 & 2006-02-26 & Flujo_detr & Degradado & Previo al 2006-02-26 \\
\hline 2 & $2006-02-26$ & Flujo_detr & Degradado & Previo al 2006-02-26 \\
\hline 2 & 2006-02-26 & Flujo_detr & Juvenil & Previo al 2006-02-26 \\
\hline 2 & 2006-02-26 & Flujo_detr & Juvenil & Previo al 2006-02-26 \\
\hline 2 & $2006-02-26$ & Flujo_detr & Juvenil & Previo al 2006-02-26 \\
\hline 2 & 2006-02-26 & Flujo_detr & Juvenil & Previo al 2006-02-26 \\
\hline 2 & 2006-02-26 & Flujo_detr & Variable & Previo al 2006-02-26 \\
\hline
\end{tabular}

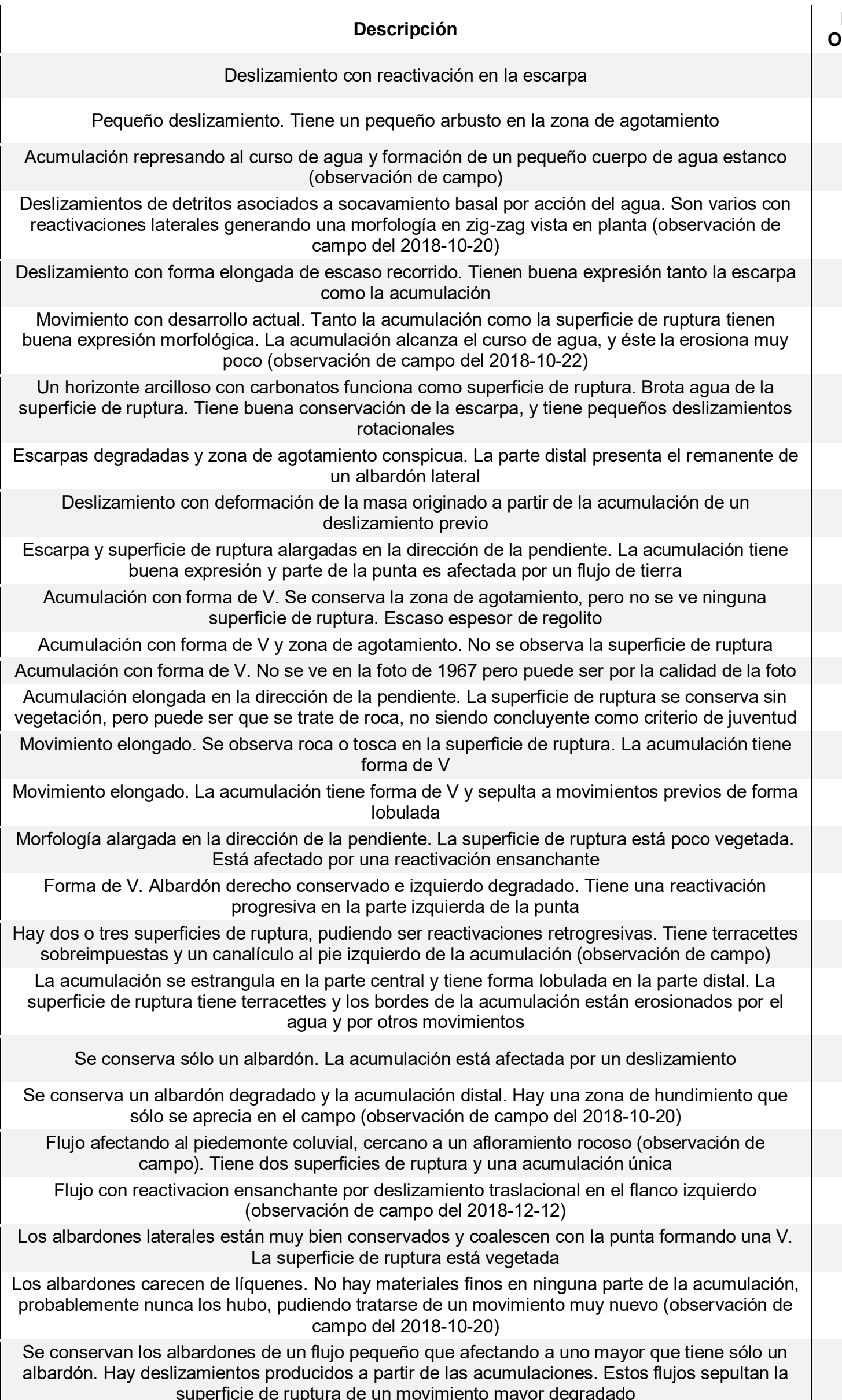

\begin{tabular}{|c|c|c|c|}
\hline $\begin{array}{l}\text { Escala de } \\
\text { Observación }\end{array}$ & Imagen & Longitud & Latitud \\
\hline IMG & Google Earth & -62.224182 & -37.754054 \\
\hline IMG & Google Earth & -62.228681 & -37.754771 \\
\hline IMG & Google Earth & -62.174473 & -37.731970 \\
\hline IMG & $\begin{array}{l}\text { Google Earth y } \\
\text { Bing }\end{array}$ & -62.144006 & -37.760098 \\
\hline IMG & Google Earth & -62.129199 & -37.763686 \\
\hline IMG & Google Earth & -62.128672 & -37.773348 \\
\hline IMG & $\begin{array}{c}\text { C384-20 y Google } \\
\text { Earth }\end{array}$ & -62.118096 & -37.785292 \\
\hline IMG & Google Earth & -62.236682 & -37.737104 \\
\hline IMG & Google Earth & -62.221451 & -37.741272 \\
\hline IMG & Google Earth & -62.150443 & -37.752420 \\
\hline IMG & Google Earth & -62.150718 & -37.759850 \\
\hline IMG & Google Earth & -62.133432 & $\begin{array}{l}37.774712 \\
37705500\end{array}$ \\
\hline IMG & II-R656-57 & -62.118299 & -37.785588 \\
\hline IMG & Google Earth & -62.150081 & -37.760727 \\
\hline IMG & $\begin{array}{c}\text { Google Earth y } \\
\text { C383-17 }\end{array}$ & -62.145112 & -37.749689 \\
\hline IMG & $\begin{array}{l}\text { Google Earth y } \\
\text { dron }\end{array}$ & -62.146347 & -37.748490 \\
\hline IMG & Google Earth & -62.141497 & -37.767936 \\
\hline IMG & Google Earth & -62.232545 & -37.739057 \\
\hline IMG & Google Earth & -62.224025 & -37.742110 \\
\hline IMG & Google Earth & -62.149530 & -37.753261 \\
\hline IMG & Google Earth & -62.146535 & -37.760265 \\
\hline IMG & Google Earth & -62.150851 & -37.784622 \\
\hline IMG & Google Earth & -62.216163 & -37.744740 \\
\hline IMG & Google Earth & -62.220325 & -37.747740 \\
\hline IMG & Google Earth & -62.144835 & -37.759279 \\
\hline IMG & Google Earth & -62.130509 & -37.760471 \\
\hline IMG & $\begin{array}{l}\text { Google Earth y } \\
\text { dron }\end{array}$ & -62.140963 & -37.769241 \\
\hline
\end{tabular}




\begin{tabular}{|c|c|c|c|c|}
\hline Sub-zona & $\begin{array}{l}\text { Fecha de } \\
\text { Observación }\end{array}$ & Tipo & Estado & Edad relativa \\
\hline 2 & 2006-02-26 & Flujo_tier & Degradado & Previo al 2006-02-26 \\
\hline 2 & $2006-02-26$ & Flujo_tier & Degradado & Previo al 2006-02-26 \\
\hline 2 & 2006-02-26 & Flujo_tier & Degradado & Previo al 2006-02-26 \\
\hline 2 & 2006-02-26 & Flujo_tier & Degradado & Previo al 2006-02-26 \\
\hline 2 & $2006-02-26$ & Flujo_tier & Juvenil & Actual \\
\hline 2 & 2006-02-26 & Flujo_tier & Juvenil & Actual \\
\hline 2 & 2006-02-26 & Flujo_tier & Juvenil & Actual \\
\hline 2 & 2006-02-26 & Flujo_tier & Juvenil & Actual \\
\hline 2 & 2006-02-26 & Flujo_tier & Juvenil & Actual \\
\hline 2 & 2015-12-18 & Desl_gen & Indef & Previo al 2015-12-18 \\
\hline 2 & 2015-12-18 & DesI_rotac & Juvenil & Previo al 2015-12-18 \\
\hline 2 & 2015-12-18 & DesI_rotac & Juvenil & $\begin{array}{l}\text { Entre el 2006-02-26 y } \\
\text { el 2015-12-18 }\end{array}$ \\
\hline 2 & 2015-12-18 & DesI_trasl & Juvenil & $\begin{array}{l}\text { Entre el 2006-02-26 y } \\
\text { el 2015-12-18 }\end{array}$ \\
\hline 2 & 2015-12-18 & Flujo_detr & Juvenil & $\begin{array}{l}\text { Entre el 2006-02-26 y } \\
\text { el 2015-12-18 }\end{array}$ \\
\hline 2 & 2018-10-20 & DesI_trasl & Juvenil & Previo al 2018-10-20 \\
\hline 2 & 2018-10-22 & Complejo & Juvenil & Actual \\
\hline 2 & 2018-12-12 & Flujo_tier & Juvenil & Actual \\
\hline 2 & 2018-12-12 & Flujo_tier & Juvenil & Actual \\
\hline 3 & $1967-07-03$ & Complejo & Variable & Previo al 1967-07-03 \\
\hline 3 & $1967-07-03$ & Complejo & Variable & Previo al 1967-07-03 \\
\hline 3 & $1967-07-03$ & Complejo & Variable & Previo al 1967-07-03 \\
\hline 3 & 1967-07-03 & Desl_rotac & Degradado & Previo al 1967-07-03 \\
\hline 3 & $1967-07-03$ & Flujo_detr & Degradado & Previo al 1967-07-03 \\
\hline 3 & 1967-07-03 & Flujo_detr & Indef & Previo al 1967-07-03 \\
\hline 3 & $1967-09-21$ & Complejo & Degradado & Previo al 1967-09-21 \\
\hline
\end{tabular}

Escarpa bien definida, $1 \mathrm{~m}$ de altura. Acumulación vegetada (observación de campo 2018-10-20) El espesor de suelo es escaso; la roca está muy cerca (observación de campo)

Morfología alargada. La acumulación tiene forma lobulada, se encuentra parcialmente afectada y es erosionada en su parte derecha por un curso de
zona de agotamiento con desarrollo de terracettes

Se conserva la acumulación, de morfologia lobada. La zona de hund identificable pero no se observa la superficie de ruptura ni la escarpa. Tiene deslizamientos pequeños en la punta

Presenta una zona de agotamiento conspicua y una acumulación con bloques rocosos con fábrica epositados ladera abajo

Flujo de tierra en actual desarrollo. Tiene una zona de agotamiento parcialmente sepultada por (a) el $2019-09-19$

Etapa inicial. Se vio en el campo (2018-12-08) agua acumulada en un sitio donde hacía 15 días que no llovia, en la bajada coluvial fina, y se observó acción de animales Flujo de tierra con acción de animales (observación de campo)

Escarpa cóncava y acumulación de poco recorrido. Se ve casi igual que en el 2006-02-26 Cabeceras de cárcava asociada a un manantial. Las escarpas de la cárcava tienen movimientos, algunos previos al 2006-02-26, otros entre esta fecha y el 2015-12-18. Hay una superficie de ruptura en desarrollo en la cabecera derecha

Pequeño deslizamiento afectando el límite entre la ladera distal y la faja aluvial

La superficie de ruptura está expuesta, parece tosca o roca. La acumulación tiene muy buena expresion morfológica. En el 2006 se ve una concentración de humedad, pero la acumulación aún no se había desarrollado

Presenta un albardón con buena expresión morfológica y una acumulación poco vegetada. La acumulación es lobulada y tiene material aportado por un pequeño deslizamiento Sepulta a movimiento mayor mucho más antiguo

Conjunto de deslizamientos traslacionales y flujos de tierra con desarrollo actual. Se observan fracturas y superficies de ruptura en el suelo (observación de campo). Los movimientos tienen

Escarpa conspicua, acumulación de agua en la zona de hundimiento y desarrollo de una Escalación con deformación de la masa. Parte de los materiales finos de la acumulación son
lacion lavados y redepositados en un abanico fino distal (observación de campo)

Escarpa en desarrollo, acumulación de agua en la zona de hundimiento y desarrollo de una

Movimiento grande con varias reactivaciones de deslizamientos y flujos. No se puede reconocer étipo de movimiento era inicialmente. Calcretes expuestos en el flanco izquierdo (observación de campo)

Conjunto de movimientos. El principal es un flujo de detritos, del cual se conservan ambos ardones, el derecho con mayor expresiôn. Tiene reactivaciones ensanchantes y progresivas. Hay una zona de hundimiento muy grande al pie de una canaleta rocosa

Conjunto de desizamientos traslacionales y rotacionales afectando la tosca. Hay reactivaciones ensanchantes, progresivas y retrogresivas. Hay una reactivación lateral actual que se produce

La acumulación tiene poca expresión y reactivaciones, y la escarpa tiene terracettes. En las imágenes del 2006 ya no se observa. Tenía ambos albardones y reactivaciones en sus laterales

Conserva ambos albardones y la superficie de ruptura, pero la acumulación no es identificable. Actualmente está degradado por otros movimientos, lavado y se conserva sólo el albardón Conjunto de deslizamientos rotacionales. Hay una escarpa mayor y reactivaciones dentro de la superficie de ruptura (observación de campo). Se ha formado un curso de agua en el borde

\begin{tabular}{|c|c|c|c|}
\hline $\begin{array}{l}\text { Escala de } \\
\text { Observación }\end{array}$ & Imagen & Longitud & Latitud \\
\hline IMG & Google Earth & -62.265304 & -37.760237 \\
\hline IMG & Google Earth & -62.239336 & -37.760360 \\
\hline IMG & $\begin{array}{l}\text { Google Earth y } \\
\text { dron }\end{array}$ & -62.145055 & -37.747686 \\
\hline IMG & Google Earth & -62.142059 & -37.768489 \\
\hline IMG & Google Earth & -62.242900 & -37.745581 \\
\hline IMG & Google Earth & -62.237962 & -37.746187 \\
\hline IMG & Google Earth & -62.223088 & -37.779578 \\
\hline IMG & Google Earth & -62.224618 & -37.779219 \\
\hline IMG & Google Earth & -62.217519 & -37.775339 \\
\hline IMG & Bing & -62.161739 & -37.744589 \\
\hline IMG & Bing & -62.219893 & -37.774695 \\
\hline IMG & $\begin{array}{l}\text { Google Earth, } \\
\text { Bing y dron }\end{array}$ & -62.144035 & -37.768221 \\
\hline IMG & $\begin{array}{l}\text { Google Earth y } \\
\text { Bing }\end{array}$ & -62.148416 & -37.784943 \\
\hline IMG & Bing & -62.149372 & -37.751868 \\
\hline CMP & Campo & -62.132068 & -37.758388 \\
\hline IMG & Google Earth & -62.128127 & -37.772778 \\
\hline IMG & Google Earth & -62.243848 & -37.755226 \\
\hline IMG & Google Earth & -62.243430 & -37.755361 \\
\hline IMG & II-R651-66 & -62.177414 & -37.950107 \\
\hline IMG & II-R651-66 y dron & -62.175893 & -37.948801 \\
\hline IMG & $\begin{array}{l}\text { II-R651-66 y } \\
\text { Google Earth }\end{array}$ & -62.181569 & -37.940816 \\
\hline IMG & II-R651-66 & -62.155943 & -37.939404 \\
\hline IMG & II-R651-66 & -62.177214 & -37.946372 \\
\hline IMG & II-R651-66 & -62.176264 & -37.945848 \\
\hline IMG & II-RH651-076 & -62.154644 & -37.9366 \\
\hline
\end{tabular}




\begin{tabular}{|c|c|c|c|c|}
\hline Sub-zona & $\begin{array}{l}\text { Fecha de } \\
\text { Observación }\end{array}$ & Tipo & Estado & Edad relativa \\
\hline 3 & $1967-09-21$ & Complejo & Degradado & Previo al 1967-09-21 \\
\hline 3 & 1967-09-21 & Complejo & Variable & Previo al 1967-09-21 \\
\hline 3 & 1967-09-21 & Complejo & Variable & Previo al 1967-09-21 \\
\hline 3 & 1967-09-21 & Complejo & Variable & Previo al 1967-09-21 \\
\hline 3 & 1967-09-21 & Complejo & Variable & Previo al 1967-09-21 \\
\hline 3 & 1967-09-21 & Desc & Degradado & Previo al 1967-09-21 \\
\hline 3 & 1967-09-21 & Desc & Degradado & Previo al 1967-09-21 \\
\hline 3 & $1967-09-21$ & Desc & Degradado & Previo al 1967-09-21 \\
\hline 3 & 1967-09-21 & Desl_gen & Degradado & Previo al 1967-09-21 \\
\hline 3 & 1967-09-21 & Desl_gen & Degradado & Previo al 1967-09-21 \\
\hline 3 & 1967-09-21 & DesI_gen & Degradado & Previo al 1967-09-21 \\
\hline 3 & 1967-09-21 & DesI_rotac & Degradado & Previo al 1967-09-21 \\
\hline 3 & 1967-09-21 & Desl_rotac & Degradado & Previo al 1967-09-21 \\
\hline 3 & 1967-09-21 & DesI_trasl & Degradado & Previo al 1967-09-21 \\
\hline 3 & $196 /-09-21$ & DesI_trasl & Degrado & Previo al $196 /-09-21$ \\
\hline 3 & 1967-09-21 & Desl_trasl & Indef & Previo al 1967-09-21 \\
\hline 3 & 1967-09-21 & DesI_trasl & Indef & Previo al 1967-09-21 \\
\hline 3 & 1967-09-21 & Desl_trasl & Variable & Previo al 1967-09-21 \\
\hline 3 & 1967-09-21 & Flujo_detr & Degradado & Previo al 1967-09-21 \\
\hline 3 & 1967-09-21 & Flujo_detr & Degradado & Previo al 1967-09-21 \\
\hline 3 & $1967-09-21$ & Flujo_detr & Degradado & Previo al 1967-09-21 \\
\hline 3 & 1967-09-21 & Flujo_detr & Degradado & Previo al 1967-09-21 \\
\hline 3 & 2006-02-26 & Complejo & Variable & Previo al 2006-02-26 \\
\hline 3 & $2006-02-26$ & Complejo & Variable & Previo \\
\hline
\end{tabular}

Conjunto de deslizamientos rotacionales y traslacionales. Las acumulaciones distales scarpas son de a un deslizamiento mayor con reactivaciones en la acumulación. Las escarpantos posteriores que sepultan la superficie de ruptura previas
de

Conjunto de deslizamientos y flujos de detritos. Hay reactivaciones entre 1967 y el 2006-02-26. Un deslizamiento desvía un curso de agua

Conjunto de deslizamientos rotacionales y traslacionales. Hay un deslizamiento rotacional mayor con reactivaciones retro, progresivas y ensanchantes. Hay superficies de ruptura Detritos de Ladera

Conjunto de movimientos de morfología elongada en la dirección de la pendiente. Hay algunas juveniles en el 2006
jectivaciones retrogresivas pequeñas producidas entre

Conjunto de flujos de detritos, de tierra y deslizamientos traslacionales. Algunos se ven juveniles otros degradados el 2015-12-19. Los más juveniles se ubican ladera arriba. El flujo de tierra

Zona de hundimiento de deslizamiento o flujo. Prácticamente no se identifica el 2006-02-26 Se conserva sólo parte de una acumulación, erosionada por un cauce. La forma del cauce parece bordear la zona de hundimiento

Se conserva sólo la acumulación con una morfología similar a una

Se conserva la acumulación y una zona de agotamiento con muy poca expresión morfológica. La escarpa esta degradada (observación de campo del 2018-03-22) Sólo se conserva la superficie de ruptura

Se conservan la acumulación y la zona de hundimiento. La acumulación está degradada y

iento grande del cual se conservan la acumulación, la zona de hundimiento y par escarpa, la última parcialmente sepultada por un deslizamiento traslacional. Tiene una eactivación ensanchante en el flanco derecho

Deslizamiento con una gran zona de hundimiento donde se genera un cuerpo de agua. Represa Lazocion Lumulación tiene mejor expresión exagerada por excavación lateral debido a la acción hídrica Dos deslizamientos de los cuales el menor afecta la escarpa del mayor más antiguo La expresión de la acumulación mayor está exagerada por la acción hídrica en uno de sus bordes. Desviaban a un cauce que actualmente los erosiona
Despresion de la acumulación mayor está exagerada por la ación

Deslizamiento aparentemente joven en una imagen del 2006-02-26, pero con poca expresión en 1967. En el 2006 se ven dos escarpas y una acumulación muy conspicua. Aguas arriba hay un zona elongada en la dirección de la pendiente que concentra el agua

Deslizamiento con poca expresión morfológica, con reactivación de flujo de detritos entre el 1967 $09-21$ y el 2006-02-26

Movimiento mayor con reactivaciones traslacionales producidas entre 1967 y el 2006-02-26

Forma de $\mathrm{V}$, escarpa no distinguible, pero con albardones y zona de hundimiento presentes

Se ve bien la superficie de ruptura y la punta de la acumulación. Los albardones no tienen buena expresión morfológica, pero en la imagen del 2006-02-26 se los ablican dos lineaciones de bloques según la dirección de la pendiente

Flujos de detritos mútitiples, con varios albardones y acumulaciones degradadas por cursos de gua. Hay reactivaciones progresivas y retrogresivas entre 1967 y el 2006-02-26 Se conservan la superficie de ruptura y ambos albardones, aunque por partes. Está afectado por Conjunto de deslizamientos y flujos de detritos superpuestos, dificiles de separar. Unos ocurrieron 作 09-21, pero algunos se produjeron antes. Los más modernos tienen mayor expresión de flujo.

\begin{tabular}{|c|c|c|c|}
\hline $\begin{array}{l}\text { Escala de } \\
\text { Observación }\end{array}$ & Imagen & Longitud & Latitud \\
\hline IMG & $\begin{array}{l}\text { II-RH651-076 y } \\
\text { Google Ear }\end{array}$ & -62.156813 & -37.933717 \\
\hline IMG & Google Earth & -62.154895 & -37.934108 \\
\hline IMG & II-RH651-076 & -62.150312 & -37.938349 \\
\hline IMG & $\begin{array}{l}\text { II-RH651-076 y } \\
\text { Google Earth }\end{array}$ & -62.142491 & -37.924772 \\
\hline IMG & $\begin{array}{c}\text { II-RH651-076 y } \\
\text { Bing }\end{array}$ & -62.137150 & -37.921682 \\
\hline IMG & $\begin{array}{l}\text { II-RH651-076 y } \\
\text { Google Earth }\end{array}$ & -62.137586 & -37.920834 \\
\hline IMG & $\begin{array}{c}\text { II-RH651-076 y } \\
\text { Bing }\end{array}$ & -62.130792 & -37.925587 \\
\hline IMG & $\begin{array}{c}\text { II-RH651-076 y } \\
\text { Bing }\end{array}$ & -62.129772 & -37.925299 \\
\hline IMG & II-RH651-076 & -62.155202 & -37.937727 \\
\hline IMG & II-RH651-076 & -62.154998 & -37.936373 \\
\hline IMG & II-RH651-076 & -62.150448 & -37.936450 \\
\hline IMG & II-RH651-077 & -62.144735 & -37.929439 \\
\hline IMG & $\begin{array}{l}\text { II-RH651-076 y } \\
\text { Google Earth }\end{array}$ & -62.143104 & -37.926704 \\
\hline IMG & $\begin{array}{l}\text { II-RH651-076 y } \\
\text { Google Earth }\end{array}$ & -62.150843 & -37.930247 \\
\hline IMG & II-RH651-076 & -62.141777 & -37.923814 \\
\hline IMG & $\begin{array}{l}\text { II-RH651-076 y } \\
\text { Google Earth }\end{array}$ & -62.158752 & -37.932304 \\
\hline IMG & $\begin{array}{l}\text { I-RH651-076 y } \\
\text { Google Earth }\end{array}$ & -62.143523 & -37.926753 \\
\hline IMG & $\begin{array}{l}\text { II-RH651-076 y } \\
\text { Google Earth }\end{array}$ & -62.144008 & -37.927806 \\
\hline IMG & $\begin{array}{l}\text { II-RH651-076 y } \\
\text { Google Earth }\end{array}$ & -62.149851 & -37.933149 \\
\hline IMG & $\begin{array}{l}\text { II-RH651-076 y } \\
\text { Google Earth }\end{array}$ & -62.151506 & -37.930658 \\
\hline IMG & $\begin{array}{l}\text { II-RH651-076 y } \\
\text { Google Earth }\end{array}$ & -62.146534 & -37.930542 \\
\hline IMG & $\begin{array}{c}\text { II-RH651-077 y } \\
\text { Bing }\end{array}$ & -62.144523 & -37.928334 \\
\hline IMG & $\begin{array}{l}\text { II-RH651-076 y } \\
\text { Google Earth }\end{array}$ & -62.143063 & -37.922995 \\
\hline IMG & $\begin{array}{l}\text { II-RH651-076 y } \\
\text { Google Earth }\end{array}$ & -62.141538 & -37.920677 \\
\hline
\end{tabular}




\begin{tabular}{|c|c|c|c|c|}
\hline Sub-zona & $\begin{array}{l}\text { Fecha de } \\
\text { Observación }\end{array}$ & Tipo & Estado & Edad relativa \\
\hline 3 & $2006-02-26$ & Desc & Indef & $\begin{array}{l}\text { Entre el 1967-09-21 y } \\
\text { el 2006-02-26 }\end{array}$ \\
\hline 3 & $2006-02-26$ & Desl_rotac & Juvenil & $\begin{array}{l}\text { Entre el 1967-09-21 y } \\
\text { el 2006-02-26 }\end{array}$ \\
\hline 3 & $2006-02-26$ & Desl_trasl & Degradado & Previo al 2006-02-26 \\
\hline 3 & $2006-02-26$ & DesI_trasl & Juvenil & $\begin{array}{l}\text { Entre el 1967-09-21 y } \\
\text { el 2006-02-26 }\end{array}$ \\
\hline 3 & $2006-02-26$ & Flujo_desl & Juvenil & Previo al $2006-02-26$ \\
\hline 3 & $2006-02-26$ & Flujo_desI & Juvenil & $\begin{array}{l}\text { Entre el 1967-09-21 y } \\
\text { el 2006-02-26 }\end{array}$ \\
\hline 3 & $2006-02-26$ & Flujo_detr & Degradado & $\begin{array}{l}\text { Entre el 1967-09-21 y } \\
\text { el 2006-02-26 }\end{array}$ \\
\hline 3 & $2006-02-26$ & Flujo_detr & Juvenil & $\begin{array}{l}\text { Entre el 1967-09-21 y } \\
\text { el 2006-02-26 }\end{array}$ \\
\hline 3 & 2006-02-26 & Flujo_tier & Indef & Previo al 2006-02-26 \\
\hline 3 & 2006-02-26 & Flujo_tier & Juvenil & Previo al 2006-02-26 \\
\hline 3 & 2006-02-26 & Flujo_tier & Juvenil & Previo al 2006-02-26 \\
\hline 3 & $2006-02-26$ & Vuelco_sue & Degradado & Previo al 2006-02-26 \\
\hline 3 & $2015-12-18$ & Complejo & Variable & Previo al 2015-12-18 \\
\hline 3 & 2015-12-18 & Flujo_tier & Variable & Previo al 215-12-18 \\
\hline 3 & 2018-03-20 & Desl_trasl & Juvenil & $\begin{array}{l}\text { Entre el 2015-12-18 y } \\
\text { el 2018-03-20 }\end{array}$ \\
\hline 3 & 2018-03-20 & Desl_trasl & Juvenil & $\begin{array}{l}\text { Entre el 2015-12-18 y } \\
\text { el 2018-03-20 }\end{array}$ \\
\hline 3 & 1967-07-03 & Complejo & Variable & Previo al $1967-07-03$ \\
\hline 3 & $1967-07-03$ & Complejo & Variable & Previo al $1967-07-03$ \\
\hline 3 & $1967-07-03$ & Complejo & Variable & Previo al $1967-07-03$ \\
\hline 3 & 1967-07-03 & DesI_rotac & Degradado & Previo al 1967-07-03 \\
\hline 3 & 1967-07-03 & Flujo_detr & Degradado & Previo al 1967-07-03 \\
\hline 3 & $1967-07-03$ & Flujo_detr & Indef & Previo al 1967-07-03 \\
\hline 3 & $1967-09-21$ & Complejo & Degradado & Previo al 1967-09-21 \\
\hline 3 & $1967-0$ & omplejo & Degradado & Previo al 1967-09-21 \\
\hline
\end{tabular}

Escala de

Imagen

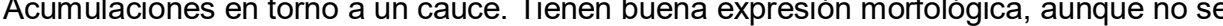
rápida por estar en un cauce

En notorio el cambio de vegetación en la zona de hundimiento

Se conserva la acumulación y la superficie de ruptura con forma más o menos irregular. Está muy cerca de los afloramientos rocosos. La acumulación cubre parte de la escarpa de un movimiento previo mayor

Escarpa con forma cóncava y escasa separación de la masa. La acumulación está bien definida y sepulta la zona de agotamiento de un flujo de detritos antiguo

Múltiples con tosca y alloramion pequeño
Movimiento ención tiene forma de $V$. Tien

Movimiento elongado en la dirección de la pendiente, cuya acumulación tiene forma de V. Tiene buena expresión morfológica, aunque la superficie de ruptura está vegetada

Tiene ambos albardones, aunque mal preservados (observación de campo del 2019-01-19). Se produjo afectando a un deslizamiento traslacional mayor, previo al 1967-09-21

\section{Albardones bien definidos y acumulación presente}

La escarpa tiene buena expresión, pero la acumulación está bastante vegetada y no tiene buena expresion morfológica. La acumulación tiene forma lobulada, y se observa una superposición sobre una acumulación más antigua (posible actividad múltiple) La escarpa es rectilinea y tiene reactivaciones retrogresivas. El material es limoso y esta muy
deformado. Se asocia a caminos de animales (observación de campo del 2018-03-22) Se observa una acumulación con mucha deformación de la masa, y dos escarpas pequeñas de
posibles reactivaciones

Vuelco de un bloque de suelo de varios metros con un camino de animales degradando e contacto entre éste y el terreno no afectado (observación de campo del 2018-03-21) Conjunto de flujos de detritos y deslizamientos traslacionales. Hay una reactivación producida luego del 2006-02-26, otras entre el 1967-09-21 y el 2006-02-26, y otros movimientos son previos Flujo cuya masa tiene mucha deformación, con acumulación elongada y lobulada. Ya estaba el 1967-09-21, pero es mayor en el 2015 y se ven sectores sin vegetación contrastantes con el entorno

Deslizamiento pequeño reactivando la escarpa degradada de un movimiento complejo mucho mayor. Los bloques están desenterrados y aún no creció la vegetación (observación de campo) Deslizamiento pequeño reactivando la escarpa degradada de un movimiento complejo mayor.
LOs bloques están desenterrados y aún no creció la vegetación (observación de campo) LOs bloques están desenterrados y aún no creció la vegetación (observación de campo) Movimiento grande con varias reactivaciones de deslizamientos y flujos. No se puede reconocer
qué tipo de movimiento era inicialmente. Calcretes expuestos en el flanco izquierdo (observación
de campo) Conjunto de movimientos. El principal es un flujo de detritos, del cual se conservan ambos
bardones, el derecho con mayor expresión. Tiene reactivaciones ensanchantes y progresivas. Hay una zona de hundimiento muy grande al pie de una canaleta rocosa
Hagres

Conjunto de deslizamientos traslacionales y rotacionales afectando la tosca. Hay reactivaciones ensanchantes, progresivas y retrogresivas. Hay una reactivación lateral actual que se produce

La acumulación tiene poca expresión y reactivaciones, y la escarpa tiene terracettes

En las imágenes del 2006 ya no se observa. Tenía ambos albardones y reactivaciones en sus laterales

Conserva ambos albardones y la superficie de ruptura, pero la acumulación no es identificable. Actualmente está degradado por otros movimientos, lavado y se conserva sólo el albardón derecho (observación de campo del 2018-03-20)

Conjunto de deslizamientos rotacionales. Hay una escarpa mayor y reactivaciones dentro de la superficie de ruptura (observación de campo). Se ha formado un curso de agua en el borde derecho de la acumulación, donde también hay reactivaciones

Conjunto de deslizamientos rotacionales y traslacionales. Las acumulaciones distales

ponden a un deslizamiento mayor con reactivaciones en la acumulación. Las escarpas son

\begin{tabular}{l|l} 
Google Earth & -62.150729
\end{tabular}

Google Earth

Google Earth

$-62.137275$

RH651-076 y Google Earth

Google Earth

II-RH651-077 y

Google Earth Google Earth y Bing

Google Earth y

Google Earth

Google Earth y

Google Earth y
campo

-RH651-076,

Google y Bing

II-RH651-077 y

Bing

Dron

II-R651-66

$-62.150609$

$-62.147581$

$-62.144185$

$-62.151197$

$-62.155842$

$-62.159381$

$-62.148850$

$-62.172586$

$-62.135316$

$-62.143872$

$-62.178200$

$-62.178200$

$-62.177414$

II-R651-66 y dron $\quad-62.175893$

II-R651-66 y

$-62.181569$

II-R651-66

II-R651-66

II-R651-66

$-62.155943$

$-62.177214$

$-62.176264$

II-RH651-076

$-62.154644$

II-RH651-076 y

Google Earth
$-37.931057$

$-37.930483$

$-37.928993$

$-37.927800$

$-37.935846$

$-37.930116$

$-37.926408$

$-37.930537$

$-37.936784$

$-37.940270$

$-37.936997$

$-37.936452$

$-37.930194$

$-37.929299$

$-37.949547$

$-37.949547$

$-37.950107$

$-37.948801$

$-37.940816$

$-37.939404$

$-37.946372$

$-37.945848$

$-37.936684$

\begin{tabular}{l|l}
-62.156813 & -37.933717
\end{tabular} 


\begin{tabular}{|c|c|c|c|c|}
\hline Sub-zona & $\begin{array}{l}\text { Fecha de } \\
\text { Observación }\end{array}$ & Tipo & Estado & Edad relativa \\
\hline 3 & 1967-09-21 & Complejo & Variable & Previo al 1967-09-21 \\
\hline 3 & $1967-09-21$ & Complejo & Variable & Previo al 1967-09-21 \\
\hline 3 & 1967-09-21 & Complejo & Variable & Previo al 1967-09-21 \\
\hline 3 & 1967-09-21 & Complejo & Variable & Previo al 1967-09-21 \\
\hline 3 & 1967-09-21 & Desc & Degradado & Previo al 1967-09-21 \\
\hline 3 & 1967-09-21 & Desc & Degradado & Previo al 1967-09-21 \\
\hline 3 & 1967-09-21 & Desc & Degradado & Previo al 1967-09-21 \\
\hline 3 & 1967-09-21 & Desl_gen & Degradado & Previo al 1967-09-21 \\
\hline 3 & 1967-09-21 & Desl_gen & Degradado & Previo al 1967-09-21 \\
\hline 3 & 1967-09-21 & Desl_gen & Degradado & Previo al 1967-09-21 \\
\hline 3 & 1967-09-21 & Desl_rotac & Degradado & Previo al 1967-09-21 \\
\hline 3 & 1967-09-21 & Desl_rotac & Degradado & Previo al 1967-09-21 \\
\hline 3 & 1967-09-21 & Desl_trasl & Degradado & Previo al 1967-09-21 \\
\hline 3 & 1967-09-21 & Desl_trasl & Degrado & Previo al 1967-09-21 \\
\hline 3 & 1967-09-21 & Desl_trasl & Indef & Previo al 1967-09-21 \\
\hline 3 & 1967-09-21 & Desl_trasl & Indef & Previo al 1967-09-21 \\
\hline 3 & 1967-09-21 & Desl_trasl & Variable & Previo al 1967-09-21 \\
\hline 3 & 1967-09-21 & Flujo_detr & Degradado & Previo al 1967-09-21 \\
\hline 3 & 1967-09-21 & Flujo_detr & Degradado & Previo al 1967-09-21 \\
\hline 3 & 1967-09-21 & Flujo_detr & Degradado & Previo al 1967-09-21 \\
\hline 3 & 1967-09-21 & Flujo_detr & Degradado & Previo al 1967-09-21 \\
\hline 3 & 2006-02-26 & Complejo & Variable & Previo al 2006-02-26 \\
\hline 3 & $2006-02-26$ & Complejo & Variable & Previo al 2006-02-26 \\
\hline 3 & $2006-02-26$ & Desc & Indef & $\begin{array}{l}\text { Entre el 1967-09-21 y } \\
\text { el 2006-02-26 }\end{array}$ \\
\hline 3 & $2006-02-26$ & Desl_rotac & Juvenil & $\begin{array}{l}\text { Entre el 1967-09-21 y } \\
\text { el 2006-02-26 }\end{array}$ \\
\hline
\end{tabular}

Conjunto de deslizamientos y flujos de detritos. Hay reactivaciones entre 1967 y el 2006-02-26. desizaniesto

(a) muy degradado con reactivaciones retro, progresivas y ensanchantes. Hay superficies de ruptura en contacto Mb. Cementado-Mb. Suelto de los Detritos de Ladera

Conjunto de movimientos elongados en la dirección de la pendiente. Hay algunas reactivaciones retrogresivas pequeñas producidas entre 1967 y el 2006-02-26, que se ven juveniles en el 2006 Conjunto de flujos de detritos, de tierra y deslizamientos traslacionales. Algunos se ven juveniles y otros degradados el 2015-12-19. Los más juveniles se ubican ladera arriba. El flujo de tierra parece actual, es el que mejor expresión tiene

Zona de hundimiento de deslizamiento o flujo. Prácticamente no se identifica el 2006-02-26 Se conserva sólo parte de una acumulación, erosionada por un cauce. La forma del cauce parece bordear la zona de hundimiento

Se conserva sólo la acumulación con una morfología similar a una $V$

Se conserva la acumulación y una zona de agotamiento con muy poca expresión morfológica. La escarpa está degradada (observación de campo del 2018-03-22)

$$
\text { Sólo se conserva la superficie de ruptura }
$$

Se conservan la acumulación y la zona de hundimiento. La acumulación está degradada y

Movimiento grande del cual se conservan la acumulación, la zona de hundimiento y parte de la escarpa, la última parcialmente sepultada por un deslizamiento traslacional. Tiene una

Deslizamiento con una gran zona de hundimiento donde se genera un cuerpo de agua. Represa a La zona de hundimiento se conserva pero no la escarpa En la imagen de 2006-02-26 la acumulación tiene mejor expresión debido a una exageración por excavación de sus bordes debido a la acción hídrica

Dos deslizamientos, de los cuales el menor afecta la escarpa del mayor, más antiguo. La Desviaban a un cauce que actualmente los erosiona

Deslizamiento aparentemente joven en una imagen del 2006-02-26, pero con poca expresión en 1967. En el 2006 se ven dos escarpas y una acumulaciôn muy conspicua. Aguas arriba hay una zona elongada en la dirección de la pendiente que concentra el agua

Deslizamiento con poca expresión morfológica, con reactivación de flujo de detritos entre el 1967 -

Movimiento mayor con numerosas reactivaciones traslacionales entre 1967 y el 2006-02-26

Forma de $\mathrm{V}$, escarpa no distinguible, pero con albardones y zona de hundimiento presentes

Se ve bien la superficie de ruptura y la punta de la acumulación. Los albardones no tienen buena expresión morfológica, pero en y imagen del 2006-02-26 se identifican dos lineaciones de bloques según la dirección de la pendiente

lujos de detritos múltiples, con varios albardones y acumulaciones degradadas por cursos de gua. Hay reactivaciones progresivas y retrogresivas entre 1967 y el 2006-02-26

Se conservan la superficie de ruptura y ambos albardones, aunque por partes. Está afectado por muchos movimientos, algunos posteriores a 1967

Conjunto de deslizamientos y flujos de detritos, difíciles de separar unos de otros, ya que se superponen entre si. Algunos ocurrieron antes y otros después del 1967-09-21. La mayoria de las reactivaciones son retrogresivas

Conjunto de deslizamientos y flujos de detritos. En general se ven juveniles, producidos luego de Acumulaciones en torno a un cauce. Tienen buena expresión morfológica, aunque no se conservan las escarpas. Esto no determina que sean antiguas, ya que su erosión puede ser

\begin{tabular}{|c|c|c|c|}
\hline $\begin{array}{l}\text { Escala de } \\
\text { Observación }\end{array}$ & Imagen & Longitud & Latitud \\
\hline IMG & Google Earth & -62.154895 & -37.934108 \\
\hline IMG & II-RH651-076 & -62.150312 & -37.938340 \\
\hline IMG & $\begin{array}{l}\text { II-RH651-076 y } \\
\text { Google Earth }\end{array}$ & -62.142491 & -37.924772 \\
\hline IMG & $\begin{array}{c}\text { II-RH651-076 y } \\
\text { Bing }\end{array}$ & -62.137150 & -37.921682 \\
\hline IMG & $\begin{array}{l}\text { II-RH651-076 y } \\
\text { Google Ear }\end{array}$ & -62.137586 & -37.920834 \\
\hline IMG & $\begin{array}{c}\text { II-RH651-076 y } \\
\text { Bing }\end{array}$ & -62.130792 & -37.925587 \\
\hline IMG & $\begin{array}{c}\text { II-RH651-076 y } \\
\text { Bing }\end{array}$ & -62.129772 & -37.925290 \\
\hline IMG & II-RH651-076 & -62.155202 & -37.937727 \\
\hline IMG & II-RH651-076 & -62.154998 & -37.936373 \\
\hline IMG & II-RH651-076 & -62.150448 & -37.936450 \\
\hline IMG & II-RH651-077 & -62.144735 & -37.929439 \\
\hline IMG & $\begin{array}{l}\text { II-RH651-076 y } \\
\text { Google Earth }\end{array}$ & -62.143104 & -37.926704 \\
\hline IMG & $\begin{array}{l}\text { II-RH651-076 y } \\
\text { Google Earth }\end{array}$ & -62.150843 & -37.930247 \\
\hline IMG & II-RH651-076 & -62.141777 & -37.923814 \\
\hline IMG & $\begin{array}{l}\text { II-RH651-076 y } \\
\text { Google Earth }\end{array}$ & -62.158752 & -37.932304 \\
\hline IMG & $\begin{array}{l}\text { II-RH651-076 y } \\
\text { Google Earth }\end{array}$ & -62.143523 & -37.926753 \\
\hline IMG & $\begin{array}{l}\text { II-RH651-076 y } \\
\text { Google Earth }\end{array}$ & -62.144008 & -37.927806 \\
\hline IMG & $\begin{array}{l}\text { II-RH651-076 y } \\
\text { Google Earth }\end{array}$ & -62.149851 & -37.933149 \\
\hline IMG & $\begin{array}{l}\text { II-RH651-076 y } \\
\text { Google Earth }\end{array}$ & -62.151506 & -37.930658 \\
\hline IMG & $\begin{array}{l}\text { II-RH651-076 y } \\
\text { Google Earth }\end{array}$ & -62.146534 & -37.930542 \\
\hline IMG & $\begin{array}{c}\text { II-RH651-077 y } \\
\text { Bing }\end{array}$ & -62.144523 & -37.928334 \\
\hline IMG & $\begin{array}{l}\text { II-RH651-076 y } \\
\text { Google Earth }\end{array}$ & -62.143063 & -37.922995 \\
\hline IMG & $\begin{array}{l}\text { II-RH651-076 y } \\
\text { Google Earth }\end{array}$ & -62.141538 & -37.920677 \\
\hline IMG & Google Earth & -62.150729 & -37.93105 \\
\hline IMG & Google Earth & -62.137275 & -37.930483 \\
\hline
\end{tabular}




\begin{tabular}{|c|c|c|c|c|c|c|c|c|c|}
\hline Sub-zona & $\begin{array}{l}\text { Fecha de } \\
\text { Observación }\end{array}$ & Tipo & Estado & Edad relativa & Descripción & $\begin{array}{l}\text { Escala de } \\
\text { Observación }\end{array}$ & Imagen & Longitud & Latitud \\
\hline 3 & $2006-02-26$ & Desl_trasl & Degradado & Previo al 2006-02-26 & $\begin{array}{l}\text { Se conserva la acumulación y la superficie de ruptura con forma más o menos irregular. Está muy } \\
\text { cerca de los afloramientos rocosos. La acumulación cubre parte de la escarpa de un movimiento } \\
\text { previo mayor }\end{array}$ & IMG & Google Earth & -62.145596 & -37.928993 \\
\hline 3 & 2006-02-26 & Desl_trasl & Juvenil & $\begin{array}{l}\text { Entre el } 1967-09-21 \text { y } \\
\quad \text { el } 2006-02-26\end{array}$ & $\begin{array}{c}\text { Escarpa con forma cóncava y escasa separación de la masa. La acumulación está bien definida y } \\
\text { sepulta la zona de agotamiento de un flujo de detritos antiguo }\end{array}$ & IMG & $\begin{array}{l}\text { Google Earth y } \\
\text { Bing }\end{array}$ & -62.144801 & -37.927800 \\
\hline 3 & 2006-02-26 & Flujo_desl & Juvenil & Previo al 2006-02-26 & $\begin{array}{l}\text { Múltiples con tosca y afloramientos muy cerca. Tuvieron que agregar un pedazo de alambrado y } \\
\text { poner piedras (observación de campo del 2019-01-19). En } 1967 \text { ya estaba, pero era mucho más } \\
\text { pequeño }\end{array}$ & IMG & $\begin{array}{l}\text { II-RH651-076 y } \\
\text { Google Ear }\end{array}$ & -62.150609 & -37.935846 \\
\hline 3 & 2006-02-26 & Flujo_desl & Juvenil & $\begin{array}{l}\text { Entre el } 1967-09-21 \text { y } \\
\quad \text { el } 2006-02-26\end{array}$ & $\begin{array}{l}\text { Movimiento elongado en la dirección de la pendiente, cuya acumulación tiene forma de V. Tiene } \\
\text { buena expresión morfológica, aunque la superficie de ruptura está vegetada }\end{array}$ & IMG & Google Earth & -62.147581 & -37.930116 \\
\hline 3 & 2006-02-26 & Flujo_detr & Degradado & $\begin{array}{l}\text { Entre el 1967-09-21 y } \\
\quad \text { el 2006-02-26 }\end{array}$ & $\begin{array}{l}\text { Tiene ambos albardones, aunque mal preservados (observación de campo del 2019-01-19). Se } \\
\text { produjo afectando a un deslizamiento traslacional mayor, previo al 1967-09-21 }\end{array}$ & IMG & $\begin{array}{l}\text { II-RH651-077 y } \\
\text { Google Earth }\end{array}$ & -62.144185 & -37.926408 \\
\hline 3 & $2006-02-26$ & Flujo_detr & Juvenil & $\begin{array}{l}\text { Entre el 1967-09-21 y } \\
\text { el 2006-02-26 }\end{array}$ & Albardones bien definidos y acumulación presente & IMG & $\begin{array}{l}\text { Google Earth y } \\
\text { Bing }\end{array}$ & -62.151197 & -37.930537 \\
\hline 3 & $2006-02-26$ & Flujo_tier & Indef & Previo al 2006-02-26 & $\begin{array}{l}\text { La escarpa tiene buena expresión, pero la acumulación está bastante vegetada y no tiene buena } \\
\text { expresión morfológica. La acumulación tiene forma lobulada, y se observa una superposición } \\
\text { sobre una acumulación más antigua (posible actividad múltiple) }\end{array}$ & IMG & $\begin{array}{l}\text { Google Earth y } \\
\text { Bing }\end{array}$ & -62.155842 & -37.936784 \\
\hline 3 & 2006-02-26 & Flujo_tier & Juvenil & Previo al 2006-02-26 & $\begin{array}{l}\text { La escarpa es rectilínea y tiene reactivaciones retrogresivas. El material es limoso y está muy } \\
\text { deformado. Se asocia a caminos de animales (observación de campo del 2018-03-22) }\end{array}$ & IMG & Google Earth & -62.159381 & -37.940270 \\
\hline 3 & 2006-02-26 & Flujo_tier & Juvenil & Previo al 2006-02-26 & $\begin{array}{l}\text { Se observa una acumulación con mucha deformación de la masa, y dos escarpas pequeñas de } \\
\text { posibles reactivaciones }\end{array}$ & IMG & $\begin{array}{l}\text { Google Earth y } \\
\text { Bing }\end{array}$ & -62.148850 & -37.936997 \\
\hline 3 & 2006-02-26 & Vuelco_sue & Degradado & Previo al 2006-02-26 & $\begin{array}{l}\text { Vuelco de un bloque de suelo de varios metros con un camino de animales degradando el } \\
\text { contacto entre éste y el terreno no afectado (observación de campo del 2018-03-21) }\end{array}$ & IMG & $\begin{array}{l}\text { Google Earth y } \\
\text { campo }\end{array}$ & -62.172586 & -37.936452 \\
\hline 3 & 2015-12-18 & Complejo & Variable & Previo al 2015-12-18 & $\begin{array}{l}\text { Conjunto de flujos de detritos y deslizamientos traslacionales. Hay una reactivación producida } \\
\text { luego del 2006-02-26, otras entre el 1967-09-21 y el 2006-02-26, y otros movimientos son previos } \\
\text { al 1967-09-21 }\end{array}$ & IMG & $\begin{array}{l}\text { II-RH651-076, } \\
\text { Google y Bing }\end{array}$ & -62.135316 & -37.930194 \\
\hline 3 & 2015-12-18 & Flujo_tier & Variable & Previo al 215-12-18 & $\begin{array}{l}\text { Flujo cuya masa tiene mucha deformación, con acumulación elongada y lobulada. Ya estaba el } \\
\text { 1967-09-21, pero es mayor en el } 2015 \text { y se ven sectores sin vegetación contrastantes con el } \\
\text { entorno }\end{array}$ & IMG & $\begin{array}{l}\text { II-RH651-077 y } \\
\text { Bing }\end{array}$ & -62.143872 & -37.929299 \\
\hline 3 & 2018-03-20 & Desl_trasl & Juvenil & $\begin{array}{l}\text { Entre el 2015-12-18 y } \\
\text { el 2018-03-20 }\end{array}$ & $\begin{array}{l}\text { Deslizamiento pequeño reactivando la escarpa degradada de un movimiento complejo mayor. Los } \\
\text { bloques están desenterrados y aún no creció la vegetación (observación de campo) }\end{array}$ & IMG & Dron & -62.178200 & -37.949547 \\
\hline
\end{tabular}




\begin{tabular}{|c|c|c|c|c|}
\hline Sub-zona & $\begin{array}{l}\text { Fecha de } \\
\text { Observación }\end{array}$ & Tipo & Estado & Edad relativa \\
\hline 2 & $2006-02-26$ & Caída_roca & Juvenil & Previo al 2006-02-26 \\
\hline 2 & 2006-02-26 & Desc & Degradado & Previo al 2006-02-26 \\
\hline 2 & 2006-02-26 & Desl_trasl & Juvenil & Previo al 2006-02-26 \\
\hline 2 & 2011-12-12 & Desc & Degradado & Previo al 2006-02-26 \\
\hline 2 & 2015-12-18 & DesI_gen & Indef & Previo al 2015-12-18 \\
\hline 2 & 2015-12-18 & Desl_gen & Indef & Previo al 2015-12-18 \\
\hline 2 & 2015-12-18 & DesI_rotac & Juvenil & $\begin{array}{l}\text { Entre el 2006-02-26 y } \\
\text { el 2015-12-18 }\end{array}$ \\
\hline 2 & $2015-12-18$ & Pipping & Juvenil & Previo al 2015-12-18 \\
\hline 2 & 2015-12-18 & Pipping & Juvenil & Previo al 2015-12-18 \\
\hline 2 & 2016-04-15 & Caída_roca & Juvenil & Previo al 2016-04-15 \\
\hline 2 & 2016-04-15 & Caída_roca & Juvenil & Previo al 2016-04-15 \\
\hline 2 & 2016-04-15 & Caida_suel & Juvenil & Previo al 2016-04-15 \\
\hline 2 & 2016-04-15 & Caida_suel & Juvenil & Previo al 2016-04-15 \\
\hline 2 & 2016-04-15 & Desc & Degradado & Previo al 2016-04-15 \\
\hline 2 & 2016-04-15 & Vuelco_sue & Juvenil & Actual \\
\hline 2 & 2016-04-16 & Caída_roca & Juvenil & Actual \\
\hline 2 & 2016-04-16 & Caída_roca & Juvenil & Actual \\
\hline 2 & 2016-04-16 & Caída_roca & Juvenil & Actual \\
\hline 2 & 2016-04-16 & Caída_roca & Juvenil & Actual \\
\hline 2 & 2016-04-16 & Caída_roca & Juvenil & Actual \\
\hline 2 & 2016-04-16 & DesI_rotac & Degradado & Previo al 2016-04-16 \\
\hline 2 & 2016-04-18 & DesI_suelo & Juvenil & Previo al 2016-04-18 \\
\hline 2 & 2016-04-19 & Caida_suel & Juvenil & Previo al 2016-04-19 \\
\hline 2 & 2016-04-19 & Desl_suelo & Juvenil & Previo al 2016-04-19 \\
\hline 2 & 2016-04-19 & Caída_roca & Juvenil & Actual \\
\hline 2 & 2016-04-19 & Caída_roca & Juvenil & Previo al 2016-05-19 \\
\hline 2 & 2016-04-19 & Caída_roca & Juvenil & Actual \\
\hline 2 & 2016-07-17 & Desl_gen & Indef & Previo al 2006-02-26 \\
\hline 2 & 2016-07-20 & Caída_roca & Juvenil & Actual \\
\hline 2 & 2016-07-20 & Caída_roca & Juvenil & Actual \\
\hline 2 & 2016-07-20 & Caída_roca & Juvenil & Actual \\
\hline 2 & $2016-07-20$ & Caída_roca & Juvenil & Actual \\
\hline 2 & $2016-07-20$ & Caida_suel & Degradado & Previo al 2016-07-20 \\
\hline 2 & $2016-07-21$ & Desl_trasl & Degradado & Previo al 2016-07-21 \\
\hline 2 & 2016-07-21 & Desl_trasl & Juvenil & Actual \\
\hline 2 & 2016-07-22 & Caída_roca & Degradado & Previo al 2016-07-22 \\
\hline 2 & 2016-07-22 & Desl_gen & Degradado & Previo al 2006-02-26 \\
\hline 2 & $2016-07-23$ & Vuelco_roc & Juvenil & Actual \\
\hline 2 & 2017-01-29 & DesI_rotac & Juvenil & Previo al 2017-01-29 \\
\hline 2 & 2017-01-29 & Desl_trasl & Degradado & Previo al 2006-02-26 \\
\hline 2 & 2017-05-19 & Caída_roca & Juvenil & Actual \\
\hline 2 & 2017-05-19 & Caída_roca & Juvenil & Actual \\
\hline 2 & $2017-05-20$ & Caída_roca & Juvenil & Actual \\
\hline 2 & 2017-05-20 & Caida_suel & Indef & Previo al 2017-05-20 \\
\hline 2 & 2017-05-21 & Caída_roca & Juvenil & Actual \\
\hline
\end{tabular}

INVENTARIO DE MOVIMIENTOS EN MASA NO CARTOGRAFIADOS

\begin{tabular}{|c|c|c|c|c|}
\hline Descripción & $\begin{array}{l}\text { Escala de } \\
\text { Observación }\end{array}$ & Imagen & Longitud & Latitud \\
\hline Sector de caídas de roca, vaca como escala & IMG & CAMP8 20181211 & -62.231022 & -37.7444 \\
\hline Deslizamiento o vuelco de suelo & IMG & DRONE CAMP7 & -62.123679 & -37.7691 \\
\hline Deslizamiento planar de roca & IMG & CAMP8 20111211 & -62.229030 & -37.7449 \\
\hline Deslizamiento traslacional o flujo de detritos, muy lavado & IMG & CAMP8 20181212 & -62.218931 & -37.7479 \\
\hline $\begin{array}{l}\text { Superficie de ruptura con agua brotando y terracettes. La acumulación no tiene buena expresión } \\
\text { morfológica. }\end{array}$ & IMG & Bing & -62.173499 & -37.7352 \\
\hline $\begin{array}{l}\text { Escarpa cóncava y acumulación de escaso recorrido. Se ve prácticamente igual que en el 2006- } \\
\qquad 02-26 .\end{array}$ & IMG & Bing & -62.161642 & -37.7444 \\
\hline Afecta la margen interna (convexa) del curso de agua. & IMG & Bing & -62.165317 & -37.7420 \\
\hline fecta las cabeceras de un curso de agua y se produce en el límite entre la planicie y la ladera. & IMG & Bing & -62.157775 & -37.7540 \\
\hline Múltiple & IMG & Bing & -62.159128 & -37.7516 \\
\hline Cara sin líquenes en el frente escarpado. Al pie hay bloques frescos & IMG & CAMP1 20150415 & -62.161525 & -37.7439 \\
\hline Árboles rotos por caídas & IMG & CAMP1 20150415 & -62.161619 & -37.7428 \\
\hline Acción de animales & CMP & CAMP1 20150415 & -62.166400 & -37.7416 \\
\hline Pipping en frente de retroceso de cárcava & IMG & CAMP1 20150415 & -62.166320 & -37.7494 \\
\hline $\begin{array}{l}\text { Lomada degradada por curso de agua y reactivaciones progresivas de deslizamientos } \\
\text { rotacionales }\end{array}$ & CMP & CAMP1 20150415 & -62.162115 & -37.7461 \\
\hline Vuelcos caídas y Pipping surgente de un paleosuelo enterrado & CMP & & -62.165223 & -37.7448 \\
\hline Acción de animales, muchos bloques pateados y amontonamientos de detritos & CMP & CAMP1 20150416 & -62.168676 & -37.7387 \\
\hline Caídas afectando árboles. Se escuchan caer bloques & IMG & Campo & -62.167486 & -37.7384 \\
\hline Caídas afectando árboles. Se escuchan caer bloques & IMG & Campo & -62.167650 & -37.7382 \\
\hline Caídas afectando árboles. Se escuchan caer bloques & IMG & Campo & -62.167054 & -37.7386 \\
\hline Caídas afectando árboles. Se escuchan caer bloques & IMG & Campo & -62.167884 & -37.7385 \\
\hline Terracettes en toda la superficie de ruptura & CMP & CAMP1 20150416 & -62.170771 & -37.7374 \\
\hline Deslizamiento en camino & IMG & CAMP1 20150418 & -62.132109 & -37.7858 \\
\hline Caídas afectando terraza & IMG & CAMP1 20150419 & -62.121930 & -37.7895 \\
\hline Deslizamiento en barrancas de curso de agua & IMG & CAMP1 20150419 & -62.117463 & -37.7858 \\
\hline Aleros y frentes escarpados fracturados & IMG & CAMP1 20150415 & -62.119894 & -37.7886 \\
\hline Árbol impactado & CMP & & -62.119911 & -37.7904 \\
\hline Aleros $y$ frentes escarpados fracturados & IMG & CAMP1 20150415 & -62.119596 & -37.7885 \\
\hline $\begin{array}{l}\text { sumulación visible sólo en el terreno. La vegetación es muy alta y brota agua. Hay pocos detritos } \\
\text { en superficie. }\end{array}$ & CMP & CAMP2 20160717 & -62.176268 & -37.7504 \\
\hline Caídas múltiples de rocas por pateaduras. Frente escarpado ahogado y coalescencia de conos & CMP & CAMP2 20160720 & -62.180817 & -37.7579 \\
\hline Caídas múltiples de rocas por pateaduras. Frente escarpado ahogado y coalescencia de conos & CMP & CAMP2 20160720 & -62.181335 & -37.7581 \\
\hline Caídas múltiples de rocas por pateaduras. Frente escarpado ahogado y coalescencia de conos & CMP & CAMP2 20160720 & -62.180796 & -37.7575 \\
\hline Caídas múltiples de rocas por pateaduras. Frente escarpado ahogado y coalescencia de conos & CMP & CAMP2 20160720 & -62.181250 & -37.7577 \\
\hline Restos de los bloques de suelo por vegetación seca formando un talud & CMP & CAMP2 20160720 & -62.173357 & -37.7433 \\
\hline $\begin{array}{l}\text { Bloques con liquenes. El deslizamiento afecta a un piedemonte antiguo y sus bloques } \\
\text { permanecen en planicie de inundación excepcional }\end{array}$ & CMP & CAMP2 20160721 & -62.178488 & -37.7532 \\
\hline Deslizamientos múltiples de suelo afectando piedemonte antiguo. Ausencia de vegetación & IMG & CAMP2 20160721 & -62.178329 & -37.7532 \\
\hline Bloques con líquenes. Fracturas en los afloramientos & CMP & CAMP2 20160722 & -62.199033 & -37.7257 \\
\hline Deslizamiento en contacto entre roca y regolito & CMP & CAMP2 20160722 & -62.213630 & -37.7174 \\
\hline Se está produciendo lentamente & CMP & CAMP2 20160723 & -62.185933 & -37.7572 \\
\hline Afecta regolito, esta vegetado pero en el perfil tiene buena expresión & IMG & CAMP3 20170129 & -62.213366 & -37.7171 \\
\hline Superficie de ruptura de deslizamiento en contacto entre tosca y regolito & CMP & & -62.213785 & -37.7172 \\
\hline Bloques volteados por acción de animales, tanto en arboleda como a cielo abierto & CMP & & -62.168400 & -37.7391 \\
\hline Clasto volteado apoyado sobre paja, con líquenes hacia abajo. Acción de animales & CMP & & -62.168404 & -37.7390 \\
\hline o de roca. La actividad es sostenida en el tiempo, ya que hay bloques del núcle & CMP & CAMP4 20170520 & -62.170739 & -37.7380 \\
\hline Bloques caídos permaneciendo en el cauce & CMP & CAMP4 20170520 & -62.171674 & -37.7389 \\
\hline Acción de animales. Bloque & CMP & CAMP4 20170521 & -62.157816 & -37.7465 \\
\hline
\end{tabular}




\begin{tabular}{|c|c|c|c|c|}
\hline Sub-zona & $\begin{array}{l}\text { Fecha de } \\
\text { Observación }\end{array}$ & Tipo & Estado & Edad relativa \\
\hline 2 & 2017-05-21 & Caída_roca & Juvenil & Actual \\
\hline 2 & 2017-05-21 & Caída_roca & Juvenil & Actual \\
\hline 2 & 2017-05-21 & Caída_roca & Juvenil & Actual \\
\hline 2 & $2017-05-21$ & Caída_roca & Juvenil & Actual \\
\hline 2 & 2017-05-21 & Caida_suel & Juvenil & Previo al 2017-05-21 \\
\hline 2 & 2017-05-22 & Caída_roca & Juvenil & Actual \\
\hline 2 & $2017-05-22$ & Caída_roca & Juvenil & Actual \\
\hline 2 & 2017-05-22 & Caída_roca & Juvenil & Actual \\
\hline 2 & 2017-05-22 & Caída_roca & Juvenil & Actual \\
\hline 2 & 2017-05-22 & Caída_roca & Juvenil & Actual \\
\hline 2 & 2017-05-22 & Caída_roca & Juvenil & Actual \\
\hline 2 & 2017-05-22 & Caída_roca & Juvenil & Actual \\
\hline 2 & $2017-05-22$ & Caída_roca & Juvenil & Actual \\
\hline 2 & 2017-05-22 & Caída_roca & Juvenil & Actual \\
\hline 2 & 2017-05-22 & Caida_suel & Juvenil & Previo al 2017-05-22 \\
\hline 2 & 2017-05-22 & Desl_trasl & Juvenil & Previo al 2017-05-22 \\
\hline 2 & 2017-05-22 & Vuelco_sue & Degradado & Previo al 2017-05-22 \\
\hline 2 & $2017-05-23$ & Desı_gen & Degradado & Previo al 2006-02-26 \\
\hline 2 & 2017-05-24 & Caída_roca & Juvenil & Previo al 2017-05-24 \\
\hline 2 & 2017-05-24 & Caída_roca & Juvenil & Previo al 2017-05-24 \\
\hline 2 & 2017-05-24 & Caída_roca & Juvenil & Previo al 2017-05-24 \\
\hline 2 & 2017-05-24 & Caída_roca & Juvenil & Previo al 2017-05-24 \\
\hline 2 & 2017-05-24 & Caída_roca & Juvenil & Actual \\
\hline 2 & 2017-05-24 & DesI_trasl & Degradado & Previo al 2017-05-24 \\
\hline 2 & $2017-07-23$ & DesI_gen & Degradado & Previo al 2017-07-23 \\
\hline 2 & 2018-09-20 & Caída_roca & Juvenil & Previo al 2018-09-20 \\
\hline 2 & 2018-09-20 & Caída_roca & Juvenil & Actual \\
\hline 2 & 2018-09-20 & Caída_roca & Juvenil & Actual \\
\hline 2 & 2018-10-20 & Complejo & Degradado & Previo al 2018-10-20 \\
\hline 2 & 2018-10-20 & Desc & Indef & Previo al 2018-10-20 \\
\hline 2 & 2018-10-20 & Desl_cuña & Degradado & Previo al 2018-10-20 \\
\hline 2 & 2018-10-20 & Desl_cuña & Degradado & Previo al 2018-10-20 \\
\hline 2 & 2018-10-20 & Desl_cuña & Degradado & Previo al 2018-10-20 \\
\hline 2 & 2018-10-20 & Desi_gen & Indef & Previo al 2018-10-20 \\
\hline 2 & $2018-10-20$ & Desl_roca & Indef & Previo al 2018-10-20 \\
\hline 2 & 2018-10-20 & DesI_rotac & Indef & Previo al 2018-10-20 \\
\hline 2 & 2018-10-20 & DesI_rotac & Juvenil & Actual \\
\hline 2 & 2018-10-20 & Desl_suelo & Juvenil & Previo al 2018-10-20 \\
\hline 2 & 2018-10-20 & Desl_suelo & Juvenil & Actual \\
\hline 2 & 2018-10-20 & Desl_trasl & Degradado & Previo al 2018-10-20 \\
\hline 2 & 2018-10-20 & Desl_trasl & Juvenil & Previo al 2018-10-20 \\
\hline 2 & 2018-10-20 & Flujo_detr & Degradado & Previo al 2018-10-20 \\
\hline 2 & 2018-10-20 & Vuelco_roc & Juvenil & Previo al 2018-10-20 \\
\hline 2 & 2018-10-22 & Caída_roca & Juvenil & Actual \\
\hline 2 & 2018-10-22 & DesI_cuña & Juvenil & Previo al 2006-02-26 \\
\hline 2 & 2018-10-22 & Desi_gen & Degradado & Previo al 2006-02-26 \\
\hline 2 & 2018-10-22 & Desl_gen & Juvenil & Previo al 2018-10-22 \\
\hline 2 & 2018-10-22 & Vuelco_roc & Variable & Previo al 2018-10-23 \\
\hline 2 & 2018-10-22 & Vuelco_roc & Variable & Previo al 2018-10-23 \\
\hline 2 & $2018-10-23$ & Caída & Juvenil & Actual \\
\hline
\end{tabular}

Descripción

Acción de animales. Bloques volteados, cornisas y pavimentos de detritos Acción de animales. Bloques volteados, cornisas y pavimentos de detritos Acción de animales. Bloques volteados, cornisas y pavimentos de detritos

Acción de animals. Bloques volteados, cornisas y pavimentos de detritos Sector de caídas y vuelcos de suelo

Sendero de árboles caídos, algunos impactados

Clastos volteados, senderos, cornisas y pavimento de detritos

Clastos volteados, senderos, cornisas y pavimento de detritos

Clastos volteados, senderos, comisas y pavimento de detritos

Clastos volteados, senderos, cornisas y pavimento de detritos

Clastos volteados, senderos, cornisas y pavimento de detritos

Clastos volteados, senderos, cornisas y pavimento de detritos

Clastos volteados, senderos, cornisas y pavimento de detritos

$$
\text { Bloque caído y socavamiento }
$$

Deslizamiento de detritos en parte terminal de ladera, aportando material al curso Caída o vuelco de suelo afectando aluvio

No se observan las superficies de ruptura, pero hay lomadas degradadas con terracettes ladera abajo

\section{adera extraplomada}

Desplome asociado a cascada y caíds de rocas afectando árboles en cono de detritos Caída de algún bloque que se desintegró en una cascada Caída de bloques golpeando arboles

Bloque trabado ente alloramientos, susceptible a caíd Afecta a corte de ladera por curso de agua

Pequeño desliza Bloque grande caído con bordes filosos Sendero de árboles caidos e impaciados Sector con abundantes caídas

Deslizamientos con reactivaciones. Cronología relativa en esquema en papel Movimiento antiguo en camino

Deslizamientos, vuelcos y caidas. En general antiguos de grandes bloques Desliz de grandes bloques Deslizamiento de grandes bloques$$
\text { Asociado a manantial }
$$

$$
\text { Fracturas abiertas }
$$

Agua que se insume y genera slumps

Rotacionales en curso de agua, podrian ser parte de la evolución normal del aluvio Bloque de suelo individualizado con fractura de alto ángulo

Deslizamiento traslacional múttiple afectando corte de camino y alambrado

Deslizamiento de bloques rocosos de poco recorrido, unos metros

Deslizamiento planar grande de roca con desintegración del bloque principal Flujo degradado con rotacionales

Varios vuelcos en un frente escarpado de filitas-esquistos Caídas de grandes bloques

Bloques desintegrados

Lomada degradada por curso de agua. La escarpa no se ve Deslizamiento en curso de agua

Actividad mútiple, algunos recientes con pocos líquenes

Actividad múlitiple, algunos recientes con pocos liquenes

\begin{tabular}{|c|c|}
\hline $\begin{array}{l}\text { Escala de } \\
\text { Observación }\end{array}$ & Imagen \\
\hline CMP & CAMP4 20170521 \\
\hline CMP & CAMP4 20170521 \\
\hline CMP & CAMP4 20170521 \\
\hline CMP & CAMP4 20170521 \\
\hline CMP & CAMP4 20170521 \\
\hline CMP & CAMP4 20170522 \\
\hline CMP & CAMP4 20170522 \\
\hline CMP & CAMP4 20170522 \\
\hline CMP & CAMP4 20170522 \\
\hline CMP & CAMP4 20170522 \\
\hline CMP & CAMP4 20170522 \\
\hline CMP & CAMP4 20170522 \\
\hline CMP & CAMP4 20170522 \\
\hline CMP & CAMP4 20170522 \\
\hline IMG & CAMP4 20170522 \\
\hline IMG & CAMP4 20170522 \\
\hline CMP & CAMP4 20170522 \\
\hline CMP & CAMP4 20170523 \\
\hline CMP & \\
\hline IMG & CAMP4 20170524 \\
\hline CMP & CAMP4 20170524 \\
\hline CMP & CAMP4 20170524 \\
\hline CMP & CAMP4 20170524 \\
\hline CMP & CAMP4 20170524 \\
\hline CMP & Campo \\
\hline IMG & CAMP6 20180920 \\
\hline IMG & CAMP6 20180920 \\
\hline IMG & CAMP6 20180920 \\
\hline IMG & CAMP7 20181020 \\
\hline CMP & CAMP7 20181020 \\
\hline CMP & CAMP7 20181020 \\
\hline CMP & CAMP7 20181020 \\
\hline CMP & CAMP7 20181020 \\
\hline CMP & CAMP7 20181020 \\
\hline CMP & CAMP7 20181020 \\
\hline CMP & CAMP7 20181020 \\
\hline IMG & CAMP7 20181020 \\
\hline CMP & CAMP7 20181020 \\
\hline IMG & CAMP7 20181020 \\
\hline CMP & CAMP7 20181020 \\
\hline IMG & CAMP7 20181020 \\
\hline CMP & CAMP7 20181020 \\
\hline IMG & CAMP7 20181020 \\
\hline IMG & CAMP7 20181022 \\
\hline CMP & CAMP7 20181022 \\
\hline CMP & CAMP7 20181022 \\
\hline IMG & CAMP7 20181022 \\
\hline CMP & CAMP7 20181022 \\
\hline CMP & CAMP7 20181022 \\
\hline CMP & CAMP7 20181023 \\
\hline
\end{tabular}

Caídas y Pipping vinculado a cuevas de peludo o vizcacha

Longitud 


\begin{tabular}{|c|c|c|c|c|}
\hline Sub-zona & $\begin{array}{l}\text { Fecha de } \\
\text { Observación }\end{array}$ & Tipo & Estado & Edad relativa \\
\hline 2 & $2018-10-23$ & Caída & Juvenil & Actual \\
\hline 2 & 2018-10-23 & Caída_roca & Juvenil & Previo al 2018-10-23 \\
\hline 2 & 2018-10-23 & Complejo & Degradado & Previo al 2018-10-23 \\
\hline 2 & 2018-10-23 & DesI_suelo & Juvenil & Previo al 2018-10-23 \\
\hline 2 & $2018-10-23$ & Vuelco_roc & Juvenil & Previo al 2018-10-23 \\
\hline 2 & 2018-12-08 & Desc & Degradado & Previo al 2018-12-08 \\
\hline 2 & 2018-12-08 & Desc & Degradado & Previo al 2006-02-26 \\
\hline 2 & 2018-12-08 & Desc & Juvenil & Previo al 2006-02-26 \\
\hline 2 & 2018-12-08 & Desl_gen & Degradado & Previo al 2015-12-18 \\
\hline 2 & 2018-12-09 & Caída_roca & Juvenil & Previo al 2018-12-09 \\
\hline 2 & 2018-12-09 & Caída_roca & Juvenil & Previo al 2018-12-09 \\
\hline 2 & 2018-12-09 & Desl_gen & Indef & Previo al 2018-12-09 \\
\hline 2 & 2018-12-09 & Desl_suelo & Juvenil & Previo al 2018-12-09 \\
\hline 2 & 2018-12-09 & Flujo_detr & Degradado & Previo al 2018-12-09 \\
\hline 2 & 2018-12-09 & Flujo_detr & Indef & Previo al 2018-12-09 \\
\hline 2 & 2018-12-11 & Desc & Degradado & Previo al 2006-02-26 \\
\hline 2 & 2018-12-11 & Desc & Degradado & Previo al 2018-12-11 \\
\hline 2 & 2018-12-11 & Desc & Degradado & Previo al 2018-12-11 \\
\hline 2 & 2018-12-11 & Desl_gen & Degradado & Previo al 2006-02-26 \\
\hline 2 & $2018-12-11$ & Desl_suelo & Juvenil & Previo al 2018-12-11 \\
\hline 2 & 2018-12-11 & Desl_trasl & Degradado & Previo al 2006-02-26 \\
\hline 2 & 2018-12-11 & Desl_trasl & Degradado & Previo al 2018-12-11 \\
\hline 2 & 2018-12-11 & Desl_trasl & Degradado & Previo al 2018-12-11 \\
\hline 2 & 2018-12-11 & Desl_trasl & Juvenil & Previo al 2018-12-11 \\
\hline 2 & 2018-12-11 & Flujo_detr & Degradado & Previo al 2006-02-26 \\
\hline 2 & 2018-12-12 & Caída_roca & Degradado & Previo al 2018-12-12 \\
\hline 2 & 2018-12-12 & Caída_roca & Juvenil & Actual \\
\hline 2 & 2018-12-12 & Caída_roca & Juvenil & Previo al 2006-02-26 \\
\hline 2 & 2018-12-12 & Desc & Degradado & Previo al 2018-12-12 \\
\hline 2 & 2018-12-12 & Desl_gen & Degradado & Previo al 2018-12-12 \\
\hline 2 & 2018-12-12 & Desi_gen & Indef & Previo al 2018-12-12 \\
\hline 2 & 2018-12-12 & Desl_trasl & Degradado & $\begin{array}{l}\text { Entre el 2011-04-10 y } \\
\text { el 2015-12-18 }\end{array}$ \\
\hline 2 & 2018-12-12 & Desl_trasl & Degradado & Previo al 2006-02-26 \\
\hline 2 & 2018-12-12 & Desl_trasl & Degradado & Previo al 2006-02-26 \\
\hline 2 & 2018-12-12 & Desl_trasl & Indef & Previo al 2018-12-12 \\
\hline 2 & 2018-12-12 & Flujo_detr & Degradado & Previo al 2018-12-12 \\
\hline 2 & 2018-12-12 & Flujo_tier & Degradado & Actual \\
\hline 2 & 2018-12-12 & Flujo-tier & Degradado & Previo al 2006-02-26 \\
\hline 2 & 2018-12-12 & Vuelco_roc & Degradado & Previo al 2011-04-10 \\
\hline 2 & 2018-12-12 & Vuelco_roc & Indef & Previo al 2018-12-12 \\
\hline 2 & 2019-01-22 & Desl_gen & Degradado & Previo al 2006-02-26 \\
\hline 2 & 2019-01-22 & Desl_gen & Juvenil & Previo al 2006-02-26 \\
\hline 2 & 2019-01-22 & Desl_gen & Juvenil & Previo al 2006-02-26 \\
\hline
\end{tabular}

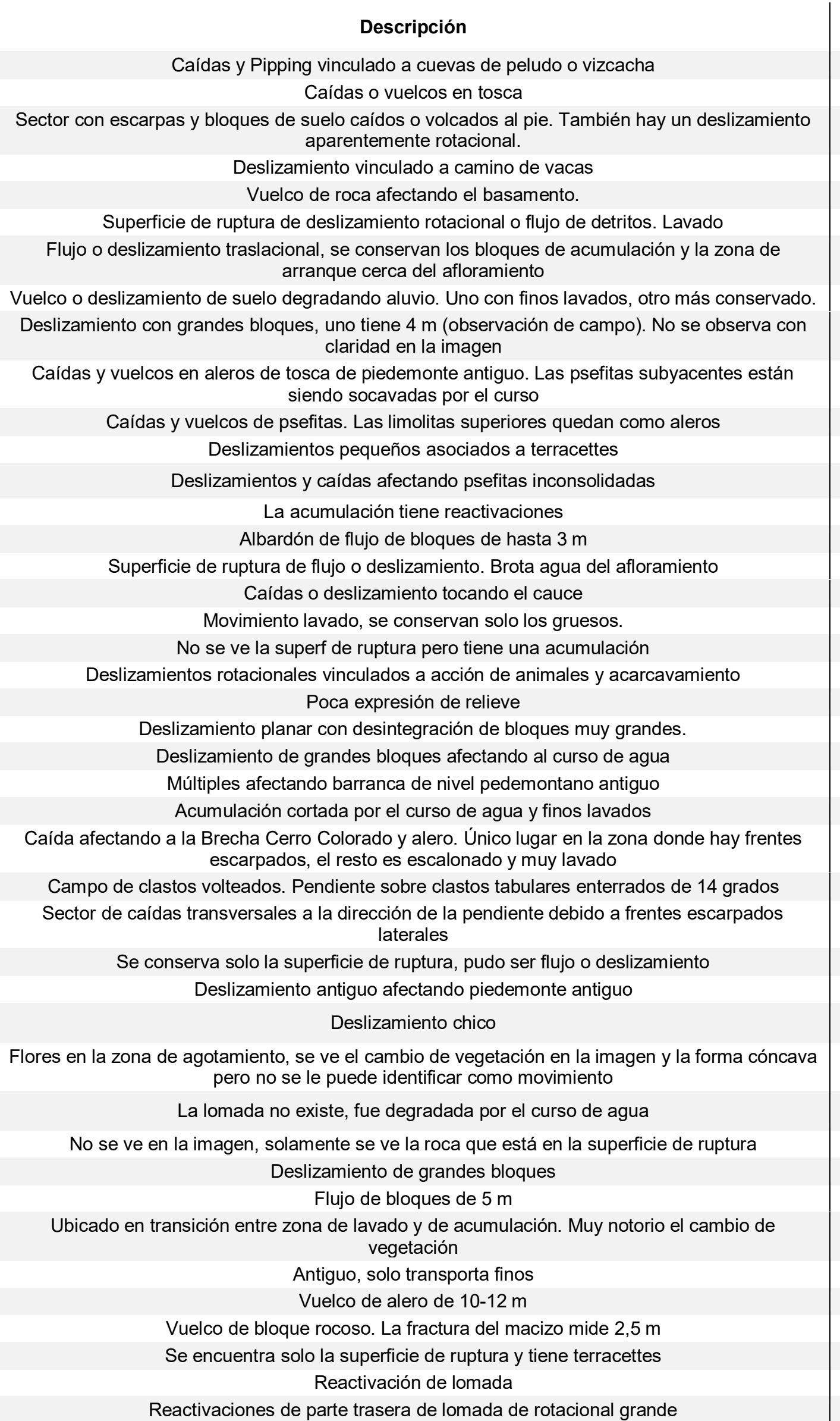

\begin{tabular}{|c|c|c|c|}
\hline $\begin{array}{l}\text { Escala de } \\
\text { Observación }\end{array}$ & Imagen & Longitud & Latitud \\
\hline CMP & CAMP7 20181023 & -62.272894 & -37.7644 \\
\hline IMG & CAMP7 20181023 & -62.267578 & -37.7544 \\
\hline CMP & CAMP7 20181023 & -62.256362 & -37.7501 \\
\hline IMG & CAMP7 20181023 & -62.259173 & -37.7509 \\
\hline CMP & CAMP7 20181023 & -62.262209 & -37.7561 \\
\hline CMP & CAMP8 20181208 & -62.228289 & -37.7808 \\
\hline CMP & CAMP8 20181208 & -62.227377 & -37.7799 \\
\hline IMG & CAMP8 20181208 & -62.228974 & -37.7833 \\
\hline CMP & & -62.227866 & -37.7801 \\
\hline IMG & CAMP8 20181209 & -62.214786 & -37.7733 \\
\hline IMG & CAMP8 20181209 & -62.219538 & -37.7812 \\
\hline CMP & & -62.218465 & -37.7696 \\
\hline IMG & CAMP8 20181209 & -62.223384 & -37.7823 \\
\hline CMP & CAMP8 20181209 & -62.218269 & -37.7692 \\
\hline CMP & CAMP8 20181209 & -62.215979 & -37.7710 \\
\hline CMP & CAMP8 20181211 & -62.232353 & -37.7405 \\
\hline CMP & CAMP8 20181211 & -62.228492 & -37.7419 \\
\hline CMP & CAMP8 20181211 & -62.227735 & -37.7448 \\
\hline CMP & CAMP8 20181211 & -62.248860 & -37.7468 \\
\hline CMP & & -62.256522 & -37.7545 \\
\hline CMP & CAMP8 20181211 & -62.240036 & -37.7445 \\
\hline CMP & CAMP8 20181211 & -62.227397 & -37.7383 \\
\hline CMP & CAMP8 20181211 & -62.227721 & -37.7386 \\
\hline IMG & CAMP8 20181211 & -62.249343 & -37.7474 \\
\hline CMP & CAMP8 20181211 & -62.244349 & -37.7457 \\
\hline CMP & CAMP8 20181212 & -62.237119 & -37.7589 \\
\hline CMP & CAMP8 20181212 & -62.246179 & -37.7504 \\
\hline IMG & CAMP8 20181212 & -62.216280 & -37.7468 \\
\hline CMP & CAMP8 20181212 & -62.222335 & -37.7493 \\
\hline CMP & CAMP8 20181212 & -62.237889 & -37.7569 \\
\hline CMP & & -62.224734 & -37.7565 \\
\hline CMP & CAMP8 20181212 & -62.219851 & -37.7439 \\
\hline CMP & CAMP8 20181212 & -62.222961 & -37.7429 \\
\hline CMP & CAMP8 20181212 & -62.223333 & -37.7429 \\
\hline CMP & CAMP8 20181212 & -62.221707 & -37.7501 \\
\hline CMP & CAMP8 20181212 & -62.221527 & -37.7494 \\
\hline IMG & CAMP8 20181212 & -62.246692 & -37.7498 \\
\hline IMG & CAMP8 20181212 & -62.247733 & -37.7522 \\
\hline CMP & CAMP8 20181212 & -62.220789 & -37.7489 \\
\hline CMP & CAMP8 20181212 & -62.217986 & -37.7455 \\
\hline IMG & CAMP9 20190122 & -62.142896 & -37.7499 \\
\hline IMG & CAMP9 20190122 & -62.144225 & -37.7494 \\
\hline IMG & Google Earth & -62.143455 & -37.7498 \\
\hline
\end{tabular}




\begin{tabular}{|c|c|c|c|c|c|c|c|c|c|}
\hline Sub-zona & $\begin{array}{l}\text { Fecha de } \\
\text { Observación }\end{array}$ & Tipo & Estado & Edad relativa & Descripción & $\begin{array}{l}\text { Escala de } \\
\text { Observación }\end{array}$ & Imagen & Longitud & Latitud \\
\hline 3 & $2006-02-26$ & Desc & Degradado & Previo al 2006-02-26 & Caída, vuelco o deslizamiento de suelo, solo se conserva la superficie de ruptura & IMG & Google Earth & -62.146610 & -37.9379 \\
\hline 3 & $2006-02-26$ & Desc & Degradado & Previo al 2006-02-26 & Caída, vuelco o deslizamiento de suelo, solo se conserva la superficie de ruptura & IMG & Google Earth & -62.148821 & -37.9397 \\
\hline 3 & $2006-02-26$ & Desc & Degradado & Previo al 2006-02-26 & Caída, vuelco o deslizamiento de suelo, solo se conserva la superficie de ruptura & IMG & Google Earth & -62.149011 & -37.9403 \\
\hline 3 & 2018-03-20 & Caída_roca & Juvenil & Actual & Núcleo de roca & CMP & CAMP5 20180320 & -62.177940 & -37.9501 \\
\hline 3 & 2018-03-20 & Desl_suelo & Degradado & Previo al 2018-03-20 & Asociado a entrante de animales & CMP & CAMP5 20180320 & -62.167876 & -37.9433 \\
\hline 3 & 2018-03-20 & DesI_suelo & Juvenil & Previo al 2018-03-20 & Deslizamiento afectando la barranca. Escaso desplazamiento, parte de la masa queda colgada. & CMP & CAMP5 20180320 & -62.156205 & -37.9393 \\
\hline 3 & 2018-03-20 & DesI_suelo & Variable & Previo al 2018-03-20 & Deslizamientos vinculados a acción de animales & CMP & CAMP5 20180320 & -62.172871 & -37.9363 \\
\hline 3 & 2018-03-21 & Caída_roca & Juvenil & Previo al 2018-03-21 & Caídas y vuelcos & CMP & CAMP5 20180321 & -62.157752 & -37.9351 \\
\hline 3 & 2018-03-21 & Caída_roca & Juvenil & Previo al 2018-03-21 & Caídas y vuelcos & CMP & CAMP5 20180321 & -62.158128 & -37.9353 \\
\hline 3 & 2018-03-21 & Desc & Degradado & Previo al 2018-03-21 & Caída o vuelco de suelo por socavamiento basal & CMP & CAMP5 20180321 & -62.156219 & -37.9423 \\
\hline 3 & 2018-03-21 & Vuelco_roc & Juvenil & Previo al 2018-03-21 & Vuelco en laja y caídas cerca & IMG & CAMP5 20180321 & -62.178221 & -37.9428 \\
\hline 3 & 2018-03-21 & Vuelco_roc & Juvenil & Previo al 2018-03-21 & Vuelco en laja y caídas cerca & IMG & CAMP5 20180321 & -62.178009 & -37.9422 \\
\hline 3 & 2018-03-21 & Vuelco_roc & Juvenil & Previo al 2018-03-21 & Vuelco en laja y caídas cerca & IMG & CAMP5 20180321 & -62.177342 & -37.9429 \\
\hline 3 & 2018-03-21 & Vuelco_roc & Juvenil & Previo al 2018-03-21 & Vuelco en laja y caídas cerca & IMG & CAMP5 20180321 & -62.177256 & -37.9422 \\
\hline 3 & 2018-03-22 & Caída_roca & Juvenil & Actual & Clastos pateados y cornisa de detritos & CMP & CAMP5 20180322 & -62.162724 & -37.9385 \\
\hline 3 & 2018-03-22 & DesI_trasl & Degradado & Previo al 2018-03-22 & Asociado a manantial y escarpa degradada por pisoteo & CMP & CAMP5 20180322 & -62.161145 & -37.9396 \\
\hline 3 & 2018-03-22 & Vuelco_roc & Indef & Previo al 2018-03-22 & Vuelco en laja hacia el costado & CMP & CAMP5 20180322 & -62.165075 & -37.9394 \\
\hline 3 & 2018-09-17 & Caída_roca & Juvenil & Actual & Sector de caídas & IMG & CAMP6 20180917 & -62.180026 & -37.9413 \\
\hline 3 & 2018-09-17 & Caída_roca & Juvenil & Actual & Sector de caídas & IMG & CAMP6 20180917 & -62.180530 & -37.9413 \\
\hline 3 & 2018-09-17 & Caída_roca & Juvenil & Actual & Sector de caídas & IMG & CAMP6 20180917 & -62.179487 & -37.9416 \\
\hline 3 & 2018-09-17 & Caída_roca & Juvenil & Actual & Sector de caídas & IMG & CAMP6 20180917 & -62.180204 & -37.9407 \\
\hline 3 & 2018-09-17 & Caída_roca & Juvenil & Actual & Sector de caídas & IMG & CAMP6 20180917 & -62.179331 & -37.9407 \\
\hline 3 & 2019-01-19 & Caída_roca & Juvenil & Previo al 2019-01-19 & Caída en cueva & IMG & CAMP9 20190119 & -62.150325 & -37.9350 \\
\hline 3 & 2019-01-19 & DesI_roca & Indef & Previo al 2015-12-18 & Deslizamientos en bloque & CMP & CAMP9 20190119 & -62.140685 & -37.9300 \\
\hline 3 & 2019-01-19 & DesI_suelo & Juvenil & Previo al 2019-01-19 & Deslizamiento afectando depósitos finos de un abanico & IMG & & -62.156439 & -37.9416 \\
\hline 3 & 2019-01-23 & Vuelco_roc & Indef & Previo al 2019-01-23 & Vuelco en remanente de afloramiento & CMP & & -62.170453 & -37.9537 \\
\hline
\end{tabular}


Movimientos en masa en las sierras de Bravard y Curamalal,

Sierras Australes de la Provincia de Buenos Aires.

Juan Manuel Susena 


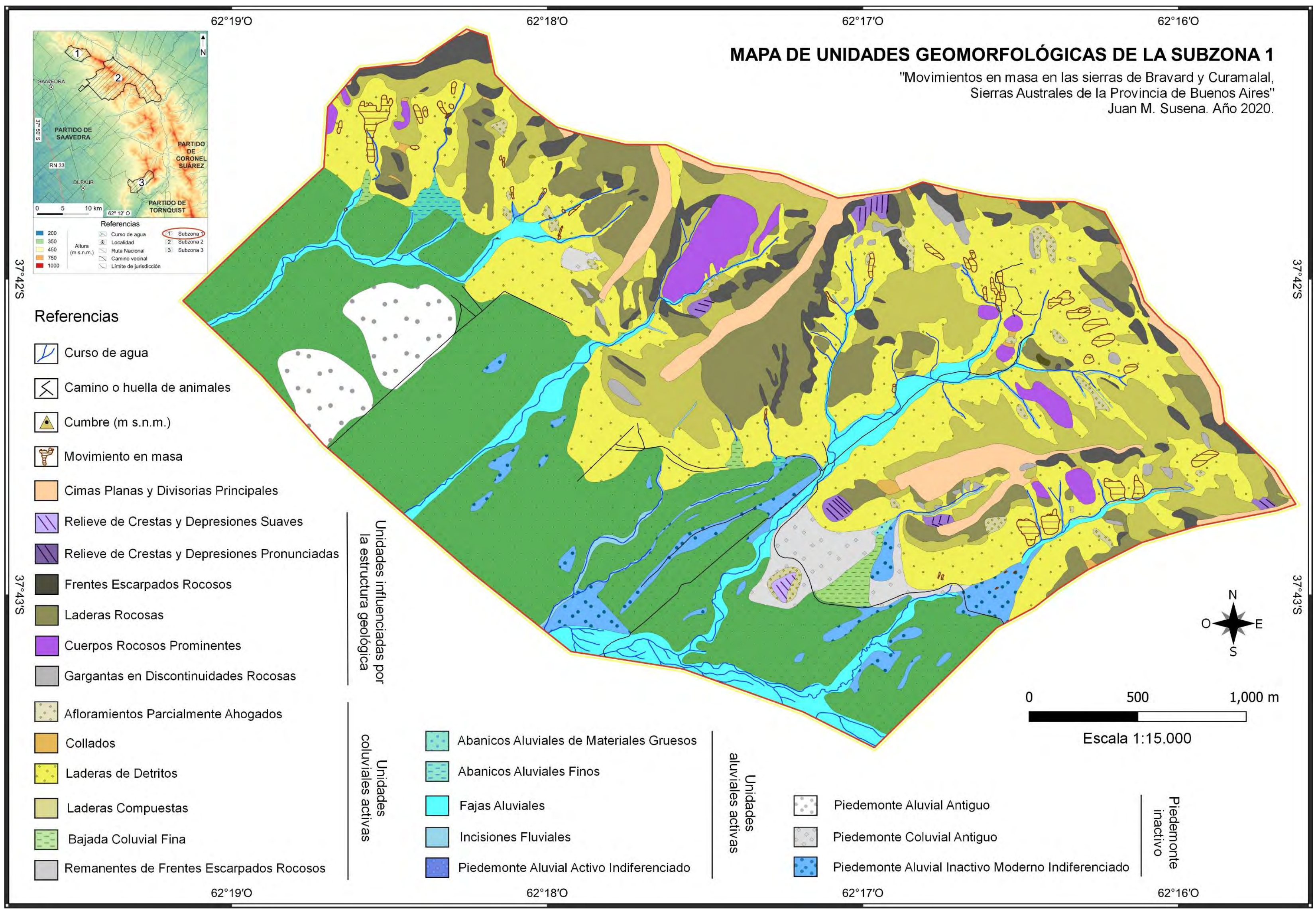

ACLARACIÓN: El tamaño original del mapa es A3. Para ver en tamaño real, remitirse a la versión impresa o al archivo de imagen adjunto. 
Movimientos en masa en las sierras de Bravard y Curamalal,

Sierras Australes de la Provincia de Buenos Aires.

Juan Manuel Susena 
MAPA DE UNIDADES GEMORFOLÓGICAS DE LA SUBZONA 2 (las referencias son las mismas que en el mapa de la subzona 1)

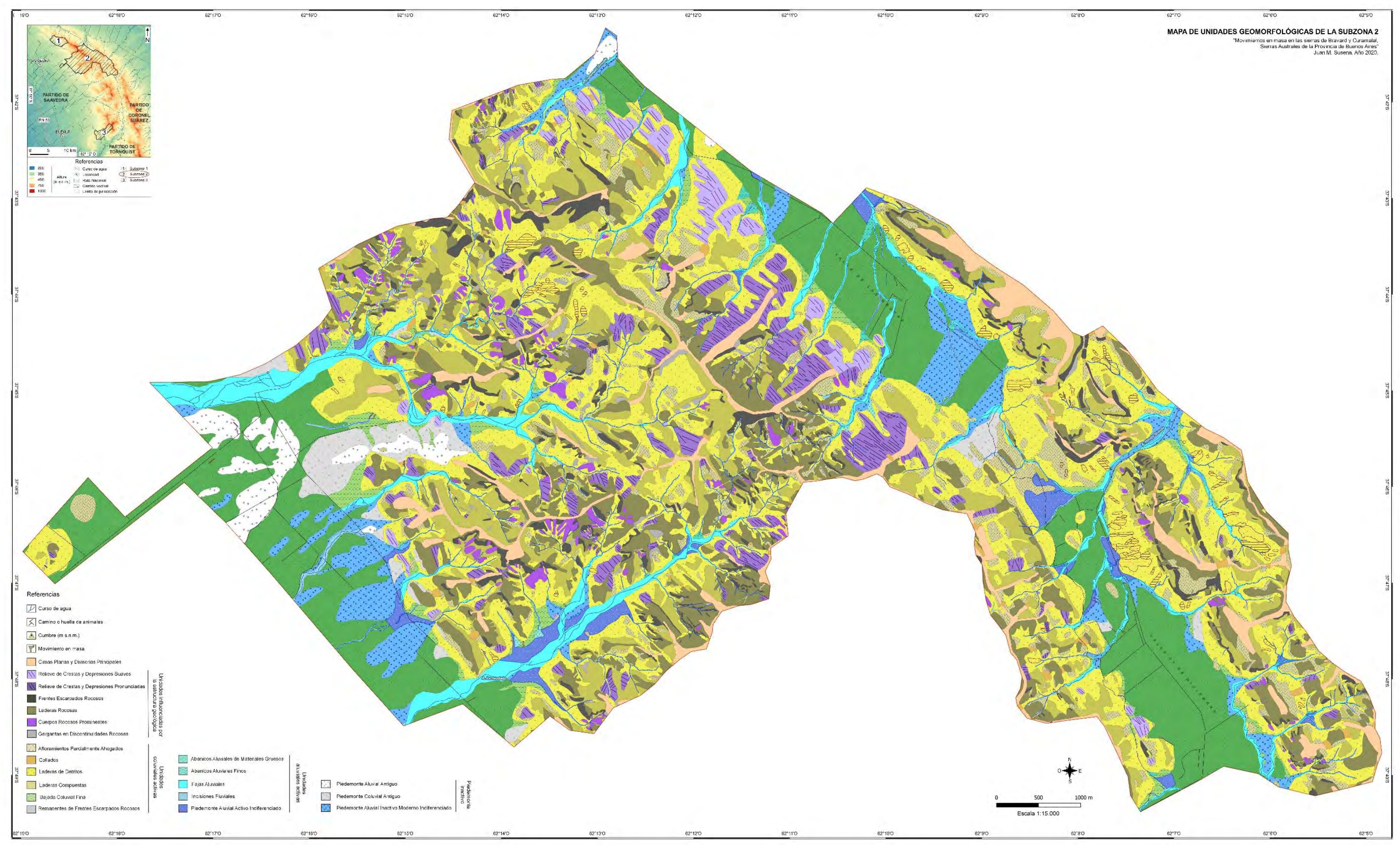

ACLARACIÓN: El tamaño original del mapa es A0. Para ver en tamaño original, remitirse a la versión impresa o al archivo de imagen adjunto. 
Movimientos en masa en las sierras de Bravard y Curamalal,

Sierras Australes de la Provincia de Buenos Aires.

Juan Manuel Susena 


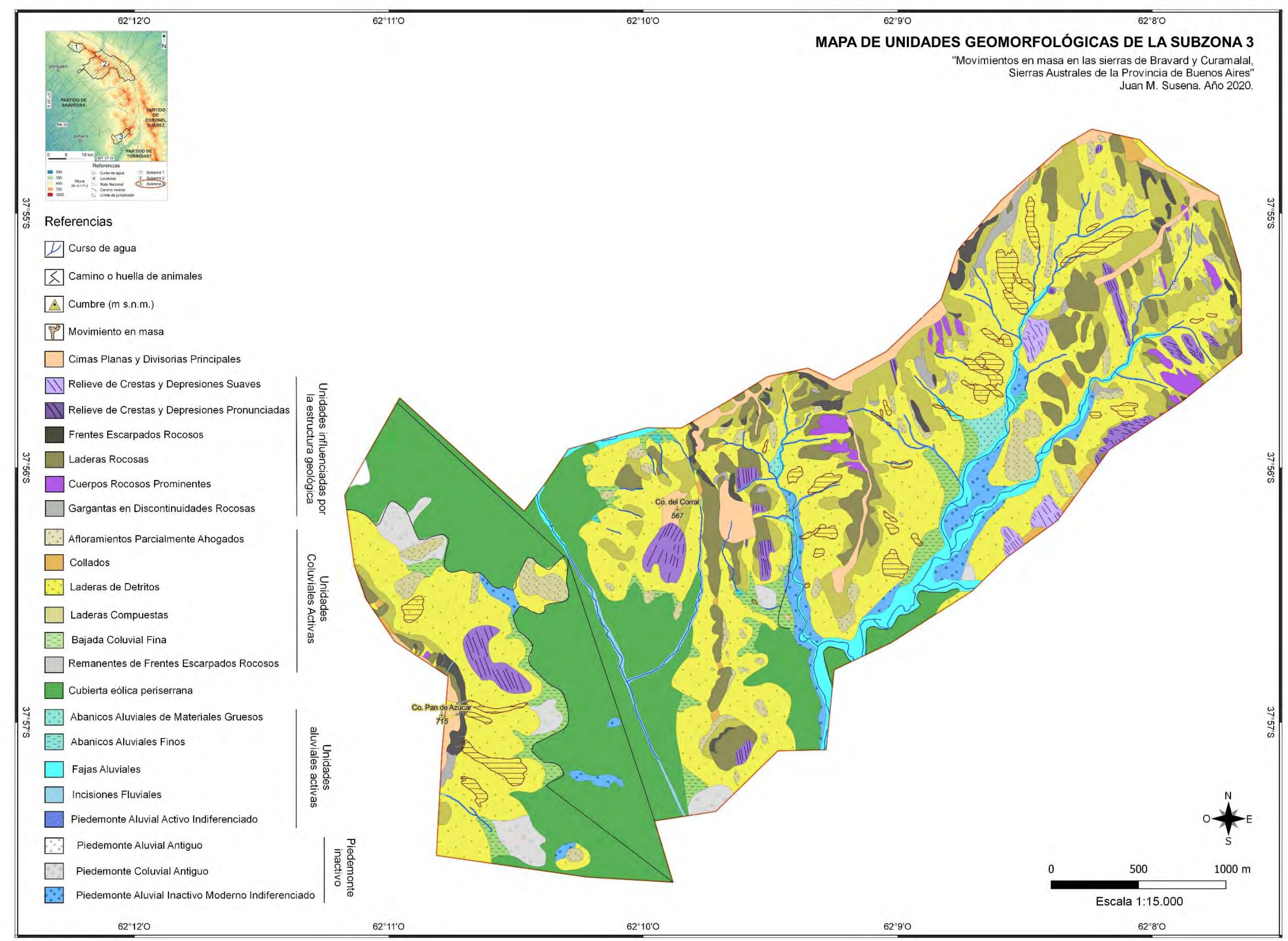

ACLARACIÓN: El tamaño original del mapa es A2. Para ver en tamaño original, remitirse a la versión impresa o al archivo de imagen adjunto. 
Movimientos en masa en las sierras de Bravard y Curamalal,

Sierras Australes de la Provincia de Buenos Aires.

Juan Manuel Susena 